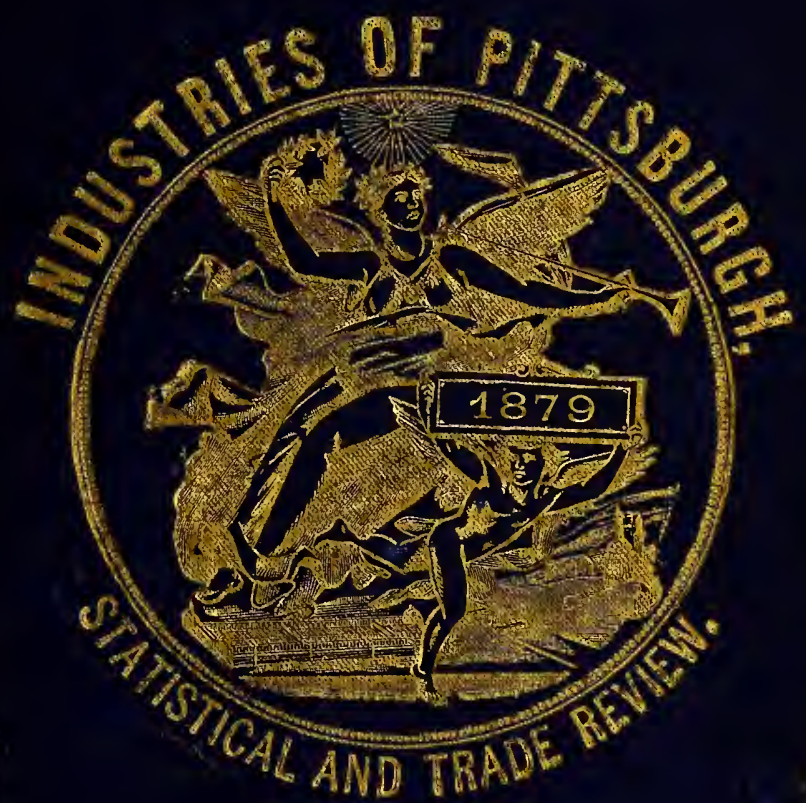



Tomplenoments

Moprowar assoente 812 . 



\section{HC \\ $10 \%$ \\ P4 169 \\ INDUSTRIES OF PITTSBURGH. \\ Nis 4 \\ Trade, Commerce and Manufactures.}

HISTORICAL AND DESCRIPTIVE REVIEW.

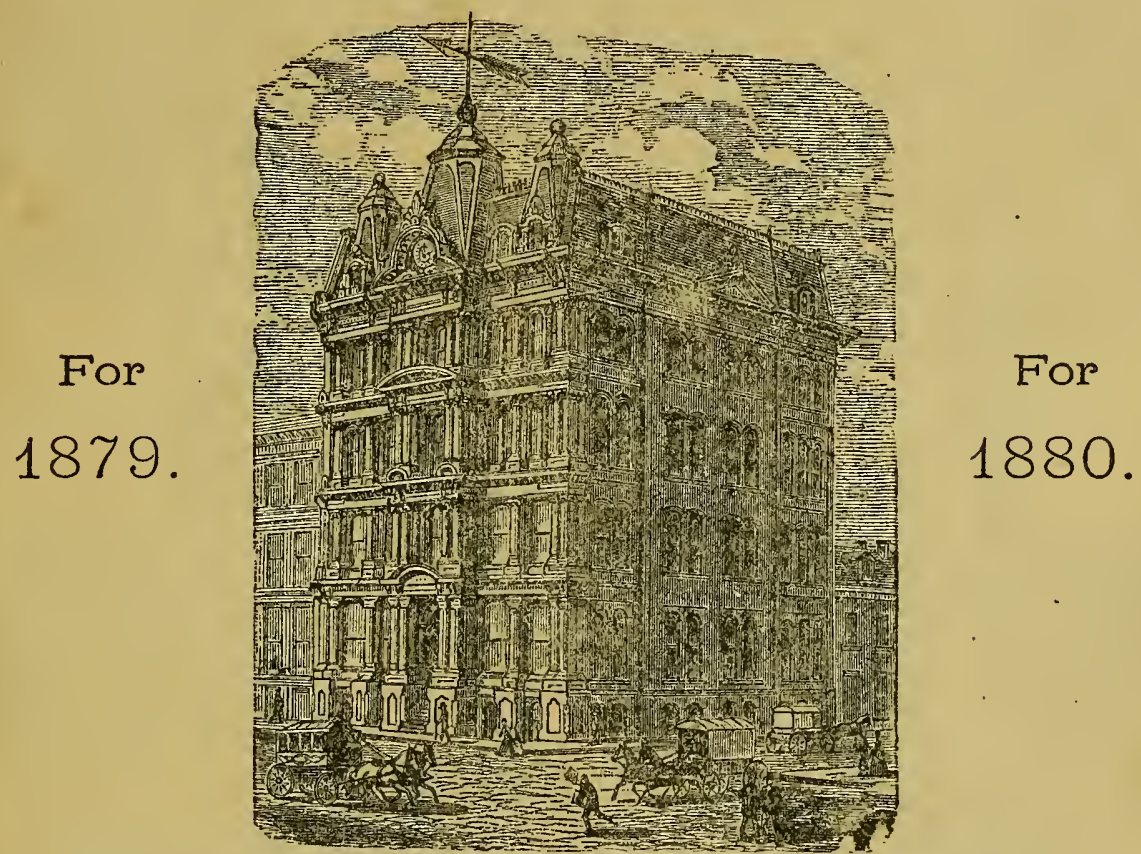

Pittsburgh Chamber of Commerce-Germania Banl Building, corner Wood and Diamond Sirets.

Officers of the Chamber of Commerce for 1879-80.

President,

J. K. MOOLUEAD.

WILLIAM E. SCHMERTZ, JOHN H. RICKETSON,

Secretary,

S. L. MCHENRY.

WILLIAM FREW, R. C. GRAY

SIMON BEYMER,

JOHN B. JACKSON

GEORGE A. KELLY

CHARLES MEYRAN,
Vice Presidents, HENRY HIOIDDIIIP, REUBEN MILLEI, H. W. OLIVER, JR.

Trcasurer

CHARLES MEYRAN.

Directors, JOSEPH G. SIEBENECK, JOHN S. SLAGLE, GEORGE H. ANDERSON, RAI,PH BAGAIEY, T. BRENT SWEARINGEN,
JOHN IR. NCCUNL,

Superintendent, N. GI: $\Lambda_{+\infty}^{m} A N$ MURPIIY

JAMES II. HOPEIXS, JAMES LA UGHLIN, Jn., A. J. SMITH,

WVILLIAN A. MCINTOSI, FLIANK S. BISSEL

\section{PITTSBURGH :}

RICHARD EDWARDS, EDITOR AND PUBLISHER. 1879 .

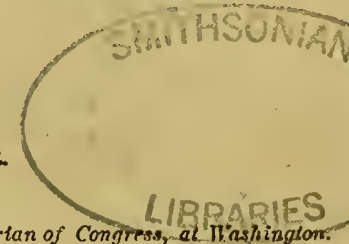




\section{PREFATORY.}

In nlacing this work in the hands of the public, the publisher feels no hesitancy in expressing the assured conviction that no volume heretofore issued, relating to Pittsburgh and its industries, contains so great an amount of useful, if not indispensable information.

For nearly six montls a staff of reporters and writers, numbering at times more than a score, representing, in their separate departments, unusual ability, have been engaged in obtaining all possible facts within the compass of our design, and giving them a readable and orderly corsstruction.

Embracing both cities and their environs within a radius of many miles, every trade, manufacture or mercantile enterprise has been sedulously and fully depicted-no frm or establishnent of any prominence being willingly excluded from these pages.

No small expense has been entailed upon the publisher in providing the illustrations with which the work is embellished, and no efforts have been spared to secure such excellence, so far as its mechanical production is concerned, as shall give it an attractive appearance to every reader. A careful perusal of this volume, on the part of those residing at a distance or unfamiliar with the marvelous diversity of the resources of Pittsburgh, is earnestly commended as certain to excite interest and likely to suggest experimental relations, at least, that must conduce to the future profit of all parties.

The acknowledgments of the publisher are due to the Pittsburgh Chamber of Commerce for the aid and co-operation extended in the task undertaken, without which the enterprise would have been shorn of no small part of the brilliant success that has attended it. To Hon. J. K. Moorhead, President Chamber of Commerce; Wm. E. Schmertz, Esq., President Third National Bank; J. D. Weeks, Esq.. Associate Editor Iron Age; Frederick K. Saward, Esq., Editor Coal Trade Journal; Hon. Thomas W. Davis, Collector Internal Revenue; American Almanac for 1879, by Ainsworth R. Spafford, Librarian of Congress; Wm. G. Johnston \& Co., Stationers; and Geo. A. Kelly, of Geo. A. Kelly \& Co., for substantial encouragement and highly-valued assistance, the publisher also returns the most cordial assurances of appreciation, and, with the belief that his labors will prove not altogrether ineffectual in conducing to the general welfare of the business community, he subscribes himself

RICHARD EDWARDS.

\section{Industries of Pennsylvania, Statistical and Historical Review.}

BSE THIS PAMPHLET IS COMPLETE, and is a portion of a large Illustrated Volume of about 2,000 pages, of great value and importance to Farmers, Merchants, Travelers, Emigrants, and all residing in or interested in the growth and prosperity of Pennsylvania and its various Industrial and Professional pursuits.

Communication from Gov. Henry M. Hoyt.

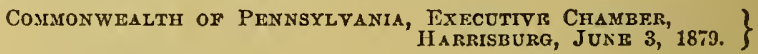

MR. RICHARD EDWARDB:

****** Knowing your great experience and the success and value of your former publications, I can most cordially commend the undertaking to the public, and respectfully request all those in chargo of the various public and private institurions and enterprises of the State, to extend to you the facillties necessary to enable you to prosecute the work, and givo you such encouragement as will guarantee its speedy publication.

Yours Very Truly,

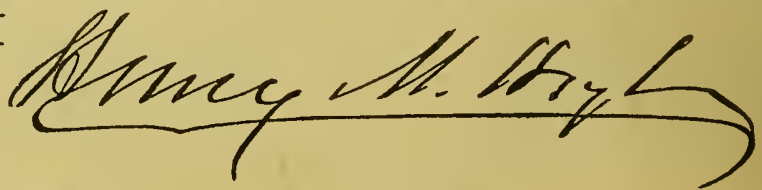

Resolution of the Pittsburgh Chamber of Commerce.

Resolved, That, appreclating the laudable character and magnitude of this undertaking, the Pittsburgh Chamber of Conmerce cordially recommend this enterprise as conducive to the public good, and suggest such co-operation and encouragement by our business comnunity as shall ensure its early publication and its success. 


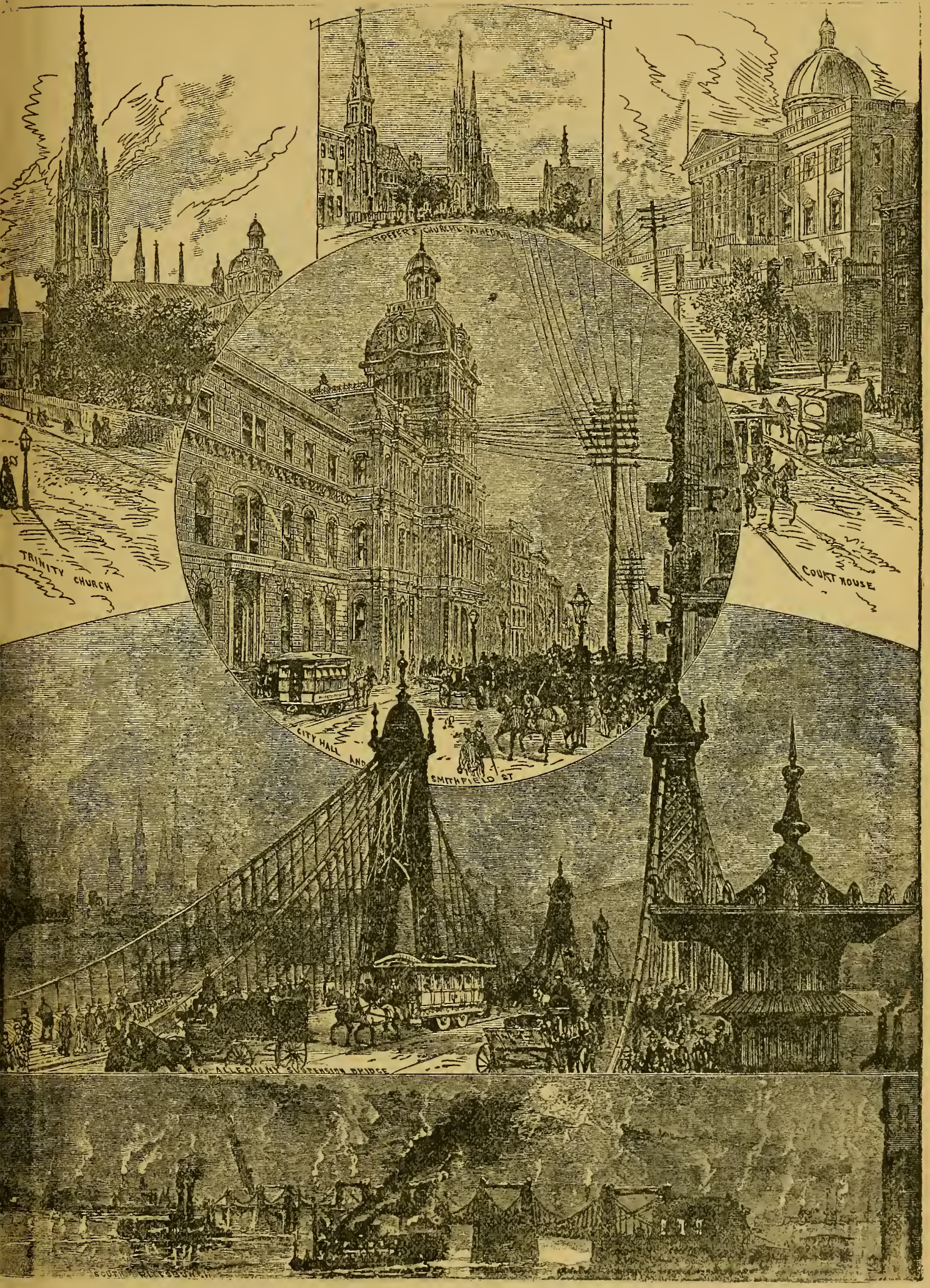




\section{ALPHABETICAL INDEX.}

Atwood Paxon, Fine Sluirts PAOE

Atwod Paxon, Fine Shirt............................... 254

Arınstrong Frank, Coal Dealer................................ 101

Albree de Co., Boots and Shoes................................ 112

Allegheny Insurance Co...................... 113

Ahlers C. F., Merchunt Tailor........................... 113

A nderson Walter, Mercbant Tailor........................... 115

Ayers D. \& Co., Live Stock Central Yards, ctc............. 122

Arrott Jas. WV.. Fire, Marine and Lifo Insurance A..... 13

A veruann \& Co., Dry Goods, Carpels, etc.................. 137

Allegheny Collegiate Institute.............................. $] 40$

Agnew \& Co., Flint-Glass Vials, etc........................ 144

Artisans' Insurance Co............................................. 149

Armstroug Chas H. \& Son......................................... 150

Armstrong S. P. \& Co., Wholesale and Retail Grocers 153

Acker \& Carr, Stoves, Ranges, etc........................... 357

Atchison Thos., Teamster..................................... 163

Allegheny Gun Works...................................... 16t

Appel Henry, Boots, Shoes and Gaiters....................... 177

Andriessen Fred., Wines and Liquors....................... 178

Alter 0. T., Tinware, Stoves, etc............................. 173

Allinder D. G., 11. D................................. 179

Anderson W. B., Oyster, Produce and Commission..... 200

Artisans' Deposit B:tnk. ................................. 87

Armstrong Bro. \& Co., M'f'rs Corks and Bungs........... 88

Adams \& Co. Table Glassware ............................. 89

Andriessen A., Wines and Liquors.............................. 91

A rwor A., Druggist ............................................. 92

Arnold J.' Mrs., Books, Stationery, etc..................... 95

Alleghen y Steam Liundry....................................... 210

Abel Kin \& Cn., Window G] Wiss.................................. 211

Axthelm Ernst, Etua Sewing Macline................... 217

A rmstrong \& MicKelvy, M'f'rs White Lead, etc........... 220

Alleghen y Brewer............................................ 22: 2

A bel \& Voellger, Bot1lers Best's Lager Beer.................. 227

Aland Jos. J., Merchant Taílor.............................. 228

Anderson A. A. \& Son, Book and Jol, Printers............. 24I

Anderson \& Co., Pittshurgh Steel Works..................... 242

Albee S. V., Practical Business Photographer............ 25:

Americin Bink.................................................... 261

Arsenal Bank.

Brown Brothers, Family Groceries

Bown James \& Son, Euterprise Guin W................... 255

Berkshire life Insurince Co................................... 10j

Beymer, Bauman \& Co., Whito Lead ............................. 106

Bernd J. D. \& Co., Importers and Milliners................ 111

Barrett ( 7. B. \& $(n)$, Wholesale Jewelers.................. 114

Bennett W m. P., Blank Books, Binding, et $(* \ldots \ldots \ldots \ldots . . .115$

Brown, Murphy \& Fertig, Sewer Pipe, etc.................. 118

Bunting W. A., Stencil Works................................. 123

Boas D. K., Druggist and Chemist............................. 126

Bricker A. \& Sons, Commissinn Merchants................... 126

Bridge \& Bowman, Practical Plumbers ....................... 136

Bakewell, Pears \& Co., Glass Works......................... 136

Birmingham Foundry und Machine Shop .................. I38

Beatty R., Son \& Co., Wholesale Commission, etc....... 141

Burn Wm.......................................................... 264

Boyd Brus. Fine Confections................................ 143

Beckert \& Bros., Florists and Seedsmen.................... 152

Brown Thomas, Plumber, etc................................. 151

B:trker G. B.. Grocer........................

Beattie H., (iroceries and Provisions.......................... If)

Bepler Hotel................................................. 1it

Bater W w., Hats, Caps and Furnishing Goods........... J fi $\mathrm{i}$

Berger Titus, House and Sign Painter.................... 163

Bostwick W W. S., Magnese Bronze Factory................. 11 9

Beiter R. \& Co., Brush Block Manufacturers.............. 170

Brown WII. C., Mlarble and Granle Works............... 17t

Beringer W. C. \& Co.. Claim and Patent Agents......... 372

Basler Horace R., Music Publisher, etc. .................. 17.

Byme \& McCabe, I ivery and Sale Stable

Barker Wm., Jr., Wnol Dealer..

Buvinger C. W. M. M.. Pl ysician and Surge............. 17

Bidwell D. W. C. \& Co., Powder Co....................... 175

Bates G. S., Fire Insurance......

Bnehme MIrs. E. J. \& Son, Watchmakers and Jewelers 17.

Blei] H. F.. Dry Goods, Groceries, etc..................... 17.

Bvrne P., Groceries and Provisions........................... 1 i

Bartels August, Florist................................ 17 )

Breitweiser M., Groceries, Flour, Sptces, etc............... 191

Bell, 'Thom psuu \& Co......................................... 216
Baxmyer \& Co

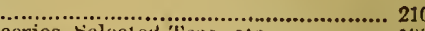
Beeson \& McMorris, Designers and Engravers

Bown W. T. \& Bro., Coffee Ronsters.

Blaney Gibsoll, Flour and Feed

Benz L \& Bros Contractors und Builater.

Brugemau H.

Barr John U. A r. Grucer, Wholesile and Ketail....... 207 . Architect........................................ 208 B.tuer G. F., looking-Glass Frames, etc...

Balsley \& Lutton, Notions, Druggi ts, etc.

Beck Washington, M'f'er of Glass Molds.

Buffum J. (: \& Co., Mranufaeturer's and Bottlers.

Beinhatuer L. \& Son, Jivery and Salc Statlele

Ballard Johı .J., Manufacturer Cigars and Tobacco... Bragdon Jobn C., Wood Cirver.

Bedilion T. P., Jeweler.

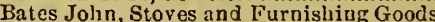

illing's Patent Horse Shoe..

irmingham Fire Insurance Co.

Barckley Sam'l, Grocers' Produce, etc.

Boyle \& McGlincliey, Undertaking and Livery.

Best \& Co., Printers

Butz Edward M., Arehilect.

Bunt Johu G., Leather, Ilides, etc...

Jeach C. H., Practical Druggist..........................

Byers A. M. \& Co., Wrought Iron and Lap-Welded Galvanized Iron Pipe

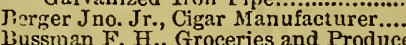

Briggs \& Drum, Com. Il ercliants of Cattle,Hogs \& Sheen 262 Baxmyer F, \& Co, Flour, Feed Groceries, etc Bissell \& Co., Stoves, Ranges, Grates, Fenders, etc.... 262

Camphell C. P., Insurance Agent.

Casliey IV. J., Groceries and Provisions...................

Cunningham \& Co., Glatss Works.

Cain Thos A rine Boots and Shoes... Crawford John, Stencils, Steel Stannps, etc................ 101 Central Refining Co.............. Collius H. E. \& Co., Brokers in Pig Iron, etc............. 114 Campll, Williamson \& Dick, Dry Goods............... 117

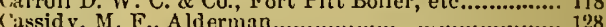
Childs H. \& Co., Wholesale Boots ant Shoes................ 128 Childs H.\& Co., Wholesale Boots and Slioes.............. 128 Crter Bros, \& Co., Wholesale Grocers Carter H., Sewing Machine Bazar.................... 112 Cooper W Wu. \& Co., Wholesale Groeers...... Crea Gralıum \& Cn., Stoves, Ranıes, etc................... 148 Culmer Spring (4)., Spiral Springs ... Colebaugh, W. H , Photogripher............................. 151 Curry George, Flour. Grain, Hay, etc........................ 156 Clark H. H., Mr. D., Phvsiciun and Surgeon............... 160 Crawford Harris, Groceries.... Connelly .j. H. \& Son, Agents Fire Extinguisliers...... 170 Cushing \& liox, Real listate Brokers Camphell \& Lauffer, Marble, Granite, etc.................... $]$ T0 Cluley J. F., Hnuse and Sign Painter......................... 171 Cain M. B., Shoe Store...................................... Is Casey \& Fogarty, Wines and Liquors.......................... $18 t$ Cruiksltank Z., Groceries................................... 195 Cowler D.. M. D., Homeopat hic Physician and Surgeou 195 Cosgrove Jno. S., Undertaker and Embalmer... 199 Cruilkshink Bros., Grocers, Wholesale and Retail........ 200 Charles \& Mcisurtry, Patent Int-Pressed Nuis......... 203 Clark A. I.., Carpenter and Builder.......................... 20. Connelly Péter, Blacksmitl .............................. 205 Cruikshank Z., Flour and Produce.......................... 201 Coyne \& Hatrv, Patent Automalic Nail Scicetors...... $12 \bar{J}$ Croner A. G Tin, Copper and Sheet-Irom Ware....... 87 Central Bumk Tin, Copper and Sheet-Iron Warc........ Cruikshank Bros., Grocers............................................ $9 \bar{s}$

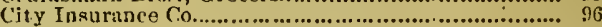
Colîtins John K., Cigar Factory................................ 219 Chautaugui Iake Ire Co

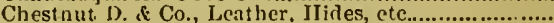

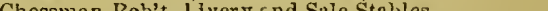
Cook F., Mruuficturer of Cigars Cochran \& Bro., Contractors and Builders.................... 213 Consolitluted Gas Co. ......................................... 2t

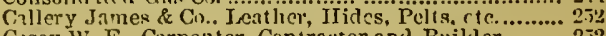
C.ısey WV. F., Carpenter, Contractor and Builder........ 252 


\section{INDEX.}

Craig \& Vilson, Groceries and Feed

Central Hotel, Goo. J. Bridge, Proprietor.

261

Dilworth J. S. \& Co., IVloolesale Grocers

Dun R. G. \& Co., The Mercantile Agency.

Duncan \& Thompson's Brusl, Manufictory................. 109

Diehl J. P. \& Son, Wall Paper....................................... 115

Dravo iVni.. Mc C., Oits............................................. 117

Dawes John L. Sons \& Co., Druggist's Glassware...... 119

Ditbbs B. L. H., Photographer.................................. 120

Denison Lewis A., Grocer....................................... 123

Duncan Geo. \& Sons, Glass Mian ufacturers.................. 133

Dobbs \& Risinger, Bant Wood Work....................... 142

Durkin M., Dealer in Coal.......................................... 159

Davis Thos. D., BI. D.................................................. 166

Darragh MIrs. S. L., Artist.................................. 1G8

Dunlevy J. B., Dental Depot................................... 171

Dithridge Chimney Compan y................................ 172

Donaldson John L., Wines and Liquors........................ 181

Dicksnn, Stewart \& Co., Conl Office............................. 184

Dietrich Frank, Butcher and Dealer in all Meats...... 19.

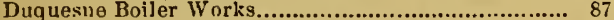

Drape Jas. W., A uctioneer, Real Estate, etc............... 90

Deebold Jnseph, Groceries and Prorisions..................... 91

Dietz R. \& Bro., Bont and Shoe Man'frs...

Delaware Mutual Silfety Ins. Co...

Diamond National Bank

Dauh Henry Fashionable MI trehant Tailor

Dean Jolin H., Groceries and Flour

Doriver XI. J., Marble Works........................................ 210

Duncan James, Family Groceries............................... 215

Dorflinger Theo., Druggist................................................ 226

Davis, Chambers \& Co., Leat Works.......................... 231

........ 232

Dielf, Alckert, Photographer................................. 245

Fast End Hotel

Fist End Marble Works

Eilenhermer O., Log Cabin Cigar Storo....

East End Carriage Manufactory................................. 16.5

Ede George, Carpets Oil ciotis etc..................... 170

Evans T. 1R, M. D , Physiciun and Surgeon................... 177

Eichenlaub iv. F., Furniture WVareroonis...................... 177

Ehlers \& Herman, Undertakers. .................................. 185

Excelsior Planing Mills............................................. 190

Eberhart \& Ober, Lager Beer Brcwers, etc..................... 203

Eberhart \& Ober, Brewers and Maltsters...................... 81

Elwood \& McCracken, Grain Merchants .................... 96

Enterprise Planing Dill.......................................... 216

Edgar Thnmpson Steel Co........................................... 218

limpire Oil Works................................................ 232

Evans J. T., Marble and Stone-Cutter.......................... 250

Ehrstein Josepl, Druggist...................................... 25.3

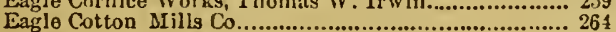

Fullerton \& Son, Tobacco and Cigars

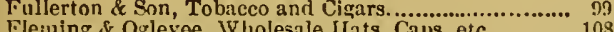

Fairbanks standard Scales

Fleislman Bros., Trimulings, Millinery, etc................. 114

lindis $L_{2 .}$ \& Son, Cluthing, etc............................... 12.

Farrell is. J Plumbing, Gas Fitting, etc....................... 122

Freehold Bank, Discount and Depnsit..................... 129

Fawcett Thos. \& Sons, Bituminons Coal..................... 13॥

Freil Chas., Soda, Mineral Waters, etc........................... 13.

Fuirman WVm., Undertaker, etc....................................... 139

Fire XI. is Bro., Dry Goods, etc...................................... 1-13

Fruehlich Jolm, Wines and Liquors.............................. 147

Jinch Jos. S. \& Co.. Distillers ...................................... 150

Fickeigen $H$., Hats and Furnishing Goods.................. 16!

Fetzer J. J. \& Bro., ( $r$ rocerics, Ters, etc.................... 16.)

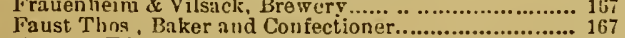

lioerster B livard, Wall Paper......................................... 169

Fetzer A. M.., House Furnishing Goods, etc.................... 176

Fergugon \& Co.. Bonk and Job Printers..................... 177

First Natinna] Bank .......................................... 179

Furmers and Mechanics Bank.................................... 179

Fulurer Ins., Foreign and Domestic ivines.................... 179

Fifth A venue Iotel............................................... 15G
PSGE

French Gale, Surgeon Dentist. 188

Fis, wer J. O., M. D., Dentist............................................ 190

Fort Pit toal Co., Ariners and Shippers of (ras Coaj.... 191

Forster J. J., Groceries, Dry Guods, Wall Paper, etc... 19.

Flanagan \& Kling, Horse Sloers............................. 199

Fleming, Agnew \& Co., stamped and Japanned Ware. 82

l'ichtel F Grocer

Flaccus ivm. \& Son. Tauners.............................. 225

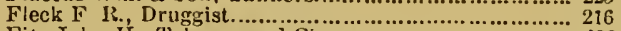

Fitz Juhn H., Tubaeco and Cigars..................................... 222

Fleming Thos., Grocer and Biker............................ 223

Fiedler Albert, Manufacturer swiss Bitters............... 224

Franz \& Dentenberg, Curri:tge Builders..................... 2225

First National Bank of Allegheny . ............................. 231

Fulton's S in \& Co., Bell and Brass Founders............... 253
Frick H. C. \& Co., Alanufacturers of Connells 2511 c Coke 257

Grabowsky Win., Silk Hat Munufacturer..

Grogan \& Yerz, Juwert Dinufacturer................... 103

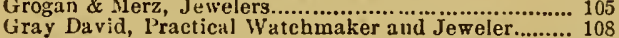

Gr1liam Manufacturing Co....................................... 109

Getty \& Cn., Distillers \& IVholesale Liquor Dealers..... 111

Guckert W.I. \& Co., Desks, Tables, etc................... 112

Griffith W. L. \& Co., Millinery and Trimuinings............ 1:30

Gray's [ron Line, Freight Transportation.................... 134

Gangwisch John, Allegheny Valley Biewery................. 137

Grahau \& Courtney, Salt Manufact urers.................... 144

Gleim Perry M., Druggist, ctc.............................. 146

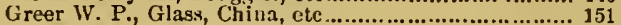

(iross E. W. Fire Iusuranco Agency.............................. 155

Gregg Jas. P. Jr., Fashionable Hatter........................ 162

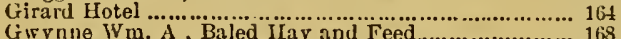

Giv ynne Wm. A, Baled Ilay and Feed........................... 168

Guckenheimer A. \& Bros., Whi_kies......................... 176

German Savings and Deposit Bank ......................... 178

Goettman Jacob, Baker and Confectioner............... 178

German Fire Insurance Co .......................................... 184

(ielleland J. A., Dry Goods, Clotiliig, etc................... 185

Garduer Bros., Fire Brick, Tile and vurtace Blocks... 19:

Glesenkaup L, \& Co., Carriage Manufacturers.......... 199

Greineisen F. C., Druggist....... ............................ 208

Gray John \& Co., Dry Goods, Notions, cte................... 214

Gray Wm. E., Dry Gnods and Millmery.................... "21

Gallagher \& House, Boots and Shoes............................ 215

Gardner Chas., MIerchant Tailor ................................. 2332

Grim Darid, Carringe MIanufacturer ...................... 234

Garrow II. S., Florist................................................. 2 $2 \pm 1$

Great. Western Hay, Grain and Feed House, Jas. Gri-

liam \& Son..................................................... 250

Greene G. W. \& B. F. \& Co., II' 'rs of Ingot Brass..... 258

Holtzman H., Practical Decorative Upholsterer......... 97

Hutchinson A. A. \& Bro., Coal und Coke................... 97

Hoting C. \&ons, (irain, Hay, Straw, otc...................... 99

Hugles J. P., Cigar Mitnufacturer.............................. 100

Hulley Jacob B. \& Co........... 101

H ıgue Walter E., (fold anil Silver Plater................... 101

Hoftman J. MI. \& Cu, Pianus and Orgaus....................... 104

II amilton A., Fish, Oysters and (Game ........................ 104

IIunter Joseph R., M erchandise Broker.................... 106

Hughes Jas. P., W all Paper, etc............................... 107

IIantilton S., Pianos and Or.tans................................... 112

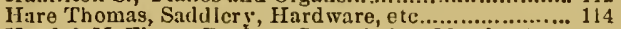

Hcad \& McElroy, Produce Commission Merchants.... 118

Hodge, Goddurd \& Co., Wholesale Jewelers................ 121

Hostetter \& Smith, Stomach Bitters......................... 127

Heckel C. C., Mercliunt Tailor ........................................ 138

Hare S. W. \& Co., Plumbers and Gas Fitters............. 111

Horue Jos. \& Cn., Dry Goods, Notions, etc.................. 145

Hamiltun W. H. \& Co., Glass Manufacturers............... 145

Hiller

Hamilton, Lemimon, A rnold \& Co ................ 149

Hay James, Plumfer, Steam and Gas Fitter............... $\imath^{2}$

Halpin \& Humbert, Plumbers, ete.............................. 1.24

Huesner M[rs. C., Groceries and I'rodice...................... 156

IH unter Divid, Cigars, Tobatcen, etc........................... 1,58

IIarvey L., Bonks and Stationery ........................... 1.99

Huhuck I'eter, Butter and Eggs............................. 10 ?

Hauna E. S., M1. D ................................................. 163

Harbaugh A.' J., Granite and Marblo Wi.................. 166

Hager M. H., Wỉall Paper, Notions, etc..................... 166

IIaslett $F$. . M. \& Co., Nut aud Bolt Works................... 163 
INDEX.

IIauch C. Mrs., Watches, Clocks, etc

IIitcheock, McCreary \& Co., Grain, ete.

Hippely I, Flour, Grain and Mill Feed................... 182

Hines Mr. J., Dry Goods, Alillinery, Notious, etc....... 195

Hughes Geo. W., Cigar MIanufacturer......................... 197

Hartdung Theodore, MLerchant Tailor..................... 198

Heckman Adam, Wine and Liquor Saloon ................ 199

Haines J. B., Wholesale Dry Groods........................... 202

Home Hotel.................................................... 204

Heintz MIrs. J. C., Dry Goods and Notions................... 205

Hussey, Howe \& Co., Manfr's. of Steel.......................... 85

Haslage Wm., Jobber and Retailer in Groceries, etc.... 86

Hedges S. B. \& Co., Com. Merchants for Cattle, etc....

Holdship \& Irwin, American Oil Works...

Hechelnian W. W., MI. D

Hollinger J. S., Merchant's Dining Rooms...................

Hamburger Ph., Rye and Bourbon Wh hiskies

Haldeman \& Johnston, Coach and Wagon Makers................

Hussey C. G. \& Co., Rolling Mills

Helbling W., Butcher..........................

Husack W w. Flour, Oats, etc

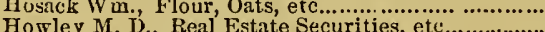

Himpe F, Bottling House......................................... 22

Herron Wm. A.\& Son, Real Estate Agents................ 245

Husse y C. G. \& Co., Pittsburgh Copper and Brass Works 246

Heiucman Otto E., Watchıaker and Jeweler............ 250

Humboldt Fire Ins. Co............................................ 253

Hermes Peter \& Bro., Milk and Butter Dealers.......... 259

Huntington Dr. J. E., Dentist....................................... 259

Hains Geo. S............................................................ 239

Irwin Geo. M., Grain and Provision Broker.

Iron City Bridge Works Provision Broker................ 131

Irwin John M. \& Son, Furniture Manufacturers........... 144

Iron City Flour Mills..................................................... 162

Ihmsen Glass Company, Colored Glassware............... 176

ron an W. H Rosedale Foundry ........................ 210

Iron City Marble Works............................................... 234

Isabella Furnace Co., Manufacturers of Pig Iron.......... 245

Iron City College, J. C. Smith, A. M., Principal.......... 248

Improved Mercantilc Agency, Bradstreet Company... 25

Irwin James, Globe Street Lamps, Vapor Burners, etc. 259

Jackson I., Star Clothier

Jones J. B. \& Bro, Wholesale Iron Metal, etc.............

Jones $H$. Curpet Weaver

Jones, Robert M., Pattern and Model Works.............. 161

Jenkins M. L., Boots, Shoes, Hats, Caps, etc................. 16.5

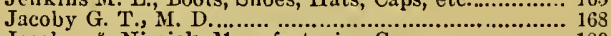

Jacobus \& Nimick Manufacturing Co........................... 1s 1 so

Jeffries R. B., M'f'r Cigurs, Wholesale and Retail....... 187

Jarvis \& Adans, Manufacturers Domestic Hardware... 190

Johnson, Egye \& Earl, Wholesale Grocers.................. 238

Juniata Bolt Works, Gillespie Bros. \& Co................. 241
Jackman A. \& Sous, Exchange Livery Stables.......... 250

Kaufman, Oppenheimer \& Co., Wholesale Clothiers.... 99
Kramer \& Seifert, Oysters, Yeast, etc........................ 102

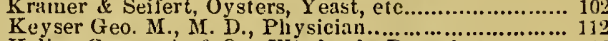

Kelley George A. \& Co., W holesale Druggists.............. 116

Kornblum, Optician................................................... 118

Kaercher J. B., Hard ware and Cutlery.......................... 118

Kirk Arthur, Powder and Miners' Supplies.................. 119

Keystone Paper Co................................................. 124

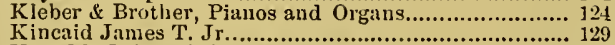

Kay, McKnight \& Co., Machinery and Supplics........... 139

Klemm Wm., Plumber, Gas-Fitter, etc.................... 140

Kirkpatrick, Beale \& Co., Sheet Iron, etc................... 145

Kelley \& Jones, Steam-W arming, etc.....

Klinzing \& Co., Boots, Shoes and Gaiters.................... Its

Keil P. \& Son, Commission Merchants.......................... 152

Kratzer W. N. Jr., Mattrésses, Bedding, etc.................. I53

Kinn W. L. \& Co., Leather, Oils, etc......................... 155

Kenurott Geo. Tin, Copper, Briss, etc

King Wm., A derman and Police MLagistrate............... 162

Kelley Chils. H. \& Co., Sewing-Machine Attachuentis 177

Konstanzer Otto, Baker and Confectionery................. 1s

Keller Jacob, Wines and Liquors.................................. 189

Kane C., Scrap Iron, steel and Metal

Keystoue Boiler, Forge und Anvil Works...................
Kier Bros., Manufacturers of Fire Briek.

PAGE

Kessler Martin, Baker and Confectioner................ 197 K cil Jno. Sr., Flour, Grain, etc., Wholesale and Iietail 198 Keil Jno. Jr, Groceries, Dry Goods, Notions, etc........ 198 Kaiser $\mathrm{F}^{2}$. Wines and Liquors Kennedy C. S., Wines and Liquors................................ 203 Keystone Tannery................................................. 205 Koch Arnold, Pharmaceutist........................................ 208 Keystoue Gas-Liglit Co........................................ 84 Krehan Ernest G., Interpreter of Courts, etc............. 86 Keystone Axle Works..................... 93 Kemler John W., Watches, Clocks, ctc........................ 94 Keystone Chain Works............................................. 209 King Son \& Co., Crystal Giasswarc................................... 212 Ferr W m., Carpenter and Builder.................................. 215 Krebs Otto, Lithographer....................................... 218

Kober Frederick, Tanks, Oil Barrels, etc...................... 224

Keil J. J., Druggist and Pharmacist............................... 226

Krut A., W W aron-Maker

Keystone Bridge Co....................................................... 242 Kreps \& Bowers, Hard ware and Cutlery........................ 243 Kemper Joln, Boots and Sboes.................................... 244 Kuhn Bros., Wholesale and Retail Grocers................ 247 Kimmel Joseph \& Co., Druggists and Pharnaceutists 250
Kulılman C. F., Wholesale and Retail Grocer............ 253

Langenhcim \& Shepard, Flour and Groceries.............. 9s Lyons \& Co., Citizens Oil VWorks. Loughridge Jas., Brush Manufacturer............................. 107 Lanz H., Boots and Shoes............................................... 113 Lea Robert, Engine Builder and Machinist..................... 115 Lashel \& Walter, Commission Merchunts................... 120 Laughlain \& Dean, Ship Chandlers, etc...................... 123 Lageman \& Bro., Groceries, Tea, Flour, etc................ 124 Limegrover Samuel R., Baker and Confectioner........... 125 Luehbe \& Bro., Wholesale and Retail Grocers............... 126 London Tea Huuse......................................................... 127 Lange Kenned y F., Ea.kle Pliarmacy ............................... 128 Lee \& Marshall, Wool Dealers................................. 129 Littell James, Wholesale Wines and Liquors................. 139 Levis \& Bickel, Solicitons of Patents . Logan, Gregg \& Co., W holesale Hard ware.................... 158 Legge J. H., MI. D., Physician and Surgeon................... 166 Lohmeyer $F$. A., litncy Confectioner......................... 179 Land G. W., Tin, Copper and Sheet Iron Ware.......... 172 Lawrence Bank....................... 177 Lance H. J., Wooden Pumps.................................... 180 Levy Henry, Hosier' v, Notions, etc................................. 183 Lindsay S. Jr., \& Co., Flour and Groceries................... 185 Leslie A. H., Ins. and Real Estate Agent...................... 189 Iloyd H., Son \& Co., Kensington Iron Works............ 194 Lusk John, Tin, Copper, Sheet Iron Ware, etc............ 197 Levy J., Philada. Brtmeh Clothing House.................. 203 Lanz, Matthew \& Son, Bolts, Nuts and Wasizers......... 207 Livingston \& Co., Novelty Works, Iron Founders, etc 208

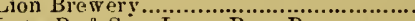
Lutz D. \& Sor, Lager Beer Brewers............................. \$2

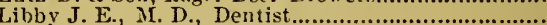
Livingston Novelty Works............................................. 211 Lutz D. \& Son, Brewers.......................................... 2220 Lrdick John A., Groceries.............................................. 228 Le Moyne Dr. F, Surgeon and Physician..................... 258 Leatheroid Manufacturing Co....................................... 261 Lubbers B. HI., Wines and Liquor.............................. 260 Ludewig G., Bottlen Beer, Foreign and Domestic Wines 258 Lindsay \& MleCutcheon, Iron Mianuficturers................ 260 Lupton W. B. \& Co., Slate Roofers................................ 241 Louder Chas..................................................................... 264

McKain Bros., Dry Goods aud Carpets...................... 263 AreKenna A \& T Trass Founders Milliken Jimes \& Co Furniture .................... is Mellor \& Hendricks, Pjanos and Orgitns........................... 98 AlcAndrew 'lliomas, livery and Sale Stables................. 99 Midgley W. H., Groceries and Confectionery.............. 102 M yers \& Co., Pork aud Beef Packers...................... 102 Moser Louis, Notary Puhlic, Ship Agent, etc............. 104 Mrckee James, Waichmaker and Jeweler, McNish A. M., Sash, Blind and Door Machiner.......... 108 Monongahela Insurance Co.................................... 109 McKnight H. D. \& Co., Eclipse Steam Pump Works.. 110 Mc.CandIcss, Jamison \& Co., Dry Goods, ctc............. 112 Miller, Forse \& Co." Wholesale Licuors................... 119 McElroy \& Co., Broms, Brushes, etc....................... 120 McNally James A., Importer and Jobber................... 125 Maclean Jos. Bookseller and Bookhinder..................... 130 Metealf, Paul \& Co., Veron: Tool Works...................... 133

Maginn Chas. \& Co., Wholesale Confectioner.............. 134 
INDEX.

MicQuiston Jas. \& Co., Pitts. Galvanizing Works......... 135 Morrow \& Co., Manfr's. Street Lamps......................... 136 MECance T. \& J. T., AIerchant Tiailors...................... 137 Mercer E B Tens and Groceries ............... 144 IIcGrath L. T., Grocer.......................................... 146 Mitchel] \& Co., Stove Minufacturers............................. 147 Milligan W. J., Groceries and Provisions................... 150 Malsch F., Meat Market........................................... 152 Manufacturers and Merchants Ins. Co..................... 15McHenry \& Huod, (i)m, and Wholesale Grain Dealers 150 McFerron James, Groceries and Provisions................. 156 Moore J. IV. \& Co., Coach and Wagon Builders.......... 158 Murdoch John R. \& A., Florists, etc......................... 159 McNary W m. H., Hats, Caps, etc............................. 160 Marsland R. S., MTerchant Tailor................................ 160 McClar:ın R. M1., A pothecar Netz \& Reil, Drugs, Paints, Oils, etc......................... 161 McClelland S. T., Fashionable Hat ter............................ 164 Metzgar D. H., Surgeon Dentist.................................. 166 Martin S. \& W.' H., Lumber, Sash, Doors, etc............... 169 MIcDonough A., Groceries aud Liquors..................... 169 Molirhoif Mrs. M. L., Millier and Dressmaker............ 171 Mcintire \& Brand, Grocers

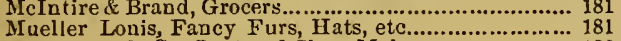
Mueller Lonis, Fancy Furs, Hats, etc...................... 181 Manley \& Hill, Dining Rooms.

Manning House.

Maxwell W.' H., Glass Labels, Glassware, etc............... 190 Mitchell Geo. B. \& Co., Iron Com. Merchants.............. 194 MIcCrickurt. W. J., Wines und Liquors, Wholesale........ 197

McKelvey J. A., Carriage anıl Harness Bazaar.

McQuigg \& Grove, Groceries and Teas.......................... 198

I eans R. W., Druggist................................................ 198

Mitiler J. F., Pattern and Model Niaker....................... 199

MI.Crackent 'Ww., Dry Goods....................................... 200

May M., Stenm Dyer and Scourer............................ 200

M cCread y J. A., MI. D......................................... 201

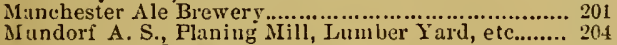
M undori A. S., Planing Mill, Lumber Yard, etc......... 204 Moore J. F., Carpenter and Builder.............................. 297 AIcConway, Torley \& Co., Eagle Malleable Iron Works \& McKeesport Iron Works........................................ 81 Mackeown, Thompson \& Co., Drug Hotise................... 87 MIcFarland J. W. \& Co., Carpets................................... 85 MI ussler Jolin, Mrett MLarket...................................... 90 Mahood Samuel, Teas and Groceries................................. 93 McCord \& Co., Hats, Caps, Furs, etc.......................... 96 Marshall, Kennedy's \& Co., Flour Mills aud tierator. Marine National Bank........................................... 216 Merchants' and Manu.acturers' National Biok......... 2 '8 McKibben James, General Teaming.......................... 22:4 MacCorl Geo. T., M.D., Physician and Surgeon.......... 226 Iever A. F., Dry Goods, Millinery, etc.....................298 Mrckee S. Penn. Glass Works.......... 229 Miller \& Houston, Groceries and Provisions................ 233 McClurg Jas. \& Co., Crarker Bakers and Contectioner's 231 McSteen M., Plumber, Brass Founder, etc................ 235 Mitcleell Win. \& Co., Hosiery, Notions, etc.................... 258 Milholland Juseph, Groceries and Prodice................ 242 Moreland Thomas B., Agent, Undertaking and Livery 244 Iranchester Coal Yird. A Metropolitan National Bauk............................................ 245 Mahle: W m., Watches, Clocks, Jewelrrand silverware 250 IIcMichael Thos., Grain, Flour and Produce.............. 256

Nieman \& Ahlers, Merchant Tailors.

Natcher Jolsn ' $T$., Carpenter and Builde1....................... 122

Northrop A. \& Co., Sbeet-Iron Roofing, etc................ 132

N. X. and Cleveland Gas Conl Co............................ 149

Nellis, Shriver \& Cn., Agricultural Steels, etc............. 155

National Planing Mill ............ 164

Nimick W. A., Transfer Co......................................... 183

Naser M. V., Clothing, Furnishing Groods, etc............. 187

Nobbs.J B., Stoves and House-Furnishing Goods....... 194

Nisbet W m. W., Druggist....................................... 246

O'Donnell J. C. Groceries and Provisions .............. 163

()' Leary A., China, Glass and Queensware.................. 111

Oehmler R. C. Paints ctc.

Orr James, M. D., Dentist............................................. 145

O'Jally John F.. Attorney-at-Law .............................. 158

Ochse Henry W., Oil Cloths, Dry Goods. 163

Offord E., Hardware Tinware, etc.

Orr James L., Real Estate Agent and Broker............. 198
Owens James, Plastering, Cement, etc. Odd Fellows' Savings Bank

Jows Savings Bank .................................. 211

Clahidusen H. F., Plumber, Gas-Fitter, etc................ 221

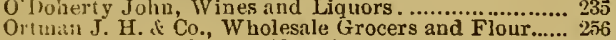
Paxson Atrood, Custom Fine Shirts........................... 254

Potzer Alph J., Fats, Cans and Furnishing Fonds... 99 Prentice \& Hackett, Cement, Lime, eit...................... 100 Pittsburgh Show Case Co........................................ 103 Paulson F. G., Fashionable Hatter............................. 10. 115

Pittsburgh and Connellsville Coke Co........................... 107

Porter \& Donaldson, Wholesale Millinery.................... 110

Pickersgill Ww. Jr, Manf'r. Boots and Shoes........... 111

Pittsburgli Tar Chemical Works............................... 121

Phelan James, Hosiery and Gents' Goods, etc.............. 123

Pennsylvania Lead Co., Sinelters, etc.......................... 124

Pittsburgh Wire Works...................................... 126

Porter W. H., Alderman aud Deputy Mlayor................ 127

Pennsylvania Insurance Co......... 15

Patterson Brothers, Livery Staule.......................... 157

Pretshold E., Tin and Hollow W are.............................. 167

Pittsburgh Car Wheel Works......................................... 174

Pieper August, Roots and Shoes............................... 188

Pinkerton Mrs. M. M., Fine Millinery.................... 198

Porter H. K. \& Co., Light Locomotives

Pittshurgh Planing Mills, Penn A v., bet. 31st and 32d 201

Pittslurgh Planing Mills, Penn Av, and 26th St........ 205

Peoples Savings Bank of Pittsburgh......................... 84

Park, Scott \& Co., Copper....................................... 85

Pitsburgl Bank for Savings................................... 90

Peeples John, Gobies and Provars

Price Wm. G. \& Co., Iron Founders, etc......................... 209

Presbyterian Book Store............................................... 210

Patrick P \& $\mathrm{C} o$, Bankers............................................ 212

Penn Planing Mill.......................................... 213

Palmer R. H. \& Co., Hats, Caps, Furs, etc............... 215

Peoples National Bank......................................... 219

Penusy] vania Female College..................................... 227

Parslow A., Barrel Factory........................................ 229

Pier, Daunals \& Co., Brewers...................................... 233

Penn. Bank..................................................... 233

Potzer D. J., Hats, Caps and Furnishing Goods......... 234

Patterson Rody, Jr., Livery Stable.............................. 279

Pjttsburgh Catholic College..................................... 247

Pitisburgh Encaustic Tile Co................................. 248

Paragon Oil and Grease Works, W. J. Smith \& Co ..... 249

Pittsh'gh Steel Casting Co., Mrôrs. Imp. Steel Castings, 251

Pittsurigh Dry Docks, Reed \& Kreps........................ 255

Runette Wilson \& Sons, Dry Croods

Rankin M. W., Wholesale Grocer and Commission....... 98

Robison Brothers, Coal Merchants................................ 106

Reineke H. \& Cn., Gas and Stean Fitters................... 10 10

Roberts E. P. \& Son, Jewelers.................................. 117

Roller Theophilus, Wholesale and Retail Furniture... 119

Poller Mrs. S. A., Millinery, Dress Making, etc......... 119

Rosenbaum \& Co., Trimmings, Millivery, etc............. 120

Reineman A. R. \& Bro., Florists................................. 123

Rees James, Machinery ........................................ 125

Rose Thomas \& Son, Boots and Shoes...................... 128

Rowbottom W nu., Pructical Plumber,

Rindrian Adam, Bonts and Shoes........................... 142

Risher J. C. d Co , Coal Office.................................. 153

Reed \& Smith, Seets and Implements......................... 159

Runette Char]es, Clothing, Hats, Caps, etc.................. 161

Robison Jaunes, M. D....................................... 162

Rex T. A. M. D., Plıysician and Surgeon................. 169

Russell \& Thomas, Scrap Iron.............

Rossiter E. A., Bostnn Clothing House...................... 17.

Robinson S. MI., Photographer........................................ 17

Renshaw John A. \& Co., Grocers.................................... 180

Risacher ir ., Dealer in Meats of all kinds.................... 186

Rodney R. T., Unclertaker and Embalmer.................. 199

Ritter George, Bilker and Confectioner

Reed J. S. \& Son, Planing Mill, Box Factory, etc...... 204

Risher D. \& Co., I. X. L. Tug Link Co............................ 82

Ruch Jaenb \& Bro., Carriage Manufacturers.................. 90

Russell James, Bonts and Shoes........................... 91

Reinecke E. W., Eagle Pharmacy........................... 93

Richards W. H. \& Co., Turners and Machinists......... 214

Rolinson James A., Coal, Lime, etc......................... 2223

Robinson Bros., Bankers........................................ 232

Reiling F. \& Son, Iron Railing and Wire Works......... 258

Ruff Herman, Practical Hat ter............................... 260

Pieel \& Co., Advertisers' Agents.............................. 260

Reerl James R. \& Co., Diamonds, Watches and Jewelry 243 
INDEX.

Snively \& Radelitle, Wall Paper. Smith L. H. \& Co., Stoves, Grates, eto........................... Spear $A T$, D Oculist and Aurist.

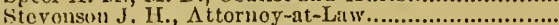

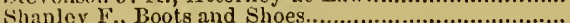
steele $\mathrm{J}$, Wats and Dhoes... Soev yn F. Mereliant Tailor. Stiferth Jolim, Wines and Liquor: Soners, Brother \& Co Produco Dealers, (a................. Sehnabel G. A Carriace ATunufactury Snith, Son \& Co. Launs and Glassware. Strughton \& Haid, House and Sign Pain ter's.... Sehomaker \& Co., Commission Merehants... St. James Hotel.

Suydam, Lawrenco \& Co., White Lead, ete.

Smith L. H., Brooms, Bruslies, et

Smith J. \& Son, Steam Dyers, ete.

Schneidor Max, Dyeing, Seonring, elc.

Seott Charles A., Book and Job Printer.

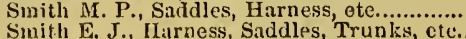

Sehanb A Leuf Tobreco

Sleitz Louis, Drugrist and Apotheeary

Sleitz A Smith Wm., Real Estate and Insurance Agency... Schneider A ug., Boots, Shoes, etc.

Schwarz Fred. C., Cabinet-Miaker

Sarver W. J., TWatches, Clocks and Jewelry.

Spengler A. C., Hard ware and F'urnishing Goods.

Spring Ed ward, Pharmaceutist.

Shoffer Samuel, Grocer.

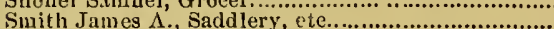

Stur Firt $\mathrm{Br}$., Sadd

Schmidt E. W., Wines, Liquors, et

Stuart Jas. H., Mantels, Monuments, cte.

Schleiler G., Dry Goods

Serentli-A renue Hotel...

Sebimdt \& Friday, Wines s nd Liquors.......................

Slado John J., Booksoller, Newsdealer, etc...................

Sippel MI., ALerehant Tailor.

Stutz S., Mining and Mechanieal Engineer.

spreen Fretl., Nierehant Titilor.

Smith Lee S., Dental Depot.

Situel, Luno \& Co. Produco Com

Seott Charlos S., Surtoon Dentist....

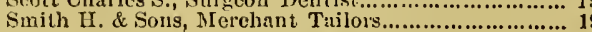

Schuidt Henry, Pharmateeutist.

Smith $W^{m}$. H., Flour Commission

Sperber.J. \& A Artists and Photographers............. 196

Sherriff it ILazely, Iron and Wood-Working Diachinery 202

Skyles \& Co., Tallow Chandlers.................... 20

Stevenson J.'\& Co., Pork-Packors, ete........................... 205

Straub \& Co., Brewers......................................... 206

Sofiel Peter Boots and Shoes

Seilnig William A., Butcher.

Stewart T. B. \& Son, Nealers in Coal.

Stewart W m. II., M. D.

South Pittsbursh Planing Milil................

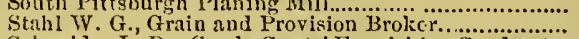

Schneider J., Dry Goods, Gents' Furnishing Goods, ete.

Speer \& Alorgul, Tin, Copper, eto

Stewart, Estep \& Co., Druggists' Glassware, etc............ Stuff, John A., Groceries and Provisions.

Sell Joseph, Huts, Caps and Furnishing Goods..........

Seemd Ave. Caach Line.

Stoner \& McClare, Saw Dilils.

Shore W W. \& Co., Groceries and P'roduic.....................

Storeh E., Marble, Granito and Stone Worls

Sadier J. F. i Co. Forwarding and Comuission.

Scluneider $\mathrm{S}$, Boota and Shoes a...

Sinkey Bros., Briek-Minkers

Stevenson J. M., M. D.

Shoc and Leather Bank. Ciark \& Co.......................... 247

Sinith W. S., Undertaker and Ëmbalmer.................... 250

Snider N. 11., Dealer in Groceries and Produee............ 251

Scmmelrock Wan., Undertaking and Livery Stables... 251

Sexauer Gust. A., House, Sign and Freseo Painter..... 252

Sisters of Merey Academy...

Smith Wm. \& Sons, Nationnl fonndry and Pipeworks 255

Sweitzer Eugene, Dyer and Scourer........................... 255

Smith Jenry J., Dry Goods and Notion..................... 256

Stur Brewery, C.Beuertein, Bro.dCo., Benneti'sitation 257

St.Ch:trles Livery and Sale Stables, J. I. Skelton, Prop'r 258 Seip P., Confectioneries and Candies, Breat and Catke 260 Star lire Briek Works, Harbison \& W ilker ............... 173

Tlıma Jolın, reather and Shoo Findings.

'ownseud \& Co., Rivets and Wire...
Tiegel B., Merchant Tailor.

The Enterprise Exchange

The Westinghouse Air Brake Co...

Totten \& Co. Fulton Foundry.

\&

Taylor Isaae, Importer 1)ry Goods, ttc........................ 138

The Singer Mff'g. Co., Sewing Machincs....................... 143

Truxel] J. II, Tin Type Rooms.......................... 143

Thomas W. Merehant Tailor.

Trimble \& Co., Contractors and Builders.

The United States Iron and Tin Plate Co

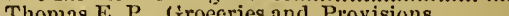

The Mrutual Gilass Compauy.......................................... 197 Thompson $A$. W., Tin, Copper and Sheet Iron Ware. 200 The Roeliester Tumbler Co., of Pittsburgh................. 83 Tradesmen's National Bank................................. 88 Third National Bank............................. The Anderson Sash Balanee............................................ 209

Thomas A.J., Contraetor and Bullder..................... 217 Turnbull Jos. \& Co., Niners and Shippers of Coal...... 221 Tod House, Youngstown, Ohio................................. 230 Thompson Andrew, Flint and Green Glass Mondds... 248 The Bank of Pittsburgh . The Pittsburgh Cabinet Co., (Limited)......................... 261 Union Planing Mill Company ................................... 131 Union Chain Works, Rei er \& Co............................. 136 Upperman \& Bro., Livery and Boarding.................... 163 Urbach Frederiek, Saddles and Harness....................... 163 Unjon National Bank ...................... 92 Ursuline Aeademy...

Voigt, Mahood \& Co., Com. and Produce.

Vowinkel \& Bivenour, Thholosale Liquors

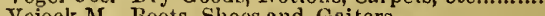
Veiock M., Boots, Shoes and Gaiters........................ 152 Voskamp B. IH. \& Co., Wholesale Grocers.................... 181 Volz Louis, Plain and Fancy Job Printing.................... is 155 Voelker \& Bru\&genan, Merelıant Xailors.................... 187 Vulean Steam Boiler and Sheet Iron Works................. 83 Voelter Julius, New York Trade Stock Yards............. 90 Wolf, Lane \& Co., 1 Iard ware and Cutlery ..................... 98 Weiler Brothers, W holesalo Liquors........................... 103 Weisen berger P'. S. \& Co., Varnish and Japan Works 103 Welster, Gray \& Co., Importing Tailors................... 105 Wanamaker John \& Co., Clothie Wells C. F. \& Co., Penn'a. White Lend Works............ 106 White, Orr \& Co., Dry Goods................................. 116 Waring E. J. \& Co., Star Oil Works............................... 117 Woodruff Sleeping and Parlor Coaeh Co....................... 122 Wattles W. W. Jew eler...................................... 126 Willison J. P., Undertaker and Embalmer.................... 129 Woodwell \& Co., IFardwarc.............. 131 Western Insuranee Company .............................. 131 Whiteley T. W., Terra Cotta Ware, etc....................... 134 Walker T. Melin, Marble and Granite Works............. 139 Weyman \& Bro., Tobaceo................................... 140 Wattley C. \& Co., Enbroideries, Lices, etc............... 146

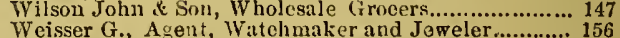

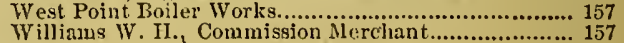

Wittmer Geo. \& Co., Iee Dealers................................. 158 Western Exchange Hotel......................................... 159 Walter's P. Jr., Druggist......................................... 165 Williams Jas. L., Undertaker and Embalmer........... 171 Walton Wı., Dry Goods, Millinery, ete...................... 181 Wilkinson Jas. W., Stationer and B, etapller............ 184 Wightman Thos. \& Co., Fruit Jars, Bottles, etc.......... 1s7 W:illice Archibald, Wholesale Grocer........................ 189 Wilson Thos., Manf'r. Taffy and Candles.................... 192 Wilson, Walker \& Co., Union Forge and Iron Mili..... 89 Wassell E. D. \& Bro., Scrap Irou, ete...................... 213

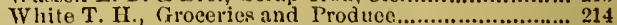

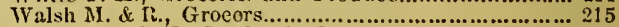
Wadsworth S. F., Dealer in Co:il.................................... 216 Winterton $\Lambda$ le and Beer Brewer.................................... 217 Wilson J. Parke, Agent Hardware, ete....................... 219 Wilhelm Heury, Lager Beer Brewer.......................... 221 Woodburn James W., Marble Works........................... 222 White .Tay M., Drugs, Chemicals, etc........................ 225 Wild S. C.., Dry Goods, Millinery, etc.......................... 229 Ward R. B, London Bakery ............................... 232 Yeager C. \& Co., Wholesnle Dry Crods, ete.............. 117 Young Jaeob, Groeeries and Produce ............................ 83 Young MIrs. F. M., Dressmaker and Milliner................ 225 Youne James, Livery and Undertaking...................... 230 Zacharias E. \& $\mathrm{G}$. H., Cigar Makers............................. 9 Zeh John, House and Sign Painter........................... 255 


\section{ADDITIONAL INDEX.}

Allegheny Valley R. R.

PAGE

Alleglueny Cencrul Hotel

A tlas Works, Machinery and Castings......................... 268

Anehor Saviues Bank ..................................... 238

Alishutz id Co., Lafayette Stovo Works...................... 238

Bilıus C. M., \{set. in Germatı)...... ...................... 266

Braun Dithiel, Groceries.................................... 26fi

Bronder Jacol, J., Groceries.

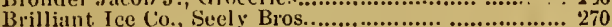

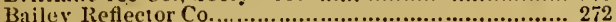

Bildridge Robt. S., MeKeesport................................. 250

Bluckley Joseph, Cual and Coke............................... 259

Bradstreet Mereantile Ageney ............................ 251

Central JIotel, Walsh d Andelsou, PJoprietors.......... 258

Clark M. E., Mckeesport.......... ㄲ.................... 250

Carter Bros., American S. and C. Window Glass....... 258

Coleman H., (i roceries......................................... 236

Coyle C. S., Míkesprort...................................... 250

Chambers J. B. \& Bro., Contractors and Builders........ 260

Devore W. II., Undertaker.............................. 270

Dietrich WV., Livery....................................... 260

Dilworth, Purter \& Co., Rail and Boat Spilies............ 263

Dexter Spring Co................................................ 256

Dutf A. K., Livery.

Davis, Prof. Slatek, Instructor.

Evans \& Co........................... Groceries.

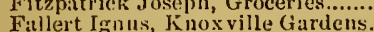

Fallert Ignus, Knoxvill

Garrison A. \&' Co.

roeddel A., Restaurant

Grundy T.. Carpet Weaver.

Gamble J. N., MLKeesport.

Garett D. IV., Ovsters, de

Grall, Bemnett d Co., Iron Mill

Ganster Joseph, Union Hotel.

Gibson \& Co., Merehant Tailors.

Hodgson H. M., McKeesport.

Harrison W. E., MEKeesport.

Horn Martin, Miclieesport..

Hunter W. W., NCKeesport

Hoflinan A., McKeesport.

Hugus i Hacke, Dry Goods...

Hemiup R. S., Drv Goods, ete

Hall IV. J., Agt., Tobacco and Cigars.

Henning Adam, Sacldles and Harness.

Hoeveler \& Co., Franklin Glue Works.

Howe Sewing Machine Co...

lillewori, Summer Resort, W. S. Jackson

Ittel Philip, FInm, Feed, erc.

Iolunston Geo. B., Dry Goods, ete.

Kirchhoff C., Translator...

Kossler WV m., Tin, Copper, ete.

Knox, Morris \& Co., Coal and Coke.

Kuehneisen A., Haits and Caps.......

Kleiu W w. C., Groceries..
Kelly G. M., M. D

PAGE

Lan

Lewis, Òliver \& Phillips, Irou Bolts......................... 230

Lowe Josial, Groceries, et c...................................... 257

McVay \& Walker, Cars, Castings, etc.......................... $21 \mathrm{i}$

Mlartin WV. A., Groceries.

Monongabela Ineline Plane

McKeever Bros., Barrel and JKeg Manufactur('rs........ 259

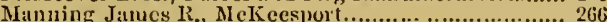

Monyer J. B., Mckilesport ................................... 86

Miller Reuben, arK Kesport.................................... 260

Martin II. F., MeKeesport ............

Meslı1 August, Sioves and Tiuware.................... 260

Mic Coy Thomas, Oysters, etc............................... 240

Arckee Joseph.

Mecully w m. \& Co., Gilass Works........................... 254

Iount-Oliver Ineline-Plane Railwny Co................... 272

National Garden, Mount Oliver........................ 250

Neel \& W ampler, McKecsport Planing M̈ills............. 200

New York Grajhie................ 255

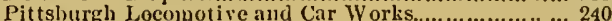

Passuzore Geo, IV NI. K cesport.

Pitsburgh and Lake Eive Railyond............................. 230

Pittsburgh, Ft. W. and Chicago Railway................... 255

Prient, Page \& Co., How e Scales..........

Phillips, Nimick \& Co., Sligo Iron Mills..................... 2: 20

Price W. H., Banner Tea House.......................... $2 \% 0$

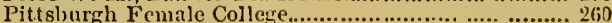

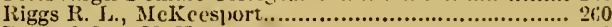

Ryan \& Son, MeKeesport........................................ 260

Rankin Manuíacturing C'u., Butehers' Supplie............ 260

Reuck Harry, Tobaceo and Cigars.........

Reichenbach John, A le and Lager Beer.................. 257

Richards J. B., Real Estate. Lit

Ransey \& Co., Druggists........................................... 260

Schoeller \& Bro, Mckeesport.................................... 250

Siratton Janes, MeKeesport..................................... 250

Skelley H. C.. McKeesport.......................................... 26

Shaw .J. D., Taxidermist.................................... 101

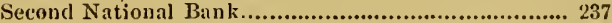

St. Clair Hotel, C. P. Bailey, Prop'r....................... 240

St. Vincent's Albey and College................................ 268

Starz Christ., Buker, ete......................................... 270

Schuetz W $\mathrm{ni} .$, Wagun-Maker................................... 270

Seely C. B., Real Estate, etc................................ 270

Tea George W., Druggist...................................... 268

The Amber Brewery, F. L. Oher \& Bro.................... 26.

United States Show-Case Works.............................. 226

Union Chain Works .................................... If 6

Velte \& Co., Engine Manufacturers............................

Vatson G McKeesport Goods, etc...

West W. H., McKesijort

Weaver \& Co., Advertising Agents.......................... 2:?!)

Wilson Albert H., Druggist...................................... 239

Wilson, Suyder \& Co., Brass Fouter....................... 2C5
Addison, $\mathrm{W}$ m

A yres, N. G G........................... 2 il

Agnew \& Co

Ahlers, C. F

Balph, R. A. \& James..

Black, James I.

Barton, A. J.

Brown, Marshilil..........................

Brown, A. M.

Burnwin, IIill...

Burgwin, Hill..... .......................

Boothe WVin...

Bigger H. J

Bovd S. \& Co.

Bidwell D. IV. C. ¿ Co.

Borland J. H. \& $\mathrm{Co}$

B:tkewell \& Kerr.

Jarton of Solis..

Bruce \& Nerrley

Bissell \& $\mathrm{Co}$

Jurgwin H. \& G. C

Bowinan \& Frazier...

Beringer WV C. \& Co..................

Brown Geo. B \& Co..................

Colter James P.

Cohen Josiuh
269

B

C

D

267

267

269

269

269

273

275
275
275

275

A

A

(

(?

H

II

I

257

207
Christ.y B. C..

Comings Ed. G

Ciok Newton S............ 27

Cimnelly J. H. ¿i. Sons, Agents...

Coyne \& Hatry

Cun!uingham $S$. W

Chaifaint Wm. L

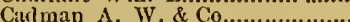

Cuthbert S. \& Son

Cilldwell J. M

Curran Wm. J.

Clevelund Paper $\mathrm{Co}$

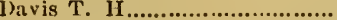

)ithridge Chm. Co. (limited)..

Tillis IVm. II

Edmondson John $\mathrm{F}$

Fulton W. E. F

eltermau Gilbert I....................

Friend Kennedy $\mathrm{D}$.

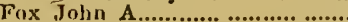

Flitek J. B.

Frew iv. N.

Fairbanks i $\dddot{C}$

Ferguson Jolin 8

Flaccus Wm. \& Son.................. II

Frazier Robt. S......................... 273
Gray \& Co., John

Gardner $0 . \mathrm{K}$

Gray Josepli $\mathrm{H}$

(ialbreth E. Edgr

Guthrie Geo. IV

Golden J. C.

Gray's Iron line.

Gardner Bros.

Guckert W Wu. \& Co

(irogan \& Merz.

Gia iv mi. E.

Godfrey \& Clark

IJolland R. Mr..

Hersh Geo.

II ay A. B.

Housenan $M$. II....................... 27

Horner C. M............................... 27

IIasbrouck C

Holman W. A

IIend \& M cElroy

Holmes WV. II.

Iraslage $W$

Iranipe $\mathrm{F}$.

Hampton \& Dalzel

Irolliman J. M. \& Co

Iron City College.
I

267

273

A

(

I:

II

67

71

271
273
273

C

D

F

C 
Jack Thomas $J$

Jones E P.

Johnston A. .

Jordiu IVm. J.

Johnson, Eagye \& Eiri...

Johnston A. C

Kay Fredric $\mathrm{G}$

Kerr S. W

Kenuedy \& Doty

Kelly Frank......

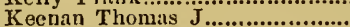

Kay James I

Kier Bros

Kirkpatrick, Beale \& Co

Kaercher J. B.

Keystone Paper Co...

Kcystene Gaslight Co. (limited).

Knox \& Reed

Kerr Jolın $\mathrm{H}$

Kinex

Koethen J. Ludewig......................

Klom:tn Chas. 11

Lambie Jolsn S

Lyon Walter.

Large John $\mathrm{R}$
Lewis W. A.....

Levis \& Bickel

Lloyd H., Son \& Co.

Luebbe \& Bro

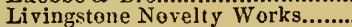

Lightenheld G.J

MrKely J. Erastus

AcCombs John C

McLean G. W.

McFarland T. Mi.

NicCorkle R. E ......................... 269

McGeary Bros.

McNally James A

MlcIntyre John

MeKenna Charles F

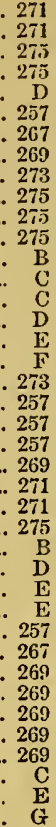

Miller A. S

Milligan S. C

Morcland W. C

Moreland John D.

I oore W. D

Magee F. II

Mills \& Co

Mundorf A. S

Marrou Jolun

Iontooth E. A. \& Bro

Morrison J. S. \& A. P.

Metcalf, Paul \&. Co.

Irulholland \& McGaffiek

Montooth \& Brother.

Meyer Heury.

New York \& Cleveland Gas Coal Co

Over James.....

O'Brien Chas...

Pennock Isaac iI

Plumer Lewis

Porte James H

Purviance W. S

Powers Chas. L

Patterson W. S........

Porter \& Donaldson

Pitterson A. C...

Parker T. S.

Petty Robt. $\mathrm{B}$

Pickersoill iv w............................ 2 2

Pittshurgh Car Wheel Works....

Pittsburgh Transfer Co.

Patterson Rody, Jr

Pittshurgh Bank for Siving........

Paxton W. N

Phillips Ormslyy

Robinson, Rea \& $\mathrm{C} \theta$.
Rex D. J.

Reardon WIII.

Rainsey J. D...

Rush House.

lichards

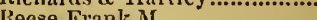

Reese Trank Af................................ 275

Righer J. C. \& Ca

Rolib \& Fitzsimmous............... 269

Robb J. M. \& W. F..................... 275

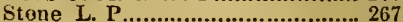

Sipe William A................................. 269

Sliaw John E................................... 269

Stewart Robert E........................ 269

Stone Willialn A .......................... 271

Speer John Ewing.......................... 273

Slagle \& Wiley ............................................. 273

Stoner James Mi.................................. 273

Schoyer S., Jr.................................. 275

Smith Frank W........................... 275

Scott Chas. A ................................ B

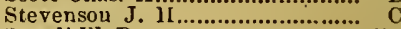

Sewell W. R............................ 271

\section{BEAVER FALLS.}

Algeo Burial Casket Works......... 59 Beaver Falls Cutlery Co.............. 60 Beaver Fulls llills, Flour, Feed, ete. 61 Co-operative Flint GlissCo.(Lim.) Co-operative Foundry Association 60 Daridson, A., Coal, Coke, etc....... 63 Emerson Saw Works.................... 62 Hall, A.S.\& R.W., Buggies, Wagons 62 Penn Bridge Works. Pittsburgh Hinge Co. (Limited)... 6 Wolf, A. F., Stoves, etc............... Western File Works (Limited)...... 6 Garlner House, Chicago................
S. MI. CHESSMAN \& BRO, dealers in Hardware, Farming Implements, [ron, Nails, Glass, \&c., also F']our, Feed and Produce, Bridge Street.

PHILIP B. MeWILLIAMS, dealer in Builderg' and other Hardware, Agricultural Implements, Fine Tablo and Pocket Cutlery, Window Glass, Putty, \&c., Cor. Penu Av. opposite Collins Av.

W $\triangle$ LTER IIERGUSON \& CO., wholesale and retail dealers in Family Groceries, 171 and 173 Chestuut Street, near Walnut. Ask for Silver Baking Powder. Best in use.

J. L. WYLAND. Established 1861. Wholesale and retail dealer in all kinds of Easterm, Lik ke and River Fish, No. 76 East Ohio Street, Carner Saudusky, Allegheny, Pa.

UNION BARREI, AND CASK FACTORY. M. Walsh, ninnufacturer of Flour, Cement and Glass Barrels, Cor. 9th and Washington Sts., Pittsburgh, South Side.

RICHARDS \& HARTLEY F. G. CO., Glass Manufacturers. Cor. Pride and Locust Sts., Pittsburgh.

\section{A. W. SMITH,}

\section{Builder of CARRIAGES, WAGONS \& SLEIGHS of all descriptions,}

Cor. Fourth \& Walnut Streets,

McKeesport, Pa.

ase Special attention pairl to Custorn work and Repairing. Lieudy uude and second liand work always for sale.

RICHARD SHARP.

SAMUEL M'CUNE.

\section{SHARP \& IM'CUNE,}

\section{Improted Modoc Black-Board Liquid Slating,}

Nc. 128 Beaver Avenue,

ALLEGHENY, PA,
CHAS. BELTZ, mannfacturer and dealer in Saddles, Harncss, Robes, Blankets. Whips, Fly Nets, \&c. Repairiug fine Harness a specialty. Peun Avenue, near Hilaud, E. E.

W. HAECKLER, Watchmaker and Jeweler, dealer in Watches, Clocks, Jewelry, Spectacles, \&c. Repairing of Watches, Clocks, Jewelry, Spectacles, \&c, done promptly. Terms strictly cash. Neir corner 26th and Carson Streets, No. 2527, S. S., Pittsluurgh, Pa.

A. B. URBEN, practical Pharmacist and Druggist, 257 Webster A venue, corner Roberts Street, Pittsburgh. Prescriptions carefully compounded night and day.

A. J. STEEIE, 58 and 60 Anderson Street, near the Hand St. Bridge, Allegheriy City. ['a., manufactures all descriptions of Wagens, Carts, Drays and Spring Wagons, Wheelbarrows, Trucks. Skids, \&c. Particular attention paid to repairing and Jou Black suithing.

ERNST LUFT, English and German Book and Joh Printer, Book Binder, \&c., No. 135 Smithtield Street, Mrasonic Bank, Pittsburgh.

ROBERT M'ELDOUNEY, House and Sign Painter,

No. 35 Seventh Ave.

Otto E. Heineman,

WATCHMAKER \& JEWELER, No. 118 OHIO STREST,

Allegheny, Pa.

P. H. ITTEL, Dealer in

FLOUR, GRAIN, SEEDS,

Mrill Feed, Potatoes, Hay, Straw, Salt \& Produce generally, No. $\mathbf{3 6 2}$ Otio Street. All'gheny City, Jre.

O'HARA GLASS CO., (Limited),-Jas. B. Lyon \& Co., 30th St. \& A. V. R. R., Maniffacturers of Flint Glass.

One of the oldest Glass Manufactories in the West. 


\section{SISTERS OF MERCY ACADEMY, Webster Av.}

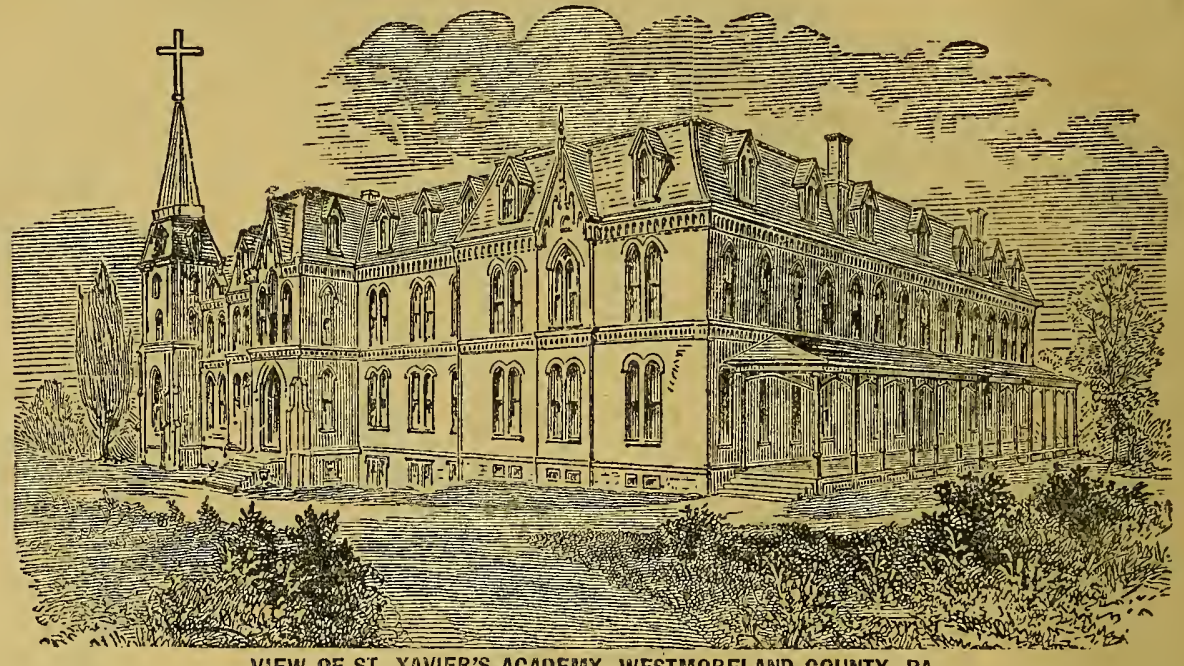

VIEW OF ST. XAVIER'S ACADEMY, WESTMORELAND COUNTY, PA.

Through the kindness of the Sisters resident at the Convent of Mercy located on Webster avenue, we are enabled to furnish to following sketeh of that order as it exists in Pittshurgh, showing the aims, object, and benevolent, eliaritable and educational works of this noble band of sclf-sacrificing wumen, whose lubors among the ponr, tiestitute and sulfiering at home as well as on the battleficlds during the recent $V$ Var, have endeared them to the heartsof Protestants as well is Catholics in every section of the Union. The Sisters of Arercy first came to Pit tsburgh in December, 1843, at the invitation and solicitation of the Rt. Rev. Dr. O'Connor, first Catholje Bishop of Pittsburgh, to establish their order in that then newly-erected diocese. This was the original foundation of the order in the United States. Seven Sisters, the Mother Superior being Sister Mary Francis Warde, cmanating from the Convent of Mercy at Carlow, Ircland, volnnteered for the American Mission and established their tirst con ront on Penn avenue in a building rented from Dr. Speer and adjoining his residence. Two years later, for the better accommodation of their increasinz numbers and their school wilich had been opened in September, 1844 , they were compelled to seek more commodions quirters and removed to "Concert Hall," on the site of the present "Library Building." The special ohjects, or "Works of Mercy," to which the Sisters devote themselves, are: The edncation of female youth in every grade of societ $y$, the noor heing especially cared for-the visitation of the sick and the protection of distressed womn of good claracter. Since coming to tbis country until the present time the Sisters lave lalored indefatigably in these works, and have now nnder their charge the following charitable and educational institutions: ST. PAUL'S RoMAN CATIOLIC ORPHAN ASYLUM, which is loeated on Tanna Hill, and supports annually an a Ferage of 250 orphans of both suses from the age of two years upwards until suitable homes can be provided or they are enabled to support i hemselves respectably. The institute is supported by the roluntary costributions of Catloolics and the benevolence of oiher denominations. Trie MERCY Hospital, whieh was the first hospital estalllished in Pittsburgh, opened January 1, 1847, at "Concert Hall," the spacious apartment styled the "ball room" being appropriated for this purpose, the selcet schinol hitherto ocenpying it being removed to one of the smaller houses aljoining. The principal phrsicians of the city hare ever since formed the medical staff of this hospital. The ilist who volunteered their valuable services were the late Drs. Ga\%ar, Addicon and Dan'l. Me.XIeal, Sen, and the present venerable und esteemed Dr. Bruce. The present staff is composed of Drs. Jos. Diclison, Shaw, Sargeants, Christy, March, IIengest and Lee. The building now ocrupied as Mercy Hospital is situated on Stephenson street and was built by the people of Pittsburgh and opened in May, 1S48. THE Convent of Mrecy, which is locnted on Vebster avenue, was erceted by the community from menns brought to it by its memlers, and is the Mother House of the community. The Mother Superior and the Sisters who form her council reside here, and here are trained the young ladies who enter the convent with the intention of hocoming members of the community. These are forbiden by rule to bind themselves by any obligation for tivo years and a half, this time being devoted to study and the practice of the duties to which they are to devote themselves. Sinould they become members of the community, a majority of whose rotes are required before they can rceeire the habit of the order and for their profession. The Sisters in this house teach the following parochial sehools: ST. PAUL's CATIEDRaL Schools, the girl's department of which is attached to the Conrent building, and was erected hy St. Paul's congregation, and the boy's department in a school building near the Cathedral-OUr LADY OF Mivery

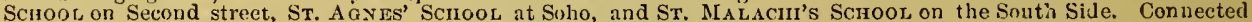
with he Couvent is also ST. AT'Y's ACAD thoroush cducation in the higher departments of study, as also in vocal and instrumental music, drawing, and the various branches of needlework. Religions instruction to Catholics is made an important matter wherever tho Sisters teach, while children of Protestant parents are nejther aslied nor cxpected to participate in the religious nbservances or instruction. At tlie Convent of Mercy, ST. PATRICK's on Seventeenth street, ST. MARY's on Fortysixth strept and ST. BRIDGET's Church on Enocls strect, the Sisters have also schools where the san:e enurse of study is pursued as at the Mother House on Webster strect. They hive also a Convent with schools connerted in Allegheny City, and at ICKeesport, Alleghen County, and at Lat robe, St. Xaviers. ST. XAViER'S ACADEMY is situated ahout three miles from Latrobe, in one of the most he:lthy sections of Western Pennsylvania, sufficiently elevated to command from every point an extensive view of the delightful country which surrouncs it. The thuildings are spacious and elegant, capable of accommodating upwards of one hundred and fifty boarders; there is amply play ground, the water and the products of the soil aro excellent and abundant. Parents may rest satisfied that every attention will he paid to the comfort of the children placed at this institution, while the utinost care will be taken to nourish in their minds those principles of virtue and religinn, which alone can make education profitable.

The number of pupils receiving instruction from the Sisters of Mercy in the Diocese of Pittshurgh is wot less than five thousand. The members of the community, at present numbering one hundred and seventy-five, are princi-ally the daughters of Irish or American parents, with some of French, (iermatn and Belgian origin, while not a few are natives of Pittsburgh and daughters of some of the oldest and most respected citizens. 


\title{
INDUSTRIES OF PENNSYLVANIA.
}

\section{CITY OF PITTSBURGH AND ALLEGHENY.}

\author{
HISTORICAL AND DESCRIPTIVE REVIEV.
}

I NSTITUTIONS, INDUSTRIES, COMMERCE AND TRADE, B USINESS AND PROGRESIVE MEN.

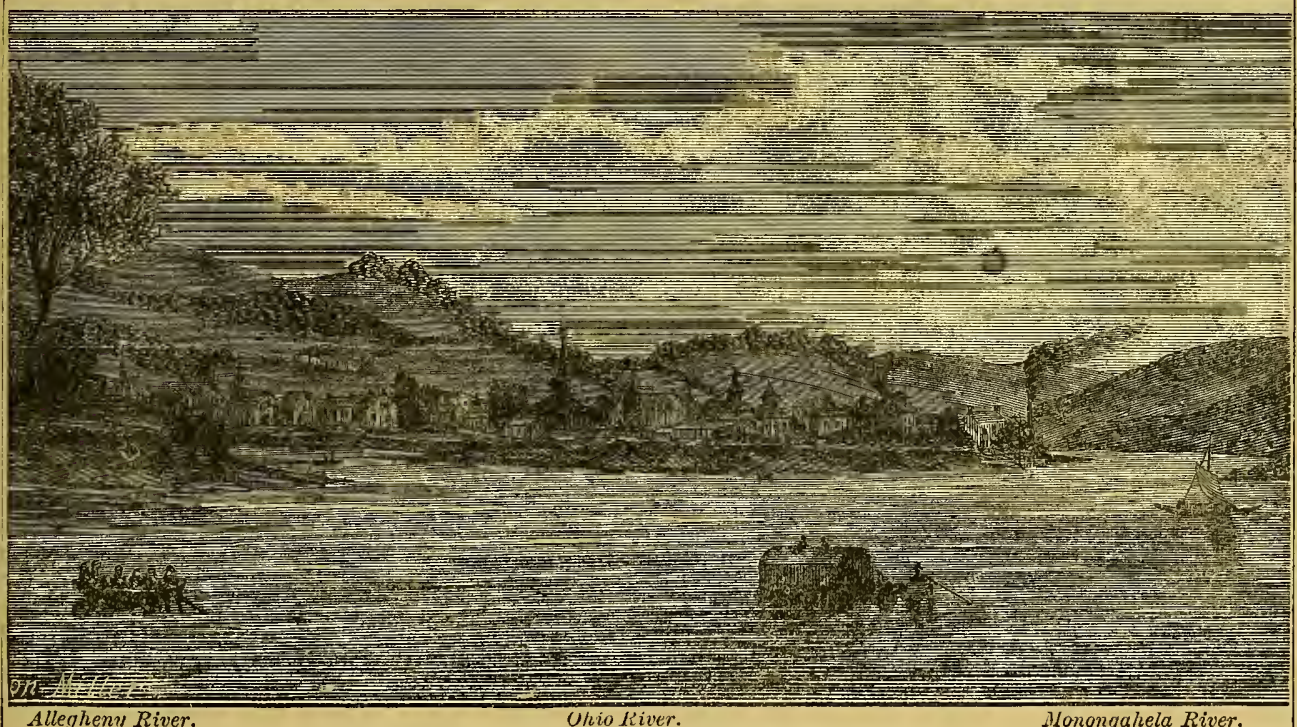
Allegheny River.

\section{VIEW OF PITTSBURGH IN 1817.}

In the compilation of this work, having for its object and main design a fair delineation of the Pittsburgh of the present, it is not intended to present any elaborate history of the past, except in so far as it may be found necessary by statistics and other means to exhibit contrasts that shall make the salient points of its existing characteristics or conditions more vivid and comprehensible. In the language of a celebrated American writer, "Pittsburgh is the most intensely interesting city on this continent," and round its cradle has been thrown, by poet and historian, the glamor of a romance through which we see the combat of two mighty trans-A tlantic antagonists and distinguish the war-cries of their savage adherents.

This spot was hallowed by the adventurous steps of the youthful Washington, and from this point, at the "meeting of the waters," cne hundred and twenty-six jears ago, his calm eye surveyed the matchless beauty of the wintry scene before him, and with an appreliension that grasped as by intuition all the advantages of the position, he "chose the station" that marked the very westward boundaries in the " march of empire," the skirmish line of civilization. Here was constructed the fortress, which falling into the hands of the enemy at the beginning of the seven-years' French and Indian War, was christened by its captors "FORT DUQEESNE," and aronnd which group tales of fortitude and foray, "treason, strategems and spoils" that still haunt the imagination and read like Oriental fictions to the rising generations. The illustrations present views of Pittsburgh as it appeared in 1817 and the old Blockhonse of 1764 . All those events, however, connected with the early history of our city have been briefly arranged in chronological order for the reference of the reader, the plan of this work not involving more of antiquity than is necessary for a copious understanding of the Pittsburgh of to-day, its commercial advantages, institutions and resources.

\section{GEOGRAPHICALLY,}

the city is located in latitude $40^{\circ} 26^{\prime} 34^{\prime \prime} \mathrm{N}$; longitude $80^{\circ} 2^{\prime} 38^{\prime \prime} \mathrm{W}$.; its topography being marked by many peculiarities, which give it an individuality of appearance possessed by no other town in America. 


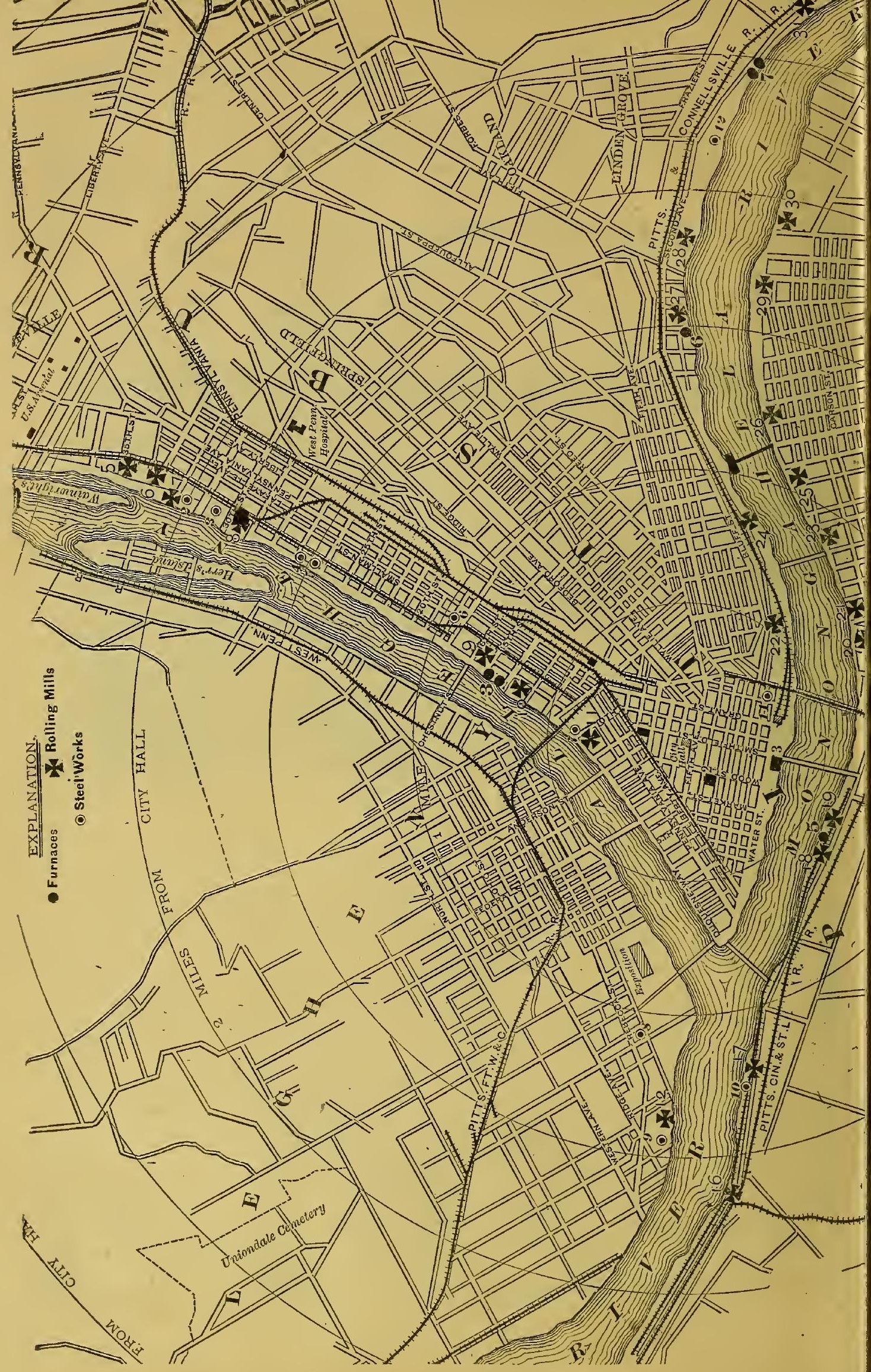


Situated at the confluence of the Allegheny and Monongahela rivers, the point from which begins the Ohio is the west extreme of the city proper, and the spot where a century ago clustered a hamlet of less than a score of primitive frontier shanties and log huts, forming the nucleus round which clustered ard grew a splendid municipality. From this vantage ground, looking towards the great receding river, the national highway to the Gulf of Yéxico, and often called by travelers the "Rhine of America," the observer can see upon his right, across the commingling waters of the crystal Allegheny, which here merges into the Ohio, the city of Allegheny lining the banks of the streams as far east and west as the eye can reach and stretching back over a rising plain for more than a mile to the hills that crown the distance. On the left appear the tremendous bluffs that confront the Monongahela, at whose base along the margins of the yellow water are strung to the southeast further than can be seen countless manufactories for iron, steel and ylass, the noise of whose machinery never ceases, the incessant crash of labor and dense volumes of smoke filling the air for miles in every direction.

The tributary rivers diverging from this point at a generally obtuse angle, cause it to widen "rapidly, a rise gradually taking place from the level of high water mark to an elevation of several hundred feet, forming

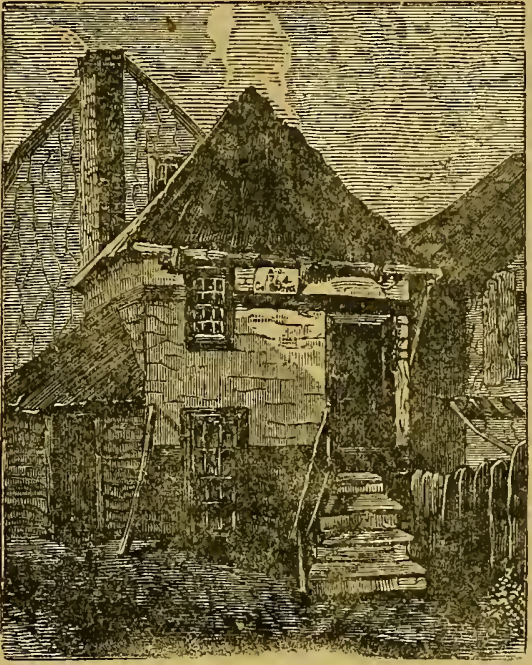

The Oid Block House,

The Oud Block House,
Built by Col. Boquet, 1764. Still standing on Point Alley, near Penn Street.

the site of the city of Pittsburgh, the line of which extends along the course of both streams between eight and nine miles - a direct line from river to river marking the eastern boundary. - All those thickly-settled manufacturing districts lying on the south side of the Monongahela river have been within the past few years consolidated with the old city. They embrace a very considerable amount of territory, and were formerly, and are yet casually referred to, as Birmingham, Brownstown, Mt. Washington, Sligo, Saw Mill Pun, etc.

The western portion of the city is densely built, and from the contracted ideas of the early settlers, each of whom desired to live within range of the fort, the streets have not that spacious breadth so characteristic of prairie towns; from this reason, as well as to avoid an atmosphere never entirely free from smoke, this part of the city is devoted almost exclusively to business purposes, nearly all whose means or occupation permit, residing either at the East End, in Allegheny, or some railway suburb.

This change has talien place mostly within the past fifteen or twenty years, and is not only advantageous in the centralization of traffic, but highly conducive to the general sanitary condition, placing Pittsburgh among the most healthy cities in the country.

\section{IN APPEARANCE,}

from any surrounding stand-point, Pittsburgh presents a most striking and impressive sight. The graceful grade at which it builds up from the point and water levels to the high central plateau is extremely attractive, while the innumerable spires and domes produce an effect of architectural beauty unusually captivating. The public and private edifices are both numerous and costly, many of them being perfect illustrations of the adaptability of iron for building purposes, and monuments worthy of the Iron City in this direction. Of the ten bridges, six of which cross the Allegheny, and four the Monongahela, inside the city limits, five are of this material; the viaduct. spanning the latter at its junction with the Ohio being regarded as one of the most superb triumphs of modern engineering; new in design, solid in structure and of enormous strength, it grasps the river at one splen-

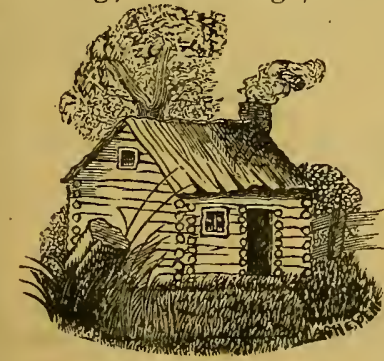

First Log Cabin erected in Allegheny, 1783. did sweep, and imparts a feeling to the mind altogether creditable to the engineer who projected it and the capital that made its erection possible.

The iron bridges ot the P'gh, Ft. W. \& C. R. R., and the P. C. \& St. L. R. R., respectively crossing the Allegheny and Monongahela rivers, are also masterpieces of engineering science and mechanical art, especially in the case of the former which was erected in lieu of a wooden structure, the demolition of the old and the construction of the new proceeding simultaneously, without interfering for one hour with the regular traffic of the road, which contiuned to run its trains as usual.

The wire suspension bridge at the foot of Sixth street, connecting Pittsburgh and Allegheny, formerly known as the St. Clair street bridge, is always the object of much attention on the part of 
strangers visiting the city, for its massive amplitude and graceful lines. It was the design of the elder Roebling, and when finished, in 1860, was considered as capping the climax of his fame in bridge architecture.

\section{PUBLIC WORKS AND BUILDINGS.}

Springing from a thrifty Scotch, Welsh and Irish ancestry, the Pittsburghers have given more care to those substantial material advantages for which they are noted, and their acquisition, than devoted theinselves greatly to the outward adornment of the city, or schemes involving its embellishment. Some excuse for this indifference may be also found in the fact that the soot and sulphur in the atmosphere soon militate seriously against the appearance of the finest structure, and more than all, the bulk of the populace, especially the more afluent classes, living in the outskirts or suburbs of the city, prefer to direct their attention to the improvement of those districts rather than to the scenes of their daily tnil.

Marked advances, however, have taken place in this matter during the decade that has elapsed, and it is now confidently asserted that, in proportion to its population, Pittsburgh has spent more money on public works, improvements, streets and buildings than any city in the United States.

The Municipal Hall is one evidence offered of the truth of the above statement, and as the seat of the city government is wortly of a more detailed description than our space permits. Architecturally the building is one of the most handsome in Pittsburuh ; constructed of solid white sandstone, at a cost of $\$ 700,000$, every convenience and modern appliance was intreduced necessary to make it complete in all respects. Here are the offices of the Mayor, Controller, Engineer and Chief of Police, on the first floor; to the second are allotted the Couneil Chambers, City Clerk and Attorney, the Boards of Viewers and Health, and Water Assessors. Upon the mezzanine floor will be found the offices of the Street Commissioner, Buildiner Inspector, and Council Messenger. The third floor is devoted to the uses of the Boards of Fire Commissioners and City Assessments, Water Extension Committee, Mechanical and Civil Engineers, Dranghting Rooms, etc.; on the fourth floor is the office of the Fire Alarm Telegraph, with which the city is supplied, as well as a thoroughly disciplined paid Fire Department, and above this the

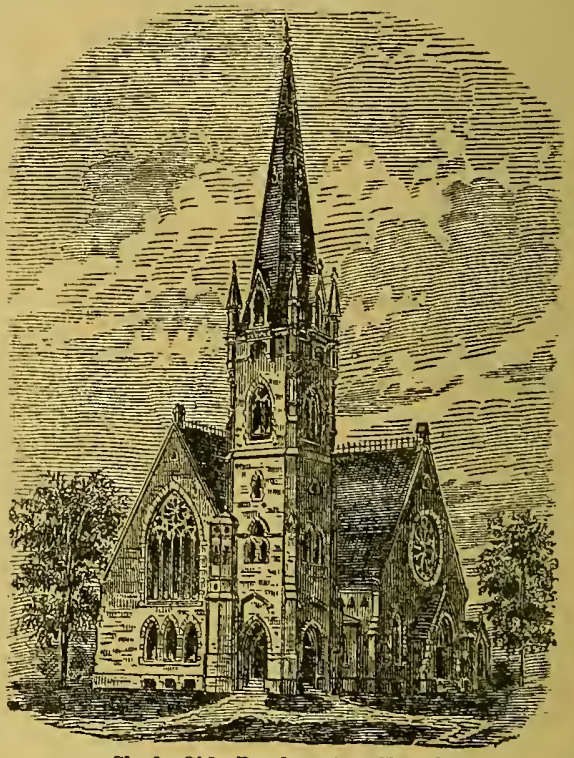

Shady-Side Presbyterian Church.

cupola, which contains the turret clock and alarm bell. This clock, by a system of telegraph wires, and arrangements made with Prof. S. P. Langley, of the Allegheny Astronomical Observatory, is connected with the stellar clock of that institution, with which it moves in exact unison, affording a reliable and uniform standard of time for the entire community, from which all railroad schedules are estimated, labor begun and ended, and all the machinery of life regulated.

In the construction of the new Water Works Pittsburgh again illustrated a decided disinclination to do anything by halves, and in 1872 a system of water improvements was inangurated on so vast a scale as to require for the purpose the purehase of over one hundred acres, seven years of coustant labor, and a total cost of over $\$+, 000,000$. The new reservoirs, of which there are two, are situated at the East End, about five miles from the business portion of the city, on the lighest obtainable elevation above the Allegheny river, from which the water is supplied. These reservoirs have an agurregate capacity of 128,000,000 rallons, the mains by which they are supplied nnd the engines, boiler's, and pumping apparatus being npon a scale simply stupendous. This colossal project, which is now in operation, with some modification of the original plans, together with one hundred miles of pipe with which the city is Jaid, will : Ifford water facilities in the future, amply sufficient to supply a population three times as great as at present, the consumption now being about $15,000,000$ gallons per day.

'This thoughtful provision for posterity is characteristic, in a great measure, of such municipal lecrislation as has obtained under the enlarged views of late years, and stamps the city government as being eminently wise, and enlighterie 1 by a policy that demands more scope than can be afforded by the narrow limits of the present diay for its operation and completion.

From pnblic works and buildings to those resultant from private enterprise, the transition is an easy one, and here the many beantifinl struetures scattered throughout the city present a wide field for comment and deseription. Amonir those of greatest interest, the churches naturally come first, and of these in both cities there are not less in all than two hnndred-many of more than ordinary magnitude and arehitectural mannificence. Perhaps the inost perfect in regrard to the latter quality is the Trinity Episcopal Church on Sixth avenue, which, besides having the finest chime 
of bells in the city, has no superior in America as an enduring monument of artistic design and rare excellence in execution.

St. Paul's Catholic Cathedral is, with one exception, said to be the largest church in the United States, and is a very imposing structure, having an interior remarkable for its pillared vastness and simplicity of style. Of other churches worthy of the visits and attention of strangers, the following are but a few of the most prominent: the First Presbyterian, on Wood street; the 'Third Presbyterian and German Lutheran, on Sixth avenue; Christ's M. E. Church, on Penn avenue, \&c.

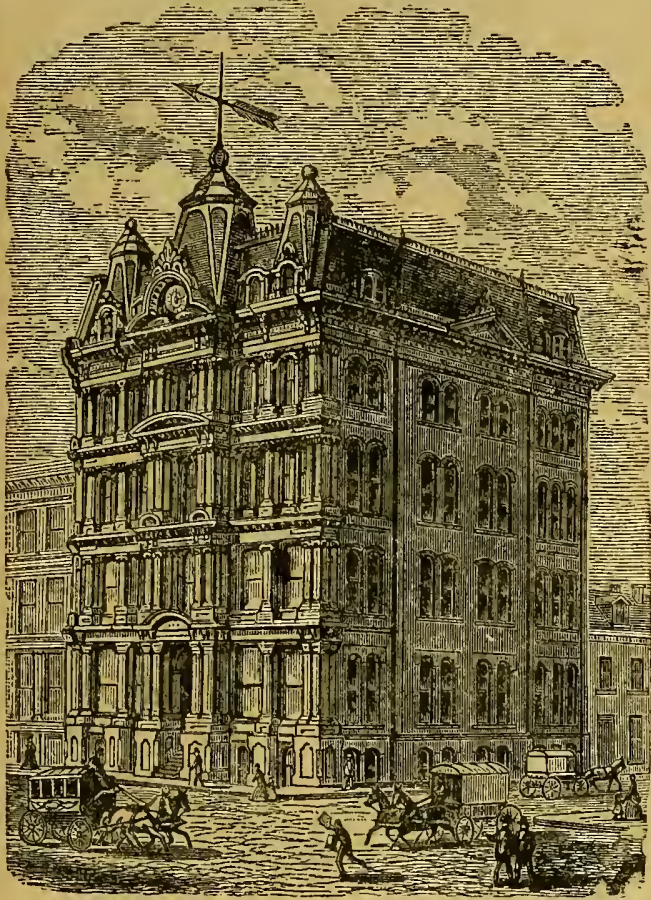

Germania Bank Builaing, cor. Wood St. and Diamond Alley.

Of its commercial buildings, I'ittsburgh can boast with equal truth-many of them illustrating the best styles of what may be called American mercantile architecture, conspicuous examples being seen in the building of the First National Bank, Dollar Savings Bank, Exchange National Bank, Second National Bank, Third National Bank, the Iron Bank Block, Fifth avenue, the Germania Savings Bank, which contains the rooms of the Chamber of Commerce, the Pittsburgh Safe Deposit Company, the Bank of Pittsburgh, the M. and M. National Bank, the Dispatch Building, Hostetter's Block, Library Hall, the First National Bank of Allegheny, the building of W.m. Semple, and others, so numerous as to require omission.

In its business portion the lron City always wears an air of thrift and industry, which is in marked contrast to many equally larre but less favored places, and, in its suburbs, the truth is evident to the most partial observer, that no city can show such lovely environs, with so great a diversity of ever captivating landscapes, dotted so profusely with the homes and villas of her thousands of opulent and comfortable citizens.

No description, however elaborate, conld be so couched as to give a stranger an adequate view in his mind's eye of Pittsburgh, because of its vast dissimilarity to every other city upon the continent, this very uniqueness defeating all comparison. From so far as we have cared to go in this direction, the non-resident reader (and this work is designed mainly for such) may have gleaned some approximate iclea of the general plan and appearance of the city, the accompanying illustrations rendering efficient aid in this direction, and leaving him with these, other matters of more interest and import arise and demard attention.

\section{A COMMERCIAL CENTER.}

The first question that naturally and promptly arises in regard to any community claimm to be a trade center, is, "How is it related, and what are its connections with the rest of the world $\rho "$ To this query an answer with reference to Pittsburgh leads to a discussion of those facilities by which she is placed in communication with the consumers of her products, who are found in every habitable quarter of the globe.

The river highways that nature furnished are in the first instance the conspicuous channels by which communication is most easily secured and maintained with remote centers of traffic, and by this means, and with the advantages thus afforded. Pittsburgh commands an unequalled position, gaining uninterrupted entrance into the interior of not less than eighteen of the most fertile and wealthy States in the Union, as well as reaching unchecked, the Central and South American States, which already form an important objective point for her exports, and inviting markets, that become annually more available. This field alone, for commercial operations, opens up to the practical and progressive observer, a future of splendid prosperity for Pittsburgh, toward which she is rapidly bending her steps, and for the attainment of which her energies are being exerted to the fullest extent.

The first move in this direction has been taken by the general government, by the inauguration of the jetty system at the mouth of the Mississippi, and an appropriation for the improvement of the Ohio river.

The former enterprise, under the charge of Capt. J. B. Eads, has already proved successful to an unlooked-for deuree, while the works-upon the latter project are yet unfinished aud untested.

The plan for the improvement of the Ohio river is almost too well known to require extended notice here. It may be stated, however, that the scheme involves the construction of dams at such 
intervals along a great part of its course as shall preserve a uniform stage of water, and thus admit of navigation during the entire year. Heretofore this has been impossible on account of low water, which for many months put a period to all traffic by this means.

The work upon the first dam of the series was commenced in 1878 , at Davis Island, a point about five miles below the city, and is now being pushed rapidly forward, several hundred men being employed upon the works. For this structure the French plan has been adopted by the best engineers in the employment of the government as being the most available and altogether practicable. This is the same system used to slackwater the Seine, and affords certain advantages that are possessed by no other dam in so perfect a degree. The main features of the structure being that the entire dam can be sectionally and rapidly depressed till it lies flat upon the bed of the stream when the natural stage of water is sufficient without artificial aids, and its equally prompt elevation when desired. This whole operation, as well as the management of the locks, will, it is said, require the labor of but two men, so admirable are the mechanical appliances by which the entire structure is controlled and regulated.

It is inpossible to overestimate the advantages that will accrue to Pittsburgh by the completion of this system of improvements, and safe to assert that

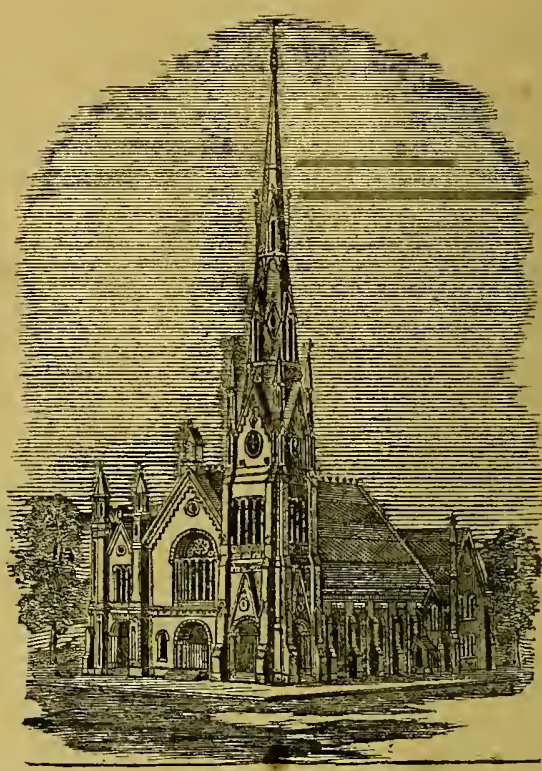

Third Presbyterian C'hureh. under its inflnence a new era of prosperity will dawn upon her that has no parallel in the past. The opening of a cheap and reliable means of shipment to those countries that, with an ordinary course of development, are bound to become our most profitable customers, will have an effect upon the commerce, trade and manufactures of Pittsburgh not yet fully realized by the strongest advocates of the improvement of the Ohio river.

Some facts collated from the report of the "Chief of the Bureau of Statistics," on commerce, navigation and foreign commerce, for the year 1878 , may perhaps convey some idea of the increasing magnitnde of the exports of the United States to those countries whose chief wants lie in the direction of Pittsburgh's products, and to many of whom we shall shortly have direct access by water.

The table shows the comparative difference between the amounts of the present exports and those of twenty years since, and must convey a significant lesson to every intelligent reader:

EXPORTS FROM THE UNITED STATES.

Argentine Republic

Brazil

Central American States.

Danish West Indies (estimated)

French West Indies and French Guiana

West Indies, Honduras and Guiana (British)

Hayti and San Domingo.

Mexico..

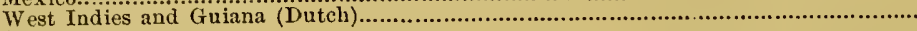

Cuba

Porto Rico..............

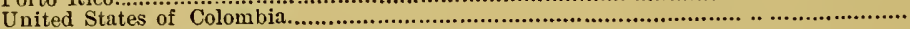

Uruguay.......

Venezuela

These figures afford a very just conception of the rapid increase of a trade to which Pittsburgh must look in the future for the bulk of her revenue, and to which she is invited through the increased facilities resulting from the improvements to which reference has been made.

The INonongahela river, which has been navigated for more than a third of a century by means only of a system of locks and dams, is an evidence in a comparatively small way of the usefulness of such a procedure, and its ultimate benefits in making tributary to Pittsburgh one of the most productive valleys both in coal and agricultural resources to be found in the Union.

\section{RAILROADS.}

Some account of the artificial channels to the outer world properly follows a description of the natural and most ancient avenues; and in these creations of toil, capital and genius, Pittsburgh is certainly not behind any of her sister municipalities, being the point of junction for no less than ten railroads, most of them trunk lines. 
Of these roads, the Pennsylvania Central, as being the oldest and perhaps the most important, should be entitled to the first position, as not only affording the directest route to the seaboard cities; but, pursuing a conrse through the most materially prolific portions of the State, which it traverses latitudinally for three hundred and fifty miles, this great artery of traffic places Pittsburgh within ten or twelve hours of the Atlantic ports, and connects with the entire system of eastern railroads.

The Baltimore \& Ohio Railroad presents another favorite outlet to the East by a route veering to the south-east and making its objective point, Baltimore, through the Monongahela and Cumberland valleys, and mineral lands that will be referred to hereafter in connection with natural products.

Both the above roads are active competitors for the trade of Pittsburgh, and are justly regarded as two of the best managed organizations in the United States, combining in themselves an amount of talent and capital which inures greatly to the benefit of the commerce of this city.

By the Allegheny Valley Railroad north-eastwardly, the central trunk lines of New York are reached and connections made for the lake routes west, or all points east.

The most important ontlet to the West is afforded by the Pittsburgh, Et. Wayne \& Chicago Railroad, which, in operation twenty-five years or more, has done no little to promote the conmercial relations of Pittsburgh with the West and North-IVest. This road, at various points, taps the network of railways which ramify over the whole West, and proves the shortest for trans-continental travel.

The Pittsburgh, Cincinnati \& St. Louis Railroad presents another channel to the West by a southerly course, reaching the points named in its title by the most direct and available routes, connecting and interlacing roads that place the States of Ohio, West Virginia, Indiana und Illinois within easy reach of the Iron City.

The Cleveland \& Pittsburgh Railroad opens a northern track for travel and trade, which, with the Pittsburgh \& Erie Railroad, and the Pittsburgh \& Lake Erie Road (the latter being the last brilliant evidence of Pittsburgh's enterprise), affords such ample communication with the lakes and the trunk lines to the North-West as leaves nothing in this direction for the most ambitious citizen to desire.

Besides the roads already mentioned, the following, of a present local character, are not by any means to be ignored: the Pittsburgh, Virginia \& Charleston Railroad, whose projected point of completion is indicated in its title, is in operation only for about twenty-five miles along the southern bank of the Monongahela river; the West Pennsylvania Railroad, which traverses the north side of the Allegheny river for an equal or greater distance, an outlet from the great oil fields of Pennsylvania: and the Pittsburgh \& Castle Shannon Railroad, a narrow gauge railway connecting at present with the Pittsburgh \& Southern R. R., local environs, and coal nines of great magnitude.

These eleven great arteries, through which the vivifying tide of traffic is forever streaming, certainly confer a position upon Pittsburgh, so far as these facilities extend, that can not be otherwise than of the highest advantage to her commercial and productive thrift. We present herewith some statistical facts and figures in connection with these roads that will prove of interest to the reader as showing not only the advantages they confer upon Pittsburgh, but the wealth and resources of the regions through which they pass within an established trade radius.

From the report of Mr. William Wilcox, Inspector of the First Bituminous Coal District of Pennsylvania, for 1878 , to the State Secretary of Internal Affairs, the following data have been collated: This district embraces the counties of Allegheny, Washington, Greene, Fayette. Westmoreland, Somerset and Bedford, and lies to the south, south-east and south-west of Pittshurgh; the two last named counties being the most remote easterly and possessing in all but 12 mines worthy of record. The whole district is one of the most productive in the world, and contains inexhaustible supplies of this min-

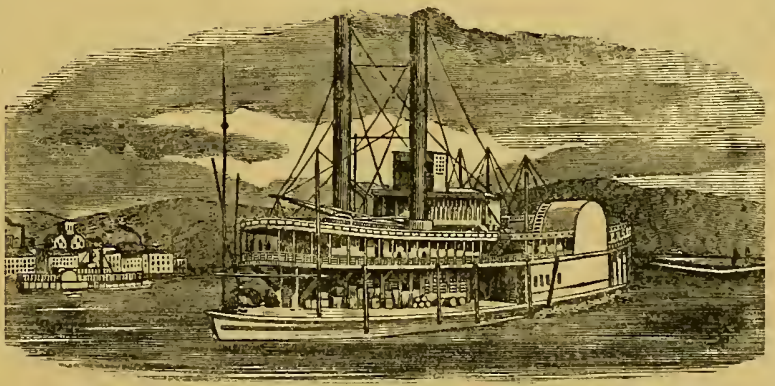

Picture of the once famous Pittsburgh and Cincinnati Packet "Allegheny." Time from Louisville to Cincinnati, $9 \mathrm{hrs.,} 50 \mathrm{min.}$, Receiving the Horns from the celebrated Stcamer Telegruph No. 2. eral, the quality of which for manufacturing, illuminating or heating purposes is unsurpased.

Along the lines of these various railroads are placed the mines which supply the bulk of all the bituminous coal consumed in the United States, their distribution is shown by the following table, the trunk lines including the various branches in brackets:-

$\{$ Pittsburgh, Cinn. \& St. L. R. R. $\}$

$\{$ Chartier's Valley R. W. 22 Collieries. *

Pittsburgh \& Castle Shannon do. 


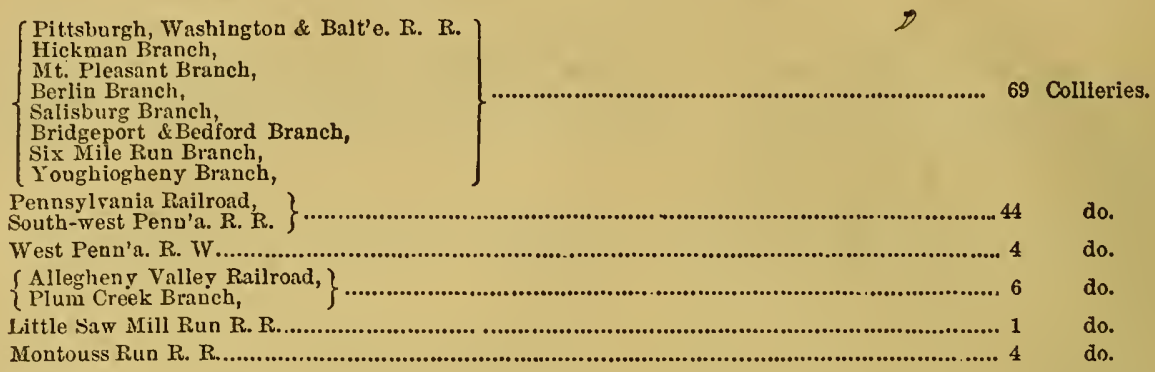

Besides the mines above enumerated, all of which are immediately within the tributary range of Pittsburgh, it may be well, while confined to the first, bituminous district, to state that there are upon the AIonongahela river 86 mines, and upon the Youghiogheny river 3 mines, independent of railway facilities, making a total of 244 bituminous coal mines, the aggregate product of which for the year 1878 was, as closely estimated by the Inspector from satisfactory data, nut coal and slack not included, $9,372,881$ tons of 2000 pounds each. To attain this result is required the labor of over 18,000 operatives directly, besides a number impossible to estimate in the immediate contingent occupations of shipping and maintaining the necessary roads, machinery, barges, steamers and general appliances. The dependent manufacture of colie alone engages the attention of forty-one firms, who operate in all 3,902 ovens and manufacture annually $75,577,200$ bushels of coke, employing directly about 1,000 laborers and others. The prodigious increase that has tilken place in this branch of industry may be more readily observed by a comparison, which indicates simnificantly the vitality in herent in the resonrces of this city. In 1842 Messrs. S. \& J. Cochran, who are still engaged in the business, began the first manufacture of colie in this district by the construction of two ovens on the Youghiogheny, the product of which as a very hazardous venture, they shipped on a flat boat to Cincinnati, where it arrived in safety, and found a more ready market than the projectors of the enterprise lad at first dared to expect. This carco consisted of six thousand bushels, and at that time was considered a very considerable one. In 1878 the shipments of coke to western and south-western parts from the Nonongahela and Youghiogheny valleys amomuted to $65,697,000$ bushels with every appearance of a substantial and continued increase in the tratiic, and a more universal demand. These are some of the facts presented by the State Inspector of mines for the First Bituminous Coal District of Pennsylvania.

The report of the Inspector for the Second District, Mr. J. J. Daris, is almost equally interesting as this section lring to the north and embracing those counties situated in between Lake Erie and the New York line, and Allegheny and Westmoreland counties on the sonth, is also a territory over which extends the influence of Pittsburgh, its capital, labor and commerce. In this district of the bituminous coal divisions of the State are 58 mines, nearly half of which are located in Clarion and Mercer counties, which are directly accessible by the Allegheny Valley and the Frie \& Pittsburgh railroads and their branches. Iin the operations for which these mines form a basis are employed over 2,000 workers in the various departments, the production in 1878 being about 675,000 tons of coal, exclusive of slack and nut. The manufacture of coke in this district is a very large additional item to swell the importance of the natural resources in this department, and it is to be regretted, though the law under which be acts does not require it, that Mr. Daris failed in his report to the Secretary of the Interior to give accurate statistics in reference to this important department of the coal trade.

In a valuable article read by Wm. P. Shinn, Esq., chairman of the Edgar Thomson Steel Works, (Limited,) before the American Institute of Mining Engineers, convened in this city, May 13,1879 , it is stated, in commenting upon the coal interest, of which Pittsburgh is the centre, that the surroundiug area in Pennsylvania alone of bituminons coal is not less than 15,000 square miles, exclusive of the tracts easy of access in Ohio and West Virginia. From the same authority it appears that the total production of coal in the United States during the year 1878 was $49,130,584$ tons, of which Pennsylvania supplied 17,605,262 tons of anthracite and 13,500,000 tons of bituminous, or over 63 per cent. of all the coal mined in the United States. The soft coal prodnced in the Pittsburgh districts representing not less than 50 per cent. of all the bituminous produced in the country, the true importance of which is not thoroughly understood without consideration.

From the same paper some figures are taken with reference to the increase in the manufacture of coke that deserve attention, as being highly indicative of the vital forces constantly operating to enlarge the borders of Pittsburgh's prosperity. From the most reliable data, and in accordance with the estimates of expert and experienced producers, it appears that the following table, stated in tous of $2,000 \mathrm{lbs}$. is as nearly correct as possible:
1875, Coke produced
1876 ,
1877 ,
"16
".
..........
666,495 tons.
1878 , 
A n increase of nearly 100 per cent. in the short period of four years, and with no evidences of abatement in growth during the current twelve months. Such evidences of splendid progress, while calculated to fill the mind of a stranger with astonishment, has no such effect upon the average Pittsburgher, who sur-

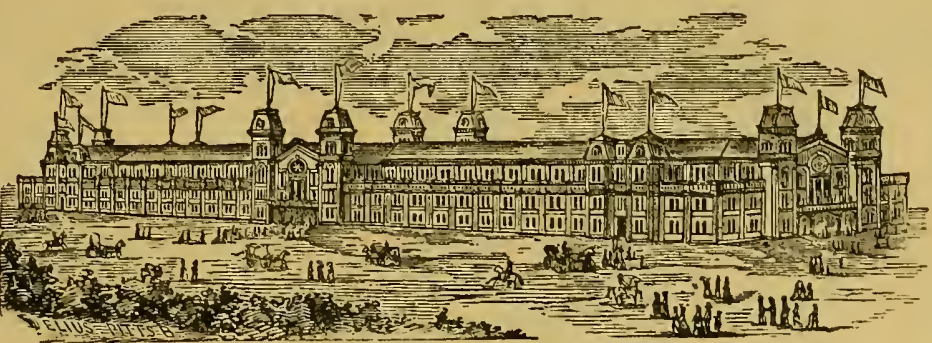

Exposition Buildings, Allegheny City.

veys such results with a calmness devoid of enthusiasm, as being quite in the natural order of his experience in the past, and equally to be expected as the outcome of the future.

The matchless advantages possessed by Pittsburgh for the manufacture of coke, is an ample assnrance that, no matter what unfortunate contingencies may arise in time to come, this must always be the main source of supplies for the entire country in this commodity, which also guarantees a perpetuity to this location as the centre for the production of pig iron, a reflection which suggests some consideration of the great staple and ponderous industry wherein lies the pith and puissance of Pittsburgh as the manufacturing stronghold of America.

\section{THE IRON TRADE.}

Around the early history of every modern industry that has had and still exerts a pregnant influence upon the condition of the race is centered an interest, an absorbing attraction, that manifests itself in the significance attached to the labors of the historian and archrologist, who with un. daunted resolution delve after the details of germinal facts.

The circumstances surrounding the erection of the first blast furnace in Pittsburch, the nationality, characteristics and mental complection of its projector. his hopes, fears, first trials. strugrgles and conquests, would furnish matter for a story of no less real importance than that of many a half forgotten empire, and would assuredly captivate by episodes of more living human sympathy. But little of such material however has been preserved, and as the last competent writer on the subject we borrow from the paper of $\mathrm{Mr}$. Shinn the following succiuct sketch, which begins in this connection upon the topic of Pig Iron: "The first blast furnace erected in the immediate vicinity" of Pittsburgh was located on Two-Mile Run, near the present Shadyside station, on the Penusylvania railroad. Is was built by George Anshutz, about 1792, and was operated only abont two years, as its location appears to have been a mistake, based upon the supposition that iron ore was to be found in that vicinity. It was not until 1859 that the second blast furnace-and the first of the existing furnaces in. Pittsburgh - was built by Graff, Bennett \& $\mathrm{Co}$., on the south side of the Mlonongahela river, and known as "Clinton" Furnace. The pig iron industry of Pittshursh is therefore less than twenty years old at this date. There are now twelve blast furnaces in Pittsburm and its immediate vicinity, and three more in progress; the annual capacity of which, when the three named are completed, will be about 486,000 net tons of 2,000 pounds.

The furmaces are in detail as follows:

\begin{tabular}{|c|c|c|c|c|c|}
\hline Built. & Name. & Owned by & Height. & Bosh. & $\begin{array}{c}\text { Annual } \\
\text { Capacity } \\
\text { T'ons. }\end{array}$ \\
\hline 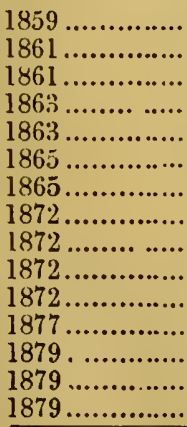 & $\begin{array}{l}\text { Clinton. } \\
\text { Eliza No. } 1 . \\
\text { Eliza No. } 2 . \\
\text { Superior No. } 1 . \\
\text { Superior No. } 2 . \\
\text { Shoenberger No } 1 . \\
\text { Shoenberger No } 2 . \\
\text { Isabella No. } 1 . \\
\text { Isabella No. } 2 . \\
\text { Soho. } \\
\text { Lucy No. 1. } \\
\text { Lucy No. } 2 . \\
\text { Furnace A. } \\
\text { Furnace B. } \\
\text { Furnace C. }\end{array}$ & $\begin{array}{l}\text { Graff, Bennett \& Co. } \\
\text { Laughlins \& Co. } \\
\text { Superior Iron Co. } \\
\text { Shoenberger, Blair \& Co. } \\
\text { Isabella Furnace Co. } \\
\text { "“ } \\
\text { Moorehead, McLeane \& Co } \\
\text { Lucy Furnace Co. } \\
\text { Ed. Thomson Steel Co. (L) } \\
\text { "“ " " }\end{array}$ & $\begin{array}{l}45 \text { feet. } \\
60 \text { “" } \\
60 \\
45 \\
45 \\
62 \\
62 \\
75 \\
75 \\
75 \\
65 \\
75\end{array}$ & 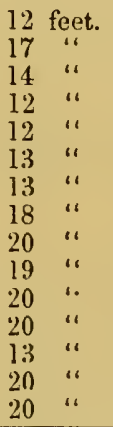 & $\begin{array}{l}80,000 \\
31,000 \\
85,000 \\
25,000 \\
45.000 \\
45,000\end{array}$ \\
\hline
\end{tabular}

The following table, compiled from the statistics of the American Iron Trade as furnished by James M. Swank, secretary of the American Iron and Steel Association, shows the proportion which 
the product of Pennsylvania pig iron bore to that of the United States, and the proportion which the pig iron produced in Allegheny county bore to that of Pennsylvania, and the whole United States respectively, during the years 1874 to 1878 inclusive, all stated in tons of $2,000 \mathrm{lbs}$ : :

\begin{tabular}{|c|c|c|c|c|c|c|}
\hline \multirow[b]{2}{*}{$Y_{E A R}}$. & \multirow[b]{2}{*}{$\begin{array}{c}\text { Pig iron } \\
\text { made in } \\
\text { Uniter }^{r^{2}} \text { tates. }\end{array}$} & \multirow[b]{2}{*}{$\begin{array}{c}\text { Pig iron } \\
\text { made in } \\
\text { Pennsylvania. }\end{array}$} & \multirow{2}{*}{$\begin{array}{l}\text { Per cent. } \\
\text { of total } \\
\text { product. }\end{array}$} & \multicolumn{3}{|c|}{$\begin{array}{l}\text { Pig iron made in Alle- } \\
\text { gheny county. }\end{array}$} \\
\hline & & & & & 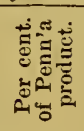 & 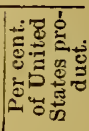 \\
\hline $\mid \begin{array}{l}1874 \ldots \ldots \ldots \ldots \\
1875 \ldots \ldots \ldots \ldots \\
1876 \ldots \ldots \ldots \\
1877 \ldots \ldots \ldots \ldots \\
1878 \ldots \ldots \ldots \ldots\end{array}$ & $\begin{array}{l}2,689,413 \\
2,266,581 \\
.2,093,236 \\
2,314,585 \\
2,577,361\end{array}$ & $\begin{array}{r}1,213,133 \\
960,884 \\
1,009,613 \\
1.153,356 \\
1,342,633\end{array}$ & $\begin{array}{l}45.11 \\
42.40 \\
48.23 \\
49.83 \\
52.09\end{array}$ & $\begin{array}{l}143,660 \\
131,856 \\
128,555 \\
141,749 \\
217,299\end{array}$ & $\begin{array}{l}11.84 \\
13.72 \\
12.73 \\
12.29 \\
16.18\end{array}$ & $\begin{array}{l}5.35 \\
5.82 \\
6.14 \\
5.12 \\
8.40\end{array}$ \\
\hline
\end{tabular}

From this statement it will be seen that the pig iron product of Allegheny county has steadily increased from $534-100$ per cent. of the product of the United States in 1874 to 840 -100 per cent. or almost exactly one-twelfth-in 1878.

The amount of pig iron brought into Pittsburgh by rail and river during 1878 , was 250,476 gross tons, equal to 280,533 net tons; adding to this the pig iron made in Allegheny county during the year, 217,290 net tons, makes a total of pig iron made and brought into Allegheny county during the year 1878 of 497,832 net tons; or $1932-100$ per cent.-nearly one-fifth - of the total product of pig iron for the United States. To this add muck bars, 2,033 net tons; blooms and billets, 35,791 net tons; scrap iron, 64,536 net tons, and we have a grand total of 600,192 net tons of pig iron, muck bar, blooms, billets and scrap, most or all of which was consumed in Allegheny county during the year 1878, an amount nearly equal to one-fourth of the whole pig iron production of the United States for that year.

\section{ROLLED IRON.}

The first rolling mill in Allegheny county, owned by Christopler Cowan, was built in 1812, and known as the Pittsburgh Rolling Mill. And the second the Union Rolling Mill-not the present mill of that name-was built in 1819, and was accidentally blown up and permanently dismantled in 1829, the machinery being taken to Covington, Kentucky. This mill had four puddling furnaces, the first in Pittsburgh; it was also the first mill in Pittsburgh to roll bar iron, and was the largest and most extensive mill of the kind in the western country.

The Grant Hill Iron Works were erected in 1821, by William B. Hays and Darid Adams, near where the Court Honse now stands.

The Juniata Iron Works were erected in 1824, and were owned by Dr. Peter Shoenberger. The Sligo Mill was erected in 1825 where it now stands, by Robert T. Stewart and John Lyon.

Pig metal for the supply of these mills was mostly brought from the Juniata Valler, which also supplied them with blooms. The Juniata pig iron and blooms were hauled over the Allegheny Mountains to Johnstown, nsually on sleds in the winter season, and taken down the Conemaugh, Kiskiminetas and Allegheny to Pittsburgh on the spring and fall freshets. In 1821 Pittsburgh had 8 rolling mills, using 6,000 tons blooms, chiefly from the Juniata Valley, and 1,500 tons of pig metal.

In 1856 there were in Allegheny county 25 rolling mills and 33 foundries. The six rolling mills in existence in 1826 employed 281 hands, and made 5230 tons of iron, ralued at $\$ 559.000$ and consumed 561,700 bushels of coal. In 1879 the situation in this regard is as follows:

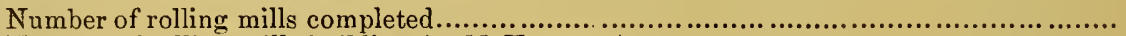

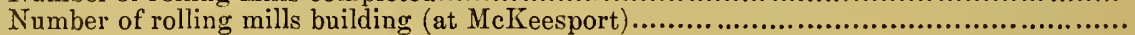

Number of common puddling furnaces.

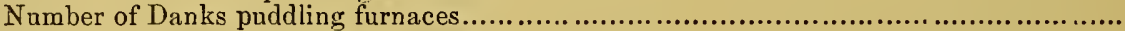

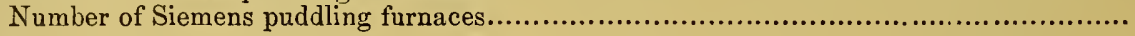

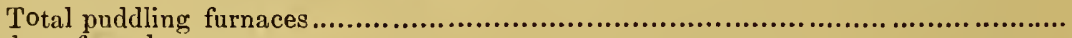

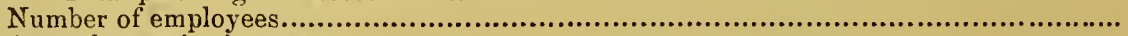

Annual capacity in tons................................................................ 500,000

The number of single puddling furnaces in rolling mills in the United States-connting a double furnace as equivalent to two single-was in 1878,4463 , so that the number in Allegheny county was 17 7-10 per cent. of the number of puddling furnaces in the United States, while the number of rolling mills in the United States being 340, Allegheny county contained 10 per cent. of their number.

The following table shows the amount of rolled iron, including sheets and nail plates, produced in Allegheny county and in the United States during the years 1874 to 1878 , stated in tons of 2,000 lb. : 
TOTAL ROLLED IRON, INCLUDING NAILS.

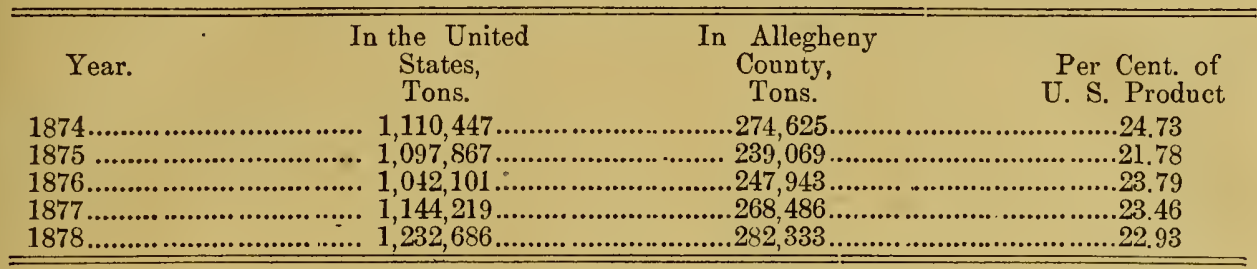

It will be seen that the proportion of rolled iron-exclusive of rails-made in Allegheny county has varied from 24.73-100 per cent. in 1874 to $22.93-100$ per cent. in 1878 of the whole product of rolled iron-exclusive of iron rails-made in the United States. The falling off in percentage of the rolled product, indicated since 1874, is mainly, if not wholly, owing to the fact that the wages paid puddlers and other rolling-mill expert labor in Pittsburgh are from 30 to 50 per cent. higher than is paid for similar labor in rolling mills east of Pittsburgh. Six of the rolling mills have connected with them nail mills, having an aggregate of 472 nail machines, which produced, in 1874 , $562,995 \mathrm{kegs}$ of nails of $100 \mathrm{lbs}$. each, and, in 1878, 441,013 kegs, the former being $11.45-100$ per cent., and the latter being $10.10-100$ per cent. of the product of the United States; the reason for the reduced proportion being attributable to the same causes as that given for rolled iron.

Allegheny county has many specialties in iron among its nanufactures, prominent among which are, Messrs. Jones \& Laughlins' cold-rolled iron, for shafting, piston rods, etc.; Messrs. W. D. Wood $\&$ Co.'s planished sheet iron, the only successful rival of the Russia sheet iron; the Tin and Terne Plate Works of the United States Iron and Tin Plate Co., and Messrs. Kirkpatrick, Beale \& Co., the only manufacturers of that material in the United States; and Andrew Kloman's Universal Mill, for the manufacture of weldless eye-bars and other bridge material, by a new and highly successful process, applicable to iron, but which is particnlarly successful with steel.

The specialties above enumerated are only such as are found nowhere else in this country, there being mally other specialties manufactured here which are not, however, exclusively products of this county.

In glancing at the iron trade of Pittsburgh, that branch of it which relates to founding and casting is second in importance, labor and capital, to the rolling-mill interests, and equally prominent so far as the chief celebrity of this city is concerned. The first iron foundry was established in Pittsburgh in 1803. This industry having effected a lodgement here grew with all the vitality of an indigenous plant. So considerable has been the advancement made in this direction that it has become an accepted fact that in large work or small, from a thumb latch to a columbiad carrying a ball weighing 1000 pounds, the facilities which Pittsburgh enjoys for casting iron or steel are not duplicated on this continent. From the first foundry erected in this city in 1803 and the direct line of its business successors, has been turned out ordnance that has bellowed in three wars of the Republic. Over 2,000 guns and mortars were cast during the war of the Rebellion, and from Perry's victory on Lake Erie to the battle of the Wilderness the resolute "dogs of war" cradled in Pittsburgh; have been ever ready to persuade for peace with most eloquent enunciation.

A detailed history of the first Pittsburgh foundry would make interesting and instruetive reading, but each enterprise of this description is filled with matter to attract, and the general plan must in this department of the work be adhered to. In Pittsburgh at the present time are, including roll and heavy machine, general stove and malleable iron founderies and machine shops and founderies combined, not less than about forty separate establishments engaged in these closely allied industries, besides which there are extensive forges, engine and machine shops, plows and agricultural implement works, manufactories for steam pumps, builders and domestic hardware, saddlery goods, locomotives, bolts and nuts, spikes and rivets, iron bridges, wrought iron pipe and boiler flues, cast iron pipe, boilers, stills and tanks, wire iron fences, car wheels, chains, horse-shoes, nails, sheet iron, and in short every possible article for the construction of which modern skill and invention have regarded iron as the best or cheapest material. These operations employ thousands of expert artisans, whose wages are higher than paid any similar class of workmen in the world, creating a reactive influence upon the community at large that is promotive of the most satisfactory results.

\section{STEEL.}

Pittsburgh stands pre-eminently at the head of the crucible steel production of this country In 1813 there was a steel furnace here owned by Tuper \& McKowan, probably making only blistel. steel. In 1829 an Euglishman named Broadmeadow, made blister steel at Pittsburgh, and about 1831 made a cast steel of low grade in pots of his own manufacture. His works were located at Bayardstown, now Fifth ward, near the old Fifth ward Market House. Josiah Anlirim \& Sons, file makers, Pittsburgh, are said to have succeeded in making their own steel about 1830 . In 1831 Messrs. Whitmore \& Havens successfully produced blister steel at Pittsburgh. In 1833 the firm of

NowE.-The product given for Allegheny county in Mr. Swank's report includes iron rails; but the only iron rails made in Allegheny county from 1874 to 1878 were of very light patterns, from 12 to $201 \mathrm{~b}$., and but rery small in quantity. 
G. \& J. H. Shoenberger commenced to manufacture blister steel here. At about 1840 the firm of Isaac Jones \& William Coleman was formed at Pittsburgh, and manufactured blister and spring steel, which business they successfully prosecuted until 1845, when they were succeeded by Jones \& Quigg, who built the Pittsburgh Steel Works. In 1846 Coleman \& Hailman commenced the inanufacture of blister and plow steel, and subsequently made all but first-quality east steel.

In 1850 there were in Penusylvania thirteen works, with an annual product of 6,078 tons, of which six works, with a capacity of 3278 tons, were in Pittsburgh. In 1853 the firm of Singer, Nimick \& Co., which had been organized in 1848 , was successful in producing the higher grades of cast steel for saw, machinery and agricultural purposes. In 1859 Messrs. Hussey, Wells \& Co. were successful in malking crucible cast steel of the best quality; and in 1862 Messrs. Park, Bro. \& Co. accomplished the same result. There are now in Allegheny county :

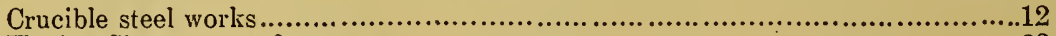

Having Siemens pot furnaces..................................................................33, with 1123 pots.

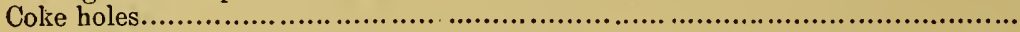

Total pots.

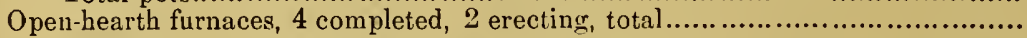

$\frac{223}{1346}$

The erection of the Edgar Thomson Steel Works, the only Bessemer steel works in Allegheny county, was commenced by Carnegie, McCandless \& Co. in the spring of 1873 , and in 1874 the organization was changed in name to "The Edgar Thompson Steel Co., Limited." Their works, located at Bessemer Station, on the Pennsylvania railroad and Baltimore and Ohio railroad and on the Monongahela river, commenced operations on September 1st, 1875. They have two Bessemer converter's, blooming mill, and rail and billet mill, and a five-ton forge hammer. The company is also erecting three blast furnaces on its ground near the steel works. This company, although its works have been in operation less than four years, reached in 1878 the largest output in rails and billets made by any works in the United States in any one year, and the largest output of Bessemer ingots made by any "two ccnverter" plant in the world.

The production of the various qualities of steel in the United States, and in Allegheny county, respectively, during 1877 and 1878 , was as follows, stated in tons of $2000 \mathrm{lbs}$.:

\begin{tabular}{|c|c|c|c|c|c|c|}
\hline \multirow{3}{*}{ Kinds of Steel. } & \multirow{2}{*}{\multicolumn{2}{|c|}{$\begin{array}{l}\text { United States. } \\
\text { Total Product. }\end{array}$}} & \multicolumn{4}{|c|}{ Alleghent County. } \\
\hline & & & \multicolumn{2}{|c|}{ Total Product. } & \multicolumn{2}{|c|}{$\begin{array}{l}\text { Proportion of } \\
\text { United States } \\
\text { Product. }\end{array}$} \\
\hline & 1877. & 1878. & 1877. & 1878. & $\begin{array}{c}\text { Per ct. } \\
1877 .\end{array}$ & $\begin{array}{l}\text { Per et } \\
1878 .\end{array}$ \\
\hline Bessemer steel ingots... & 560,587 & 732,226 & 73,278 & 99,344 & 13.07 & 13.57 \\
\hline Open-hearth steel ingot & 25,031 & 36,126 & 800 & 1,025 & 3.20 & 2.84 \\
\hline Crucible cast-steel................... & 40,430 & 42,906 & 24,747 & 27,365 & 61.34 & 64.95 \\
\hline 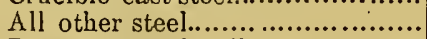 & 11,924 & 8,556 & 8,323 & 6,579 & 70. & 76.90 \\
\hline Bessemer steel rails................ & 432,169 & $5.50,398$ & 54,635 & 72,246 & 12.65 & 1313 \\
\hline
\end{tabular}

Of the total product of Bessemer and open-hearth steel ingots in the United States, in 1877, there was made in Allegheny county 12.65 per cent., and of the total product of the United States in 1878, Allegheny county manufactured 13.06 per cent. Of the total product of crucible, cast, blister and puddled steel manufactured in the United States in 1877, Allegheny county produced 63.16 per cent.; and of the product of the United States in 1878, Allegheny county produced 66.93 per cent.

The percentage of product in open-hearth steel has heretofore been low, but there hare been erected and put in operation since January 1,1879 , two open-hearth steel fnrnaces-one by Anderson \& Co.. and one by Hussey, Howe \& Co.; two others are in process of erection by Shoenberger, Blair \& Co., and Mr. Thomas S. Blair is about to start his open-hearth furnace at Gilenwood, heretofore operated in connection with the manufacture of iron sponge. When the open-hearth furnaces now being erected are completed, Allegheny county will take the lead in open-hearth steel, as she has heretofore done in crucible steel.

Pittsburgh has many specialties in steel manufacture, probably the most important of which is the higher qualities of tool steel, which, during the past ten years, have almost entirely supplanted, in the markets of this country the English tool steel-a result reached only after the most patient effirt and in opposition to the most determined prejudice of the manufacturers and users of tool steels.

It is notable, also, in connection with the Bessemer steel manufacture, that the steel for the cables of the East-river bridge was manufactured here into wire rod by Anderson \& Co., and that the steel for the Glasgow bridge over the Missouri river, the first all-steel bridge in this country, was manufactured under the "Hay" process by the Edgar.Thompson Steel Co., Limited, and rolled by Hussey, Howe \& Co., and Andrew Kloman, into the various shapes used in constructing that bridge. 


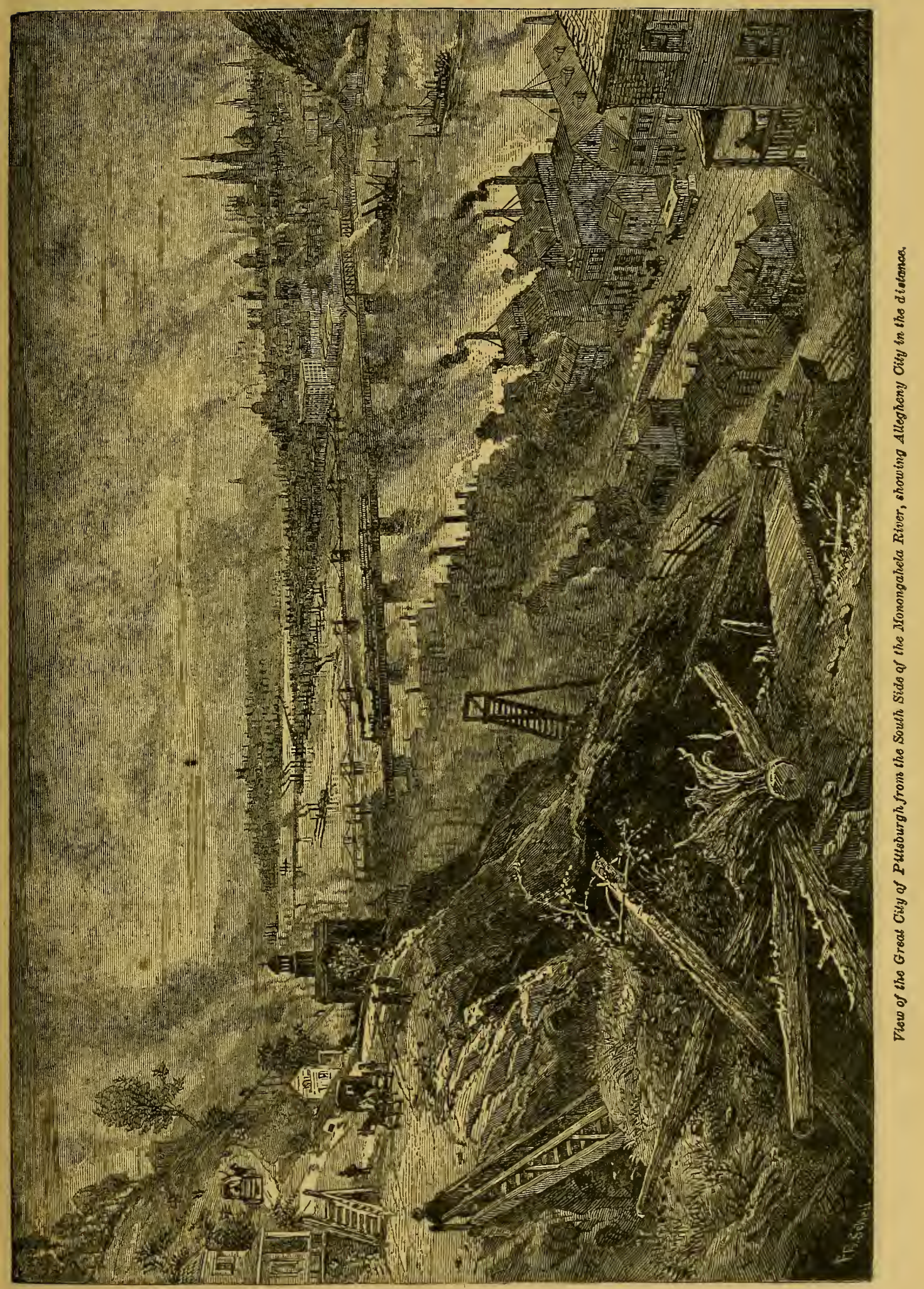




\section{GLASS.}

In that part of this work which is devoted to the details of the varions industrial enterprises of Pittsburgh will be found much matter pertaining to the glass trade, which will amply repay the perusal of the reader and convey a very satisfactory idea of the extent and importance of our resources in this direction, which ranks first in prominence after iron and steel.

The first glass house in Pittsburgh is said to have been in operation in 1795, and was located near what is now called "Glass House Ripple," in the Ohio river. It is, however, on record that Gen. James O Hara and Major Isaac Craig commenced ar'angements for the manufacture of glass in 1796 with an eight-pot furnace. In 1807 George Robiuson and Edward Ensel commenced the manufacture of flint glass, and in 1808 they were sold out to Messrs. Bakewell \& Page; their successors, Messrs. Bakewell, Pears \& Co., having carried on the business to the present time. In 1826 there were in operation in Pittsburgh and vicinity seven glass works, with a capacity of 27,000 boxes of window glass, and of flint glass to the value of $\$ 30,000$. The number of glass manufactories now in Pittsburgh, is as follows:

\begin{tabular}{|c|c|c|c|}
\hline 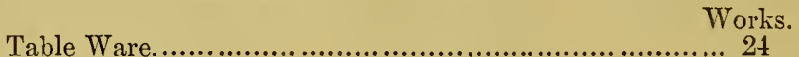 & $\begin{array}{l}\text { Pots. } \\
242\end{array}$ & $\underset{1.895}{\text { Hands. }}$ & $\begin{array}{r}\text { Product. } \\
\$ 2,000,000\end{array}$ \\
\hline 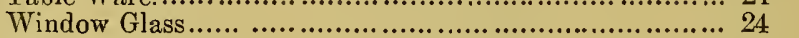 & 234 & 1,200 & $2,000,000$ \\
\hline Flint Glass Bottles........................................... 8 & 66 & 619 & 420,000 \\
\hline Glass Chimneys.............................................. 9 & 90 & 790 & 500,000 \\
\hline Green Glass Bottle....................................... 10 & 67 & 944 & $1,200,000$ \\
\hline Total... & 699 & 5,448 & $\$ 6,120,000$ \\
\hline
\end{tabular}

The amount of glass manufactured in Allegheny county is about one-half the total production of the entire United States, and from every reasonable indication will not only maintain this supremacy, but even become more pre-eminently prosperous in this branch of manufactures. A conclusion of this kind seems not to be avoided, from the fact that every year marks some surprising improvement for the rapid and accurate manipulation of this material, under patents which are held exclusively by Pittsburgh producers. During the past few months one extensive manufacturer on the South Side has discovered and perfected a process, by which goods are produced in almost exact imitation of the finest French ceramic ware, a result never heretofore obtained in glass, and on every side is observed the sedulous application of more effective appliances, for the retention and enlargement of this staple industry, and its more comprehensive development. One fact in relation to the glass trade of Pittsburgh bears more than ordinary significance, when considered with reference to the future aggrandizement of this department of our resources, and that is the gratifying increase of an export trade, that but a few years since had no existence whatsoever.

In accordance with the annual report of the Chief of the Bureau of Statistics on the Commerce and Navigation of the United States for the fiscal year ending June 30, 1878, it appears that in 1871 the exports of glass and glasswale amounted to $\$ 466,447$, and for $1878 \$ 869,68 \%$, an increase of nearly 100 per cent., making the prediction a safe one that for the fiscal year just closing the exports will amount to over one million dollars.

These figures at first to the casual observer may not seem to carry the real importance that should be ascribed to them, but when it is considered that England, France, Belgium, Italy and other countries are largely engaged in supplying the world with glass and glassware, under the protection of ancient guilds, and the advantages of cheap labor, materials and an established trade; the progress made in this direction by a far removed inland city of a new continent, should be regarded as little less than marvelous, and should have the effect of inciting renewed and active efforts for the accomplishinent of annually greater results.

\section{PETROLEUM.}

But two decades have passed away sirice the systematic commercial production of petroleum staggered the credulity of the whole world, and hurried to Western Pennsylvania all the drifting argonauts of fortune from Nova Scotia to New Mexico.

No such exodus to any given locality had hitherto been known in this country or perhaps in any other. Not even during the gold excitement were the shores of California visited with crowds so vast or heterogeneous. Towns of no small magnitude actually sprang into existence in the night like mushrooms, and the oil regions of the Kieystone State were metamorphosed almost by nagic from deserted wilderuess into thriving, populous communities, while sudden wealth poured from the punctured bosom of mother earth, with a copious prodigality that seemed absolutely limitless. The consequent excitement of that period in which Pittsburgh was deeply involved and the immediate conversion of numerous refineries which had been erected for the distillation of coal into refineries for petroleum, is a well remembered phase of local history. This city became at once the virtual centre of the oil trade of the world, a position still sustained, and of which it would be difficult to deprive her.

The production of petroleum in 1859 , though far from being a discovery in one sense, was in another a very important one. As early in the history of America as 1627 the fact of its existence was made a matter of comment by a French missionary, Joseph Dalaroche, in letters written from near that locality which has lately become so prolific of oil known as the Bradford regions. De 
Charlevoix, a French historian, traveler and Jesuit, in his Historie de la Nouvelle France, recounts from his journal of May 1721, the fact of their being at the bead waters of the Allegheny fountains, which are like oil, having the taste of iron, with a "piquante odeur, " and being used by the natives for the alleviation of pain.

This is regarded as the first reliable mention of petroleum in Pennsylvania, and to a greater or less extent from that time its existence has been generally recognized. For many years, prior to 1859 , it was gathered from the pools and waters of oil creek by absorption in blankets or woolen fabrics which were spread upon the surface of the stream and at intervals wrung out. By this tedious process the annual product may have reached perhaps a bundred barrels, which was known as Seneca oil, rock oil or naptha, being sold as a medicament for certain diseases, especially those of a rheumatic character. Kier's Petroleum Liniment was well known during the period between 1851 and 1859--60. This preparation was manufactured by Mr. Samuel Kier, a resident of this city, by whose advice the first commercial oil producer conmenced operations, and in whose shop was constructed the first oil rig, primative tools that would now be regarded as curiously obsolete.

Supplied with these implements, Col. E. L. Drake, of New Haven, Connecticut, began to bore for oil at Titusville, exactly twenty years ago (June, 1859), and after laboring for more than two months was rewarded by striking a twenty-five barrel well, and from that moment began the prodigious excitement before referred to, and petroleum became an article of commerce with a dominant interest of its own. Ten years from the date of its first production on this basis the annual amount exported to foreign countries, especially to Europe, in crude, refined and the various products of petroleun had reached the sum of $\$ 31,122,338$, the bulk of which was handled in Pittsburgh and controlled by Pittsburgh capital. For the fiscal year ending June 30, 1878, the export of this commodity had reached the amount of $\$ 46,574,974$, a result not to have been anticipated, as during that year the production had more than ever overstepped the bounds of demand, reducing the value of petroleum to figures lower than had been known up to that period.

The following table presents a summary of the production of petroleum in the United States, by which it will appear that from Pennsylvania emanates 98 per cent. of all the natural oil found in the country:

PRODUCTION OF CRUDE PETROLEUM.

1877.

Pennsylvania

West Virginia..................................

Kentucky and Tennessee....................

California .......................................

Ohio. $13,135,65 \mathrm{~L}$ barrels. 77,172

73,000

73,000

36,500

$13,490,171$
1878.

$15,165,462$ barrels.

250,000

75,000

75,000

45,000

$15,608,462$

When it is remembered that nearly 6,000,000 barrels of petroleum were refined in Pittsburgh during the past year, to say nothing of the shipping and handling of other vast quantities, some idea may be gained of the wealth which is derived from this source alone by this immediate locality. The largest manufactory and market contiguous to the oil regions of Pennsylvania, Pittsburgh has, from the supply of tools, engines, tubing, barrels, materials and merchandise, secured a very considerable annual revenue, which seems in no danger of immediate reduction. Such being in brief the history of the oil trade, it can hardly be denied that it forms an episode in the annals of commerce for which there is absolutely no parallel and no precedent, and to which in no small degree the prosperity of Pittsbnrgh may be readily traced.

\section{MISCELLANEOUS RESOURCES AND PRODUCTIONS.}

The coal, coke, iron, steel, glass and oil interests of Pittsburgh have now been passed in rapid review, and though from these various sources are formed the very bulwarks of our commercial thrift, which are, fortunately, staunch enough to prevent all hostile inroads, still there are innumerable lesser interests which all converge to fill out symmetrically the full development of Pittsburgh's resources and advantages, and are well worthy of attention.

Among these, the manufacture of cotton goods bas from a very early period engaged considerable capital, and furnished occupation for a large number of operatives. The mills in this locality are situated in Allegheny City, and are five in number--two being of extraordinary magnitude. These mills, in the aggregate, run 36,000 spindles, 800 looms and 350 cards-the total number of employees ranging between 1200 and 1500 , to whom are paid about $\$ 250,000$ annually; the production, during the same period, varying, of course, in value, with the state of the market, but considered at the present time to be not less than $\$ 1,000,000$.

The manufacture of white lead is carried on extensively in this community, and with uniform success to those engaged in this department of industry, as well as the establishment of a reputation for a superior article that is peculiar to Pittsburgh. In the two cities there are eight factories for the corroding of lead and the making of derivative contingent products, which employ not less than 225 hands, to whom is paid about $\$ 125,000$ per annum. The consumption of raw material by these concerns amounts to 6,500 tons of pig lead annually, 200,000 gallons linseed oil and $300,000 \mathrm{lbs}$. 
acetic acid, besides kegs, cane and boxes, in due proportion-the total product in paint leads, \&c. in kegs of 25 lbs., being about 700,000 packages. Many of these worlks also prepare paints and colors upon a scale of considerable magnitude, and more than one has lately given attention to the manufacture of iron-oxide paint, which is establishing a superiority for certain purposes that makes it more desirable and considerably cheaper than lead paints.

The production of salt in this city, which, owing to the low price of this eommodity, seems to be but of small importance, is yet attended with a very considerable revenue, and is obtained with such ease and convenience as to attract attention. It was demonstrated some years since, in making experimental borings for oil, that salt water might be found under either of the cities almust anywhere at a depth of from 800 to 2000 feet. One manufactory of this description possesses a well 1600 feet deep, which spouts brine at the rate of from 800 to 900 barrels per day, the water being ejected by the force of natural gas, which is collected and used for lighting and beating the works. Of the four establishments in operation, the value of the product annually is about $\$ 130,000$, and is remarkable for purity and whiteness.

In alluding to natural gas, it may be said that it is more than a conjecture that, at from 2000 to 3000 feet from the surface, exist those veins of carburetted hydrogen so commonly struck in the oil regions of Butler county, where, for an extended period, this gas has been burning in an uninterrupted and unquenchable stream. Some years since a question arose in regard to the possible utilization of this wonderful product for purposes of iron and glass manufacturing, and a line of pipe was laid to the nearest gas well, 18 miles distant, connecting at this end with the extensive rolling mills of Spang, Chalfant \& Co., which are located on the north side of the Allegheny river, above the city. The experiment proved a complete success, and, though many alterations were required, the mills from that time have been operated solely by this novel and inexpensive fuel. Some idea may be gained of the enormons pressure exerted by this gas from the fact that an Indiarubber ball was shot through the entire length of the pipe in 16 minutes. The Rochester Tumbler Co., situated about 25 miles from the citr, on the Ohio river, is also supplied from two wells on the premises, with the same convenient combustible, which is found to be far superior in the process of annealing to any other fuel. Many other concerns are also in possession of this advantage, and the presumption generally obtains that, at no distant day, a complete revolution may be effected in all manufacturing operations requiring heat, by this means.

Looking at the ponderous resources with which Pittsburgh is naturally endowed-coal, iron, petroleum, gas -it is impossible, takilig into account her felicitous geographical position, to avoid the conclusion that she is but in the very morning of her greatness, merely tipped by the slanting beams of a prosperity that shall, in coning years, deluge with golden showers of unaliojed success. The rapid growth of the city has created a demand for building materials that greatly fosters several important industries which derive from this development a continual impetus. First among these may be noted the manufacture of brick, which is carried on upon a very extensive scale, there being not less than 25 separate manufactories of building brick, and ten of fire brick and tile, employing, in all, from 800 to 1000 workmen; the products realizing not far from $\$ 1,000,000$ annually.

The lumber interest, in this connection, is also of conspicuous importance, and involves in itself snfficient eapital and labor to make it of no small in port. The territory in Pennsylvania and New York watered by the sources of the Allegheny river was for many years the main and almost only source of supply for timber possessed by Pittsburgh, and so great was the drain upon this section that, in 1831, the amount of lumber anuually floated was estimated at,30,000,000 feet, which, for 10 or 15 years, gradually increased, till the probable anuual receint of lumber by the Allegheny river exceeded $50,000,000$ feet. Such an enormons decimation of the forests, however, could not continue always, and this, together with the devastations of fire, impaired materially the productive richness of this district. The demand, however, was in no way abated; on the contrary, the necessity for lnmber became more urgent, and the construction of railroads through western Pennsylvania about that time, fortuuately. opened up new regions in this State, as well as by the lakes, secured connection with the great forest of Canada, Michigan and the Northwest. In this city, at the present time, are engaged in the lumber business, having saw-mills and yards, or planing-mills, sash, door and box factories, not less than 75 different colicerns, whose operations employ about 1300 laborers and artisans, and to whom is paid, in the aggregate, more than half a million dollars annually - the total products having an estimated yearly value of $\$ 3.500,000$.

As contingent industry, consuming a large amount of lumber and wood of varions kinds, the raanufacture of furniture is not to be ignored. Pursuing this industry are from 12 to 15 concerns in the cities, whose agrregate output is estimated at nearly a million dollars annually, engaging the labor of from 300 to 400 artificers and others, and consuming certain classes of hardware, marble, upholstery goods and varnish, to a large amount.

Another interest employing considerable quantities of lumber and hard woods is that related to the manufacture of wagoins and carriages. In this branch of industrial art are found in the cities abnut thirty establishments, some of them very extensive and willely celebrated for the elegant finish and designs, as well as the substantial character of their work. More than $400 \mathrm{ar}-$ tisans are engaged in the various branches of this trade, and when the ralue of repairs is taken into consideration in connection with the manufacture, the aggregate business of these concerns may be estimated as about $\$ 750,000$ per year. 
The manufacture of barrels and kegs forms no unimportant factor in the general prosperity, to which it adds materially. From the refiners of petroleum and manufictirers of nails and white lead comes a great demand for articles of this description, to supply which there are about twenty cooperages, either independent or in connection with oil refineries, involving the labor of not less than from 500 to 600 coopers, whose work results in an annual product valued at $\$ 1,250,000$.

Elsewhere will be found a table compiled from the very latest and most reliable sources of information, showing the exact number of tirms, individuals and corporatioss engaged in each separate manufacture, vocation or mercantile pursuit, a glance at which, together with a perusal of the detailed descriptive notices contained in this volume will afford all the facts upon these varions matters that can be considered practicable. There are almost innumerable avenues pertaining to manufactures of less importance through which we have conducted the realer in the articles abore referred to, and to which special consideration is invited, as making up the sum of Pittsburgh's stamina; and, as before remarked, the object of this sketch does not involve minute particulars, these being furnished in another department, but rather breadth of drawing and effect.

\section{MERCANTILE AND FINANCIAL.}

It is frequently urged by comparative strangers with regard to the mercantile interests of Pittsburgh, that they lack force, importance or aggressiveness, and whilc freely admitting the preeminent greatness of our manufacturing operations, allege that in trade wo are far behind other cities of like or less population. As applied to the past the truth of these strictures can not be readily gainsaid; but as relating to the present condition of affairs they are certainly in wide contravention of the facts.

The assertion may seem startling and perhaps paradoxical, $t$ ut it is neverthele-s a verity that lieretofore the mercantile interests of Pittsburgh have been relarded by too much prosperity. In ordinary business ventures l'ittsburgh mercliants absolutely slept upon their oars, and the favoring trade-winds of smiling circumstance :sctually wafted them into snug financial harbors, while their only knowledge of storms was confined to casual dreams, singested by the far uff thurder of disasters elsewhere. When the complications arising from the monetary convulsions of 1873 , involverl Pittsburgh, there was a general and wide awakening of these somnolent mariners, and a struggle began with unpropitious elements in which many feeming goodly crafts were swamped, but in which was displayed, almost for the first time, some native vigor, resolution and laborious activity which saved the fleet and taught a salutary lesson worth milions. Under the influence of the instruction so unwelcome to the learner, it is shown that during the past six or seven years, in the teeth of great obstructions, the mercantile strength, influence and operations of this city have palpably angmented, and that an era of undoubted energy has begun that will lead to the most satisfactory results. In the lepartments of dry good;, boots and shoes, hardware of all descriptions, - much of which, especially in fine tools, is manufactured here-leather, liquors, drugs, clothing and cloths, groceries, crockery and earthen ware, pork and provisions, grain, flour and nualt liquors, etc., in a wholesale way, there has been a marked development by the determined extension of a trade radius which has been aicled in no limited degree by lately acquired advantages in railroa $i$ competitions of unusual importance. The outlook for the future with reference to the commercial thrift of this city has never appeared in such luminous colors, and the field for enterprise in this direction presents as many solid inducements for the investment of pluck and capital as any in the country. With the experience of the past as a guide, Pittsburgh is fast achieving a position in this regard to which she has always been justly entitled; from which she has been debarred ouly by a sentiment of intense conservatism and too much good fortune. As they stand to-day, the character of the fit ancial institutions of this city will compare favorably, for solvent stability and correct management, with the monelary concerns of any city in the world, and their prosperity may be takcn as a sure barometer, indicative of the general condition of affairs. As a conclusive evidence that they are prosperous it may be stated that there are in Pittslurgh seventy-one banks and banking institutions with an aggregate capital of about $\$ 20,000,000$ and an aggregate surplus of over $\$ 4,000,000$, which is a showing that must be taken as proof of robust financial health. Many of these banks

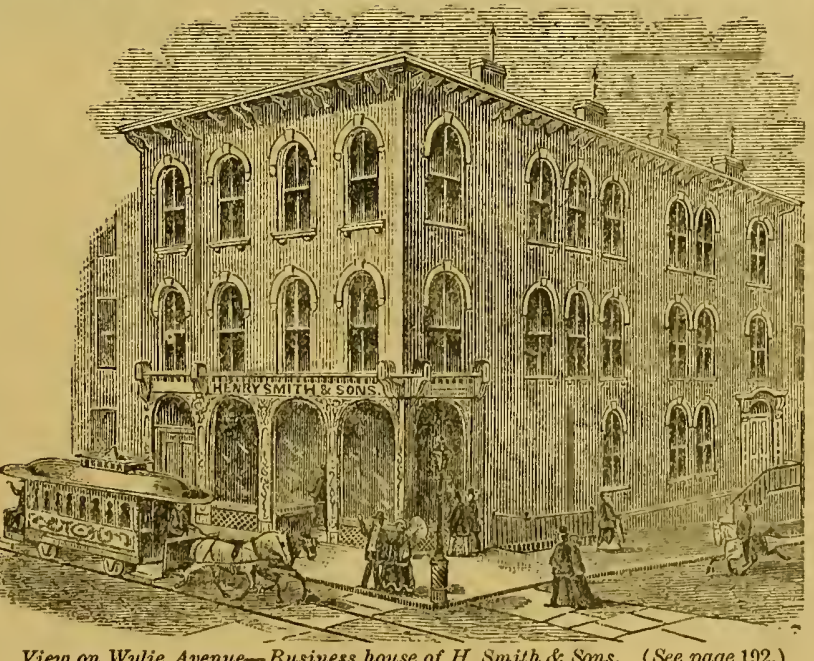


are of such antiquity as to be indissolubly identified with not only the history of this city, but that of the nation. The Bank of Pittsburgh in a career of sixty-five years has made in trying times advances to the general Government, and through every financial crisis that has occurred during its existence has paid its circulation liabilities in gold, except in 1837 when it suspended specie payments for a few days at the instance of the citizens who assembled in convention for the purpose of making such a request, laboring under the needless apprehension that the demands upon the coin resources of the institution would be greater than it could meet. From the organization of this bank till the present time the fidnciary concerns of Pittsburgh have justly acquired an unusually fair reputation for being conducted upon the safest and most reliable principles. The number of failures that have occurred among them are indeed very limited, confined mainly to private enterprises, and, except in one or two instances, far from being of disastrous magnitude. The same remark may be made with reference to the fire insurance organizations, the outrrowth of Pittsburgh capital, of which there are nearly half as many as there are banks, some of which carry on an underwriting business which extends over the entire United States, adding no little to the general revenue of the city.

The solvency of Pittsburgh insurance companies has been so conspicuous as to occasion a wide recognition of the fact that, while not assuming vast or unwieldy proportions, they afford eqnal security and protection with the most vaunted institutions elsewhere, and are conducted with vigilance and discretion. The total amount of capital invested in the fireinsurance companies of these cities, in round numbers, amounts to not less than $\$+, 500,000$ a sum which represents the accumulations as well as capital of the twenty-four joint-stock fire-insurance companies, having their home offices in these cities, and emanating from local enterprise. It has been asserted that Pittsburgh, more than any other city of like population in the United States, felt the depressing infiuences (following the year 1873) which disordered the values of the entire country, but a careful examination will prove that in reality this community has absolutely suffered less than any other of even approximate dimensions. In 1874 and 1875 the trade, manufactures and commerce went forward with unabated prosperity, seemingly unaffected by the torpor that began to paralyze other places. In 1876 some premonitions began to obtrude themselves, more indicative, however, of future than real present trouble; work was plenty - no one was compelled to an enforced idleness, and though there had, it is true, been some serious failures, it can not be said that, up to this time, contractions had seriously grappled Pittsburgh in dead earn-

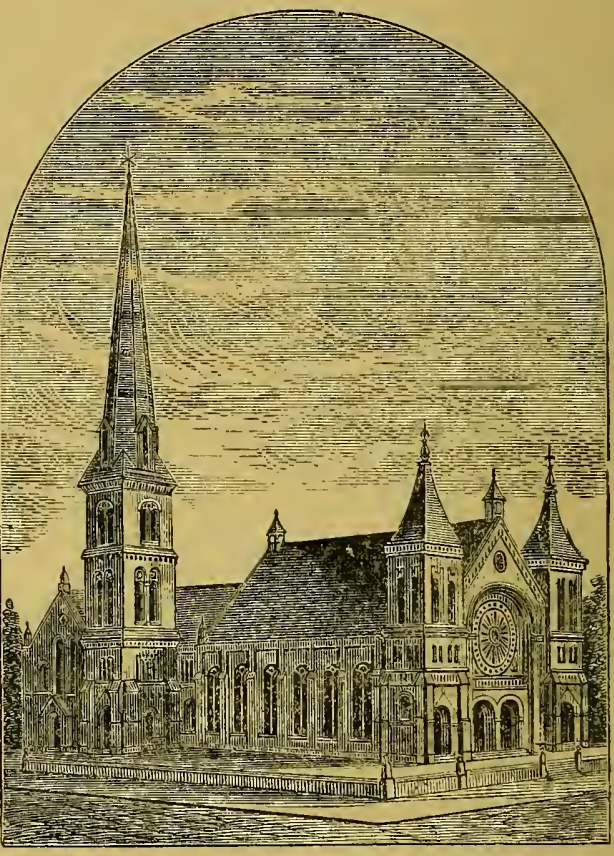

Fourth Baptist Church. est, or that the conflict between existing conditions and inevitable results had assumed an aspect other than that of a lively skirmish, in which a great deal of smoke and dust is produced, with but little damage or destruction. During the two years that followed, however, the combat deepened, and a goodly number on the defensive were carried from the field, "dead for a ducat," hipped in pocket and drained of fiduciary fluids. Even during this period the hum and roar of Pittsburgh's industries never ceased. No crowds of idle men loitered in the parks or thronged the thoronghfares, giving ocular evidence of commercial prostration-no soup-houses were necessary-and no extraordinary charitable disbursements demanded, as was the case in almost every other manufacturing city in the world.

And now, in the middle of the year 1879, it may be emphatically asseverated, withont the aid of an active imagination or assumptions that germinate alone in hope, but with a solid phalanx of supporting facts at hand, that Pittsburgh has finally and assmredly crossed the rocky isthmus of adversity that debarred from pacific waters, and has resumed a voyage farored by auspicious gales, and signs that indicate prolonged prosperity in a manner unmistakable. In coal, iron, glass, and other products and manufactures, active operations are rife on all sides; prices firmer, a better demand, and a feeling of general security to which the community has long been a stranger. Mills, factories, furnaces, forges, foundries and mines are resonant with the reiterant clangor of labor, and a tidal wave of commercial good fortune floods every industrial avenue. 
PUBLIC INSTITUTIONS, EDUCATIONAL FACILITIES, THE PRESS, \&c., \&C.

In pursuing reflections with reference to the material advantages of Pittsburgh in regard to its resources and the prestige that it has acquired as a manufacturing center, it should not be overlooked that, in other respects, it has developed with an equal pace, and that, in the organization of public, charitable and benevolent institutions, schools, colleges, hospitals, libraries and other means for the education of humanity or the amelioration of the condition of the unfortunate, provision has been made in keeping with the most enlightened views of a Christian community and the dictates of the highest civilization.

From the last report of the State Superintendent of Public Instruction, it appear's that there are in the cities of Pittsburgh and Allegheny 78 school buildings, 61 of which are constructed of brick or stone in the most substantial manner, involving the most approved arraligements for ventilation, heating and the general convenience and comfort alike of pupil and preceptor. These buildings are subdivided into 628 schools, governed by local school boards and central boards of education. Six hundred and forty-one teachers, male and female, are employed in these schools, which are so grided and arranged that by progressive advances the scholar may-beginning in the primary department-graduate from the central high school with a finished academic and classic education, entirely at the public expense. Aside from the benefits conferred by this comprehensive system, there are numerous educational institutions for both sexes which afford almost unrivalled advantages for the acquisition of the higher branches of culture. Some of these have attained a wide celebrity, and number among their classes students from the most remote States. The Western University of Peunsylvania is perhaps the best illustration of the truth of this statement. The college was chartered by the State in 1819, and

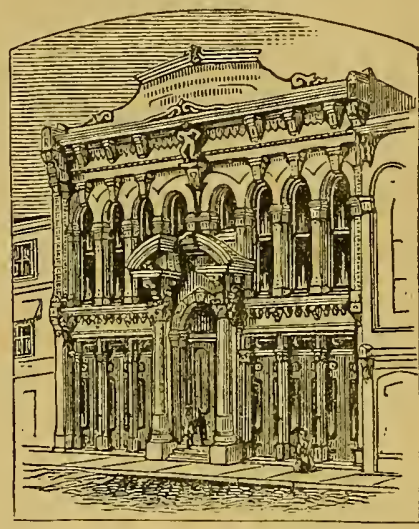

Pittsburgh Savings Bank. a splendid building erected, which was formally opened in 1822, but unfortunately consumed during the great fire of 1845 , with all its philosophic appliances, collections, archives and libraries. Another structure, howerer, was shortly erected on Duquesne Way, which was also burnt down in 1849, the course of instruction being thereupon suspended until the present University building was built, on Ross and Diamond Sts., opposite the Court House, in 1855. From that time the institntion has flourished with wonderful vitality. In 1858 George Woods, LL.D., was appointed Chancellor, a position which, for 21 years, he has filled with marked usefulness and ability. I)uring this period the University has been liberally endowed by public-spirited citizens, and those who perhaps recoguized the beneficial influence of the institution upon their own early training. One of the most prominent patrons of the collegre, William Thaw, Esq., alone became its sponsor for $\$ 100,000$, which was donated in such a manrer as to cost the generous giver nearly double that sum. By the aid of these endowments it has become possible to reduce the tuition fees to a merely nominal sum, while greatly enlarging the curriculum, which now embraces a range equal, to the highest acquirements, including ancient and modern languages, military and civil engineering, natural sciences. laws, \&c. - the advantages for the study of astrouomy in connection with the Allegheny Observators, aud the lectures of Prof. Samuel P. Langley, the well-known astronomer and one of the faculty, not being equaled in the United States. With ample cabinets-reological, natural, historical, conchological-libraries, scientific apparatus of the finest mechanism, and a faculty of 16 accomplished educators, it is but a natural result that the Western University of Pennsylvania should have achieved its present prominence. The faculty and board of trustees are composed of representative men from various denominations: Wm. Thaw, Hen.J. K. Moorhead, Wm. Frew, Jas. Park, Jr, Dr. C. G. Hussey, Rt. Rev. J. K. Kerfoot, Rt. Rev. D. R. Kerr, D. D., Hon. F. H. Collier, John Harper, Esq., and others serving in the latter capacity. On the other hand, perhaps the most useful institution for the proper education of womeu, in this community, sprung from the well-directed efforts of the Methodist denomination in the establishment, a quarter of a century ago, of the Pittsburgh Female College, which was chartered by special act in 1854. This school, which has undoubtedly done much to promote a hirh degree of female culture, is under the immediate direction of Rev. I. C. Pershing, D. D., for 20 years president of the faculty, and the contingent supervision of a board of trustees composed of 24 gentlemen of the hirhest standing, presided over by the Rev. Bishop, M. Simpson. D. D., one of the brightest Juminaries of the Methodist denomination. The course of study pursued at this institution embraces not only those branches pertaining to the solid resources of the human mind, classic and modern langruages, English literature, mathematics, moral and mental philosophy and the natural sciences, but includes instruction in those polite accomplishments which are almost as essential. In this department a conservatory of music forms a prominent feature, and an art school for culture in drawing, painting and plastic art, affords more than ordinary advantages. Established upon the highest principles of usefulness, as a primary design, without thouglit of pecuniary advautage other than essential to perpetuite the college apon a self-sustaining basis, the school has become a prominent institution of learning, and pre- 
sents advantages in a numerous faculty, of exceptionally solid attainments, and terms of marked moderation, that attract pupils from all sections of the country. Under the æris of the Episcopalian denominatiou, the Bishop Bowman Institute, a collegiate school for young ladies, has assumed a prominent position anong the educational establishments of the State, taling a high rank on the score of broad usefilness and able management. This academy has been established for about 17 years, its aims being to impart a "thorough and liberal Christian education," more than usual attention being directed to the solid branches of academic culture, and the discipline of the mind to effective and original action. To these aims the school has proved adequate in a marked degree, a success due in no limited measure to the labor and inffuence of the rector, Rev. Robert. J. Coster, M. A., and a faculty of rare scholastic accomplishments. The institution was chartered in 1866 by the State, and is under the contingent supervision of a board of trustees, the chief executive officer of which is the Rt. Rev. John Barrett Kerfoot, D. D., LL. D., whose official visits to the sehool and lectures on moral philosophy and the evidences of Clxistianity, lend additional advantages of a high order to those already enumerated.

The Pennsylvania Female College is another denominational school for the edueation of young ladies, as its n:me implies, under the especial protection of Presbyterian sponsors. The organization was chartered in 1869 , and the buildings, which are remarkable for beauty and magnitude, firished and oceupied in 1870 , from which time the academy has been educationally successful. In this connection it would be extremely ungracious to omit mention of one of the most admirable is well as useful edueational institutions in the country, viz., the Pittsburgh School of Design for Women. This art school was organized and ineorporated in 1865, with the object of affording greater opportunities for the education of women than heretofore possessed, and presenting them all the advantages to be derived from a systematic training in the technical as well as theoretical knowledge of art. Its mission was a high one, but it has already accomplished a noble work among its graduates, being found able, and, in many cases, talented artists, and competent instructors in tine art, designing, architecture, mechanical drawing, \&c. The school is mainly dependent upon the voluntary contributions of those interested in the work, and affords a wortly channel for the wisest benevolence and public spirit. 'The cfficers and directors of the school are among the mnst prominent and esteemed members of the community, and the faculty consists of Annie W. Henderson and Olive Turney, who were among the first graduates in 1871. In speaking of matters connected with art and the general educational advantages of Pittsburgh, the Art Society should

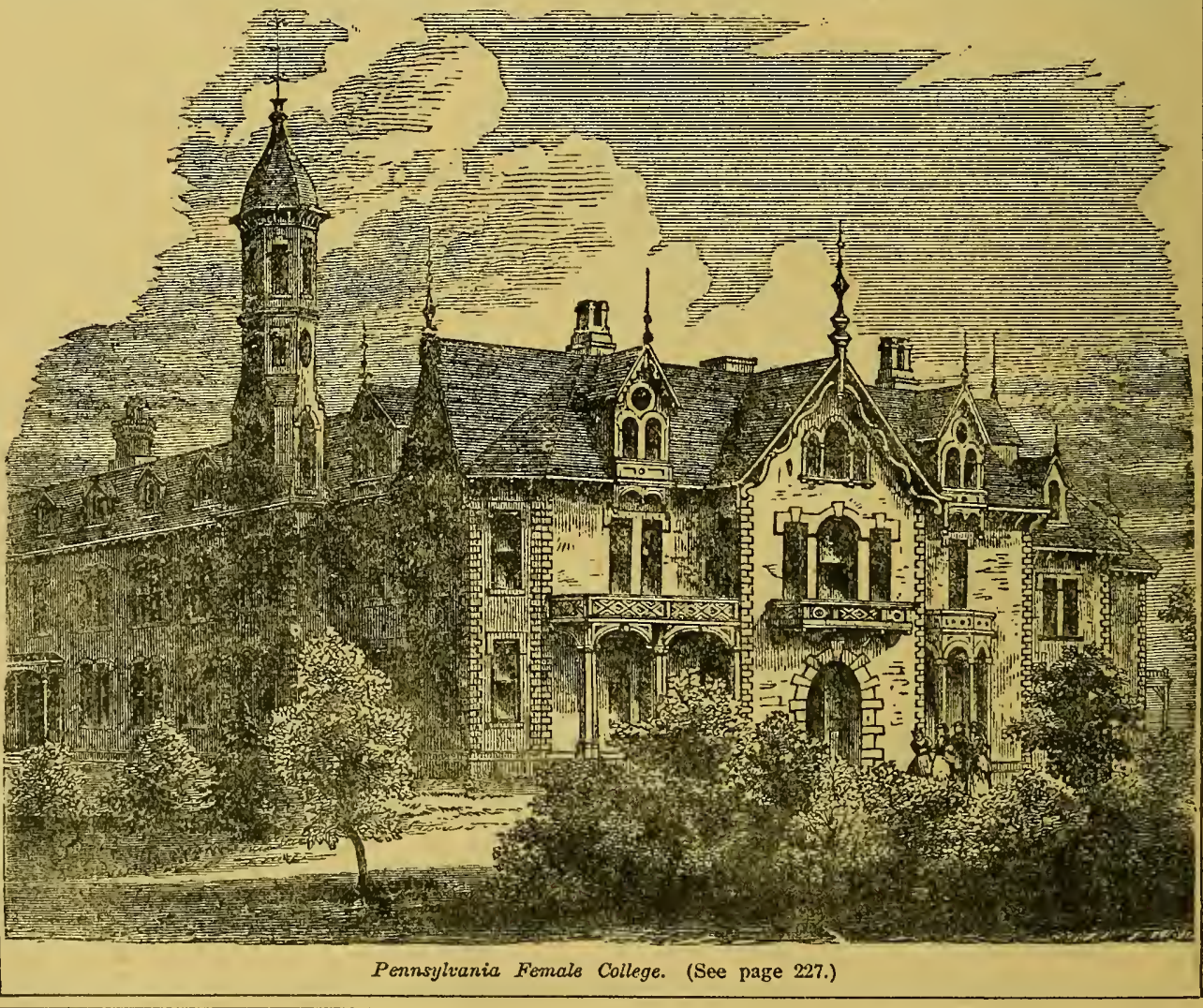


not be forgotten, being an institution highly promotive of culture in music, painting, literature and plastic art. This association was organized in $1872-3$, Rev. S. F. Scovel, D. D., being the frst president-Wm. R 'Thompson, Esq., having occupied this position for some years, being at present the chief executive officer. One hundred members are enrolled upon the books of the society, many of whom are noted musicians, artists and literati, or representatives of the higliest intellectual cultivation of the community. The meetings are held semi-monthly during the Winter in the gallery of the Pittsburgh Library Association, and afford means for instruction and entertainment of the most attractive and elevating character.

The above reference to the Pittsburgh Library Association suggests tlis valuable public institution, which has perhaps filled as wide a field of usefulness in the promotion of general edncation as any similar organization in the western portion of the State. Founded in 1847 , the society has numbered among its officers gentlemen of the highest social position, of commanding influence and ability, who have given no little time, labor and talent to foster the intelligence of the community by the establishment of this library upon a substantial and permanent basis. That its condition at the present time more nearly approximates this standard than ever heretofore is mainly due to the tact and energy of $\mathrm{Mr}$. William N. Riddle, who, as president of the Association during the past two years, was greatly instrumental in organizing two brilliant semi-social schemes-the Bazaar of Nations and the Library Loan Association-from the profits of which the liblary has been placed upon an excellent footing. From the report of the librarian it appears that over 15,000 volumes are now upon the shelves of the institution, with a rapid annual ratio of increase yreater than in the past. The officers of the Association, incumbent at the present time, are as follows: Wm. N. Riddle, President; Alexander Laughlin. Jr., VicePresident; Wm. II. D. Barr, Secretary; Wm. Thaw, Jr., Treasurer; Directors, Fred. Rinehart, 'I'. Brent Swearingen, S. George, Jr., W. L. Chalfant, W. P. Schell, Jr., and Willis L. Eaton. The bnilding occupied by the library was built expressly with a view to its proper accommodation. and is one of the most splendid and sumptuous structures in Pittsburgh, the main hall of the librars being perhaps the handsomest apartinent for the nurpose in the country, elegantly furnished. with appointments and embellishments of great artistic merit and beanty. Though this library is not entirely free to the public, yet the annual charge for membership is so small as to plaee its advantaces within the reach of all who desire to embrace them, the number inscribed upon the rolls of membership at present being between 1300 and 1500 , with erery indication of rapid augmentation. The library hall building, while, as before remarked, being built mainly with a view to the advantage and accommodation of the library, was the work of the Library Hail Company, a joint-stock corporation, organized in 1869 for the special purpose indicated. This companr, though entirelr distinct from the Pittsburgh Library Association, really emanated from it, and succeeded, throngh the capital and interest contributed by members of that Association, in the admirable accomplishment of its desiorn. The existence of the library hall building is a powerful confirmation of the a'oove statement, and, as before remarked, is one of the most sumptnous structures in the countrr. It was erected at a total cost of $\$ 290,000$, the materials employed in the construction of the facade, which is extremely unique and beantiful in architectural design, being gray stone, while the wlole ponderous edifice is solidly and accurately built. Besides coutaining choice and spacious apartments, halls, galleries, ante-rooms, \&c., \&c., for the library, the building contains the fincst public hall in Pittsburah, capable of seating 1400 people, elegantly furnished, and stited in scenery and stage appliances for dramatic, operatic and other exhibitions, concerts, lectures, \&c.. and is by all means the favorite hall for such and kindred purposes. In addition to this, the buildingr is fitted with an art gallery and music room, properly liglited from the top, and in every way adapted to the purposes for which it was designed. The first or ground floor and basements are devoted to trade purposes, resulting in a handsome revenue from this and all somrces. Charles J. Clarkie. Esq., is president of the company, in connection with which, as directors and officers, will be fonnd many of our first citizens.

Allegheny City is also supplied with a copions library, which is maintained entirely at the public expense and by voluntary contributions, ample rooms being provided for it in the mumeipal buildings. In Allegheny is also located the Western Theological Seminary of the Presbyterian Church, which was established in 1831, the college building being first located on what is now known as Seminary Hill. This structure, however, was destrored in the Winter of 1854 , and the present structure erected in 1855 on Ridge Arenue, being a large and commodions bnilding. For more than a third of a century this celebrated Seminary has been the focal point in the West, as Princeton in the East, for the education of clergymen of the Presbyterian denomination, and has performed a great work through this means in the evangelization of the country. It appears that, under the regulations governing this college, no charge is made for tuition or room, and all other expenses are so modified as to meet the most limited means, makin! it possible for any earnest and resolute pupil to gradıate at an expense within compass of the narrowest resources. The faculty consists of six eminent divines, as follows: Rev. Samuel Jennings, D. D.. LI. D., Rev. Hm. H. Hornblower, D. D., Rev. William H. Jeffers, D. D., Rev. Samuel H. Kellogg, D. D., Rev. Berijamin B. Warfield, A. M., Rev. Luther Halsey, D. D., LL. D.; the trustees, directors and other officers being among the inost prominent in the clerical or lay society of the denomination.

In its provisions for the poor, unfortunate, sick, criminal, or insane, Pittsburgh has given the most striking assurances of being possessed of an active philanthropy that has not been surpassed 
by any community in America. In attestation of this assertion, it may be well to point out a few of the most prominent charities for the benefit of those at a distance, to whom it is desirable to convey a just conception of Pittsburgh as it is in every material or social aspect.

The Western Pennsylvania Hospital for the Insane, located at Dixmont, eight miles from the eity over the P., Ft. W. and C. R. R., is perhaps one of the best conducted and most useful institutions of this character in the country. The brildings are vast and complete, so far as liuman ingenuity and unlimited means can devise or produce, costing in all nearly $\$ 1,000,000$. Surrounding the main structure lies a domain of 320 acres, the State, cities and various counties in West Pennsylvania contributing to its support by appropriation, or a charge exacted for the care and maintenance of patients from the various localities.

The Homeopathic Hospital is an institution emanating exclusively from the benevolence of those believing in the superior efficacy of this school of medicine; nor has it received the aid to which it is entitled by the State, though its advantages are provided gratuitously for the indigent, who are supplied with attention, medicines, treatment, maintenance and surgical care during their entire requirements. The institution was incorporated in 1866, under the title of The Homeopathic Medical and Surgical Hospital and Dispensary of Pittsburgh, and from that period has been sustained entirely by voluntary contributions. The board of trustees includes the names of many of the most prominent and liberal men in the city. The medical board consists of one consulting physician, four surgeons, four physicians, two obstetricians, and ten áispensary physicians-21 medical men in all. representing the highest efficiency in the homeopathic practice of medicine.

The Pittsburgh Infirmary, which owes its existence to the philanthropic efforts of Rev. W. A. Passarant, is another institution designed to afford relief for the sick and unfortunate. It was founded in 1848 and chartered two year's later, performing from its first establishment a noble work in the aid freely bestowed upon those appealing for help, regardless of race, creed or condition.

The Mercy Hospital, though under the charge of the Sisters of Mercy, is equally broad in its provisions for the sick, and affords admirable facilities, the buildings being lartre and rery commodious. The solicitude of the Sisters has made this institution widely useful and entitled to the general consideration in a marked degree.

Besides the foregroing, there are numerous other benevolent establishments, whose names will briefly convey an idea of their purposes without further description: Home for the Friendless, designed for destitute children; Allegheny Widows' Home; Home for Agred Protestant Women; 'The Home for Destitute Women; Boarding Home for Working Women; The Sheltering Arms, a

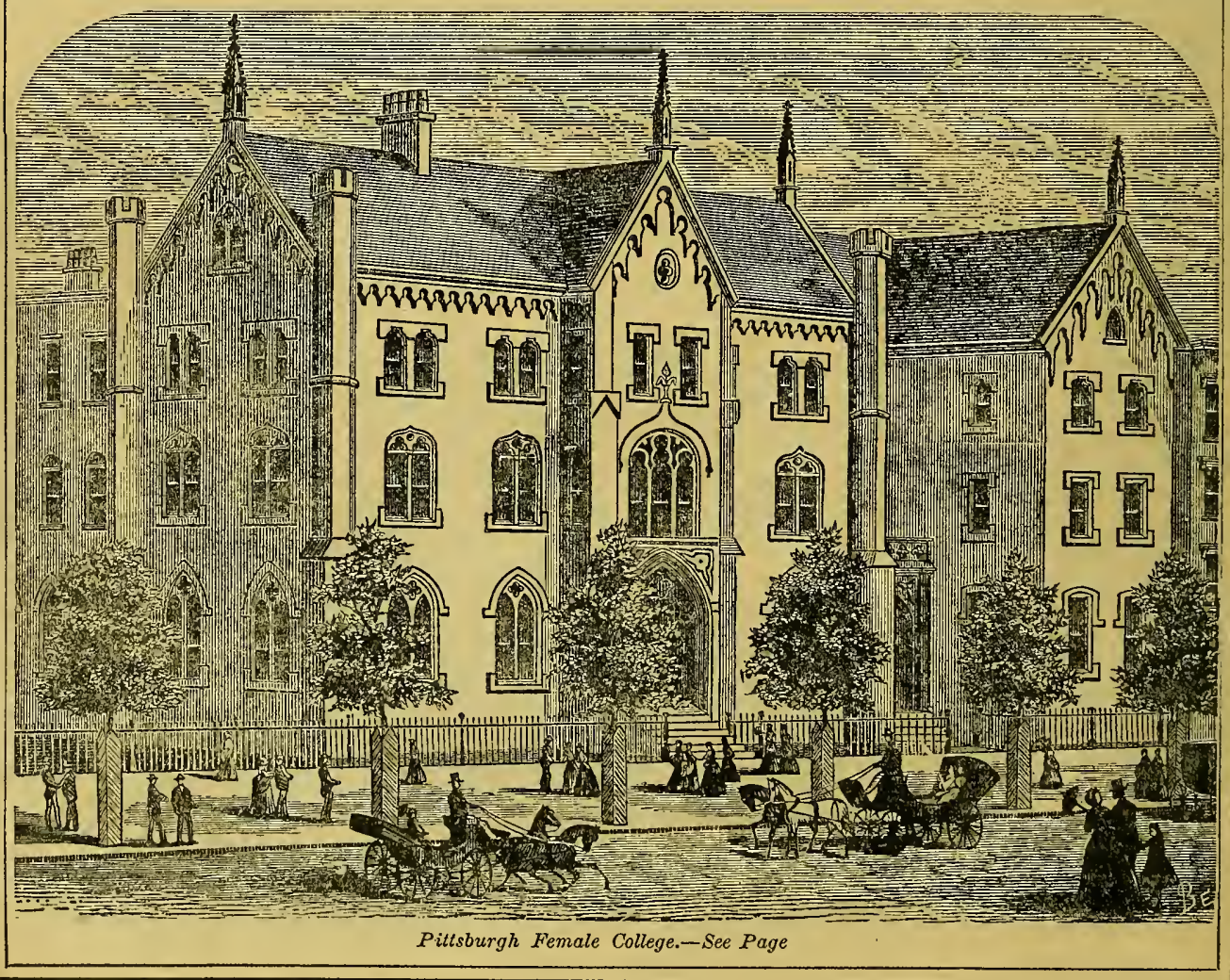


reformatory and home for unfortunate girls and young women; Home of Industry; and Home of the Little Sisters of the Poor; besides two orphan asylums being under the charge of the Sisters of Mercy, who richly deserve the title by which they are known. There are also two other orphan asylums and an institution for the education of deaf and dumb children.

The municipal arrangements for the support of what may be called the pauper portion of the community are admirable, and by the conjunction of farms, which are worked mainly by the inmates of these establishments, they are made, to a great extent, self-supporting, thus relieving able and provident citizens from an onerous load of taxation for the maintenance of the poor. These observations are particularly appropriate to the Pittsburgh poor farm, which is located at Hornestead, on the Monongahela river, about eight miles from the city, and has been, for the past two or three years, urder the excellent and systematic management of Mr. G. L. Braun, who has, during his incumbency as superintendent, not only made many improvements conducive to the health and comfort of the inmates, but, by judicious economy and the bigh cultivation of abont 90 acres of arable land pertaining to the domain, has reduced the cost of the actual maintenance of eacli inmate to the sum of 20 and four-sevenths cents per day, or considerably less than that required by any similar institution in the State. The property, in all, attached to this almslionse, is about 149 acres, and it is reasonably assumed that, with 150 acres additional and a management equal in efficiency to the present, the entire establishment might be made self-supporting. A valuable and necessary addition is being made to this institution by the erection of a separate and suitable building for the accommodation of the insane and demented, for the proper care of whom no adequate provision is possible with the present limited room and between $: 300$ and 400 inmates, varying with the seasons. 'This structure is a tbree-story brick building, $43 \times 195$ feet, designed by T. I). Evans, architect, and constructed in the most substantial manner, being particularly remarkable for the introduction of the mose perfect system of heating and ventilation ever devised, and extraordinary moderation in cost, which, for a municipal building, is the occasion of very favorable comment.

The Pennsylvania Reform School, at Morganza, on the P., C. ald St. L. R. R., a short ride from the city, is another of those splendid charities for wlich our city is becoming noted. Ihis institution was established in 1854 as a House of Refuge, where the young and vicious of both sexes might, by compulsory training and education, be brought into a better moral and intellectual condition, fitting them for useful and responsible positions in society. With this olject, a large building was erected near the lower part of Allegheny City, where, until 1876, was pursued what is called, in reformatory parlance, the "congregate system," part of which required the restraining intluences of bolts, bars, walls and donjon keeps. In conformity with more modern ideas, howerer, and the introduction of methods requiring the abandonment of physical restraints, the establishment of the school at Morganza upon the "family system" was projected. In pursuance of this plan, over 500 acres were purchased at the above place and six separate buildings erected-one main and five family dwellings, the plans approved being those furnished by E. M. Butz, Esq.. architect. These buildings resemble, in external appearance and internal appointments, the best clnss of the largest private dwellings, except the female department and main structure, which are of greater dimensions. Over half a million dollars was spent in the execution of this project, the wisdom of which is not questioned. About 320 inmates are now being educated and maintained by the institution, which came formally under the sole control of the State during the current rear. Upon the abandonment of the old structure before referred to, that building was convererl to the State, and is now undergoing changes, alterations and extensions, on the basis of plans lesigned by E. M. Butz, by which it will become a detaclyed part of the Western Penitentiary.

Much could be said in this connection of the truly civilized mode of conducting our penal institutions, the workhouse at Claremont being a remarkable illustration of the beneficent effects of a colijuriction of salutary, useful and profitable labor and moral restraint, leadinir not ouly to the improvement of the convict in every re spect, but the maintenance, to a great degree, of the institution upon a selfsupporting basis.

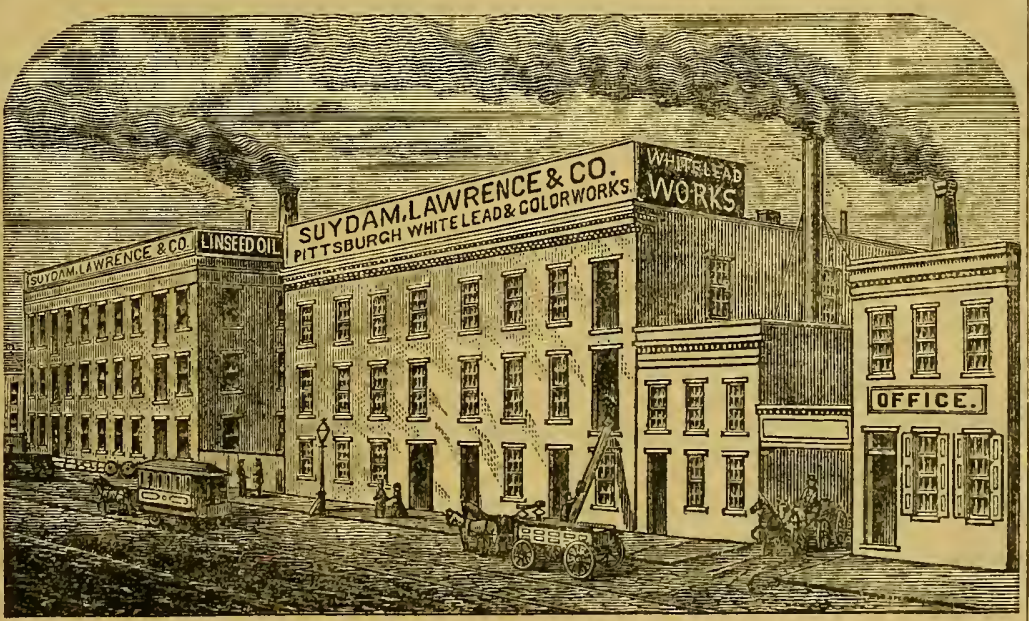


These are a few of the most prominent of those organized efforts for the improvement of the needy, the instruction of the ignorant, and the care of the destitute or criminal, for which Pittsburgh is entitled to the esteem of the humane; in addition to which there are fruit and flower charities, societies for the prevention of cruelty to children or animals, an association of bankers and bank clerks, for mutual benefit and assistance, of which Mr. Wm. N. Riddle is president, an influential club for the preservation of the fish and game of the State, law and order societies, and numerous other institutions, supplying special needs, or in the performance of noble work, evincing the vital operations of an active public spirit, greatly conducive to the social welfare of the whole community.

In proportion to its population, it has been frequently asserted that Pittsburgh supports more daily nerspapers than any other city in the country, nor has any advance agent of any company, providing exhibitions for the public, been found willing to controvert this statement; such, on the contrary, vehemently endorse the truth of the allegation, sometimes profanely and sometimes tearfully, as they gerrymander from one office to the other. In any event, Pittsburgh is well supplied with journals, the general standing of which is nearly all that could be desired. We shall mention, briefly, in the order of seniority, the most prominent:

The Commercin. Gazette, now conducted by King, Reed \& Co., was established in 1786 as the Pittsburgh Gazette, and, by the purchase of the Commercial, in 1878, effected a consolidation of the two papers, by which the title was appropriately changed to the present style. This morning journal is the organ of the Republican party in Western Pennsylvania. It has a large circulatinn-is ably conducted, especially with reference to politics and mercantile affairs, producing a handsome revenue, and exerting an actire influence upon all questions of public import. A weekly edition is also issued.

The Evening Chronicle was founded in 1841 as a morning paper, but was subsequently changed in 1848 to an evening journal. It is now and bas been for many years owned and published by Joseph G. Seibeneck, Esq., who conducts it independent of politics, but not without a distinctive and conservative policy. As a family journal, this paper has a large circulation, and is a general favorite with all classes of the community, especially long residents in this section. The weekly edition forms a valuable addition to the journals of the city.

'THe DaILY Post, as the only organ of the Democratic party in Western Pennsylvania, occupies a place peculiarly its own, having an extensive circulation and wielding a strong influence in all matters pertaining to the party of which it is the mouthpiece. It was established in 1842 , and has been owned and conducted for many years by James P. Barr \& Co. A weekly edition is also issued, which fiuds numerous subseribers in all parts of the State. The Post is ably conducted, and, in a financial point of view, is successful to a marlied degree.

The Pitrsburgh Daily Dispatch was established in 1846 by the late Col. J. Herron Foster, and was published at first as a penny paper. In 1865 Daniel O'Neill and A. W. Rook purchased one-half interest in the concern, which was then in no flourishing condition, and in 1867 , on the demise of Col. Foster, became sole proprietors. The extraordinary talent for journalism, political acumen and business ability possessed by Mr. O'Neill soon caused the paper to assume a foremost place among local publications, and in a short time the Dispatch became the leading representative journal of this end of the State. The aggressive vigor with which it was conducted resulted in a circulation of from 13,000 to 14,000 daily, and an almost princely revenue. On the demise of Mr. O'Neill, in 1877, Mr. A. W. Rook, the surviving partner, associated with him Mr. Eugene M. O'Neill, under the style of Rook \& O'Neill, subsequently changed to Rook, O'Neill \& Co., by the admission of Mr. Chas. A. Carroll. The Dispatch is independently Republican, politically and is cleverly conducted in all departments, being justly regarded as one of the most influential and profitable journals in Pennsylvania. A weelily issue is published, which has a wide support.

T'He Lvening Liader was founded in 1870 by John W. Pittock, and is now owned and conducted by the Leader Publishing Company, which publishes, in addition to the evening paper, a dollar weekly and Sunday issue, the latter having a very extensive circulation, being the largest and best conducted Sunday journal in the city. In politics, the Leader is not allied to any party, but is none the less pronounced in its views upon all matters either in church or State. It is popular with a large class of the community-displays ability in its managenent, and secures a very satisfactory revenue.

T'He Sunday Critic, published by Carson, Haslett\& Clark, has been established for some jears, and is now settled upon a solid footing. It is Democratic in politics, has a good circulation, and is a well-managed and readable sheet.

T'He Sunday Globe. - This paper is owned and conducted by J. Breen, who has succeeded in making it a vivacious and peppery journal, with a large subseription list, a good advertising patronage, and the other essentials for a healthy and prosperous existence.

T'he class papers are the AMERICAN JouRnal OF INDUSTRY, an enterprising and valuable sheet published in the interest of manufacturers by Geo. E. Williams, Esq., and the Po'trenY AND GlassWARE Reporter, which emanates from the same source. Though founded within a linited period, these journals have attained a pronounced success, and may be justly regarded as representative trade papers and vigorous exponents of the industries of this section.

The American Mandfacturer is also an excellent paper, conducted in a very circumspect manner. 
The Evening Telegraph was first published in 1873 by a joint-stock company, which finally surrendered the journal to the control of Ralph Bagaley, Esq., who has conducted it for some years with satisfactory results. In toue, the paper is Republican, and aims to inspire confidence by an honest and fearless course. Its manarement is in able hauds, and the journal is achieving the respect of the community, which is evinced by a rapidly enlarging subscription list. The Telegraph has also a weekly edition, and in all respects gives solid proofs of success.

The Allegheny Lvexing MaI, is the only jourial published in Allegheny. It has a good circulation-is a spicy little sheet, and is conducted editorially by Mr. Jobn B. Kennedy.

Besides the abore English, there are three German dailies, the most important of which is the Fremeits Freond, owned and published by Messrs. S. and W. Neeb. It is the Republican organ for the Germans, and is an official paper for both cities and the county. It is conducted with a large sliare of financial success. The other German papers are the VolksBLatT and REPUBLIKANER.

The religious element of the community contributes to the success of several denominational journals whose names are indicative of general characteristics: The Presbrterian Banner, The Methodist Recorder, The Pitrsburgh Christian Advocate, the organ of the M. E. Church, The United Presbrterias: The Catholic, and othel's, published weekly.

The Hardware Reporter, publislied simultaneously at Pittsburgh, Cleveland and Chicago, and the American Manufacturer and Iron World at Pittsburgh and New York, published by the National Iron and Steel Publishing Company, are the leading publications of the nation, representative of the iron and hardware trades. The manager and trcasurer, Mr. Frank Woods, is one of the most thoroughly posted and ablest trarle journalists in the countrs. To the iron and steel manufacturer, to the dealer, to the hardware merchant, whether the extensive importer and exporter or the retail dealer, either The Hardware Reporter or the American Mannfacturer should be their weekly visitor. Address National Iron and Steel Publishing Co., 97 Wood Street, Pittsburgh.

$\mathrm{Y}$ IVASG.-It is estimated that in Western Pennsylvania alone there is a Welsh population of more than 50,000, while in the collieries and iron worlis of Ohio and the West there are undoubtedly as many more. This large class of Welsh-spealing citizens is fortunate in the possession of a really first-class weekly newspaper, printed in their own language by " $Y$ " Wasg Printing Company," of which Mr. Jenkin Jones is President; $\mathrm{Mr}$. Joseph D. Jones, Vice-President; Mr. Thomas IV. Davis, Secretary; Mr. D. IV. Lloyd, Treasurer; and Mr. R. T. Daniels, Managing Editor. $Y$ Wasg is a neat and attractive eight-page paper, ably edited and conducted in the interest of the Welsh people of this section, whose industry and peculiar qualifications have done so much toward the development of the iron and coal interests of Western Pennsylvania. It is the only Welsh newspaper west of the Allecheny mountains, and, with one exception, the only one published in this country. Its circulation throughout Pennsylvania, Ohio and the West, is large and steadily increasing, and as an advertising medium for those desirous of reaching this class of trade, it is nnequalled by any paper in the city.

In this brief summary of the salient points and obvious advantages of Pittsburgh, it has been necessury to conderise too much to permit of the production of a sketch that should possess the advantages of a careful literary production; nor was labor in this direction considered necessary or essential. It would have been pleasant to have loitered with the reader round old historic scenes and landmarks of the past - to recall names that liave figured in the annals of the nation, and legends that may not be forgotten in connection with alnost classic haunts; but the relentless propulsion of our theme and object forbade. Innestri has been the reiterated cry, and for its evidences the reader is referred to the sketches and descriptions of Pittsburgh's laborers and labors, with which this work is replete.

\section{THE PENNSYLVANIA RAILROAD COMPANY.}

Thero is no feature of American progress and enterprise which wore favorably impresses the mind of the foreign tourist than the admirable system of railway managenient, the magniticent coaches, the solid and substautial road beds, and the elegant structures used for depots and stations by the great railroad corporations of this country. In all these clepartinents the Pennsylvania Railroad Company stands pre-eminently and conspicuously at the head, and the various connections of this company, intersecting with iron bands nearly every section of the Union, furnish means of communication for husiness men and pleasure seekers at once, the mosi direct, the most picturesque and beautiful, the most convenient and the most comfortable of any road in the world. Railways being now the coummon highways of the land, the managers of the Pennsylvania Railroad Conıpany have made every effort, in their power, to accomodate the traveling propensities of the restless and progressi re people by well equipped and pleasant routes extending throughout the varied and interesting scenery of the Middle, Easters, Northern and Southern States of the Union. The numerous and widely diverging lines of the company, following the course of beautiful rivers, penetrating the fastnesses of giant mountains, reaching the restless waves of the mighty ocean, and menudering through romantic vales and sylvan scenes of breezy heights, reaching from the home of the pilgrion fathers and the earliest settlement to the greai and groving cities of the $W$ est. afford ficilitics for sight seers and ple:tsure seekers unrivalled on the continent and unsurpassed by those furnished by any other company in the world. By arrangements recently completed, the Pennsylvania Company is now prepared to furnish excursion tickets at special rates to and from almost espry prominent point of interest on the continent at greatiy reduced rates. This compauy has general ticket affices in all the prineipal cities of the Union, presided over by atfabie and accomodating gentlemen, who are always happy to turnish fult and explicit intormation to travelers relative to the various routes controlled by the company, and an elegintly illustrated work on Summer Excursion Routes has been carcfully prepared under the supervision of competent wrilers, which will be furnished upon application at the different offices, and which will be found an indispensable vade mecum to pleasure seekers and summer tourists. The main offices of the company are located in Philadelplia, Mr. Frank Thomson, geueral manager; Mr. L. P. Farmer, general passsenger and ticket agent; Mr. Chas. E. Pugh, general superintendent.

The general ticket office of the Western district is located at No.78 Fifth avenue, cor. Smith ficld streel, Piltsburgh.

The general ticket offee of the Western district is located at No. 78 Fifth avenuc, cor. Smithficld streel, Piltsburgh.
Mr. Robert Pitcairn is the general agent and superintendent for this division. All the gentlewen connected with this company are noted for their ability in the various departnents in which they are engaged, being selected solely with an eye to their fitness and general qualifications. 


\section{BEAVER FALLS。}

is thriving and prosperous town with her varied industrial establishments, as being closely identified with the great manufacturing interests of Western Pennsylvania, is worthy of most favorable consideration in these pages.

On the banks of the Beaver River, that at this point sweeps in a graceful curve along the base of the eastern hills, that rise abruptly from its borders to a beight of 100 feet or more, in a broad, beautiful valley, sloping back to a range of bills on the west, along whose base the P., Ft. W. \& C. R. R. bends, this attractive and growing young city, that dates her foundation back but a half score years, is situated. A more beautifin spot for a city is seldom seen, by her gifts Nature having been very bountiful to this favored plice. In addition to the beanty of the scenery and attractiveness of the situation, its healthfulness, etc., one of the finest water powers in the country is here afforded. In the hills that surround the place are stored inexhaustible supplies of coal that is easily mined and transported to the places of consumption. The hills are covered with large quantities of timber of various kinds of hard wood, that are valuable for many purposes. The surrounding country is one of the finest agricultural districts in the state, by which abundant and cheap supplies of food for the busy thousands, who in the varied worlsshops are producing the many artieles that find markets in all parts of the world, bringing wealth, contentment and happiness to her homes, is assured. Proximity to the sources of supply of raw materials is another advantage enjoyed.

Numerous coal pits are opened into the adjacent hills and an abundant supply is brought forth. The Water Power was secured by building dams across the Beaver River, whicl in all seasons affords an abundant and never failing supply. The dam at this point was built in the construction of the P. \& I. E. Canal many years ago, a fall of 20 feet or more is obtained, and this great natural power is utilized by a large number of factories that line the banks of the river in the vicinity of the race, and there is yet abundant room for other establishments. By the completion of the new P. \& I. E. R. R. a competing line is now had to all parts of the country, a consideration in these days of Railway monopolies and discrimination of the greatest importance. The Ohio River is distant but $2 \frac{1}{2}$ miles, by which connection is had with the great natural highways of the West.

The manufacturing interests that have been attracted here in the short period of ber growth are of a greatly diversified character-embracing a number of the finest establishments in their particular branch of industry in the United States, and which are remarkable, in many respects, for their splendid equipment, the superiority of their products and the great success they have attained. Mention of each separate industry is given in detail in these pages. 'The town is abundantly and inexpensively supplied with water by the Holley system, the engine being driven by a 42 -inch water wheel with a capacity to supply four times the quantity of water now required. Fire plugs are distributed throughout the city, the pressure being sufficient to throw water to the tops of the highest buildings. A fine reservoir, with fine storage capacity, has been constructed, trom which the water after being filtered is distributed throughout the mains. The Fire Department is well equipped with a steamer, Babcock engine, an abundant supply of hose and other apparatus, and has proved to be very efficient. The town is well lighted, numerons gas lamps being erected along the streets.

A spirit of enterprise and inprovement pervades the whole place and progress seems to be the watchword with all. The water power, which is now very fine, is proposed to be enlarged by the building of another dam with 30 feet fall, that will give a tenfold increased power and afford abundant facilities for largely increased manufacturing interest that is being attracted to this point by the great advantages afforded. A new iron bridge, 700 feet long, is in process of erection by the Penn Bridge Works of this place across the Beaver River, at the upper end of the town, that will bring a large and wealthy agricultural district in direct communication with it and prove of great advantage to the mercantile interests of the place, which are already of a greatly diversified nature.

The natural beauty of the place, its healthfulness and central locality, have been the important considerations in the selection of this point for the location of the Reformed Presbyterian Unirersity, which will be removed from Geneva, O., here, where the Harmony Society have generonsly donated them 10 acres of beautiful ground most admirably located.

\section{CHURCHES.}

There are now 8 churches in the town, some of them very handsome and substantial structures, -two Methodist, two Presbyterian, one Reformed Presbyterian, one Episcopalian, one German Lutheran, one Evangelical.

A handsome Public School building is situated near the centre of the town. There are many fine and substantial business houses located on Main street, and many fine private residences in different parts of the place. The streets are admirably laid out, are wide and airy, and the neat and attractive cottages of the busy artisans who find employment in the various mannfactories, surrounded with shrubbery and flowers, present a picture of contentment and happiness that is foreign 
to the dwellings of the toiling millions in some of the great manufacturing centres. The population is estimated at from 6000 to 7000 , and will scarcely fall short of the latter figure. The distance to Pittsburgh, with the interests of which this place is intimately connected, is but 30 miles by rail.

It is appropriate, in connection with this review of Beaver Falls of to-day, to glance at some of the causes that have contributed to the wonderful growth of the place, aside from the many natural adyantages briefly mentioned above, and the men whose foresight, energy and public spirit have been the means of attracting to this point the industries that have brilt up the place and the name of Beaver Falls known throughout the world as a great industrial centre. The property upon which the town is now built, something over ten years ago, came into possession of the Harmony Society at Economy, a community of people, who perhaps will be recognized more generally under the name of the Economites, who, for many years, have been located a few miles from the place in a town built by themselves, called Economy, and who, by their industry and frugality, have accumulated great wealth. Having loaned a large amount of money secured by mortgage, they were eventually compelled to take the property, which they were desirous of selling; failing to secure a purchaser for it at what they considered its value, Messrs. Baker and Henrie, Trustees of the Society, decided to lay out a town and sell the property off in lots. The services of the men to whose energy and abilities perhaps more than any other cause is Beaver Falls indebted for her position to-day. Messrs. H. 'T. \& J. Reeves were called into requisition, and the property placed in their hands as Agents for the Society. These gentlemen bad been previously recognized as among the most enterprising and reliable Real Estate operators in this section, and realizing the great mutual advantages of the place for manufacturing purposes and the advantages to be derived from the establishment of industrial interests on the property, directed their efforts toward inducing manufaeturers to locate in the town, to whom the liberal inducements were extended as well as material aid by the Harmony Society. Among the first establishments to locate here was the cutlery works, which was originally started in Rochester, a few miles below this place. Messrs. Reeves induced the proprietors to remove to Beaver Falls, where other enterprises have rapidly followed, generously fostered and encouraged by the liberal policy of the Harmony Society, guided by the wisdom of Messrs. Henrie and Lenz, Trustees.

Messrs. Reeves and Judge Hice, the able counsel of the Society, have been the active instruments of building this thriving young city, which, guided by their wisdom and aided by the abundant capital of the Society, has risen to such solid proportions in the short period of 10 rears, and as these gentlemen are still actually guiding the varied interests of the place, and pushing with characteristic energy every enterprise that could tend to increase the prosperity of the town, and overseeing their aim, and the great interests of the society, in their connection with the various industries located here, must naturally feel great gratification as they look upon the wonderful results of their well directed efforts. Possessing so many natural adrantages, encouraged and fostered by the farseeing and liberal policy of the patrons of the place, no place in the United States offers more inducements to malufacturers than Beaver Falls, whose future must be as brilliant as it will be enduring.

\section{ALGEO BURIAL CASKET WORKS, -W.G.Algeod Son, Beaver Falls, Pa.}

These fine and excellently equipped werks were established by Messrs. Algeo \& Son in 1874, and have been in the enjoyment of a presperous and growing trade since their beginning. They are admirably located on the banks of the Beaver river, supplied with abundant water power by which the machinery is driven. They are fitted with complete and perfect machinery, and are in every respect nost conveniently and systematically arranged. The building, which was built with a view to the requirements of the business, is $40 \times 100$ feet in size, 2 stories high, and in all respects is a most pleasant and convenient establishment, representing an investment of $\$ 26,000$. The product of the establishment, Burial Caskets, Coffins, etc., have attained il wide reputalion for their superior make and fine finish. Their trade is derived mainly from the Eastern cities of Baltimore, Washington, I'hiladelphia, Buffalo and Rechester, N. Y. A patented improvement, the invention of the Algeos, is used on all their coffins and adds greatly to their populitrity. It consists of a rim forming an inside tinisi arranged for neatly and quickly attaching the linings thereto. This improvenent has met with high appreciation by undertakers everywhere, and has tended largely to give Algeo's Cotfins their high reputation over all other makes. A stcady and increasing demand keeps his works constantly in operation, giving emplorment to 20 hands, with a monthly pay-roll of $\$ 1,000$. This firm are also manufacturiug a sand-papering machine of their own design, having originally built one for their own use and finding it to surpass any ma-

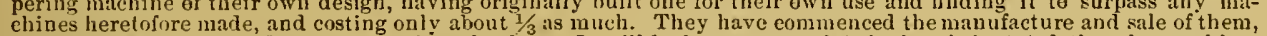
and are mecting with a flattering number of orders. It will be better appreciated when it is stated that the machine, which is now sold at $\$ 150$, car do as much and as perfect.werk as the $\$ 450$ machines, and are simpler and more easily kept in order. U. Bird, 73 Water st., is the Pittsburgh agent for the machines, where samples can be seen. Mr. W. G. Algee is a native of Alleglyeny, horn in 1830 , he learned the trade of cabiuet maker early in life, with the old firm of T. B. Young \& $\mathrm{Co}$ of that city. Prior to engaging in his present prospereus enterprise he was engaged a number of years in the furniture business in Pittshurgh. His son, the junior nember of the firm, was horn in Pittsburgh, and has grown up in the lusiness with his father, acquiring a thorough knowledge of it in all its details. Enterprising, prompt and reliable the firm of W. G. Algeo \& Son occupy a leading position among the manufacturers in their line and can present advantiges to the trade not easily duplicited by cotemporaneous establishments.

ST. CHARLES HOTEL, COLUMBUS, O. James C. Dunn, Proprietor.

\section{Popular Prices, $-\$ 2.00$ Per Day.}

The mest centrally located hotel in the city. Street cars pass the denr every five minutes to all the depots and all parts of the eity. The superior excellence of this elegant hotel wilt be sustained as heretefore. Its central location is unsurpassed,being conrenient to all retail steres, and all places of amusement. 


\section{BEA VER FALLS CUTLERY CO. - Beaver Falls, $P a$.}

In the whole range of thls work, Revident. will bo the whole range of thls work, reviewhy tho greal and wonderfully diversiced indust will bo found no more noted establishments nor any entitled to moro favorable consideration in these pages than inally as a private compiny. Dr. C. G. Hussey, Hon. 'T. M. Howo and other prominent gentlemen boing connected with it, anong the number Mr. Jas. W. Brown, who was Prosident of the comprany for a considerable time and largely contributel by his talents towards placing it on a suecesslul basis at the start. In 1870 the concern was changed to 8 joint stock $\mathrm{Co}$., the ownership passing largely into the hands of the Harmony Society. Mr. Henry T. Feeves wats elect-

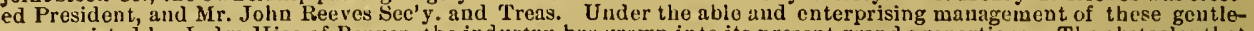
unen, assisted by Judge Hice of Beaver, the industry has grown in to its present grand proportions. The obstacles that had to be overcome in placing the institution in its preselit prosperous condition c:In scarcely be appreciated by those tot having had experience in such matters, and wonld have disheartened less resolutc men than those who were fortunately at the head of it. A mong many others, the procurement of skilled labor was one of the earlier difficulties met with ; for a period of 4 years a force of Chinamen werc employed, who, in a slort time, became prolicient workmen and rendered entire satisfaction to their employers. The overconing of the prejudice existing against American cutlery, was a task of still greater difficulty and years of paticnt effort were required to convince the public that American manufacturers contd produce 25 good an urticle as any in the old world. This has bcen done, and foreign cutlery is rapidly disappearing from our markets, which are being abundantly supplied with the products of American skill and of nquality that bids fair to surpass in the near future, tho finost goods of the English makers. 'These works are situated near the Beaver Ri ver, and in close proximity to the P. \& L. E. R. R. and the P. Ft. W. \& C. R. R. The buildings which are built of brick and stone in the most substantial manner, covering an area of 2 acres, were specially designed to meet all the requirements of this industry, and are as tinely equipped und arranged as an $y$ similar establishment in the world, and in the passession of a quanticy of patented and greatly improved machinery and processes of manufacture are in this respect. much superior to all others. The products of the establishment consist of all grades and kinds hiat repation for superiority that is fully merited and that has created a demand that is taxin the inll capacity of the works to supply. A new department is now (1879) being iuaugurated for the manufacture of Solid steel Scissors the works to supply. A new department is now (1879) being iuagurated for the blanufacture of Solid Steel Scissors be on the market, and will doubtless speedily win their way to public favor by their excellent qualify. The Steel employed in the production of their table Cutlery is made at the steel works of this place, which have been run principally in connection with the cutlery works, and is rolled under a patented process exclusively owned by the Co., by which the bevels of the knifes and forks are perfected on the long strips of steel as they are rolled into slaape, the blades being perfected by thls single operation, thus obviating all neressity for forging cach blade separately as is done in other estilhlishments, and securing perfect nniformity and great improvement in quality of the blades. The reheating, hammering and tempering by the ordinary method which tends to lower the quality of the steel by the burning out of the carbon, is entirely done awas with by this jrocess, which has greatly improved as well as cheapened the products of theso works. The strips, after coming from the rolls, bear the marks of the blades, which are simply cut apart by shear's, when they are ready for the grinder and polisher. 200 of these blades can he rolled per minute, and the cajacity of the Cutlery $C_{0}$. is equivalent to 1200 dozen of their finished goods per day, boxed ready for the markct. Althourh titted with nost perfect machinery that inventive genius can devise, most of which is peculiar to these works, 250 to 300 skilled operatives are yet einployed in the cutlery works. Their goods are distributed to the trade from the great trade centers, Philadelphia, Chicago, New York, Pittsluargh, etc. This sketch of these celelirated Works would be incomplete without mention of the Greal $\mathrm{K}$ nife and Fork, the largest ever made in the world, and which are marvels of mechanical skill and beaut.y. The entire knife is 9 feet and 7 juclies, and width of blade ten inches. The Knife and Fork cost in production more than $\$ 1500$. The handles are of solid ivory, each using an entire Elephant's tusk, they are perfect specimens of the carver's art. The blade, which is polished like a mirror, is beautifully and artistically etched, and among the beautiful designs contains an excellent portrait of Ex-Gov. Hartranft. It would require a man 9 feet square and forty-eight feet high, whose weight must be 100,000 lbs., to gracefully manipulate the steel. The work was all done by the regular employees of the com jany. Mention should be inade also of the great improvement in fuel that has been attained by the boring of a well in the vicinity of the works, from which an abundant supply of natural gas is obtained, by which the works are lighted and beated. The heat supplied by the gas is much more even and under more perfect control, and is free from sulphur and other deleterious substances that interfered with the perfection of the goods that is now obtainable. Both steam and water power is emploved in driving the machincry. The trade mark of the establishment is a very appropriate and suggestive one. A prostrate lion, on which the eagle with outstretched wings is proudly standing. Mr. H. T. Reeves, the President of the company, gives his personal attention and supervision to the enire business management of the estahlishmeut, in which he is assisted and advised by Mr. John Reeves and Judge Hice. Not alone for the production of a class of goods superior to that produced elsewhere in the world, and the great ad vantage thev are able to present to the trade in their products is the Beaver Falls Cutlery Co. entitled to consideration, but the grand results that have been achieved, and the victory g:ined for American Industry and the overthrow of English competition entitles the Beaver Falls Cutlery Co. and the enterprising and talented men to whose perse verance and skill the accomplishments of these results are due, to high praise and great consideration at the hands of the Anverican people.

CO-OPERATIVE FOUNDRT ASSOCIATION,-Beaver Falls, Pa.

Among the many successful and prosperous Industrial and manufacturing establishments in this enterprising and thriving young city, the Co-operative Foundry Assoniation occupies a prominent position. The enterprise was founded in 1872, and under the able management that has guided its afficirs, has attained a prominence in their line of products highly gratifying to the association. The main products of the estublishment consist of a variety of Cook and Parlor Stoves, Hollow Ware and fine Castings of all descriptions. The plant of the association is large and well equipped, consisting of 2 large buildings, $30 \times 172$ feet each in extent, and Warehouse $43 \times 60$ feet. All good, substantial luildings erected with an cspecial view to the requirements of the business. The machinery and appliances, with which they are fitted, are of most approved and valuable kinds. The motive power is supplied by a fine engine. The whole es-
tablishuent in all its departments is coveniently arranged and adapted to the work done, and is in charge of thoroughly experienced and practical men throughout. The prodicts of the establishment have at tained a wide celebrity for their many excellent qualities and bandsome linish. Their trade is quite extensive, reacling over the greater part of the West and throughont this State. The high quality of their products are bringing them a largely increasing trade from year to year, and their works are taxed to their full capacity to meet the demand. 30 hands are employed, to whon $\$ 1200$ monthly is disbursed. The management of the Association is in the hands of weli-known enterprising gentlenen, who are pushing the industry with commendable energy. The business is managed by a board of Directors, cousisting of James Todd, I'res't, Gawn Ward, Treasurer, Henry ililler, Secretary, Thos. Christian, Henry Doffert, L. M. Armor. W. Shaner. Mr. Todd is a native of Pa., born in 1815 . He came to Beaver Falls 12 rears ago, since which time he has been connected with the foundry from its commencement, having been book-keeper for the Association; prior to that time he was identified with River pursuits, living at Brownsville, Pa. Mr. M. is a native of Beaver Co., he has been connected with the association since its commenccment. Mrr. Gawn Ward is also a native of this (o. He is a well known enterprising Groceryman, of the place. He docs not give his exclusive attention to the businese management of the concern. These gentlemen, in their management of the affairs of the association, have largely contributed to its success and popularity. The establishment is in every way rehiahle and its products rank among the best goods in the market. 
WESTERN FILE WORIS, Limited.-Beaver Falls, $P a$.

In reviewing the great industries of this section, and giving brief sketches of the notable establishments that apring into existeuce it the biddinr of the genius of progress and enterprise, muny instances of remarkable achlevements, and the successful accomplishment of what liut a little while ago seemed inpossible, are met with. And within the range of this whole work, containing accounts of the great and wonderfully diversified industries of this State, it is dutibtful, if there will be found a single instance in which American skill aod capital havo achieved a more signal trinmph, than is instanced in the results achieved by the Western File Co., that havo grown to be the liargest File works in the world. The many trimmphs of Ameriean Industry have been due mainly to the improved methods of mannfacturing and the introduction of labor saving machinery, enal,ling A merican manuficturers to compete with the low-priced lahor prevailing in forejgn cutntries. It wis for a loog time thought jmpossible to devise any machine that could cut a file equal to the hand cut file, for reasons, that it is not neccssary in the limits of this article to give. This result has heen more than successfully accomplished, as the nerfect machinery that is now used by this company, is producing files that have, in many critical tests, been provell superior to the hand made files of the best. English brands, and other machine made files. The following extract from the Chicago Commercial Advertiser of June 26,1879 , explains the point of superiority in the machines used : "It is alone for the Western Filn Co. "Limited" to say that with their dasly capacity of 1000 dozen they combine, in their now perfect machinery, in which they use a loose chisel not in any way fast. in or to the liammer, and with as free aetion as if held with the hand, all the advantages of the hand-cut file with a uniform force, accuracy and perfection heretofore unattained, many of which advantages have had to be sacrificed in all tooth desired, the Westcrn File Co. "Limited," are enabled to furnish files suecially adapted to different kinds of work-for inacline filing; for planer knives and tlie hardest steel worked for cast iron and other rough usage and guarantee them superior to ordinary files for such work." Every description of files are inade, from the most delicate needle files, for Jewcler's work, to the largest sizes used by machinists, embracing over 1000 different varieties. The products of these works have not only established their supremacy in all the American markets, but are heing sold in different parts of the world, from many foreign countries there is coming a sleadily increasing demand. They have entered into active enmpetition in European markets with the Shefficld files, are rapidly establishing their superiority there. The magnitude of these works, their wonderful achievements in successfully overcoming comlined foreign competilion, and sending their products to the very doors of their great competitors, all speak volumes for the slill and ability that has heen displayed ly the managentent, who merit the favoral,le cunsideration of the country, for the notable victury they have gained for American Industry. These works, before stated, the largest in the world, were founded in 1869 by Blake \& Fessenden, and have been in continuous nperCapital. The capital stock all paid un is $\$ 216,000$. A very large amount of steel is used. Ail of which is the finest grades to be had und of American make. The works are devoted exclnsively to the production of files, finest grades to be had und of American make. The works are devoted exclissively to the production of files, them frous al. parts of the world. The buildings are very substantial brick structures, consistiog of 1 main building, 500 feet. long, 2 stories high, having fuur I stary wings, another 300 feet long, and two others 60 feet long each, and a number of other sinaller buildings adapted to particular uses. They ar vers eljgibly located, enjoyfording every convenience fur the receipt of material and the shipment of products. They are in point of equip fording every convenience fur the rccipt of material and the shipment of products. They are in point of equip ivus, most of wlich is peculiar to these works, is employcd throughout. A nother advantage possessed by this Company is the use of natural gas for annenling and other purposes, as the files are not brought in eontact with the sulphur and other impurities which all coal contitins in a greater or less degree, and which are well known to be injurious to steel. It is also admitted by the best steel workers that the natural gas is very superior for heating, either for forging, annealing or hardening. Throughout the entire works the most thornugh system prevails, 150 of their cutting machines are employed. A large numlier of workmen lind constant employment, to whom large sums are dislursed for Wages. The "Western" is the most populir lirand made. Other brands are made for jobbing houses to order. The following guarantee, which the Company sencls nut with their gonds, shonld be strong enough to satisfy anyone: The Western File Co., "Limited," guarantees to furnisl files, all kinds, and for all purposes, the most superior for both pany has lieen most liberal and enterprising, and in the grand yuceess that has been altained, they are uow reaping pany has heen most liberal and enterprising,

Mr. Jas. M. Fessenden ts Chairman. He is a gentleman of long practical experience in the business. He has general supervision of the manufacturing operations, the sarious departments of the works heing under tlo immediate direction of skilled superintendents. Mr. E. J. Blake is Secretary, and Mr. F. Fishey, Treasurer. The husiness man-
agement in their hands is conducted with marked ability and success. In every respect these grent works present advantages to the consumers of files, that are, perhaps, uot equalled by any similar establishment in the world.

\section{BEA VER FAIIS MILIS, -Wm. Mellon \& Sons, Dealers in Flour, Feed \& Grain.}

The old Mills forming the subject of the present sketch, were first established alout 75 years ago by anme Quakers, who had settled in this country. It was afterwarls owned and operated ly Mr. Janes Pattersoil, a gentleman w!o was largely juterested in this part of the cuunty, for a number of years undergoing some changes and improvements, but being permitted to become badly oul of ropairs, it passed from the latter gentleman into the hands of W. W'. Wallace, Sam'l Accleary, 'T. Nollie, Wm. Mckee and some other Pittshuryh gentlemen, who, under the name of the Beaver Falls Mijl Co., Hade many alteratious and improvements, substitutiog new and modern machinery for the old, that liad done duty for so long a jeriod and greatly enlarsed the eapacity. The Mills were controlled and operated by this company for some years, tinally pussing into the lands of the present firm in 1874, who have successfully operated them since. The firm have enjoyed a large and very prosperous county trade from the surroudding rich agricultural region, and the Mill has heretofore been mainly rmployer in this kind of trade, grinding all kinds of wrain that was brought to its dours. The completion of the new P. \& E. E. R. R., which passes in close proxinnity of the Mill, hits greatly interfered wath this profitable br.mch of busincss. hy ereating an olsstacle to the access to mill of country ieams unaccustomed to the locounotive. This necessituted is chinge in sume departments of the mill, which has been promptly made, in order to prodluce a different quality of flust from that whicli had formerly been made, which was a good tlour, adapted to the county trade enjoyed. The mill is now equipped and is making the new process flour, which, under the lirand of the Beaver Falls Milss family flour, enjoys is very high local reputation and is in every way a very excellent flour. The uill is capable of griniting ahout 50 ou bushels of grain per day, and the produnt is all aljsorhed liy the home market. The unill is driven by water pover, with a fall of ahnut 19 feet, and having 3 water wheels, with an aggregate power equivalent to 50 linrse power. IJnder its present enterprising management it has been kept in nerfeci order and improvements sdded to kcep nace wilh the arlvanee of tleage. Mr. Win. Mellon is a na-

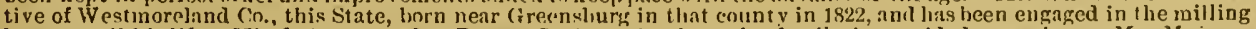
business all his life. His father moved to $\mathrm{B}^{\prime}$ acor $\mathrm{C}^{\prime}$. In $18 \mathrm{t} 6$, where the family has resided ever since. Mr. M. is an enterpri ing gentleman, closely identified with tha intereats of this growine and prosperous community and is justly esteemed as one of the prominent citizens. ifr. W. A. Mellnoll is in native of Beavir Cne, he has eharge of the office and books of the firm, in which position lie enjoys the confidence of all the patrons of the cstablisbinent. 


\section{A. S. \& R. W. HALL,-Manufrs. of Buggies, Barouches, Spring Wagons, \&c.}

This enterprising and prosporous firm founded thelr present industry in May 1875 Afulberry Street, Beaver Falls. been mate, entuged hallitics ereated, and an extonslvo and growing trulo built up. Tho buildings ereted by them to acemmothto thoir husiness are a substandial two-slory frame building $26 \times 50$ feet, with largo busement, and a blacksunth shop $21 \times 50$ foet. Tho eapital at lirst fuvesterl was small, tut has inerensed from time to time, until now there is invested from $\$ 7000$ to $\$ 8000$ in buildings and stock, and an anmul lusiness anounting from $\$ 8000$ to $\$ 11,000$ is dunc, 8 hands aro cmployed tn the mannfacture of all kinds of hight vehicles, buggies, earriages, coaches, spring wagons, ke. The atuality of the work of this firm is equat in every respect to the best work turned out in the country. The gentlemen compesing the tim aro thoroughly reliable and practienl workmen, and will not turn out any inferior work. Their trade has aheoly extonded into aljoining countes und states and into Maryland. They are taxed to their full capacity

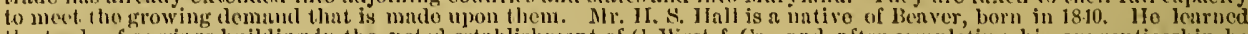

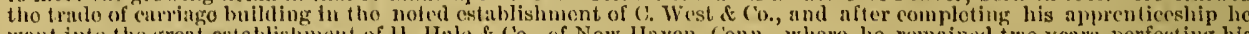
went into tho great establislment of 11 . IIale \& Co.. of Now IIaven, Conn, where ho remained two years perfenting his knowlelge of tho trale. Ho possesses all the requlsites for building a large establishment in the enterpriso in which he is enguged. He was an membor of the tirm of Wuener, lingham of Ilull, of Now Brighton, for a period of 3 years, prior to foundug his present establishment. $R$. W. Iall is also a native of licaver Co. ho learned the trallo of machinist in Wellsville, (O, , und followed it unthl engthing with his brother in their present bisiness, aking chargo of tho forging and bheksmithing department of the works, as well as devoling his atiention to the sale of the products. Both gentlemen devole their personal attention to the manufituring, and are regarded as in overy way a reliable and onterprising firm.

EMERSON SA W WORKS,-Emerson, Smith \& Co., Beaver Falls, Pa.

In the entime rangy of this work, revlowing the industrint interesis of the State, no establishment will be found more worthy of eousideration, none thut has achleved more notable triumphs for Ameriean skill and in rentivegenius, than the

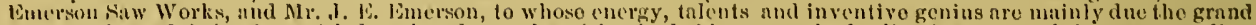

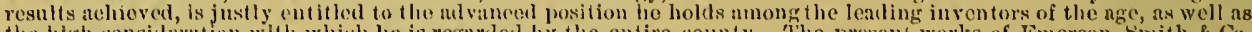
the high consideration with which he is regarded hy tho entire county. Tho present works of Emerson, smith \& Co. were fomblol in 1871 on a much smuller seate than at prescnt prevals, the rapid growth of the lousiness having neces-

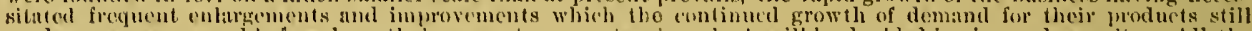
renders noessing, and before long their present very uxtensive plant will bo doubled in si\%o and capacity. All tho

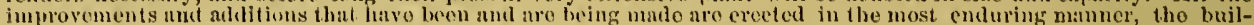
dings boing built of stomo in \& very substanthul way, that will last for generations. They new cover un aren of 1 acre of ground, with 2 aeres of aljoining ground, that will doubtless in a few years also be nilized in tho enlargement of the works and the extension of their lacilities. Tho entire works are fitted with the most perfeet machinery that can

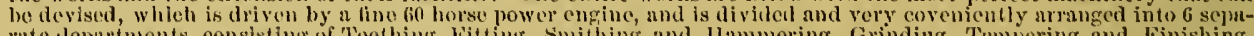
rate lopartments, consisting of 'Toothing, Fitting, Smithing and llammering, Grinding, Tempering and Finishing. The wholo being under tho direet supervision of Arr. Emerson himself, who, with years of practieal oxperience and knowledge derived from a elesse stuly of the requirements of a perliet salw-is perhaps the most seicutifie say maker In the world. The estullishment now muks ns one of the largest in tho $U$. S. It is most eligibly situated on the banks of Baber liver, with comveniont acess to an ahumdanee of ehemp fuel, having in addition the advantages of a natural gas with in close proximity to the works, which is now Ireing utilized to supply light to the buillings, and is

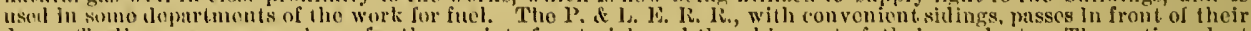
door, athording every convenience for the receipt of materials mul the shipment of their products. The entiro plant represonts an investment of $\$ 75,000$. Wrom 35 to 10 lumels are employed in the various departments of the works, all of whom are skilbel mechanies. Ditmas'us fempered saws of all descriptions are mate, but the main products of the works consint of the spediaties helow mentioned, viz: Lmersolt's l'atent Planer Sitws, for general uso; Emerson's Patent Flange 'Toothed saws, for general usu; Eunerson's l'nunt Clipper lilango Toothel Saws; Emerson's l'ntent Lum-

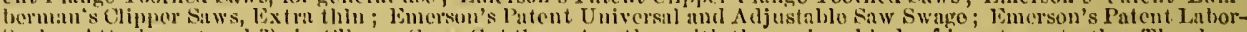

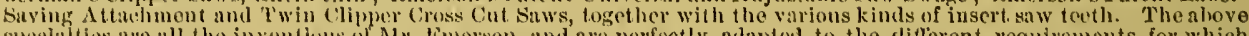

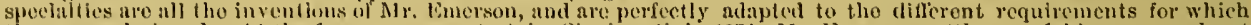
they were designed. At the famous saw contest in Cincimnti in 187.t, Mr. Emerson, with ono of his saws made at these works, fully tomonstrated their superiority over all other kinds, and earrict off tho purso of $\$ 100$ in gold and all the preminus that were awathed, as well as huving cartied ofl the mroniums at wherever they have been exhibited, for hoth solit and adjustuble test suws. Tho grand achievements of these works are matters for justitiable mride, and no estahlishment in the workl ean present 1 more splendid record. A thorough knewhedge of, and close atiention to the business. They use only of the very lest guality of materinl, and the employment of tho most skillful workmen have contributel to the restils altainel. 'The P'aner sitw tooth is now one of tho principal spectalties invenfed liy

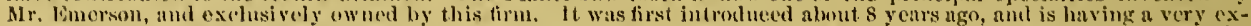
tensive sale, it is clesigned to obviate tho needssity of filing, and so cheaply uro they made and suppliel, that it is fur cheapre to uso the planer bit, than fo lite the saws; they ure sold at thren ecrits cach. The many very highly compliuentary letters reeed ved ly the firm from their debighled cetstomers in all purts of the country and world, fully atfest the great superiority of the planere teoth and other styles of saws here male, spmee will not permit of mention of the very mumerous ingenius inventions of great ntility, relating to the saw business, that have ben male by Mr. Emerson, and that are manufactured at these works, his invertive genius secms to bave covered tho whole range of sawing and sawInill applianes and derlsed the many improvements that have made his name so well known throughout the whole

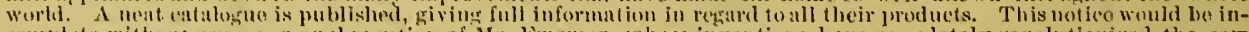
complete without some personal mution of Mr. limerson, whese inventions hatre completely revolutionized the saw

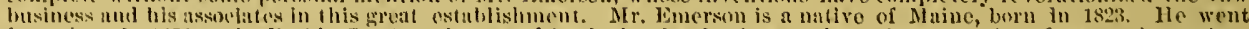

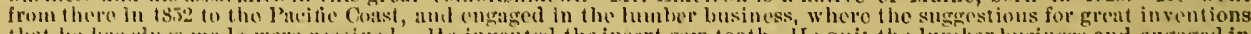

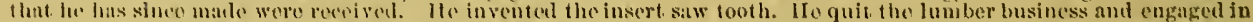

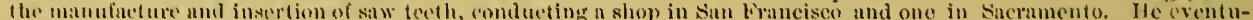

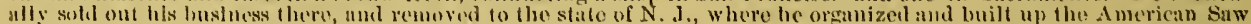

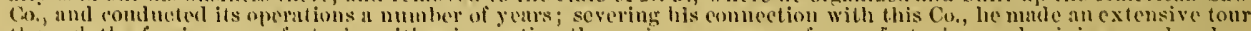
through the foreign manulacturing eities, inspecting the various processes of manufacturing, and ganing much valua-

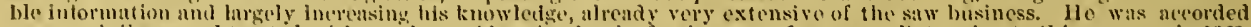
many privileges and troted with much consileration by the foreign manufacturers. licturning to this eountry in 1869 ,

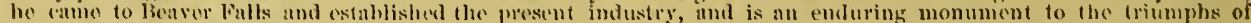

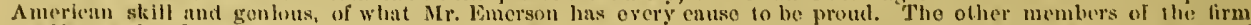
ate Messiss, los. 13. Smith und Julius le. Kurt\%. Mr. Smith wis formerly a lirge eontractor and builder, and severul of the premineut builulugs of Piteshurgh were crected by him, including the tine Union Depot that was destroyed by tho great July riots. Ife does not laka an artive interest in the business management, having retired from active businoss purstits. Mr. Jutius 15 , Kurt\%, the junior member of the firm, has chargo of the financial attitirs and generat onle buslness, a position for which he is emtnently qualitied by vears of practical experience, luving

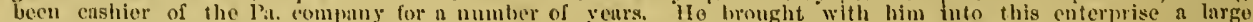
personal aequalntanee with the bisiness interests of the country with ability of a high order. The tirm of limerson, Smbth of Co., in thoir particulir lino of products, stands umrivalled by any cotemuonucous establislment in the world, and no word of commentation can more than oxpress the full nwitrd of merit that is justly their due, and their products are rapidly supplanting all other makos in overy part of the world, being far in advance In all the desirnble requisites in tirst elass articles of all other nakes, Alention should be mute of the fact that Ameriean steel is exelusively used in theso works, having jroven in overy respect equal to the best linglish steel over made, and in some resperes superior. 


\section{A. F. WOLF,-Manufacturer of Stoves and Hollow Ware, Beaver Falls, Pa.}

Among the number of tine maufacturing estinblishments in Beaver Falls, there are none more complete or perfectly arrauged in their way than the splentid new Stove Works of Mr. A. F. Wolf, whieh are worthy of more than passing notice, in a work reviewing the industries of this seetion. These works were originally founded by $A$. F. Wolf \& Co., afterwards earried on by Messrs. Hildenhrand \& Wolf in 1868 , on a mueh smaller seale than at present exists. In 1870 Mr. Hillenbrand withdrew from the tirm and tho business has since been condueted by Mir. Wolf himself. It bas gradually grown and inereased under the enterprising management of Mr. W., and onlarged faeilities were added from time to time to keep pace with the demand for his produets. A tine establishment had thus been built up, when, in the early part of the present year (1879) the entire establishment with all the valuablo patterns was burned to the ground, and the labor and toil of yeirs suddenly destroyed. With eharacteristic energy, Mr. W. inmediately set about repairing his loss, and in a brief time his present the works rero ereeted. They are in many respects model ones, and are as completely and conveniently arrunged as could possibly be desired, and every facility is aflorded for the perfeet and convenient manufacture of the ditjerent elasses of produets hero made. 'The building is 225 feet squaro, and the diflerent departments arranged in the most systematic mamer. The works are supplied with all the latest and most approved machinery requisite in this branch of industry. A new and eomplete set of patterns have taken the place of those destroyed, and the works in every respeet are superior to tho old ones. The cupola has a capacity of 7 tons. From $\$ 12,000$ to $\$ 15,000$ is invested in the plant, white a latge stock of Stoves and Hollow Waro is carried, as well as large quantities of raw material. 45 to 50 hands are employed, to whom $\$ 2,200$ per month is paid for wages. These works, in point of equipment and character of products, will compare most. favorably with any in the United States. The trade extends throughout the West and many parls of tho East. Shipments havo been made to Japan, from whenee a protitahle trade may yet be derived. $\Lambda$ spirit of progress and improvement pervades the whole establishment, improvements being eontinually made to their atready very excellent produets. Among some of the improvements that have been devised, the front top feed on all the cook stoves made, is one that has proven of great utility and convenience, and though tirst invented and adopted by Mr. Wolf on his stoves, has been adopted by many of the stove makers throughout the country, Mr. Wolf baving negleeted to jrotect himself by taking out patents. The invention is a very perfect and convenient.one, allorling an opening for supplying fuel without permitting the smoko and dust to escape from the stove, or without removing jots or kettles from it. "This, with other improvements, has given to the produets of this foundry an extended reputation, and has plaeed the "Iroward Coal Cook stove" and the "Woman's Rigits Wood Stove," in the front rank of the most popular stoves in the eountry. The praetieal working of the foundry is under the eharge of Mr. K. A. Thumpson, the superintendent, who is a thoroughly experienced stovo maker, and a gentleman of intelligenco and ability. Mr. Wolf is a native of Laneaster Co., this State, he has been engaged in the present. husiness since 1868 , prior to that time he had heen engaged in mereantile pursuits in Indiana and Obio. He is an enterprising publie spirited gentlemun, faking an aetive interest in the afficirs of the eommunity, with the interests of which he is closely idontitied. With the most perfect faeilities, large experienee and abundant means, Mr. Wolf is enabled to present advantages to the trade not easily duplieated in this or any other market.

\section{A. DAVIDSON,--Miner and Manufacturer of Coal and Coke, Beaver Falls, Pa.}

The hills adjoining the town of Beaver falls contain an abundant store of Coal, the vein being 3 feet thiek and the coal of an excellent quality. A number of pits are in operation along tho hillside-the most prominent and extensive being those of Alr. A. Davidson, which are locaterl on the line of the l'ittshurgh, Ft W. \& $C$. RY. on the western side of the town. Two main entries are driven into the hillside, from which the eoal is brought forth and run down an incline to the foot of the hill, where MIr. Davidson has recently erected a large building, $72 \times 16$ feet, with back building $45 \times 60$ feet, most conveniently arranged for loading, ete.. where the coal is screened and stored, and louded into wagens or ears for delivery to eustomers. The eapacity of these mines is from 75 to 100 tons per day, and from 10 to 30 miners are employed. The trade is mainly local, many of the maunfacturiug establishments being supplied from these works, besides a lirge number of private families. Coke is manufactured also, oll a limited sealo, the eoal making a good coke for somo purposes. Mr. Davidson is a uative of this jlace, and has been engaged in the cual business here since 1868, sinee whieh time his business has grown into its present large proportions. Prior to engaging in the coal buslness he was cugaged in the lumber business. He is a gentleman well known and esteemed in the community with whose interests lie is identlfiel. Ile is now prepared, with the increased facilities that have been addel to his works, to meet any demand that may be made upon lins.

\section{CO-OPERATIVE FLINT GLASS CO., Limited.}

Manufacturers of all kinds of Flint Glassware.

This new and extensive establishment, originated and successfully establishud by a number of practical Glass workers who eonceived the idea of uniting their savings and labor and establishing a faetory of their own, where the products of their willing hands might bo forned,-is deserving of particular mention in a detailed review of the great industries of this section. The faetory, which was ready for work and started up on the i8th of May 1879 within 3 wonths after ground had been broken-was built ly tho members of tho company, who all went to work with willing hands, and in this brief time had the satisfietion of having eompleted one of tho most perfeetly equipped and arranged glass faetories in the U. S. The works are most conveniently loeated and rare judgment was displayed in the selection of the site. The raw material is brought direct to their doers liy the P.\& $L_{\text {, E }}$. R. R., and the products of the factory" ile rolled direetly into the ears. The men in all the diflirent departinents are thoroughly experienced and skilled workmen, and are nearly all stoekholders in the eompany. The elass of work turned out evers the whole range of flint glassware and cmbraces n great varjety, of table ware, bar goods, jelly tumblers, toilet urticles, lamps, and every coneeivable variety of plain aud faney ware. The quality of the glass that. is now being mado here, is beyond a doubt equal in every respeet to nny heretofore made in the U. S. 'The results of their first 6 months' operations liavo been most gratifying, as they wero greeted with a rupidly increasing number of orlers from all parts of the enuntry, taxing their works to their uimost eapacity to meet the demand Notwithstanding the jealousy with which many of the older glass manufacturers of this section, who would gladly confine the produetions to themselves, look upon this new enterprise atul their wise predictions of failure, the suceess of the cnlerprise is now fully assured, and the fojular Co-Operative Flint (Glass Co are in a manly manner pushing their way to the favor of the trade in all parts of the eountry to the disadvantage of the older combinations. Mr. I. Stoclir, the elatiman of the company, is also General Superintendent of the works. He is a thoroughly (*ompetent and experiencel glass worker and an enterpising and popular gentleman, possegsing every requisite for the position ho holds. Mh. Jos. K. 13rown, the Secretary and and popular gentleman, possestion of the euterprise is maiuly due, bas becil connected with the glass business for Treasurer, to whom the inception of the enterprise is mainly due, has becil connected with the glass business for sight into tho details of the business managoment of the glass business, and formed an extensive acquaintance wilh the trade throughout the enuntry. He is well fitted for the position he bolds, and possesses unany qualities that have sceured for him the esteem of his associates, as well as all who know him. The members of the company throughout aro all men of eharaeter and exprrience, who liave enjover the confideneo of the eommunity in which they havo lived, and bring inte their now enterprise the liearty cond-will of the entire public.

With abundant facilities, cheap transportation, possessing within itself skilled and praetical workmen in erery department, and a deternimation to merit the Tighest suceess, this eompany is fully competent to hold their own against any adverse cireumstances that may arise, und to protuee artieles as low as any eoneern in the U. S. Prompt and reliable, all orders ontrusted to thelr hands are cxecuted in the most satisfactory inanner. 
The greatly $d$ 'yersified character as wcll as the magnitude of the $($ feat industrial establishments that lave sprung into existence at the bidding of the genius of enterprise and progress in this great Iron centre of Americn, is perhaps but faintly realized by even her own citizens, and the value and importance of a work of this nature, conveying some adequate idea of the magnitude, extent and variety of the great industries of this section, is auparent to all who give the subject thought, and the dissemination of such knowledge as herein contained, throughout all parts of the world, must be largely conducive to the interests of all in any way connocted with the prosperity of the community at large, as well as the individual establishments themselves.

The Pittsburgh Hinge Co, Limited, pursuing a special brauch of manufacture, of a class of articles adapted to the great agricultural interests of the country, on a scale of great magnitude, are deserving of uncre than crdinary consideration in these pages. The company was organized in 1875 , and leased the works at Beaver fialls now occupied, which had previously been operated by the firm of Reiter \& Armor, in the exclusive manufacture of Hinges. These works since coming into the hands of the present company lave becn greatly improved and enlurged, and facilities added for the manufacture of the many varieties of goods now made. The plant consists of one main 3-stury fraine building 70 ly 140 feet, one 3-story stone building $5 \mathrm{~J}$ Ly 120 feet, chain shop 120 by 180 feet. The whole estalslishment is titted with machinery of the most perfect kind, much of which is novel and peculiar to this establishment, and is admirably adapted to the work that it so wonderfully performs. The uachinery is driven by water power aggregating 120-horse power. The machinery (the patent belonging exclusively to this Co.) for making their celelurated Quadrate Barb Fence Wire, is the nost perlect in the world and gives to this establishment a great advantage over any contemporaneous concern in the same line. The works are capable of producing two car loads of their various goods per day. Their trade extends to all parts of Auerica, and their products are rapidly finding foreign warkets, possessing undoubted superior qualities. lirom 250 to 300 hands are employed in the workshops trade reaches in the neighborhood of half a million dollars anmually. The products of these works consist of al The rieties of agricultural chinins, such as Cuil, Well, Trace, IJalter, Log Chatins, etc. IIame Clips, Crow bars, Harrow Teeth, Fire Shovels and Pokers, Strap and T Hinges, Screw and Strap Hinges, Single Trees, Doutıle Trees, Neck Yokes, Wrought Iron Seat Hooks, Clevises, Wagon and Plow Nails pointed by hand, patent Picket and Tent Pins, Lap Rings, Repair Links, aud a great variety of other agricultural hardware. No other establishuent in the U. S. covers the
sime range of products as this. Wherever these products lowie heen sold, they have met with the approval of all who have used them, and they rank anong the best goods in the market.

THE QU.IDRATJE B.Inn FliNCE IVIKE. - One of their leading specialties is an article that so perfectly supplies a want long felt, so fully meeting all the requirements of a durable, perfect and cheıp fenco that, though of coupuratively recent introduction, the demand for it lias grown so rapidly that the capacity of the works have heen fully taxed to meet the demand. The advantages of the barb fence are so numeroms, while heiug the cheapest fence viade, thit it is apparent to all that the demand for it will continue to increase mure rapidly in the future than heretofore. The advantages possessed by the Quadrate Barb Wire over other styles are set forih in the following claim: Having four points standing at right angles. Bitch barb is tirmly fastened to its place und warranter not to become loose or slide along the wlre. The barbs remain equally firm on single and $t w i s t+d$ wire. The wire is $t$ isted by a process that does nut

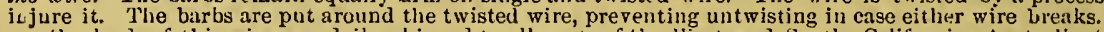

Car-loads of this wire are daily shipped to all parts of the West and South, California, A ustrallia, South America, and other distant parts. Mr. J. H. McNahon, Treasurer, has charge of the business unangement of the estublishment, to whom all cumbunications stould be addrissed. He is a native of Pitsburgh and has lieen identitied with the iron business since boyhood. The patrons of the establishment will find in him a gentlemall of high character, at whose hands they will receive the fairest trea tment.

The Pittsburgh Hinge Co. in their great products offer inducemeats to the trade that are not easily duplicated by any establishmeut in the United States.

\section{PENN BRIDGE WORKS, -S. T. White, C. E., Beaver Falls, Pa.}

These Works were originally founded in 1864 by T. B. White \& Sons, at New Brighton, on a much smaller scale than at pres+llt prevails. In 1876 the firm was dissalved, and the business has since then been conducted by his son, Mr. T. S. White. On tise first of April 1879 she works were removed to their present location in Beatver Falls, where at much more eligible situation was secured, affording greatly increased facilities for the rapidly enlarging lousiness. New works were erected, which are 60 feet wide and 241 feet long, finely fitted with uev and inproved machinery and convenient and necessary appliances for the successful prosecution of work, and in masy resjects are very complete and well equipped. All the modern appliances and machinery required for the most perfect work are to be found in them

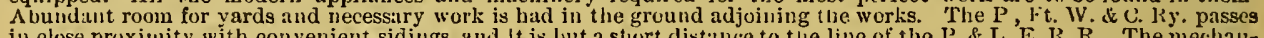
ical departwent of the work is under the direct supervision of Mistance to the line of the I'. \& L. E. R. R. The mechanlthorough knowledge of bridge architecture reuders him peculiarly fitfed for the business 30 to 40 hands are emplored in the works, to whom from $\$ 1000$ to $\$ 1500$ per month are paid. lirum 8000 to 12,000 tons of iron are consumed annually. The trade of the Penn Bridge Works extends to wany distant parts of the U. S.. bridges liaving been erecied in Massichuset.ts, Iowa, Missouri, Mississippi and nfany other States, while a large amount of work is clone in building county bridges throughout neighboring counties, contiguous to these works. Nlans of the fine iro. br:dges on the line of the P. \& L. E. R. R. were erected by these works. A 700 foot irou tridge across the Beaver at this pomt is now in process of erection by them. The fine bridges on l lock and Vater st., Muadville, l'a, whish are prominest fur their symmetry and beanty, were also erected by Mr. Whute. These worlis with their ncw and enlanged iucilities are prepared to do work in any part of the country on as reasonable terins as any establislmont, and can take contracts and execute work in the inost prompt and satisfactory manner. Nany improvements suggested by ycars of practical experience and study have been made, and are peculiar to these works; among other notable pointe, cast iron details in the collstruction of bridges liaving been done a way with. The tracle of these works, alrealy large, is ralpidly extending. Mr. T. S. White was born in New Brighton in 1852. He has thuroughly qualified himself by study for the business in which he is engaged. Ile is a gradunte of Cornell lJniversity in the degree of Civil Engineer, and since that timc has been connceted with these works. The Penn Works in their br:ancli of business offer superiur inducements and are worthy of unst favorable consideratiou at the liands of thuse requiring their class of work.

\section{GARDNER HOUSE, CHICA GO.-Jevett Wilcox, Manager.}

\section{CORNER MICHIGAN AVENUE AND JACKSON ST.-Rates $\$ 2.60$ and $\$ 3.00$ per day.}

The GARDNER, in als the appointments, Juxuries and comforts of a lirst-class hotel, hats no superior in the city. Mr. Jewett Wilcox (late of the Tremiont) having assumed the management, calls the :ttention of his friends, patrons, and the traveling public generally to the fact that in point of desirable surroundings, the Gurdner-being situated on one of the loroadest and nost fashionahle avenues in the city, dircetly facining the like, from which it is only separated by the park in front of the house-lias many advantages in its attractive location nut josscssel by an other hotel in the city. 250 romns newly and elegan,ly furnisherl; convenient to all places of amuscunent; only one illnck from strent cars running to all parts of the city. This short distance is more than compensated fint thy the delighiful lirezes fium the lake, making the Gard ner unequalled as a Summer Hotel. SPLCIAL CONTRACTS inide to delegations, excuisions, conventions and permanent guests. 

1825-1877.

(Compiled from the Reports of the Secretary of the Treasury for 1863 and 1873, the Cornmercial and Financial Chronicle, Reports of the N. Y. Chamber of Commerce, and the N. Y. Shipping List and Price Current.)

The following table, carefully compiled from the sources indicated, takes the prices of the twelve monihs in ench year, selecting the highest and lowest quotation for each article. It is to be understood, where no mention of quality is made, that the price quoted is for the cheapest grade of each commodity.

The prices are those of the New York ruarket.

\begin{tabular}{|c|c|c|c|c|c|c|c|c|c|c|c|c|c|c|c|c|c|}
\hline \multirow{3}{*}{ Year. } & \multicolumn{2}{|c|}{ Beef, Mess. } & Butter. & \multicolumn{2}{|c|}{ Cheese. } & \multicolumn{2}{|c|}{$\begin{array}{c}\text { Coal. } \\
\text { Antluracite. }\end{array}$} & \multicolumn{2}{|c|}{$\begin{array}{l}\text { Coffee, } \\
\text { Rio. }\end{array}$} & \multicolumn{2}{|c|}{ Corn. } & \multicolumn{2}{|c|}{$\begin{array}{l}\text { Cotton, } \\
\text { Upland. }\end{array}$} & \multicolumn{2}{|c|}{ Flour, West. } & \multicolumn{2}{|c|}{ Hauss. } \\
\hline & \multicolumn{2}{|c|}{ Bhl. } & \multirow{2}{*}{\multicolumn{2}{|c|}{$\frac{\text { lb. }}{\text { L. H. }}$}} & lb. & & Din. & & & Bus & & 1 & & $\overline{\mathrm{B}}$ & & - 16 & \\
\hline & & H. & & & & L & H. & & $\overline{\mathrm{H}}$. & & $\mathrm{H}$ & & & & & & \\
\hline & & & & & & & & & & $\mathrm{cts}$ & & 91 & & & & $\overline{c t s}$ & \\
\hline & 03 & 1200 & 2 & 22 & & 800 & 110 & & 19 & 42 & $7 \%$ & 13 & $2 i$ & 325 & & & $i 1$ \\
\hline & 00 & 10001 & & 18 & 12 & 1101 & & & 13 & 62 & & & 14 & 425 & & & \\
\hline & 50 & 9751 & 12 & 22 & 10 & 1 1) 50 & 12 & 14 & 15 & 54 & $7 \%$ & & 12 & & & 10 & $1 \%$ \\
\hline & 5) & 100 & & 18 & 7 & $100)$ & & & 15 & $41 i$ & 6 & & 13 & & & & \\
\hline & $801)$ & 10501 & 12 & 164 & 4 & $10(0)$ & & 12 & 13 & 48 & & & 11 & & & & 10 \\
\hline & 762 & $\left.\begin{array}{ll}10 & 00\end{array}\right]$ & & 66 & 8 & & 120 & 10 & 12 & 48 & & & $1: 3$ & & & & 11 \\
\hline & 700 & 9251 & & 18 & 8 & $6 ! 0$ & 90 & 110 & 13 & 54 & & & 11 & & 725 & 9 & \\
\hline & 837 & 10751 & 12 & 185 & 7 & 850 & 1 th 0 & 12 & 14 & $50)$ & & & 12 & & & 9 & 1 \\
\hline & 50 & 11 & & $2(1)$ & () & $5: 0$ & 100 & 11 & 14 & 6ว & & 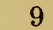 & 17 & & & & \\
\hline & $51)$ & 10 & 12 & 17 & 9 & $5 !$ & & 11 & 12 & $5:$ & & 10 & & & & & \\
\hline & 875 & 135 & & 22 & 9 & $5:$ & & 11 & 13 & 70 & & & 0 & & & 8 & \\
\hline & 925 & 135 & 10 & $\begin{array}{ll}26 & 7\end{array}$ & 12 & 7 & 11 & 11 & 13 & 83 & & 1 & 20 & & 102. & 9 & 17 \\
\hline & 1100 & & & $24 \quad \dot{7}$ & 12 & & 11 & 9 & 121 & 00 & & & 18 & & & 9 & \\
\hline & $1 \pm 0$ & 16 & 17 & 27 & 10 & 7 & & 9 & $12{ }^{2}$ & 76 & 100 & & 12 & & $00^{\prime}$ & 10) & 1: \\
\hline & 125 & 16 & & 258 & 12 & & & 9 & 12 & 75 & & 11 & 16 & & & 11) & \\
\hline & & 14 & & 21 & 9 & & 85 & 9 & 12 & 4 & 6 & & 10 & & & 4 & \\
\hline & 70 & 102 & 8 & 15 & 7 & 6 & 9 & 9 & 11 & & & & & & & & \\
\hline & 62 & 825 & 9 & 15 & () & & & 6 & 10 & & & & 9 & & & 4 & \\
\hline & 6 & 83 & 6 & 11 & 6 & & & 6 & 9 & & & & 8 & & & 3 & \\
\hline & & 67 & 8 & 14) & 7 & & & 6 & 7 & & & & 9 & & & & \\
\hline & 50 & 97 & 9 & 176 & 8 & 4 & 60 & 5 & 8 & 4 & & & 9 & & & 5 & 10 \\
\hline & 6 & 85 & & 176 & 8 & & & 6 & 8 & & & & !) & & & & \\
\hline & 25 & 137 & & $2: 2$ & 8 & & & 6 & 8 & & & & 12 & & & 6 & \\
\hline & & 13 & & 5 & & & & 5 & 8 & & & & & & & & \\
\hline & & 11 & & & 7 & & & 5 & 10 & & & & 11 & & & (i) & 1 \\
\hline & 8 & & & 4 & 4 & & & $n$ & 14 & & & & & & & & \\
\hline & & & & & 8 & & & 7 & ] & & & & 14 & & & & \\
\hline & 825 & 17 & & 2.9 & 6 & & & 7 & 11 & & & & & & & 8 & 10 \\
\hline & 70 & & & 24 & 8 & & & & 1 & & & & & & & & \\
\hline & 800 & 3 & 15 & fi & 12 & & & 8 & ] & & & & & & & 7 & 1 \\
\hline & & & & & 6 & & & & 1 & & 11 & & & & & & \\
\hline & co & 12 & & & 11 & & & 9 & 1 & & & & 12 & & & 9 & 1 \\
\hline & & 5 & & & 5 & & & 10 & 1 & & & & & & & & \\
\hline & & 12 & & & u & & & 9 & 1 & & 11 & & & & & & \\
\hline & 5 & & 14 & & 2 & & & & & & 1 & & & & & & \\
\hline & & & & & 12 & & & & 1 & & & & & & & 111 & 1 \\
\hline & & 6 & 8 & & 2 & & & & 1 & & & & & & & 7 & 1 \\
\hline & & 10 & & & & & & & 3 & & & & & & & & \\
\hline & & & & & & & & & 33 & & & & & & & 5 & \\
\hline & & & & & & & & & & & & & & & & & \\
\hline & 90 & & & & & & & & & & & & & & & & \\
\hline & 110 & & & & & & & & 21 & & & & & & & & \\
\hline & & & & & & & & 17 & 191 & & & & & & & & \\
\hline & & & & & & & & & & & & & & & & & \\
\hline & & & & & & & & & & & & & & & & & \\
\hline & & & & & & & & & & & & & & & & & \\
\hline & & & & & & & & 12 & & & & & & & & & \\
\hline & 40 & 12 & & & 0 & & & & & & & & & & & & \\
\hline & & 12 & & & $11 i$ & & & & $2: 3$ & & & & & & & ; & \\
\hline & & 1 & & & 17 & & & & 28 & 5 & & & & & & & \\
\hline & & & & & & & -7 & & 21 & & & & & & & & \\
\hline & 85 & 31 & 15 & 8 & 13 & & & & 2 & 3 & & & & & & & \\
\hline & 950 & 11 & & & & & & & & & & & & & & & \\
\hline
\end{tabular}




\section{6}

\section{OWEST AND HIGHEST PRICES OF COMMODITIFS FOR FIFIY-THREE YEARS- $1825-1877$.}

(Coinpiled from the Reports of the Secretary of the Treasury for 1863 and 1873 , the Commercial and Financial Chronicle, Reports of the N. Y. Chamber of Commerce, and the N. Y. Shipping, List and P'rice Current.)

NoTE.-In the Amerlcan A Imanac and Treasury of Facts for 1878, pp. 278-9, appeared a tahle of prices compiled on the basis of the averare price of each article in New York, the 1st of January of each year. Such a lable, however useful, fails to give the data which are important in forming a judgment of the whole range of prices for each year. The following table, carcfully compiled from the sources indicated, takes the prices of the twelve months in each yenr, selecting the lighest and lowest quntation for each article. It is to be understood, where no mention of quality is made, that the price quoted is for the cheapest grade of each commodity.

\begin{tabular}{|c|c|c|c|c|c|c|c|c|c|c|c|c|c|c|c|c|}
\hline \multirow[t]{3}{*}{ Years. } & \multicolumn{2}{|c|}{ Pork, Mess. } & \multicolumn{2}{|c|}{ Rice. } & \multicolumn{2}{|c|}{$\begin{array}{c}\text { Salt, } \\
\text { Liverpool. }\end{array}$} & \multicolumn{2}{|c|}{$\begin{array}{l}\text { Sugar, } \\
\text { Raw. }\end{array}$} & \multirow{2}{*}{\multicolumn{2}{|c|}{$\mid \begin{array}{l}\text { Tolnce } \\
\text { col Ky. } \\
\text { Leaf. }\end{array}$}} & \multicolumn{2}{|c|}{ Wheat. } & \multicolumn{2}{|c|}{ Whiskey. } & \multicolumn{2}{|c|}{ Wool. } \\
\hline & & & 100 & bs. & $\mathrm{Sac}$ & & & & & & Busl & & G: & a). & Ib. & \\
\hline & $L$. & $H$ & $L$. & H. & L. & H. & & & & $H$. & $L$. & $H$. & & $H$ & & II. \\
\hline & & & & & & & & & et & s. & & & & & cts & \\
\hline & 200 & 4. & 2110 & 400 & 237 & 300 & & & 3 & 9 & 75 & 10 & 25 & 31 & & 38 \\
\hline & 00 & 1200 & 200 & $\begin{array}{ll}3 & 87\end{array}$ & 212 & 260 & 6 & 10 & 3 & 8 & 84 & 102 & $\because 6$ & 36 & 28 & 38 \\
\hline & 25 & 152 & 250 & 400 & 215 & 235 & 6 & 10 & 3 & 6 & $91)$ & $\begin{array}{ll}1 & 25\end{array}$ & $\because 5$ & 35 & $\therefore 0$ & 30 \\
\hline & 1200 & 1500 & 50 & 401 & 225 & 325 & 6 & ]11 & 3 & 6 & 95 & 162 & 20) & ngl & 21) & 30 \\
\hline & 01) & 13 & 250 & 3 & 212 & 300 & 5 & 9 & 5 & & 100 & & 21, & $21 i$ & 18 & 27 \\
\hline & 00 & 1550 & 2110 & 3511 & 175 & 250 & 6 & 9 & $\ddot{3}$ & $\pi$ & 100 & & 21 & 32 & 16 & 30 \\
\hline & 10 & 15 & & 41 & 175 & 225 & 4 & & 3 & & 06 & & 27 & 37 & 21 & 35 \\
\hline & 1250 & 14 & 275 & 4 & 175 & 250 & 5 & 7 & 3 & 6 & 12 & & 26 & & ח & 35 \\
\hline & 1250 & 17. & 275 & 3 & 160 & 200 & 5 & $\vdots$ & 3 & & 15 & & 20 & & 27 & 35 \\
\hline & 75 & 150 & 225 & 3 & 140 & 18 & 5 & 8 & 4 & 8 & 102 & & 211 & & $\dddot{5}$ & 3: \\
\hline & 50 & 18 & 275 & & 147 & 25 & 6 & (4) & 6 & 11 & 104 & 150 & 30) & & $\div 5$ & 40 \\
\hline & 300 & 0 & 30 & & & $21:$ & 7 & 11 & 6 & 10 & 37 & & 31 & & 35 & St \\
\hline & 160 & 4 & 31 & 5 & 120 & 262 & 5 & 8 & 3 & 9 & 155 & & 20 & & $\because 8$ & 50 \\
\hline & $11 ; 50$ & 5 & 3 & & 162 & 237 & 6 & 8 & 4 & 13 & & & 0 & & 28 & 41 \\
\hline & 1450 & 235 & 30 & 5 & 144 & 2 & 6 & & s & 16 & 115 & & 28 & & 37 & 41 \\
\hline & 1300 & 161 & 275 & & 14 & 1 & 4 & 8 & 3 & 16 & 9.5 & & 21 & & 20) & 3 \\
\hline & 875 & 13 & & & 14 & 15 & 4 & 7 & 4 & 14 & 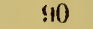 & & 9 & & 211 & 31 \\
\hline & 675 & 1) 2 & & & 13 & 22 & 3 & 7 & 2 & 9 & 8.3 & 1 & 16 & & 18 & 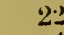 \\
\hline & 750 & 115 & 187 & & 135 & 10 & 3 & 7 & 2 & 7 & 8 & 1 & & & 17 & 2 \\
\hline & 850 & 11) 2 & 225 & 3 & $1 \div 5$ & 15 & 5 & 7 & 2 & 6 & 82 & & 21 & & 25 & 37 \\
\hline & $9: 5$ & 147 & 262 & & 132 & 14 & 3 & & 2 & 7 & 85 & & $20^{\circ}$ & & $\because 4$ & : \\
\hline & 962 & 133 & 287 & 45 & $1: 5$ & 15 & 5 & 8 & 2 & 7 & 80 & & 18 & & 18 & 28 \\
\hline & $10: 5$ & 16 & & 13 & 120 & & & & 2 & $\varepsilon$ & 105 & $1 !$ & $2 t$ & & $2: 3$ & 30 \\
\hline & $90 \subset$ & 13 & 775 & 13 & 1 :อ5 & 1 & 10 & 15) & 3 & \& & 9 & & 21 & & & \\
\hline & 987 & 14 & & & 12 & & & & 3 & 9 & 120 & & 20 & & 25 & \\
\hline & 100 & 118 & & & 115 & 1. & 4 & 7 & 5 & 14) & $\begin{array}{lll}109 & 09\end{array}$ & & 23 & & & 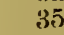 \\
\hline & . $06 \geq 0$ & 5 & & & 1112 & 1 & 4 & & 3 & 14 & 93 & & 20 & 27 & & 41 \\
\hline & & & & & 10 & & & & & 4 & & & & & 6 & t. \\
\hline & 1300 & 19 & & & 112 & 1 & 4 & 6 & 4 & 101 & & & & $\therefore:$ & 38 & \\
\hline & & 6 & & & 14 & & 3 & & 5 & 1) & & & 26 & & 25 & \\
\hline & 50 ב 12 & 23 & & & 90 & 1 . & 4 & 8 & 6 & 1.) & & & & & 24 & \\
\hline & 162 & 1 & & & 80 & $\begin{array}{ll}1 & 0.5\end{array}$ & 6 & 111) & 6 & 16; & & & & & 0 & \\
\hline & & & & & & & & 11 & 7 & & & & & & & 4. \\
\hline & & 19 & & & & & s & & 6 & 18 & & & & & & \\
\hline & & 1 & & & & 10 & & & 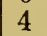 & & & & & & 34 & 43 \\
\hline & & 197 & & & ti & 115 & t & & 3 & 1 & & & & & & 8 \\
\hline & & 8 & & & & & & & 3 & & & & & & & \\
\hline & & 4 & & & & & & 11 & & & & & & & & \\
\hline & 11 & 8 & & & & & & & 8 & & & & & & & \\
\hline & & $4: 3$ & 70 & & & & & 25 & 8 & & & & & & 75 & 11 () \\
\hline & 190 & 315 & 975 & & & & & 17 & 7 & & & & & & & \\
\hline & & & & & & & & & & & & & & & & \\
\hline & 1890 & 24 & & & & & & 10 & J & & & & & & & \\
\hline & & 29 & & & & 2 & & & 8 & & & & & & & \\
\hline & 2150 & 3 & & & & & & ]:3 & & & & & i) & & & \\
\hline & 20 & 30 & & & & & 9 & 10) & 7 & & & & ב & & & \\
\hline & & & & & & & & 10 & & & & & & & & \\
\hline & & ; & & & & & & & & & & & 2 & & & \\
\hline & & 19 & & & & & 7 & 9 & 0 & & & & & & & \\
\hline & & 24 & i 7 & $10 \mathrm{C}$ & 11 & & & & & & 9 & & 2 & & & \\
\hline & 180 & 22 & & & $1 \mathrm{j}$ & $2:$ & 7 & !) & 9 & 2 & & & & & & \\
\hline & & 223 & & & & 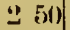 & & 100 & 7 & 19 & & & 04 & & 25 & 4: \\
\hline & & & & & & & & & & $1 i^{i}$ & 106 & 1851 & 04 & ] 19 & 32 & 43 \\
\hline
\end{tabular}




\section{NOTES ON THE GEOLOGY OF PITTSBURGH. \\ By B. C. JILLSON, M. D., Ph. D.}

At a meeting of the Chamber of Commerce, held June 3,1879 , Dr. B. C. Jillson, by special invitation, read a paper entitled, "Notes on the Geology of Pittsburgh." After its reading a committee was appointed to request the paper for publication in the forthcoming work of Mr. Richard Edwards on "The Industries of Pittsburgh."

It is said to be a wise provision of Nature which causes grcat rivers to flow near large clties; so we find it also a wise provision of Nature which, in like manner-though not always so evident to the casual observer-shapes the physical features of the country in such a way as to gire great ad vantages to one particular spot over another. Pittsburghers justly pride themselres on what they bave done liy their iudustry, energy aud business habits. Industry and energy, under intelligent guidance, will overcome all difficulties. Our fathers perceived the advantages of this locality which Nature had prepared for us, and availed themselves of it, and their sons have wisely followed in their footsteps. But have we done all we caln do? Have we improved all the advantages which Nature bas poured on us with such a lavish liand? Let us look at some of the geological ad vantuges of this locality.

Starting from the Atlantic seaboard and going west, we notice a wonderful difference in the physical features of the couniry in every few miles' travel. At first we find the rocks hard and coarse, and composed of various ingredients, bent and $t$ wisted so that they have no form or comeliness. Soon, however, these irregularities clinge, and wo find the rocks arranged in regular layers, forming ridges or waves, which increase in size till the huge folds familiar to us as the Allegheny mountains are reached. From the Allegheny mountains west ward the wares grow less and less through Jolanstown, Latrobe, Irwins, bardly perceptible in Pittsburgh, and gradually disappearing in the boundless prairies farther west. Clase examination shows that these rocks were folded by intense pressure and were accompanied by great heat, and that the migbty engine which accomplished this work was far east. The effect on tlie coal jllustrates this. The coal beds of Thode Island and Mussachusetts, estimated at 500 square miles, are pressed out of all shape-the maximum bed, thirteen feet in thickness, dwindling, away in many places to a tuere thread jammed into the hard uet:umorphic rock. The coal, too, has been so changed by heat that it is seldom used for fuel. Its character is well illustrated by the story of two New Englanders who were once conversing on the destruction of the world ly fire, when one of them remarked that if he were here at that time, and found the world was burning up, he would run and stand on tho Rliode Island coal banks, for he was sure they would be the last things to burn. Furtlier west, in the anthracite coal reglon, we tind the seams bent into nearly crery conceivable shape, dipping sometimes at one angle and sometimes at another-sometimes with the strike iu one dircction and sometimes at another, thongh in general from the north-east to the south-west. Farther west, at the Broad-Top field, the coal is neither anthracite nor bituminous, but partiking of the nature of both, and, tberefore, called semi-bituminous, and bere in Pittslurgh we find, for the first time, the coal jure bituminous, unaffected by pr...sure or beat, with all its chemical and physical characters well preserved. Our coal is located on the eastern border of an extensive coal field, which was unaffected by those agents which naturally clianged the coal and made such havoc with the layers of rcek further eust. But there is another aspect of this coal ficld which deserves our cousidcration, if we wouid realize how much Pittsburgh is indebted to Nature's slow and continusus labor long ages ago. The rocks in this vicinity are nearly liorizontal. Standing at the "Point," where the Allegheny and Monongahela unite to form the Ohio, we sec, opposite, Conl Ilill or Mt. Washington, rising abruptly, from the very brink of the river, more than 400 feet. This hill is comllosed of layers of rock arranged horizontally, with just enough difference in color and external appearnnce to be recoguized at this distance. At the base we sce about 100 feet of an olive or buff-colored slanle, and dircetly above it a layer of sandstone 75 or 80 feet thick, of a graj color and somerhat micaceous. Resting on this sandstone are layers of shale and limestone, the whole forming a bed of about 125 feet in thickness. Three nundred feet above the river we see distinctly the layer of coal, like a broad, black liclt, girdling the hill. Upon the layer of coal rests at least 100 feet of shales, sandstones and limestones. Up an $\mathrm{l}$ down the left bank of the Monongahcla and Obio, as fir as the eye can reach, these belts of rock can be plainly scen, undeviatingly in the order and position described. Looking now acrnss the Allegheny, in the rear of Allegheny City, we see exactly the same arrangement of rock-sliale corresponding to shale, sandstone to sandstone, limestune to limestone, to the fop of the hill, while beyond and at a greater licight we find the coal. Looking up the Allegheny river, we see the layer of shale forming Troy Hill, while at a greater height, in the dim distance, we see the openings in the coal layer. At the Union Depot we find the 100 feet of shale calped by the sandstone layer in the quarry back of the IIigh School building, while near the top of the hill the coal makes its appe:trance. These horizental strata which we see on every side, answering liyer to layer, are silent witnesses of the past They show plainly that the general surface of the surrounding country was at one time about 403 feet above where we now stand. If the rocks which form our county had bcen the hard granitic and metamorphic rocks of the custcrn part of our State, our valuable conl beds would hive remained covercd, and only accessible from the surface through more than 100 feet of solid rock, with all the attendant labor and expense; while all the advantages which Pittsburgh now ponsesses in the easy accessibilily to its co:l would have been wholly lost. But the rain, the snow, the frost, have worn aw wy und disintegrated our soft rocks, so that the whole surfuce of our county is agreeably diversified witb hill and dale, notonly adding to the beaty of the scencry, but, what is of more practicel value, permitting us everywhere to enter our coal scam at the surfice. Of this coal seam, the eminent geologist and celebrated traveler, Sir Cliarles Lyell, says: "I was truly astonished, now that I had entered the hydrograplical basin of the Ohio, at beholding the richness of the seams of coal, which appeared everywhere on the flanks of the hills, and at the botloms of the vatleys, and which are accessible in a degree I never witwessed elsewhere." Had the mighty power which folded the eastern rocks into liuge wares extended its influence to this part of the State, ourcoal banks, instead of being horizontal, would have been upheared at various angles, and the many faults would have added materially to the cxpense of mining. Each of onr large rivers, the Alleglseny, the Ifonongahela, the Youghiogheny, and the Ohio rivers, as well as 
Chartier's creek, Pine creck, Gerty's run, and, in fact, all our streams, both great and small, once flowed more than 200 feet above their present level. I have traced and unaped these ancient rivers through their various windings for 75 miles, from beyond Perryopolis, in Fayette county, through " White-Oak Levcl," back of Mickcesport, throngh Swissvule, Wilkinsburg and East Liberty. Fron this point one brasch passed through Bloomfield, Fricndship Grove, the upper part of Allegheny cemetery, and along the top of Troy hill to Hilldale cemetery. The other branch passed through Shady Side, Bellefield, Oakland, and along the tisp of Boyd's hill and Seminary hill, Allegheny, uniting with the first branch at Hilldale cemetery. From this point the uoited branches passed around the lhills lack of Manchester, making its first appearance on the present Ohio near the mouth of Wood's run. From this point it followed the general direction of the present Ohio, leaving its mark on each side of the river, in some placcs nearly 300 feet above the present water level. Since that time these rivers have somewhat changed their course, though not their general direction, digging the deep ditch for their present bed, in which ditch Pittsburgh has since been built. Were it not for this benevolent action on the part of Nature ages before we were born, our coal would now be elevated from the mines uy machinery, with its attendant trouble and expense, iustead of being mined as now, above the river, and sliot into barges by its own wcight. As thcse rivers wore away the rocks, they several times changed their course in liuited localities. The Alleglieny river at one time passed to the right of Seminary hill, its gravelly bottum forming the plain on which Allegheny City now stands. At a later date, it forced its way to the left of Seminary hill, making the channel in which it has since remained. The head of the Ohio was at one time at Hilldale cemetery, at another near Iunchester, and at a still later date at Suke's run, at the base of Boyd's hill, a mile above its present position. Every where tliese ancient rivers wrote the history of their movements.

Let us briefly note a few of the hieroglyphics they lave left, more easily translated than the hieroglyphics on the Egyptian monuments, which so long haffled the skill of our best scholars. The deposit of sand in Perryopolis utilizcd by the glass house there, and the immense number of bonlders scattered over the immediate vicinits" ; Finley's Sandwash in East Liberty, and the beds of sandstone, gravel and clay, and boulders deposited in that valley; the sand in the upper part of Allegheny Cemetery ; the beds of clay which have proved a source of protit to the owners of Boyd's Hill; the top of Troy Hill, as level as a flool for two or three miles; the deposit of gravel in which the basin for the Allegheny water works is placed; the immense beds of gravel near Hilldale Cemetery; the four feet of grarel on the top of IICKee's Rocks; the Terraces on the right bank of the Ohio on which Bellevue and other places are situated; the immense quantity of boulders at Beaver and Rochester, which for scores of years have becn drawn upon to pare the streets of our city; the beautiful terraces which marked its flood tides and former level, notedly those in McKeesport, in East Liberty Valley, the second bank in Allegheny and the four banks so plainly shown in the early settlement of our city, the largest and highest being the one on which Trinity Church and its surronnding grave-yard now stands.

Until the oil discovery a few years ago the Allegheny river was noted for its pure, clear water, while the Monongahela was equally well known as a muddy stream. Where they united at "the Point" the action of each river could be easily traced by the color of its waters. The Monongahela coming from the sonth and passing over the soft shales and clays and limestones of the carboniferous period, becane muddy from this source, while the Allegheny flowing through a region of hard conglomerates and sandstones remained clear. There is another marked difference in the character of these two rivers. The valley traversed by the Allegheny is narrower and the force of the stream much greater. From Oil City to Pittsburgh, a distance of 132 miles, the fall is 277 feet, averaging 2.1 feet per $m i l e$. while the more sluggish turrent of the Monongahela may be illustrated by the fact that the difference in the water level between Brownsville and Pittsburgh, a distance of $60 \mathrm{miles}$, is only 32 feet, averaging about six inclics 10 the mile. The Monongahela, therefore, brings down only finc sediment, while the force of the Allegheny is sufficient to move sand, gravel and fragnents of rock of considerable size. It also happens that the Allegheny and Monougaliela rivers strike the point at different angles and that the space between them upon which Pittsburgh stands was formed wholly from material brought by the Allegheny from the more northern part of the State. The larger part of botli Pittsburgh and Alleghen y are built on plains made up of porons layers of angular and rounded sand and gravel, and not upon a solid, impervious stratum of clag, such as the Monougahela would bave producerl. This seemingly slight difference in the direction of these two rivers and the difference in the character of their sedinent has formed in no slight manner the bygienic condition of our city. The early settlers built upon the plain 40 feet above low water mark. The porous nature of the soll and the surface drainage was then sufficient; but. the present size o: nur city demands careful and systematic sewage if we would escape those zymotic diseases which result from the veglect of the unst simple hygienic laws. With respect to drainage, few cities are more favored by nature tlisn ours. The hillside wards require no blasting for sewer-pipes, the rock being easily removed with the pick, while the wards of the old city can be easily excavated with the spade. The reservoirs of our water worky are of ample size, capahle of supplying our people with an abundance of water for many years to come, wluile one of them is located more than 500 feet above the river. With such natural and artificial advantages why should not Pittsburgh be the cleanest city in the United States, and forever prevent a repetition of the South Side diphtheria cpidemic of 1877 and the Reform School typhoid fever epidewic of 1875 , both of which were greatly aggravated, if not directly caused, by improperly constructed aud grossly neglected sewer pipes? A nother peculiar feature of the two rivers which bound our city, is the unsynmetrical character of their rise and fal]. Being large rivers and draining a considerable extent of country, they are like all large rivers subject to times of great and sudden overflow. The Allegheny rises in Southern New York, nearly $43^{\circ}$ $\mathrm{N}$, and the Monongahela in West Virginia, about $39^{\circ} \mathrm{N}$. These sources, then, being some $4^{\circ}$ apart, are, of course, subject to local influences of a very different character, and the tide or rise of these rivers are quite different. One river may be quite low and the other at flood-tide, and a little time after the reverse may be the case. The materiai brought down the river and the decomposing vegetable matter on its banks and on the low ground near the shores, produced much malarial sickness, but the settlement of the neighborhood, with the natural and necessary improvements on the shores, has nearly eradicated the disease. Of course, the sudden and great rise and fall of the rivers still continues, and is carefully watched by those whose business necessities require it. A metcorological phenomenon connected in 
some way with theso rivers or with the deep gorges through which they pass, is worthy of careful consideration. Sometimes a rain storm will come up the Olio and either pass up the Allegheny Valley or up the MIonongahela Valley, or, dividing, will not unfrequently pass up both. Sometimes a storm will pass across from one river to the other, confined to a very limited area. A few Sundays ago it rained hard on Ilerron's Hill, while in the lower ward of the city and at Shady Side 110 rain fell. A few days after it rained hard in the lower part of the city, with none at Millvale Station on the P. R. R. I think I never saw it rain harder than it did at the Union Depot some two years ago, but not a drop fell at Lawrenceville R. R. station. Many other similar illustrations could be given. You all remember the terrible calanity which befel our city in July, 1874, when $t$ wo hundred persons lost their lives at Butcher's Run. A few careful observers. with the proper instruments, taking systematic and syncronous observations over the area described, would, in a few years, I doubt not, be able to explain the laws which govern these singular movenents.

Our rocks, as you well know, belong to the carboniferous system. The rocks forming this system are conglomerates, shales and sandstones, more rarely limestones. They oscur in various alternations with an occasional bed of coal between them. All the coal beds taken togetber make not more than one-fiftieth of the whole thickiess. Just here in Pitsburgh we have but one layer of coal in situ, though to the north we bave coal beds which are geologically lower thau our own, and to the south we have coal beds that are geologically higher than our own; the rocks hero in Pittsburgh, not being exactly horizontal, but dipping slightly to the south, so that the rocks concealed from view below the bed of the river outerop farther north, and the rocks which top our highest bills, extend over the whole country to the south of us. On the left or west bank of the Monongahela, opposite Pittsburgh, a steep bluff rises from the bank of the river 450 feet. The highest rocks are not well exposed, but the occasional outcrops show that they constitute a part of the great limestone formation which shows itself in all the counties sonth of Pittshurgh, between the Chestnut Ridge and Obio River. "It may be traced up the Monongahela River from Pittshurgh to the Virginia line." It varies in thickness from a few feet to fifty or seventy-five and is often mixed with thick layers of sandstone and shales. It makes a most excellent lime and is extensively burned in the eastern and southern part of our county. While there are several other layers of limestone in this vicinity geologically lower than the one under consideration, they are quite thin and make but poor line, and are but little used.

H. D. Rodgers says, "It is the most extensive and valuable deposit in the valley of the Monongahela, or any where else in the western counties of the State." Between the limestone layer just described and the Pittsburgl coal are layers of a yellow ferruginous shale interspersed with a gray, slaty, and in many places very micaceous sandstone, ahout 75 or 80 feet thick. The Pittshurgh coal seam comes next in order. The peculiar features of the Pittsburgh coal are well known to you. The late Henry D. Rodgers calls it "coal of the purest kind," and J. P. Lesley says, "It is pure bituminous coal, yielding 40 to 45 cubic feet of gas to ten pounds of coal where best known and very free from sulphur." But there are some other characteristics of this bed which makes it of peculiar value to the geologist. Its duil character and its great extent of surface make it a landmark-the base line of carboniferous geology. This remarkable bed has been identified over an area of 20,000 square miles and is everywhere the same double bed. It is found in Virginia, Ohio, Kentucky and in other parts of our own State, and everywhere the impure slate above retains its proportionate relation to the whole mass. For example, in our eight-foot vein we bave five or six feet of solid coal below, with abont two feet of impure coal above. In the Cumberland basin where the vein is twelve or fourteen feet in thickness, we have nine or ten feet of coal below and three or four feet of the shaly structure ahove. At Wheeling, Virginia, with its six-foot vein, at Athens, Ohio, with its fire-foot vein, at Guyandotte, West Virginia with its two or three-foot vein, this peculiarity is preserved. Is it not strange that over a country as great as 20,000 square miles the circumstances should bave been so similar as first to permit and foster the growth of vegetable matter for a long time, and tinen to cover it so universally, over this whole area, with sand and clay and an imperiect vegetation? The amount of vegetable matter necessary to form one foot of coal has been estimated to be about eight feet, or over 60 feet for such a bed as that of Pittsburgh.

Below the coal there are some eight or ten layers of limestone from one to two feet thick, and separated frow each other by layers of dark-colored shale-the whole forming a bed of about twenty-five feet in thickness. The sliale or sandstone upon which this bed rests is about thirty-fire feet thick, and in some places is composed almost wholly of shale, while in other localities the shale passes into very thin layers, and the sandstone expands into blocks sufficiently thick for building purposes. Below this we find a bed of limestone four feet thick, separated from another two-foot vein by 12 feet of yellowish shale. Below this last layer of limestone are 35 feet of buff shale, and theu another layer of limestone three feet in thickness-hard, compact, and of a yellowish color. This rests on a stratum of shale marked with iron, sometimes passing into a coarse, slaty sandstone-the whole 10 or 12 feet thick. Then follows a red or mottled shale, 12 feet in thickness, sometimes wanting, but generally exposed around Pittsburgh. All the layers just deseribed which lie below the coal have as yet been of no great value to Pittsburgh. The iron is a mere trace, the shale of no practical value, and the limestone is so thin as to be of little importance as a source of lime for masonry or agriculture. The next layer is one of considerable value, being a sandstone 75 or 80 feet in thickness, and extensively used for building purposes. It varies in color, quality and appearance, heing generally of a gray color, sometimes very micaceous, with the ware and ripple marks well shown. It also varies nuch in durability, sometimes remaining unchanged for years, but often weathering badly and crumbling on exposure. Great care should therefore be used in its selection. The court house shows the weathering action in a marked degree. Stone from other quarries, but belonging to the same geological layer, are in general inuch more durable and serve a good purpose. Most of the stone, however, now used for heavy masonry in our city, comes by rail from some distance, notably from Freeport and other places up the Allegheny-from Baden and Beaver, down the Ohio-and from Ligonier, Westuoreland county, on the Pennsylvania Central Railroad. The stone from the Allegheny and Ohio belong to the Freeport, Butler and Mahouing gronps-are geologically lower than our Pittsburgh rocks-are concealed from view below the bed of our rivers, but crop out farther north. The Ligonier sandstone is probably the same laver as our Pittsburgh sandstone just described, but much more durable. At the base of the hills which surround our city we find 100 feet of olive or buff-colored shale, which seems universal throughout the county. The lower part of this 
led is easily dccomposed, weathering into a stiff claty, while tho upper part is of a harder structurc, often contuining thick layers of sandstone, with, in some localities, fine impression of plants. This rock is sounetimes divided very regularly by numerous straight, vertical planes of fracture, parallel to one another, separating it into large, angular blocks, giving to the rocks where it occurs a front like a fortification. On a level with the river, but generally coulcealed by detritus, is a layer of black slate, two feet in thickness, resting on a bed of coal about one foot thick. Theso layers liave been notleed in Wilkins, Versailles, Indiana, Ross and Shaler townships, in cach case having about the same thickness, and in many cases the appearance and properties of cannel coal. Where it outcrops along Butcher's run, on each side of the Perrysville road, it is a good bituminous cotl.

The rocks coucealod from vicw below the bod of the river are not so wcll known; and, although there are many borings in this immediate vicinity, littlo or no attempt is made to keep a correct account of the layel's jassed through. When this is done, it is generally a difficult matter for any but an experienecd person to distinguish hetween coal and black slate, and the nature of the rock bored, except in hardness, color, and the like general characteristics. As all our rocks dip slightly to tho south, the gencral character of the rocks below our eity can be determined by their outcrop farther north. * * * * * * ** * * * * * * * * * * *

Before closing, permit me to call your attention to a discovery of much interest connected with the pre-Adamic history of our city. At a pullic lecture given in the High-School building, winter before last, I had the pleasure of showing a fossil tooth of the Elephas primogenus, or Mammoth, and also of one of another species of elephant famillarly known as the Mastodon. The Mammoth's tooth was exhumed from the gravel while excavating for the piers of the Point bridge. It was in good condition, and is now in the possession of a gentleman living on the South Side. The Mastodon's tooth was found in the Obio near Sewickley. On exposure, it soon fell to pieces, but with care and skill it was restored. I have just learned that Prof. Ward, of Rochester, N. Y., will, this year, place in the Expositjon building his restoration of the large Mammoth found wcll preserved in the ice cliffs in Silheria. This restoration will give some idea of the first settlers of Pittshurgh, who once roaued over our hills and iuhalited our valleys.

\section{PITTSBURGH COAL AND COKE REGION.}

The business that is done here in the course of the year is most difficult to ascertain, as the railway companies do not separare their tonnaye into that carried throngh, and that for local use. It is safe to estimate the sun total from the inmediate vicinity at 5,200,000 tons. This is mainly forwarded to points North, South, East and West, by rail and water. The shipments of coal and coke by the river to points below the city last year amounted to over 2.627 .750 tons.

The coal shipped down the Ohio river from the neighborliood of Pittshurgh is obtained fron receipts through the medium of the Monongahela slack-water navigation system, and the coal curried by the Saw-mill Run Railway. The totals are as below :-

Coal and slack from Pool No. 1.

Coal and slack from Pool No. 2 ....... $12,237,465$ bushels.

Coal and slack from Pool No. 3 $34.263,450$ bushiels.

Coal and slack from Pool No. 4 $11,3336,100$ hushiels.

Total Coke ..................................................................... 6, 887,000 bushels. $12,101,210$ bu:hels.

Saw-mill Rui Railroad Coal Tonnage total it $1878 \ldots \ldots . . .2,321,991$ bush., or 88,235 net tons.

'The above rives the tonnage that starts ont from the several mines along the rontes namerl and is what is known as 'river' coal. A portion is left for local consumption in Piltsburgh, Allegheny, etc., and the following is a summary of the entire morement of coal and colie:

Coal by slack-water. $69,9: 38,255$ r,ushels.

Coke by slack-water. $6.887,000$ hushels.

Coal by Saw-mill Run Railroad $2,321,991$ bushels.

T'otal movement....

Shipments down the Olio.

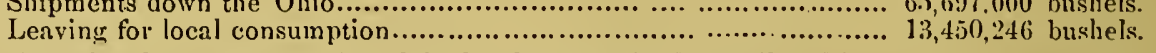

There is a large amount of coal for local use received by rail and it may be estimated at twice as much as the above quantity. Estimate 25 bushels to the net ton.

The first Bituminous coal district of Pcnnsylvania embraces the counties of Washingrton, Westmoreland, Fayette, Green, Somerset, Bedford and nearly all of Alleghenty. There were two hundrerl and forty-four mines, employing more than ten men, of which two lundred and seventeen were in operation during the year 1878 :

Number of men employed insicle the mines, estimated........................... 15, 190

Number employed outside, estimated.............................................

Estimated amount of coal produced in the whole district in tons of $2,000 \mathrm{lbs} \ldots . .9 .372,881$

Estimated average price paid (exclusice of nut coal) for mining per ton of $2,000 \mathrm{lbs} 42$ cents.

Estimated number of tons mined per miner............................................. 5 (io

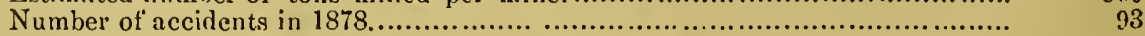

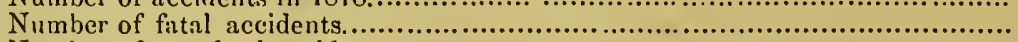

Number of non-fatal accidents.........................................................

Estimated amount of coal produced for each fatal accidcr.t, in tous...................

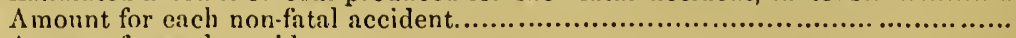

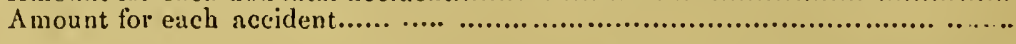


The colie industry in this district is a most important one. There are 3,902 overs, with a daily capacity of '241,9.24 bushels. 'They are all located at Westmoreland and Fayette counties, and l'an two-thirds time upon the average.

In coking the coal, the beehive oven is in universal use in the Connellsville region. These ovens vary, at the different works, from 11 to 12 feet in diameter and from 5 to 6 feet in height. Jhe working is very simple. 'The coal is dumped through an opening in the crown of the furnace and spread evenly on the floor to the average depth of 2 feet for 48 -hour coke and $2 \frac{1}{2}$ feet for 72 -hour. The front opening through which the colie is discharged, is at first nearly closed with brick, luted with loam. The heat of the oven from the previous coline fires the charge. and as the coling progresses the air is more and more shut off by luting the openings, and finally closing the roof openings. 'lhe average charge is 100 bushels of coal at 76 lbs., and the rield in colie 120 bushels at 40 lbs., making the percentage yield 63 , or 1.6 tons of coal to 1 ton of colie. The average time of coking is 48 hours, with 72 lours for that burned over Sunday. 24 -houx colie is sometimes madf. The $72-$ hour coke is firmer colie than either of the others, but it is questionable whether it is a bettel firrnace colie. When the colie is thoroughly burned the dour is removed and the colie is cooled by water thrown in from a hose, and then drawn.

The statistics of this trade are surprising. The manufacture began in the wintel of $1841-2$. According to the latest information we have, there are 3,668 ovens in the Connellsville region, and nearly all are in operation. Annual output at present is about $1,500,000$ tous.

\section{MONONGAHELA COAL REGION.}

By means of its slack-water navigation, the Monongahela river is made navigable at all seasnns of the year, and boats carryine eight huudred tons are passed down. "The city of Pittsburgh is supplied mainly by railroad, and the larger portion of the coal br river is run down the Ohio and Mississippi to the lower markets. The following statement of slipments by the slack-water navigation from 1845 to date, is of interest:

\begin{tabular}{|c|c|c|c|}
\hline YE IR. & *Toxs. & YEAR. & TONS. \\
\hline $1815 \ldots \ldots \ldots \ldots . . . . . .$. & 184,200 & $1857 \ldots$ & $1,158,939$ \\
\hline $18+6 \ldots \ldots \ldots \ldots \ldots$ & 311,156 & $1858 \ldots \ldots \ldots \ldots . . . . .$. & $1,027,866$ \\
\hline $1847 \ldots \ldots \ldots \ldots \ldots . . . . .$. & 385,805 & $1859 \ldots$. & $1,131,467$ \\
\hline $1818 \ldots \ldots \ldots \ldots \ldots$ & 392,774 & 1860. & $1,517,909$ \\
\hline $1849 \ldots \ldots \ldots \ldots \ldots$ & $398,3+0$ & $1861 .$. & 834,630 \\
\hline $1850 \ldots \ldots \ldots \ldots \ldots$ & 491,918 & $1862 \ldots$ & 743,358 \\
\hline 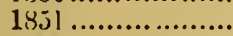 & 490,850 & $1863 \ldots$ & $1,134,150$ \\
\hline $185, \ldots \ldots \ldots \ldots \ldots$ & $585,2: 33$ & ................ & $1,40^{\circ}, 828$ \\
\hline $18.53 \ldots \ldots \ldots \ldots \ldots$ & $6: 28,654$ & .. $\ldots \ldots \ldots \ldots . .$. & $1,580,79$ \\
\hline $185+\ldots \ldots \ldots \ldots \ldots . . . .$. & 693,278 & $1866 \ldots \ldots \ldots \ldots \ldots$ & $1,704,21$ \\
\hline $1855 \ldots \ldots \ldots \ldots \ldots$ & 889,360 & (.............. & $1,202,90$ \\
\hline $1856 \ldots . . . \ldots \ldots \ldots . . . .$. & $35: 3,364$ & ................ & $1,812,0$ \\
\hline
\end{tabular}

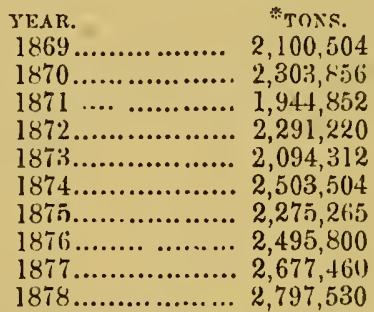

* We liave estimated 25 bushels of 80 lbs, to the ton of 2,000 lbs.

The business done br the various railroads entering or passing through this coal field, is indicated by the fact that in 1878 the Pennsylvania Railroad carried upwards of $1,429,428$ tons from this district. In this connection, the cost of transporting coals over waterwars, as from Pittsburgl to New Orleans, is of value. 'The distance is something like 2,000 miles, the rate is abont 33 cents per bushel, or $\$ 1.05$ per ton of $2,240 \mathrm{lbs}$; the ordinary time being about two weeks when all circumstances are fivorable. From Pittsburgh to Louisville, Kr., the distance is six huridred miles: the cost $1 \frac{3}{4}$ cents per bushel, including return of empty craft; and the time five dars. Coke forms a considerable item in the business from this regrion. Some 129.000 tons were shipned last year. It weighs $40 \mathrm{ll}$ s. to the bushel, and $62 \mathrm{2}$ lbs. of colie represents $100 \mathrm{lbs}$. of coal, so that of the total product of this region in $1878,1,5 \pm 8,428$ tons was sent out by rail.

\section{SHIPMENTS OF COAL AND COKE BY THE MONONGAHELA NAVIGATION COMPANY.}

In connection with the table just given we ald below the statistics of total sbipments of conl and coke by the Monougaluela Nivigation Company from 1844. when the first shipments were made, to 1878 , for which we are indebted to the personal courtesy of Hon. J. K. Mosihead, the president of the company. The shipments are given in bushels, each thousand busliels being reg:trded as the equivalent of 38 gross tons, which makes the weight of a "bushel 85.12 pounds.

\begin{tabular}{lc|cc|cc|cc} 
Years. & Bushels. & Yrars. & Bushels. & Years. & Bushels. & Years. & Bushels. \\
1841 & 737,150 & 1853 & $15,716,367$ & 1862 & $18,583,956$ & 1871 & $48,621,300$ \\
1845 & $4,605,185$ & 1854 & $17,331,946$ & 1863 & $26,444,252$ & 1872 & $57,80,500$ \\
1846 & $7,778,911$ & 1855 & $22,231,009$ & 1864 & $35,070,917$ & 1873 & $58,276,995$ \\
1847 & $9.645,127$ & 1856 & $8,584,095$ & 1865 & $39,522,792$ & 1874 & $65,881,700$ \\
1848 & $9,819,361$ & 18.77 & $28,973,596$ & 1866 & $42,605,310$ & 1875 & $63,707,500$ \\
1849 & $9,708,507$ & 18.58 & $25,696,669$ & 1867 & $30,072,700$ & 1876 & $68,481,000$ \\
1850 & $12,297,967$ & 1859 & $28,286,671$ & 1868 & $45,301,000$ & 1877 & $79,480,918$ \\
1851 & $12,5.21,228$ & 1860 & $37,947,732$ & 1869 & $52,512,600$ & 1878 & $76,825,255$ \\
1852 & $14,630,841$ & 1861 & $20,865,722$ & 1870 & $57,596,400$ & Totul, & $1,153,646,169$
\end{tabular}




\section{COAL TRADE OF THE UNION.}

We give below the tonnage for the year 1869 , as per census reports made in 1870 , together with figures for the year 1878 , where available; in other cases we have made a careful estimate, based upon our reports of the trade in the various States:

\begin{tabular}{|c|c|c|c|c|c|}
\hline & 1869-tons. & 1878-tons. & & 1869-tons. & $\begin{array}{r}\text { 1878-tons. } \\
300,000\end{array}$ \\
\hline Antliracite..... & $\begin{array}{r}13,866,180 \\
798,517\end{array}$ & $17,605,262$ & 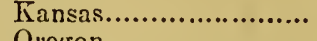 & 32,938 & 300,000 \\
\hline ....... & $2,629,563$ & $\begin{array}{r}13,500,000 \\
3,500,000\end{array}$ & Michigran ...... & 21,150 & $\begin{array}{r}200,000 \\
30.000\end{array}$ \\
\hline & & & California................... & & 600,000 \\
\hline & 1,81 ? & 1,67 & and ......... & 14,000 & \\
\hline ............ & 621,930 & 900.0 & ....... & & 200. \\
\hline ............... & 608,8 & & & & \\
\hline .................. & 437,870 & & & & \\
\hline (................ & & & Wa & & \\
\hline ............ & 150,582 & & 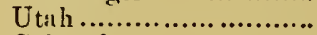 & & \\
\hline .......... & & & Colorado................. & 4,500 & 367,000 \\
\hline & & & Total, & $31,11 \digamma^{\prime}, 595$ & 130,584 \\
\hline
\end{tabular}

COAL TRAFFIC OF THE PENNSYLVANIA RAILROAD.

Disteict.

YEAR 1878.

YEAR 1877.

YEAR 1876.

694,180

54,738

87,905

189,394

42,985

$1,340,744$

184,464

187,345

58,483

39,010

39,010
635,990

786,039

64,905

$1,374,396$

$107, \mathrm{~S} 40$

94,685

10,789

D. H. \& W. Anthracite
Lewisburg Antluracite.

Coke.

Westmoreland region

Cok

692,586
78,766

429,438

128,918

Total in tons of 2,000 lbs. - coal .............................................. $\overline{3,920,766}$

Total in tons of $2,000 \mathrm{lbs}$. - coke.

$1,085,990$

$4,086,674$

687,172 65.999 44,461 147,512 50,916

$1,190,48$ 209,315

173,324

57,797

157,150

539,640

896,590

59,462

162,126

95,434

8,863

$4,018,159$

819,125

IRON AND STEEL PRODUCTION OF PITTSBIIRGH AND ALLEGHENY COUNTY, PENNSYLVANIA, FROM 1874 TO 1878.

So much interest is taken in the progress of the iron and steel industries of Pittsburgh and vicinity, that we have annually for several years given the statisties of their production exceptional prominence. In the following table these statistics for the past five years are presented:

\begin{tabular}{|c|c|c|c|c|c|}
\hline YEARS. & $\begin{array}{l}\text { Number } \\
\text { of Iron } \\
\text { Rolling } \\
\text { Mills. }\end{array}$ & $\begin{array}{l}\text { Product of Iron Rails, } \\
\text { Bar, Angle, Bolt, Rod } \\
\text { and Iloop. Net tons. }\end{array}$ & $\begin{array}{l}\text { Product of Sheet and } \\
\text { Plate, except Nail } \\
\text { Plate. Net tons. }\end{array}$ & $\begin{array}{l}\text { Product of } \\
\text { Nails. Kegs } \\
\text { of } 100 \mathrm{lbs} \text {. }\end{array}$ & $\begin{array}{c}\text { Total Rolled Tron, } \\
\text { including Nails. } \\
\text { Net tons. }\end{array}$ \\
\hline $1874 \ldots \ldots \ldots . . . . . . .$. & 31 & 194,114 & 52,361 & 562,995 & 274,625 \\
\hline $1875 \ldots \ldots \ldots \ldots \ldots$ & 31 & 171,178 & 45,773 & 442,359 & 239.069 \\
\hline $1876 \ldots \ldots \ldots \ldots \ldots$ & 31 & 189,511 & 31,488 & $5: 38,874$ & 247,943 \\
\hline $1877 \ldots \ldots . . . \ldots \ldots \ldots$ & 31 & 208,342 & 30,254 & 5997,806 & 268,486 \\
\hline $1878 \ldots . . . . . . . . . . .$. & 31 & 226,687 & 33,445 & 444,013 & 282,333 \\
\hline
\end{tabular}

\begin{tabular}{|c|c|c|c|c|c|c|}
\hline YEARS. & $\begin{array}{l}\text { Number } \\
\text { of Blast } \\
\text { Furnaces }\end{array}$ & $\begin{array}{l}\text { Make of Pig } \\
\text { Iron. } \\
\text { Net tons. }\end{array}$ & $\begin{array}{c}\text { Number of } \\
\text { steel } \\
\text { Works. }\end{array}$ & $\begin{array}{l}\text { Make of } \\
\text { Crucible Steel. } \\
\text { Net tons. }\end{array}$ & $\begin{array}{l}\text { Make of all nther Steel, } \\
\text { including Bessemer } \\
\text { Ingots. Net tons. }\end{array}$ & $\begin{array}{l}\text { Total make } \\
\text { of Steel. } \\
\text { Net tons }\end{array}$ \\
\hline 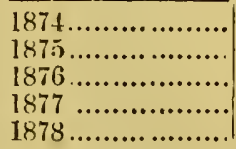 & $\begin{array}{l}11 \\
11 \\
11 \\
12 \\
12\end{array}$ & $\begin{array}{l}143.660 \\
131,856 \\
128,555 \\
141,749 \\
217,299\end{array}$ & $\begin{array}{l}11^{\frac{* 4}{*}} \\
14^{*} \\
14^{*} \\
14^{* *} \\
14^{* *}\end{array}$ & $\begin{array}{l}17,915 \\
22,942 \\
25,009 \\
24,747 \\
27,866\end{array}$ & $\begin{array}{r}6,000 \\
15,498 \\
54,467 \\
82,401 \\
106,948\end{array}$ & $\begin{array}{r}2: 7,915 \\
38,440 \\
79,476 \\
107,148 \\
134,814\end{array}$ \\
\hline
\end{tabular}

* Bessemer steel included; four of these works are aḷo iron rolling mills. 


\section{AMERICAN RAILROAD BUILDING-1878.}

The fact is worthy of record, that during 1878, there was a greater number of miles of railway built in America, than for any year since 1873. The details are given below, and are all collated from the Railroad Gazette:

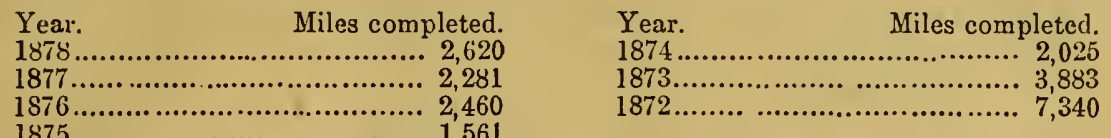

During the year just ended, Minnesota built 338 miles; Iowa, 255; Colorado, 193, of which 86 were of three foot guage; Pennsylvania, 182; New York, 142; J'exas, 118; and at the other ex treme, New Jersey, but three miles; Massachusetts, six, and Arliansas, seven.

\section{IMMIGRATION INTO THE UNITED STATES, 1820-1878.}

Prior to the year 1820 , no statistics of immigration were officially kept. By the act of Congress of March 2,1819, collectors of customs were required to keep a record and make a quarterly. return to the Treasury of all passengers arriving in their respectire districts from foreign ports; and these reports, published from time to time by the officers of the Treasury Department, constitute the sources of information as to the growth and progress of immigration. Ihe total number of foreign-born passengers arriving at the ports of the United Stutes, in the several years from 1820 to 1870 , inclusive, is given below.

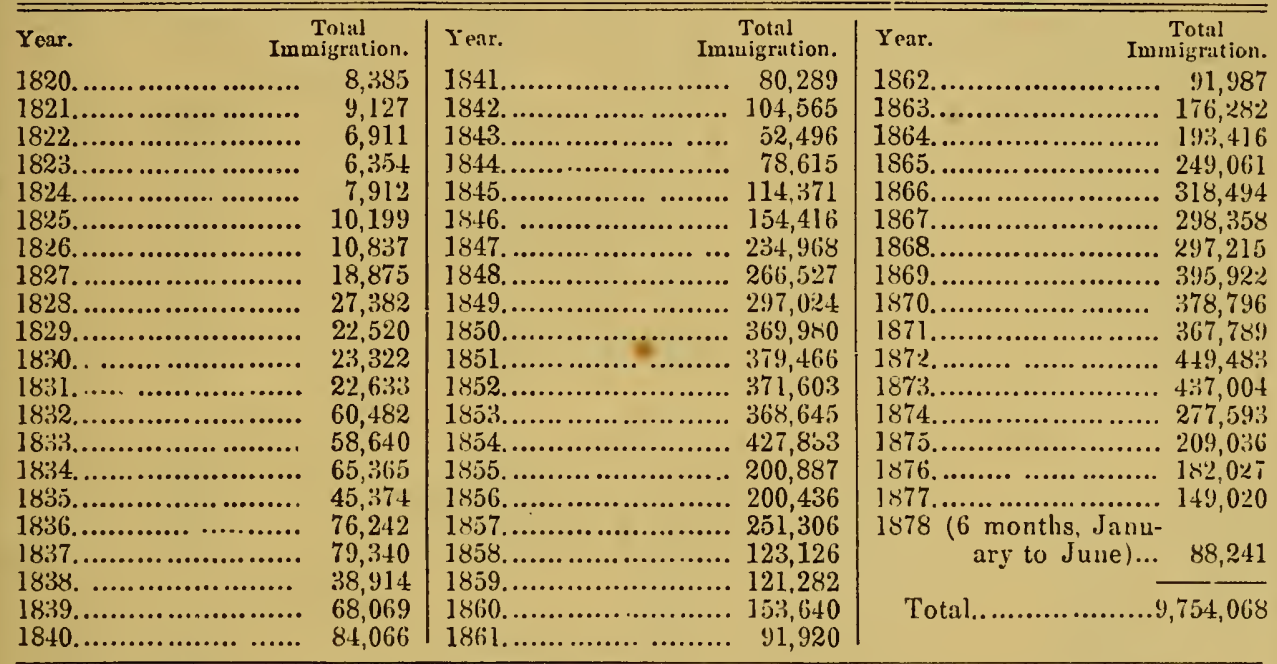

Note.-The above figures, from 1850 to 1877 , are for calendar years-Janutury 1si to December 31st. Other statements of immigration vary, being for fiscal yeurs ending June 30th. Another siource of variation is that some tables give the total number of aliens arriving in the United States; otleers what is called the net immigration only. As Ihe. latter is not ascertainable for all the years, the figures above given represent the total immigration of aliens in each year.

CHINESE IMMIGRATION INTO THE UNITED STATES FOR EACH CALENDAR YEAR FROM 1855 TO 1876, INCLUSIVE.

\begin{tabular}{|c|c|c|c|c|c|}
\hline Year. & Number. & Year. & Number. & Year. & Number \\
\hline $1855 \ldots \ldots \ldots \ldots \ldots \ldots . . . . . . . . .$. & 3,526 & $1864 \ldots$. & .. 2,795 & $1873 \ldots$ & 18,154 \\
\hline 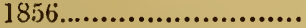 & 4,733 & $1865 \ldots$ & 2,942 & $1874 \ldots$ & $16,65 \mathrm{l}$ \\
\hline $1857 \ldots \ldots \ldots \ldots \ldots \ldots$ & 5,944 & $1866 \ldots \ldots \ldots \ldots \ldots \ldots \ldots$ & 2,385 & .... $\ldots \ldots \ldots \ldots, \ldots$ & $19,0: 33$ \\
\hline $1858 . . . . . . . . . . . . . . . . . . . .$. & 5,128 & $1867 \ldots \ldots \ldots \ldots \ldots \ldots \ldots \ldots \ldots \ldots$ & .. 3,863 & (n................... & 16.879 \\
\hline $1859 . . . . \ldots \ldots \ldots . . . . . . . . . .$. & 3,457 & $1868, \ldots \ldots \ldots \ldots \ldots \ldots$ & .. 10,684 & $1877 \ldots \ldots \ldots$. & 10,379 \\
\hline $1860 \ldots \ldots \ldots \ldots \ldots \ldots \ldots$ & 5,467 & $1869 \ldots \ldots \ldots \ldots \ldots \ldots \ldots \ldots$ & . 14,902 & 1878 (January to June) & 6,269 \\
\hline $1861 \ldots \ldots \ldots \ldots \ldots \ldots \ldots \ldots$ & 7,518 & $1870 \ldots \ldots \ldots \ldots \ldots \ldots \ldots$ & .. 11,943 & & \\
\hline $1862 \ldots \ldots \ldots \ldots \ldots \ldots \ldots \ldots$ & 3,633 & $1871 \ldots \ldots \ldots \ldots \ldots \ldots \ldots$ & . $\quad 6,039$ & Total........ & 0,110 \\
\hline $186: 3 \ldots \ldots \ldots \ldots \ldots \ldots \ldots \ldots$ & 7,214 & $1872 \ldots \ldots \ldots \ldots \ldots \ldots \ldots \ldots$ & .. 10,642 & & \\
\hline
\end{tabular}

Nот k.-The statement is made that nearly one-half of all the Chinese who have arrived in the United States have returned to their bative conntry. 
FIRES IN FIFTEEN YEARS-LIST OF THE MOST DESTRUCTIVE FIRES IN ALLEGHENY COUNTY SINCE $1864-$ GROSS LOSS NEARLY $\$ 10,500,000$-INSURANOE NEARLY $\$ 6,000,000$.

Mr. James E. Stevenson, late Fire Mirshal, has farored us with a list of the principal losers by fire in Allegheny County from August 20th, 1864, to March 23d, 1879, as follows:

Year 1864.

Chess, Smythe \& Co..........................\$ $93,070 \quad \$ 56,925$ Year 1865.

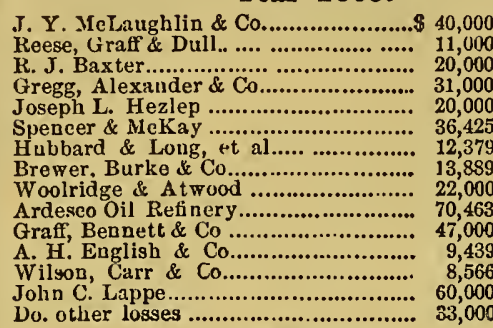

Year 1866.

Citizen's Passenger Railway.............\$ 24,000

Dicksou, Marshall \& Co ...................... 16,200

Kautfmun \& Oppenheimer................. 21,897

Fahnestock, Hazlet \& Sebwartz ....... 11,124

Oluhausen \& Crawford........................... 10,548

Johu Heath et al................................ 41,300

Pittshurgh Forge \& Irou Co ............. 12,000

Guthrie \& Sill .................................... 31,215

Pittsburgh Acid Co.......................... 53,625

Kier \& Mitchell et al ........................ 12,200

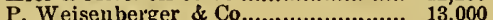

Lafayette Hatll....................................... 50,842

Union Iron Company........................... 14,000

Hayes \& Stewart et al ........................ 35,000

Wormser, M yers \& Co.......................... 68,000

A rdeseo Oil Co................................... 35,000

Laughlin \& Co.......................................... 65,000

James Bennry....................................... 20,800

W. \& D. Rineliart ........................................ 22, 22,648

Fleruing, Torrence \& Co.......................... 33,069

\section{Year 1867.}

White, Berger \& Co

Chess, Smythe \& Co................................ 47,153

Atlas Works ........................................... 18,000

Miller, Barr \& Parkin......................... 20,231

Lafferty \& Co. et al.......................... 27,000

Wood \& Lukens................................. 11,0 11,5

Gillespie \& Mitchell............................ 11,049

Collins \& Wright.................................... 16,534

Reese, Graff \& Dilil................................. 22,000

Zug \& Co........................................ 17,000

\section{Year 1868.}

A. F. Engl lsh \& Co. et al ...................\$117,563 Stuekrath \& Co ................................... 15,000 Plttsburgh Bclt Company ..................... 50,000 William Semple ................................. 6,300

.... 119,000

(1)

J. \& W. Gaskell.................................. 18,012

Sirnb \& Zahringer..................................... $\quad 7,185$

Bellefield Church ................................ 18,300

\section{Year 1869.}

Pittsburgh Glass Company .............\$ 10,000

Evans, Clow, Dalzell \& Co.................... 30,800

James Bown............................................ 8, 8,913

Hlawatha House ...................................... 24,535

Semple, Reynolds \& Co...................... 21,561

Lit Belle Steel Works. .................... 27,187

Forsy the Bros. \& Co . ................... 2?0,6so

House of Refuge Shops ........................ 13,000

John F. Wolfe et al., Sick'pt.............. 33,757

Pennsylvania Salt Co.......................... 25,000

Cubbage \& Ferguson ............................ 15,000

A rmstrong Bros. \& Co ....................... 16,134

Frazier Bros......................................... 28,000
$\$ 10,200$

11,000

7,500

6,000

11,000

36,425

12,379

13,889

22,000

50,882

17,000

9,439

8,566

8,000

$\$ 11,781$

16,200

21,897

7,700

9,500

14,000

10,000

21,000

26,551

11,000

8,000

41,221

9,600

25,236

(7,

18,034

12,875

15,000

22,648

23,069

27,622

$\$ 8,000$

45,060

13,230

10,000

11,865

8,873
11,549

11,549
6,000

16,534

14,850

5,440
12,830

12,830

69,853

15,000

87,999

6,300

18,300

18,012

4,510

14,800

$\$ 9,765$

19,813

7,032

6,535

15,646

16,689

71,987

7,500
14,745

17,511

8,100

9,506
S. J. \& J. N. Large.

Gross Loss. Ins. Paid.

Little \& Baird

George Smith \& Co.............................. $\quad 26,500$

\section{Year 1870.}

Mellinger, Estep \& Co.........................\$ 11,443

Livingston Brothers ....................... $\$ 11,400$

Douglass \& Hayes................................... 19,000

Jackson, MieEwen \& Co........................ 7,650

Sharpsburg Bridge................................. 45,000

Forsy the Brot.hers ... ........................... 13,500

Ring Oil Cotnpan y........................... 83,000

Natioual \& Citizen's Oil Compan y....... 33,245

H. W. C. Tweddle.......

Kirkpatrick \& Co .................................... 11,500

Reese, (7raff \& Dull................................... 6,300

James Callery et al......................... 34,500

Pittsburgh Tanning Co. ct al .............. 22,000

Kenned $y$ \& Brother....................... 109,283

John B. Kenned y ...........................

Jones \& Nimiek ........................................ 157,000

Chambers \& Co........................................ 11,987

Year 1871.

Lane Brothers et al......................\$ 21,183

Snith \& Portcr et al............................. 82,000

Rylay \& Robinson ............................. 20,000

Howard \& Son et al.......................... 85,000

St. Bridget's R. C. Chureh.................. 27,000

Eleventh Ward School House............ 9, 9,200

Bailey, Farrell \& Co $0 . . . . . .17,200$

W. D. Wood \& Co.................................... 25,000

Jacob Franz ...................................... 8, 8,

Sampson's IL eirs.................................. 9,000

Wm. MeKce it Co.............................. 24,800

George G. Miller........................... 30,000

MeKnight \& Co...................................... 56,585

H. M. Bole......................................... 45,000

Year 1872.

Jones \& Laughlin................................\$169,435

D. P. Reighard............................... 10,000

Waring and others ......................... 15,000

B. L. Fahnestock............................... 75, 743

W. B. Lupton \& Co............................... 20,900

H:artje, W ylle \& Co............................ 90,604

Joseph Wailton.

Year 1873.

Hamllton, Lemon \& Co....................\$38,960 William Graff \& Co.............................. 41,000 National 'Tube Works.............................. 103,372

Arbuckle \& Co................................. 10,649 J. $K$. Noorhend .............................. \$ 44,525

Keefer \& Herchenroctlier et al........... 81,804

Mulen, Steen \& Co............................. 11,455

Freeman \& Burgcr................................... 28,214

George W. Jordan .............................. 10,000

J W. Lewis ................................... 33,000

W. Smith \& Son .............................. 13,612

Jo'n Phillips ............................. 18,090

Stewart, Cook if Co............................... 14,267

G. E. Williams \& Co.............................. 10,907

\section{Year 1874.}

Bellerue School House....... \$ 11,000

A. Garrison

Pittsburgh Car Works........................... 16,453

Appe \& Rogers, and others................... 88,350

Alleghen y Car Company ....................... 25,000

iv. Frank \& Sons................................. 23,330

Great Alleghen v Fire....................... 244,709

Standard Oil Works........................... 40,000

Fairview Uil works................................. 43,729

Reese, Owens \& Co.................................... 26, 2618

Jrihn Appel et al.................................. 23,8

oil Works, Herr's Island........................ 30,700

R. P. Burgan et : :l.......................... 14,000

10,525
7,183

115,500

$6,5.30$

27,350

26,500
10,040

86,193

7,454

6,801

7,650
35,000

7,500

20,000

33,245

70,235

11,500

5,276

18,742

$\mathbf{7 8 , 4 3 2}$

7,150

60,000

11,987

\$ 19,183

39,395

7,000

29,500

15,000

9,200

14,200

21,800

$\dddot{56,585}$

13,003

$\$ 82,500$

51........

8,700

55,000

S 24,977

41,000

40,500

$10,6-19$

3,504

9,455

$\begin{array}{r}\mathbf{9}, 000 \\ \hline\end{array}$

10,162

13,612

12,500

14,267

10,007

$\$ 7,000$

16,453

23,900

14,250

22,530

27,

27,

43,729

26,918
7,632

5,000

14,000

7,000 
Year 1875.

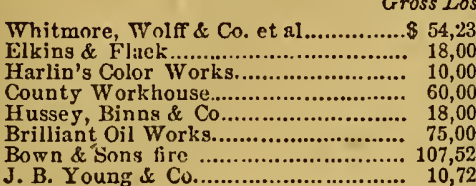

Year 1876.

Snuth Side Flour Mill....................\$ 42,147

Paine, Ablett \& Tripp et al........... 35,995

Tarentum Canp (iround .................... 35,000

Berger's Bueket Factury ......................... 15,000

National Tulse Works.......................... 10,500

American Oil Works Tank.................... 20,705

Lindsay \& MfeCutcheon...................... 30,000

Frame Row, Mransfield........................... 15,970

W Fliceus \& Son

La Belle Steel Wurks............................... 156,500

\section{Ycar 1877.}

Fort Pitt Boiler Works......................\$46,495

Manstield \& Co.................................. 20,000

Davis, Chambers \& Co.................... 55,923

Pittsburgh Steel Company............ 23,788

Jacobus \& Nimick .............. 132,468

Johu A. McK ee \& Sons........................... 35,807

A. Hartupee \& Co.................................. 104,631

MeKeesport Car Works......................... 94,145

Gilmore \& Co............................... 16.060

Fittsburgh Dispateh et al.................... 28, 28,5
Year 1878.

Ins. Paid.

54,236

13,608

10,000

22,700

13,314

58,950

68,950
90,927

90,927
10,720

$\$ 24,337$

31,681

7,730

10,000

10,500

$20,70 \overline{5}$

27,612

11,580

15,944

55,000

$\$ 19,045$

16,735

45,408

23,788

91,570

25,795

84,683

65,610

15,779

21,061 eaeh case.
Grose Loss. Ind Paid. $\$ 40,295$ \& 29,585 Fleming, Agnew \& Co.........................\$ $\$ 40,29$

G. MeKee et al., planing mill............ 11,184 Armstrong Bros. \& Co., cork facto"'. 70,900

Lewis, Oliver \& Phillips, foundry. 11,096

Pittsburgh WVagon Works Shop........... 32,575

Reymer Bros., eandy :atory.............. 24,662

3,824.

56,939

7,098

1,406

24,662

\section{Recapitulation.}

Comparative statement of the number of fires, gross loss, and insurance paid from A ugust 20, 1864, to Mareh 23,1879 , the year ending the fourth Monday of March in

\begin{tabular}{|c|c|c|c|c|c|}
\hline & $\begin{array}{c}\text { No. of } \\
\text { Fires. }\end{array}$ & & $\begin{array}{l}\text { Gross } \\
\text { Loss. }\end{array}$ & & $\begin{array}{l}\text { urnnee } \\
\text { Puid. }\end{array}$ \\
\hline 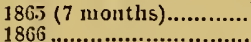 & $\begin{array}{l}33 \\
64\end{array}$ & 8 & $\begin{array}{l}266,128 \\
741,295\end{array}$ & $\$$ & 126,481 \\
\hline & $\begin{array}{l}64 \\
81\end{array}$ & & $\begin{array}{l}741,225 \\
868,150\end{array}$ & & $\begin{array}{l}336,01 \cdot 1 \\
500,528\end{array}$ \\
\hline ....... & 77 & & 815,559 & & $311,26-1$ \\
\hline & 122 & & & & \\
\hline & 127 & & 852 & & \\
\hline & 296 & & 1,349 & & \\
\hline & 298 & & 664 & & \\
\hline & 326 & & & & \\
\hline & 198 & & 667 & & \\
\hline & 302 & & 809 & & \\
\hline . & 322 & & & & \\
\hline & 271 & & & & \\
\hline & 36 & & & & \\
\hline & 2 & & 324,842 & & 205,6 \\
\hline $\mathrm{T}$ & & & 387 & & $7 \times 7$ \\
\hline
\end{tabular}

Statistics of THE AMERICAN IRON TRADE, and of THE PITTSBURGH IRON TRADE, For 1877 and 1878.

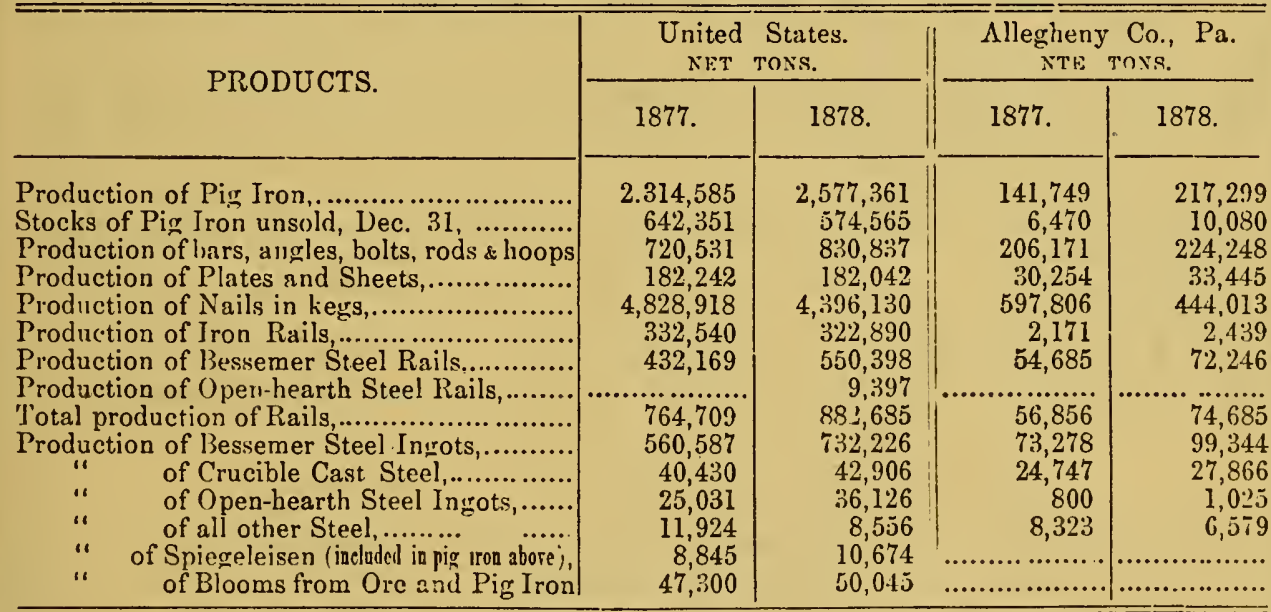

\section{ADDITIONAL STATISTICS.}

Value of Iron and Steel Imports,

Value of Iron and Steel Exports.

Miles of Railway constructed

Number of Iminimrants,

Tonnage of Iron Ships built (in fiscal years) ,....................

Net Imports of Merchandise (in fiscal years),...

Domestic Exports of Merchandise (in fiscal years),

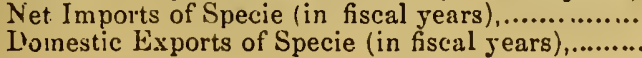

\begin{tabular}{|r|r|}
\hline \multicolumn{2}{|c|}{ United States. } \\
\cline { 2 - 2 } 1877. & \multicolumn{1}{|c|}{1878.} \\
\hline$\$ 9.195,368$ & $\$ 8,943,043$ \\
$16,659,675$ & $13,260,369$ \\
2,177 & 2,747 \\
130,503 & 153,207 \\
$1,025,129$ & $1,125,231$ \\
5,927 & 26,960 \\
$\$ 438,518,130$ & $\$ 422,895,034$ \\
$589,670,224$ & $680,709,258$ \\
$27,746,915$ & $23,134,074$ \\
$43,134,738$ & 27,061885 \\
& \\
\hline
\end{tabular}

United States. 
PRICES IN DOLLARS OF AMERICAN IRON RAILS IN PHILADELPIIA, FROM 1847 TO 1879. PkR TON OF 2,240 LBS.

Compiled by Tho American Iron and Steel Association, from tho sales books of several prominent Philadelphics Iron Merchants.

\begin{tabular}{|c|c|c|c|c|c|c|c|c|c|c|c|c|c|c|}
\hline 岕 & 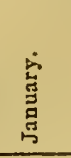 & 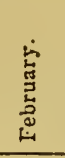 & 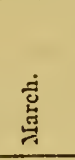 & 范 & 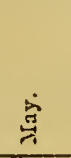 & 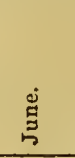 & 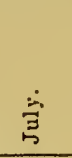 & 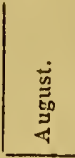 & 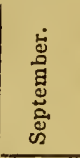 & 용 & 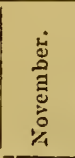 & 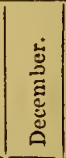 & 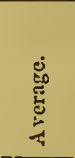 & $\begin{array}{l}50 \\
60 \\
5 \\
4 \\
4 \\
4\end{array}$ \\
\hline & $\$$ & & $\$$ & $\$$ & $\$$ & $\$$ & $\$$ & $\$$ & $\$$ & $\$$ & $\$$ & $\$$ & $\$$ & \\
\hline $1817 \ldots$ & & $72 / 3$ & $701 / 8$ & 70 & 70 & 70 & $691 \%$ & $691 / 3$ & $671 / 9$ & 67 & $671 / 2$ & $671 / 2$ & & 100 \\
\hline 48 & 63 & 63 & 63 & 63 & 63 & 63 & 63 & $617 \%$ & $611 / 3$ & 61 & $6 \mathrm{i}^{2}$ & $6 i^{2}$ & $621 / 1$ & 100 \\
\hline $1849 \ldots \ldots$ & 61 & $571 / 3$ & $533 / 4$ & $531 / 3$ & $541 / 4$ & $531 / 2$ & $531 / 2$ & 5319 & $52^{\circ}$ & $511 / 2$ & $51 \frac{1}{2}$ & $511 / 2$ & $5.37 \%$ & 100 \\
\hline 1850 .. & 47 & $47 \%$ & $48^{-x}$ & $49^{\circ}$ & $49^{-2}$ & 50 & $46^{-2}$ & $46^{3 / 3} / 4$ & $471 / 2$ & 48 & $43^{2}$ & $+48^{-2}$ & $+47 \%$ & 100 \\
\hline $1851 \ldots . .$. & 43 & +45 & $471 / 3$ & 45 & 45 & 48 & 46 & $451 / 3$ & $45^{-2}$ & 45 & 46 & $f+61 / 2$ & $+1.50 \%$ & 100 \\
\hline $1852 \ldots \ldots$ & $461 / 3$ & $461 / 3$ & 4613 & $461 / 3$ & $461 / 3$ & $46 \%$ & $46^{1 / 3}$ & $46 \%$ & $473 / 4$ & $492 / 3$ & 51 & $61^{-17}$ & 48.38 & 100 \\
\hline $1853 \ldots . .$. & $741 \%$ & $771 \%$ & $771 / 2$ & $771 / 2$ & $771 / 2$ & $771 / 2$ & $771 / 2$ & $771 \%$ & $771 / 2$ & $771 \%$ & $771 / 3$ & $771 / 2$ & 7719 & 100 \\
\hline 1854 & 81 & 81 & 81 & 81 & $81^{-}$ & 81 & 81 & 81 & 81 & $81^{\prime 2}$ & $771 / 2$ & $7: 31$ & $80 \frac{1}{8}$ & 100 \\
\hline $1855 \ldots . .$. & 70 & 65 & $621 / 3$ & $621 / 2$ & 60 & $581 / 3$ & $591 / 2$ & $591 / 2$ & $641 / 2$ & 65 & 65 & 63 & 62 & 100 \\
\hline ........... & $621 / 3$ & $6221 / 8$ & 63318 & 65 & 65 & $65^{3}$ & $65^{2}$ & $65^{2}$ & $65^{-2}$ & 65 & 65 & 64 & $6 \pm 38$ & 100 \\
\hline $1857 \ldots$ & $651 \%$ & $651 / 2$ & 6119 & $65^{3} / 4$ & 67 & 67 & 67 & 67 & 67 & 67 & $581 / 2$ & 50 & 6119 & 100 \\
\hline 185 & 50 & 60 & 50 & 50 & 50 & 50 & 50 & 50 & 50 & 50 & 50 & 50 & $50^{-7}$ & 100 \\
\hline 1859 .. & $493 / 4$ & $49^{1 / 4}$ & $491 / 4$ & $501 / 4$ & $501 / 4$ & $501 / 4$ & $49^{3} / 4$ & $483 / 4$ & $483 / 4$ & $483 / 4$ & $483 / 4$ & 483 & $493 / 8$ & 100 \\
\hline 1860 . & $48 \% 4$ & $483 / 4$ & $48 \% 4$ & $483 \%$ & $483 / 4$ & $483 \%$ & $483 \%$ & 46 & $47^{9}$ & $471 / 2$ & $471 / 2$ & $46^{1} / 8$ & & 100 \\
\hline 1861. & 44 & 44 & 44 & 44 & 44 & 44 & 44 & $431 / 6$ & 43 & $413 / 8$ & $361 / 2$ & $361 / 2$ & $423 / 8$ & 110 \\
\hline $186^{\circ}$ & $361 / 3$ & $361 / 3$ & $411 / 2$ & $411 / 2$ & $411 / 2$ & $411 / 3$ & 411/3 & $411 \%$ & 43 & $43^{33}$ & 46 & 46 & $41^{3 / 3} / 4$ & 113 \\
\hline 1863. & $721 / 2$ & 6933 & $721 / 4$ & $731 / 2$ & $731 / 2$ & $78 \%$ & $811 / 2$ & 7338 & $721 / 2$ & $791 / 2$ & $871 / 2$ & $\mid 871 / 2$ & $767 \%$ & 145 \\
\hline 1864. & $94^{\prime 2}$ & 1011 & $105^{-4}$ & $1111^{2}$ & 120 & $1271 / 2$ & $1411 / 2$ & $1521 / 2$ & 8153,43 & $140^{-2}$ & $133^{3} / 4$ & $132^{-2}$ & T126 & 201 \\
\hline $1865 . . . .$. & $125 \%$ & $121 \%$ & $1161 / 4$ & $1081 / 2$ & $902 / 4$ & $84 \frac{14}{4}$ & $821 / 2$ & $861 / 4$ & 90 & $921 / 3$ & 95 & 91 & $985 / 8$ & 157 \\
\hline $1866 \ldots . . .$. & $90^{\circ}$ & 90 & $873 / 4$ & $24^{33} 4$ & $81^{-x}$ & $853 / 4$ & $863 / 8$ & $87^{-4}$ & $875 / 8$ & $87 \%$ & 85 & 85 & $86^{30} / 4$ & 140 \\
\hline 1867. & 85 & 85 & $811 / 4$ & $827 \%$ & $821 / 2$ & 8213 & 821 & $821 / 2$ & 8219 & $821 / 2$ & $821 / 2$ & $821 / 2$ & $831 / 8$ & 138 \\
\hline & $81 \% / 3$ & 79 & $79^{-1}$ & 79 & 79 & 79 & 79 & $79^{-2}$ & 79 & $781 / 4$ & 76 & 7834 & 7878 & 140 \\
\hline 1869. & $766^{3} / 4$ & 76 & 76 & 76 & 76 & 76 & 76 & 80 & $781 / 2$ & $781 / 3$ & $781 / 3$ & $781 \frac{7}{2}$ & 7719 & 136 \\
\hline & 74 & $721 / 3$ & $721 / 2$ & $721 / 3$ & $721 / 8$ & $7: 21 / 2$ & $721 / 2$ & $721 / 2$ & $721 / 2$ & $721 / 2$ & $701 \%$ & $70^{-2}$ & $721 / 3$ & 115 \\
\hline & $681 / 4$ & $69^{-3}$ & $69^{2}$ & 6913 & $71^{-8}$ & $7 i^{2}$ & 71 & $71^{2}$ & $71^{-2}$ & $71^{2}$ & $71^{-2}$ & 71 & 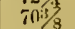 & 112 \\
\hline & $71 \frac{15}{3}$ & $75^{5} / 8$ & $811 / 8$ & $837 \%$ & $901 / 2$ & 90 & 89 & $873 / 4$ & $88^{3} / 4$ & $88^{3} / 4$ & $88^{3} / 4$ & $8.51 / 2$ & 8.18 & 112 \\
\hline $18 \bar{i} 3$. & $831 / 3$ & 83 & $83^{\circ}$ & 82 & so & 78 & 76 & $75^{-4}$ & 75 & $70^{-4}$ & 68 & $66^{2}$ & $762 \%$ & 113 \\
\hline & 66 & 64 & 62 & 60 & 60 & 60 & 60 & 58 & & $5 \overline{5}$ & 52 & 50 & $58 \%$ & 112 \\
\hline is7 & 50 & 50 & 50 & 49 & 49 & 49 & $481 / 2$ & 47 & $461 / 2$ & 46 & $451 / 2$ & $4: 3 / 4$ & $473 \frac{3}{4}$ & 114 \\
\hline & $431 / 2$ & 43 & $421 / 2$ & 42 & 42 & 41 & 41 & $4 i$ & $40^{-2}$ & 40 & 3913 & $39^{4}$ & $411 / 4$ & 110 \\
\hline 1877. & 38 & 38 & 38 & $371 / 3$ & 37 & $341 / 2$ & 342 & 34 & 33 & $\$ 321 / 2$ & 33 & 33 & 3.5 & 105 \\
\hline $1878 \ldots \ldots$ & $331 / 2$ & $331 / 4$ & $331 / 2$ & $331 / 3$ & $331 / 2$ & $331 / 2$ & 34 & 34 & 34 & 34 & 34 & 34 & $\| 333 \% 4$ & 102 \\
\hline $1879 \ldots \ldots$ & & $31 \% / 2$ & 35 & $35 \%$ & & & & & & & & & & 100 \\
\hline
\end{tabular}

From 1847 to 1860 from Philadelphia prices current, except for years 1850 and 1851, for which estimates were furnished by Ir. S. J. Ieeves. From 18066 to 1879 from Bulletin of The Ainerican Iron and Steel Association, averaged from weekly quotatiuns.

Drices averaged for years to nearest eighth. * For latter part of 1857 prlces were probably ouly nominal. † Uncertain.

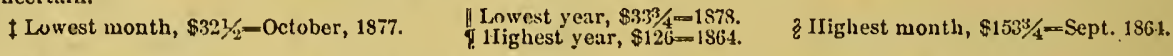

The annual premlum on gold is calculated from daily quotations of gold sales in the Bankers' Magazine.

PRICES IN DOLLARS OF AMERICAN BESSEMER STEEI, RAILS, AT WORKS, FROM 1868 TO 1879. Prir Ton of 2,240 LBS.

\begin{tabular}{|c|c|c|c|c|c|c|c|c|c|c|c|c|c|}
\hline 勿 & 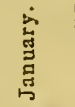 & 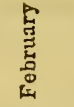 & 竎 & 莣 & $\stackrel{\dot{\mathrm{s}}}{\vec{\sigma}}$ & $\underset{g}{\stackrel{g}{\Xi}}$ & $\underset{3}{3}$ & 总 & 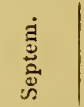 & 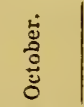 & 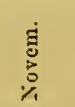 & 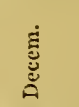 & 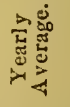 \\
\hline 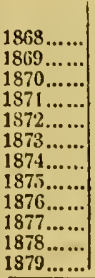 & $\begin{array}{c}\$ \\
165 \\
145 \\
110 \\
95 \\
1041 / 2 \\
121 \\
1171 / 2 \\
71 \\
67 \\
49 \\
41 \\
41\end{array}$ & $\begin{array}{c}\$ \\
1671 / 3 \\
1431 / 4 \\
110 \\
96 \\
104 \\
120 \\
1171 / 2 \\
71 \\
65 \\
49 \\
411 / 2 \\
42\end{array}$ & $\begin{array}{l}\$ \\
174 \\
135 \\
1081 / 2 \\
106 \\
1041 / 4 \\
12: 1 / 2 \\
115 \\
71 \\
62 \\
49 \\
411 / 2 \\
43\end{array}$ & $\begin{array}{c}\$ \\
172 \\
134 \\
107 \\
95 \\
111 / / 3 \\
1201 / 4 \\
983 / 3 \\
69 \\
62 \\
49 \\
42 \\
421 / 2\end{array}$ & $\begin{array}{l}\$ \\
165 \\
1301 / 4 \\
106 \\
103 \\
110 \\
120 \\
981 / 3 \\
79 \\
62 \\
471 / 4 \\
431 / 2 \\
\ldots \ldots \ldots\end{array}$ & $\begin{array}{c}\$ \\
1621 / 2 \\
128 \\
1091 / 4 \\
104 \\
113 \\
1213 / 4 \\
961 / 4 \\
69 \\
60 \\
461 / 3 \\
43\end{array}$ & $\begin{array}{l}\$ \\
150 \\
130 \\
110 \\
1033 / 4 \\
1141 / 3 \\
121^{3 / 4} \\
91 \\
69 \\
59 \\
451 / 4 \\
431 / 2 \\
\ldots \ldots \ldots \ldots\end{array}$ & $\begin{array}{l}\$ \\
150 \\
130 \\
110 \\
104 \\
1151 / 4 \\
1213 / 4 \\
891 / 4 \\
69 \\
59 \\
413 / 4 \\
421 / 2 \\
\ldots \ldots \ldots \ldots\end{array}$ & $\begin{array}{l}\$ \\
150 \\
130 \\
1083 / 4 \\
106 \\
114 \\
118 \\
781 / 4 \\
69 \\
56 \\
44 \\
421 / 2 \\
\ldots \ldots\end{array}$ & $\begin{array}{c}\$ \\
150 \\
1301 / 3 \\
1011 / 3 \\
105^{33 / 4} \\
1131 / 2 \\
120 \\
781 / 4 \\
67 \\
54 \\
421 / 4 \\
42 ! \\
\ldots \ldots \ldots\end{array}$ & $\begin{array}{l}\$ \\
148 \\
1301 / 4 \\
1021 / 3 \\
1051 / 4 \\
118 \\
120 \\
752 / 3 \\
66 \\
53 \\
40^{1} 1 / 2 \\
42\end{array}$ & $\begin{array}{l}\$ \\
1471 / 2 \\
120 \\
98 \\
1061 / 3 \\
1203: 4 \\
120 \\
752 / 3 \\
65 \\
52 \\
411 / 2 \\
41\end{array}$ & $\begin{array}{l}\$ \\
1781 / 3 \\
1321 / 4 \\
100^{6} / 4 \\
1021 / 2 \\
112 \\
1201 / 3 \\
941 / 4 \\
68^{3} / 1 \\
591 / 4 \\
451 / 3 \\
121 / 4\end{array}$ \\
\hline
\end{tabular}


WHOLESALE STORE PRICES IN DOLLARS OF BEST REFINED ROLLED BAR IRON IN PIILADELPIIA, FROM 1844 TO 1879. PER TON OF 2,240 POUNDS.

\begin{tabular}{|c|c|c|c|c|c|c|c|c|c|c|c|c|c|}
\hline 岕 & 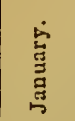 & 岂 & 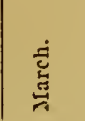 & 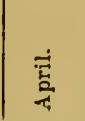 & $\dot{\vec{Z}}$ & 离 & $\stackrel{亡}{\Xi}$ & 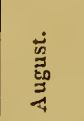 & 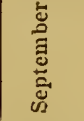 & 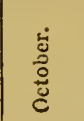 & 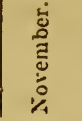 & 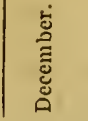 & 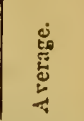 \\
\hline & $\$$ & $\$$ & $\$$ & $\$$ & $\$$ & $\$$ & $\$$ & $\$$ & $\$$ & $\$$ & $\$$ & $\$$ & $\$$ \\
\hline $1844 \ldots \ldots$ & 9000 & 9000 & $90 \quad 00$ & 9000 & 9000 & 8250 & 8250 & 8260 & $8: 60$ & 82 โ10 & 8260 & 82 so & 8562 \\
\hline $1845 \ldots$ & $8: 514$ & $87 \quad 60$ & 9260 & 10000 & 1000,1 & 10010111 & $90 \quad 00$ & $92 \quad 60$ & $92 \quad 60$ & 9260 & $9 ; 00$ & $9501)$ & 9375 \\
\hline & 9.500 & 9500 & $90 \quad 00$ & 9260 & 9260 & 9253 & 95110 & 9250 & 90 & $90 \mathrm{U}^{\prime}$ & 9000 & 8500 & 9166 \\
\hline $47 \ldots . .$. & $8 \overline{3} 00$ & 8500 & 8500 & 8500 & 8500 & 90110 & 90010 & 85110 & 8750 & 8500 & 85 (1) & 85.0 & $800 t$ \\
\hline $1848 \ldots \ldots$ & 8500 & 8500 & 8500 & 8500 & $85 \div 10$ & 800.1 & 80011 & 811011 & 70 (1) & 76 ou & 6750 & 7000 & 7033 \\
\hline $49 \ldots \ldots$ & 7000 & 7000 & 7000 & 7000 & 70 os & 70 (III) & 0500 & 65011 & 0500 & 65 uv & 6 o 10 & 656 & 67 no \\
\hline $50 \ldots \ldots$ & $6501)$ & 6500 & 6500 & 6260 & (6) 111 & 57 511 & $57 \quad 60$ & 5750 & $n 710$ & $50 \quad 41)$ & $6060)$ & $5 b \quad 010$ & 59 h4 \\
\hline $351 \ldots \ldots$ & 6505 & 5500 & 5500 & bis 00 & $65 \quad 110$ & $55 \mathrm{l11})$ & $650 "$ & $05 \mathrm{Im}$ & 54011 & 6401 & 64 OH & 54110 & 5406 \\
\hline $1852 \ldots . .$. & 5400 & 5400 & 5260 & 5260 & 5251 & 6260 & 5260 & 5500 & 60 (11) & $7_{0} 00$ & 7000 & & \\
\hline $53 \ldots . .$. & $9001)$ & $90 \quad 00$ & 9000 & $87 \quad 60$ & 8500 & $80 \backsim 0$ & $80 \mathrm{nn}$ & 77511 & 7751 & 8010 & 8000 & 8600 & 8350 \\
\hline $1854 \ldots \ldots$ & 9000 & 9000 & 90 on & $90 \quad 00$ & 91100 & 9250 & 95 vu & $9 \overline{5} 01)$ & 9500 & 92 60 & 9000 & 9000 & 9133 \\
\hline 55 & 8250 & 8000 & 7600 & 7. 50 & 7010 & 7000 & $70 \mathrm{oil}$ & 7260 & 72 50 & 7500 & 77 ho & $77: 0$ & 7468 \\
\hline $50 \ldots$ & $75 \quad 00$ & 7750 & 7750 & 7750 & $7 / 500$ & 7250 & $70(11)$ & 70011 & 7250 & 7261 & 7250 & 72 К0 & 7376 \\
\hline $57 \ldots \ldots$ & $7251)$ & 7250 & 7250 & 7260 & $72 \quad 60$ & 725 , & 7000 & 700.10 & 700 & 70 i1 & 70011 & o7 10 & 7101 \\
\hline $1858 \ldots \ldots$ & 6500 & 6500 & 6500 & 6250 & 62511 & 6500 & $02 \quad 511$ & Gil in & 60 (II) & 6000 & (60 00 & 6000 & $02 \quad 29$ \\
\hline 1 & 6000 & 600 & 6000 & 6000 & 60011 & 60 011 & 60 O"1 & ou 110 & 60 on & 60 (11) & 6000 & 6000 & 6000 \\
\hline is & 6000 & 570 & 5750 & 5750 & $5750)$ & 67 5.1 & 5750 & 60011 & 6000 & 6000 & 6000 & 6000 & 5875 \\
\hline $1861 \ldots \ldots$ & 6000 & 6000 & 6000 & 0000 & 0000 & 6i) 110 & 0000 & (1) 010 & 02 51) & $62 \mathrm{nt}$ & 62 ho & 0210 & 6083 \\
\hline $1862 \ldots \ldots$ & 6260 & 0250 & 6250 & $62 \quad 50$ & 65 iII) & 6500 & 70 & $72 \mathrm{sn}$ & $76 \quad 00$ & 7760 & 82 h0 & 8710 & 7042 \\
\hline $63 \ldots$ & 8750 & 90 & 3000 & 9000 & 90110 & 87611 & 8750 & 87 Gil & 87 ho & 9000 & 9500 & 11000 & \\
\hline $1864 \ldots . . .$. & 11500 & 12500 & 13000 & 14000 & $150)$ & 1601.0 & 16500 & 171100 & 16010 & $15001)$ & 14750 & 14500 & 14046 \\
\hline $1805 \ldots . . .$. & 14250 & 13500 & 13000 & 11000 & $101) 110$ & 9261 & 9000 & 850 ) & 92 h) & 9500 & 10000 & 10500 & 10038 \\
\hline $1860 \ldots$ & 10500 & 10000 & 9750 & 9500 & $9251)$ & 05 & $105 \mathrm{G10}$ & $\sin (10)$ & 100110 & 9780 & 9500 & $\begin{array}{lll}95 & 0\end{array}$ & 9813 \\
\hline $1867 \ldots$ & 9500 & 925 & 9250 & 9000 & 87 511 & 8750 & 85 ili & 8260 & 8260 & 8250 & 8250 & 8,00 & \\
\hline $1868 \ldots$ & 8500 & 8500 & 8500 & 8760 & 87511 & 87 5. & 85 (III) & 85011 & 8500 & 8500 & 8500 & 8300 & 8563 \\
\hline $1869 \ldots$ & 8260 & 8250 & 8250 & 8250 & 8260 & $82 \quad 60$ & 82511 & $82 \mathrm{hll}$ & 8000 & 80 vi) & 8000 & 8000 & 8160 \\
\hline 187 & 8000 & 77 & 7750 & 7750 & 75 & 775 & 80 & 85 (11) & 8200 & 8000 & 7710 & $77 \div 0$ & 78 \\
\hline $771 .$. & 7250 & 750 & 7500 & 7760 & $750 ?$ & 7750 & 7750 & 80011 & $8: 50$ & 82 h" & 82 ho & 8500 & 7854 \\
\hline $1872 \ldots$ & 7392 & 7840 & 8736 & 9108 & 9632 & 9856 & 10314 & $10 \div 28$ & $107 \quad 52$ & 11872 & $107 \quad 52$ & 10080 & 97 \\
\hline 18 & 963 & 9403 & $96 \quad 32$ & $9 f 08$ & $94 \quad 09$ & 9184 & $85 \quad 12$ & 8288 & 8004 & 7610 & 7392 & 71 & \\
\hline $1874 \ldots$ & 7392 & 73 & 710 & 71 & 67 & 07211 & 6272 & 67211 & o7 20 & 0720 & 0272 & 0272 & \\
\hline $1875 \ldots$ & 6272 & 6048 & 0272 & 0.272 & 0272 & 6272 & $627 ?$ & (11) 4 is & (6) 48 & 6048 & be 00 & Sơ 00 & 6088 \\
\hline 187 & 5600 & 5264 & 5264 & $52 \quad 64$ & 5201 & 5264 & 6204 & 5264 & 6040 & 5040 & $10 \$ 0$ & 40 & H. 03 \\
\hline $1877 \ldots . . .$. & 4872 & 47 & $\begin{array}{l}4704 \\
0\end{array}$ & 4480 & 4481 & 4480 & $448 n$ & 44811 & 4480 & 14811 & 4480 & 4480 & $45 \quad 55$ \\
\hline & 4480 & 4480 & 4480 & 4480 & 4480 & 4480 & 1480 & 1480 & 4480 & 4260 & 4260 & $42 \mathrm{hg}$ & 1424 \\
\hline & 403 & 4256 & 4480 & 4480 & & & & & & & & & \\
\hline
\end{tabular}

The highest price in any month in tho above tallo was reached in August, $1861, \$ 170$; the lowest prices in any month was in January, $18 \% 9,540.32$. The highest a verage prico reached in any year was in $1864, \$ 14646$; the luwest

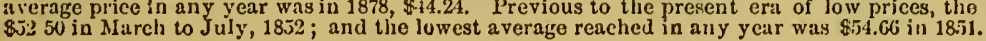

\section{PRODUCTION OF ANTHRACITE COAL.}

The following figures of tho production of anthracite coal are taken from a table prepared for the Coxl Trade Journal by John II. Jones. The aggregate amount of anthraclte marketed according to this statement foots up over $307,000,000$ tons :

\begin{tabular}{|c|c|c|c|}
\hline Year. & Tons. & Year. & Tons. \\
\hline $1820 .$. & 365 & 1850. & $3,358,799$ \\
\hline $1821 .$. & 1,073 & 1851 & $4,448,916$ \\
\hline 1822. & $3,: 20$ & 18.52. & $4,893,471$ \\
\hline 1823. & 6,951 & 1853. & $5,195,151$ \\
\hline $1824 .$. & 11,108 & 1854. & $6,202,334$ \\
\hline $1825 \ldots$ & 31,893 & $1855 \ldots$ & $6, C 08,567$ \\
\hline 1826. & 43,047 & $1856 .$. & $6,927,550$ \\
\hline $1827 \ldots$ & 63,434 & $1857 .$. & $6,644,941$ \\
\hline .......... & 77,516 & $1858 \ldots$ & $6,839,360$ \\
\hline ...... & 112,083 & $1859 . .$. & $7,808,255$ \\
\hline $1830 .$. & 174,734 & $1860 \ldots$ & $8,513,123$ \\
\hline $1831 .$. & 176,80 & $1861 .$. & $7,954,264$ \\
\hline 1832. & 363,271 & 1862. & $7,869,497$ \\
\hline $1833^{\circ}$. & 487,749 & 1863... & $9,566,006$ \\
\hline 1834... & $376,6: 36$ & $1864 .$. & $10,177,475$ \\
\hline $1835 .$. & 560,758 & $1865 \ldots$ & $9,652,391$ \\
\hline $1836 .$. & 634,117 & $1866 \ldots$ & $12,703,882$ \\
\hline ........ & 869,441 & $1867 \ldots$ & $12,988,725$ \\
\hline $1838 .$. & 738,697 & 1868. & $13,801,465$ \\
\hline $1839 \ldots$ & 818,402 & $1869 \ldots$ & $13,8 \mathrm{G} 6,180$ \\
\hline $1840 .$. & 864,379 & 1870. & 1G. 182,191 \\
\hline $1811 \ldots$ & 959,773 & 1871. & $15,699,721$ \\
\hline $842 \ldots$ & $1,108,412$ & $1872 \ldots . . . . . . \ldots \ldots \ldots$ & $19,660,778$ \\
\hline (................ & $1,263,598$ & $1873 \ldots \ldots \ldots \ldots \ldots \ldots \ldots$ & $21,227,952$ \\
\hline $44 \ldots$ & $1,630,850$ & $1874 \ldots \ldots \ldots \ldots \ldots \ldots \ldots$ & $20,145,121$ \\
\hline & $2,013,013$ & $1875 \ldots \ldots \ldots \ldots \ldots \ldots$ & $19,712,472$ \\
\hline $6 \ldots$ & $2,314,005$ & $1876 \ldots \ldots \ldots \ldots \ldots \ldots$ & $18,501,011$ \\
\hline $7 \ldots .$. & $2,882,309$ & $1877 \ldots \ldots \ldots \ldots \ldots$ & $20,828,178$ \\
\hline 849 & 324290 & & \\
\hline
\end{tabular}

\section{EXPORTS OF COAL.}

Shipments of coal to forcign ports, for the fiscal year endiug June 30, 1878:

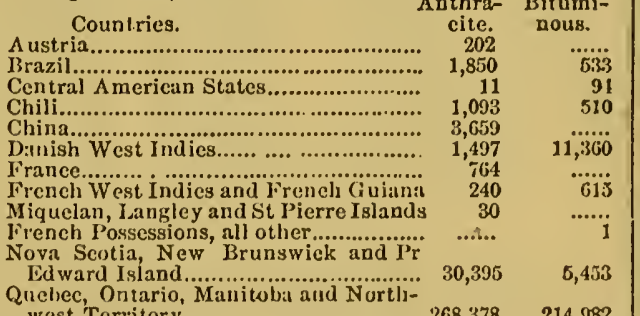

west Territory ............................... 268,378

British Columbia ............................ 17

$\begin{array}{lr}\text { Newfoundlland and Labrador.............. } & 98 \\ \text { British West Indies and Ifonduras..... } & 1,471\end{array}$

$\begin{array}{lr}\text { British West Indies and Ifonduras....... } & 1,471 \\ \text { British Fast Indies.............................. } & 454\end{array}$

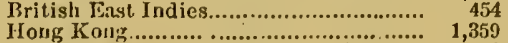

British Possessions in A usiratasia.......... 10

Ilawaiian Islands............................... 842

Iray ti............................................... $2,3,360$

$\begin{array}{rr}\text { Italy } \ldots \ldots \ldots \ldots \ldots \ldots \ldots \ldots \ldots \ldots \ldots \ldots \ldots \ldots \ldots \ldots \ldots \ldots \ldots \ldots & 2,360\end{array}$

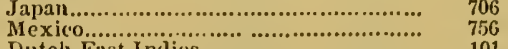

Dutch East Indies................................. 101

Peru ............................................ 1,878

Azore, Madeira and Cape Verdo Islands
San Domingo.....................................

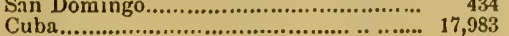

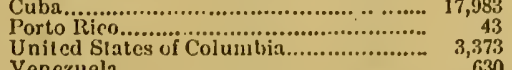

214,982

22

1,222

…....

257

16

3,144

$\ldots \ldots$.

62,613 17,131

681

Total...................................... 3490,661 


\section{INTERNAL, REVENUE, TWEN'IYY-SECOND PA. DISTRICT.}

The following tubulated stntesnents of the revenue derived from spirits, tobacco, fermented liquors, banks, bankers, \&c., for the yenrs ending Junc 30,1878 , and June 30, 1879, is compiled from the reports of Hon. Thomas IV. Davis, Collector of Internal Revenue for the 'Twenty-second Penusylvania District:

FOR THE FISCAL YEAR ENDING JUNE $30,1878$.

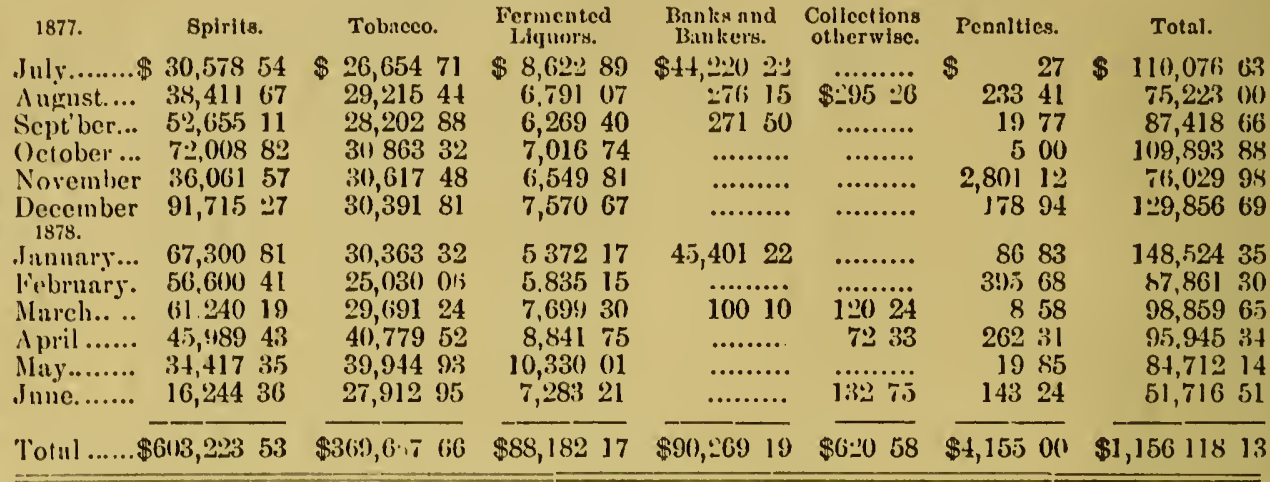

FOR THE FISCAL YEAR ENDING JUNE $30,1879$.

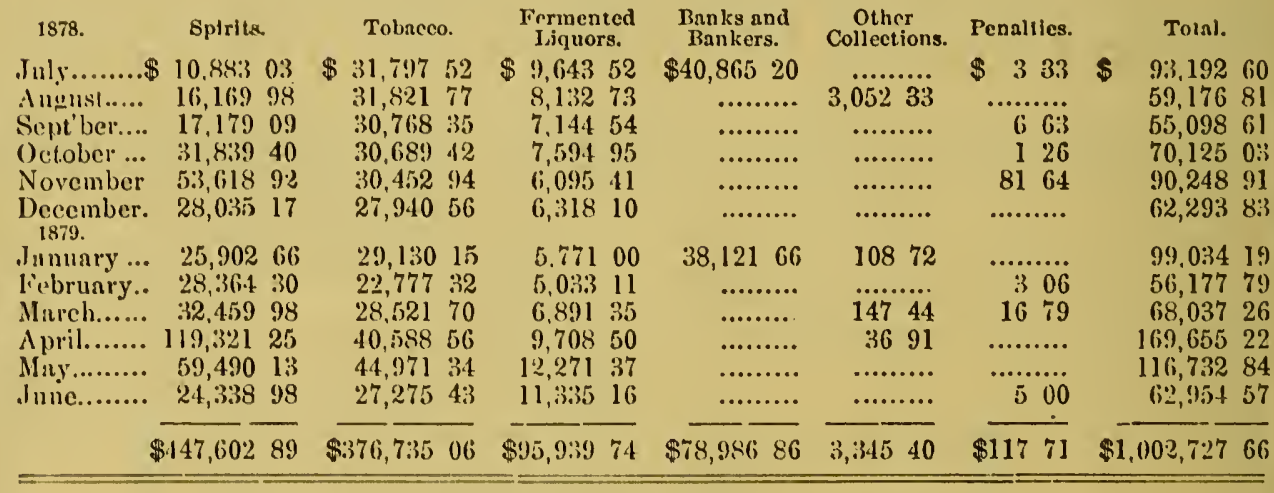

\section{YEARLY PRICES OF COAL.}

We give below prices for Sehnylkill White Ash Lurup coal, on board ressels at Philadelphin, from 1834 to 1878 , inclusive, prepared originally by W. G. Neilson, and continued by J. M. Swank, loing the averuge rates obtained from sales during the yenr:

\begin{tabular}{|c|c|c|}
\hline Pricas. & I'rices. & Years. \\
\hline $183.1 \ldots \ldots \ldots \ldots \$ 184$ & $\$ 3.16$ &.$\$ 411$ \\
\hline $18: 35 \ldots \ldots \ldots \ldots \ldots+84$ & ......... & $1857 \ldots \ldots \ldots \ldots 387$ \\
\hline $1836 \ldots \ldots \ldots \ldots 664$ & $1847 \ldots \ldots \ldots \ldots . . . .380$ & $1858 \ldots \ldots \ldots \ldots . . .343$ \\
\hline $18: 37 \ldots \ldots \ldots \ldots 6672$ & $1848 \ldots \ldots \ldots \ldots .350$ & $1859 \ldots \ldots \ldots \ldots .325$ \\
\hline $1838, \ldots \ldots \ldots \ldots, 527$ & $18.19 \ldots \ldots \ldots \ldots 362$ & $1860 \ldots \ldots \ldots . .$. \\
\hline $1,839 \ldots \ldots \ldots \ldots 500$ & $1850 \ldots \ldots \ldots \ldots . \ldots 364$ & $1861 \ldots \ldots \ldots \ldots . . .339$ \\
\hline $1840 \ldots \ldots \ldots \ldots 491$ & $1851 \ldots \ldots \ldots \ldots .31$ & $186: \ldots \ldots \ldots \ldots+14$ \\
\hline $1841 \ldots . . . \ldots \ldots$ 5 $7 !$ & $1852 \ldots \ldots \ldots \ldots$ & $186,3 \ldots \ldots \ldots \ldots 606$ \\
\hline $1812 \ldots \ldots \ldots \ldots . \ldots 418$ & 1853.......... 370 & $186+\ldots \ldots \ldots \ldots+\ldots+8$ \\
\hline $18.13 \ldots \ldots \ldots \ldots . . . . .327$ & $1854 \ldots \ldots \ldots \ldots \ldots 50 . \ldots$ & $1865 \ldots \ldots \ldots \ldots .786$ \\
\hline $1844 \ldots \ldots \ldots \ldots . .320$ & $1855 \ldots \ldots \ldots \ldots+49$ & $1866 . . \ldots \ldots \ldots 580$ \\
\hline
\end{tabular}

Jowest avernge for year. $†$ llighest averngo lor year.

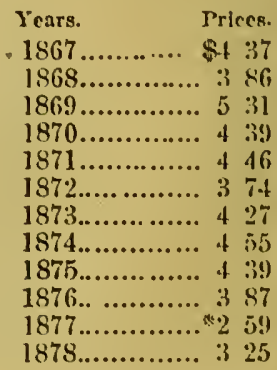




\section{THE LEGAL TON AND BUSHEL IN PENNSYLVANIA.}

The L egislature of Pennsylvania have enacted in reference to what constitutes a bushel or a ton of Bitunninous coal.

Secrion 1. That from and after the passinge of this act, the standing weight of Bituminous roal in this Commonwealth, shall be seventy-six pounds to the bushel, and two thousand pounds shall be one ton.

SECTion 2. If any persnn or persons enqaged in the business of mining Bituıninous coal, sliall fix or establish any other number of pounds by agreement or contract to be a bushel of Bituminous coal, than is provided for in the first section of this act, such per'son or persons shall be guilty of misdemennor; and upon conviction therenf shall be sentenced to pay a fine not less than five hundred, and not exceeding one thousand dollars, and all penalties recovered under this act shall be paid into the treasury of the State.

\section{THE BUSINESS AND POPLLATION OF PITTSBURGH.}

In the preparation of $n$ work of this description, much difficulty is experienced in obtaining reliable statistics, and no doubt the lar'rer number of fault-finders will be those who have refused to give our reporters information relative to their business through fear of tax-collectors, resenue officers, or from an inexcusable stupidity or want of enterprise and husiness sagacity. We latve spared no effort or expense to make this work the most coinplete coinpendium of the business interests of Pittsburgh and Al'egheny ever published, and all failures must be attributed to parties who have refused to aid us br their co-operation. We append herewith a tabulated statement of the number of firms and establishments engaged in the different branches of business, carefully compiled firom the Pittsburgh Directories of 1866,1876 and 1879 . While we do not claim that the numbers given are perfectly accurate, we believe that in most branches of business they will sliow a firomable increase; and where any rlecrease may appear we have no doubt it is owing to the finilure on the part of the Directory agents to obtain the full information desired. The population of l'iltsburgh and Allegheny, as shown by the Uniterl States Census, was, in 1840, 81,155: in 1850, 1:38,290; in $1860,178,831$; in $1870,262,201$. It is estimated now, hy the most reliable judges, that, in 1880 , the population will sinount, in round numbers, to fully 350.000 . While, at times, during the past decade. the various branches of business carried on in Pittsibur roh and its environs have been temporarily uffected by the general stagnation of business in alt parts of the country, the indications ure now favorable for 1 steady and gratifying incresse in all the industrial pursuits which have given to Pittsburgh a world-wide reputution as a great manufacturing and producing metropolis.

\section{BUSINESS S'TATISTICS OF PITTSBURGH.}

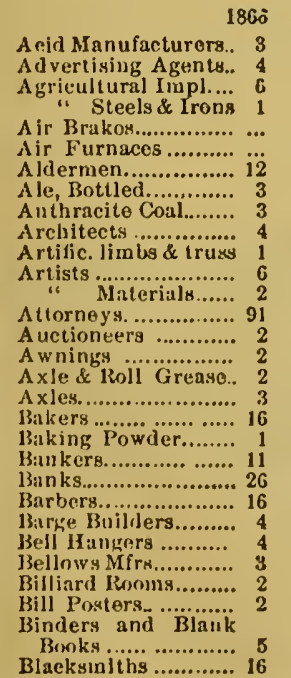

\begin{tabular}{|c|c|c|}
\hline 1876 & 1879 & 1866 \\
\hline 1 & 2 & B3lk. T,ead Crucib]es.. \\
\hline 3 & 3 & Block Hakers........... \\
\hline 7 & 9 & Hoat Siorts................. \\
\hline 2 & 4 & Hoiler Makers.......... \\
\hline$\overline{1}$ & 1 & Bolts and Nutr........ \\
\hline $\mathbf{3}$ & 4 & Book \& Job P'rinters.. 14 \\
\hline 78 & 49 & Jookseller's und siı- \\
\hline 3 & 5 & tioners ................ 10 \\
\hline 2 & 4 & Boots and Slioes, re- \\
\hline 17 & $1: 1$ & tail ..................... 10 \\
\hline 2 & 2 & do., wholesile...... 16 \\
\hline 16 & 12 & Boot \& Sloe Makers.. 10 \\
\hline 2 & 2 & I3uttlers ................... \\
\hline 279 & 313 & Box Factories........... \\
\hline 8 & 8 & Hrass Founders........ 12 \\
\hline 5 & 7 & Brass Goods.............. 2 \\
\hline 2 & 3 & Brewers ................. 11 \\
\hline 5 & 5 & Brick layers \& Job- \\
\hline 108 & 86 & bers........................ \\
\hline 2 & 2 & Bridge Builders........ \\
\hline 6 & 6 & Jrokers-Strok \& Bill \\
\hline 82 & 6.5 & l3room Mfrr............. \\
\hline 75 & 84 & Brush Mfrs............. 1 \\
\hline 2 & 4 & Butchers ................ 12 \\
\hline 6 & 11 & Butcher's Torls........ 2 \\
\hline 2 & 3 & Cannel (rimds............. \\
\hline 7 & 3 & Carpenters \& Build- \\
\hline & & 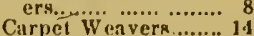 \\
\hline 13 & 12 & Carpels of Oil Cloths \\
\hline 31 & 25 & Curriage 1 frs............ \\
\hline
\end{tabular}

1876
2
3
2
15
4
36
34
151
9
85
4
10
14
2
19
3
2
29
6
7
148
2
4
52
12
13
15

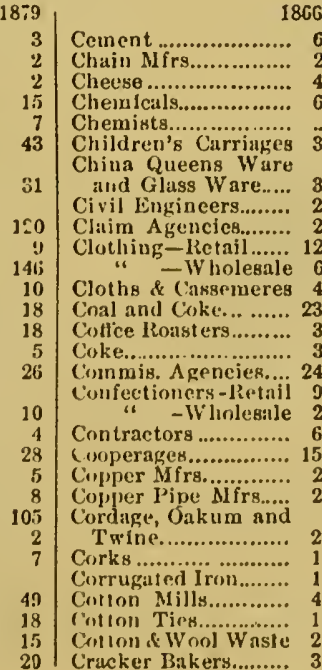

18,6

$18: 9$ 
INDUSTRIES OF PENXSYLVANIA.

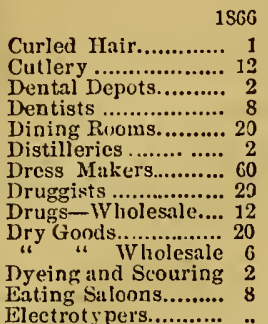

Electroty pers...........

Embroideries in d

Laces ....... ...........

Employment Otfices 2

Engine Builders........ 15

Engravers............... 2

Fxpress Conipani......

Faney (roods.............

File Works...............

Fire Brick.

Fish

Florists ....................

Flour-Wholesale..... 11

Flour,Grain \& Feed.. 13

Flouring Mills.

Forges

Foreign Fruits..........

Founders... ........... 19

Fresco Päinters.........

Furnace Builders..... 2

Furniture ............. 1

Gas Pipe.....

Gas \& Steam Fitters 18

Gas \& Water Pipc.... 2

Gents' Furvishing Goods.

Glass Mirs..............

Glass Moulds a $n d$

Presses.

Glass Striners............

Glue Mfrs. ............. 1

Granite Works........ 2

Grist Mill Machin'y 1

Grocers-Retail 28

" - Wholesale. 33

rim Hose...

Gum Packing.............

Guns and Pistols...... 5

Hair Goods

Hard ware .......... 11

Harness Makers....... 3

Hats, Caps and Furs.. 6

Horse Shwers........... 14

Hosiery and Gloves.. 2

House Furnishing

Goods .................. 3

Ice Companies ......... 1

Ins. Agts. \& Brokers 30

Ins. Co.'s-Fire....... 80

Ins. Co.'s-Life...... 39

Iron Railings, Prison

Cells, \&c............... 2

Iron Feite s and

Railings.................

and Roofing

Iron \& Nail Mfrs...... 25

Japanned IVare.........

Jewelers ................ 11

Kid Gloves................

lamp Chimmers....... 2

Iard Oil Mfrs...........

Lead Fipe ................

Hose. Hides, öils

Leather Hides, Oils

Leather \& Findings.. 2

Light $G$ ra y I $r$ on

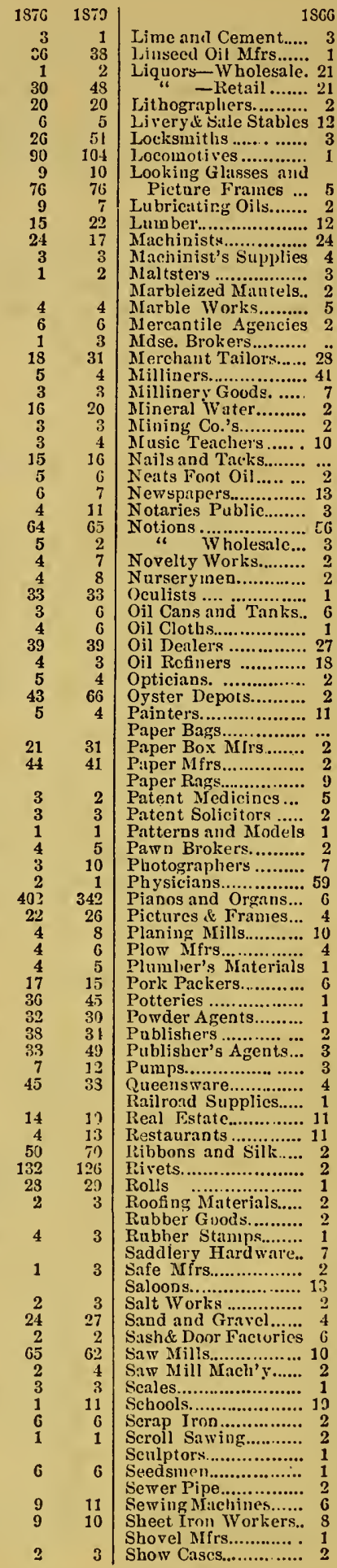

\section{S\% 18\%}

5 - 9 Silver\& Gold Plating

\begin{tabular}{rr|l} 
& 4 & Slate Roofing............ \\
$\ldots$ & 2.1 & Soap and Cund les......
\end{tabular}

$100 \quad 105 \quad \begin{aligned} & \text { Soda Asli.................. } \\ & \text { Soda. }\end{aligned}$

3 Spices.

89 Spikes and Rivets...

Stair Builders..........

Staves...............

Steamboat Agents......

5 Steambont Joiners....

1 Steam Fitters.

33 Steam Pumps

Steamslip Agency...

Steel.

18

Stcel Stamips............

3 Stencil Cutters.........

18 Stencil Stock Nlfrs...

106

3

3
13

16

\section{3}

\section{24}

24
16
4

\section{9}

65
4

3

Stills ......................

Stills ...................... 3

Stoves...................... 13

Stucco WVorkers.........

Surveyors..................

Tailor's Trimmings.. 2

Tanks (Iron)...........

Tanners....................

Telegraph Co.'s........

Terra Cotta Ware.....

Tinners a n d $\mathrm{T}$ in

Iron Ware. Slieet

Tinners Sitock............

Tobacco Leaf............. 1

Tobaceo ind Cigars

$\rightarrow$ Retail...............

Tobaces and Cigars

-Wholesile..........

Tow Boat Offices.........

Toys ..................... 2

Trumings \& .............

Trunks \& Valises....

Undertakers...............

Upholst. $\cdot$ res ................

Varnish....................

Veterin:ury Surgeons

Vinegar ...................

Vagon Makers..........

Whip Affrs..................

White Lead

Window Shirdes.........

Wire Works.............

Wood Carvers............. 2

Wood Enuravers...... 1

Wnod Turners ........ 2

Wood \& iVillow W: Wre

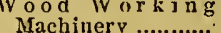

Wool ........................

Woolen Milis............ 3

Wrought Iron Pije... 2

Yeast..........

ODGis-

Masonic................. 15

A. O. U. W............ 28

Knights of Pythias ...

G. A. R..

I. O. R. M

H URCIILS-

Baptist................. 12

Catholic................. 19

Disciples.

Episcopal ................

Ev. Lutheran.

Meth. Episconal.... 29

African M. E......... ...

Presbyterian.......... 36

Linited Pres...

Ruformed Pres....... ...

Cunberland Pres... ...

Jewish Svnigougues $\ddot{1}$ 


\section{To the People of Pittsburgh,}

\section{BUSINESS MEN OF PENNSYLVANIA AND THE GREAT WEST.}

We present to our readers and business community herewith a brief historical review of the prominent business houses and manufacturing firms of the City of Pittsburgh. It will be interesting as an exhibit of the growth of the city for the past thirty years. The notices, as a group, embrace numbers of substantial and enterprising firms in every department of trade, including many specialties not to be obtained in any other market, and will be an assurance to those contemplating a visit for the purpose of purchasing supplies, that their every want can be more fully satisfied, on as favorable terms, than at any other point in the United States.

\section{McCONWAY, TORLEY \& CO.-Eagle Malleable Iron Works,}

Cor. 25 th \& Liberty Sts.

The supremacy of Pittsburgh as an iron manufacturing centre is never so clearly demonstrated as by a detailed inpection one after the other of those various firms and establisliments that by the development of this great staple industry have secured for our municapality the well deserved title of Iron city. In making such a review the firm of MeConway, Torley \& Co., in the particular liranch of the trade with which it is identified, will have to be accorded the first place, not only on account of the mignitude of its business but also with reference to the amplitude of its facilities and the quality of its products. The house was originally established in 1868 under the style and hy Lewis \& Co., who gare place to the present proprietors some years since, the latter baving greatly increased the resources as well as the ineaus and applances for a more which their facilities are particularly compreberisive and complete. To this end the plant which covers about half an acre, is supplied witi one cupola and two air furnaces, four annealing furnaces, one plant which covers about half an acre, is supplied witi one cupola and two air furnaces, four annealing furnaces, onc
powerful steam engine with 10-inch cylinder, 18-inch stroke, and other machinery of the hest devices. From 50 to 60 operatives, most of whom are expert mechanics are employed by the firm, wliose trade reaches from Maine to California, all over the Uuited States and is rapidly increasing. Mr. Wm. McCon way is a native of Ireland, where he was born in 1842 ; upon the removal of his parents 10 this country and ejty in 1849, he accompanied them, and when but twelve years of age began the acquisition of his present vocation. He belongs to the representative class of what may be called "self-made inen." Mr. John J. Torley was horn in New York, in 1830, and during the same year was brought to Pittsburgh with whose interests and vicissitudes he has been connected all his life, ly the closest ties of public spirit and personal prosperity. These gentlemeu are active partners in the house of IcCniway, Torley \& Co, whose oper:ltions are conducted by these gentlemen, demonstrating in its success the wisdom of the policy upon which it is carried on, and achieving the esteem and contidence of the trade and the general public.

\section{EBERHARDT \& OBER,-Lager Beer Brewers and Maltsters,}

The business was first established by Mr. C. Eherhardt in 1852. The frm was changed to Eberhardt \& Ober in 1870. The husiness was cotnmenced on a very small capital and has increased very largely. Mr. Eberlardt was the third person who commenced the hrewing of Lager Beer in Allegheny County. The buildings consist of one twustory frame structure, $40 \times 44$, malt house, $50 \times 85$, four stories high, with a capacity of 20,000 bushels; brewery and boiler-house, two-story brick stru ture $40 \times 50$. The power cousists of two large hoilers 20 feet long by 42 inches in diameter, and two engines of 20 and 15 -horse power respectirely. They have three large rock vaults with a capacity of 5,000 barrels, and are abo't erecting a large new jeo house, 50x80, with a cellar underneath of 4,000 barrels capacity and a capacity of 2,000 tons of ice. Connected with their ponds and jce-houses in the country is a large steam elevator with a capacity of lifting 800 tons per day. They employ fifteen liands constantly and their pay-roll averages $\$ 175$ per week. The Lager Beer manufactured is not excelled by any in Western Pennsylrania. Having heen permitted a complete inspection of the establishment, we have no hesitation in pronouncing it one of the very lest and most comcomplete inspection of
plete in the country.

\section{McKEESPORT IRON WORKS, -W. D. Wood \& Co., Office, 111 Water St.}

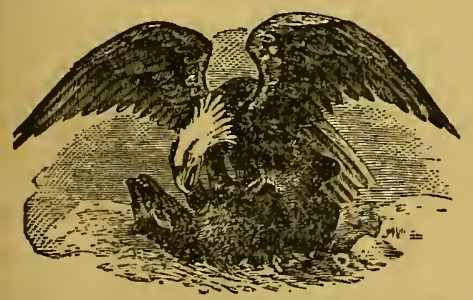

Manufacturers of Patent Planished Sheet Iron. Works, Mfireesport, Pa.

The McKeesport Iron Works are eligibly situnted on the bank of the Monongahela River, eleven miles above Pittsburgh, covering an area of five arres, and affording employment to about 300 inen. The senior partner of the firm, Mr. W. D. Wood, some thirty years ago began a series of experiments in the manufacture of sheet iron, the end sought after being to produce as durable and as finely finisbed an article as the "Pussia Iron." Many others in this country and in Europe have nade similar attempts, but lie alone succeeded, and the McKeesport Iron Works is to-day the only mill outside of Russia manufacturing this class of iron. The firm (composed of W.D. Wood and lis sons, Richard G. and Alan W. Wood,) commenced manufacturing an article in initation of Russia Iron as early as 1851 , at the works pictured above, (then just built). In the year 1870 they made a great improvement in their process, and the produet was sold as American Russia Sheet Iron. In 1873 further improvements were made, Including their Patent Planishing Process, and since then the product has leen sold as Patent Planished Shcet Iron. This iron is equal in all respects to the Imported Russia. The principal railroad lincs in the Unitcd States and Canada have adopted the Patent Planished Iron for covering their locomotives and for mounting the stoves in the passcnger coaches. The Company also manufacture tirec other gralcs of sheet iron, known to the trade as the smooth surfaced common, charesal, and Juniata. Patent Plinished Sheet Iron is made exclusively of the best hammered charcoal hloom iron (made at the Alckeesport Iron Works) and finished under planishing hammers weighing ahout three tons, striking 300 blows per minute. with an estimated force of 20 tous to earh strole. This planishing process imparts to it that beautiful gloss and dappled appearance of Russi. Ircn, and closes the rores so effectually that it will resist the action of the atmosphere fully as long. The capacity of t'20 worls $i_{3}$ about 80,000 packs of Plavisbed and about 5,000 tons of all kinds of sheet jron per annum. 


\section{FLEIIING, AGNEW \& CO.-Stamped \& Japanned Ware,}

This extensive establishment was founded in 1856 by Mr. John Fleming in a comparatively small way. He continued the business alone fur two years, when Mr. Joseph Torrence was alnitted as a partner, under the style of Fleming \& Torrence. In $1865 \mathrm{new}$ partners being admitted the firm becume Fleming, Torrence \& $\mathrm{Co}$., and in 1868 it changed to its present style of Fleming, Agnew \& Co., who have ever since carried on the business. The members of the firm as it now stands are Mr. John Fleming, Mr. Edward Agnew and Mr. John Hamilton, all of whom are thoroughly practical business men, through whose skill and experience this branch of industry has been largely developed and extended. They occupy as wilrerooms and office a substantial four-story brick structure $50 \times 60$ feet, and as a manufactory a similar four-story building directly opposite on the same street $60 \times 75$ feet in size, in which they emplop seventy-five hands, with a pay-roll anountiug to about $\$ 2,500$ per month. In this factory they have the best and most approved machinery to be found in any establishment of this kiud in the United States, with one forty-horse power engine and boiler, the finest in the eity.

The facilities enjoyed by this house for turning out superior articles rapidly are not surpassed. They carry an average stock of abolit $\$ 60,000$, and their annual sales amount to not less than $\$ 210,000$; their tricle extending all orer the Union. Among the various articles manufactured by this firm which have given them such a wide-spread reput:ation, we may mention Japanned cake boxes, candlesticks, canisters, cash boxes, coal hods and vases, cuspadores, tea caddies, toilet sers in great variety, bowls and pitchers, tin toys, miner lamps, and every article in that line that may be required. Stamped ware, including every variety of plates, cake pans, patty pan, pot and kettle covers and bottoms, dippers, milk pans, wash basins, etc. They are also extensive importers of and dealers in tinner's stock, tin plate metals, etc. This house stands prominent among the leading branches of industry and has contributed largely to the resources and reputation of the Iron city at home and abroad. Mr. Fleming and Mr. Hamilton are natives of Pennsylvauia, and Mr. Agnew was born in the county Down, Ircland, but for many years has been a resident of this city.

\section{LION BREWERY,-Corner of Vineal and Villa Sts.}

This large and commodious establishment, the Lion Brewery, is where the fnest and hest quality of Lager Beer is manufactured. The brewery was first started in 1858 by Hechelwan \& (il.-changed to the Lion Brewing Co. in 1874, in 1878 to Lutz \& Walz, and to D. Lutz \& Son in 1879. The entire establishment consists of fire luildings, as follows: One two-story frame, $28 \times 46$, one three-story brick, $54 \times 72$, one two-story brick storehouse, $30 \mathrm{x} 42$, one two-story frame, $30 \times 42$, and an ice-house, 46x72, with a capacity of 1,200 tons. They turn out about 12,000 barrels of beer anvually, and the business amounts to the comfortable sum of $\$ 70,000$ per year, with a stock on band of $\$ 18,000$. They have eighteen hands constantly employed and their pay-roll amounts to $\$ 20$ per week. The power consists of one boiler, one engine of 26-horse power. The quality and excellence of their Lager Beer is not surpassed by any lrewery in Western Pennsylvania and finds a ready and rapid sale in all parts of the country. Everything in and about the establishment is conducted in a neat and orderly manner.

\section{LUTZ \& SON,-Lager Beer Brewers, Nos. 1 to 11 Spring Garden Av., Allegheny.}

The above firm is amongst the largest and most extensive brewers of Lager Beer in Western Pennsylvania. Their establishment, commonly known as the Allegheny Brewery, is located at NCS. 1, 3, 5, 7, 9 and 11 Spring Garden avenue, Allegheny. The business was first estahlished by Lutz \& Walz in 1853 on a very small capital, which has largely increased and now amounts to the large and nlagnificent sum of $\$ 105,000$ per annum, with a stock on hand of $\$ 20,000$. The firm was dissolved in March, 1879, by the death of Mr. Walz, and Mr. Anton Lutz was admitted into partnership. The brewery is one of the largest and most complete in Western Penusyl vania, and turns out ahout 15,000 barrels of beer annually. The buildings consist of one tliree-story brick, 50x44, one three-story brick, 32x140, one two-story brick, $50 \times 108$, and one two-story brick, $25 \times 36$ feet in size, one boiler and one engine of 32 -horse power. The firm has a wide reputation for the quality and excellence of their beer and command a large and extensive trade. Mr. D. Lutz, the senior member of the firm, was born in Wurtemburg in 1822 and came to Allegheny in 1848. Anton Lutz was born in Pittsburgh in 1853.

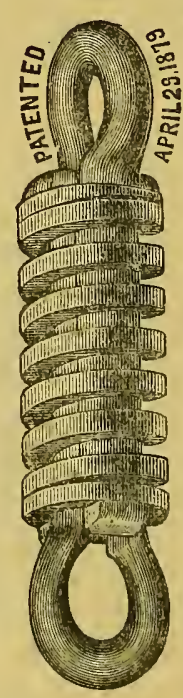

\section{RISHER \& CO.-I. X. L. Tug Link, 62 Wood St.}

The inventor or manufacturer of every useful and ingenious device or apparatus, especially such as either mitigates toil or increases its efficacy, is not only to be regarded with consideration by the community to which he belongs, but is in reality the means of affording a new outlet for lahor and $\overrightarrow{\widetilde{Z}}$ capital, perhaps otherwise unemployed. In devising the I. X. L. Tug Link, Messrs. Daniel Risher, Jr, and Daniel R. Mcclure, as D. Risher \& Co., may properly be classed among those to whom these remarks apply as in the manufacture of their specialty they are not only supplying an appliance greatly needed, but contribute iu no snall degree to the comfort and ease of draft animals. The Tug Link of which the accompan ying cut presents an admirable idea, is designed as an intermediate attachment between the single tree and trace on all road vehicles and agricullural implements, and its action not. only tends to increase the durability of gear and harness by the neutralization of all shocks in starting or jars from sudden obstructions, but lessens the racket upon the horse l,y softening the strains upon the collar. These links are warranted not to get out of order more than an ordinury trace chain, and are constructed for simple and easy application with ring hook or open link; are sold at the very unoderate price of $\$ 1.75$ per pair. Those ordering by mail should describe which of the above styles they desire. Endorsements of this effective little apparatus come from all parts of the country and are backed by the best houses in Pittsburgh.

Thomas C. Jenkins, the well known wholesale grocer, says: "They are the most complete invention vet introduced."

C. P. Markle \& Sons, the celebraled naper manufacturers, write: "We consider your Tugs a greater benefit and saving than the springs of a huggy or wagon,"

Mr. C. S. Sedgewick, the agent of the Adams Express Co., remarks, after describing the action of the link at some length: "They have my hearty endorsement as avoiding concussions and protecting the shoulders of the horses."

These with hundreds of others, after extended trial and experiment, concur in one uniform testimony to the value of the I. X. L. Tug Link. They are also beginning the manufacturing of a valuable improvement of a perwanent sinring attachment to the end of the whiffle tree for buggies and carriages, to which is a secure fastening for the traces; advantages attained by this article are a saving to traces and a great comfort and ease to the rider, giving much more regular motion to the vehicle. Both members of the house are natives of this city and were born respectively in 1842 and 1846 . They are energetic, ingenious, practical and reliable gentlemen, well known in this community and richly entitled to the signal success that has and is attending their efforts. 


\section{VULCAN STEAM BOILER \& SHEET IRON WORYS.}

James ArC Neil \& Bro, Railroad Street, between $29 t h$ \& $30 t h$ Sts.

The general remarks elsewhere are particularly applicable to the firm of Janes McNeil \& Bro., proprietors of the Vulcan Steam Boiler and Sheet Iron Works, and manufacturers of every description of steam boilers, portable and stationary, oil stills and tanks, whiskey stills, blast furnaces, silver furnaces, and all kinds of sheet ron work, and of the Iron city in this particular line, was founded in 1865 , at first. on a complatively small scale and witl moderate means, but their business has since increased to such an extent that they have been compelled to considerally enlarge their facilities, and the amount of capital now invested by this house is large. Their trade, which extends over a great portion of the United States and Territories, amounts to many thousands of dollars per annum and is steadily increasing. Their office and works are located on Railroad street, between 29 th and $30 t h$, and cover an area of $100 \times 135$ feet, supplied with the most complete ind perfect michinery, tools and appliances, to be found in any similar establishment in the West. Tha business is systematicalif conducted under two general sub-divisions, viz: boiler department and machine department, in whick thirt $y$-five skilled and experienced workmen are constantly employed under the immediate supervision of the nember's of the tiru, who are loth thoroughly practical mechanics. The various articles manufactured by this well known tirm, a portion of which we have enumerated above, are of the best material and most thorough workinauslip. The second-hand machinery and engines offered by them are thoroughly overhauled, repaired and put in perfect order, hefore offering them for sale, and customers may depend upon finding them exactly as represented. Niessrs. McNeil \& Bro. have recently shipped a fipe silv $r$ smelting iurnace to Leadville, Colorido, on the order of one of the leading mining companies of that section, and are expecting further orders from that vicinity with the development of the inmense resources of that argentiferous region. They constructed some beautiful flangres for iron firms in the city which were exhibited at the Centennial Exhilition in Philadelphia in 1876. and attracted much attention and very complimentary comments. While there may be other houses in the city witl l.ırger enpital and more extensire works, we are sufe in saying that there are none wiils more perfect and complete machinery and facilities and none more widely and favorably known for the superiority and reliability of their products. The inembers of the firm are conscientious and energetic business men, who have attuined their present eminence in the losiness in which they are eng:lged by their own unaided efforts, industry, perseverance and probity. Mr. James McNeil, the senior member of the firm, is a native of Scotland, and was boru in 1837, and has resided in the United States since be was thirteen years of age. If is a boiler maker by trade and worked at that business many years betore embarking in his present lusiness, acquiritig a thorough practical knowledge of the tracle in all its departments, and has hat charge of some large mitnufacturing establishments in the East $i$ " that line of business. Mr. MeNeil is hichly respected as a citizen, and las oceupied the pusition of school director lor many years. Mr. Thomas MeNeil, junior nember of the firm, was born in Scotland in 1847. He is a practical machinist and has had a long experience in that branch of business. He has been a menuber of the school board and stands very high in the community in which he resides. He was elected to represent his ward in the City Councils, hut removing from the district before the commencement of his term, rrigned the position to which he had been called hy a thattering majority. Both members of the firm are gentlemen of sterling integrity and worth and noted for their enterprise, business qualifications and unquestionable reliability in all matters pertaining to the social walks of life as well as in their commereial transactions.

\section{THE ROCHESTER TUMBLER CO., OF PITTSBURGH, PA.}

\section{Office, Liberty and Ninth Sts.; Works, Rochester, Pa.}

Organized by Pittsburgh capital and directed by Pittsburgh enterprise, the Rochester Tumbler Compan and its operations are justly entitled to consideration in any work devoted to a detailed review of the industries of ihis city. From its organization, in 1872, till the present, the suceess that has attended the enterprise has been happily commensurate with the capacity and resolution of those to whose direction the business was entrusted. The works were lucated at Rochester, on the line of the P., Ft. W. and C. R. R., alout 35 miles from the city, this spot being chosen not only for unrivalled facilities iu shipping or receiving freights by railroad from all points, and the further dvant:iges conferred in the same direction by the Ohio river, upon whose banks the plant is situated, but mainly on aceou $t$ of an inexhaustible flow of natural gas from two wells upon the premises, hy means of which the expense fur fiel is greatly modified, and certain portions of the work 1 erformed with more speed and perfectiou than attilined by any previous methods. The works, when first constructed, were considered extensive, but the steadily increasing demand upon the resources of the Company for production required additions and enlargements of the manufactory fr. m time to time, in order to keep pa e with the growing trade, until, at this period of its history, the works a:"e three times as large as at first constructed, with four times the productive capacity, and are, beyond question, the most extensive of the kind in the world. Every appliance or improved apparatus that modern ingenuity can devise or ample capital supply is to be found in this fictory not only for the manufucture of glassware, but the construction of all the necessiry pots, ulolds and models required in the business, the motive power for operating the machinery leing furnislyed $200 \times 200$ feet, constitute the plant, which covers in all an area of $21 / 2$ acres-fire-pronf buildings heing used for the security of molds, uodels, \&c.; a provision found only in this estab)ishment. The work is subdivided into seven departments, wnich embrace not only the constructive portions of the manufacture, but the miking of boxes, ]rteling, shipping, mold and model-making, clerical, \&e., employing in all 300 operatives and expert artisans, at an expense of $\$ 9,000$ per month, the working yedr occupying 50 weeks, the fires never having been put out since the commencement of the enterprise. The advantages derived from the use of natural gas (before referred to), which issues continually from two wells upon the premises, each 1200 feet deep, and originally sunk for oil (?), are very olvinus, as cheapening production and making the best fuel known for annealing glass and preserving its color, luster and translucency, for wlich properties the goods manufactured l,y the Rochester Tumbler Company have acquired a reputation that is coextensive with the trade of the concern, which is not contined to the United States, but reaches Great Britain, Germany, Spain, Russia, South Africa, South America, Cuba, Japan, A tsstralia, Britisli America, and, in fact, almost every available market in the world. The magnitude of the enterprise cannot be readily shown without the art of the illustrator, but, from the fact that the works are eapable of turning out 25.000 dozens of Tumblers per reek, snme idea may he gained of their extent. In the production of choice and beautiful designs in Tumblers and bar goods, this Compan $\mathrm{y}$ is unrivaller, continual improveruents in this directinn keeping it constantly in advance of the trade, and ensuring benefits to customers not to be duplicated by an y cotemporaneous concern, entitling the Rochester Tumbler Company to the splendid success : $:$ has so richly deserved, and which has proved of so great an advantage in fostering the industrial thrift of this community.

\section{JACOB YOUNG,-Groceries and Produce, No. 2525 Sarah St.}

This establishment was started hy Mr. Young in 1875, wit h a small capital, which he bas since considerably increased. He keeps a full and general assortment of all kinds of goods generally found in a first-class Grocery and Provision Store, includiug Fruits and Vegetables, Choice Fanily Flour, Sugars, Coffees, Teas, Spices, Dried Meats, Canned Goods, \&e. Mr. Young is always attentive and obliging to his eustomers. He occupies a conmodious store-runm, whieh he keeps fitled with the freshest and best class of goods for home and family use. Mr. Young was born in this city in 1818 . IIe is emineutly worthy the liberal patronage he receires. 


\section{SPANG, CHAIFANT \& CO.-Etna Rolling Mills, Office, Sandusky St., Allegh'y.}

No general description of the staple industries of Pittsburgh, however carefully compiled, or even reduced to a statistical basis, could possibly give one, unfamiliar with this great. workshop of America, an adequate idea of its real magnitude, especially with relation to the manufacture of Iron. By a review of each estahishment engaged in this enterprise only, can a reasonable conception be conveyed of the ponderous interests involved hy the trade in this city, or material be furnished for a proper appreciation of the development, resources and capacities of this community. To supply such information in detail is the object of this work, and in so doing the mills of Messrs. Spang, Chalfant \& Co. are entitled to more than ordinary consideration. These works were established, originally, in 1828 hy H. S. Spang, and are outranked in age by not wore than one or two similar concerns in Western Pennsylvania or the entire West, and may be catalogued in the same class with reference to size and importance. When first constructed, the mills, though dependent on water power and employing not more than 50 operatives in all, were considered for that period remarkably extensive, and for nearly 10 years, under the original unanagenent, pursued a successful and useful career. In 1837 C. F. Spang, James McAuley and Joseph Long assumed control of the husiness under the sty le of Spang \& Co., a title which remained unchanged until 1858, though the last named partner was associated with the cnterprise but 12 months. The latter date marks the period when the existing firm, composed of Messrs. C. H. Spang, J. W. Chalfant, C. B. Herron and Geo. A. Chalfant, succeeded to the business, and from that time to the present the history of the enterprise is distinguished by a series of enlargements, improvements and a vast increase in uroduction, as welI as greater pericction in the inethods cmployed and general results.

The scope of manufacture has also been widely extended. Originally confined to the product of MIerchant Bar and Blooms, the output of the mills now consists of Bar Iron, Nails, Boiler Plate and Wrought Iron, lap weldef Tuhes for boilers and Stcam Pipe. In this latter branch of manufacture the firm is the pioneer west of the Alleghenies, and was the first to engage in this department of the trade, obtaining from the outset a celebrity for work of this description that has been sedulously maintaincd and enhanced hy the application of every modern appliance likeiy to increase the excellence of this product. The mills are located at Etna, a point about 5 miles alove the city proper, in the Nortls Side of the Allegheny River. In an article in the New York Times of March 27, 1877, upon the iron interests of Pittshurgh, considerable space is devoted to a description of these villls, from the fact that the fuel eniploved for all the operations, involved by the working of iron and machinery, consists of natural gas conveyed by a line of pipe 18 miles long from the oil regions in Butler County. In the adaptation of puddling and heating furnaces, and for the use of this gas, material changes were required, and obstacles to be overcome that taxed both the ingenuity and capital of the firm to no meagre exient. All difficulties, however, were finally removed, and, for the first time in the history of tho iron industry, gas was used alone, without the adjunct of any other fuel, for the purpose of manufacturing iron snccessfully ju every process to which it is suhjected, requiring heat.

The plant at Etna consists of $t$ wo rolling mills and two pipe mills, in which are employed alont 450 operatives, whose earnings average from $\$ 20,000$ to $\$ 25,000$ per month, nine batteries of boilers and ten steam engines heing necessary for the supply of motive power, much of the machinery being of the heaviest construction. Part of the apparatus consists of 22 puddling furnaces, 9 heating furnaces, 6 trains of rolls, 22 uail and spike machines and other appliances, some of which belong exclusively to the firm under letters patent, especially such as pertain to the rapid and perfect construction of sockets and couplings for wrought iron pipes, the capacity of the mills heing not less than 12,000 tons per annum. It is hardly necessary to say that the house of Spang, Chalfant \& Cn. occupies a positinn among its cotemporaries devoid of blemish. The impetus given to the industries of this community by the capital and enterprise of the firm is not un recognized, and the general consideration with whicls it is resarded is the natural outgrowt h of a carcer, which for more than half a century has embodied the highest principles of conmercial integrity and personal honor.

PEOPLES SAVINGS BANK OF PITTSBURGH, -81 Fourth $A v$.

The marked success attendant upon the career and operations of the Peoples Savings Bank of Pittshurgh is of such a pronounced and obvious character as tn demand more than ordinary attention in making a careful review of the fiduciary institutions of this city. This bank was established in the Fall of 1866 , its chief executive officer heing the late lamented Henry Lloyd ; William Rea, Esq., Vice President, Mr. S. F. vnn Bonnhorst occupving the positions of Secretary and Treasurer, trusts which he still holds. The charter authorized a capital stock of $\$ 300,000$, hut the report of the Treasurer for the first year of its existence shows that while $\$ 100,000$ in stock had heen subscribed, hut $\$ 34,920$ had been actually paid in, the installment system for making payments heing adopted, to encourage the investment of those of small means. From that time every annual report shows a marked increase in deposits, assets and general usefu]ness. In 1872 the capital was increased to the full extent of its charter limit, which now gives the bank the largest capital of any similar institution in the State. Upon the 30th of July, 1867, the total assets of the concern were $\$ 102,388.75$, and on the 30 th of $J_{11} \mathrm{l}, 1878$, they had reached the prodigioins aggregate of $\$ 1,314,176.08$, including a contiogent or surplus fund of $\$ 80,000$, a showing that reflects the highest credit upon the skill and integritv that contributed to such a splendid result. The present nficers of the hank are as follows:-W W. Rea and Thomas Wightiman. President, Vice President and also Trustees: Messrs. E. P. Jones, Att'y at Law, Edward fregg, nf Log:n, Gregg \& Co., hardware; Hon. J. K. Moorliead, Geo. Wilsnn, Esq., Ex-mayor of the city ; Hon. Edwin H. Stowe, president judge of Common Pleas Court; Jno. A. Caughey, of Caughey \& Robinson, metal dealers: and David Mrck. Lloyd, Ist National Bank of Altoona, trustees; S. F. von Bonnhorst, Secretary and Treasurer, and N. G. von Bonuhorst, Teller and Bonkkeeper. Such being the management, the success of the enterprise was a foregone conclusion, und the high position it occupies among the financial concerns of this city, is a sufficient guarantee that its course has been directed hy a wise and honorable policy.

\section{KEYSTONE GAS LIGHT CO. (Limited),-0ffice, 44 Ninth St.}

Since Pittshurgh became the commercial center of the oil-producing regions of Pennsyl vania, man y attempts have been made here and elsewhere, with a greater or less share of success, to rapidly con vert the lighter products evolved in the process of distillation or refining into gas for illuminating purposes. In A pril, 1878, was incorporated the Keystone Gas Light Co. (limited), with a capital of $\$ 6.500$, having for jts ohject the manufacture of a device that should greatly improve upon all previous methods of producing gas from oil or its products and providing a cbeap, hrilliant and safe illuminatnr, thoroughly applicable to every purpose for which coal gas is now used. The success of the enterprise so far has been commensurate with the undoubted advantages obtained hy the process to which it claims exclusive title. The principle upon which the apparatus is constructed is simple but incenious and consists of the "ame being utilized to manufacture the gas consumed by it. A tank containing naphtha is placed above a Belden hurner and so connecled with it that the contents in transit are re-distilled and issue from the burner carbureted hydrogen. The whole arrangement is economic and efficacious, the estimated cost of one burner beins stated at. ahout one mill an hour. Since its organization the stock has been increased to $\$ 8,000$, the officers being. II. S. A. Stcwart, President, H. Campbell, Secretary and Treasurer. Managers-Henry Holdship, H. S. A. Stewirt, ir. Canspbell, Lewis Irwin, and Harry C. Caupbell, all of whom are intimately associated with the oil trade and recngnixer as nractical and thorougthly respensible gentlemen in every respect. By addressing the company at the above address, those at a distance will be placed in possession of the details of the enterprise. 


\section{HUSSEY, HOWE \& CO.-Mfrs. of Steel; Office \& Works, 17 th St. \& Penn Av.}

There have heen certain epochs in the history of the American Iron trade so rital in import and of such orerwhelming signiticance with regard to the future of all mechanic and most industrial arts, as to arrest at unce the profound at teution of all who trace the records of the development and elaboration of our material resources. The inauguration of the manufacture of crucible cast and open hearth steel, marks an era of this description, the full force of which, with reference to the growth and prosperity of Pittsburgh, will ouly be fully realized by the historian of a remote subsequent period, who will then he able to observe with unclouded vision the momentous consequences that hinge upon it. To the house of Hussey, llowe $\mathcal{E}$ Co. is justly ascribed the merit of first producing steel that khould compete with the best imported English brands, and finally effecting an entire revolution of the trade, not only in this country, but in England. This result, lowerer, was only achieved by years of unremitting endeavor, and the expenditure of nearly half a million of money before the efforts of the firm in this direction were crowned by a complete and signal success. The obstacles and discouragements to which the projectors of this enterprise were subjected required, in the lighest degree, cournge, tenacity of purpose and resolution to overcome. It was asserted on the part of the foreign minufacturer's liat the texture, quality and properties of American ore and iron were unsuited to the proper manufacture of steel, and that even the characteristics of our coke and coal were unfitted for this purpose. Wlien these allegations had been entirely confuted by the actual product of steel that would compare favoralily with any made in the worid, it becuue diticult to induce Americau consumers to even give it a fair trial, so entirely prejudiced liad they become by the arguments of British importers and producers. Every obstruction, however, finally disappeared before the unrivalled excellence of the steel, and the deternination of its mitnufacturers.

The firm was originally established in 1858 , the plant being located on the corner of 17 th st. and Penn are., covering an area of about one acre, and consiclered at that time prodigions in extent. The work of production was commenced in April, 1859, and was regarded as an undertaking that was certain to culminate in the same disaster that had overwhelued every prerious attempt, in a similar direction, wade in this country up to that time. Proceeding, however, with the greatest circumspection, for nearly a year the etforts of the frm can hardly be said to hare been more than a series of skillful and cautious experiments. Every grade of American iron was tested, and the results of each operation closely scrutinized. During the first three months but 10 tons of steel were produced, and after the lapse of 15 mont hs the total product had reaclied but 280 tons. New methods were employed, and it was demonstratcd that the English system of roasting the iron between layers of charcoal before the tinal crucible carbonization, could he dispensed with entirely, and the whole operation contined to the crucible alone. This was a discorcry of paramount jmportance, and is properjy attriiuted to this firm, as being the first to devise and carry it to asuccessful issue. The introduction of tool steel to the American trade had from the first a considerable effect upon the price of the imported article, and as it gradually became better known and was found to answer perfectly every requisite, the demand rapidly increased, ncessitating enlarged facilities, which were promptly supplied. Additional works were erected, which now occupy an area of over four acres, and are equipped with. the most perfect apparatus and luachinery knowa to the trade. These appliances consist in part of eight trains of rolls, eight steam engines, with several batteries of boilers, twenty in all, nine steam hammers, five toil hammers, one hundred and two coke melting furnaces, four twent $y$-four pot Siemen furnaces for melting by gas, Siemen's Martin open hearth furnace, besides steam sleurs, bydranlic presses, \&c. The proutuct consists in all descriptions of the finest quality of tnol steel, and all kinds of agricultural and other and for armor and ship plates, out of which they have furnished in the last few months some 1,500 tons to hiuila a bridge across the Missouri River at Glasgow, Mo, on the Chicago and Alton R. R. This is the first bridge luilt entircly of steel in the United States, and, perhaps, in the world. It was completed in April last, and has given the most eomplete satisfaction. As to the quality, Mr. Ames, of the Chicopee Ames Manufacturing Company of MIissicliusetts, testitied hefore a congressional committee, that in the conversion to sibres of 200 tons of this material, a luss was sustilined of less than two per cent. in defective metal, a result never equalled by the use of the hest English strel. The members of this firm are gentleuten too well known in this city to require mention of a personal character. Commencing operations with a capacity of about 300 tons of steel jer annum, the resources of the enterprise have been so enlarged as to be capable of producins at present from 10,000 to 12,000 tons vearly. As promotive of the gencral industrial welfare, the firm of Hussey, Howe \& Co. perform a work of great nagnitude in this direction, employing frcm 500 to 600 skilled workuen, at an average outlay of from $\$ 2 \$, 000$ to $\$ 30,000$ per month, and conducting a busincss that reaches almost every State of the Union, and increases with a fteady and prosperous development. The most extensive enterprise of the lind upon this continent, its listory is closely identified with the most important interests of Pittsburgh and the commurity at large. Since its inception the importation of English steel has fallen away to less than one-tenth of its former bulk, and there is evcry appearance that under existing conditions jt may terminate altogether, and to all intents an! purposes is now a dead letter. While enterprising and honorable, the liusiness policy of the firm is liberal, and in this respect has few compeers in this city, no house having achjered so remarkable a success, and at the same tine retained the high consicleration of the trade, iud the cordial esteem of tlie public, whose ad rantage has been fustered so materially by its operations.

\section{PARK, SCOTT \& CO.-Copper, Office, 122 Second Av.}

As one of the only two houses in Pittsburgh engaged in the smelting and rolling of copper, the firm of Park, Scott $\&$ Co. is not properly to escape inention in this work. The history of this house and its predecessors carefully vresented in detail, would involve so much of the commercial career and growth of Pittshurgh as to occupy more space than could be accorded, even if the necessary facts were at hand to supply the material. In brief, however, the original founder of the firm was Mr. James Park, Sr., who established hinself in 1813 as a wholesale dealer in grocerjes and metals, a combination at that time by no means uncommon. For thirty years, during what may be designated in local history as the pack saddle, mule train and canal epoch, MIr. Park pursued his avocations with uniform success, laying the basis for a substantial fortune, and upon his demise in 1843 resigning the business to his sons $D$. E. and $J$. Park, Jr., who under the style of James Park \& Sons continued the trade, confining themselves, however, exclusively to transactions in metals In 1846 the house became Park, McCurdy \& Co. and tinally in 1877 assumed its present stalus and title. From the inception of the firm to this day, during the few changes that have taken place in its namagement and composition, it has never failed to occupy a prominent place among the institutions of the Iron city, or exert an active influence in the promotion of every measure that scemed likely to redound to the general advantage. The products of the firm consist of rolled lake superior copper, refined sheets, bars and ingots, or special shapes inade to orcler. The plant is an extensive one, the machinery and appliances heing of the best modern description, employing the lahor of numerous skilled mechanies and ordinary workmen. In its business policy and charteristics the firm is liberal, ellterprising and honorable, commanding the respect of the community and inspiring a degree of confidence that few hous's are ever so fortumate as to acquire.

\section{J. E. IIBBY,-Dentist, No. 4309 Butler St.}

Dr. J. E. Libby, Dentist, has his Office and Dental Rooms at No. 4309 Butler St., where his skill and abilities are rapidly making success. The Doctor was born in Carroll county, Ohio. He learned his profession under the tuition of Dr. Templeton, of this eity-a dentist of high abilities and culture. He afterwards attended the Pennsylvania College of Dental Surgery, in Philadelphia, completing his education and fully graduating him for the successful practice of Dentistry. IHe began the practice of his profession in this city, and afterwards, in 1877, removed to Lawrenceville. 
WILIIAII HASLAGE,-Jobber and Retailer in Groceries, Provisions, de.

A striking example of progress, and of what energy, knowledge of husiness and fair dealing may aceonrilish, is afforded liy the history of this well-known house, which has become one of the business landmarks of the lity. Mr. Haslage was horn in Gernany in 1827, and came to this city in 1845. After being engaged about two years as is clerk, he started business for himself on the South side in an extremely small way, having a capital of but \$29. By attention to his business it gradually grew, and he removed to the Diamond. From the small beginning ahove mentioned, his business has grown to be the largest in the retail grocery line in the city, the stock usually being valned at about $\$ 75,000$, and sales amounting to $\$ 200,000$ vearly. The extensive building, erected for the purposes of Mr. Haslage's extensive business, is a hive of industry and activity. The store room has a front of 30 feet, and a depth of 150 fcet. There are four floors, connected ly elevators operated by steam power. The upper floors are used for storing goods, and also for roasting coffee and grinding and packing coffee, spices, etc. The carrying on of these operations in the building under the direct supervision of the proprietor, enables the honse to guarantee the purity and good qualiıy of all the packed goods they put upon the market, and has given to their coffees and spices a reputation second to none. The same care and attention have heen given to every other department and have made it one of the most noteworthy of our flourishing business houses. Some idea of the extent of its business may be gained from the fact that it gives employment to about 25 persons in various capacities, and its pay-roll amounts to about $\$ 1,000$ per month. In addition to Groceries and Family Supplies in general, the first specialty of the house is in dealing in tine Teas, in which line a larger quantity is sold by Wm. Haslage, at retail, than by any two jobbers in the city together, at wholesile. The secret of the immense tea trade of this house, which reaches over 50,000 pounds rearly, lies in the advantages aftorded customer's in procuring here the sime mixtures as ean be obtained in any part of Europe, the same which has given London, Belfast and other European eities such a reputation as tea centers. These. with other tine groceries, are imported direet by Mr. Haslage, and he is the exclusive dealer in this city for these choice gords. The second specialty of the house is the importation of pure Brandies and Wines for medical purposes; also of domestic wines, prineipally of Mrr. Haslage's own production. The entire business of this house is transacted strictly upon a cash basis, and no deviation is made from the estahlished prices of goods. Its trade is extended in erery direction from the eity within a radius of 150 miles. Mr. Haslage's business qualifications have been called into requisition in several corporations. He has filled the office of Director in the Artisans Insurance Company since its organization, and for the past four yeurs has been a Director in the German National Bank.

\section{S. B. HEDGES \& CO.-Com. Mer. for Cattle, Hogs \& Sheep. Central Stock Yards.}

Among the tens of thousands of producers this work will reach, showing the various industries and avocations of the Iron City, there will be a large number who are interested in the raising, buying and slipping of cattle, hogs and sheep, and as the advantages here presented will directly interest them, we append a brief notice of one of the most enterprising and worthy firms connected with the stock yards of this city. Messrs. S. B. Hedges \& Co, are successrirs to the firm of Hedges \& Taylur, who started in this business in 1867. Mr. Taylor retiring from the firm, Mr. S. B. Hedges continued the business in connection with others whose names are not essential to this sketch, and after some few changes, the present reliable company was established, consisting of Messrs. S. B. Hedges, the head and senior member of the Company, who was, in connection wirla Mr. Taylor, the original founder of this important business enterprise, and H. B. Pepper and Mr. F. Hedges, a brother of Mr. S. B. Hedges, eacli of whom is thoroughly conversant with the business in all its details, thus forming one of the most prompt and reliable firms operating in this line of business in Pittsburgh. They control a eash capital of $\$ 40,000$ and transact a very large and lucrative business, although, on account of discriminations in freight and general depression in business of all kinds, this branch has been lirgely reduced from former years, when the business was more than $\$ 1,000,000$ annually. This brief stateinent will convey to producers and dealers throughout the country the ample facilities enjoyed by this firm and insure entire confidenee in their transactions. S. B. Hedges \& Co. are Commission Merchants tor the sale of Hogs, Cattle and Sheep, with their office located at the Central Stock Yards, where all communjeations may be addressed. They employ one book-keeper and a thoroughly eompetent salesman, besides giving their personal attention to the details of their extensive business. Mr. S. B. Hedges was born in Ohio in 1829. Mr. F. Hedges was also born in that State in 1834, and Mr. H. B. Pepper was born in Chester County, this State, in 1851. This firm enjoys a high and honorable reputation in the city and country.

\section{HOLDSHIP \& IR WIN,-American Oil Works, Office, 49 Fifth Avenue.}

One of the first refiueries erected in Pittsburgh after the production of petroleum in Pennsylvania, was the Woodville Oil WVorks, built by Henry and George Holdship in 1859-60. Purchasing the American Works (formerly called the "Forsyth Oil Works"), in 1870, the Whodville Works were removed to the same site and merged into one concern. At that time these works were the llargest in eapacity in the State, and even at this time are exceeded in these respects by but three or four refineries in this section. In 1864 Mr. George Holdship retired from the business and was sueceeded by Mr. Lewis Irwin. The works are located near Sharpsburg Station, within the limits of the citr, and cover an area of about seven acres. When in full uperation the produce 5,000 lrarrels of refined oil per week, fifty men being required to conduct the various processes, whose earnjngs are about $\$ 2,500$ per montls. There are some facts in regard to the career of this firm and its operations that single it out from all others and entitle it to more than usual consideration, and while we are debarred by the character of this work from any further comment on this subject, it must he proper to say that the evidences given by this tirm of a high standard of personal and eommercial honor and spotless integrity, are such as to place it in a position peculiarly its owu. Both members of the firm are natives of Pittsburgh, widely known to the community at large and in no small degree aiding in various ways its development and prosperity.

\section{EIRN EST G. KREHAN,-Interpreter for the Courts, Alderman, Conveyancer, etc.}

The career of Alderman Krehan has been one of such eminent usefuiness as to entile him to brief recognition in these pages. A native of Weimar, Germany, where he was born Oet. 30, 18:35, at the early age of eighteen, impelled hy the wost laudable youthful aspirations, he emigrated to this country, and after residing at Buffalo, N. Y., for one year, came to Pittsburgh in 1854 , and for a quarter of a century has juentified himself with the best interests of the community. Soon after his arrival in this city he applied himself to the drug business, in which he shortly became an adept, comencing operations for himself in 1860, quitting the same in 1866, since which time he has continued, in spite of other pressing demands upon his time, to ocenpy a higl position in the profession. Under the administration of Presidents Lineoln and Johnson he was appointed Postmaster of Birmingham, which was not at that time annexed to Pittsturgh by consolidation, and in 1867 was ereated official Interpreter of the Allegheny County Courts by Gov. Geary, whose action was confirmed by the Senate of Pennsylvania, and in 1876 he was reappointed by Gov. Hartranft for a term of three years. As Alderman of the $29 \mathrm{th}$ ward, 'Squire Krehan was elected in 1870, a ehoice which proved so satisfactory to his eonstituents that he was again elected to the same nffice in 1875, his term in this capacity not expiring till March, 1880. Expert as a linguist, clement, but just, as an alderman, and reliahle in his profession and all relations with others, 'Squire Krehan deserves the esteem which he lias achieved and the friendship which his uniform course has inspired. 


\section{DUQUESIE BOILER WORKS,-James Thorn \& Co., Dliquesne Way $\& 2 d$ St.}

Familiar with the constitution, manufacture and capabilities of iron in all its forms, from the crude ore to the finished plate, the skilled mechillics aud enterprising manufacturers of Pittsburgl find no olstarles in the construction of any thing of which iron is the material or forms a component part, from the smallest tack requiring tbonsands to make a pound, to an oceall steamship of the most magniticent proportions. In every branch of industry pertaining to the various specialties of iron-working are representative houses whose names have become familiar not only throughmore largely to spread the fame and reputation of Pittsburgh, as the great industrial center of the western hemispliere, than that of Messrs. James Thorn \& Co., proprietors of the Duquesne Boiler Works and manuacturers of Steam Boilers, Oil Stills and Tanks, Agitators, Salt Pans, and every description of Wrougbt and Sheet-Iron Work, including Steel and Iron Hulls for vessels, steamboats, barges, \&c. This business was established hy Thos. MeColloster \& Eschebann, in 1840, and others, and, after various changes in style of firm and management, came into possession of the present proprietors in 1861 . The premises occulvied by this firm are on the corner of Second St. and Duquesne Way, covering an area of $150 \times 200$ feet, with spacious and conveniently-arranged buildings for the prosecution of their business in all its departments, and the most perfect and complete machinery and tools to be found in any similar establishment in the country, including a steam engine of 25 horse-power. Thirty-five skilled hands are constantly employed at these extensive works, with a monthly pay-roll aggregating about $\$ 1,800$. Their trade is principally derived from the two cities, the oil regions and the steambont interests of our own and western rivers, iron nills, etc., although they are rapidly acquiring not only a national but a world-wide celebrity. During the year 1878 this firm constructed for an English company a steel steamship hull, for use in South American waters, which not only gave the most perfect satisfaction, but surpassed their utmost expectations, drawing only 22 inches of water, whereas those of English build which bad previously been constructed for the same purpose were found to be utterly impracticable and unserviceable in the shallow waters of the Magdalene river, drawing more than four feet of water. This liull was manufactured and completed entirely in Pittsburgh, and then taken apart and shipped in sections hy rail to New York, thence to South America, where it was put together agnin ly men sent from this establishment for that purpose. The wood work for this steanship was also built in this city by Miessrs. Slack \& Sholes, a description of which will he found in this work under the article devoted to that firm. Messrs Thorn \& Co. are now negotiating for the construction of two other large hulls for New York parties, and are making arrangements to considerably enlarge their works and increase their facilities. Both members of this firm are thorough, practical mechanics. Mr. Jinnes Thorn is a blacksmith, and during the war of the rebellion was in the employ of the United States government, in the construction of government gumboats. He is an energetic, enterprising business man, and thoroughly con rersant with all the details of the business in which he is engaged. Jr. James Reese, the other partner, is a practical nuachinist. and, in connection with his interest in this business, carries on extensive machine and engine works at the corner of Fourth St. and? Duquesne Way. It is to the enterprise, ability and skill of such gentlemen as these that our city is largely indebted for the proud position she occupies to-day among the manufacturing cities of the world.

\section{MA CKEOWN, THOMPSON \& CO.-Oldest Wholesale Drug House in the city.}

i95 Liberty Street.

As the Oldest Wholesale Drug House in the city, conspicuous for the general extent of its business and resources, the firm of MIcKeown, Thom detail the Industries of Pittsburgh. Mr. John Hanlon, the pioneer druggist of this cily, was the founder of this house in 1825 , with very limited capital and in an extremely small way. With the natural growth of the city the trade grew in proportion until it became a marked feature, and passing into the hands of the present firm nrany years ago, wils considerably augmented and a new inupetus given to the concern. The premises of the house are ninst eligible, situated at 195 Liberty street, and consist of one large four-story brick edifice with finished basenent, $22 \times 110$ feet, containing a carefully selected assortment to tlie value of from $\$ 40,000$ to $\$ 50,000$, forming the basis tor an annual trade of $\$ 120,000$ to $\$ 150,000$, exclusively at wholesale. In connection witb the drug business, cmbracing : 11 and singular conplete supplies in this branch, this house is recognized as general headquarters for Paints of all kinds, Spirits of Turpentine, Resin and Pine Tar, Sperm, Whale, Fish, Lard, Engine and Lubricating Oils, etc. In these articles they deal very largely, sales of Pure Lead alone amounting to one hundred tons per annum. Twelve hands are eluploycd in the various departments of the trade, which has gradually extended over Western Pennsylvania, Easteru Ohio and West Virginia, and is increasing yearly under the liberal and enterprising policy of the firm. All the memthers of this firm are natives of this city, to the prosperity of which their thrift and enterprise has largely contributed. In those parlicular lines in which Messrs. Mackeown, Thompson \& Co. are engaged, they are heartily commended as
being reliable and agreeable people to deal with, having facilities for the supply of the trade which cannot be duplicated in Pittsburgh and which are certain to afford buyers every ad vantage in price, quality and circumstance.

\section{ARTISANS DEPOSIT BANK,-Corner of Third Av, and Wood St.}

The financial institutions of Pittshurgh, though numerous, are ret, as a rule, characterizer by a fair and hopeful degree of prosperity aud a general management safe aud conservative, though enterprising. These remarks are as applicable to the Artisans Deposit Bank as any similar concern in this city, of which it fornis pirt of the fiduciary system. The bank was organized in 1870 and incorporated under the State law, with a paid-up capital of $\$ 180,000$, with collections and exchange, some idea of the ability of its nianagement may be derived from the fact that since its estabcollections and exchange, somite it has paid from its earnings as dividends to the stockholders about $\$ 100,000$. Such success is of course owing to the fidelity with which the officers have admunistered their trusts, and withnut any fortuitous conditions of finance or trade during the period of the existence of the institution. From its inception to the present time 1 Iessrs. W m H. Smith and J. F. Stark have respectively occupied the positions of president and caslier, the former being also president of the Artisans Insurance Co. The directors are, besides the chief exerutive, Nessrs. dohn Dunlap, manufacturer of tinware; J. P. Barr, editor and proprietor of the Daily and Weekly Post; James McGinnis; W. S. Jackson, Idlewood Hotel; J. T. Colvin, of Colvin, Atwell \& $\mathrm{Co}$, wholesale grocers ; F. II. Hutchinson, secretary and treasurer of the liort Wayne Railway Co; Joln J. Pettit, of J. J. Pettit \& Co., produce, and L Glesenkamp, of L. Glesenkanp \& Co, carriage manufacturers. The cashier's staff is now composed of James P. Gelston, teller and book-keeper, and W'm. W. Miller, Messenger. The success of the Artisans Dcposit Bank under such control is equal to that of any institution started under similar conditions and auspices, and the consideration in which it is held speaks strougly in its fator as a solid and popular institution.

\section{A. G. CRONER,-Tin, Copper and Sneet-Iron Ware, St. Clair St., Mt. Washington.}

This business, purchased from his predecessor, M[r. Reigle, has been carried on hy Mr. Croncr since the Spring of 1878 , having then started with a good capital, which he has since increased. He has an extended custom and trade for many miles around, carrying a fair stock on hand of Tin, Copper and Sheet-Iron Ware, variety of Stoves, Hardware and Honse-furnishing Goods. Stoves exchanged and repaired, Tin-Roofing and Job Work of all kinds promptly attended to. All work warranted to give satisfaction. Mr. Croner was born in Washington county, Pconsylvania, in 1851 , aud began business bere in this city in 1878 , and is wcll deserving of public patronage. 


\section{TRADESMENS NATIONAL BANK,-Cor. Wood St. \& Fourth Av.}

The Tradesmens National Bank is another of the finaneial institutions of Pittsburgh, the wisdom of whose management has been endorsed by suecess, as well as by the high position it enjoys in the esteem and consideration of the community. This bank was organized upon its present basis January 1st, 1865, with a eapital of $\$ 400,000$, and was shortly afterwards appointed as a United States depository for this district. The officers are prominent in the various industries of this city and are as follows :-A. Bradley, Esq., President, and senior member of the firm of A. Bradley \& Co., stove founders, lias occupied this position since the establishment of the hank. Wm. Vankirk, Esq., Vice President, associated with the same firm, and Mr. Cyrus Clarke, Jr., for twelve years performing the duties of caslitier with recognized ability. The directors besides the President and Viee President, are Messrs. John Dunlap, Jas. MI. Schonnmaker, Jno. F. Drayo, W. Dewes Wood, Oliver P. Scaife, Sullivan Johnson and John C. Risher; gentlemen so well known as successfui increhants, manufacturers and producers, as to require no personal mention. The staff of the cashier is composed of Messrs. Ross W. Drum, teller; E. L. Goff, ass't. teller; A. J. Lawrence, General bonkkeeper; J. B. Van Wagener, individual bonkkeeper; $R$. M. Ditvis, discount and loan clerk; J. K. Craw ford, corresponding elerk, and Samuel Story, messenger. That the operations of the bank have been ably conducted requires no other demonstration than that up to Jinuary $1,1879, \$ 528,000$ had been paid the stockholders as dividends and a surplus accumulated of over $\$ 100,000$. Very few banks in this city have done better, or more deservedly enjoy the coufidence and respect of the public.

\section{ARMSTRONG, BRO. \& CO.-Mfrs. of Corks and Bungs, 24th \& Railroad Sts.}

The manufacture of Corks ancl Bungs is extensively carried on at the corner of Twentyfourth and Railroad streets, by the firm of Armstrong, Bro. \& C'o. The business was originated in this city, in 1854, by Mr. Harry Overington, on a comparatively small scale, and with moderate means, on smithfield street. He was succeeded by the firm of Jolın D. Glass \& Co., and they in turn by Armstrong, Bro. \& Co., who considerably jncreased the facilities and enlarged the business. In 1862 they removed to Third street, now Third avenue, where they re-modeled and enlarged the spacious three-story brick structure, which had been previously occupied by Lewis, Oliver \& Phillips. They remained in this location for six years, when they were compelled to seek more commodious quarters, and removed to the large donble warehouse, Nos. 44 and 46 First a venue. In 1878 ibe entire establishment was destroyed by fire, and the firm immediately proceeded to erect their present commodious and spacious manutactory, which is four stories in height, and built in the form of an " $L$," with a frontage of two hundred feet on Twentyfourth street, and one hunthe nost perfect and complete machinery. The trade of States, from the Atlantic Ocean to the Pacific slope. They employ on an average ahout one hundred and seventy-five hands, with a weekly pay-roll argregating about $\$ 1,200$ They import the raw material directly from the cork forests of sunny Spain, and manufacture every deseription of Corks, from the most diminutive sizes to the largest known to the trade, and cut cork to any lesired shaje and style, such as life preservers, \&e. Shavings from the factory are largely used for the manufacture of beds and mattresses, and are highly commended for that purpose by all who have them. In addition to the manufaeture of Corks this firm has a large factory in Warsaw, 1ndiana, whore they produce an immense number of compressed wooden bungs for barrels, which meet with a ready sale for a variety of purposes.

Mr. T. 11. Armstrong is a native of New York City, and was born in 1836. Hc has resided in Pittsburgh sinee he was ten years of age, and since 1860 has been identified with the cork husiuess, having been a member of the firm of Jno. D. Glass \& Co. Mr. A. J. Arinstrong was born in Allegheny City in 1817, and has been a life-long resident of this with this establishment during the entire period. cer of the house. was born in New York eity in 1837, and came to this city at the age of three years and entered the fer of the louse. Was born in wew oral organization. He was a genial, affable and highly respected gentleman in all the walks of life and univerfirm at its organization. He was a genial, aftable and lighly respected gentleman in all the walks of life and univer-
silly esteemed and resperted ; he died in Octoher 1878 . At the time of his decease he was a member of the hoard of directors of the United States bank and had for many years heen regarded as one of the most nolle, conseientious and honorable individuals in the ranks of Pittsbursh's representative men. The surviving members of the firm are enterprising, able and energetic gentlemen of the highest standing and of unsullied reputation.

\section{J. W. IMCFARIAND \& CO.-Carpets, No. 101 Fifth Av.}

Among the several firms in Pittsburgh engaged in the Carpet trade, perliaps none will bear a farorable comparison, with reference to extent, gencral appointments and maguitule, as well as variet $y$ of stock, with the enterprise of Messrs. J. W. MeFariand \& Co. This widely-known house was establisbed in 1863, under the style of MICFarland, Collins \& Co., the senior partner-J. WV. MrFarland-heing, in reatity, the sole manager and active worker of the concern, and in 1877 the title of the firm hecame as at present, the Company being nominal except in so far as representing some iuterests vested in the business by members of the family of Mr. McFarland. The premises occupied by the house are situated most cligibly on Fifth Av., the main thoroughfare of the city, next door to the Post Office-the building, an ornate, wire-front structure, heing one of the handsomest in Pitshurgh. Three floors of this edifice, each being $30 \times 120$ feet in dimensions, are engrossed by the firm and fitted up for the rapid and convenient transaction of business, in a manner wortly of the ehtiracter and stinding of the concern. Two patent elevators eonduce to the pleusunt avoidance of stairways, while the general furnisling is all that could be desired-the shelving on one floor :lone, which is sustained hy iron rods and braces from the ceilings, ensting over $\$ 1000$. The first floor is occupied as the main salestoom, and is not only admirably lighted, but is laid with South Carolina yellow pine of unusually tine quality, and has an altitude of 20 feet, which, with other advantages in the way of decoration, dc., makes it, perhaps. the most clegant and spacious business apartment in the city. The second and third floors are used as store, stork and work-rooms in the upholstery department, whjch brauch of the trade is earried on very extensively, the whole force of employees being five sulesmen, two elerks, two porters, one dliver, four upholsterers, six sewing girls--making a statf of 19 assistants iu all; besides which, a teaus of horses and two wagons are required for the delivery of yoods througl the cities and to steamboats, railways, \&c. The stock embraces Carpets of every grade, make and quality, imported and domestic, Window shades and Fjxtures in great variety, Curtains, Cornires, Floor and Table Cloths. Mattings, Rugs, Iruggets, Oil Cloths and every species of floor covering, having an average value of from $\$ 15,000$ to $\$ 20.000$ - the annual business amounting to $\$ 40,000$ and upwarls. NIr. NicFarland is a native of Franklin county, Penusylvania, born in 1833. Tle became a resident of this city when 20 years of age, and, for more than a quarter of a century, has exerted a marked influence in his rocation, to the benefit of the general public, by whom he is justly estermed as the oldest as well as the most widely experienced Jepresentative of the business in Pittsburgh. Mr. MeFarland is a remarkably rapid and decisive thinker and a pleasingly fluent speaker. In his thorongh and detailed knowledge of everything pertaining to or contingent upon his occupation he has few compecers; nor are his attainments limised to the channels of trade and commerce. Prompt, reliable, liberal, wilh an activity and industry that knows no patuse, he has made his house a lavorite one for those who have once appreciated the advantages to le derived there in prices: and, more than all, that considerate and honest advice which no one is hetter able or more willing to offer than Mr. MeFarland. With these ficilities, natural and acnuired, it is no matter of surprise that the trade of this firm has embraced not only western Pennsylvania, hut a large part of W est Virginia and Ohio-orders having been received even from Iowa and Missouri, as the result of a business policy based upon principles that none waly suecessfully ignore. 
WILSON, W ALIKR \& CO.-Union Forge and Iron Mill, 29th \& Railroad Sts.

It is only by a careful review in detail of the industries of Pittsburgh that any adequate idea can be gained in regard to the real magnitude of those interests which are of such vital importance, not only to this community, lut the Ameriean publie at lirgrc. It being the main object of this work to present such facts, bricf descriptions of the principal manufacturing enterprises are not only proper but essential, and in this connection the firm of Messrs. Wilson, Walker \& $\mathrm{Co}$. is entifled to more than passing notiec. The Union Forge and Iron Mill was established in 1861, by Messrs. Kloman \& Phipps, who were sueeeded by Mcssrs. Carnegie, Kloman \& Co. in 1866, and earried on the business until 1873, when the present firm was organized, being composed individually of Jolin T. \& James R. Wilson and John Walker as gencral partners, and Andrew Carncgic, of New York, as speeial part ner. Under this management tho scope of the mill was greatly increased and its facilities in all departments much enlarged. The main mill now covers an area of $90 \times 300$ feet, the blacksmith shop $72 \times 250$ fect and the forge and machine slop $72 \times 200$ feet, which, together with ot her buildings of smaller dimensions, oceupy an area of about two aeres. To operate the powerful and in many instanees intrieate machinery with which the works are thoroughly equipped, requires ten stean engines of various powers and ten boilers, the apparatus consisting in part of tifteen single puddling furnaces, six heating furnaces nine steam hammers, five trains of rolls, ove 18 , one 15 and one 10 inch and two universal plate trains. With these ces, nine steam lianees and facilities, the produets of the mill are of the finest grades known, and consist of all descriptions of railroad car and locomotive forgings, b:tr iron, unirersal mill plates, bridge jrons and special shapes of all kinds to order, shafting, splice bars, \&e., and for the manufacture of these specialties the works are said to be the best furnished and most extensive in the United States. Besides the oxdinary machinery usually found in such establishments and generally known to the trade, Mr. J.' 'T. Wilson, who is a practical iron worker and mechanician, has deviset and invented numerous pieces of mechanism for special purposes, labor and time saving, that are only to be found in this mill and will rreally add to the general efficaey of the work, the total productive capacity being about 12,000 tons per annum. The operatjves emploved at these works range from 175 to 350 and average about 350 , which represents the maintenance of two thousand individuals, and conveys an jdea of the nsefulness of the firm in the promotion of the industrial welfare of the eomıunity. The plant being located upon the line of the Alleglseny Valley $R$. $R$. With connectjng sidings, possesses eertain advantages in making direct shipments upon all roads centering in Pittshurgh not easily duplicated, and the introduetion of the wires of the Western Union Telegraph Co. into the office adds still further to the faility for transacting a business which ranges over the entire United States and Canadian Provinces. As a firm the not going ton far to say that the house of Wilson, Walker \& Co. lias achicved a position and suceess acquired hy it is not going ton fir to say that the honse of Wilson, Walker \& Co. has achicved a position and suceess acquired hy
few of its cotemporaries, and enjoys the high estcem of the trade and the consideration of the general public, which derives such marked advantages from its enterprise and capacity.

\section{PETER SOFFEL,-Boots and Shoes, Sycamore St., 32d Ward.}

Among the industries of the City of Pittsburgh to whieh this work is devoted, there is scarcely any one class outside of the great Iron and Giass trade which deserves more liberal notice than that of the general Boot and shoe tracte. So great is the competition, that greater encrgy and enterprise are essertial to success, and in this connection we desire to call attention to the excellent store and stoek of Mr. I'eter Suttel, located on Sycumore street in the 32d Ward. This calliness was started by the present proprictor in 1S6I, with eomparatively smiall capital, but which has been very materially increased by the liberal patronage he has constantly received since that time. He earries a stock ranging from $\$ 2,500$ to $\$ 4,000$, embracing the nost desirable and reliable goods for Men, Women, Boys. Misses or Children, and his prices are lower than his competitors. The length of time Mr. Soffel has been in lusiness has enabled lim to establish an enviable reputation for fatir and square dealing, and given him great popularity in lis wart. He was twice a nember of the Borough Council, also School Directur previous to this part of the city bcing incorporated in the city limits. Mr. Solfel was born in Germany in 18:38, and came to this eity in $185 \bar{t}$, where be eujoys a flourishing trade and the esteem and eonfidence of a large eircle of friends aud patruus.

\section{ADAMS \& CO.-Table Glassware; Office \& Works, 10th \& Williams Sts., South Side.}

In making a detailed review of the glass trade, as having a powerful inlluence upon the industries of Pittsburgh the well-known house ot Adams \& Co., manufacturers of Crystal Glassware, should not be overlooked. This tirm was originated in 1851 by and under the style of Adams, Maeklin \& Co. who com menecd operations under many disadvantages and with a capital that would now be considered altogether inadequate. The business prospered, however, under a shrewd and practical management, and hecame an established suceess after several years of unremitting exertion on the part of its projectors. In 1861 a ehange in the firm took place, the title beeoming as at present, the members of the house now being John Adams, Esq., Geo. F. Easton, Godfried Niller, A. A. Adama Jus

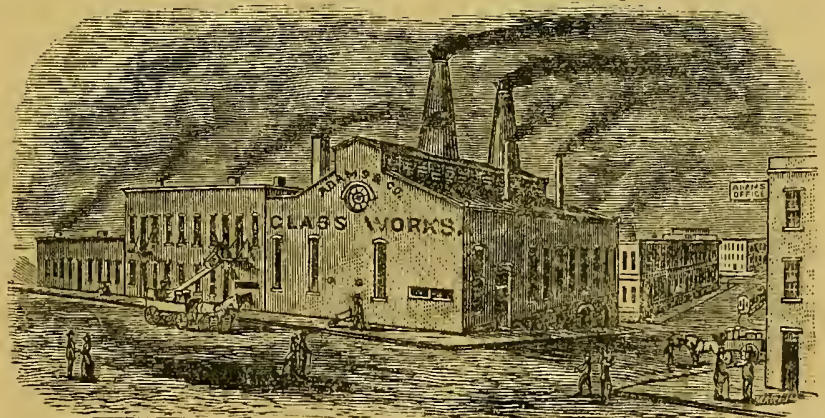
Dilzell, and W. Adains - all of whoin take an active interest in the work. 1 he plant is located, as ahove, in Williams St., South Side, and has been greatly enlarged and inproved since the sucression of the existing firm. It ronsists of five large huildings, covering in all an arca of ahout two acres, and containing two factories and two furnaces, liaving, in all, 23 pots, one engine and boiler, besides all the necessary maehinery and appliances for conducting operations upon the largest scale.

Here are employed about 200 expert artisans, to pay whom a weekly dishursement is entailcd upon the lirm of $\$ 2,000$, the total annual business transacted amonnting to between $\$ 175,(000$ and $\$ 200,000$, and extending throughont the Uuited States, Canadi, Cuba and South America. The proiluets of the firm are widely known for superior excellence, in finish and design; they consist mainly of Table Glassware, Lamp Chimneys, Lamps and Jelly Tumblers, greatly improved, upon which the firm holds several patents, the right to manufacture being exclusively confined to this house. Of the several members of the firm, all are natives of Allegheny county except Mr. Miller, who was borm in Germany. Mr. John Adams, the scnior partner, is closely identilied with the industrial development of this city, heing conneeted with many institutions prominent for their usefulness. As a late member of the city councils, lif influence was always dirceted to the support of those measures which secmed hest calculated to promote the general good; and, as a director of the Iron and Glass Dollar Savings Bank, sireet railway companies, and llic Flint Glass Association, Mr. Adams has done no little to foster the resources of this city. The firm, of which he is the estemed bead, upon a policy of honotable as well as liberal dealing, and cau olfer ad vantages to the trade that make it a most. demrabio house with which to establish relations. 


\section{PITTSBURGH BANK FOR SAVINGS,-No.6l Fourth Av.}

This favorite financial institution was incorporated under a special charter by the Legislature of Pennsylvania A pril 11, 1862, as the "Dime savings Institution of Pittsburgh," a title which gave place, however, subsecluently to that at present employed, which conveys very clearly the main olject of its organization. That the design of its founders has been realized to a marked degree, may be ceallily inferred from some figur's taken from the Thirt $y$-tirst Semi-annual Attested Report, which shows the available assets of the concern to be $\$ 675,332.64$, and a contingent or surplus fund of $\$ 91,715.77$ - or $\$ 16,745.77$ more than the capital stock. Such results are of course almost entirely due to the conservative and conscientious unanner in which the affairs of the bank have been managed, and necessarily redound to the credit of those to whom the business has been entrusted. Among these it may be natural to expect to find some of the most prominent names in the city -an anticipation by no means defeated, as proved by the followin list of officers and directors:-Geo. A. Berry, Esq., President-also Presilent of Citizens' National Bank, Director of Monongahela Iusurance Co., and connected with numerous other institutions; John Seott, Esq., and James Park, Jr. Vice Presidents, the former being President of the Allegheny Valley R. R., also President of the P. V. \& C. R. R., Director of the Nerchants' and Manufact urers' National Bank, and largely interested in the manufacturing interests of the community. The latter is of the firm of Park Bro's. \& Co., proprietors of the Black Dianond Steel Works and intimately identified with the development of the natural resources of Pittsburgh ; Mr. Chas. G. Milnor, Treasurer and Secretary, well known for an extended banking experience prior to his connection with this institution; Mr. David W. Jones, Teller and Book-keeper, also an expert in his department of the business. The Board of Mamagers, while. including the president and vice-presidents heretofore named, consists also of the following gentlemen:-A. Bradley, Esq., President of the Tradesmen's National Bituk and senior partner in the house of A. Bradley \& Co., stove founders; R. C. Schmirtz, Esq., President of the Aljemania Insurance Co. and lurgely engaged in the glass trade. Hon. J:mes L. Graham, influentially allied to numerous important organizations; Frank Rahm, Esq., President of the Woodruff Sleeping Car Co. and L. M. Plumer, Esq., A ttorney at Law, Solicitor. Under the management and direction of such officers and managers, the signal success that hits attended the eareer of the Pittsburgh Bank for Savings becomes readily accounted for, and a future of equal prosperity and usefulness seems as certainly assured.

\section{JULIUS VOETTER,-New York Hog Trade Stock Yards, East End.}

A bout two-thirds of the stock disposed of are sold in the New York market and the other third here, in Philadelphiil and other points. In handling loogs for the New York trade, Mr. Julius Voetter does a yearly business of over half a million dollars. He commenced here in 1856 in a small way, with a capital of only $\$ 200$ or $\$ 300$, but under his judicious management it has increased until it now reaches, if it does not exceed $\$ 15,000$. He occupies an office at the stock yards and may also be communicated with at J. D. Huffman's butcher shop. He employs ten men, with a monthity pay-roll of $\$ 800$. His business is conducted under two separate departments, in the first of which he bas associated with him Mr. J. G. Struble in the butchering department and Mr. J. D. Huffinan. At tilis plice on Penn avenue they use one enciue boiler, two meat choppers and lard tanks. Mr. Voetter is a natire of Germany, boru at Wurtemburg Nov. 15, 1836 . He came to Pittslurgh in 1856, and to the stock yards in 1864. He commenced business in $18 \overline{4} 4$ at Salem, Ohio, and has been actively engaged in the stock trade ever since.

\section{JACOB RUCH \& BRO.-Carriage Manufacturers, $304 \& 306$ 5th Av.}

The gentlemen composing this firm are both natives of this city and were horn on the very street where now stands the factory they operate. Estalulisined in 1876 , on a capital of about $\$ 4,000$, which has since been augmented, it nuay now safely be placed at $\$ 12,000$. They carry a stock of $\$ 9,000$ and transict an annual business of from $\$ 10,000$ to $\$ 12,000$. Their factory is two stories high and $50 \mathrm{xi} 00$ feet in size, and is divided into four departments, viz.: Woodworking, Blaeksnithing, Trinming and Painting. Ten hands are employed, with a pay-roll amounting to \$110 per week. The work turned out embraces Barouches, Doctors Phaetons, Jaggers and Buck Wagons, etc. This concern is noted for the excellence of their work, employing none but the best mechanics and using only the best material. Coich work made to order is one of the specialtics of this house. The success attending this establishment is evidence of its appreciation by the citizens. Jacob Ruch was born in 1840 and Fred. Ruch in 1838.

\section{JOHN MUSSLER,-Meat Market, 127 Beaver Av., Allegheny.}

This is one of the old established and successful business houses of the city, having been estahlished more than forty years ago by the present proprietor. Mr. Mussler is a native of Germany, but he has resided in Allegheny since 1837 , and been engaged in his present line of business since 1839. His extensive establisliment is located at vo. 127 Benver a venue, and consists of a th ree-story brick building $20 \times 55$, occupied as a meat market with three smaller buildings in the rear. He is assisted by his son and does his own slaughtering; customers may lye assured of procuring at ali times the choicest and freshest meats in the market. Beef, pork, mutton, lamb, veal, \&c., replenished daily and all kinds of pickled and smoked meats, sausages, \&c. ; his anuual sales will reach at least $\$ 15,000$. MIr. Mussler's establishment is desirably located and his surroundings are such that he enjoys the patronage of many of the principal families of the city.

\section{JAS. W. DRAPE,-Auctioneer, Real Estate and Insurance, 112 Federal St., Allegheny.}

This well-known knight of the hammer and master of "going going, gone!" began hnsiness in 1872, and has conducted it with marked success. The business transacted ranges from $\$ 150,000$ to $\$ 200,000$ yearly, with gradual increase. The business of such a man is multifarious, special attention being given to buying and selling Stocks, and negotiating Mortgages, and acts as Notary Public, House Agent, Appraiser, Broker, etc. Mrr. Drape employs tbree hands. His lusiness is ehiefly in Allegheny County, but extends on occasions into various parts of Ohio. He was horn in Scotland in 1837 and came to this city in 1866. He began in Pittslurgh in 1868 a general jobbing business in natifs, hardware, etc., and in this line did a very large business. He is enterprising and has a great personal and prom fessional popularity.

W. W. HECHELM AN, M. D.-65 Madison Av., Cor. Washington St, Allegheny.

This well-known Physician and Surgeon commenced his professional career in Alleghen y City in 1871. He graduated at Jefferson Medical College, Philadelphia, in 1869, and also resided as a medical student for some time at Munich, Germany, and graduated in 1870 at that place. In the Franco-Prussian War he was engaged as surceon and profited greatly in a professional way by the opporlunities afforded him. Dr. Hechelman givos special attention to diseases of the eye and ear. His treatment of such cases is said to be eminently successful. For the treatment of these delicate organs he has the latest and most improved instruments. The doctor bas a large and growing practice in Alleghen City, Pittsburgh, Birmingham and throughont the county generally. He was born in Germany in 1848, and came to this city in 1860 , and is an honor to the profession. 


\section{E. \& G. H. ZACHARIAS,-Cigar Manufacturers, 723 Penn Av.}

Among the prominent houses engaged in the manufacture of rigars in this city, re would make mention of E. \& G. H. Zacliarias, proprietors of factory No. 118, located at No. 723 Peun avenue, and also proprietors of the cigar store on sinithfield street in the Central Hotel building. This house wits extablished in 1862 by the present proprietors, at first in a small way as a retail cigar store, but their business rapidly increased and tbey engaged in the nanufacture of cigars, which they now carry on extensivel, employing a number of hands, making both band and unould work, rangin in price from $\$ 15$ to $\$ 70$ jer thousand. The celebrated "Chanpion" brand is their specialty, it is a five cent cigar which meets with popular favor. Their factory on Penn avenue is a three-story brick structure 14x60 feet in size. Their Smithtield street establishment under the Central Hotel is filled with a choice stuck of foreign and domestic cigars and manufactured tobacco of the finest brands. Their husiness at both places is both wholesale and retail, carrying an average stock of about 60,000 cigars, principally of their own manuficture with trade all over this and other States. Mrr. E. Zacharias has charge of the factory and store at 723 Penn avenue, from which the wholesale and reiail trale is principally supplied; Mr. Gr. H. Zarharias attends to the management of the Smitlifield street establishment. Both brotliers are natives of Marylund, but have resided in Pitsburgh for over twenty years.

\section{A. ANDRIESSEN,-Dealer in Wines and Liquors, 173 Federal St., Allegheny.}

Was formerly engaged in business at Nos. 40 and 42 Ohio street, and remored to his present place of business in the new and elegant buildings adjoining the Franklin Savings Bank. Was born at Detroit, Mich. in 1849, and canle to Allegheny in 1872. He keeps constantly on hand a choice assortument of foreign and domestic wines and Jiquors, and is also a large and extensive dealer in the far famed wines and brandies of California tbe "Golden State." siarting in lusiness with the limited capital of $\$ 4,000$, he has increased it to about $\$ 8,000$. His stock of liquors amounts to $\$ 10,000$, and his sales foot up annually to $\$ 20,000$. Parties in want of good pure liquors for inedical crother use can he suited, both as regards price and quality, hy calling on him. All brands of pure, unadulterated Manongahela Rye Whiskey, from one to ten years old, are kept constantly on hand, and warranted superior to any in the city. Remember No. 173 Federal street, Allegheny, Pa.

\section{F. FICHTEL,-Grocer, 15 Carson St.}

Mr. Fichtel, who established his present business in 1877, is among the best known dealers in Groceries on the South Side. His stock, which amounts to $\$ 15,000$, comprises every thing usually found in a first-class establishment of the kind. The store, which is $32 \times 60$ feet in size, is one of the most commodious business structures in that section of the city. The annual sales amount to $\$ 20,000$ and are steadily increasing. The success that has attended this gentleman since he has been engaged in his present business is an evidence that his establishment will always be ranked among the leading concerns of the kind in the city.

\section{WI. A. SEILING,-Butcher, 141 Beaver Av.}

The business now conducted by Mr. Seiling was originally established by Mr. Hugh Murphy. Mr. Seiling became proprietor in 1877, and under his nianagement the business has steadily increased. He occupies the two-story brick building, $18 \times 40$, at No. 111 Beaver avenue, with a stock averaging in value ibunt $\$ 300$, and transacts a yearly business of not less than $\$ 8,000$. He keeps a choice variety of fresh Meats, Beef, Pork, Veal, lamb, Mutton, \&c., and all kinds of smoked and pickled meats for family use. His prices are as low as the lowest. Mr. Seiling was born in Allegheny City, where he has a large and extensive acquaintance.

\section{T. B. STEW ART \& SON,-Dealers in Coal, cor. 43d St. \& A. V. R. R.}

The office and rards of this firm are located at the corner of 43rd st. and A. V. R. R., where the business was started by Mr. Stewart 22 years ago. They have $t$ wo large coal yards, with convenient sidings and tracks, one being $70 \times 150$ feet, and the otber $50 \times 160$ feet, from which the very superior coal of the N. Y. \& Cleveland Gas and Coke Co. is delivered to their customers. They are now delivering from 30,000 to 40,000 bushels of Coal per month, mainly to private families. Mr. Stewart was horn iu Pittsburgh, in 1824, and has lived there ever since. He learned the carpenter trade, working at it for a number of years, afterwards engaging in his present business. Mr. Stewart has been connected with the public affairs of his ward for many years, and is prominently identified with the public. schools, being still a member of the school board of his ward.

\section{JOSEPH DIEBOLD,-Groceries \& Provisions, Cor. 11th and Bradford Sts.}

This is one of the oldest Grocery stores in this part of the city, haring been originally started by Mr. Jobn Trigesser alsout 30 years ago. In $1870 \mathrm{it}$ came into the hands of Mr. Diebold, and by his excellent buciness management has worked up an established trade that will compare well with similar stores in this part of the city. He keeps a general assortment of first-class Groceries and Provisions, such as are demanded by every home, and sells at very low figures. He occupies a two-story brick structure, $40 \times 40$ feet in size, and gives bis personal attention to the business assisted by members of his own family. He was horn in this city in 1839, and is at present a member of the Council from the 29th Ward. Occupying a prominent position, he wields a strong influence in his section of the city.

\section{J. S. HOLLINGER,-Merchants' Dining Rooms, 46 South Diamond St., Allegheny.}

This excellent caterer and enterprising man of business opened his rooms in 1876 and since that time has furnished thousands of "square" meals in the highest style of modern cookery, at the most reasonable rates. His rooms are models of taste and cleanliness and nothing is wanting on his tables to satisfy the niost fastirlious epicure. Mlr. Hollinger occupies a building adapted to his business in all respects, and the stand being in the Diamond is most eligible. His building is $20 \times 45$ feet. He employs eight assistants, smpplying the choicest delicacies of the seasnn. Mr. Hollinger was born in Fayette County, Pa., in 1833 and came to this city in 1836 . He is a man of worth and respeclalility.

\section{J AMES RUSSELI,-Boots and Shoes, No.92 Federal St., Allegheny.}

This enterprising shoe dealer succecded the frm of Russel \& Kahn in 1869 with a large capital. The amount of his present stock may be placed at $\$ 25,000$, and his annual sales do not fail short of $\$ 35,000$. These figures will serve to show the extent of the trade, which is both wholesale and retail. Five salesmen are employcd, with a weekly pay-roll of $\$ 10$. The trade embraces both cities, count $y$-and adjacent regions. Mr. Fussell was horn in Philadelphia in 1828 and raue to this city in 1354. He legan business here in 1870 witll his son-in-law, Mr. Kahn, who dicd in 1877 . Mr. Russell is an excellent man of business, iurelligent apd enterprising. 


\section{THIRD NATIONAL BANK, - Nos. $146 \& 148$ Wood St.}

Justly ranked among the most solid fiduciary institutions of Pittsburgh, the Third National Bank takes a prominent place, and exerts an active influence upon the financial condition of this community. This bank was or anized in 1864 , with a capital of $\$ 300,000$, which has subsequently increased to $\$ 500,000$ as at present. The management from its inception has undergone but coinparatively few chinges. The President. W. E. Schmertz, Esq., has tilled that position with distinction for about 14 years. Mr. W $\mathrm{m}$. Steinmeyer has occupied the office of Casiler for more than eiglit years, and though the board of directors, from death and other causes, has been suhject to the greatest mutations, yet the policy upon which the institution was first conducted, has never changed, and its wisdoum has been amply demonstrated by a success that is remarkable even among the successful. As an evidence of this it is but necessary to state that the profits of the bank, as paid to stockholders in dividends, amount to nearly $\$ \$ 00,000$ in all siluce its establishment, leaving a present surplus of $\$ 145,000$. The directors, of which the following is a list, are more than usually prominent in their various vocations or professions, and represent not only a vast amount of wealth, but the solid and conservative element of the comuunit. : W. E. Schmertz, Chas. Meyran, Geo. D. McGrew, Henry Dallmeyer, Peter Keil, Chas. F. Wells, Jno. Daub, A. C. Draro, and Jno. M. Kennedy. With such a inanagenient the Third National Bank is a favorite institution, and while achieving success in all legitimate banking operations, has at the same time retained the respect and consideration of the community.

\section{UNION NATIONAL BANK,-Cor. 4th Av. \& Market St.}

The success that has attended the career of this well known financial institution has heen a matter of frequent remark and in reviewing the monetary organizations in this city, a rank nust be accorded it anong the first cotemporaneous concerns in Pittsburgh. The Union National Bank commenced business under the National Bank act of the general government, Febriary 1 st, $186 \overline{5}$, with a capital of $\$ 250,000$, and its surplus at the present time is over $\$ 200,000$ and undivided profits $\$ 35,558$ a juretty liealth commentary upon the ability with which the institution is managed and the acumen that directs its affairs. Mr. John R. McCune, a gentleman whose active interest in every measure promotive of the general good, has been displayed on many occasions, occupies the position of chief executive officer of the bank, and Mr. R. S. Smith, assisted by C. F. Dean, performs the duties of cashier with tact and discrimination. The business of the Union National Bank is very extensive, the deposits averaging considerably orer half a million dollars, the loans and discounts at the last statement being $\$ 712,727$. General banking operations are transacted, collections made on all points and exchanges effected in Europe or the East. Conducted upon a policy that involves the highest commercial code, the Union National Bank is justly entitled to a prosperity achieved, while conserving at the same time the public confidence, esteem and consideration.

\section{PH. HAMBURGER,-Rye and Bourbon Whiskies, 29 \& 30 Diamond Square,}

Mr. Hamburger commenced business in 1870 , with a comparatively small capital, which has since increased about 600 per cent. He occupies the entire three-story hrick building, fronting on Diamond Square 24 feet, and extending back 120 feet, carrying a stock of fine old Monongahela Rye and Bourbon Whiskies, Wines, Liquors, Brandies, Rums, Gins, \&c., of both foreign and domestic manufacture, valued at not less than $\$ 25,000$. . He transacts a large and constantly increasing business throughout the two cities, Western Pennsylvania, Ohio and West Virginia, amounting to $\$ 100,000$ or $\$ 100,250$ per annum. Mr. Hamburger gives his personal attention to the business and employs five assistants in the various departments of his establishment. This house is noted for the pure and unadulterated old Whiskies always on hand, and the uniform reliability of all goods kept in stock. Mr. Hamburger is a native of Germany, but has for many years resided in this city, and been actively engaged in husiness here.

\section{R. DIETZ \& BRO.-Boot and Shoe Manufacturers, 243 Federal St., Allegheny.}

At 243 Federal street, west side, above the parks, and adjoining Geo. Ritter's, is the boot and shoe store of Messrs. R. Dietz \& Bro., who were lourn in Germany, and emigrated to this country and settled in Allegheny in 1860 . Their business is carried on in a large three-story brick building, $20 \times 60$ feet in size. Messrs. Dietz \& Bro. both being tirstclass workmen, they command a large custom trade, and have bad a gradual increase in trade. Their stock of fine French calf-skin boots cannot be surpassed by any house in the city. They warrant good stock and neat fits, and do what they agree.

\section{A. ARMOR,-Druggist, 57 Taylor Av., Allegheny.}

The establishment of A. Arnior is on the corner of Taylor ave. and Monterey strcet, on the line of the Pleasant Valley Passenger hailway. The building is a large and commodious two-story brick structure. Mr. Armor keeps a clioice assortment of pure drugs and perfumeries which will be sold at bottom fignres. He has increased his business largely, now doing a trade of $\$ 5,000$ per year, with a stock on hand of $\$ 4,000$. Arr. Armor was born in Guernsey Co., Ohio, in 1851, came to Allegheny in 1370, and engaged as clerk with Jos. Park, Esq., until 1873, when he engaged in lusiness at 50 Taylor ave., firm of Ramsey \& A rmor. The firm was dissolved in 1875 by the withdrawal of Mr. Ramsey. In March, 1s78, Mr. Armor removed to this present location.

\section{G. F. BAUER,-Looking Glasses, Picture Frames, etc., 87 Beaver Av., Allegheny.}

Every description of Looking Glasses, from the finest French Plate to the more common and less expensive grades, may le found in great variety at the establishment of Mr. G. F. Baner, No 87 Beaver avenue. He also keeps a fne assortment of ylain and colored Engravings, Lithographs, Chromos and other works of art and niamufactures Picture and Looking Glass Frames in gilt, walnut or an y material desired. He also keeps in stock a full line of frames suitable for any kind of picture. The average stock carried by him is valued at about $\$ 500$. He does a tlourishing business, which is steadily increasing, and with light expense can offer rare inducements.

\section{JACOB PFIEL,-Groceries and Provisions, No. 1111 Bradford St.}

The Grocery and Provision business is of Interest to every family, and to the citizens of the South Side, we direct attention in this work to the House of Mr. Jacob Pfiel at No. 1111 Bradford street. You will find here a desirable assortment of Groceries and Provisions, embracing Teas, Coffees, Sugars, Spices, Canned Goods, Soaps, Coal Oil and a hundred other articles suited to house and table, and can buy of him on reasonable ternss. He occupies a three story brick building, $18 \times 30$ feet in size, and you will find it a pleasant trading place. Ile started in business in 1875 with a limited capital, and has met with a very good trade. He was born in Butler Co. Pa., in 1848 and came to this city in lis youth. 


\section{KEYSTONE AXLE WORKS,-Ahlborn \& Neckerman, Thirty-third St.}

The importance of a work of this character can uardly be overrated in its compilation of the business industries of this city, especially when we remember that in many obscure streets great nlanulictories are in operation, turnirig out valualie and curious articles of which even our own citizens are eutirely ignorant. The manufacture of iron axles for buggies, carriages and every description of vehicles is extensivet 3 carried on in this city by the frm of $A$ lilborn \& Neckeriuan at the Keystone Axle Works on Thirty-third St. In 1864 the members of the firm were engaged in the malufacture of tools ior oil wells and in the following year founded the present company with a capital invested of $\$ 24,000$. This was the first establishment of $i$ ts kind started in I'ittsburgh, and ever since its inception, its business has been such as to fully realize the most sanguive expectalions of the tirm. Their factory buildings cover an area of $78 \times 1211$ feet and are furnished with the most complete und perfect machinery of every description required in this line of business, jncluding a patent taper lithe for turning axles, the invention of Mr. Neckerman, and used wy no otlier establishment in the world. Twenty skilled hands are constantly employed in the various departments of the business, at il monthly expense of about $\$ 1,000$, and one thirty horse-power engine furnishes the motive power Their trade is througliont the West, extending to the Pacific Cuast with a not inconsiderable demand from many of the Eastern States. The articles manufactured are of a superior quality, both as regards' material used, style of workmanship and finish. The membrs of the firm are thorough practical mechanics, fully conversant with all the details and requirements of the business in which they are engaged. Mr. A H. Ahlborn and Mr. Neckerman are both natives of Germany and have been identified with Pittsburgl, the former since 1832 and Mr. Neckerman since 1810. Mr. A hthorn in 184: and i 84:3 assisted in the construction of the Iron Ship, Michigan, the first iron vessel ever built in Pittsburgh. Tbis was shipped in pieces to Lake Erie and there put together. Mr. Neckerman held the position of master mecilanic of Allegheny Arsenal until the formation of the partnership in which he is now interested. Both memhers of the firm are gentlenen of uuimpeachable integrity, and stand deservedly high in the esteem and contidence of the community. They lave both held positions of honor and trust to the entire satisfaction of their constituency, and as meubers of the city government have always been conspicuous in their efforts to develop the resources and increase the prosperity and welfare of the municipality. They are both justly entitled to a prominent position anoug the represeutative self-made men of the Iron City.

\section{BAISLEY \& LUTTON,-Notions, Druggist Sundries, Field \& Parlor Games,}

und Children's Carringes, No. 1 \&8 Federal st., dlleglewy.

Perhaps no firm in either city is more entitled to notice in the particular line of their business than the House of Messrs. Balsley \& Lutton. With an extensive stock embracing all the varicties of Notions and Uruggist Sundries, Field and Parlor Games, Children's Carriages, besides many other articles in the way of 'Toys, Wooden and Wicker ware, and all those countless : articles included under the name of Fancy Goods, this tirm, as joblers, can well offer to the trade such facilities in selection, and advantages in prices as can not be duplicated by any house in the city. The premises occupied by the firm at No. 128 Federal St.. are most eligibly located and of sufficient dimensions to accommodate a stock ranging from $\$ 15,000$ to $\$ 20,000$, and affurd scope for a rapidly increasing trade, that already extends over a large part of three states. The building is a substantial three story brick, 20 xI10 feet, supplied with ail the requisite appointments for conducting the business, 10 assistants being engaged in the various branches of the wholesale and retail departments. Of the individual members of the firm. Mr. Chas. C. Balsley is the senior partner, he was born in Pittsburyls in 1836, and has not only been closely illentitied irith the industrial interests of the city, bnt has acquired an experience of the most comprehensive character, the Lenefits of which he is ever ready to place at the disposal of those with whom he has relations. Mr. Albert Lutton is also a native of this city, and though 13 years younger than $11 r$. Balsley, has obtained a thorough knowledge of the lusiness, having heen engaged in the sanie, during the past five years. The frm was established in 1874, and has achieved an unexpected measure of success, leading to many iniprovements and the general extension of its resources, and added capracities for the transaction of a flourishing trade. Widely known and respected it is not too much to assert that the house of Balsles \& Lutton is not only able to compet $\theta$ in its line with any cotemporaneous concern in the West, hut has a repute for eviterprise and probity that makes it a nost desirable one, with which to establish pleasant aud permauent relations.

\section{F. W. REINECKE'S EAGIE PHARIACY, 1930 Carson St., S. S.}

This very competent Druggist has but recently commenced business, but in a way that plainly indicates bis intention of remaining in it. He began with a $\mathrm{capital}$ of $\$ 2,000$ and this was invested in the very best drugs and such as were especially adapted to the denauds of the trade. His stock at present announts to $\$ 3,000$, and this is in constant process of prudent enlargement. The building occupied is a three-story brick structure 18x70 feet in size. It is complete in all details of arrangements, and evinces in every part the taste and culture of the proprietor. The increasing business of Mr. Reinecke bas rendered necessary an assistant, while the business essential to a Drug Store is most carefully attended to. Prescriptions are tuade $a$ specialt $y$ in the fullest sense of that tern, besides a great variety of articles of taste and luxury, such as toilet articles, etco, are found on the shelves and in the bandsome cases of the establishment. The business, for the most part, is local, and yet extends even beyond this particular locality. Mr. Reinecke was born in this city and has received an clucation which fits him for the profession he has chosen, being it graduate of the class of '77-'78 Philadelphia College of Pliarmacy. He possesses that thorough knowledge of his business which is so indispensaljle to an accurate and reliable druggist.

\section{SAMUEL MAHOOD,-Teas and Groceries, Collins Av. \& Station St., East End.}

Mr. Mahnod was formerly a member of the firm of Voigt \& Mahood, Wholesale Com. Merchants on Liberty Street, Pittsburgh. In January, 1878, he established the "Golden Canister Tea Emporium " at the location above given, where he may now be found with a full assortment of choice family Groceries, Lixtra Fanily Flour, Teas, sugars, Coffees, Spices and in fact every article usually found in a first class metropolitan grocery store. He uccupies a store room $3 \times 60$, emploring two assistants, carrying a stock of about $\$ 2,000$ to $\$ 3,000$ and transacting a flourishing lunsiness of about $\$ 10,000$ to $\$ 1:, 000$ per annum. He numbers anong his regular customers many of the first families of the East End. II. Mahood was born in Ireland in 1839 , but has for many years been a resident of Pittslurgh.

\section{WM. H. STEW ART, M. D.,-Butler St., opp. Cemery Gate.}

Dr. Stewart has his office on Butler St, opposile the cemetery gate, where he has been in successful practice for a considerable time, having removed to that location from Allegheny ('ity, where he had previously been engaged in practice. Ile was born in Alleghany, Co. Md., in 1847 and came to Pittsburgh 10 years ago. He studied Medicine with Jr. O. A. Nicholson of Jllerheny City and graduated at the Cincinnati College of Medicine and Surgery, after which he began practice with his preceptor, Dr. Nicholson, in Allegheny City, removing from there to his present location after the death of the Iatter. The Dr. gained his education and qualified himself for his profession by lis own unaided eftort. IJe is a gentleman of the highest standing among the medical fratervity, enjoying the confidence and esteem of the public and is building up a prosperous practice. 


\section{SOUTH PITTSBURGH PIANING MILL CO.}

Cor. Third d Chestuut Sts., South sille.

An establishment so extensive and promoting to such a considerahle degree the ind ustrial welfare of the community, als that of the Sonth Pittsburgh Planing dill Co., is juruperly a subject for more than passing mention in this work. The Cumpany was organized in 1871 by Juseph Orr, and incuporated under the laws of Penn'a with a capital of 550,000 . The plant is located at the corner of Third ant Chestnut streets, the premises consisting of more than une acre, luust of which is corered by the buildings, the business being clivided into three departments, viz: Box factorr, sash and door factory and lumber yard. The capital stock of the Company is now increased to $\$ 56,000$ and the tracte

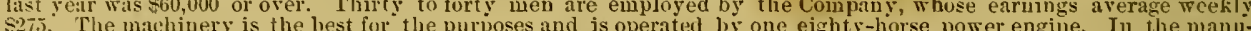
fatture of flooring, weather-hourding, frames, doors, sasb, shutters, mantles, stairs, mouldings and glass boxes this company excel, and also deal in frauing lumber, shingles and laths, and exeeute to order scroll sawing and turning, besides dealing generally in lumber of all teseriptions. The immediate management of the business rests with $A$. L. Sheaffer, President and Treasurer; James Shaw, Secretary ; a board of six directors exercising a general supervision at stated times. That the career of the Company has been eminently suecessful, is owing in no small degree to the ability with which its operative and tinancial afliirs are cunducted, and the reliable and enterprising policy that eharacterizes its business. The Comp:uy is one of the favorite institutions upon the south side.

\section{BOYIE \& CO.-Granite and Marble Works, $295 \& 297$ Penin Av.}

Messrs. Boyle \& Co. are importers and manufacturers of Granite and Marble Work of every description, making a specialty of tine Cemetery Work, Monuments, Grave stones, Tablets, Statuary, \&c. The house was founcted in 1572 by Ir. John Wilkins. Jr., who was succeeded by the present proprietors Jan. 1, 1878, under whose judicious management the business has considerably increased. They oceupy the spacious and centrally located premises, $45 x 90$, at Nus. 295 and 297 Penn avenue, with suitable buildings for manufacturing purposes, sales-room and oftice, carrying a large and judieiously selected stock of manufactured articles and unterial in the rough, consisting of native and foreign granites, marbles, fe., of the various shades and qualities, turning out some elegant specimens of artistic worls pertaining to this line of business. Seren skilled workmen are regularly employed, their semi-montbly pay-roll aggregating about \&450. Their trade, which is principally located in the city and suburbs, amounts to not less than \$9,000 per annum, and is steadily increasing. Fine Gronite and Marble work is the specialty for whieh this honse is noted, although every description of stone work is promptls and carefully supplied for building and other purposes. This estahlistiment is fast gaining an enviable reputation for the artistic and elegant morkmanship of their various products, and for their reasunable charges. Some beautiful speeimens of MIr. Boyle's skill are on exhihition at lis ware-rooms. Mr. P. Boyle was boln in Ireland, in 18:35, and has resided in Pittsburgh for the past thirteen or fourteen vears. He is a practical stone eutter, and learned lis trade in Baltimore, Md. He has worked at it coutinuously fur the past twenty years, and is thoroughly conversint with every detail of the business.

\section{W. G. STAHI, -Grain and Provision Broker, 293 Liberty St.}

Mrr. Stahl commenced husiness in this city more than two years ago as a Grain and General Provision Broker, conducting his business in the same manner as similar dealers have done suecessfully in the great grain centres of Chicago Hilwakee and other large cities. His lusiness during that period has steadily increased, and his ventures lave been universally successful and uniformly acceptable to his numerous customers. Some idea of the exteut ani magnitude of his business may be gained from the fact that during the month of April, 1879, his hooks show that in gr:tin alone his transations amounted to the purchase and sale of over one million one hundred and sixty thousand hushels. He also does a large brokerage business in the staudad and staple artieles of provisions of every deseription. His relations and facilities are such that he can purchase or sell any given quantity of grain or provisions at short notice and on the uost satisfactory margins. His office is located on the same flour with that of the W estern Union Telegraph Company, and he is all times in direct communication with the Board of Trale, Chambers of Commerce and beaviest operators in IIilwaukee, Chicago and the great grin centres of the conntry. His business is prineipally derived from local demands and from parties desirous of speculating in grain and provisions, and exeeeds by far thit of any other similar establishment in the city. Mr. Stahl is an enternrising wide awake and energetic young man, a uative of Penusprl rania and born in 1850 . In the line of business in which he is engaged he stands preeminently at the head and his prospects for the future are most encouraging.

\section{CENTRAL BANK, -No. 47 Fifth Av.}

Among the many cotemporaneous financial institutions in this eily the Central Bank has, since its establishment in 1\$66, waintained a position of undoubted consideration. Incorporated under the State laws, with a capital of s100,000, from its organization Thomas Fawcett, Esq., has filled the position of chiel exeentive officer. This genticulan is lirgely engaged in the coal trade, in connection with the firm of Thos. Fawcett \& Sons, and is associated with other important enterprises. Mr. Madison Builey, Viee President, is also extensively interested in the coal business, : int is of the tirm of Whightim, Bailey \& Co. March Hunnings, Esq.. Castier, has been connected with the bank from the date of its organization, with a prior experience in banking of many yours. Messrs. A. Kramer, Teller, ant M. Y. Robertson, Bookkeeper, are also adepts in their respective departments. The operations of the Bank are mainly in the line of general loans, discounts, deposits, exchange, de., and are uf consideral,le magnitude. The manageinent is marked by a safe and conservative policy. which has greatly aided the strength and standing of the institution. Altogether the Central B:mk is conceded to be one of the most desirable monetary coneerns in Pittsburgly with wlich to estahlish relations.

J. SCHNEIDER,-Dry Goods, Gents' Furnishing Goods, \&c., 1735 Carson St., S. S.

Mr. Schneider commenced business with a small eapital, but has heen so successful in the pursuit of Jegitinate gain that his stock on hanil now amounts to $\$ 15,000$, and his annual sales ringe from $\$ 25,000$ to $\$ 35,000$. His store consists of a three-story brick building 20x60 feet, hesides a reur building eonnected with the store, filled with Dry Goods, Trimmings, Gents' Furnishing Goods, se., in which he enjoys a flourishing trade and general popularity. He was born in Germany in 1830 , and came to this city in 1864.

JOHN W. KEMLER,-Watches, Clocks, etc., 1823 Carson St.

Mr. Kemler, who is located at No. 1823 Carson st., near 19th st., commenced business in 1S61, without capital. He has suceeded in building up a trale which now reaclics about $\$ 5,000$ per anmum, and carries a stock of Watches, Clocks, Spectacles, Jewelry and espeeially Opera Glasses in large variety. His store occupies a building $20 x i 5 \mathrm{j}$ fect, tilled with neat and desirable gonds. He was born in (iermany, in 1837 , and eame to this city in 184 . He has Jong represented his ward in the city conneil, and has a large infuence in that part of the eity. 


\section{WASHINGTON BECK, -Mf'r. of Glass Moulds, Machinery}

for Pressing and Worling Glass, 56, 58 \& 60 Sixteenth St., South Side.

A mong the many ingenious and expert mechanicians that lave fouml ample scope for their abilities in this city, Mr. Washington Beck, expecially in that particular branch of his trade which relates to the manufacture of glass mould and presses, machinery for pressing and working glass, is said to have no compeer. This reputation has been justly earued by twenty years of constant application, labor and invention. The business having been estatilishod in 1859 upon a limited scale, has increased gradually under the influence of more prosperons conditions to its present magnitulle. The premises occupied ly Mr. Beck at present are certainly in great contrast with the original shop, and con-
sist of one large two-story building $60 \times 80$ feet, thoroughly equipped with the best machinery known to the trade, much of it being entirely new in device and invented by the proprietor to accomplish eertain given oljects. Here are employed twenty skilled unechanies whose weekly earnings average from $\$ 200$ to $\$ 250 ;$ a ten-lorse power engine being required to supply the motive fore. As an illustration of the special character of the bulk of the work it may be stated that since Jall. 1, 1s79, wr within six months, Mr. Beck lias heen awarded no less thin nine patents for machinery appliances and derices relating to the improved manipulation and manufature of glass, and the main part of the business cousists in a constant surcession of new designs and inventions tending to the more perfect and rajid liandling of this material in all its various forms. Mr. Beck is a native of Pittshurgh and was lorn on the south side in 1839. The reputation he has established is not confined to this country, hut leads to a business in Europe, Canada auri Japan, which aursregaies from $\$ 20,000$ to $\$ 25,000$ annually. With the largest establishnent of the kind in the Uniter States and facilities that are unapproaclied anywhere, ilr. Beck's enterprise is universally appreciated by the glass trade.

\section{DELA WARE IMUTUAI SAFETY INS. CO. of Philadelphia, \\ P. A. Madeira, Agent, Branch Office, 68 Fourth Av.}

The Deluware commenced business in 1835 with a guarantee capital of $\$ 100,000$, subseription notes, twenty-five per cent. pitid in in cash. In 1848 the assets of the Cumprany amounted to $\$ 222,053.06$; in 1858 by resolution of the loard of dirretors the guartintee capital was discontinued and a cash capital of $\$ 360,000$ substituted, made up of seventy-five per cent, in the serip of the Company and twenty-five percent. in cash. In 1858 the assets of the Company amounted to $\$ 698,801.70$, they are now over $\$ 2,000,000$. The Delitware is the oldest and most successful Comprany in America, combining a cash capital with the mutual principle wherehy the assured participates in the profits, without incurring iny liability whatever beyond the premium patil. As to the conditions on which scrip is issued refer to published statements of the Company. In.18t4 an agency for the Company was established fn this city, and five years later Mr. P. A. Nadeira became $\mathrm{its}$ representative, and for thirty years the relations be then bore to the concern have renained in every material point unclianged, a circunstince as unusual as it is sattsfactory. The Delaware is no fair weather craft, calculated to navigate only in calm and placid waters, but has bulfetted the fiery billows for nearly forty-four years, with what success a reference to the present condition of the Company will show.

\section{J. C. BUFFUIM \& CO.-Manufacturers and Bottlers, $39 \& 41$ Market St.}

For more than thirty years the name of Mr. Buffum has been identified in this eity with the manufacture of Soda Vater, Syrups, Ront Beer and Ginger Ale, and with the bottling business which has become one of considerable mas nitule and importance. Starting in $18+5$ with noderate meaus the business of this house has steadily increased until at the present time thiriy-five to firty hands are employed with a weekly pay-roll aggregating inore than $\$ 300$, and nine wagons are engaged in delivering gords to customers in the two cities and to the various rail road depots, to supply their country customers. An aserage stock of not less than $\$ 30,000$ to $\$ 40,000$ is carried by this firm, and their annual siles will reach $\$ 50,000$. Messrs. Butfum \& Co. manufacture a superior article of Soda Water and choice fruit syrups of every Havor, W Veiss Beer, Ginser Ale and Root Beer, and bottle immense quantities of Ale, Cider, Lager Beer, Porter, Ec makiny a specialty of the hest grudes of Cincinnati and Milwaukee Lager Beer for table and family use, The import direct large invoices of the standari articles of English and Scotch Ales, Brown Stout and London Porter in the wool and bottle for the trade, hotels and families. Their Weiss Beer has attained a very high reputation and is highly recoinmended for its squerior quality and gencral excellence. They have one encine and all the necessary machinery reguisite in their extensive establishment, which is located in the spacious double three-story warehouse $40 \times 100$ feet with cellars, at Nos, 39 to 44 Market street. This is one of the oldest, most extensive and best known est:ablishments of the kind in the IV est, and the hich estimation in which the house is held has been secured by the enersy, enterprise and reliability of the firm and the superior quality of all goods manufactured and sold by them.

SPEER \& MORGAN,-Tin, \& Copperware, etc., 75 Frankstown near Station.

These genllemen commenced business on a moderate capital, which their increasing trade has enabled them to angment consilerably. They earı a full stock of Stoves, Ranges, Grate Fronts and House Furnishing Goods, and Inanufacture Tin, Copper and Sheet Iron ware, giving special attention to roofing and spouting; their annual sules are from $\$ 3,000$ to $\$ 1,000$. The store necupied by them, and well filled with attractive and substantial wares, is $18 \times 50$ feet in size. The tirm consists of Jolin speer and Oliver Morgan, young and energetic merchants. Their businpss promises to take a front rank in the East. Enll. Both gentlemen are natives of this city, Mr. Speer having been born in 1848 and Mr. Moruta in 1847 . M1r. Speer served with honor throughout the rebellion in the 5 th Penn'a heary artillery both gentlemen stand deservedly high in the community.

\section{CRUIKSHANII BROS.-Grocers, Cor. Monterey St. and Taylor Av., Allegheny.}

These two young and enterprising merchants opened this establishment early in the present year with from $\$ 2,000$ to $\$ 2,500$ worth of well selected stock, embracing every variety of Groceries Canned Fruits and Vegetalsles and an excellent assortment of all articles found in a first-class grocery and producc house. They ocenpy a well located brick building, and cmploy one hand in addition to their own services, which they give exclusively to the business. George L. Cruikshank was horn in Allegheny, in 1856, and his brother, John $\mathrm{F}^{*}$., in 1869. They are hoth thoroughly acquainted with all the details and requirements of the grocery trate, and are hoth perserering and progressive husines: men, and do a trade of alout $\$ 25,000$ per annum. They are conteous and polite to everyone, and popular with all who hise de:llings with them.

MRS. J. ARNOLD,-Books, Stationery \& Fancy Goods, 98 Federal St., Allegheny.

Mrs. Arnold commenced business, at hêr present location, in March, 1865. She occupies a three-story lirick building, $20 \times 60$, with a tinely selected assortinent of Books in great variety, Stationery, Toys and Fancy Articles. IIere may be found the most elegant and recherelze styles, and large variety for children and grown people. Mrs. A ruold was born in Ireland, Jan. 6, 1827, and has resided in Allegheny City since 1834. 


\section{CITY INSURAiNCE CO. of the City of Pittsburgh,-0ffice, 64 Fourth Av.}

Incorporated April 1870, as a Fire, Marine and Inland Insurance Company, this institution commenced business December 15, 1870, and through all the commercially disastrous periods since, has continued yearly to angment and increase its operations and its usefulness, until it is now regarded as one of the substantial associations of the Iron city. Robert J. Anderson, Es/., President, is well known throughout the country as a stecl manufacturer of unsurpassed energy and public enterprise, whose works in extent and capacity will rank with the most extensive in the world. Capt. R. J. Grace, the Vice President and General Agent, is known as an able underwriter; the Treasurer, MIr. Wilson Cunningham, is ove of the solid wen of our city, having been at the head of the glass manufacturing business for a number of years, and adds strengt/s and stability to the organization; and Jolın L. Gloninger, Esq., Secretary; all being well and favoralily known to the publie. It is in no small degrce owing to their exertions that the City Insurance Company has made so udmirable a reputation as a reliable and healthy institution. With a paicl up cash capital of $\$ 100,000$ and assets that reach nearly double that sum, the business of the Company has been uniformly prosperous, doing a moderate agency business with conservatism and prudence, and has been equally suecessful in this brunch ne of the most active and successful agencies being conducted by Messrs. Wm. L. Tete \& Co., whose office is located at 129 South 4th street, Pliladelphia. Managed by sn proticient a corps, to whose prolyity and discernment is added the advice of a loard of directors, who are cliosen from among the leading citizens in various pursuits, who have made its career so brilliant in the past; a more fivorable condition of general finance and trade must redound to its benefit to a marked degree, and insure a growth and importance commensurate with the ability of its management and liberal policy.

\section{McCORD \& CO.-Wholesale \& Retail Hats, Caps, Furs, \&c., 131 Wood St.}

The origin of this honse dates back to 1798, when the business was established by Mr. Rnbert Peeples and con ducted by him for about eighteen years, when he withdrew, after a career of 20 years, in favor of McKce d Grabani, who in turn were succeeded by MeLain, King \& McCord in 1833. This firm continued for soine time, clianging finally to IIcCord \& King, and at last to the present style and status which has remained practically unaliered for many yeirs ; the several members of the house being John D., James S., J.mes E. and Andrew McCord. The premises occupied are situated as above and consist of one extensive five-story building stocked to the value of $\$ 50,000$, with every variety of Hats, Caps, Furs and Straw Gonds, pertaining to a thoroughly managed concern in this line. It is not the province of this work to deal in fulsome laudation, but in this case it is sate to assert that while no concern in the city occupies a more respectable position, none has been conducted upon a more conservative, safe and honorable policy, and this statement is due as much to its predecessors as the present firn. I ith sueh characteristies and a career extending over four-fifths of a century, it is a uatural sequence that the business of the house should be as extensive as it is in this respect reaching for its trade not only throughout Penn'a, but the adjacent States. and in every way. standing at the head of its cotemporaries, both in the advantages offered to buyers and the general range and quality of goods.

\section{DIAMOND NATIONAL BANK,-Cor. 5th Av. \& Liberty St.}

Originally organized as the Diamond Savings Bank in 1870-the seope and increasing prosperity of its first years led to its re-construction in 1875 as a National bank, since which time the suceess of the institution has been so proliounced as to rank it anong the first financial concerns in the Iron City. The management is placed in the hands of Mr. A. Gurrison, of the tirm of A. Garrison \& Co., as Presideat; Wm. M. Hersh, Esq., Vice President, and Mr. John S. Senlly, Cashier; with a board of clireetor's composed of men prominent and esteemed in their respective vocations. With a capital stock of $\$ 200,000$ and deposits to the amount of $\$ 327,224.44$, lo:uns and discounts $\$ 332,470.69$, surplus and undivided profits $\$ 7,310.23$, it may readily be seen that the Diamond National Bank is governed by a rigid conservative policy - so much so that no customer is allowed to borrow more than $\$ 5,000$ upon the same endorsements. Under tliese circumstances the bank is regarded upon a par with many of its cotemporaries who perbaps seek to oceupy a IIIore conspicuous position.

\section{HENRY DAUB,-Fashionable Merchant Tailor, Cor. 38th \& Butler Sts.}

Mr. Daub began business in 1861 in partnership with Henry Cappel, under the firm name of Daub \& Cappel; at that time they were located at No. 185 Smithfield strect. In $1865 \mathrm{Mr}$. Cappel retired from the firm and the business was continued by Mr. Ditub until 1871, when he removed to the large three-story brick building on the corner of 38 th and Butler streets ; he carries $\$ 4,500$ worth of stock and does a loeal business of about $\$ 12,000$, in good times nicre. Mr. $1.14 \mathrm{~b}$ was born in Germany in the year 1830 , came to the United States in 1849 . He has figured considerably in the local politics of the city-lie was a nember of the City Council in 1868-9, was also a member of the Scliool Botrd at the sauce time and still is, from the 15th ward. Mr. Daub is and has been for several years a Director of the Metropolitan National B.tnk of the 17th Ward; is President of the Enterprise Insurance Company of this city.

\section{JOHN H. DEAN,-Groceries \& Flour, 91 Rebecca St., Allegheny.}

Desirably located in a populous section of the beautiful city of Allegheny, the Grocery, Flour and Produce Honse of $\mathrm{Mr}$. John $\mathrm{H}$. Dean is worthy of notice jn a work devoted to the business interests of tle two cities. This house was established in $187+$ by the present proprictor with moderate means and in a comparatirely small way, but during the p ist five yeal's lis trade has steadily inereased and he now transacts an annual business of not less than $\$ 30,000$. He occupies the two-story brick building $18 \times 4 \cdot 5$ at No. 91 Rebecca street, carrying a stock of about \$3,500 conlprising a full line of choice family uroceries, fruits, surars, coffees, teas, spices and cxtra brands of flour. Mr. Dean gives his personal attention to the business and employs two assistants. His trade is of the better class and is steadily increasing from year to year. Mr. Dean is a nativ of Pittsburgh, and was horn in 1853. He is an energetic and reliable business man thoroughly conversant with the business in which he is engaged.

\section{ELWOOD \& McCRACKEN,-Grain Merchants, 365 Liberty St.}

The firm of Elwood \& MeCracken liave a standing in the grain and feed trade and extensive business that gives them a prominence entitled to due consideration. Established with a fair capitul ly. $\mathrm{B}$. D. Elwood and B. McCracken under the above style, in 1373, the firm with a comprehensive knowledge and experience in the business, devoted itself particularly to haudling flour, feed, grain, seels and wool, making a specialty of rye. Their excellent business capacity lias enabled them to reach the sum of $\$ 150,000$ annually. The business premises are eapacious and consist of one large three-story brick edifice $25 \times 110$ feet. Mr. Elwond is a Pennsylvanian, and came to Pittsturgh in 1872; Mr. MeCracken has been a resident of this city for 20 veurs, and bnth have had an active and successful career. Referring to the Second National Bank, and Allen, Kirkpatrick \& Co., this city, and James Steel \& Co., Philadelphia, the firm is estcemed for its thorough reliability. 


\section{A. \& T. M'KENNA,-Brass Founders, No. 122 Third Ave.}

Every description of fine Brass-work is manufactured by this well known house, which was established in 1856 , by $A$ \& J. M'Kenna, who were succeeded in 1875 by the present proprietors. The capital invested in the business is $\$ 18,000$ and their anumal sales reach about $\$ 35,000$. They occupy three floors, each $30 \times 85$, at 122 Third Ave., and their business is confined exclusively to brass work, of which they manufacture and carry in stock a large assortment, consisting in part of Ale and Beer Cocks, Foot Rails, Counter Rails, Back Rails, Window Guards, Door Pulls, \&c. They are also exelusive manufacturers of M'Kenua's Patent Combination Pump and Ventilating Faucet for drawing and preserving Ale and Beer. These articles are made with great care and specially adapted for the Saloon and Liquor trade. This Faucet was patented by Mr. M'Kenna, and is no longer an experiment, as over seven thousand are now in use all over the United States, and in every instance they give perfect satisfaction. This firm also make a specialty of fitting up Show Windows with movable and stationary Rails, Brackets, \&c., such as are used by Tailors, Furnishing stores, Mlillineries, Hatters and Variety stores. They employ fifteen skilled workmen in their manufacturing department, with a weekly pay roll amounting to about $\$ 200$. One eight horse-power Engine furnishes the motive power for their nachinery which is of the hest and most approved pattern. The trade of this house is in more than thirty states, and the superior quality of their goods have given them a national reputation. They sell more goods at present in St. Louis than in of age. Mr. T. M'Kenna is a native and lifelong resident of Pittsburgh, where he was born in 1836.

\section{P. CAMPBELL,-Insurance Agent, No. 46 Wood St.}

Mr. Campbell has been engaged in the Insurance business in Pittsburgh since 1875, and now represents some of the leading Companies of Europe and America, among which we may mention The North German of Hamburgh, Germany, with a capital of $\$ 1,125,000$. The New York City of New York, cash capital $\$ 300,000$. The Clinton of New York, cash capital $\$ 250,000$. The Trade of New Jersey, capital $\$ 200,000$. The Merchants, and Mechanies of Virginia, capital $\$ 250,000$, and others equally reliable. His business, which is principally in Pittsburgh and Allegheny, amounts to ahout $\$ 22,000$ per annum in premiums. Mr. Campbell was born in Pittsburgh in 1852, and is a lifelong resident of the city. His business will compare favorably with that of any other agent in the city.

\section{H. HOLTZMAN, (formerly Holtznan \& Wiederhold,) Practical Decorative Upholsterer, 74 Wood St.}

The reputation of Mr. Holtzman, as a practical Upholsterer, during twenty years experience in Pittshurgh, has become so well established, that it would be a work of supererogation to comment upon it, in a work of this description. The house of Holtzman and Wiederhold was established in 1859, and for twenty years it has sustained the reputation of being the leading Upholstery Establishment of Pittsburgh. In January 1879, Mr. Wiederhold retired from the firm, and the business is now conducted by Mr. Holtzman, who occupies four floors of the building, No. $7 \pm$ Wood St., each $14 \times 55$, carrying a stock of about $\$ 8,000$, comprising every description of Window Decorations, Lace Curtains and Lambrequins, Cornices and Cornice Poles of the Queen Anne and Eastlake Styles, and new and elegant designs in Walnut, Ehony, Ash, Gilt and Brass, Spring Beds and Mattresses of all kinds, Comforts, Pillows, \&c. He pays special attention to fitting and putting down carpets, cleansing lace curtains, \&c. His yearly trade amounts to about $\$ 30,000$ to $\$ 50,000$, and he gives employment to fourteen hands in his two departments of Upholstery, Cornice and Drapery rooms, which latter department is the specialty of this house. Mr. Holtzman was born in Alsace, then a portion of France, in 1835. He came to this country in 1855, and to Pittsburgh the same year, where he has since resided.

\section{JOHN THOMA,-Leather and Shoe Findings, 74 Smithfield St.}

The trade in Leather and Shoe Findings, and the manufacture of Boot, Shoe and Gaiter Uppers is carried on to a considerable extent in Pittshurgh, and forms no inconsiderable item of her annual trade and commerce. One of the principal merchants engaged in this line of business, is Mr. John Thoma, who occupies three floors of the building, 20x55 feet, situated at 74 Smith field St., giving steady employment to two experienced hands, and carrying an average stock a mounting in value to about $\$ 10,000$, MIr. Thoma was born in Germany in 1825 . He arrived in America in the year 1852 and located in Pittsburgh in 1855 . In 1865 he commenced business for himself and now transacts an annual business of $\$ 18,000$ to $\$ 20,000$, which compares favorably with that of any similar establishment in the Iron City. His trade is principally local, and the manufacture of Uppers is one of the specialties of this House.

\section{SNIVELY \& RADCLIFFE,-Wall Paper, 173 Smithfield Street.}

One of the leading houses engaged in the Wall Paper business in Pittsburgh is that of Snively and Radeliffe, wholesale and retail dealers in Wall Paper, Window Shades, Shade Cloth, Oil Cloths, \&c., at No. 173 Smithfield street. This house was established in 1876, by the present proprietors, Mr. John S. Snively and Mr. Wm. Radcliffe, both natives of Alleghen y county and residents of Pittsburgh since childhood. They carry a stock of goods pertaining to their line valued at about $\$ 6,000$, and transact a yearly business, principally of a local nature, amounting to about $\$ 15,000$. The size of their salesroom is $19 \times 60$ feet, and the specialty of this house is Wall Paper, of which they keep a full line of all the latest styles and most desirable patterns.

\section{A. A. HUTCHINSON \& BRO.-Coal and Coke, No. 94 Fifth Avenue.}

The superiority of the celebrated Connellsville Coke, for foundries, blast furnaces, breweries and other large manufacturing establishments, is well known in almost every section of the United States, and the manufacture and shipment of the same constitutes a very important item of the business interests of the Smoky City. One of the largest concerns engaged in this branch of business is that of A. A. Hutchinson \& Bro., the members of the firm being Messrs. A. A \& T B. Hutchinson. The firm was established by its present members in $18 \pi 2$, and their office is now located at No. 94 Fifth Av. They are very extensively engaged in the mining of the well known Connellsville Coal and the manufacture of a superior article of Coke therefrom, for which they were awarded a diploma and wedal at the late Centennial Exposition in Philadelphia. Their uines, which are known as the "Globe" and "Standard" Mines, are Jocated in the line of the Mt. Pleasant R. R., near Broadford, Fayette co., Pennsylvania, one tract measuring one hundred and seventyfive acres, and another one hundred and fifty acres, from which a very superior article of coal is obtained, capacity 350 tons Coke per day. They employ at their mines two hundred hands and their monthly pay-roll aggregates abont $\$ 8,000$. The demand for their Coke is principally west and in the various manufacturing towns and cities on the Ohio River, although they ship to all parts of the United States, both East and West, from the cities of the Seaboard to Salt Lake City. The amount of capital invested by thisfirm is over $\$ 150,000$ and their annual trade varies from $\$ 150$, m0 to $\$ 200,000$. Mr. A. A. Hutchinson was born in Ireland in 1844, and Mr. T. B. Hutchinson two years later. They arrived in this country in $\mathbf{1 8 5 0}$ and came to Pittsburgh the same year and have resided in the city ever since. 


\section{JAMIES MILIIKEN \& CO.-Furniture, No. 89 Smithfield St.}

So mich pride is now taken in the ornamentation of our homes, that Fine Furniture has become an indispensable article to all who desire to keep up with the progressive spirit of the age.

Prominent among the business houses of the Iron City engaged in this line of trade is that of James Milliken \& Co., at No. 89 Smithfield Street, (Howard Block). This firm was estahlished in 1875 by the present proprietors, Messrs. James and A. Millikin. Both gentlemen are natives of Ireland. The senior partner came to the United States in 1856 and settled in Pittsburgh, and the junior member of the firm ten years later. They occupy four stories and the basement $18 \mathrm{by}$ 60 , and their large and elegant stock is selected with great care,-beauty of design, durability and general excellence heing the desideratum always in view. The members of the firm give their personal attention to the business, and three assistants are required in their sales department. This business, which is that of general Furniture dealers, is largely local, although they have quite an extensive trade in Western Pennsylvania, Eastern Ohio and West Virginia. Notwithstanding the general depression in business and the unprecedented competition in their particular line, their sales during the past year have been large, and all the indications for the future are very flattering.

\section{IM. W. RANIIN, -Wholesale Grocer \& Commission Merchant, No.10 Smithfield St.}

Mr. Rankin, who occnpies the four-story warehouse $21 \times 76$, at No. 10 Smithfield street, (opposite the Monongahela House, ) is a native of Ohio, having been born in the "Buckeye State" in 1826. He came to Pittsburgh in 1845, and ten years later founded the business in which he is now engaged. He carries a stock ranging from $\$ 12,000$ to $\$ 15,000$, and transacts a yearly business of from $\$ 75,000$ to $\$ 100,000$, employing four hands. His trade is principally in Ohio and Pennsylvania, and in addition to the line of goods directly pertaining to the Grocery business, he deals extensively in Provisions, Cheese, Carbon and Lard Oils, etc., etc.

\section{W. J. CASIR IX,-Groceries, Provisions, \&c., No. 25 Smithfield St.}

There are in Pittsburgh a large number of business houses, whose principal trade is connected with tne River interests, furnishing supplies to the rast fleet of steamboats, which make Pittsburgh their headquarters. Prominent among the establishments making this branch of trade a specialty, is the house of Mr. W. J. Caskey, located at No. 25 Smithfield street, in convenient proximity to the Monongahela Wharf, which is the general rendervous of steamboat and river men.

Mr. Caskey was born in Pittsburgh in 1843, and having always resided here, has a very large acquaintance among the business men of his native city. In 1874 he commenced business for himself, and his career since that time has been marked by a degree of success which has been truly encouraging. He occupies three entire floors of the spacious warehouse, $20 \times 85$ feet, at the number abore mentioned, where with a stock averaging from $\$ 8,000$ to $\$ 10,000$, his annual sales reach from $\$ 40,000$ to $\$ 50,000$. Mr. Caskey employs four assistants, and his local trade, in addition to that derived from the River, is large and steadily increasing.

\section{MELTOR \& HENRICKS,-Pianos and Organs, No. 79 Fifth Avenue.}

For nearly half a century the name of "Mellor" has been familiar to the musical portion of the community of this section of the country, for in 1831 MIr. John H. Mellor established himself in the Smoky City as a dealer in Pianos and Musical Merchandise, since which time the business has continued in the family name with but few variations in the style of the firm. In $1878 \mathrm{Mr}$. Charles C. Mellor, at that time sole proprietor of the establishment, disposed of his interest in the sheet music and smaller instrument department to Mr. Geo. Kappel, and associated with himself Mr. J. R. Henricks for the purpose of dealing exclusively in Pianos and Organs.

These gentiemen occupy four floors of the elegant warehouse 60x240 feet, at No. 79 Fifth A venue, carrying a stock of from one hundred to one hundred and fifty Pianos and Organs, employing seven assistants at this point and having agencies all through the country. Their annual business amounts to more than $\$ 100,000$, which is not confined to any particular section, although largely distributed through Pennsylvania and Eastern Ohio. The line of instruments princjpally represented by this firm are the celebrated Weber aud Hazelton Pianos and the Mason \& Hamlin, and Palace Organs, although in their extensire stock may be found instruments of almost every manuiacture known. Mr. C. C. Mellor was born in Pittsburgh in $\mathbf{1 8 3 6}$ and has since his youthful days been identified with the music trade of his natire city. Both members of the firm are gentlemen thoroughly conversant with the business in which they are engaged, and all representations made by either may be implicitly relied upon.

\section{LANGENHEIM \& SHIEPARD,-Flour \& Groceries, 52 \& 54 Seventh Ave.}

This house was established fifteen years ago hy Schomaker \& Langenbeim, who were succeeded by the present firm in 1877. Mr. G Langenhein was born in Germany in 1834 and has been a resident of Pittsburgh for the past twentyfour years. Mr. Otis Shepard, his partner, is a native of Pittsburgh, where he was born in 1835. He is a lifelong resident of the Iron City. They occupy the large double warehouse at Nos. $52 \& 54$ Seventh are., carrying a stock of $\$ 10,000$ to $\$ 65,000$. Their trade, which is principally in the states of Pennsylvania and Ohio, amounts from about half a million to a million dollars annually and compares favorably with that of any other house engaged in the same line of business West of the Mountains. They handle immense quantities of Flour and a general line of Groceries, Provisions, \&c. This is one of the representative business houses of Pittsburgh in point of size, amount of business transacted, mercantile integrity and unquestioned reliability.

\section{WOLFE, IANE \& CO,-Hardware and Cutlery, No. 50 Wood St.}

Conspicuous among the representative business houses of Pittsburgh, that of Wolff, Lane \& Co., importers and dealers in every description of Hardware and Cutlery, may be mentioned. This house was founded in 1836 as Whitmore \& Wolff. It subsequently became Whitmore, Wolff, Lane \& Co., and in 1877 the present firm succeded, the individual members of which are $C$. H. Wolff, Thos. H. Lane, John D. Cherry, G. M. T. Taylor and Horace G. Darsie. They occupy the spacious ware-rooms at No. 50 Wood St., 20x120 feet, the entire four floors and basement, being filled with every variety of Goods pertaining to this line of business. These ware-rooms are undoubtedly the best arranged and most completely fitted up of any in the United States, for conveniently carrying on such an extensive business. Their trade, which extends thronghout the States of Pennsylvania, Ohio, West Virginia and Virginia, amounts in round numbers to not less than $\$ 200,000$ per annum. In addition to the members of the firm, who give their personal attention to the business, twelve salesnen and clerks are employed, and the business of the house will compare favorably with that of any similar establisbment in the West. 


\section{ALPH. J. POTZER,-Hats, Caps \& Furnishing Goods, 334 Liberty St.}

Mr. Potzer was born in Salem, Westmoreland County, Pennsylvania in 1847, but has been a resident of Pittsburgh since 1852. The present establishment was started by him in 1877. He occupies the store No. 334 Liberty Street, 20x60, with a stock of goods valued at about $\$ 6,000$, consisting of Hats, Caps and Gent's Furnishing Goods in great variet5. His sales, which amount to from $\$ 8,000$ to $\$ 10,000$ per year, are principally to residents of the Simoky City and customers living along the line of the Pennsylvania Railroad. Mrr. Potzer has a complete and well selected assortment of all articles pertaining to gentlemen's head wear, and furnishing goods, and his prices are uniformly low.

\section{J. FULLERTON \& SON,-Tobacco and Cigars, No. 332 Liberty St.}

This house, which was established in $1837 \mathrm{by}$ Mr. Fullerton senior, is the oldest in the city with but a single exception, engaged in this line of trade. Mr. John Fullerton was born in Ireland in 1810, and came to the United States in 1823, settling in Pittsburgh the same year. In 1837 he established the business of manufacturer and dealer in Cigars, which was continued under his name until 1870 , when by the admission of his son, Mr. W. W. Fullerton, as a partner, the firm name became as above. Mr. Fullerton junior, was born in Pittsburgh in 1845, and has since resided in the city. They occupy the large and spacious ware rooms, 20x65, at $\$ 0.332$ Liberty street, where they carry on a jobbing trade in all varieties of manufactured Tobacco and Cigars, amounting to not less than $\$ 100,000$ to $\$ 125,000$ per aunum, and carrying a stock estimated at about $\$ 14,000$. Their trade is principally in Penusslvania and Ohio, although they frequently fill large orders from other States. They sell a larger quantity of Cigars than any other house in the city, their sales last year exceeding $\$ 3,000,000$ of the various grades and qualities. Their stock embraces all lines of goods pertaining to the trade, but the specialty of this house is Cigars, of which they have forty-two brands of their own, which have a widespread and well deserved popularity, and are sold in almost every State in the Union.

\section{THOMAS McANDREW,-Livery and Sale Stable, No. 117 Third Ave.}

The premises occupied by Mr. McAndrew at No. 117 Third avenue, opposite St. Charles Hotel, are $20 \times 100$ feet in size and conveniently arranged for the business in which he is engaged. He commenced at this location during the present year, and has already secured a satisfactory business. He now has four fine horses and carriages to hire, and will undoubtedly soon largely increase his facilities. Mr. McAndrew was born in Ireland in 1834, came to the United States in 1860 and to Pittsburgh in 1865.

\section{HOTING \& SONS,-Grain, Hay, Straw \& Mill Feed, 119 Water St, \& 156 First Av.}

The four story warehouse, $20 \times 180$ feet, at No 119 Water street and extending through to First avenue, is occupied by the above named firm as a Grain, Hay and Feed Store. The house was established in 1875 as Irren and Hoting. In 1876 the present firm sucreeded to the business, which now amounts to about $\$ 22,000$ per annum. The amount of capital invested in the business is $\$ 8,000$, and they carry a stock of from $\$ 1,000$ to $\$ 1,500$, giving employment to three assistants. This trade is principaly local and along the lines of the B. \& O., and the P. V. \& C., Railroads. IIr. C. Hoting was born in Germany in 1825, he came to the United States in 1850 and settled in Pittsburgh the same year. Mr. G. C. Hoting was born in Allegheny City in 1859, and MIr. R. C. Hoting in the same place in 1853. They are actire and energetic business men and stand well in the mercantile community.

\section{CUNNINGHAIS \& CO.-Pittsburgh City Glass Works, No. 109 Water St.}

With Pittsburgh as the acknowledged Headquarters of the Glass trade of the United States, it is eminently fitting that she should also contain within her corporate limits the largest glass manufactory in this country. The Pittsburrh Cits Glass Works were founded 1n 1849 by Mr. Cunningham, two other brothers and Mr. George Duncan. In 1865 the firm became Cunninghams \& Ihmsen, and continued under that style until 1878, when it was disso'ved by the purchase of the interest of Dominick Ihmsen by the remaining partners, and the firm name became Cunninghams \& Co. The business was started in a comparatively snall way with but one factory. They now have three extensire factories, making these works the largest in the United States. The capital in vested by this firm is $\$ 250,000$, and the average stock carried by them is from $\$ 60,000$ to $\$ 80,000$. Their annual business is correspoudingly large. Their works are located on 26th Street, south side, and with all the buildings criver two entire blocks. They have one office at the works and another at their ware rooms, No. 109 Water street, at their factories they employ from 250 to 300 workmen at a weekly expense of about \$2,000. Their trade extends all over the Uuited States and from Canada to Nexico. They manufacture all kinds of Glass ware, Window Glass and Bottles. Mr. Wilson Cunningham was horn in 1812. Mr. Robert Cunningham in 1817 and Mr. D. O. Cunninghan, son of the senior member of the firm, in 1834 . They are all natives of Allegheny county and highly respected as public spirited citizens and reliable energetic business men.

\section{KAUFMAN, OPPEN HEIMER \& CO.-Wholesale Clothiers, 233 Liberty St.}

As Jobbers and Dealers in Clothing, Piece Goods and Tailors' Trimmings of all descriptions, and Mannfacturers, the above house is not to be omitted in any just record of the history of the industries of Pittsburgh, and has had no small bearing upon the general welfare of the community.

Established as a retail concern in 1851, under the title of Klee \& Kaufman, in Allegheny, the business was removed to Pittsburgh in 1860, and from that period has been devoted exclusively to the wholesale trade. In 1865 Mr. Klee withdrew, and Mr. M. Oppenheimer and his brother became partners in this house under the ahove style, which has not been changed, though the junior partner retired some time ago, leaving the "Co." merely nominal.

From the commencement to the present time success has attended the operations of this concern. Started with a capital of the most limited character, the business has constantly increased and the resources augmented proportionately.

From a comparatively unimportant foundation the business bas grown to the dimensions of not less than $\$ 250,000$ per annum and still enlarges.

The premises occupied by the firm at the present time are of the most ample and complete dimensions, consisting of one large four-story stone front brick building $20 \times 240$ feet, running from Liberty through to Penn avenue. This firm manufacture all the clothing sold by them. They employ constantly 150 men and women in the manufacturing of IIen's, Youths' and Boys' Clothing, besides their hands in the store, counting-house and salesrooms. The present partnership has existed 14 years, and prior to that time Mr. Kaufman was connected with Mr. Klee for a like period.

In all, for 28 years, the senior partner of this house has been identified with the industries, progress and development of this city, adding no little to its reputation as a commercial centre.

Not only in Pennsylvania, but in the contiquous States, this house has prosecuted a successful trade, to such a degree that the establishment is now justly regarded as taking rank among the first of its kind in the community, and is well entitled to the consideration in which it is universally beld. 


\section{J. S. DIL W ORTH \& CO. - Wholesale Grocers, Nos. 130 \& 132 Second Ave.}

Among the representative business houses of Pittsburgh the name of Dilworth has for mnny years occupied high and honorable positions, and in the wholesale grocery trade the firm of J. S. Dilworth \& Co., has for nearly forty years been recognized as the leading one of the Iron City. This house was established in 1840 by John S. and Joseph Dilworth, and became as at present in 1847, since which time the business has been conducted nuder the same name and style, although Mr. J. S. Dilworth the founder of the house is no longer living. The present partners are W. P. Dilworth (who was born in Pjitsburgh in 1844), De Witt Dilworth (borll in Pittsburgh in 1853), and James W. Houston (born in Ireland in 1852, but for many years a resident of Pittsburgh). The capital invested in the business is $\$ 60,000$. The amount of stock carried by the firm ranges from $\$ 35,000$ to $\$ 40,000$ and their annual sales exceed $\$ 550,000$. Ther occupy the spacious warehouse, $40 \times 85$ feet, three stories and basement, at Nos. 130 \& 132 Second avenue, and employ ten salesmen and assistants. Their trade, which will compare favorably with any house in the city, is principally witbin a radius of 150 miles of Pittsburgh, in Western Pennsylvania and Eastern Ohio. While they keep a full line of all articles pertaining to the Grocery trade, the specialty of this house is in New Orleans Sugars, Syrups and Molasses.

\section{VOIGT, MAHOOD \& CO.,-Commission and Produce, Merchants, 257 Liberty St.}

As a very important branch of the commercial industries of Pittsburg, the Commission Produce businesss is entitled to a large slare of consideration, in which connection it would be impossible to overlook the house of Voigt, Mahood \& Co., occupying, as it does, perhaps the most conspicuous position of anj concern in that line of mercantile enterprise.

Established iu 1861 , by L. H. Voigt, Esq., with a capital of but $\$ 500$, the concern seemed at once to achieve a signal success, the business of the first year being over $\$ 10,000$, increasing during the latter part of the war to the enormous sum of half a million dollars per annum; and, even now, at the rednction in the price of all produce and commodities, the business runs up iato mavy thousands annually.

With so little capital to start upon, the inference is that there must have been some compensating balance for this lack in the energy and natural aptitude and capacity of its founder to have produced with such limited means such considerable results. Such an assumption does but simple justice to the firm whose relations extend, not alone over the entire United States, but include every conceivable line of produce merchandise and Pittsburgh manufactured goods.

The firm is composed, under the above title, of L. H. Voigt and A. M. Voigt. They occupy as business premises No. 257 Liberty street-an ample three-story brick house, $22 \times 110$, with basement-employ 10 hands, and one five-horse power engine for hoisting. It is regarded as the largest commission house in the city, and has a standing and repute commensurate with the extent and solidity of its business.

\section{PRENTICE \& HACKETT,-Cement, Lime, etc., Nos. 46, 48 \& 50 Ninth St.}

The house of Prentice \& Hackett was established in 1877 and is the only one in the city importing the genuine Portland Cenent direct from foreign countries. They are also sole agents for the celebrated Buckeye Cement, and deal largely in Rosendale, Louisville and other American Cements, White Lime, Calcined and Land Plaster, White Sand, Marble Dust, Whiting, Kalsomine, Sewer Pipe, Stove Pipes, Chimney Tops, Flue Linings, Tena Cotta Ware, Fire Brick, Grate Tile, Fire Clay and Fertilizers. They occupy the extensive premises at the number named, employing five hands, and transacting a large and flourishing trade in the articles named, extending over Western Pennsylvania, Eastern Ohio and Western Virginia. This House, with its large facilities, is always prepared to take large contracts in their line. The Lake Erie and Pittsburgh railroad line was furnished by this firm with the hydranlic cement in the inasonry work of that road. The Government also selected this well-known firm to furnish it with supplies on their work in Western Virginia, as did also the Navigation Company. The Westmoreland and Indiana County Works received their supplies from this eaergetic firm. Both members of the firm are natives of the State and have had many years practical experience in their business.

\section{J. P. HUGHES,-Cigar Manufacturer, No. 27 Fourth Avenue.}

There is a large number of elgar manufacturies in the Smoky City, and the annual production of this class of goods constitutes no insignificant item in the general aggregate of her commercial importance. Mr. J. P. Hughes, whose place of business is now located at No. 27 Fourth A venue, is one of the prominent cigar manufacturers and dealers of Pittsburgh, turning out annually about 700,000 of the various brands and grades. Mr. Hughes was born in Pittsburgh in 1837 , is a practical cigar maker himself, and eriploys in his establishment six experienced hands regularly, at a weekly expense of about $\$ 50$. He has been engaged in business in his own name for abont six years, and many of the brands manufactured by him have acquired a national reputation and well deserved popularity. He occupies as salesroom and manufactory the four-story brick building, $25 \times 60$, at No. 27 Fourth Avenue, where he carries an average stock of from 80,000 to 100,000 cigars of various grades, valued at about $\$ 2,000$, and transacts an anunal business of over $\$ 10,0110$. His retail trade is principally local and his wholesale business extends throughout many of the towns of Western Pennsylvania. Among the leading brands mauufactured by Mr. Hughes we may mention "High Life," "Excelsior," "Jewel," and "Prefacto." He is also exclusive proprietor of ten or a dozen other favorite brauds, ranging in price from $\$ 10$ to $\$ 60$ per thousand. The robaccos used by Mr. Hughes are Kentucky and Ohio for stogies, and for the other brands, Havana, Pennsylvania, Massachusetts and Connecticut. He also keeps constantly on hand a full liae of manufactured Tobacco, Snuff and Smokers' Articles.

\section{JAMES BOWN \& SON,-Enterprise Gun Works, 136 and 138 Wood Street.}

For more than thirty years the name of Mr. Bown has been identified with the gun business in the Iron City, the Enterprise Gun Works having been established in 1848 by Bown \& Tetley. In 1862, Mr. James Bown became sole proprietor, and in 1871, Mr. Wm. H. Bown, his son, was admitted and the firm name becane James Bown \& Son, under which style it has continued to the present day. They occupy three floors of the large double store, $30 \mathrm{x} 60$, at Nos. 136 and $138 \mathrm{Wood}$ street, employing twenty-six skilled workmen, and their weekly pay-roll amounts to about \$275. Their stock, which is full and complete in every variety of Guns, Rifles, Revolvers, Fishing Tackle, Sportsmen's Articles in General, Razors, Scissors, Pocket and Table Cutlery, is estimated at from $\$ 20,000$ to $\$ 25,000$, and their annual trade is now about $\$ 70,000$, extending over the greater portion of the United States from the Atlantic to the Pacific Ocean. While they are large manufacturers of Rifles, Rifle-barrels, Shot Guns, etc., they also deal extensively in the best articles of foreign and American make, doing a large wholesale as well as retail business. They carry the finest lines of Cutlery to be found in the West and the motto of the firm for more than a quarter of a century has been "Quick Sales and Small Profits."

Mr. James Bown was born in England in 1823, and at the age of ten years came to this country with his parents, and in 1843 became a resident of Pittsburgh. Mr. Wm. H. Bown was born in the Iron City in 1847 and has never lived in any other place.

Both these gentlemen are thoroughly conversant with every detall of the business in which they are engaged and the requirements of the trade in this locality. 


\section{THOS. A. CAIN,-Fine Boots and Shoes, Fifth Avenue and Market Street.}

Prominent among the retail houses of the Smoky City, in the Boot and Shoe Line, is that of Thos. A. Cain. It was at first founded forty years ago by H. P. Cain, and continued by him twenty-two years. At the expiration of that time he was succeeded by T. A. Cain, the present proprietor. The house was originally started in a small way, but through the tact and high business qualifications of the founder, as well as his son, the present proprietor, his trade has largely increased, and he enjoys to-day the patronage of most of the leading families and merchant princes of Pittsburgh, transacting the largest retail business of any house in this line. Mr. Cain occupies the entire three-story brick building, 18x 40, at the corner of Fifth A venue and Market street, employing nine assistants, and carrying the most complete and varied stock of fine goods to be found in the city. His trade is largely in the cities of Pittsburgh and Allegheny, but he numbers among his regular customers many of the leading citizens of the principal towns within a radius of tivo hundred miles. MIr. Cain was born in Pittsburgh in October, 1839, and has been a life-long resident of the city, and for many years identified with the boot and shoe trade of his native place.

\section{J. D. SHA W,-Taxidermist, 235 Penn Avenue.}

The Art of Taxidermy is one that must commend itself to all persons of refinement and culture. As we observe the bright-winged inhabitants of tlie air flitting joyously by, we cannot fail to admire, and admiring, we wish for some means to preserve and perpetuate thcir beauties when Death shall have claimed them for his own and they otherwise would have mouldered away into nothingness. Those of our citizens who have visited our Expositions must have been attracted by the magnificent collection of birls and animals exbibited by that artist in his profession, Mr. J. D. Shaw. Mr. Shaw has been engaged in business for thirteen years, and at his present location for the past five years. Mr. Shaw can stuff anything on sea or land, from the tiny jeweled humming-bird that glances by like a thing of light, to tlie ponderous elephant from his native jungles in the East. All are alike to him, and so perfect and life-like are his specimens that we almost expect to hear the birds warble their sweetest songs. M1r. Shaw was born in England in 1827, and came to this country in 1852. His trade is scattered all over this section of country. He is the only person exclusively engaged in this business in the city. Mrr. Shaw's work is all done to order. He preserves specimeus of the feathered and aninal tribes in a thoroughly satisfactory manner. He received a silver medal for stuffed birds and animals at the first Pittsburgh Industrial Exposition, at present located at 258 th Street.

\section{JACOB B. HUBLEY \& CO.-No. 195 Penn Ave.}

This House is undoubtedly the "Delamonico" of Pittsburgh and was established in the year 1824 by Mr. Rob't. Knox, with one barrel of four giren to him by a well-known steamboat man, on condition that said knox would build an oven and furnish for each barrel of flour one barrel of crackers for the use of said steamboat man. The offer was accepted, and from that small beginning has the present well-known house grown. This house was first established on what is now known as First A venue, near Wood Street. In 1831 the store was removed to more spacious rooms on aecount of increasing business. The present senior member of the house, Jacob B. Hubley, entered the old house at the age of nine years, and was a faithful assistant from 1834 until the death of Rob't. Knox, at which time he took charge of the business in his own interest. Alex. F. Hay, a prominent young business man, is the Co. In Dec., 1870, the business still growing and a more central location desired, the store was moved to its present place, the Library Hall Building, on Penn Avenue. This house is liberally patronized by the elite of the city, on account of its unsurpassed cusine department. This spacious establishment is arranged in the most convenient nanner, affording ample facilities for conducting business in a style and elegance equal to the most refined and modern to be found in this country, and also giving more sittisfaction to the customers of the house. No expense bas been spared in fitting up the rooms with rich and costly furniture and other appointments, to make the place both elegant and attractive. Their stock has been selected with much care, embracing every variety of confectionary and dainties.

We have also noticed that this house is always prcpared to furnish promptly, on short notice, everything necessary for Weddings, Parties, Banquets, etc. Ice Creams and Ices, in exquisitely designed moulds, Jellics and Fancy Cakes, and ornamented Pyramids, of different kinds, of the most artistic finish known to the trade. They have superior provision made for supplying Breakfast, Dinner and Supper to Ladies, Gentlemen and Families, to order, of every thing the warket affords, in season. Their spacious Dining Parlor has a capacity for seating as high as 150 persons at once.

This popular establishment employs 20 hands, to assist in transacting the business. The furniture of the rooms is composed of black walnut, ground glass and niarble, and the floor is laid in handsone mosaic.

Mr. Hubly is a native of Pittsburgh and has followed his business for upwards of forty years.

\section{WALTER E. HAGUE,-Gold, Silver and Nickel Plater, 738 Wood St.}

Mr. Hague was born in Sheffield, England, in 1841. He came to this country in 1864 and located in Pittsburgh in 1870 , where he succeeded Mfr. A. R. Nininger, who had then been engaged in the business for about une year, under the name and style of the "Pittsburgh Gold, Silver and Nickel Plating Works."

This line of business was at that time comparatively in its infancy, but, during the past nine years, Mr. Hague, by close attention to business, has succeeded in building up a trade which is second to none in the West. His factory, which is located on Virgin Alley, above Wood Street, is $30 \times 120$ feet in dimensions, and he gives emuloyment to ten workmen, with an average pay roll of about $\$ 100$ per week. His office is at No 138 wood Street, and he dwes the largest jobbing business of any similar establishment outside of New York or Philadelphia. His trade is principally in Pennsylvania, Ohio and West Virginia. Mr. Hague is the inventor and originator of a peculiar process of eleetro-lironzing, which is understood by no other parties in the United States. He makes a specialty of Fire Iron Stands of elegant designs and superior workmanship, besides doing every description of work pertaining to his line. The quality of work turned out by Mr. Hague is fullly equal, if not superior to that of any similar concern in this country or Europe.

\section{FRANK ARMSTRONG,-Coal Dealer, Cor. Fourth Avenue and Try Street.}

Energy and enterprise characterize the business of Mr. Frank Armstrong, successor to the Pittsburgh National Coal and Coke Co., situated at cor. Fourth Avenue and Try Street. It was commenced by the said company in 1864, and passed into the skillful management of Mr. Armstrong in 1876.

Fifteen men are employed at office and yard and another yard in the Sixteenth Ward requires eighteen to twenty men, with a weekly pay roll of $\$ 1,500$.

Mr. Armstrong deals in Pan Handle Coal, mined by the Consolidated Coal Mining Company, of Cincinnati, O. He also deals in Pittsburgh Coke, and keeps always on hand an abundant supply of Nut Coal and Slack. His yearly sales aggregate fully $\$ 80,000$.

Mr. Armistrong was born in the County of Tyrone, Ireland, in 1845, and eame from thence direct to Pittsburgh in 1364. As a business man, he is considered among the foremost in our city. In social circles le is universally esteemed. 


\section{W. H. MIDGLEY,-Groceries and Confectionery, No. 227 Penn Ave.}

The building now occupied by Mr. Midgley is one of the old familiar landmarks of the Smoky Citr, having been known as i Grocery corner for more than thirty years. It is located on what has been called the Connolly property for nearly half a century, and is familiar to every native Pittsburgher of the last generation. The first grocery store upon this site was established about 1810 by Mr. Connolly, who was succeeded by Paul and Gibson, they in turn by Mr. Strouse, followed by Midgley and Lesche, the immediate predecessors of the present proprietor. The building now standing upon this corner is a four story brick structure, $22 \times 30$, and is occupied by Mr. Midgley as a manufactory of Confectionery as well as dealer in every variety of fine Groceries, Choice Teas, sugars, Coffees, dc. Mlr. Midgley makes a specialty of Elaine, of which he sells large quantities. He employs two assistants and transacts a flourishing business. He has also been prominently ilentified with the oil interests in the oil regions for the past fifteen years.

\section{E. H. MYERS \& CO.-Pork \& Beef Packers, Nos. $217 \& 219$ Liberty St, cor. 7 th St.}

It is well in recording the various industries of any community to give more than mere passing mention to those firms or men in any particular branch of trade who have achieved high positions through the force of native ability, unaidel either by the capital of others or any influences, save those evoked by their own capacity. Such a firm is that of $\mathrm{E}$. H. Mrers \& Co., the senior partner being a striking exemplification of what may justly be called a self-made man. A German by birth and an agriculturalist by occupation in that country, he came to this city without resourecs, at the age of 22 , and after working some time at the very modest compensation even in those days, of $\$ 10$ per month, started a small grocery store on Wylie St., making this his first mercantile venture, 34 years ago. From its very inception succuss seemed to attend his efforts, and for nine, years he remained in the same location, at the end of that time removing to No. 201 Liberty St., where as a wholesale grocer and jobber in Provisions, \&c., he continued for five years more, annually increasing his capital and enlarging his connections and resources. At the close of this period he purchased the property at NOS. 217 and 219 Liberty street, and demolishing the old bnildings with which it was encumbered, erected the structure now occupied by the House, being a four story edifice $40 \times 58$ feet, thoroughly adapted for the business in every way, and one of the most substantial and handsome buildings on this thoroughfare. As a pioneer in the meat and provision trade and as one of the first packers in this section of country, Mr. Myers discorered at an early date the profit of bringing meats from Chicago; but not content with this, and perceiving the advantages of that city as a base of operations in euring, packing and obtaining supplies, he bought three acres contiguous to the Union Stock Yards, and at an expense of $\$ 103,000$ built thereupon one of the most complete packing in houses the United States, $144 \times 170$ feet, with an L reaching back 194 feet and baving a capacity of such extent as to make the slaughter of 2,500 hogs per day of no nncommon occurrence. Besides the building on Liberty street heretofore mentioned, which is the center from which all he business is conducted-four other large store houses, situated in convenient parts of the city, are used as warehouses for the storage of stock, and are during most seasons of the year taxed to their fullest capacity. As Pork and Beef packers and curers of choice Sugar Cured Hams, Shoulders, Dried Beef, Breakfast Bacon, as well as general dealers in Provisions, Lard, Cheese, Carbon and Lard Oils, etc., E. H. Myers \& Co. stand at the head of the trade, not only in the magnitude of their transactions, but the excellence of all their products. Twenty men are employed by the house in this city, and six special agents resident in various trade centers of the country, assist in carrying on a business which has reached an average of $\$ 700.000$ per annum and steadily increasing. MIr. J. Stevenson, the Co, has no interest in the business, but retains one-third interest in the real estate situate at 217 \& 219 Liberty street. This firm is indissolubly connected with the advancement of Pittsburgh and the development of its commercial and industrial resources.

\section{A. W. CADMAN \& CO.-Brass Works \& Foundry, Duquesne Way and Sixth St.}

This house was founded in 1860 by Cadman \& Crawford, who carried on the business until 1869, when the firm became $\mathrm{S}$. Cadman \& Son, under which style it was continued until 1877 , when Mr. A. W. Cadman became sole proprietur. The business conducted by this house is that of brass manufactures, Pipe Fitters and dealers in Brass and Iron F'ittings for Ste:m, Water, Gas and Oil, manufacturing and repairing light machinery in brass or iron, and making to order castings in Iron, Brass, Bronze or Soft Metals. They occupy the large two story brick structure, corner of Duquesne Way and Sixth street, $38 \times 125$, emploving ten hands and using one ten-horse porver encine. Their business, which extends throughout the conntry within a circuit of two hundred niles, now amounts to alout $\$ 20.000$ per annum, and will compare favorably with any similar establishment in the Smoky city. Mr. Cadman is a native of Pittsburgh, a thorough practical mechanic and workman, having followed the business for the past fifteen years.

\section{KRAMER \& SEIFERT,-Oysters, Yeast, Dried Beef, \&c., cor. Penn Av. \& 8th St.}

This well known house was established in 1870 , and at that time was deroted exclusively to the introduction of Fleishman's Compressed Yeast, at various times since other branches have been added to the trade which now embraces Fresh Cut Dried Beef, Oysters (arrow brand), Jellies and canned goods generally. Beginning with limited resources and but one horse and wagon, the firm now employ numerous assistants, besides five wagons, which barely suffice to supply the 680 retail grocers of the city and environs, who require constant supplies. As a branch of industry the trade in fresh cut dried beef has assumcd proportions that are increasing daily under the management of this firm, who carefully cure, and prepare it by rejecting all fat, bone or superfluous matter, pack in half pound packages, which, if not disposed of by the retailer while fresh are returned, and exchanged for that which is.

In oysters, canned goods and sardines the business is constantly enlarging, and to those at home or within the range of our commerce, who deal in these commodities, this house is cordially recommended.

\section{AIKEN \& WAILACE,-Produce Commission Merchants, 185 Liberty St.}

Liberty Street seems to be, at the present time, the general headquarters for the produce business in Pittsburgh and the amount of trade in this line annually transacted upon this thoroughfare, forms a large and important iten of the commerce of the Smoky City. Prominent among the business houses engaged in this line of business, we may mention that of Messrs. Aiken \& Wallace, at No. 185 Liberty Street. The members of this firm arc Mr. John Aiken and Mr. John Wallace, who have been associated in business since 1871 , under the firm name and style above given. Mr. Aiken had, however, heen engaged in business for himself for eight years previous to that time. "They occupy the large three-story brick warehouse, $22 \times 110$, at the number named, with basement, and transact a business averaging $\$ 75,000$ per annum, giving employment to four assistants, and dealing in every description of Country Produce, making a specialty of Potatoes, Sweet Potatoes, Foreign Fruits, etc. These gentlemen pay particular attention to consignments from abroad, and guarantee prompt and satisfactory returns. Mr. Thomas E. Renton is book-keeper for the firm, and is a gentleman thoroughly qualified for the position which he occupies. We can rouch for the high reputation and unquestionable integrity of this House. 
WEILER BROTHERS,-Wholesale Liquors, No. 159 First Ave.

The wholesale Liquor house of Weiler Brothers was established in 1871 by the present proprietors, with a capital of \$5, 000. They are distillers' agents for Manongahela Rye Whiskies and importers and dealers in Wines, Gins and Brandies. They carry a stock of fine goods, valued at from $\$ 9,000$ to $\$ 10,000$, and their trade, which is distributed through Pennsylvauia, ohio and West Virginia, amounts to about $\$ 40,000$ per annum. They have no particular specialty, except the general excellence and purity of all liquors handled by them. The members of the firm are Mr. E. Weilei, who was born in Germany in 1812 and eame to the United States in 1855, and Mr. A. Weiler, born in the same place in 1845 and a resident of the United States since 1858. The trade of this house is steadily increasing throughout the United States.

\section{W. P. TOWNSEND \& CO.--Rivets and Wire, 19 and 21 Market St.}

The above House was founded in the year 1816 by Rob't. Townsend, father of the present liead of the firm. The present firm, however, consists of W. P. Townsend and his two sons, Chas. C. and Edward P. Townsend. The business was commenced in a very small way and has always been conducted within the family since its foumlation, some sixt $\mathrm{y}-$ three years ago. The firm employ thirty hands, with a pay-roll amounting to $\$ 2,000$ per month. The buiJding consists of a wareroom and office, being a brick structure three stories high, $40 \times 70$ feet. The factory of the firm is located at Falleston, on Beaver River, and is $50 \times 300$ feet, substantially built of brick and stone. The motive power is supplied by turbine water wheels, with ample steam power that can be substituted in time of low water. The capacity of these works is one thousand tons of finished work per annum. The Rivet Department is not surpassed, nor perhaps equalled, in this country. The productions of the House find a ready sale all over the United States. The members of the firm are all natives of Pennsylvania.

\section{PITTSBURGH SEIOW CASE CO.-54 Ninth St.}

The office and warerooms of this company are located at No. 54 Ninth Street, and their factory, which is $34 \times 75$ feet in si\%e, on Grant Street. Their salesroom is $20 \times 30$, and they have a tine stock of elegant German silver and Walnut Show Cases of French Plate and American Glass, at prices ranging from $\$ 8$ to $\$ \overline{0} 0$. The members of the company are Mr. T. MeNulty and Mr. Wm. Friebertshauser, with a eapital invested of abont $\$ 9,000$. Their trade, which is principally in Pennsylvania, Ohio and West Yirginia, amounts to about $\$ 14,000$ per annun. The company was founded by Mr. MeNulty in January, 1878 . He had fur eight years previously been in charge of one of the largest show case establishments in the city and is a thorough, practical workman in that line of business. Mr. Friebertshauser, who is also a practical workman, purchased an interest in the concern in March, 1878, since which time it has been conducted successiully by these two gentlemen, who do a sale, cash business and stand well financially.

\section{A. IYONS \& CO.-Citizens' Oil Works, Cor. Seventh St. and Duquesne Way.}

The "Citizens' Oil Works" was originally established as an incorporated company, but are now owned exclusively by the above-nentioned firm, and, under their management, the business has largely increased. The works, which are located at the corner of Butler and Bridge Streets, on the line of the Allegheny Valley Railroad, cover an area of nons than seven acres and furnish employment to abcht two hundred hands. They are divided into three devartments, as follows: Parafine Wax Works, Barrel Mlanufactory and Carbon Oil Refinery. The machinery employed are eight engines, twelve force-pumps and two hatteries of boilers, in addition to the smaller machinery required. The calracity of the works is 350 barrels of paraffine wax per month, the largest production of any works in the country, with a single exception. Ten thousand barrels of refined oil per month, while the barrel manufactory turns out from twenty-five to thirty thousand packages every month. The packages or barrels manufactured ly this firm are noted for their tightness, the percentage of leakage being much less than that in paekages of other manufacturers. This fapt is corroborated by official statistics and is an important item to lie eonsidered by clealers and shijpers. The various productions of this house are all exported to Europe, England being the principal depot. The annual business transacted by this House reaches an enormous amount, as will be seen from the extent of their productions. Both memivers of the firm, Mr. A. Lyons and R. Hemmick, have been residents of l'ittsburgh for many years.

\section{P. S. WEISENBERGIR \& CO.-Keystone Varnish and Japan Works,}

Office, No. 2 Duquesne Way, Pittsburgh; Factory, Mair St., Allegheny.

As a comparatively new branch of industry in this community, the enterprise of the ahove firm deserves more than passing mention. Established but three years ago, the business has already grown from the linited amount of $\$ 3,100$ sales per annuuv to $\$ 10,000$, and is rapidly increasing.

For the following grades of varnish this house has already established a reputation that earries with it a guarantee of the excellence of their manufactures: Black Baking Japan, No. Y, for Japanners, Stamping Companies, etc.; No. 2, for Iron Founders and Mannfacturers of Hardware; Asphaltum Self-drying Varnish, for Carriage liakers, ete; Cotton Tie Varnish ; Turpentine Jajan Dryer; Benzine Japan Jryer; with Special Varnishes, expressly for Trunks, Waroms, Furniture, ete., etc. Already these goods find a ready market, not only in our own State, but in West Virginia, Oliio, Western New York, Illinois, Indiana, Missouri and other States.

A thorough knowledge of the business on the part of Mr. Weisenherger and his partner, Mr. H. Padrlock, insures a product that will eompare favorably, if not surpass in quality that of the largest Eastern houses, while the liberal and prompt way in which the concern is conducted, speaks in the highest terms of the estimation in which the firm is held by its customers and the public at large.

\section{WM. GRABOWSKY,-Silk Hat Manufacturer, No. 233 Penn Av.}

This House was established in its present location four years ago by Mrr. Grabowsky, who is a practical Hatter and Nanufacturer of many years experience. He occupies the three-story brick edifice at No. 233. Penn Avenue and enploys three skilled and experienced workmen, transacting a busincss of about $\$ 3,000$ per annum, and carrying an average stock of $\$ 2,000$. Ife manufactures silk and felt hats extensively for the trade, supplying many of the principal dealers in the city, besides carrying on a large retail business, selling Fine Hats, of every deseription, at wholesale prices. His specialty is in Cleaning, Repairing and Renovating Hats, and Relining and Making-over Ladies' Furs.

IIr. Grabowsky was born in Hamburg, Germany, in 1853, and came to the United States in 1873 . By his thorough knowledge of the trade, strict attention to business, and unimpeachable integrity, he has built up a business which is eminently gratifying and satisfactory and is steadily increasing. This House does not solicit work outside of its office -all parties, therefore, soliciting work for this House, are imposing on the public. 


\section{J. M. HOFEMANN \& CO.-Pianos and Organs, No. 141 Smithfield St.}

Although this firm was established as recently as 1878 in its present location, Mr. Hoffman has been for many years identified with the musical instrument business of Pittshurgh and is widely and favorably known in the musical community. They are sole agents in Pittsburgh for the celebrated Lohmer \& Co. Pianos, Jubilee Organs and other reliable makes, besides keeping a line of Musical Instruments, : uch as Guitars, Violins, Flutes, Accordeons, Strings, etc., of every description. They occupy three floors, $25 \times 90$, at No. 141 Smithfield Street, between Fifth and Sixth Avenues, and carry a stock of about $\$ 10,000$ to $\$ 12,000$. Owing to their extensive acquaintance and well-known reliability, they do a large and flourisling business in the two cities and surrounding districts.

\section{VOWINKEL \& BIVENOUR,-Wholesale Liquor Merchants, 27 Wood St.}

This firm was established in August, 1878 , and already ranks as one of the represen tative business bouses of the Smoky City. Mr. Vowinkel, the senior member of the firm, has been a resident of Pittsburgly for the past five years, and his partner for nearly double that time, during which period both gentlemen bave established an enviable reputation for industry, probity and fair dealing.

They occupy three entire floors of the large and commodions warehouse No. 27 Wood Street, with a full and complete assortment of the purest and choicest Brandies, Whiskies aud Wines to be found in the West. At present they carry a stock of about $\$ 10,000 \mathrm{w}$ orth, and their trade is constantly increasing. While the principal portion of their business is in Pittsburgh and its immediate vicinity, they employ traveling salesman through the Western portions of Pennsylvania and Eastern Ohio, where their particular specialties of Pure Rye Whiskies and California Wines have already become famous. This firm employs three men in their warehouse, in addition to the force upon the road, and as they deal exclusively in the best and purest of Foreign and Domestic Wines and Liquors, dealers throughout this section may at all times be assured of procuring the very best articies in the market and at reasonable prices.

\section{JOHN CRA WFORD,-Stencils, Steel Stamps, Rubber Stamps, \&c., 184 Liberty St.}

It is rare to find one engaged in a business of this kind so thoroughly adapted to its requirements in every particular as is Mr. John Crawford. He has not only become familiar with every feature by close study and application, but is gifted with a natural talent of ingenuity which is higher and more essential than all the rudimentary isstructions of the work shop. Possessing these native qualifications and skill, with careful study and experience he is capable of a greater variety and more perfect workmanship than could possibly be executed without them. His facilities for the manufacture of Stencils, Steel Stamps, Rubber Stamps, Burning Brands, Seals, etc., are unsurpassed, and come directly in the line of the requirements of every manufacturing establishment aud business nian. No establishment in this or any other city can produce better work nor at more reasonable rates. He also does Engraving, and manufactures Steel Dies, Notary Public and other Seals for Lodges and Societies, Hotel and Railroad Checks, Key Tags, Flour Brands, and deals in Stencil Inks and Brushes. His establishment, though second in size in the city, is not second in point of excellence of workmanship and promptness of execution. His place of business can be found at No. 184 Liberty street, where lie carries a stock of about $\$ 1,000$, keeps two assistants, and is farored with a good and gradually increasing trade. The business was first started in April, 1878, and while his trade is chiefly confined to Pittsourgh and Allegheny City, it is gradually extending through Western Pennsylvania and Ohio. Mr. Craw ford is a native of this city, having been born here in 1833, and has, since coming to tlre age of manhood, always done business in this city. We cheerfully commend him to the favorable consideration of those desiring anything in his line.

\section{A. HAMILTON,-Fish, Oysters and Game, 184 Liberty St.}

This excellent and popular depot for Fisli, Oysters and Game, is ably and cfficiently conducted by Mr. A. Hamilton at 184 Liberty street, where he keeps a stock constantly on hand in their seasnn, which will tempt the epicure and attract the notice of dealers in the city and surrounding country. In 1878, Mr. Hamilton took possession of this store as successor to R. J. Edie \& Co., and hy his industry and excellent business qualifications has built up and increased the business very materially. He does both a wholesale and retail business, extending over the city and surrounding country, and will always be found prompt in filling orders for anything in his line. In Oysters he makes a specialty of the "Signal" braild, the choicest Baltimore Oysters. He also deals in Fish and Game, in its season, Canned Goods, Pickles, etc. He employs three hands, and keeps one wagon running for delivering goods and shipping. Under his energetic management his trade will continue to widen and increase, from year to year, both at home and abroad.

\section{LOUIS MOESER,-Notary Public, ShipAgent, etc., 142 Smithfield St.}

Mr. Moeser was born in Germany in 1846. He came to this country in 1869 and to Pittsburgh the same year. In 1872 he opened an office as General Steam Ship Agent and is the oldest resident agent in the city for the "American" and "Red Star" lines. He also represents the North German Lloyã, Hamburg-American Packet Co, and nearly all the Europeau Stcamship Liues, and transacts a large European Banking, Exchange and Collection business, furnishing Drafts of any required amount on the principal and most reliable bankers in the old world. HIis office is $12 \times 29$ feet in size, and Mr. Moeser has every facility for transacting business and imparting information relatire to the sailing of steamships, price of passage and exchange of foreign money. He also transacts every description of Notarial business, being duly commissioned by the Governor of Peunsylvania as Notary Public. His business is principally in Pittsburgh and Allegheny County, and is as large as that of any other agent in the city.

\section{O'BYRNE BROS.-Publishers and Book Binders, 143 Wood St.}

This House, though established as late as 1874, has given marked evidences of ritality in the rapid increase and general character of its business. Founded by MI. A. and J. J. O'Byrne, the firm hare made specialties of certain standard and invaluable works, among which may be mentioned the Encyclopedia Brittanirica, the Encyclopedia of Chemistry, Picturesque Ireland, and other standard publications, such as Family Bihles, various elegant editions of the Poets, Histories, etc.

Already the business of the firm, through the employment of twenty to twent -five salesmen and canrassers, extends not only throughout Western Pennsylvania, but several adjacent States, and gives ample evidence that its operations are conducted upon strict business principles and with a view to the establishment of a large and permanent concern. The Messrs. O'Byrne bave been residents of this city for about five years, and have, in that comparatirely concern. The Messrs. O'Byrne have been residents of this city for about five years, and have, in that comparatively
short period, not only built up a large and growing industry, affording employment for a numerous corps of assistants, but have acquired a reputation for thrift and integrity upon which any firm might be justly congratulated. 


\section{H. SMITH \& CO.-Stoves, Grates, \&c., No. 49 Sixth St.}

The beauty of style and finish of the celebrated Wellman's Reflector Stoves aud Grates, manufactured by Messrs. L. H. Smith \& Co., at No. 49 Sixth street, has added another laurel to Pittsburgh's reputation as headquarters for. no relties in the iron and glass liue. The marbleized Slate Mantels on exhibition at this establishment are also models in their way, and most beautiful specimens of that description of work. This House also deals in Chilson's New Cone Furnaces, Hot air Registers, Veutilators, Common Grates, Fronts, \&c. This house was established in 1869 in a comparatively small way, but to-day they stand prominent among the leading establishments of this kind in the city for fine work, and their sales now reach a large and very satisfactory sum. They occupy the three story warehouse, 22 by $8 \bar{i}$ at the location above named, employing fifteen assistants, and carrying a large and elegant assortment of the above mentioned goods and all articles pertaining to this line. Their marbleized mantels range in price from $\$ 15,00$ to $\$ 150,00$. Their trade is principally located in the two cities, although they ship many articles to the various towns of Western Pennsylrania, Eastern Ohio and West Virginia. Mr. L. H. Smith is a native of Pitsburgh. He is a business mau of high standing and undoubtable integrity.

\section{GROGAIN \& MERZ,-Jewelers, Cor. Fifth Avenue and Market street.}

This house was established in a comparatively small way, 35 years ago, by Alex. Richardson, and from him it was passed to his brother, H. Richardson \& Co., who were afterward succeeded by L. MIcIntosh \& Co, who were in turn succeeded by the firm who occupy the building at present. The increasing deniand for artistic and strictly choice goods in their line has prompted them to keep on hand an unusually large stock of the same. They strive to keep a choice assortment of goods, from which may be chosen, at any time, beautiful and appropriate wedding and holiday gifts; at this house at all times may be found carefully selected Diamonds of first quality, handsomely mounted, a rich assortment of Cameos and Intaglios, Lockets, Watches, Chains, \&c. Their business will anount to $\$ 50,000$ per an1uum. Their building is a spacious three story brick, $22 \times 60$ feet. In order that their business may be attended to promptly, they employ fire hands, and their pay roll amounts to about $\$ 250$ per month. The trade of the lrouse is principally in and near the city. Mr. J. C. Grogan is a native of Pittsburgh, and is a practical and punctual business man. Mr. Merz, a German by birth, is a competent and practical Watchmaker and Jeweler. This house in every respect, is certaiuly one of the leading houses in its line of goods in our city.

\section{F. G. PAULSON,-Fashionable Hatter, 113 Wood St.}

It is an incontrovertible fact that there is no article of personal attire which so directly affects the appearance as that of lats or caps, and in the counection ve desire to call attention to the Fashionable Hat, Cap, and Fur House of Mr. Frank G. Paulson, situated at No. 113 Wood street. This is one of the oldest business houses in the city, having been started by the Hon. C. H. Paulson in 1836, and conducted by him with uniform success up to 1875, when it came into the bands of the present proprietor. This House bas long been HEADQUA RTERs for the best styles and qualities of goods in this line, as the former proprietor, Hon. C. H. Paulson, has long been associated with the business interests of the city and identified prominently with politics, state and national affairs, giving him an extended acquaintance and general popularity. He was elected State Senator for the 44th District of Pennsylvania in 1878, which position he still occupies. Under the present management, this store will lose none of its attractive features in point of stock, style or qualities of goods, nor in the ability of its management. It still continnes to be the leader in Hats and Caps, and for the Fall and Winter trade a fine display of elegant Furs is always to be found at 113 Wood street. Mr. Frank G. Paulson is a son of Hon. C. H. Paulson, and has been long enough associated with the business and with the people of Pittsburgh to establish for limself an enviable reputation as a gentleman and enterprising business man. He carries a stock always complete in point of variety and styles, at prices always lowest for the quality. Occupying three floor's of an ample building, the first floor being used as a sales room.

\section{WEBSTER GRAY \& CO.-Importing Tailors, No. 191 Penn Ave.}

As a firm of the oldest standing in this community, and one closely connected in its history with the progress and development of trade in Pittsburgh, the house of Messrs. Webster, Gray \& Co., is entitled to more than passing mention in this publication. Founded nearly half a century ago by Samuel Gray, Esq., the firm has always been recognized as occupying the very highest position, and maintaining it by the superior character of its work and the signal intelligeuce of its management. In $1866 \mathrm{Mr}$. Webster Gray was admitted to an interest in the concern under the above style, and by the demise of Saml. Gray, Esq., his father, has in turn become the senior representative of the house. Dealing with the highest class of custom, this trade has been strictly maintained by the direct importation of the fin st grades of foreign goods, and the employment only of those who are most thoroughly skilled as workmen and cutters. As contributing in no small degree to the industries of the city, this concern employ not less than 25 hands and at times considerably more. The establishnent is perhaps the most recherche' in Pittsburgh, and is the resort of those whose taste demands the very best that can be procured, at prices that are now considered almost fabulously low. In style, make, quality, and all those points that are ahsolutely essential in a perfect suit, this house is unsurpassed, swile its experience and general character is the highest guarantee of satisfaction in every respect.

\section{JOHN WANAMAKER \& CO.-Clothiers, 29 Fifth Avenue.}

For a long series of years the House of Jno. Wanamaker \& Co., Pliladelphia, discorered that they had acquired a very considerable trade in this city of such a class as to warrant them in sending two or three men here several times annually for the purpose of taking orders. Gradually, however, as the character of this House and its work becaune better known, the demand for its goods became too large to manage in this way, and in A pril, 1878, therefore, the present splendid estahlishment was opened at No. 29 Fifth Aveuue, as a branch of the Philadelphia House, and has since done a business commensurate with the standing of the firm and the enormous stock of goods carried.

In the various departments of Custom Work, Merchant Tailoring, Men's, Youths' and Boy's' Readr-marle Clothing, Rubber and Furnishing Goods, etc., this House has acquired a reputation perhaps unequalled in the United States, for cheapness, variety, excelleuce, and perfectly-titting, well-made garments.

Occupying a building four stories in height, $23 \times 100$ feet, and employing nine salesmen, the estahlishment in evory appointment and facility is regarded as being the finest and most extensive in the city.

Mr. Nicholas Baggs, who manages the business of this branch, has been for many years connected with the firm and thoroughly understands the liberal and enterprising spirit that characterizes all the operations of this IIouse. Having vested so large an interest here, the Messrs. Wanamaker regard themselves so much citizens as to be vitally concerned in every movement that affects the prosperity of this community and are justly entitled to the high position they have achieved for themselves by the exercise of integrity and the extraordinary commercial sagacity with which they are endowed. 


\section{BERISSHRE LIFE INS. CO., of Pittsfield, Mass.}

Geo. W. English, General Agent, No. 67 Fourth Are.

The Berkshire Life Ins. Co., is known as one of the oldest in the United States, being chartered in 1851 . It has accumulated assets to the amount of $\$ 3,400,000$ and affurds all the security and advantages to the insured that can be obtained from any similar first class institution. An agency for this company was established in this city nine years ago, and in Jauuary 1878, Mr. Geo. W. English took the general managenient of this district, and the various sub-agencies throughout Western Pennsylvania and bordering States. Nr. English was born in the central part of this state, coming to Pittsburgh in 1870 , where he was identified with the press for many years. He employs three solicitors, and brings to his work an adaptamist produce rerults of reciprocal advantage to all concerned.

\section{BEYMER, BAUMAN \& CO.-Prop'rs Standard White Lead Works,}

\section{Office No. 42 Fifth Ave., Works, Pennsylvania Ave., Allegheny City.}

Messrs. Beymer, Bauman \& Co., have done much in giving creditable character to this class of Pittsburgh manufacturers, their products being sold in every State of the Union, Wast of the Rocky Mountains, and are universally recognized for chemical purity and other points of excellence. Established in 1867 with a capital of $\$ 250,000$, the business of the firm has reached $\$ 400,000$ annually. The works in Allegbeny City cover an area of $1 \frac{1}{2}$ acres, and being supplied with the finest machinery and every late approved appliance, produce from about 6 to 7 tons of Lead daily with a capacity of 3,000 tons per annum, employ 40 hands, requiring a weekly disbursement of over $\$ 400$, besides, which six assistants are required in the clerical departments and on the road. The inembers of the firm $S$. Beymer, $R$. $F$, Bauman and C. F. Wells, are all residents of this city, having been closely identified with its interests for over 25 years and are at present influentially connected with many of our largest and most important commercial and financial iustitutions. With the determination of manufacturing a faultless article of white lead, this house has achieved its olject. From all sources endorsements are received, touching its perfect freedom from all foreign ingredients. The highest official authorities ot the United States Navy made a special report June 7,1878 , announcing that after the most thorough tests, it was ascertained that the White Lead of Messrs. Beymer, Bauman \& Co." "was strictly pure without trace of silver, antimony or other alloy, of perfect whiteness, and under the same conditions covering $81 / 4$ per cent. more surface than the best fead heretofore known to the department." As manufacturers of Red Lead, Orange Nlineral and Potters' Lead, the firm are equally successful.

\section{F. WELLS \& CO.-Pennsylvania White Lead Works,}

Works, River Ave, Allegheny City, Office, No. 42 Fifth Ave.

One of the oldest in the State. These works were established 35 years ago by B. A. Falmestock, succeeded subsequently by Falmestock, Hazlett \& Sehwardtz, and acquired fiually by the present proprietors in 1875 . The works are situated in Allegheny City and rank only second in size and importance to any in the country. They ecver $3 / 4$ of an acre, with a producing capacity of 1,500 to 2,000 tons annually and are furnished with steam engines, boilers and all the latest and best machinery used in the manufacture of White Lead. Thirty hands are employed at tire factory and four clerks and salesmen in other departments, entailing an outlay of not less than $\$ 350$ per week. The vested capital is $\$ 125,000$ and the business amounts to $\$ 250,000$ annually

The members of the firm are Messrs. C. F. Wells, S. Beymer, R. F. Bauman and Wm. Steinmeyer, men of public enterprise and spirit. The trade of the House extends to all parts of the country, and its product js highly esteemed for its unvarying purity and long established reputation for general excellence. This House stands second to none, and enjoys, in a marked degree, the confidence and respect of those with whom they establish business lelations.

\section{ROBISON BROTHERS,-Coal Merchants,}

Foot of Seventh Street, Pittsburgh, and Anderson St. \& River Ave, Allegheny.

The history of the four young men composing the above named firm furnishes au admirable iliustration and lesson, of what may be accomplished by indomitable energy and perseverance. In 1872 the four brothers, Robisot, emliarked in the coal husiness with almost boundless means and unlimited credit. Their father, during a busy and most successful career, had accumulated a fortune, but died during the year, leaving to his sons six hundred acres of coal lauds with a mine in successful operation, over sixteen bundred acres of valuable land in the oil regions, and cash and bank stock to the amount of a million dollars or more. He had handled in one rear 1,800, 000 bushels of coal, in addition to an extensive pork packiug and grocery establishment, and been considered one of the solid men in Pittsbugh. But the panic came, and in a single season they saw the wealth, accumulated by so much labor aud ditticulty by their honored parent, swept away, and for a time it seemed a complete financial annihilation. Possessed of stout hearts and iron wills, they struggled on to recover their lost prestige and to achieve for themselves the same success which had signalized their father's business career. To their credit be it said, that to a certain extent they have succeeded, and give evidence that they are made of the metal which is purificd and strengthened by trial They have now several oil wells in successful operation, and an extensive coal mine on the Mranongabela, from whence they receive their supplies. They are prepared with ample facilities to deliver to any part of Pittsburgh or Allegheny. In 1876 they met with a loss of sixteen coal boats and other coal property, amounting in value to over $\$ 15,000$, but in spite of all these reverses they are undaunted, hurd working, energetic business men, in whose "lexicon there is no such word as fail."

\section{JOSEPE R. HUNTER,-Merchandise Broker, 265 Liberty St.}

Not only is Mr. Hunter widely esteemed and respected as a business man of energy and integrity, but as a promime stands preeminently conspicuous. As president of the "Old Home" branch of the Young Men's Christian Temperance Union for the past two years, and a prominent advocate of temperance since the commencement of the "Murphy movement" in the Winter of 1876 , Mr. Hunter has tone most effective service and won for himself the gratitude and esteem of thousands. He was born in ifercer county, Pennsylvania, in 1825, but has been a resident of littsburgh for twenty-eight years, during which period he has been actively engaged in 1. iness, in which he has built up a large and flourisling trade among the wholesale grocers of Pittshurgh and Allegheny Cities, with whom his business is exelusively conducted. The lines of goods principally handled by sir. Hunter are Coffee, Sugar, Rice, Lard, Oil, Soaps, \&c. Over 25,000 bags of Coffee are represented at his office by sample, and other goods in proportionate quantities. The aggregate amount of sales transacted through Mr. Hunter is not less than $\$ 1,000,000$. He represents all the leading sugar refineries and heavy importing houses of the East. 


\section{PITTSBURGH \& CONNELLSVILLE COKE CO.}

Office, No. 83 Wood St., Works at Conuellsville, at which point all sales are male.

So extensive is the coal interest and so thoroughly identified with Pittsburgh, that a notice of the prominent dealers is highly essential. Among such organizations none is deserviug of more prominent and copjons nention than the Pittsburgh \& Connellspille Coke Co. Incorporated under the mining and manufacturing laws of Pennsylvauia in 186t, with a capital stock of $\$ 150,000$, the concern at once took rank among the largest and most energetic producers in the country. The present officers, who have been connected with it trom its inception, are Mcssrs. J. M. Bailey, Prest., John Wilhelm, Jr. Sect'y., and John F. Dravo, Treasurer and General Manager, to whose ability and thorough knowledge is due its signal success. The possessions of the company are mainly located llear Connellsville in Fayette county, and consist of 300 acres of the finest coal property in Pennsylvania, in which numerous shafts are sunk and mines operated, four powerful engines and seven boilers, extensive hoisting and pumping apparatus, and machiuery for elevating coal through the shafts, besides ovens, for converting it into coke, the greater part of the production being thus used. Five hundred and twenty men are employed in these various operations, requiring an average monthly disbursement of about $\$ 7,500$. The excellence of the production is recognized by iron manufacturers all over the United States, and the State Secretary of Internal Affairs, in his report on Industrial statistics, Vol 3, 1874-5, says that "the Pittsburgh Coal Seam," in which the wines of the company are located, "is from six to ten feet thick, containing an excess of bituminous matter, and yielding a large percentage of excellent coke." For the manufacture of illuminating gas, this coal is considered unequalled, and the coke of this company manufactured from the Connellsville Tein finds a ready market, not only at home, but is consumed in large quantities both in Eastern and Western States, the annual sales which are all made at the mines, amounting to $\$ 105,600$, and increasing even under the present reduced price of the product. Few men in this community are nore widely known than Mr. Jno. F. Dravo, a native of Westmoreland Co., Pa., where he was born in 1819, he came to Pittsburgh at an early age, and for nearly half a century has been conspicuous in promoting the commercial and industrial welfare of this city. Active in every public untertaking, Vice President of the Chamber of Commerce, Vice Pres't and Director of the Morganza Reform school and intimately conforceable speaker, Mr. Dravo has justly earned the respect and consideration in which he is held. The orgauization with which he is most identified, has arrived under his management at a productive capacity of 25,000 bushels per day, and takes rank at the present time with the largest enterprises of the kind in Pennsylvania.

\section{JOS. R. HUGHES, -Wall Paper, \&c., 107 Market St.}

Mr. Hughes has been actively engaged in business since 1818, and in his present location since 1860, during which time his trade has steadily increased, until it now reaches the handsome sum of $\$ 25,000$ annually. He occupies three stories of the building, No. 107 Market street, near Fifth avenue, employing five assistants and carrying an average stock of about $\$ 20,000$ in value, embracing every variety of fine Wall Paper, Dados, and Window shades, and all articles pertaining to this line of business. His trade is principally in the two cities and the adjacent counties. Mr. Hughes is a native of the Smoky City, and rell and favorably known as a citizen and as a business man of undoubted integrity and reliability. To all classes of customers, this House can always offer inducements not excelled by any other House in Pittsburgh.

\section{JAS. LOUGHRIDGE,-Brush Manufacturer, \&c., No. 171 Smithfield St.}

A notice of all important branches of business of this city of the present day, is of interest to all, ard essential to a complete history of the progress and grow th of the community for the information and instruction of the present as well as coming generatious. The establishnent now owned and carried on by Mr. James Loughridge, was founded in 1854 by Loughridge and Maxwell, and in 1861 the present proprietor assumed the entire management and control of the business. He carries a stock at the present time valued at from $\$ 8,000$ to $\$ 10,000$, consisting chiefly of Brushes, Children's Carriages, Looking Glass \& Picture Frames, etc., and transacts a busiuess of not less than $\$ 15,000$ per annum. He manufactures nearly every article in stock, his specialties being Brushes of every description and Children's Carriages. He is patentee and sole proprietor of a patent oscillating spring front for children's carriages, which is a great improvement upon anything heretofore in use. This is the only manufactory of children's earriages in the city, and in that line Mr. Loughridge enjoys a large and lucrative business. At present he employs but four hands, but at times the force is largeIy increased. Mr. Loughridge was born in the city of Baltimore, Md., in 1829. He came to Pittsburgh in 1846 and learned the trade of brush maker in this city. His establishment is noted for the excellent quality of Brushes manufactured, and his trade throughout the city and surrounding country is correspondingly large. Machine brushes of every kind are made to order in the most thorough manner.

\section{H. REINEKE \& CO.-Gas \& Steam Fitters, No. 61 Wood St.}

Some ten years since, the firm of Wallace, Caritt \& Co., dealers in Chandeliers, Gas Fixtures, \&c., was established in Pitshurgh. These gentlemen were succeeded by Messrs. Reineke \& Wilson, and in 1878 the firm name and style wis again changed to H. Reineke \& Co., F. A. Reineke \& J. P. Reineke being admitted. The senior member of the present firm is a native of Germany, but has resided in the Iron City for the jast thirty-five years. The juuior partners are both natives and life-long residents of Pittsburgh. 'They occupy the first floor and basenent of No. 61 Wood street, extending back some one hundred feet, which is divided into sales and inechanical departments. Their lusiness is botl wholesale and retail, and they carry a stock complete in variety and excellence, consisting principally of Chandeliers, Steam and Gas Fixtures, Lift and Force Pumps, Iron and Lead Pipe, Brackets, \&c. Their trade, which is principally in the $t$ wo cities and immediate vicinity, amounts to about $\$ 20,000$ annually. In their manufacturing department they employ from four to eight workmen, and make a specialty of re-bronzing and gilding Chandeliers, \&c. The members of the firm are practical plumbers and gas fitters, and give their personal atteution to the various departments of their extensive business.

\section{JAMES MoKEE,-Watchmaker and Jeweler, No. 13 Fifth Ave.}

Mr. McKee is a thorough practical Watchmaker and Jeweler of more than fifteen years experience, is a native 0 Pittsburgh, learned his trade in the city and has resided here all his life. He commenced business for himself June 1 st 1877, at his present location, No. 13 Fifth Ave., his annual business now amounting to about $\$ 5,000$. He occupies the three story brick building, $15 \times 15$ feet in size, employing four assistants, carrying a small selected stock of Watches, Clocks and Jewelry, making a specialty of fine watch and clock repairing, in which he does a very large and flourishing business. He numbers among his customers many of the leading cjtizens of Pittsburgl, Allegheny and the conntry within a radius of fifty miles in all directions. He cmploys only careful and experienced workmen and his prices for repairing are lower than any other establishment in the city. 


\section{R. G. DUN \& CO.-The Mercantile Agency, 63,65\&67 Fourth Av. A. B. Wigley, Man.}

It would be almost impossible to write an account of the commercial and industrial history of this city without making frequent reference to the Mercantile Agendy of R. G. Dun \& Co. Founded by Lewis Tappan \& Co., in New York in 1841, a branch office was opened in Pittsburgh in 1852, and through all the financial and mercantile mutations that have convulsed the whole country during this extended period the institution to which illusion is made, has remained unshaken and practically unchanged, save in its growing range of uscfulness and nore substantial position.

As a subtle, permeating moral force to restrain evils and correct abuses in the commercial community, it would be hard to overrate the utility of this agency, whose operations in this country are only limited by the bounds of civilization. The territory over which the Pittsburg office bas special jurisdiction includes a large portion of Western Pennsylvania, Eastern Ohio and Western Virginia, but is, of course, connected with every other office in the United States and Canadas by daily coinmunication by mail and telegraphic cyphers.

The resident manager, MIr. A. B. Wigley, has been in charge of this office for three years, previously occupying the same position at Toledo, $O$., and Louisville, $K y$. His efficiency as an agency man has never been questioned and his management of this branch has been productive of the best results, both in the inerease of business and promptness with which information is obtained and transmitted, as well as a general systematic thoroughness that redounds greatly to the benefit of all concerned.

The premises oceupied by the establishment are at Nos. 63,65 and 67 Fourth Avenue, Pittsburgh. They are ample in dimensions, and perfectly fitted and furnished throughout. A staff of fourteen clerks and reporters is required to conduet the business in its various departments, special attention being paid to the accumulation of facts from all parts of the United States with regard to the condition and financial standing of those engaged in the Iron, Glass and Crockery trades. Messrs. R. G. Dun \& Co. claim to be the oldest and largest mercantile agency in the world, and it is generally understood that no one las had the temerity to dispute or contradict this assertion; in any event, the position this institution has gained in the esteem of the intelligent business public, is a sufficient guarantee of its necessity and undoubted importance for the protection of commeree and trade and manufactures.

\section{J. M. HARTFORD, -Wholesale Auctioneer and Commission Merchant, 109 Wood St.}

Regular trade sales of Boots, Shoes and other Merchandise have long been in vogue in the Eastern cities, but it was reserved for Mr. J. M. Hartford to inaugurate and popularize such a movement in the Smoky City. Mr. Hart ford commenced business as a wholesale dealer iu Boots and Shoes in 1872, and for about three years confined himself to that line of business. In 1875, he entered the field as a Wholesale Auctioneer and General Commission Merchant, since which time, notwithstanding the general depression in other branches of trade, he has steadily progressed, until his regular weekly sales have become one of the features of Pittsburgh, inereasing trade and importance in a commerci:ll point of view. Mr. Hartford oceupies four floors at No. 109 Wood Street, with a branch office at No. 102 Pearl Street, Boston. At his Pittsburgh establishment he employs twelve assistants, and althougl lis trade is principally local, large numbers of country dealers from the surrounding towns are attracted to the city by the inducements lield out by him. His regular trade sales, to dealers only, are held on Wednesday of each week, and usually attract a large number of retailers and general merchants from the two eities and adjacent territory. Mr. Hartforl solicits cousignments from all parts of the country and makes liberal advances on all goods entrusted to his care, and looks out carefully for the interests ot his customers. He is a gentleman of high social standing in the community, is a member of the Common Council from the Eleventh Ward, aud, in the Spring of 1879 , was elected to the position of clerk of that body.

\section{FLEMING \& OGLEVEE, -Wholesale Dealers in Hats, Caps \& Furs, 139 Wood St.}

This business was originally started by $\mathrm{Mr}$. Wm. Fleming in 1846. During the intervening years some changes in the management occurred, when in 1875, Mr. Fleming associated with him in the business Mr. J. W. Oglevee. They have the largest and most complete stock of Hats and Caps, Straw Goods, Ladies' Furs and Robes of all kinds to be found in this eity, and are able to offer inducenents to the trade in competition with New York, Philadelphia, Cleveland or with a choice line of Ladies' Furs and Fur Goods, in which they do an extensive manuficturing business. They are with a choice line of Ladies Furs and Fur Goods, in which they do an extensive manuficturing business. They are
exclusive agents for Dunlap \& Co's. Hats, and have a large sale of superior styles of tlieir own designs, prepared speeially for each season. With the present depreciated prices their trade will averige about $\$ 160,000$ per annum, extending through Western Pennsylvania, West Virginia, and Eastern and Central Ohio. Their book-keeper is $\mathrm{S}$. H. W addell; traveling salesmen aie L. N. Fickeisen, James F. McQuaid and J. V. A urentz, who are always authorized to give luwest quotations; besides this, seven meu are employed inside the Uouse. Mr. Fleming is a native of this city. Dir. Oglevee is a native of Fayette County. Pennsylvania. As a firm they hear an excellent reputation in every respect as a leading is a native of Fayette County, Pennsylvania. As a firm they hear an exeelient reputation in every respect as a leading
House in the trade. In the Retail Department this tirm have lately instituted the One Price, Cash System, which is a new feature in the Hat trade and gives them speeial advantages.

\section{A. M. McNISH, -Sash, Blind and Door Machinery, etc., No. 116 Liberty St.}

Mr. A. M. McNish is a brother of the late Henry L MeNish, one of the founders of the firm of MeNish \& Butler, dissolved by the death of the former in 1871. Mr. Butier is earrying on business under the old firm name, althongh exelusively engaged in manufacturing specialties, and the general business of McNish \& Butler is now handlel by $\mathrm{A}$. M MeNish, who started in business for himself in 1s78, after having thirteen years' experience in the old House, which with his acquaintance has already secured for him a thriving and prosperous trade. Mr. MeNish deals largely in all kinds of Sash, Blind and Door Machinery, Woodworth Planers and Machinists' Tools, Pulley's, Hangers, Shaftiug, 13elting, Lace Leather and Belt Hooks, Pattern Letters, 'Twist Drills and Supplies of all descriptious. He is also Agent for Gardner's Patent Compensation Governor, one of the most important inventions of the age, and which should be used by every establishment in the country employing steam power. The trade of this House is steadily increasing and reaches every section of Western Pennsylvania, Eastern Ohio and West Virginia. He is largely patronized by builders of the two cities. Mr. McNish is a native of New York State, but has resided in Pittsburgh for many years.

\section{DA VID GRAY,-Practical Watchmaker and Jeweler, No. 11 Fifth Ave.}

Mr. Gray was born in Ireland July 4, 1845, and learned bis trade in that country many years ago. He has for more than fifteen years been engaged in this line of business with many of the leading houses in England and Ireland, where he acquired a thorough praetical knowledge of all its details. In 1878 he established the business now conducted by him at No.11 Fifth Avenue, and has since met with success. He occupies two stories of the building, employing one assistant, besides giving his personal attention to the business. His trade is principally local, but the prompt and carcful attention given to all work entrusted to him has given him an enviable reputation as a skillful workman and his trade is steadily increasing. He makes a specialty of fine Watch and Clock Repairing, guaranteeing all his work and nuaking his prices moderate and satisfactory. 


\section{W. E. SCHMERTZ \& CO.-Boots, Shoes and Rubbers, 43 Fifth Ave.}

Among the many industries that have tended to extend and enlarge the commercial and manufacturing importance of Pittsburgh, perhaps no one has had a more favorable influence upon the mercantile relations of this community than the shoe trade, and certainly no house in that trade exhibits more energy and enterprise than the subject of this brief sketch. Established in 1818 by W. E. Schmertz, with but limited capital and meagre resources, under his management the business gradually merged out of comparative obscurity, until it became and has remained for years, a controlling influence to the entire trade. In 1860, the style of the House became as above, Mr. T. A. Kam merer became a partner of the concern, other partners came in in 1869, composing the firm at the present time.

The business premises occupied and owned by W.' E. Schmertz \& Co., are, for many reasons, worthy of particular attention. Situated on the principal thoroughfare of the city, they consist of a handsome iron-front building, $25 \times 240$ feet, four stories in height, with finished basement under the whole edifice. Here are ware and salesrooms of ample magnitude, counting rooms and offices with all modern appliances, such as steam elevators and heating apparatns, every arrangement being perfectly adapted for convenience and comfort in the transaction of the business. Here also are accommodations for a stock that ranges in value from $\$ 150,000$ to $\$ 175,000$, and a trade that reaches $\$ 600,000$ per annum. Ten traveling salesmen are kept continually upon the road, 330 hands, the majority of whom are convicts at the
Western Penitentiary, are employed in the manufacture of Boots and shoes, 40 skilled workmen being engaged upon the finest grades of Ladies, Misses' and Children's wear known to the trade. This battalion of operatives require a disbursement of about $\$ 60,000$ a year and turn out about 30,000 pairs of Boots, Shoes, Gaiters, etc., per month, establishing the fact of this House being the largest in the State of Pennsylvania.

Through Western Pennsylvania, Ohio, West Virginia, Indiana and over the far Wust to Colorado, I)ilioto and California, through the South and North-west, the products of this House find a perpeinal market and an increasing reputation. In view of the standing resources and public benefits conferred by this firm, sume brief mentir.n of its members may not be inappropriate in a commenorative publication of this kind, and will inspire with evcry lecade an increasing interest. The senior partner, W. E. Schmertz, Esq., was born in Prussia in 1826 ; coming with his father to this city in 1832 he became identified with his present business at the age of twenty-t wo scars, and rom that perind bis career has been among those most worthy of imitation. As President of the Third National Bank, Vice President of the Chamber of Commerce, Trustee of the Dollar Savings Bank, Director of the Exposition Society, and connected with other of which any citizen of this common wealth might be proud.

Mr. Kammerer, born in 1834 and a native of Pittsburgh, has always been prominent in fostering every public provement that seemed likely to conduce to the general good. Mr. Dunning and Mr. Murray are respectively natives of Ohio and Pennsyl vania, but have been residents of this city for some years. As a firm, it is not too much to say of them that in all those attributes that lead to success and universal consideration W. E. Schmertz \& Co. have been endowed to a remarkable degree.

\section{DUNCAN \& THOMPSONS,-Brush Manufactory, No. 37 Fifth Ave.}

The reputation of Pittsburgh Brushes extends throughout the United States and even to the islands of the Atlantic and Pacific Ocean. A mong the leading manufacturers in this city, we may mention the reliable and enterprising House of Duncan \& Thompson, who, although comparatively young in the business, are gentlemen thoroughly conversant with every detail of the trade as manufacturers and energetic business men. The Honse was established in 1875 by Duncan \& Dilks, who conducted the business until October, 1877, when Mr. Dilks retired and was succeeded by Mr. John W. Thompson. In January, 1879, the firm became Duncan \& Thompsons. Mr. John D. Thompson, the founder of the firm of J. D. Thompson \& Co., became a partner. His long experience in the manufacture of brushes justifies the claim of the leading Brush House in Pittsburgh. While they manufacture and keep in stock a full assortment of all kinds of Brushcs, their specialty is their celebrated brand of Paint, Varnish, White Wash and Kalsomine Brushes, of which they are sole manufacturers, and which are considered by the trade superior to any in the market.

They occupy the large two-story building at No. 37 Fifth Avenue, 120 feet deep, and employ a large number of experienced workmen. Their trade at present is among the jobbers, retailers and artizans of Western PennsyIvania and adjacent territory, hut the reputation of their goods is rapidly spreading throughout the West and South. They carry an a verage stock of from $\$ 15,000$ to $\$ 18,000$, with a yearly business exceeding $\$ 60,000$. Mr. Duncan was born in Butler County, Pennsylvania, in 1844, and has resided in Pittsburgh since 1865. Mrr. J. D. Thompison is a native of Scotland, and came to Pittsburgh in 1836. Mr. John W. Thompson is a son of the last-named gentleman and was born in Allegheny in 1854.

\section{MONONGAFELA INSURANCE CO.-0ffice, No. 89 Fourth Ave.}

The Monongahela Insurance Co., of Pittsburgh, has been in existence for the past quarter of a century, having been incorporated in 1854. Their actual eash capital is $\$ 175,000$, and their business, which amounts to about $\$ 30,000$ per annum, is conducted in a manner eminently worthy of the business reputation of the well-known gentlemen composing its Board of Directors and General Managers. Their business is Marine, Inland and General Fire Insurance, aud is principally local, being confined almost exclusively within the limits of Allegheny County. The officers of the Company are Wm. A. Caldwell, President, Geo. A. Berry, Vice President, John II. Claney, Secretary, and F. A. Dohrman, Sulveyor, with the following Board of Directors: Wm. A. Caldwell, President, Geo. A. Berry, Vice Presidcnt, William Rea, Robert Dalzell, William Means, James Woodburn, R. H. Palmer, James McCandless, David M. Smith, Gco. W. Dilworth, Charles Atwell, Henry Hays, James A. MeDevitt, William Cooper.

\section{GILLIAM IAN'F'G. CO.-Saddlery Hardware, etc., 97 and 99 Third Ave.}

Established in 1867 by the present proprietor, A. Gilliam, Esq., this concern has grown from very limitcd proportions to a prominent position among the industries of the Iron City. The premises now occupied in this branch of manufacture consist of one large four-story double-brick edifice, at Nos. 97 and 99 Third Avenue, 30x84 feet, the first tloor being used for sales and exhibition room, offices, counting rooms, etc., and the rest of the building for mannfacturing all kinds of Saddlery Hardware, Gig-saddles and Gilliam's Patent Coach Pads, etc. In comparison with other similar establishments, it may be said that this is the only one west of the Alleghenies, all the goods manufactured here being original in design with Mr. Gilliam and protected by letters patent from infringement. Owing largely to this fact, the trade of the House has extended from Canada to California, and it is claimed that in quality, design and
cheapness no honse in the United States can produce such satisfactory results. Fifty hands, two traveling salesmen, clerks, etc., are required to conduct the business, the machinery consisting of ten sewing machines and numerous stcam presses, dies and other appliances for cutting ont stock and securing rapid and perfect work.

Mr. Gilliam is a native of Central Obio and was formerly engaged in manufacturing business of a similar line of goods in Ciucinnati. removing to this city in 1867, since which time he has done no little to promote its industries, and has become thoroughly identified with its development and prosperity. No house enjoys a higher position commercially than the Gilliam Manufacturing Company, which, considering the liberal and enterprising spirit that actuates its operations. is as natural as it is justly deserved. 


\section{A. M. SPEER, M. D.-Oculist and Aurist, No. 212 Penn Ave.}

The treatment of Diseases of the Eye and Ear is one of the most difficult and delicate departments of the medical profession, and of late years it has been almost entirely given over by the most reliable practitioners in the country to those who make it their especial study. While many irresponsible physicians, anxious only to secure their fees, will attempt treatment of those delicate organs, without knowing or understanding their peculiarities, it will be noticed that the best and most reliable doctors of medicine will recommend their patients to the services of some successful and responsible oculist and aurist for treatment and cure.

Dr. Speer is a native of Pittsburgh, and has resided in the Iron City for forty-five years, excepting two years spent in Europe and five years as Surgeon in the Army. He graduated at Jefferson College, Philadelphia, and afterwards studied in the best medical schools of Europe. He now devotes his special attention to Diseases of the Eye and Ear. His father is one of the oldest and best known physicians of Pittsburgh, having been in continual practice here since 1825. Ten years since he retired, after a successful and honorable career of more than half a century. Dr. A. M. Speer, whose office is located at No. 212 Penn Avenue, is a thorough and practical physician and has met with marked success in the specialty for which he is noted.

\section{FAIRBANK'S STANDARD SCALES.-H. C. Dickinson, Agt.,48Wood St.}

The well-known and deservedly popular Scales manufactured by Fairbanks \& Co., at St. Johnshury, Vermont, are universally acknowledged to be the standard, not only in this country, but in many foreign countries. This old-established and reliable House is represented in Pittsburgh by MIr. H. C. Dickinson, whose headquarters is at No. 48 Wood Street. They have Deen established here since 1866 and occupy three stories and basement of the spacions warehouse Fairbanks, which he offers at factory prices. He also takes orders for the firm, shipping directly from the works, if desired. Mr. Dickinson has sole control of the "Type Writer" for this section and is Agent for the most approved styles of Lawn Mowers and Hancock's Patent Inspirator, an invention which has received the highest encomiums from all who have given it a trial. Grocer's Fixtures form an important feature of his business, which amounts to from $\$ 60,000$ to $\$ 75,000$ per annum. They make a specialty of Fairbank's Scales and of repairing the same. His trade extends through Western Pennsylvania, Eastern Ohio and West Virginia, and ten assistants are required in his extensive establishment. Mr. Dickinson has been a resident of Pittsburgh since 1866, where he has built up a large and flourishing business, and and a name which is unblenished in the commercial world.

\section{PORTER \& DONALDSON, -Wholesale Millinery, Cor. 5th Av. \& Liberty St.}

This enterprising House, which now ranks as the leading Wholesale Millinery Establishment of Pittsburgh, was founded in 1867 by succeeding to an old established House in Steubeuville Ohio. In that place an annual business of $\$ 100,000$ was done under the firm name of Porter, Donaidson \& Co. In 1872 the present House was established in Pittsburgh, but the above-named members of the firm still retained their interest in the old House at Steubenville.

In 1878 the firm was divided, Mess's. Porter \& Donaldson assuming the entire ownership and control of the Pittsburgh branch and the other members of the firm continuing the Steubenville House. They occupy here the second and third floors of the new and elegant edifice corner of Liberty Street and Fitth Avenue, 35x100 feet, which is filled with an extensive and well-selected assortment of seasonable millinery goods, consisting of Ribbons, Laces, Flowers, Feathers, Hats, Bonnets, Silks, Velvets, etc. They carry an a verage stock of about $\$ 30,000$, although at certain seasons the valuation will reach double that amount, and transact an annual business exceeding $\$ 200,000$, which is principally located in Western Pennsylvania, Ohio, West Virginia and adjoining States. They employ thirteen clerks and saleswen, and their trade is exclusively wholesale. They import direct a large portion of their foreipn goods and are recognized as gentlemen of enterprise, ability and strict integrity. To the Jobber or Retail Dealer, this House presents advantages not equalled by any other House in Pittsburgh.

\section{H. D. MeINIGHT \& CO.-Eclipse Steam Pump Works, First Ave. \& Ferry St.}

The articles manufactured at these extensive works are principally Steam Pumping Machinery and Pumps of every description, and the celebrated Eclipse Steam Boiler. This House has long been noted for their excellent quality of work, for their complete and unrivalled machincry and facilities for manufacturing, and under the new managers they will in no wise deteriorate or fall short of the reputation of previous years. These works were established in 1853 by Mr. Davison Plillips, whoconclucted the business for five years, when Mr. Wm. H. Cluley was admitted as a nartner under the firm name of Phillins \& Cluley. In 1873 this firm was suceeded by S. D. Flubbard \& ('o., who earried on the business for five years, when, in 1878, the present proprietors assumed the sole control. The business now amounts in round uumbers to not less than $\$ 100,000$ per anuum. The "Eelipse" Works occupy the large four-story structure, $36 \times 100$ feet, at the corner of First A veune ad Ferry Street, employing twenty hands, with a monthly pay-roll averagin $\$ 1,500$. The motive power for their extensive machinery is supplied ty one powerful sixty-horse power engine.

They manufacture the celelorated Eclipse Balance-Wheel Steam Pump, which has been pronounced by mechanical experts the best and most reliable steam poum now in use having excellent qualities which will commend it to all who will investigate. They are made for both bot and cold water. At the Centennial Exposition in Philadelphia, in 1876, these pumps were awarded the highest Medal of Honor and a Diploma of Merit. Every pump furnished by this establishment is fully guaranteed. In addition to the various pumps for feeding boilers, Messrs. Mrc Knight \& Co. make a specialty of Pumps for the following purposes: Water Works, Mining, Oil Refinery, Oil Tauks, Soap, Lye, Lard, Vinegar, Tar, Tallow, Benzine, Bleacheries, Gas Works, etc., etc., and, in fact, every deseription or strle of Pump which by any possibility may be required. They also pay special attention to Repairing of all kinds in connection. The trade of these works extends all over the United States.

\section{NIEMAN \& AHLERS,-Merchant Tailors, \& Furnishing Goods, 101 Smithfield St.}

The elegant establishment of Nieman \& Ahlers, located at No. 101 Smithfield Street, three doors from Fifth A renue las long been famous as the headquarters for fine Clothing and Gentlemen's Furnishing Goods. This House was established in 1854 by H. H. Nieman. In $1861 \mathrm{Mr}$. H. Allers became associated with him under the preseut firm name and style, and their business has largely increased under the judicious management of these enterprising gentlemen. They occupy the entire four floors, each $20 \times 60$, in Howard Block, at the number indicated, and earry a ful line of desirable fabries for gentlemen's wear, together with a large and judiciously selected assortment of Gents Furnishing Goods. They make a specialty of manufacturing Fine Suits to order, in the most thorough, fashionable and workmanlike mauner. The value of their stock is about $\$ 9,000$ and the annual business amounts from $\$ 30,000$ to $\$ 10,000$. They employ from twenty-five to thirty hands in their manufacturing department and their business is one of the largest in the eity. Mr. H. H. Nieman was born in Germany in 1832; he came to the United States in 1846 and to Pittshurgh the same year. Mr. $\mathrm{H}$. Ahlers is also a native of Gernany, where he was born in 1832 . He has been a resillent of Pittsburgh since 1852 . 


\section{J.D. BERND \& CO.-Importers \& Wholesale Millinery Goods,Cor.5th Av.\& Marketst.}

Mr. J. D. Bernd, the founder of this House, now in the seventeenth year of its existence, was born in the picturesque little village called Hohen-Solms, near Giesen, on the line of railway between Frankfort-on-IIain and Cassel, in Germany. He came to this country at four years of age and received an elementary education in Philadelphia. His parents were in comfortable circumstances and held in high esteem in their old home in Germany. His father, a man of considerable culture and sterling integrity, meeting with reverses after coming here, made it incumbent on the children to earn a living, and thus the subject of this sketch, at the age of thirteen, commenced his career, and rose from humble errand boy, at a salary of fifty cents a week, through the various gradations of salesman, in various lines of business, trareling for his respective firns, which occasionally brought him to Pittsburgh. This is down to 1857 , when his firw in Philadelphia (Mr. B. having a mere nominal interest in the business) succumbed to the panic, when he went to New York City. Still pursuing his vocation as traveling salesman until the Spring of 1861, he was sent out here to open a branch Millinery House, and the following Spring (1862) commenced here on his own account.

He first occupied the second-story front room over (then) Reed's Jewelry Store, at 94 Fifth A venue. The next season (Fall 1862) he occupied the second story over what is now Jno. Wanamaker \& Co's. In the Spring of 1863 he moved to his present location, occupying at that time only the second story of this building. Here the business gradually increased, until the year 1870, when the building was enlarged, making a frontage on jrarket Street of forty feet and seventy-five feet on Fifth A venue. The firm then became J. D. Bernd \& Co. by the admission of Mr. E. B. Eckstein as partner and occupying the entire three stories of the premises. The three stories were built to accommodate the increasing business of the firm, putting in elevator and all modern improvements, J. D. Bernd \& Co. naking all the interior embellishments and conveniences, making them the best adapted lofts for their business in this city, and, for that matter, any city in this country.

In $1873 \mathrm{Mr}$. S. L. Fleishman became a partner, with the view of adding notions and otherwise extending the business, but the panic followed, and it became necessary to contract instead of expanding. Mr. Fleishman retired from the business January 1, 1875. In 1877, Messrs. C. B. Elben and S. M. Rose, two of the head salesmen, were admitted to a silent interest in the House. In 1878 , r. E. B. Eckstein opened a Retail Branch IIouse in St. Louis, as Bernd \& Eckstein. This business at the end of the first year became such an assured success that Mr. Eckstein assumed the St. Louis business on his account, leaving MIr. J. D. Bernd to continue the Pittsburgh House. MIr. Bernd has been twice to Europe since his advent in Pittsburgh, each time importing goods and forming permanent connections with that view. They hare a nominal office in Paris and an active one in New York City represented by a burer; besides, Mr. Bernd and Messrs. Rose and Elben are also frequently in the market. They use a fifty-trip firm book orer the Pennsylvania Railroad to New York. These books are good only for a year, which gives evidence of the enterprise and energy displayed by this firm. Their sales range from $\$ 225,000$ to $\$ 250,000$ per annum, and being almost entirely Millinery Goods, gires it a comnercial rank and standing among the largest of its class. Their business is largely in the two cities and through Eastern Ohio, Western Pennsylvania and West Virginia. Their stores for neatness and cleanliness are considered the model ones in this city, and are constantly commented on as to how a place can be kept so clean and fresh in Pittsburgh.

The business in all its various details of management is conducted upon principles of pure mercantile integrity, and it is to these merits that the eredit, reputation and confidence of the House owes its success.

\section{WII PICKERSGIIL, Jr.-Man'fr. \& Jobber of Boots \& Shoes, 149 Wood St.}

As pursuing a very important branch of industry bearing upon the general commercial prosperity and mercantile thrift of this city, the House of Wm. Pickersgill, Jr., may not be overlooked in a publication whose special object will be attained in the proper display of the natural resources and acquired advantages of Pittsburgh as a great center of manufacturers and productive trade.

This House was established in 1859 , and for nearly a quarter of a century has continued a career whose success has been uninterrupted by the various convulsions, political and financial, that have taken place during that eventful period. Very early in its history Mr. Pickersgill perceired the advantages likely to accrue to his customers and himself from the establishment of a manufactory, where not only every grade of goods might be produced, but where special orders could be filled with promptness and economy, enabling him to compete on equal grounds with the Eastern manufacturers. From this idea originated his present extensive factory (in the rear of the warehouse and sales rooms), a large brick building, 20x 80 fect, three stories in height, where are constantly employed from forty-fire to fifty skilled operatives and from which is turned out work in every department that will bear comparison with that emanating from the largest and hest known manufactories in the country. With these facilities, and occupring one of the largest business edifices in the city, a trade that extends through Pennsylrania and Ohio, West Virginia Iowa Indiana and Illinois, Mr. Pickerscill has established an annual business that will average about $\$ 250,000$, and requires in its various departments, aside from the manufactory, six traveling salesmen, two book-keepers, five city salesmen and other employes.

Altogether, the House of Mr. Pickersgill takes equal rank with any in the State and is entitled to consideration as such, while the principles upon which it is conducted are alike liberal and enterprising. As a business man the as one who has always conserved the public interest in erery reformatory measure, he has achieved a place in the esteem of the community as richly deserved as it is sincere.

\section{A. O'LEARY,-China, Glass and Queensware, No. 73 Wood St.}

One of the oldest Houses in its line in this city is that of MIr. A. O'Leary, now situated at No. 73 Wood Street. The business was first started by Juhn J. O'Leary in 1854 , with a capital of $\$ 10,000$, and conducted by lim up to 1871 , when he was succeeded by the present proprietor who has perfected arrangements for meeting the wants of the trade upon as good terms as any house in Cleveland or Philadelphia. IIe carries a stock of about $\$ 10,000$, consisting of erery desirable variety of Foreign and Domestic China, Glass and Queensware, and occupies three floors and basement of an ample building, where he employs three men and is doing a trade of about $\$ 30,060$ per annum, throngh Western Pennsylvania, but has a large city trade. His Retail Department offers special inducements and attracts a large patronage. IIr. O'Leary handles English and French Goods quite extensirely and imports directly from foreign manufacturers. He is thirty-five years of age, a native of this city, and an euterprising busiuess man.

\section{GETTY \& CO.-Distillers \& Wholesale Dealers in Whiskey, 184 \& 186 First Ave.}

The house of Getty \& Co., was founded in 1872 by Mr. James GettJ, Jr., who is at present sole proprietor. Mr. Get.ty was born in Philadelphia, but became a resident of Pittsburgh at an early age. He deals largely in Wines, Liquors, \&c., carrying a stock of about $\$ 5,000$, and transacting a business of $\$ 30,000$ per annum. His trade is principally located in Pittshurgh and vicinity, and he makes a specialty of supplying families with the purest and best articles of old Janongahela Rye Whiskey. His stores are looeted at Nos. 184 \& 186 First a venue, being $36 x 50$ fcet in size. To all, in want of a pure article of unadulterated liquors for medicinal or family use, we can confidently recommend the house of Getty and Co., whose goods are selected expressly for the purposes named. 


\section{McCANDLESS, JAMISON \& CO.-Dry Goods and Notions, 103 Wood St.}

This House was established in 1838 by Gregg \& McCandless, succeeded by J. M. McCandless \& Co. in 1851, and by the present style of firun in 1854, with a few changes in its members which are now conposed of Jas. MeCandless, Thomas Jamison and J. M. Simpson, who are still conducting the business, Mr. McCandless residing in the East, where he manages the purchasing department of the concern at No. 214 Chestnut Street, Philadelphia.

As the oldest, and one of the largest Dry Goods Houses in this city, its commercial connections range not alone over the State of Pennsylvania, but Eastern Ohio, West Virginia and Maryland, together with other points more distantly removed. Unshaken by the financial disasters that have wrecked less solid and conservative firms, the history of this House for forty-one years is one of the most pointed exponents possible of the business thrift and able inanagement of the concein, which in spite of all general depression has continued to increase its strength, trade and special facilities.

In the departments of Woolens, Domestic Blankets and Flannels, this House offers inducements to buyers which are not only unrivalled in this but in any other market, and forms the bulk of the enormous business done by the firm, which in this city is conducted by Messrs. Jamison and Simpson, resident partners, whose names are synonymous with that liberal commercial rectitude for which the House has always been characterized.

\section{ALBREE \& CO.-Boots and Shoes, No. 71 Wood St.}

This House was established by Mr. Geo. Albree more than half a century ago, during which period the business has been conducted without interruption, regardless of general commercial derangements, financial panies, or social upheavals. $A \mathrm{~s}$ the oldest Shoe house in the West, it is at the same time perhaps the best known, from the remarkable characteristics of its founder, whose unflinching integrity, great liberality, and financial solvency, are as widely recognized as his marked proficiency as a meteorologist. In 1876 Mr. Geo. Albree retired from active participation in the business, and was succeeded under the above title by his son, Jos. Albree, and W. P. Thomson, who still maintain the established conservative proclivities of the House, at the same time infusing into the business an energy that keeps it abreast of the times and in sharp competition with younger cotemporaries in the same trade. The business premises occupied by the firm are of ample dimensions for the storage and display of a stock extraordinary for excellence, and the uniform care displayed in its selection. The jobbing trade of the house extends beyond our own into two or three adjacent States. while the retail department, to which the house is giving close attention and great variety of styles to the custom, at prices ranging usually lower than the excluseively retail houses, embraces the highest class of dealers and buyers within the commercial range of this city and home patrons.

\section{DR. GEORGE H. KEYSER,-Physician, $120 \& 240$ Penn Ave.}

For many years the name of Doctor Keyser has been "familiar as household words" to most of the families of Pittsburgh and the towns within a radius of three hundred miles, not only by reason of the wonderful cures he has performed in his professional capacity, but the excellence and efficacy of the many preparations from his laboratory. Dr. Keyser is a native of Franklin county, Pa., but has for many year's resided in Pittsburgh. He is a graduate of two medical schools, both allopathic and eclectic, and has attained considerable celebrity as a surgeon. He has been a practitioner for the past thirty-five years and met with the most gratifying success. of late years he has abandoned the allopathic system of treatment and devotes his attention principally to the treatment and cure of chronic diseases. Probably no physician living to-day has devoted so much attention and study to diseases of the lungs and pulmonary organs, and we are confident that no one has effected so many permanent cures of the most difficult cases. The doctor has been a well known, highly respected and honored citizen of Pittsburgh for thirty-one years, during twenty-seven of which, he was proprietor of the leading drug store of the City, on Wood street. For a number of years he was president of the eclectic medical association of Allegheny county, and has always enjoyed the most unbounded confidence and respect of the profession. His offices at present are at No. 120 and at 240 Penn Ave., his lahoratory being at the latter number, where he manufactures and distributes all over the country, his famous preparations known as "Dr. Keyser's Lung Cure or Pulmonary Restorative," "Dr. Keyser's Pectoral Cough Syrup" and other medicines of his own exclusive discovery and manufacture. The virtues of his widely known and justly celebrated medicines are known and appreciated by invalids in all parts of the world, and we can only advise all afficted with diseases of the lungs or pulmonary organs, to call on Dr. Keyser, or send for bis valuable works, which will be forwarded free on application as above.

\section{WM. GUCKERT \& CO.-Desks, Tables, Wardrobes, Cherry \& Strawberry Alleys.}

The manufacture of Extension and Centre Tables, Wardrobes, Office Desks, Book Cases and similar articles is carried on extensively in connection with that of Banisters, Newel posts, Hand Railings, \&c., by Messrs. William Guckert $\&$ Co., at their factories, corner of Cherry and Strawberry alleys, between Smithfield \& Grant Sts. This business was established in 1849 by Valentine Guckert \& Bro., who were succeeded in 1878 by the present proprietors Messrs. William, Anthony and Frank Guckert, all of whom are natives and life-long residents of Allegheny county. They occupy two large factories at the location mentioned ahove, one, four stories in height, $50 \times 60$ feet in size, which is used for the manufacture of every description of cabinet work, and another, three stories high, $25 \times 60$, wliere wood turning, scroll sawing and jobbing of all kinc's is carried on. The capital employed in the business is $\$ 15,000$, and their trade, which is larger than that of any similar establishment in the West, extends through Pennsylvania, Ohio, Virginia, West Virginia and many of the other States. The specialty of this house is the manufacture of Centre and Extension Tables, of which they keep a large stock on hand and manufacture to order from any desired material and in any size or style. They also manufacture a variety of styles of Brackets from their own patterns and designs, besides giving their careful attention to every description of job work in their line.

\section{S. HAMILTON,-Pianos and Organs, 87 Fifth Ave.}

In 1871 the firm of S. Hamilton \& Co. was established, and in $1875 \mathrm{Mr}$. Hamilton became sole proprietor. The line of business carried on by him is that of wholesale and retail dealer in Pianos and Organs, being the only house in this city dealing exclusively in these instruments. He occupies the spacious sales rooms, $20 \times 120$ feet, at No. 87 Fifth avenue, nearly opposite the Pittsburgh Opera House, witl a stock of these goods valued at from $\$ 20,000$ to $\$ 25,000$, doing an annual business of $\$ 150,000$, which is the largest in that line of any house in the city. Mr. Hamilton is agent for the celehrated Decker Bros. Pianos and the Estey Cottage Organs, both of which articles have acquired a worldwide reputation as being second to none manufactured. While be makes a specialty of these superior articles, he also keeps a large line of cheaper grades and other makes, which, owing to the superior advantages possessed hy him, he is enabled to sell at great bargains. Mr. Hamilton is a native of Allegheny county, and well known and widely esteemed as a citizen and business man. 


\section{ALIEGHENY INSURANCE CO.-Office, No. 67 Fourth Ave.}

Incorporated twenty years ago under the laws of Pennsylvania, as a Fire and Marine Insurance Co., the $A l l e-$ gheny Insurance Company began business April 4th, 1859, and is therefore intimately connected with the most vital periods of our commercial and municipal history. Among those who were interested in the inception of this organization as applicants for a charter and stockholders, are observed names that can never be omitted from a record of the ind ustries of Pittsburgh; the list is given entire, because many of them have passed away, leaving untarnislied names and a projected intluence that must affect every institution with which they were connected. Incorporation Commissioners: Hon. Thos. M. Howe, Jas. B. Murray, Esq., Dr. C. G. Hussey, Harvey Childs, Esq., Wm. M. Lyon, Esq., Geo. IV. Cass, Capt. Robt. Beer, R. B. Sterling, James Laughlin, Alexander Speer, Mark W. WVatson, and Robt. Patrick. The present officers of the company are as follows: John Irwin, Jr., Prest., Jas. S. IrcCord, Vice Prest., C. G. Donnell, Secty., and Capt. Wm. Dean, Gen'l Ag't., all heing natives of Pennsylvauia, except Capt. Dean, who was born in Columbiana Co., Ohio, but has been connected with this company for twenty years, and for thirty ysats previous was engaged in the River traffic between this point and Cincinnati as captain upon the old Packet line. Mr. Irwin is a nember of the firm of T. H. Nevin \& Co., White Lead Manufacturers, in Allegheny City, and Mr. McCord is now senior partner of the old house of McCord \& Co., Hatters, No. 131 Wood st., and Mr. Donuell has always been intimately identified with the Insurance business as an able underwriter. So officered and managed, this company
has stood the various disasters of nearly a quarter of a century with untlinching solvency. It has paid all its losses promptly and rarely passed a dividend. With a paid up capital of $\$ 100,000$ it has accumulated assets to the amount of $\$ 131,173,63$, with a surplus of over $\$ 16,000$. The policy of its management from the first has been a liberal and a just one, the natural result being that no similar institution in the city is regarded with greater favor or respect.

\section{CENTRAL REFINING CO.-Office, 173 Wood Street.}

The gigantic growth and present importance of the Oil Trade in Pennsylvania, and especially with reference to its bearing upon the business of Pittsburgh, may be perhaps somewhat illustrated by a brief account of the operations of the Central Refining Company, which was incorporated in 1873, the officers being IV. M. McKelvey, President, Wm. Frew, Esq., Vice President, and F. J. Gillespie, Secretary and Treasurer, the capital stock being $\$ 255,300$. The property of the Company consists of one Refinery and Barrel Factory at Kennedy's Station on the West Pennsylvania Railroad, and one Refinery at Sharpsburg, on the same road, eighteen buildings, substantially constructed, forty tanks, two steam ongines, fourteen stean pumps, with other machinery, together with all the modern apparatus of the barrel factory, covering in all nearly fifty acres. Here are employed about 350 hands in the various departments, requiring a monthly disbursement of $\$ 12,000$ and producing 40,000 barrels of Refined Oil per month, all of which finds its way to European and other foreign markets.

\section{J. H. STEVENSON,-Attorney at Law, No. 100 Fifth Ave.}

In addition to his regular law practice, Mr. Stevenson is Notary Public, Real Estate Agent, Patent Attorney and Solicitor. He has been established in Pittsburgh since 1871 and enjoys a large and lucrative patronage. His Real Estate business is large, extending through Western Pennsylvania, and having a thorongh understanding of the Patent business, examinations of claims and securing patents has been very successful in that line. Mr. Stevenson was born in Lawrence county, Pia., in 1842. He received his early education in the public schools of New Castle, Pa., and read law with J. Smith Du Shane, Esq., then district attorney of Lawrence connty. He was admitted to the bar in 1868 at New Castle, where he practiced successfully for two years. He afterwards practiced three years in Beaver county, from which place he removed to Pittsburgh, where he has met with the most encouraging success and established a high reputation.

\section{F. AHLERS,-Merchant Tailor, No. 77 Smithfield St.}

This house was established in 1867 as Ahlers and Bayha, the latter retiring from the firm in 1872 and Mr. Ahlers becoming sole proprietor. He has stock amounting in value to $\$ 4,000$, and at present is transacting an annual business of $\$ 15,000$, although ai times it has amounted to as high as $\$ 25,000$. He has eleven men in his employ, to whom he pays an average salary of $\$ 14$ per week. His trade, which is large, and rapidly increasing, is located principally in the city and surrounding country. Mr. A hlers' goods are of the best quality, and the fit and style of his suits are unequalled in the city. He was born in Germany in 1834, and came to Pittsburgh in 1857, where be has since resided.

\section{H. LANZ,-Boots and Shoes, 113 Market Street, at Junction of Market and Liberty Sts.}

Mr. Lanz is classed among the few first-class workmen in the city. His neat establishment is divided into two departments, viz:-Manufactory and Salesroom in which departments five hands men who are thoroughly first-class workmen, are busily employed. Mr. Lanz carries a stock ranging from $\$ 2,000$ to $\$ 3,000$, composed of the very best articles that can be manufactured. He deals in all kinds of Men and Boys', as well as Misses' and Ladies' Goods, both of the heavy and fine manufacture. Mr. Lanz has been engaged in this business for about twenty years, and formerly was established at No. 21 Diamond Street, where he had hosts of customers and friends whom he still retains. His trade is located mainly in the city and is rapidly increasing since his removal to Market and Liberty

\section{R. C. OEHMLER, - No. 78 Fourth Avenue.}

Painter, Proprietor \& M 'r of Oehmler's Patent Star Gold Paint, Liquid \& Blackboard Slating.

For fifteen years Mr. Oehmler has been one of the most prosperous painters in our city and still gives employment to 6 or 8 hands, and often to a large number, in the capacity of house, office, sign and ornamental painting, gilding, etc. He is the patentee and manufacturer of Oehmler's Patent Star Goln Paint Liquid, "Ready Made Sizing" and Oehmler's Slating for Blackboards, all three of which are the results of his thorough knowledge of oils, paints and metals, after close study and untiring experiments. The Star Gold Paint Liquid and the Blackboard Slating are his specialties. The former being a composition used in the form of paint, which gives a bright, durable, bronze surface to metals to which it is applied, superior to any other preparation in the world; the latter, also in a form to be applied as paint, has had practical tests in our own public schools and has manifested all he claims for it as a superior slating surface for marking, distinctiveness and easiness of erasure, and an excellent blackboard surface, applicable either to plaster, wood or paper. His products have alread y attained a celebrity throughout this conntry and Europe, and can be found in nearly every paint and drug store, being represented in our own city by Geo. A. Kelly \& Co., and other first class houses. 


\section{H. E. COLLINS \& CO.-Brokers in Pig Iron \& Metals, 175 Wood St., Cor. Liberty.}

As Special Dealers and Brokers in Ores, Iron, Zinc, Lead and Metals, Pig Iron, Spelter, Spiegeleisen, Ferro, Manganese and Copper, New Iron and Steel Rails, Old Iron and Steel Rails and Car Wheels, Bessemer Rail Ends, etc., this city that places them at the head of this very important branch of industry.

Mr. Collins is originally from New York State, and Mr. Jas. H. Murdock (the Co. of the firm) is a native of Ohio, both, however, being intimately identified with the iron tracle of Missouri and Pennsylvania for fifteen years. Thoroughly educated in their business and practically familiar with the metals, and metallurgical properties, grades, distinctions and qualities of the products in which they deal, this House can offer advantages to its customers not surpassed by any similar coneern in the country. The wide extent from which this firm draws consignments embraces every metal and ore-producing State, the Canadas and Great Britain, relations heing established wherever the least advantage is to be gained or the slightest benefit accrues to those for whom they are commissioned to act.

Though the career as a firm of $\mathbf{H}$. E. Collins \& Co. has dated only from 1877 , the progress they have made in that short period and the rapidly increasing importance of the House would be sufficient evidence, were others wanting, that the energy, knowledge and enterprise displayed by it is a natural result, in the esteem and high consideration with which it is held.

\section{FLEISHMAN BROS.-Trimmings, Millinery \& Fancy Goods, No. 92 Market St.}

Founded by S. C. \& E. Fleishman in 1875 as jobbers and retail dealers in Millinery, Fancy Goods, Flowers, Trimmings and general Furnishing, this house soon became a prominent one from the enterprising and successful manner of its competition with older cotemporaries. With a very comprehensive experience in the business, together with Eastern and importing connections that insure every advantage that can be desired from a careful scrutiny of the markets, the MIessrs. Fleishman are almost always enabled to offer extraordinary advantages to bu yers, and are rapidly establishing this fact by the remarkable increase of their trade and the favor with which the hoinse is regarded by the best buyers in the city. In Kid Gloves and Corsets, made specially for them, and protected with their own trade mark, the firm make a specialty, and in this line are beyond competition. Another specialty of the house is their millinery department, which is always represented with a choice selection of trimmed hats, and others not trimmed, accommodating parties by trimming to order, which gives employment to a large force of trimmers who occupy the second floor of the building. With handsome and commodious premises in the verv best location, a numerous staff of assistants, and a stock noted for the good taste evinced in selection, the house of il essrs. Fleishman Bros. is heartily commended to the public as affording facilities in their line of trade hard to duplicate in this or any other city.

\section{THOMAS HARE, -Saddlery Hardware and Carriage Trimmings, 135 Wood Street.}

This branch of business has assumed extensive proportions, and this old-established House has long enjoyed a remunerative patronage, offering as it has in the past and still continues to do, the best facilities to the trade for supplying articles in this line upon the most favorable terms. This business was originally started in 1856 by McWhinney, Hare \& Co. In 1861 the Company was dropped from the firm. In 1866 it became Thomas Hare \& Brother. Upon the death of his brother in January, 1878, Mr. Thomas Hare assumed the entire control of the business, which he continues to conduct with most encon raging results and business ability. He carries a stock of from $\$ 40,000$ to $\$ 50,000$ and his annual sales will reach about $\$ 125,000$. His place of business is at 135 Wood Street, above Fifth $A$ renue, where he occupies four floors and basement of an ample building and employs eight inside clerks and keeps two traveling salesmen, with trade principally through Ohio and Western Pennsylvania. He carries large and diversified lines of Saddler's Hardware, both foreign and domestic, and Carriage Trimmings of all desirable kinds. His thorough acquaintance with the business and superior facilities enable him to offer the closest figures to the trade and to compete with any house in this city, or with Cleveland or Philadelphia. Mr. Hare has been a resident of Pittsburgh since 1847, and is consequently closely identified with its business interests and prosperity.

\section{G. B. BARRETT \& CO.-Wholesale Jewelers, \&c., No. 77 Fifth Avenue.}

Pittshurgh combines more geographical advantages of position than any inland city of the United States. Within a radius of four hundred miles from the Iron City some of the following States entire and portions of otlers may be reached: Penusylvania, New York, Massachusetts, Vermont, Connecticut, Rhode Island, Delaware, New Jersey, Maryland, Virginia, West Virginia, Ohio, North Carolina, South Carolina, Tennessee, Kentucky, Indiana, Illinois, Michigan and Canada West. With such a vast scope for the sale of her manufactures and merchandise, is it any wonder that she stands to-day celebrated for the magnitude and extent of her trade and for the enterprise of her merchants and business men? In every branch of trade required in the United States, Pittsburgh can boast of representative business houses which compare farorably with any in the Eastern cities. In the line of Fine Watehes, Diamonds and Jewelry, the House of G. B. Barrett \& Co., of No. 77 Fifth Arenue, takes rank among the leading and most reliable in the land. The firm was established in 1871 by the present proprietors, Mr. G. B. Barrett and Mr. Wallace Patrick. They occupy two floors, $25 \times 82$, emploving nine clerks and assistants and transacting a vearly business of from $\$ 100,000$ to $\$ 200,000$, which is principally in Pennsylvania, Ohio, Maryland, Virginia, West Virginia and territory adjacent. They carry a stock of $\$ 50,000$ to $\$ 60,000$, are extensive importers of Diamonds, Watches, Jewelry, Clocks, Watch-makers' Materials, etc. Mr. Barrett is a native of Eastern Obio, where he was born in 1834 . He has been a resident of Pittsburgh since 1869. Mr. Patrick was born in Ireland in 1829, but has for many years lived and done business in Pittsburgh. This is the largest wholesale jobbing house in Pittsburgh in the jewelry line.

JOHN J. McCORMICK,-European Steamship Agent, Smithfield St. \& Fourth Av.

The leading agent in Pittsburgh for the various European Steamship Lines, and also holds first, fifth and tenth position amongt the leading agents of the U. S. For the National Iine, first in the United States, Inman fifth, Cunard, ninth, is Mr. John J. McCormick, whose office is located at the corner of Smithfield Street and Fourth Arenue. Mr. McCormick was born in the city of Brooklyn, N. Y., in 1834, and came to Pittsburgh in 1865 . In the year 1868 he opened an office as General Steamship Agent, and the business under his management has grown to be one of considerable importance. Mr. McCormick directly represents the following well-known lines, viz: Cunard, Inman, White Star, National, American, Guion, Anchor, State, Red Star, etc., and Steamers to San Francisco, Australia, Bermuda, Nassau, Savannah, Florida, etc. He also procures drafts for £1 and upwards on the leading and most responsible banks of Dublin, Belfast, London, Glasgow and at Companies' offices in London, Liverpool, Queenstown, Belfast, Derry and Glasgow, and attends to the obtaining of Passports and otlier Notarial business. His business, besides being largely of a local character, extends through the States of Pennsylvania, Ohio, Kansas, Nebraska, Colorado, and many of the Western States. 


\section{WI. P. BENNETT,-Blank Books, Binding, etc., No. 94 Fifth Avenue.}

For excellence of workmanship, quality of material, beauty of design and durability, the specimens of Blank Books turned out from the Bindery of Mrr. Wm. P. Bennett will compare favorably with those of an y other establishment in the country. The business was founded in 1859 by $\mathrm{J}$. R. Welden and in 1875 it passed into the hands of Mr. Bennett, who is a thorough, practical workman and master of his trade. Mr. Bennett is a native and life-long resident of Allegheny City, where be was born in 1851. He carries a stock of about $\$ 1,200$ and transacts a yearly business of from $\$ 16,000$ to $\$ 20,000$ in the manufacture of Blank Books and all kinds of work pertaining to a General Book Bindery. He occupies two thoors, $22 \times 65$, at No. 94 Fifth A venue, giving employment to fifteen hands, with a weekly pay-roll amounting to about $\$ 150.00$. His trade, which is confined principally to the two cities and adjacent country, is of the best class and is steadily increasing. Mir. Bennett's specialties are Blank Book Work and Sunday-School Supplies.

\section{F. SHANLEY, -Boots and Shoes, 46 Smithfield Street.}

The business now conducted br Mr. Shanley at No. 46 Smithfield Street, between Third and Fourth Arenues was established in 1865 by Mr. T. II eCartan. In 1870, Mr. Shanley was admitted as a partner under the firm name of IcCartan \& Shanley. In 1874, the style of firm was again changed to Shanley \& Kelley, and in 1877 Mr. Shanley became sole proprietor. Under all these changes of administration the popularity of the goods manufactured by this House has remained unchanged and the trade has steadily increased until it has become as extensive as that of any similar estabiishment in the city. Mr. Shanley occupies the entire three-story building, 20x65 feet, at the number mentioned, with a stock valued at from $\$ 12,000$ to $\$ 16,000$. His yearly business exceeds $\$ 30,000$ and extends all over the country, Mr. Shanley having customers even in California and Texas. He employs twelve first-elass workmen, whose pay amounts to about $\$ 125.00$ per week. The manufacture of fine Boots and Shoes for Ladies and Gentlemen, is a specialty of this House and Mr. Shanley numbers among his regular customers a large number of the first families of the Smoky City as well as of adjoining States. Mr. Shanley was born in Ireland in 1843 and came to the United States in 1866, locating in Pittsburgh, where he has since resided.

WALTER ANDERSON,-Merchant Tailor,Cor.Wood \& 6th Av.\& 226 Liberty St.

There is no longer a question as to the propriety of the employment of a competent Merchant Tailor, with those who appreciate properly fitting garments. Clothes made for nohody in particular, never fit an ybody in particular. One of the most popular establishments of this kind in this city is that of MIr. Walter Anderson, whose place of business is situated as above. The business was started in March, 1875, and has met with marked success ever since its commencement. Mr. Anderson was born in Scotland in 1834, and came to this country in 1865 . He will be found a pleasant and reliable gentleman to transact business with, and as he employs only first class experienced cutters and workhands, you are assured perfect fitting and well made garments. This, he is at all times prepared to guarantee. His stock of price goods embraces Fine Cloths, English and French Cassimeres and all the most popular styles for coats, pants, vests or suits. He carries a stock of about $\$ 6,000$, which is constantly being replenished from the most reliable manufacturers and importers in the country, and the annual sales are about $\$ 25,000$. A bout twenty liands are employed in the manufacturing department, and his facilities for desirable goods, neat fits and lowest prices are unsurpassed by an $y$ establishment of the kind, East or West.

\section{ROBERT LEA,-Engine Builder and Machinist, Cor. First Avenue and Ferry Street.}

Peculiarly noted for its numerous mcchanical industries, and especially those pertaining to the manufacture of machincry and the conversion of iron in all its forms, the establishment of Mr. Robert Lea becomes a natural subject of eomment in a publication deroted to a thorough display of the resources of Pittsburgh and its gradual development.

Apprenticed as a boy in 1833, at seventeen years of age, to the firm of Stockhouse \& Tomlinson, the pioneer niachinists of this city, Mr. Lea became, upon the acquirement of his trade, a member of the tirm of Warden, Nicholson \& Co. (Mr. Lea and Mr. Mrarleite forming the "Co""), which firm, in 1844, built the entire machinery for" the J. MI. IV hite, the famous swift Mississippi steamboat, whose time still remains on record as never having heen beaten, Mr. Lea making the patterns for all the machinery.) subsequently Warden \& Lea, succeeded by Robert Lea in 1854, and continuing without change from that period. With a grandfather who was a soldier in the French and Indian War of 1758 under General Forbes, and residing in the homestead where his father and himself were reared, Mr. Leal may indeed be regarded as having a more than ordinary interest in the welfare of this community, and vitally interested through his present enterprises as well as the traditions of the past, with everything that pertains to or bears upon the prosperity of the Iron City.

Though commencing business in a very small way and with but limited means, a steady increase has taken place, which puts this house upon a par with any in the city. Occupying premises that cover $60 x 104$ feet, the works are divided in to four departments, viz:-Pattern Shop, Machine Shop, Foundry and Blacksmith Shop, the machinery of which is of the most superior kind and is operated by a twenty-horse power engine. Here Marine and stationary Steam Engines are constructed of various designs and every desired capacity, Putterns made, and Castings of all descriptions in iron made to order. From thirty to thirty-five men are engaged, nearly all of whom are skilled artizans.

To the matter of Steamboat Machinery, Engines and Blacksmithing special attention is given, and the work turned out by this establishment has achieved a reputation that has extended the trade of the House to many of the adjacent and Western States. During the prolonged business career of Mr. Lea he has been not unfrequently identified with numerous civic and social reforms and connected with many of the staunehest institutions in Pitishurgh, such as Banks, Insurance Companies and other corporations. Always excrting an influence for good, he is weil entitled to the high esteem with which he is universally regarded, the rich results of a life of laborious integrity.

\section{J. P. DIEHL \& SON,-Wall Paper, No. 175 Liberty Street.}

This house, though having been established as late as 1877 , has already taken a prominence in the Wall Papcr trade that places it among those that stand at the head of business in this community and entitles it to mention in ia work of this kind. Started by J. P. and H. J. P. Diehl, father and son, under the above style, these gentlemen brought an extented experience to the work, the senior partner having been conneeted with the husiness for 20 years in this city, the junior half that time. With an ample capital for reasonable requirements the firm secured the premises at No. 175 Liberty Street, consisting of one threc-story brick building, with baseuent, the whole of whicli is vecupied by the house for a storage and arrangement of one of the most complete and elegant assortments of the Wall Paper and Costly Hangings to be found in this eity. From the cheapest paper at 8 cents per roll to that at $\$ 15$ this house can supply ail grades, together with every variety of decoration and-ornament, suitable for modern and antique styles of furnishing. Five or six hands are employed in the business, which extends not only to the city and environs, but over a large purt of Western Pennsylvani: and adjaeent States. Carrying a stock valued at over $\$ 10,000$, the firm afford the most admirable facilities for a selection in all grades, styles and prices, and have established a reputation for integrity ancl general reliability that tends to make all dealings with them of the most satisfactory character. 


\section{S. BOYD \& CO.--Looking Glasses, Pictures and Frames, No. 100 Wood Street.}

The headquarters in Pittsburgh for Looking Glasses, Frames, Fine Pictures, Elegant Eugravings and Works of Art, is at thc establishment of S. Boyd \& Co., No. 100 Wood Street. This House was founded in 1865 by Boyd, Murray \& Fawcett, who were succeeder by Boyd \& Murray, and in 1874 the firm becaue S. Boyd \& Co. Their large and spacions salesrooms at the number nained are $23 \times 85$ feet, and they occupy the entire four stories and basement, carrying a stock ranging in value from $\$ 16,000$ to $\$ 19,000$ and employing here ten assistants. Their stock comprises a large line of elegant Plate Glass Mirrors, Fine Engravings, Chromos, Lithographs, Photograplis, Stutuettes and articles of virtu. Their factory is located at the corner of Ferry Street and First Avenue, occupying one floor $40 \times 80$ and employing ten workmcn. They manufacture the finest description of Mirror Frames and also those of a cheaper and more common grade, employing a different set of hands on each kind. They also manufacture every description of Cheap Frames, and have pushed their business in this department to such an extent that their trade reaches every portion of the country. They sell largely to the trade in Louisville, Cincinuati, St. Louis, Chicago and other Western cities, and their trade in the Last is even larger than in the Western States. The inanufacture of Cheap Frames and Fine Walnut Mirror Frames is a specialty of this flouse. At their salesrooms the Fine Art Department is the most noticeable specialty and the display of Fine Engravings cannot be excelled. Mr. S. Boyd was born in Washington County, Pennsylvania, in 1821 , and came to Pittsburgh in 1845. Mr. D. S. Boyd is also a native of Washington County, and Mr. J. B. Nevin, the junior member of the firm, was born in Beaver county of this State. This is oue of the most reliable and straightforward firms in our city, well deserving the very large patronage which they enjoy.

\section{A. J. STEELE,-Wagon Maker, 58 and 60 Anderson Street.}

Mr. Steele commenced the business in which he is now engaged in 1862, with a capital of only $\$ 125$. This he has increased until he now constantly keeps on hand a stock of $\$ 1500$ to $\$ 2,000$ and does an annual business of from $\$ 6,000$ to $\$ 10,000$. Ife occupies a building $41 \times 80$ feet and three stories high, with good yard attached, and employs seven men in the several departments, with a pay-roll of \$52 per week. Every description of Wagons, Carts, Drays and Spring Wagons, Wheel Barrows, Trucks, Skids, etc., are here manufactured in the best and most durable manner, and, at the same time, particular attention is paid to Repairing and Job Blacksmithing. His trade is local.

Mr. Stecle was born in Jefferson County, Pennsylvania, A pril 7, 1835, and came to this city nine years later. He began business on Washington Street, Pittsburgh, in May, 1862. He is widely known and esteemed.

\section{WHITE, ORR \& CO.-Dry Goods, No. 35 Fifth Avenue.}

One of the oldest Retail Dry Goods Houses in the West was established in 1828 by Geo. R. White, Esq., now deceased, and'continued at the prescnt time under the above title by Messrs. James Wh hite and R. Leslie Orr, the latter being the eldest son of Mr. Robert Orr, also deceased, formerly the active partner in the House and well-known as being a man of great ability, possessed in a remarkable degree with the highest sense of personal and eommercial honor.

No House in the same line of business stands higher than Messrs. White, Orr \& Co., for the character of its trade and the uniformly exccllent quality of the goods in which they deal-especially in Linens, Dress Goods, Hosiery, White Goods, Silks, Cloaks and Sliawls, Curtains and Domestic Fabrics, etc. The premises occupied by the firns are perhaps the inost spacious and clegant in the city - centrally and prominently located, every convenience and facility is afforded buyers, who by the extent of the annual trade freely attest the esteem in which this House is held.

\section{GEO. A. KELIY \& CO. -Wholesale Druggists, Cor. Wood St. \& First Ave.}

As an important factor in the growth and general progress of this city, the Drug trade has played no insignificant part, as might be illustrated by the detailed history of the above house, which was established during the infancy of our commerce, half a century ago, by B. A. Fahnestock \& Co., who were succeeded in 1872 by the above firm, composed at present of Geo. A. Kelly, Capt. Jehu P. Smith, (Estate of) and Van R. Smith.

The business premises occupied by the house are located on the corner of First A vente and Wood St., and consist of a large four-story double brick edifice, admirably situated and adapted for the trade. The departments are numerous and embrace Paints, Oils, Varnishes, Dyc-Staffs, American and Foreign Chemicals, with a large and complete assortment of Drugs and Druggists' Sundries, Perfumery, \&c., \&c., aggregating a stock of the average value of $\$ 100,000$ with a businesss that requires the employment of 19 hands, and a weekly disbursement for salaries of over $\$ 300$. Mr. Geo. A. Kelly is a native of this city, where he was born in $1832 ;$ at a very early age his education was commenced in the Drug business, which he acquired thoroughly in all its branches, and witl which he has been intimately identified all his life. Upon succeeding tlie firm of B. A. Fahnestock \& Co., he became associated in business with Capt. Jehu P. Smith, who dying several years subsequently, his son Van $R$. Smith, who had been engaged in the house since 1872, was admitted to an interest in 1876. Prominent in every public movement that seemed to promise a greater degree of prosperity and commercial importance for the Iron City, Mr. Kelly has achieved a reputation for business vigor and intellectual aptitude, that has given great weight to every undertaking in which he has been concerned. As a firm Geo. A. Kelly \& Co. stand, in its resources, magnitude of its transactions and high busiuess qualities, at the head of the trade in this city, justly esteemed for those attributes, Jiberality, integrity and thrift, which invariably conduce to solid and lasting success.

\section{B. TIEGEL,-Merchant Tailor, No. 53 Smithfield Street.}

For niore than a decade, the name and fauve of Mr. B. Tiegel, as a Fashionable and Reliable Merchant Tailor, has been familiar to the citizens of Pittsburgh and IVesteru Pennsylvania, where he has a large and profitable business acquaintance. And not alone throughout this immediate section has his reputation extended, for his customers may be found in nearly every Western State and Territory. From the mines of Colorado, the growing cities of the far II'est, even unto the sunny slopes of the Pacific Oceau are orders received for garments of MIr. Tiegel's unanufacture. Strict attention to business, uudeviating honesty, and the artistic excellence of his fits, are undoubtedly the secrets of his success in business.

Mr. Tiegel is a native of Breslau, Province of Silesia, Prussia, and was born in the year 1845. At the age of nine years he came to the United States, and in 1865 he remuved to Pittsburgh, where he his since resided. In 1868 he commenced business for himself, on a comparatively moderate scale, and to-day his Establishment will compare favorably with any similar one in the United States. He employs regularly from six to fourteen experienced workmen, his weekly pay roll at times amounting to nearly two hundred dollars. Carrying a carefully selected stock of the best inaterials of from $\$ 4,000$ to $\$ 5,000$ in villue, his annual trade amounts to nearly tweity thousand dollars. He accupies the entire building (four stories), 20x:30 feet in dimensions, at No. 53 Smithfield Street, besides having a considerable portion of bis manufacturing done by oulside parties. 


\section{CAMPBELL, WILLIAMSON \& DICK,-Dry Goods, 83 \& 85 Fifth Ave.}

This is the leading house in Pittshurgh doing an exclusively cash business in the Dry Goods line. It was established in 1871 by the present proprietors under the title of the "People's Store," a name which has since become widely known and deservedly popular tbroughout the two cities and the adjoining territory. The niembers of the tirm are: Mr. William Camplell, who was born in Perthshire, Scotland, and came to the United States in 1S65 aud Jocated in Pittshurgh in 1571; Mr. Andrew Williamson, a native of Frfeshire, Scotland, born in 1838, a resident. of the United States since 1865, and of Pittsburgh since 1871; Mr. Peter Dick was born at Paisley, Scotland, and came to America at the age of eighteen, aud Jocated in Pittshrgh eight years ago. They occupy two floors of the spacious "Masonic Hall Building," Nos. S3 and S5 Fifth Avenue, 50x110 teet, and carry on a General Wholesale and Retail Business in Dry 作 employ from twenty-five to thirty clerks and assistants, and in the Winter season manufacture large quantities of Ladies' Cloaks and Suits. In the Summer they unanfacture Ladies' Dresses in great varicty. Their regular trade is principally derived from the two cities and the towns of Pennsylvania and Obio within a radius of tro hundred miles, with considerable transient business from all parts of the Union.

\section{E. P. ROBERTS \& SONS,-Jevelers, No. 16 Fifth Avenue.}

One of the best known and oldest establishments of its kind in Pittsburgh is that of Messrs. E. P. Roberis \& Sons. Established thirty years ago by J. M. Roberts, Esq, whose demise in 1866 occasioned a change to the present firm. Nio house in this community has enjoyed a more deserved popularity. The individual-members of the firm are E. P., $S$. F. and $C$. $W$. Roberts, all of whom give their personal attention to the business, which embraces a manufacturing department where erery class of work is elegantly and artistically made to order The stuck, valued at $\$ 30,000$, is not so remarkable for its extent. as the exquisite taste and judgment evinced in its selection. In the matter of Silver and Silver Plated Ware, Diamonds, Jewels, Ornaments, and especially fine Clocks and American Watches, this house can perhaps offer facilities to buyers, in the way of selection and price, not to be duplicated west of New Yurk. Fire assistants are constantly employed, and the trade, amounting to $\$ 10,000$ annually, extends througb Pennsylyania aud adjacent States. Messis. E P. Roberts \& Sons are all natives of Pittsburgh, and bave done no small service in promoting the mercantile credit and thrift of the Iron City.

\section{W M. Mc. C. DRA VO,--0ils, No. 99 Water Street.}

The subject of this brief sketch was born in the City of Pittsburgh in 1834, and has, in a weasure, grown up with the business of the city, and been for a number of years connected with the leading branches of the city's industries; having formerly been connected with the coal trade, and since $1876 \mathrm{in}$ his present business of IVholesale and Retail Dealer in Lubricating and Signal-Light Oils. These are manufactured for the special trade of this house and are always perfectly pure and reliable, and of sucb a quality as to have built up for the house of W. Me. C. Dravo an influential reputation with the river trade which forms the chief patronage of this house. To dealers throughout the city, and the entire country, as well as to those ellgaged in the river traffic, the Editor respectfully calls attention to the full line and choice Oils of this house, as I. X. I. Engine Oil, Head-Light Oil, Carbon Oil, Natural Lubricating Oil, Pit Car Oil, \&c., as well as to his department of Engineers' Supplies in Machinery Grease, Belt Stuffing, and ivhite and Red Lead, Colors and Varnishes, Lamp Globes aud Wicks, etc., all of which they will find at the lowest market prices.

\section{YEAGER \& CO.-Wholesale Dry Goods, \&c., No. 110 Market Street.}

Established forty years since, by Christian Yeager, the senior partner of the present firm, this house is perhaps as intimately connected and identified with the development and prosperity of Pittsburgh as any commercial enterprise in the city. A native of Lancaster, Pa., Mr. Yeager settled in this cominunity in 1835 , and in 1839 began his present business, in a small way, with but a very linited capital in cash, but generally endowed with business ability of a bigh order, energy, economy and iutegrity, and with these as his main dependencies be founded the present bouse. In a history extending over nearly half a century, no house can exhibit a more untarnished career, with the rapid growth of the city, its trade prospered, and for over thirty years it has been a direct importer of every elass and grade of Fancy Goods, Toys, Notions and Fabrics, its sales having reached as high as $\$ 360,000$ per annum. As an enterprising, but remarkably conservative man, Mr. Yenger bas alwaws been the custodjan of numerous public and private trusts, and is at the present time President of the Penusylvania Insurance Co., a Vice-President of the Dollar Savings Bank, Director of Mlechanics' National Bank, member of sereral Benerolent Societies, and more or less interested in the Reformatory Institutions of the State.

Dealing largely in Dry Goods, lincy Goods and Hosiery, this house pursues the poliey of having no traveling salesman, i plan which if generally adopted would aldd greatly to the profit of producer, dealer and consumer. For this and other reasons, the results of a long and varied experience, the firm is prepared to ofler advantages to the trade hardly to be duplicated in this country, and a stock of goods that for extent and variety would be impossible to match in the State.

H. C. Yeager is the company of the house, and has under his special charge the books and clerical department. The premises of the firm are ample and consist of the five story brick building No. 110 Market Street, 21x 80 feet, and stocked with goods from basement to roof. Nine assistants are employed here to aid in the conduct of the business which ranges over Pennsylvania, Ohio and West Virginia. In the consideration of the community no bouse takes a higher rank, or is more deserving of the success which it has achieved, or the spotless reputation it bears.

\section{E. J. W ARING \& CO.-Star Oil Works, Office, No. 49 Fifth Avenue.}

Refinery, Bennett's Strition, W. P. R. R.

Eleren years ago this business was established by Mfessrs. Lafferty \& Waring. Sulsequent'y, in 1868, Mr. Lafferty died and was succeeded by J. H. Ralston, Esq.. and the firm became Ralston \& Waring. till his death in 1872, when the above title was assunied. When the firm first began business, they did so with a Jimited capital, which, howerer, was enlarged from time to time until the capacity of the works now reaches 26,000 barrels crude oil, monthly. Conveniently located, on the Allegheny River near Bennett's Station, W. P. R.R., the works consist of five buildings, with numerous tanks, stills, etc., which occupy five acres of ground, and afford every facility for the business. The average trade of the concern is sbout $\$ 300,000$ per annum, and the monthly pay roll, when in full operation, will amount to froun $\$ 1,600$ to $\$ 1,800$, and a force of fort $y$-five hauds employed. - Mr. Waring is a native of Saratoga Co., New York, and is now thirty-one years old. He came to Pittsburgh in 1865 and has since been intimately identified with the oil trade. Possessed of no ordinary business ability, as well as a high sense of personal rectitude, lis great success is regarded as being as natural as it is well deserved, and entitles him fairly to occupy the elevatcd position he has achieved in commercial and social circles. 
KORNBLUM,-Optician, No. 25 Fifth Ave.

Though having been a resident of Pittsburgh for only three years, Mr. Kornblum has already established a reputation of being the best optician and most eapable dealcr in philosophic intruments of any man in this city. A natire of Austria, he acquired his profession under the best scientific masters of his vocation in Vienna and Europe, and since his residence in America for 16 years has devoted himself entirely to the attainment of perfection, in his chosen profession, with the most signal success. His wide experience as an optician has been followed by a reputation that places him in correspondence with the most distinguished men from all sections of the country, who desire to avail
themselves of his marked proficiency. Upon every point relating to the eye and its diseases and defects, he is thoroughly posted, and by a merely superficial observation gauges the strength of the organ in any case and selects lenses of the appropriate power. At his present locution, to wlich he has just removed, will be found a complete and carefully selected stock of Spectacles, and every varicty of rare scientific and philosophic instruments, the work of the best makers in this country and in Europe. Those at a distance may be assured that any orders by mail or enquiries, will receive prompt and intelligent responses, and further that any business placed in the hands of Mr. Kornblum, will result in the most satisfactory manner and a continued appreciation of his unquestioned abilities.

\section{W. C. CARROLL \& CO.-Fort Pitt Boiler, Bridge and Tank Works.}

\section{Comer Third Ave, and Liberty St, and Second Ave. and Short st.}

The history of this house has been so intimately connected with the development of the trade of Pittsburgh, that no record of the industries of this community would be complete that did not take cognizance of the firm of D. W. C. Carroll \& Co. and its predecessors. Established in 18+3, the business was founded by M. Stackhouse, Esq., succeeded by H. Busha \& Co., who preceded C. Gutendorf \& Co., who gave place to Caroll and snyder, who were succeeded by the present proprietors, D. W. C. Carroll and R. G. Jones, under the caption title, in 1872; the business premises and works of the firm occupy an entire square fronting on four streets, short and Liberty Streets, and Second and Third Avenues, consisting of a substantial brick building, ranging from one to three stories in hight, well supplied with the most approved machinery, consisting in part of one 45 horse power engine with two boilers of 40 and 15 horse power respectively, 10 foot plate rolls, 2 pairs power shears for cutting the heaviest iron plate, 9 power punches for boiler plates, one plate planing machine, 8 vertical drills and many other pieces of ingenious mechanism and tools proper to the trade, making in all the best equipped works in the city, or west of the Allegheny Mountains. The extent to which the business of this concern has reached is not limited to the United States, but embraces Mexico, much of South America and Canada, finding customers in fact in nearly all parts of the world.

In the manuiacture of Steam Boiler and Heavy Plate, Iron Bridges, Buildings, Oil Tanks, Gas Holders, and Sheet Iron Work generally, this House has few rivals and no superiors. The first Oil Refining appliances, Tanks, Stills, etc., ever manufactured in this city, were constructed by this establishment, which still maintains a celebrity uneqnalled for this class of work. The iron dredge boat "G. W. R. Bailey," used by Capt. J. B. Eads in his excavation of the Mississippi Jetties, was built by this firm, who have, perhaps, made more steamboat outfits in their line than any other concern in the business. For some years the manufacture of boilers for agricultural machinery has engaged the attention of the House as a specialty, their admirable facilities insuring work of a high order of excellence in this department, which is rapidly assuming greater importance.

The firm employ seventy-6 ve men in the business and do a trade that approximates a quarter of a million dollars annually. Mr. C. H. Parker, the manager, is a gentlemau of wide experience, a native of Providence, R. I., and formerly engineer of the National Bridge Works, of Boston, Mass. The members of the firm are both natives of Pittsburgh and have al ways resided here, intimately involved in the iron trade, and, as a firm, it is not too much to say that in every respect it stands at the highest point in the estimation of its cotemporaries and the commercial world at large.

\section{HEAD \& McELROT,-Produce Commission Merchants, No. 249 Liberty Street.}

Dealers in Butter, Eggs, Cheese, Flour, Grain, Seeds, Fruit, Vegetables \&c.

This house refers by permission to the Hon. Robt. Sidell, Mayor of Pittsburgh, Messrs. Arbuckles \& Co., wholesale Grocers, Geo. S. Head, Esq., President of Second National Bank, Pittsburgh. Head \& McElroy began business in thcir present location, April, 1876, succeeding the old and well-known Wholesale Grocery House of Head \& Metzgar. They occupy the fine four-story, iron-front warehouse No. 249 Liberty Street, the location being the choicest for this style of business in the city, the largest and most complete warehouse used in the produce commission business
in Pittsburgh, having a deptll of 120 feet, four lofty stories, a splendid cool cellar, steam engine, two elevators, one of which is operated by steam, two offices with speaking tubes and telephone, and all the modern appliances for the careful and prompt despatch of business. With these facilities and a full force of efficient hands, all business is transacted promptly, accurately and intelligently, and upon sound bnsiness principles. Head \& MreElroy, during the three years in which they have been in business, have built up a trade that will not snffer by comparison with the oldest established louse in the trade in Pittsburgh. The plan pursued by this Honse has been to sell without delay all consignments and to make prompt returns therefor, which, judging from their success, seems to commend itself to the favor of shippers as the correct method of doing business. They also make liberal ad vances upon non-perishable goods, where it is desired. Any one having business in this line can feel assured that it could not be entrusted to safer hancls.

\section{J. B. IR AERCHER,-Hardware and Cutlery, 73 Market Street.}

The IIardware House of J. B. Kaercher was established at the ahove locntion in 1877 , and from a comparatively moderate beginning has, within the past two years, met with eucouraging success, and he now transacts a business of about $\$ 12,000$ per annum. Mr. Kaercher occupies three floors of the huilding at No. 73 Market Street, 13x60, and carries a general line of Hardware and Cutlery, embracing all the leading and staple articles known to the trade. His business is principally local. Mr. Kaercher is a native of Pittsburgh, having beell born in 1859, and has had six years experience in the business.

\section{BROWN, MURPHY \& FERTIG.-Sewer-Pipe,Cement, etc.,}

\section{No. 65 and 67 Sandusky Sireet, Allegheny.}

The firm of Brown, Murphy \& Fertig was established January 1, 1878, as successors to Mr. Charles Brown. Their office and yard are located at Nos. 65 and 67 Sandusky Street, which is the Headquarters in Allegheny for the celebrated Akron Sewer Pipe. They are also wholesale and retail dealers in all the standard brands of Hydraulic Cement, Terra Cotta Chimney-tops, Hot and Cold Air Flue Linings, Chimney Flues and other Terra Cotta Goods, Fire Brick, Grate Tile and Ground Fire Clay, White Sand, Lime, Plaster, ete. The building occupied by them is a three-story structure, $30 \times 100$, with a commodious yard adjoining. They carry an average stock of about $\$ 8,000$ and transact a business in the two eities and surrounding towns which is principally local, amounting to $\$ 15,000$ per annum. The individual members of the firm are Charles Brown, J. G. Murphy and Frank Fertig. 


\section{MILLER, FORSE \& CO.-Wholesale Liquors, No. 253 Liberty St.}

As a representative House in the line of one of the largest commercial and manufacturing industries of this city, and, at the same time, one of the oldest, the firm of Miller, Forse \& Co. are entitled to more than brief mention in a publication of this deseription. Founded in 18:1, or neirly halt a century ago, by Wm. Miller, Esq., who began business upon al eapital ot $\$ 1,000$, the fortunes of the House have been as intimately connected with the rise and development of the industries of Pittsburgh as any concern in the community. For many years the business was conducted by Mr. Niller alone, and during that period he not only established a reputation for honor and responsibility that ranked him first among the pioneer business men of the eity, but laid the foundations of a great monetary success.

In 1866, by the death of Chas. Ricketson, the style of the House was changed to Wm. MLiller. In 1 S69, howerer, the firm title became Wm. Miller \& Co., remaining as such till 1872, when Mr. Miller, having accumulated a fortune estimated to be not less than $\$ 1,000,000$, dissolved the partnership by his demise and the present firm shortly succeeded, being composed of Morris Miller, Esq., nephew of Wm. Miller, Esq., and Wm. H. Forse, who conduct the business upon the same principles, respecting those traditional rules of the House, upou which its prosperity has hinged so largely.

Having just removed to the four-story, iron-front edifice, $23 \times 125$ feet, at No. 253 Liberty Street, the firm are perhaps better prepared to afford those facilities to the trade for which they have always been notcd-especially in the line of Old Monongahela Rye Whiskies, the celebrated "Cabinet Whiskey," Pure Imported Wines, Brandies, Ales, Cigars, etc. Messrs. Miller, Forse \& Co. ean not be surpassed either in the quality of goods or fair and liberal terms. With a trade extending to almost every State in the Union, and aggregating not less than $\$ 125,000$ per annum, and steadily increasing, this House may be regarded as a favorite anong those retailers who demand a brand upon which to rely with implicit confidence. Such a brand is that of this firm and to the scrupulously preserved purity of their wares may be traced the signal success of their operations.

THEOPHILUS ROLLER, - Wholesale \& Retail M' facturer of Parior Furniture, No. 122 ohio street, Allegheny City.

The goods manufactured at the abore-mentioned establishment have attained a well-merited reputation among the residents of both cities for their beauty of design and elegance of finish. Being almost the only house in the city which makes a specialty of Parlor Furniture, and employing only experienced workmen. Mr. Roller enjors a trade of $\$ 15,000$ to $\$ 18,000$ per year, and carries a stock valued at $\$ 16,000$. The business is divided into three departments, comprising the salesroom at No. 122 Ohio Street, the mauufactory, on Cedar A venue, which is $24 \times 150$ feet, and where twelve men are employed at salaries aggregating $\$ 100$ per week, and the warehouse on A very Street. The proprietor, Theophilus Roller, was born in Germany in October, 1836, and came to this country in March, 1859. In 1873 he began business at his present location, with a eapital of $\$ 2,000$, which he has since increased to $\$ 5,000$. Mr. Roller, being a practical mechanic, has introduced several valuable improvements in his business-among other things he has invented and patented a reversible spring mattress, which is well known among all dealers in furniture, and which has a large sale.

\section{MRS. T. A. ROLLER,-Millinery, Dress \& Cloak Making, 122 Ohio St., Allegheny.}

One of the most extensive Millinery and Dress and Cloak Making establishments in Allegheny City is that of Mrs. T. A. Roller at No. 122 Ohio Street. The building itself is a large one, measuring $18 \times 100$ feet, and contains ample space for the accommodation of the three departments of the business, viz:-Dress Making, Cloak Making and Millinery, which require the services of thirty hands. Besides these, there are three salesladies employed in the store proper, and the pay-roll weekly reaches the sum of $\$ 140$. The proprietress, Mrs. Roller, was born in France, Feb. 22 , 1835 , and came to this city in 1851 , where, in 1861 , she erected the building which she at present occupies. At that time her capital was only $\$ 50$, but by the use of those talents for her business which are peculiar to her countrywomen, and $\mathrm{by}$ the exercise of good taste and judgment in the selection of designs, she has since increased it to $\$ 20,000$, and has built up a trade throughout the two cities and surrounding country which amounts to $\$ 20,000$ anGoods is one of the best in either Pittsburgh or Alleghen y City.

\section{ARTHUR KIRK,-Powder, and Miner's Supplies, No. 19 Seventh Street.}

Mr. Kirk was born in Scotland in 1825, but has been a resident of. Pittsburgh since 1839, and prominently identified with the business interests and material prosperity of this city for many years. Although not a politician, Mr. Kirk is a public-spirited gentleman whose name has frequently been connected with public affairs. He tstablished the business in which he is now engaged, as dealer in Powder, Quarrying and Miner's Supplies, ete., in 1867, but had previously been actively engaged in mercantile pursuits for over twenty years. His trade has steadily increased, as may be seen from the fact that during the first year of business he disposed of only two hundred packages, while up to the commencement of the panic ten thousand packages were disposed of annually. He occupies a large and conveniently arranged office at trade is in the State of Pennsylvania, Ohio and W est Virginia. His past honorable business career is a sufficient
guarantee for a successful future. In the same office with Mr. Kirk is N. G. Ayres, his son-in-law, who is the authorguarantee for a successful future. In the same office with
ized agent for the well-known Austin Powder Company.

\section{JOHN L. DA WES, SONS \& CO.-Druggists' Glassware, No. 81 Third Avenue.}

This honse was established in $186+$ by .John L. Dawes, Sr., being the pioneer of this business west of the Allegbenies. Later, E. L. Dawes and John L. Dawes, Jr., were admitted, and now form the only firm in Pittsburgh eugaged in manufacturing Glass, Labels for Druggists, and making a specialty of supplying that trade with glassware and general sundries. The premises occupied by the firm are situated as above, where eight assistants are employed in the manufacture of "Dawes' Patent Label," which for neatness, durability and economy has no rival in the market, and has created a demand throughout the United States and Canada. Mr. Dawes, Sr., has been a resident of this city for nearly forty rears; he has been identified in many ways with its progress and development. His sons are natives of Pittsburgh; they have a thoroughly detailed knowledge of their business, and are constantly making improvements that tend very greatly to its increase, and ad vantage. The house always carries a large stock of Labels and Glassware, which are sold by sample and manufactured to order, and it is not saying too much to renark, that occupying in a certain sense the position of a monopolist, this fact would never be suspected from the liberal and square manner in which the business is conducted. 


\section{ROSENBAUIM \& CO.-Trimmings, Millinery and Notions, 91 Market Street.}

The largest and best known house in Pittsburgh engaged in this line of bnsiness is that of Rosenbaum \& Co., who have recently removed their quarters to the elegant and spacious sales rooms, No. 91 II:arket Street, where they occnpy three lloors, each $18 \times 90$ feet, completely stocked with a fresh, fashionable and elegant assortment of Millinery Goods Trimmings and Notions. The liouse was foumled eleven years ago by Mr. Rosenbaum and another gentlenan, and since that time the business has steadily and rapidly increased, until the sales now reach the round sum of $\$ 120,000$ per annum. 'They carry a stock of not less than $\$ 41,001$, and are in receipt of all the latest styles and designs in Foreign and Domestic Millinery and Trimmings simultaneously with their appearance in the New York and Philadelphia markets. Their openings are attended by the elite of the two cities and surrounding towns, and this house has come to be justly celebrated by the ladies as the headquarters for fashionable and elegant styles. Mlessrs. Rosenbaum \& Co. employ the services of twenty-five clerks and assistants in their Establishment, with a weekly pay roll amounting to about \$200. Mr. Rosenbaum is a native of Germany, but has resided in this country for about sixteen years.

\section{B. L. H. DABBS,-Artist Photographer, Cor. Market and Liberty Sts.}

Mr. Dabbs commenced business in this eity in 1861 and opened rooms for the sale of Photograplic Materials. He was very successful and had a large trade, cxtending through several States. Becoming interested in the art of Photography and finding he had both inclination, taste and knowledge for it, he opened rooms in Allegheny. Almost at once he took the lead in that branch and has kept that position ever since. His thorough and practical mercantile education has been greatly in his favor, giving lim the business sense of proving by actual demonstration that as good pietnres could be made in Pittsburgh as any where in the world; he has been going on, steadily improving from the very commencement of his business career. In 1863 he removed to this city, as he found that his trade increased faster than the facilities he was possessed of in Allegheny would keep pace with, he therefore fitted up a gallery, studio and reception rooms on Sixth street, such as had never been seen before in this locality, and which were abandoned in 1875, only to take possession of his present premises, and now has without any question as complete facilitics for carrying on his business as can be obtained. The rooms which he now occupies were built according to his own plans and ideas, eonsequently they are just what are needed. His past experience tunght him just what was most desirable, he has one of the finest plate glass skylights in the United States. He always examines carefully into every thing new that is ever intrortuced in Photography, and if he considers it practicable and any improvement on what he has hitherto used, never fails to adopt it. Acting on this principle he bought the right for the making of the new permanent prints by the Carbon process, and through this method he has been most suecessful in obtaining beautiful results in porcelain pictures. There is the most pleasing variety in his pictures, his positions are all characterized by an ease aud grace which very few photographers can obtain. WV consider MIr. Dabbs' greatest success lies in this, he studies the sitter and aims to give to each one such a position as will best suit them, and this he almost seems to know by intuition. He takes a pride and a great pleasure in his work, which materially helps him in the good results which he obtains.

\section{F. SOEVYN, - Merchant Tailor, No. 238 Penn Avenue.}

Mr. Soevyn is a prictical cutter and has had over thirty years experience as a Tailor, thus being enabled to not only understand every detail of the business, lut to give perfect satisfaction to his customers. He lans been established in his present line for about five years, during which time he has secured the patronage and contidence of many af the leading gentlemen of Pittsburgh, in all cases giving the most undoubted satisfaction, and establishing a reputation second to none engaged in the same business. He keeps on hand a carefully selected and fashionable stock of the hest foreign and domestic fabries for gentlemen's wear, from which to select, and his garments are all made up in the most thorough and workman-like manner. His business is exclusively Custom Work, and lis specialty is in the manufueture of fashionable dress and business suits at prices to suit the times.

\section{JOHIN SEIFERTH,-Wines and Liquors, Nos. 27 and 29 Market Street.}

Mr. Seiferth has been engaged in his present line of business in the old First Ward for the past $t$ went $y$-one years, and at his present location for sixteen years. He is a weli known and highly respected business man and a proninent citizen of the smoky City. He now occupies the three story brick warehouse, fronting on Market street $371 / 2$ feet and exteuding back on second a venue so feet, where lie keepls a large and finely selected stock of pure Wines and Iiquors, both Imported and Domestic. He is an extensive rectifier and carries on both a wholesalc and retail busines, amounting to not less than $\$ 25,000$ per annum, employing three hauds, and nraking a specialty of Pure Unadulterated Wines and Liquor's for family use. Mr. Seiferth has in stock some of the oldest and purest Liquors to be found in the city, and his trate, which is both beal and country, is of the very best class. He was born in Germany in 1829, but has for man y years resided iu Pittsburgh and been identified with the mereantile and spiritual welfare, being a prominent and consistent member of the German Lutheran Church.

\section{IASHEL \& WALTER.-Commission Merchants. \&c., 54, 56 \& 58 Ferry St.}

These gentlemen are engaged in the business of general Commission Merchants and dealers in Flour, Grain, Mill Feed, Hay, Produce, de.e, and pay special attention to the buying and selling of Horses. They have good stabling in connection with their cstablishment for the accommodation of patrons. The business was established in 1875 by Mr. Murry Trimble, who was exchsively in the feed lusiness and was succeded in 1879 by the present firm. They carry a stock of orer \$2,000, while their annual business will amount to many thousands of dollars. They oceupy the premises 60x60 foet at the numbers above numet. The members of the firm devote their personal attention to the business and employ one assistant. Their sales are principally made in the city and surrounding tow as, and they receive consignments from almost every section of the country. Mr. $\dot{r}$. A. Lashel was born in Pennsylvania in $1 \dot{s} 45$ and is an experieneed business man of many years standing. Mr. J. T. Walter, the junior member of the firm, takes no active part in the business, but his son, i. J. Walter, fills that position with ability, he having a long experience in the Commission business befure embirking in the enterprise in which he is now engaged.

MeELROY \& CO.-Brooms, Brushes, Paper, Paper stock, \&c., $80 \& 82$ Third Ave

This firm do a business of from $\$ 80,000$ to $\$ 100,000$ cmploying in their manufacturing and assorting departments 3.5 hands, who, with the aid of the best machinery to assist in making "hand-made" Brooms and Brushes, turn out the best work known to the trade. Hugh MeElroy, one of the firm, is senior partner in the Choshocton Paper Co. of Choshocton, Ohio; whose mill manufactures the Paper handled by M[cElroy \& Co. and deal largely in Fags and other Paper stock, etc. The firm is one of the most solid of the city and is at all times reliable. 


\section{PITTSBURGH TAR CHEMICAL WORKS. $-H$. A. Clifford $\&$ Co.,}

No. 170 Rebeca Street, Allegheny City.

Few persons, not familiar with the business, have any conception of the variety of articles manufactured from that, to many, repulsive looking and smelling naterial known as Tar. The Pittsburch Tar Chemical Works is the only manufactory in this city of this description of goods. The Works were establisbed by D. Hostetter, Otto Wnth, and $\mathrm{A}$. Herz, with an original capital of $\$ 10,000$, which they increased to $\$ 25,000$. The present proprietors are $H$. A. Clifford and Emil Schalk, doing business under the firm name and style of $H$. A. Clifford \& Co, and they increased the capital to $\$ 10,000$. The premises occupied by this firm are $145 \times 300$ feet in size, containing five buildings and four slieds. The dimensions of the buildings are respectively as follows: $40 \times 80$ feet, $30 \times 60$ feet, $20 \times 30$ fect, $20 \times 30$ feet and $18 \times 50$ feet. Their laboratory and works are fitted with all the requisite appliances and nachinery for the distillation and manufacture of their various products. The works require one 5-horse power engine and one 8-horse power boiler, and furnish employment to eight hands with a monthly pay roll aggregating about $\$ 425$. They carry a stock of about $\$ 25,000$, and their annual business will reach, if not exceed that amount. Their trade is principally local although they ship goods occasionally to different portions of the United States. The works will compare favorably with similar establishments in St. Louis and Chicago manufacturing the same class of goods. Among the various articles for which they have established a high reputation, we may mention, Roofing Cement, Paving Cement and Composition, Dead Oil, Napthaline, Crude Benzole, Pure White Rectified Benzole, Iron Varnish, Cotton Tie Varnish, Crude and Refined Carbolic Acid, Carbolate Powder, "Universal Disinfectant" and Oil Myrbane, an article used extensively for perfuming Soaps in place of Almond Oil.

Mr. H. $\Lambda$. Clifford is a native of New Hampshire and came to this city in 1874 ; and his son, Mr. Charles W. Clifford, is book-keeper and superintendent of the clerical and corresponding department.

\section{HODGE, GODDARD \& CO.-Wholesale Jewelers, No. 43 Fifth Avenue.}

No history of the Industries of Pittsburgh would be complete without frequent reference to the trade in which the above house is engaged, and in which it has achieved so prominent a position. Established in 1864 by Messrs. Scott \& Hennegen, that firm was shortly succeeded by Scott, Hennegen \& Co., whin were followed by Scott, Barrett \& Co., then J. T. Scott \& Co., and finally by the present firm, composed of Messr's. W. C. Hodge, Geo. E. Goddard and E. W. Hill, making a specialty of American Watches. They represent the Waltham, Springfield, and Elgin Watch Cos., whose superb products are known for their accuracy over the entire world, and are remarkable for the perfection of their construction and matchless time keeping qualities, being regarded as absolutely Hawless in the Jatter respect.-As Importers, Jobbers, and Manufacturers of Jewelry, Clocks, Watches, Silver and Silver Plated Ware, Dinner Sets, Tea Sets, etc., with ever $y$ variety of goods suitable for all occasions, this house offers facilities to the trade that are unsurpassed between Philadelphia and Chicago. As an evidence of this fact may be cited the remarkable growth of a business, which of a most limited character at its inception, has reached the proportions of one of the largest houses in the West. Exclusive of the individual members, each of whom takes an active part in the business, the firm employ four salesmen, two of whom are constantly on the road, one skilled engraver and designer, one watch-maker, two jewelry-jobbers, and several other assistants. Engaged exclusively in Jobbing, the trade of this house extends through Western Pennsylvania, West Virginia, Ohio and Indiana, its products being highly regarded in the trade for beauty and originality of design, special ittention having been directed to perfect all goods in these respects. As a firm, Messrs. Hodge, Goddard \& Co. stand at the head of the Wholesale Jewelry trade in this cily, carrying the largest stoek and doing the most extended business, and are regarded with esteem and consideration by all with whom they come in contact. Their business policy is just and liberal, resulting naturally in the marked success that has attended their operations.

\section{SOMERS, BROTHER \& CO.,}

\section{¿11 LIBERTY STREET,}

\section{Produce Dealers and Shippers,}

\section{and General Commission Merchants.}

There are few kinds of business which have the capacity of a wider range and scope tlian the business in which Messrs. Somers, Bro. \& Co. are engaged. These gentlemen commenced business at No. 177 Libcrty Street, in 1876, witl a comprehensive knowledge of its responsibilities and requirements, and have, by their straightforward lusiness transactions, established a flourishing trade, and, at the same time, won the confidence of all with whom they have had dealings. The gradual increase in their business made it necessary to secure more convenient quarters, and they subsequently removed to No. 202 Liberty Street, and later, again to enlarge their business space and facilities, to their present location, No. 211 Liberty Street. Their transactions embrace a General Produce and Commission business, receiving and disposing of Consignments of Produce, Fruits or Dairy Products, as well as Buyers and Shippers. We know of no house in this city to whon we could more cordially commend country dealers, nor any whose facilities are better for the disposition of any products placed in their hands. They occupy four floors and basement of a capacious building, employ seven persons in the different departments of their business, and their annual transartions will reach at least $\$ 100,000$. They receive consignments from all parts of Ohio, Indiana, Maryland, New York, West Virginia, Kentucky and this-State, with sales principally in this city and vicinity and shipments to Eastern cities. The firm is composed of J. L. \& Charles Somers, men of excellent business qualifications, formerly of Beaver County, this State.

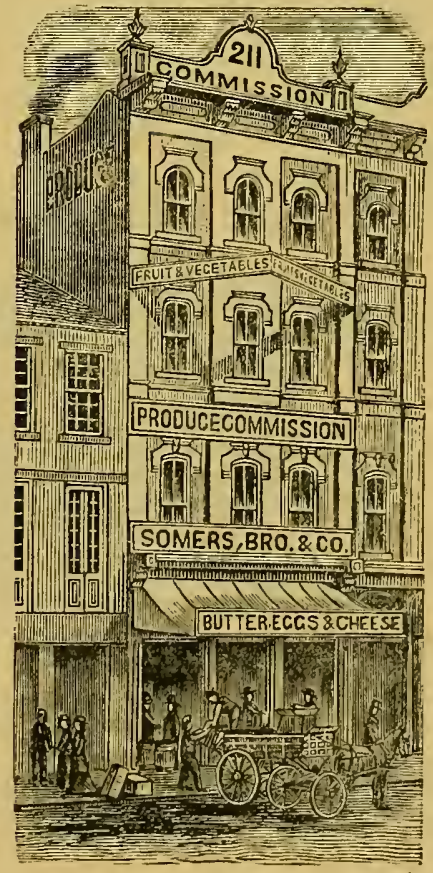




\section{JOHN T. NATCHER,-Carpenter and Builder, Nos. $125 \& 127$ First Avenue.}

Ino. T. Nateher was born in Carlisle, Penusylvania, in 18-17. He commenced the trade, which he has followed in this city with such signal sucess, in his native town in 1 stis. Four yours after he eame to l'ittsburgh, where he has re-

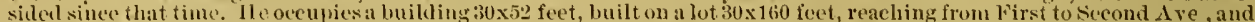
has an annu:l busincss of from $\$ 50,000$ to $\$ 5,000$. He furnishes st eady emrloyment to from 40 to 50 hituds, at an average salary of $\$ 1.75$ per cliem each. Through the eity and vicinity are landmarks of his mechanical ability, some of the tinest sfructures of arehitectural skill are pointed wut as erected by him, viz: "The First l'reshytertin chureh on the

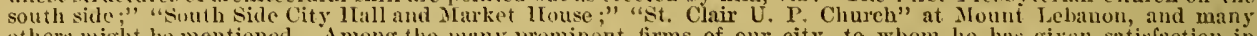
others might be mentioned. Among the many prominent hirms of our city, to whom he has giren satisfaction in buikling and repairing, we mir mention a few as follows: A. Garrison \& Co.. Robison, Rea d. Co., Roht. J. A nderson ¿Co., Wm. Clark \& Co., MeTritosh. Hemphill \& Co. Zug of Co., besides numerous others. His shop is the best resulated one in the city, perfectly equipped and systemized, and filled with none but the liest of meehanies. Thus repiresented and located he is perfectly prepared to give estimates and perform ail jobs on contracts iu the best manner, either by day or contract, making a specialty of mill and foundry work, also giving special attention to erecting steam and hanil crines of all sizes, in which, as with other work executed by him, he has established a reputation equal to the best of his eotemporaries, and well descrved.

I. FUNDIS \& SON.-Clothing \& Furnishing Goods, 57 Frankstown Ave, East End.

One of the leading houses of the East Fnd is that of L. Fundis \& Son, dealers in Ready Male Clothing, Hats, Caps and Gents' Furnishing Goods, situated at No. 57 Frankstown A renue, in the fine brick bloek ow ned ly the firm. The sales room now occupied by the house is $20 \times 60$, and is stocked with a full and complete issortment of articles pertaining to the lines enumerated. This house was founded in 1852 by Mr. L. Fundis with a eapital of \$300, whieh has by careful management and shrew (l business tact increased to nut less than son,006, which is prineipally invested on Real Estate, clear of all eneumbrance. The stock now earried ly the firm is ahout 56,000 , and their annual sales reach $\$ 12,000$, which are principally to residents of the East End and surounding distriets. The members of the firm

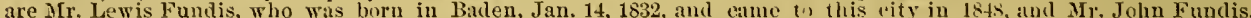
born at East hiberty, Dee, 14, 18.58. They are wide awake, enterprising and entrgetic business men, as the brilliant sucess which has attended their business career will sutheiently indicate.

\section{AYRES \& CO.-Live Stock, Central Stock Yards, East End.}

The present firm was established January 10, 1879, by Mr. D. Arres, Jr., and Arr. H. A. Holdridge, as Commission Dealers in Live Stock. IIr. Arres lias for the past twelve years becul identified with the business at the Central Stock Yards and connected with the firms of II edges, Hufl \& Co., Cochran, Ayres is Co., and Hamilton, Longry \& Co. The oftice of this firm is at the stoek Yards, East End, and they do an exelusively Commission Business in Cattle, Hogs and Sheep. They employ two men at an a verage expense of \$125 per month. Mr. A yes was born at Kalida, Putnam Co., O., in 1841, and came to Pittsburgh in 1867. Mrr. lloldrilge was burn in Knox Co., 0 ., in 1840, and came to this eity in is78. They are wide-awake and energetic young men aud do a thriving business.

M. J. FARRELI,-Plumbing, Gas \& Steam Fitting, No. 236 Penn Ave.

Though apparently dirersified, the various branches of business in which Mr. Farrell is engaged form one complete whole and are interlinked. In addition to the occupation of Locksmith and Bell-hanger he is an experienced Plumber and Gas and Steampipe liitter, manufacturer of Stencilplates and Materials, Steel and Rubber Stamps. Repairer of every description of Small IIachinery, Cutlery and Ifousehold IIechanism, and general dealer in Harlware, Loeks, Jeys, Cutlery, etc., at No. 236 Penn Avenue, between 7 th an 8 th Streets. Mr. Farrell is a native of Ireland, but has been a resident of the United States for many years and for over twenty years engaged in his present line of business in this rity. His premise's are $20 \times 50$ feet in size and he employes three experienced workmen with an excellent local trade.

\section{WOODRUFF SLEEPING AND PARLOR COACH CO.}

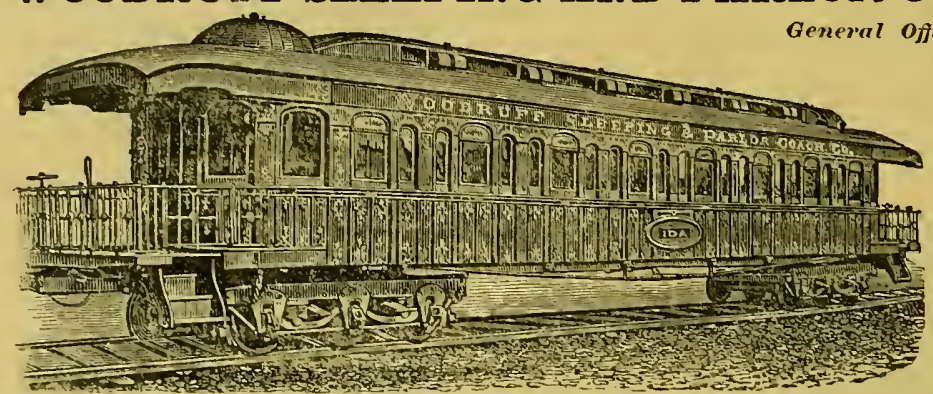
Parlor Coach Compun $y$ is a stoek compiny, incorporated Jamuary, 1872, by special charter, with a paid up eapital of $\$ 500,000$ and charter privilege of $\$ 5,000,000$. The ofticer's are as follows: Frank Rahm, Presilent, James lrwin, Viee President, and Augustus Trump, Secretary. The object of the Compiny is the controlling and running over rarious lines of railroacls sleeping and Parlor Coaches combined that shall, through the perfection of all previous desigus by the late Jonah Woodruft' (the originator of the sleeping and Parlor Coach idea), surpass all others in leduced ribration, improved rentilation, stupression of ricket and friction, increased safety in the aljustment of the eentre of gravity-nearer the floor-jemoval of herths from over the trueks, and other adiantages, special amnng which is doing away with dead weight of at least six tons as compared with other sleeping cars, and being the only ears manufuctured that are built with electric bell at each berth, which enables passengers to at once summon the porter to the respective berth ealling, when anything is desired, being of speeial advantage to ladies with children, besiles a general clegance and sumptuous convenfence hitherto unapproached in any ears previously manufictured or designed. The business of the Company has already become extensive on many of the roads throughout the United States, where not less than eighty of these cars add greatly to the comfort and convenience of the general public, and are the first company to reluce their rates twenty-five per cent. from former prices, but enhince greatly the earuings of the respective roads upon which they are cmployed. 


\section{IAUGHLIN \& DEAN,-ShipChandlers, Boat Stores, Groceries, \&c., 90 Water St.}

In compiling a reeord of the business houses of the City and in making mention of the City's commerce and river trafie, we have a two-fold reason for noticing the lonse of Laughlin $\&$ Dean, first, as a new promincnt business house on the river for their lonefit, and secondly, for the benetit of the readers of this volume Uoing a navigation business, in directing their attention to the fine stock of supplies here to be found in the necessaries appurtenant to the shipping interests of our city, by way of ropes, cordage, oils, calking materials, provisions, zroceries, dee. At the store of this firm, which oceupies three Hoors of a building, $25 x 80$ feet, nay be found not oniy a full line of goods above inentioned, but also a complete stork of choice and staple grocosics, irosh country produec and dairy produets, as butter, cheese, eggs, fruits, vogetables and fowls, this lecing indeed headquarters oin Water street for these every day necessities, whose real merit lies in their purity and freshness, which is alway. here guaranteed. In addition to these lines the firm make specialties of St. Louis flours, the leading of which is the celebrated "Chester" brand bought direet from the mills as per order of this house. B. M. Laughlin and John D. Dean, who eompose the firm, are luoth well known to the trade, and we are safe in conmending to our river readers the fulfilment of their every want at satisfactory prices.

\section{JAMES PHELAN,-Hosiery and Gents' Furnishing Goods, No, 32 Fifth Avenue.}

The "Old Stand Stocking Store" is one of the landmarks on Fiftl avenue. It wasstarterl in 1839 by Michael Daly, uncle of the jresent proprietor. Mr. Pliclan succeeded to the business in 18ij, having been connected with the hous as early as 1850. Three floors are liere oceupied by a stock of goods amounting in value to alout $\$ 20,000$. The husines embraces Hosiery and Furnishing Goods, and the sales require the attention of five persons in the store. Sivecial attention is given to fine imported goods, and the best selections are made frons English, French, Gernan, Irish and Scotch manufactures, among which may be noted the Irish Balbriggan Goods and Scotch Underwear. 'The house has also a high reputation for its manufacture of well-fitting shirts of the best quality of material. For fine goods, large variety, ehoice seleetion of goods and reliability of guarantees, Mr. Phelan's house has a reputation of whjch an y business man might be proud.

\section{LOUIS A. DENISON.-Grocer, Penn and Frankstown Avenues, East End.}

In a bloek of three-story buildings fronting on both Penn and Frankstown Avenues, East End, owned by the Denison brotliers, is loeated the well arranged firceery Store of Louis A. Denison. This house was established in 1833 by Mr. William L. Denison, father of the present proprietor, who cane to Pittslourgh in 1832 from Connectieut. After his death, which occurred in 1873 , the business was eonducted under the firm name and style of W. L. Denison's Sons until Jan. 1, 1879, when Mr. Lonis A. Uenison beeame sole proprietor. The house is now one of the most popular in the East End, and the business will eompare favorably with that of any similar establisliment in the city proper. His store is $20 \times 70$, fronting on both the streets named, and four assistants are constantly employed. MIr. Denison was lorn in Pittsburgli in 1851, and may appropriately be elassed among her most prosperous and enterprising young merelrants.

\section{A R. REINEMAN \& BRO. - Wholesale \& Retail Florists, 25 Fifth Avenue.}

The relightful industry of the florist has increased with the growing wealth and luxury of this eity to such an extent, as to form a very important lactor in the general urosperity and resourees. Among those houses that have secured by their enterprise and energy more than usual prominence in this department, may be mentioned the Messrs. A. R. \& E. C. Reineman, who, under tlue caption title, founded their business more than a year ago, with facilities that placed them at once in the front rank as commercial and botanieal florists. The Garden Houses of the tirm are loeated on Troy Hill, and eonsist of about 10 acres of garden thoroughly stocked with the choieest variety of trees shrubs and plants to be found in this seetion of the country. The Green Ilouse, which is lieated by steam and a 25 horse pow er engine covers an area alone of about an acre and eontains a selection of rare indigenous and tropical flowers and flowering plants. From this source the store at No. 25 Fifth a venue is supplied with daily floral additions to its stock, and eliarming decorations furnished for every soeial or funeral occasion. Ordcrs from abroad are promptly filled, for Flowers eut or otherwise, Plants, Bulbs, Faney Stands, Baskets and Vines of every description. With these facilities and all the added alvantages to be derived from an enlarged r.xperience and thorough familiarity with the work, the Messrs. Reineman are to no small degree deserving of the hearty support and consideration of the community.

\section{JACKSON,-"Star Clothier," 322 Liberty Street.}

One of the unost eomplete and extensive stocks of Ready Marle Clothing and Gentlemen's Furnishing Goods to he found in Pittsburgh, nay lee seen at the well known "STAR" Clothing Emporium of Mr. I. Jackson, whicli is located at No. 322 Liberty street, corner of Oak alley. The store room is $15 \times 60$ feet and is filled with a line of the most desirable and fashionable gords in the market, estimated at not less than $\$ 10,000$ in value. He has a large city trade a well as an extensive and lucrative eustom along the line of the Pennsylvania Riailroad, amounting to $\$ 10,000$ or $\$ 12,000$ annualiy. In addition to the Clothing and Furnishing Croods business, Mr. Jaekson makes a specialty of manıfaeturing fine suits to order, baving a merehant tailoring department in connection with his establislıment in which he emplnes a number of first class workmen. Mr. Jaekson was born in Germany in 1844. Ife came ts the United States in 1860 and to Pittsiurgh in 1874, when the present business was established by him.

\section{W. A. BUNTING,-Stencil Works, $25 \& 27$ Fifth Avenue.}

Mr. Bunting started his business in 1869 at No. 11 Market street, afterwarls removed to 184 Liberty street, and becaure locuted as above in A pril 1878. His business embraees the eutting of Steneils, Stecl Stanips and Purning Brands, the manufacture of Seal Presses, Rubber Stamps, Pibbon Stamps, Dies, Seals, \&e., also Electrot yping and Stereotyping. The office and exhilition rooms are on the 2nd floor, the manufacturing department on the 4 th. Eight inen are employed in cutting, manufacturing, \&e, one on stecl stamps and burning hrands, two on seal presses, one on rubber stanips, one on ribbon stamps, one printer, one clerk and one office boy. New designs in letters and dies are eonstantly heing produeed. A new article is metal-hodjed rubluer tyve for hand presses, suporior to any other. This house is the leading ove in its line in the city, and equal to New York houses in variety and seope of work and in the exeeution of the same. Its trade extends from Karrisburgh, Pa.. to Indiana and further West, through which district he lias numerous agents, and solieits correspondence from those who wish a pleasant and paying lusiness. The proprietor is the inventor of the "Eureka Cigar lox Brand," the most convenient and rapid stamp in the world, and makes a specialty of its manufacture. He was born in Maryland in 18.16, and has been a resirlent of Pittsburgh since 1869. 


\section{KEYSTONE PAPER CO.-Nos. $126 \& 128$ Second Avenue.}

This company was established in $187 S$ by Capt. C. C. Markle and J. K. Cass, for the purpose of handling the produets of the West Newton, Mill Grore and Roaring Spring l'aper Milis, Capt. Markle being a member of the well known house of C. P. Markle \& Sons, proprietors of the two first naned plants, and Mr. Cass of the firm of Morrison, Bire Cass, owners of the Roaring Spring Mills. Engrossing the total product of these extensive concerns, the lieystone Paper $\mathrm{Co}$. finds a market for 600,000 pounds of paper per month, involving annual transactions of over one milliou dollars, at the present unprecedented prices, and ranging over the entire United States; a considerable export trade being done with Cuba and other forcirn points. The larger part of the business of the house lies in the line of News Printing and Book Paper, but includes Hardware, Manillas, Express, Tea, Glass, Rag and Straw Wrapping, Roofing Felt, Lining Felt, and Printed Wrappings, cte., affording buyers all the range and facilities that can he offered by any contemporaneous concern in the country. Some idea of the capacity of the house may be gained from the fact that the West Newton Nills alone corer an area of over two aeres, and employ 160 skilled operatives, to pay whom an anuual outlay is necessary of between $\$ 60,000$ and $\$ 75,059$. Of the four mills under control of the company each manufactures four different kinds of paper, the machinery in all of them being the best that modern ingenuity can devise, or capital and enterprise supply.

Capt. Markle is the resident partner and is personally alert in every department of the business, supervising the operations of the mills at West Newton, and conducting the financial and rarious other transactions at the office and ware roons in Second A renue. A native of W estmoreland Co., Pa., the Captain was horn in 1840; he served through the late Var of the Rebellion with honorable distinetion, and remoring to Pittsburgh in 1867 has since that time been largely identified with the industrial interests of the community, not only in the line of his present vocation, but extensively connected with the manufacture of coke along the line of the B. E O.R.R. The successful operation of numerous direrse enterprises has made Capt. Markle widely known in this city and surroundings, where his extraordinary business capacities hare been universally recognized and appreciated as being of the highest order. His partner in the Keystone Co., Mrr. J. K. Cass, was born at Coshoeton, O., 1844, and is a nephew of Gen. Geo. W. Cass. He removed to this city in 1877 , and shortly thereafter to New York, where he conducts the extensive Fastern business of the company at No. 22 Vesey Street. As a firm with whom to establish permanent relations, the Keystone Paper Co. is perhaps one of the most desirable in the country. Liberal, decisire and honorable, with a product unsurpassed for exeellence in any market, and facilities that defeat all competition, the house is thoroughly commended to the public as entirely meriting the high consideration of which it is the object.

\section{H. W. LAGEMAN \& BRO.-Groceries, Tea, Flour, \&c.,}

\section{Corner Frankstown Avenne and Station Street, East End.}

This firm suceeded Adam Mohler in his business, in March, 1877, and hare since increased their trade, until it now ranks with the most prominent of the East End grocery houses. Their stock, usually to the value of about $\$ 3,500$, is composed of the clioicest artieles to be obtained, and their business, which is about $\$ 25,000$ yearly, requires the attention of three men (two salesmen and a delirery-man) besides the proprietors, the pay roll being $\$ 100$ monthly. Their capital, which was originally $\$ 2,000$, has laigely increased, while their uniform system of fair dealing and conrteous endeavors to please, have extended their trade throughout East Liberty and the surrounding villages of Homewood, Dallas and Wilkinshurg. Their store, a three-story briek building, $20 \times$ in feet, is situated in one of the most prominent locations in the East End, and this, added to the facts hefore mentioned, has seeured them a large and respectable class of trade. Both members of the firm are natives of this eity; Herman W. Lageman having been born December 13, 1854, and H. J. Lageman, August 5, 1S49. They have resided here all their lires, and are therefore too well known to require a more extended notice.

\section{PENNSYLVANIA IEAD CO.-Smelters and Refiners, 0ffice, 44 Wood St.}

Adding in no small degree to the general industrial thrift of this community, the Pennsrlyania naturally demands the attention of a work, the objective point of whose aim is a proper and detailed displa of the resources and advantages of Pittsburgh. Organized in 1S72, under the mining and manufacturing laws of Penusylvania, as the Pittsburgh Smelting and Refining Company, the title was ehanged the following year to the present style, as being more appropriate and descriptive. A close corporation, $j$ ts operations in the smelting and refining of lead for the use of corroders and others, have been a warded the most signal suceess, the busincss having constantly augmented from the inception of the enterprise to the present time, and still rapidly inereasing. The plant of the company is loeated at Mansfield, a short distance west of the eity, upon the line of the P. C. \& St. L. R.R., and some idea of the magnitude of the works may he gained from the fact that sixty men are constantly enplored, and that last year 12,500 tons of lead were brought to a state of chemical purity and freedom from every trace of foreign matter or alloy that would affect or impair the product of the corroder. The prineipal markets for these goods are found in Pittsburgh, Chicago, New York, Philadelphia, and other large cities of the East and West. The officers of the company are Mr. J. E. Schwartz, President, J.B. Arnold, Esq., Secretary, hoth men well known to the community and long identified with the manufacturing interests of this city, and as there are few institutions that have achiered co great a degree of prosperity in so limited a period, so there are perhaps still fewer that oceupy in every respect a higher position, or one subjected to less cavil.

\section{H. KLEBER \& BRO.-Pianos and Organs, No. 122 Wood St.}

For the past quarter of a eentury the firm of $\mathrm{H}$. Kleber \& Bro. has been known in Pittsburgh, as dealers in musical merchandise. It is the oldest house engaged in that line of business, under the original firm name and style, now in the Snoky City. It was established in 18 is by Henry Kleber, who two years after took his brother Augustus into partnership. These are gentlemen of unquestioned business integrity, whose long experience in the business gives them advantages which are enjoyed by few. They oceupy the spacious five story building No. 122 Wood St., $20 \times 80$ feet, and are sole agents in Pittsburgh for the celebrated Steinway and Chickering Pianos, which agency they have held since 1857. They have also been the exclusive agents for the world renowned Burdett Organs for the past twenty years, during which time their sales have far exceeded those of any other instruments of that deseription. They have at present on exhibition about eighty pianos and some sixty organs of various syles, and they also carry one hundred and fifty pianos for rent. The amount of stoek generally kept on hand is valued at about $\$ \$ 0,000$. In addition to the large number of pianos and organs to be found at this establishnent ther keep erery deseription of musical instruments known to the trade, and the largest line of general nusieal merchandise to be found West of New Y ork City. Their trade is distributed through Western Pennsylrania, Eastern Ohio and West Virginia, and the amount of their annual sales exceeds $\$ 150,000$. MIr. H. Kleber and Mr. Augustus Kleber, the two gentlenien composing the firm, were both born in Germany, but came to this country when very young, and have been residents of the United States since 1832 . 


\section{JAMES REES,-Machinery, Duquesne Way and 4th St.}

Among those enterprises that have made Pittsburgh celebrated for its splendid mechanical success, that of $\mathbf{M r}$. James Rees is perhaps entitled to particular mention in a work designed to exlibit in detail the varied resources and capabilities of this city. For more than a quarter of a century this house has engaged in the manufacture of every grade and class of machinery, including Marine and Land Engines, Saw and Sugar Mills, Steam Boilers, Oil Tanks, Salt Pans, \&c. Blast Furnace machinery, Iron und Brass Castiugs, and Pipes, Steam Pumps, de., all of which from the perfection of construction and mechanical excellence have established a reputation that is not confined to the United States. As a builder of Steam Boats, in Wood, Steel, or Iron worker, he has perhaps performed his greatest feats as a uechanician, and achieved the most signal success. The first steel steam boat ever constructed in the United States was built last year by this liouse, under the direction of Jas. Rees' son, Thos. M., who went to Siouth America and superintended its construction, and after its completion made a successful trial trip on the Magdalena River, for trade on the Magdalena IRiver in South America, and it has been a matter of comment and congratulation by the press of the country that this tirst effort, opening up so wide a field for industry and capital, was attended by the most sitisfactory results, weeting more than all the requirements demanded, and accomplishing with ease a sueed of ten miles an hour against a five mile current. The plant of Mr. Rees is located on the Alleglieny River, at the foot of 4th St, and is about as completely equipped as modern improvement and inventive talent can suggest. The buildings cover an area of over lalf an acre and afford ample conveniences for the business. A large force of mechanics are employed here, requiring a large weekly outlay. The annual trade of the concern is very large, and extends through the United States and to other countries. Mr. James Rees, the founder of the establishment in 1854 , and still at its head, is originally from Wales. He came to this country when but a youth, and by the exercise of sterling virtues and great constructive ingenuity, has become a representative, and a self made man of the truest type. As the inventor of a Patent Steam Boat Hull, and the best adjustator cut-off for Steam Engines in use, Mr. Pees is widely known on all the rivers of the West, the latter invention being applied to nearly all the steamboats navigating the Ohio River. The commencement of his career was attended with great difficuitics, small returns, and no capital. Its outcome reflects credit upon the Iron City, and entitles him to the high estimation of all honest promoters of Industry.

\section{A. G. HATRY,-Iron Commission.-COYNE \& HATRY,-Machine Builders. Office: 114 \& 115 Water St.-Worls: Cor. 2sth and Smallman St., Pittsburgh.}

Among those extensively engaged in the salc of Iron, Nails, Stecl, Borax, and particularly Rail Road supplies in manufactured metal, Mr. A. G. Hatry occupies a prominent place, especially in the last named department of his business, from the fact of having nocumpetitors in this city. Besides conducting a commission trade in these products Mr. Hatry carries a very considerable stock, requiring a capital of over $\$ 20,000$, enabling him to transact with greater facility a business that extends over the cntire United States, and a verages between $\$ 500,000$ and $\$ 1,000,000$ annually. These figures seem to establish the fact pretty conclusively that Mr. Hatry either has it in his power to offer the trad unusual advantages, or that his ability for the business is of no common order, the real source of such prosperity being probably found in a happy conjunction of both facilities and abilities. The extent to which the transactions of the house are carried, will appear more striking when it is known that the liusincss was only established in 1874 , thougli Mr. Hatry had been a resident of this city for nine years prior to that date, and previously a citizen of Ohio, from whicl State he entered the Union Army during the late rebellion, and served with distinction for four years, obtaining the rank of Colonel nearly two years before the close of the war.-In 1875 be associated himself with MIr. John Coyne, under the style of COYNE \& HATRY, for the purpose of manufacturing, as sole patentees and in rentors, the Patent Automatic Nail Selectors, and Improved Cut Nail Machines, the former being one of the most useful derices for the rapid automatic rejection of inferior nails ever conceived, and proves an invaluable apparatus in every nai factory where introduced. The plant of the firm is situated at the corner of 28 th and Smallman Sts., and is amply equipped for the manufacture of these specialties, in which a business is transacted annnally of about $\$ 100,000$. - Irr. Coyne is a native of England, and has resided in Pittshurch about 10 years. His personal attention and superintendence is given to the constructire departments of the w.rk, and as an accomplished meclianician he has few equals. In every respect the house is a reliable one and highly conducive in its operations to the industrial prosperity and advancement of the city.

\section{JAMES A. MCNALLY,-Importer and Jobber of Woolens, No. 60 Wood St.}

As one of the only $t$ wo houses engaged exclusively as jobbers of piece goods in this city, the trade and establishment of Mr. James A. MeNally are worthy of more than passing mention in this work. Not alone from the extent and magnitude of his transactions, but the extraordinary ability that has been displayed in securing, from so comparatively small an origin, so sirual a success. A native of the County Doun, Ireland, Mfr. McNally came to this city in 1856 , and ten years liter established his present business, which from its inception to the present time has been constantly enlarging the trade now extending over a large portion of the middle, Western and Pacitic States, a very considerable traffic being done in California, in all amounting to over a quarter of a million annually. The premises of the house are located as above, and consist of one large double brick building, three stories high, $25 \times 90$ feet, on the corner of Wood St. and 4th A venue, stocked with foreign and domestic woolens to the value of from $\$ 65,000$ to $\$ 70,000$, carefully selected and adapted expressly for merchant tailors, with whom the trade of the eoncern is carried on, to transact which 8 assistants are required. Importing direct from European markets, Mr. McNally has estahlished relations that enable lim to compete, in the advantages offered the trade, with any firm in the country, while his dealings with the producers of domestic fabrics are equally satisfactory. Energetic, talented, and reliahle, MIr. MICNally has unade a very conspicuous mark upon the commerce and trade of his adopted eity, with whose interesty be hay been closely in volved for nearly a quarter of a century, and whose prosperity he has materially promoted.

\section{SAMUEL R. LIMEGROVER,-Baker and Confectioner,}

Penn Avenue, opposite Collins St., East End.

The "Excelsior Bakery" and Steam Ice Cream Works is located on Penn Avenue, opposite Collins Strect, at the East End. It was originally established by Daniel E. Bown, who was succeeded by M. Samuel R. Limegrovo in the early part of the present year. The various articles manufactured at this establishment are noted for their excellence, and the business is steadily incrensing. In addition to the products of his Bakery Mr. Limegrover keeps a fine assortment of Choice Confectionery, Fruits, Jellies, Canned Goods, \&c. One steam engine and boiler is used, and four ment of Choice Confectionery, Fruits, Jellies, Canned Goods, \&c. One stenm engine and boiler is used, and four
hands are employed at the establishment. A speciality of Mr. Limegrover is in furnishing Wedding Parties, Society and Party Dinners and Suppers, and entertainments or festivals of any description. His facilities for this part of tho business are unsurpassed, and his well known taste and skill in such matters enables liim to give unbounded satisfaction. He carries a stock of about $\$ 1000$, and his annual business reaches between $\$ 3000$ and $\$ 4000$. Mr. Limegrover was born at Sharpsturg, Allegheny County, Jan. 1, 1555, and commenced business at his present location. 


\section{K. BOAS,-Druggist \& Chemist, Butler \& 43rd Streets.}

At the corner of Butler and 43d Strects is one of the most elegantly fitted and handsomely arranged Drug Stores and Pharmacies in this city. The genial, popular and enterprising gentleman, Mr. Boas, will be found with the most complete, varicd, handsome and elegant stock of Drugs, Chemicals, Perfumery, Toilet Articles, fine lnstruments, etc., to be fonnd any where in this city, everything being new, fresh and clean. The room is handsomely located on the corner, is 17 feel. front and 40 feet deep, is filled with Mirble Counters, Prescription Case of elegant designs, handsomely plated Show Cases alud Fixtures of all kinds of most neat and tasteful patterns. Mr. Boas has been located at junction of Penn A ve. and Butler st. for 6 years, selling out there early in 1879, and opening bis present, beautiful store, at an expense of about $\$ S, 000$.

Mr. Boas was born in York, Pa., in 1846, came to Pittsburgh in 1873. He served two terms of enlistunent in the Union Army, first in the 130th Pennsylvania Volunteers, afterwards in the 195th, being but 15 years of age, when first enlisting. He participatel in all the arduous services of his regiment, going through all their campaigns, marches and battles. He was the youngest man in his corps; after close of the war he graduated at Dickinson College, Carlisle, Pa. During his Senior year at that institution he was Assistant Instructor in the Laboratory to Dr. C. J. Henns, Professor of Chemistry and Natural Sciences. After graduating he went to No. C. and engaged in business and was burned out in 1872, then came to Pitlsburgh and entered the Drug business in partnership with Mr. Cornman as Cornman and Boas, at Penu Ave. and Butler Street, sold out his interest to Cornman in 1874 and went into the establishment of MeClarran and McKennan, where he remaived but a short time, having to return to the old place. Mr. Cornman not being able to fulfill his contracts, being involved, and resume the business which he assumed with liabilities, shortly extinguishing the debt and placing the business in prosperous condition. He remained at the business until recently, when he sold out to $\mathrm{Ar}$. Tea. Mr. Boas has taken considerable interest in political matters, and wields a large influence in the community where he is known.

\section{A. BRICIRE \& SONS,-Commission Merchants, No. 199 Liberty St.}

One of the most favorably known and prominent Commission Houses on this busy thoroughfare is that of A. Bricker and Sons, which was founded in a small way in 1865 . Their business however has steadily increased since that date, until it reaches the handsome amount of $\$ 100,000$ per annum, and is regularly improving each succeeding year. They occupy the entire building, three stories and basement, $22 \times 110$ feet at No. 199 Liberty St., and transact a general Commission business in Flour, Grain, Fruit, Butter, Cheese, Lard and every description of country produce, employing four assistants. Mr. A. Bricker, father of the present proprietors and one of the founders of the house (now deceased), was a gentleman of more than ordinary business sagacity and foresight, and his sons, David and Levi Bricker, who now carry on the business, are worthy representatives of their respected sire. As originally established, the business of this bouse was confined to Flour, Feed and Grain, but shortly before the death of Mr. Bricker, Senior, it was changed to its present line with gratifying results. By judicious management, strict attention to business and undoubted business integrity the young men of the firm have succeeded in making a large increase annually to their trade, and the bouse to-day ranks as one of the first in that line of business in the Iron City.

\section{LUEBBE \& BRO.-Wholesale and Retail Grocers, Nos. $23 \& 24$ Diamond}

This extensive establishment was founded many years ago by J. D. Draro, Esq. The firm afterwards became Haslage and Co., who were in turn succeeded by the present proprietors, Messrs. William and Henry Luebbe, both natives of (iermany, but for many years residents of Pittsburgh and connected with the firm of Haslage and Co. since 1857. They occupy a large double warehouse, $40 \times 115$ feet, at the number above given, which is filled from basement to attic with a large and complete stock of every description of goods pertaining to the Grocery trade, and a choice assortment of pure Wines and Liquors, employing eleven clerks and salesmen. They do a large and flourishing business in the city and all the surrounding towns, comparing favorably with that of any other house in the same line of business in the city.

\section{PITTSBURGH WHRE WORTS,-James R. Taylor \& Co., No.35 MarketSt.}

The manufacture of Wire Work of every description, plain and ornamental Wrought Iron Railings for parks, lawns, verandas and cemetery lots is carried on very extensively by the firm of James R. Taylor and Co., at No. 35 Market St. This house was established in 1812 by James R. Taylor aud Co. In 1874, Mr. C. Dean, after ten years faithful service in the establishment, was admitted as a partner. The increase in their business has been very large within the past few years. The main building occupied by them at the location named, is four stories high, $25 \times 125$, and they also occupy three floors ot an adjoining building of the same dimensions. They employ about twenty hands with all the latest and most approved machinery for the speedy production of all work in their line, and earry a stock of about $\$ 8,000$, transacting an aunual business of about $\$ 35,000$. This house has of late years been particularly noted for the elegant designs of Wrought lron Fences mauufactured by them, and they make a specialty of an improved Fly Screen for windows and doors, made to fit any desired size or shape. Mr. Taylor is a thorough master of this branch of industry and bas resided in this city for many years. Nr. Vean was born in Pittsburgh in 1850. Both members of the firm are practical workmen and energetic and reliable business men.

\section{W. W. W ATTLES,-Jeweler, No. 30 Fifth Avenue.}

The assertion may be safely made that no Retail Jewelry House in the city is regarded with more favor than that of $11 \mathrm{r}$. W. W. Wattles. Estalilished twenty years ago by the present proprietor, the business has gradually augmented from very limited proportions to an annual trike of $\$ 50,000$, and a stock unsurpassed for variety, richness, or tasteful selection. In these respects the house has acquired a reputation that is an assurance to its customers that they could not here buy an inferior article even if they would, no second qualities ever being tolerated in this establishiment For elerant assortments of fine WVatches of the hest makes, Rings, Jewelry, Jewels, and especially in Diamonds, the house of W. W. Wattles has a wide celehrity, while in the countless articles of taste and utility in Silver and Plated Ware, French Clocks, Bronzes, Ceramies, Bric a Brac, and some articles of virtu, Dinner and Tea Sets, Urns, Tureens, Epcrgnes, Lavratory, Cologne and Toilet Sets, Fruil Stands, Cake Baskets, Casters, Candiesticks and Candelabras, the house presents advantages to the buyer that can hardly he duplicated in the West.-As a native of Pennsylvania Mlr. Wattles came to the lron City 26 years ago, and from that period has been identified with bis present occupation. It is but simple justice to say that he has always maintained a position, both as a private individual and a business man, that has won for him in no stinted measure the confidence and consideration of his fellow-citizens, who at various times have endowed him with posts of responsibilities and trusts, which have been discharged with scrupulous nidelity. At the present time Mr. Wattles is Treasurer of Thiel College, Greenville, Pa. 


\section{W. H. PORTER,-Alderman and Deputy Mayor, Cor. Butler and 37th Streets.}

This popular gentleman and upright and honorable officer is located on Butler Street between 35 th and 36th Sts. He was elected to the position of Alderman in 1872, in which capacity he has continuousiy served since that date with honor to himself and to the great satisfaction of the people of his and adjacent districts. He was appointed Deputy Mayor of 5th Poliee District, Feb. 1, 1878, at the time the present Mayor assumed the Chief Mragistracy of the City, in which capacity he has rendered efficient services, and given the highest satisfaction. There is no more efficient officer, nor one who has won a greater degree of respect and confidence by his honorable, upright and gentlemanly course, than Alderman Porter. He takes an active interest in political matters, and exerts a large influence in the councils of his party, and by the high esteen, in which he is held, commands a very large influence in his, and adjacent districts. He was born near Frederieksburg, Va., in 1839, eame to this city at the age of eighteen, and entered the furniture business in the 12 th, and afterwards in the 15 th Ward. During the War he enlisted in the 123rd Pennsylvania Volunteers, Col. Clark's Regiment. At the expiration of his term of service he entered the Naval Service of the Government and was stationed a long time at New Orleans. At the close of the war he returned and emharkerl in the furniture business, in which he continued until elected to his present office in 1872. He is an in telligent gentleman of high character, and possesses the respect and esteem of all who know him.

\section{LONDON TEA HOUSE,-Martin \& Collins, No. 3604 Butler Street.}

The large and fine establishment of the rery enterprising firm of Martin \& Collins is located at 3604 Butler Strect, where they have a very large room, $20 \times 60$ feet, well arranged for their business, completely stocked with as fine a stock of Groceries, Teas, Flour, Provisions, etc., to be found in any establishment in the East End; a fine and tasteful display of their varied stock is made showing the good taste of the proprietors. These young gentlemen opened their present establishment in 1878, and since then has begun a new era in the grocery business in this part of the city. They began with small capital, but since their start have manifested the highest business qualifications, greatest cnterprise, and remarkahle energy in pushing their business forward to the very promincrit position they now occupy. They possess a thorough appreciation of the wants and demands of the public, which fact has enabled them to so adjust their prices and cunduct their business as to draw in so short a time the exceedingly large patronage they now enjoy, and enahles them to do the business, reaching to $\$ 25,000$ ver annum, they are now doing. The rapid rise and success of this establishment is a remarkable one and speaks well for the enterprising gentlemen.

Both of the proprietors are natives of Pittsburgh, Mr. G. S. Martin having been born in 1853, and Mr. A. H. Collins in 1849. They brought with them a thorough, practical and experienced knowledge of their lusiness, having heretofore been connecterl with the grocery trade. They do business strictly on the cash basis. These gentlemen are both quite young, but the energy and abilit $y$ they have shown since starting are rapidly sending them to a community in which they have located, hy their upright, honorable course and courteous manner.

\section{HOSTETTER \& SMITH,-Stomach Bitters, Nos. 57 to 61 Water St.}

It is very safe to assert that no firm extant has done more than Messrs. Hostetier \& Smith to advertise Pittsburgh, not onl $y$ in America, but the most remote regions of the habitable globe, as well as promote to no small deuree the wealth and industrial thrift of this community. With such a marked reputation, they are peculiarly fit objects for mention in a work devoted exclusivcly t, a detailed disclosure of the resources of the Iron City. Established more than a quarter of a century ago, at its inception the enterprise involved but a very limited capital, and facilities (comparatively) of the most meagre kind. At that early period in its history, the firm occupied part of a building on Hostetter's Stomach Bitters wonld scarcely number half a dozen. The business however, containcd tlie elements of suecess, and under the consummate tact and resolution of its projectors annually increased, with rapidly augmentive revenues and proportionately enlar fred facilities in every department. The extent to which the operations of this house have reached may be illustrated by the fact that in 1866 it became necessary to do all its own printing no firm in Pittsburgh, or perhaps in the whole country, being capable of produeing, either in kind or quantity, the work requisite in carrying on the trade of Hostetter \& Smith. In the Printing and Binding devartments, alone, are now employed eiglity comproitors, pressmen and others. The equipment in machinery consists in part of 10 large now employed eiglity compositors, pressmen and others. The equipment in machinery consists in part of 10 large cylinder presses, and 8 smaller ones, all of which arc kept running ten months during the year upon the publication
of Hostetter's Illustrated Unitcr States Almanacs, which are printed in the English, German, Dutch, French, Spanish, Welsh, Norwegian, Swedish and Bohemian languages. This Almanac was first issued in 1862 and was published only in German and English, increasing its edition each year and reaching in the year 1867 one million copies, which were disseminated in these two languages. Still increasing its edition each rear it reacherl, in 1876, 9,000,000 copies, which were produced that year in all the various languages above enumerated, the average issue per year at the present time bcing $10,500,000$ copies, consuming annually 16,000 reams of white paper, and about 2000 reams for covers alone. When first estaj)lished the nanufacture of Bitters was entirely a manual operation. The enormous increase in production, however, made this process impracticaljle, and machinery and apparatus of the best construction, with a capacity for putting up 500 dozen bottles per day, is now einployed in preparing and bottling the Bitters, which are made entirely from the chricest remedial ronts, harks ond herbs, the active essences and freshly expressed juices of which are preservel in chemically pure spirits, forming a compound of the most remarkable vital force and efficacy, peculiarly active in the rapid and in many cases almost miraculous relief afforded in all diseases arising from climatic causes or derangements of which an impaired stomach is the prime oceasion. In this departinent of the work 14 ponderous tanks are used, 15 feet in diameter and 5 teet high, and 10 tanks 8 fcet high and 6 feet in diameter, and here are employed, in manufact uring, packing and slipping, not less than 50 hands. The buildings now oceupied and owned hy the firin are at Nos. $5 \pi, 58,59,60$ and 61 Water St. Thev esver an area of over half an aere, are four stories in height, and are admirably situated for purposes of shipment by rail or viver, through which mediunss large quantities ar shipped to all parts of the United States and territories, to South America, Australia and other forcign countries. Nine accoutants, correspondents, \&e, are engaged in the counting rooms of the firm, and it is not an orer-estimate to say that in its dircet and enntingent operations, such as the gathering and growing of the necessary medicinal drugs, the nanufacture of the paper with its dependent industries, the product of grain and its conversion to spirit, \&c., \&c. the house employs directly and indirectly the labor of 1000 people daily, and so far, aside from the intrinsie merits of its specialty, becomes a great factor in pronoting the general good.

The senior partner, Dr. David Hostetter, is a native of Lancaster Co., Pa., where he was born Jan. 23 , 1819 ; removing to this city in 18.53, his whole history since has been attended with the most brilliant and suecessful business achievements. Not confining his talents to limits of that vocation that has made his name so celebrated, he has taken an interest in the develnment of the various resources of Pittsburgh, and conjoining the advantages of the conumunity with his $0 \mathrm{wn}$, has pursued both with resistless activity, the broadest eomprehension, and the most effective results. Geo. W. Smith, Esq., the junior partner, is also anative of Laneaster Co., Pa., and was horn in the eity of that name Feb. 22, 1823. He, too, is largely engaged in other enterprises, and way be regarded, in the fullest sense, as a selfmade man, liberal, intelligent and sincere. As a firm jerhaps no house in Pittsburgh is entitled to a higher place none, certainl $y$, is accorded a more universal or unfeigned consideration. 


\section{THOMAS ROSE \& SON,-Boots and Shoes, No.19 Diamond Street.}

One of the oldest and hest known Retail and Custom Manufacturing Boot and Shoe Stores in the city was estal,lished by Mr. Thomas Rose in 1839, and for nearly half a century has heen an important factor in supplying the wants of the Pittshurgh public in this essential line of trade. The premises occupied are centrally located and commodions, the upper floor being devoted to the making of Custom Boots and shoes and repairing, where five mechanics are employed. The first floor comprises the salesroom for machine and hand-made work, in which a stock of about $\$ 10,000$ is generally carried, consisting of a full and well assorted line of Children's, Misses', Ladies' Shoes and Gaiters, and Boys', Youths', and Men's Boots and Shoes, lought directly from Eastern manufacturers, which en..bles the house to compete in prices and styles with an eontemporaries, to the decided advantage of the customer. As a firm, this house is so well established for their strict adherence to trathful representation and reliability in business honor, that any comment from us would be nnnecessary to further their well deserved popularity. The senior member, a resident of this city for forty-five years, has built for himself a high reputation, while the junior member, Mr. A. N. Rose, is acknowledged as one of our most thoroughly upright young business men.

\section{F. CASSIDY,-Alderman, 94 Third Avenue.}

The subject of this sketch, M. F. Cassidy, Esq., was born in this city, September 26, 1839, and before entering, as the people's ehoice, upon the daties of the office of which he is noiv the incumbent, was engaged in mercantile pursuits, having in early life been for several years in the merchant tailoring business, as partner in the firm of Kane \& Duffy of Sixth Street, later was of the firm of M. F. Cassidy \& Co., Produce Commission Merchants, and was called in 1872 to fill the Aldermanic chair of the 1st Ward. Filling the office so ably and so satisfactorily to his constituents, it was their pleasure to continue him in the same position of trust in 1875 , when he was re-elected for another term. Not only as a careful advocate of the city's interest in the Conncil Chamber does he acquit himself most deservedly of the people's support, but in all matters pertaining to his private office business, he has ever proved an upright magistrate, a careful business agent and a worthy incumbent.

\section{H. CHILDS \& CO.-Wholesale Boots \& Shoes, 133 Wood Street.}

The first Boot and Shoe House established West of the Allegheny Monntains was that of John Albree, at Pittsburgh, in the year 1817. The business smbsequently passed into the hands of Albree \& Childs, who were in turn succeeded by $\mathbf{H}$. Childs and Co., under which style the business has now been condueted for over forty years. Mr. Harvey Childs, Jr, and Mr. Ross Johnston, the members of the present firm, are both natives of Pittsburgh, and they have al ways been identified with the shoe trade of this section of the country. They occupy the entire tive stories and basement of the elegant and commodious building, No. 133 Wood Street, and carry a stock of from $\$ 40,000$ to $\$ 75,000$, comprising as full and complete an assortment as can be found in any similar establishment in the Union. They employ four traveling salesmen with an extensive business acquaintance and flourishing trade in Western Pennsylvania, Eastern Ohio, West Virginia, Kentueky and Maryland. Few mercantile houses in the United States can boast of sueh a long continued, honorable and suecessful business career as that of $\mathrm{H}$. Childs \& Co., and it is but seldom that any one firm continues so long engaged, unchanged, in the same line of business.

\section{KENNEDY F. IANGE, Eagle Pharmacy, Cor. Butler \& 37 th St.}

At the corner of Butler and 37 th Streets, the handsome and attraetive Eagle Pharmacy is loeated, and is stocked with the finest and most complete stoek of Drugs, Chemicals, Fine Iustruments, Toilet and Fancy Articles, in endless variety, and the finest quality to be found in the city, and which are arranged and displayed in an extraordinarily attractive manner. Mr. Jange carries a stock of goods to the amount of $\$ 8,000$, and is doing a business of $\$ 12,000$ or upwards per annum. This is one of the most noted establishments in this part of the city, and enjoys a repntation of which Mr. L. has a right to be proud. Mr. L., the genial proprietor, is a highly accomplished and popular gentleman, possessing the confidence of the business community and enjoying the respect and generous patronage of an appreciative public. The business, which was started by Mr. L. in 1867 with a small capital, has grown into its present handsome proportions through the untiring energy and enterprise of its proprietor. Mr. L. occupies a very handsomely located and beautiful store room and three-story building on the corner, and the handsome and heantiful display of his goods embellished with an attractive show of beautiful and rare plants during the Summer season, is the subject of general remark and commendation. Mr. L. also possesses the esteem and eonfidence of the medical fraternity iu an eminent degree. He was born in the city of Pittsburgh in 1845, is a son of Dr. Lange, a well known and highly respected citizen and accomplished physician. He has lived in this city ever since, and since reaching the age of inaturity has been identified with the local politics of the city. He is now, and has been for some years, a member of the Central Board of Education, a position that he fills with honor to himself and the satisfaction of the community. He is a leading and popular Republican, and wields an important influence in the councils of his party and in the community with the interests of which he is so closely identified.

\section{THE ENTERPRISE EXCHANGE,-Chas, Hilger, Proprietor.}

The most popular, respectable and high-toned resort in the East End is the Enterprise Exchange, which under the liberal, careful and upright management of the very genial, courteous and popular gentleman Mr. Chas. Hilger the proprietor, enjoys a high degree of popularity and is patronized by the most prominent and enterprising citizens of Lawrenceville, and is the favorite resort of the leading citizens. Mr. H. has won for establishment so high a reputation by keeping a liouse of the highest character, and in the most respectable order, nothing hut the most gentlemanly behavior is for a moment tolerated, such resorts and such men are an honor to the community in which they are found. Mr. Hilger is also proprietor of another fine establishment farther out of the city, which is also a fovorite resort during the summer season.

Mr. H. was born in Baden, Germany, in the year 1842, he eame to the U. S. when a child and located in Louisville, Ky., since a number of years. During the war he left there and went to Chicago, where he remained but a short time, removing from there to Pittsburgh. He enlisted in the Union Aruny, serving 9 months until the close of war, was discharged at Riehmond, Va., returning again to this city, where for a time he was engaged as Commercial Salesman. Entering his present business in 1867 in connection with 3 . B. Pierson, the latter retiring from the Co. partnership at the end of tlie first year, since which MIr. HI. has conducted the business himself in such manner, as to win the esteem, confidence and respect of the entire community. He is a young gentleman of intelligence and enterprise, takes great $j$ interest in the political affairs in his ward, exerts a large and important influence, he has been a member of the school Board for 6 rears and is now a member of Select Conncil of the city, in which position he will be found exerting his influence in the interests of true reform. Mr. Hilger's popularity lias heen won by his manly and honorable course, during the ten years or more of business connection with the people of this section. 


\section{JAMES T. KINCAID, Jr.-No. 107 First Ave.}

This manufactory of Steamboat and Hotel Cooking Stoves, Tin Ware, \&c., is equal to the best, and occupies two floors, the upper one being used as a manufactory. Five hands are in constant employment, manufacturing Tin, Copper and Sheet Iron Wares. The greatest variety and choicest workmanship is done here of any place in the city, consuming over $\$ 12,000$ worth of stock per annum. The firm was organized in 1815 by Lewis Peterson, with whom Jas. T. Kincaid, Sr., learned his trade, and afterward became partner and in 1840 proprietor. In 1866 the firm beeame "Jas. T. Kincaid \& Sons," and passed into the hands of the present owner in 1874. "The Steamboat and Hotel Conking Stoves of this firm are original witl the former firm of Peterson $\&$ Co. They are male of wrought iron, and are known and ackuowledged to be the best in use. All the steamboats on the rivers use them in preference to any otlucr. Mr. James T. Kincaid is a native of Pittsburgh, born in 1828. He learned the business, which he has always followed, with his father, who was long known and respected in this city.

\section{LEE \& MARSHALL, -Wool Dealers, 90 Water Street.}

This is a business which is but little understood by the masses, and its magnitude is hut inadequately appreciated by the general public. The capital invested in this line of tradc is very large and the business is onc of the important features of our national prosperity. The bome supply of wool is not equal to the demand and constimption, and large quantities are imported form foreign countries. The house of Lee and Marshall is composed of Mr. Ilugh Lee and Mr. James L. Marshall. They hatve been engaged in business on Liberty Street for the past thirty-five years, and for twenty-four vears under the present firm name and style. They have agents in the various wool growing districts buying for them on commission, and they handle on an average about 250,000 pounds of wool per year. Their sales are almost exclusively to eastern manufacturers and dealers for whom they principally purchase and ship, althougb frequently buying on their own account and holding it for an advance in price.

\section{FREEHOLD BANK.-Discount and Deposit, No. 68 Smithfield Street.}

Contingent upon and identified with the industries of Pittsburgh, the Freelold Bank is justly regardel as one of the most solid, conservative and responsible financial institutions in the city. Organized under the State laws in 1870 , with a capital of $\$ 200,000$, the bank became a success from its very inception, under the management and direction of the following well known gentlemen: E. Housc, Esq., President, J. P. Speer, Cashier, L. II. Widney, Teller, the Board of Directors being Messis. E. House, John Paul, John Machin, T. W. Davis, C. L. Magee, Jared M. Brush, and T. S. Biglow.

The building owned and occupied on the first floor by the bank is a handsome stone front edifice, $40 \times 60$ feet, and three stories high, centrally located, and regarded as being a very valuable property. Taken altogether, no similar institution possesses a higher rank either on the score of solvency or able management, and the Freeliold Bank may justly be regarded as one of the representative financial establishiments of the Iron City.

\section{J. P. WILIISON,-Undertaker and Embalmer, No. 4015 Butler St.}

This very polite, courteous and popular gentleman, and accomplished Undertaker and Embalmer is to be found at 4015 Butler St., where he opened his establishment, and otfered his valued services to the public in that part of the city in 1877, since which time his genial manners, high acconplishments, and prompt and careful attention to all business entrusted to his hands and the wants of the public, he has rapidly grown in favor, enlarged his business, and widened his already large circle of acquaintances and patrons. His energy and determination will achicre success in whatever enterprises he may engage. He was born in Allegheny County in 1842, worked on the farm of his father until 18 years of age, then learned the blacksmith trade. He enlisted at the beginning of the war in the fomons 6 ? nd Pa. Vol., Col. Sain Block, and served during the entire war, being wounded six times, but escaping without being scriously maimed or crippled, although bearing the scars of the "leaden hail." During his term of enlistment he prudently saved his money paid him by the Government, with which, after the close of the war, he was enabled to gratify a noble and lofty ambition to educate himself. He applied himself to study closely for a considerable period. In 1866, through the efforts of an influential friend he secured the appointment of clerk iu the Hotlse of Representatives at Harrisburg, which position he held with credit to himself, and the satisfaction of lis friends for two years After that he entered the Dry House of J. J. Bender \& Co. as Bonk-keeper, leaving there to accept the position Cashier in the Office of the P. C. \& St. L. R. R., in which position he served seven years, after which he embarked i? his present enterprise, in which he is meeting with encouraging success. Mr. Willison is well and popularly known in his cominunity, actively participates in the public and political matters of his ward, and exerts an important infuence in matters of that kind.

\section{JOS. VOGEL,-Dry Goods, Notions, Carpets, Oil Cloths, \&c., No. 3702 Butler St.}

The large, handsome and splendily stocked establishment of Mr. Vngel is lncated at. No. 3702 Butler St., and is recognized as ooe of the most prominent Dry Goods houses in the East End. The ronm owned and occupled hy Mr.V., is 20 feet front and 75 feet deep, the building being a fine 3-story hrick. The store is filled from end to end witli as large. viried and attractive line of goods as any one could dlesire, and the stock is kept supnlied witi frequent in roices of all the latest novelties and newest patterns. The beautiful manner in which the goods are displared, the perfect. neatness in which everything in the estallishment is kept, everything in perfect order Not a speck of dust allowed to accumulate anywhere, as is too frequently the case in many establishments, spealks volumes for the good tuste, and the high appriciation of the advantiges to be derived from an attractive anl pleasant place in who takes much pride in $\mathrm{Mr}$ Jos. manly and courtcous treatment towards all the pitrons of the establishment, as well as by lis popularity and general high character in the conmunity adds much to the high esteen in which the establishment is and general high character in the community adds much to the high esteem in which the estallishment is
held. The estahlislmuent is floing a large and growing husiness, reaching very large fignres annually. Vogel's is known by everybody in this part of the city and favorahly mention the establishment on all handis. Nir Jos. Vogel first began business in this eity 25 years ago as a Merchant Tailor on Liberty St. with limiteri eapital, but by elise attention to business, and enterprising ahility rapidly_accumulated eapital, he continued in that lusinfess until 9 years ago when he removed to Law renceville and engaged in the Dry Gonds business. Mr. Vogel was born in Germany and came to the U. S. in 1837, first lacating in Buffalo. N. Y., afterwards removing th this city, he has arecumulated considerable means during his long and busy career in this city, and is an honored and highly respecterl citizen, and an upriglit homorable Gentleman. The two sans of Mr. Vogel, John and Jnsoph, give their close attention to the busines; they are both young men of pnpular and agreeable manners, with whom it is a pleasure to deal, and who are highly respected by the cummunity in which they reside. 


\section{W. L. GRIETETE CO.-Millinery and Trimmings, No. 76 Market St.}

W. L. Grifititu \& Co., whose plate of husiness is as above, have a just reason to feel prond of the sucess which they have achievel in estublishing themsel ves in such a prominent position in connection with the millinery trade of our city. 'T'hey are dealers in all lines of Litlies' and (rents' Furnishing (ivols, Millinery, Trimmings, IRiblons, Feathers, de., de., and tocupy two light and spacicus floors, as sales and manufacturing departments, in which ten salesmen and numerous trimmers, de., are employed, while the members of the firm, Mlessrs. W. L. and S. L. (iriflith, pay personal supervision to the lusiness. Over the millinery department, as superintendent, Nrs. S. L. Grithith, a
lady who possesses at thurough linowledge of the business, is daily in attendance. This house carry a large and diversified stock of $\$ 10,0010$ in ralue, where every want, in this line of goods, way be as fully and economically fulfilled as at any place in the city. In adtition to the attractions usual to such a house, here may be found, also, headquarters for the celebated Hoinorest's l'atterns, the most reliable in the country. This tirm, although estahlished as late as 1875, has achiered i reenenizel success and reputation, both iu business relations and in social connections, which maty well be wortly of th. sustrnance and patronage of both our own residents, and those visiting nur city from neighboring eities and $t_{2 w} 1 \mathrm{~s}$, will always find $\mathrm{it}$ to their advantage in visiting the house of W. I. Grifitl \& Co., at No. 76 Markel st.

\section{EPHRAIM CIA T,-Hosiery, Gloves, Notions, \&c., No. 37 Diamond St.}

This W'(ll ostalilished and snceessful jobbing and retail house is of eigheen years' standing, and carries a large rariety of gueds in the line of Hosiery, Notions, Gloves, Yarns, and Gentlemen's Furnishing Groods, the ustal amount of stock being ahout $\$ 15,000$. There are four floors in the building, all of which are used in the business of the house. Five hands are usually engaged in the business, attending to the wants of the trate at the housc, while one traveling salesmin, in the person of Mr. Phil. Baer, represents the house through Western Pennsylvania, Ohio, and West. Virginia. The well-earned reputation of the house has given it a large and steadily increasing trade, and its stock is as complete as any in the city. Mr. Clay was born in England in 1818, has been in this State for about 30 years, the last 18 of which have been spent in this city and in the business he has so successfully cstablished.

\section{JOSEPH IMA CLEAN,-Bookseller and Bookbinder, Room 3, N0. 41 Fifth Ave.}

As a dealer in Books, making a speciaity of mechanical scientific and art works, and rure publications, it is safe to assert, that Mr. Joseph Maclem possesses a more dctailed, as well as comprehensive knowledge of his husiness, than any competitor in this eity, and can at the same time otlor alvantages to the regular or casnai hook buyer, that may not lie duplieated in the West. For mor't than ren years AIr. Maclean was associated with the widely known pullishing firm of Gebhie and Barrie, Philalelphia, and in conjunction with them establishel a Book lIouse in Pittsburgh 187t, which however mas subsequently remored to New lork, of which place Mr. Machean herame a resident. Betmcen the last named period, and $18 \mathrm{i}$, however, he was a frequent visitor to this city, maintaining his relatious with the tracle here, and finally in that year engaged in bnsiness for himself, exclusively at the above location.

The premises occupied by Arr. Maclean are admirably suited for the book trate, and are stocked with a choice assortment of special works in the lines mentioned, as well as a large miscellaneous collection in the province of general first class literature, classical and modern, the stock heing of an average value of about five thousaud dollars. To this spot resort many of the prominent book lovers and buycrs of this city. Fincling invariably something curious, rare or new, upon the well filled shelres, to reward them for the quest, constant additions being made in all departmenis, through the foreign or eastern comnections, estaklished by the energetic proprietor. As sole agent for the Harper Brothers in this eity, Mr. Maclean controls the sate of Stanley's cclebrated work in $\Lambda$ frica, "Through the Dark ('ontinent" and deals largely in other subscription books, for reference generally, or in particular branches of mechanies, chemistry or the arts etc., et. Indefatigable in the pursuit of his business, for which he possesses marked talent and appreciative comprehension, Mr. Maclean's relations are mainly with the highest and most intelligent classes of the community, to whom he can always ofter advantages in the purchiase of books, and the selection of libraries not to be equalled by any cotemporary, eitlier here or in the eastern cities, and which hare given him a position in the trade rarely acquired except by years of exertion and experience. In the department of Binding, Mr. Maclean has eflected special arrungements with the hest binders in Philadelphia, by which the tinest work is invariably insurcd, at the most moderate outlay. In every respect this estahlishment is a model one, the proprietor being thoroughly deserving of the patronage and consideration of the public, to whom his enterprlse is cordially commended.

\section{THOS. FA W CETT \& SONS,-Bituminous Coal, Office, 87 Water St.}

In the great coal interests of Western Pennsylvania, so closely identified with the indusiries and derclopment of this community, a review of the trade in extent, and the mode of carrying it on in respect to transportation to other points must prove interesting to every reader of this volmme, either in or out of this city. In compiling such a review perhaps no citizen of Pittslurgh is more fully posted, and more capable of giving to our readers an idea of the scope and extent of changes that have occurred in the last quarter of a century, than Thomas Fawcett, Sen., Esq. at whose office our reporter obtained the information for 1 he formation of this brief notice, regarding the operntions of this trm (composed of Thomas Fawcett, Sen., James T. Faweet, and Thomas Fawcett, Jr.), which may be taken as an illustration of the ad vancement and improvement attained in this line of industry.

Succeding his father, Mr. James Fawcett, who commenced the miniug of conl, and wholesale dealing in the same as early in our city's history as 1831 , and was accorchingly one of our earliest miners and coal merchants, 1 tr. Thomas Fawceit, Sen., had, upon entering into business in 1850, at the age of 23 years, a knowledge and experience in the coal trade possessed by few young men of those days. At this date (1550), before the general use of steamboats and tugs, coal was floated down with the current of the river to cities south of us, requiring to every pair of boats, witl a capacity of 40,000 bushels, 25 men to guide and hindle them. Througl the different gradations of changes from year to year, this firm have kept pace with, and made large original improvements, until now a single tow-boat will convey 20 coal boats and barres, having a capacity of 500,000 bushels, manned with but $30 \mathrm{men}$ slowing an advancement in this branch of nearly 1000 per cent. over those of former days. Bringing these vast ad vantages in practical use, this firm now ow and operate two large tow-boats, 50 barges, holding 12,000 bushels cach, and 100 coal boats, holding 24,000 bushels each, which are called in requisition, in addition to one tug-boat for harbor use, in effecting for them an outlet for the immense amount of coal mined from their mines at Green Springs, opposite Braddnck's Field, where they own over 100 acres of excellent coal land, from which are yearly extracted not less than $6,000,000$ bushels of bituminous coal, which is, to a large extent, shipped down the Ohio and Nississipri Rirers as far South as New Orleans, at which point the house have a yard for the sale of their coal to the wholesale und retail trade of that city, in addition to which large numbers of cotton presses, steamships and steamboats are supplied, both along the rivers at different points, and at the intermediate cities lining the banks between Pittshurgh and New Orleans. 'To carry on the business of Fuwcett \& Sons 200 men are engaged in the different branches of mining, shipping and handling, to whom are monthly distributed about $\$ 12,000$ in payment for their labor. As a representative firm in the coal trade, that of Thomas Fawceti \& Sons may.ummistakably be styled the largest shippers down the river, and the oldest in the city, being the ouly firm engaged continuousiy since 1850 , and justly deserving the large trade they have built up and so successfully hold. The senior member was born in this city in 1827, and in addition to the part he has taken in the promotion of. our industries in the capacity in which he is most prominent, he has contributed largely in capital, time and influence to the upbuilding and upholding of our financial institutions. 


\section{GEO. M. IRWIN,-Grain and Provision Broker, No. 55 5th Ave.}

Hardly to be classed under the Industries of Pittsburgh, and yet intimately connected with them, by association, the business of MIr. Geo. M. Irwin, as a Grain and Provision Broker, demands recognition in this work. A native of Beaver Co., Pa., Major Irwin has been a resident of this city for over 10 years, and sinee 1875 has devoted himself with great and deserved success to his present occupation. In constant connection, by wire, with the corn and grain exchanges of Chicago and the West, and with extraordinary advantages in the prominence and sagacity of his correspondents, no man is better able to form a judgment oll the tluctuations of the market, or direct with greater success the operations of margin buyers. His tact and experience in this respect has been a matter of frequent comment by the press, as well as a source of handsome profit to his elients. The method of Maj. Irwin is such that buyers or sellers through him, for future acceptance or delivery, manipulate their own investments, the same being deposited ill a National Bank for mutual protection, a small percentage only in each pool or transaction going to the broker. As a means of realizing rapid and considerable returns upon small ventures, the operations of Maj. Irwin show pretty conclusively that capital so employed is subject to no more risk than if vested in ordinary trade transactions or commercial or other products, while the profits are likely to be, from the systen in use, measurably greater. As a judicious, cautious and adroit adviser, Mr. Irwin has repeatedly given evidence of marked capacity. Those at a distance who desire to avail themselves of the advantages he offers can do so by correspondence, as well as by personal interview.

\section{UNION PLANING MILL COMPANY, -No. 50 18th St., South side.}

As no unimportant factor among the industries of Pittsburgh, in connection with the lumber trade, the above corporation is worthy of special mention in this work, both from the extent of its operations and high standing in other respects. Chartered in 1866, with a eapital stock of $\$ 20,000$, the affairs of the company have been so ably and faithfully managed that each year has brought ahout an increasing business, enlarged resources, and a great range of usefulness. The officers at present are: James Icllasters, President, Wm. Wigman, D. Sinutte and S. Hamilton, Direetors, and A. H. Hunter, Secretary and Book-keeper. The premises occupied by the establishment are situated as ahove, and consist of one large building, $40 \times 120$ feet, with extensive wings, eontaining the most improved and perfect machinery for the manufacture and construction of Sashes, Window Frames, Doors and Donr Frames, Mouldings, Weather Boarding and Flooring, Boxes of all descriptions, \&e., \&c., One large engine and steam hoiler are required to drive the various mechanical appliances, and 35 to 40 employees are constantly engaged, nccasioning a disbursement of from $\$ 450$ to $\$ 600$ per week. In the matter of the manufacture of boxes for glass and other wares, this concern does a larger business than any of its cotemporaries, not confining its works only to this immediate locality, but extending it $t i$ it wille range through this and adjacent States, aggregating a trade of not less than $\$ 95,000$ annually. The Presidel $t$ of the campany is likewise President of the Farmers and Mechanies Bank, and well known for his enterprising connection with the progress and development of the resources of this comnunity. The concern takes its standing from those who are concerned in it, and is therefore regarded with the highest favor, as being perhaps the best appointed and most earefully managed Planing Mill in this section of the State.

\section{JOS. WOODWELL \& CO.-Hardware, Cor. Wood St. and Second Ave.}

Among the many firms engaged in the above line of trade in this city, none occupy a more sulsstantial position than the subject of this sketch. Established March 1st, 1845, as Wood well and Walker, the latter partner soon retired leaving the firm title as at present. 'Two buildings 4-stories high, 140 feet in length with two ample liasements, are barely sufficient to contain a stock, which rarely runs below a valuation of $\$ 100,000$, consisting of every variety of foreign and domestic Hardware, Cutleries, Saws, Shovels and Spades, Harvest and Agricultural Tools, Builders, Machinists, Rail way and Calinet Hardware, Chains, Anvils etc, ete.

The firm which is composed of Mr. Joseph Woodwell and two Sons, W. K. and Jos. R. does a large and increasing bnsiness in Railroad supplies, as well as a very extensive retail trade, the result of the long establishment of the house, and the extended acquaintance of its members, which reaches with their business into three or four contiguous States. Besides posessing all the advantages above enumerated, this firm have the special agency for the celebrated Nicholson Files, Wond Ornaments and the most complete assortment of Iron, Steel, Brass and Copper, Wire to be found west of the mountains. From 14 to 20 employees are regularly retained in the various department of the business, wlich involve sales of from $\$ 150,000$ to $\$ 200,000$ per annum. The general characteristies of this house for tinancial sotvency, thorough conception of the lusiness in which they are engaged, together with a high standard of personal and commereial honor, would reflect credit upon any community, and inake the untarnished recurd of nearly thirty-five years a souree of private and public satisfaction.

\section{WESTERN INSURANCE COMPAN Y,-Granite Building, 81 Wood St.}

This old and reliahle Company was incorporated by the Legislature of Pennsy-lvania, March 20, 1849, the first company chartered in this city after the disastrous Fire, that occurred on the 10 tl of $\Lambda$ pril 1845 , and now the oldest Fire and Marine $C o$. in the city, with cash capital of $\$ 225,000, A$ ssets $\$ 317,607.25$. The management of this sound and prosperous company is not excelled by any other similar organization in the conntry. The directors were truly fortunate in the selection of a financial officer and general business manager in the person of Wm. P. Herlert, sceretary, who has been in charge of the business over a quarter of a century. The vast number of risks, that he has liandled, the enormous amount of losses paid the prompt adjustment of claims when necessary, has given the Western an enviable reputation, both at home and abroad. The careful and judicious course pursued by the management, lias been the means of making the stock of this comprany one of the best for investment to be found in the city, when we learn that they have paid their stockholders in dividends nearly four dollars for one investerl. As an illustration of the character of the management, and probity in condueting the very large and inereasing business of this company, we may refer to tlie showing of the handsome amout of Assets of $\$ 317,607,25$, after paying losses in 30 years of their existence of nearly 1,000 ,000. The managers have givel evidense of rare ability in selecting business, and their judgement has lieen verified in the success, which has been acquired. The business of the Western has bren principally of a local character, and within reach of the officers, that an aecurate examination of each risk could be had. We herewith present the names of the board for the year 1879 :

President, Alexander Nimick, V. President 1st National Bank, of firms of Nimick \& Co.

Phitlins, Nimick \& Co. and President Jacobus \& Nimick MI's. Co., etc. ete. $\mathrm{R}$, Miller Jr., President Monongahela Bridure company, David 11 . Pong of Hubluard, Bakewell and Co, John P. Meciane President Union National Bank, Charles J. Clarke President Library Hall company, Capt. Wm. S. Evans, President of Missouri River Transportation company, Pliillip Requier of Requier and Brothers, Wholesale Grocers etr., William Morrison, Capitalist, 11. Sellers McKee of McKee and Bros., Glass Manufacturers, John B. Jackson Member of city council, lion. L. K. Mnorehead, President of Monongahela Nav. Co. and President of Chamber of Commerce, Hon. Edwin II. Stowe President, .Judge com. Pleas No. 1., Wm. Frew, first Vice Presilent Standard Oil company. In this list are found the names of solid men of Pittsburgh, and of men who are the architects of their own fortunes. 


\section{THE WESTINGHOUSE AIR BRAKE CO.}

Office d: II orks: Liberty Street, Between 24th and 25th Streets.

It is tolerably safe to say that no one special branch of our manufacturing industries has disseminated more widely a knowledge of Pittsbur'sh and its characteristics, than the Westinghouse Air Brake Co. Certainly none more entitled to copious mention in any work professing to display in its proper light, the resources, advantages and development of the Iron City. Based ipon the masterly invention of George Westinghonse, Jr., the manufacture of the Autountic Air Brake was commenced by the patentee and Ralph Bagaley, Lsq., vearly ten years ago, creating an absolute revolution in the matter of handling railroad trains, greatly increasing the safety of travel, and reducing running expenses, with many other striking advantages. The importance and novelty of this unique appliance, attracted at once univers bl :ittention resulting in the formation of an incorporated Joint Stock Company, with a capital of $\$ 300,000$ paid in, for the purpose of a more extensive manufacture of the Air Brake. Of this Association, Geo. Westinghouse, Jr. was elected President, Ralph Bagaley Secretary and Treasurer, and T. W. Welsh Superintendent, and under the man:agement of these gentlemen to the present time the company has attrined an almost umparalleled degree of prosperity, extending its operations not only throughout the entire United States and Canadas, but introducing its inventions into Mexico, Cubia, South America, Enrland, France, Germany, Russia, Scotland, Ireland, A ustralia, New Zealancl, India, and in fict in almost every country in the world where railruats are in process of cunstruction, or have become a necessity.

The works of the corporation are unusually complete in every mechanical detail, they occupy an area $100 \times 261$ feet, containing two engines and boilers aggregating ninety horse power, and tine machinery espccially invented or designed for the work performed. One hundred and fifty skilled artizans are constantly employed, occasioning an anunal disbursement to this source alone of $\$ \$ 4,000$. Besides the construction of the original Automatic Air Brake, other devices involving much the same principle have been invented by Mr. Westingliouse, covering Train Brakes, Freight Brakes, Westinghouse and Snith Vacuum Brakes and Locomotive Driver Brakes, all of which are manufactured br the company, protected by numerous patents in this country and abroad.

Geo. Westingliouse, Jr. is a native of Schenectady, N. Y., and is still a young man. He acquired his knowledge of mechanies in the Agricultural Implement Works of his father in his vative city, but removed to this city in 1868, where after combatting numerous discouragements he finally established the founditions of a signal success.

Mr. B igaley is a native of Pittsburgh, his father W Wm. Bagaley, Esq., was one of the most talented business men this city ever produced; methodical, enterprising and comprehensive in character, he was twenty-five years ago a representative man, and did as much perhaps as any one, in ad vancing the prosperity of this community. Mr. Ralph Bagaley from the inception of his business career has been constantly engrossed in the manufacture of machinery in some of its many branches. As one of the projectors and officer's of the Westinghouse Co., as well as proprietor of the Pittsburch Trening Telegraph, he is widely known, and this in connection with various interests in fingncial and civic institutions has given him an influence always justly exercised and well deserved. With an annual revenue averaging half a million dollars, and a practical usefnlness almost philanthropic, it is not a matter of surprise that the Westinghouse Air Brnke Co. occupies a place in the Industries of Pittsburgh as honorable as it is well merited.

\section{A. NORTHROP \& CO.-Sheet Iron Roofing \& Building Materials, 97 st Ave.}

Among those industries contingeut upon er springing from the Iron trade, and the material outgrowth of improvement and invention may be classed the enterprise of the above firm, which is of such a character and of so great a usefulness as to entitle it to more than mere mention in a publication, doroted exclusively to a detailed display of the resources of Pittsburgh. Composed as a firm of $\mathrm{A}$. Northrop and Henry S. are natives of Ohio and were established in business at Elyrin in that State for 25 years, prior to their removal to this city. A finished mechanic in Tin and Sheet Iron, with a comprehensive knowledge of liow these materials should be worked to secure the best results. Mr. A. Northrop became

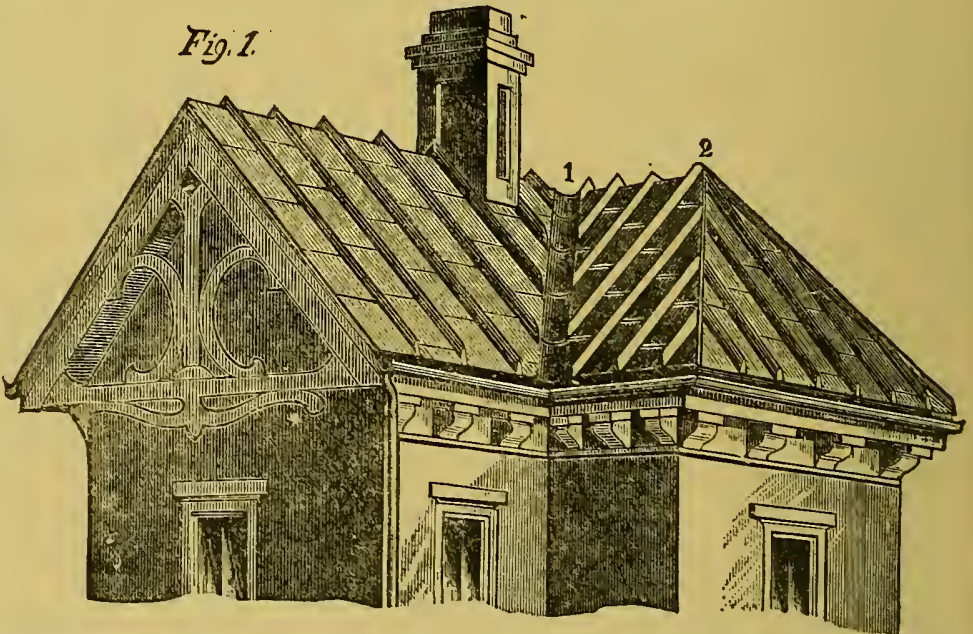
inventor and patentee of certain improrements in Iron Rnofing, Siding and Ceiling, that must eventually effect a vast chinge in the method and expense of constructing buildings of every description, and which are now producing ritdical alterations and advantages. By the mode of application introduced by this house, Iron Roofing becomes unt only impervious to the action of water and fire, but ornamental and durable to the last degree as well as exceedingly economical. Some of the adrantages claimed for it, which elaims are substantialed by the strongest testimonials and the most disinterested authorities, are that it not only possesses the features abore refered to but that it is suitable for all classes of buildings, is wind and lightning proof simple of application. No nails or screws through the Sheets, can be perfectly fitted to climners, sky lights, hips, valleys and gutters One of the great advantages of this method lies in the fact, that the Rnof can be taken apart, moved at pleature and utilized as often as desired, and is so prepared for shipment with printed instructions, as to be easily applied br any ordinary mechanic. The same advantages hold good in regard to the siding, which affords a flawless protection to all weathers and all clinuates, as well as adding great strength to the structure. The ceiling is perhaps the best ever dcrised, beth in sppearance and for the relief afforded from falling plaster, the breaking off, of rhich is only a question of time. Besides the manufacture of this valuable in rention A. Nortlirop \& Co are large manufacturers and dealers in Sheet Iron Cornice, Gutters, Fire-proof Shutters, Roofing, Paint, etc. etc. Their facilities are extensive and a rapidly increasing trade, which extends all over the United States and Canada, demonstrates the favor with which their improvements are being received and appreciated. To those intending to construct new edifices or repair old ones, this firm is most henrtily commended, their entire business policy being characterized by thoroughness, promptness and probity, their work speaks for itself wherever known. 
CHARIES FREIL,-Soda and Mineral Waters and Bottling House, 956 Penn Ave.

The bottling business, as conducted by Mr. Charles Freil at No. 956 Penn Avenue, is entitled to more tlian a passing notiee in a work devoted to the business industries and interests of the Smoky City. Established in 1867 by the present proprietor, these works now occupy two spacious buildings, one, $24 \times 120$, at the location named, and one fronting on Libert.y Street, 30x100 feet. They have all the apparatus and appliances for earrying on an extensive business in the manufucture of Soda and Mineral W aters, Sarsaparilla, \&c, and for bottling Ale, Porter, Cider and Lager Beer. They have a capacity for bottling 2000 dozen bottles per day, and the works are as complete and well arranaged as any in the West. Mr. Freil keeps four wagons constantly employed in delivering goods, and his trade extends through the two cities, Western Pennsylvania, Eastern Ohio and West Virginia. Mr. Freil was born in Londonderry, Ireland, in 1846. He cane to the United States in 1860 without means, working his passage to this country. He at first worked on a farm, afterwards on the river and in several different branches of industry, until be accumulated sufficient capital to establish himsclf in business. He opened a tavern in 1865, and met with gratifying success until 1867, when he sold out and embarked in his present business, in which, by energy and enterprise, he has accumulated considerable property, owning the buildings in whieh he is loeated, and other property in the city. The success that has attended Mr. Freil's enterprises in business, and the prominent position attained in the business community, starting without means, is an indication of great ability and energy. He is a gentleman, highly respected and esteemed by all who know him, for his general qualities, and upright, honorable life.

\section{GEO. DUNCAN \& SONS.-Glass Manufacturers, 10th St. South Side.}

In a work devoted to a minute display of the resourees and advantages of this community, the Glass manufacturing industries must occupy a position of importance commensurate with the prosperity anct general development of Pittsburgh traceable to this source. Conspicuous among those firms that have added no little to the celebrity of our products in this department of trade, the house of Geo. Duncan \& Sons must always occupy a place that, in many respects, eelipses all competitors. This firm was originally established, in 1866, by Ripley \& Co., assuming its present title in 1874, and composed individually of Messrs. Geo. Dunean, Jas. E. Dunean and A. H. Heisey, all practical glass makers, with a comprehensive knowledge and extended experienee in the business, and all natives of this eity, the senior partner having been engaged in this vocation for over a quarter of a century. For the specialties, to the perfect production of which this house is devoted, it has achieved a wide spread and splendid reputation, distancing all competitors in the manufacture of Table and Bar Glassware of chaste and elegant designs, finisled to a wonderful degree of excellenee; engraved, cut, stained and etched in such a manner by new processes and lahor saving methods as to rival in appearance the finest cut glass, at a vast reduction in price. It is not saying too much to assert that in the production of Table Sets, Elaborate Lamps, and superior Bar Goods the firm of freo. Duncan \& Sons can not be surpassed.

The plant of the house is extensive and occupies 18 lots, covering a total area of about two acres, subdivided into factories, mould shops, paeking rooms, stoek and sample rooms, offices, \&e., \&c. A powerful engine and loiler are required to drive the machinery, and 150 skilled artizans are employed at an averace outlay of $\$ 1400$ per weck. With these and other unequalled facilities the firm transact a trade areraging $\$ 150,000$ per annum, and extending throughout the United States, Mexico, Cuba, South America, and other foreign countries, contributing greatly to the general wealth of this community, and fostering to a large degree its matevial prosperity. As a firm the house of Gen. Duncan \& Sons is regarded as being at the head of the trade, and is justly entitled to the high consideration, resultant ulion an honorable and enterprising career.

\section{METCALF, PAUL \& CO.-Verona Tool Works, Office, No. 1 McCance Block.}

A braneh of those great Iron Industries that have made Pittsburgh the center of this production in the United States, the house of Metealf, Paul \& Co. can not properly be omitted from a work exclusively direeted to a detailed description of the resources, development and special advantages of this city. Established by Messrs. O. Metealf and J. W. Paul under the above style in 1873 , the efforts of the firm were directed to the manufaeture of solid steel tools, prarticularly such as are used in the construction or repair of Rail Road tracks. The works were erected at Verona, a few miles from the eity, on the Alleghen y Valley R. R., and speciall y adated in construction to the required purpose, being equipped with the best mechanical appliances that every modern improvement could suggest, and sueh processes adapted for the more perfect preparation and finisn of the naterial used, as should seeure a product absolutely flawless. In the attainment of this desideratum the firm inet with the most signal success, and the almost instant celebrity that followed led to a trade that at the present time is not limited to the United States, but extends to Brazil, South Africa, and the West Indies, the Soutb American trade having grown to sueh proportions as to require the establishment of a branch office at Rio Janeiro. As manufacturers of solid steel tools exelusively, the firm of Metealf, Palul \& Co. have really no compeer in this country, and for lightness, strength, durability and economy their work is recognized and appreciated by every construetive engineer for its matchless superiority. The works at Verona are ample in extent, cover-

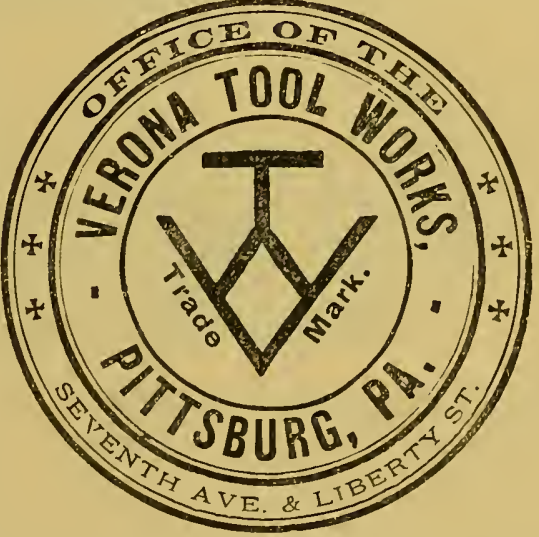

ing an area of nearly half an acre, one 50 horse power engine is required to drive the machinery, and 43 skiller operatives are constantly employed, making a disbursement necessary to this source alone of about $\$ 60,000$ annu:lly. The rapid increase of the business of the house at home has kept equal pace with its foreign operations, and for " nreater convenience in transaeting trade with the West and North-West, a tributary establishment, trade house avd office, at No. 40 Dearborn St., Chicago, affords in this direction all the neeessary faeilities.

Mr. Metcalf is a native of Pittsburgh, born in 1840 . He has always made his permanent residence in this city and, within the range of his influenee and domain, has to an equal extent with any other one citizen fostered and eonserved, in every possible wav, the interests of this city. The financial, elerical and general business management of the liouse fall to his eare, while Mr. Paul, who is also a Pittsburgher by hirth, gives his personal supervision to the operative, manufacturing departments of the work, for which he is adniirably fitted by an cnlarged experienee and thorough education as a meehanician. During its comparatively short existanee as a firn, the house of Metcalf, Paul \& Co. have achieved a suceess so signal and complete as to rank them with the best and most extensive manufacturing enterprises in this or any other city. Closely irlentified with Pittsburgh, its development, industrial grow th, and general prosperity, promoting all these to the greatest degree possible, the proprietors of the Verona Tool Works are deservedly awarded the highest consideration on the part of the community for which they have done so much. 


\section{T. W. WHITELEI,-Commission Merchant, Terra Cotta Ware, \&c., 244 Penn Ave.}

The rapidly increasing demand for Terra Cotta Ware in the shape of Flues, Sewer, Stove Pipes, \&c., and the absolute necessity of these appliances in all modern structures, suggested the idea of establishing a commission agency in this eity for the sale and storage of such merchandise. A bout one year ago, therefore, Mr. Whiteley commenced business, representing the Excelsior sewer pipe and fire brick works of P. Connor \& Bros., located at Eiliottsville, Jefferson county, 0. , and other leading potteries in Ohio, including other articles in the same line, such as Fire Brick, Tile, White Lime, Caleined and Land Plaster, Cements, Stoue Crockery, Lawn Vases, Pots, \&c. The wisdom of his enterprise has already been amply shown by an annual trade of over $\$ 20,000$, which is fast developing into larger proportions, and affords conveniences to the general public locally and at a distance for making purchases at lowest rates heretofore unobtainable. Those who desire any information with reference to such particulars in connection with the business not otherwise easily got at, will find Mr. Whitely by correspondence or otherwise, ready to import any knowledge within his jurisdiction.

\section{CHARIES MAGINN \& CO.-Wholesale Confectioner, 183 Liberty St.}

Mr. Charles Maginn, proprietor of the "Liberty Candy Works" and wholesale Confectioner, has been engaged in business under the present style, and at lis present location since 1875. Previous to that time, from 1857 until he established this house, he was a partner in the firm of E. and C. Maginn, a concern which transacted an annual business of some $\$ 250,000$. Since starting in business for himself, Mr. Maginn's trade has steadily increased, until his yearly sales reach the handsome sum of $\$ 90,000$, with fair prospects of rivaling the business of the old firm in cours of time. He occupies four floors and basement of the elegant stone front Warehouse, 22x110, located at No. 183 Liberty Street, as manufactory and sales rooms, and employs about twenty-five hauds in the various departments of his establishment. His trade extends through Pennsylvania, Eastern Ohio, West Virginia and Maryland, and compares favorably with that of any other house in the same line. His stock comprises every description of Fine Confectionery, Canned Goods, Foreign Fruits, Nuts, Sardines, etc. etc.

\section{JAS. W. ARROTT,-Fire, Marine \& Life Insurance Agent, Office, 167 Wood St.}

In presenting the name of Mr. Arrott to the public, it will at once be recognized as one well known to all, as associated in giving security to the citizens of Pittsburgh and Allegheny county against the ravages of the devouring element. His name is a guarantee, that in case of loss, promptness will follow the amounts of damage ascertained, and quick payment will ensue, hence his popularity and success in this eity. During the last 20 years he has written policies amounting to almost untold nillions of dollars, in the same time he has adjusted losses running up to hundreds of thousands of dollars. In his agency be has employed three clerks, who are constantly engared in attending to the details of the office, whilst MIr. A. gives his whole time to the general management. The following list comprises some of the staunchest Companies in this country and Europe, which are represented by him; viz.: Cuntinental Fire Insurance Co.; German American Insurance Co; Guaranty Fire Insurance Co.; Hanover Fire Insurance Co.; Holfiman Fire Insurance Co.; Merchants Fire Insurance Co. ; Ningara Fire Insurance Co.; Queen Fire Insurance Co.; Royal Canadi.u Fire 'Insurance Co.; Roger Williams Insurance Co. ; Shawmut Insurance Co.; New York Life Insturance Co.

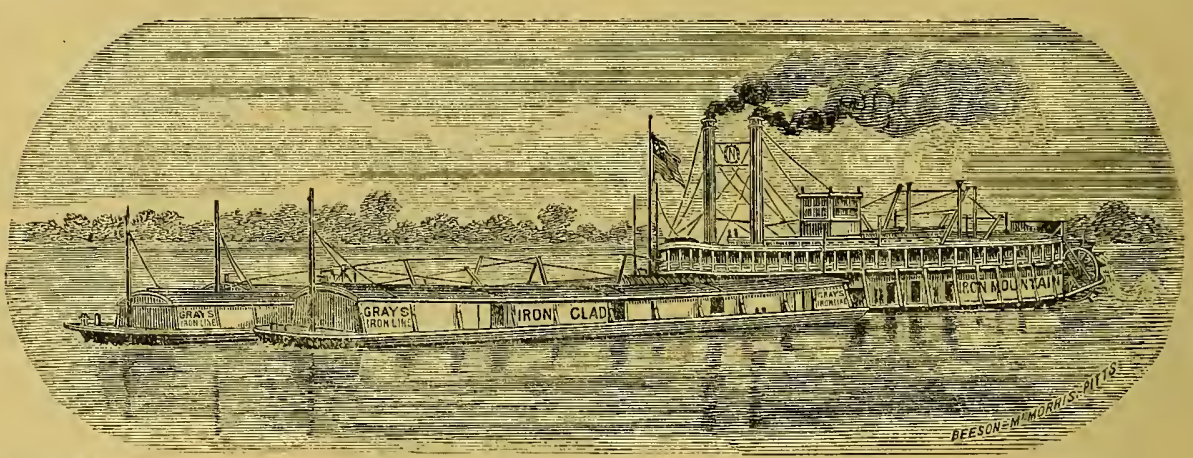

\section{GRA Y'S IRON LINE,-Freight Transportation, Office, 94 Water St.}

Contingent upon the industrial manufactures of Pittsburgh, Gray's Iron Line is entitled to particular mention in any records, from which may be derived a detailed knowledge of the varions resources of this city. As the Pioneer Line of Barge Transportation of general merchandise from Pittsburgh it was established in 1863, with a view to afford shippers reater facilities in the river transportation of heary freights to points in the West, North and South-West from which they would otherwise have been virtually cut off, the Iron Line at once became a permanent intitution, conducive in the highest degree to the advantage of manufactures, and consequently to the entire community. In the line of heavy freight transportation the company gives special attention to that of Steel and Iron Rails and Pittsburgh manufactures from Pittsburgh to all points. The Proprietors of what has now become an enterprise of more than ordinary importance, are Capt. R. C. Griy and Capt. M. W. Bett\%hoover, the former acting as ceneral manager, W. $\mathrm{P}$. IcConnell and J. H. Dunlip heing respectively secretary and superintendent.

As the largest undertaking of the kind in this part of the country for inland navagation, and river transportation the facilities of this company are somewhat extended and consist of the Steamers Iron Hountain, W. C. Gray Master ; Fearless, Thos. Greenlee, MIaster and Ironsides, Jas. McDonald Master, 35 model barges for regular freights, Irou etc., etc., and 5 barges designed for carrying bulk grain, having a total capacity of $\$ 140,000$ bushels with a tonnage of 1400 tons each. For safety, speed and economy this Line has justly achieved a matchless reputation, as may be inferred from the continued addition's made to it, and its long and nseful career. No men in Pittsburgli are better known, or more highly esteemed than Capts. Gray and Bettzhoover. Their connection with the growth and prosperity of the Iron City has been a very intimate one. Grays Iron Line is but one of many beneficial enterprises to which they have lent their names and advanced their capital, employing in this branch of their business, alone, over $100 \mathrm{men}$. They may well be entitled to consideration as promoting in no small degree the industries of Pittsburgh. 
JAMES MCQUISTON \& CO.-Pittsburgh Galvanizing Wks., 26th\& Railroad Sts.

A very important industry contingent upon the use and manufacture of Iron, adding to its durability appearance, and arlapting it for many purposes otherwise out of its range, is the process of (ialvanizing a business of Which Messrs. James MeQuiston and Co. make a successful speeiality. Established in 1871 at the present lucation, the firm was at first McQuiston \& Kraft, the latter however withdrawing in 1873 left the title of the louse as at present, the company being nominal. The plant is a very extensive one, and covers an area of netuly one acre, fection, which the skill and assiduity of Mr. MicQuiston has secured in results, war be illustrated by the perthat he alone has been entirely successful in galvanizing Cast Iron Bath Tuls, a desidcratum achieved only by superior knowledge and experience, as well as unapproached facilities. The latter may be estimated by the capacity, which is from 6 to 10 tons of Wrought Iron Pipe per day and six tons Sheet Iron, proving that the establisliment is second to none in the country, and complete in every respect. The business under the management of Mr. MeQuiston is rapidly increasing, a very conclusire evidence of the ability with which it is noanaged, and the thorough excellence of the work turned out. When in full operation 20 hands are employed in the work, many of whom are skilled and experienced workmen. The enterprise of James McQuiston \& $\mathrm{C} 0$. is heartily commended as adding no little to the industrial prosperity of the city, and filling a highly useful and necessary place. Prompt, reliable and enterprising, the firm has acquired a position to which it is justly mntitled by the exercise of these characteristics, for which it is widely known and respected. Galvinize 100 dozen Coal Hods per diem.

\section{CARTER BROTHERS \& CO. - Wholesale Grocers, No. $259 \& 261$ Liberty St,}

In a history of the advance and development of Pittsburgh, whth reference to conmercial affairs, the Wholesale Grocery trade must always occupy a very prominent position, as having conducer in no small degree to the present mercantile importance of this community. Among those houses whose extended transactions and high standing entitle them to more than casual mention is that of Messrs. Carter Brothers \& Co., Wholesale Grocers and Coffee Roasters, making specialties of Teas and Toluaccos. Established Jan. 1, 1867, by John A. Carter and David A. Carter under the above style, the "Co." being nominal, the firm soon took a conspicuous place for its energy and the rapid increase of its business. Commencing with but a comparatively small capital, the house at the present time carries an average stock of from $\$ 40,000$ to $\$ 50,000$, while their yearly sales will compure farorable with that of any other house in the same line of business. The ample business premises of the firm are situated as above, and consist of one large building, 35x114 feet, with steam elevators for hoisting, and steam engine for grinding and wasting coffee. Nine hands are eniployed in the various departments, the trade of the house extending through Pennsylvania, Olino and West Virginia. The partners are natives of Washington $\mathrm{Cn}$., Pa., came to Pittshurgh 12 years ago, and since that time bave taken an active part in promoting the general advantages of the city, and have gained a reputation for themselves that entitles them to the esteem and consideration of the community.

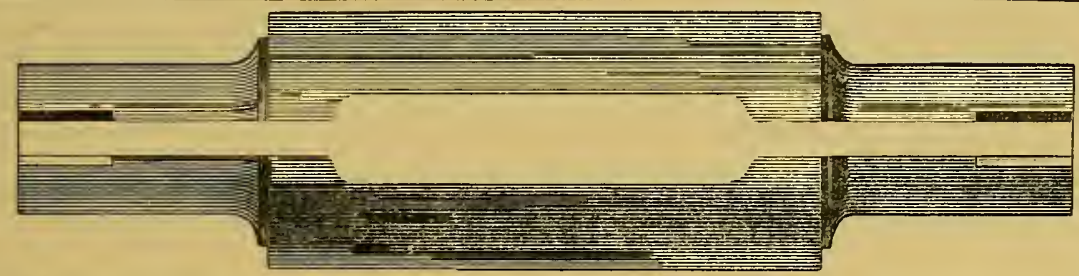

TOTTEN \& CO.-Fulton Foundry, Cor. 24th and R. R. Sts.

Pursuing a special branch in the conversion and manufacture of iron, and conducting a business of great magnitude and importance to the industrial prosperity of the city, the bouse of Totten \& Co. is not to be onitted fromi a work seeking to set forth in detail some adequate exhibit of the resources of Pittsburgh. The business wlich is now conducted, under the above style, by Messrs. Robt. C. Totten and N. B. Hogg, was originally established by the former in 1863, and from its very inception has not only been eminently successful. lut achieved a suecial position and reputation of its own, for the manufacture of Hollow Chill Rolls, and Rolling Mill Machinery. In the invention of the Hollow Chill Roll, (protected by letters patent 1869 and 1877,) Mr. Totten became the discoverer, aiter rears of lahor and investigation, of one of the most raluable appliances known in the manufacture of iron. It is not the intention in this work to explain the principles upon which this roll is constructed, or from which its superior merits are derived. The success attendant upon its introduction to the trade is the highest guarantee of its usefulness, 90 mills having been supplied with them during the past two years, over 520 rolls being in operation. Of these 11 essrs. Totten \& Co. are sole manufacturers, and possess ample facilities for supplying them in anv lensth, and from 5 to 36 inches in diameter. Besides this important improvement the firm are the only manufacturers of Chillerl Rolls cast to shape, securing advantages in the uniform density and durability, of grooved surfaces never before attained, and possessing other merits that have stood the sererest tests during the past 12 years.

The plant of the firm is located on $24 \mathrm{th}$ St., and covers an area of some three acres, the machine shop leing $70 \times 120$ feet, and the foundry $85 \times 225$ feet, containing much machinery of remarkable size and power, including can turn fly wheels twenty-five feet in diameter, chill rolls 30x108 inches, one planing machine ton feet wide by thirt $v^{-}$-six feet long, being the largest piece of mechanism of the kind in the United States, except one at the Charleston Navy Yard, and other appliances, operated by two powerful steam engines and hoilers. Some idea of the capacity of the works may be indicated by the fact that a plate for moulding plate glass was constructed here, weighing 81,000 lbs. which was planed on one side to a perfect surface, being perhaps the most ponderous work of the kind ever executed in the country. In the manufacture of Heinles Combined Friction and Cog Pinions the firm enjoy a monopoly, and are noted as well for their various makes, Roll Pinjons, Gearings and Mill Machinery. The senior partner was formerly connected with the Fort Pitt Foundry, whose products in the casting of heavy ordinance have a world wide repute. Here Mr. Totten acquired the practical and metallurgical knowledge that has been of such manifest usefulness in his present enterprise, and which, for more than a quarter of a century, has connected him with the industrial interests of Pittshurgh. The testimonials and flattering commendations received unsought by the firnı during the past few years, would fill many pages of this volume. It is enough, however, to say, in this connection, that no house occupies a higher place, or is more entitled to the position achieved than Messrs. Totten \& Co. of the Fulton Foundry.

Messrs. Totten \& Co. are now filling an order from England for Hollow Chill Rolls, and expecting other orders from Europe. They are largely engaged in the manufacture of Nail Machines, having erected most of the largest Nail Factories West of the Allegheny Mountains as well as some in the East. They have recently sent to England Nail Machinery for cutting steel nails, a branch that must also become prominent in the near future in this conntry. They have erected some 30 first-class Rolling Mrills in the past 15 years, more than an $\mathrm{y}$ other similar establishment in the country, and of necessity have the most modern patterns for this class of work. 


\section{S. MORROW \& CO.-Manufacturers of Street Lamps, Cor. Market St. \& First Ave.}

The firm of S. Morrow \& Co. is of late formation, but this statement should not be construed to convey the idea that the members of the firm are novices in the line of business in which they are engaged. The founder of the house, S. MLorrow, Esq., wils, previous to his death in February, 1878, for 45 year\% identified with the manufaeturing interests of this city, and established the business of which his present suceessors are now the worthy representatives. The new firm, doing busiuess under the style of "S. Morrow \& Co." is composed of Mr. J. Liloud Lytle and Mr. Janies Morrow, the son of the tormer proprietor, who suceeds as a partner, with a full knowledge of the lamp business and tire wants of trade. With every faeility before possessed, and the addition of new and improved maehinery, and the infusion of fresh vigor and euterprise, the present tirm may be relied upon as not only keeping up the standard of perfection in the produets that charaeterized the house of S. Morrow, but making advancement in every detail that the times require and pursuing a eourse ereditable to themselves and to the Iron City. To this end they will continne to manufaeture the Round Globe Street Lamp (of which S. Morrow was the in ventor), whieh has long been aeknowledged to be the neatest and most consistent lamp for illuminating streets, parks and entranees that has ever been produced in this country, and other special and ordinary designs for stock in trade and to order, including the Square City Street Lamp, both for gas and with gasoline tank attachment, appropriate for use in eity or town. In this line of industry this constitutes the only manufactory of Street Lamps in our eity, and have the most complete equipments for carrying on the bnsiness West of the mountains. As a firm that of S. Morrow \& Co. is of the most highly commendable character, and to old patrons of the former proprietor, and to all others throughout the eountry, who wish estimates for either public or private eon tracts, we would respeetfully call attention to this house, believing that we are serving the purpose of this work, in so doing, to the greatest advantage to the publie.

\section{UNION CHAIN WORKS,-Reiter \& Co., 29th and R. R. Sts.}

The manufaeture of Chain of erery description is earried on extensively by the firm of Reiter \& Co., at the corner of 29 th and R. R. Sts. The present frin was established in 1878, but Mr. Reiter, Sr., has been for many years prominently identified with the manufacturing interests of this city, having been olle of the original founders of the La Belle Steel Works. They manufaeture in their extensive works, which are well located, conveniently arranged and fitted with exeellent machinery, driven by a fine engine, a very superior quality of ehains. The greatest care is taken to produce none but first-elass work, and no chains of an inferior quality are permitted to be sent out from this establishment, all being submitted to a thorough practical test before going to their eustomers. The iron used is the best quality and highest grades to he had. The purpose and design of the firm is to make an A. No. 1 chain, equal in all respects to the luost eelebrated English brands. Wherever their chains have gone or been used they have given the lighest satisfaction. They employ none but skilled workmen, who, by the system of testing employed in the establishment, are stimulated to the greatest eare in their work. They manufacture now at the rate of 600 tons of ehain per anuum, and are having a steadily increasing demand for their products in different parts of the country.

Mr. Geo. Reiter, senior member of the firm. was born in Baltimore, Mrd., but has for many years resided in Pittsburgh, and has been largely interested in the manufaeture of Iron and Steel, and closely identified with other important industries and the general interests of the city. He is well and favorable known, and is a highly respeeted and

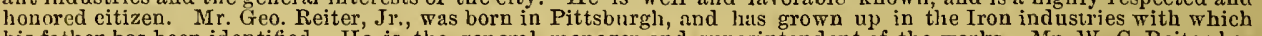
his father has been identified. He is the general manager and superintendent of the works. Mr. W. C. Reiter has chirge of the office busiuess and books of the firm. Both the sons are young possessed of energy and business experience, and the establishment is one in which the Iron City may feel a justifieable pride. Father and sons, in establishing their enterprise, whieh in a measure is a new one in this eity, bring into its management large experience in a business point of view, and great energy. They are men of the very highest character, and the firm is every way reliable and trustworthy, and fully merits the high esteem in which it is held, and the largest sueeess in their enterprise.

\section{BRIDGE \& BOWMAN,-Practical Plumbers, No. 28 West Ohio St., Allegheny.}

The Plumbing establishment of Bridge \& Bowman, located at No. 28 West Ohio St., Allegheny, was founded in 1871 by the present proprietors. They oceupy a three story brick building, 20x70 feet, and employ on an average six skilled workmen. Their weekly pay-roll amounts to about $\$ 75$. For the past three years their business bas averaged $\$ 18,000$ per annum, but previous to the "hard times," eommeneing in 1876, it would reach a much larger sum. Both members of the firm are practical plumbers, Steam and Gas fitters, and they are general dealers in Gas Fixtures, Lead Pipe, Sheet Lead, Hydrauts, Pumps, \&e. Their trade is located principally in the city and its immediate vicinity, and will compare farorably with that of any similar establishment. Mr. Bridge is a natire of England, and was born in 1839 , and came to this country when a child. Mr. Bowman was born in Allegheny City in 1848, and has always resided there.

\section{BAKEWELL, PEARS \& CO.-Pittsburgh Flint Glass Works, South Side.}

Among those firms which are most intimately conneeted with the history of Pittshurgh, its infant struggles, growtl and subsequent prosperity, sharing and promoting every matter of pullie interest, the louse of Bakerwell. Pears \& Co. will assuredly take a prominent position. For three-quarters of a century its career has been elosely allied to the Glass trade in all its varions stages, and to a marked degree ennducive to the thrift and importance that places this branch of our manufaetures upou so solid a footing. Established in 1808, under the style of Bakewell, Payn \& Bakewell, the suecess of the enterprise, as the first of its kind west of the Alleghany mountains, was assured from its inception. In 1840 the firn name was ehanged to its present style hy the admi-sion of $\lambda / r$. J. P. Pears, who, for 30 vears, until his death in 1874, was one of the most prominent of our glass manufaeturers. The present flrm, wliose indiridual mombers areBenj. B. Campheli, Thomas C., Benj. B., and Harry P. Pears, succeeded to the business in 1878. These gentlemen are descended from the original founders of the enterpirise, and may be stid to have an acquired as well as inherited knowledge of the Glass trade, which is evidently turned to the best interests of the house, in securing a general superiority of work in those specialties for whieh the firm has become celebrated. In 1854 the plant of Bakewell, Pears \& Co. was removed from its ancient site on the ground now oceupied by the $B$. \& 0 . R. $R$. depot to its present loeation in Bingham St. South Side. In making this change various improrements were made, ind tlie factories considerably enlarged and more perfectly adapted to the modern requirements of the business. The establishment now oceupies an area of several acres, consisting of 2 furnaees, 10 pots each; 2 warehouses, $40 \times 125$ each, and iron-clad; store house, paeking room, cutting shops, offices, and other butldings, supplied with one engine and boiler for driving the machinery-25 horse power, and engaging the labor of 125 artizans and others, necessitating a weekly disbursement of over $\$ 1,400$. The wares manufactured by this house are mainly in the line of alt deseriptions of Crystal Glass and Cut Table Ware, Bar Serviee, Druggists' Furniture, Lanteru Glasses, and all sorts of blowu and pressed goods, together with the finest cut, etched and engraved ware, for which they have achieved a reputation unsurpassed, if equalled, by any competitor in the country. With such a product and sueh a history, it is not too much to assert that the firm of Bakewell, Pears \& Co. is regarded in every respeet as being representitive of the Glass trade, and the general enterprise of the community. 
JOHN GANGWISCH,-Allegheny Valley Brewery, Foot of 46th Street.

The annual increase in the consumption of malt liquors, has not only been of the highest advantage to the agricultural producer of gruin, but in affording a channel for the occupation of labor and ciljital, has done much to enhanee the industrial thrift of the community, both ju the employment of numerous operatives and the suggestion of more temperate and frugal habits, on the part of the public at large. Engaged in this useful industry, Mr. John Gaugwisch est:tblished the Allegheny Valley Brewery in 1876 after a long, varied and comprehensive experience. Born in Baden, Germany in 1821, Mr. Gangwisch came to the United States when 27 years of age, first having acquired a thorough knowledge of brewing both in a practical and theoretical manner. Here lie worked for many years as foreman in the establishment of John Beck, the pioneer brewer of this eity, engaging subsequently in business for limself, in company with two others, as partners, and purchasing a planing mill on Liberty St, whicll was fitted up and adapted fur use in his special vocation. This property being purchased eventually by the P. R. R. Co., he afterwards erected the Union Brewery before the construction of the present plant. The Allegheny Valley Brewery is one of the uost prominent establishunents of the kind in the city, it represents an investment of over $\$ 50,000$ and is adapted to the business, by the introduction of every modern appliance or appointment necessary for the perfection of the product, and supplied with ample cellars 60 feet deep, surmounted by ice houses, securing at all times a low and even temperature. The buildings are extensive and cover, in connection with yards aud ice ponds, an area of not less than one acre, having a eapacity of 10,000 barrels, at which it is now running, with a large local trade, to supply which three wagons are required, heav y shipments being made daily to the survounding country.

MI. E. J. Reinhardt, a nephew of MIr. Gangwisch and for many years book-keeper for the Smithfield National Bank, has cliarge of the books and general business of the concerns, and is well fitted for the responsibilities of the position. The trade mark of the establishment as indicated in all their barrels, is blue and green, while the excellence of the Beer produced is testitied to by the favor it has secured, being considered equal in flavor, color and purity to any brand made in the United States.

\section{T. \& J. T. IMeCANCE,-Merchant Tailors, No. 196 Liberty St.}

There is perhaps no firm in Pittslurgh, in the same line of business, that is better or more widely known than that of Messrs. T. \& J. T. McCance. Established iu 18t5, and during the 34 years that have since elapsed, identified with the growth, industries and prosperity of the city, the house is certainly deserving of more than brief mention. With ample facilities for a large and increasing business the house of Messrs. Mrcance have more than ordinary advantages to offer their customers. As importers direct of the finest fabrics of France and England, an unusually choice assortment of these goods will always be found in hand, together with the best products of American looms. Twenty skilled operatives are employed in the custom department, two cutters and several sewers. The premises are of the most spacious, consisting of sales and exhibition room, $26 \times 110$ feet, located as above, stocked with the choicest goods known to the trade. As a firm the house of T. \& J. T. MreCance occupy a position, and have attained a repute, that emanates from years of toil and patient endeavor, supplemented by those qualities of commercial and personal integrity that have always been at the basis of their transactions, entitling them to the esteem and respect of the community, with whose progressive development they have been so closely allied.

\section{AVERMANN \& CO.-Dry Goods, Trimmings, Carpets, Wall Paper, etc.}

The very large and prosperous establishment of $A$ vermann \& Co. is located on Penn A venue, between 33d and 34th Sts., with a branch on same avenue, near 41 st St., at both of which places they are doing a large and prosperous trade. The business was first started by B. A vermann, in 1867, near the present location, in a small room, and witls small capital. It increased so rapidly that in a short time he was compelled to move in to the large store room now occupied by the firm. It is 20 feet front by 75 feet in depth, and is filled witl a very large. complete and choice assortment of the various goods in their line to the amount of $\$ 20,000$. Mr. Rud. Westerman and Mr. Henry A vermann were admitted into partnership with Mr. B. A vermann after removal to the new rooms. The firm is one of the most prosperous, in their line of trade, in that portion of the city in which they are located. The business has been irom the commencement in the eliarge of Mr. Henry A vermann, to whose popularity, enterprise, ability and business tact is mainly due the great success of the establishment, and the large annual business, amounting to $\$ 25,000$, they are now doing. The branch store near 41st St. in in charge of a younger brother of MIr. H. A vermann, who also displays the same business qualifications as his brother, and is doing a very fine business.-Mr. Bernard A vermann, the senior menber of the firm, was born in Germany in 1824, and came to the United States about 32 year's ago; has worked uearly ever since at Shoen berger's Iron Works, accumul'ting, while working there, his capital to start the business of which he is now the honored head, and from which he is now deriving so handsome an income.

\section{G. A. SCHN ABEL,-Carriage Manufactory, Penn Ave. \& 37st Street.}

Among the many branches of industry, which have contributed to the wide spread reputation of Pittshurgh as a manufacturing centre, that of farriage Building in its varinus branehes, is one of the most important. The superiority of Pittsburgls Wagons and Carriages is acknowledged wherever they have been used One of the leading manufactories in this line, is that of Mr. G. A. Schnabel, wliose extensive works are located at the corner of Penn Ave. and 31st Street. The lusiness was established in 1860 by Mr. Martin Schnabl, father of the present proprietor, who conducted it until his death, which occurred in 1873 , when s.Ir. G. A. Schnabel succeeded. The main buililings are two in number at the location named, one $24 \times 65$, and one $48 \times 130$ with numerous other smaller buildings and a spacious yard. Mr. Sehnabel carries a stock of ahout $\$ 10,060$ and manufactures every description of I.ight (arriages, Express and Road Wagons, Spring and Coach Top Wagons, and Velicles of every kind required, paying especial attention to ordered work. He aims at the highest degiee of excellence, and the greatest durability in all work turned out, and the reputation of this establishment for rclia-
bility keeps a full force of skilled workmen employed all the time, and the trade which is principally local at present, is gradually extending to different parts of the country. Mr. Schnabel was born in Pittshurgli in 1854, and was educaled to the business in his fither's establishment, acquiring a thorough and complete knowledge tliercof, on every detail and department. He is a young man of fine business ability and attainments energetic, enterp=ising reliable, and is pushing his already large business with commendable zeal and vigor. 

THOMPSON, EPPING \& CARPENTER-Keystone Steam Pump Works,

In the manufieture, design and inveration of Stean Pumps, it is safe to assert that no firm in the West has achiered a higher reputation than that of Atessis. Thumpson, Epping d. Carpenter, whose plant is lereated as above, ant who, from the extent and chatreter of the busincss transacted, are entithed to spechal mention in this work. The tirm which was

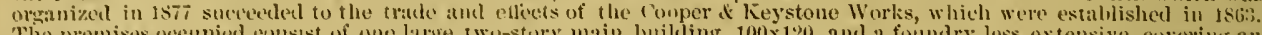
The premises oreupied consist of onc large twa-story main building, 100x120, and a foundry less extensive, covering an

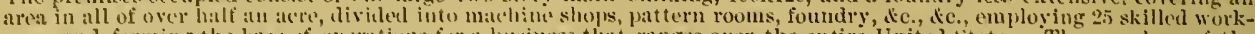
men, and forming the base of operations for a business that ranges over the entire United states. The members of the firm are all natives of Pittsburgh, and are as follows: J. 1). Thompson, Henry Epping, and W1. 11. (arpenter, the latter having charge of the gencral business; the general management being in the hands of shr. Elpping. The proalucts of the house are mainly in the line of stem l'umps, many of which are mantactured uncter letters patent owned by and

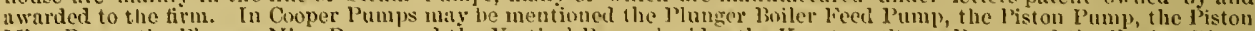
Atine Pump, the l'lunger Ifine Pump, and the Vertiul Pump, hesides the Kegstone Steam l'ump and the Epping Direet Aeting Pump-all being adapted and speefally fitted for certain uses, which they perfeetly subserve, as shown by testimonials from the highest nuthorities, jucluding engineers, mechanieians and manufacturers that would oecupy many pages of this work. In addition to the munfacture of Steam l'umps, Brass Castings for Rolling Mlills, tingine and Railroid Work, are made fo order, the facilities of the establishment insuring the bist class of work at the lenst possilile expense. In every respeet the house of Messrs. Thompsou, Epping d (arpenter is a most desirable one with which to tages, or guarantee, in the aecomplishment of every work undertaken, nure satistactory results.

\section{BIRMINGHAM FOUNDRY and Machine Shop,-Manufacturers}

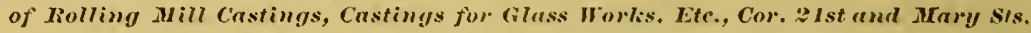

In the iron interest, Pittshurgh stands speeially prominent; her iron moduet are unsurpassed wherever introduced. Among the prominent and reliable estahlishments in this braneh of inlustry, and one that is entitled to a brief notice in this volume, is that above mentioned; not beeause of its magnitude or specialties, but for its ample facilities and superior productions. It was established by teo. 1. Fisher, Jeter Wentzel, and others. It has enlared its facilities and kept apace with the times. It hats a cipital invested of not less than 550,000 . The machinery ancl material neeessary to peosecute the business suecessfully involves an expenditure of $\$ 15,000$. An ammal business of some $\$ 30,000$ is done, even in these times, when hw priess and geueral depression is prevalent. The works oceupr three buildings, with a frontage on 2 st of 4 feet, and a depth of SS feet. In addition to these commotious huildings, the grounds attaehed and used for husiness purposes corer an area $120 \times 1$ to feet. The foumdry and machine sliop are spracious and complete in all their requirements. Eighteen skilled mechanies are enployed, at an expeuse of \$1,000 per month. The motive power to propel the various machinery is furnished by a 20 -horse power engine. The tracte of this estalilishment is principally lobal and in a healthy, growing eondition. The owners are energetice using every legitimate means to extent and enlarge their trade. They rely for their increase and prosperity on their promptness and the superior clanacter of all work podmed. They take special prite in their alsility for turning out maelninery and castings ndapted for grass works. The tirm consists of Geo. L. Fisher, D. I. Thomas, and lerer Wentzel. Mr. Fisher was born in (iermany in 15:39. Mi. Thomas was born in Pittsburgh in 15\%2. Mr. Wentzel was born in Germany in 1830 . He eame to l'ittsbursh in 184t. They are all we'l and farorably known in business circles. Their enterprise and good social standing entitle them to respect and confidence as citizens and suceessful business men.

\section{WILIIAM FAIRMAN,-Undertaker \& Embalmer, 41 West Ohio St., Allegheny.}

This is one of the oldest undertaking establishments in the two eities, having been established orer half u eentury ago by Mr. Robert Faiman, father of the present proprietor, who died Oet. 5,1575 , in his $72 d$ year, and suceessfully conduet ed the husiness for t3 $^{3}$ years. Mro. Wh. Fairmun has been in business for himself some 15 years, but is now condueting the old husiness established by his father. Je occupies a three-story lurick building, isx120, at the location above numed, aud carries a full stoek of Caskets, Cotbins, shrouds, :tud all things pertaining to the business. He also embalms bodies by the most approved processes, and at reasonable rates. IIis anmul business anounts to about slo,000 in the two eities :ind surrounding town. Mr. Furman was born in Allegheny City in 1840, and is a lifelong resident of the city.

\section{C. HECKEL,-Merchant Tailor, No. 131 Federal St., Allegheny.}

Among the many merchant tailoring establishments of Pittsburgh and Allegheny, we commend Mr. C. C. Heckel,

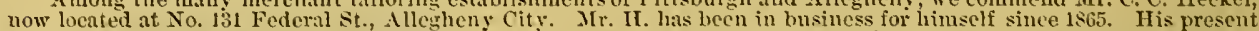
salesroom is $13 \times 75$ feet, and his stock cousist of a tine and seasonable assortment of the latest styles and most desirable fabries for gentlemen's wear of both foreign and domestic manufacture, selected expressly for this market, which he is prepared to make to order into (rirments or suits in the latest and most fashionable manuer. Fine Dress Suits, for instance, made in the best manner for $\$ 20$, upwart. II cetrries a stock of about $\$ 3,000$ to $\$ 4,000$, and lis annual busiuess reaches $\$ 16,000$. He employs 10 tirst-class $w(1) \mathrm{km} m$, and allows no work to go out of an inferior quality. Mr. Heckel wis born in Germany in is34, and came to this country in 1849 .

\section{ISAAC TA YLOR,-Importer and Wholesale Dealer in Dry Goods, \&c., 129 Wood St.}

The many ad rantages possessed by the city of Pittsburgh, as a commercial as well as manufaeturing center, shonht not be orerlooked by those who have hitherto vegarded it as simply the grand headlyuarters of the iron and glass trades of the United States. With facilities unsurpasserl by those of her sister eitie's, Pittshurgh has become an important commereial metropolis, and purchasers from abroad are rapidly beeming convinced of the fact that they ean purchase Dry Gools and other articles here as low as in tho New York or Philadelphia markets, and at a considcrable saving of time, freight and other expenses. In ennection with the Dry Gooks trade, the housc of Isaae Taylor, at. No, 129 Wood St., may be mentioned as one of the most prominent in our eity. Established in 1851 , the business since that time has been conducted by $3 \mathrm{r}$. Taylor in person, who now oceupies the entire building of four floors and basement, at the number above namied, giving emjloyment to seven clerks and assistants, and a number of traveling salesmen, with an extensive trade thronghout the western portion of Pennsylyania, Olio, Virginia and West Virginia. Mr. 'Taylor imports th portion of his foreirn coods direct, and his domestic falbries are purchased directly of the manufacturers. The rarions departments of his establislment are well supplied with the most desirable articles required by the retailer or country merchant, and it has ever been his aim to treat his customers in such a uanner as to retuin their eonfidence and respect. 


\section{J. P. SMITH, SON \& CO.-Lamps and Glassware, No. 189 Liberty St.}

Pittshurgh is noted tliroughout the country as the headruarters of the Cilass trarle of the United States, aud that she is justly entitled to that proud position may be realily helieved after even a cursory glance thromgh somm of tha leadiur establislinents of the suoky (jity engaged in that line of business. Prominent among her representative houses we may inention that of J. P. Sinith, Sin is Cb., which oceupies tlie entire four stories and basement of the spacious briek warehouse at No. 399 Liberty st, $22 \times 110$, and filled from cellar to attic with a magniticently arranger and julieiously selected stock of Lanns in every varisty, the cut (jlass Ware, Silverware, lBronzes, Majolica Wane, lisq., who continued the business alone until 1870, when his som, Mr. W $n$. L. Sinith, was arlinitted, the firm name and" st yle beconing as above. Mr. S. H. Windley has been the competent and efficient head book-kceper of the estahlishment sines 1569 . In 1870 the business transacted by this house did not exeed $\$ 70,000$, but in 1878 it had reached the limulsone sum of $\$ 168,000$. The tirm comploys seventeen assistants, and in addition to the alove, five traveling salesum, representing the interests of the house all through the Southern and Westcru States. The business is divided into two departments, wholesale and retail, and the louse is eonsidered one of the most solid and reliable in its line in tlie West.

IRON CITY BRIDGE WORKS, - C. J. Schultz, Prop., 2007 Garson St. S.S.

At the Iron City Bridge Works are manufactured Iron Lattice, Truss, A rch and Plate Bridges; also Jron Viarlucts, Railroad Turn 'Tubles, Trestles, de., Iron Roofs, Steeples, Cranes, Iron Buildiugs and Bridge Bolts. Work'of this nature uecessitates spacious buiklings, of which this firm possess two: one on Sidney St. in dimension 50 feet frolut hy 156 feet in lepth, and one on 2 sth st., 50 feet front by 120 feet in deptls. Tlie power is furnislied by a $40-l$ sorse fuw er engine, requiring two boilers. The number of hands employed varies necessarily witls tlie asmount of orrers the tira may have in hand, all of the work being lone on orler ; this number has ranged from 25 to 200. In the jerfecting of the work four Departments are inade use of: 1st, Macline, 2nd, Forging, 3d, Fitting, 4th, Rivoting. The produet ions all being mede to order, in consequence the amount of stock carried and annual business must fluctuate considerably according to circumstancoss. The present stock is valued at about $\$ 10,000$. Last year's businoss anounted to \$j), $0(0)$, hut somle years has reached $\$ 200,000$. The trade of the Iron City Bridge Works is not local only, but exteluds both East and IV est. The specialties are Iron Bridges, Iron Buildings and Prison Work.

Mr. C. J. Schultz, the proprietor, was horn in the city of Luelsec, fermary, in 1823 . Ife came th New York in 1819, started business in Cincinnati in 1854, from whence lse reinoved his business to Pittsburgh in 1850. MIr. Schult\% begall his business carrier alone, and with but small capital. His energy and prudonce have built lim lais bresent fortune. That lie is a man of character, far above the ordinary, is evidenced by thes many positions of trust and lornor held by him, select City Councilman, Direetor of Banks, President of Rail Road Connany, Manager of Allogheny (i)unty. Work IIouse and Insurance Companies, Board of Eilucation, and inany otiers indicative of worlh and uprightness. The Iron City Brilge Works do not fear to contrast their productions with those of any like enterprises ity of durability combined with strength.

\section{T. MEHIN W ALKER,-Marble and Granite Worker, 161 Lacock St., Allegheny.}

Mr. Walker is a thorough practical Marble and Granite Worker, and learned his trade in Allegheny City. He enmmeneed business in his own name in oct. 1878, with a capital of $\$ 1000$. He has three men employed, and his prospects are remarkably favorable. His business has steadily increaser since he began, and lids fair to rival that of many
older houses. Ife manufactures every deseription of Marlole and Granite Monuments and II earl Stones, Wlite and Colored Marb]e, Mantles in a variety of elegant designs, and deals in Marble, Plaster of Paris, Lime and Cement. Grave work is the specialty of Mr. Walker, and he has turned out some very elegant sfiecimens of this description of work. Mr. Walker was born in Washington $\mathrm{Co}$. Pa., in 1857, and has been a resident of Allegheny since 1869 . His trade extends through Western Pennsylvania, West Virginia and Eastern Ohio.

\section{JAMES LITTELL, - Wholesale Wines and Liquors, 237 Liberty St.}

Fol more than a quarter of a century the name of Mr. James I.ittell has been identified with the business interests and material prosperity of the Sinoky City. The extensive business house of which he is at present sole proprietor was established seventeen years ago as Littell \& Mechlin, and continued by them until 1875, wlsen Mr. Mechlin withdrew from the firm. This is generally recognized as the most extensive as well as the most reliable and important establishuent of its kind in the city. Mr. Littell imports largely of the finer qualities of pure Wines, Brandies and Lirjuors, and deals extensively in the best grades of American Whiskies, de. The specialty of this house is the well known brand of "Old MI Whisky," which, for purity and excellence, is unequalled. Mr. Littell occupies the old stand, which, for seventeen years, has bern the headquarters of the trarle, and is a large and commodigus three-story brick structure, $22 \times 200$ feet, at No.237 Liherty St., and his annual sales amount to not less than $\$ 250,000$. Mr. P. S. Ogden is the accomplished and reliable bookkecper of this house, and J. C. Bruff, as traveling agent, represents its interests on the road. The business is in the two cities, the oil regions and the neigluboring towns of I'ennsylvania, Oinio and West Virginia. Mr. Littell was horn in Olio in 1824, but has resiled in Pittshurgh for the past 40 years. IIe is a member of the city council from the 21, st ward, and is at present chairnan of the finance committee. He was for some time city gauger, and, in every position which he has been called upon to fill, has done credit to himself and secured the conlidence and esteem of his constituents and associates.

\section{KAY, McKNIGHT \& CO.-Machinery and Supplies, No. 80 Water St.}

The business now ennducted by the above named firm was estahlisher in 1868 by fieorge H. Stover \& Co., Mr Kay being then in their employ. In 1875 they were sucereded by the present proprietors, who have added largely to the business of the old house. They accupy the spacious four story ware-house at No. 80 Water St., extending through to First $A$ ve, and transact an annual business of about $\$ 125,000$. They manufarture the Lewis Patent fl ydraulic Jack, and rfal extensively in Marhinery ant Mechanical Supplies of every duscription, Steam Pumping Nachinery. Iron and Wool Working Tools, Belting, Hose, Cordage, Oakuin, \&c., and are agents for the following well known and popular artieles: the Blake Stean Pump, Bulkley Patent Condenser, Canden Pipe Cutting Machine. Chapman Open Way Valve, N. Y. Belting \& Packing Co.'s liuhber Croods, Cotton, Linen and Pubber lfose, Iron and Wond Working Machinery, Portable and Stationary Engines and Boilers, American and English Wire Pojpe, Corrlage and Oakum of all grades, Best Oak-tanned Leather Belting, Emery, Emery Wheels and Machines, Spun Cutton, Waste, and supplies of all kinds for Manufacturers, Steam Boats and Oil Wells. Their trade is located in Pittsburgh and vicinity, and in the States of Ohio and West Virginia. Mr. W. MeKnight and Mr. J. C. Kay are the present nembers of the firm, and were both horn in Pittsburgh in 1850. Although young men they have marle for themselves an honorable rreorrl in the mercantile crommunity, and built uj a business which will compare favorably with that of any similar estublishment in the United States. 


\section{WM. ROWBOTTOM,-Practical Plumber \& Gas Fitter, 260 Beaver Ave., Allegheny.}

As early as 1350 the firm of Bartley \& Rowbottom was established in that portion of the city, then known as Manchester. In $1871 \mathrm{MI}$. Rowbottom purchased the interest of Mr. Bartley, and has since conducted the business in his own name. He occupies the first floor of the spacious three story brick edifice, $20 \times 100$, at No. 260 Beaver A venue, currrying on the business of Plumber, Gas and Steam Fitter, ani dealer in Gas Fixtures, Steam Fittings, Sheet Lead, Lead Pipes, Sewer Pipes, Hose, \&e. His business is conducted in three separate departiuents, the front twenty feet of the premises being used as sales room and office, the next forty-five feet as the working department, and the remainder of the room for storage. Mr. Rowbottom is a practical mechanic, and gives his personal attention to the business. He employs six hands, with a weekly pay-roll averaging about $\$ 50$. His stock, which is full and complete in all its departments, is valued at about $\$ 4000$, and his annual business reaches from $\$ 12,000$ to $\$ 15,000$, which is largely of a local character. Mr. Rowbottom was born in Philadelphia, in 1829, but has for many years resided in Allegheny, taking an active interest in municipal affairs. He is at present member of City Council from his ward, and has held that position for several terms, greatly to his own eredit, and to the satisfaction of his constituents. He is a public spirited citizen, and an energetic aud thoroughly reliable business man, possessing the entire confidence and respect of the commuuity in which be resides.

\section{ALLEGHENY COLLEGIATE INSTITUTE, -30 stockton $A v$.}

Rev. Thos. C. Strong, D. D., is the president and founder of this institution, which comprises in its curriculum the regular college course, requiring the usual Freshman, Sophomore, Junior and Senior terms of attendance-a thorough preliminary examination being of course requisite for admission to the Freshman class. The facuIty conprises seven teachers, and the Institute itself (which was opened in September, 1878) is located at No.30 Stockton Avenue, Allegheny City, and fronts on one of the many parks which beautify that city. The attendance, at present, is principally from Alregheny City, but the College will be prepared, at the opening of the next collegiate year, to supply boarding and receive pupils from a distance. Dr. Strong, the president, was born at Flatbush, L. I., May 23, 1824, and is an alumnus of Union College, N. Y., being a member of the class of 1841. He is also a graduate of Rutgers Theological Seminary, class of 1845 , and was ordained a minister November 12 th of that year, when he at once assumed the pastorate of the Reformed Churches at Rosendale and Bloouingdale, Ulster County, N. Y. He settled at Newtown, L. I., Dec. 12, 1819, where he was called to the pulpit of the Bleecker-street Reformed Dutcb Church, at New York city, where he remained until May, 1866 . He then removed to Ithaca, N. Y., and from that place went to Aurora, Cayuga Co., N. Y., Dec. 13, 1871. He accepted the presidency of Wells College, and thenee removed to this city in August, 1875. Dr. Strong, besides being the president of the Collegiate Institute, is also pastor of the Central Presbyterian Church, Smithfield street, Piltsburgh.

\section{WM. IIEMM,-Plumber, Gas and Steam Fitter,-3208 Penn Av.}

The most extensive and complete PIumling establishment in this part of the city is that of Wn. Klemm, at No. 3208 Penn A venue. His establishment is fittel with engine und hoiler, and machinery of different kinds of the newest and most approved styles. Every kind of Plumbing ippliances, Pipes, Fixtures, etc., etc, are to be found here, and all kinds of Plumbing work is done in the most prompt and reliable manner. Particular attention is given to fitting houses with gas and water. Mr. Klemn began the Plumbing business, near his present place, in 1865, in partnership with a Mr. Dietrich. In $1870 \mathrm{Mr}$. Dietrich retired from the firm. Mr. Klemm continued the business, gradually enlarging his works. In $1878 \mathrm{Mr}$. Klemm's entire establishment was burned out completely, since rhen he built his present convenient, handsome and well arranged estallishment. He was born in Gernany, in 1839, eame to the U. S. with his parents in 1810, and four years later to this city on a raft down the Alleghen $y$ River. Early in life he learned the Locksmith trade, then he learnect the trade of Glass Mould Making, after which he learned his third trade, the Plumbing trade, and started in his present successful business in 1865 . Mr. Klemm is a gentleman of bigh eharacter. He has been a member of the School Board of his ward, possessing the esteem of all.

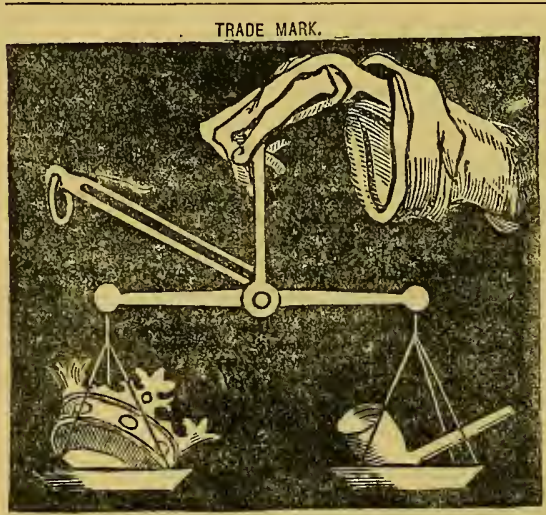

\section{WEYMAN \& BRO.-Tobacco.}

No. 81 smithfield st.

Factory-Nos. 5 \& 7 Union St. and 112 Liberty St.

Emploving thousands of operatives and producing an annual revenue to this city of not less than $\$ 3,000,000$ - half a luillion of which is prohalily disbursed for labor, the Tobacco business is justly regarded as an interest of the utmost importunce, and conlucive in no small degree to the industrial and commercial thrift of this community. Among those liouses that have been greatly instrumental in promoting the interests of this branch of trade the Wevmans-father and sons-have been conspicuous. More than haif a century bas elapsed since Mr. George Weyman established the business now conducted by his son, MIr. B. F. Weyman, on behalf of the estate. Beginning in a very small way, the founder of the house, contending with many difficulties, gradually increased his financial resources, extended his oprerations, and eventually acquired a position in this community that few men have been so happy as to attain, and perlaps fewer still so richly merited. A man of comprehensive views, large capabilities, marked benevolence and probity, Mr. George Weyman was universally esteemed and respected. Conducted uuder the title assumed at the demise of its originator, the business has contiuued to prosper, and stands now among the largest producers in the State. They manufacture all kinds of Chewing and Smoking Tobacco, and Snuff-the article made by this firm being considered by the trade and consumers as superior to any other brand. The aetual amount of production cannot be obtained. The wlolesale part of the business is transaeted from the factory, which is located at 112 Liberty St., and Nos. 5 and 7 Union St. The building is a 4-story brick, $40 \times 110$ feet, containing all the necessary machinery and appljances for the successiul prosecution of the trade; 31 hands are employed here, and the products find a ready salo through Pennsylvauia, Ohio, Indiana, Illinois, West Virqinia, and other States. The store at No. 81 Smithfield St. is devoted exclusively to the retail trade, and does an extensive business in all grades of Tobacco, making a specialt.y of Imported and Domestic Cigars. Mr. B. F. Weyman--who, as betore remarked, conducts all the operations of the concern-is a native of this city, born in 1842, and has always resided here. His career, both in civil and military life, lias been an honorable one. Those having relations with this house may depend upon receiving all the advantages that result from a long experience, large facilities, and undoubted reliability. 


\section{STOUGHTON \& HAID,-House and Sign Painters, 45 Fourth Avenue.}

The nembers of the above named firm are W. R. Stoughton and L. E. Haid. These gentlemen are both practical workmen, and were formerly engaged in busiuess individually, but in Jauuary 1878 associated themsel ves as partners. This firm nccupy two Hoors and basement in the three story brick building at No. 45 Fourth Ave., 20x45 feet, and give employment to from fifteen to twenty experienced painters, with a weekly pay-roll averaging about $\$ 150$. They enjoy a prospcrous trade in the city and surrounding districts, and do only the very best work. Mr. Stoughton is a Pennsylvanian by birth, having been born in 1848, and Mr. Haid is a native of Germany, born in 1845. Both gentlemen stand ligh aud cnjoy the confidence of the community.

\section{R. BEATTY, SON \& CO. - Wholesale Commission Merchants and Flour Dealers.} No. 193 Liberty St.

The large and spacious edifice at No. 193 Liberty St., $22 \times 120$, with four stories and capacious basement, is occupied by the firm of P. Beatty, Son \& Co., successors to $H$. Riddle, Son \& Co., Wholcsale Commission Merchants for the sule of Country Produce, and extensive dealers in Flour. This house was founded in 18.50 , and bas been in possession of the present proprictors for five years. The members of the firm are R. Beatty, R. W. Beatty and J. Beatty, and six assistants are employed. The annual business of the house is about $\$ 75,000$. $\$ 250,000$ has been reached when prices were high. They receive consignments from all the Western States, and their trade extends all over the two cities and adjacent territory. To consigners from an y section this house afford unsurpassed facilities. Its senior member is well and fivorably known in business circles for more than 30 years. Their estallished connections with shippers in the various large eities of the East secures them advantages that enable them to dispose of all consignments with satisfactory results.

\section{W. H. BAKEWELL,-Awnings and Awning Frames, No. 2 Isabella St., Allegheny.}

Mr. Bakewell is a thorough, practical Sail, Awning and Tent manufacturer, having carried on one of, the leading establishments of New York previous to coning here. He has been at his present locition since May, 1877, and has huilt up a large and flourishing trade in the two cities and among the river men. He manufactures all kinds of house and store Awnings and Awning Frames, Canvis Horse Covers and Feed Bags, Wagon and Express Covers, Tents of every description and size, and attends to Sail-making in all its branches, and the Canvasing of steamboat decks. His specialty is in the manufacture of fine and ornamental Window Awnings. Mr. Bakewell was born in New York city, Feb. 16, 1826 , and has resided in Allegheny for the past two years.

\section{S. W. HARE \& CO.-Practical Plumbers and Gas Fitters, 1825 Carson St., S. S.}

This well-known establishment owes its origin to Mr. S. W. Hare, who commeneed here in 1865. His business has bcen uore than usually successful, and as convincing evidence of its growth and extent, we find the amount of stock held by the firm to be almost $\$ 1,000$. This, though large, is demanded by the volume of business, which yearly runs up to $\$ 9,000$. This speaks well for the quality of the work done at this establishment. Two buildings are occupied by up Chandeliers for gas and oil, Lead and Sewer Pipe, I.amps, \&c., are constantly in stock, and offered at the lowest ruling rates. As the firm consists of practical mechanics, the work intrusted to them is always executed in a substantial manner, and rarely fails to afford the fullest satisfaction. Mr. Hare was born in St. Louis in 1845, and came to this city in 1847. He enjoys the respect, in a high degree, of his fellow citizens.

\section{EAST END HOTEL,-Penn Avenue, East End. James Ives, Proprietor.}

In the East End are to be found some of the most elegant residences and beautiful grounds to be found in any city - two of the main thoroughfares leading through this attractive portion of Pittsburgh. The suburbs are laid with wooden pavemeyts, and near their junction is situated the East End Hotel (formerly Eastern Exchange). It is an excellent hotel, affording a delightful home for families and others who desire good boarding and the conveniences of a first-class house, combined with the attractions of the suburbs, and free from the sinoke and dust of the city. The house oecupies a commanding position, surrounded by ample grounds, with a beautiful lawn in front, provided with conveniences for the comfort and pleasture of guests on summer evenings. The hotel building is connmodious and furnished with all the modern conveniences. It is four stories in height, has 100 chanb 3 rs, and accommodations for 300 guests. Its halls, dining rooms, parlors and sitting rooms are lar:re, well lighted and ventilated, and thoroughly fitted up and furnished. It is a desirable place for private families, business men, persons of place

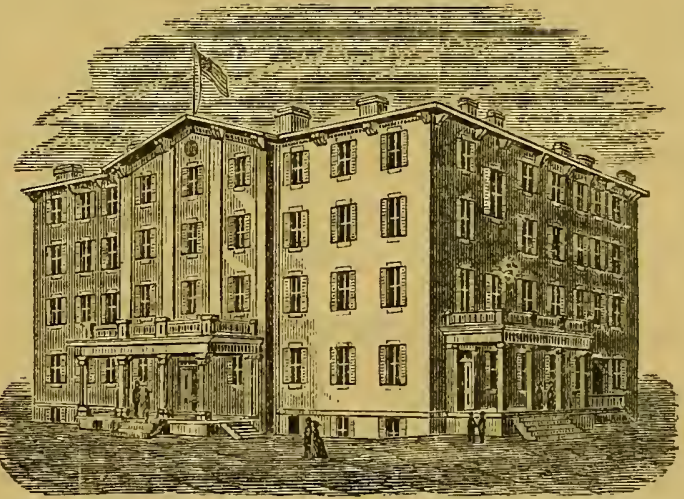
lome, whilst at the same time each one can enjoy retirement and privacy. The convenience of the house to the Pennsylvania R iilroad, and the frcquent passing of trains to and from the Union Depot, the large amount of husiness transacted at the stock yards in the vicinity, give the house also a large transient custom. The rates, both for temporary guests and permanent boarders, are exccedingly moderate. The gas used in this establishment is manufactured on the premises. Over 30 assistants are cinploved in the loouse, making expense for help about $\$ 450$ per month. The proprietor, Mr. James Ives, has had charge of the house since, 1873 , and personally superintends its management, giving the mist thorough attention to all the details, neglecting nothing which can add to the pleasure or comfort of guests. He is a native of England, having been born in Hertforclshire in 1846. Previously to coming to Pittsburgh, he was for a number of years cnnnected with prominent hotels in New York city, and is thoronghly experienced in hotel management. Mr. S. F. Haverstick, elerk, and Mr. S. Goldin, room clerk, are also gentlemen of hotel experience, as well as attentive and courteous to all. 


\section{SCHOMAKER \& CO.-Commission Merchants, 198 and 200 Ohio St., Allegheny.}

Since April, 1877, the firm of Schomaker \& Co. lias been located at Nos. 198 and 200 Ohio St., Allegheny. Previous to that time, Mr. Wm. Schomaker had been for 17 years in business in Puttshurgh. The firm now uceuries the large double watehouse at the numlers named above, and transacts a general Commission Business, as well as dealing in Flour, Grain aul Feed, at wholesale only. They carry an average stock of about $\$ 10,000$, and their aunual sales reach the roumd sum of $\$ 120,000$. Onc bookkeeper and tive other assistants are employed in the establishment, and the trade of this house exienis through l'ittshurgh, Allegheny, and many of the aljoining counties. Mr. William Schomaker was born in (iemany in 1829, and came to this eity in 1842. Mr. F. D. Schomaker was born in Allegheny City in 1854 , and has since residicl there.

\section{DOBBS \& RISINGER,-Bent Wood Work, Smallman St., near 25th.}

The firm or Dobbs \& Risinger was founded in June, 1874. Mr. Dobbs had formerly been engaged in busincss at New Brighton, Penn. December 1,1575 , the factory was removed to Wheeling, West Virginia, where it is still loeated. In February, 1878 , the $y$ opened their office and wareroms at the present location, where they carry a complete line of Bent Wood Work, and Carriage and Wagon Materials, with home and foreign trale, and they employ latest improved machinery. The members of the firm are Rev. George Dobbs and Mr. Smith Risinger. Rev. Mr. Dobhs was born in Washington County, Penn., in 1814. He was left an orphan at the age of five years, and owes his success to his own energy. He was raised on a fam, and at an early age learned the trade of chair framer. He was subsequently engaged in the coal and lumber business. He started in the Bent Wood business at New Brighton, where he laid the foundation of the present prosperous house. Mr. Risinger is a native Pennsylvanian, and is a carpenter by trade, and followed that business until engaging in the present line. He has the management of the faciory at Wheeling, and thoroughly understands the business. The "Industries of Pittsburgh" spreads to the rorld information of many finc establishments that are known to but a few even of its citizens. The firm of Dobbs d Risinger is composed of gentlemen of high character and ability.

\section{H. CARTER,-Sezving Machine Bazar, Corner Fifth Ave. and Market St.}

At his "Bazar" all the leading Sewing Machines in use are sold, bought and exchanged, and a variety of all makes of machines and attachments are to be found in stock, including manufacturing as well as family machines. It is not an agency confined to one machine, but a general Sewing Nachine Bazar, where all linds can be compared and tested, and exchanges made. A repair department is also attached. In addition to the sewing machines all sorts of appliances, at tachments and requisites for machines are kept, such as bemmers, fellers, braiders, needles, oil, thread, ete. Nachines are sold on weekly and monthly paynents, as well as for cash, and a good assortment always on hand to select frou. Mr. Carter was born in England, in 18.7, and has been in Pittsburgh 17 years. His present business has been establishcd some two years, previous to which he was business manager for different sewing machine companies, and has an experience in the sewing machine business of 14 years in this eity.

\section{WIM. COOPER \& CO.-Wholesale Grocers, 215 Liberty St.}

The business was founded in 1837, under the firm name of Cooper \& Young, who continued as partners till 1846. $\mathrm{Mr}$. Young withdrew, succeded br Wm. Cooper, Esq., (the present senior partner,) who, with bis brother James, under the title of Cooper \& Bro., conducted the business till 18 49 , when William went to California, where he engaged in mercantile occupations for three years. Returuing about 1852 he again entered the firm, which became known from that time as $W \mathrm{~m}$. Cooper \& Co. In 1857 , through the death of James Cooper, A.S. Getty and John Cooper were admitted, no change; however, being made in its style. John Cooper dying in 1s 76 , the surviving partners continued the business. William Cooper, Esq., was born in Irelaud, and came to this country when quite young. His experience in business atfairs is remakably comprehensive. Mr. Getty is a native of. Pennsylyania. He has been honorably connected with many public enterprises. This business occupies a large three story huilding, $20 \times 90$ feet, with ample cellars, all of which is engrossed by the firm, whose regular trade will average $\$ 150,000$ per annum. The specialties of this house are Wholesale Groceries, dealing largely in Fish and Feathers.

\section{ADAM RODRIAN,-Boots and Shoes, 119 Rebecca St., Allegheny.}

As a manufacturer of fine Boots and Shoes, Mr. Rodrinn has established an enviable reputation and enjoys the patronage of many of the leading families of Allegheny City. As he devotes his attention almost exclusively to custom work, his stock on himd is not necessarily very large, but does a good annual business, and steadily increasing. He employs experienced workmen, besides giving his personal attention to the business. His particular specialty is fine Custom Work and Repairing, and no job is allowed to leare his shop or store unless it is thoroughly and carefilly tinished in the best and most workmanlike manner. Mr. Rodrian is a native of Germany, but has long resided in the conntry, and his establishment, at No. 119 Rebece St., Allegheny, is well and favorably known.

\section{ST. JAMES HOTEL,-Liberty St., opp. Union Depot; J. K. Lanahan, Proprietor.}

Conducted both on the American and European plan, this farorite Hotel is an institution so well known and appreciated in Pittsburgh as to demand consideration in a work seeking to properly display in detail the resources of the city. The St. James is 4 monument to the enterprise and public spirit of its projector and proprietor, Mr. James K. Lanahan, by whom it was built, furnished and formally opened in 1867 , and since that period has been universally regarded not only as the most pleasant aud conrenient resort for all classes of the traveling public, but as one of the most home-like and comfortable public houses in Pittsburgh. Being conducted on the foreign as well as American plan, the choice of either is at the option of every guest, and the St. James is the only hotel in the city that affords these facilities. Located immediately opposite the Union Depot, on Liberty St., the site is most ad rantageous for travelers and others; and the general accommoditions, attendanee, furnishing, ventilation, bar and menu are all that can be desired, the charges at the same time being extremely moderate. The dimensions of the premises are $60 \times 100$ feet-the edifice being four stories in height and supplied with every facility for escape in case of fire or other accidents; all of which, however, are earefully provided against. Mr. Lanahan is one of the most widely knowa and esteemed citizens of this community. Originally from Ireland, he came to this country in 1845 , and for vearly a third of a century has been closely identified with Pittsburgh in the development of her varions commercial and productive interests, and as a member of city councils has invariably exerted an active influence for good upon the legisIative government of the city and its public measures and improvements. As proprietor of the St. James, he is a considerate and genia] host, never neglecting the well-being of his guests, and always promoting their ease and enjoyment, retaining their esteem, to which he is richly entitled. 


\section{SUYDAM, LA WRENCE \& CO.-Pittsburgh White Lead and Oil Works,}

office. 450 Irebecea st., Alleglion.

As an interest of great importance to the industrial thrift of the community, the manufacture of White Lead has long held a prominent place. Of those largel $y$ engaged in this branch of manufacture, the house of Snydum, Lawrence \& Cis., who atre the present successors to the oldest White Lead works in this seetion of country, established as it was in 1832, are entitled to particular mention, not alone [rom the extent of their operations in this directiou, but also on account of their conjoining, with the corroding of lead, the manufacture of Linseed Oil. This department of the business hat been carried on successfully for a series of years by MIr. M. B. Suydam, before the existence of the present tirn (which was established in 1877), united both industries under one management, the advantages of which to those familiar with either branch of trade are obvious. The plant of the tirm is situated on Rebeca St., in Allegheny City, and consists of two large three-story brick buildings, one of which is devoted to the nianufacture of Lead, the other to the production of Linseed Oil. The former, in its machinery and general appointments and aparat us, is perhaps one of the most complete establishments of the kind in the United States, and in all its departments, from the corroding berls to the packing room, in vats, mills and pumps, is about as perfect as ingenuity and capital can make it. In White and Red Lead Colors and Putty the product is a large one. The capacity for mauufacturing White Lead alone is 1,000 tons annually, while 200,000 gallons of Linseed Oil are expressed yearly in the building devoted to this purpose. Three powerful stetm engines are required to operate the machinery of the works, and $30 \mathrm{men}$ are constantly employed in the various departments. The goods prepared by this firm are marked and highly esteemed for their purity and excellence of color; they find a rearly market through Pennsylvania, Ohio, Michigan, Indiana and New York-the demand increasing at a very satisfactory ratio. As a firm, Messis. Suydam, Law rence \& Co. stand among the most proninent of their cotemporaries, and are heartily commended in every respect as being bonorable and reliable people with whom to establish thie most gratifying relations.

\section{FIRE \& BRO.-Dry Goods, Trimmings, \&c., 100 \& 102 Federal St., Allegheny.}

One of the leading houses engaged in the Dry Goods and Trimming business, in the two cities, is that of M. Fire \& Bro., whose warerooms are located at Nos. 100 and 102 Federal St., Allegheny. They occupy the double three-story louilding at the numbers given above, with a frontage of 35 feet on Federal St., and extending back 60 feet. Each floor is tilled with an admirably selected assortment of Dry Goods, Trimmings, dec, selected expressly for this market by one of the luost judicious buyers in the city, and is estimated at not less thian $\$ 30,000$ to $\$ 10,000$. They transact a wholesale and retail business, their trade being principally in the two cities and within a radius of 50 miles; their annual sales reaching $\$ 50,000$. Within the past iew months the increase in their business lias compelled them to enlarge their quarters, and they have now greater facilities than ever for the display of their fine stock and for waiting upon their customers. The members of the tirm are Mathias and Charles Fire, hoth of whom are natives of Germany, but for more than a score of years residents of Allegheny City and identified with the Dry Goods trade, in which they now rank among the leading louses.

\section{THE SINGER MFG. CO.-Serving Machines, No. 10 th St.}

For nearly a third of a century the branch office of the Singer Manufacturiug Company has been estallished in Pittsluurgh, during which period it has been so intimately connected with every interest of the comnunity, and so promotive of the general benefit as to demand special mention in this work. It is perliaps safe to assert that no Sewing Machine ever attained such a popularity, or deserved its phenominal success more richly than the Singer Sewing Machine. The local branch of this company has always been regarded as an important one, not only from the extent of the community immediately surrounding it, but flom the large district it controls, having established sub-agencies throughout West Pennsyl vania and contiguous States, embracing such points as Wheeling, Parkersburg, Keyser, Grafton, Huntington, Charleston, Lewisburg in West Virginia, and Johnstown, Greensburg, Indiana, Uniontown, Butler, IcKeesport, St. Petersburg, New Brightou, Washington, Alleghen y City, Brookville, Clearfield, and the South Side and East End of this city in West Pennsylvania, Marietta, Steubenville, and Gallipolis in Obio, requiring in all the services of over three liundred men to transact the business, whicb amounted in 1578 to over $\$ 300,000$. Their enormous returns, it should be remembered, are. in spite of the fact that the expiration of the Singer patents has led to the competition of numerous upstarts, who endeavor (in vain, however, it seems) to divert the public from its appreciation of the exquisite workmanship, durability and finish that has always characterized the products of the Singer manufactory, and it is therefore highly gratif iting an active vitality, resulting as wuch from the intrinsic merits of the macline as the ability displayed in managing so vast a trade. IIr. R. W. Steadman has for many years represented the company at this point. He is distinguished for his thorough comprehension of all the details of the business, and other valuable characteristics, which have no small influence in conducing to the prosperity of the concern which he rejresents.

\section{J. H. TRUXELL, -Tin Type Rooms, Cor. 5th Ave. and Market St.}

The entire third story of the large building, $16 \times 100$, at the corner of Market St. and 5 th Ave., has been occupied as a Photograph or tin type gallery for the past twenty-five years under various proprictors, one of the last owners being the late Mr. W. W. Charles, one of Pittburgh's most accomplished and gifted artists. The rooms were fitted up exclusively for this business with all the latest and most moderu appliances and conveniences, and are admirably lighted and arranged. In Siept., 1877, Mr. Truxel became owner and proprietor, and under the name of the Boston Tin Type Rooms has built up a large and flourishing business, making tin types a specialty, for which style of pictures be has acquired an en riable reputation in the two cities and surrounding towns. Il is pictures are true to life, and in an artistic point of view superior to many of the photographs taken by other louses, and much cheaper and more satisfactory. Mr. Truxell was born in West Virginia, in 1552, and learned his tradle in Wheeling some ten years ago, since which time he has given his exclusive attention to the business. Persons desiring fine pictures at moderate prices should give him a call.

\section{BOYD BROS.-Fine Confections, No. 27 Federal St., Allegheny.}

The Confectionery and Bakery of Boyd Bros., located at No. 27 Federal St., Allegheny, near the Suspension Bridge, was established in November, 1878, by Messrs. W. W. and J. D. Boyd, and the regular increase in their business since that time is evidence of the popularity of the articles manufactured and sold by them. They oceupy the spacious store rooms, $22 \times 120$ feet, in the four story brick structure at the location named, employing five assistants, and earrying a stock of about $\$ 3000$ in value, embracing every variety of choice confections of their own manufacture, and Foreign Fruits, Nuts, \&c. Both members of the firm are natives of Allegheny, and well and favorably known in the city of their birth, and throughout the surrounding towns. Their location is adnirably adapted for the line of business in which they are engaged, being central and on the main thoroughfare connecting the two cities, and near the Allegheny depots. Their stock is always fresh and desirable, and their prices corresponding to the times. 


\section{E. B. MERCER,-Teas \& Groceries, No. 80 Federal Street, Allegheny.}

This old and reliable Grocery House was established in 1812 by Mercer and Robinson, who wero succeeded by Mercer and Son, under which st:yle the basiness was conducted until 1878, when Mr. E. 13 Nercer became sole owner and proprietor. He necupies the spacions three-story brick warehouse, $23 \times 80$, at No 80 Foderal St.. directly opposite the Prittsburgli, Fort Wayıe and Chicago $k$. K. Hepot. Carrying als extensi ve stock of fine Teals, Choice Family Grocerics, Pure Spices, Sugars, Colfees, Roasted and Green, Canned Goods, Salt, Nails, White Wine and Cider Vinegar, and all articles usually found in a first class metrupolitan establishment of this description. Fish in great variety is the particular specialty for which this house is noted. NIr Mlercer's stock is valued at from $\$ 4,000$ to $\$ \hat{0}, 000$, aud his annual sales reach $\$ 21,000$, which are principally to parties in Allegheuy, Beaver and Butler counties. He has a large and flourishing trade, along the lines of Pittsburgli, Furt Wayne and Clicago, and the West Pentsylvania R. Rs. Mr. Mercer is a native and life-long resident of Allegheny City, where he was born in 1852. and is the wortlyy representative of a family name, which has for nearly furty years been indeutibed with the Grocery trade of Allegheny county.

\section{H. SMITH,-Brooms, Brushes and Grocers' Sundries, 41 Wood St.}

People not thoroughly familiar with the business avenues of Pittshurgh often surmise that we have bere one grand workshop of Iron and Steel productions, overlooking entirely the less extensive, but equally important manufactures of commercial requisites, and imagine that the branclies of trude usual to other cities are here neglected. One stuoll througl our busy thoroughfares will dispel the latter idea, and a stop at L. H. Suith's manufactory and store room will prove that in the line of Brooms and Brushes our city can compete with the best Eastern and other Western houses, hoth as to quality, style, finish and price. Established in 1874, as L. H. Smith \& Co., Mr. Smith became sole proprietor after a short duration of co-partnership, and has condncted the business with such success as to reach, in sales of Brooms, Brushes, Paper, Paper sacks, Wooden Ware, Staple Groceries and Grocer's' Sundries, an aggregation of $\$ 85,000$ annually, with an increasing trade through Western Pennsylvania, Ohio and West Virginia, and other more remnte sections, employing, in various capacities, 24 hands at the factory, store and upon the road. A native of this State, born in 1847, Mr. L. H. Smith has been, since the attainnent of his twentieth year, a citizen of Pitsburgh. and interested in mercantile industries, in which he has shown a marked proficiency, a strict integrity, and acquired a well deserved trade and reputation.

AGNEW \& CO. - Flint Glass, Vials \& Bottles, 0ffice, 153 1st Ave. Works, South Side.

Among the industries for which Pittshurgh is particularly noted, the manufact ure of Glass occupies the second position only in importance and as a source of commercial and industrial thrift. Occupying no inconspicuous place ainong its cotemporaries, the house of Aguew \& (o. are well deserving of special mention in a work designed to disclose in detail the resources and advantages of this city, as a producing and mereantile center. The plant of the firm is located on the Sonth Side of the Monongaliela Rirer, and consists in part of one main buildiug, 40x60 feet, and numerous smaller structures, covering in all an area of about one-third of an acre. The furnace is built upon an inıproved plan. It contains six large double mouth patent pots, and in eapacity may be classed with an ordinary 8 pot furnace. Here 55 operatives are engaged, for 10 months, in the manufacturing of every variety of Flint Glass, Vials, and Bottles, of staple sizes or to order, the product of this concern being remirkable for its perfection, enjoying a reputation for excellence over the entire United States. For the item of labor alone a weekly disbursement is necessary of $\$ 425$. The a verage annual sales of the house are at present about $\$ 40,000$, and rapidly increasing. Mr. Jolin Agnew, who supervises the operative part of the business, is regarded as a pioneer in the Glass trade of Pittsburgh, and is perhaps the oldest practical Glass manufacturer in this community, having completed his apprenticeship to Wm. MIcCully in 1837, and ever since that periorl be n intimately concerned in promoting the advancement and prosperity of this industry. The trade of the house extends over various States besides our own, iuc]uding Illinois, Indiana, Iowa. Louisiana, Marvland, Missouri, California, New York, Ohio, Oregon, Tennesee, Texas, West Virginia, Wisconsin, Michigan and the Canadas. Though there may be larger firms in the business than that of Agnew \& Co., none produce better goods, occupy a higher position, or are mure reliable and deservedly popular.

\section{JOHIN M. IRWIN \& SON,-Manufacturers of Furniture. 97 Smithfield St.}

This is one of the old reliable business houses of Pittsburgh, having been established in 1842, as John M. Irwin \& Co., under which style it continued until 1877 , when it becume as above. They are exteusive dealers in Furniture of every description, and manufacture most of the Furniture themselves Their factory is located at Nos. 13.15 and 17 Old A venue, and is $30 \times 120$, four stories high. Here they employ 38 experienced workmen, and their weekly pay-roll amounts to ahout $\$ 400$. Their sales-rooms are located at No. 97 Smitlitield St. (Howard Block), and are $20 \mathrm{x} 60$ feet ov the first floor, and $40 \times 60$ on the second, third and fourth. In addition to the hisiness carried on here, they manufacture largely for the retail trade. Thiey carry an average stock of ahout $\$ 35,000$, and their sales are correspondingly large. Mr. John M. Irwin was born in Pittslurgh in 1816, and is a life-long resident of the city. He is one of the oldest business meu in the city. Mr. James S. Irwin, his son and partner, is a native of Pittsburgli, and was born in 1847.

GRAHAII \& COURTNRY,-Salt M'f'rs, 254 \& 256 Beaver Av., Allegheny.

Adding materially to the industrial thrift of the community, and by actual production increasing the wealth and resources of the city, the tirm of Grahan \& Courtney should receive more than passing mention in a pulilication displaying in a detailed way the advantages, facilities and possibilities of Pittsburgh and its environs. More tlian 20 years ago the present plant of the firm was established by Mr M. M. Ross, who began in a very snuall way, the husiness leing sugrested by the accidental discovery of an inexhatustible salt well on the premises. In 1 ser $M_{\text {Messrs. G Graham }}$ \& Courtney succeeded to the concern, and at once hegan a series of improvements, and tlje application of new methods, that placed the works upon a par with any of a similas character in the country. As now enlarged, the establishment consists of one large hrick and frame two-story building, locited on the corver of Beaver Ave. and Juniata St., covering an area of half an acre, and clevoted entirely to the manufacture of Salt, the warehouse being at the corner of 1 arket and Juniati Sts., a one-story luitling, $48 \times 1000$ feet, where il stock is usually carried of from $\$ 8,000$ to $\$ 10,000$. The appliances and machinery of the works proper consist partly in one engine, 12 horse power, tind one boiler, $81 / 2$ feet wille by 100 feet long, and 4 feet deep, requiring, to operate, 400 bushels of coal ver diem. There are, besides, 5 lir re evaporating tanks, 9 feet wide by from 20 inches to 4 feet deep, traversed from end to end by copper steam-pipes. Ten employees are engaged in the works besides the proprietors, making a dislursement necessary of abont $\$ 6,000$ annually. The character of the product for purity and whiteness finds it a ready market in Pennsylpania and adjoining States, the sales anounting to $\$ 25,000 \mathrm{per}$ aunum, and increasing. Both partners actively participate in business. Mr. James Graham is nriginally from Ireland, coming to this city with his parents at a very early age. Mr. J. M. identified with and promoting the best interests of the efty, the house of Graban \& Courtney are regarded with the highest estecm as indispensable members of the producing coluluunity. 


\title{
JOSEPH HORNE \& CO.-Dry Goods, Notions, Straw Goods \& Millinery.
}

No. 77 d 79 Market St. \& 197, 199 \& 201 Penn Ave.

In recording an $y$ adequate account of the industries of Pittsburgh, and the progress made during the last quarter of a century in commercial and manuficturing importance, it would be impossible to omit. ntention of the house of Joseph Horne and Co. Established by the present Senior partner in 1848, the resources and trade of this concern have more than kept equal pace with the general prosperity of the Iron City. Fonnded with but a limited capital, but conducted with every advantage to be derived from a stainless lousiness policy, the success of the house inereased with each succeeding year, until at the present time it stands at the head of all similar establishments in Western Pennsylvania. With the rapid enlargement of its operations, it becanse necessary to add to the executive iorce of the
house, and with this end at various times, some of those who were most prominently connected with its prosperity, were admitted to the firm, which assumed the above title, and the business was divided into two destinct departments, occupying separate buildinus, each with $\mathrm{its}$ special jurpose. The wholesale house remained at the old location No. 77 and 79 Miarket St., appropriating the entire original premises, three stories $32 \times 120$, and a purposely constructed nnex. The firm in this division are Jos. Horne, C. B. Sliea, J. F. Jolunson and A. P. Burch field, all of whon exereise an active personal supervision of affairs. The retail department was removed to Nos. 197, 199 and 201 Penn A ve., upion the completion of Young. Men's Mercantile Library buildiug. The premises here occupied embrace 3 stores, with a frontage of 60 feet on Penn Ave., 180 feet in depth. It is one of the nost complete and spacious edifices in the city, securing the bulk of the first floor, arranging and fitting it in such way, as to make it the most sumpt uous sales room in the city. The dssistants. Doing a business that has reached an a verage of $\$ 1,500,000$ annually, with a staff of 140 euployees, this house affords facilities for buyers unequaled in the West, both from the advantiges derived from its employees, this house affords facilities for buyers unequaled in the West, both from the advantiges derived from its
great resources, and its enterprise in importing and enlarged connections. Conducing in so high a degree to the substantial benefit of the community, and indentified so closely with the growth and commercial well being of this city, the house of $J$. Horne \& Co. occupies a place in the general consideration, that redounds no little to the establishment of a reputation for Pittsburgb in keepıng with its real merits.

\section{DR. JAMES ORR,-Dentist, No. 77 Smithfield St.}

The dental parlors of Dr. Orr, at No. 77 Smithfield street. are centrally and desirably located and are fitted up in an elegant and attractive manner. Dr. Orr commenced his studies with Dr. S. P. Hulliheu of Wheeling, West Virginia, in 1852, and practiced in that city from 1857 to 1861 , wheu he removed to this city and opened an office. He has been eminently successful here and enjoys a large and lucrative practice. He is a thoroughly competent and skillful operator, and devotes his attention exclusively to the profession in which he is engaged. He has the tinest and most complete variety of instruments and apparatus for carrying on the business in all its departments, and in the manufacture of artificial teetl he has no superior in this country. In the nse of anæsthetics Dr. Orr is proticient, and has met with unvarying success in all cases where he has adninistered them. As an evidence of the estimation in which he is held by his brother professionals it may be stated, that Dr. Orr held the position of President of the Pittshurgh Dental Association from 1861 to 1862. In every description of fine work pertaining to Dental Surgery he particularly excels, having for many years made it his special study. His reputation is not confined to the limits of the two cities, as his practice extends through the adjoining counties, and even into Ohio and Western Virginia. Dr. Orr is a native of Washington Co., Pennsylvania, and was born in 1823. He hats resided in Pittsburgh since 1861.

\section{KIRKPATRICK, BEALE \& CO.-Sheet Iron and Terne Plate,}

\author{
office, 1+3 Ist Ave. Works, Leechburg, Pa.
}

Among those indnstries that it becomes the special province of this work to display, the firm of Messrs. Kirkpatrick. Beale \& Co. occupy no inconspicunus position, and from the character and magnitucle of their operations are entitled to more than brief mention. Cunn'cted in 1868 with the Siberian Iron Works, carried on by Messrs. Rogers \& Burchfield, they succeeded the latter firm in 1877 , and have since continued to prosecute the business with resolution and signal success, the sales averaging $\$ 215,000$ annually. The plant of the firm is located at Leechburg, Pit., a short distance from this city, and consists of numerous buildings, all admirably adapted, and huilt especially for the purposes to which they are applied; covering an area of over six acres, and containing, together with other improved unachinery, two trains of Rolls, five Puddling Furuaces, six Noolling Fires, several engines with an aggregate power of 200 horses, produciug the finest brands of Sheet Iron and Terne Plate of all grudes. The general office and ware rooms are located at No. 143 st A venue. The dimensions of these premises are $25 \times 90$ feet, and three stories high. Their trade, which is all ordered work, consists mainly of Shovel Iron, I ock Iron, Tea Truy Iron, Trunk Iron. Stove Body Iron, Stamping Iron, all grades, Cold Rolled Iron, all grades, special sizes being malde or cut to order, and Terne Plate. For these specialties the firm have acquired a reputation that is unsurpassed, and justly arises from the excellent character of these products.-MIr. Kirkpatrick and Mr. Beale are hoth natives of Pennsylvania, and have always been identified with the industrial interests of the community, as promoted through the Iinn tride. Mr. J. C. Wallace, the Company, is originally from Ireland, but has been closely connected with the maufacturing development of our resources for nearly thirty years. No firm orcupies a higher or more en viable position than Messss. Kirkpatrick, Beale \& Co., and none can inore easily maintain and perpetuate the esteem in which they are held by their cotemporaries and the public at liarge.

\section{W. H. HAMILTON \& CO.-Glass Manufacturers, Office, No. 26 Wcod St.}

Identified with one of those great special industries, for which Pittshurgh has established a wide celebrity, the house of W. H. Hamilton \& Co. is one of the widest and most favorahly known houses in Pittshurgh in this line of business. Founded in 1863 by the same firm, composed of W. H., J. T. \& J. S. Hamilton, to each of whom was ascriberl a different depariment in the work, the house has become favorably known, and with an annually increasing trade has fixed itself firmly among its coteniporaries with enlarged facilities, not only ample, hut perhaps unexrelled. The warehouse and counting rooms occupied hy the firm, are at No 26 Wond St., the whole of one large huilding being used for these purposes. The factories are located on 20 th \& 21 st \& Railroad Sts., and consist o1 five buildings, covering an area of about one acre, thoroughly adapted by prolonged experience and constant improvement to the business. Here are employed one hundred and seventy-five men and boys, skilled in the special manufactures of this concern, requiring a disbursement to this source alone of $\$ 84,000$ per annum. Every appliance in the way of steam power and labor-saving apparatus is brought into application, to secure the rapid execution and nerfect finish of the product, which consists exclusively of every gradr, kind and description of Flint Glass, Vials and Bottles. Particular product, which consists exclusively of every gradr, kind and description of Flint Glass, Vials and Bottles. Partichiar attained a very wide celebrity in the trade. With an extended influence, always exerted in behalf of the industries of Pittsburgh, and continuously directed in airl of every movement that will conduce more greatly to that end, the house of W. H. Hamilton \& Co. occupy a position that is equally honorable to itsclf and the community from which it originated. 


\section{PERRY M. GLEIM,-Druggist, \&c., Rebecca St. \& Allegheny Ave., Allegheny.}

The neat and attractive Pharmacy at the corner of Rebecca St. and Allegheny Ave. was established in 1873 by $\mathrm{Mr}$. Gleim, the present proprietor, with a moderate capital, which, during the past six years, has considerably increased. $\mathrm{H}$ is store, which is located in a two-story frame building, $18 \times 45$, is stocked with a full and complete line of Drugs and Medicines of the purest and best quality, Perfumeries, Brushes, Soaps, Toilet Articles and Fancy Goods, valued at about $\$ 2,500$. Mr. Gleim, being a graduate of the Philarlelphia College of Pharmacy, and haring had 12 years' practical experience in the Drug business, makes a specialty of preparing and compounding physicians' prescriptions in an accurate and careful manner, having in his employ competent assistance, and enjoys the confidence of the leading physicians in the city. His trade is of a local character, and vill compare favorably with that of any similar establishment in the two cities. Mr. Gleim was born in Harrisburg, Pa., in 1851, but has resided in Allegheny for a number of years.

\section{LEVIS \& BICKEL,-Solicitors of Patents, 131 Fifth Avenue.}

These gentlemen have both had considerable experience and extended practice as Counselors at Patent Law and Solicitors of Patents, although their present partnership and association dates back only to 1878 . They occupy offices at No. 131 Fifth A ve., a few doors abore Smithtield St., and their business extends throughout Pennsylvania, Ohio and many of the other States, thus enabling them to successfully prosecute all claims and secure information directly from headquarters. They attend carefully to all business before the Patent Office and Patent causes in the courts, prosecute all classes of Government claims, \&c., and furnish applicants with all information relative to procuring Patents, the modus operandi, \&c., \&c. Both gentlemen are highl y recommended, and enjoy the confidence and respect of all with whom they have had occasion to transact business. Mr. O. D. Levis was born in Zelienople, Butler County Pennsylvania, in 1835 , and came to Pittsburgh in 1857. Mr. C. K. Bickel was born in Columbus, Ohio, in 1853, and located in Pittsburgh in 1875.

\section{WATTLEY \& CO.-Embroideries, Laces, \&c., 109 Federal St., Allegheny.}

The elegant and extensive establishment of C. Wattley \& Co., located at 109 Federal St., Allegheny City, is the recognized headquarters for the latest, most fashionable and novel designs in fine Embroideries, Laces, Trimmings and Furnishing Goods. This house was established in 1867 by the present proprietors. Their stock is now full and complete, comprising every variety of fine Embroideries, Laces, Trimmings, and Ladies' and Gents' Furnishing Goods of foreign and domestic manufacture. They occupy a spacious three-story brick structure, $231 / 2 \times 110$ feet. Their trade is located in the city and neighboring towns, aud is increasing so rapidly that the firm have been compelled to seek more coumodious quarters, and have now in process of construction a new and elegant business house at No. 109 Federal St., which will be ready for occupancy about October 1, 1879. The firm of C. Wattley \& Co. consists oi Chas. Wattley and Jno. Thompson; the latter is of the firm of Thompson \& Lyons, linseed oil manufacturers.

\section{KELLY \& JON ES,-Steam Warming and Ventilating Apparatus, 141 First Ave.}

This house, which was established in 1875, sueceederl the Angell and Blake manufacturing company of New York City in this section. They occupy four floors, each $25 \times 80$, at No. 141 First A venue, carrying a stock of from $\$ 5,000$ to $\$ 10,000$ exclusive of machinery, and transacting an annual business of from $\$ 80,000$ to $\$ 100,000$, which extends all over the country, and is principally connected with public works and with the trade everywliere. They manufacture Steam Warming and Ventilating Apparatus for either low or high pressure laundry machinery, steam pumps, steam boiling kettles, boilers for power etc., employing from fifteen to twenty hands with a weekly pay roll aunounting to about $\$ 200$. They have now before the Patent office two new inventions in Radiators and Heating Boilers, upon which they will obtain patents, in addition to two others already secured by letters patent. They are making improvements all the time, many of which are of a rery important character. Their specialty in manufacturing is in Steam Heating Apparatus, which they supply largely to public buildings, and to the trade all over the United States and Canada. Mr. J. T. Kelly was born in Allegheny City in 1850, and was engaged in business in Youngstown, Ohio, for four year's previous to coming here. Mr. George M. Jones was born in Lancaster, Pa., in 185̄1, but has resided in Pittslurgh since 1872. He receired his business education in New York City, where he became familiar with the Steam Heating business. The capital invested $b y$ this firm is $\$ 15,000$.

\section{J. SMITH \& SON,-Steam Dyers and Scourers, 52 Fourth Ave.}

The Steam Dying and Scouring establishment of J. Smith and Son was started in 1865 in a comparatively small way, but by strict attention to business, and the excellence of their work, their trade has steadily increased until they now occupy the three-story brick building, $24 \times 29$, at No. 52 Fourth A v., and do a business that will compare favorably with that of any similar house in the city. They have one large steam boiler, and the work is attended to by Mr. Suith and his four sons, who are all practical and experienced workmen in their line. They have added a branch house, located at No. 1511 Carson Street, South Side, under the charge of Joseph Smith, one of the Sons referred to above. This branch of the establishment is in operation since April 1879, but was previously conducted by Henry Helman since 1867 under Joseph's supervision. This house is doing a satisfactory business. To the residents of South Side we can cordially recommend this establishment. They will find Dyeing and Scouring of all kinds for ladies and gentlemen done with promptness, and in the most satisfactory manner. Mr. Smith, Sr., was born in England in 1817, and learned his trade there; H.W. and Joseph, his two eldest sons, were also born in England. Samuel and Chas. are both natives of Alleghen y City. The firm does every description of Dyeing and Scouring, making a specialty of Dyeing and Cleaning red gloves and plumes.

\section{T. M'GRATH,-Grocer, 1918 Carson St., Pittsburgh, S. S.}

This well-known gentleman occupies the premises above mentioned; it was previously conducted as a grocery by Chas. Hook, who was succeeded by Peter Schlegel. He, in turn, was succeeded by Mr. M'Grath, the present owner. Like a great majority of business inen, he commenced with very limited capital. By close attention to business he has greatly enlarged and extended the moderate trade of Mr. Schlegel. Mr. M'Grath's present stock of Groceries is worth at least $\$ 2,000$, and his annual sales do not fall short of $\$ 11,000$. His very convenient and well arranged store is a three-story brick, 20 feet front and 38 feet deep. An active lad assists $\boldsymbol{M}^{\prime} \mathrm{Grath}$ in his store, and the amount of business done is such as to afford them little idleness. The trade is chiefly local, and keeps pace vith the improvement in the times. Mr. M'Grath was born iu Ohio, in 1843 but has resided since infancy in this city, and is a highly respected citizen. 
JOHN WILSON \& SON,-Wholesale Grocers, No. 297 Liberty St.

The statement has frequently been made that in her devotion to manufactures Pittsburgh has neglected her mercantile or commercial opportunities. Whether this is true of other branches of trade or not, the remark is certainly not applicable to her Wholesale Grocery establishments, as may be seen by reference to the notices of her leading rerjresentative houses, and the statistics furnished relative to their importance and extensive trade in other portions of this work. Possessing almost unexampled facilities in her geographical position and modes of transportation, as well as in the enterprise and bigh standing of her leading merchants in this line, Pittsburgh can to-day furnish the staple articles of Groceries at prices which will compete successfully with Eastern dealers, and effect a great saving in freight to retailers throughout Western Pennsylvania, Eastern Ohio, West Virginia and the towns and cities along the banks of the Ohio River, and on the lines of the various Railroads centering here. Prominent among the bouses engaged in the Wholesale Grocery trade may appropriately be mentioned that of John Wilson \& Son, whose ware-rooms are located in the spacious and elegant four-story iron front building, 22x110, at No. 297 Liberty Street. This house was founded about thirty-three years ago by Mr. John Wilson, the present senior member of the firm, and Mr. John Watt, under whose management and administration the business was successfully conducted until 1869, when the present firm was established with Mr. George W Wilson as junjor partner. Their present quarters have been fitted up expressly for the convenience of the firm, and are supplied with an engine and boiler for hoisting purposes, and for beating the building during the winter season. They employ seven or eight assistants at a weekly expense of about $\$ 100$, and carry a full and complete line of choice groceries, comprising every article pertaining to this line, averaging in value about $\$ 60,000$. Their trade is principally in Middle and Western Pennsylvania and Eastern Ohio, and their annual sales will reach $\$ 300,000$. This house has never employed traveling salesmen, and is opposed to this system of drumming up business. They depend solely on the well established reputation of their house for public patronage. It is undoubiedly the only safe and legitimate method of transacting business.-Mr. John Wilson is a native of Ireland, but he has resided in Pittsburgh since 1842, and during all that time been actively engaged in business and identified with the Wholesale Grocery trade of the Smoky City. Mr. George W. Wilson was born in Pittsburgh in 1816 , and is a thorough, practical and wide awake business man.

\section{MITCHELI \& CO.-Stove Manufacturers, 14th and Etna Sts.}

No city in the Union has achieved such a deservedly wide-spread repntation as an industrial center as Pittsburgh. It stands to-day the foremost manufacturing city in the Union, and Iron in its manifold forms and varieties of manufacture is the principal and prime factor of her immense wealth and importance. The house of Mitchell \& Co., manufacturers of every description of Stoves and Ranges, is the oldest establishment in the city engaged in that line of business with one solitary exception, and that bouse antedates it only one year. It was founded in 1828 hy Thonas Mitchell, Thomas Sweeney and Mr. Campbell. After various changes in the firm name and style, it became Mitchell, Stephenson \& $\mathrm{Co}_{0}$, and by them the business was successfully conducted until 1878, when it became as at present, Mitchell \& Co. Fifty years ago, when originally started, the business was conducted in a small way, but, owing to the superior quality of articles manufactured hy this house, it steadily increased, until, at one time, it reached as high as $\$ 150,000$ per annum. Owing to the decrease in price of manufactured articles and the general depression of business in all branches, the present trade will hardly reach that amount, although it is one of the largest and best known houses in the city. Their warehouse and foundry buildings are located on the corner of Fourteenth and Etna Sts., and comprise one four-story brick structure with a frontage of 204 feet 6 inches on Etna St., with a depth of 30 feet, and a onestory brick foundry building, $175 \times 100$. The works have a capacity of 1,500 tons of finished work, and will compare farorably for size, capacity and general completeness of appointments, with any in the Western States. One 35-horse power engine furnishes the motive power for their extensive machinery, and 70 hands are constantly employed, with a monthly pay-roll averaging about $\$ 3,500$. They manufacture every variety of Stoves and Grates of the latest designs and most elaborate patterns, and their goods are noted for superiority of material and finish. Mr. Mitchell is a native of Pittsburgh, and has for many years been identified with her iron interests and manufactories.

\section{J. B. JONES \& BRO. -Wholesale Iron, Metal \& Steel, $73 \& 74$ River Ave., Allegheny.}

The iron interests of Pittsburgh are of course the most prominent and best known of all others. Among the foremost dealers in manufactured Iron, Metals, etc., is the firm of J. B. Jones \& Bro., which was inaugurated in 1872 by $\mathrm{J}, \mathrm{B}$. Jones alone, and in 1874 assumed its present name by the admission of James Jones. This firm keep in stock an assortment of Metals, including Copper, Brass, Lead and Zinc, valued at $\$ 2,500$, and transact a business of $\$ 35,000$ to $\$ 50,000$ anmually. Their establishment, including the metal yard, is 80 by 100 feet, and the power for the scrap nill is furnished by an engine and boiler of approved make; from 6 to 7 men being employed, running daily three pair of
shears, eutting from a rail down to sheet iron. They make a specialty of cut No. 1 Scrap for crucibles for steel works. Both partners are native Alleghenians, J. B. Jones having been born in 1847, and James in 1853; and this fact, taken in connection with their prices being always put down to the lowest possible figure, has secured them a reputation and trade extending not only throughout this, but all the adjoining counties and Eastern Ohio.

MAX SCHNEIDER,-Dyeing, Scouring and Refinishing Works, 253 Penn Ave.

This gentleman has been established in business at the abore location for the past seven years, during which time his trade has largely increased, amounting to between $\$ 3,000$ and $\$ 4,000$ per annum. Mr. Schneider occupies a brick building, $16 \times 95$, has one boiler, and employs three hands. He makes a specialty of Cleaning Lace Curtains and Blankets in a superior and highly satisfactory manner ; also Cleans and Dyes all kinds of Fabrics for ladies' and gentlemen's wear. He makes a -necialty of Dyeing and Cleaning Kid Gloves and Feathers, attending to all orders promptly. Mr. Schneider's trade is located in the city and surrounding country. He is a practical Dyer, having followed the business for 11 years, and understands all its details thoroughly, and never fails to give complete satisfaction.

\section{JOHN FROEHLICH, -Wines and Liquors, No. 464 Penn Ave.}

Mr. Froehlich commenced business for himself in 1868 in a comparatively small way and with moderate means. Since that time his trade has steadily increased and his capital augmented to a considerable extent. Between three and four years ago he erected the elegant brick building (three stories, with Mansard roof) which he now occupies. It has a frontage of $16 \frac{1}{2}$ feet on Penn St., extending back 100 feet, and is one of the finest and most imposing struetures on the avenue. Mr. Froehlich carries a full line of ehoice foreign and domestic Wines, Brandies, Gins, \&c., making a specialty of pure old Monongahela Rye Whiskies of superior quality and perfect purity. His average stock will amount in value to about $\$ 5,000$, and his annual sales will exceed $\$ 15,000$. He bas established an enviable reputation for keeping only the purest and best articles, free from adulterations, and his trade is steadily increasing throughout the city and adjoining towns. Mr. Froehlich was born in Germany, but has resided in Pittsburgh since 1855, where he has accumulated a handsome property and built up a flourishing and lucrative business. 


\section{J. HENDERSON \& BROS.-Wholesale Druggists, No. 507 th Ave.}

One of the most prominent firms cngaged in the Wholesale Drug trade in this city is that of J. Henderson \& Bros., which, estahlishcd in 1841 by W. Henderson, Esq., has always maintained a high position, aequiring from year to year a larger trade, and more available facilities. In 1859 , at the retirement of its founder, the present firm assumed control of the business, which has been conducted in a manner so entirely successful that the average sales are now about $\$ 100,000$ annually, employing the labor's of ten assistants, under the activo supervision of J. and A. C. Henderson, the respective members of the firm. The premises occupied and owned by the house are locited as above, and consist of one substantial brick edificc, having five floors, $24 \times 90$ feet, all of which is required in the transaction of the business, a large proportion of which is in the manufacture and sale of proprietary remedies, ownerl exclusively, and prepared hy this tirm-Henderson's Carmiuative, Cough Syrup, Cottige IV orm Candy, and Essence of Jaunica (Yinger, all of which are widely celebrated as being among the most ellective and efficacious medicines ever used. 'The Henderson hrothers are both natives of Westnoreland Co., this State, and were born respectively in 1822 and 1826 , coming to Pjtshurgh at a very early age, and devoting themselves to the Drug business as a life occupatjon. The ample measure of success attendant upon the efforts of this house has been largely due to the enterprising, houorable and liberal policy that has always characterizcd its operations, and it is just to say, that no firm in this city has achieved a bigher reputation for these qualities than that of Messrs. J. Henderson and Bros.

\section{CHARLES A. SCOTT,-Book and Job Printer, 132 Fifth Avenue.}

Not every person who has learned the trade is capable of "setting up" or designing a traly artistic specimen of job printing. To the mechanical portion of the business should be added the careful, critical eye of an artist, competent to "lay out" a job in a tasteful and elegant manner, and to execute it in such a style as to please the fancy and attract the attention. $\Lambda$ mong the many persons engaged in the Job Printing business in the Iron City, we helieve there is no one who turns nut more elegant and truly artistic work than Mr Charles A. Scott, whose office is to he found in the Methodist Recorder Building, No. 132 Fifth A venuc. Mr. Scott was born in the city of Allegheny in 1851, and established himself in the Printing busincss in Pittsburgh in 1872, doing every description of fine Book and Job work, Newspaper work, \&c., giving constant employment to eight bands, and at some seasons of the year requiring even additional force. Although the greater portion of his business is of a local character, he numbers customers in almost every State in the Union. A thorough practical prinier himself, Mr. Scott employs only first-class workmen, and his business is steadily increasing from year to year. Mr. Scott is agent for Allegheny Co. for Cott's Inproved Reversible Tiblet Biotter, which has many advantages over an y other now in use; first, hecause it allow's the use of both sides of the blotting sheet, or its removal entirely and substitution of a new one; second, it prevents the hinge of the blotter from becoming limber when a part of the block of paner is used; third, the clate lines of bill heads and statements are always covered by the blotter. These points make it the most handy and complete blotter on the market.

\section{CREA, GRAFAM \& CO.-Stoves, Ranges, \&c., 316 Beaver Ave., Allegheny.}

Warerooms, :6: Liberty st, I'ittshurgh.

The above named firm conmenced business in 1877, under rather discouraging circumstances at first, their buildings being cntirely destroyed by fire before they were completed. Nothing daunted, however, by their misfortunes, they immediately commenced to rehuilu, and erected works even larger than originally conteniplated. 'The grounds occupied by this firm have a frontage of 100 fcet on Beaver A venue, extending back 130 leet to an alley, on which are erected three conveniently arranged huildings, the first being 20x70, and used as the fitting and pattern llepartment, the second, $18 \times 25$, as the Enameling department, and the third, 50x60, as Foundry. Ten hands are employed in the various departments, at an averuge monthly expense of $\$ 350$. One twelve-horse power engine and one twenty-horse power bniler furnish the motive power for their machinery. This firm has recently opened a salesrooin at No. 262 Liberty St., Pittsburgh, where a fine line of Stoves, Ranges, Grates, Fronts, Fenders, ctc., are on exhibition, all of their own special designs and manufacture, reflecting great credit upon the young aud enterurising house. MIr. John Crea and Mr. Wm. Graham are both natives of Ircland, and came to this country in their early youth. NIr. James E. Crea, who has charge of the books and office department, is a native of Allegheny City, where be has alwiys risided.

\section{JOHN RLINZING \& CO.-Boots, Shoes and Gaiters, 1817 Carson St., S. S.}

$\mathrm{Mr}$. Klinzing succeeded $\mathrm{G}$. Conley, and has not heen long in the business. He bas, howerer, every reason to contimue it, and finds the demand for his work and his goods equal to his expectations His present stock is worth $\$ 2000$, and this stock is constantly replenishing with work done in his own shop. Mr. Klinzing occupies a two-story brick building, with a front of 20 feet, and a depth of $60 \mathrm{fcet}$. His prices are very reasonable, and his custom work, of which he bas a considerable share, is of the best quality. Repairing is neatly and promptly done by. Mr. Klinging. His industry and attention to business will be certain to insure success. Mr. Klinzing was born in this city in 1857, and is well known and respected by his townsmen.

\section{H. A. JONES,-Carpet Weaver, Fifth Ave. and Liberty St.}

Mr. Jones commenced business in his present line, about 12 years ago, in a small way, doing all his orn work. He now employs four laands and four looms, and turns out annually about 5,000 yards of Carpet. He necupies the basement. floor at the corner of Fifth Ave. and Liberty St., 30x30 feet, and has also a factory in the 16th ward. He manufactures Carpets to order and earries a stock of List and Rag Carpets, of his own make, of a superior quality, which he offer's at very low prices. Mr. Jones is a native of Scotland, and learned his trade in that country. He was one of the first men cngaged in the oil business in this State, and to him much credit is due for the development of the oil regious ol the present dity.

\section{A. HILLER,-Tin, Copper and Sheet Iron Ware, Stoves, House Furnishing Goods, \&c., 1815 Carsone st., s' s.}

Mr. Hiller succeded Geo. L. Fischer in the business he now carries on so successfully. His stock is estimated at $\$ 1,500$, and his business yearly reaches the handsome amount of $\$ 5,500$. The buildings occupied by the works of $\mathrm{MIr}$. Hiller are a threc-story brick structure, 24 feet front and 45 feet deep and a trorkshop in the rear of 16 feet by 35 feet. The premises include store, workshop and wareroom. Two hands are employed besides the proprietor, and the Tie premises include store, workshop and wareonl. Two hands are employed besides the proprietor, ant the
monthly wages paid out will anount to $\$ 150$. The trade is chiefly local, and the work done by Mr. Hiller liein substantial and thorough, gives very general satisfaction. The demand for all his manulactures is such as to promise a gratifying increase at no distant day. Mr. Hiller was born in Germany in 184i, and came to this city in 1856 . He is a quiet, respectable und worthy citizen. 


\section{N. Y. \& CLEVELAND GAS COAL CO.-Gen. Office, 89 Wood St.}

The past and present importance of the coal trade with reference to the industries of Pittsburgh, as well as the development of the resourees of the whole country, can hardly be over-estimated. It has attracted a vast amount of capital frolu other States and cities, and aumerous companies liave been organized for the purpose of develofiog this prominent branch of the industries of this eommunity A Anong the most noteworthy of such institutions is the New York and Cleveland Gas Coal Co., a joint stock company, with a eapital of $\$ 600,000$, chartered some years since under the inining and manufacturing laws of Pennsylvania, and officered as follows: Wm. A. McIntosh, Esq., President; A. Carnegie, Lsq., Vice President; Wm. P. DeArmit, Esq, Treasurer, and T. Axworthy, Ageut at Cleveland, Ohio.

As niners and shippers of Youghiogheny Coal the operations of this company are extended and colnprehensive, and while about two-thirds of their product is consumed by Pittsburgh, the balance tinds a market in niany of the Western cities for the purposes of gas companies, for which it is peculiarly available. Two of the mines of this eorporation are located at 'Turtle Creek, 15 miles east of this eity on the $P$. R. R.-three on the A. V. $R$. R., situated respectively eight and eighteen miles east. The total cperations of the company engage the labor of 700 men, two

locomotives working on the tracks of the company, between the headings of
five uiles, and 250 rail road ears, machinery and modern mining appliances.

The product of the company will reach half a million tous of coal annually-worth from $\$ 800,000$ to $1,000,000$, according to the condition of narkets and the rate paid for mining. As one of the largest institutions of the kind engaged in this vast industry so promotivo of the general advantage, the New York \& Cleveland Gas Coal Co. deserves special mention, as well for the extent of its operations as the liberal and conservative policy with which they are conducted.

\section{ARTISANS INSURANCE COMPANY,-Cor. Wood St. and $3 d$ Ave.}

It is a fact worthy of the marked attention, both of capitalists and the public, that throughout the great commercial depression, beginning in 1873, and occasioning the most unparalleled losses by the failure of corporitions and private lirms and individuals, the underwriting compasies of this city, though perhaps curtailed in the extent of their business, have presented is solid front of solveney to the storm, which has not so far been broken in one single ease. Among those wetl known corporations in this department that are cupable of sustaining almost any pressure, the Artisaus Insurance Co. is conspicuouslv prominent. Incorporated under the Insuraace laws of Pennsylvania, in 1866, wittl a capital stock paid up of $\$ 100,000$, the company commenced and has since continued its career under the most favorable circumstances and judicious management. The officers and directors are well known as being largely and successfully engitged in other branclies of business, and as men possessed of ample resourees. The President, Mr. Wm. H. Simith, is also chiel cxecutive officer of the Artisans Deposit Bank. Mr. John Moorhead, Viee Pres't, is engrossed in the irou commission business and other enterprises. Among the directors are names bearing great significance in connection with some important industry. A braham Garrison, of the firm of A. Garrison \& Co., one of the oldest and most responsible firms in the city, is ilso President of the Diamond National Bank; Mr. Janes P. Barr is eclitor and proprietur of the Daily and Weekly Pust; Malcolm Hay, Esq., is widely recognized as one of the first Attorneys at the Pennsylvania bar; John Dunlap, uanufacturer of Tin Ware, has the largest establishment of its kind in Pittsburgh; Wul. Haslage and sullivan Johnson are successful Grocers; Madison Baily, Coal merchant and Vice Pres't of the Central Bank; Frank M. Hutchinsun, Sect'y of the P., F. W. \& C. R. R.; John Birmingham, of Birminglam, Watson \& Co., Anehor. Cutton Mills; and D. McKee, of McKee \& Co., Glass ulanufacturers. The Secretary of the company, Mr. A. J. Barr, is well known among the fraternity of underwriters in this eity as baving unusual capacity for the conduct of the business. $T$. II. Jeger, No. $334 \mathrm{~W}$ annut St., Philadelphia, is the agent of the company in that eity. Cautious in the assumplion of risks, and prompt in the payment of losses, the Artisans Insurance Company is a farorite with all clilsses, and entirely merits the success attendiug its operations.

HAMILTON, LEMIMON, ARNOLD \& CO.-Excelsior Coffins \& Caskets.

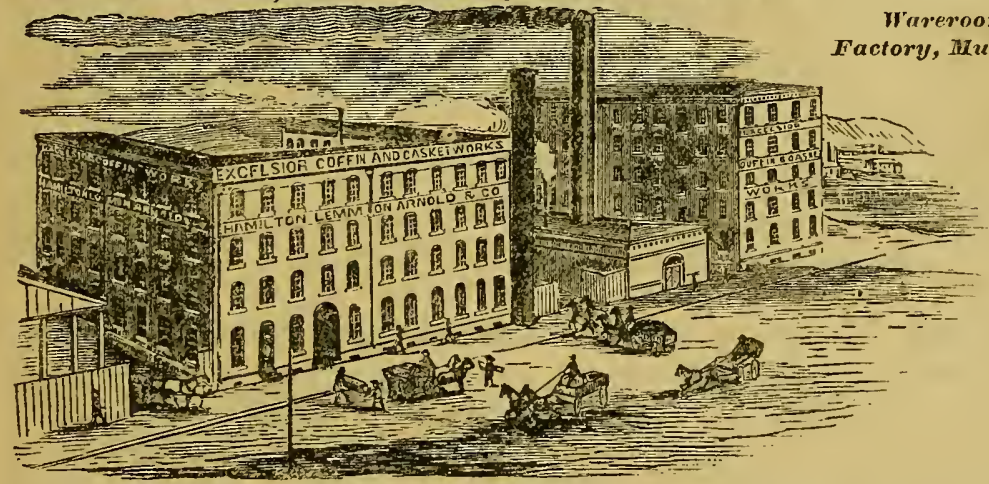

this special line Tn this special line of ing enterprise theturperhaps no house in the known, or one more entitled to extended notice in a work devoted exclusively to a display of the resources in detail of the Iron City.

Established in 1864 , the firm is composed at present of the following members, each of whom takes an active personal in terest and supervision in some departnient of the work. Wm. Hamilton, Brice lemmon, Jas.

T. Arnold, J. W. Carnahan, John H. Mower and Adam Ammon, all practical men, either in the operative or business subdivisions of the concern. The plant is located on Mulberry street, in the lower part of Allegleny City, on the banks of the Ohio river and eontiguous to the freight offices of the Pittsburgh and Cleveland Railroad Co. It consists of four extensive bnildings, one, two, four and five stories high, the two first mentioned having dimensions of $40 \times 120$ feet each, and the last respectively $120 \times 86$ feet and 40x160 feet, covering in all an area of nearly three acres. Here are employed 132 skilled mechanies, 2 engines and 3 boilers of 80 -horse power each, and 2 pumping engines. All the machinery being of the most perfect character, much of it designed and applied originally for the special uses to which it is adapted. The manufactures of the firm consist of Burial Cases, Caskets and Coffins of Fine Posewood, Walnut, Imitation Rosewood, Gloss White, Ebonized and numerous other styles and materials, for the elegance of which a reputation has been established all over the country, promoting a trade that comprehends in extent the entire United States. The firm are large mannfacturers of Handles, Plates, Screws, Linings, Robes, ete., resulting in an annual trade equal in amount to the capital stock- $\$ 250,000$-and steadily increasing.

With so useful a place among the general industries, and a trade so large and produetive of such a satisfactory revenue, the house of Hamilton, Lemmon, A rnold \& Co. exert no small influence npon the general prosperity, and are justly classed in their specialty among the first houses in the United States. 


\section{CHAS. H. ARMSTRONG \& SON,-Pure Youghiogheny \& Connellsville Coal.}

Offices and Yards, Liherty \& 29th Sts., \& foot of Ross St. \& 2d Av., near Moorhead's Mill.

This minnt house, whoso reputalion is contensive with the United States, deserves more space at our hands th:u we tsullly bestow upon similar estublistments. Its history will he foum enterating and instructive. Mr. Armstrong, the senior mentier of the tirm, was born in heland and emigrated to this comntry in 1838 . Upon his arrival in the Unlted States, he cugaged in arriculture in the Wast, and after some time happily spent in this honorable calling, atuc to pitsbumb. Here he took for a semson employment in lead works, but directed by a hearty and nat-

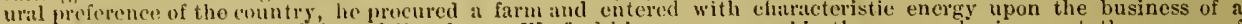
din the corner of Fulion stret and Centre avene. But, as before, the restless eucrgy of his charicter proupted change, and although his intenrity and eapacity must have commanded suceess, he also quitted this husincss, and, in 1856 , fonnd a proper field for the cxercise of his talents and enterprise in the Coul and Coke lusiness. With this vast and growing business his name has boen identiticl for almost a qumter of a century. We shall now say a few words about the extent and inportance of tho Coal and Coko husiness of Chas. II. Armstrong and Son. 'The coal mines of this firm are situutel on the Youm howheny river, and uro considered anong the most exteusive in that fumous region. Miners to the number of 200 find constant and remunerative employucut at these works, and coal to the amount of 300 tons is daily hrought forlh from the dark caverus of the earth. From this coal coke of the best quality is produced, and such is its remutation that it now has the undisputed control of the market as being amost indispensable in the smelting of sted] and generil operations of the foundry. 'This kind of coke is techmically known as slaked coke. lis mannfacture is made a strecialty by this establishment, the coke being entirely free from sulphur aud other noxious jupurities. As maty be inferred from the extent and eapacity of this tirm, many of the largest iron houses of the city are supplicel by it with eoal and coke and a large and increasing demand comes from private families. $A$ store, admirable in all its arrangements, is kept at the mines for the accommodation of the workmen. This great and thriving establishment fus heen built up and sustained by the industry aud encrgy of Mr. Armstrong. Seldom has such success been better deserved or more modestly enjoyed. The native character of the man, frank, sucial, upright and geniat, is untouched by the selfisluness which sometimes accompanics the accumulation of riches and a successful career. The sterling ifulities of the man are rendered more conspicuous and servicenble by his success in life, hut would have adorned his character under the most adverse circumstances. We may add that Mr. Armstrong rejresented the citizens of tho 'fwelfth Warl many years in our city councils. He was a most popular and efticient member. Mr. Armstrong was also the originator of the "Consolidated Gas Company," and its first president. Its success was laruely due to his judicious services and enlightened supervision.

C. 11. Armstrong, Hr, the younger member of the tirm, was bolu in Pittshurgh in the year 1854 , and growing $11 p$ in the business of his father has thoroughly mastered it in all its multiplicity of details and ramifications, being specially conversut in every department of the establishment. He possessos great and varied at taimments and is a very popular young gentleutiu.

\section{JOS. S. FINCHI \& CO.-Distillers of the Golden Wedding Rye Whiskey,}

\section{second and Chestmut sts., south side.}

Among the various extensive manufacturing ustahishments, which have given the city of Pittshurgh a world-wide reputation as a great industrial centre, we douht if any single one has contributed more to that end, than the mammoth distilleries of Joseph S. Finch c Co, whose celebrated brand of Grolden Wedding Rye Whiskey may now he fombl in almost every portion of the globe, and in every clime where a first class, strictly pure and unadulterated article is appreciated. This house was founded by the present proprietors in 1863 , with moderate means and in a comparatirety small way, but at its very inception it acquireul, and has since maintained a very high reputation for the reneral exceltence and uniform reliability of the coods manufactured, and its business has incrensed with rapid strides, until it to-day ranks anong the foremost establishments of its kind in the United States. Messrs. Finch \& Co. have now a stock in bouted warehouse valued at not less than $\$ 600,000$, and their annual sales will exceed half a million dollars, with a constautly increasing demand from all sections of the country. Six spacious and commodious structures are artureth to carry on this extensive husiness, which are loeated on Second and Chestnut streets, south Sitle, nim are of the following dimensions respectively, one $60 \times 150$, one $110 \times 110$, one $50 \times 81$, one $40 \times 50$, one $75 \times 110$ with one buildint used for oflices $23 \times 73$. All the machinery used is of the latest and most approred construction. We may especially mention the powerful sixty-horse power engine, four donble-flue boilers 28 feet long by 48 inches in dianeter, and tive of $\mathrm{Ml} \cdot \mathrm{Kuight}$ \& $\mathrm{Co}$ 's. periected steam pumps. Twenty experienced workmen are constantly emplosed in the rarious departments at a monthly expense of $\$ 1,200$. Mr. linch is the inventor of a peculiar process of remoring deleterious substances and peculiar favor of new whisker, rettining all its healthful and nutritious qualities, and the late product of the still treated in this manner, has all smonthiess and other moperties ordinarily ar'quired only by aye, and hecomes at once palatable, exhilarating ame beneficial to the consumer. Th is is an imporiant desideratum, as the tiner grades of Whiskey can be attorlecl at lower priees than when they are subjected to the risks, expenses and outily of cilpital required in the ordinaly process of acquiring these properties. The individual members of the tirm are Dirssis. Joseph S. Finch and John W. Painter, both gentlemen well and favorably known in the mercantile community, and highly respected in the vitrious relations of life It is to the enterprise, ability and energy of such houses as this, that the Smoky City is indebted for the proud position she hulds among the eities of the Union.

\section{W. J. MILIIGAN, - Groceries \& Provisions, Bidwell \& Pennsy/vania Ave., Allegheny.}

Ir. Milligan became proprietor of the old established and well known grocery store, corner Bidwell and Pennsyl vania arenues, in Mturch, $187 \mathrm{~s}$. This house has been in cxistence for many years and has alwars enjoyed a liberal foutromge. Mr. Milligan carries a well selected stock of Fine Tras and Cloice Family Groceries of every description, ant fresh vegetables in season. His stock is valued at about $\$ 2500$, and his anum sales will reach $\$ 20,000$. He occupies a spacious three-story brick builling, 20x60, employing two hands at a monthly expense of $\$ 150$. He has a large loral tride in the immediate vicinity of his cstallishment, and ulso transacts considerable business with the residents of the rural districts adjacent, especially among the furmers and gardeners of Allegheny county. Mr. Mfiltigan was born in Allegheny in 1856 , and hits alwars resided in the city, where he has a large circle of acquaintances, and has establistied a prosuerous ind thourishing business.

\section{P. SMITH, -Saddles, Harness and Trunks, No. 37 West Diamond St., Allegheny.}

This business was established in 1871 by Mr. Smith in a small way, and with limited capital. By strict attention to business and the uniform excellence and superior quality of all his work, his trade has steadily increased, until it now will compare fatorably with any similar establishmevit in the eity. He occupies the entire building, two-story brick, 20xin0, at No, 37 West Dianonil street, carrying a full and complete stock of Saddles, Harness, Collars, Bridles, Whips, Trunks, ete., valued at uot less than $\$ 3,000$, and transecting on anumal business amounting to me than $\$ 10,000$. Ile gives constant employment to five exprerienced workmon, at a wcekly expense of about $\$ 60$. His trade is located principally in Allerheny and in a circuit of tift $y$ miles. Mr. Smith is a native of allentown, Pa., and was born in 1s.S. 1Le learned his trade in Pitsburgh, and is a carefnl, conscientious and competent workman. 
CULMER SPRING CO.-Spiral Springs, Office \& Works, Cor. 26th \& Liberty St.

The special branch of manufacturing industry persued by the Culmer spring Co., is one of sucl impriance, and withal so conducive to the industrial al vantages of the community, as to be deserving of particular mention in this work. The present organization was founded in 1873, and in 1874 they purchased and added to their already large and growing business, the entire lusiness, good will, stock and plant of the Kevstone Spiral Spring Works, which were organized in 1868, thus alding to their own growing business the extended trate of that concerm. Mr. Henry A. Breed being President and Treasurer, and Messrs. (ieo. W. Morris and Thos. C. Carson special Traveling A fents of the eoncern. The plant of the company is located as above, and consists of one large building, thoroughly adapted for the purposes required, in size and general appointment, being $100 \mathrm{ft}$. square and supplied with tire most powerful maclinery for the nanufacture, test and conpression of springs. The material eniployed by the company is invariably of the best quality of Pittsiurgh Crucible Cast Spring Steel made, selected and kept in stock by the inanufacturer especially for this concern, whose treatment of the metal by furnaces of its own design, and proccsses resulting from wide experience and metallurgieal knowledge, is calculated to retain in its highest perfection the elastic qualities of the steel, and elininate such imperfections as may have followed the first processes of its manufacture. Before being applied to any given object, each Spring is subjected to the most rigid and systematic tests, thus insuring thorough reliability in every ease. The main product of the eompany is in Rail Way Car Springs, for broad and narrow gauge

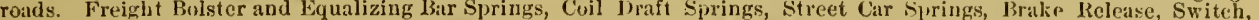
Valve and IIachinery Springs of every description, and it is not an exaggeration to say, that no cotemporaneous concern in the country produces more satisfactory results, if equals the quality of the gools turned out hy the Culmer spring Co. They make a specialty of Spiral Springs. A very general knowledge of this fact on the part of Rail Wity authorities at home and abroad, has led to at dentund for these springs, that engages the constant activity of the works and insures a large and increasing revenue.

Mr. Breed, who as President and Treasurer takes cluarge of the general business as well as the finances of the Co., is a native of this eity, and a son of the late Greorge Breed, Eq., one of the old mereliants of the regine, whom Pittsburghers are proud to remember. Since 1860 , when but 18 years of age, Mr. Breed has been immersed in business, : $11-$ ding to the industrial well being of the community, and promoting within the range of bis influence the nuanuficturing interests of the Iron City. Possessed of numerous valuable patents, unrivalled facilities and adroitly iuantiged, the Culmer Spring Co. is fully entitled to the higli position it occupies, and the signal prosperity that attends its operations.

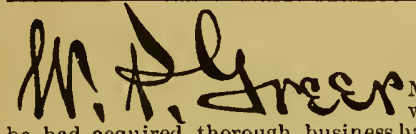

Glass, China, Queensware, \&c., 134 Wood St.

The house of Greer \& Laughlin, of which W. P. Greer is successor, was opened May 31, 1877, with a small but very carefully selected stock of China and Gilasse ware. Mr. Greer had no previous experience in the business, but fortunately he had acquired thorongh business habits, which long continued practice had so rooted into his life that they seemed a part of his character. Combined with these he also possessed rare good taste, which experience had cultivated and refined. The house of Greer \& Laughlin was successful from the outset, and soon at tracted the attentloo of the better classes, especially those interested in the Keramic art. Here they found the rarest novelties and oddities, the quaintest designs, and the most curious specimens that French, Dutch, English, Irish and Aneriean potters and artists ever contributed to the Keramics of the world. Early in 1878 Mr. Laughlin withdrew from the house, aud since that time Mr. (ireer has continued the business alone. If is trade has stearlily inproved, and he lias been compelled to inerense his stock fourfold in order to meet this growing demand. Three large floors, each $22 \times 60$ feet, cellar and attic are nacked with fine Freneh china from the celehrated Havilands, creamy-locking English wares from the famous potteries of Joln Edwards, beautiful Chamber Sets of the most popular nanufacturers, and Glass and Stone Ware from all quarters of the globe. Mr. (ireer's business is exclusively retail. He employs from four to six men constantly. and carries a stock varying in value from $\$ 15,000$ to $\$ 20.000$. Mr. Greer is somewhat eceentrie in his notions and ideas, serupulously eorrect in his dealings, and very prompt in meeting all his engagenents. Ile went to work for himself when but fifteen years of age, and whell quite young was admifted to a partnerslip by J. W. Carnahan, a shoe merchant of Market street. On retirng from this firn he entered the owns considerable real estate in Pittsburgh, ane now owns and lives in the house in which he was born.

\section{PENNSYLVANIA INSURANCE CO.-Germania Bank Buildings,}

Cor. Woort "nal Diamond Sts.

As a representative home Insurance Company that has been the outgrowth from the utilization of the surplus capital of our community, the P'ennsylvania Insurance Co. demands special attention in a work devoted to a detailed review of our city's business and institutions. The original charter, granted in 1852, gave the company power to insure live stock only. In $\mathbf{1 8 5 4}$ more extensive franchises were secured, and the conpany, under these, changed its business to that of Fire and Marine Insurance, and later dropped the Marine and lectame Fire Instrance exclusively, including in its liberal business policy the insurance against loss of damage by lightuing, an indemnity afforderl liy very few companies. Since its incorporation its management has been such as to show the most sat isfactory results, and guarantee to the public and policyholders the most positive proof of its elements of growth and solidity.

This is what is known to the insurance fraternity as an " $\Lambda$ gency Company," and has established angencies in Philadelphia, Lancaster, McKeesjort, Belle Veruon, Washington, D. C., St. Louis and at other points through whicls sections of the country the company has become recognized with public favor, in a very deservedly eminent degree. With a paid up eapital of $\$ 115,800$, and assets Jan. 1,1879 , of $\$ 179,122.31$, the manamement is sueh as to make the stork of this company a safe and lucrative investment, and to be a source of great satisfaction to the insured, as being a $100 \mathrm{i}-$ tive source of renumeration in case of disaster. The officers of the company are among our most sulistantial and c"ireful business men and ablest underwriters to wit : C. Yeager, Pres't. C. C. Boyle, Vice-1'res't, Thomas D. Keller, Si:cretary, with a board of Directors, composed of equally prominent and reliable cilizens.

\section{JAMES HAY,-Practical Plumber, Steam \& Gas Fitter, No. 12 Ohio St., Allegheny.}

Mr. Hay is a practical plumber and mechanic of twenty-three years' experience and hats been engaged in business for himself for the past nine years. He was for six years loeated in the Allegheny Diamond, lout for the past three years has occupied the two-story hrick building, $20 \mathrm{x} 60$, at No. 12 Ohí Street, where he may now be founcl. He carries on the general business of Plumber, Gas and Steam Fitter and House Drainer. Amone the specialties of his business are Sheet Lead work of every description Tanks and Agitators lined and either wiped or burned with hydrogen blow-pipe. Country residences supplied with water by 1 ydraulic Rams, Cellars Ccmented on Concreterl, and all kinds of repairing attended to. He is also sole manufacturer of McK issock's Patent A utomatic Water Closet r'istcrn, a valuable invention, which is being widely introduced. Ife carries a stock of about $\$ 1,000$, and his annual husiness amounts to $\$ 11,000$. He employs six competent and experienced workmen, whose weekly pay amousts to $\$ 75$. His business is principally in the city and on the better class of country residences. Mr. Hay was born in Scotland in 1843 , and eaine to the United States in 1869. 


\section{BECKERT \& BROS.-Florists and Seedsmen, No. 53 Federal St., Allegheny.}

One of the most attractice floral displays to be seen in the two cities, is at the establishment of J. Beckert and Bros. 53 faderal St. Alterheny. This old well known house was founded about 50 vears ago by Christian Beckert, sr. father of the present proprietors, who have been engaged in the business about twenty-fice years. The increase in their trade has been lirge and encouraging, they now carry a stock of about $\$ 20,000$, comprising every article required in a first-cliss Seed and Florill estahlishment, their warerooms, $22 \times 100$, three flours, are filled to repletion with a beantiful assortment of choice l'lants, Flower and Vegetable Seers, Flowers, Slirubs and Bulbs, together with fancy Baskets, Auuria, Fernerius, Brackets, plain and ornamental Flower l'ots, ete. The tirm ocenpies eleven greenhouses, situa , A Tro for the growing of the hardier varieties of Flowers and Vegetable Plants. Their large and extensive nursery contains all the necessary convenience and buildings requisite for the suecessful propagation of Flowers and Fruits, and the prosecution of the business in which they are engaged. They have twenty-two acres of ground in a high state of cultivation, employing a large force of practical hands. The members of the firm have had a life long experience in the business, and are thoroughly practical in all the details of the business. The cut-flower department is made a distinct feature of their business. Having a number of greenhouses specially arranged for the promotion of Blooms, they can supply at all times an abundance of fresh and choice flowers for weddings, funerals or other decorative purposses; special attention is also deveted to the decoration of churches, lialls and parlors. In this branch of industry, this old and reliable establishment stands specially prominent, if not at the head. In beautiful and artistic floral decorations, in rariety and quality of productions, this house stands second to none in this sectiou of country.

\section{P. KEIL \& SON,-Commission Merchants, No. 331 Liberty St.}

This old and reliable house was first founded by Siebert, Thompson and Keil. The firm name and style has undergone many changes, among which we notice "Siebert, Keil and Ritchart", "Peter Keil", "Rea aud Keil." In 187i Mr.J. T. Keil a son was admitted, and the present firm name was established. It will be noticen through all the changes, the present name Keil his been prominently associated with this house for more than twenty years. This establishment has oceupied a hirh position monr the representative business houses of the smoky city. Receive consignments from all sections of the country, and their commission tranactions are very extensive. They also deal largely in Grain, purchasing exclusively for eash, thus enabling them to offer extraordinary inducements to purchasers. Barley and Malt are the specialties of this house, of which articles they handle immense quantities in the course of the year. They oceujy the commodious four-story brick warehouse, $221 \% 2 \times 110$, at No. 33I Liberty St., employing two assistants and iransacting an annual business of aloout $\$ 128,000$. From the nature of their business, it is unnecessar to cary a large stock on hond, as they are constantly receiving and shipping gools pertaining to their line of business. Their trade is largely local, alt hough it extends to a greater or less extent all over the Union. Mr. P. Keil is a native of Germany, but came to this country when a child. He has for many years been identified with the business interests of Pittsburgh.

\section{F. MAISCH,--First Ward Meat Market, No. 260 Rebecca St., Allegheny.}

Mr. Malsch, the enterprising proprietor of the First Ward Meat Market at No. 260 Reberca St., Allegheny City, is a native of Germany, but came in this country when twelve years of age. He has followed the lutcliering husiness since a young man, and for the past eighteen years in his own name. His present location has been occupied by him for ten years, and he has built up a flourishing and lucrative business, killing about one hundred and fifty beeves, averaging 1,400 poumds each, and a large number of calves, sheep and hogs annually. He furnishes customers with the rery hest firesh meat in the market, and cures a considerable quantity besides mianufacturing Sausage for his own trade. He owns the huilding occupied by him as residence and market, which is an elegant two-story brick $6+x 100$ with gothic roof and furnished in the best manner. Uis slaughter and ice houses are on the same premises, making it one of the most convenient establishments of its branch in Allegheny City. In an architectural point of view the edifice is a eredit to himself and that portion of the city in which he resides.

\section{IM. VEIOCK, --Boots, Shoes and Gaiters, No.137 Federal St., Allegheny.}

An experience of over thirty years as a practical Boot and Shoe Maker gives $\mathrm{Mr}$. Veiock ad vantages whlch are possessed hy few. The present business was established by Mr. Veiock in 1547 upon a comparatively small scale, hut as his trade increased, he has from time to time enlarged lis store and added new improvements and facilities. He now occupies the two-story brick building, 13×90, at No. 137 Federal strect, Allegheny, and employs on an average four or five experienced workmen. All work turned out by him is made from the best French and Domestic Calf, and is superior, both as to quality, comfort and style. Mr. Veiock enjoys the patronace of many of the first families in the city and surrounding towns and is a thorocighly reliable gentleman to deal with. He has been a resident of Allegheny City since $18+0$.

\section{E. J.SMITH,,-Harness, Saddles, Trunks, \&c., No. 37 South Diamond St., Allegheny.}

Mr. Smith started in business eight years ago with his irother, and for five years they continued together and did a flourishing business. In 1876 the firm dissolycd and Mr. E. J. Smith opened at his present location, No. 37 South Diamond street, next door to the Bepler Hotel, where he nccupies the large two-story brick building, 20x160, employing four experienced hands in the manufacture of Harness, Saddles, Whips and Trunks, and carries a stock of ahout $\$ 4,000$, transacting a business of from $\$ 10,000$ in $\$ 12,000$ annually. His trade, which is derived from the city and adjacent towns, is steadily inereasing. Mr. Smith was bern in Berks county, Pa., and has been a resident of Allegheny since 1862 .

\section{W. THOMAS,-Merchant Tailor, No. 301 Beaver Av., Allegheny.}

The residents of that portion of Allegheny City formerly known as Manchester are familiar with the name of $M r$. Thomat, who has been estahlished in the Merchant Tailoring busines in that locality for the past ten year's. His salesroom is situated at No. 301 Beaver A venue, and is a capacious and conveniently arranged apartment, $20 x 140$ stocked with in finc :ssortment of foreign and clomestic piece goods of the most desirable fabries, from which he is prepared to make to order tine fitting and stylish suits at prices ranging from $\$ 15$ to $\$ 10$. Mr Thomas is a practical tailor und cutter and employs six experienced workmen. Doing his own cutting, and being at a comparatively small expense, lie can offir better indurements than those who are compelled to pily exorbitant rents in the city proper. Mr. Thomas is a native of lingland and came here tifteen years ago. 


\section{J. C. RISHER \& CO.-Coal, Office, No. I/6 Water St.}

As the center of the coal trade of Western Pennsylvania, and the source of supplies upon which the West and South mainly depend for fuel, hoth for domestic and manufacturing purposes, Pitsiturgh is the basis for enormous operations in this product, condueted by numerous corporate and indiviclual enterprises, requiring in the aggregate gimost unlinited resources and the lahor of thousands of men in the various deparinents. Among those firnis whose transactions bave assumed the greatest magnitude may be properly classed that of .J. C. Risher it Co., which, estalslished in 1861 by the senior partuer and Mr. Steplien S. Crump, has continued from that time, and under the same title and management, the successful prosecution of the trade, which is dividel into three distinet departments, vi\%: producing, shipping and selling. As produeers, the tirm have unrivalled advantages in the possession of 350 acres of coal land, situated on the second pool of the Monongahela river, about half a mile above MeFeesport, at Drarosburg. From the mines upon this property are extracted $2,000,000$ bushels of coal annually, and here are employed 200 mineis and others necessary to the success of the work. The shipping department includes a saw-mill and hoat-yard on tlie property at Drarosburg for making and repairing the boats, barges and flats of the company, and in this part of 1 he labor 25 men are engaged. The firm own and run a regular line of 100 barges between the mines and fiouthern markets and 40 coal boats. Numerous hands are employed in the transportation department, entailing an expense upon the Company of $\$ 1,600$ per month, the total cost of labor anuually being about $\$ 75,000$. In addition to the assets already mentioned, the list might be extended almost indefinitely by enunierating the bujldings for dwellings anr other purposes on the property, mules, cars, tracks, shoots, sereens, steam engines, and all the various appliances and improvements naturally appertaining to so considerable a scheme.

In disposing of its products the firm avoids the local market entirely and divides it about equally between Cincinnati, Louisville and $\mathrm{New}$ Orleans, in which places are regular agencies for its disposal to the retailers.

After a prosperous and successful career of nearly twenty years, the firm of J. C. Risher \& Co. are pretty generally recognized as being among the very first in the trade, having acquired a reputation in that. period tbat reflects the highest eredit upon those characteristies of promptness, reliability and enterprise for which the house is $k$ uown. Promoting the industrial interests of the community and conducing in no small degree to its general welfare, the firm of J. C. Risher \& Co. is certainly deserving of the estimation in which it is held and the results attending its etfort and enterprise.

W. N. IRATZER, Jr.-Mattresses, Bedding \& Curtain Goods,37 Ohio St. Allegheny.

The Mattress and Bedding warehouse at No. 37 Ohio street, nine doors from the Diamond, west of Fcrleral street, was established in 1872 and hils been condncted hy different owners, by whom a large bnsiness wis done, until. in 1878, Mr. Kratzer became owner and proprietor, and under his management the business bas steadily incrcased to the present day. Mr. Kratzer oceupies the briek building, $18 \times 60$, at the number named, emploving nine hands at a weekly expense exceeding $\$ 50$, and earrying a stock valued at about $\$ 2,000$. His yearly sales will approximate $\$ 8,000$. He manufactures Mattresses and Bedding of every description and keeps a fine assortment of Curtain Goods. The specialty of this house is in renovating feathers, for whieh purpose steam is used, and the most approved processes are adopted. Mr. Kratzer has the sole and exclusive right to manufacture the celebrated Palace Bed Lounge, which is noted for its nerfect siniplicity of construction, being so contrived as to be easily taken to pieces and cleaned in a few moments, offering no harbor for those pests of the household, bed-hugs. It possesses all the essential qualities of a first-elass bed for ease and comfort, and is not only economical but ornamental. Mr. Kratzer is a native of Penusylvania, and was born in 1856 . Ho is an energetic and thoronghly reliable young business man.

S. P. ARIISTRONG \& CO. -Wh'sale \& Retail Grocers, 41 S. Diamond, Allegheny.

The well-known Wholesale and Retail Grocery House at No. 41 Sontl Diamond, Allegheny, was founded by Kirk \& Allen, who erected the building now occupied by S. P. Armstrong \& Co. twent $\mathrm{r}$-three years ago. They were succeeded by Horne \& Riddle, who carried on the business for five years, when the firm became IIorne \& Hadley, whe continued for two years, or until 1868 , when the present proprietors came in possession. They carry an average stock of about $\$ 8,000$, comprising a general assortment of Fine Family Groceries, Choice Teas, Flour, Sugar, Colfee, Salt, Fish, Bacon and Country Produce, employing four assistants and transacting an annual business of over $\$ 50,000$. In more prosperous times their sales have reached $\$ 100,000$ per year. Their trade is principally in the two eities and throughout Allegheny, Beaver, Butler and Lawrenee counties and along the lines of the P., Ft. W. \& $C$. and the West Penn. R. P's. In the season this firm are extensive buyers of Wool and Seeds, and are well and favorably known throughout the country districts as honorable, fair dealing gentlemen in whom every confidence may be placed. Mr. Armstrong is a native of Allegheny City and has been actively engaged in the grocery business since he was a young man.

\section{W. E. COLEBA U GH,-Photographer, No. 19 Federal Street, Allegheny.}

While it must be admitted that the sun cannot fail to reproduce whatever object is placed hefore the eamera, it is still a fact that the success of a photographie likeness must depend largely upon the artistic skill of the operator in selecting the proper position and light, and in finishing the picture in a proper manner, after the sun has eompleted his portion of the task. An artist who understands the various details and minor requisites to complete a sutisfactory phutograph is entitled to high rank in his profession, and such a one we can recommend in the person of W. H. Colfbaugh, at No. 19 Federal street, Allegheny. This art gallery was established by Mr. Langfitt several years ago. He was succeeded hy Mr. Chas. A. Trapp, and in the Autumn of 1877 by the present proprietor. His rooms are admirably lighted and arranged, and the pictures taken by him will compare favorably with those from any metropolitan baugh is a nativo Pennsylvanian and was born in 1927 . He is an artist who thoroughly understands his business and always gives satisfaction to his patrons.

\section{A. SCHA U B,--Leaf Tobacco, 317 Liberty St.}

Contingent upon the Tobacco trade and its numerous conneeting industries, depends much of the prosperity of Pittsburgh, entiting those engaged in this branch of business to no small degree of consideration in this volume. At present a wholesale dealer in Leaf Tobacco, Mr. Schaub commenced business for himself 20 years ago on T'enth St. with a limited capital, aside from his industry und native aptitude for the able management of affairs. On the first of Jin. 1879 he noved into the premises located as above, sufficiently ample in dimensions, being $181 / 2 \times 110$, to afford scope for the enlargement of a rapidly growing trade. Here will he found a choice lot of selected Leaf, to suit the various grades of manufaeture, aiways at the lowest narket rates, and even discounting these at times. The stock varies in value from $\$ 10,000$ to $\$ 20,000$, and the business will probably a verage $\$ 25,000$ to $\$ 40,000$ per annum. Mr. Schaub is originally from Germany, but having been a resident of this city for 21 years, is thoroughly identified with its general interests, to promote which he has lahored verv effeetively. Enterprising, honest and energetic, Mr. Schaub is bighly respected and cordially commended to the trado in Pennsylvania and adjoining States. 
JAMES B. YOUNG \& CO.-Phøix Roll Works, 41 st \& $42 d$ Sts., on A. V. R. R.

Among those speeinl branches of manufaeturing industry, for which Piltshurgh is peculiarly noted, the Phonix Roll Works have attininel a prominener that deserves more that palssing mention in a work devoted to a detailed exJ. B. Youn and remained some years, aud sold out to Mlessrs. Bagiley and Ballnan in 1s7t, who successfully con-

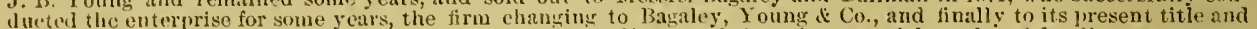
membership in 1s73. Originally a general foundry, it was discovered that the material employed for diverse purposes should be in structure and quality of diflerent grades for partieular ends, and that for the perfect casting of Rolls and Pinions, a uniformity in metal and process should be adhered to, incompatalle with a miscellaneous business. In the mantfacture of these specialties, therefore, the firm became exclusively engrossed, and the results achieved have been in the most marked degree signally successful. The present plant of the house is situated as above, oceupying in all an area of over an acre, t0 hands being employed, at an average monthly expense of $\$ 2,000$. The trade, which extenils over the entire Union, amounts to about $\$ 80,000$ annually, and is gradually increasing. The works are divided into two main departments, viz., founding and curning, the machinery and meehanieal applianees and apparatus, throughout, being as perfeet as inventive genius can devise or capital procure. Some idea of the capaeity of this establishment may be gained from the fact that, with many other tine pieces of eonstrnctive mechanism, will be found 7 cranes, 11 roll lathes, 1 polisher, 1 planer, 1 maehine lathe, 1 drill press, and a complete pattern shop, the motive power being supplied by a $18 \times 30$ engine. The individual members of the firm are Messrs. James B. Young, J.S. Seanan and Robert Sleeth, the last two being practicul meehanies, Mr. Seaman directing the turning and finishing departments, and Mr. Sleeth having charge and supervision of the foundry, the business and finaneial operations of the concern demanding the attention of Mr. Youmg. The specinlties for whieh the house is celebrated are the SemiSteel Mixtures for Rolls and Pinions, patented by the firm, also Double Spiral Pinions, Iron Chill and Sand Rolls, and the members of this eoncern are widely known and elosely identified with the industrjal progress of the city. MIr. Young being an native of this place, born in 1827 , a member of select eouncils from the 17th and also one of the first direetors of the ward chamber of eommerce, and always interested in promoting those measures best eondueive to the well-being of the eommunity. Mrr. Seaman was born in 1539 at Harmony, Pa.. and for a quarter of a century has resided in Pittsburgh, while IIr. Sleeth, though originally from Ireland, born in 1828, has been respected as a citi\%en of this eity for ahout 34 years. In the particular branch of business pursued, the firm of James $\mathrm{B}$. Young \& Co. have no cotemporaries who produce the same class, grade or character of work, and but few who cau offer adrantages at all comparable to those gnaranteed by this concern, a statement well attested by the experience of among the large number of works, the Edgar Thomson Steel Works, Black Diamond Steel Works and Union Iron Mrills of this city to which reference is made, all these establishments having in use the rolls manufactured by this firm. There are no other establishments in the world that make an exclusive specialty, and devote so large a space to the manufacture of Rolls and Pinions, and the large success attained speak volumes for the foresight and enterprise of the firm.

\section{THOMAS BROW W,-Plumber, Gas \& Steam Pipe Fitter, 55 Federal St., Allegheny.}

For more than thirty years this house has been in successful operation under variuns administrations. It. was founded by Jathit, Olden and Baliffi, and contimued by them until 1560, when the firm was dissolved, and Baliff and Brown suceeeded to the husiness. In 1865 Irr. Carson was aduitted under the firm name of Balifl, Brown and carson. In 1870 the tirm again became Baliff and Brown, and in $1575 \mathrm{Mr}$. Brown became sole proprietor. He is at present the oldest plumber in Allegheny engaged in this busiuess, and probably the best known of any one in the two cities. Ife learned his trade in l'ittshurgh with the well known house of sheriff and Tate nearly a quarter of a eentury ago, and is a thorough practical workman in all branches of the business. Ho now oceupies the commodious warerooms No. 55 Fexleral St, employiur ten hands at a weekly expense of $\$ 140$. He carries a stock of about $\$ 5,000$, and transaets an anuual business of not less than $\$ 15,000$ in the two cities and surrounding towns, doing every deseription of Plumbing, Steam and Gas Fitting, etc. Mr. John $\mathrm{R}$. Watson, the popular book-keeper of this louse, has been with it through all its various changes. Mr. Thomas Brown is a native of Allegineny City and has for many years been identified with the business and material prosperity. He has been in the council for over twelve years, and is at present a memher from the third Wanl. He is a gentleman highly esteemed in the community, and as a suceessful busiuess mau may be ranked among her forenost citizens.

\section{HAIPIN \& HUMBERT,-Plumbers, Gas \& Steam Fitters, $30 \& 35$ th Ave.}

This is one of the best known louses in the Smoky City engaged in this line of trade. It. was founded twenty-two vears a ro by W, and S. Jarvis with a sunll capital and limited facilities. The business was condueted by them for seven years, when the firm name heeame Jarvis, Halpin of $C$., who condueted the business successfully for fourteen years. On the first of February 1878 the present firm name was established under the judicious management of Halpin if Humbert. 'The trade of this house has largely inereased, from earetul investigations it is apparent this establishmeut does a business largely in execss of any other house devoted exclusively to the same line of business, while its patrons are largely eomposed of the leading business and wealthy classes. Willian Halpin, the Sr. memler. was born in Ireland in 1830 , eame to this country in 1847. Mr. Chas. H. Humbert is a native of Pittsburgh, and was born in 1853. He is a praetical Plumber and a gentleman of long experience in that line. They ocenpy the spacious three-story hrick edifice $22 \times 60$ at the uumbers mentioned above, giving employment to tifteen experienced workmen, with a weekly pay roll averaging $\$ 150$. They keep a full line of Gas Fixtures, Iron, Stone and Lead Pipe and Water Fixtures in general. 'They are also sole agents for the Backus Water Motor and the Globe Ventilator and Chimney Cap, and make a specialty of refinshing Gas Fixtures of every aescription. They have in use a hand serew cutting machine, that is noted for its perfect and rapid work. Their trade, which is steadily on the increase, is principally derired from the eity and surrounding towns.

\section{MANUFACTURERS \& MERCHANTS INS. CO.-87 Wood St.}

\section{Capital, $\$ 250,000$. - Assets January 1 st, 1879, \$341,405.39.}

Pittsburgh, to its size and population, affords the most ample protection against the firy element of any city in

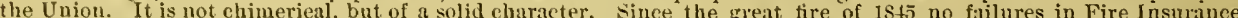
Conuanies of any note have occurred, nll the local eompanies prior to the disastrous fire were suddenly bankrupted at that time, and nover able to proceed in doing business as Insurance companies. Iruch had been learned from that disastrous occurrence, however, and the Insurance business was established at a more substantial basis. Such is the chatreter of the company that heads this artiele. It has through its career pail many losses, and stands unscathed and stauneh as any of its competitors, with assets of nearly \$342,000, and shows a surplus over all liabilities of \$56,898.53. We herewith present the names of the officers and menbers of the board of directors for the year 1879: James I. Bennet, President, John W. Ch:ilfant Vice President, J. II. Kenney, Secretary, A. Ammon, General Agent, Directors: James I. Bennett,John W. Chalfant, A. E. W. Painter, Robert Lèa, I. C. Pershing, Wru. Walker, M. W. Watson, Joseph Walton, John Wilson, S. F. ron Bonnhorst, C. W. Bachelor, W. G. Park. The names here presented are so well known that no culogy is necessary to convince the public of the elaims of the Manufaeturers and Merchants Insurnuce Company of Pittsburgh, Pn., for public patronage. 
NELLIS, SHRIVER \& CO.-Agricultural Steels \& Irons, Rebecca St., Allegheny.

Among the most prominent manufacturing concerns in Pittsburgh or its surroundings the firm of Nellis, Sluriver $\&$ Co. occupy a position that entitles it to consideration in this work. The plant of this house is located or bounded by Rebecci and Sturgeon Sts. and South and Allegheny Aves., Allegheny City, and was establishell in 1871 hy $\mathrm{A}$.. Nellis, the senior partner of the present firm. The grounds upon which the works are situated, are $300 x 300$ feet, and the buildings cover an area of nearly an acre, being divided iuto six operative departments, eniploying 100 hands, most of whom are skilled mechanics. A sixty-horse power engine is used to move the machinery, much of which is of the fiuest character, adapted and designed for special purposes, and a battery of three boilers, argregating T5-hrise power, furnishes the necessary steam. The products of this cxtensive establishment consist mainly in Nellis' Original Harpoon Horse Hay Fork, Steel or Wrought and Malleable Iron Fencings and Castings, Nellis' Gripple and 'ulleys and Steels for Plows, and other agricultural implements; also Nellis' Patent Cast Tool Steel Castiurs, which seem to be almost indestructible, and may be so tempered as to be exactly adapted to any variety or conformation of siil. The demand for these appliances, owing to superior merit, recognized by ligh awards and medals at the Centenuial Exposition, has led to a rapidly increasing trade, and its extension over the entire United States and Canadian provinces. Of the individual members of the firm, the senior partner is a native of New York state, and has becll a rosident of Pittsburgh since 1870. The enterprise with which he is identified was founded under the style of A. J. Nellis \& Co., Mr. John Crawford being his partner, after whose demise Messrs. S. P. Shriver and J. H. Stokes liecame partners, forming the basis of the existing firm. Both these gentlemen are natives of Pennsylvania, the former settling in Pittsburgh as early as 1835 , and the latter in 1860 . Both from the extent of its operations, the character of its products, and the impetus given to the industries of the community, this house has achieved a conspicuous place among others in a cotemporaneous line of business. The vast improvements made by Mr. Nellis in Cast, Cast steel for l'low Shares, Harpoon Hay Forks and other appliances, and the monopoly in them, possessed by the firm, is alone suffieient to entitle it to more than ordinary attention. Besides these, however, numerous other articles are manufactured, all of which are of the finest make, and material such as to insure the greatest degree of durability and power. Witl these undoubted advantages and facilities Messrs. Nellis, Schriver \& Co. offer inducements to the trade that can not be surpassed, and which buyers will find largely to their interest to favorably consider.

\section{E. W. GROSS,-Fire Insurance Agency, Sixth Ave., cor. of Liberty St.}

At this day no prudent business man or owner of property fails to provide against possible disaster and loss from fire, and consequently there is no industry or business associated with the interests of Pittsburgh more deserving of special attention. The agency of Mr. E. W. Gross was first opened in this eity in 1870 , and in conscquence of the popularity and reliable character of the companies he represents, and his eminent qualifications for the position lie fills, he has met with remarkable success, notwithstanding the stringency of the times. The companies he represents are: The Germania Fire Insurance Compan y of New York, which has a cash capital of $\$ 500,000$, a net surplus, Jan. 1 , 1879 , of $\$ 754,423.72$, and available assets of $\$ 1,678,828.80$; main office, 175 Broad way, $N$. Y. The United Fireman's Insurance Company of Philadelphia, established in 1860, one of the safest companies in the country. This company his a capital of $\$ 200,000$, and assets, March 1st, 1879, of over $\$ 654,000$. Home office, 408 Walnut street, Philadelphia. The Ger'mau Insurance Company of Pittsburgh is also one of the companies he represents. It is rapidly growing in popular favor and contidence. Mr. Gross is one of the best posted men upon Insurance in the State, and thcse companies are fortunate in securing such able management for the city of Pittsburgh. He is prepared to take risks upon dwellings, manufacturing establishments, merchandise and household furniture at the lowest current rates, and, as is eminently proper, great care is exercised in the selection of risks. Six solicitors are employed with the business of this agency, chiefly confined to Pittsburyh, Allegheny and vicinity. Those interested iu Insurance will do well to call aud consult with Mr. E. W. Gross, No. 5 Sixth A ve., corner of Liberty St.

\section{MCHENRY \& HOOD,-Commission \& Wholesale Dealers in Grain, Seeds. \&c.} Cor. Liberty and Smithfield sts.

For many years the firm of Messrs. McHenry and Hood have occupied a prominent and highly responsible position anjong the Conmission Merchants and Grain Dealers of this city. The house was originally established in 1866 by $\mathrm{S}$. L. McHenry, the present Sr. partner, and by the admission of Mir. John Hood six months later, became as at present with the existing title. The business of the firm as heretofore indicated is mainly in Grain, giving special at tention to Wheat, both as independent Dealers and upon a Commission basis, the transactious annually anounting to 5100,100 , with a capital of from $\$ 15,000$ to $\$ 20,000$, the trade not only being largely local, but extending to the great (irain matrkcts West and East. To those, who are engaged in husiness in Pittsburgh, any commendation of this house would be altogether superfluous; for those readers of this work, who reside beyond the local reports of our prominent firms, it may be well to say, that the references of Messrs. MIcHenry and Hood are, Hitchcock, McCreery \& Co., Marshall, Rennedys \& Co, Citizens National Bank, all of Pittsburgh, and Rumsey, Bro. \& Co. of Chicago, and George M. Hord \& Co, Cincinuti. Both members of the firm are natives of Pennsylvania, and each for many years identified with the commerial interests of this community, which they have done no little to promote. As a desirable firm, with which to establish pleasant and profitable relations, $M \mathrm{CHenry}$ and Hood are not only highly esteemed, but fully entitled to the prosperity that has attended an honorable career

\section{LOUIS STEITZ,-Druggist and Apothecary, No. 157 Pennsylvania Av., Allegheny.}

Mr. Steitz, who is an accomplished pharınaceutist and chemist, commenced business at his present locition eleven years ago. He has built up a flourishing business, keeping a full and complete stock of pure drugs, cliemirals, fancy soaps, perfumery, toilet articles, and all goods pertaining to his line, valued at between $\$ 4,000$ and $\$ 5,000$, and his annual business amounts to not less than $\$ 10,000$. He occupies the four-story brick structure, $20 \times 60$, at No. 157 Peunsylvania Avenue, and employs two competent and reliable assistints, himself giving special attention to filling and compounding with accuracy physicians prescription. Mr. Steitz was horn in Germany, and has resided in this city since 1864. He is a thorough practical chemist.

\section{W. I. KANN \& CO.-Leather, Oils, Findings, \&c., No. 213 Liberty St.}

The house of W. L. Kann \& Co., was founded in 1865 by Gustav Kann, who for 12 years continucd the business. In 1877 he was succeeded by the present proprietors, under the firm name of W. I. Kann \& Co. Both of these gentlemen arc natives of Pennsylvania. They occupy three floors of the extensive warehouse, 30x150, at No. 213 Liherty st. They keep a large stock of manufactured leather of every description, oils, findings, ete. They iure the manufacturers They keep a large stock of manufactured leather of every description, oils, findings, ete. They are the manufacturers
of the reliable brand of calf skin known as "Imperials, "whicl is making a reputation on account of its many superior qualities, comparing in all respects to the best imported French calf. The firm have also a large currying shop in Allegheny City, where they make a specialty of furnishing harness leather, \&c. Their trale extends through Pennsylvania, Virginia, Ohio and many of the Western States. 


\section{SPENCER, MCKAY \& CO.-Maltsters \& Brewers of Ale, Porter \& Lager Beer.}

The superiority of the Ale and Porter manufactured by the above well known firm has for many years been

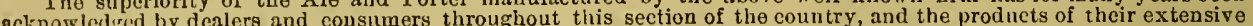
acknowledged by dealers and consumers throughout this section of the country, and the products of their extemsive establishment have aiways met with a ready sale. W feature which promises to meet with universal approval. At an immensu outlay they have perfected arrangements for manufacturing a superior quality of Lager Beer, the first brewing of which was placed upon the market May $3 \mathrm{~d}$ of the present year, and has heen prononnced hy eonnoisseurs to be superior to any of the foreign brands which, owing more to the importunities of agents than to their intrinsie merits, superior to any of the lorelgh in this eity to a considerable extent. For years past Pittsburgh has been sending millions of dollars to other cities for beer. It is to be hoped that the movement so successfully inaugurited by this firm will soon establish tho fact that our city, so long and widely noted for its superior ale and porter, can also produce beer of unsurpassed quality, and thereby secure the leritimate benefits of home production for ample facilities, and all the esgential requisites for producing a first-elass quality of Lager Beer. This brewery stands second to none East or West. Its present capacity is 200 barrels per day. The Phonix Brewcry was established in 1862 by Mr. Joseph Spen. r end Tr. James DI Kay, and since that time the capital invested has been increased at least 300 per cent., their cxtensive buildings, three in number, on 24 th and Smallman streets, cover over $21 / 2$ acres of ground, and are fitted with all the machinery and appurtenances requisite for conducting their immense business. One larse boiler and three engines, of 40,12 and 10-borse power respectivcly, are in constant use, and all their arrangements are first-class in every particular. Their vaults for the storage of Ale, Beer and Porter are probably the finest in the city, and the entire establishment, in all its departments, will compare fitvorably with any in the West. The average valuation of their stock is about $\$ 200,000$, and their trade, which ex tends through middle and Western Pennsylvania, Ohio, Indiana, Kentucky, Virginia, West Virginia and Maryland, will reach $\$ 160,000$ per anuum. Seventy men are regularly employed at this establishment, with a weekl v pay-roll aggregating $\$ 842$. Mir. W $\mathrm{m}$. Lock hart is principal book keeper and cashier with two assistants in tho office and clerical department, and three salesmen devote their alteution to the interests of the house in the city and suburban towns. R. N. Ray, who has represented the interests of the firm for 13 years through the South and other sections of the country, is now the general agent for this eity. He is undoubtedly the right man in the right place. The individual members of the frm, as at present organized, are Joseph Spencer, James McKay, Robert Watson and Robert Liddell. Mr. Speneer is a native of England, and has resided in Pittsburgh since 1843. Mr. McKay was born in Ircland, and came to this city in 1850. Mr. Watson is also a native of Ireland, and bas been a resident of the Iron City for the past 35 years. MIr. Liddell was born in England, and came to Pittsliurgh in 1850, since which time he has been prominently identified with her business interests and material welfare and prosperity. At the last municipal election, held in 1877 , he was elected Mayor of the eity by a flattering majority, and since his ind nction to office has tilled that responsible position with great credit to hiniself and to the universal satisfaction of the citizens of all elasses and political views.

\section{G. WEISSER, Agent,-Watchmaker and Jeweler, No 601 Penn Av.}

Mr. Weisser commenced business in 1854 with a small capital of $\$ 500$. In 1869 he was enabled to erect the elegant and spucious three-story brick building now occupied by him as store and residence. This building has a frontage of 21 feet on Penn A venue and extends back 100 feet. The frst floor of which is occupied as sales room and work room. He carries a stock at present valued at about $\$ 11,000$ and his yearly sales will reach over $\$ 5,000$. He also keeps a full line of Forcign and American watches, an elegant assortment of solid silver and plated ware, jewclry, clocks and all articles pertaining to this line. His two sons are both practical watchmakers and jewelers and assist him in the business. Mr. Weisser was born in Germany, in 1818, and learned his trade in that country. He came to the United States in 1S 2 . The failure of a bank sometime since caused him heary loss, but he immediately set to work to repair bis losses and is once more on the high road to success.

\section{J. KOENIG \& BRO.-Watchmakers and Jewelers, No. 579 Penn Av.}

One of the most noticeable establishments along Penn Avenue is the tastefully arranged and elegantly stocked fewelry store of J. Koouig \& Bro, loeated in the three-story brick builling $171 / 2 \times 50$, and No. 579 . This house was founded in 1855 hy Mir. J. Konjg, with a capital of only \$1.000. In 1875 MIr. August Knnig was admitted. Both gentlomen are practic:ll and experienced watchmakers. Their average stock is ralued at about $\$ 30,000$, comp prising a full line of Foreign and American watches, solid and plated silver ware of the latest designs, French, German and American cloeks, rings, brooches, chains and fine jewelry of every description. Their annual sales amount to $\$ 8,000$ to $\$ 10,000$, and their business is steadily increasing. Fine watch repairing is tho specialty for which this house is particularly celebrated. Both members of the firm are natives of Prussia, but have for miny years resided in Pittsburgh.

JAMES McFERRON-Groceries and Produce, No. 290 Beaver Av., Allegheny.

Mr. James McFerron is located on Beaver Avenue, where he started his business four years ago. He now occuples the three-story brick building, 20x50 at No. 290 Beaver A venue, corner of Washington Avenue, with a stock valued at not less than $\$ 2,000$, and transaets an annual business of over $\$ 15,000$. He carries a full line of choice groceries, teas, flour, provisions and produce. Mr. MicFerron was born ia Ircland, in 18.2, and has been a resident of $\Lambda$ lloghen y since 1864 . II e enjoys the patronage and confidence of many of the leading families in that portion of tho eity formerly designated as Minnchester.

\section{GEORGE CURRY,-Flour, Grain, Hay \& Feed, 995 Penn Av.}

In 1854 George Curry opened the first Feed store in the Eastern district of Pittsburgh in his present loration, doing a good business. Mr. Curry was horn in Ireland in 1831 near the city of Belfast. He was engared in the wholesale and retiil grocery business in the house of his brother in England, but came to the United States in 1851 ind wis employed in the construction of the Pennsylvania R. R. Mr. Curry has been very successful by his energy and industry, and thuugh he has a competence, he still persues his vocation.

\section{IMRS. C. HEUSNER,-Groceries and Produce, No. 133 Pennsylvania Av., Allegh'y.}

This well-known grocery house was established in $185 \mathrm{~s}$ with small capital, but gradually increased until it will now compare favorably with any similar establishment in this section of the city. Mrs. Heusner oceupies as store and dwelling the spacious three-story brick building $24 \times 65$, at No. 133 Pennsylvania Avenue, carrying a full and general assortment of choice family groceries, teas, coffees, sugars, spices, fruits, canned goods, produce, \&c., ralued at about $\$ 1,500$. Her trado is principally local and her annual sales will reach fully $\$ 15000$. 


\section{WEST POINT BOILER WORKS, -R Munroe, No. 13 Water St.}

The importance of all industrial enterprises contingent upon the iron trade of Pittsburgh can hardly be orerestimated, and among these, occupying a prominent positlon, the West Point Loiler Works of 12. Mrunroc are deBerving of more than brief mention in a wurk devoted to a proper detailed exhibit of the resourecs of this city. In 1835, or ne:rrly half a eentury aro, these works were establisbed by $\mathbf{M l}$. James Leitcli, one of the pionecr mechanicians of this community. Twenty-four years later they passed in to the possession of the firul of Watson \& $\mathrm{M}$ unroc, who carried on the business till 1875, when, by the withdrawal of the senior partner, Cil. Munroc assumed sole ownership and las since pursucd alone the successiul operation of trade.

The plant is located as ahore, at No.13 Water street, upon what is known as the "Point," from whieh tho name is derived. It consists of four buildings, of various dimensions, and covers an area of nearly two acres. Here the mautfacture of Steam Boilers, Still Tanks, and Shect Iron Work generally is carried on upon an extensive scale, every possible advantage being securcd in the use of the best machincry and improved appliances, including automatic punching machines and rolls, one set of which are 13 fect in length, the motive force being supplied by a 40-horse power steam engine. From 40 to 60 skilled nechanics ars engaged upon the work, involving an avcrago outlay of $\$ 103.00$ per weck, the resultan the United States.

Many improvements have been made in the construction of boilers by this house since its establishment. The location of a man-hole plate immediately heneath the tubes in tubular boilers is an original desirn with Col. Munroe, and is more perfectly conducive to the thoroush cleansing of the boiler than hy any other arrangenent. The work turned out by this establishment is celebrated for excellent and careful workmanslip as well as great durability and strength, the experience of more than twenty years enabling Col. Munroe to select not onl y the best materials adapted to the construction of the work, but to direct the mechanical opcrations personally, jn such a way as to secure the very best results. In his special line of manufacture Col. Nunroe is not surpassed liy any of his cotemporaries, and for promptuess and undoubted reliability has achicved a position that entitles him to no suall degree of consideration among those who have fostered aud promoted the best interests of Pittsburgh.

\section{PATTERSON BROS.-Livery Stables, \&c., 28 Ninth St. and Frankstown Av.}

Therc are two livery stables owned hy this firm, one at No. 28 Ninth Street and the other on Frankstown A venue, between Penn and Station strects, East End, both of which are supplied with new and clegant bugsies, carriages, etc. Their horses are noted for their speed ind good appearance, while their chasges ure as reasonable as those of any similar establishment in the city. They attend promptly and efficiently to undcrtaking in all its branches, and furnish earriages for weddings, concerts and parties on the most moderate terms. The stable at No. 28 Ninth Street is $30 \times 60$ feet, and the one in the East. End measures 40 feet in width by 75 in depth, giving ample accommodations for the boarding of loorses by the day or week. Messrs. Patterson may certainly claim to be thoroughly conversant with their business, they having in 1875 succeded their father, who had heen engaged in the same ocieupation since 1839. They began business with a capital of about $\$ 2,500$, and now value their stock at $\$ 5,000$, while the yearly business aggregates a bout the same amount. Benton Patterson was born in 18-12; Edward is two y (ars younger, and both have resided in this city all their lires.

\section{A. P. DAVIS \& CO.-General Insurance Agents, 67 Fourth Av.}

The Fire Insurance Agency of Major A. P. Davls, doing husiness under firm name of A. P. Darls and Co, was established in 187? with the representaliou of the Nationil Fire Insurance Co. of New York, the Virrinia Firo and Marine of Richmond, Va., and the Home Insurance $(\dot{\omega}$. of Columbus, $O$. A native of New Englind, Mrijor Dalvis was educated to the Insurance business in the East before making Pittsuurgh his home (having liad it: experieuce from lis early youth up), and cimne t" this city with a thorough knowledge of underwriting in all its details. During the time intervening since 1872, various additions and ehanges have beell wade in the companies represented and he now heads his list witl. the "Old Conne cticut Fire Insurance Co." of Hlartford, with assets of one and a half million; also the Northern of Jew York and or her tirst-class companies enjoying the implicit confidence of the respective managers. These availing themselves of these aclvantages can rest assured in having safe and reliable policies in the hands of an upright and reliable business man, who will consult the true interest of policy holders, and that lusses will be promptly and justly paid.

\section{THOMAS ROWS WLL,-Livery and Sale Stables, 979 and 981 Penn Av.}

Few men in this part of the city are more widely or favorably known than Thomas Rowswell. Mr. Rowswell was born in Perth $A$ mboy, N. J., in 1834. In 1839 lis father, now decensed, remored to Pittsburrl, bringing his fanily with him. Young Thomas learned the tr.de of a gliss blower, at which trade he worked until 1875, (30 vears), principally in the employ of $W \mathrm{~m}$. NeCully \& Co. In 1875 he started in the livery business, the original firm heing RowsTrell \& Griffith. In $1877 \mathrm{Mr}$. Griffith retired. He does a large livery and undertaking business, to the latter lie gives special attention. Mr. Rowswc]l has always been popular amongst the pcople n[ Jis neighborhood. Hle represented his ward in the City Council for several years, and was it mentber ol the School Doard almost ever since he reached his majority. Good rigs are kept, good horses and reasonalle eharges.

\section{ACKER \& CARR,-Stjves, Ranges, etc., No. 5 Frankstown Av., East End.}

Edward Acker began this business in 1871, in 1875 Henry Carr was admitted to rartnersbip. They now do a husiness of $\$ 8,000$. Deil in stoves, rancres and grate fronts, and nlanufacture all descrintions of tin, copper and shect iron ware. They also keep on hand oil, lamps, linterns and house furnishing goods generally. Their speciality j8 tinroofing and sponting; both are praetical workmen. Mr. A cker was born in Phillipsburg, Beaver county, Pa., June 4, 1841 , and came to Ohio in 1857. Mr. Carr is a native of Ireland, and was born in 1845, rouning to this city in 1846. Both learned their trade in the city, and possess the confidence of the residents of their locality. Their stuck is valued at $\$ 4,000$, and they cinploy two workmen whose salarics aggregate $\$ 80$ monthly. The capital upon which this business was originally started, has increased by well-merited success from $\$ 1,000$ to $\$ 4,000$.

\section{W. H. WILLIAMS, - Commission Merchant, Highland and Penn Av., East End.}

Mr. Williams commenced business for himself at the corner of Thirtieth Street and Penn Ave., in 1877. In March 1878, Je removed to his present location, which is $20 \times 60$ feet in dimensions, where he transacts a general conluission business and deals in flour, gratin, seeds, millfeed, \&e. His original capital was $\$ 600$, he now carries at stcek of about $\$ 1,500$ and his annual sales now amount to $\$ 12,000$. Mr. Williams was born at the East End, July 22, 1852, and was formerly teller of the Unlted States Savings Bink of Pittsburgb. He is a gentleman of energy and business tact ind stands bigh in the communlty in which he resides. 


\section{JOHN F. O'MALLY,-Attorney at Law, 91 Grant St.}

This gentleman, like many others who have reflected honor upon the land of their birth, as well as that of their adoption, was born in Ireland in 1853, and emigrated to this country in 1867 . With that insatiable thirst for knowladopt that marks the children of uenius, Mr. O'Mally at once entered college in this city, and prosecuted his studies with so much ardor and industry that, after two years, he left the institution with the reputation of large attainments and sound scholarship. Mr. O'Nally experienced the usual vicissitudes of life at this early period of his career, and while the bright future was yet distant and shadowy, chance or fortune determined Mr. O'Mally to artistic pursuits, and he learned the art of lithographic engraving, but of this uncongenial employment he soon grew weary, and now his growing ambition suggested the bar as his proper sphere. He accordingly entered the office of Hon. M. Joseph Gazzam ger. Conch as aw student. Under the able tuition of these distinguished practitioners, and ex-Mally made rapid progress in his legal studies, and grasped the fundamental principles of legal jurisprudence in a remarkably short time. After a most creditable examination by an able committee that show cd him no favor, and he asked none, he was admitted to the practice in the courts of Allegheny County in 1874. Possessing a fine voice and person, a read y and manly elaquence, a graceful elocution and undaunted courage, Mr. O'Mally came to the bar with man y personal ad vantages, besides those that flow directly from the highest culture and un wearied application. He at once took a prominent place at a bar unsurpassed if equalled in our State, and has held that place ever since his admission, undisputed and unchallenged. Mr. O'Mally could not resist the temptation to enter the political arena, and did yeoman service for Horace Greeley in 1872, and supported in $1876 \mathrm{Mr}$. Tilden with an ability, an eloquence and enthusiasm that made the name of Mr. O'Mally a household word in every district in Western Pennsylvania. He is again willing, at the first trumpet call of his party, to buckle on his armor, and do heroic hat tle in the cause of his heloved democracy. Mr. O'Maliy has a large and lucrative practice in the rarious courts of the county, as well as in the Supreme Court of the State, and in the United States Courts. Few at his age have attained such eminence in his profession, and he is vet far, as we venture to hope, from the zenith of his fame.

\section{LOGAN, GREGG \& CO.-Wholesale Hardware, No. 52 Wood St.}

The extensive Hard ware establishment of Logan, Gregg and Co. is located at No. 52 Wood St., sign of the mammoth padlock. This house was founded in 1831 by Logan and Kennedy. The firm afterwards became Logan, Wilson and padock house at the number above given, and carry a large stock of general Hardware and Cutlery, transacting an annual business ranging from $\$ 150,000$ to $\$ 175,000$, and employing ten clerks and salesmen. Their trade is located principally in Eastern Ohio and Western Pennsylvania, although they have customers in the far West, shipping to Michigan, Utah, Colorado and Nevada. Their specialties are Belting, Mill Supplies and Building Hardware, of which they carry complete lines in great variety. The members of the firm are Mr. Geo. B. Logan, who was born in Allegheny City in 1845, Mr. Edward Gregr, also a native of Alleghen y Co, where he was born in 1816, aud Mlr. T. A. Parke, who was borr in West Virginia but has resided in Pittsburgh since 1863. The business ot the house will compare favorably with that of any similar establishment in the West.

\section{WILSON RUNETTE \& SONS,-Dry Goods, Cor. 42d and Butler Sts.}

It will douhtless astonish many of our "down town" readers, who are not familiar with this section of the city, to learn that the largest and finest Dry Goods salesroom in the city is that of Messrs. Wilson Ruuette \& Sons, located at tbe corner of $42 d$ and Butler Sts.; but that such is an undeniable fact may be verified by a visit to this extensive emporium. The house was established in 1871 by Wilson Runette, Esq., the present Sr. member of the firm, on a comparatively moderate scale. Two sons, A. K. Runette and Jno., were afterwards admitted, when the firm proceeded to erect their present large establishment. Mr. Runette Sr. was born in Ireland in 1819, and came to this country in 1864, embarking in the Dry Goods business three years later in his own name. He possesses all the characteristic enterprise and energy for which the sons of Erin's Isle are noted, and may just!y he classed among the enterprising business men of the Smoky City. The two Jr. members of the firm have enjoyed the advantages of a long experience in the business, and are well qualified by nature and education to conduct the business.

\section{J. W. MOORE \& CO.-Coach and Wagon Builders, $857 \& 859$ Liberty St.}

The firm of J. W. Moore \& Co. was founded in 1567 by the present members, who carried on the business until 1876 at the corner of Washington and Bedford streets, when they purchased the present location of Mr. J. G. Klages, who had been engaged in the same line of business for a number of years. They occupy a three story building $40 x 100$ feet with a yard of the same dimensions, and manufacture wagons, coaches, buggies and every description of vehicles in a very superior style of workmanship. They carry an average stock of about $\$ 10,000$ and do a large and flourishing business and put up finest and most reliable work. Mr. J. WV. Moore was born in Prussia in 1840, but came to this country with his parents when an infant; he learned the trade of coach and carriage maker; he served with credit and distinction for three years in the Union army during the war of the rebellion as a member of the 4th Penn'a. Cavalry; at the close of the war he returned to his trade and soon after embarked in business in his own name. Mr. C. 11. Wise, his partuer, was horn in Butler county in $\mathbf{1 8 4 1}$ and learned his trade there. Both members of the firm are wide awake, enterprising business men. They now employ eleren hands in their establishment and their trade is rapidly increasing.

\section{GEO. WITTMER \& CO.-lce Dealers.}

The manufacture of large quantities of beer and other causes have stimulated this branch of husiness far beyond its former limits. These gentlemen started the business in Etna and now have over 18,000 tons, embracing three ice houses of large dimensions on Harris' Island, near the W. P. Railroad. A patent elevator is used for handling the ice, operated by an engine and boiler of 16 -horse power. During the ice harvest they employ 100 hands, in stimmer about eight. The firm consists of II. \& J. Wittmer, both born in Germany; the former in 1825, the latter in 1843 . George Wiltmer has a farm of 62 acres in Salor township, which he works and where he resides. They also have a grocery in condection with the ice business and keep a general stock.

\section{DAVID HUNTER,-Dealer in Cigars, Tobacco, \&c., 351 Butler St.}

This establishment is located on Butler St. near Thirty-fifth, where Mr. Hunter commenced business in 1875, now haviug a good stock of Cigars, Tobacco, etc., and doing a good retail buciness. Mr. H. was horn in Westmoreland this State in 1846, and came to Pittsburgh in 1868. He worked in the Sligo Iron Mills of Lyon, Shorb and Co. for many years, until starting in present business. Mr. H. served 13 months in the Union Army, participating in some severe struggles. 


\section{REED \& SMITH,-Seed's and Implements, 137 Liberty St.}

This eninent house if the most prominent as it is the oldest establishment in that line of business in the city, and enjoys a reputution for high eharacter, of which the proprietors liave a right to be proud. The house was established in 1866 by the lamented Rev. J. Knox, whose fame as the fruit king of America was as extended as the country. It was an outgrowth of his great and noted establishment, 29 Fifth Avenue, where he began the seed business nan y years prior to that $d a t e$, and the growth of the business requiring more room he opened the Liberty Street rooms. It afterwards passed into the hands of his son, W. W. Knox, who after conducting it very sucessful for some time sold it to Messrs. Scobie, Reed \& Smith, the first two named having been connected with the establishment for some years previously. In $1878 \mathrm{Mr}$. Scobie retired from the firm and the business passed in to the hands of the remaining mombers, Reed $\&$ Smith, who have been conducting it very successfully and with increased energy ever since. It is an establishment deserving more than a passing notice in a work devoted to the industrial and commercial pursuit of Pittsl)urgh. The business of this establishment is conducted on the highest principles of honor, with great energy and ability and to these facts, togelher with the genial, courtcous manners of the accomplished head of the firm, Mr. J. A. Reed, is due the eminent success it has attained and the prominent position it oceupies in the commercial atfairs of the city. The establishment is metropolitan in all its features, and a large, varied and complete stock of the best and most popular malzes of agricultural and horticultural implements, tools and machinery, of various styles, patterns, sizes, \&c., is at all times to be found in their very extensive warerooms. The building oceupied being 24 feet front, $112 \mathrm{ft}$. deep and 5 stories high, and from top to bottom are stored stocks of reapers, mowers, plows, among the latter a large number of the famous South Bend chilled plows, which are rapidly supplanting every other make, and implements and tools in endless variety adapted to all classes of farming or gardening work. Their retail and wholesale seed department is also a special feature of the establishment, to which the elosest attention is paid and which is in charge of a very competent, able and experienced seedsman. The reputation of "Kurs seeds" is not surpassed by that of any other brand in the United States, and their seeds find a market in every State in the Union. They also deal very extensively in artificial manures, handling none but the highest grades and most celebrated brands. The farming interests of Western Pa., East Ohio and West Va., are largely suppplied by this house with these manures as well as implements and seeds. The business reaches in the neigbborhood of $\$ 75,000$ per annum, and is continually widening and increasing. The house is well known and highly appreciated, not alone throughout this and adjoining States, but throughout the entire Union. in the service of his country as a prirate in the gallant 101 st Pa. Reg't., where by his gallantry he rose to the rank of lieutenaut, although yet a boy. Shortly after the close of the war he entered the present establishment in the capacity of a clerk for the Rev. J. Knox, from whence by his abilities and energy he has risen to the responsible position of the head of the large establishment, and which he has proven himself fully competent to successfully fill and of which he is every way worthy. He is a young gentleman of high charaeter, great energy and extended popularity and ranks high among the business community.

\section{JOHN R. \& A. MURDOCH, -Nurserymen, Florists, \&c., 112 Smithfield St.}

There are few houses existing in the United States at this time, engaged in the pursuit of floriculture as a business, that are better or more widely known than that of John R. \& A. Murdoch. Lstablished in 1840 by Mr. Jolin Murdoch, Sr., father of the present proprietors, the business was conducted by him for a quarter of a century with marked ability and success, reverting to his sons in 1865 , who have still enlarged the business, facilities and reputation of the concern. John R. \& A. Murdoch are natives of this eity, born respectively 1835 and 1840 , having always been comnected with their present vocation and identified with the ind ustrial derelopment of the community. The greenhouses of the firm are loeated on Fifth A renue, 14th Ward, at the East End, and are 17 in number and 65 feet in average length. The nurseries are in the 22nd Ward on Forbes Street, and occupy about one-half of a farm containing 100 acres. The premises iu the city are at 112 Smithfield St., opposite the post-office, and consist of one large three story brick building $20 \times 60$, with every convenienec requisite in the business. The trade of the nouse is between $\$ 35,000$ and $\$ 50,000$ annually, the stock maintaining a value of from $\$ 30,000$ to $\$ 40,000 ; 15$ to 25 hands being employed in the various departinents of the works. The speciality for which the firm is celebrated is "cut flower, " and in this line they are perhaps without a rival-having aecumulated, regardless of trouble and expense, the rarest and most costly and beautiful, foreign and indigenous tlowering plants, vines and shrubs, with a profusion of exotics and tropical growths In superb floral decurations and designs this firm has never bcen eclipsed liy any western house, a reputation achieved during its extended histor'y and justly nerited and deserved through this city and Western Penn'a. Johu R. \& A. Murdoch are well known as beng entirely reliable, prompt, energetic and entitled to the confidence of the public in every respect. As pioneers in the rocation of the nurseryman, florist and seedsman, they have done no little to enhance the usefulness of their business, and those at a distance with whom they may have relations can dejend with safety upon the representatious made or goods sold by John R. \& A. Murdoch.

\section{WESTERN EXCHANGE HOTEL, Ely Wicoff, Proprietor, East Liberty.}

The Western Exchange Hotel at Fast Liberty, opposite depot, is a four-story building $32 \times 40$, conveniently arranged for the purpose, is prepared to accommodate a large number of guests, and stabling for about sixty horses. For Farners visiting the East End markets, the Western Exchange is general headquarters, and Mr. Ely Wicotf, the proprietor, is deservedly popular. The rooms are neatly and comfortably furnished, the table is first-class in every particular and the rates reduced to popular prices. Mr. W icoff is a native of New Jersey and was born in 1822 . He eame to this city in 1850. Twenty years of his life have been spent as a railroad contractor, but since 1865 he has been engaged in the hotel business. He was formerly proprietor of a hot cl on the South Side, but in February 1874 he assumed the management of the Western Exchange, where he has built up a flourishing and satisfaetory business, doing about $\$ 3,000$ to $\$ 5,000$ per year.

\section{DURKIN, - Dealer in Coal, Mellon's Building, Station St., East End.} Among the dealers in this line in the East End, Mr. Durkin is one of the most actire. His office is loeated near the
railroad station. Mr. D. has a Coal Mine leased at the head of Lincoln Ave. just beyond the city, and mines the coal he supplies to his customers. The coal is of the best quality and is delivered in good condition and without waste and accumulation of slack. He supplies the East End gas works and otber establishments, besides having a large custom among private families of that portion of the city. Besides supplying bituminous Coal from his own mine, he furnishes anthracite Coal of all grades. Ir. Durkin was born in Ireland in 1842, eame to this city in 1862, and has been in business on his own account since 1874 .

\section{HARVEY,-Books and Stationery, 11 Frankstown Av., East End.}

Those desiring hooks or stationery should call at the establishment of L. Harrey, where the best varities of stationery and a fine assortment of books are kept constantly on hand. The establishment was started by $\mathrm{L}$. HIarvey \& Co. with only $\$ 200$ capital in 1860 , and became as now 4 years later. The capital now invested is about $\$ 3,000$, with annual sales over $\$ 6,000$. The building is $13 \times 60$ feet in size and is commodious and well arranged. Mr. Leonard Harvey is a native of Germany, born in 1843, and has becn in this city since 1850 . He began business in East Liberty, previous to which he was engaged in steam boating. 


\section{H. H. CLARK, M. D.-Physician and Surgeon, Butler St.. near Penn Av.}

Thero is perhaps in no business, or literary avocation, nor indeed in any department of life, a more devoted and falthful clias of men than is found in tho medical Iraternity, It is a professional calling for the lighlest qualitications of heid and heart, the deepent research and most profound stuly: It carries with it. the highest responsibilities that umst lo horme by its followers. Constant ente lahorious and patient study and earnest, enterprising research is exacted of those who hive (nnlered tho ranks, if they would ke(p) step with the rapid stricles that are being made in all its raried and wonderful departments of serence and ethics. No broaler fields of reseureh are to lo found in life than it afiords, no ligher studies are presented to the consideration of the tinite mind, except the study of the intinite, no more Intricaio and elitlicult problems are presented to ment than thase daily coming to the attention and reguiring the thought of the medical man. Il uman distress and suffering, in all their most srushing forms, are daily presented to their view, appealing to their doepest sympathies, and stimulating their greatest energies. Amil the pestilenee that "walketh apy of their fiththful performance of duty. The world inderd prosents lo view no class of men who so generally and fathfully are found at lheir posts of duty in times of danger and distress. 'Too often, too, are the services of the earnest, patient Physician depreciated aud undervalned by those who should feel and manifest the deepest gratitude for services reuclered. It is a profession that exaets the practice of the highest principles of honor on the part of its dlevotees. Life presents no more honorable ealling, and affords no better lichli for devoloping the nolilest qualities of min.

'The sulject of the mesent sketch, Dr. H. H. Clark, in the years that he has devoted to his profession, has proveu himselt eminently worthy of the high calling, and has achieved a suecess and prominence in the profession that $4 n-$ titlo him to more than passing notice in a work setting forth a brief sketeh of the men who figure in the history of the day. It is alwitys a pleasure to record the suceess of men who, unaided, and through difficulties and trials during youth and early mamliood, riso superior to all opposition, and surmount the man y obstacles continually arising in their on willd progress, and achieve a suceess and prominence in any department of life, and muel more so in the walks calliug for learning and superior knowletge. Dr. Clark was bora in Ireland on July 4, 184t, and the returu of each anniversary of Ameriean independenee eomes with added pleasure to lim. IFis purents, who wore very poor, emigrated to the United states, with their fimily, when he was bat 3 years of age, his recollections of the seenes of his mativity are therefore very indlstinct, while possessing many of the generous frank traits of the Irish character, he is thoroughly Amerleun in sentiment. His fither dying when lie was quite young, he was compelled to earnest etlort aud labor to atil in the support of his willowed mother, but possessing a noble ambition and desire for knowledge, his evenings were spent at nirlit-sehool, where he aceuired by e:unest, faithful application and study the fundamental principles of an education. "The self-saterifice and self-control manifested in such justances can searcely be appreciated by many, exeept those, who through the same trials have found their way to eminentec, but when it is considered that the hright, joyous hour's of youth, hours of ploasure and play, the sloouts of morry companions must go unliceded, and all he sturificed to tho calls of the noble ambition and lofty aspiration that look bey ond the present tu the greater and more in-
portant events of life. when the sunny hours of youth are patssed, wiJl aid the imagination in realizing the strength of will required. The spitee allot ted to i sketsh of this kind will not permit of as extended a history of the early struggles and incidents of the doctur, as it would be pleasant to give.

II wats employed as errand boy in a prominent business of the eity for some time, constantly attending his gtudies at night. $1 \mathrm{It}$, after becoming older, secured a clerkship at a moderate salary in an dry goots louse on 5 th ave., where ise remuined three years, still pursuing earuestly his studies. Ife at the end of that time went into the office of Dr. Dume:m, tund began the study of medicine, but remained there but a short time, roing back to liss clerkship. Bix months later wint hind him in the oftice of Dr. Walters, where he earnestly and with his usuil energy again began the study of medicine. IIe remained under the tuition of Dr. WV. for four years, and during that time by earnest, elose, persistent study livid the foundation for his future suecess. He afterwards attended the eclebrated lellevue Mledical cillego, gruduating from that institution with honor in February 1868 . He shortly afterwards began practice in lis present locatlon, where he has continued ever since. From the beginning the doctor has mot with flattering suceess in his professional eareer, and in tho 12 years sinee has gained a very extensive and luerntive pructiee and accumulated "I moderate fortune. The doctor, while being proticient in all departments of medical science, and giving attention lo "Ill tiranches of practice, yet naturilly prefers the higher and nobler department of surgery, to which lie devotes much study and rosearch, and in which he has attained an eminence seldom acquired at so early an age. His time and talents aro lingely employed in this lirmeh of his prietice, and he hiss sucenssfully performed some of the most difticult gperations that usually come under the skill of the surgion. Ile holds the responsible position of Surgecon to the Uniun Iron Mills, lhe Luey liurnaces and the Keystone Bridge Works, and also the position of medieal examiner for 'Travelers Accident Lifo Insuranee Company, and is a leading member' of the Alleglieny (\%o. Medieal Society. Frank, renerous and kind-hearted he has won the atleetions of all classes, and is respected and honored not alone for his professlontl attaimments, but for the high qualities of a gentleman and upright citizen. His oflice and residence is ov liutler st., ne:r l'enu ave, and the street ears pass his door every three minutes.

\section{W M. H. McN AR Y, - Hats, Caps, and Gents' Furnishing Goods, 3820 Butler St.}

With a fino stock of latest styles of IIats, Caps and Gents' Furnishing Goods displayed and arrnnged with the most porfect neatness and greatest tuste this cuterprising and agreeable gentleman, Mr. A[eNary, will be found ever ready to greet his man y friends and pitrons. The business at this point was started in 18 Tound since that time lias gradually increased. John $\Lambda$. MrNiny, tho son of tho proprietor, who is a very agreeable young gentleman, gives his attention Hlso to the husiness. Mr. MleNary was born in Ohio, but has been living in Alleghen Co. for 35 years, He bas been chlyged in farming for 30 years in Snowdon township, ancl of course is well and favorably known in that seetion, as well as in tho eounty at livge. II hats mingled in the politieal atfitirs of the county, exercising a strong intlueuce.

\section{W M. SMITH, -Real Estate \& Insurance Agency, Cor. 47th and Butler Sts.}

Will be found at eorner 47 th and l3utler Sts., where he gives his attention to insuring, renting and selling property

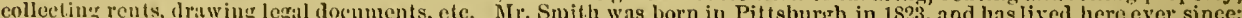
at the age of 22 he murried and engured in grocery buxiness in Lawrenceville, at a time when the 17 th ward was an enlire forest - now thickly populated. II continued in that business 21 years; he was the first postmaster appointed in Ianrenceville, being also postmaster again when the office was discontinued. He has held varions positions of trust in the Borough, being one of the old settlers.

\section{R. S. MARSI_AND,-Merchant Tailor, Penn \& 27th Sts.}

For first elass elothing call unon Mr. R. S. Marsland, Cor. Penn and 2ith Sts. IIc is a practical cutter, kecping a full lino of piece goods of foreign and domestie umenfacture doint strictly a custom business cuploying only first-class แWsistants and guaranteeing good fits. He is a native of Now York City, but has residen in Pittsburgh sinee 18:12, during which timo he has been engagel at his trafle as a cutter. Eight years ago he started in business Ior himself and has establlkhed in satisfactory trade. Mr. Mrarsland is u prominent member of tho M. E. Cluurch and stands very high in the community. 


\section{CHARIES RUINETTE,-Clothing, Hats, Caps, \&c., 4304 \& 4306 Butler St.}

Few establisliments in the lower portion of the city, of a sinilar character, will surpass that of Nlr. Runctte, between $43 \mathrm{~d}$ and 44 th Sts, on Butler. The business wis founded in 1878 hy the present proprietor ilt No 430t, ifter six monthis experience it was found necessary to increase his facilities and lie secured the adjoining store at No, 4306 . 1]e now occupies both rooms, and also the upper stories with a full and complete stock of fine clothing of his own manufacture, furnishing goods, hats, calps, fce, employing about twenty hands and paying out a large amount of money weekly. The salesrooms aue each $22 \times 62$, and the value of his stock on hand is not less than $\$ 15,000$. He also transacts a large merchant tailoring husiness. Mr. Runnette bas been actively engaged in business since boy houd, having been educated to the dry goods business. His emporium of trade is an ornament and a credit to this portion of the city and will compare favorably with any similar establishment in the country. Mr. Li. is a young gentleman of great energy, and very argreeable and popular manners, and his inany customers visiting his estalulishonent are treated in the inost cordial manner. The high natural business qualifications with which he is gifted have in the short period of time phaced him in the very front rank of the leading business men of the city.

The successful prosecution of a business enterprise requires a higl degree of ability and intelligence, when such is combined with a natural genius for business pursuits. The result will always he as it has lieen in the case of Mr. Li. The knowing how, where and when to buy a stock of goods is an important element in any lusiness. Mr. R. possessing this knowledge in an eminent degree enables him to give to his customers tlie benefit of his alsilities, and to furnish them goods at a greatly less price than other surrounding establishments, and this is one of the great reasons of lifs success. Such men soon make for themsclves a reputation worthy of record among the enterprising and successful iuell of the day.

\section{R. M. McCLARAN,-Apothecary, Liberty Block, Penn Av., East End.}

The leading drug store of the East End is that of Dr. McClaran, located in Liberty Block on Penn Ave. It was established in 1865 by the present proprietor, and for fourteen years has sustained an envialble reputation for accuracy in componnding medicines and putting up physicians' prescriptions, and the purity and excellence of all articles dispensed. Commencing with i capital of $\$ 1,500$, Dr. McClaran has now $\$ \overline{5}, 000$ invested in the business, a full line of pure Drugs and Chemicals, Patent Medicines, Pcrfumery, Toilet Articles, Brushes and Fancy Goods. etc., with the contidence of physicians and citizens of the East End. "Dr. McClaran's anuual sales will reach about $\$ 10,000$. It is store-room is $18 \times 60$ in size. Dr. McClaran was born in Bl:tirsville, Indiana Co., Penn., in 18t0, and came to this city about fifteen vears arn. He finjslied his course of studies in 1859, and lirst engaged in business at the Last End. Ho is a unember of the city council from 19th ward.

\section{GEO. IKENNGOTT,-Tin, Copper, Brass \& Sheet Iron Ware, Hardware, \&c.}

\section{Bretwen sisth de $36+h$ sts.}

Among the number of stores and successful businesses in this part of the city the Tin and Hardware of the upright gentleman, Geo. Kenngott, between 35th and 36th sts., on Butler st., occupies a prominent position. Mr. Kenngott began the business at his present place in 1862 . He soon extended his husiness, and now carries a very large and varied stuck of goods of all deseriptions in his line, and he is able to supply his customers with any article called for at the most reasonable prices. The building, which is owned by Mr. K., is 21 feet front and 76 feet deep. This is one of the oldest establishments of the kind in this part of the eity. During his 17 years of business life at this point he has succeeded in accumulating considerable means, ancl is now the owner of a large amount of property. He was born in Wuertenberg, Germany, in 1836, and came to the United States in 185t. He learned and followed Tinning, working in different establishments until he embarked in business for limself, and in which lie has bcen eminently successful.

\section{ROBERT M. JONES,-Pattern and Model Works, 882 to 888 Penn Av.}

The extensive Pattern and Model Works now located at 882 to 888 Penn Avenue, were estallished about twenty years ago by Mr. Jones; at first in a small way on Mechanie Street. From there be renoved to the Atlas Works and from thence 10 his present location in 1878 , where be occupies two buildings, one $35 \times 45$ and one $30 \times 30$, filled with the best and most approved machinery for the manufacture of models of every description and patterns for castiugs, \&c. He employs twelve skilled and exjerienced workmen, and supplies many of the large founderies, iron works and machine shops of this city. Mr. Jones is a native of New York City, where he was horn in 1821, but came lo this city with lis parents when but two years of age. In 1836 his fatber died and since that time he has been the architect of his own fortune and may lie cited as one of the self-made men of the Iron city. He originally worked at the trade of cabinet inaking but. subsequently abandoned that husiness for his present occupation. He workerl for a number of years as pattern maker at the Fort Pitt Works; his present works reflect credit upon the business tact, ability and enterprising spirit.

\section{AUG. SCHNEIDER,-Boots, Shoes and Gaiters, Cor. 38th \& Butler Sts.}

The store of $\mathrm{Mr}$. Schneider fs located at the corner of 38th and Butler Sts., where he started in 1870. He now has a large and well stocked store and is doing a prosperous husiness, giving special altention to custom wirk. Mlr. Schneider was horn in Bayonne, Europe, in 1815, came to the United States in 1865, baving accumulated some capital engaged in his present business.

\section{G. B. BARKER,-Grocer, Sharpsburg, Pa.}

This branch of husiness cannot be overlooked by any family. This is one of the leading houses of Sharnshurg. It is located at the corner of Canal and Main Sts. Mr. G. B. Barker embarked in this trade here in 1869 with $\$ 3,000$ eapital; since then he has connected with it the news business, keeping all popular daily and weekly papers, perioclicals and magazines, also a choice stock of groceries, provisions, \&c., doing a business of about $\$ 4,000$ jer anmum. He occupies a two-story brick buitding $30 \times 40$ feet, known as the "Bee Hive." He has been postmuster here for a number of years; born in England in 1825, came here in 1856.

METZ \& REIL, -Drugs, Paints, Oils, etc., Etna, Pa.

No house in Etna is more prominent in this husiness tban that of Messrs. Metz \& Rej], who a few vears since started in business on their own account, investing about $\$ 1,500$. Their store is in a onc-story frame building $20 \times 22$, in volich they carry a stock of about $\$ 2,000$. F. M. Metz and J. J. Reil are both young men, the former born in Wayne Co.. (). in 1854, and the latter in Sharpsturg, the sanıe year. Taking no prominent part in politics they liave industriously confined their energies to building up their business with sure success. 


\section{IRON CITY FLOUR MILLS,-Whitmyre, Brungard \& Co., 38th St. \&A. V.R.R.}

The Iron City Flour Mills were established in 1s7t by the present proprietors, who removed to this city from Wooster, Ohin, where they had for four yours previous been engaged in the sume line of husiness. Their works at the corner of $38+1$ st. and $A$. V. R. R. are fitted up with all the latest ipproved machinery, ancl atre as conplete as any in the United States. Three large boilers and a 100-horse power engine furnish the motive power, and the mills have a eapacity of 200 barrels per dieu. The main building is $100 \times 120$ feet, and 13 hands are constantly employed, the monthly pay-roll averaging about \$500. They manufacture a superior quality of thour by a patent process, and the reputation po their luands extends hrough IV estern Penusylvania and Eastern Ohio, where their trale is principally locatrit. The firm earries a stock of about $\$ 60,000$, and their annu:1 sales retch $\$ 150,000$. Their flour is noted for its general excellence, and meets with a ready sale. The memiers of the tim are gentlemen of experience in the husiness, and are active, energetic and thoroughly reliable business men. Their mills are a credit to the city, and deserve a prominent position umong that class of manufactories in a review of the business interests of Pittsburgh. Mr. David Whitmyre was born in Lawrence Co., Pal., in 1836, from there went to Ohio, when a young man, being raised on a farm, on which he worked until about 25 years of age, when he engaged in the milliug business at Wooster, Ohin, afterwirils removing to this city. He is a gentleman of high eharacter and respectability. He has charge of the mill as general mannger. Jno. Brungard, born in Ohio in 1841 , was also raised on a farm. He engaged in Mereantile business for rix years at New Mrdaletown, Ohio, from there to Wooster in milling business, and from there to this city. He is the general buiness financial manager of the uills.

\section{DR. JAMES ROBISON, - Butler St., near 37th.}

The popularity, high social position and exalted professional reputation of Dr. Robison has been won hy years of devotion und close application to his professional luties, and patient attention to the suffering community. He was horn near Morgantown, W. Ya., in 1811, received at literary education at Jetlersen College, Cinonslurg, Pil., heing a class-mate of some of the eminent men of the day, as well as some who figured prominently in public life years ayn. He graduated from Olio Medical College in 1841, practicen medicine 3 rears in Fayette Co. this State, removing to Lawrenceville, a part of this city, in 1845 , a few days prior to the great Pittshurgh fire, enthusiastically entering into the practice of his profession, to which he has continuously and laborinusly devoted his closest attention to the present. time, and still, thougly stricken with years and suffering with disease yields to calls. He has beel intimately associated with the growth and progress of the wards contiguous to the Allegheny Arsenal. He built his present haidsome residence on Butler st. in 1850. During the war he was appointed Surgeon in the army, servinga numlyer of months in the valley of Virginia. Was a volunteer. Surgeon in the army of the Potomat after the battles of the seven days, and Mtal vern Hill rendering efficient service to the Govermment. For a period of more than 10 vears was acting assistalit U.S. Surreon at Alleghen Arsenal, being relieved therefrom in 1876, at whiel time the office was discontinued. He was one the originators of the Metropolitan National Bank, and has served eontinuously in the directory of that institution since its organization, and is a leading member of the Presbyterian Church.

\section{EAST END MARBLE WORKS,-William B. Smith,}

Moghland Av, urar Penu Av. Fust Fud.

The East End Marble Works were established in Mtarch, 1879, by Mr. William B. Suitl, the present proprietor who is a thorough, practical marble cutter, having learned the trade with Mr. James B. Cooper of Perry Co., and mastered the business before starting for himself. Ho manufact ures every description of Monuments, Tonlis, HearlStones, Furniture Teps, Tiles for Floors, Vestibules, de. He makes a specialty of Mantle work and every description of Marble masonry. Mir. Smith was born in Perry Co., Pa., Oet. 8, 1839, and eame to Pittsburgh in 1S71. His establishment is located on Highland near Penn ave., offering strong indueements to those interested.

\section{WM. KING,-Alderman and Police Magistrate. -Office, 4508 Butler St.}

Mr. King has served the eity in his present capacity the four years past to the entire satisfaction of the people, who elected him to the position which he fills with honor. He was Deputy Mayor 2 vears of this time, under the anministraton of W.C. McCarthy, the predecessor 10 our present Mayor. Mr. King was born in Carlisle, Pa., in 1S39, coming to Pittsburgh in 1845 , where he has resided cversiace. He served 3 years in the famous Hamptou Battery, that went to the support of the government from this city during the war. He is a plasterer and stucco worker lyy trade, at which occupation he has continuonsly worked up to the time of his election to the position le now fills. He enjoys a high degree of popularity in his ward.

\section{H. BEATTIE,-Groceries and Provisions, 43rd St., bet. 9th \& Willow Sts.}

Mr. Beattic's grocery store is located on 43 rd st. between 9 th and willow sts, where he engaged in the business in 1S75; having a good location and enjoying the patronage of the better class, he is doing in good trade. Mr. Beattie was born in Ireland, in 1828, came to the United States in 1844, and has worked continuously at his trade of iron moulding working for the same establishment. (Mitchell \& Pennock, where he commenced), now Mitchell, Stevenson \& Co, al the time, until meeting with a serious accident, disabling him from futher work, after which lic engaged in his present business.

\section{J AS. P. GREGG, Jr. -Fashionable Hatter, 135 Federal St., Allegheny.}

The well-known fashionahle Hat House at No. 135 Federal street, Allegheny, was established ahout twent $y-f$ ve years aro by $\mathrm{Mr}$ John Boggrs, who was succeeted in $1860 \mathrm{by}$ the present proprietnr, Mr. James P. Gregg, Jr. He ocenpies the two-story brick building 12x80 feet, at the loatinu above named with a fine stock of fishinnable hats and caps, employing two assistants and transacting an anmual husiness ranging from $\$ 15,000$ to $\$ 1 \$, 000$. MIr. Gregg has enjoyed the reputation of heing the leading hatter of Allegheny for nearly twenty years. He was horn in Allegheny in is 13 and has been a life-long resident of this city. He is at present a member of Council from the Second Ward.

\section{PETER HUBUCK, -Butter and Eggs, 4312 Butler St.}

Located at 4312 Butler st., Mrr. Hubuck keeps the best and freshest butter and eggs the market affords, supplying with none but a superior article. Mfr. H. engaged in his present business in $187 \mathrm{~S}$, and is building up a prosperous tracle. He was born in Steubenville, 0 , in $15+8$, coming to this city in 1869 , working at his trade of boiler maker until engnging in present busiuess. 


\section{J. C. O'DONNELI,-Groceries and Provisions, Cor. Penn Av. and Hazlett St.}

It is always a pleasure to record the suceess of wen who by their individual eftorts and own lndustry rise from the humbler waltis of tife to promiuenee in the liusincss ol professiunal world, and the bricf sketch of the present subject is given with admiration for the courage, endurance and success attuined in the struggles of his life. Mr. J. C. O'Dunlell is located on Penll ave., corner Hazlett alley, in the 1 intll Ward, where he has the iuost extensive grocery and pruvision business in this part of the city. He occulies a three-story lnick luilding 31 feet front le 78 leet in denth, and curries a very large, complete and varied stock of yroceries, provisiuns, etc., to the amount of $\$ 10,060$ or more, and is doing a business of from $\$ 35,000$ to $\$ 50,000$ per ammum. He started in the grocery business at his present location in 1867 with small eapital, which he was entubled to increatse rapidly. Yis business has continued to grow and bis popularity to increase. He was born in Butler $(0$. ., l'at, in $18: 3$, cume to Pittsburgh in 1854 and worked at the puddling furnace in Shoenberger's Irun M[ills for a time; he afterwards secured employment in the same capacity with the tirm of of Reese, (iratf \& Wouds, being the first empioyec engaged by that firm, when they began business in 1863 . He remained with them some ycars, prudently saving his earnings, which in the course of time amounted to suffeicut to enable bim to stat in his business in a stiall way, but which has grown into its present very large proportions, under his careful and conscicntious manigeuent. He is a director of the Metropolitan National Bank of the Last End; he has also been a prominent member of City Councils fur the past three years; he takes an active and leading interest in all public uatters.

\section{UPPERMAN \& BRO.-Livery and Boarding, Penn Av., bet. 33d and 34th Sts.}

These popular stables are locate 1 on Penn ave., bet. $33 d \& 34$ th sts., where the proprietors eluharked in the business in 1878. They carry stock :muuutin' to uear $\$ 5,000$, and are doing a very prosperous business. Thes give special attention to Undertaking in all its l,ranches. Their stock is of the liest eharacter, and every thing ahout the estal)lishment is kept in the nost perfeet ord'r. The success and prosperity of the firm ane due to the prompt and eareful manner in which all business entrusted to their care is attended to, and their upright and honorable deaing. The firm is composed of John and Wu. H. Upperinsn, both of whom are natires of Pittshurgh, Johu having been born in 1845 , and $W_{m} . H$. in 1st7, and have lived in this city ever since. John early in life learned the trade of tanning and currying, at which he worked two years, leaving that to embark in the Shoe business. He is now proprietor of the fine and well stocked shue store at the corner of Penn avc. and 3id st., in which he carries a very complete and ehoice stock of Boots and shoes to the amount of $\$ 5,000$, and in when the is duing a very large business to the extent of $\$ 12$, toun to $\$ 15,000$ per annum. He is a prominent member of eity eouneils, in which position he has served the past two years, and wields al large influenc". Wm. learned the machinist trade with Reesy \& Bro., at which he worked for ten years, aecumulating by cemomy some capital with which he cubarked in the livery business ncar his present location, afterwards entering into partnership witli his brother.

\section{O. EILENBERGER,-The Log Cabin Cigar Store, 1309 Penn. Av.}

The ncat, attra tive and well stucked Log Cabin Cigar Store is located at No. 1309 Penn ave., where Mr. Eilenberger, the proprietor, began the business with a very small ciljital, but which has increased greatly, and now he is doing a large and prosperous business to the amount of $\$ 8,000$ per annnm. IIe carries a stock to the ainount of $\$ 2,000$. He employs two hands in manufacturing Cigars. He was horn in Germany, in 1843, and eame to Pittsburgh in 1849 , where he has resided ever since, learning the tobaceo business early in life, in this city, saving by economy his own eapital to enable him to sturt for himself. IIs is a popular young gentleman, a leading ucmber of the National party, and exerts an important intluenec in the councils of his party.

\section{THUMAS ATCHISOIN,-Teamster, Small \& 25th St.}

No better illustration of what may be accomplished by honest industry, indomitable pluck and irrepressible energy Heed be rited than the case of Mr. Thomas $\Lambda$ tebison, the well-known and popular teamster of the East End. Comucncing business for lumself eleven years ago with but one team, he has continued to prosper uniil he now owns six four-hor'se teams and transacts a business of which he may justly feel proud. He dres a large amount of hanling for several leading manufactories and business bous s. Mr. Atchison was born in Ireland in 1816, but lats resided in this country since 18.j3. Ho worked at teaming fo: otuer parties at first, but is now engaged in business for himself with protit and credit to himselt.

\section{DR. E. S. HANN A, -No. 4311 Butler St.}

Dr. Hanna has been in the sucessful practire of his profession since 1861, coming here from Jefferson Co., Ohio. During the 18 years of professional life in this city, the Dr. bas attaincl an cminent position in the medical profession, and is in the highest standing with the medical fraternity. He has oceupicd the responsible positions of Surgeon to the Alleghen y Co. Workhouse for 9 yeurs, erer since its organization; surgeon to the A. V. R. R. for 10 years; physician to the Church Hume Urphan Asylum for 16 years, in which positions the Dr. has rendered services. He is the suflicient father of the inventor of "Leatheroid," "a material manufactured from paper lyy chemieal process, forming a substitute for leather (see Leatheroid M'f'g. Co, in these pages). The Dr. Was born in Steubenville, 0., in 1828, studicel medicine with Drs. B. Mayers and L. B. Dursey of that eity, graduated with honor at Jefferson Medical Coliege, and began praetice in Cinciunati, Olijo, afterwards removing to this city. The Dr. is a cultured gentleman us well as an tminent Physician.

FREDERICK URBA CH, -Saddles and Harness, Etna. Pa.

Indispensable to a Borough like Etna is the shop of Mr. Urbach. He startert in 1871 on $\$ 500$; his shep now is a two-story building $36 \times 45$ feet; keeps atout $\$ 400$ worth of work on hand and manufactures saddles, harness or anything in the line to order, as well as doing repairing promptly to order; doing a lussiness of about $\$ i 00$ per annum. He was born in Germany in 184t, came to this place in 1571; is doing a good business.

HEN RY W. OCESE,-Oil Gloths, Dry Goods, Notions, ctc., Etna, Pa.

Henry W. Ochse, in the Borough of Etna, dcaler in dry goods, notions, oil clnths, fuents' furnishing goods, ctc., starled business severil years since on a capilal of $\$ 2,000$, and now has a trade of alout $\$ 7,000$ a year, carryine about $\$ 3.000$ in stock, occupying a building $20 \times 0$ ó feet; he was born in Etaa in 1850 and has resided in the Borongh ever since. He is owner of the building he occupies on Butler plank road. 
Visitors desirous of avoiding the smoke and dust of Pittshurgh, and vet being within convenient distance of her busing the com forts of a home and first-class accommurlations at moderate prices. This popular house is located on Federal St., only one square from the Suspension Bridge, and two squares from the depots of the Pittsburgl, Ft. Wayne and Chicago R. R., and the West Pa. R. R. It is in convenient proximity to the Exposition Building, and the coliseum and all the public buildings, places of amusement, and leading business houses of Pittsburgh can he reached by horse cars which pass the door every few winutes. Mr. Chas. E. WVollendale, the grenial and popular proprietor, succeeded Joseph Keating, Esq., in March 1878, and duriug his occupancy lias unde many improvements in the house and furnishing of the rooms. He emplovs one clerk, and his yearly business, which is both transient and local, anounts to from $\$ 12,000$ to $\$ 13,000$. In connection with the house is a finely stocked bar, where the choicest wines and liquors are kept, and a billiard room fitted up with the most approved style of tables. The culinury department is presided over by first-class cooks, and the apartments and appurtenances of the dining room are tirst-class. The sleeping apartments, twenty-two in number, are neitly and comfortably furnished, and no efforts are sparcd by the proprictor or clerks to render the staly of guests pleasint and agrecable. Mr. Wolfendale was born in Allegheny City, Jan. 28, 1848.

\section{NATIONAL PLANING MILL,-Joseph A. Steen,}

Nis. 61,66 and fis racock St., Alleghen?.

The National Planing Mill, Sash, Door and Box Faetory of Mr. Joseph A. Stcen is said to be the most complete establishment of its kind $\mathrm{in}_{\mathrm{t}} \mathrm{this}$ section of the country. The husiness was established in 1870 hy MIullen, Steen \& Co. A single building, 410x100 feet, was at that time sutticient for all the requirements of the business. In MIay, 1873, this building was destroyed by fire, but was at once reluilt o:1 all enlarged scale, and the works now occupy a substatitial 1 hreestory brick building, $75 x(0)$, sutplied with all the unodern conveniences and appliances. One 75 -horse power engine, with 40 -inch boilers and 22-feet thue, is tixed to its utmost capacit: to furnish motive power for the machinery constantly in use. Steam elevalors, capable of hoisting 2.000 feet of Jumber, are employed, and hot air is forced into the dryer by one of Sturtevant's improved blowers, and, in cold weather, heats the entire building. In addition to the manufacture of Sash, Doors, Frames, Monldingrs, stair lails, Balusters, Newel Posts, \&c., Mr. Steen does every description of Turning and Scroll-Silwing to order, and kecps a large slock if rongh and diessed Lumber, Shingles, de., constantly on hand. His business now a verages about $\$(1), 003$ per annum. and is steadily increasing. He carries at all times a stock of hest and most desirable seismed lumber in various slapes and sizes, and furnishes constant employment to 20 hands, with a monthly pay-roll amounting to $\$ 30 \%$, or more. Mr. Davill Brown is bookkeeper, aud attends to the office business. MIr. Steeu is a liative of this State, and has resided in Allegheny nearly all his life.

\section{TRIMBLE \& CO.-Contractors and Builders, 245 Beaver Av., Allegheny.}

The business now conducted by the above named firm was established in 1861 by Geland, Crawford \& Trimble and by them continued until 1867 , when they were suceeded hy Trimble, McIntire \& Co., which firm conducted the business until 1875. Messrs. Wm. F. \& John H. Trimble doing business under the firm name of Trimble: \& Co., occupy the premises No. 245 Beaver a venue, Allegheny city, $150 \times 120$ feet. Their factory building is I wo storics $48 \times 70$, of brick with engine house attaclied, conttining one fifty-horso powcr engine and latest machines. They cimploy cighteen experienced workmen at a monthly expense of about $\$ 000$. They manufacture doors, sash, fiooring, siding and monldings, requiring over 200,000 feet of lumber per annum; they also do scroll sawing of every description to order. They are extensive contractors and builders, and making a specialty of railroad contracts, building station houses, depots, freight houses, \&c. Their annual business anounts to over $\$ 50,000$. They are both natives of Butler Co., Penn'a., and have resided in Allegheny since $18 b \dot{1}$

\section{ALLEGHENY GUN WORKS,-Jno. Fleeger, 49 ohio St.}

Mr. Fleeger, proprietor of the Allegheny Gun Works, has carried on the gun-smithing business in Allegheny city since 1831. He occupied a stand on Diamenid strest for over thirty years and has been in lis present locention aloui two years, where he occupies a building $18 \times 27$ feet and carries a stock valued ut about $\$ 5,000$. IIc manufactures to order sporting :tnd target rifles, and carrics a stock of fine English lirech and muzzle loading shot guns, r(volvers, cartridges and ammunition. Mranufacturing and repairing is a speciality. MIr. John Fleeger and his son, William A. l'leeger, are both practical gunsmitbs. Fine specimens of his work on exhibition.

\section{S. T. McCLELLAND,-Fashionable Hatter, 121 Federal St., Allegheny.}

The establislıment of Mr. McClelland is headquarters for gentleman's head wcar in Alleglieny city. It was founded by biun in 1868 . He occupies a three-story brick huilding $18 \times 00$, desirably located on the Brondway of Allethelly, at No. 121 Federal street. His stock will amount to between $\$ 1,000$ and $\$ 5,000$ and his ycarly salcs $\$ 10,000$. Mr. McClelland gives his personal at tention to the business and employs one assistant. His stock is alwars fresh and of the latest and most desirable styles. Mr. McClelland enjoys the patronage of the first families of Allegheny and surrounding towns.

\section{BEPLER HOTEL, -South-West Cor. of Diamond, Allegheny.}

The Bepler Hotel on the south-west corner of the Allegheny Diamond, offers inducement to those desiring comfortable quarters, which zan but commend it to the attention of the traveling public. This housc was established in July, 1866, by Mr. Ad:m Bepler and conducted by him until his death, which occurred in March, 1876; now earried on by his heirs. It is a large three-story brick biilding $40 \times 120$; stable accoumodation for 115 horses This house is noted for its comforts and excellent accommodations. The table is supplied at all times with the best the market affords. Mr. C Geist attends to the office, and is a courteous, affuble gentleman. The terms of this liouse are only one dollar per day to transient guests.

\section{H. FICKEISEN,--Hats and Furnishing Goods, 299 Beaver Av., Allegheuy.}

The leading house in this section of the city for Hats, Caps and Gents' Furnishing Goods is that of Mr. H. Fickeisen, at No. 299 Beaver a venue, where he occupies a brick building $16 \times 140$, with a stock of men's and boys' hats, caps and furnishing goods. With small expenses he offers extraordinary inducements to purchasers. He was born in Alleghen $y$ in 1852, and has been established in his. present line of business for five years. 
J. J. FETZER \& BRO.-Croceries, Teas and China Ware, Cor. Butler \& Main Sts.

These gentlemen started their business in 1868 with small capital, which by their ability and energy they have rapidly incre:Ised until now they carry a stock of $\$ \bar{j}, 000$ or upwards, and are doing an inmense retulil business, with their rooms stocked with stiperior goods. They own and built the large three-story block $36 \times 80$ feet, where ther are located and the corner roon of which is devoted to their growing business, the adjoining room being occupied by a brother in the hardware business. The Messrs. Fetzer are enterprising business men and keep a stock of the best groceries to be found in the city. Those who have occasion to deal with them will al ways be treated with greatest courtesy and dealt with iu the most generous and upright manner. They keep the best class of goods in the line and sell at closest figures, and are enterprising and reliable men. The members of the firm are J. J. Fetzer and C. F. ( $\dot{r}$. Fetzer, both of whom were born in w wrtemberg, Germany, came to the United States in 1848 ; parents located on a farm, on which Mr. J. J. Fetzer worked for a time, aftewards engaged in the manufacture of blue, by which industries he accumulated some capital which lie invested in business of the preseut firm. C. F. G. Fetzer, after coming to this country was engaged in different commercial houses in this city, acquiring a practical iusiness education, previous to entering into partucrship with his brother. These gentlemen are both popular business men.

\section{WM. BAUR,-Hats, Caps, Gents' Furnishing Goods, 3624 Butler St.}

The courteous, popular and genial gentleman and enterprising young business man, Mr. Wm. Baur, will be found at No. 3624 Butler Street, where in his large and well arranged store room will he found the largest and most complete stock of Hats, Caps and Gents' Furnishing Goods of all the latest styles and patterns and of the finest quality to be found in any establishment in this part of the city. Mr. Baur first opened his store in this part of the city in 1869 , with very limited capital and some misgivings as to the success of the enterprise; but by strict attention to busines he steadily enlarged and increased his business from the beginning, until now carrying a stock of $\$ 4,000$ and upwards and doing a business of from $\$ 10,000$ to $\$ 15,000$ per annum. Mr. B.'s is now the longest established hat store in this part of the city ; during the ten years of his business career here he witnessed seven or eight unsucessful at tempts on the pirt of others to establish a rival business. Mr. B. is a native of the ward in which he is now doing business, having been born there in 1816, and growing up in it, and seeing it grow up ahout him. He learned the trade of lithographing and carving when quite young in the establishment of B. Singerly \& Co., afterwards relinquishing it to èmbark in his present business.

\section{EAST END CARRIAGE IMANUFACTORY,-Joseph Grim,}

Some of the finest wagons in use in the two cities are from the well known mannfactory of Mr. Joseph Grim, which was established by the rirn of Grim \& Reese, who were succeeded by the present proprietor in 1877. He has invested a capital of $\$ 1000$, and occupies two buildings, one $30 \times 30$ and one $30 \times 60$, on Penn avenue, near Hiland. The wood-working, black-smithing, painting and trimming departments are each in charge of skilled and competent workmen. His annual trade reaches $\$ 4000$ to $\$ 5000$, and he gives employment to six hands. Mr. Grim is a natise of Beaver Co., Pa., born in 1836, learned his trade as tritumer with Johnson Bros., of Allegheny City, but afterwards removed to New Haven, Ct., where he learned the other branches. He commenced business for himself in this city, and has built up a flourishing trade.

\section{IM. L. JEN KINS, -Boots, Shoes, Hats, Caps, etc., Main St., Sharpsburg, Pa.}

Mr. Jenkins was born in Chester Co.. West Virginia, January 11, 1855, and came to this city in March 1872; in 1874 he commenced business for himself in Sharpshurg amounting now to about $\$ 12,000$. He carries at stock of all styles and varieties of Boots, Shoes, Hats, Caps, Trunks, etc. ralued at $\$ 5,000$; doing first-class custom work and repairing. His store is 15 by 75 feet, situated on the principal thorough fare of the town.

\section{FREDERICK C. SCHW ARZ,-Cabinet Maker, 136 Ohio St., Allegheny.}

The picture frame and general cahinet making estahlishment of Frederick C. Schwarz, is locater at No. 136 Ohio street. Allegheny City, in a building 16xs2 feet, and three stories in heirht. Mr. Schwarz began business in 1873 with but $\$ 300$ capital, and he has since increased it to fro:n $\$ 5,000$ to $\$ 6,000$. Believing that investments in the hest. machinery pilys, Mr. Sehwarz is supplied with the most approvel tools and unachinery, among which is a scroll and circular toring machine in one piece. His skill has secured a large trade in the surrounding counties, valued at frnm $\$ 2,500$ to $\$ 3.000$ per ye:ır, and his stock, which is of a superior character, amounts to about $\$ 2,000$ to $\$ 3,500$. Nr. Schwar\% was born in (rermany, August 7, 1826, and came to Allegheny City in 1569, where in 1873 he begall his present business. He is president of the Ohio Street Building and Loan Association, and now serving his fourth year.

\section{W.J.SARVER,-Watches, Clocks and Jewelry, 46 Federal St., Allegheny.}

One of the best known and most reliable jewelry estahlishments in the two cities, is that of Mr. W. J. Sarver, located at No. 46 Federal street, Allegheny. This house was founded in 1862 by Craft \& Sarver with moderate capital. Two vears later the firm became Sarver \& Brown, and in $1869 \mathrm{Mr}$. Darver became sole owner and proprietor. From its very inception the husiness has steadily increased. Mr. Sarver carries a fine stock of Watches, Clocks and Jewelry of every description, valued at not less than $\$ 6,000$ and his yearly trade $\$ 5,000$. Mr. Sawer's specialty is fine Howard and Elgin Watches; his sales department is $20 \times 40$ feet in size. Particular attention is given to fine watch repairing; he manufactures to order solid goods of every description pertaining to the jewelry live. Mr. Sawer was born in Allegheny City, Angust 4, 1840.

\section{P. W ALTERS, Jr.-Druggist, 64 Chestnut St., Allegheny.}

Mr. P. Walters, Jr., was born in Pittslurgh, March 21st, 1839, and began husiness for hiuself at No. 194 Federal St., Allegheny City, whence he removed to his present place in 1570. This location has been used for many years as a drug store. The inerease of Mr. Walter's capitalfrom $\$ 570$ to $\$ 15.000$ demonstrates his ability, and that his goods has'c given universal satisfaction. He keens on hand a stock of drugs and chemicals, together with a full line of white lead, paints, oils and varnishes, valued at $\$ 5,000$ to $\$ 7,000$, and transacts a yearly business of $\$ 10,000$. MIr. Walter eninloys two salesmen, who are experienced in the compounding of physician's prescriptions, auc his customers are distributed throughout the en tire county. 


\section{A. J. HARBAUGH,-Granite and Marble Works, Butler, bet. $47 \& 48$ Sts.}

The Granile and Marble Works of Mr. A. J. IIarbaugh on Butler strent, between 47 th and 48 th streets, are among the most extensive and complete in the West. The business was started by Mr. H. in 1860 without capital-but by the irost extery and push he rapidly extended lis business, and placed in such a prosperous condition that he now has $\$ 30,000$ invested in it and rauks among the leading concerns of the kind in the country. He was the first to introduce the manufacture of granite for unonumental work in this city. His works have 310 feet of shop room, being a four story trick building with a very handsome stone front, and is fitted out with all the: most approved machinery used in the business. IIny of the finest and uost noteworthy monuments ind statues in Allegheny and adjoining eemeteries in this and other western cities and towns were erected by 11 r. II. Among the number as being very remarkable works of art, may be mentioned the sitting statue and pedestal of l).miel O'Neill, a work that ranks with that of the hest artists of the old or new world, ( $\mathrm{Mr}$. W. Matyer being the sculptor). The Meclurg monument, 35 feet high, with large statue; Alex. Spcer monument, Cochran monument, Johns' mounment, and many others of publie note. Mr. Fred. Mayer, the emment sculptor, employed in this establishment, is an artist of the very highest merit, whose work in all respeets is equal to that of any sculptor in the world-MIr. Mayer is a sculptor of rare alility. MIr. Harbaugh in seeuring the services of Mr. Matyer, las shown his appreciation of art and manifested his enterprising spirit. Mr. Harbaugh was born in Alleglıeny city in 1831, learned the trade of marble cutting when young, and has followcl it ever sinee. He served in the Union army until the close of the war, in the 155 th $\mathrm{Pa}$. Vols. - hiving left his business to serve his eountry, which he resumed after returning. Mr. Harbitugh invites the elosest inspectiou; the public are in vited to call and see and judge for themselves.

\section{DR. J. H. LEGGE,-Physician and Surgeon.}

The medical profession is one of the noblest calling, affording unbounded opportunities for the exercise of the highest qualities of heart and intellect, one to which it man may devote the purest aims of life; it profession requiringr the most careful preparation and profoundest study and research, such as are also progressive and cultured. Failures of suecess are attributiblo to a want of some of these qualifications, sometimes nearly all of them and yet as a rule, true merit will be rewarded with sueeess. The subject of this sketch, Dr. J. H. Le rye, is a gentleman of high attaininents and professional learning, and an honor to the profession. He wis born in England July 13th, 1S35, and came to the United States with his parents in 1850. He is descended in a dircet line from Sir Thonas Legre, the first earl of Dartmouth, who was the founder of the family in the fourtcenth century. This lineage is direct inale descent, and he is donbtless the rightful heir to the Willey estate, and earldom of Dirtmouth. Hle graduated the Jefferson Nedical College of Philadelphia in 1858, having personally undergone a rigid course of study under an eminent Physician. After graduating he began practice in the city of Wheeling, W. Va., with marked snccess. 11e cane to Pittsburgh in 1870 , where a broader field of usefulness opened to him. His abilities were soon recognized hy the medictl lraternity and he soon achieved popularity and prominence here. A elose student and observer he has always kept patce with the times. Every new discovery meets at his hand prompt investigation, and he is quick to avail himself of everything ol merit, and to discard the worthless or obsolete. His ruyid adherence to the code of ethics, and his requirements ind reeotnition of the praetice of same on the part of his inedieal brethren, has gained for him the highest respect and contidenee.

\section{IR. H. HAGER,-Wall Papers, Oil Cloths, Window Shades, Notions, \&c.}

This establishment is located on Butler st. opposite 36 th st., where the business was started by C. T. Iauer in 1868 , who sold out to Mr. Mr. H. Hager in 1S7j. He enl:rryed the stock and increased the business; he now has il large and tine store room completely stoeked with Wall Paper, Shades, Notions, Oil Cloths, Fancy Goods, Parian Marble Statuary, Children's Carriages, etc, ete., having about $\$ 6,000$ invested in the stoek, and is doing a prosperous local business. He was horn in Alsice, France, in 1817, e:me to the United States in 1852, eoming to Pittshurgh 4 years after his arrival in this country. He enlisted when but 14 years of age as drummer-boy in Gist Pa. vols., serving three years in that eapacity with his regiment, participating in all the campaigns and hard service of his regiment, without a day off duty. At elose of war he returned to Pittsburgh, and worked at various things, until embarking in the grocery business, which he sold out after three years to engage in present business.

\section{HARRIS CRA WFORD,-Groceries, Frankstown Av., 19th Ward, East End.}

This is one of the best known and most universally patronized grocery stores in the East End. Mr. Crawford was horn in the same ward (the 19th) in which he now does husiness, October 23, 1848, and is therefore well known by all the residents of the East End. IIe went into husiness in $A$ pril, 1871 , with a capital of $\$ 1,000$, and owing to his large acquitutance and the excellent character of his stock, he has now, jneluding real estate, a capital valued at $\$ 10,000$, and his yearly trade is estimated at $\$ 10,000$ Mr. Craw ford employs two assistants and keeps on hand a regular groeery uess is, that goods are always delivered promptly and frue of eharse.

\section{THOS. D. DAVIS, M. D.-Penn Av., East End.}

Although only a resident of Pittsburgh for the past two years, Dr. Davis is well and farorably known as a skillful physician and surgeon. He was born in Morgantown, Vil., 18 10, graduited at Jefferson College, Cumonsburg, and studied his profession and graduated at the Jefferson ALedieal College, Philadelphia, in 1869. The doctor aceepted il position on the medical staff of the Philadelphia Hospital immediately after gruluating, and remained in that capacity for two years, when he removed to Dayton, Ohio. After practieing in that city for five years, with signal suecess, on aceount of impaired health was compelled to seek a elimate free from malaria, and he accordingly settled here in November, 1877. Dr. Divis' ability mily bo measured by the fact that, iu his short residence here, he has built up for himself a practice valued at $\$ 3,000$ per year.

\section{H. METZGAR,-Surgeon Dentist, Penn \& Frankstown Aves., East End.}

The Dental Rooms of Dr. Metzgar are loeated in the Deunison Block, corner of Penn and Frankstown avenues, East Enul. The Dr. is a gentleman of experience, who has devoted unueh at tention and study to his profession, and who stands high as a competent dentist. He is a native of Westmoreland Co. Pn., and was liorn in 1840 . He removed to this eity in 1Si0. and hits practiced his profession here since 1875 with marked success. He studied with Dr. Fisher of his native eounty, and wils admitted to practice in 1865 . He attends personally to all his patrons, and all work performed ly him is guaranteed. His business now amounts to about $\$ 1500$ per annum. Dr. Metzgar posseses many adrantages for executing tine work. 
FRAUEN HEIM \& VILSACK,-Iron City Brewery, Liberty Ave., \& 34th St.

II:d all the Breweries in Pittsburgh, during the pist ye:urs, mantufacturel the quality of beer wade by the famous Irou City Brewery, the introduction and large sale of the many brauds of Western Beer in this market would have been au utter itupossibility. Many of them have awakened to the fact, that the poor quality of their goods has been the une:tus of loss of trade, only when they liave realized that it has been lost. These facts, lowever, will ultimately prove a great advantage to the reliable ureweries of this city, who have always uade good beer, in stimulating their enterprise and efforts to produce an article superior to an ything hitherto produced in this or any oller city. Notwithstanding the high quality of the beer that has ever been produced liy this establishwent, their jresent products : ire in every respect equal to the finest beer ever sold in this city, and superior to many of the brinds of

foreign beer that has found a mar-
ket here. The ligh quality of the beer now produced, will not only have the tendency of driving out of this market

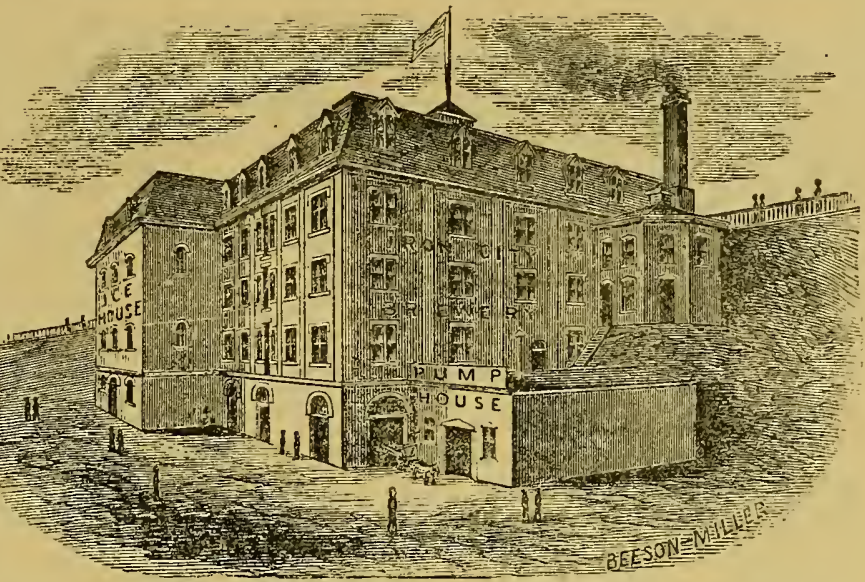
all foreign brands, but cle long will take the home market of many of the western lreweries that are now shipping here. Pittsburgh beer will in the near future be as popular in the West as her iren aud glass. It is useless, perhaps, to speak of the folly, not to say the want of public spirit and pride in home industries on the part of dealers and consumers in senling west for beer, when a better article, and we say BETTER without any reservation whatever, can be delivered at their doors fresh from the vaults of our heme breweries every morniug. Among the many fine establishments in this line in this city are Fraucnheim \& Vilsack, Liberty Ave., and 34th Street.

One of the mist complete and extensive Beer Brewerics in the United States is that now conducted by the above named well known and thoroughly reliable firm, and the reputation of their superior brands of beer extends over Pennsylvania and all the adjoining States. The Iron City Brewery was founded in 1869 by Frauenheim, Miller \& Co., in a comparatively small way at first, near Seventecnth St. They remained in this location for abont five years, when they removed to their present site and crected the commodious and well arrauged building which they now occupy, $85 \times 100$ in size, containing four stories with mansard roof. Three years later they added a three story brick structure, $50 \times 100$, in order to better accommodate their steadily increasing trade. These buildings are surplicd with all the latest and most approved machinery and appliances required in the business and liave a capacity for manufacturing about 50,000 barrels per annum. Twenty-five to thirty skilled and experienced workmen are coustantly employed, with a pay roll averaging about $\$ 1,300$ per month. They carry an average stock of about 10,000 barrels of Beer and the total valuation of stock, materials, de is not less than $\$ 150,000$. Their anuual sales will eompare favor-

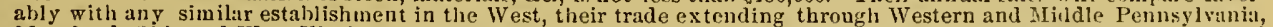
Maryland, ohio and West Virginia. The present members of the firm are Mr. Edward Franenheim and Mr. Ieopold Vilsack, gentlemen well and favorably known in business circles as honorable, energetic and enterplising representatives of the great industrial interests of the Iron City. Mr. Elward Franenheim is a native of Gernany. He was burn in 1820 and came to the United States in 1842 . He was for some time engaged in the groccry business in the ninth ward, Pittsburgh, in partnership with Mr. August Hoevler, afterwards removing to Fiftl avenue, where he remaned for eleven years. He commenced in business with small capital, but by industry, economy and close application, accumulated consideralle neans, which he invested in his present business and which has steadily increaserl until he is now the possessor of a handsome fortune. Mr. Fraucnheim has represented his will in the city council with credit and ahility. and his son, Mr. A. Frauenhein, who is also connected with this establishment as book keeper, is now counciluan elect from the 15th ward. He is a young gentleman of accomplishments, very popular with the people and an honored, respected citizen. Mr. Leopold Vilsack was born in Pittsburgh in 1838 . He was, during his boy hood, engaged in working on a farm, but, having an inclination for a more active business carecr, came to Pittsburgl and learned the trade of brewer at Bennett's Brewery and afterwards asseciated himself with Mr. Fratienhein as a partner in the present firm, where he has accumulated a considerable fortune, the result of his own encrgy and ability. Mr. Miller retiring six years ago and Mr. Hoevler, another partner, having previously dicd. Mr. Vilsiek devotes his personal attention 10 the general management and supervision of the Brewery, and to his abilities as a maltster and hrewer, together with great energy and hich business qualification is due much of the popularit $y$ of this house. Mr. Frauenheim attends to the business details and financial department of the estalilishnent. The Iron City Brewery occupies an envitble position among the manufactories of Pitsburgh and has been the means of extending the fame of the city as a great business centre.

\section{E. PRETSHOLD,-Dealer in Tin and Hollow Ware, 53 Chestnut St., Allegheny City.}

No. 53 Chestnut street is occupied by the above-named gentleman, manufacturer and dealer in Tin and Irollow Ware. His facilities for manufacturing these articles are unusually large, and being a practical tinner himself. Mr. Pretshold was born in McKeesport in this county, April 25, 1860, coming to this city in 1866, where he learned his trade with the well known firm of Weldon \& Kelly. He opened his present establishment in April, 1878, witls no cıpital but $\$ 35$. His capital is now $\$ 500$, stock $\$ 800$, yearly trade $\$ 6,000$. He invented a bread pan machine, which is a great convenience and meets general approval.

\section{THOS. FAUST,-Baker \& Confectioner, 267 Lacock St., Allegheny.}

None are more worthy of mention in this line than Mr. Thos. Fansi, at 267 Lacock street, dealer in bread, cakes, candies, nuts, \&c. He is well known for the superior quality and freshness of his bread stuffs all over Allegheny City. He commenced business in 186.5 with a capital of from $\$ 200$ to $\$ 300$, which increased to from $\$ 1,000$ to $\$ 2,000$. At present he keeps a constant stock of $\$ 2,500$ and does an annual business of more than $\$ 10,000$. His establishment is diviled into two departments, viz:--store and bakery. He employs tive hands, with an average pay roll of $\$ 25$ jer week. $\mathrm{He}$ is a native of (iermany, horn June 1837, and came to this city in 1853, whore he began business himself $t$ welve ycars later. He was in the war of the rebellion and served long and well. 


\section{Dr. G T. JACOBY. -3708 Butler St.}

The medical profession is a calling that exacts the most patient, tiresome and self-sacrificing service, affording opportunities for the exercise of the noblest qualities of head and heart; it requires its followers to he the most enterprising and active men in science and ethics. It lias heen honorerl with some of earth's noblest men, exacting also the highest principle of honor. G. 'T. Jacoby whose office and residence is located at No. 3708 Butler street, is in esteemed member of the profession to which he has devoted the best years and the greatest energies of his life durin the past 25 years without the loss of 25 days. During the niost of the time the Dr. has been continually jresset with hard service, having at one time a practice extending over 100 square niles. Compelled to go at the cal of the suffering night and day; possessing great energy and a robust constitution, he was enabled to endure the bard service for a time, but years and trial warned him that the severe strain of his physical nature would bave to be relaxed. He, with yreat promptness, determincd to give up his country practice and remove to the city where he could still devote lis time talents and aftainments to the service of his fellow-men in the calling of his choice. He came to Lawrencerille and hought his present tine residence in 1866 , since which he has earnestly and laboriously cnntinued practice in which he has been remarkably successful. His attainments as a physician, his earnest devotion to his profession, his enterprising spirit, always leading him to keep fully up and sometiues in ad vance of the discoveries of scientists. He was born in France in 1828 and came to the United States with his parents when eight years of age. They came direct to this city where they located near the place they have resided ever since. He studied medicine with his father, who practiced many yeurs ago on Fifth Avenue and in Allegheny City, and who is still living, hale and active at a very advanced age, though having retired from active practice with an ample Iortune, living in Tarentum, Pa. The Dr. attended and graduated from two promiuent medical colleges in this country; he began practice in Tarentum, in 185t, meeting with deserved success from the start, afterwards located at Harmarsville, in Allegheny County, where he continued for many years, during which time be built an excellent practice and repulation, being eminently successful in the treatment of ill classes ot disease and especially so in diphtheria, at the time it first made its appearance. The Dr. adopted an original treatment which proverl eminently successful and which has since been accepted by the medical world as the most successful. During the thirteen years of his residence in Lawrenceville, he has leen continuously actively engaged in practice, and gained the very large practice and high reputation as a successful physician, and is largel y interested in valuathle city property. As a pliysician he is widely known and has achieved an eminent position in the medical world. He is honored and esteemed as an upright gentleman and worthy and influentia! citizen. He was surgeon six years to St. Francis Hospital, a position he had to resign on account of the large demands on his time in his private practice.

E. M. IASLETT \& CO.-Keystone Nut \& Bolt Works, Cor. Main \& Cherry Sts., Al.

In regard to size and facilities for the prosecution of their business, this firm is particularly fortunate in the selection of their buildiur which is of an "L" shape, having a frontage of 50 feet on Main street, and extending back 1?0 feet, where a wing extends at right angles to the main building, a further distance of 120 feet. F. M. Haslett, the projector of the present estallishment, was born in Allegheny City, Oct. 2, 1851, and in 1871 commenced bis business career witl Fahuestock, Haslett \& Schwartz. In 1876 he had accumulated sufficient capital to assume the principal control of the business himself, and the firm having extended their facilities and increased their resources, are at present trinsacting a business throughout the West and South, which is among the largest done by any similar establishment in Western Penusylvania. They employ a force of 70 men and boys, the month]y pay roll amounting to $\$ 2,500$, and use in the prosecution of their business an engine of 60 -liorse power and boiler of corresponding size.

\section{MRS. S. L. DARRAGH,-Artist, No. 712 Federal Street, Allegheny City.}

An appreciation of the fine arts is considered to be one of the highest forms of cultivation, and one of the best known among our local artists is the sulject of this notice, Mrs. S. L. Darragb. She was born in Baltimore, Md., Nov. $3,18+5$, and early evinced a talent for sketching, which, under the guidance of experienced masters, soon ripened into that style, distinguished for correctness of drawing and warmth of coloring, which has won for her a high position among the artists of this city aud seeured for her work the encomiums, not only of our local connoisseurs, but also of those of the large western cilies. Mrs. Darragh particularly excels in portrait painting and drawing. It is worthy of note that although Mrs. Darragh has only been actively engaged in her profession for about six years (having opened her studio to the public in July, 1873), she has serured in the two cities, as well as Cincinnati and Louisville, a large and critical class of patrons among the most prominent citizens.

\section{A. C. SPENGLER,-Hardware, House Furnishing Goods, etc., Penn Av., East End.}

Mr. Spengler after becoming a thorough workman in his line, established himself in business in 1869, and has built up a trade which is steadily increasing, amounting now to over $\$ 8,000$ annually. His store room is 98 feet in depth, with work-shor on the second story. The store is supplied with a general variety of Hard ware, Garden Implements, Sloves, Ranges and House Furnishing Grods, together with an assortment of Queensware, Crockery, etc. The variety of urticles embraced under each head would nake a formidable list in this line. He also does tin-roofing, spouting, etc., having two men employed for that purpose and general jobbing work in tin, sheet iron, etc. Mr. Spengler was born in Jackson, Miss., November 19, 1846, came to Pittsburgl, October 15th, 1864; learned his trade and business in the East End, where he has since been so successful.

\section{TITUS BERGER,-House and Sign Painter.}

Is located at No. 3811 Butler st. Commenced business in 1871, continuing therein ever since, succeeding in that time in tuilding up a large and prosperous business by his ahility, promptness and energy. He does all kinds of plitin and funcy painting, frescoing, etc., in the highest style of art, his business extending throughout Alleglieny County. Mr. Berger wis horn in Germany, in 1844, and came to the United States in 1860, coming to this city within one year after. He learned his trade in this city, going to it when 8 years old, continuing at it ever since, a fact that fully accounts for the superior merit of Mr. Berger's work. He was superintendent of the painting department of the Allegheny Valley R. R. Co. for 11 years, in which position he reudered efficient services, and gave very general satisfaction. He resigned his position there in 1871 to embark in his present business, in which he his been eminently successful.

\section{WIM. A. GW YNNE,-Baled Hay \& Feed, $503 \& 505$. Fifth Av.}

The business now conducted ly Mr. Gwynne was originally established by Mr. Otsis Hess, who was succeeded by the present proprietor in 1857. He carries a full stock of Oats, Corn, Baled Hay, Chops, Mill Feed, \&c., valued at about $\$ 4,000$, and has an available capital of $\$ 10,000$; annual sales $\$ 5,000$. Mr. Gw ynne owns the premises and building at Nos. 503 and 505 Fifth Avenue; the latter being a one-story iron clad structure, $40 \times 90$, where he offers inducements to purchasers. He was boru in Ireland, January 29,1825 , and has resided in Pittshurgh for the past thirty years. 


\section{EDWARD SPRING,-Pharmaceutist, 24th St. \& Penn Av.}

The elegantly arranged and thoroughly stocked Pharnacy, at the corner of 24tl street and Penn arenue was cstablished April 1st, 1875 , by Mr. Edward Spring, the present proprietor, is a gentleuan of long experience anil possessing a thorough practical kuowledge of the business in all its details and departments. His establishment is desirably located and fitted up in the most tasteful style, and his stock of pure drugs and chemicils, medicines, perfumery, toilet articles, etc., is full and complete. Mr. Spring is a thoroughly educated plarmaceutist and devotes special attention to the careful preparation of family recipes and physicians prescriptions, enjoying the confidence of the members of the medical fraternity throughout the city. Mr. Spring was torn at Stuttgardt, Germany, in 1842, and was engaged in the wholesale drug business in the old country. He came to the United States in 1858 , and was for a period engaged in the same line of business in Pliladelphia. During the war of the rebellion he served for five years in the Union army, as a member of the gallant 21st and 75th Penn'a. Vol's., holding the position of hospital steward from the commencement to the close of the war; after receiving an honorable discharge he re-cngaced in the drug business in Philadelphia, where he remained for three years. He then removed to Allegheny City, and for two years carried on the same business, afterward le sold out his interest in that city and removed to his present location, where he is doing itlourishing business and is highly esteemed by all with whow he is thrown in contact, either in a social or business ray. He is thoroughly conversant with both the English and German languages.

\section{WIM. S. BOSTWICK.-Manganese Bronze Foundry, 33rd St. \& A. V. R. R.}

These works are located corner 33rd and A. V. R. R. They were started by E. Bostwick, father of present propricLor, in 1s70, and at his death, in 1876, passed into the hands of his son. The foundry covers a space of $100 \times 140$ feet and is fitted with all the necessary appliances for successfully carrying un the business. MIr. Bost wick is the sole minufaclurer of Manganese Bronze Castings; a superior composition being niore durable and stronger than brass. He uses in manufacturing about 200,000 lbs. of this composition per annum-his trade extends throughout the West generally. Mr. Bostwick was born in Lansing, Michigan, in 1858; his parents moving to this city when he was quite young. He worked for 10 years in the foundry of his father, acquiring a thorongh and practicat knowledge of the business. Although quite young, be possesses a degree of energy and business experience well qualif ving him to successiully carry on his rapidly increasing business. Mr. Bostwick by his energy and enterprise is rapidly introducing his manufactures throughout the country, and wherever any of his goods are used they meet with the highest commendation and give the greatest satisfaction. He possesses a business ability and energy of a hirh order and is engaged in an enterprive affording him fine facilities for the exercise of these qualities that are rapidly pushing him to a prominent position mong the rising young manufacturers of the cits. The composition is being used more and more cach rear is its qualities of it are becoming known for engines, locomotives, car and rolling mill hrasses, etc., and is destiued to reach in very extensive use. The greatest promptness is exercised in the execution of all orders estrustcd to lis hands, which are also gotten up in the very best manner.

\section{EDW ARD FOERSTER,-New Wall Paper Store, 94 Federal St., Allegheny.}

This store was opened by Mr. Foerster in 1879, and is therefore a new candidate for the patronage of the public. But the business was begun under the most favorable auspices, the entire stock hein new and of the latest patterns, and purchased at rates exceptionably low. The business thus far bas surpassed the highest expectations of $11 \mathrm{r}$. Foerster. The trade of the house is strictly confined to Wall Paper and Window shatcs, but these articles are found in their fullest varieties and numberless attractions. Two obliging gentlemen are employed in this store, and customers are assured of nost courteous attention. The trade lies in the city and county. Mrr. Focrster was born in (iermany in 1824 , and came to this city in 1839. He was a most efficient nuember of the school board for 16 years. In lis business his patrons will find hiin a pleasanı gentleman and excellent business nan.

\section{T. A. REX, M. D.,-Physician and Surgeon, 377 Fifth Av.}

Dr. Rex is a native of Philadelphia, born Feb. 10, 1838. He at first adopted the profession of eivil engineer, and in that capacity in $185 \overline{7}$, assisted in the construction of the Washington (D. C.), aqueduct in the engineer corpls under Capt. N. C. Meigs, U. S. A. He then entered the Philadelphia College of Plarmacy and graduated in 1861 with higl honors, subsequently pursued a conrse of studies at Georgetown Ifedical College, from which institution he graduated in 1865 and served for eight months as assistant surgeon in the Uniter States Army. He graduated with distinguislied honors at the University of Pennsylvania in 1860 and located in Pittsburgh the same year, commencing the practiec of his profession. Accomplished scholar, physician and surgeon, he is eninently qualitied for his responsible position. His office is 377 Fifth avenue.

\section{SAMUEL SHEFFER,-Grocer, Frankstown Av.. East End.}

This well-established grocery house which supplies the wants of a large nunber of families in the East End and surrounding country, was formerly kept by Mr. Peter sprague. The present proprietor succeeded to the husiness in 1877 , starting on a capital of about $\$ 1,100$. The yearly sales now amount to from $\$ 10,000$ to $\$ 12,000$. He keeps a general assortment of fanily groceries, with Flour, Teas, Provisions, Produre, etc., in variety sufficient to supply the usual demand for family use. Mr. S. was born in Wilmore Camliria Co. Pa., Marcls 4, 184t, and eame to this city in 1866. He served in Col. Samuel iV. Black's regiment during the war of 'the rebellion, Irom June 1863, until the surrender at Appomatox Court House, iu A pril 1860 .

\section{S. \& W. H. MARTIN,-Lumber, Sash, Doors \& Blinds, 258 Fifth Av.}

These gentlemen have heen identified with the lumber trade of the city since 1863 , when the concern was started. At their yard may be found a full line of Doors, Sash, Shutters. Joulting and Flooring, as well as building lumber of all kinds. The stock carried being from $\$ 10,000$ to $\$ 15,000$, while the husiness of the firm will amount fully to $\$ 30,000$ per annum. These gentlemen are well and favorably known. The senior nember of the firm was born in lreland in 1818, came to the United States in 1823, while Mr. W. H. 11. was born in Johnstown, Pa., in 182s.

\section{A. McDONOUGH,-Groceries and Liquors, Penn Av. \& 30th St.}

Prominent in the north-east district is this store, though the proprietor is but 30 rears of age. He has been engaged in businegs five years. Was born in Ireland, came here in 1868; was first employed in Keystone Bridge Co. until 1874. He keeps a good stock and does a good trade. Has in vested in some valiable real estate-is courteous and at tentive to all. 


\section{J. H. CONNELIY \& SON, Agents,-Fire Extinguishers, 272 Liberty St.}

It will be but a few years before water is entirely superseded by those chemical combinations that were formerly considered so impracticable as a fire extinguisher. The consolidation of all the Fire Extinguishing Companies in the United States, with the purchase of all leiters patent pertaining thereto, is the result of Pittsburgh enterprise and capital, and is deserving of more than passing attention. "The Consolidated Fire Extinguisher Co. Was for'uned by the establishment of a joint stock company, with a capital of $\$ 350,000$, which securing control of the "Babcock" of "Chicago, the "Champion" of Louisville, the "Peerless" of Philadelphia and the "Connelly" of Pittsburgh, effected a conjunction of these in one grand central plant, and by the appropriation of the peculiar merits of each are now manufacturirg chemical Fire Extinguishers that have been tested hundreds of times with the most perfect success. The officers and directors of the organization are, Major Wm. Frew, Pres't. ; Geo. Bingliam, Vice Pres't. and Treasurer; B. L. Crawford, Secretary ; Chas. M. Martin, General Manager; E. W'. Neff, Superiutendent ; Chas. Lockhart and Mr. J. H. Connelly, Directors; the latter being also resident agent for the company in this city, and the inventor and patentee of the most perfect and valuable Extinguisher in the consolidation. A native of Canonshurg, Penn'a, where he way born in 1818, Dr. Connelly was educated and graduated at Washington and Jefferson College, at his native place, and selecting the profession of weelieıne, attended the Jefferson Medical College in Philadelphia, receiving his degree and diplomi in 1850. For 19 or 20 years thereafter he practiced his prufession with merked success in Pennsylvania and West Virginia. The peculiar bent of his mind, however, was directed to chemical and mechanical science, and to the Improvement of ancient processes by the application of modern thought. In 1874 with this idea he began to experiment with chemical extinguishers, and in 1875 secured his first patent, man $y$ others following subsequently. Not alone in this but in other departments, Dr. Connelly has achieved the reputation of being one of, if not the best practical inventor in this cummunity. As resident agent for the Consolidated Fire Extinguisher Company, he has secured suitable premises at the above location in the Seventh A venue Hotel, where may be inspected at all times a varied assortment of the fiultless machines made by the company, including all sizes, from the convenient litnd apparatus to the chemical engine, for city or town use. Such as are regarded as being indespensable in New York. Chicago, and the largest is well as the smallest cities of the country. Sudden in action, prompt in efficacy and avoiding the spoilation occasioned by the use of water, the machines of the Consolidated Fire Extinguishing Co. must inevitably supplant ercry other mode now employed for the suppression of fires. Those interested in this matter are cordially commended to J. H. Cunnelly \& Sun.

\section{CUSHING \& FOX,-Real Estate Brokers, \&c., 4318 Butler St.}

These gentlemen opened their office in $\mathbf{1 8 7 5}$, and have charge of a large amount of property and are doing a good bnsiness in renting, insuring, selling foreign exchange, drawing legal papers, etc. They are also agents for a numler uf foreign steamship lines; doing a general Keal Estate, Broker, Insurance and Collecting business. Mr. P. M. Cushing was born iu Ireland, came to the United States when about 21 years of age, enlisting in the service of the government at Allegheny Arsenal, and served as clerk in quarter-master's department; at the close of the war hie entered the auditor's department of the P., Ft.W. \& C. R R. Leaving these and engaging in business of Steanship Agency with Mr. Bingham ; leaving those to embark in present business. Mr. George Fox was born in Germany, in 1824, came to the United States in i839; worked for 30 years in Allegheny Arsenal, entering the machine slop when a boy, and worked up to the highest grade. After work stopped at the arsenal MI. Fox wis engaged in the grocery business for some years afterwards. He is one of the oldest settlers of Lawrenceville, now 17th ward of the city. Was a member of City Councils for somo time, taking an active interest in public aflairs.

\section{R. BEITER \& CO.-Brush Block Manufacturers, 20th and Mulberry Sts.}

The manufacture of Brush Blocks is carried on quite extensirely by the above named firm at their factory, corner of 20 th and Mulberry sts. The house was cstablished in 1866 by Mr. R. Beiter on Lacock st., Allegheny City, where lie had a fine shop. He was burned out during the same year with almost a total luss. Mr. F. S. Barney is now associated with him, and the firm occupies a shop fitted up with improved wachinery, which is used by no other establishment in the city, giving unequaled facilities. The trade of this house extends all over the United States, and amounts to not less than $\$ 10,000$ to $\$ 15,000$ per annum. Mr. R. Beiter is a native of Germany, and was born in 1844 . He came to this country at the age of four years. After learning the trade of brushmaker he worked as journeyman for a number of years. Despite repeated misfortunes he has met with success. Mr. Barney formerly resided in Geneva, Ohio, where he was born in 1829, and was engaged in mercantile pursuits until engagingwin the present business, and is the inventor of the new machinery now in use at this factory, of which the tirm are the exclusive owners, and which is destined to create a revolution in this branch of industry.

\section{JAMES A. SMITH,-Saddlery \& Harness, Frankstown Av., 19th Ward, East End.}

Mr. James A. Smith was born in this city, Jaruary 2, 1821, and learned his trade here. In 1869, with a very modest capital, he began business in the East End, and now employs two assistants and 1 ransacts a yearly business of $\$ 1,000$ to $\$ 1,500$. Mr. Suith's Harness and Saddles are too well known to require an y commendation, and his repairing is unexcelled in neatness and strength. He keeps in stock, besides the ordinary harness and siddlery, an issortment if trunks, valises, sacks, etc., valued at $\$ 100$, while his trade, located in the $19 t \mathrm{~h}, 20 \mathrm{th}$ and 21 st wards, is rapidly increasing.

EAST END PLANING MILI, -S. Brown, Prop'r, Euclid \& Broad Sts., E. Liberty.

This Planing Mill-the only one in East End, was established originally by Messrs. Sill \& Negley. In Octoher, 1875 , $11 \mathrm{r}$. Samuel Brown became sole proprietor, and he still carries on the business successfully. The capital invested is aboul $\$ 5,000$ und the yearly business amounts to over $\$ 6,000$. The main building is $50 \times 100$ feet with another $25 \times 80$. He employs four machine hands and six bench workmen, with a monthly pay roll averaging \&400. Je manufartures Sish, Doors, Shutters, Frames, Mrouldings, Brackets, Flooring, Siding and Frame Lumber and does scroll sawing and turning to order. Mr. Brown was born in Pittsburgh, October 27, 18:37, and has been a life-long resident of the city, aud is an energetic and enterprising business man. His post office address is "'Station A."

\section{CAMPBELL \& LAUFFER,-Marble, Granite and Stone, 1725 Carson St.}

These workmen and skillful mechanics began business witl a moderate capital. A large amount of work is turned out at their shop for the various cemeteries, bespeaking great skill of excention. The shop of Camplesll d. Lauffer is $20 \times 35$ feet, and the yard attached is $120 \mathrm{ft}$. deep. They employ five hands, with a monthly pay roll of $\$ 200$. All work done here for the cemeteries, and it alone forns a large portion of the business, receives special attention at the hands of the proprietors. MI essrs. Cainpbell \& Lautfer are natives of Pittsburgh, the former being born here in January 1S51, and the latter in December 1858. 


\section{J. B. DUNLEVY,-Dental Depot, 132 Third Av.}

The wonderful changes effected by modern invention in the useful arts and sciences is nowhere manifcsted so abriously as in the direction of improved dental appliances. The ancicnt Tournequet of half a century aro lias given place to tiue and complicuted instruments and even apparatus, that not only relieves the patient froul all piliu duriug the most serere operations, but even takes away the knuwledge of its progress. Tu supply the modern dental practitioner with all the varied applianees and materials necessary to the successful pursuit of his vocation, lias become an important branch of industry by itself, engiging the labor and attention of theus.unds of artistus, operati is and de:llers in the United states, becoming a source of wo inconsiderable revenue. Amoug thuse in our own city, My. J. 13. Jumlevy occupies perhaps the most prominent pusition both with reference to the extent of his trade, its long establishment and as a min ufacturer of gold foil. Orivinally commenced in 1837, by Thos. Uttington, the business e:ture into the hands of Mr. Dunlery in 1849, who has since continued it with the most satisfactory success. He is lucated at. No. 13\% Third arenue, and in commodious apsirtments; and the annual trade, which reaches largely througliout the Western and Southeru st:ttes, being faverable and increasing. Every article known to the trade, from teeth to dentul chitirs, including all stundurd works on dentistry, are in stuck and can be furnished at the lowest figures; 110 one in western Penn'a, or perhaps the entire West, his had a more valuable or comprehensive experience in the line of his oc'up:ttion. As a careful, reliable and prompt business man, with a complete knowledge of every detail, kecping pace with all the i:dvauces made in each department of the trade, Mr. Dunlevy can offer inducements that cannot be surpassed west if the Allerbeuy mountaius.

W M. C. BROWN,-Eagle Marble and Granite Works, Butler St., opp. Centre St.

Among the notewerthy Marble and Granite Works in this or neighboring cities is that of Mr. W. C. Brown on Butler st., upp. cemetery gate. The works are well arranged and located, and are titted with whatever alphliances and machinery that is foumd serviceable in this line of business. Piles of Granite blocks, Marble sialss, de., scattered about the yurds attest the large business done, while neatly displity ed are Headstoues, Nunuments aud Memorials of various styles, sizes and prices of the tinest workmanship, avd of varied materials, from which his patrons are enabled to select. Mr. Brown occupies a leading position in his business, and has erected many of the tiner and must noteworthy Headstones, Monuments and Memorials in Allegheny and neighboring cemeteries in this city and the different parts of the country, his fame as a first class artist having extended tbroughout the adjoining counties and Statt:s. Those who are in necd of marble er sranite work of any description, either for memorial work or bulding purposes, will find these works able to offer rare inducements, and orders executed with the greatest care and promptness.

Mr. Brown started in business in 1859 with small capilal, which he has greatly inereased since then by his busiiness ability. He now has thousands of dollars invested in his business, and gives to it his personil attentiun. Ho was born in Allegheny city in 1s35, learned the trade of marble cutting when quite young, and has worked at it all his life. He was U. S. Assessor during the war, has served lis ward in the city councils for a number of ycars, oceupying a leading and influential position in that body. He is a popular, public spirited gentleman, enjeying a bigh degree of public fávor.

J. F. CLUIEY,-House \& Sign Painter, Dealer in Mixed Paints, etc., 134 Smithfield St.

This well known house was founded in 1850 by Mr. Joln F. Cluley. He now occupies the entire three floors and basement of the business structure, $20 \times 50$, at $\mathrm{N} \theta$. 131 snithtield strcet, where be keeps Ready Mixed P:ints, Putty; Winduw Glass, Uils, Turpentine, Varnishes, French Plate, Sheet, Skylight and Flonr Glass, and Painters' materials generally. Mr. Cluley does every description ol house and ormumental painting and makes a specialty of sign work in all its branches. Many of the wost elaborate aud elegant specimens of fine sign painting to be found in the two cities are from this establishment. He employs those who are thereuglnly aequainted with all the details of the business. The glass signs with metallic lnacks, manufactured by Mr. Cluley, are models of artistic workmanship i:a that line, and are uot only ornamental but very durable. In banner painting Jir. Cluley has no superior, and in fict he is ackonwledged to be at the head of his profession in this city. Nr. Cluley is at native of Pittslurgl, was born in 1823, and has al ways resided in the eity.

\section{MRS. M. L. MOHRHOFF,-Milliner and Dressmaker, 1737 Carson St., S. S.}

This well known fushionalle estublishment was begun by C. F. and M. L. Mehrhoff in 1873. Her present stack of millinery is always varied and in season, and she transacts with her fair customers a business amounting yeurly to quite a large sum. The store occupies a large brick building, with a front of 22 feet and a depth of 60 fect. The business of Mrs, Mohrhoff embraces (wo distinct departments, namely, millinery and dressmaking. Eacli is well patronized, as her establishment is noted for st $y^{\prime} \mathrm{c}$ and good taste. Slie employs a number of lady assistants during tho busy season. Those who call will find, in addition to Hats, Bonnets, Ribbons and Flowers, a full line of Trimmings, as well as an elegant assurtment of Laldies' and Gentlemen's Furnishing Goods, at satisfactory prices.

\section{MRS. C. HAUCH.-Watches, Clocks and Jewelry, No. 295 Fifth Av.}

The Jewelry establishment now condueted by Mrs. Catherine Hauch (late Mrs. C. Berger) was founded in 1853 by Mr. Charles F. Berger, without means. He eontinued the busiuess until his deatl in 1858 , at which time lis capical amaunted to $\$ 100$. Mr's. Berger thell assumed the mangement of the business, and she has notv an avalable capital of 5000 . She oceupies the two-story briek building, 22x32, at No. 295 Fifth avenue, with a finely selected stock of Wutches, Clocks, spectacles and Jewelry of every description, valued at about $\$ 6,000$, doing a busiticss of over $\$ 1,000$ per annum. She employs an assistant at a salary of $\$ 10$ per month, and makes a specialty of repairing fine watclies, clocks and all kinds of jewelry. Sle was born in Baden, Germany, Nov. 22, 1833, and cane to the United States in 1846, coming direct to Pittsburgh.

\section{JAS. L. WILLIAMS,-Undertaker and Embalmer, 305 Fifth Av.}

The first undertaking establishment in Pittsburgh was started in 1545 by Mr. Robert Williams, father ef the subject of this notice. He commenced business in this line with a eapital of $\$ 1,000$ and retired in 1572 with a handsome competence. Alr. James $L$. Williams succeeded to the business in 1873 , commenciug with very moderate means. Ho has now $\$ 6,000$ in vested in the business and carries a stock of Coffins, Caskets and other articles pertaining to this line valued at abuut $\$ 2,000$, and transacts an annuatbusiness of not less than $\$ 15,000$, occupies the two story lrick building, $41 \times 108$, at No. 305 Fifth a venue, and employs two assistants with a montbly pay roll of $\$ 100$. His reours are kept open dity and night. He attends to untertuking in all its branches, making a specialty of Embalming bodies by the most approved process. Mr. Williams was born in Pittsburgl, A ug. 22, 1852. IIe was elected scheol-director for the 7 th wird in 1877 , for four years. 


\section{DITHRIDGE CHIMNEY CO.,(Limited,)-FlintGlass LampChimneys, 17th St. S.S.}

In consillering the varinus industries of Pittsburgh, the (rlass trade assumes an importance with reference to the wealth and general prosperity of the community, that commends it to the most careful attention of any work bearing upon the resources of the Iron City. In this connection the Dithridge Chimney Co., (Limited,) from the nuaguitude upon the resources of the Iter of its operations would receive fitting consideration. This enteryrise was established in 1861 by E. D. Dithridge, Esq., who may he said to have originated the manufaeture of Ialmp Climneys, which he hegan in a very small way at first, but which finally developed into one of the most important interests in the glass irade. The business reverted to the present organization which assumed the shape of a linuited stock company, acquiring a eharter under a special law, "The Limited Co Partnership Act" of Pa., re-commeneing operations in 1878, from which time its husiness has steadily and rapidly increased. The plant of the concern is regarded as one of the largest in the city, and consist of numerous substantial buildings, covering in all over one acre and a half, containing 2 large 10 pot furnaces, with packing, grinding and other departments. Here are employed from 150 to 175 skilled workmen, necessitating a weekly disbursement, for lisbor alone, of about \$1,500. A 20 -horse power stean engine and boiler are required to operate the maehinery in use, the most careful attention being paid to the perfection of al apparatus connected with the superior finisl of the work, new designs being eonstantly devised, and the higliest results obtained in the preparation and manufacture of the material employed. In these two latter respeets the company has achieved a wide and permanent celelrity to its wares, finding a ready market not only throughout the United States, but exports in large quantities being made to Cuba, South America and the Sandwicls Islands, resulting in a trade ihat a verages from $\$ 175,000$ to $\$ 200,000$ annually.

The officers of the company are $\mathrm{L}$. M. Plumer, chairman, Wm. Vankirk, Sec'y and Treas, and E. D. Dithridge, Gen'l Sup't., gentlemen of extendled business experience and thornugh knowledge of the requirements of the trade not only known for their connection with this corporation, lut taking an active and influential part in the gene ral interests of the community as offieers of various financial, underwriting, henevolent and other institutions. Devoted exclusively to the manufacture of Lamp Chimneys, the Dithridge Chimney Co. (Limited,) oceupies a position among its cotemporaries that s]eaks volumes for the ability and tact with which its business is conducted.

\section{W. C. BERINGER \& CO.-Claim \& Patent Agents, 116 Smithfield St.}

The firm of W. C. Beringer \& Co. was established in 1871 by the present members, Mr. W. C. Beringer and $M r$. William Burris. They give their personal attention to the prosecution of all elains against the government for pensions, hack pay, hounties and prize money, having unequalled facilities for transacting business of this description. Ir. Beringer, who has had long experience in the business has charse of the Pittsburgh oftice, while MIr. Burris resiles in Washington and carries on the branch office in that city. Having access to the various departments at the Capitol he possesses advantages whicl must be appreciated by those having occasion to require the services of these gentlenien. They receive applications from all parts of the country and settle alrout fifteen lundred claims annually. They have in all eases met with unqualified success and given satisfaction to their clients. Thoroughly informed upon all points of patent law and matters relating to hounties and pensions to soldiers and sailors, they are prepared to give full information to applicants and attend to procuring patents or pensions in the most efficient manner. The firm makes a speciality of the sale of patents ot every description, in which line they do a large and lucrative lusiness, with an acquaintance extending throughout the States and territories. They employ at the Pittsburgh office two clerks, whose tiwe is entirely occupied in preparing papers pertaining to their extensive business. Mr. Beringer was born in Allegheny City in 1852 and is a life-long resident liere.

\section{F. A. LOHMEY ER,-Fancy Confectionery, Toys, \&c., 232 Ohio St., Allegheny.}

This gentleman succeeded Lohmeyer \& Bro. in 1879, which firm established the house in 1875 . The present stock is estimated at \$3,500, with a vearly trade of ahout the same amount. Mr. Lohnever occupies a very comnodions store well adapted to the trade; bakery, confectionery and wholesale and retail store, being the.nnly manufacturer of fancy toys in this city; Christmas toys a speciality. Besides the large trade this house has at home, it has earried jts business into various W' estern States, notably Ohio and West Virginia. Mr. Lohmeyer was born in Allegheny in 1853, and coinmenced business in $\mathbf{1 8 7 5}$. He is amongst our most estimable citizens and suecessful merehants.

\section{GEORGE EDE,-Carpets, Oil Cloths, Mattings, \&c., 182 0hio St., Allegheny.}

Among the houses dealing in Carpets, Oil Cloths, Mattings, Window Sbades, Table Cloths, \&c., Mr. George Fde, $1 S 2$ Ohio street, is one of the best known. II. Ede commenced business fn 1867 at his present loution, with a capital of $\$ 4,500$; in the twelve years ensuing he has erected the spacious two-story brick building $17 \times 67$ feet, which he at present occupies, and has increased his capital to $\$ 10,000$, while his yearly business is valued at $\$ 15,000$. JIr. Ede keeps on hand a stock of the most approved patterns of Carpets, Oil Cloths, Miattings, Window Shades, Tahle Cloths, fe.. to the value of $\$ 1,500$, and manufactures eottage, list and rag carnets, as well as weaving an y desired pattern to orrer; lis already widely extended reputation and business, Mr. Ede has reason to count upon fully as gratif ying a future.

\section{HORACE R. BASLER.-Music Publisher and Dealer in Musical Instruments.}

The music establishment of Mr. Basler is located at No. 3712 Butler St., where he started the business in 1877 with small capital, which he has increased, enlarging his stock and extending his trade. He now has a very fine stnck of Music, MIusical Instruments, and the various things pertaining to his trade in his large and handsome room, and is doing a fair business. Mr. Basler is an accomplished musician, playing on all kinds of instruments, in an expert manner, and composes music with great facility. He was horn in New Lisbon, $O$., in 1855, and came to Pittshurgh in 1860. Ife worked a number of years in a glass factory, afterwarrs learned the machinist trade and enntinued at it for some years, saving his earnings, which he invested in his present business, in which he is meeting with an encouraging degree of success.

\section{G. W. LAND,-Tin, Copper and Sheet Iron Ware, 139 Beaver Av., Allegheny.}

The manufacture of every deseription of Tin, Copper and Sheet Iron Ware, Rnofing, Guttering and Spouting is carried on at No. 139 Beaver avenue by Mr. G. W' Land, who also denls in Stoves Grates Grate Fronts, \&c., earryin a stock of ahout $\$ 500$, and transacting an annual business of over $\$ 1200$. Mr. Land is a practical tin worker, and attends personally to lis business with the assistance of one apprentice. He occupies a three-story frame building, $16 \times 32$. Mr. Land is a Pennsylvanian hy birth, and an active, energetic business man, with an excellent prospect of ultimately building up a large and important business. 


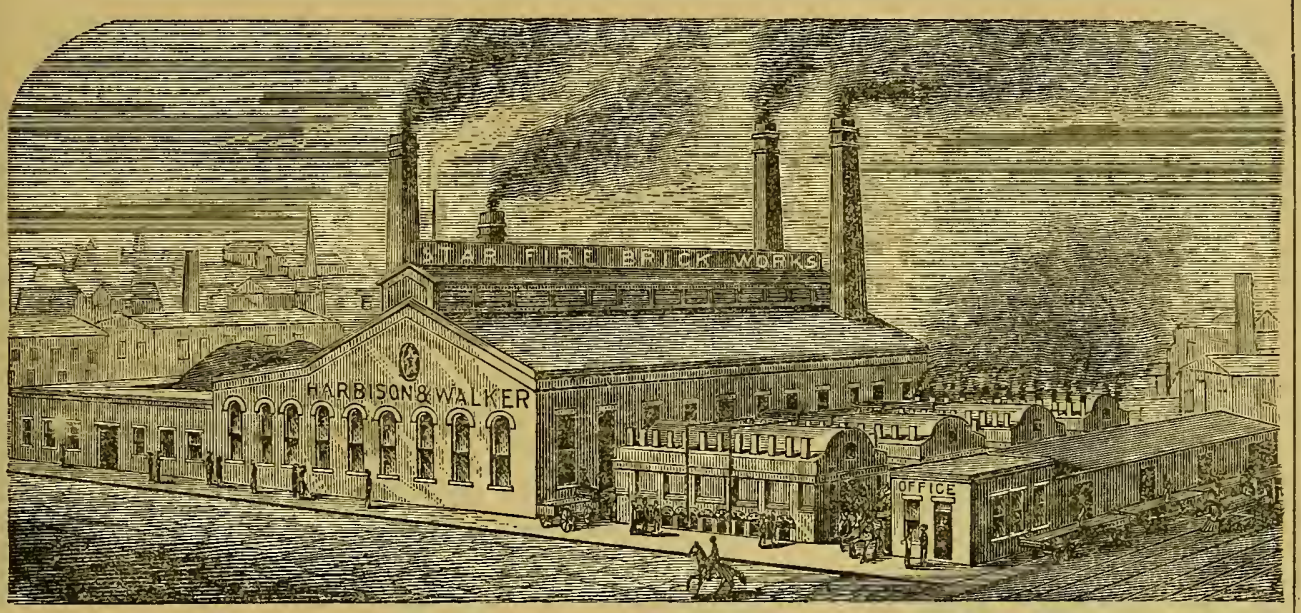

STAR FIRE BRICK WORKS,-Harbison and Walker, $22 d \&$ Railroad Sts.

Prominent among the various industries, which make up the general sum total of Pittshurgh's material wealth and general prosperity, nay be mentioned the manufacture of fire lirick, which is extensively carried on by a number of firms, whose products will aggregate considerably more than half a million dollars per annun. The largest and most extensive house engaged in this line of business in the city is that of Harhison \& Walker, proprietors of the celelurated Star Fire Brick Works, cnrner of twenty-second and Railroad streets. These works were estatablished in 1865 by the "Star Fire Brick Co." a joint stock company, with a capital of $\$ 16,000$, with Mr. S. P. Harbison as nanager. In 1875 the present fion was organized and succeeded to the business, and tha capital was increased to $\$ 100,000$. The main building occupied as manufactory is $96 \times 120$ feet, with a stnck house, $48 \times 120$ feet, and about fifty hands are regularly enployed, with it weekly pay-roll averaging $\$ 450$. These works are supplied with the most perfect machinery for the purposes required. The clay mills, clay washing machine and calcining kiln are of cspecial interest, and are undoubtedly the most perfect machines that can be devised for the work. One $18 \times 30$ inch cylinder engine and twelve sections of eclipse stean boiler furnish the motive power. This firm carries an average stock of crude and manufactured material of $\$ 16,0,0$ to $\$ 18,000$, and transact an annual business of between $\$ 70,000$ and $\$ 80,000$, with a trade extending all over the United States, from New England to the Mississippi, and from Lake Superior to the Gulf of Mexico. Messrs. Harbison \& Walker are patentees and sole manufacturers of an improved tile covering for steam boilers. This is particularly applicable for stationary boilers, and, while it is no more expensive than ordinary covering, pnssesses many advantages over any other style in use. This tile covering leaves a dead air space between the tile and the boiler, and while it cannot in any way injure the iron of the hoiler, it can readily be renoved for the purpose of making repairs and replaced without injury to the coveriug. It is destined ultimately to supersede all other coverings in use. The specialties in fire brick nianufactured by this firm are the celebrated Benezet and Clarion Brands, which are unsurpassed as linings for blast furnaces, owing to the highly refractory quality of the stock used, and the process of manufacture. They manufacture every description of Rolling Mill and Furnace Shapes, Boiler Tile, Grate Tile, Stove Linings and specialties for glass manufacturers, locomotives, coke ovens, gas works, iron spiegel, brass and other cupolas. They carry in stock immense quantities of their celebrated Fire Clays, which they can supply at all times, by the barrel or carload. Everything pertaining to this branch of business is either carried in stock or can be manufactured to order at short notice. Mr. Hay Walker is a native of Scotland, born at Haddington in 1816. He came to this country in 1833, and has been for many years identified with various industries in this city. He does not devote his personal attention to these works. His son, Mr. H. Walker, is general manager of the works, and is a gentleman of skill anl : ahility, born at Bukerstown, Pa., in 1840, and has for many years been engaged in this line of business. He devoles his personal at tention to the general business and tinancial management of the establishment.

\section{E. W. SCHMIDT,-Wines, Liquors, Cigars, \&c., 3816 Butler St.}

The handsome and attractive store of Mr. E. W. Schmidt is located at No. 3816 Butler St. He is rery well known to the Pittshurgh public, (especially the business portion) has recently opened his most complete and elegant Liquor House in this city. The main sales roon is $18 \times 60$ feet $\mathrm{in}$ size and fitted un and arranged in an almost faultless manuer. The stock embraces all the best and most popular brands of Rye, Wheat, Bourbon and Imported Wliskies, and a full line of Brandies, Wines, Gins, Cigars, \&c., both in original packages and in quantities to suit smaller purchasers. Mr. schmidt was born in Pittsburgh in 1855, he attended the college of Notre Dame, Pa., for 2 years, after which he entered the rommercial department of the Iron City College, from whicl institution he graduated and entered at once the great Liquor House of Sclimidt and Friday, (Mr. S. being his uncle) as general book keeper. Here he remained 4 vears. On resigning this situation he accepted a position in the city treasurer's office under Col. Kilgore. This clerkship he gave up to enter upon his present business.

Mr. Schmidt carries about $\$ 5,000$ worth of stock to which he is steadily adding as his trade increases, and although in business for himself but a few months, his personal popularity and the excellence of his goods have already placed him well on the higliway to success.

\section{RUSSELL \& THOMAS,-Scrap Iron, Cor. 4th St. \& Duquesne Way.}

Engaged in one of the most useful industries dependent upon the Iron trade, the well known house of Messrs. Russell \& Thomas is gladly mentioned in the "Industries of Pittsburgh." The business was fonnded hy iVarren Springer, whin was succeeded hy the abovc house within the past few years. Wholesale dealers iu Wrought and Cast scrap Iron, and all kinds nold metal, this house has acquired a trade of fosiues premises of the concern occupy nearly half a square, six men with teams, \&c., being required to bandle the wares and attend to the shipment and receipt of metal. Mr. Clus. T. Russell, the junior partner, is a native of this city Mr. N. M. Thomas, who is bolh superintendent and manager, was born in Canada, where he was engaged in the manufacturing business, coming to this city in 1874. As a firm they aro enterprising and are held in bigh esteem both socially and commercially. 


\section{PITTSBURGH CAR WHEEL WORKS,-John L. Gill, Jr., Proprietor,}

Strangers entcring Pittsburgh orer the Pittsburgh, Ft. Wayne \& Chicago Railroad from the West, long before reaching the Union Dejot, are impressed with the fact that her manufacturing establishments are conducted upon a grand scate and for uiles through Allegheny City the extensive works on the banks of the Ohio are ohjects of wonder to the traveler. Prominent anming the manufacturing estalblishments that greet the eye are the spacious struct ures occupied by the Pittsburgl Cir Wheel Works of $\mathbf{I r}$. John L. Gill. Jr. This is the only foundry of its kind in the city and is locatel o: Preble avenue, Allerheuy, oceupying an area of three and a half acres of ground with commodious and conveniently arrunged buildings for earrying on the work in all its departmenis. This business was establislied here in 1870 hy IIr John L. Gill, Jr, with his father, who founded the extensive car and car whcel works at Colunhus, Ohin. The matin building is of brick $60 \times 140$ in size, and though but one story is.tlirty-live feet in height. The machine shop is $3 \overline{5} \times 100$ feet with an $L$ of ahout the same size. About sixty experienced and skilled workmen are regularly cuployed at this establishment, with a monthly pay-roll aggregating $\$ 2,500$. One large 80 -horse power engine furnishes the motive power for the extensive machinery which is all of the most approved designs, and combines all the latest improvements. Cold blast charcoal metal is almost exclusively used at this foundry, of which uaterial : ibout 4,500 tons are used annually. The cippicity of the works is 45,000 whecls per annum, and the capital invested in the business about $\$ 200,000$, and the annu:al business is correspondingly large. Here are manufactured the very best quality of Palace and Passenger co:tch, freight car and locomotive truck wheels, and make a speciality of boring and titting wheels when required. A superior nut tapping machine, patented by Mr. Gill, is manufactured by him, which will tap ten kers of $3 / 8$ nuts per day. Ir. Gill hats in use Jor determining the quality of irons used in his works a new and improved testing machine, designed and patented by himself and was built in these works; he is now building similar ones for s:le. Mr. John L. Gill, Jre, wits born in Columbus, Ohio, and although yet a young iuan is justly entitled to a prominent position among the representative business men of Pittsburgh, to whose enterprise, ahility and sigicity the Irou City is largely indebted for the prominent positiou she holds as an industrial centre.

\section{E. A. ROSSITER,-Boston Clothing House, 95 Smithfield St.}

This well known house was established in 1872 , in this city, as a branch of the extensive enterprise of Messrs. Jord:ın, Clark \& Co., of Boston. Mr. E. A. Russiter, who had leen associated with the firn for a scries of years, having charge of $\mathrm{it}$, under his able management it sprang into immediate poptlarity. The object of the loouse, so far as its customers were concerned was briefly, to supply ready-made clothing for men, youths and boys, that should in style fit, and make equal the productions of the best merchant tailors, and to afford a scope in selection not excelled, at prices that should not admit of competition. In these designs it is not too much to assert that the success of the concern was simply unparalleled, and in 1878 Mr. Rossiter became sole proprietor and still conducts the business upon the s:me fixed policy first inaugurated by himsell. The stock offered for selection will average in value from $\$ 12,000$ to $\$ 20,000$. New styles in cut and material constantly arriving, while the husiness will range from $\$ 60,000$ to $\$ 100,000$ per annum. The premises occupicd are ample and centrally located, consisting of one large inur-story edifice $20 \times 60$, filicd with every essential for a first-class clothing and furnishing house. Mr. Russiter is a native of New England, and was horn in New H:mpshire in 1s41; his character is well known as above reproach for integrity and fair dealing, and his enterprise is heartily commended to the public at large.

\section{BYRNE \& MCCABE,-Livery \& Sale Stables, cor. Butler \& 35th Sts.}

The very popular and enterprising roung firm of Byrne \& McCabe have their extensive and well stocked stahlea and office on the corner of Butler and 35 th strects, wherc the busincss was started in 1877, now having $\$ 5,000$ invested ill stock, etc., and are doing il rery prosperous business to the amount of $\$ 9,000$ per annum. The succcss and popularity of these well known stables is due to the fact that they aim to, and are successful in treating patrons in the most liheral and courteous manncr-giving satisfaction in every respect-attending to their business with the greatest promptness. Their stock is of the best quality and everything about the estalylishment denotes an air of business. Mr. P. C. Byrne was born in Pittsburch in 1854, and is a son of the well known cnntractor. B. Byrne, Esq.; he has lived in this city ever since his lirth. Mr. T. A JicCabc was born in this city in 1815 . He first learned the trude of horse siner, at which he worked for snme time. He afterwards embarked in the cigar and tolacco business on Penn avenue, which he afterwards sold out to engage in his present business in connection with Mr. Byrne.

\section{WILIIAIM BARKER, Jro-Wool Dealer, 78 Diamond St.}

This is the only house in the city engaged exclusively in the business of buying and selling wool on their orn account, and the murnitudo of the husiness may be inferred from the fact that Mr. Barker handles annually from 100,000 to $500,000 \mathrm{lbs}$ of wool, and his trade extends all over the United States. In adaition to being the only exclusirely wool homse in the city, it is one of the oldest busincss establishments in Western [’ennsylrania, having been founded more than sixty years ago by Mr. William Barker, Sr., uncle of the present proprietor, and during all that period it has cnjoved an enviable reputation. The stock varies with the season and the demand from abroad. MIr. Barker occupies the entire five floors of the spacious brick huilding 20x40, at No, 78 Dinmond strect, first donr ahove Smith field, and during the wool season employs a large number of buyers in varinus sections of the wronl producing reginns. He curries a full stnck of wonl sacks for the convenienec of producers. Mr. Barker was born in Fingland in 183-, but rame to this country at the age of five ycars, has resided in Pittsburgh since 1S39, and bas been for many years identified with the wool trade in this section.

\section{S. M. ROBINজON,-Photographer, $2 \& 4$ Sixth St.}

Identified closely with the art industries of Pittsburgh, Mr. Robinson and his work hare acquircd an rnviahle celehrity. The husiness to which Mr. Rohinson succeeded entirely in 1876, was founded br Mr. Trevor M[c'Clury in 1871, and from !\$72 until the time of the succession of the preseut proprietor was under the style nf McClury \& Rolinsnn. A native of Maasachusetrs, Mr. Robinson learned his art under the best photographers in the United States, and li ts pursued it steadily

As an artist in Photography and crayon portraiture, Mr. Rohinson prodnecs mork that will comparn farorably with the best in the world for Siftness in tone and perfection of finish, evincins as nearly as the heliosrib'vic art moy, all the charma of true high art. The appointments are perfect to produce flawlessresults, scenic hack-grounts, revolving back grounds, ingenious arr.ungements for managing the light to arcomnlislı any desired effect; double and solar canvas with all most modern appliances; but this would not he sufficient without the true artistic skill of a practical artist, and in this respect Mr. Rolrinson has no competitor in the city. Tlioseat a distanee who desire portraits and pictures, (or copies of such), that are in themsel wes eloni ent commentaries upon the possihilities of art, shnuld by no means omit an opportunity of visiting the studio of $.1 \mathrm{r}$. Robiuson ; this will give the most perfect idea of what good photography really is. 
C. W. BUVIN GER, M. D.-Physician \& Surgeon, Butler St., bet. 44th \& 45th St.

Dr. Buvinger is located on Butler street, between 44th and 45th streets, where he hus been engaged in the successful practice of Medicine and Surgery since the close of the WVar, duri!n which time he has accumulated considerabie ineuns and established a high reputation as a Y'hysieian and Surgeon and an honored und respected citizen. The Doctor was born in York County, Pa., in 1832. His parents removed to Ohio when he "as but two yeals of age, at a time when it was considered the Far West. His parents were pour and early in life he was thrown on his own resources, after baving been given such a limited amount of schooling as his father was abie to give him luspired with a noble ambition and with an undaunted courage, he determined to secure an education and qualifi: himself for the higher walks of life. The struggles and trials, hopes and discouragements, encountered in his devoted efforts and his final success, are matters of great interest, worthy of recurd, for the encouragement of young men similarly situated. With a passionate fundness for study, he was compelled to seck such employment as lie tould secure during the day, giving his nights to study. Teaching country schools, when such were to be obtained, silving and economizing at every point, with a noble selfreliance and iudependenee, to accumulate means to fit him for college and for the study of medicine and attendance of medienl cullere. All these things he accomplished by his ow unaided efforts. He secured a literary education at the Ohio IVesleyan University - afterwards studied m+dicine and entered the University of $\mathrm{N}$. $\mathrm{Y}$-beforegraduating yielded to the eall of his country and entered the U. S. service as surgeon of the Sth O. Vol., which served in (ien. I.egan's 15th Corps iu the Army of Tenn. After the close of the war lie graduated with honor from the Long Island Medical College, and c:ume to Pittsburgh, where lie mirried and went into practice. He is still a close student, applying himself to the study of everything pertaining to the profession.

\section{W. C. BIDWELL \& CO.-General Agents Dupont Powder Co., 143 Water St.}

The above house, representing one of the oldest and most prominent manufacturing firms in the linited States. is justly enticled to particular comment. For thirty yeurs Mr. D. W. C. Bidwell has anaintaiued an unbroken connection with the Dupont Powder Co. as resident agent in this city. The celebrity of their manufacture is not contined to America-it finds a market wherever the commerce of this country extends, and is esteemed as the best powder in the world for explosive force, purity, and uniformity of strength. (ireat advantages are derived in safety and cost of transportation over other brands from the filt that Dupont's gunpowder is packed in patent iron kegs, thus making it impervious to moisture and materially lessening liability to aecidents by fire, leakage or in liandling. The demand for this article has continually increased since its first introduction, the business having grown to such an extent as to require two magazines in the environs of this city capable of storing $\&, 000$ kegs each, and the establishment of unuerous agencies in Western Pennsylvania and adjacrnt states, all supplied with smaller magazines. With suelı facilities the importance and extent of the business in this setion is a mitter readily accounted for, its increase being limited only by the natural fluctuations in the development of our resuurces.

\section{G. S. BA TES, - Fire Insurance and Real Estate Agency, 4510 Butler St.}

The Fire Insurance and Real Estate Office of Mr. Bates is located at No. 4510 Butler street, where he cominenced the husiness in 1862, continuing therein to the present time, where he is doing a large and prosperous business in Insuring, Ienting and Collecting. Mr. Bates mis l,orn in Connecticut in 1808, came to Pittsburgh in 1836, aud engaged in the jron working business. Shurtly afterwards he secured employment in the U. S. Arsenal, where he continucd to work for 23 years-after which he opened his lie:l Estate and Insurance Office. Mir. B. is one of the oldest settler's nuw living in Lawrenceville, now the $15 \mathrm{th}$ and $17 \mathrm{th}$ Wards. He remembers when that part of the city (now densely pupulated) was a native forest, and he has witnessed the building of the greater portion of that handsome portion of ihe sity. Mr. B. was elected and served three successive terms to the office of Burgess of the old borough of Lawrenceville and bas tilled many other positions of public trust.

\section{MRS. E. J. BOEHME \& SON, - Watchmakers \& Jevelers, 4124 Butler St.}

The fine retailing establishment of the above firm is licated at No. 4124 Butler street, where the business was started in 1865 by E. J. Boehme, Esq. At his death in 187.;, his widow, Mrs. E. J. B., and her son, Geo. E. Buelune, continued the business under the firm name of Mrs. E. J. Buehme \& Son. Their larte and litndsomely fitted storeroum, $20 \times 45$ feet in size, is completely st.ucked with an elegant assortme:t of Clocks, Watclies, Fiue Jewelry, ete. They earry about $\$ 8,000$ worth of stock, and do al large and paying local business. Geo. E. Boehne, the manager of the liusiness, w. s born in Germany, and came to the United States whe:l he wiss 14 years old. Ife grew up in the watchmaking and jewelry business of his father, thereby acquiring a thorough and practical knowledge of the business in all its various details.

\section{H. F. BLEIL,-Dry Goods, Groceries, etc., Etna.}

Suburban towns, like Etna, command a country as well as city trade, and therefore a variety is essential. This store was established by F. Bleil in 18ü1, succeded Ly H. F. Bleil in 1876. He is lucated on Butler Plank lioal, ankl keeps Dry Gouds, Groceries, tlard ware, Queensware, Flour. Feed, Hay, etc. He carries a stock of about $\$ 2,50$ ? and dues a husiness of about $\$ 12,(1))$ jer aunum i:I lis storerom, which is $20 \times$ i) feet in size, doing a good trade. He was born in this place in 1819 , was elected councilman of the burough in February last.

\section{P. BYRNE,-Groceries and Provisions, 25th St. and Penn Av.}

The Grocery and Provision Store of Mr Byrne is at No. 899 Penn avenue, corner of 25 th street. He has a couvplete stock of Groeeries and Provisions of all kinds and does a flourishing business. His store is 2.j.5. feet in size and is unted for variety and excellence of goods He wats born in lreland in 1811, caine to this country at the age of five years. He learned the trade of eurrier and worked at it for a number of years. He exerts a strong influence in the district and ward.

\section{E, OFFORD,-Hardware, Tinware, \&c., Butler St., bet. 35th \& 36 th.}

Among the leading houses in this line is that of $\mathrm{E}$. Offord, dealer in Hardware and manufacturer of Tin, Copper and Slieet Iron ware. He began husiness in 1873, coming here from Brownsville, Pa., where he had carried on business befure, his room is 60 feet deep and well stocked witl Hardware stores and Tinware. Keeping desirable goods and sellingat low fiwules he lias worked up a good established trade to which he gives close attention. He was loorn in Brownsville, Pa., in 1844, coming here in 1873 . He lias an enviable reputation which he has merited. 


\section{A. GUCKENHEIMER \& BROS.-Copper Distilled Pure Rye Whiskies, \\ Dis dis rirst Ar.}

The world renownel distillers of the celebrated brands of " inckenheimer's l'ure Rye Whiskies," have their headquarters in P'ittshurgh, and although their distilleries are located in anotler county, they are entitled to a prominent pusition in a work of this deseription among the representative business houses of Pittsburgh. Their principal offices and warerooms are located in the spacious double structures at Nos. 93 and 95 First avenue. This house stands preeminently at the head of all similar establishments in the country, and we are enabled to furnish our readers witl a brief sketch of the extensive buildings occupied by them. The individual members of the firm are A. Guckenheimer, S. Wertheimer, E. Wertheimer and I. Wertheiner, and for more than twenty years under the same style the business has been suecessfully condueted. Their distilleries are located at Freeport, Armstrong counly, Penn'a., and cover many acres of ground on the line of the West Penn. railroad, whose tracks intersect the prenises, which have an extendeed frontage on the Allegleny liver. The distillery, proper, is a two-story brick luilding $361 / 2 \times 180$ feet, and a two-story frame structure $31 \times 95$ feet; loth supplied with tlie most approved machinery and appurtenances. Their matin warehouse is a mammoth four-story brick edilice $70 \times 305$ feet, with stone foundations of extral width and solidity, especially constructed to sustain the immense weight when filled to its utmost capacity, which is 25,000 harrels of whiskey. All the walls and timbers are of the heaviest description. Thin huilding is one of the most sulsstantial and complete as well as the largest distillery warehouse in the country. Another three-story briek building for the same purprose and with a capacity for storing 6,000 barrels of whiskey is $84 \times 52$ feet and both warehouses are heated by steam. This firu unanuacture their ow malt cxclusively, and their malt house is a four-story brick building $53 x 110$ feet in size, supplied with a kjln thirty feet square. Their srain warehouses are also of mammoth proportions, one being a one-stery frume building with stone foundation 30x150 feet in size with a storage eapacity of 20.000 bushels of grain, and :nother one-story frame building likewise with stone foundation $65 x 22$ feet, with a capacity for storing 8,000 bushels of grain, of which artiele the firm al ways carries an immense stock on hand of the best grades. Their storage room for enupty barrels is obtained in a two-story frame building $45 \times 34$, and their conper shop is at two-story frame structure, witl stone foundation $40 \times 100$ feet in size. The firm manufactures every package used in their husiness from the best Indiani o:k st:ıres. The barrels are all hand made by the most experienced workmen aud bound by extra heavy hoop iron. In connection with their cooperuge department are extensive sheds for seasoning and storing material, where the staves are kept for three years before they are ready for use. The business offices are models of comfort and elegance, and are situated in a beautiful one-story brick structure 40x25, finislied in the most elahorate siyle of art in liard wood with desks and furniture to correspond. The guards above the desks are of magnifieent French plate glass, ornamented with monograms of the firm. They are supplied with gas and steam heating apparatus and carpeted with Linoleum and elegant Brussels earpet. The fire and burglar proof vault is made with stone floor and head six inches thick, over 30,000 bricks and fifteen barrels of cement were used in its construction. Forty-eight experienced hands are constantly employed at these works with a monthly pay-roll aggregating \$3,100. One sixty-horse power and one forty-horse power engine are required at this establishment and six large boilers, four of whicli are four flued, 24 feet in length and 42 inches in diameter, and the other two are two flucd 26 feet in length and 40 inches in dianetcr. From this eursory view of the capacity of this house it will not appear strange to our readers that their whiskies can be found in every section of the United States, if not in every quarter of the globe. Mr. I. Werthejmer presides over the Freejort office and gives his personal attention to the clerical furce there employed. Mr. E. Wertheimer oecupies the responsible position of President of the First National Bank of Freeport, and exercises a general supervision over the distillery and its manifold departments. The trade in the larger cities of the West is ably attended to by Mr. S. Wertheimer, while the senior menber of the firm, Mr. A. Guekenneimer, attends to the general husiness of the firm at the lome office in this city. Mr. A. A. Soloruon, an experienced and aceomplished gentleman, has offices it No. 34 Broadway N. Y. and at No. 121 Walnut street, Philadelphia, from which he attends to the wants of consumers in these eities and represents the interests of the house throughout the Lastern States. By the admirable arrangements thus noticed each member of the firm has his regularly allot ted department and every detail of the business is under the inmediate supervision of one of the parties most interested.

IHMSEN GLASS CO. (Limited.)-Colored Glassware, Cor. 14th \& Neville Sts., S. S.

The yearly increasing demand for glass jars and lottles for various commercial uses, as well as the preservation of fruit, malt liquors, ete., has given an impetus to the glass trade in Pittsburgh that is without a parallel and has led to al largely increased produetion in this elass of goods. The Ihusen Glass Co. (limited), was organized and incorporated in 1878 , with a capital stoek of $\$ 22,000$, having a special view to the matnufacture of wares in this line, an ohject which hits been most suecessfully attained. The plant of the Company is an extensive one. It covers an area of about two acres and is fully supplied with every appliance and mechanieal device that leads to the perfection and finish of the product. Some 80 men and boys are employed at these works, requiring an aggregate weekly disbursement of alsout $\$ 2,500$, resulting in a trade that extends over the West, North and South-west, through which territory they are represented by triveling salesmen and established local agents. The officers of the company are Jacob Hahn, Esq., President, and C. Ihmsen, Jr, Secretary and Treasurer, both of whom are well and widely known to the business community, the name Ihmsen being almost historically connected with the growth and development of the glass trade in this eity. Both these gentlemen are natives of Pittsburgh and bave long been connected with its manufacturing interests. 'The mauner in which the operations are conducted under their supervision speaks in the higliest terms of the knowledge, experience and ability which they bring to the work, making the Company not only highly successful in the ordiuary business acceptation, but placing it in a position, through an homorable and liberal policy, that entitles it to the respeet of the trade aud the consideration of the public.

\section{A. M. FETZER,-Manufacturer and Dealer in House Furnishing Goods, etc.}

'The fine establishunent of Mr. Fetzer is located on Butler st., near 42nd st., near which place he started in the lusiness in 1868. witlı very small capital, which by close attention to business he rapidly inereased, enlarging his stoek atnd extending his business, afterwards remoring to his present large and fine store roum, 20x60 feet in size, which is well stockesl with a good assortment of all the varions goods in his line, and in rear of which he carries on the manufitcture of 'Cin, Sheet. Iron and Copper Ware of all kinds. He is now doing a large and prosperous husiness, which he has built up liy his own enterprise and alility. He was horn in Germany in 1840, and came to the United States when 7 years of age. He served 9 months in the 106 th Pa. Vol. dluring the war.

\section{E. MYRICK,-Hardware, Farm Implements, \&c., Main St., Sharpsburg.}

Mr. E. Myrick on Main street, Sharpsburg, has a fine business in general Hardware, Farm Machinery, \& \&c., which attracts a large country trade, he also keeps Cutlery, Paints, Oils, Glass, Putty, Sportsnan's supplies, Seeds, \&c., embracing a large and attractive stock. He was born in New York State and came here in 1873, subsequentJy locating in Sharpsburgh. He is a man of extensive knowledge and business qualification. Doing business on a cash basis he makes no bad debts and gives close figures in all brinches of his business. He oceupies a two story brick building, $30 \times 95$ feet, and enjoys a tlourishing trade. 


\section{CHAS. H. KELIY \& CO.-Sewing Machine Attachments, 6 \& 8 Sixth St.}

As an industry contingent upon the manufacture and trade in Sewing Machines, the firm of Chas. H. Kelly \& Co. occupy an important and useful position. Both members of the concern, Chas. H. Kelly and A. F. Allewelt, are natives of Penn':t., the former from Lancaster and the latter from Hanover. Educated as practical maclinists, expert in the higher branclies of their avocation, they came to this city in 1872, and in 1874 starting with :t very limited capital in cash, but considerable backing in the way of business and mechanical talent, which on the basis of the tirst years trade has increased 200 per cent. and is still growing rapidly, with a stock at this time of $\$ 10,000$ and an annual revenue of about $\$ 30,000$. Manufacturing and dealing in all kinds of Serving Machine Attachments, extra finished needles, oil, parts, belts, screws, dic., and giving particular attention to re-building, repairing and re-japaning sewing machines; the firm is also engaged in the manufacture of the singer Machine since the expiring of the patents. With a trace extending over IV estern Penn'a. and the adjacent states, the house of Chas. H. Kelly \& Co. are not only well known abroad, but highly esteemed at home.

\section{HENRY APPEL, -Boots, Shoes \& Fine Gaiters, 4303 Butler St.}

The handsome and elegantly stocked shoe store of Mr. Appel is located at No. 4308 Butler street, in Klopfer's block, 25 feet front and 50 feet deep. The stock carried amounts to $\$ 5,000$ or upwards, of Boots, Shoes, etc.; he is not excelled by that of any establishment in the city. Mr. A ppel has a thorough and extensive knowledge of the Boot and Shoe trade to which he gives his close study, enabling him to offer to his patrons a very superior class of goods of the latest styles, making his the leading house in this line in this part of the city. His own manufacture of Boots \& Shoes, to which special attention is given, ranks as the best goods of that kind; and biscustom work has a very high reputation. He also does l'epairing to order. Mr. A. was born in Germany in 1840, came to the United States in 1860. Learning the trade in this city, he afterwards entered the establishment of J.. H Borland \& Co., where he remained a number of years. In 1869 he opened his present business, at first in a small way, which his energy and ability has rapiclly built up until the present, where he is doing a business of $\$ 15.000$ or upwards per annum, and enjoying popular favor.

\section{LA WRENCE BANT.-}

This very flourishing institntion was originally organized in 1865 , under the name of the Lawrence Savings Bank of Lawrenceville. In 1877 a stock company was formed, with a capital of $\$ 80,000$, adopting the name of The Lawrence Bank. It has heen managed with signal ability, caution and foresight. W. W. Young, the President, was born in Pittshurgh, in 1832, and has been prominently connected with the leading industries of the city for many years. He also represents his ward in the city councils. John Horr, the cashier, is also a native of this cit.y, born in 1837 . Mr. Hoerr entered the 78th Regiment P. V. at the commencement of our civil war, and served with credit to its close. Upon returning to Pittsburgh he entered mercantile life, with whicb he is still associated. This bank has been exceptionally fortunate in the choice of its officers. Mr. Young was horn here of parents of high social position, his father being among the most successful and respected merchants of earlier days. All those who have dealings with this bank will tind its officers courteous and obliging within the scope of business comity.

\section{T. R. EVANS, M. D.-Physician and Surgeon, cor. of Butler and 38th Sts.}

Dr. Thos. R. Evans, the modest and accomplished subject of this sketch, is located at the corner of Butler and 38 th sts., where he began the practice of medicine in 1875 , being associated with his uncle, the well known and eminent physician, Dr. Jas. Robiuson, whose large and extended practice required the aid of an able assistant, since which time Dr. Evans has been attentively and closely applying himself to his profession, relieving his uncle from which time Dr. Evans has been attentively and closely applying himself to his profession, relieving his uncle from ing his practice by his ability and accomplishments as physician, surgeon and gentlenian. The doctor niaintains the highest standing among the medical fraternity by his attainments and courtesy. He was born in Bedford Co.. Pa., in 1843 , received a literary education at the State Normal School, studied medicine with the eminent physician and surgeon Dr. Saml. T. Davis, of Lancaster, Pa attended the University of Mrichigan, graduated with honor trons the medical department of that institution iu 1873, entered the practice of medicine in the State of Indiana, where he remained in successful practice, coming from thence to relieve and assist his uncle. Since his location in this part of the city, Dr. Evins has won the respect and contidence of the entire community by his honorable and gentlemanly deportwent, and high attainments ats a physician.

\section{FERGUSON \& CO.-Book and Job Printers, No. 159 Smithfield St.}

Mercantile printing in all its varieties is the specialty for which the house of Ferguson \& Co., No. 159 Smithfield st., is noted. The firm commenced business in 1877, although Mr. Ferguson had been engaged for seven yeurz jreviously in the same line of business, as a member of the firm of Davis \& Co. They transact a general Buok and Job Printing business, turning out some admirable specimens of artistic typography. Two sons of Mr. Ferguson are issociated with him as the "Co.," both of whom are practical printers, and give their personal attention to the busincss. Two additional hands are also constantly employed, and two job presses of the latest design and nodern improvements. Their business, which will amount to not less than $\$ 5,000$ per annum, will comprare favorably witil that of any similar establishment in the eity. Their card work, circulars and letter heads are models in their way, and caunot be excelled. Mr. R. S. Ferguson was born in Westmoreland Co., Pa., in 1833, came to Pittsburgh in 1849, and learned the trade of printer here. His two sons and partners, Mr. W. A. and Mr. S. H. Ferguson, are still young men, and were born in Pittsburgh.

\section{W. F. EICHENLAUB,-Furniture Warerooms, 3505 Butler St.}

The large Furnitnre establishment of Mr. Eichenlaub is located at No. 3505 Butler st.., where his eandsome storeroom, 20x60 feet in size, 2 stories high, is crowded full of fine furniture of every description, which is sold at the lowest eity prices. The establishment is recognized as the leading furniture house of the East End, and is of course doing a very large and prosperous husiness. Mr. Eichenlaub carries a stock to the amount of $\$ 70,000$ to $\$ 100,000$. The business was started by Frank Eichenlaub, with small capital, and came into the possession of the present proprietor in 1874. Since then he has greatly enlarged and increased his stock and extended his trade. Selling at elosest figures, lie is patronized by the wost appreciative buyers. Mr. Eichenlaub was born in Butler Co., Pa., in 1851 . He came to Pittsburgh in 1867, learned the trade of wood-turner in the establishment of Seibert \& Co., and after completiug the trade he embarked in the furniture business, in which he has been quite successful. 


\section{W. DOU GLASS \& SONS-Steam Boilers \& Sheet Iron Work,39\&41 Carson St.,S.S.}

In 1833, now nearly half a century ago, the senior partner of the above firm, Mr. W. Douglass, established the business to which his sons, James L. and John, were admitted in 1869, under the existing style. A native of Washington County, Pa., Mr. Douglass was born in 1811, and, as will be observed, began active operations on his own account upon arriving at the age of twenty-two. His means were limited and the inception of his eareer was checkered by many reverses and difficulties; still, with undaunted resolution and a natural talent for his vocation, he worked on gradually overcoming every disaster, and, with native perseverance, finally placing his enterprise upon a solid and enduring foundation. The plant of the firm is now located at Nos. 39 and 41 Carson street, Sonth Side, covering an area of $100 \times 200$ feet and possessing facilities that are of marked value. The annual business transacted at present prices is about $\$ 50,000$, and from 25 to 28 hands employed, many of whom are skillful artificers, at a cost to the firm of $\$ 350$ semi-monthly. The machinery with which the works are equipped is operated by a 20 -liorse power steam engine, and the class of work executed embracing the construction of Steam Boilers, Tanks, Stills, Evaporating Pans, and all kinds of Sheet Iron Work, special attention being given to Boat Building, contracts made for the Construction of Boats, Tugs, Tow Boats, Propellers and every grade of steam craft. The work of this house is celebrated for its excellence, orders being filled from all parts of the United States. In the manufacture of Douglass \& Brown's Patent Upright Boiler, the firm have an exclusive monopoly, and, without describing the principles of this boiler in detail, it may be said that the firm guarantee it to be more safe, simple, durable and economical, and to make more steam than any twoflue boiler of the same diameter. In substantiation of this statement Messrs. Douglass \& Sons refer to the firm of Brown, Bonnell \& Co., Youngstown, Ohio, and the Monongaluela Incline Plane Co., of this city. In conclusion ix is but just to say, that among the many manufacturing concerns of this city and surronndings, none have achieved a reputation and standing more desirable than Messrs. W. Douglass it Sons.

\section{FREDERICK ANDRIESSEN,-Wines \& Liquors, 40 \& 42 Ohio St., Allegh.}

Among the Wholesale Liquor houses of Pittsburgh and Allegheny no one stands higher or enjoys a more enviable reputation than that of Mr. Frederick Andriessen, at Nos. 40 and 42 Ohio street. This house was established in 1862 by the present proprietor, and since that time has enjoved a liberal patronage. He keeps only the purest articles and sells them at the most reasonable prices. His stock comprises pure old Rye and Bourbon Whiskies, French Brandies, Holl:mi (xins, Port, Sherry, Rhine and California Wines, and imported Ales and Porters. His salesrooms are located in a three-story brick building, $30 \times 90$ feet, and belongs to himself. He employs two assistants. His trade, which is derived from the two cities, and towns within a radions of fifty miles, is large and steadily increasing. Mr. Andriesseu was born in Prussia, in 1836, and came to this country in $\mathbf{1 8 6 0 . ~ H e ~ h a s ~ r e s i d e d ~ i n ~ A l l e g h e n y ~ f o r ~ m a n y ~ y e a r s . ~}$

\section{GERMAN SAVINGS AND DEPOSIT BANK,-}

The financial institutions organized and directed by the German element in this community seem to be founded upon a solid and conservalive policy. A favorite among these is the German Savings and Deposit Bank, established under the State laws in 1871, designed mainly by its founders as a savings institution, but with ample scope for the transaction of a general banking business. The capital of the concern is $\$ 89,000$, and considerable operations are effected in New York and European Exchange, the Eastern correspondents of the bank being the Importers and Traders National Bank, New York, and the Central National Bank of Philadelphia. Gregor Fox, Esq., is the President of this institution, Frederick Maul, Esq., Vice President, and E. G. Scholze, Esq., Cashier. The loard of directors, besides the two chief executive officers, consists of the following: Anthony Henger, Joseph Ploger, Anton Hennigen, Frank A. Ziefel, Adan Franz, Cliarles Espy, Jacob Gommel, John Arnsberg, Ferdinand Benz, Jacob Roth, Bernard Krugh. So officered and directed the bank can not fail to continue a career of success.

J AS. H. STU ART,-Mantles, Monuments \& Tombstones, 815 Carson St., South Side.

As a mauufacturer of Mantles, Monuments and Tombstones, besides being a contractor for the execution of all kinds of Cemetery and Building Stone Work, Mr. Stuart has au experience of many years and has acquired a reputar tion for promptness, reliability and artistic work that reflects the lighest credit upon his works. Located at 815 Carson street, these works occupy a space of $36 \times 100$ feet, stocked to the extent of about $\$ 6,000$, the annual business exceeding that sum three or four times. Sixteen hands are employed here (many of them being expert artisans) requir. ing a weekly disbursement of abont $\$ 150$. Besides the constructive portions of his trade, Mr. Stuart deals to a considerable extent in Foreign and Domestic Marbles, Granites, etc., in which he can offer special advantages to the trade through Pennsylvania and Eastern Ohio. A native of Ireland and a resident of this city since 1861, Mr. Stuart had the experience of the best advantages in the art of Monumental and Tombstone construction in Boston, New York, Pliiladelphia, Baltimore and this city, and is fully identified with the iadustrial interests of this community.

\section{O. T. ALTER,-Tinware, Stoves, Hardware, \&c., 4504 Butler St.}

The enterprising establishment of Mr. O. T. Alter is located at $460 \pm$ Butler street, where he manufactures Tin, Copper and Sheet-Iron Ware, and is prepared to to Roofing. Scouting, Guttering and Repairing and Job Work to order in this line. He also keeps a full line of Heating and Cooking Stoves, is sole agent for Monitor Oil Stoves, and deals in General Hard ware, House Furnishing Goods, ete. His storeroom-built by himself-is $20 \times 50$ feet in size, of brick, with a work-shop in the rear. His stock will always be found complete, and we call special attention to the ex. cellent supply of Monitor Oil Stores of all sizes. This invention is very ingenious and will be appreciated by the public, especially all housekeepers, for its neatness and convenience. - It makes no dirt and can be set anywhere.

Mr. Alter was born in Indiana County, this State, in 1846, aud came to Pittsburgh twelve years ago. He is a practical workman of many years' experience. He commenced business for himself in 1571 and has built up a large and prosperous business.

\section{JACOB GOETTMAN,-Baker and Confectioner, 37 Chestnut St., Allegheny.}

The subject of our sketch commenced business on Main street, Allegheny City, in 1866. In April, 1873, he removed to his present location, and his success in business has been such that his capital, which was originally but $\$ 300$, has increased to $\$ 30,000$, and his trade has spread throughout the two cities and the adjacent counties Mr. Goettman employs in his business three experienced hands, and being a practical haker and confectioner himself, nothing but a superior class of goods is manufactured. A stock of foreign and domestic Fruits, Nuts, Caramel Goods, and Ice Cream Pyramids, together with Jelly, Pound, Fruit, Lady and Fancy Cakes of every description, valued at $\$ 500$, is constantly kept on hand, and the yearly business $\$ 5,000$ to $\$ 6,000$. Mr. Goettman was born in Germany in 1843 , and came to this city in 1852 . He selected his present store, which offers ample accommodations, being $20 x 56$ feet, and four stories high, and situated in a prominent location. 


\section{FIRST NATIONAL BANK,-Cor. of 5th Av, and Wood St.}

Originally organized as the Pittshurgh Trust Co., in 1852, the First National Bank assumed its present status in 1863 , shortly after erecting the splendid structure which it now occupies and which has been mentioned heretofore in the editorial introduction to this work. With a capital of $\$ 750,000$, and a line of deposits larger than confided to any similar financial institution in Pittsburgh, this bank bas not only pursued a career of uninterrupted prosperity for more than a quarter of a century, but transacts to-day the most extensive banking operations known in this community. Mr. James Laughlin, a member of the firm of Jones \& Latghlin, Iron mannfacturers, has since the foundation of the institution been its chief executive officer. Mr. Jno. D. Soully, cashier, has also been connected with the bank in this capacity for a like period, and Mr Chas. E. Speer, ass't eashier, having been identified with his present position for 25 vears. The Board of Directors of the First National Bank is composed of prominent representatives of the liest business talent in this eity, consisting besides the President, Mr. Laughlin, of Mr. Alexander Nimick, Vice Pres., of Nimick \& Co., Irou manufacturers, Pres't of the Western Insurance Co. and associated with many of the first institutions and enterprises in Pennsylvania; Rolert S. Hays, Esq., retired merchant; J. H. McKiloy, of the house of Armstrong \& McKiloy, White Lead manufacturers; Thomas Wightman, Glass manufacturer; Jas. S. McCord, Esq., of MeCord \& Co.; James H. Lindsay, of Lindsay \& McCutcheon, Iron manufacturers; John Wilson, Esq., of J. Wilson, Son \& Co., Grocers; and J. Painter, Esq., of the firm of J. Painter \& Sons, manufacturers of Hoop Iron. The general management of the bank, vested in such hands, could hardly fail to be eminently successful, and conservative to a marked degree. The officers composing the cashier's staft are as follows : D. O. Barr, first teller, Geo. J. Gorman, second teller, B. S. Crumpton, ass't teller, W. S. Kuhn, ass't teller, B. L. Crawford, general bookkeeper, B. W. Finney, ass't bookkeeper, J. N. MeCreary, indisidual bookkeeper, H. W. MIoor, discount clerk, C. P. McKnight, collection clerk, D. W. Semple, corresponding clerk, Geo. Bryan, first messenger, P. Kerr, second messenger, and two watchwan, M. Quinn and D. J. Kerr. Conducting a general banking business in loans, discounts, collections and exchange on all points, with New York correspondence in the Third and Fourth National Bank of that city, and in Philadel hhia the Girard National Bank, being remarkable for the prompt, systematic method upon which its affiairs are managed, the First National Bauk of Pittsburgh is an institute that fitly represents the solvency and success of the Iron City.

FARIMERS \& MECHANICS BANK,-Carson and 18th St., South Side.

Among the banking institutions of this city the Farmers and Mechanies Bank of the South Side is widely recognized as a favorite. This institution was organized and incorporated in 1872, under the State laws of Pennsylvania, with a capital of $\$ 155,000$, and from that period to the present time has pursued a career of unluroken prosperity. Besides the general banking business, transacted in loans, discounts and deposits, the bank does New York and European exchange, drawing bills on London, Paris and other foreign centers, the Eastern correspondence being mainly confined to the National Park Bank, New York, and the Tradesmen National Bank, Philadelphia. James McMasters, Esq., occupies the chief executive position, Mr. Abijah Hays being Vice President, H. F. Voygt, Cashier, and John S. MIeMaster, Teller, the management of these gentlemen resulting in a handsome surplus. The Director's are as follows, and are representative men upon the South Side, engaged in various commercial and manufacturing jursuits, all interested in the iudustrial thrift of the community : Messrs. Fred. Briggs, Thos. Coffin, D. O. Cunnincham, Jas. MeGeary, John Nusser, J. H. Ortman, Henry Rattleman, C. J. Schultz and Wm. Stewart. With this board super'vising the business of the institution, its solvency is undoubted, and the annual increase of its business demonstrates
the confidence with which it is regarded by the public at large.

\section{G. ALIINDER, M. D.-Office at No. $9243 d$ st.}

Dr. Allinder recently removed to his present location from Butler street, where he had been for some years. The Doctor was born in Pittsburgh in 1846 - educated at the Western University of that city-studied medicine with Rob't. M. Tindle, M. D.--attended lectures at the University of Pa., graduating from that noted institution in 1869. After graduating began practice in Allegheny City, afterwards removing to present vicinity, where he has succeeded in building up a lucrative practice. The Doctor is an accomplished, agreeable gentleman, in the highest standing among his medical brethren. His father, Wm. Allinder, who is is still living at the advanced age of $7 \delta$, full of vigor and activity, was one of the original anti-slavery men in this city, combating the great evil at a time when it required a high degree of courage to assert anti-slavery sentiments. He wrote an able article in a periodical published by him ealled the Christian Witness, in which he, in a convincing manner, upset the theory of the Divine origin of the institution. An attempt was made to mob his establishment, and a time set for the carrying out of the fiendish scheme, headed by a notorious rough. Pierce Brennan, who kept a doggery on Fifth avenue. The intended attempt came to the ears of MIr. A., who called on Mayor Irwin for a posse of police to protect him, which was furnished in time to repel the mob and protect the estahlishment. Mr. A. was not to he intimillated in this manner, but boldly continued the fight against slavery, and happily lives to see the full realization of his dreams and the grand triumph of the principles he so boldly advocated.

\section{AUGUST BARTELS,-Florist, No. 185 Ridge Av., Allegheny.}

The Greenhouses and Gardens of Mrr. August Bartels, located at No. 185 Ridge avenue, are worthy of the attention of all gentlemen or ladies of taste and culture. Here may be found a profuse display of exotics and native plants in great variety, to please the eye and gratify the love of the beautiful. His conservatories are models of neatness and beauty, and are three in number, heing each respectively $10 \times 40$ feet, $10 \times 40$ feet and $18 \times 40$ feet in size, warmed by three large heating furnaces to tropical temperature and tilled to repletion with the choicest flowers. Mr. Bartels is prepared to furnish bedding plants or cuttings as desired, and nukes a specialt $y$ of boquets and cut flowers in beautiful designs for weddings, funerals, parties, church or parlor decorations, or any purpose required at short notice and at moderate prices. Altlough established on a small capital l,y Mr. Bartels, who is a thorough, practical gardener and florist, his business has steadily increased until it will comprare favorably with any similar establishment in the cily. He has now a stock of about $\$ 1,500$ in value and transacts a larse and thriving business. Mr. Bartels is a native of Gerwany, but has resided in this country for a number of years.

\section{JOSEPF FUHRER,-Foreign \& Domestic Wines, Butler St., near 37th St.}

It is of the greatest importance for purchasers of liquor to procure the very best, and the question arises, where ean the very best be had? Go to Joseph Fuhrer, Butler street, near 37th street, Wholesale Liquor Dealer and Importer of Foreign and Domestic Wines, Pure Monongahela Rye Whiskies, etc. MÍr. Fuhrer started with small capital fourteen years ago, in his present. ward, and so wonderful was the increase of his business in that space of time that the present valuation of his stoek amounts to $\$ 10,000$, while the amount of his husiness reaches $\$ 20,000$ per annum. Mr. F. occupies a building 20 feet front and 50 feet deep, employs two assistants, ancl his an tracle exteneling throughout the entire county. He was horn in Allegheny County and has resided in sume county ever since, with the business interests of which he is prominently identified. 


\section{JACOBUS \& NIMICK M'P'G CO.-Office, Bank of Commerce B'ldg, Wood St.}

A careful, detailed examination or review of the various enterprises of a maunfacturing character that have given Pittsburgh the celebrity it enjoys, will inviriably produce a constant succession of surprises. This in a great measure min be owing to the fact that as the populatiou in the city proper increases, the works that were fornerly on the outskirts becurme closely euvironed and crowded upon; property increases in value out of all proportion to its original cost, and liable to taxation upou a new basis every few years is fillally sold, the plant re-located in the suburbs on an extended scale and the business goes on with renewed impetus. So the daily evidences of its existence in volumes of smoke and the roar of machinery are no longer so many illustrations of industrial thrift; the works that vibrated with the clash of labor are unsuggeste 1 by the quiet commerce that fills their place, and when in its new position, grown aluost out of recognitiou, the establishment demauds attention, a slight shock of pleased astonishment can hardly be avoided.

Among the many manufacturing enterprises to which these remarks apply, perhaps none affords a more striking example of their truth than the Jacobus \& Niuick Manufacturing Co., whose plant for years on Diamond street, was removed in 1877 to Jucobus Station, a lew miles wost of the city, on the P. C. \& St. L. R. R., where, with greater facilities and more ample rcsources, the business incrases at a rapid ratio. Aside from the present and pist importance of its operalions shis corporation is entitled to more than brief mention, from the fact of its historical relation with the developmeuts of the maunfacturing interests here and the eharacter of $i$ ts products, which it is perfectly safe to assert are not excelled in finisi or quality, if equalled by au y cotemporaneons concern in the world. The origin of the company will be fund in the novelty works established ahuost half a century since, and the variety works founded in 1855 , both contributing after several ehanges to the formation of the Jacobus \& Nimick Manuf'y Co. in 1863. Chartered under the mining and manufacturing laws of Peun'a, with a capital stock of $\$ 150,000$, che officers being Alexander Nimick, President; Sannel H. Jacobus, General Manager and Treasurer; and A. H. Elwell, Superintendent, for the past two years. The buildings of the company were erected with the sule view of being entirely adapted to the rapid, convenient and eflective manulacture ol the special wares produced by the concern. The main structure is an imposiug brick edifice, four stories high with a central tower, smoke stacks, and covering an area $40 x 400$ feet, and adjoining the foundry which is ane-story building of the same material 70x250 feet. The japaning building is two-stories high $40 \times 80$ feet; the engine room an entirely suparate erection, is of one-story and $30 x 60$ feet, liesides which there are gas louses, tanks and apparatus for lighting the estabishment, a tin louse and numerous other buildings of less importance for packing, tinishing, storiug, \&c., coverius in all a grand total area of about three acres. Here are constantly employed 350 operatives, requiring an outlay for labor alone on the part of the company of over $\$ 1,500$ per week, aud here also will be found machinery which is in splendid adaptation to the work required, and mathematic accuracy as well as speed in action is justly considered as perfect as modern inverition joined to cupital and euterprise could devise; kept in motion by a steun engine of 125-horse power, supplied by two boilers of great strength and magnitude, and during a larger part of the year is operated night and day.

A mere list of the hundreds of separate articles manufactured by the concern would fill several pages of this rolume, the illustrated catalogue of its w.ures contains over 33 pages imperial octavo, substantially bound, aud may be had upon application by mail or otherwise free of charge; the main proulucts, however, consist of door locks, latches, butts, knobs, scales, coffee mills aud genuine bronze metal, hardware used by builders in public and private buildings, hesicles book racks for church pews and railroad coaches, scale weights, tine irons, shutter and bolt drops for steanboats, Fuirbauk and Union combination platform scales, shutter knobs, bars and Hush and hook sash lifts; special attention being given to the produetion of new and choice designs in brouze, silver and nickle plated and builders hardware generally. 'The confessed superiority of these goods in elegance, durability aud cheapuess, has resulted in a trade that extends not only over the entire United States, but leads to large and increasing exports to English, Freuch, German, Russian aud other markets, and sales that agogregate nearly a quarter of a million anvually, three branch houses having been establisbed to facilitate these operations-New York, Graham \& Haines, No. 113 Chambers street; Baltimore, eling salesmen constantly upon the road. Mr. Nimick, who is regarded as a pioneer in this branch of manufacture, has beeu connected with the company as president since jts origin. Nr. Jucobus, who directs the general business manarement of the concern, is a native of Brookly n, N. Y., where he was huln in 1841 , coming to this city wjth his father, Rev. M. W. Jacobus, D. D., L. L. D., in 1851, his connection with the company dating from 1864 . In all its departments the operations of the company are maunged with tact, ability and signal success, contributing in a large degree not only to the jeputation ol Pittsurgh as a manufacturing centre, but greatly promoting the industry and wealth of the cormunity. In is sperial line of product the Jacobus \& Nimick Manufacturing Co. has no competitor west of the Alleghen mountains, and none any where that can either offer such marked advantages in price, or supoly goods of such uneyualled perfection. Determined to be in advance of its cotemporaries in every respect, it is no adulation to say that the company achieves this object beyond all cavil, and this, together with the higis standard of commercial honor and enterprise upon which it is conducted, way well deserve the respect universally accorded to it.

\section{H. J. LAN CE,-Manufacturer of all kinds of Wood Pumps, No. 1245 Penn Av.}

H. J. Lance, manufacturer of all kinds of Wooden Pumps, is engaged in the business at No. 1245 Penn avenue, where the manufacture of Wooden Pumps has been carried on for twenty y ears, having been first established by Geo. MreCoy who sold out two years ago to MIr. Lance. Woodeu Pumps of all descriptions are made here by MIr. L., making a specialty, however, of large pumps for deep wells. Mr. L. was born in Beaver Co., Pal, in 18t4, came to Pittsburgh in 1864; having learned the pump-maling trade, has worked at it all his life, accumulating by his industry cousiderable means. He is a gentleman possessing the confidence and esteem of the community generally.

\section{JOHN A. RENSHA W \& CO.-Family Grocers, 269 Liberty St., Cor. of 9th St.}

The Wholesale and Retail Grocery and Tea establishment of John A. Renslaw \& Co., at No. 269 Liberty street, is the leading house in the city, making a specialty of Fine staple aud Fincy Groceries, Teas, Canned and Bottled Goods, lioreign Conserves, Pickles, Fruits, l'ish, etc. The house was founded in 1853 by Mr. Jno. A. Renshaw and Mr. Francis Bailey, under the firm name of Bailey \& Revsluaw, with a capital stock of $\$ 10,000$, which has since increased over 200 per cent. The present firm is composed of Mr. John A. Renshaw and Mr. John D. Carson, both natives of Pennsylvania. They occupy the entire four-story brick structure corner of Liberty and Ninth streets, carrying a large and carefully selected stock of Choice Family Groceries of the finer grades, Teas, Cotfiees, Spices, etc. They do a wholesale and retail business of not less than $\$ 100,000$ autually, employing seven assistants.

\section{G. SCHLEITER,-Dry Goods, No. 89 Market St.}

This house was established fifteen vears ago by Gardner \& Slater, who carried on the business for three years, when they were succeeded by the firm of $G$. Schleiter $\&$ Co. In $1876 \mathrm{Mr}$. Schleiter became sole proprietor and under his judicious management the business has increased, until the house to-day is ranked among the largest and most prosperous of the Iron City engaged in that line of trade. Ar. Schleiter was born in Germany in I839, and came to this country when a young man. He has had a long experience in the Dry Goods live, is a careful and close buy er, a thorongh judge of quality and value, and conversant with all the requirements of his trade. He keeps a large and elegant assortment of Silks, Dress Goods in great variety, Cloaks, Shawls, etc., employs twelve clerks and salesmen at a weekly expense of about $\$ 100$. His yearly sales amount to not less than $\$ 100,000$. 


\section{M'INTIRE \& BRAND,-Grocers, No. 4208 Butler St.}

One of the most extensive Grocery Establishments in the city, and the largest by far in that section of the city in which it is located, is that of Messrs. $11^{\prime}$ Intire \& Brand, at No. 4208 Butler St. These gentlemen started in the grocery line in 1871 in a bnilding neur their present quarters, and in a comparatively smull way, removing shortly afterwards to their present commodious warerooms in the large brick building, 25x90, owned by the tirm, where they transact a flourishing and steadily increasing business. They carry a large and complete stock of Choice Family Groceries, Flour, Teas, Sugars, Coffees, Spices, and in fact every article usually found in a first class, well regulated estahlishment of this description, varying in ralue from $\$ 10,000$ to $\$ 15,000$. Their annual trade will average more than $\$ 75,000$ and has reached as high as $\$ 100,000$. Buying strictly for cash and adhering to the cash system in their dealings with customers, they are enabled to sell goods on a very small margin. Both members of the firm derote their personal attention to the business, and the honse has achieved an enviahle reputation for mercantile integrity. Ifr. D. R al attention to the business, and the honse has achieved an enviahe reputation for mercantile integrity. Ifr. D. M. many years bas been identified with the busincss interests of the city. For three years he carried on the Drug lusiness on Fifth avcnue, and has been engaged in various other business enterprises in different locations, in which he lias been uniformly successful and during his comparatively brief business career has acquired a handsome competence through his own exertions, haviug started in life without caujital, save in energy and determination to succeed. He now oceupies the important position of President of the Metropolitan National Bank of Pittsburgh, and has been prominently connected with several other financial institutions. NI. Frederick Brand was born in Germany in 1834 and came to the United States in 1856. He worked on a farm for a number of years. By industry and economy he accumulated sufficient capital to engage in the grocery business in a small way at first, afterwards associating himself with $\mathrm{Mr}$. M'Intire and moving to their present location; they bave done a prosperous and steadily increasing business, and the frm is fully entitled to a prominent position among the representative business bouses of the Iron City.

\section{WII. W ALTON,-Dry Goods, Millinery, Notions and Carpets, 4310 Butler St.}

Mr. Walton's fine establishment is located at 4310 Butler St., where he has a large store room, $20 \mathrm{ft}$. front by $75 \mathrm{ft}$. deep, completely stocked with every thing in the above mentioned line, and where he is doing a large and growing business, extending throughout a large part of the East ead of the city. His estallishment enjoys a high degree of popularity, and which has been earned by the just and honorable dealings and enterprise. He has merited and is in every way worthy of the generous patromage bestowed on him. Mr. Walion was born in Birmingham, England, in 1833, came to the U.S. in 1864 and embarked in the Jewelry business in this city, continuing therein until engaging in the present business in 1874. Mr. Walton was among the first of the Pittsburgh Fire Commissioners, having been elected at the same time and serving on the Commission with Capt. J. H. Stewart and R. W. Mackey, aiding by his counsel and active efforts in perfecting one of Pittsburgh's most noted institutions. He is deputy tax collector of the city, takes a lively interest in public affairs, wielding intluence in polities in his ward and city, and possesses the esteem and confidence of the community.

\section{JOHN I. DON ALDSON,-Wholesale Wines \& Liquors, $376 \& 378$ Penn Av.}

One of the best known and deservedly popular wholesale liquor establishments of the Smoky Cit5, is that of Mr. John L. Donajdson, at Nos. 377 \& 378 Penn avenue, near Eleventh street. Mr. Donaldson commenced business for himself in Sept. 1874, at his present location, where be occupies the entire four floors of the spacious warehouse, 20x120, and carries a finely selected stock of Foreign and Domestic Wines and Liquors, Brandies, Gins, Rums, \&c., making a specialty of pure old Rye and Manongahela Whiskies. His present stock is valued at about $\$ 10,000$ anci inis trade, which extends throughout the two cities and the adjoining counties, will reach more than $\$ 25,000$ annually. Mr. Donaldson is a native of the old fonrth ward, Ptitsburgh, and was born in 1845 . He is a young man of energy, enterprise and business ability, with a large acquaintance throughout the two cities, and deservedily popular in private life and in the mercantile community. Since the very inception of his business career he has transacted a large and flourishiug business, which is steadily increasing from year to year. As he aims to kcep only the best and purest qualikies of unadulterated articles, the trade can always rely upon procuring of Mr. Donaldson the most desirable goods and at reasonable prices.

\section{LOUIS MUELLER,-Fancy Furs, Hats \& Caps, 20 sixth St.}

Engaged in the manufacture of Fancy Furs, Hats and Caps, and dealer in Buffalo Pobes, \&c., the house of Louis Mueller has a reputation extending throughout the neighboring counties and states. Mr. Mueller is located on the spacious building $18 \times 70$ at No. 20 Sixth street, (late St. Clair,) near the suspension bridge, was born in Germany in 1826 . He came to the United States in October 1849, and resiled for some time in Philadelphia, afterwards remoring to California ; in 1858 he located in Pittsburgh, where he has since resided. He started in business twenty years ago with a comparatively small capital, but hy industry and close application to business he has accnnulated considerable means and now carries a stock of about $\$ 10,000$ in value, consisting of a full line of Fancy Furs, Buffulo Robes, Hats, Caps, \&c. and makes a s secialty of altering, repairing and cleaning furs of every description, employing three assistants regularly and transacting a business of not less than $\$ 10,000$ per annum. This being the only establishment of its kind in the city, and the business is steadily increasing from year to year.

\section{B. H. VOSKAMP \& CO.-Wholesale Grocers, 343 Liberty St.}

The well-known wholesale Grocery House now conducted by B. H. Voskamp \& Co., was founded in 1862 by Seghmeyer \& Voskamp, and in 1872 Mr. B. Ir. Voskamp became sole pruprietor, under the firm name and style above given. He occupies the entire three-story brick warehouse $25 \times 110$ at No. 213 Liberty street, carrying a full and conplete stock of Groceries, Flour, Provisions and country jroduce generally, varying in value from $\$ 25,000$ to $\$ 30,000$. IIe cmploys one book-keeper, one salesman, three general assistants, and keeps two fine double teans in constant use, delivering goods to his virious customers in the citics and to the different railroad depots. Mir. Voskamp buys strictly for cash and is thus enabled to offer extraordinary inducements to the trade. He transacts a large local business and has an extensive trade througliout Western Pennsylvania, Eastern Ohio and West Virginia; his annual sales amounting to not

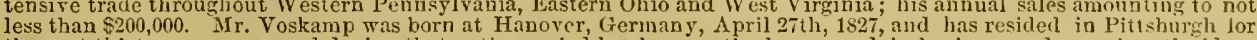
the past thirty-one years, and during that entire period bas been actively engaged in business and promincntly identified for many ycars with her mercantile prosperity doing much to develope her wholesale trade and placing the cit in the proud position she now holds as a commercial as well as manufacturing metropolis. He is il public spirited and liberal-minded gentleman, taking an active part in whatever tends to the hest intercsts and welfare of his adopted city. During the years 1576 and 1877 he represented his ward in the Common Cuuncil to the entire satisfaction of his eonstituents and with credit to himself. Ir. Voskimp is justly entitled to a prominent position among the self-male aud representative business men of the Iron City. 


\section{THE UNITED STATES IRON AND TIN PLATE CO.}

\section{Irain Office, Demmler Station, Pa., Office, 118 Smithfield St.}

This important industry was organized and incorporated in 1873, under the mining and manufacturing laws of Pa. The Company was first established with the design of producing tin and terne plates, the autlorized capital was $\$ 400$,The Cond in August 1874, the works having been constructed in the interim went into active operation. Success imme-

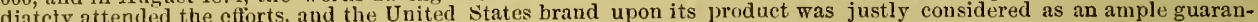
tee of cxcellence. Ore production in England, however, and a misconstruction of the tariff law at home, relating to this class of goods, virtually abolishing all protection, made it impossibte for the American manufacturer to compete successfully while paying labor double the price demanded abroad. Carefully and with great foresight adjusting their business to escape these unexpected contingencies, they devoted their entire resources to the manufacture of fine sheet ness to escape their success has become conspicuous, the demands being so great as to cover the whole capacity of the works for months in advance; the annual sales amounting to not less than $\$ 230,000$. The works having facilities for works for months in advance; the annual sales amounting to not less than $\$ 230,000$. The works having facilities for Monongahela river, immediately below McKeesport; the works cover an area of five acres, the property of the Company being double those dimensions. Machinery of the most perfect and powerful cbaracter is employed, consisting in part of four puddling furnaces, four nabbling fires, one heating furnace, two double sheet mill furnaces, three annealing furnaces and four tinning stacks, besides one large hammer with 6.000 lbs. stroke, one large mill engine of 500 horse-power, one blast engine of 80-horse power, four smaller engines rauging from 5 to 20 horse-power, and a battery of four boilers with 900 horse-power. One hundred and fifty hands are employed here, to pay whom a semi-monthly disbursenient is requisite of ahout $\$ 3,000$. The officers of the corporation are at present: J. H. Demmler, President; D. J. Thomas, Vice President; James Niwick, G. W. Coffin, F. E. Schenk, F. Close, E. Shoemalker, H. H. Demmler and W. C. Cronemeyer being Directors; II. H. Demmler, Treasurer; W. C. Cronemeyer, Secretary ; Samuel Truby and Albert J. Denmiler, mill managers, and Otto Rossler and Herman Heeren, bookkeepers. Among these names will be noticed mans of those which have figured prominently before the public in connection with the interests and prosperity of the
city, adding solidity to every enterprise with which they are identified, and under whose influence the United States Iron and Tin Plate Company have achieved so great a degree of prosperity and such well merited consideration.

\section{HITCHCOCK, MCCREARY \& CO.-Grain and Commission,}

Cor. Smithfield and Liberty Sts.

Established in 1859 , as Huffman, MeCreary \& Co., this firnu assumed one year later its present style, composed of L. P. Hitchcock, Wm. MeCreary and John H. McCreary, dealing in Grain, making a specialty of iWheat, and also operating as Commission Dealers in this branch of products. The premises first nccupied by the house were on $2 d$ avenue, at that time the center of the wholesale trade of the cits, where it remained for about seven years, removing in 1866 to 319 Liberty st, chancing locations again within the past few months to the offices situated as above, in McCance building. The trade of the house consists mainly in the purchase of grain in the Western States, and its shipment and supply to the local and Eastern markets, and in this direction the operations of the firm are said to exceed in extent those of any otjer firm in this city. It was mainly owing to the exertions of this concern that the first urain etevator was erected in Pittsburgh, while its connection with other enterprises, conducive to the punlic benent or convenience, las caused it to be long recognized as one of the most public spirited firms in the Iron City. Ir. Hitcheock is a native of Hartford, Conv., where he was born in 1811, but has been identified with the interests of this community for over a quarter of a century. Mr. Wm. McCreary is originally from Washington County, this State, being born in 1829, and remoring to this city, with his brother, John H. McCreary, in 1855 . The latter was born in 1836. In the commission department the firm has established an enviable reputation for promptness and reliability. This house has perhaps done as mnch to advance the industrial interests, and develop the latent resources of the community as any other one concern. Beginning with restricted resources at first, it has acquired a position in commercial circles to which few houses ever attain, and an increasing range of usefulness that entitles it to the general esteem and respect.

\section{JAMES M. WIIKINSON,-Stationer \& Bookseller, Cor. 5th Av. \& Wood St.}

Of the several firms or individuals in this city engaged in the Book, Stationery and Printing business, it may be safely asserted that none are better stocked or conducted with a more thorough knowledge of the requirements of the trade, than the establishment of Mr. James Mr. Wilkinson. For many vears connected with one of the oldest Book and Stationery stores in the city whose business was mainly intrusted to his care, and subsequently with R. S. Davis \& Co., whom he succeeded in 1878. The career of Mr. Wilkinson for more than 12 years in his present vocation has given him an experience, the advantages of which are observed daily in the management of his lusiness. which is rapidly increasing. Loctted on the corner of 5th avenue and Wood street, the premises occupied by Mrr. Wilkinson are in the very centre of the business portion of the city; they consist of one double four-story brick building, the lower floors being deroted to retailing and the upper to jobling, for which the house has peculiar advantages, in connection with eastern manufacturers and importers. The stock of stationery carried by this establishment is the most complete and hest selected in the citv, always embracing evervthing desirable, new, rare or costty. In miscellaneous and Sunday or common school hooks the selection is equally wide and includes an assortment in the purchase of which great care has been displayed. Besides these essentials utr. Wilkinson makes a specialty of supplying steamboat and commercial books, blanks and printing of alt kinds, evincing a taste and discrimination in this department highly conducive to the satisfaction of his customers and the bealthy pnlargement of this trade in this line. The minor articles pertaining to the business are by no means overlooked: Wilkinson's best lead pencils surpass Faber's and at half the price To fancy goods he has given particular attention, his store being an attractive bazaar for all kinds of charming nic-nacks allied to the trade ; archery and croquet goods being in great force. With an elegant site and establishment, a stock averaging in value about $\$ 35,000$ and an annual business of nearly double that amonint, the enterprise of Mr. Wilkinson is justly entitlerl to the consideration and patronatge of the public, and its projector to the esteem that energy, reliability and talent always inspire.

\section{W. G. MAHAFFEY,-Boot \& Shoe Maker, 102 Fourth Avenue.}

The art of making Boots and Shoes to fit the feet of the wearers with nicety, and afford no pain or injury to corns bunions or growing natils, is one of sufficient importance to demand some attention. Mr. WV. G. MIahaffey has acquired this art hy fong experience and considerable study. His claims, as the only anatomical shoe maker in these cities, are well foumled. MIore than this, it is asserted that he is the only real artist in this section of the State, in the matter of accurately adapting the last to its particnlar work, so that not a single flaw or defect shall be found in the finished articte. A native of Indiana Co., Pa., Mr. Mahaftey was born in 1836, removed to Pittsburgh nearly 20 years ago, and has since become prominently known in his vocation, at which, since 1864 , he has worked for hiniself. Those who once enjoy the luxury of wearing boots or shoes of his construction will never wear other makes, and, ons a consequence, Mir. Mahafler's trade is pret.ty widely extended. Iadies and gentlemen will find it greatly to their comfort. to call on Mr. Mahaffey, who is not only unsurpassed as a skillful maker of fine boots, shoes, gaiters and slippers, but guarantees such fits as shall make pedestrianism a matter of thorough enjoyment and delight, instead of the unutterable torment it frequently becomes. 


\section{W. A. NIMICK,--Pittsburgh Transfer Co., General Office, No. 182 Second Av.}

The business of transferring and forwarding freights in this city, as conducted under the management of $\mathbf{M r}$. TV. A. Nimick, has grown within the past few years to such importance and dimensions as to properly denand classification among the industries of Pitsburgh. The fact of there being no central freight depot in this city, common to all the lines of railways centering bere, makes the necessity of such an enterprise extremely apparent. 'From the P'gh. \& Lake Erie, B. \& O., P'gh., Va. \& Charleston, and P'gh. Southern Railroads, comes much of the business of tie Transfer Co., besides connecting with all the various lines of steamboats that reach this port. Besides the regular freight transfer traffic, goods are forwarded to all parts of the United States and Canadian Provinces. Baggage delivered to all sections of the cities and surroundings or checked through to all points from residences or hotels to destination, and passengers called for in time to make any given train or boat. Freight consigned in care of the Pittsburgh Transfer Company will be forwarded to any point designated or delivered in any part of Pittsburgh or Allegheny. These operations require the assistance of 30 hands, 54 horses and 24 vehicles of all descriptions, together with the constant oversight and supervision of Mr. Nimick, whose success has been such tliat besides owning the large outfit mentioned, the business has reached large proportions, extending throughout the United States and Canadas. The business was established by Mr. Nimick four years since, under his own name, changing to that of the Pittsburgh Transfer Co. on the completion of the P \&. L. E. R. R. A native of Allegheuy City, Mr. Nimick was brought up in New Orleans, returning to his birth-place before the breaking out of the late war. Endowed with fine business and executive ability, his energy in the prosecution of his business has led to the most satisfactory lesults-so much so that the Company of which he is the
dustry and prosperity of the Iron City.

\section{MILIS \& CO.-Pittsburgh Chemical Works, Lye \& Cements, 260 Liberty St.}

As the largest and most extensive dealers in Cements in Pittsburgh and the sole manufacturers of Concentrated Lye and Ka-Lye (the latter being a specialty), the firm of Mills \& Co. come fully within the scope of any work bearing upon the industries of this city. Besides the products above mentioned, the trade includes White Lime, Sand, Caleined and Land Plaster, and other Fertilizers, besides Drain Tiles and Sewer Pipe, Chimney Tops, Grate Tiles, Fire Brick and Terra Cotta Ware. The business was established under the same style in 1868 , and from that time has been increasing annually. The premises occupied, on Liberty street, consist of one large building having five floors and dimensions of $20 \times 80$ feet. The Lye manufactory is located at Homestead, Pa., and includes two buildings, one being of brick, $30 \times 60$ feet, the other of wood, $15 \times 40$ feet, besides which the firm lave a warehouse for storing at No. 211 First avenue $24 \times 65$ feet, and another for the same purpose on Virgin alley. The trade of the bouse ranges mainly within a radius of 200 miles of this city and amounts to between $\$ 50,000$ and $\$ 60,000$ annually. The several members of the firm are as follows: Isaac Mills, Jr., Geo. Sheppard, J. Brankstone and S. C. Bullock, all of wholl are actively engaged in operating the business, aided by eleven or more emplores. Enterprising, reliable and honorable in dealing, the tirm of Mills \& Co. are widely and favorably known in this community for these characteristics and are very justly accorded the general confidence of the public and a high place in the esteem of the trade.

\section{SEVENTE AV. HOTEL-Elias J. Unger \& Co., Prop's., Cor.7th Av. \& Liberty St.}

Constructed within the past few years, the Seventh Avenue Hotel has already achieved a place in the consideration of the public that ranks it equal to any cotemporaneous establishment in the United States, and reflects credit upon the enterprise that designed it, the ability that conducts it, and the community that patronize it. in everything that pertains to the comfort and well-being of its guests, this hotel is a sample of perfection. In the unatter of sumptuous furnishing, stean elevators, bath roums, heating and ventilating arrangements, spavious dining rooms and parlors, airy hall-ways, prompt and polite attention, with confessedly the best menu in the city, the popularity of the "Seventh Avenue" is not, in the light of these advantages, surprising. Five stories in beight, and one of the niost imposing editices in the city, the house contains 150 rooms for guests and is supplied throughout with water and conveliiently placed fire escapes, so that no possible danger could assail the inmates in case of fire. Perhaps no gentlemen in the State are more capable than E. J. Unger, Esq., and Mr. Henry Kanaga. The former has a national reputition as being for more than ten years proprietor of the Union Depot Hotel of this eity, destroyed in 1877 during the labor riots, and combines in himself such qualities as have made him a favorite with the traveling public ancl a citizen to whom is accorded the bighest consideration. Mr. Kanaga is likewise well-known and widel $\mathrm{r}$ esteemed in this community, not only as being connected with this hotel since its opening. but his former managenent of the Girard House, Philadelphia. The Seventh Arenue Hotel occupies a place rarely achieved by any similar establishment.

\section{HENRY LEVY-Hosiery, Notions Furnishing Goods, Peddlers'Supplies, 84 Diamond.}

As a Wholesale Dealer and Jobber of Hosiery, Notions, Gentlemen's Furnishing Goods and Peddler's Gencral Supplies, Mr. Henry Lery has acquired au excellent business and a solid position in the commercial community of Pittsburgh. The premises he occupies are eligibly situated and consist of a spacious three-story building, $20 \times 120$ feet at No $\$ 4$ Diamond street. Here, with a stock valued at from $\$ 5,000$ to $\$ 6,000$, Mr. Levy conducts a trude of ahout $\$ 10,000$ annually, besides which be carries on successfully a General Store at Penn Station in Westmoreland Co., Pil,, which nets a very satisfactory yearly return for the capital in vested. A large part of the trade of Mr. Lery is in supplying peddlers with a general assortment of such goods as they are likely to require or can dispose of at a profit, offering better inducements to this itinerant trade than any other man in the business. Having connections in New York and the Eastern markets, enables him to buy always upon such terms as involve "bed-rock" prices to his customers.

Mr. Levy is a native of Poland, born in 1836 . At the age of 21 he came to this country and since 1872 has been a resident of this eity, with the business interests of which he has been more or less identified ever since. Prompt and reliable in all his transactions, Mr. Henry Levy has already acquired a trade that reaches throughout the city and surrounding portions of the State.

\section{MANLEY \& HILL,-Keystone Dining Rooms, 293 Liberty St.}

The Keystone Dining Rooms were established in 1868 by Mr. Wm. Simpson, In April, 1879, Mr. Amel Manler, a gentleman of long experience in the leading hotels and restaurants of the country assumed the manacement and proprietorship of these model rooms, which are eligibly located in the very beart of the husiness community at No. 293 Liberty street. The dining rooms are $25 \times 110$ feet, fitted $u p$ in the neatest and most elegant style, with a seating capacity for about sjxty persons at one time. The tables always present a handsome appearance, the ware being of the finest, while the viinds are not only admirably cooked, but served in the most attractive style. Mr. Manley has a large number of regular boarders, and the average attendance at his tables is about 150 persons ner day. The finest meals in the city at 25 cents each and weekly board for $\$ 4$. He gives bis personal supervision to the business, employs only first-class cooks and attentive waiters. 


\section{GERIAN FIRE INSURANCE CO.-Cor. Wood St. \& Sixth Av.}

One of the most safe, solvent and conservative Fire Insurance Companies in Pittsburgh, the "German" claims notice in this work as being in man y respects a ropresentative institution. The above underwriting organization was established in 1862 with a eash capital of $\$ 100,000$, which has been since increased to double that sum, and from its very inception has proved a signal success. The oflicer's of the Company at the present time are: Messrs. C. Barchfelt, President; Jos. Lang, Vice President ; F. L. Gross, Secretary, and F. W. Krugh, Ass't. Secretary; are gentlemen willely known in comnection with the enterprise that has been directed under their management, with sucl skill and discernment. Since entering upon its career the Company las paid losses to the amount of $\$ 181,467.73$, in spite of which considerable ontlay, over $\$ 266,000$ has been divided among the stockholders as protits ; leaving the available assets of the concern at the present date over $\$ 350,000$, and net surplus $\$ 104,042.60$. This handsome showing is sufficient to convince the reader of certain facts in regard to this Company that ean hardly be disputed:-1. It has been honestly managed. 2. Its business has been cautiously conducted and risks carefully selected. 3. Its investments have been safer and good. 4. Experience and ability have characterized and guided its operations. The business of the Company reaches not only through Penn'a, but Ohio, Illinois, Missouri and California, as well as being largely centered in this city, where it is looked upon as a favorite aud supported accordingly.

\section{SCHIMIDT \& FRIDAY,-Wines and Liquors, 384 \& 386 Penn Av.}

For nearly half a century this old established and well-known house has been the recognized headquarters in Pittsburch for pure and unadulterated Wines and Liquors for uedicinal and family use. The house was founded in 1836 by Mr. William Schmidt, who for nearly twenty years oceupied a prominent position among the represcontative business houses of the Iron City. In 1855 he was succeeded by Mr. Joseph Schmidt, who for ten years sustuined the well earned reputation of the original proprietor. In 1865 Mr. Willim J. Friday associated himself with Mr. Sehmidt under the firm name and style of Schmidt. \& Friday, and these gentlemen have since conducted the business with signal ability and marked success, and the house to-day is the most extensive of its kind in Pittslurgh. 'They occupy the spacious and commodious donble wirehouse 30x120 with four floors and basement at Nos. 384 and 386 Penn avenue, (near the Union Depot), carrying an average stock of about $\$ 125,000$, consisting of every variety of Foreign wines, brandies, gins, rums and cordials, pure rye, wheat and Bourbon whiskies of the choicest biands, from the most renowned distilleries of the country. They enjoy a large city trade with a liberal patronage from dealer's and druggists throughout Eastern Ohio, Western Pennsylvania, WVest Virginia and other States; their annual sales reaching $\$ 200,000$. In addition to the stock carried in their warchouse Messrs. Schmidt \& Friday keep constantly on hand in houded warehonse large quantities of pure whiskies, and have a capital in vested in the business of not less than $\$ 150,000$. Both members of the tirm are natives of Pittsburgh and have for many years been prominently identified with the wholesale liquor tride. Four assistants are constantly employed by this house, one as bookkeeper, one as traveling salesman and two as resident salesmen and general assistants in the store.

\section{B. CAIN,-Eagle Shoe Store, 87 Smithfield St.}

Every business venture that bears upon its face the stamp of genuine enterprise, whether in its youth or age, is justly entitled to more or less consideration in this work. Upon these grounds the establishment of Mr. M. B. Cain. though but lately founded, is not to be omitted, particularly as in the shoe trade was a vacant niche, which by the discernment of Mr. Cain has been no longer left unoccupied. Besides a general assortment of ladies, misses', children's, men's and boys' wear, all of the finest grades and makes, to the value of $\$ 10,000$, or more. Mr. Cain has made particular provision for the wants of gentlemen by securing a remarkably choice stock of thoroughly sterling and stylish goods, which, by means of certain special advantages accorded him by the manufacturers, he is enabled to offer at prices never before duplicated in Pittsburgh. This assertion is made with a substantial knowledge of the facts, and the public ean verify the statement if skeptical, very much to the profit of those who are led to do so, Mr. Cain is a native of this city, and was boru bere in 1852. He has been identified with the shoe business for many years, and has acquired an experience that will make the Eagle Shoe Store the resort of the best cash burers in Pittshurgh and envirous. Of the many engaged in the same business, Mir. Cain takes a front rank for enterprise, reliability and liberality, and for these and other admirable qualities should receive the support of the public, and the consideration of the community, to which he gives an impetus in the right direction.

\section{DICIRSON, STEWART \& CO.-Coal, Office, 567 Liberty St.}

One of the best known firms in the Coal trade, as well as one of the oldest now extant, the house of Dickson, Sterart \& Co. is properly entitlel to more than mere mention in this work. More than a quarter of a century ago this enterprise was commenced by the same firm and under the existing title, the demise of MIr. Stewart, though changing the partnership individually, hat no other practical result, as the interest remaines rested in his heirs. Since 1852 tha house has pursued the route upon which it started, with hut few variations from a uniform prosperity. The mines of the company are located at Turtle Creek, about 12 miles from the city, on the Pennsylvania R. R., and are very cxtensive, sixty hands being regularly employed, resulting in a product of 700,000 bushels of the best bituminous coal known to this market annually, anil a trade of about $\$ 50,000$ per year. Mr. T. C. Dickson, the senior partner and manager of the concern, was born in Ireland, in 1827, and accomplanied his parents to this country and city when but 5 vears of age. He is a man of comprehensive knowledue of general commercial business and affairs. His career has been inarked by il policy of rectitude, and many positions of responsibility and trust have been filled br him with great ability. As conducing to the industrial thrift of the community, this tirm has contributed largely, and is entitled to the cstecm and respect which it has acquired in so large a measure.

\section{CASEY \& FOGARTY,-Wholesale Wines \& Liquors, No. 339 Liberty St.}

The well-known Wholesale Liquor estahlishment now conducted by Casey \& Fogarty dates back its origin more than forty yeirs, having been founded in 1837 by Robert $M$ Loore, Esq., whe was succeeded in 1855 by the firm of Black \& Wookls. In 1869 Mr. Black retired and Mr. W Wonds continued the business alone until Mar, 1869 when Mr. T. D. Casey became a partner, the firm name and stvle being Rolert Woods \& Co. In August, 1571, Mr. Woods retired and MIr. T. C. Forarty associated himseli with MI. Cascy and the tirm became as at present, They inow occupy the spacions four-story brick warchouse, $24 \times 80$, at No. 339 Liberty street, the same building occupied by Rohert Watson from 1845 until 1855 . With a few exceptions it is the oldest liquor house in the city. The firm constantly carries a stock of $\$ 25,000$ to $\$ 30,00 n$, comprising every variety of the Choicest Wines, Brandies, Gins, Rums, etc., of their own importation and a full line of Pure and Unadulternted Old Rye and Bourbon Whiskies from the best distilleries in the country. Their stock is selected with great care, especially for their own trade, which is of the better class througln out Eastern and Western Peunsylvania, Eastern Ohio and WVestern Virginia, and their annual sales will reach from $\$ 100,000$ to $\$ 12 ., 000$. Both members of the firm are gentlemen of long experience in this line and derote their personal altention to the management of their extensire business, employing four assistants as general salesmen. They have bolh resided in Pittsburgh for many ycars and heen prominently identitied with the business in which they are engaged. 
FIFTH AVE. HOTEL,-Frank McCoy \& Bro., Proprietors, $131 \& 133$ Liberty St.

Half a century ago, long before the sound of a locomotive-wlistle had been heard west of the Allegheny Mountains, and when the traveler, arriving at the end of his journey, alighted from a stage coach, the old "Black II orse Tavern" stood where now stands this well known commercial house. The unpretentions one aud a half story frame building, that formerly divided the honors in this line of business, lias long since bren suryliunted by a sulstantial edifice, fronting 92 feet on Liberty St., and extending back 112 feet, being four stories hirls. This builling was erected by Mr. Samucl Hare, in 1854, when the "Blick Horse Tavern" became a thing of the past, and Frare's Hotel came into existence. For 22 years this house was well and favorably known, not only to the residents of Western Pennsylvania who oceasionally visited this metropolis, but to thousands all over the country, traveling lor business or pleasure who availed themselves of its accommodations. In $187 \mathrm{~b} \mathrm{Mr}$. Hare resigned all interest and control of the house, ani it passed successively into the hands of Messrs. Hugh Keys and Joseph Wright, and in Aurust, 1878, the present proprietors assumed its management. It is needless to enumerate the various changes that have taken place in its internal arrangements since Messrs. AIcCoy \& Bro. have assumed its control. Sutice it to sity that the Fifilh Ave. Hotel is now ranked amoug the best houses in the eity. They have put the house and every department in conplete repair, and supply their table with the ehoicest the market affords, and, what is equally important, lrave one of the hest and most experienced cooks, as well as attentive and courteous waiters. The location is central, situated alont equal distance from the court house, post office, railroad depots and steamboat landings. The proprietors of this house, in order to make it first-class in every respect, have put their price at the nominal firure of $\$ 1.50$ per day. In connection may be found one of the finest stables in the city, also one of the principal depots for the sale of stock in Western Pennsylvania. It is situated in the rear of the hotel, is $92 \times 125$ feet in size, and affords accommodations for 150 heads of horses, is light and well ventilated. In the various changes that liave taken place in the management of this old stand, the traveling public have probably never bad more careful and assiduous caterers to their confort than the present proprietors of this house extend.

\section{S. IINDSAY, Jr., \& CO.-Flour and Groceries, 157 Liberty St.}

Among the prominent dealers in Flour, Groceries, \&c., is the above firm, occupying 3 floors of No. 157 Liberty St. each $15 \times 100$ feet in size, in which is carried one of the finest stocks of Flour and Groceries to be found in the eity, ranging in value from $\$ 10,000$ to $\$ 12,000$. Two hands are employed to assist in carrying on this business, amounting to over $\$ 75,000$ per annum. The firm is especially noted for its manufacture of Flour, in which it particularly execls. It was started in 1831 by Samuel Lindsar, the fither of the present proprietor, who was horn in Ireland in 1794 and came to the United States in 1814, and to Pittsburch soon after, being thus one of the pioncer business men of Pittsburgh. Mr. S. Lindsay, Jr, is a native of Pittsburgh, born in 1833 . Wm. Mr. Lindsay, bookkeeper of the firm, is a brother of Mr. Lindsay, Sr, and was born in this city, in 1549.

\section{LOUIS VOLZ,-Plain \& Fancy Job Printing, 137 Smithfield St.}

Although he exccutes every description of fine mercantile and job printing in the highest style of the art, the specialty for which Mr. Volz is particularly noted is German and Commercial printing in all its branches. His office, located at No. $137 \mathrm{Smith}$ field street, is supplied with new and desirable fonts of all the latest styles and novel varieties of jol type, selected by Mr. Volz expressly to meet the requirements of his trade. IIe commeneed husiness at his present location in 1874 and his trade amoun ts to not less than $\$ 3,000$ per annum. He employs three practical printers who are familiar with hoth the English and German languages. Two Liberty jiresses, (one quarter niedium and one eighth medium) of the latest patterns. Mr. Volz enjoys the patronage of many of the leading German merehants and business houses. He was boru in Hesse Darmstadt, Germany, in 1845, and came to the United States in 1872, locating in Pittsburgli the same year.

\section{EHLERS \& HERMAN,-Undertakers- deifienteftafter-Livery Stable.}

No. 100 Mradisose Avo, Allegheny.

These gentlemen commenced business at their present stand in 1874. They have had a very liberal share of patronage since they embarked in their business, and their present stock is valued at $\$ 3,000$, while the annual anmount of business is about $\$ 10,000$. They not only do Undertaking (Seidienbeftattinta) in all its hranches, but keep Livery ancl Sale Stables. C. W. Ehlers and Henry Herman compose the firm. Mr. Ehlers alone controls the livery department, while the undertaking establishment is under the joint management of the partners. Their rates and prices are among the lowest in the trade, and their coffins, caskets and funcral goods are of the lest quality. Mr. Elilers was born in Germany, in 1S39, and came to this city in 1854. Mr. Herman was born in Switzerland, in 1833, and came to this eity in 1846. They are industrious and energetic men.

\section{J. A. GILIELA ND,-Dry Goods, Notions and Clothing, 133 Beaver Av., Allegheny.}

Mr. Gilleland occupies the three-story brick structure, 24x60, at No. 133 Beaver arenue, Allegheny City, where he carries a large and elegant assortment of general Dry Goods, Ladies' and Gents' Furnishing Goods, Trimmings, Notions and Small Wares, and also a large stock of Clothing and fine piece goods, of botl foreign imd domestic manufacture, making a specialty of mercliant tailuring, in wlich department he has secured the servicess of a first-elase cutter, and employs nine hands, with an average monthly pay-roll of $\$ 100$. The husiness was established by $M$ r. Gilleland many years ago, and has steadily increaserl from year to year, until he now transacts an annual busincss of not less than $\$ 16,000$, and carries a stock of over $\$ 6,000$, which is full and complete in all its departments. His trade, which is both local and transient, will compare favorably with that of any similar establishment in the two cities. Mr. Gilleland is a native and life-long resident of Allegheny City, and his establishment is one of the largest in this section of the city.

\section{HIPPELY,-Flour, Grain and Mill Feed, Nos. 294 and 360 Ohio St., Allegheny.}

This very flourishing establishment was started by Hippely \& Vickers in 1864, wilh a capital of less than $\$ 500$. The business of the house may be measured by its increased capital, which now runs 11 to $\$ 15,000$. The stock on hand is selclom less than $\$ 5,000$, and the business transarted yearly is about $\$ 70,000$. Mr. II ippely oceupics two stores, one $25 \times 55$ feet, and the other $25 \times 105$ feet, two stories high, and well adapted to the husiness-each doing a wholesale and retail business, and empoying, in both, five men. Besides the proprietor two salesmen are cmploycd, with trarle in this and adjoining counties. Mr. Hippely was born in lrie, Pa., in 18.1, and cane to this city in 18G1. IIe has heen eity weigh-master, and is now a direetor of the Workman's Savings Bank. He is energetic in busiuess, and popular as a citizen. 


\section{A. FREN CH \& CO.-Cast Steel Spring Works, Office \& Works Cor. 21 st \& Liberty St.}

For many years it has been pretty thoroughly understond throughout the entire country, that for the supply of every article, material or product used in the construction and maintenance of railways and railway relling stock and machinery, Pitsburgh was the central depot; nor lats the reputation of the Iron City in this respect been limited to our own contineut, as is proved hy the faet that annually. increasing exports of this class of goods to England, France, Auslralia and South America, show the high estimation in which they are held abroad. Upon the various seientific and mechanical problems, the solution of which engendered the perfection of the American railway system-perhaps an amount of inventive genius has been direeted that would more than counterbalance the combined efforts of the rest of the world in this branch of develolment. One of the most puzzling questions which arose during the early history of railroading was that, with reference to the proper application and best material and construction of springs. This point of really paramount importance engaged the study and attention of inventors for years, gradual iruprovements taking place step by step, until the introduction of the Elliptic Steel Springs, manufactured by A. French \& Co., in 186t, which at once achieved all that hat been desired and striven for, and more than had been expected. To the credit of the perception and applieation of the principles upon which these springs are constructed and employed, Mr. Aaron French is undoubtedly entitled-his experiments and observations as a railway blacksmith having led him to the eonclusion that by a formation of springs that should at all times possess uniformity of action with reference to varying strains - the total weight being apportioned equally upon the whole spring, instead of npon the weakest portion, the great desideratum would be obtained. To the tmbodyment of this idea in a practical form Mr. French devoted himself and was not long in arriving, through the aid afforded by the crucible cast steel, the properties of which were at traeting great attention at that time-at a very satisfactory conclusion of his labor. Iu conjunclion with Mr. Calvin Wells, of the firm of Hussey, Wells \& Co., manuficturers of steel, an organization was effected under the style of $\Lambda$. French \& Co., (for the exclusive production of elliptic cast steel springs for railroad ears and locomotives, which at once acquired 'a prominent position and an assured success. The features of Elliptics, which make them unapproachable as springs, are their slow notions to an almost nnlimited extent with their power of absorbing many disturbinces in one notion, and the time they take to recover without abruptness from the immediate effeets of such disturbances. The faeilities enjoyed by Messrs. A. French \& Co., for the manufacture of these springs are unrivaled on this continent, both for the perfection of mechanical appliances and machinery used, the material employed as also the patent hot compressed bands, and the principles of construction, all combining to evolve a product, which for thorough excellenee with durability, elasticity and uniformity is so far matchless.

The plant of the firm is lowated on the corner of Twenty-First and Liberty streets, and is one of the most extensive establishments in the eity $;$ the buildings, which are substantial and appropriate, covering an area of $100 \times 265$ feet. Here are employed so earuings amount to not less than $\$ 5,000$ per month, the anmua to England, Australia and the Sonth American States. At the Centenary Exposition of 1876 , the highest a ward with medal was conferred upon the work of this firm, the diploma reading, "For good designs, excellenee of workmanship and material, uniformity of action and durability"-words applied to no other similar exhibit. Of the members of the firm, Mr. French is a native of Ohio, where he was born in 1823, removing permanently to Pittshurgh in 1864, since which time he has heen active in the promotion of the enterprise with which he is so elosely identitied. Mr. Calvin Wells was born in (iennessee Co., New York, in 1827, and has been a resident of this city for thirt $y$-two vears, during which period he has been engaged in developing the manufacluring interests of the community. The claracter of the tirm is too widely known to require any emment here; it is one of the vitalizing institutions of the eity, and as such, has acquired a place in the consideration of the public to which it is most equitably entitled.

\section{JOHN J. SHADE,-Bookseller, Newsdealer and Stationer, 3706 Butler St.}

Mr. Shade is doing a prosperous hnsiness of about $\$ 5,000$ per annum. The business was first started by Geo. Shale, father of the present owner, in 1862; at his death, in 1872, the store came into the hands of the present owner, John J. Shade, who was born in Germany in 1845 , eame to Pittsburgh in 1855 and learned the printer's trade. He served 9 months in the 136th Regt. Pa. Vols., anci was engaged in some very inurortant battles. Mr, shade is a gentleman possessing business qualities of a high order, doing a very prusperous trade in his neat and well arranged store room, is honored and respected by all who know him for his strict integrity and high ebaracter. Shade is known throughout the entire portion of the city in which he does business.

\section{THE MORRIS PRINTING IHOUSE,-1311 Carson St.}

This establishnent was founded by F. D. Morris, Esq., its present proprietor, in 1871, and has been steadily increasing in public favor and extending its business ever since. It has excellent facilities for doing every variety of Commereial Job Printing, Ruling, ele. The Morris Printing llouse occupies a three-story brick building 20 feet front by 40 feet deep. A neat little engine and upright tubular boiler are used, and from four to seven men are employed. Mir. Morris was born in Philadelphia in $18 \bar{t} 4$ and came to this city in $186 \bar{\tau}$. As a printer he has displayed a taste which his made his work popular. He is a refined and cultured gentleman and enjoys universal respect :nil esteem.

\section{RISACHER, -Dealer in all kinds of Meats, Butler St., bet. 36 th \& 37 th Sts.}

On Butler street, between 36th and 37th streets, will be found the well-stocked, neatly kept and popular Meat Market of the genial and clever young gentleman Mareel Risacher, where he engaged in the meat business in August, $1 s i 7$, with very small capital, which, by his agreeable manners and by keeping the finest quality of meats, has from the stirt steadily enlarged and extended. He is now in the enjoyment of a rory large and prosperous trade. Fis establishment is fittel with a very complete ice-house and refrigerator, in which he is able to keep a large stock of fresh meat in prime condition at all seasons. Mr. R. was born in France in 1854 and came to the Uniteo States in 1871. Wurking for a few years at the butchering business, saving his earnings, which, in a short time supplied bis capital with which to emlark in business for himself, in which, though quite young and having but recently started, be has achicved a very notable suceess.

\section{SIPPEL,-Merchant Tailor, Hats, Caps \& Gents' Furnishing Goods, 4210 Butler St.}

Mrr. Sirpel will be found at No. 4210 Butler street, where he has a good stoek of Hats, Caps, Gent's Furnishing Foods, with the latest styles of Cloths for Custom Work. To his Merchant Tailoring establishment he devotes particular attention, enjoving a high reputation and guaranteeing perfeet fits. Mr. S. commeneed his present business with a (atpilal of $\$ 75$, in 1875 , having, through unfortunate real estate investments, previously lost a considerable fortune. With this small capital, hacked by energy and self-reliance, he has suceeded in building up a good trade. He was born in Germany in 1834; came to the United States in 1852; learned the tailoring trade in the old country and has worked at it ever since. Mr. S. is now doing much of his own work with his own bands, doing it well, thus gaining a high reputation. 


\section{S. STU TZ,-Mining and Mechanical Engineer, No. 961/2 Fourth Av.}

Mr. Stutz is of French parentage, but was born near strasburg, Germany, in 1833. He graduated with high honors at the celebrated Saarbruek College in 185t, and in the following year entered the mining school of that eity, from which he graduated in 1859 . Determined to become thoroughly profieient in the profession of his choice, lie afterwards entered the Bichum Mining School, where he graluated in a special course in 1860. During the liranco Prussian War he served as a French Soldier in the National Guarls, participating in all the engagements in which that veteran organization took part, until the close of the war. He was in Paris during the reign of the commune and came to the United States in 1871 . 'The first two years of his residence in this country he held the rcsponsible position of Civil Engiveer of the city of Massillon, Ohio. Relinquishing that position he entered the ofiee of the Westinghouse $A$ ir Brake company of this city, as draftsman and engineer. Five years ago he engaged in business for himself and opened an office at No. 961/2 Fourth A venue. Mr. Stutz is a thorough jractical mining and meehanical engincer and is prepared to furnish plans and estimate for opening and working mines, for inclined planes, wire rope tramways, loisting maehillery, etc., making a specialty of the erection of patent coal and ore crushing and washing machinery and coke ovens. He is now devoting his attention, principally to the development of his own patents, on Cual Washing Machinery and machinery for separating impurities of all kinds from the earbon of coal previous to its use or manufacture into coke. The benefits to be derived from the use of a pure fuel in metallurgieal operations are evident to proprietors of blast furnaces and others engaged in similar business, and the inventions of Mr. Stutz, which are secured by letters patent, dated respectively Mareh 20, 1877, August 14, 1877, Dee. 18, 1877 and May 14, 1878, are believed to lee as near perfection as ean be attined for this purpose. Many of his coal crushing and separating michines are in operation in Pittsburgh and through the Bituminous Coal regions of Western Pennsylvana, several near Chattanooga, Tenn., one in Alabama and others in diflerent portions of the United States, all of which give the most perfect satisfaetion. Companies wishing to erect machinery or to ascertain by practical test the coking and other qualities of their coal will receive prompt mation as to the working of his machinery and the benefits resulting therefrom will be furnished.

\section{THOS. WIGHTMAN \& CO.- Fruit Jars, Bottles \& Window Glass, 43 Wood St.}

The importanee of the glass trade to Pittsburgh and its great influence upon the prosperity of the community las been a very frequent subject of comment, but it is not till each separate venture in this nanufacture is examined that the true magnitude of the industry is understood or appreeiated. Among those houses juost largely engaged in nuaking Bottles, Drugyist's Glassware, Jars and Window Glass, that of Mr. Wightman and Co. may justly be accorderl the highest rank both with regard to the quality of the product and its value. Part of the plant of the firm, which is located on the South Side, 34th ward, is historically connected with the inception of the manufacture of glass in this city, having been established by Col. O'Hara in 1796, who prosecuted the business for some time, giving place to Frederick Iorenz, Sr, who immediately preceled Wm. M'Cully \& Co., of which firm Mr. Thomas Wightman was a nember. At. his date, about 1834 , the faeilities were limited to one factory, aud a product of $\$ 40,000$ yearly, against a group of four factories at the present time, in the 24th ward, while in the 36 th ward are located the Eclipse Glass Works, bought by $11 \mathrm{r}$. Wightman, of this firm, in 1871. 'These works were ereeted by Fahnestock, Alhree \& Co., but nol operated to any great extent, till they came in to his hands. They cover all area of over two acres, and in the jar season are also almost entirely devoted to the manufacture of the mason jar. The house is doing an annual husiness of $\$ 200,000$ at the unprecedentedly low prices that govern the market. The two plants now occupy about ten acres in area, and employ a force of 300 skilled workmen, requiring a weekly disbursement of from $\$ 2,500$ to $\$ 3,000$. The products in Window (ilass have not been surpassed in quality by any cotemporaneous concern in this country, and from continued improvenents in this braneh it is reasonably anticipated, that within a very lintited time the Plate and Window (ilass of this house will equal in every respect, luster, elearness, strength, ete., the product of Freneh factories. Adder to the immense products of the house, they also handle the celebrated De Puaw American Plate Glass, being the exelusive agents for this section of the country. Progressive, enterprising and liberal, it is too much to assert that no firm in Pittsburgh has done more to promote the welfare and industrial thrift of the community, than this well known house, offering in their products pronounced inducements in prices and quality.

\section{R. B. JEFFRIES, -Manuf'r, Wholesale \& Retail Dealer in Cigars, 4006 Butler St.}

The establishment of Mr. Jefries is loeated at 4006 Butler street, where he engaged in the husiness of manufacturing cigars in 1877. Mr. J. employs in his factory six hands, keeping them fully eniployed all the time, turning out over a half-million eigars annually. He enjoys a good trade and is now doing a large and prosperous business, both wholesale and retail. He was born in Virginia in 1837 , was left an orphan when quite young, laving his own way to make in life. He came to Pittsburgh in 1854 , and worked at lis trade here in different places, until by close economy and is now prospering.

\section{V. NASER,-Clothing, Merch't Tailoring, Gents' Furnishing Goods, 4004 Butler St.}

A mong the most attractive and best stocked stores on Butler street is that of M. V. Naser at No. 4004 Butler street. He occupies a large, beautiful room, with very handsome show windows that are always decorated with the most tempting display of the latest novelties and most attractive goods in his line. Mr. Naser opened his store in 1878 , and already he is doing a prosperous business. Fashionable young gents can always be fitted out at this popular place in the most complete and stylish manner. Mr. N. makes a specialty of Merchant Tailoring, employing the nust fashionablealld skilled cuiters and workmen, and warrants neat fits. Mr. N. was born fn. Pittslurgh in 1818 . He is a son of John Naser, one of the first settlers of Lawrenceville, who used to.keep the hotel near the car stables and was proprietor of the old bus line that ran between $\mathrm{L}$. and the city prior to the building of the Citizen's Pass. Ruilway. Fle was raised in this part of the eity and since childhood has witnessed its growth. He kept tavern opposite carstablestwclve years, previous to his present business, which he sold out. Mr. $\mathrm{N}$. is a young gentleman of energy and agreealle wanners, which, with his extensive aequaintance in the community, is rapidly increasing lijs business.

\section{VOELKER \& BRUGGEMAN,-Merchant Tailors. 4002 Butler St.}

The handsome establishment of this enterprising young firm is at No. 4002 Butler strect, where the business was started in 1868 by Wm. Sunderman, selling out to present firm in 1879. They oechny a large, handsome store room, $25 \times 60$ feet in size, in which they earry a complete and finely-assorted stock of all the latest and most fashionable patterns of eloths, vestings, etc., to the amount of $\$ 5000$ and are doing a fine husiness, having a very fashional,le trade. Mr. August Voelker was born in Germany in 1850; came to the United States in 1868 , having learned his trade in the old country. He engaged with Mr. Sunderman at this present location and worked for lim until succeeding to the business of his former emuloyer. Mr. Fred. Bruggeman was also born in Germany in 18.51; came to the United States in 1868; worked at Medendorf's Clothing IIouse on Fifth avenue; was afterwards with Messrs. Gircling \& Jones for a number of years, leaving there to embark in his present enterprise. 


\section{HIRSCH BROTHERS,-Wholesale Cigars and Tobacco, No. 42 Sixth St.}

Among those firms that are closely identified with the Tobacco trade in this city must be noted that of Messrs. Hirsch Brothers, wholesale dealers in fine Cigars and Tobacco. Established in 1874, by the same partners, Isaac and Henry Hirsch, the business at first was conducted with but a very linited capital. The house is now transacting a trade, ranging over Pennsylvania and Ohio, to the amount of from $\$ 40,000$ to $\$ 50,000$ annually. The premises now oceupied are $22 x 60$ feet in size, and located at No. 42 Sixth st., next to the corner of Penn av. and Sixth st., the most prominent thoroughfares in Pittshurgh. Numerous assistants are engaged to aid in the manufacturing department of the trade, and a large and very well selected stock kept constantly on hand. Both members of the firm are natives of

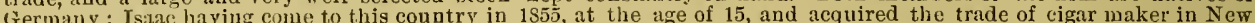
York, removing to Oil City ten years later, and in 1874 to this city. Henry, who accompanied his brother to the United States, was 6 years old. They are energetic, reliable and responsible self-made men.

GALE FRENCH,-Surgeon Dentist, No. 115 Penn Av.

As a practitioner in one of the industrial professions, Dr. Gale French is entitled to consideration in a volume devoted to a compilation of such interests in this cily. A native of Mraine, born in 1845 , Dr. Frencb studied under the most celebrated dentist in New York, and graduated at the Dental College of New York in 1870. Two ycars later lie removed to this city. Beginning as a complete stranger and without the aids to a practice that a long residence affords, Dr. French compelled recognition from the beauty of his work, the care manifested in all cases, and the confidence inspired by thoroughness in every department of his avocation. As a natural result, he soon acquired and still maintains in high degree of popularity. In the finer artistic and surgical branches of his profession, Dr. French is known not only in this eity and its environs, but with the profession throughout the West generally.

\section{AUGUST PIEPER,-Boots \& Shoes, 3704 Butler St.}

At No. 370.4 Butler street, in one of the largest, finest and best arranged rooms on the entire street, with the largest, most complete and varied stock of Boots \& Shoes in the East End, Mr. August Pieper will he found ever ready to greet with a pleasant reception any number of friends and patrons to his well-known establishment. The business was started at this point three year's ago, coming into the possession of $\mathrm{Mr}$. Pieper some time after; since then by his enterprise and business ability he has been doing a very large and steadily increasing business. No establishment in this purt of the city enjoys a higher degree of popularity or is doing a better or more prosperous business. The yopularity of the proprietor and high esteem in which the establishment is held is fully merited. Mr. P. was born in Germany, and came to the United States 11 year's ago. He learned the trade of shoemaking, at which he worked for some years, aecumulating by industry his own capitil, which has enabled him to embark in business in an extensive manner, affording him in broader field for his business qualifications.

OTTO KONSTANZER,-Bakery, Confectionery, Ice Cream Parlors,4014 Butler St.

Mr. Konstanzer's excellent establishment is large, handsomely arranged and elegantly stocked with confectionery, etc. The Ice Crtam Parlors are finely titted up-a Bread Baker is also carried on. He keeps one wagon engaged in delivering bread. Mr. K. started his business in 1873 with suall capital, increasing and enlarging as be became able. He was born in Germany in 1849; came to the United States in 1861, working at his trade as coniectioner for a time, afterwards was pastry cook at the Union Depot Hotel-hurned during the great riot-for five years, leaving there to embark in present business, accumulating by his industry his own capital.

\section{MANNING HOUSE,-Chas. Manning, Proprietor, Cor. Penn Av. \& 11th St.}

As one of the few and favorite Hotels in the eity, conducted jointly upon the European and American plan, the Manning House is deserving of special mention. More particularly on account of its establishment in 1846 and consequent identification with the solid and substantial iustitutions of the Iron City. In the early part of the present year Mir. Chas. Manning assumed control of the house and infused life into the business by his wide experience and attractive characteristics. New improvements were introduced, the hotel re-furnished, an excellent bar and restanrant attached and every modern convenience supplied for the comfort and enjoyment of the guests, who are at liberty to avail themselves of either the European or American plan. The building is spacious, $45 x 80$ feet, four stories high, containing ample and elegant accommodations, and is in every way a desirable place to stop or reside permanently. Mr. Manning, the enterprising host, is a native of this city, he has pursued his present vocation for 11 years, and has represented his section of the city in councils-alwalys being allied to the industrial prosperity of the community-fostering the same to the extent of his influence. As a lost Mr. Manning is unrivalled and is perfectly aware of how to keep a botel.

\section{J. A. MCKEE \& SONS, - Oil Refiners \& Coopers, Office 56 Fifth Av., Works 49 st.}

This firm was first established in 1858, under the title of McKee, Hocket \& Co., which continuing until 1867 was supplanted by the present firm, consisting of J. A., II. W. \& J. R. AIcKee, the senior member having resided in Pittsburgh since 1845, and his sons beng natives of this city. The "Liberty Oil Works," which is the name of their refinery, is ranked in capacity with and will compare favorably with any similar manufactory in Pittshurgh or along the Alleghen y Valley, and is capable of producing $600 \mathrm{bbls}$. of refined oil per day, at a fire test of $110^{\circ}$; the standard and exclusive quality manufactured by this firm. Frow 125 to 130 men are constantly employed in the various operations of retining, thd in the cooperage where all the barrels used in the business are made by the most perfert and ingenious appliances. The value of the entire plant is estimated at $\$ 175,000$, the products being exported entirely to European and other eountries. The increasing importance of the oil trade, and especially the continually growing foreign demand, has been promptly taken :tdvantage of by this house.

\section{FRED. SPREEN, -Merchant Tailor, 1318 Carson St., South Side.}

Mr. Spreen's handsome and popular Merchant Tailoring Establishment occupies a large three-story huilding, and is well known as an emporium of fashions for gentlemel. The store contains at least $\$ 1,000$ worth of goods ready to be made up into fine fitting garments, and is the outgrowth of a small beginning made a lew years ago. Mr. Spreen enploys three and four workmen at all times, but many more during the busy season. His specialty is custom work in which his reputation for litting is not surpassed in the city. Mr. Spreen was born in Germany, in 1835 , and came to A merica in 1859 ; as a man he is prompt, correct, reliable and agrceable. 


\section{ARCHIBALD WALLACE,-Wholesale Grocer, No. 295 Liberty St.}

Under various changes in style of firm, the grocery house of Archibuld Wallace has been in existence since 1843 , when it was founded by Mr. Henry Lambert. He conducted the business in his own nane until 1846, when Mr. John Shepton became a partier, and the firm name became Limbert \& Shepton. For a period of tilteen years the partnership continued, and the house obtained a wide-spread reputation throughout this section. In 1861 Mr. Archibald Wallace became apartner in the firm, and the style became Limbert, Shepton \& Co., and continued as such for five years. In $1866 \mathrm{Mr}$. Lambert retired, having disposed of his interest in the business to Mr. Wallace, and the title of the frm again changed, and it became Shepton and Wallace, remaining as such until 1876, Mr. Wallace became sole owner and proprietor. During the entire period of $i$ ts existence, under the various changes of administration, this house has always maintained a prominent position and a high reputation for business integrity and enterprise, and was largely instrumental in developing the grocery trade of Pittsburgh. Previous to the panic and the consequent depression in trade this bouse transacted an annual business of $\$ 1,000,000$, and that too withont the aid of traveling salcsinen, depending entirely on their merits, and the reputation they had acquired among dealers in Western and Middle Pennsylvania, Ohio and other States in which their trade was located. Latterly MIr. IVallace owing to the general depression in all branches of trade, has had no desire to push bis lusincss, and his average annual sales will now imount to about $\$ 100,000$. He occupies the entire four floors of the spacious ware-house, $20 \times 120$ feet, at No. 295 Liberty st., carrying a general stock of groceries and articles pertaining to that line, valued at about $\$ 20,000$, and employs thrce assistants. He has a large local trade, and supplies many of the leading grocers throughout western Peunsylvania and Eastern Ohio. Mr. Wallace also transacts a large and very considerable brokerage and commission business in the leading articles pertaining to bis line. Mr. A rchitiald Wallace is a native of Ireland, horn in 1830 He has resided in Pittsburgh since 1848, and has been actively engaged in the grocery business since boyhood, and prowinently identified with the wholesale trade of the city.

\section{JACOB IKELLER,-Wines and Liquors, No. 190 Smithfield St.}

Jacob Keller is perhaps as well and favorahly known as a direct importer of and dealer in pure Wines and Lifuors as on $y$ one in Pittshurgh engaged in like pursuits. The.house was established, under the firm name of Kcller \& Paulin, in 1853 , becoming as at present two years later. Mr. Feller is a native of the French province of Alsace, was born in 1825 , accompanying his parents to this country when but 12 years of age. For 41 years he has becn a resident of this city. Importing direct German, Spanish, Italian and French Wines, which are his specialties, it is safe to assert that none of these choice products leave the establishment of Mr. Keller other than in their pure condition, free from blemish as nature will permit. The premises Bccupied and owned hy Mr. Keller consist of one large and handsome brick edifice, located as above, $20 \times 110$, four stories high, and a cellerage adapted purposely for the business, which is carried on in a wholesale and retail way, stock ranging from $\$ 6,000$ to $\$ 10,000$, and an annual trade of from $\$ 10,000$ to $\$ 12,000$. Orders for goods from a distance should be accompanied by check or $P$. $O$. Order, and in every case satisfaction will result.

\section{WM. MILLER,-Duquesne Forge, Cor. 1st and Duquesne Way.}

The establishment of $\mathrm{Mr}$. Wm. Miller is entitled to a prominent place in the recorded annals of this city, 80 intimately allied as it is, to those enterprises which conduce so much to the general welfare. A native of Scotland, where, upon the banks of the Clyde, he acquired a practical and operative knowledge of iron forging in all its departments, he removed to this country while a young man, and continued his career in the same suvocation at West Point, on the Hudson. Being induced subsequently to visit this city, his thorough knowledge of the husiness, and keen discernment attracted the attention of our large manufacturers, among whom was Henry Llovd, Esq. (now dcceased) induced him to settle here permanently. With the co-operation of the gentIeman just named, Mr. Miller estullished the Duquesne Forge in 1862, which at once became noted for the size of its forgings, and the solid verfection of its work. With such a reputation the business of the concern rapidly increased, the trade extending to all parts of the country, and its resources and facilities constantly augmenting. The forge now possesses some of the finest and heariest machinery in the State, consisting in part of one five-ton hammer with 6 font stroke, one two-ton hammer with $31 / 4$ foot stroke, one storm tilt hammer of $1500 \mathrm{lhs}$., together with shears, sloter boring niachine, lathes, planes. \&c., \&c., with four large furnaces and four forging fires. Forty hands, all skilled mechanics, are employed in these works, requiring an annual disbursement of nearly $\$ 40,000$. The building occupied by the establishment is nne of the best in the country, admirably located, with a view to convenience in shipping, both by river and railroad. Heavy forging for stcamboat and locomotive machinery, bridges, and large pieces of mechanism are made a specialty, and in the excention of such work this bouse has few rivals and no superiors. In the iron trade this Duquesne Forge has a cclebrity that is not only creditable to itself, but inures greatly to the advantage and prosperity of this, the well named "Iron City" of America.

\section{KANE,-Scrap Iron, Steel and Metal, Duquesne Way, below 6th St.}

Pursuing an industry contingent upon the vast manufacturing and producing intcrests of the Iron Citv, Mr. Kane is entitled to a record among those who are identified with the progress and development of Pittsburgh. Born in 1816, and a native of Ircland, Mr. Kane immigrated to this city iu 1863, and, after a thorougl acruisition of the business, established hinself in 1871, as an iron and metal dealer. Frcm that time to the present he has met with no small share of success. His relations have been with the largest and best houses in the country, who, appreciating the manner in which he conducts his business, and the ahsolute reliance insnired by his strairht forward course, have not forgotten to demonstrate that confidence. In all departments of the Scrap Iron, Steel ind Mctal busincss, Mr. Kane: is perfectly conversant. He liandles but the best grades of stock, and makes OId R:ils, Whenls, Axles, Car Springs, and No. 1 Scrap a specialty; also in connection with the above sells Pig Iron, Blooms and Bar Iron ou commission. Commencing husiness with a limited capital, Mr. Kane has augmented his yearly business to from $\$ 50,000$ to $\$ \pi, 1,000$, and is an active co-operator in the general industrial welfare of the community.

\section{A. H. LESLIE,--Insurance \& Real Estate Agent, 4120 Butler St.}

The enterprising Real Estate and Insurance Agent, Mr. A. H. Leslie, has his office at 4120 Butler street, where he established himself in 1874, revaining at the same place ever since. During the five years elapsed he has succecded to a large and prosperous husiness in insuring, renting and selling property, collecting rents, cte. ; he now has entire charge of upwards of $\$ 400,000$ worth of property which he manages with ahility and to the satisf:ction of those interested. He is a voung man of high cliaracter and great enterprise, and since starting in the business has established a reputation for integrity and busines ability. He was born in Westmoreland county, Pa., in 1853, came to Pittsburgh in 1870 and learned the carpenter business, at which he worked but a short time; he then with soine misgivings opened his real estate office at his present location, heing an entire stranger without means or friends, but by close attention to his business, upright and honorable dealing, he soon established bis business on a soli.l basis. 


\section{W. H. MAXW ELL, -Glass Labels, Glassware, \&c., $83 \& 85$ 27th St., S. S.}

The mannfaeture of Glass Labels for druggists jars and bar bottles, glass tubing for underground telegraph lines and paper weights, ete., is a branch of industry comparatively new to this seetion, but one that is assuming consiclerable importance; the only establisliment engaged in this branch of business in Pittsburgh is that of W. H. Maxwell, at Nos. 83 and 5527 th slreet, Suth Side, which was started by Messrs. Maxwell \& McA fee, in 1875 with moderate capital. In $1876 \mathrm{Mr}$. McAfee retired and Mr. Maxwell became sole proprietor. In order to meet the demands of a rapidly growing trade lis capital was increased and the works enlarged. He finds a ready sale for all the goods he can turn out and as a eonsequence is required to carry a very heavy stoek, his principal investment being in the raw waterlal. He oceupies a building $50 \times 100$ feet in size and employs 15 hands, using a two-horse power engiue and boiler. The works are kept runniug constantly to supply the trade, which extends all over the country both east and west. Mrr. Mraxwell is the inrentor of a paper weight which he is now mauufacturiug and for which there is a large demand. They are of solid glass and can be maie with any name or advertisement desired and placed in the centre so that it will remain as bright as when new, as long as the weight endures, whicli, with ordinary usage, will be to the end of time. The weight makes a handsome piece of offiee or desk furniture. By the same process handsome door knobs and various other useful and oruamental articles are made. Other articles of which this establishment makes a specialty are the manufacture of convex photograph glass and cylinder oil cups. All of these goods he is prepared to furnish in any quantities desired at rery low rates. Mr. Maxwell was born in Wellsburg, West Va., in 1834, and came to this city in 1867 , where he has remained ever since. He first embarked in business at his present loeation, and by sheer industry, untiring energy and honesty, he has established a trade which will in time plaee him in the front rank of business men.

\section{DR. J. O. FLOW ER,-Dentist, 140 Penn Av.}

The dental parlors now oceupied by Dr. J. O. Flower, were opened in the year 1839 by Dr. Robert Vanderrort, who was one of the first three dentists who came to this eity to enter into the practice of dentistry. By strict at tention to business, and by doing first-class work, Dr. Vandervort succeeded in working himself to the head of the dental profession in this State. In the year 1859 the present proprietor commenced the study of his profession with Dr. Vantdervort. By the merest accident was Dr. Flower thrown into the positon which has since made his name honored among those of his profession. He had only the advantages of a eommon school edueation, and it was while he was attending a commereial college in this city that he became acquainted with Dr. Vandervort, who offered him a position in lis office, whieh was gladly accented. Here he remained until the year 1861 , when he entered the army. After his time of enlistment had expired and he was honorably discharged, he again returned to this city. Immediately upon his arrival here, he was tendered the position of assistant to Dr. Vandervort, which ultimately terminated in his beeoming a partner. In 1873 Dr. Vandervort retired from the practice, and Dr. Flower has since practiced his profession with marked suceess, forming an extensive and highls eultivated acquaintanee. His office is located on one of the principal streets in the city, and is known throughout the limits of both the cities of Allegheny and Pittsburgh, and the surrounding country. Upon entering his operating room, one is interested in the many articles of usefulness that are of his own design and mechanieal skill, indicating the natural inelinations whieh bave led to his sueeess in the profession.

\section{JARVIS \& ADAMS, -M'frs. Domestic Hardware, Head of Diamond St.}

This firm are large manufacturers of all kinds of domestic hard ware and light iron castings in the most artistie manner and after the best patterns. Founded in 1570 br S. Jarvis \& Adams, it assmmed its present name in 1S72. They now occupy a main building of three floors each 50x114 feet, also an L in the rear nearly half as large again besides the hasement floor which is used as an engine and eleaning room. From 50 to 60 hands are constantly employed with a pay roll running frous $\$ 400$ to $\$ 500$ per week. The principal specialties of manufacture are axel boxes of all sizes aad descriptions, embraeing between three and four thousand different patterns; patent moulded seamless thimble skeins, the only skein that can be made perfectly accurate and interehangeable. A large variety of patent punp trimuings for wood pumps of all sizes aud descriptions, and plugs or balls for welding gas pipes. They also have a large number of very valuable patents, among which may be mentioned their great labor-saving machine for moulding, which requires no experienced workman, any common workman being able with this machine to accomplish twice as much aud do better work than the most experieneed workman by the ordinary method. It is the invention of $\lambda 1 \mathrm{r}$. S. Jarvis Adaus, one of the firm, and enables them to monld castings to the hundredth part of an ineh, which is of great value in that line of work where nniformity and great accuracy are required, sueh as plugs or balls for welding gas pipe on, requiring no grinding or finishing whaterer. They are at present melting between five and six tons of metal per day. Steplen Jarris was born in AJbany, N. Y.. in 1807 , coming to Pittsburgh in 1844 , where he has since lived. S. Jarvis Adaus was also born in Albany Co., in 1837, and has lired here since early ehildhood. Both were formerly eonneeted with the old Pittsburgh Norelty Works. The firn is ove of the most prosperous in our eity, their past yearly sales being from $\$ 50,000$ to $\$ 75,000$ and rapidly increasing.

\section{EXCELSIOR PLANING MIIIS, -W. F. Richardson, Steamboat Joiner,}

For twenty-one years engaged in the above occupation, Mr. W. F. Richardson has identified himself pretty thoroughil with the productive classes of the community, and has acquired a hirl position to wlich be is fully entitled. In iddition to his special work which is that of a cabin builder and ship builder. Mr. Richardson carries on an extensive Planing Mill known as the "Excelsior," and mumufactures anl deals largely in flooring, weather-boarding, sash and door mouldings, ke. The premises oceupied consist of one ample huilding $45 \times 160$ feet, containing a full equipment of the best machinery which is operated by a powerful double piston steam engine, the in vention of the proprietor and known as Richurdson's patent Here are employed from 25 tu 30 hands, necessitating an average outlay during the year of from $\$ 150$ to \$225 per week. Mr. Richardson is a native of Allegbeny county, hut was reared in Washington county, returning ayain to this county and settline in Pittshurgh in 1845. He has by the model excellence of his work attained a reputation that has extended his trade along the Olnio Mississippi and Vissouri risers and their tributaries, and placed him at the head of his a vocation, where he enjoys the confidence of the community and ihe esteem of tue general public with which he has been idtentitied for more than a quarter of a century.

\section{E. P. THOMAS,-Groceries \& Provisions, Etna, Pa.}

For Groceries and Prorisions in Etua, call on El. P. Thomas, Esq, who started husiness sereral years since and is now tloing at yearly business of about $\$ 4,000$, carrying a stock of $\$ 500$. He oceupies a two-story frame building $32 x 35$ fect, with a general stoek of sroceries and provisions, foreign and domestic fruits, cauned goods, wooden and willow ware, queensware, limps, glasswire, ete. Mr. Thomas was born in Wales in 1827, and came to Pittshurgh in 1848 , he subsequently located in Etna, where lae was elected Justice of the Peace in 1868, for a term of five years, and in 1877 wis re-elected to the simue othce for a like term, which will expire in 1882 . 


\section{FORT PITT COAI CO.-Miners and Shippers of Gas Coal, 337 Liberty St.}

The amount of capital invested in the coal business in and around the Smoky City is not less than fifty million dollars, and the number of miner's employed in 158 collieries represented in this immediate vicinity reaches nearly 17,000. Prominent among the many firms and corporations engaged in this important branch of industry is the Fort Pitt Coal Company, incorporated under the mining and manufacturing laws of the State of Pennsylvania, with a capital of $\$ 300,000$. This Company was chartered February 14th, 1865 , and the present officers and directors are as follows: President, S. McCrickart, Esq.; Treasurer, S. Beymer; Clerk, W. M. Heyl; Manager, J. E. McCrickart. Directors-S. If. MeCrickart, Geo. S. Head, John Hays, Lucius Osgood, Wm. Rinehart, R. F. Bauman, B. L. Fahnestock James Montgomery and Martin Heyl. This list of names comprises many of Pittsburgh's most honored and successful merchants and business men, and shows that the affairs and in terests of the Company are entrusted to thoroughly competent and reliable wanagers. The mines of the Fort Pitt Coal Company are located on the main line of the Pitslurgh, Cincinnati \& St. Louis (Pan Handle) Railroad at Fort Pitt Station, ten miles west of Pittsburgh. This road and its various connections, both east and west, furnishes facilities and advantages for shipping coal to all parts of the country with promptness and despatch. In fact, by no other means could be reaehed with equal celerity and economy the great coal-consuming districts of Pennsylvania, New York, Ohio, Indiana, Illinois, Iowa, Missouri, Minnesota, Wisconsin and Michigan, and, via the great lakes, Canada. To the trade in Pittsburgh their coal is deliver ed on their own ears direct to the various works and retail merchants which they supply, thus effecting a great saving in transprortation. The prominent feature ol the business of the company (next to the superior quality of coal furnished) is "promptness" in filling all orders, however extensive, at the shortest possible notice. It is now generally conceded that the bituminous coal procured from the great Pittsburgh vein is the most satisfactory for manufacturing illuminating gas and it not unfrequently occurs that au inferior and worthless article is shipped abroad under the name of "Youghiogheny" coal by unprincipled dealers. The Fort Pitt Coal has never been sold under any other name, and in their dealings with their numerous customers, the Company has always furnished a tirst-class and reliable article of Gas Coal without any fictitious name attached. The coal mined by this Company has been thoroughly tested by some of the most competent gas managers and analytical chemists of the country, and has always been pronounced of the very hest quality. It has been extensively used in Pittsburgh and throughout the West by gas companies, rolling mills, foundries, and, in fact, by an unlimited class of consumers, fully demonstrating that it has been appreciated. With an experience of over fifteen years in the coal business and with their unrivaled facilities, the officers and directors feel confident that they can furnish the various grades and best qualities of coal, such as cannot fail to give entire sattisfaction. Their prices, which of course are always subject to variations in accordance with the advance or decline of the cost of mining, are always as low as will be consistent with a safe and legitimate business. The office of this Company is located at No. 337 Liberty street and their post office address is lock-box 314, Pittsburgh.

\section{LEE S. SMITH, -Dental Depot, No. 52 Sixth St.}

There are other enterprises, apart from iron and glass, that may not be overlooked, though perhaps not so conspicuous, which add no little in the aggregate to the general sum of Pittsburgh's prosperity. Of these an important feature is the department of Dental Goods, prominent anong which is the establishnent of Mr. Lee S. Smith, of whom a few words may not be inappropriate in a publication designed to reflect the condition of Pittshurgh and it resources. Mr. Swith was born at Cadiz, Ohio, in 1844. He came with his family to Pennsylvania at an early age and in his eighteenth year joined the army in the 101st Reg't Pa. Vol's. At the close of the war he selected the profession of surgeon-dentist, and after two years' study graduated as such; but abandoning active practice, he founded lis present business in 1866, continuing in it ever since with marked success and increasing resourees. Mrr. Smith is not only widely known in connection with his immediate vocation as a dealer in every conceivable article and appliance or piece of mechanism known to modern dentistry, but is perhaps still better recognized as one who has ever taken a prominent position in public movements tending to the good of the community at large, or the greater harmony of social relations. As a a soldier or civilian, in personal or public capacity, Mr. Smith has exhibited certain traits of character that have endeared him to his friends and secured him the high consideration of the community. With no pretence, and an undeviating adherance to fixed principles, Mr. Smith has, by little effort other than the natural force of mind, acquired a business and social standing that augurs much for his future career.

\section{KEYSTONE BOILER FORGE \& ANVIL WORIS,}

This enterprising and successful firm commenced the manufacture of Boilers in 1871, and some time afterwards added the Forge and Anvil branches to their business. Wm. Manchester was born in England in 1819 and learned the trade of a boiler-maker before coining to America. In 1840 he emigrated to the United States and secured work at whatever he could find to do. His skill as a boiler-maker, however, was soon discovered and he had all the work he could do. It may be interesting to note that Mir. Manchester did the first boiler repairing for the Pennsvivania Railmoad Company. He has been connected with various boiler manufacturing establishments in Pittsburgh, but having by his industry and economy amassed sufficient capital to commence business for himself, he did so, and his suc'ess has verified the wisdom of his course. Manchester \& Son's works occupy a building 45x120 feet. Their tracte is large and distributed over the whole country and their work bears the highest reputation, both for the excellenee of materials employed and the soundness of the workmanship. In the special branch of work to which this reliable firm give their attention, there is to be found no similar establishment enjoying a higher reputation for superior work. The Anvils and Tools made by these gentlemen are equal if not superior to any other make of this or any other country.

\section{STEEL, LANE \& CO.-Produce Commission, No. 202 Liberty St.}

Pittshurgh being one of the best markets in the country has given great prominence to the General Produce Commission business. A mong those firms that are considered as most prominent and inffnential in the bnsiness are Messrs. Steel, Lane \& Co., the individual members of the firm heing E. T. Steel, J. D. Lane and John A. Jordun, and though associated under the present style and relations for ahout two years only, they severally had a prior experience in the business. All natives of Ireland, they came to this city many years since and have taken an active part in promoting the industrial prosperity of the city. As a purely Cominission House, they are in daily receipt of consignments from Pennsylvania and contiguous States and are noted for the promptness of their operations and the stuccess of thei transactions. As a firm through which to reach a speed $y$ market, Steel, Lane \& Co. are highly esteened as responsil,le and energetic men, receiving consignments for everything in the commission trade.

M. BREITW EISER,-Choice Groceries, Flour, Spices, \&c., 131 Taggart St., Alle.

Situated on Taggart street, near the junction of Charles and Sarah streets and at the western terminus of the Pleasant Valley Passenger Railway, is the establishment of M. Breitweiser, who kceps constantly on hand a complet assortment of Groceries, Teas, Spices, Flour, Syrups, also Fine Bread, Cakes, Pies, etc. Mr. Breitweiser was horn in Germany in 1849; came to this country and setted in Pittsburgh in 1861; was engaged in business there some time and removed from there to Birmingham in 1871. Removed from there to his present place in 1877. He is at present doing a business of $\$ 12,000$ per annum, with a stock on hand of $\$ 2,500$, 


\section{CHARLES S. SCOTT,-Surgeon Dentist, 94 Wylie Av.}

This gentleman is the Son and former pupil of the celebrated surgeon dentist, Dr. Jno. Scott, who lut recently retired from the practice of his profession in this city. Dr. Chas. S. Scot is entit]ed to a lenghty notice in this report, both from the position he loolds as a scientific and skillful operator in his profession, and the nany notable improvements he has introduced in the science of applied dentistry. He was born in Pitshurgh in 1843 . Previous to attaining his majority he entered upon the study of his profession, under his father's direction, remaining under the tuition of this celebrated practitioner for 7 years; he then commenced the practice of Surgical Dentistry on his own account, spending many years in the various cities of the country, adding largely to his stock of scientific information by study and observation, and to bis skill as an operator by constant practice. He returned to his native city in 1877, and established his present husiness. Dr. Scott is located at No. 94 W ylie ave. On entering the house the visitor is shown into an elegantly furnished reception room, where everything bespeaks taste and refinement. On the second floor are two operating. rooms, while in the rear may be found the lahoratory and manufactory, where six skillful worknlell are engaged in turning out the specialties for which this establishment is celebrated. The operating departn:ent, 28 before mentioned, consists of two rooms; first, the extracting rontu, where all of the most approved appliances for extracting teeth may be found. The "anæsthetic" which is used here deserves special notice. The prefaration, the doctor's own, supersedes laughing gas or anything of the kind in common use, and is perfectly caf's, yo case being on record where the slightest injury has resulted to the patient from its use. This is one of tity rotable improvements introduced by $\mathrm{Dr}$. Scott in his practice. The second work-room, where the fine and delirate operations are performed, such as filling teeth, \&c., is light and cheerful. Two model operating chairs are in see bare, and are seldom empty. This sketch would be incomplete without a description of the two great specialties of this establishment, viz., capping natural teeth with Scott's patent porcelain and gold cap, and artificial teeth grouluced in exact imitation of the natural. 'The first is the doctor's own invention, and nsed only by him. By this, liscess teeth too far decayed to admit of flling are covered with a cap, made to fit the teeth so nicely that they are $\nabla r, 1$ with the greatest ease and comfort, while the process of decay is entirely arrested. The carving of artificial teetl; in exact imitation of watural is prolrably the finest piece of work ever turned out by the profession. The manufactsie of these teeth differs from the usual node in that etch tooth is made and set up separately when they are passed irito the hands of the engraver, who carves the surface in exact imitation of the natural tooth, so that the upper and lower jaw fit into each other perfectly. The result is that the food is masticated in place of being crushed, as with the old style, and indigestion thereby prevented. Dr. Scott is the great specialist West of the Alleghen y Mountains in the branch of applied dentistry. The doctor has a practice of $\$ 20,000$ per annum. The fitting up of his offices, laboratory, \&c., the many tine only two years at his present stand, Dr. Scott enjoys the patronage of the best class of citizens, besides hundreds who cone from various parts of the country. While there are few equally skilled there are none who occupy a higher professional, scientific or social position.

GARDNER RROS.-Fire Brick, Tile and Furnace Blocks, and Clay Gas Retorts,

No. 116 Smithfield St. Works-Lockport, Pa., and Mit. Anregr, Jumtıon, Mn.

In the manufacture of Clay Gas Retorts and Settings, Fire Brick, Tile and Furnace Bricks, etc., the firm of Gardner Brothers occupy so prominent a position as to demand nore than brief notice in this work. The business was established in 1864 by Wilson \& Gurdner, assuming the present status at the retirement of the former senior partner, the individual members of the firm now beiug James and William Gardner. The works of the concern are at Lockport, Westmoreland Co., Pa., and at Mt. Savage Junetion, Md., as bcing immediately contiguous to the most copions clay supply known within conrenient range, this material being particnlarly adapted to the purposes for which it is used, having at very high percentage of silica and allumina naturally combined in just the proper proportion to have an exceedingly high refractory nature, even when subjected to the most intense heat, and therefore particularly useful in the inanufacture of Gas Clay Retorts and Settings, Furnace Blocks and Fire Bricks. This fact having been amply demonstrated by long experience and severe tests, has given the retorts of Gardner Brothers a celetrity that extends over the entire United States and Canada, and results in a very large trade. The Gas Companies of Pittsburgh and Allegheny are supplied with these products, and the demand is so great at times as to tax the resources of the firm to the utmost, notwithstanding the large capacity of the works, which are extensive. It should be specially noticed that these Retorts are made by hand, and derive from the process of manual maninulation, valuable qualities not ot lerwise developed or obtained. The Messrs. Gardner, in pursuing this enterprise with skill and determination, have done much to advance the industrial thrift of the community, and are accorded the general esteem of the public and the commendation so well deserved.

\section{H. SMITH \& SONS,-Merchant Tailors, No. 98 Wylie Av.}

This concern was establishcd by Fenry Smith, the senior member of the firm in 184S, and is one of the oldest and best know $u$ merchant taitoring establishments in the city. Mr. Smith started with a nominal capital, and is among the number of self-made business men who owe the position they have attained to native energy, perseverance and sterling business qualities. The business of the house gradually grew in importance until 1874, when the junior members, sons of the proprietor, were admitted, forming the firm of Henry Smith \& Sons, which now ranks among the leading merchant tailoring houses, in this line, in the city, if, indeed, it can be equaled in popularity. The business transacted is strictly Merchant. Tailoring, a small but select line of Furnishing (ioods being carried to accommodate customers of the house. The building occupied, No. $98 \mathrm{~W}$ ylie avenue, cor. Federal st., is a handsome brick structure, having a frontage of 25 feet on the avenue, and extending hack 80 feet. Tlie salesroom, which occupies the entire first Hoor, and is lighted from both streets, is one of the inost handsome and commodius rooms occupied by any firm, in this line, in the city. Here are displayed a large and elegant line of piece goods, embracing the finest foreign and domestic manufactured fabries for gentlemen's suitage or separate garments, at bottom figures, and the workmanship has no superior in tits, style, or excellence. To those desiring these qualities no further comment is necessary. This concern is one of the oldest establishments of the kind in the city, and has long enjoved the patronage of the most fashionable and best class of citizens. Twenty hands are employed, requiring a disbursement of $\$ 200$ per week. The trade of the house is principally confined to the city. Henry Smith, Sr., is a native of England, but lias theen many years a resident of the Iron City, and intimately jdentified with its business interests. Messis. Jos. F. and Henry N. Smith are both natives of Pittsburgh. These gentlemen enjoy the same high social standing in the community at large that their house has always had in the business community.

THOMAS WIISON,-Manufacturer of Taffy \& Candies, 17 Federal St., Allegheny.

The establishment of Mr. Wilson is located on the west side of Federal street near the Suspension bridge, and immediately adjoining the Coliseum. The luilding is a four-story brick and stands upon the ground where once was the old homestead and mansion of Col. Robinson, one of the pioneers of Allegbeny. Mr. Wilson was born in Canada in 1842 , and comiog to this country in 1863 , settled in New York. Becoming dissatisfied there he came to Pittsbnrgh and engaged in business on W ylie avenue, removed from there to 35 Lacock street and in 1878 removed to his present location. His stock of candies and taffy are of the very best make, and command a large and ready sale. N $\mathrm{r}$. Wilson attends particularly to the manufacture of all his goods and they are excelled by none in the city. You witl find here pure articles and prices as low as any house in the city. All orders by mail promptly at tended to. 


\section{JOFN PEEPLES, -Wholesale and Retail Tobacco and Cigars, 3519 Butler St.}

This extensive establishment, known as the "Lawrence Tobacco House" was originally founded by a son of the present proprietor with a wagon, and subsequently Mr. Peeples opened his present commodious quarters as a branch of the well known city house of R. and W. Jenkinson, one of the largest cigar and tobacco houses in Western Penusylvania. After conducting the business in this manner for a while with marked success, Mr. Peeples relinquislied his connections with the old house, and assumed the entire ownership and management of the establishment as an independent house, and has built up an immense and lucrative trade. He carries an average stock of $\$ 10,000$ or orer, and keeps two wagons constantly on the road throughout Western Pennsylrania, selling and deliveriug goods. His annual sales from store and wagon will exceed $\$ 100,000$, and his business will compare favorably with that of any similar establishment in the West.

The life and services of Mr. Peeples, previous to engaging in his present line of business, are entitled to special recognition in a work devoted to the history of the industries of Pittshurgh. We append a brief sketch of some of the more important events. Mr. Peeples was born at Greensburg, in this State, in 1827 . When he was but two ycars of age his parents removed to Pittsburgh, where he has since made his home. At an early age Mr. Peeples learned the trade of blacksmith with Mr. Foal in a little old log smithy on the corner of 1 st and Liber'ty streets. For twentr year: he worked industriously and continuously in the old Sligo Iron Mills of Lyon, Shab \& Co., accumulating by economy and industry considerable money, which he subsequently invested in the oil regions, and, like many others, was successful only in losing the hard earnings of many years of toil in the slippery business. Pieturning to Pittsburgh he secured the position of superintendent of the old Crclops Iron Works, afterwards consolidated with the Iron City Forge, and now known as the Union Iron Mills, which were directly connected with the Keystone Bridge Co. While yet enguged in the old cyclops mill he commenced the manufacture of " $I$ " beams, Clannel and " $T$ " hars, and the various shapes required in the construction of Iron Bridges, Roofs and Fire Proof Bui]dings. The successful manufacture of this class of goods in this city is largely due to the energy, ability and enrnest endeavors of Ar. Peeples in
this direction. In 1872 he resigned his position of superintendent of the Union MInlls, and taking a portion of the old Coleman, Rahm \& Co.'s mill to Erie, Pa., and adding to it he erected the Erie Rolling Mill, which he conducted successfully until 1875, when, owing to the general depression in the iron trade, he resigned, and came to Pittsburgh, embarking in his present business. To Mr. Peeples belongs the honor of having produced the first merchant luar iron ever made within one hundred miles of Erie. In the manufacture of Iron for bridges, at the early period of its production here, great difficulty was experienced in cutting the various pieces to an exact length, owing to the uneren shrinkage caused by the impossibility of beating each piece to the same temperature. To overcome successfully this required the finest calculations and closest attention. In one contract of over 400 tons for the Rock Island Arsenal, MIr. Peeples was successful in filing the entire order in such a careful manner that not a single pioce was rejected and not an eighth of an inch variation. Mr. Peeples and Mr. A. Kloman, general superintendent and business manager, were induced to commence a series of experiments in order to solve the problem of cutting the iron cold, so as to secure the desired accuracy, and the result was the discovery of the "Cold Saw, "now unirersally used for cutting beam and bars of iron of any thickness to any desired length without heating. To these gentlemen the world is indebted for this great and important improvement, which was afterwards applied by them to cutting stone, and was the immediate precursor of the in vention of the Diamond Stone Saw. Mr. Peeples is entitled to most creditalle mention for ingenuity and enterprise, his intelligence and public spirit. $\mathrm{He}$ is a prominent member of the Baptist Church, and universally respected and esteemed by all who know bim.

\section{MARSHAIL, IRINEDYS \& CO.-Pittsburgh City Flour Mills and Elevator,}

One of the oldest and most widely kuown firms in the milling business in this eity, the house of Marshall, Kennedys \& Co., is en-
titled to special mention in this work, as conducing largely to the general industrial thrift. The house was originally founded by Messrs. Preyam, Kennedys \& Co., who established in 1852 , and successfully conducted for many years the celebrated Pearl Mills, formerly situated in Allegheny, on the Pennsylvania Canal, and at the time of its erection considered the largest plant of its kind in this section of the State. This mill being destroyed by fire, in 1870 , the business was removed to its present location, the firm changing to its present style, composed of A. M. Marshall and W. M. Kennedys, the former originally from Ireland, but a resident of Pittsburgh for 47

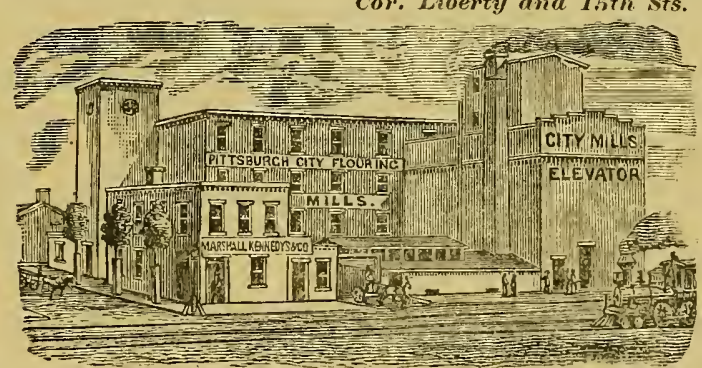

years, and the latier having been born in Allegheny City in 1844. The existing plant of the firm is regarded as one of the best and most thoroughly appointed flour mills in the country, having a capacity for producing 400 barrels of choice flour per diem, and large quantities of corn meal, chop, \&c., \&c. The buildiugs are 100x167 feet, 5 stories high with an extensive elevator adjoining, for the storage of grain and flour. 25 employees are constantly engaged in the mill, and 3 engines and a battery of 3 boilers, aggregating 350-horse power, supply the requisite force for driving the machinery. The brands of flour manufactured by the Pittsburgh City Mills, are prime farorites in this market, widely recognized for their fineness and absolute freedom from all foreign substances or adulteration. The firm have made it an inflexible rule to buy nothing but No. 1 wheat, which they are ready to purchase for cash, at highest market price, and at all times. Samples may be sent them by mail or otherwise, bags and hauling being supplied the seller free of charge, this policy also including oats and shelled corn. The bulk of the product is absorbed by the cities and in this immediate locality, the business averaging about $\$ 300,000$ per annum and steadily increasing. Enterprise and probity are characteristics for which this house is noted, and under all circumstances it is recognized that they may be implicitly relied upon. Adding to the material resources of the community and intimately connected with its development and prosperity for over a quarter of a century, the house of Marshall, Keunedys \& Co. have achieved a position as richly deserved as it is gladly accorded.

\section{ALHAMBRA HOUSE,-Robert Woods, Prop'r., 233 Federal St., Allegheny.}

The above well-known house is situated on the west side of Federal street, a short distance above the parks, and is ow ned and mauaged by Robert Woods, Esq., who was formerly engaged in business at 116 Penn street, Pittsburgh, but removed to his present location in 1866. Mr. Woods was born in Ireland, in 18:3, and came to Pittsourgh when quite young, but becoming dissatistied with the pTace removed to Allegheny, where he has since remaned. His business is carried on in a neat and substantial two-story brick building with a lot $20 x 100$ teet and is a favorite place of re-
sort for the natives of the Emerald Isle and all classes of people who are always made welcome by the obliging proprietor. His home is fitted up in a neat and tasty manner, and the best of wines and liquors are kept constantly on hand. Commencing in a small way he has built up a good trade and is doing a nice business of $\$ 2,000$ per year. Parties desiring a quiet comfortable stopping place will find at the "Alhambra" pleasant and agreeable quarters. 


\section{H. LLOYD, SON \& CO.-Kensington Iron Works, Second Av.}

It is but just, as well as proper, to assert that no house identified with the great staple trade of Pittshurgh, has done more to alvance the gencral interests of the community, as well as develop latent resources in the manufacture of iron than the widely known firm of H. Lloyd, Son \& Co. It is now more than half a century since the business was established by John 0 . McNickle in 1828 , who continued his operations till $18+5$, when the plant was destroyed hy the " rreat fire." One veur subsequently, however, it was reconstructed by various parties, who were eventually surceeded, in 1855, by the tirm of Miller, Lloyd \& Black, then Lloyd \& Black, which lecame one of the most celebrated and successful iron working concerns in America. In 1872 the demise of Mr. Black changed the style of the house to that which at present olitains, and during the current year the death of Mr. Henry Lloyd, Sr., left the business in the hands of the present proprietors. The decease of the senior partner and head of this house created a marked sensation throughout the entire iron confraternity, as well as the community at large. For a long time after this unfortunate erent the daily press teemed with items in reference to his history, and resolutions of resiect and condolence from the various eommercial and benevolent organizations with which he was connected, and to whose prosperity his influence had conduced to so great a degree. Henry Lloyd, Sr., was a colossus both in heart and intellect, and the reader will parlon this deviation from the direct objects of this work, in consideration of the vast interests which seemed to center in the talent and activity of Mr. Lloyd. The plant of the Kensington Iron Works is situated on Second ave., and is compuct, thoroughly equipped with the best machinery and appliances, and is considered one of the old and standarl mills of this great. Iron City. Numerous structures are requisite for the proper division of the various departments, and consist in part of warehouses, roll house, ore building, clay house, the mill proper, offices, de., enverjug in all an aren of about 5 acres, and engaging the labor of 150 operatives, running single turn, to whom are paid not less than from $\$ 1800$ to $\$ 2000$ week]y. The machinery and apparatus consist mainly of six teen puddling furnaces, six heating furnaces and four trains of rolls, the total capacity being ahout 11,090 tons annually, and their proclucts are Light T Rails, Flat Rails, Special Irons for Agricultural Implements, Merchant Bar, Sheet. aud Boiler Plate of the hest Common Refiued Charcoal, and Juniata Bloom Iron, for the perfection of which this house has achieved an unrivaled reputation. The remaining partners of the firm at present are Henry Lloyd, Jr., and Henry Balken. The former was born in Hollidaysburg, Pa., 18.35, and accompanied his father to this city as a child, having resided here since that time. The latter is a native of Norway, where he was born in 1841 , removing with his parents to this eountry in 1848 , and for twenty-seven years has made Pittsburgh his home. These gentlemen, who may he said to have heer brought up to the business, now conduct the same with no lack of ability, the annual transictions under ordinary circumstances renching about $\$ 400,000$, and extending to every section of the Union, especiall to the West, $N$ orth and Snuthwest. With facilities of the highest order, ample capital, and a splendid and untarnished career the linase of Henry Lloyd, Son \& Co. has acquired a place in the consideration of this community that few firms ever attain to and perbajs fewer still deserve. In the advantages offered to the trade, both in price and quality of goods, the firm compete successfully with any, aud as a desirable one with which to establisb agreeable, protitable and permanent relations has no superior.

\section{GEORGE IB. MITCHELI \& CO.-Iron Commission Merchants,}

\section{Warehouse and office, 133 1st $\mathrm{d} v$. \& $10-1$ 2nd $A v$.}

The great Iron City of Pittsburgh affurds an excellent field for the transaction of an immense business in this line of trade. With facilities unequalled, and with business experience possessed by few, the house of Genrge B. Mitchell \& Co. commenced husiness as general commission merchants for the sule of every description of Iron, Pipes and Tubes under the most auspicious and favorable circumstances February 1,1879 . Their office and warehouse are locatel at. 1331 st ave. The warehouse being $20 \times 160$, three floors and hasement, where they carry an average stock amounting to about $\$ 15.000$. From present indications, judging from what they hare already done, and their assured prospects for the future, their annual transactions will reach from $\$ 300,000$ to $\$ 500,000$. They do an exclasivels commission business, and their trade is throughout the East, West and North, with extensire business sinnections in Canada. The specialties of this house are Steam, Gas and Water Pipe Fittings. Boiler Tubes, Boiley plates and Sheet Irou, and every description of goods pertaining to the Iron tralle in these departments. Both wembers of the firm have bcen identified with the iron interests of Pittshurgh for many year's, and enjoy au extended business acquaintance in all parts of the Union. Mr. Geo. B. Mitchell, who is yet a young man, is a native of Washington Co., Pal, and came to this city in 1865. He was formerly connected with the well known and extensive louses of Shœnberger \& Co., Evans, Dalzell \& Co., and the Crescent Tube Works Co. (limited). Ar. J. E. B. Dalzell, his partner, was formerly associated with Lew is, B:iley. Dalzell \& Co., Erans, Dalzell \& Co., and more recently with the Crescent Tuhe Works Co. (limited). He is a native and life-long resident of Pittsburgh, and for many years identified with some of ber leading business houses and important manufactories.

\section{HIENRI SCHIMIDT,-Pharmaceutist, 4016 Butler St.}

The establishment of this popular. Pharmaceutist and Druggist, is located at 4016 Butler street, where he keeps in his large and elegant rooms as complete a stock of drugs, chemicals, fine instruments, fancy goods, etc., as is to he found in any establishment in the city, in the display of which his fine taste is apparent. The business was starterl at present location by Mr. S. in 1870, since when by his courtesy and popular manners he has been successful in establishing a prosperous business and securing the generous patronge of an appreciative public. Mr. Schmidt. was born in Pittsburgh in 1848, parents elying when he was quite young, he was left to make his own way in life. He entered a leading drug store in this city where he remained a considerable time, acquiring a thorough knowledge of the prescription and drug lousiness-was afterwards employed in different drug establishments as prescription clerk, until having by close economy accumulated sufficient means engaged in his present business, where he is now prospering and in the enjoyment of the respect and confidence of the medical fraternity and the community at large. Mr. Schmidt was one of the originators of the Pittshurgh College of Pharmacy and is one of the directors of the praiseworthr institntion, and is giviug his earnest efforts to successfully estahlish it has shown his public spirit in an eminent degree. He is a gentlemau of great intelligence and has had the adrantage of extended travel throughout many parts of Europe and America, acquiring mueh valuable information in the various departments of life.

\section{J. B. NOBBS, -Stoves and House Furnishing Goods, No. 940 Penn Av.}

Mr. Nobbs commenced busimess in 1863 at his present location, building up a gond trade. In 1872, owing to complications arising from no fult of his own, he was compelled to suspend, hut, determined to succeed, he started again in 1874 and has not only paid up all indelitedness contracted by other parties in his name, but has established a flourishing business. His salesroom is $25 \times 50$, with a shop adjoining of the same dimensions, built by Mrr. Nobhs. He carries a full stock of Cooking, Heating and Parlor Stores, Tin, Copper and Sheet-Imn Warc, Hardware and House Furnishing Goods of every description, and does a general jobbing business ia Gas-Fitting, Phmbing and Repairing. Mrr. Nolbs was born in Great Britain, but came to this eity when a child. He learned the trade of tin worker with $H$. $J$. Demler, and has since been connected with various estiblishments. He served for a period as foreman with MIr. Tno. B. Sheriff at his steambont works. He afterwards started a shop colner of Ferrs and Liberty streets, but sold out and accepted the position of superintendent of the tiu and sheet iron works on the Pa. R. $R$. for ten years. After leaving the R. R. shops he engaged in business at his present location. He has been a member of the school Board from his ward and enjoys the confidence and respect of the community. 


\section{W. H. HOLMES,-Rye Whiskies, Wines, Brandies and Champagnes,}

No. 117 Water St. and 154 First Av.

It is a well recognized fact over the entije United States that the hes! whiskey in the country, and perhays in the world, is manufactured in the neighborhood of Pittsburgh, and in the delightful valley of the Monongaliela. Among the most prominent distillers, and having a reputation uncqualled for the choice character of its whiskics, the house of W. H. Holmes is justly regarded as occupying a high position in the trade, its products having beconte celebrated locally among the most undoubtedly critical consumers of Rye Whiskey extant. The warehnuse of Mr. Holmes is located as above, having two frontages, on Water street, or the Levee, and on 1 st avenue. The builling is a spacious one, 37x165 feet, having 4 floors and eellar, with elevators and other conveniences, the counting rooms being upon the first floor. The distillery is in Green Co., Pa., near the Monongahela River; it is an extensive and earefullv managed establishment, heing No, 9 in the 22nd district. Besides the manufacture and sale of pure copler distilled ive Whiskies, the house also imports Wines, Brandies, (rins and Champagnes, and deals in the better class of domestic goods. The stock of Whiskey always on hand will range from 1500 to 2500 liarrels, and, though no traveling salesmen are employed, the trade ranges over the wlyole United States, and amounts to orer $\$ 150,000$ per aunum. Mr. W. H. Holmes is a native of Pennsylvania, laving been bo:u in Fivette Co., in 1827. Engaged as a practical distiller for miny years at Brownsville, Pal, he removed to Pittsburgh in 1872, since which period a unitorn and increasing success has at tended the pursuit of his business. Mr. John S. Holmes, a son of the proprietor, has charge of the hooks and elerical department, which he conduets with systematic order and ability. Aside from the attractions offered by the character of the goods in which it deals, this house is a favorite one on aceount of the pleasant relations which always exist between it and those with whom it is connected. The business policy upon which it is conducted is liberal, relial)le and enterprising, a due regard for the benefit of others entitling it to particular esteen and commendation. A statemen made in 1871 by J. W. Scott, Deputy Collector, and J. W. Hawkins, United States Storelieeper, reads as follnws: "We, the undersigned officers of internal revenue, do hereby certify that the Whiskey" minufactured lyy IV. $H$. Holmes at distillery number three, 24 th district, Penusylvania, is made as follows: Rye, 94 bushels, barle $y^{\circ}$ malt, $b$ bushels, and double copper distilled by fire."

\section{J. HINES, -Dry Goods, Millinery, Notions, Trimmings, etc. , 4114 Butler St.}

Among a number of ver $y$ handsome stores and extensive establishments in the East End, or Lawrencerille district, the dry goods and millinery store of Mr. M. J. Hines is deserving of more than passing notice, while the history of Mr. Hines is a elaaracteristic one, and is an example of many of the successful and enteryrising business men. The store-room occupied by Mr. H. is a large and handsome one, fitted up very neatly, and is stocked with ats (omple1e, varied and choice a stock of goods in his line to he folind in this part of the city, and the stock is kept up wih frequent invoices of all the latest novelties and most approved patterus, etc. Seven hands are kept. fully oreupietl in the different departments. A specialty is the Millinery department, to which great attention and care is given, and which is under the charge of a thoroughly competent and fashionalle milliner, and in this manch of his tiusiness Mr. H. enjoys a reputation for superior and excellent work. Mr. H. fully appreciates the importance and ad rantage of low prices and small profits. Mr. Hines was born in Hitrrison Co., O., in 1848. Ten years ago be removed to this city, where he secured employment, and worked at various occupations until, by economy having aecumulated a small sum, he engaged in business on a limited scale in the borougl of Sharpsburg, where he liuilt up, an extensive trade, and after remaining 5 years in that place, with commendable enterprise, resolved to seek a larg(' ${ }^{\circ}$ lield of opierations, and removed to his present location, where he now has one of the leading establishments in this part of the city.

\section{Z. CRUIKSHANK,-Groceries, 214 Arch St., Allegheny,}

Every family and every houselold has repeated and impulsive calls for articles in this line, and the citizens $n$ Allegheny find one of the most enterprising establisments of this character at No. 214 Arch street. Mr. Z. Cruikshamk started in business an the successor of $O$. Cruikshank, who commenced in 1844 . He carries a full line of choice Fanily Groceries and Provisions, Flour, Butter, Eggs, Notions, etc., and does a large and successful trade, employing three assistants. His building is a three-story briek structure, $18 \times 36$ feet, and his annual sales will aggregate $\$ 30.000$, doing both a wholesale and retail trade and dealing largely in Vegetables and Fruits in their season. Mr. Cruikshank is an enterprising citizen, and fully merits the liberal patronage he receives.

\section{DR. D. COW LEY,-Homeopathic Physician and Surgeon, Penn Av., East End.}

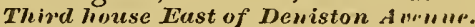

The more modern, simple and rational bomonpathic system is fast superseding the old system. Mrany of the most influential, prominent and successful physicians of Pittsburgh (whatever their former proclivities) now piactice exc'lusively this ruode of treatment. Prominent among the original homoepathists of Pittsburgh is Dr. D. Cowley. He graduated at the Homœopathic College of Pennsylvania, at. Philadelphia, in 1853, and hegan the practice of inerlicine in that city in the same year. After a residence there of ten years he removed to this city, where he prarticed in the city proper about. seven years, but for the past ten years he his devoted his attention principally to his urolession at the East End. He is the oldest graduate of any of the homseopitthic colleges now residing in Pittsburgh. Dr. Cow ley was born in the County Doun, Ireland, in 1830, but caue to llis country, with his parents, in 1832.

\section{J. J. IORSTER,-Groceries, Dry Goods, Wall Paper, \&c., Penn \& Shady Av's, E. E.}

This great variety establislıment was started by John J. Forster \& Bro, in 1870, with a capital of $\$ 4.000$. In 1872 the junior member withdrew, taking nut with him about $\$ 2,000$. Since that time the business hils been in the hitnds of J. J. Forster alone. The stock is estimated at $\$ 2,500$, and the business transacterl rear]y is at. least $\$ 6,00010$ s. The building is $36 \times 80$ feet, having two store rooms. Two hands are employed in the thriving estahlishuent, and the stock embraces a great variety of Dry Goods, Wall Paper, Notions, etc., and lowest prices prevail. No wontier its custom is great and fourishing. Mr. Forster was born in Englanrl, in 1834, and has been here since 1842. Ife hegan selling goods in East Liberty in 1852, and has continued in trade ever since. He is an enterprising merchant and worthy gentleman.

\section{FRAN K DIETRICH, -Butcher and dealer in all kinds of Meats, 1139 Penn Av.}

Mr. Frank Dietrich is located at No. 1139 Penn avenue, where he keeps the finest meat establishment in that part of the eity. He began the business at his present location in 1861 and has continued in the same place evir since, ihur-

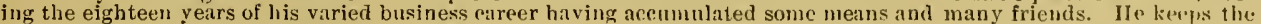
best stock of meats and best quality. He was horn in Alsare, lirance, in 1836 and came to the United Stalles in 1858. After farming and teaming he came to Pitshurgh and worked two years as apprentice at the butchering business, and then commenced for himself. He is a member of City Councils and has a high reputation in the community. 


\section{KIER BROS.-Manufacturers of Fire Brick, Office, 369 Liberty St.}

Mr. S. M. Kier, father of the three brothers constituting the above-named firm, was the pioneer of Fire-Brick manufacturers in the United States, liaving established the first works of this kind ever constructed in this country. As early as 1845, in company with another gentleman, he constructed and operated what was known as the Bolivar Works, and thus laid the foundation of this now important branch of industry in this section. Mr. Kier was in many jespects one of the most remarkable men of this century. He accomplished more towards develoying the immense resources of Western Pennsylvania than any other single individual since its settlement. Mr. S. M. Kier and his father sources of $y$ interested in the development of the salt wells on the Allegheny River, about twenty miles above Pittsburgh, the discovery of which produced a revolution in the salt trade and opened up a new source of wealth by supplying the market with an article of universal consumption which had hitherto been brought from the sea-board at an immense expense. These salt wells had for some time yielded a small amount of petroleum, which, at that day, was allowed to go to waste, as no one had discovered any use for it, when Mr. Kier became satisfied of its medicinal properties and healing qualities. He accordingly experimented with it for some time and then opened an office in Pit tshurgh and commenced bottling and introducing it throughout the country under the name of "Kier's Petroleum or Rock Oil." Many of our readers will remember the magnificently decorated wagons which nearly thirty years ago were to be seen in every city and town throughout the Union, with pictures of the good Samaritan administering aid and comfort to the sufferer. The oil thus sold was highly recommended by physicians and others and met with an immense sale, which continued for many years. The supply, however, after a while so much exceeded the demand that Mr. Kier conceived the idea of utilizing petroleum for illuminating purposes, but owing to the odor and smoke arising from it, this disposition was deemed impracticable even by many scientific men. The first attempts of Mr. Kier at distillation were not crowned with that success which he had hoped for, hut lie persevered with his investigations, and ruaking some chauges in the old style of camphene lamps, he made the important discovery that his distillate would burn under certain circumstances. From this rude beginning he went on making improvements in the quality of his distilled oil and the adaptability of his lamp, until at last, by the introduction of the "Virna" burner and the treatment of his distillate with acids, he had bronght his experiments to a close and secured to the world one of the greatest and most important discoveries of modern times. Up to this time he had enjoyed a monopoly in the production of petroleum, but the magnificent results of his inventions led to the discovery of other wells in various portions of the State and Continent, and from that day to this petroleum has been one of the most important products of Western
Pennsylvania. The original "still" is retained in the family as a priceless relic. A linited supply of this prepared oil is kept on hand to supply the wants of customers from varions sections of the country. This is a brief record of what has been accomplished by one man in developing the resources of our city and State in three important branches of industry. Mr. S. M. Kier was succeeded in the Fire-Brick business by his three sons, T. C. Kier, H. E. Kier and W. L. Kier, who are worthy representatives of their enterprising and respected father. These gentlemen manufacture the famous brand of "Salina" Fire-Brick and Tiles and Fire-Clay of a superior quality. Their productions are all manufactured with the utmost care, upon scientific princuples, and with a thorough knowledge of their combined chemical qualities. In their office are numerous cabinets filled with specimens of the various clays used in their crude and prepared state. This firm received a medal and diploma awarded by the Centennial Commission, International Exhibition at Philadelphia, in 1876, for "good reputation and standard value of Fire-Brick, Arches and Keys", and have testimonials from many of the leading manufacturers of Pittsburgh endorsing the uniform excellence and superiority of their products. Their yards and buildings cover an area of more than four acres, with two powerful engines of tifty-horse power, and all the necessary machinery and appliances for carrying on their extensive business. They mine their clay and coal on their own lands, being the only firm owning their own coal and clay lands. The ground surface of their lauds is 124 acres, depth of coal bed seven feet, and of the clay veins from six to fourteen feet. Twentyfive hands are employed at their yards and they carry an average stock of from fifteen to twenty thousand brick and tile. The reputation of their Fire-Brick and Clay and the demand for the same extends all over the country wherever there are furnaces or manufactories requiring a superior article of this description. The three brothers are all natives of Pittsburgh and have always been identified with the business interests of the city. Mr. H. E. Kier is engaged in attention to its interests and development.

\section{JAMES BEST,-Choice Family Groceries, Selected Teas, etc., 271 Federal St., Alleg'y.}

Situated on the west side of Federal street, a short distance above the Parks, is the establishment of Jas. Best, Esq, who was horn in the North of Ireland in 1809 and came to Alleghen $y$ in 1850 . He occupies a three-story brick structure, $23 \times 55$ feet in size, which is one of the neatest and most substantial buildings in the vicinity. Starting in business with a capital of only $\$ 2,000$, he has gradually inereased his trade. Stock on hand amounts to $\$ 3,000$ and his sales amount to about $\$ 12,000$ per annum. His stock of goods will be found to be of the best and purest quality. Parties making purchases at this establishment can rely upon getting the very best of goods at prices as low as any house in the city. Satisfaction guaranteed or the money refunded.

\section{WII. H. SIIITH, -Flour Commission, 382 Penn Av.}

This house, although a comparatively recent acquisition to the Commission Flour business of the city, having been started in 1877, is ranked among the well-known and most reliable concerns in this line of business. Flour is the principal article handled. Mr. Smith having close business connections with the manufacturers of the best brands in the West and he enjoys a large patronage from city dealers, at the same time disposing of considerable quantities within one hundred miles of the city. Grain and Feed form no inconsiderable portion of the business of the house, while many other articles are handled, such as usually pertain to the general commission business. The store occupied has a trontage of 20 feet on Penn avenue and extends back 120 feet, being one of the most commodious business houses on that street. As is generally the case with good houses in this line, this concern makes advances on consignments, and its business transactions will always be found prompt and reliable. Mr. Smith has been a resident of Pittsburgh for 28 years, enjoying the respect and confidence of the business community.

\section{J. \& A. SPERBER,-Artists \& Photographers, $90 \& 92$ Federal St., Allegheny.}

In no trade or profession is there required a nicer perception of the proprieties, a finer artistic training or a more accurate knowledge of the laws of perspective in light and shade. To be a good photographer requires more than an insight into the purely mechanical part of the business and in calling attention to the art gallery of Messrs. J. \& A. Sperber we can conscientiously commend these gentlemen as artists of ability and masters of their profession. Both admirably lighted and arranged, and their operating, printing and finishing or crayon rooms are nnder the charge of admirably lighted and arranged, and their operating, printing and finishing or crayon rooms are nnder the charge of
coinfetent and experienced workmen. In fine work they will compare favorably with any similar establishment East. or West. The members of the firm are John Sperber, who was born in Pittsburgh, Oct. 25, 1854, and Mr. August Sperber, born in the same place Oct. 30,1852 . Two assistants are employed who thoroughly understand ever $\mathrm{s}$ detail of the business. 


\section{THE MUTUAL GLASS CO.-S. \& J. Gallinger, 0ffice, 145 First Av.}

New York Office and Salesroom, 36 Barciay St.

For more than eleven years the house of $\mathrm{S}$. \& J. Gallinger hare been intimately identified with the glass trade of this city, conducing in no small degree to its more ample development and achieving a position worthy of more than brief consideration in this work. Estabished in 1865, under the present management, the firm became associated with several large glasss manufacturing concerns whose products they engrossed and placed upon the market with success, so much indeed as to warrant the construction of a faetory of their own in New York City, where they had always done an extensive trade, having their branch office and salesroom at No. 36 Barclay street. The manufactory in the East was put in operation about one year ago for the special object of making bronze lamps, on which they had made sereral inprovements, securing letters-patent on a socket which is by far the best and most durable in use. Ten thousand dozens of these lamps have been already manufactured and sold, which, as the product of the first year, is pretty conclusive evidence of superior merit and utility. The class of goods in which the Messrs. Gallinger deal embraces all varieties of Table and Fancy Glass Ware, Lamps, Chimneys, Bronze Lamps, Chandeliers, Bottles, Flasks, Fruit-jars, \&c. Lettering, Engraving and Etching done to order on all kinds of glassware. The trade of the house is not contined to the United States entirely, large invoices of goods being shipped to foreign countries, with a rapidly increasing business in this direction. This is one of the most encrgetic and reliable houses in the trade, being in all respects, a desirable one with which to establish permanent relations.

\section{W. J. McCRICRART,-Wholesale Wines and Liquors, No. 337 Liberty St.}

This house was founded in 1854 by Mr. S. M. McCrickart, father of the proprietor, who succeeded to the business in May, 1879. For a quarter of a century the establishment has held a prominent position anong the wholesale houses of Pittsburgh and is justly entitled to rank among the representative mercantile establishments which have given the Smoky City a national reputation. Mr. McCrickart occupies the entire four-story brick building, 21x69 feet, at No. 337 Liberty street, and the business bas been conducted in this block since 1848. He carries a full and complete line of Foreign Wines, Brandies, Gins, Rums, \&c., of his own importation, and all the leading brands of Pure Rye and Bourbon Whiskies. Mrr. McCrickart gives his personal attention to the business, employing one book-keeper and two salesmen. His annual sales for the past ten years have averaged about thirty-thousand dollars, extending throughout the eastern and western portions of Pennsylvania, Eastern Olio and West Virginia. Mr. MrcCrickart is a native of Pit.tsburgh, hort Sept 22, 1850. He is a wide-awake, energetic and reliable young unan, under whose management the well-earned reputation of this old-established house is perfectly safe.

\section{JOHN MCINTYRE,-Miner \& Shipper of Gas Coal. Office, 513 Liberty St.}

The superiority of the Gas Coal found in what is known as the great Pittsburgh coal vein is now universally aeknowledged by gas managers, manufacturers and consumers generally throughout the country. Aniong the prominent mines and shippers of this important factor of Pittsburgh's wealth and commercial importance is Mr. Juhn McIntyre. whose office is located at No. 513 Liberty street, and his miues at Wilkinsburg, Allegheny county, on the line of the Pennsylvania Railroad, and known as the Hampton mines. Mr. MeIntvre has been engaged in his present line of business for the past five years and has built up a large and flourishing business which will compare favorably with thit of any bouse in Western Pennsylvania of a similar nature. He employs at his extensive mines one hundred and seventy-five men at an expense of about $\$ 70,000$ per annum. The annual yield of the Hampton mines is ahout 65,000 tons, valued at not less than $\$ 1000,000$. One steam engine is used at these works and his facilities in every way are unsurpassed. His trade is largely local and throughout the West, and the coal furnished by him gives universal satisfaction wherever it is used. Mr. MeIntyre is a native of Pennsylvania and has for many years been identified with the coal and mining interests of Pittsburgh. He is an active and energetic business man, thoroughly conrersant with the details and requirements of the business in which he is engaged.

\section{J. A. McKELVEY,-Carriage and Harness Bazaar, No. 4 Diamond St.}

Prominent among the houses engaged in the manufacture of different varieties of vehicles, we niay mention tbat of Mr. J. A. McKelvey, whose place is known as the "Pittsourgh Curriage and Harness Bazatr." This house was established about twenty-five years ago by Mr. Join S. Shafer. In 1870 the present proprietor assumed the management. His establishment occupies the entire five-story brick structure, $60 \times 110$ feet, turning out annually ahout one hundred and fifty vehicles of various patterns. He keeps constantly on hand Carriages, Buggies, Phaetons, Road Wagons, \&c., as well as a general line of harness adapted to all uses. Mr. McKelrey is a native of Penusylrania and has long been a resident of this city.

MARTIN KESSLER, -Baker and Confectioner, No. 5 Frankstown Av., E. E.

With limited means Mr. Kessler commenced business, as his capital was not above $\$ 30$. He now has a capital of $\$ 8.000$. He carries a stock of $\$ 200$ and does a business of about $\$ 3,000$ per annum. This speaks well for the quality of the Bread, Cakes, Pies and the thousand other rood and sweet things sold by him. An ictive and obliging saleslady assists Mr. Kessler in waiting on his numerous customers, and these never leave his shop unsuited in the price or quality of articles. Mr. Kessler was born in Germany in 1835 and came to this city in 1855, where he commenced business in 1861 . He is highly respected and does a good trade.

JOEN LUST, -Tin, Copper \& Sheet-Iron Ware, Stoves, etc., 3 Frankstown Av., E. E.

Mr. Lusk commenced business in 1861 with a smsll capitaI, which he has greatly improved. The present stock of Ir. Lusk is about $\$ 3,000$ and his trade annually aggregates $\$ 5,000$. The stove room and shop cover an area of $16 \times 60$ feet. He manufactures Tin, Copper and Sheet-Iron Wire, does Roofing, Spoutiug and general Job Work to order, hesides dealing in Stoves, Grate-fronts, Hollow Ware, de. IJe employs three good worknen and his business has stealily grown since its commencement. Mr. Lusk was born in this city in 1828, and is of course well known as an honest and straightforward business man.

\section{GEO. W. HUGHES, - Cigar Manufacturer, 143 Beaver Av., Allegheny.}

Mr. Hughes is a native of Pittshurgh and a practical Cigar Manufacturer of many years' experience. He cnmmenced business for himself in 1864 at No. 143 Beaver avenue, where he occupies a two-story frame and brick building, 20x60, making severul celelirated brands of clioice cigars. He carries a stock of Fine Cigars, Tobacco and Smokers' Articles, valued at about $\$ 1,000$; annual busiuess, $\$ 6,000$. He uses only the very best quality of leaf tobacco, and his trade is constantly increasing. 


\section{JNO. IREIL, Sr.-Wholesale \& Retail Dealer in Flour, Grain, \&c., 4022 Butler St.}

The feed establishment of Mr. Keil is located at No. 4022 Butler street, where the business was begun by Mr. K. three years ago in connection with the large grocery and dry goods store adjoining, then ow ned by him and since then transferred to his son, Juo. Keil, Jr. The feed business having grown into large proportions and Mr. $K$. at his advancing age not wishing to be encumbered with so great a business as the two combined, transferred the grocery to his son. MIr. K. is one of the older settlers of Pitısburgh, having come to the city in 1832, and lived here ever since; he can tell many interesting and entertaining incidents in connection with the bistory of tbis city. He was born in Germany in 1815 and emigrated to the United States in 1830, remaining two years at Frederick, Ma., coming over the mountains from there shortly after. He worked 34 years continuously in the old sligo mill of Lyon, Sherb. C Co., being one of the most honored and respected and competent iron workers in the establishment. He possessed the esteem and confidence of the community in an eminent degree, and was burgess of the borough of MLonongahela prior to its consolidation with the city. In 1868 he removed to Lawrenceville and embarked in the grocery and dry goods business, since then lie has been very suceessful in a business point of riew, liaving amassed considerable means, and has by his upright dealings and honorable course attained a high position as an honored and respected citizen. He has served the people of his ward as a school director and has been treasurer of the board of his ward. Mr. K. has raised a lirge fimily of children who are scattered in various parts of the country.

\section{JNO. KEIL, Jr.-Groceries, Provisions, Dry Goods and Notions, 4020 Butler St.}

This establishment is located at 4020 Butler street, being the oldest establishment perhaps in Lawrenceville, now the 1,5 th and 16 th wards of the city, laving been started by Wm. Smith near 20 years ago, passing from him to Robinson \& Parker, then to Lutley \& Biros., and then in 1868 to Jno. Keil, Sr., coming into possession of the present genial and popular proprietor in 1878. It is of course a well known and popular stand, well stocked with first-class goods and is doing a large retail business. Mr. Keil was born in the 33rd ward of the city in 1838 and has made the city his home ever since. Served three years in the Union army in Col. Rowley's 102nd Pa. Vols., was wounded in the wilderness, so severely as to necessitate his discharge on account of disability, after his return from the army was engaged in various enterprises in the inevitable oil business, as well as others, prior to engaging in present business. MIr. Keil has served his county as assistant Deputy Recorder.

\section{THEODORE HARTDUNG,-Merchant Tailor, 1300 Carson St., South Side.}

Mr. Hartdung commenced business in this city some years ago on a very moderate capital, but with a thorough knowledge of his business and the close attention he has given it, has placed him in the ranks of Pittsburgh's successful business inen. He now curries from $\$ 3,000$ to $\$ \overline{5}, 000$ worth of stock and does an annual luusiness of from $\$ 9,000$ to $\$ 10,000$, employing five workwen regularly and increasing this number in the busy seasons. Custon work is his specialty, and he guarantees good fits. Mr. Hartdung was born in Germany in 1846 and cane to this country in 1864 , commencing business in this city. He is an affable and courteous gentleman, energetic and prompt in business, and possessing social qualities of a high order.

\section{ICQUIGG \& GROVE,-Choice Groceries\& Teas, 237 \& 239 Federal St., Alleg'y.}

At the large and well-known establishment of the above firm will at all times be found a choice selection of pure and unadulterated Groceries and Teas, which will be sold at prices to suit the times and as low as any house in the city. The firm have had long experience in the business and thoronglily understand the wants of the public. Their sp zeialty in their line of business is the "Pride of Allegben y Flour," being one of the finest and best brands of flour in the country. Mr. MeQuigg was born in Allegheny in 1852, and his partner, Mir. Grove, was born in York County, Pia, in 18.59. Commencing business on the limited capital of $\$ 2,500$, they have considerably increased the same and are now doing a business of $\$ 15,000$ per annum, with a stock on band at present of $\$ 3,500$. Their stock of goods will at all times be found up to the standard and second to no establishment in the city, both in regard to quality and jrices. All parties making purchases of the above firm can rely on getting the wolt li of their money and receiving polite and conrteous troatment at all times. In addition to their "Pride of Allegheny Flour," all other choice brands are kept constantly on hand.

\section{JAS. I. ORR,-Real Estate Agent \& Broker, No.61 Sandusky St., Allegheny.}

Mr. Orr commenced business as a Real Estate Agent and Broker in 1876, with a capital of $\$ 10,000$, which has since increased to $\$ 25,000$, the greater portion of which is invested in real estate. He transacts a business of about $\$ 60,000$ per annum in Collections of Rents, also negotiating Mortgages, Notes and Bonds, aud deals in Real Estate. His offices are located at No. 61 Sandusky street, and No. 71 Federal street, Allegheny. He employs one book-keeper and office clerk and three collectors. His business is principally located in Pittsburgh and Alleghenv and in buying and selling farms in the rural districts. Mr. Orr was born in Ireland July 5, 1849, hut has for 29 years been a resident of Allegheny City.

\section{R. W. MEANS,-Druggist, N. W. Corner of Federal St. \& North Av., Allegheny.}

Situated immediately opposite the parks and direct]y on the line of the Pleasant Valley Railway, cor. of Federal strect and North avenue, is the cstablishment of $\mathrm{I}$. W. II Ieans, who keeps constantly on hand a complete assortment of pure Drugs and Medicines, Toilet Articles, \&c. at fiair and reasonable prices. Mr. Means first commenced business in Allegheny, at 128 Federal street, in 1840 , and is at present doing a business of $\$ 6,000$ per year, with a stock on hand of upwards of $\$ 4,000$. His place of business is a large three-story brick structure, $20 \times 60$ feet in size, and commands a splendid view of the parks both east atnd west. MIr. Mieans is one of the most respected citizens of Allegheny and was born in Alleghen y County in 1823 . He is ably assisted in his business by his son, Mr. Wm. Means, a polite and agreeable gentleman. All can be accornmodated with medicines, de., at all hours of the night and day.

\section{MRS. M. M. PINKERTON,-Fine Millinery, 103 Federal St., Allegheny.}

Mrs. M. M. Pinkerton is located on the west side of Federal street, a short distance above the railroad depot, where she keeps a complete assortment of Fine Millinery, Trimmings, de. Mrrs. Pinkerton has had about twenty years' experience in the business and thorouchly understands the wants of her patrons. She was engaged in business at 108 Fecleril strect in 1360-removed to 103 Federal street in 1868, thence to 31 Federal street in 1876 , and in April 1,1879 came back to her present loeation. Prices as low as the lowest. Ladies will find her goods attractive and stylish and her work in trimming the most tasteful. 


\section{FLANAGAN \& ILING,-Horse Shoers, 1110 Penn Av.}

The enterprising and popular firm, Messrs. Flanagan \& Kling, is located at No. 1110 Penn avenue, where they have a very extensive shop, and where they are doing a very large business as Horse-Shoers, keeping four assistant shoers. They enjoy a higl reputation as skilled and superior workmen. The firm was organized and husiness commenced at their present location in 1868 , and from the first their upright, honorable course and superior skill brought them a large bosiness. Mr. Flanagan was born in Ireland in 1838, and came to the United States in 1847. Being an orphan boy he was raised by Wm. Ash, who was a blacksmith by trade and worked at that business many years in this city. Mr. F. was raised in the shop of his adopted parent and bas worked hard from his boyhuod up. He acquired his skiti and knowledge of the business during this period. He worked many years at journey-work in the same shop, until finally concluding to start a shop for himself, he associated with him Mr. Kling, a long-time companion in the same shop. Mr. Kling was born in Gernany in 1812, and came to the United States in 1860, he having learned his trade as horse-shoer in the old country. He enlisted in the 5 th U. S. Caralry and served with credit during the war. At the close of his term of enlistment he came to this city and secured employment in the shop of Wm. Ash, where the acquaintance was made with his partner which ripened in to a friendship that will be life-long. Since starting for themselves they have been successful in accuroulating considerable means.

\section{R. T. RODNEY,-Undertaker and Embalmer, 35 Ohio St., Allegheny.}

Mr. Rodney was born in Allegheny County, Pa., in 1839 and came to Allegheny in 1875, and has been engaged in the business of Undertaker and Enbalmer at the old stand 35 Obio street during the past four years. His business amounts to $\$ 1,800$ per year. In the art of Embalming $\mathrm{Mr}$. Rodney has but few equals and no superiors in the city. His business is carried on in a large three-story brick building, $15 \times 80$ feet in size, and is within a few doors of the City Hall, on the line of the Pittsburgh \& Allegheny Railway. If is stock of lurial Caskets, Shrouds, de., are of the finest and most elegant designs, and will at all times be found equal to the best. Mrr. Rodney was onte of the first. undertakers in the city to break up the monopoly of the livery-stable keepers and bring the price of carriages to funerals down to the reasonable imount of $\$ 3.00$.

\section{GEO. RITTER.-Baker and Confectioner, 241 Federal St.}

The Bakery and Confectionery of Geo. Ritter is situated on the west side of Federal street, above the parks, and is one of the largest and most complete establishments of its class in the city. The building is a three-story brick structure, $24 \times 60$ feet. Mr. Ritter was born in Germany in 1850, came to this country and settled in Allegheny in 1861 . He first engaged in business at No. 45 Ohio street, but owing to increase of business was colapelled to remove to his present location in 1877. Commencing business on the very small capital of $\$ 300$, he his increased the same to $\$ 14,000$, and is doing a regular business of $\$ 4,000$ per annum, with a stock on hand of $\$ 3,000$. He has several first-class workmen constantly employed, making the finest description of confections. He also manufactures the best Bread, Pies and Cakes, and is prepared to supply the choicest Cakes for Weddings or Parties. Ice Cream of all flavors constantly on haud in its season.

\section{J. F. MILIER,-Pattern \& Model Maker, rear of 167 Penn St.}

In a great manufacturing city like Pittsburgh, where almost every conceivable article constructed of metal is to be obtained the necessit $y$ for skillful and experienced pattern and model makers must be apparent. Among those who have made this branch of industry a study and occupation is Mr. J. F. Miller. Mr. Miller for the past six years has devoted his attention to the manufacture of every description of models and patterns required by inanufacturers or in ventors. He has oceupied his present location in the rear of 167 Penn street below Sixth, with entrince on Cecil's alley, for the past three ye:rs, where he has ample room and all the necessary machinery for carrying on his business in all its departments. He is supplied with steam power from the works of tne Pittsburgh Safe and Lock Company, having three skilled assistants. He has resided in Pittshurgh for the past twelve years, where he has built my a flourishing and lucrative business, amonnting to between $\$ 3,000$ and $\$ 4,000$ per annum, with trade gradually increasing each year.

\section{GLESENKAMP \& CO.-Carriage Manufacturers, $75,77 \& 79$ Liberty St.}

The firm of Messrs. L. Glesenkamp \& Co. is not to be omitted in making a sumnary of Pittshurgh's industries. Founded thirty years ago by $\mathrm{C}$. West \& Co. for more than a quarter of a century, this liouse has enjoyed a high degree of success, and the character of the work executed by this concern claims the highest commendation. In 1875 the firm changed to its present style by the suecession of Mr. L. Glesenkamp, who for years previously had been a partner with his predecessors, and Thos. S. O'Neil, almost equally well known to the tride. Since that time a marked increase has taken place in the business, which now averages $\$ 100,0000$ per annum, and employs $4 \overline{5}$ skilled worlkusen and artis.ns in the tine mechanical departments, requiring a weekly disbursenent of atmut $\$ 100$. The premises occupied liy the firm are undoubtedly the largest and most commodious of the kind west of the mountins and consist of three fourstory buildings $75 \times 240$ feet, containing work shops, machinery, varnish and paint rooms, and stock in the repository worth not less than $\$ 75,00$. Here the buyer is afforded facilities unequaled both in price and from the quality of the work for the selection of almost any vehicle known to the trade, thedexter wagons being a specialty. With a trade that extends over the entire world, it is not too much to say that much of the celcbrity attained by Ameriean velicles in England and Europe is due to the admirable and elegant work of $\mathrm{L}$. Glesenkamp \& $C o$.

\section{ADAM HECKMANN,-Wine \& Liquor Saloon, 37/ Beaver Av., Allegheny.}

Mr. Adam Heckmann keeps at all times a choice selection of the very best wines, liquors, ale, lager beer and cigars. Mr. Heckmaun was lorn in Kurhessen, Germany, in 1853, and came to this country and sețtled in Pittsluurgh in 1867, where he was engaged in the employ of Peter Gallisath, at 69 Liamond alley, where he remained about four vears. He shortly aifter engaged in business on his own account and in March 1879, becoming dissatisfied with Pittsburyh he removed to Allegheny and opened the establishment at 371 Beaver avenue. The building is a neat and attractive two-story frame $20 \times 10$ feet. He is now doing abont $\$ 3,500$ per amnnm.

\section{JNO. S. COSGROVE,-Undertaker and Embalmer, No. 27 Ohio St., Allegheny.}

Mr. Cosgrove was formerly engaged in business under the firm name of Flannery \& Cosgrove, which was dissolved Sept. 30, 1878, by the withdrawal of J. J. Flannery. The business is still continued at the old stand by Mr. Cosgrove, who is doing a business of $\$ 2,000$ per annum. The bnsiness is carried on in a large three-story brick structure $18 \times 110$. The stock of Burial Caskets, Shrouds, \&c., will at all times be found complete, with prices inoderate. He is a tirstclass artist in embalming, surpassed by none. 


\section{BEESON \& MCIMORRIS,-Designers \& Engravers on Wood, 70 Fifth Av.}

Every description of fine wool engraving is executed in the highest style of art by the above named firm. The business was established in 1865 by Mr. Beeson, who eontinued it until 1876, when Mr. James McMorris was admitted and the firm name becume as at present. Buth nembers of the firm are artists of acknowledged merit and ability. They make a specialty of fine mechanieal work, illustrations for catalogues, views of mills, manufaetories and business houses, newspalper and magazine engravings of every deseription from the finer and more artistic engravings to the inost ludicrous earicatures and silhouettes. Manufacturers of specialties ean here procnre aecurate illustrations of their various products, implements or pachinery at reasonable rates. In faet these gentlemen are prepared to furnish cuts of every description and elegant designs for business cards, stationery headings, newspaper headings, or displayed and illustrated advertisements. Their trade which amounts to not less than $\$ 5,000$ per annum extends tiroughout the two cities, Western and Middle Pennsylvania, Ohio, Virginia, Indiana, Michigan and mau y of the Southern and Western states. Mr. Jacob Beeson was born in Fayette county, Pennsylvania, in 1832. He came to this eity in 1846 and has since resided here, where he las established the reputation of being the most expert and artistic designer and engraver in the smoky eity. Mr. James McMorris was born in Philadelphia in 1849. He came to Pittsburgh in 1875, after haviug learned the business in the city of his birth, and has been very successful bere in the line in whieh he is engaged.

\section{H. IX. PORTER \& CO.-Light Locomotives, 5 Smithfield St.}

The business now condueted by Mr. Porter, under the firm name and style above given, was founded in 1866 by Smith \& Porter. In 1871 the firm beeame Porter, Bell \& Co., which firm was dissolved May 2, 1878, by the death of Mr. A. W. Bell, whose interest was purchased by Mr. Porter, the surviving partner, in December of the same year. The exclusive specialty of this house is the manufacture ul light locomotives for narrow guage railroads, contractors? use, factories, furnaces, mills, mines, and all kinds of special service for which ordinary locomotives are not practical or economical. The capital invested in this business is from $\$ 100,000$ to $\$ 150,000$. The factory and works are located at 49th and 50th streets, on A. V. R. R. and cover one aere of ground, embracing six departments which are all connected. They have one eich $y$-horse power engine, a cupola of 1,500 tons eapacity and a variety of the most approved machiner'y necessary for carryiug un so extensive a business. They employ from 100 to 150 workmen, whose wages amount io about $\$ 60,060$ per ammum. They use only the very best material and employ skilled workmen, many of whom have been edueaterl in the employ of the house. Mr. H. N. Sprague, who has been conneeted with the establishment for the past teu years, is superiutendent at the works, and W. E. Lineoln, a gentleman of experience and albility, has the management of affairs at the eity office, Mr. Thos. W. Bell represents the firm as traveling agent. The trade of this house extends all over the United States. It is one of the largest manufaetories of light locomotives in this country and will compare filvorally with any in the world.

\section{WM. MCCRACKEN,-Dry Goods, \&c., 3814 Butler St.}

This is one of the most flourishing Dry Goods Houses in Lawrenceville distriet, not one in this part of the eity offering greater inducements to trade in dry goods, trimmings, notions, etc. MIr. Wm. MeCracken, the proprietor, was born in Ireland, in 18.16, learned the trade of mehinist in his native country, and came to the United States in 1870. He tirst secured employment in Patterson, N. J., then in New York and finally settling in this city. By econr,ny and the assistance of his aecomplished wife, who is an artistic dress maker, he secured eapital to engage in business for himself. In 1876 he opened a store at No. 3511 Butler street with dress making department orer whieh his wife presided, but the growing trade demanded new quarters; the dress making department now employs 12 girls. The store is deservedly popul:ar and in both departments enjoy publie favor and liberal patronage.

\section{A. W. THOMPSON -Tin, Copper and Sheet-Iron Ware, Stoves and Hollow Ware,}

221 Ferleral St., Allegheny Cit'.

Mr. Thompson was born in Shenandoaln Valley, Pa., near the famous battle-field of Gettysburg, in the year 1824, and eame to Allegheny when quite young. He is engaged in the manufaeture of Tin, Copper and Sheet-iron ware of every deseription, and all work from his establishment warranted to be first-elass in every particular. The business is earried on in a neat two-story frame building, $20 \times 100$, and commands an excellent view of the parks. He has, notwithstanding the hard times, managed to fivorably increase his trade. Mr. Thompson is one of the oldest and most respected eitizens of Alleghury.

\section{W. B. AND ERSON,-0yster, Produce and Commission Store, 31 hio St, Allegheny.}

The neat establishment of W. B. Anderson is loeated on West Ohio street, near City Hall. The building is a large three-xtory lorick structure and presents a tine dppearance. Mr. Anderson is quite a roung man, having been born in Allegheny in 1S61. Having been engared in husiness but a short time, and starting with but al small eapital, he has hy industry and perseveranee considerably inereased the same and is doing a snug business of $\$ 4,000$ per' annum. His stock of goods will at all times he firunl pure, fresl and free from all adulterations. Persons wishing to purchase anything in his line will do well to eall and examiue his stock. Game of all kinds in season and warranted fresh.

\section{CRUIISHANK BROS.-Wholesale \& Retail Grocers, American Grocery.} Cor. Taylos dv. and Houterey St., Allegheny.

The above firm commencer business but a short time since on a capital of $\$ 2,000$, and have farorably increased it. They are doing a business of about $\$ 25,000$ per anum, with a stock on hand of about $\$ 2,000$. The members are.$T$. F. \$George L. Cruikshank, who were born in Allewheny. The building is a three-story brick 20x90 feet in size, of fine appearance; the stock of goods on hand will be found to be of the best quality. Their specialty is pure No. 1 coffee and Americun pride tlour. All persons desiring pure goods shoukl favor this establishment with a call. Prices as low as any house in the city and gouds delivered free of eharge. Strietly cash.

\section{IMA Y,-Steam Dyer and Scourer, 56 Sixth Av.}

This establishment was founded in 1872 by Messrs Slack \& May, in 1875 Mr. May becane sole proprietor. In experience and practical abjlity he has no superior in this branch in this city. To the art of dying ladies' and gentlemen's apparel of every deseription he gives special attention, warranting colors pure and clear. He also eleans and refinishes black crape, piano covers, dimask and lace curtains, and all other fine gouds. His work is done on short notice and in the must perfeet manner, which eannot fail to satisly the most eritieal. 


\section{PITTSBURGH PLANING MILLS, - B. Schmidt \& Co., Propr's,}

Penn St., bet. Thirty-first \& Thirty-second Sts.

This business embraces extensive Planing Mills, Box Factory, Lumber Yards, \&c., with lumber of all kinds, flooring, siding, sash, doors, blinds, shutters, mouldings, all kinds of boxes manufactured and on sale. Located between 31 st and 32nd streets on Penn aveuue, these works cover an area of $150 \times 336$ feet of ground, provided with latest approved machinery and facilities. They have invested nearly $\$ 60,000$ in the business and do an annual business of upwards of $\$ 30,000$, though not now running at their full capacity. They employ 12 hands with a monthly pay-roll of \$100. The business was started in 1861 by Pearson \& Co., and came in to the hands of the present firm in 1864 , who have greatly increased the facilities and business. Mr. Schmidt was born in Germany in 1826 and came to the United States in 1S-19; was employed with C. Yeager \& Co. for six years, afterwards engaged in the dry goods tralle on Market street from 1857 to 1863 ; he served in the City Council from 1869 to 1873 . The MIessrs. Lamkemeyor are natives of Germany and came to the United States in 1847 or 1848 , worked at the furniture business for others and then for themselves. The firm is composed of excelient and practical men and enjoy a high reputation.

\section{J. A. MeCREADY, M. D.-Office and Residence, 1059 Penn Av.}

Among the many skilled and competent gentlemen associated with the medical profession in this city and whose abilities have achieved success, we take pleasure in mentioning Dr. J. A. McCread y, who was born near New Iislon, Columbiana County, Ohio, in 1847 and passed the early portion of his life upon a farm. After a brief experience in the cattle business, after completing his literary education at Mt. Union College, Ohio, he read medicine with Dr. Hammond, a very prominent physician of Wellsville, Ohio, and witl Dr. Robert McCready, of Seweckly, Pa., also a gentleman of rare ability, under whose careful tuition he served a thorough training and laid the foundation for his future success. Dr. J. A McCready is a graduate of the Bellevue Medical College, of the "class of "75." He first commenced practice in Ohio, but came to this citr in 1876, where his practice and popularity have been large and his success most flattering in his practice as $w$ ell as in the high position he holds in the profession, and for his standing with the community.

\section{IMANCHESTRR ALE BREWERY,-H. Dippel, Proprietor.}

This celebrated Brewery was established several years ago by Mr. Henry Dippel, (now deceased.) The superiority of the ales manufactured by him soon brought the brewery into favorable notice and the amount of capital now inrested in the business has since considerably increased and the popularity of the ale been maintained by the presen energetic proprietor. The two buildings now occupied in the manufacture of this delicious beverage are situated on the corner of Market and Juniata streets, the main building being $40 \mathrm{x} 30 \mathrm{fcet}$, and the business is conducted in four separate departments. The machinery used is one twelve-borse power upright engine and one fiftern-horse power boiler. The number of hands at present employed is four. Mr. Dippel carries an ample stock and his annual trade, which is prineipally of a local character, amounts to about $\$ 6,000$. Wherever his ales have been introduced they give the most unqualified satisfaction end are highly recommended for their purity and general excellence. MIr. DippeI is a native of Allegheny and was born in 1842. He is a thorough practical brewer and understands all the details and requirements of the business.

\section{Z. CRUIIRSHANK,-Retail Grocer, Flour, Produce, \&c., 214 Arch St., Allegheny.}

The above establishment was opener in 1874 by Mr. Z. Cruikshank, a native of AlleghenJ, horn in 1853. Commencing business on a sumall capital he has increased it to about $\$ 2,000$, bas a stock on hand of $\$ 2,000$, and is doing the snug and comfortalile business of $\$ 18,000$ per annum. His stock of goods will at all times be found pure, sweet and fresi and free from any adulterations whaterer; his specialty is pure, choice teas of a superior quality, ehoice fruits and vegetables of all kinds kept in season. His establishment is a two-story brick house $15 \mathrm{x} 70$ feet in size. Conrteous attention given to all, and prices as low as any honse in the city.

\section{W. T. BOWN \& BRO.-Coffee Roasters, No. 9 and 11 Seventh St.}

This well known house supplies a long felt want on the part of our wholesale and retail grocers. Beginning operations with contracted facilities, the business has grown to large proportions, compelling them to remove from their old quarters to their present commodious premises, where, with the capacity for roasting 8,000 pounds of coffee daily, and the finest improved machinery, engines and other appliances, this house now takes rank as the principal establishment of the kind in the city. Their business is exclusively roasting and grinding for the trade. They use the most perfect machinery for browning, and the removal of all foreign substances in the process of roasting by a patented inrention of their own, and mills for grinding, all operated by a 25-horse power engine. Nine hands and one team are employed, hesides the firm, consisting of W. T. and S. E. Bown, the former being a native of England, but a resident of this country for a long period, the latter having been born in Alle gheuy.

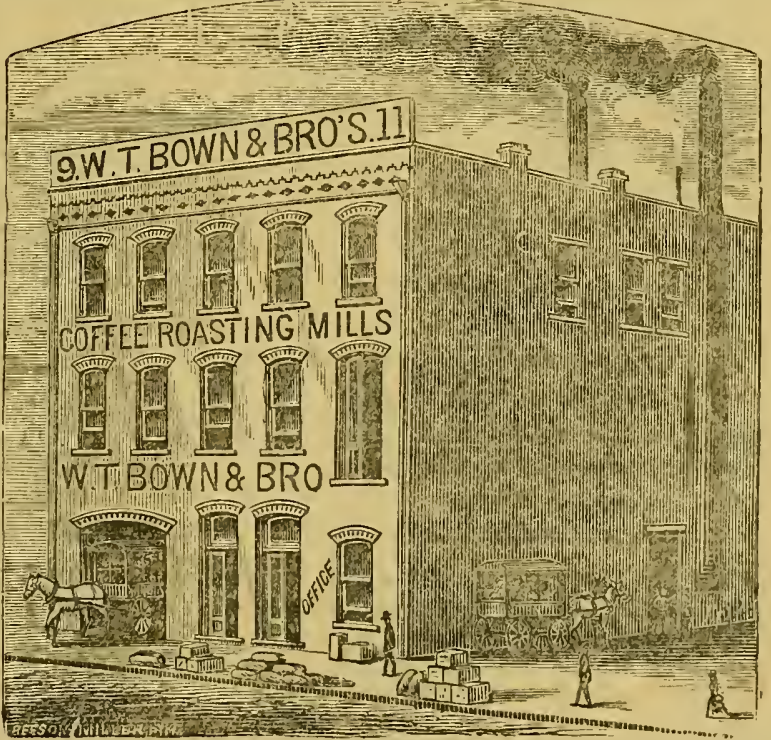




\section{SHERRIFF \& HAZELY,-Iron \& Wood Working Machinery}

and Manufacturers' Supplies, Market St. \& Third Av.

The above named firm was estahtished May 1st, 1879, both members having been previousiy engaged in the same line of business, with a thorough knowledge of all its requirentents and a practical experience of many years. Mr. Sherritf has been illentitied with the business for the past ten years and until recently was a member of the well-known firm of J. B. Sherritt; Son $\&^{\cdot} \mathrm{Co}$. Mr. Hazely is a practical machinist of long experience, who has for many years been connected with the house of M. B. Cochran \& Co., in the same business. They occupy the spacious warervoms $22 \times 70$ feet, at the corner of Market street and Third avenue, earrying a full line of every description of iron and wood working machiner y maufacturers' supplies, brass castings, gas pipe and fittings, steam gauges, belting, hose packing and the machrated "Coll" steam syphon pumps. For this pump they are the sole agents for the United States. This firm makes a leading specialty of emery wheels, and is perhaps the only house in Pittsburgh that carries a full and complete stock, embracing every size required in the trade. They also deal in new and second-hand engines, boilers, and machinery of all kinds. Mr. Sherriff is a native of Pittsburgh and enjoys an extended business acquaintance throughout this section. Mr. Hazely was born in Connecticut and has resided in this city for the past eleven years. Both gentlemen are active, energetic business men and their commercial career commences under the most favorable circumstances.

\section{J. B. HAINES,-Wholesale Dry Goods, No. 94 Wood St.}

Of those houses engaged in the Wholesale Dry Goods trade, it is entirely safe to assert that none in this eity occupy a position more entitled to consideration than that of J. B. Haines, both with reference to the high commercial standard upon which its operations are conducted and the extent of the business transacted and influence upon the market. Since its establishment in 1852, by and under the style of Hampton, Wilson \& Co., this house has always held a prominent place in the dry goods trade through all the changes incidental to a career covering a period of more than a quarter of a century. From its first title, after a continuance of some years, the house became Wilsun, Carr \& Co, which by the withdrawal of Mr. Wilson and the purchase of his interest by David MeCandless, was changed to Carr MeCandless \& Co, and to David IICCandiess in 1872, by the demise of Mr. Carr. At this time Mr. J. B. Haines was head salesman of the concern and had then been connected with it for many years. Mr. Sheibler had eharge of the books, clerieal department and much of the finances, he also had been almost brought up in the house, and when, in 1872, David McCandless retired from the dry goods trade to assume the chairmanship of the Edgar Thompson Steel Co., Limited, and engage in the wider oceupation of a manufacturer, the gentlemen just mentioned, as Haines \& Sheibier, succeeded to the business and conducted it together till 1877, when, from ill-health, Mr. Sheibler was obliged to retire and the house came under the entire control of Mr. Haines. Through all these mutations, the characteristics first exhibited by its founders seem to have passed with its proprietary interests from hand to hand, gaining some added value, rather than losing efficacy at each successive transfer, making more prominent, if possible, the honorable, enlightened and enterprising policy for which the house was always conspieuous. The late Darid IIcCandless was a striking illustration in his own person of these attributes, and possessed uot only marked talents as a business man, but that high sense of justice and rectitude that made him the ornament and excmplar of the best commercial class of society in Pittsburgh. With such an established reputation, jt is no matter of surprise that the house has always been a favorite one, appropriating a very large share of the trade transacted in this city and affording buy crs certain advantages, the results of a long connection with the most extensive manufacturers in the country, that cannot be easily duplicated by any similar conceru in the West. The facilities, so far as regards the premises occupied, for the successful operation of the business, are all that could be desired, no house having a more ample, commodious or eligibly situated building. At. No. 94 Wood street, in the very center of the mercantile traffic of the city and convenient to all prominent points, is located the handsome edifice of the house, five stories in height, thoroughly appointed throughout, having an $\mathrm{L}$ that secures an ample frontage on Diamond strect, a finished basement, and numerous other convelliences. Here may be found at all times a very complete assortment of Staple and Fancy Dry Goods, Foreign and Domestic, embracing a wide range in the varied departments of textile falories and affording an opportunity for selection rarely attainable outside of the great markets of the country, with a perfectly comprehensive knowlerige of the business and a niee discrimination as to the exact requirements of the trade. Mr. Haines has made his house a nost desirable one with which to establish pleasant and profitable relations, no one understanding better how to secure for buyers, through a wide experience, the lowest prices and best terms ohtainahle. Cordially commending this house to the trade and the public, and directiug attention to the manner in which it is conducted and the amplitude of its resources, it may be properly added that, as ranking among the fir'st in the line of its cotemporaries, the establishnient of Mr. J. B. Haines is of that class which commands the respeet of the trade and the consideration of the community at large.

\section{F. IAISER, - Wines and Liquors, No. 400 5th Av.}

This house, which is one of the best known and oldest establishcd wholesale liquor concerns in the city, was started by Mr. Kaiser in 1860 , on a nominal capital, so that the present position Mr. Kaiser has attained is due purely to his own talents and perseverance. The building now occupied is a three-story brick rarehouse, having a frontare of 60 feet on Fifth ave. and extending back 112 feet. At 406 and 408 Fifth ave. mily be found wine vaults of very considerable eapacity, which are used tor storing wincs, which are a very prominent feature in the trade of the house. A stock of $\$ 60,000$ is carried, embraeing a full line of Wines and Liquors, both foreign and domestic, while the concern is particularly noted for the fine line of Rye Whiskies and California Wines which they carry in stoek. The annual business anounts to $\$ 100,000$, and the trade of the house is principally in Western Pennsylvania, Eastern Ohio and West Virginia.

Mr. Kaiser is a native of Switzerland, and was born in 1822, but, having been identified with the business interests of the Iron City for so many years, is justly looked upon as onc of the founders of the great jobbing trade the eity now enjors. II

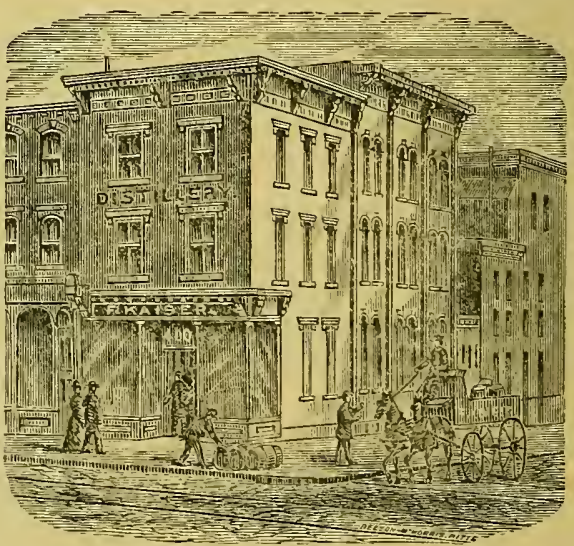
has the fullest confidence of his customers, while his standing in the business conmunity is of the highest character. 


\section{EBERHARDT \& OBER,-Lager Beer Brewers \& Maltsters,}

Mr. Eberbardk, the original founder of this now popular and extensive establishment, was the third person who engaged in the manufacture of Lager Beer in Allegheny County and the first to introduce steam power into the busiuess, which has at the present day assumed a magnitude which places it uext in importance to that of the iron, steel and glass interests of the twin cities. As early as 1852 he commenced the brewing of Lager Beer on a coniparatively suall scale, and in 1870 the present firm asumed the management and control of the business, making extensive inprovements and additions and producing a superior quality of beer which attained a wide spread and deservedly pojular celebrity throughout the two cities and adjacent territory. The extensive buildings oceupied by this firm cumprise one two-story frame structure $40 \times 44$, a four-story brick malt house, $50 \times 85$, with a capacity of 20,000 bushels, a two-story brick brewery and boiler-house, $40 \times 50$, with a mammoth steam-kettle of a capacity of 80 tarrels per day, two large boilers, 20 feet in length ly 42 inches in dianeter, and two engines of 20 and 15-horse power each respectively. Three large and splendialy arranged rock vaults for storage, which are admitted to be the finest, coolest and nost perfectly constructed in the city, have a capacity of 5,000 barrels, and a new and spacious ice-housc, 50x 80 feet in size. As they live in the Iron City, they thonght it best to construct their ice-house according to the general characteristics froin which it is named, and it will therefore be substantially built of iron, stone and brick and will cost 0 ver $\$ 20,000$. All the girders and joists will be of iron, and it wll be one of the finest and most complete structures for this purpose in the United States and will contain over two thousand tons of ice supplied from an ice pond belonging to the firu situated on Pine Creek, about six miles from the brewery where they also have another ice-house, 50x163 feet, containing seren thousand tons and furnished with a powerinl steam elevator capable of lifting eight hundred toris per day. All the huildings connected with this model establishment are supplied with the best and most perfect miachinery, apparatus and appliances known to modern science for the successful prosecution of their business. The average stork carried by this house amounts to not less than $\$ 35,000$, while their annual sales will agrregare fully $\$ 100,000$. The present production of the brewery is about $\$ 14,000$ barrels per annum, hut with their increased facilities 49,000 barrels can be readily manufactured. Every department of the establisbment is under the direct supervision of competent and skilled men, and fifteen hands are constantly employed. The quality of the Beer manufacrured by this enterprising lirm is in every respect first-class, only the best materials heing used and careful at rention paic to all the minutia of the various stages of production. Mr. Wm. Eberhardt is a native of France, where he was born in 1843. He his resided in Allegheny since he was three years of age and has been promineutly identified with the business interests and material prosperity of the city. In 1873 and $187 t$ he represented his ward in the Common Counnative of Alleghen of the firm are highly respected and honored citizens in all the various walks of lije, and the brewery under their able and judicious management, has become celebrated as one of the wost perfect and complete establisliments of its kind in the two cities.

\section{CHARIES \& MCMURTRY,-Patent Hot Pressed Nuts, \&c., 16th St.}

The inanufacture of Nuts is one of the important branches of the iron business in this citr, entitled to notice in a work of this description from the magnitude and extent of tlic husiness, and from the fact, also, that the production of these articles by machinery originated in Pittshurgh, the first machine for this purpose having lieen luijt in this city in 1850 by Messrs. Carter \& Rees. The tirm of Charles of IIcII urtry, which is to-day the leading establishment of its kind in the United States, if not in the world, was establisised in 1875 , and since that time bas uade a specialty of the inanufacture of Hot Pressed Nuts of all kinds and sizes. Their extensive establishment on Sixteenth St. is fitted up with the most complete improved machinery of every description for successfully carrying on this business in all its departments, including ample steam power and the larrest Nut machines in existence, among whicl are inprovements introduced hy this firm and important inventions of which they are patentees and sole proprietors. They latve facilities for manufacturing the largest Nuts ever made in the world by a large and powerful machine constructed on the most approved and scientific principles; and the superiority of all Nuts manufactured by this firm with their improved processes is acknowledged all over the country. The principal demand for their products is from railroad companies, bridge companies and contractors and manufacturers in all branches of industry requiring Nuts of superior quality and durability; and their trade extends all over the United States, from the Atlantic oceatn to the Pacific coast. Mr. Charles, the senior member of the firm, was for many years asssociated with the firm of Carter \& Rees, the first establishment that ever made a success of the manufacture of Hot Pressed Nuts, and is thoroughly acquainted with all the requirements oi the business. Mr. McMurtry laas also had the benefit of long experience in this peculiar branch, and both members of the firm are active, energetic and reliable business men.

\section{J. IEVY,-Phila. Branch Clothing House, 91 \& 93 Federal St., Allegheny.}

The above clothing and gents' furnishing establishment is lacated on the west side of Federal street. a short distance above the $\mathrm{P}$. R Depots, and directly on the line of the Pittsburgh \& Allegheny and the Troy Hill Passenger Ratilwars. Here will he found a choice assortment of ment and boys' clothing of every variety, gents' furnishing goods, de., sold as low as any house in Allegheny or Pittshurgh. NIr. Lery was liorn in Germany in 1838, and has resided in this country for many years His stock is large and the quality and price of goods can at all times be relied upon. Clothing of all kinds made to order and warranted to fit, and all goods guaranteed as represented. Call and be convinced.

\section{E. S. IRENNEDY,-Wines and Liquors, 1321 Carson St., S. S.}

Althougn this honse was started as late as December 1877 , it has met with a large measure of success; indeed, so successful has it been that Mr. Kenned $r$ has alread $y$ heen compelled to increase the $\$ 1,000$ canital, with which he commenced, to $\$ 5,000$, to enable him to met the demands of his rapidly inereasing trade. Mr. Kennedy makes a specialty of fine foreign Brandies and wines, which he imports directly in bond to Pittsburgh. His store and warehouse occupy a large four-story huilding, 20 feet front hy 80 feet deep, and are well stocked with cvery thing in his line. C. S Kennedy was born in Ireland, in 1848 , his parents emigrated to America, however, before he was one year old, and he was brought to Pittsburgh. He learned the trade of a glass-blower, and worked steadily at that business until the great strike of 1877 , Then, having some capital, he launched into business for himself, and las succeded beyond his expec-
tations. IIr. Kennedy is well liked in his neighborlood, and at present represents his ward (the 28th) in the city councils, to the entire satisfaction of its eitizens.

\section{W. H. SKYLES \& CO.-Tallow Chandlers, Cor. 25th \& Liberty Sts.}

Prominent among the business interests of the Iron City and occupying a position of high standing in the business world, attained through individual efforts and ability, is the firm of W. H. Skyles \& Co., Tillow Chandlers; and is this branch of tmsiness theirs is the leading house in that line in this city. Their trade which is very large, is mainly foreign, the gre:t lulk of their product being exported to foreign nurkets. A brother of Mir. Skyles, a thornughly practical and experienced gentleman, is superintendeut of the manufacturing department. The gentlemen eomposing this firm are men of character and ability, every way worthy of prominent mention and work devoted in the industrial history of the city of Pittslourgh. 


\section{HOME HOTEL, -Duquesne Way, Bet. Eighth \& Ninth Sts.}

This is an institution of which the eity of Pittsburgh may well feel proud, and which is in every way deserving patronare and generous support. It was originally established about fourteen years ago by a number of benevolent and philanthropic individuals as a bethel for the relief of the needy and deserving poor. A bout seven years ago additions were male and a spacious and elegant four-story first-class hotel was erected fronting on Duquesne Way, who most thorough manner with all the modern improvements, ineluding gas, water elosets whel haths are free to guests and no pains is spared by those in charge to make this and bath rooms on cach foor. The baths are free to guests and no pains is spared by those in charge to make this hotel in the eity, and is largely patronized by clergym. The rooms are well ventilated, handsomely furnished and strictly clean and comfortable. Ladies and gentlemen visiting the smoky eity either on business or pleasure, will here find the best of accommodations, polite attendance and a table surpassed by that of no other house in the country. The foure IIotel is pleasintly and eligibly located on the banks of the Allegheny river, commanding a fine view of the Suspeusion and Hand street bridge and the beautiful city of Allegheny, and is away from the smoke, dust and brsy din of traffic, noise and confusion of the large manufacturing establishments. Horse cars to all parts of Pittsburgh and Allegheny pass within a few steps of the door, and the main business houses are within three minutes walk. The Home Hotel is under control of a board of directors, and was established for the purpose of deriving a revenue from its receipts to aid in maintaining the Bethel, which is entirely separate from the hotel, and is a spacious establishment where hundreds can be supplied with food and lodgings at a merely nominal priee. During the inclement Teather of the winter months thousands of unfortunate persons avail themselves of its advantages. At present about sixty or seventy persons are entertained here. Rev. W. Long is superintendent of the Bethel; meals and lodgings are here furnished for five cents each. Of course at these prices the Bethel cannot be self-sustaining, and the receipts of the hotel after paying running expenses are devoted to the praiseworthy object of making up the defieieney ; thus patrons of this house not only secure all the advantages of a strietly first-class hotel, but aid a worthy and deserving charity. The rates at the Home Hotel are as low as can be afforded and are as follows: per day $\$ 1,25$, meals 25 cents, loging from 40 to 50 cents, board and Lodging per week from $\$ 5.00$ to $\$ 8.00$, and rooms per week from $\$ 2$ to $\$ 3$. MIr. J. E. H. Kelley, the general manager, is a practical hotel man of many years experience, whose popularity and goot social qualities have secured him a host of friends through all sections of the country. Mir. George H. York attends to the office department during the day and a competent assistant officiates as night clerk. These gentlemen are thoroughly conversant with their business and make every effort to please and entertain guests. In addition to the accommodations usually found at other hotels, ladies and gentlemen will liere find social and moral enjoyments of the highest order. One hundred and fifty guests can be comfortably aecommodated at the Home Hotel, which is deserving the liberal patronage of a diseriminating and generous public.

A. S. MUNDORE,-Planing Mill, Lumber Yard \& Box Factory, 23d \& Mary Sts., S. S.

One of the prominent and leading industries on the South Sirle, Pittsburgh, is the Planing Mill, Lumber Yard and Box Factory of A. S. Mundorf, at the corner of Twenty-Third and Mary streets. The business was started in 1867 by Ir. G. jundorf, who was succeded few years since by the present proprietor, who has largely increased the business. There is now in stock in the mill and yard about 200,000 feet of clear lumber and select stuff, which is below the average stock carried. The business runs from $\$ 75,000$ to $\$ 80,000$ a year and is steadily increasing. There are two buildings in use, the planing mill, a two-story frame structure, $80 \times 120$ feet, and the office buildings. The lumber vird covers an area of $264 \times 380$ feet. Twenty-five hands are constantly employed and the monthly pay-roll runs from $\$ 1.000$ to $\$ 1,500$. The capacity of the plining mill is from ten thousand to twenty thousand feet of flooring per day. Mr. Mundorf, owing to his unequalled facilities, is prepared to give estimates for the largest contracts and furnish material on short notice. In addition to the other business, this concern runs one of the most extensive box factories in the country, and deals extensively in pine and hemloek lath and shingles. They have another advantage over many other lumber dealers in having their lumber cut expressiy for them in the vast lumber regions up the Allegheny River. The power to ran this immense concern is supplied by an engine of sixty-horse power, two boilers 36 inches in diameter and '2t feet long, and the mill contains all the latest improved and most modern machinery in use in that line of business. Mr. Mundorf was born in Jefferson county, Pa., in 18.54, from whence he came to this city, where he has remained since. He occupies a leading position among the business men of the community, and his social standing in the community is of the very best.

\section{MONONGA HEIA HOUSE, -J. M. Crossan, Prop., Smithfield \& Water Sts.}

This is the lealling Hotel of Pittsburgh in all that pertains to a strictly first-class house. The original Monnngahela House was built in 1st1, but w:Is destroyed and the disastrous conflasration which swept away the greater part of the business portion of the city in 1845 . It was rebuilt upon a larger scale in 1846 and reoccupied as a hotel in the spring of 1847 . The cost of the building and lot at that time was $\$ 300,000$. In 1867 the house was remodelled and refurnished throughout, at a cost of $\$ 150,000$. The building is $160 \mathrm{fcet}$ square, five stories high, and contains 245 apartments, with spacious aud elegant parlors, large diuing room, 32x132, and another $20 \times 70$, furnished in the most tasteful and appropriate manner; suites of rooms and private parlor's for the aceonmodation of guests, and passenger and baggage elevators. The house is supplied with a complete fire department, with hose available at any moment on erery floor by means of Babcock Extinguishers, etc. An elegant billiard parlor and first-class bar are also connected with the hoise. Six hundred guests can be comfortably accommodated at one time. One hundred and ten attiches are constantly cmployed and etch department is nresiled orer by competent and experienced persons. The father of the present proprictor was the well known and highly respected proprietor of the Old Nonongahela Honse, Col. Johu ars ago, and has been proprietor of (n) United States has

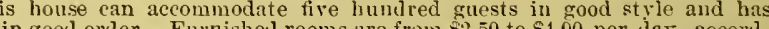
given hospitality to six lundred at one tinue in good order. Furnishel rooms are from $\$ 2.50$ to $\$ 1.00$ per day, aceording to locition, sileeial rates heing mate to tronpes and combinations of any kind where clubbing rates are required,
As one of the old landm 'rlks of the cit $y$ and an emblem of our city's past history and present prosperity, we are nrond to refer you to the old Afonongahela F́louse.

\section{J. S. REED \& SON,-Planing Mill, Box Factory \& Saw Nill, Cor. 24th St. \& Penn Av.}

The business now conducted by the abnve firm and to which it succeeded in $157 s$, was established in 1865 br Wm. Rigden, who conducted it until it came into the hands of Messrs. Reed \& Son. The establishment is well equipped for the prosecution of the thrce departments of the work, being furnished with the latest and most approred machinery which is ofcrated by a steam engine and boiler of reguisite power. The senior partner is inl expert meehanician, horn in Bedford county, Pai., in 1823. He early acquired the trade of earpenter, at which he worked for some time, and aiter scrving through the Mlexican war with distinction, he again resumed his arocation, and enlarging lis resources became a builder anl contrictor. Since his residence in Pittsburgh he has been engaged in the line of his present business in which he has been very suceessful, the proceels of his toil, howerer, being mainly lost throngh the insolvency of others. The tirm, however, with resolution and ability has retrieved its losses and is heartily commended as reliable, prompt and liberal in dealing, highly considered by those with whom it effects relations and prepared to offer unusual advantages to buyers at this or distant points. 


\section{PITTSBURGH PLANING MILIS,-Douglass \& Keally, Proprietors,}

Prominent among the industrjes and commercial pursuits of the Smoky City may be considered the general lumber interests. Among the houses engaged in the trade, the excellent firm of Douglass \& Keally stands in the front rank among the largest dealers in Western Pennsylvania. The Pittsburgh Planing Mill, of whieh these gentlemen are proprietors, is most complete in respect to machinery, stock and all appliances. They manufacture every variety of flooring weather-hoarding, sash, doors, shutters, window-frames, mouldings, etc. employing a large force of inen in the various departments. James Douglass, senior partner, was born in Ireland in 1832 and came to the United States in 1847. He worked at carpentering until 1865 , when he entered his present business in partnership with Mr. MeKee. Mr. A. D. Keally was born in this city in 1847; when thirteen years of age he commenced working for limself in a grocery store and remained in this business until he entered the service of Messrs. Douglass \& McKee as book-keeper. Upon the retirement of Mr. McKee Mr. Keally entered the firm, althougl also engaged in the grocery aud provision business at No. 1139 Penn avenue. He is at present a member of the school Board of his ward.

\section{KEXSTONE TANNERY,-J. C. Lappe, 188 to 196 Spring Garden Av., Alle'y.}

One of the largest and most extensive tanneries west of the Allegheny mountains is that of Mr. J. C. Lappe, known as the Keystone Tannery, and located on Spring Garden A vente, Allegheny City from No. 188 to 196 inclusive. This business was founded in 1812 by Mr. Lappe. There are four large buildings connected with the establishment, the main structure being $100 \times 200$ feet in size with three adjoining huildings, with a capacity for storing 2,500 cords of bark. The tannery was originally located on Chestnut street, Allegheny, but wias destroved by fire in 1865 and rebuilt at the present location the following year on a much more extended scale with inereased facilities and accommodations. The tannery is fitted up with all the requisite appliances and conveniences, and has ninety-five eapacious vats and fifteen leeches. It has a capacity for turning out six hundred sides of leather per week. Forty-six hands are regularly employed at this establishment and the leather produced is of a superior quality and conimands a ready sale in all portions of the United States. Oak tanned harness leather is the particular specialty for which the Keystone Tannery is celebrated, and this snecial production is not excelled by that manuiactured in any similar establishment in this country. Mr. Lappe is to be congratulated upon the fact that he has from a comparatirely small beginning built up by his own unaided efforts, energy and ability a business of such magnitude and proportions, and the city of Allegheny is particularly fortunate in having within its limits so snccessful and important an industry a the Keystone Tannery. Mr. Lappe is a native of Umstadt, Hesse Darmstadt, and was born in 1816 . He came to this country in 1839 and located in Allegheny city the same year. Since that period he has been actively engaged in bnsiness pursuits and is highly respected.

\section{A. L. CLARK,-Carpenter \& Builder, 225 Rebecca St., Allegheny.}

Mr. Clark is a native and life-long resident of Allegheny city. He was born in 1843 and since arriving at maturity has been identified with the business interests of the city. He is a thorough practical carpenter and builder and commenced business for himself at his present location in 1861 with moderate means bnt with a determination to succeed. He has now a capital of $\$ 3,000$ inrested and has established a flourishing and lucrative business amounting to not less than $\$ 3,000$ per annum. The premises occupied by him are $75 \times 100$ feet, on which is erected a one-story frame building $24 \times 50$. He carries on a general carpentering and jobbing business, and contracts for the construction of buildings of every description. Six hands are employed and he carries a stock valued at about $\$ 5,000$. Mr. Clark is a highly esteemed citizen and responsible business man, and at the present time holds the position of tax collector of his district.

\section{J. STEVENSON \& CO.-Pork Packers, etc., 327 and 329 Penn Av.}

The îrm of J. Stevenson \& Co. has been but recently established, althongh the senior member has been identified with this branch of business in Pittsburgh for the past twent $y$-two vears, and during a greater portion of that time associated with the well-known house of E. H. Meyers \& Co. Messrs. Stevenson \& Co. are the immediate successors of F. Sellers \& Co., which was the oldest-established pork house in the city, having been founded in 1842, and which for nearly forty years has maintained its position as the leading house in Pittsburgh in this branch of business. Messrs. Stevenson \& Co. occupy the spacious douhle warehouses Nos. 327 and 329 Penu avenue, near Tenth street, carrying a stock of not less than $\$ 60,000$, consisting of Beef, Pork, Provisions, Sugar-cured Hams, etc., and transacting a business of not less than $\$ 150,000$ per annum. Their trade extends throughout Pennsy Ivania, Eastern Ohio and 11 aryland, and will compare favorably with that of any similar establishment in the city. Mr. Stevenson has resided in Pittsburgh for the past twenty-five years and is thoroughly conversant with the business in which he is engaged, and enjoys a large and extended acquaintance with the trade throughout this section. The reputation and high standing always maintained by the old house of $F$. Sellers $\&$ Co. is safe in the hands of the present enterprising proprietors of this extensive establishment.

\section{PETER CONNELLY,-Soho Blacksmith Shop, Second Av.}

Every one who owns or uses horses and wagons is interested in taving them properly shod and ironed. For that reason we desire to call the attention of readers of this work to the establishment of Mr. Peter Conneliy, who is a practical horse shoer and general blacksmith, and understands well how a shoe should be titted to a horse as a sloeemaker does the fitting of a shoe to the feet of men or women. He also does all general blacksmithing, ironing wagons, carriages, or buggies, manufactures spikes and bolts for barges and boats, and does all general job work, in this line, promptly to order. Mr. Connelly is a gentleman whose knowledge and experience entitles him to a liberal patronage and the esteem and confidence of the public. He first started in the business in 1848. He was born in Ireland, in 1825 , and came to this eity in 1832. He was one of the atditors of Pitt Township for eleven years, also serred four years in this capacity for Oakland Township, and holds the position of councilman from the 14th wasd. His shop on 2 nd are., in 14th ward, is largely patronized by city and country. He employs three hands, and his shop is two stories and $38 \times 100$ feet in size, so there is room for all.

\section{MRS. J. C. HEINTZ,-Dry Goods \& Notions, 1401 Carson St. South Side.}

This establishment was founded by Mr. Jacob C. Heintz (since deceased), in 1864. Mrs. Heintz, successor to the business, occupies the spacious building, $24 \times 80$ feet in size, at No. 1401 Carson street, eorner of Fourtcenth, and carries a stock ranging in value from $\$ 6,000$ to $\$ 7,000$, consisting of a full assortment of Ladies' Dress Goods, Trimmings, Notions and Small Wares in great variety. The specialty of this honse is Dress Goods. Her annual sales will reach from tions and Small Wares in great variety. The specialty of this honse is Dress Goods. Her annual sales will reach from
$\$ 12,000$ to $\$ 15,000$. Mrs. Heintz devotes her personal attention to the buying and general management of the business, and her taste and judgment is highly commended by the ladies of the South Side and vicinity. 


\section{STRAUB \& SON,--Brewers, 152, 153,154 \& 155 Canal St., Allegheny.}

The increasing demand for wholesome beer is regarded as a favorable sign even by temperance people, and had all our home brewers made as pure a quality of this article as has always been made by Messrs. Straub \& Son, foreign her would never have a foothold in this eity. It is undeniably true that no firm in the world can produce a better article than has always been manufactured by MLessrs. Strubb \& Son. The head of this firm is perhaps the oldest brewer in this city, and brewed the first beer niade in Pittsburyh. The main brewery and general office is located at $152,153,154$ and 155 Canal street, Allegheny, and is as perfeet in all its arrangements as a life-long experience could make it, in its enkarged and improved condition. The business part of the concern is mainly in claarge of the junior member of the firm, Mr. Theo. F. Straub, a gentleman of high charaeter and alilities. He is a native of this city with the interests of which he has been closely identified all his life. He held the position of revenue inspector of the 23rd distriet for $t$ wo and-a-half years, an office he filled with honor and credit; he las also been eonneted with the interests of his cits and community in different positions of pnblic trust, in all of which he has shown himself possessed of executive ability, together with integrity and an unblemished character. The prominent position oceupied by this firm of late year's and its successful achievements under trying circumstances, is largely due to the earnest etrort, close attention and high business qualifieations of this gentleman, who is also perhaps one of the most accomplished aud skilled brewers in t.se United States.

The tirm in their large husiness transactions have been ably assisted by Mr. Joln $\mathrm{H}$. Stotz, who is well and favorably known to all the friends and patrons of the house, having been associated with the concern for many years-a gentleman of high abilities and an accomplished finaneier. A younger son, Mr. Jno. H. Strab, a popular and eourieous gentleman of ability and eliaracter, also gives his altention to the business, and is well and favorably known and highly estecused. In this connection it may be proper to state that $M[r .4$. W. Straub, nember of the great and wealthy brewing firm of Julius Winkelmeyer \& Co., of St. Louis, Mo., is also a son of J. N. Struub, Esq. This firm also own the Union Brewery 16th ward, Pittsburgh, one of the best breweries in the eity, under the supervision of Mr. IIerman Straub, which produces the finest quality of beer, a third concern owned by this firm in Allegheny, is not at present used. The life of the senior member of this firm is an eventful, romantic and remarkable one; it has ever been chatracterized by a determined energy and persererance even in the midst of misfortunes sufficient to distsearten many a strong man. Mr. Straub was born in Germany in 1810 and learned the trate of cooper and brewer, it being a law in thit country that no person could become master of his trade without a practical business knowledge. Mr. Straub, after completing his apprentieeship packed lis knap-sack and started upon his travels to acquire that experienee requisite to his success as a master workman. Hearin much talk of the great republic berond the seas, he hecame fired with an ambition to seek his fortune in the new world, and aceordingly invested all his capital in a tieket to the United States, and arrived in Baltimore, Mut., on the $4 \mathrm{tb}$ of July, 1831. A stranger in a strange laud, among people spenking a strange language, in the midst of the noise and eonlusion incident to the day, and without a dollar in his pockets, the sensitions of this young emigrant may be better imagined than deseribed. Almost the lirst object that greeted his sight upon landing was a robust negro woman, the first colored person he ever saw ; in wonder and amazement he gazed upon her ebon countenance for some time and felt certain in his mind that the mother of his satinic majesty wats grinning him a weleome to "the land of the free and the home of the brave." Looking around for a time he discovered a line of heav $y$ wagons about leaving Baltimore for the West, and with the driver of one of these Mr. Strauh secured a passage, agreeing to assist in earing for the horses and perforning sueh other duties as might be roquired of him. Arriving at Greensburg, in this State, where the owner of the team resided and owned a farm, Mr. Straub was given work in the larvest field at reaping grain, but on the second day he ent his fingers so severely as to ineapaeitate him for further labor in that line. He shouldered lis knap-sack again and pushed on to Pittsburgh, where he was soon fortunate enough to form the acquaintance of a tavern keeper who had come from the sane portion of Germany where he was horn, and who furnished him with lodgings and secured for him a position to work at his trade as cooper. He remained at this place for awhile, earning barely suffieient to pay liis board. He next engaged with a earpet weaver by the nane of Smith, with whom he remained for two years, leaving his wiges in his employers hands, at the expiration of that time desiring a settlement he was astounded to find that Mr. Smith was unable to pay him a eent. Almost disheartened he determined to return to the Faderland, and being penniless resolved to work his passage home, making arrangements to accompany a teamster to Baltimore as assistant, he repaired to the plitce of rendezvous, but found to his disman that the wagon had gone without him. In sore distress at this new mistortune the young man sat down and wept; plucking up fresh courage, however, he repaired to the man who had previously be-
friended him and was again assisted in obtaining employment at his trade. lle worked industriously for two years and suceeded in siving a little money. About this time he became a member of the "German Greys" " the first independent German military company organized west of the mountains. In 1834 Mr. Jaeob Beyerly, a well known titilor of that day, proposed to Mr. Straub that he should engage in the manufacture of beer, kindly assisting him by lecoming his security in starting the business on Third street. This was about the commencemeni of the beer brewing husiness in l'ittsburgh which has sibes attained such a magnitude. Mr. Strauly eommeneed with a single six barrel kettle, manufacturing his own beer and barrels and deliveriug it himseli to his eustomers on a wheetbarrow. During the first two or three years his business was quite satisfactory, although his sales of yeast in lots of one to ten cents worth amounted to more than his trade in beer during that period. He was frequently compelled to let evers his small brewings go to waste for want of a denand. A bout this time Mr. Straub married an estimable lady to whose economieal and saving traits he acknowledges his indelotedness for lis first accumulation of property and success in lusiness. In 1843 he removed to Allegheny City, where he purehased sonie real estate and engaged in brewing on a mor'c extensive scale. He subsequently opened the well known establishment in the Pittsburgh Diamond, of late years known as "Roths," which js probably the oldest beer house in the eity. He carried this on one year alone, and then engaged $\lambda \mathrm{r}$. John Roth as bar keeper, subsequently admitting him to an inter(st in the business, and then turning over to him the entire establishment, furnishing the beer from his Allegheny brewery. In $18+9 \mathrm{AIr}$. Straub commeneed the manufacture of lager and the demand at retail being large he made a great deal of money. In 1858 his brewery was destroy ed by tire with a very large stoek, which was a total loss, the fire oceurring on Sunday and his insurance polieies expiring the day before. Although Mr. Straub made every effort to find the agent of the company and have then renewed in time, he wis unalle to do so, and having lis entire capital investcl in the business he found himself again without funds or means. Pussessell, however, with a stout heart, a gool reputation, unblemished aredit and liosts of friends, he was som "on his feet" again and tlue work of rebuilding was pushed rapidly forward. MIr. Straub constructed a number of eaves for storing beer along the line of the Penusylvanial ratilnatl alout this time, portions of which are yet to be seen. In 1864 he determined to retire from netive businnss and sold out his brewery. He sonn afterwards again hecame interested in the lusiness and now at the age of seventy years he is the principal owner of three breweries, to two of which that are now being run he gives his personal attention, with the assistance of his sons proviously referred to.

\section{GIBSON BLAYNEY,-Flour \& Feed, 91 Webster Av.}

We gladly give spaee to the enterurising Flour and Feed establishment of Mr. Gibson Blayney, located at No. 91 Webster avenue. The husiness to which Mr. Blayney succeeds, is one of the long established business houses of this part of the city, hut which came in to the hands of the present proprietor in 1870 . He transacts a 5 nolesale and retail business in elioicest hrands of family flour, also oats, com, baled hay, bran, chops, mill feed, etc., and delivers to all parts of the eity. His fusiness room is $20 \times 100$ feet in size and affords ample storage room. Mr. Blayney was born in Ireland in 181\%, and came to this c'ity in 1865, and first eommeneed business in this city in 1867. His jndustry and excellent business qualitications has won hin at large circle of friends and patrons. 


\section{MATHEW IANZ \& SON,-Bolts, Nuts \& Washers, \&c.}

Twenty-Ninth and Carson St.s., South Side.

One of the leading houses in the eity engaged in the manufacture of specialties in the iron working liue is that of Mathew Lanz \& Son, whose office and works are located at the corner of Twent. $y$-ninth and Carson streets, South Side. This tirm manufactures Patent Hot Pressed Nuts, Machine and Pitt Car Bolts, Screw and Drift Bolts, Coach and Lag Screws, Corner and Rake Bands for barge yalrds, Washers, Patent Screw Hook Strap and Screw Hook and Eye Hinges, Wronght and Cut Spikes, Nails, ctc. The works were originally established in 1866 by Messrs. Price \& Co., and from that time until 1877 they changed hands several times, when the present proprietors assumed the management and eontrol, introducing several improvements and ehanges and materially increasing the facilities and capacity of the establishment. The eapital invested in the business his been eonsiderably increased and now amounts to $\$ 40,000$. They oceupy three large and conveniently arranged buildings, eovering an area respectively of $40 \times 100$ feet, $35 \times 60$ feet ani $30 \times 40$ feet, fitted up with the most eomplete and permanent machinery, especially adapted to the requirements of the business, among which partieularly notieeable is a patented machine of their own invention for the manufacture of screw hook strap hinges, and a patent improved machine for pointing spikes and harrow teeth. Several other ingenious devices, tools and machines are required in the manufacture of their peculiar products. A thirty-horse power engine and a boiler 28 feet in length and 40 inches in dianeter furnishes the motive power required in this establishment, and from five to fifteen skilled workmen find employment in the various departments, in which the $y$ transact a business of abont $\$ 20,000$ per aunum. The facilities enjoyed by this bouse are not surpassed by those of any similar establishment in the United States. The Nut and Bolt trade of Messrs. Lanz \& Son is principally local, but their Hinge trade extends over all portions of the Union, East and West, and irom Canada to the Gulf. Mr. Mathew Lanz, senior menber of the firm, is a native of Germany, born in 1826. He came to this city in 1853, and has since resided here and for a greater portion of the time been actively engaged in business. His experience has been a ehequered one and he has met with many misfortunes as well as successes; but with that untiring energy and perseveranee which has ever chitracterized his business career, he has at last succeded in overcoming all obstacles and stands to-day among the most prosperots and successful representative manufacturers of our great industrial metropolis. MLr. Charles Lanz, his son, and junior member of the firm, was born in Pittsburgh in 1856 and is an energetic, active and practical business min.

\section{BENZ \& BROS.-Contractors and Builders, 125 Twelfth St., South Side.}

The business now conducted by the firm of L. Benz \& Bros. was founded in 1848 by Mr. L. Benz, senior. father of the present proprietors, and conducted by him until 1873, when it passed into the hands of Lawrence Benz, Ferdinand Benz, John Benz and Plilip Benz, under the firm name alove given. These gentlemen occupy two extensive lot: ove covering an are: of $96 \times 110$ feet, aud one $120 \times 160$ feet, and two two-story buildings, one $20 \times 60$ and another $36 \times 90$ feet in in size, for the storage of their lumber and the manufacture of finished work pertaining to their line. One fortytive-horse power engine with a boiler 22 feet in length and 42 inches in diameter, furnish the motive power. These gentlemen are prepared to furnish estimates and eontract for the construction of any desired style of dwelling, lusiness block, church elifice, public or private buildings in the most thorough and workmanlike manner ancl at the most reasonable rates. They carry constantly on hand a stock of about $\$ 12,000$ and their annual business reaches from $\$ 50,000$ to $\$ 100,000$. The number of hands employed varies according to the seatson, but will average twenty-fire, witb a monthly pay-roll of not less than $\$ 600$. Mr. F. Benz is book-keeper and manager of the clerical. department, while the other members of the firm are all practical meehanics and are thoroughly conversant with the various departments of the business. They hive had long experience and thorough instruction under the able and successful management of their honored father and predecessor. They are natives of this city, where they have resided all their lives. They are enterprising business men and enjoy the confidence and esteem of all with whom they are brought in contact.
The firm is justly entitled to a prominent position among the representative manufaeturing and business houses of Piltsburgh.

\section{H. F. BRUGGEMAN,-Wholesale and Retail Grocer, $537 \& 539$ Penn.Av.}

The extensive Wholesale and Retail Grocery establishment at Nos. 537 and 539 Penn avenue was founded in 1568 by Mr. H. F. Bruggeman, the present proprietor, in a small way at first and with a capital of only $\$ 50$. MIr. Bruggeman learned the business with his hrother, who had for a number of years previously been engaged in the sime line of trade. He now occupies two four-story brick buildings, one $40 \times 40$ and one $40 \times 60$, at the numbers named, where ho carries i full and complete stock of choice Family Groceries, Fruils, Sugars, Coffees, Teas, Spices, Havana and Domestic Cirars, Mantfictured Tolraccos, Fine Flour, ete His average stock is abont $\$ 10,000$, and his annual sales will exceed $\$ 30,000$. Eight assistants are employed. One room is devoted exclusively to the sale of Cigars, Tobacco, Canned Goods and Fancy Groceries, of which articles Mr. Bruggentın carries an extensive stock, and his establishment is the leading one of its lind in this section of the city. Mr. Bruggeman was born in Germany, lut has resided in Pittsburgh for the past fourteen years.

\section{JAMES OW ENS,-Plastering, Cement, etc., 72 and 74 Seventh Av.}

One of the most practical, ingenious and skilled Contractors and Jobhers in this line in the city of Pittsburgh is Mr. James Owens, whose place of lusiness will be found at 72 and 74 Seventh avenue. Having thoroughly inilstered the business, he started in 1855 in a small way, but his skill soon brought him success. IIc carries in season a full supply of everything needed in his line and is now doing a business that will reach about $\$ 1,600$ per annum. He occupies part of a building $35 \times 80$ feet in size, where he may be found, when not engaged upon work, and where all orders for work may be left. His business embraces Plastering, Cumenting, Mlastic (he was the first person to introduce the latter in this city), Kalsomining and Paper Hanging, Grates Set, Chinineys Topped, and all work of this kind executed promptly on reasonable terms. He has a peculiar kind of fine wash for coloring brick and stone houses, which will preserve them against water and weather equal to the best oil or paint. His specialty is Stuceo Work, Mistic, and his new process of Water Coloring. He was born in Ireland in 1833 , and eame to this city in 1847.

\section{J. F. MOORE,-Carpenter and Builder, 72 and 74 Seventh Av.}

One of the best skilled carpenters in this city is Mr. J. F. Moore, whose place of business can be found at Nos. 72 and 74 Seventl avenue, where he occupies an office and shop $35 \times 50$ feet in size, with ample yard room, and giving employment during the busy season to from six to eight hands. He takes eontracts for all kinds of buildings and is competent to perform the best and most artistic work in this line, acknowledging no superior in the city of Pittshurgh either in skill or promptness. The business was originally started by him in 1872 with molerate capital, but backed by determined energy and a consciousness of thoroughly understanding the business in all its details. He soon met with abundant employment and is now doing his full share of business, which will avcrage about $\$ 3,500$ per annum. He has secured some of the best buildings in the city and never fails to give satisfaction in his work. He was born in Ireland in 1847, and eame to this city in $180^{\circ}$. II is a pleasant gentleman to deal with and reliable in all his business transictions. 


\section{LIVINGSTON \& CO. - Novelty Works, Iron Founders \& Mfs. of Builder's Hardware,} 243 to 25: Washington Av., Allegheuy.

The large and extensive manufactory of Livingston \& Co. is situated on Washington ave., Allegheny, near the P. F. IV. \& C. R. W. and is one of the largest and most complete estiblishments of the kind in the United States in their specialty of light cast Hard ware. The business was tirst established in 1866 on a small capital, by W. II. Burt \& L. O. Livingston, and has rapidly increased, until it now reaches the large and magnificent $\$$ sum of $\$ 100,000$ per annum, with a stock on hand of $\$ 20,000$. The building is a large two-story franc, $144 \times 144$ fect. The firm have about 35 hands constantly employed, and their pay-roll foots up to \$250 per week, and their trade extends all over the United states and Canada. They are largely engaged in the manufacture of the monitor corn sheller, a neat, durable and simple machine, weighing only about 15 pounds, and eapable of shelling a bushel of corn in five minutes. The most perfect hand corn sheller ever inveuted. There are over 20,000 now in use, and thousands of testimonials bear witness to their excellence and superiority. They have taken the medal and first premiums at the Pittsburgh Exposition, and wherever exhibited. Every sheller is warranted. Evcry farmer and poultry raiser needs one, ani the low price places them within the reach of all. The price of the sheller with separator is only $\$ 6$, and the price without separator \$5. One engine of 30-horse power and boiler are used. The members of the firm are both Eastern men. Mr. L. O. Livingston was born in Vermont in 1836, and W. H. Burt in Northampton, Mass., in 1832. They are men of enterprise, deserving of success in their undertaking. The frm are also extensively engaged in the manufacture of fine light castings of all kinds, plain, japanned, bronzed and galvanized, made to order promptly. They make a specialty also of light castings for agricultural implements and light machinery, and particular attention is called to their f:umily grist mill for farm and plantation use, and costing but the small sum of $\$ 12$. Send for circulars and price list, \&c., containing full information. Address, P. O. Box 302, Pittsburgh, Pa.

\section{RED TOP BOTTLING CO.-G. W, Holt \& Co., 1041 Penn Av.}

The young and euterprising hirm of G. W. Holt \& Co., engaged in the manufacture and bottling of Birch Beer, is located at 1041 Penn ave., where they began the business in quite a limited manner, with small capital, in 1878, doing business under the name of the Red Top Bottling Co. The firm is composed of G. W. Holt and Jno. W. Friesel, both of whom are young men of character and alility, and are pushing their business in characteristic style. The article manufactured and bottled by these gentlemen, Birch Beer, is $n$ delightful and refreshing beverage, possessing many valuable tonic and medicinal properties, as well as being a very agreeable and pleasant drink. It is in this respect superior to sarsaparilla, which in color it resembles, and which it is in many cases supplanting, as well as mineral water. It contains no alcoholic properties whatever, and in this respect can meet the approval of the most ultra temperance people. The manufacture and sale of this beverage is yet in its iufancy, and it will in time, doubtless, reach large proportions. They use a patented cork and neat bottles, and their trade mark, which is copyrighted, is a "Red Top" on all bottles. Their capacity now is 2400 bottles per day. G. W. Holt was born in Pittsburgh in 1854, was raised on a farm near the city. He was employed in grocery stores in the city for 5 years, where be gained a practical and useful business knowledge. He was afterwards engaged in saloon business in 1876, which he shortly closed out and quit, and embarked in his preseut enterprise. Mr. Friesel is also a native of Pittsburgh. He is now, and has been for a number of years, engaged iu the coffee roasting, leaving his partuer, Mr. Holt, to manage the bottling business.

\section{JOHN U. BARR,-Architect, 421/2 Sixth Street.}

Mr. John U. Barr, one of the most famous and successful architects of this section, was born in 1815. At an early age he emigrated to Muskingum County, Ohio, where he learned the trade of liouse carpenter. Having a natural taste for designing, he devoted his attention to the study of architecture at Philadelphia; came to Pittsburgh in 1836, and hy industry and close application soon became master of the protession which he has followed for the past thirty-eight years with most gratifying results. He is probably the oldest architect in this section actively engaged in this line of business, and the number of public and private buildings erected under his supervision is greater than can be shown by any other member of the profession. Among some of the most notable we may mention the Armstrong County court house, the Allegheny City buildings, the Allegheny work louse, the Pittsburgh market house, Mercer County court house and jail, and hundreds of other structures, inciuding churches, colleges, factories, hotels, business blocks and private residences throughout the country. Mr. Barr is prepired to furnish plans and specifications for any kind of public or private buildings and superintend their construction at the most reasonable rates. Mr. Barr.has two sons, Mr. John U. Barr, Jr., twenty-three years of age, is also an architect by professiou, and Mr. S. A. Barr, who occupies the same office, is engaged in tlie real estate and insurance husiness.

\section{ARNOLD KOCH,-Pharmaceutist, No. 1203 Carson St., First Nat. Bank Building.}

An important feature in connection with the business of any city are its well conducted drug establishments, and in a compreliensive work which presents in a permanent and attractive manner the business facilities of this cit $y$ we take pleasure in noticing the excellent and popular drug house of Mr. Arnold Koch, located in the First National Bank Building, No. 1203 Carson street. This business was originally started hy Mr. Koch in 1862, opposite his present location, to which he removed in 1875 , with ample capital to conduct a No. 1 drug store, and where he has enjoyed an excellent patronage. He carries at present a stock of about $\$ 8,000$, and is doing a trade that will average about $\$ 9,000$ annually. He occupies a handsome three-story brick building, $18 \times 70$ feet in size, embracing three departments, and employing two competent assistants. The stock embraces a full line of Pure Drugs and Medicines, all popular and desirable Patent Medicines, Perfumeries and Toilet Articles, and all sush articles as are usually associated with a birstclass drug house in our larger cities. Special attention is given to the preparation of physician's prescriptions, which are carefully compounded from purest medicines. Mr. Koch was horn in Germany, Oct., 1838. He began stildy in 185.2, was educated and graduated as druggist in 1857 , came to this country the same year, and to this eity in 1861 . He makes a specialty of German and other rare drugs. An accomplished druggist and scientific chemist, he richly deserves the popularity and confidence he receives.

\section{F. C. GREINEISEN,-Druggist, 746 Carson St.}

The increase in the population and constant growth of the city must have its legitimate effect upon the general business of the 3tth ward, and in connection with the leading business houses of this section of the city, we take pleasure in noticing the enterprising drug house of Mr. F. C. Greineisen, which was started by himself in 1869 . He was burncd out in 1874, but, with becouning spirit of enterprise, he rebuilt the same year, and has since been in the enjoyment of a very excellent business. He occupies a two-story brick building, $23 x+0$ feet in size, and bas it well stocked with pure Drugs and Medicines, Popular Patent Mredicines, Perfumeries and Toilet Articles, Notions, Sc., and being a thorough druggist, with a comprehensive knowledge of materia medica, takes special pains accurately to compound and fill physicians prescriptions, either in English or German. He carries a stock of about $\$ 3,000$, and transacts a business of about $\$ 5,000$ per andum. Mr. Greineisen was born 11 Germany, in 1816 , and came to this city in 1866 . He will not only be found a good druggist, but a pleasant and accommodating gentloman. He served the regular apprenticeship in Grermany, and graduated iu 1864. 


\section{KEYSTONE CHAIN WORIS,-Eisenbeis \& Helm,}

Cable, Shipping, Crane, Quarry, Rafting, Raitroad and Agricultural Chains, Rail Road St., bet. $28 t h$ \& $29 t h$ Sts.

The manufacture of chains of all descriptions is in a measure a new industry in Pittsburgh, but there is no reasou why it should not assume vast proportions in the near future, as no other point in America afiords more perfect facilities and advantages for its successful manufacture. Heretofore foreign makers have supplied the American markets, but Ameriean enterprise and capital will, ere long, drive English chains from our markets, as it has done most otlier products of which irou is the basis. The firm of Eisenbeis \& Helm manifest the characteristic enierprise in an eminent degree, and have entered a field affiording them the largest opportunities for the exercise of tlicir abilities and energy. The building occupied hy the firm is large and commodious, affording ample facilities, and is very conveniently arranged throughout and well located, affording the best facilities for shipment and receipt of material. The works are supplied with machiner $y$ necessary in the business, consisting mainly of dies and welding machines of peculiur construction, whicls do the work in the most perfect manner, which, when operated by a skillful operator, makes a weld of so perfect a form as to defy detection. The machinery is driven by a fine engine of ample powcr. The heating furnaces are novel and perfect in construction, being patented aud owncd by this firm. They are so constructed as to heat the links for welding in a perfect manner, giving a clean heat, entirely free from sulpliur, and in erer' $y$ respect of the most convenient form. But the most perfect piece of machinery used, the invention of Mr. Helm, and the patent for which is owned by the firm, and which is used exclusively by them, is the link cutter, an anparitus that recives the iron to be used from the rolls, and cuts it in to links in the most perfect manner, of any desired size, at an astonislıing rate of speed. This, in connection with the other appliances and improvements, gives to this firm the great advantages they possess over their cotemporaries, and enables them to produce chains of a quality equal, if not superior to any brand in the market. In building their industry and getting their works under full headway, as is usual in all new enterprises, many difficulties and obstacles had to be surmounted, and are still met with, among them the difficulty in procuring skilled operatives and competent forgers to work their machinery; but these are being ripidly overcome. Although but a short time in the business, they have already ieen pressed with orders, and their works are taxed to their present capacity to supply their rapidly growing trade. Mr. Eisenbeis, the business manager and hear of the firm, is a native of this country, born in 1837. He was, previous to engaging in lis present industry, engaged in the drug business in Allegheny. He brings into the business a large business experience and great energy. Mr. Helm is a native of Germany, but has resided in this country over 25 years. IIe is a thoroughly practical iron worker having been engaged all his life in that liranch of industry. He spent miny yens perfecting the machinery that is now so suceessfully used by the firm, and brings into it large practical experience as a mechanic and inventor.

\section{WIM. G. PRICE \& CO.-Iron Founders and Plumbers' Materials, 33 Wood St.}

Few houses can trace back their origin anterior to that which forms the subject of the present sketch. Originally established in 1810 by Mr. Wm. Price, grandfather of the present senior member of the firm, the business was subsequently condncted by $\mathrm{Mr}$. Wn. G. Price son of the founder and father of the present proprietor, frum 18.5 to 1875 , when he was in turn succeedel by the firm as it now stands. The office and warerooms of this establishment are located at No. 33 Woud street, corner of Second a venue, their foundry and works covering more than one acre, being bounded by Fifth a venue, Price and Col well streets. Here sixty men are constantly employed, with a semi-monthly pay-roll aggregating about $\$ 1,000$. The foundry and machine shops are fitted with all the best and latest improved machinery required for the production of the various articles manntactured by them, which consist principally of articles especially pertaining to plumbers' use, embracing iron pipe and fittings, water aud gas pipe, window weights, iron sinks, etc., dealing also in every kind of plumbers' hardware and supplies, lead pipe, brass cocks and fixtures. Their trade is largely derived from the leading cities in the Western States and will annount in round numbers to not less than $\$ 100,000$ per annum. For nearly seventy years this house has enjoyed a wide-spread and deservedly high reputation for the uniform excellent quality of their prorlucts, which meet with a ready sale. Mr. Wm. G. Price is a native of Pittsburgh and was born in 1852. He is an energetic, enterpr ising business man, and under his ahle and judicious management the high standing of this old-established and reliable house will be maintained in the future as it has been in the past by his immediate ancestors.

\section{THE ANDERSON SASH BALANCE,}

o. K. GARDNER, Manufacturer, 28th \& Railroad sts.

The Anderson Sash Balance and the Patent Car Window Balance are two important inventions, which have stood the test of time, and are pronounced by all who have used them to be the most perfect devices yet introduced for the purposes for which they are intended. They are designed to do the work and take the place of weights and pulleys in windows by the combination of a spring and cone adjusted to the wejoht of the sash, so as to form an exact balance, possessing all the advantages of weights with none of their defects. When properly adjusted the sash hangs at an exact balance, and no force or power is required to raise or lower the windows. The sash balance is highly commended by architects, builders and house-keepers, and the Car Window Bilance has been adopted by the Pennsylvania Railroud Company, and used exclusively on their cars for the past five years, giving perfect satisfaction. They are also used by the Pullman Palace Car Company on all their cars. The Balance was invented by Mr. J. C. Anrlerson in 1869. A stock company was originally organized to manufacture and introduce the improvement, under the name and style of the Anderson Balance Mfg. Co. In $1876 \mathrm{Mr}$. O. K. Gardner becaine sole proprietor and manufacturer of the Balance, and he bas since bcen pushing its sale vignrously and successfully. The works now occupied by him, at the corner of $2 S t h$ and Railroad streets, cover an area of $50 \times 75$ feet, and are supplied with all the machinery and appliances necessary to carry on the business, which is increasing from year to year as the merits of the balance become known and appreciated throughout the country. His trade extends throughout exery portion of the United States. Mr. Gardner is a native and life-long resident of Pittsburgh. He was formerly engaged in the business of contractor and builder, and is well known and highly respected, both in the social walks of life aud in the business community.

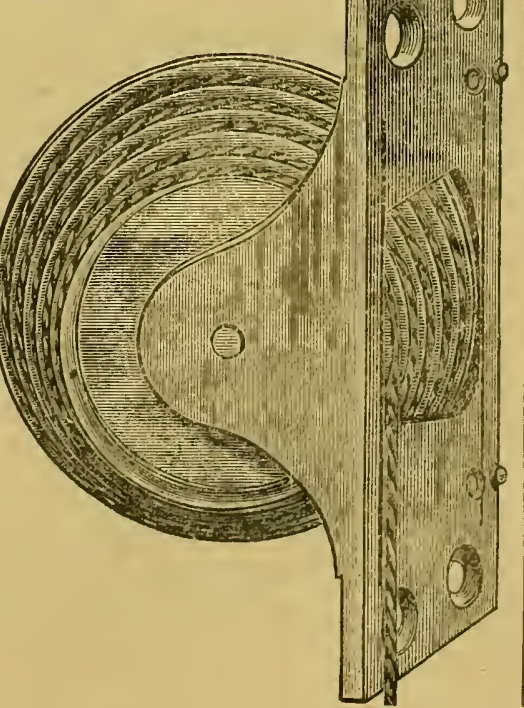




\title{
ALIEGHIENY STEAM LAUNDRY, Dyeing \& Scouring Works,
}

This extensive establishment, which is one of the largest and most complete of its kind in the West, was founded in $1869 \mathrm{by}$ Mr. Charles Pfeifer, the present proprietor, and his brother, with capital amply sufficient to meet all the requiremients of the business at that time and which has since considerably increased. Mr. Pfeifer now occupies the spacious two-story double brick structure $40 \times 50$ feet at Nos. 353 and 355 Beaver avenue, Alleghen 5 . with a central receiving office at No. 54 Federal street, near the Ft. Wayne depot. The busiuess is systematically conducted in six different departmeuts, each being in the hands of skillful and accomplished workmen assisted by labor-saving machinery of the most approved styles and designs, including one twelve-horse power engine, one cylinder boiler 15 feet in length and 36 inches in diameter, one very large aud complete cylinder wisling machine and a nunlher of smaller ones. One mammoth machine intended expressly for washing carpets, blankets and heavy articles and a variety of other appliances and apparatus, especially adapted to work of this description. He has a new method of clenning carpets worthy the consideration of every family. The Glycerine Carpet Paste has been fully tested and is warranted in every particular. By this means he cleans carpets without taking them from the floor. The process is quick, perfect and warranted to give satisfaction. Send and get circular explaining all particulars. Mr. Pfeifer has lad many years practical experience in the dyeing, scouring and refinishing business, and his works now rank among the forenost establishments of the kind in the United States. Among the specialties for which he is noted is the dyeing, cleansing and refinishing of ladies' dress goods of every kind, shawls, gloves, plumes, lace aud danask curtains, velveteen, Brusscls and iugrain carpets, and all kinds of gentlemen's and children's clothing. In the Jaundry department particular attention is devoted to doing first-class work, especially in shirts and ladies' fine underwear. Orders by mail are promptly attended to and goods are called for and delivered in all parts of the two cities. Mr. Pfeifer is a native of Germany and was born in 1830. He came to the United States wlile but a boy and has resided in Allegheny since 1869 , and been actively engaged in business during the entire period. He devotes his personal attention to the general supervision of his extensive business in which he has a capital invested of not less than $\$ 10,000$ and his annual receipts will reach $\$ 12,000$ to $\$ 15,000$. He has fiteen assistants regularly employ ed in the various departments of his establishment with a monthly pay-roll averaging about $\$ 400$, and his tride extends over the two cities and the adjacent towns and counties of Western Pennsylvauia.

I. BEINHA UER \& SON,-Livery and Sale Stables, 12 th \& Bradford Sts., S. S.

In addition to the business of Livery and Sale Stables, Messrs. Beinhauer \& Son transact a general Undertaking business in all its branches. The present firm succeeded L. Beinhauer \& Co., br whom the establishment was originally founded. The amount of capital invested is about $\$ 7,000$ and the average valuation of stock on hand is not less than $\$ 5,000$. Their stables are equipped in first-class st $y$ le with excellent horses and carriages of every description and the underiaking department is as complete as that in any similar establishment in the city. Orders left at No. 114 Grant street, opposite St. Paul's Catinedral, will always receive prompt attention. They occupy the premisos corner of Bradford and 12th streets, with a building 24 feet square and stables fronting on Bradford street 40 feet and extending back 70 feet. The business of the firm amounts to not less than $\$ 4,000$ per annum. Mr. L. Beinhauer was born in Germany in $18 \% 0$ and has resided in this city since 1853. His son, Mr. F. C. Beinbauer, was born in Butler county, $\mathrm{Pa}$, in 1858 , and with his father has been engaged in the present line of business for the past seven years.

\section{J. DORMER,-Marble Works, Fountain St., near Seventh Av.}

This business was started by Mr. Dormer and has been carried on with uniform success. He nanufactures and deals in all hinds of Foreign and American granite and marble monuments, tombstones and slabs, and also house marble work, mantels, bureau stand and other marble work, in fact everything in the line executed in best style and at most reasonable prices. Mr. Dornier is one of the most skilled worknen in this line in the city, and turns out the neatest and most elabornte work. He employs three first-class workmen with other assistants. Mrr. Domiuer was born in Troland in 1836, and came to this country in 1846, and soon after to this city. The high esteem in which deceased friends are held entitles this business to consicierat:icn among the industrios of the city, and Mr. Dormer is a highly esteemed and worthy citizen and tradeswan.

\section{IRON \& GLASS DOILAR SAVINGS BANM,}

\author{
Cov. 12th \& Corson Sts., South Side.
}

This organization was effected in 1870, and two years later (March 5, 1872,) was incorporated under a special charter with a capital of $\$ 160,000$, w lich might be increased optionally to $\$ 250,000$. The operations of the bank are strictly legitimate, consisting in loans, discounts, exchange, collectious and transient or time deposits, the latter bearing interest at 4 per cent. The officers are as follows: President, Thos. B. Atterbury ; Henry Stamm, Cashier: Directors, Messis. T. B. Aiterbury; John Adams, of Adams \& Co., Glass Manir's.; F. Baxmyer, Wm. Cowan, John Davis, Wm. Doyle, John Gallaher, Edward Hogan, E. P. Logan, John Phillips, H.' M. Rolfe, J. H. Swett and D. Wenke. With such management a surplus bas been accumulated of $\$ 2,510$ and dividends paid to an aggregate amount of about $\$ 50,000$. In short the Iron and Glass Dollar Savings Bank is a solid financial conecrn, in which the confidence of the public is not misplaced.

JOHN J. BALIARD,-Manuf'r. of Cigars \& Tobacco, 12 Wylie Av. Extension.

This business was started with small capital, which has been increased since, keeping a general assortment of the various brands of Havana and domestic cigars, iucluding fine tobacce nuanufactured by himself, lesides the different brands of tobacco and snuff, pipes of every style and variety. Mr. Ballard is a practical cigar maker, employing skillful assistants and making a specialty of manufacturing tobies. He sells both wholesale and retail at his place of business, where he has nuite an axtensive trade and gives the amplest and lullest satisfaction, giving his personal at tention to the selection of his stock as well as to the manufacture of his cigars.

\section{F.BAXMY ER \& CO.-Groceries and Provisions, No. 6, 7, $8 \& 9$ Diamond, South Side.}

Among the notable and enterprising Grocery Houses of the South Side and indeed of the city, is that of Messrs. F Baxmyer \& $\mathrm{Co}$. The business was begun by Mr. F. Baxmyer in 1858 . After conducting it for some years, he associated with him his son and son-jn-law, who have rendered valuable assistance toward increasing the usefulness of the establishment and increasing the trade with each succeeding year. They aim to carry a full and diversified stock of Groceries and Provisions, desirahle for houseliold and table use, at very low figures, also Flour, Feed, Grain, Seeds and Implements. They do an annual business of not less than $\$ 45,000$, and their store has become one of the most pojular trading places on the South Side, as well as enjoying a good country trade. They also have an agricultural department,
keeping Farmer's Tools, Machinery, \&e. Mr. Baxmyer was born in Germany in 1815, the other members of the firm are also natives of "the Fatherland," and for many years prominent business men aud resident citizens of this eity, South Side. 


\section{ABEL, KIM \& CO.-Window Glass, 70 Carson St., South Side.}

Extensively engaged in the manufacture of one of those great staples upon which is based the prosperity as well as the reputation of Pittsburgh as a producing centre, the firm of Nessrs. Abel, Kim \& Co. are entitled to more than brief notice in this work. The business was originated in 1867 by Messrs. Knox, Kim \& Co., who conducted the same for a decade with marked ability and success, the present firm dating from 1877, under whose management the concern has been enlarged and the capacity increased. The plant is situated as indicated above, and occupies an area of pearly four acres, hali of which, or more, is covered by the buildings and factories, the product being exclusively window glass, which requires three main departments in its manufacture, outside of the actual preparation of the glass, these being the blowing, flating and eutting. Seventy-five workmen are employed at these works, entailing an average weekly dishursement of about one thousand dollars. The goods manufactured by the firm are highly esteemed for strength, luster and freedom from flaws and bubbles, and are in demand throughout the Western states, where the bulk of the trade lies; a considerable business, however, being transacted to supply the home and Penn'a market. Honorable, enterprising and prompt the firm is regarded as a desirable one with whici to establish relations, which so far as their control extends must be pleasant, protitable and lasting.

\section{HALDEMAN \& JOHNSTON,-Coach \& Wagon Makers, 89 Third Av.}

The firm of Haldeman \& Johnston was founded in 1877, and in the short time in which they have been engaged in business have built up a fiourishing and lncrative trade. They manufacture every description of coaches and carriages, platform and elliptic spring wagons, flour and oil trucks, package express and delivery wacons, etc. making a specialty of the " coach top" and platform wagons of their own improved design, guaranteeing all their work to be the very best without exception. They also attend to repairing and repainting with neatuess and despatch and at reasonable rates. In the three branches or departments of their business, viz:- wheelwrighting, blacksmithing and coach painting, they employ ten skilled and experienced workmen. They occupy the entire three-story building at No. 89 Third avenue which is supplied with a full complement of machinery, tools and implements, of the best and latest improved designs and styles for successfully carrying on their extensive business. Both members of the firm are thorough practical mechanics in their respective departments, Mr. Haldeman being in charge of the blacksmithing and iron working department and Mr. Johnston of the wood working branch. Mr. Haldeman is a native of Fayette county, this State, and was born June 12, 1850 . He has resided in Pittsburgh for the past seven years. Mr. Johnston is a native of the Emerald Isle, but for twelve years has been a resident of this eity. The business of this house amounts to about rounding country.

\section{ODD FELLOWS' SAVINGS BANK, -63 Fourth $A v$.}

The Odd Fellows' Savings Bank was organized in 1872 and incorporated under the State law; its oficers are among the most esteemed and successful members of this community and are as follows:-Andrew Miller, Esq., Presiclent ; Geo. W. Rankin, Esq., Vice President; and Sauucl C. A pplegate, Cashier. The board of directors, besides including the President and Vice President, is composed of Messrs. Edward Duff, A. M. Brown, Esq., John Seiferth, S. J. Wainwright, D. P. Estep, James Gordon, R. H. King, John Woolslair, M. Schuetz, J. K. P. Duff, Jno. M. Horuer. The capital of this bank is $\$ 107,000$ and a surplus of $\$ 11,000$, which, considering the unfavorahle financial period through which it has been obliged to pass, is considerer as a remarkably fair showing-the bulk of its depositors being among the industrial classes, and the position occupied by it in the confidence of the community is the best evidence of the wisdom of its direction.

\section{LIVINGSTON NOVELTY WORIS,-Livingston \& Co.,}

M'f'rs. of Fine Light Castings, Builders' Harduare, etc., 243 to 253 Washington Av., Allegh'y.

In their particular specialt.y of Fine Light Castings for Agricultural Implements, Builders' Hardware, Light Machinery and miscellaneous small articles of iron or brass, the Novelty Works of Messrs. Livingston \& Co. undoubtedly stand at the head of all similar establishments in the United States. Their large and extensive manufactory is located on Washington avenue, Allegheny City, embracing the numbers from 243 to 253 inclusive, directly opposite the outer depot of the Pittsburgh, Fort Wayne and Chicago Railroad. The building is a large two-story frame structure, covering an area of $144 \times 144$ feet, fitted up with one powerful thirty-horse

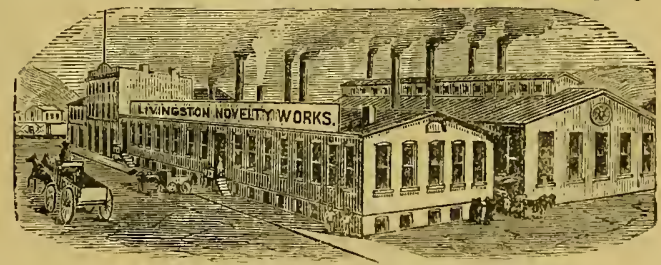
power engine and all the latest improved machinery, apparatus and appliances for carrying on their business in all its departments in which a force of thirty-five skilled workmen are constantly employed at a weekly expense aggregating not less than $\$ 250$. They mannfacture every description of fine light Castiugs, Plain, Japanned, Bronzed and Galvanized, using a high grade of A No. "1" "H. R." Charcoal Iron, which gives a clean, smooth-faced castiug, very strong and durable and easy on d rill or lathe. They also manufacture Brass Casting's to order for Rolling Mlills, Engine Builders, Plumbers, Gas-fitters and Locksmiths. The house was founded in 1866 on a comparatively small scale, by A. H. Burt, and L. O. Livingston, since which time the business has steadily increased to its present magnitude. The a verage valuation of stock carried is not less than $\$ 20,000$, while their annual sales will reach more than $\$ 100,000$. One of the leading specialties of this house for which they have aequired a national reputation, is the Monitor Corn Sheller, the most simple and perfect machine of its kind ever introduced, weighing only about fifteen pounds ant with a capacity for shelling a bushel of corn in tive minutes. More than twenty thousand of these shellers are now in use in every section of the Union from the Atlantic coast to the Pacfic slope, and from the nother'n boundary of the States to the Gulf of Mexico, and thousands of testimonials bear witness to their superiority and general excellence. They have received medals and diplomas from the Pittshurgh Exposition and wherever else exhibited. Every sheller is warranted by the manufacturers, and as they are sold at the low price of $\$ 5$, or with the separator attached at $\$ G$, they are within the reach of every farmer and poultry raiser in the country. Their improved ramily Grist Mn, for farm at the low price of $\$ 12$. Circulars and price-lists, conlaining full information relative to the manufactures and specat the low price of $\$ 12$. Circulars and price-lists, conlaining full information relative to the manufactures and spec-
ialties of this house, are sent to any part of the country upon application to the firm, whose postoffice adliress is Box 302, Pittsburgh, Pa., and orders from all portions of the United States will receive prompt attention and exceution. Mr. L. O. Livingston is a native of Vermont and was born in 1s:36. Mr. W. H. Burt wiss born in Northampton, Masss, in 1832. They are both active and energetic business men, who by their own ability and exertions have built up in the city of their adoption a large and flourishing business which has added new lustre and fame to the reputation which Pittsburgh has attained as the great mauufacturing and industrial centre of the Western Hemisphere. 


\section{KING, SON \& CO.-Crystal Glassware, Eighteenth St., South Side.}

The many improvements that have been made in the manufacture of glass and glassware during tho past fiftecn or twenty years have now here been so pronounced as in l'ittsburgh. Whatever maly be the cause, the fact lits been thoroughly estallished that our city produces goods in this matcrial not only superior in quality, but of such marked excollence and beaty of design as fo defeat all competitor's elsewlicre in the United States and compare fivorably with the products of the most celebrated French factories. Of those houses that lave taken the lead in adopting every improvenent. thit of Bl'ssirs. King, Son d Co. nust be ranked among the most proninent. This widely-known firm was established in is $6 \hat{b}^{\circ}$ uncler the sty le of Johnson, king \& Co., changing to the existing style and status three year's later. $\Lambda$ far as the fateilities for the manufacture of ghassware are concerned this house is supplied with every advantage condueive to al large and ehoice product. The plint is an extensive one, consisting of two factories, two furnaces, with an aggregate ol twenty-une pots, and every applinne, with adeguate modern machinery, olverited by two powerful steam engines. The huildings are respectively $120 \times 286$ feet and $60 \times 100$ feet in size, where are cmployed an average force of 125 expert workmen, whose earnines are about $\$ 1,200$ per weck. The trate of the house amounts to al,out. $\$ 125,000$ anmally, and is increasing more rapdly than that of many of its cotemporaries in the same branch of the business, and already extends not only over the enitre Union, but reaehes the Canadian provinces and forcign markets. Mtany of the goods made ly King, fon \& co. are manufactured under letters-patent leeld exclusively by them. A candy-jar with gum ring and glass-coverel top, which is coning into universal favor, is so protected, and numerous other articles in tho lino of table ware, har ware, line and white-ring jars, preserve and jelly glasses and jurs of new and attractive desirns. Mir. Wh. (S. king, the senior partner and muager of the concern, is well known in the community as an enterfrising and resolnte natn. Under his direction the business policy of the firm is lonorable, liberal and progressive in every respect, and for these high characteristies las attined a position it once creditable and sulusrantial.

\section{G. HUSSEY \& CO.-Copper \& Brass Rolling Mills,}

office, No 4. Fifth Avenue; Works, Second Avcnue and Monongahela River.

The house which forms the subject of this lyief notice was founded thirty rears ago by Dr. C. G. Hussey and Charles Avery, lisq., under the same style as at present, though Mr. Avery died in 1S5s, when the Hon. Thomas MI. Howe suceecded to his interest. The capital, thougl ample at the inception of the concern, has been greatly augmented since, and the works are now as large as any of the kind in the country. The mills consist of three large buildings with numerous sululler ones, covering an area of about four acres. The operative work is divided into four departments, viz.:rolling will, brass, smelting and planishing works, requring a force of one hundred men, three large engines, stamping machines aud other iuproved mechanisu for planishing, entting, turning, etc. Nany of the processes employed by this tirm are not only comparatively new inventions, but add greatly to the perfection of the work and a higher degree of finish than hitherto attained. Lispecially in the matter of planished copper this firm claims substantial advantages for their product. They have new machinery, combining the latest improvements under the Hayden and Ninard patents, for the manufacture of brass kettles, which they offer of superior quality, nnsurpassed eitfier in shape, finish or material, and at the lowest market rates for snch grades. Of unlimited resources and commercial experience, the firm stands second to none as cxponents of the results to be achieved by thrift, integrity and enterprise.

\section{STEWART, ESTEP \& CO.-Druggists' Glassware, Window Glass, \&c.,}

In a careful review of each separnte estallishment engaged in the manufacture of glass in this city, it would be impossible to overlook the extensive works of Stewart, Estep is Co., which with a product of 2,800,000 square feet of window gliss per unnum are entitled to rank amone the lirgest eonecras engaged in this branch of industry. The establishment of this business may be ascribed to Melling, Estep \& Co., which firm was composed of the present menbers and one Charles Melling, Fsq., and others, who construeted the plant in 1866. In 1871 Mr. Melling with fire other members retired and the firm style with the remaining members was changed to its present form. The works cover an area of nearly two acres, and consist in part of two furnuces having 16 pots and two factories, besides packing, cutting and llitting rooms, ete. Lere are employed about seventy-tive skilled workmen to pay, whom a weekly disbursenent is neccssary to the amount of nearly $\$ 1,500$, and here also will be found the best machinery and appliances yet devised for the manufacture of a superior quality of gliss, double and single strength, ranging from the smallest sizes to dimensions of 40x76 inches. The individual memhers of the tirm are J. S. Stewart, Harrison Estep, J. L. Jourdan, James Collins, lawrence Walker, Charles Kirchenbower and G. W. Norcross, all well-known gentlemen in connection with the great staple industry in which they are so successfully cngaged. Besides the manufacture of window glass the firm deals livgely in druggists' ginssware and apothecaries' furniture, in which they are prepared to offer special advantages to dealers and the trade. The demand for the product of this house is large and active, extending over the entire West, North and South-west, and annually increasing. Among the many Pittslurgh firms pursning the sane branch of industry no house occupies a more honorable position than that of Stewart, Estep \& Co., and none surpass it in a liberal, prompt and reliable business policy to which with its excellent quality of prodnct is owing the prosperity of the concern and the esteem with which it is regarded.

\section{R. PATRICK \& CO.-Bankers, No. 52 Fifth Av.}

Among the private financial institutions of Pittsburgh, the well known house of $R$. Patrick \& Co., is one of the oldest and most prominent. Established in 1849 by and under the stylo of Patrick \& Friend, it assumed the existing title in 1855, Mr. Triend retiring from the firm during that year. Upon the demise of Mr. R. Patrick in 1872, the operations of the house were continued by W. W. Patrick, Esq. The business transacted is strictly confined to legitimate banking, loans, discounts, collections, exchanges and deposits, and the purcbase and sale of commercial paper. For nearly a third of a century this house lias pursued a uniformly prosperous course, with a fixed policy of honorable principles that no circumstances were permitted to effect, and at present, with a capital of $\$ 210$, n00, the house is considered as on a par with the best of its compecrs. As ono of the solid institutions of the Iron City, this banking bouse is well entitled to the confidence inspircd by a career of untarnished succoss.

\section{JOHN C. BRAGDON,-Wood Carver, 78 Fourth Av.}

Among the numerous specialties in mechanic art that are iostered by the artisans of our city, that of fine wood carving in its special sphere is most extensively, if not exclusively, carried on by MIr. John C. Brusdon at the above locution. Born in Allegheny city in May 1855, his natural inclinations toward the artistic led lim to pursue a diligent course of practicc under competent instructors, and he now fills a position most admirably the want of which was long felt in this commmnity. In resturd to the fine execution of those tasty designs peculiar to himself, it is safe to assert that his profieiency is not equalled loy any cotemporary west of the mountains as evidenced hy the traile he commands from the best classes of soctety and from builders in the line of arehitectural carving, for orignal, unique and fancy carving in articles of ornamentation, furniture, etc. At his apartments are also given lessons in this worthy and nseful art, to a large class of ladies and gentlemen. This, heretofore, almost undeveloped field of industry caunot be too lighly commended to the patronage of the citizens of the two cities. 


\section{E. D. WASSELI \& BRO.--Scrap Iron, Steel and Metals, 33rd St.\& A. V. R. R.}

The handling of scrap iron, steel and other metals has loecome an important item of the trade and commerce of Pittsburhh, and several houses are largely interested in this branch of business. The firm of $\mathrm{E}$. 1). Watssell \& Brother was founded in $\mathbf{1 8 7 4}$ with comparatively small capital and moderate means, which have sinee tlat time increased to Jarge proportions. Their office and yards are located at the eorner of 33rd street and the Alleghen y Valley Ratilroad and cover a large area, one being $20 \times 100$ fect, one $72 \times 120$ feet, and a third $55 \times 120$ feet, on which are lare cunantities of serap iron, steel and other metals, averaging in value about $\$ 10,000$. The amoun of their annual transactions ranges from $\$ 40,000$ to $\$ 60,000$. They proeure their supplies from all parts of the United States, the demand being prineipally among the rolling mills and manufactories of Pittsburgh. They have two eight-ton sets of shears for cutting scrap and employ a large number of teams and men about their premises, which are conveniently aud eligibly located with a side traek from the Allerheny Valley Rail road running through their yaris. Both members of the firm are aetiv , energetic and reliable bnsiness men, thoroughly eonversant with the peculiarities and recjuirements of the business in which they are engaged. Mr. E. D. Wassell is a natjve of England, born in 1836. He has residcd in tlee United States since 1844 and for the past twenty-five years lias been identified with the industrial interests of l'iftslurgh. Previous to engaging in his present line of business ho filled the responsible position of business manager for several of the Works and the N. Alten Iron Works. Mr. William Wassell is also a nalive of England, born in 1838. IIe came to this country at the age of six yeurs, is a practieal roller and iron worker of many years experience, and bis lesen ouployed in many of the prineipal iron works of Pitsburgh. Previous to the formation of the partuership with his hrother bie worked at his trarle in the mills of Wm. Clark \& Co., the Superior Iron Works, the Union Iron Worlis ane other establishments of a similar deseription in Pittsburgh. The brothers are gentlemen of high character and standing in the community and are publie-spirited and enterprising business men.

PENN PLANING MILI,-Slack \& Sholes, Penn Av. and Third St.

The firm of Slaek \& Sholes, proprietors of the well known "Penn Planing Mills," do a extensive business as Steamboat Joiners and builders and manufacturers of Boxes and every deseription of Floorins, Weather Boarding, Sas h, Doors, Frames, Mouldings, \&c. They carry coustantly in stoek coustantly in stock,
or are prepared to manufacture to order Laths and Shingles in any quantity, and do every description of Seroll Sawing it short notiee. This house was founded by the present prolittle or no cajpital little or no cajpital, judieious manarement, the luusiness has grown steadily

until to-day its eap-

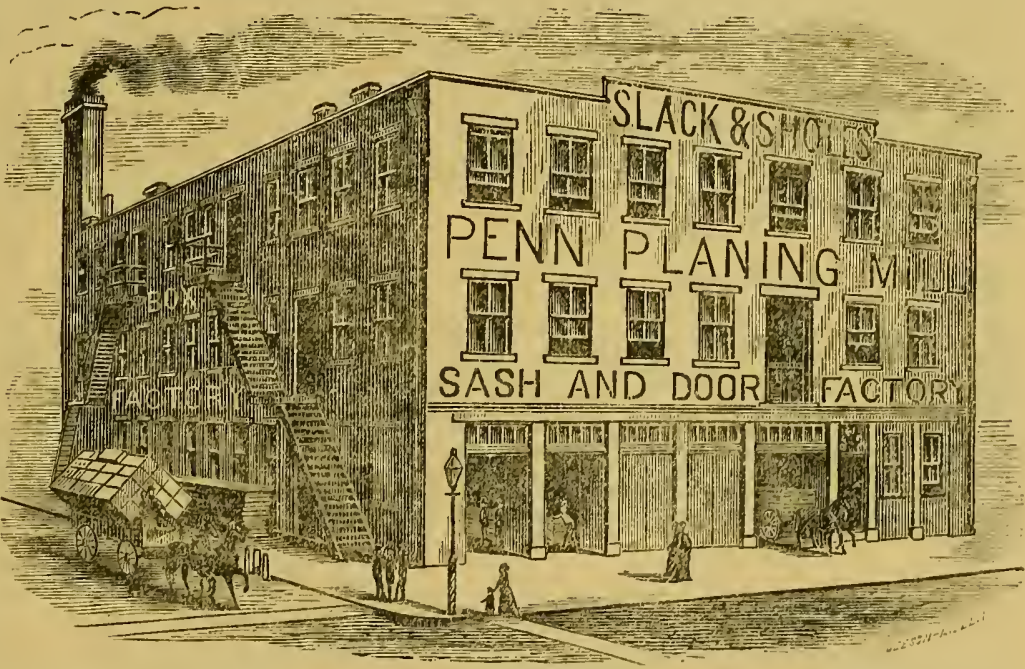
about $\$ 10,000$, and the luilding oceupied by them is a three-story structure, 60x110, besides ample yari rom.11. Their business is eondueted in three separate departments, in which thirty liands aro constantly criployed, with al fay-rinl agtregat ing over $\$ 300$ jer week. Among the machinery used, we may mention two planing madines, one floming machine, five noulding maclines, one re-sawing machine, nine circular saws and other sinaller machines, all] of the most approved patterns and designs required for the various sperialties of their business, the nutive juw er for which is supplied by one forty-five lorse power engine and two lage boilers. As steanboat buildrus and joiners this firm has a wide spread and enviable reputation. They stre prepared to eonstruct every jortion of a stean hoat, witls the excep tion of the iron work, in the most perfect and reliable manner. The wood work on numy of the finst stetmcrs on our rivers here has been done by this firm, and the degant cahins of some of our palatial fassinger boats attest their skil and ability in this direction. Then lo for constructing several other steamers for use in South Ancrienn vaters. They manufacl ure all the portions perfaining to their line in this efty, and slip in scetions to its plate of destination, sending their own workmen there to put it together. A representative from this house is at present in Sontl Ameriea, sujervising the completion of a boat for which they contracted some time since. The boats they have constructed and are now litililing, arte for service on the Aragdelena River, a mavigable stream ahout 700 utiles in length, portions of whijh are very slallow, and admit tho Jassage of only light draurht boats. The companies owning these lines in South Ameriea lind previnusly had steam-

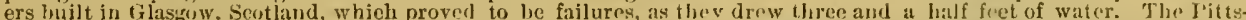
burgh built boats only draw twenty-two inches, and are specially alduted for use on this stream. They lave given the nost unbounded satisfaction in every respect. A morlel or drawine of the style of locits required was sent to this country, and witti the energy and enterprise characteristic of Pittsburgh's manufacturers, the contracts were seeured to this eity. The house of slack \& Sholes is to be eongratulated upon the suecess which has crowned thein" ("iliorts in this particular branch of industry, as well as in the planing mill, which is one of the most eomplete establishments of its kind in the West. Both members of the firm are enerretie, representative lusiness men of the great manufacturing eity of I'ittsburgh. $\mathbf{M r}$. Slatrk has for many years bern prominently identilied with State, county and municipt affairs. He is a resident of Aljegheny (jity, and las represented his ward for thirteen yeurs in the city council, and for most of that period occupied the responsible pesition of President of the select enuncil. From 1861 to $186 \bar{n}$ he was a member of the State Legislature, and his record in llat body was not only highly creditable to himself, but enivently satisfatctory to his eonstituen's. 


\section{JOFIN GRAY \& CO.-Dry Goods, Notions, \&c., 1316 Carson St., South Side.}

The popular dry goods establishment of the enterprising and dyiving firm of John Gray \& Co., at 1316 Carson st. South Sicle or Birmingham portion of this city, ranks among the leading establishments of the kind in the entire city, and is worth liberal mention in this work. No house in an y part of the eity offers greater inducements to the purchaser than this, and no establishment at least in that part of the city is more widely known or enjoys a finer trade. The popularity of the firm is due to the liberal policy and prompt bisiness habits of the proprietors and the cordial manner in which every one visiting their rooms is treated by themselves and their employees, as well as the general excellence of their stock and the complete and choice assortment that is at all times displayed and the low and popular prices at which their goods are sold. The house wis founded in 1865 by Samuel Grover, who was succeeded by the mesent firm composed of Jno. Gray and Heury Porter. The firm occupies a large and well appointed store room, divided and arranged in departments to facilitate the most orderly transaction of business. It is supplied with a carefully selected stock of about $\$ 20,000 \mathrm{in}$ value; six men are employed in the different departments of the store and the annual business reaches very large tigures. John Gray is a vative of Ireland, born in 184t, he came to this city in 1866 , and since his conncction with the business interests of the city has shown a spirit of enterprise that has achieved for himself and house an enviable position among the successful business men of the day. Henry Porter is an Englishman by birth, but has been in this country many years. He is a courteous gentleman of ability and energy.

\section{WM. E. GRA X,-Dry Goods and Millinery, 1302 Carson St., South Side.}

The south side portion of the city or Birmingham is one of the most prosperous districts in the entire city, and is the centre of a large and growing trade drawn to it from the wealthy country districts and outlying suburbs. It is noted for the many extensive iron mills and glass factories within its limits which contribute to its prosperity-of course there are many fine business tirms engaged in the various branches, some of them metropolitan in their character. A mong the number and occupying a leading position in the dry goods business is the well known and popular house of Wm. E. Gray, 1302 Carson street. This bouse was founded by W. H. Wakefield, who sold it out to its present proprietor in 1873 , since then under the able, energetic mamagement of this very popular and courteous gentleman it has had a prosperous career and its trade bas been increasing rapidly. He is now doing a business of $\$ 40,000$ or $\$ 50,000$ per aunum and carrying a stock never worth less than $\$ 20,000$. He occupies a large three-story building 24 feet front by 65 feet deep, divided in to five departments, of these the tirst is devoted to dry goods, the second to domestics, the third to carpets, the fourth to millinery and the tifth to notions, etc. Fire clerks and salesmen are constantly employed in supplying Mr. Gray's large and growing trade. Perhaps no establishment in any part of the city offers an $y$ advantages to the purchaser superior to those offered by this store, which ranks among the leading houses in the entire city and is deserving of more than passing notice in a work devoted to the business and industries of the smoky city. Mr. Gray was born in Ireland in 1846 and came to this city in 1870. His life has been spent in business pursuits, and he combines the highest characteristics of the Irish race, together with their well known frank, genial and generous qualities.

\section{JOHN A. STAFF,-Groceries and Provisions, 439 Carson St.}

This name has long been familiar to home and table of a large number of the citizens of the Smoky City, and is certainly entitled to most creditable mention among the leading grocery and provision houses of the city of Pittsburgh. $\mathrm{Mr}$. John Stalf was horn in Germany in 1819 , and came to this city in 1845, where he soon became identified with the general business and activities associated with its growth and development. It was not until 1866, however, that he engaged in his present business, in his store at No. 439 Carson St., where he now occupies a lrick building $24 \mathrm{x} 60$ feet in size, which he has amply stocked with first-class Groceries and Provisions, choice fanily Flour-the best in the market - fine Teas, Coffees, Sugars, syrups, Canned Goods, Tobacco, Cigars, Notions, and hundreds of other articles for honsehold use. Since the commencement of business he has enjoyed in good trade, which has greatly increased, and which gives promise of becoming one of the most flourishing and imporiant establishments of the kind in the city. The creditable character aud standing of himself and family have mide the store deservedly popular with the best chass of trade in the city.

\section{T. H. WHITE,-Groceries \& Produce, 92 Webster Av.}

This business was established by Mr. White in 1859 with a moderate capital, which has since then been greatly increased. He carries a stock of ahout $\$ 2,500$ and transacts an annual business of between $\$ 8,000$ and $\$ 10,000$, and occupies the building $20 \times 45$ feet in size, at 92 Webster avenue, in front of his residence, which he has well stocked with the best and freshest goods, embracing best teas, coffees, sugars, syrups, canned goods, fruits in their season, ete. His excellent management and long experience in the lusiness is met upon the part of the public with a very liberal patronage. Mr. White was born in Irẹland in 1819 and came to this city in 1856.

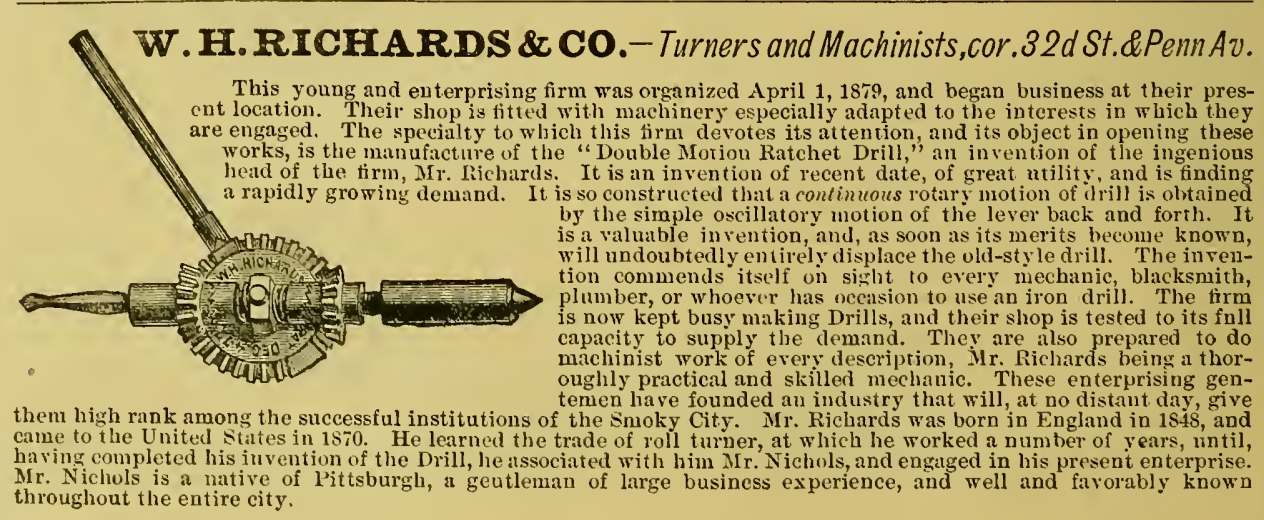




\section{WILLIAIM IRERR,-Carpenter \& Builder, 189 Webster Av.}

Mr. Kerr is the successor of Booth Brothers, who carried on this business here about 35 years ago. Taking the control in 1865 with limited capital, and being a skilled workman, be soon found ample employusent for himself and several hands, and his husiness iucreased each year, until now he employs on an average ten men and in very busy times more. During the geweral building season his stock of building materials will run from $\$ 30,000$ to $\$ 40,000$ and his facilities for promptly executing any contracts he enters in to are unsurpassed by auy contractor or liuilder in the city. Mr. Kerr has had many years experience and is himself one of the best skilled workmen to be found in this city, besides being a gentleman of excellent judgment. Those requiring his services will find him accurate in his estimates and prompt and faithful in the execution of his work. He has had the control of many of the nost important buildings, and never fails to render satisfaction to those who enploy him. His annual business transactions a ill usually run from $\$ 38,000$ to $\$ 40,000$; his headquarters are at 189 Webster avenue, where he occupies a two-story buiji: ing $26 \times 50$ feet in size, with yard room 100 feet square. His thorough and comprehensive knowledge of this business 11 all its details makes him extremely popular with the public, especially so in his execution of fine interior work. He is prepared to take contracts for all kinds of buildings and execute job work in the best manner to order. NIr. Williain Kerr was born in Ireland in 1835, and came to this city in 1851. He has always taken a deep interest in the city's welfare and prosperity as well as exercising a strong political influence in his section of the smoky city, und has several times filled the office of councilman with credit and satisfaction to his coustituents.

\section{R. H. PALMER \& CO., Limited.-Hats, Caps, Furs \& Straw Goods, 77 Wood St.}

For nearly forty years the name of Mr. R. H. Palmer has been identified not only with the hat and cap trade of Pittsburgh, but with various enterprises and institutions of the Sinoky City. The house of $\mathrm{R}$. $\mathrm{H}$. Palmer, of whom the present firm are successors, was established about forty years ago hy Mr. Palmer, on Mirket street, as dealer in ladies' straw goods, \&c. About twenty-five years ago he remored to Wood street, adding a full and general line of hats and caps. The present firm, which consists of Mr. K. H. Palmer, Mr. A. Swem and Mr. W. J. Moreland, was foumded in February, 1876, under the firm style of R. H. Palmer \& Co., Limited. They occupy the entire three-story building at No. 77 Wood street, with a fine line of Hats, Cays, Furs and Straw Goods, employing tive alssistants iu the store, and two traveling salesmen, who represent the interests of the loouse throughout Pennsylvania, Uhio and West Virginia, where their trade is at present principally located. With the facilities enjoyed by this housc there seens to be no valid reason yhy their trade in the future should not considerably increase. Mr. R. H. Palmer is a native of New Hampshire, but has resided in Pittsburgh a great portion of his life. During the palmiest days of the old "P'ittsburgh Commercial "Mr. Palmer was oue of the principal stockholders and treasurer, and much of the success of libat newspaper is owing to the vigor infused into it hy his influence. He is now one of the directors of the Monongaliela lnsurance Company, and has held several positions of prominence in the city. Mr. Swem is a young man of atbility, and has for twenty years held a position in this house as bookkeeper and tinaticial manager. He is a native of Westmoreland County, in this State. Nr. W. J. Moreland was born in Ireland, but has for many years been actively engaged in this line of business. The house is a representative one in the hat and cup trade, and stands deser vedly high in the mercantile community.

\section{JAMES DUNCAN,-Family Groceries, Cor. Fulton \& Franklin Sts.}

Mr. James Duncan, dealer in choice family Groceries and Provisions, corner of Fulton and Franklin streets, occupies an excellcnt room in a two-story brick structure $21 x 50$ feet in size, which he has fully stocked with everything in this line suited to household and table use, making a specialty of fine teas. This business was originally started by Mr. Stevenson in 1849, and after one more change in the proprietors it came into the hands of the fresent proprietor in A pril 1879. The facilities of Mr. Inncan are not surpassed by any house in the city for first-class goods and lowest prices, and families can have goods delivered without extra charge right to their door, no watter what part of the city they reside in. Mr. Duncan was born in Irelaud in 1842 and came to this city in 1869 , siuce which time he has been actively engaged and entering into business on Fifth a venue first in 1876, until eugaging in his present promisiug trade at the corner of Fulton and Franklin streets, in April, 1879.

\section{GALLAGHER \& HOUSE,-Boots and Shoes, 198 Fifth Av.}

There is jo branch of business which requires a higher degree of enterprise and business capacity than the boot and shoe trade, and in this connection we notice the excellent establishment of M essrs. Giallagher \& House, whose fashionable boot and shoe store is located at 198 Fifth avenue, corner of High street. They occupy a room $25 \times 40$ feet in size in a three-story brick building, where they kcep a choice and most desirable stock of boots and shoes for men, women, boys misses or children. They also have in connection a custoru department in which they employ first-class workmen and warrant good stock, good work and ueat fits. They also do repairing promptly to order. In their general stock they take special pains to secure the best class of Eastern and band-made work, and at the same time that which is both stylish and serviceable. Since they have heen in business they have already secured great public favor for the best stock of fashionable goods in this line. James W. Gallagher and John House, the individual members of this house, are both natives of this city, the former born in 1853 and the latter in 1842.

\section{JOSEPH SELL,-Huts, Caps \& Furnishing Goods, 1412 Carson St.}

Among the many popular and handsome establishments engaged in the retail trade in Birmingham or South Side, the store of Juseph Sell is deserving of notice. Mr. Sell started business in his present location in 1878 with a small cash capital. His store building is a two-story brick $20 \times 60$ feet in size and stocked with a large and very desirable stock of hats, caps and furnishing goods of the best quality and latest styles, and which are sold at lowest figures. Mr. Sell is carrying from $\$ 3,000$ to $\$ 4,000$ worth of stock, and is doing a very comfortable business, and all who visit his store are most courteously treated whether they purchase or not. Mrr. Sell was born in Allegheny county in 1844 and is well known in the community. He is an judustrious and energetic merchant, a social and genial companion and an upright honorable gentleman.

\section{M. \& R. W ALSH,-Grocers, \&c., Carson St., near Bridge.}

This old and established house, besides dealing extensively in Groceries, both wholesale and retail, are jobbers in Iron, Glass, and Pittsburgh manufactured artictes, and dealers in foreign and domestic Fruits and country produce generally. The house has been in operation over 30 years. Its present prosperous and enviable position shiows wfiat energy and industry may accomplisli from a comparatively small capital at the beginning. They now occupy the second Hoor of a building $32 \times 60$ feet in size, and carry a stock of general Groceries estimated at $\$ 10,000$, and transact a business of about $\$ 19,000$ annually. They also have large real estate transactions. Mr. M. Walsh was born in 1830 , and Mr. R. Walsh in 1835 . 


\section{S. F. WADSWORTH,-Dealer in Coal, 202 Beaver Av.}

The indnstries which characterize our prominent manufacturing cities are indebted to a great degree to what is known as "the black dittmond," hence it is but just, in the compilation of historical facts and figures relating to the leading business houses, manufacturing and industrial pursuits of the eities of Pittsburgh and Allegheny, that we give due importance to that branch of trade, which stands as the "power behind the tbrone"-the general coal trade. In this connection we refer to the business of Mr. S. F. Wadsworth, dealer in Mfonongahela and Saw Mill Run coal, nut coal and slack, whose office :nd yards are located at 202 Beaver avenue, foot of Locust street, being in the Sixth Ward of Allegheny city. Mr. Wadsworth commenced the coal trade here in 1876, always kecping a good supply on hand and is doing a business of about $\$ 6,000$ per annum. This business has been conducted by Mr. Wadsworth with marked s ility and to the entire salisfaction of his trade which continues to increase year after year. We should not fail to state that he never permits his stock of coal to run down, and can fill orders by mail or otherwise on very short notice. It is needless to commend the quality of coal handled by Mr. Wadsworth, becanse it is known and recognized as of excellent quality. This gentleman is a native of this city, born in 1857, and has now entered upon a business career with most flattering prospects.

\section{W. HELBIING,-Butcher, Butler St., bet. 48th \& 49th Sts.}

For the past ten years the enterprising and popular gentleman, Mr. Wm. Helbling, has carried on the butchering business at his present location on Butler street, between 48th and 49th streets. Prior to locating bere he had been for many years engaged in the same line in the Diamond Market. He has one of the finest markets to lie found in the East End, and in all its appoiutments it is a perfect model of neatness and cleanliness. He has at all times a fine stock of choicest meats of all descriptions, and dressed in the most artistic manner, and, of course, does a large business. Mr. Helbling never offer's an inferior article to his customers, and his prices are at all times as low as at any other establishment is the city. He was born in Lawrenceville (now Pittsburgh) in 1841. His father mas engaged in the butchering business, and the son was raised to it from early life, and has since successfully devoted his attention thereto. Although yet a young man he lias accumulated a handsome property, and is an enterprising and honorable business man.

\section{THOMPSON BELL \& CO.-Bankers, No. 59 Fourth Av.}

One of the oldest private banking houses in Pittshurgl, that of Mr. Thompson Bell, was established nearly a third of a century since, and from the period of its inception to the present date lias always been conducted upon a conservative policy that insured at all times a solid, solvent and satisfactory condition. Mir. Bell is a native of Pittsburgh, and has had a widely-extended experience in fiduciary affairs, having been first cashier of the Pittsburgh Safety Fund Co., which afterwards became the Farmers' Deposit Bank. He has been connected with many important public enterprises and private trusts, and in many ways has largely conduced to the general welfare of the community. The cashier of this bank, Mr. J. M. Bell, is also a native of Pittsburgh, and for many years has occupied lis present positioll, acquiring the distinction of thoroughly understanding his business. Conducting a general banking business in Loans, Discounts, Collections, Exchange and Deposits, the Bank of Thompson Bell \& Co. is cordially commended as being altogether liberal and bonorable in dealing, as well as entirely reliable in every respect.

\section{MARINE NATIONAI BANK,-Cor. 3rd Av. \& Smithfield St.}

Organized as the Commercial Banking Company in 1870, this house became a National Bank five years later under the original management which still obtaius. Established during a very unfortunate epoch, its whole course lying through the great financial Sahara of American history, this institution has notrithstanding enjoyed a prosperous eareer, and entirely unshaken has achieved a position among its cotemporsies which is the best commentary upon the manner of its uanagement, wbich in the face of general disaster could secure success. Anong its officers and directors will be found many names prominent in the commercial world and closely identified with the best interests of the community. They are as follows:-Wm. H. Everson, Esq.. President; B. F. Wilson, Esq., Viee President; MIr. W. C. Macrun, Cashjer; Mr. O. F. Wharton, 'Teller; Mr. George S. Macrum, Collection Clerk. The Directors while including the President and Vice President are :-NIessrs. J. B. Sneatlen, Jacob Klee, Wm. France, D. W. C. Bidwell, Jno. O. Phillips, Jno. L. Lewis, H. B. Hays, Andrew. Fulton, E. A. Montooth, Esq., and J. C. Risher. With a eapital rine National Bank is regarded as a favorite institution and inspires universal confidence.

\section{F. R. FL ZCK, -Druggist, 171 Beaver Av., Allegheny.}

The old established and well known Pharmacy, located at No. 171 Beaver arenue, was purchased by the present proprietor in $1 \$ \bar{i}$, and since that time has been successtully conducted by him and the trade has steadily increased. He occupies a neat and at tractive store in the three-story brick building at the number named, with a frontage of 20 feet and extending back 55 feet, where he keeps on hand a cloice stock of pure drugs and medicines, perfumeries, fancy goods, toilet artieles and everything pertaining to a well regulated estahlishment of this kind. Mr. Fleck is an experienced pharmaceutist and pays especial attention to compounding physician's prescriptions in a careful and accurate manner, using only the very purest and best ingredients. His trade, which will amount to about $\$ 6,000$ per annum, enjoys the most unbounded confidence of the leading phrsicians of the city, and his prescription business is quite an inportant item. He carries a stock of about $\$ 5,000$ and eimplors one competent and experieaced assistant. MIr. Fleck was born in Indiana county, Penn'a, in 1817, and has resided in Allegheny since 1875.

\section{ENTERPRISE PLANING MIIL,-Hahn, Harms \& Schramm,}

Cor. 1 zth and Jane Sts., S. S.

The Enterprise Planing Mill is one of the most complete and extensive establishments of its kind in the two citics. The original capital inves!ed in the business by the present proprietors was $\$ 20,000$, which has since been increased nearly one hundred per cent. The mill and yards, lonated at the corner of Seventeenth and Jane streets, South Side, cover an area of $100 \times 120$ feet. The mill covers a space $52 \times 100$ feet, and is supplied with all the requisite machinery of the most approved patterns and designs, and a 35 horse power engine, with a boiler 24 feet in length by 40 inches in diameter. The firm manufactures bere ever7 description of Flooring, Weather Boarding, Sash, Doors, Mouldings, Boxes, \&e. Stair Building, Scroll Sawing and Wood Carving are specialties. The firm are also extensire contractors and builders, and some of the finest public and private buildings in the city have been constructed by them. They carry on hand an average stock of about $\$ 7,000$, consisting of lumber in the rough and finished work pertaining to their line. Seventeen skilled workmen are constantly employed, at a weekly expense of about $\$ 220$. The annual trade of this house aggregates $\$ 35,000$ to $\$ 40,000$. Nessrs. Hahn and Harms are both natives of Germany. 'The furmer was born in 1837, and the latter in 1842 . Mr. Hahn eame to this city in 1844, where he has since resided. MIr. Harms has been in Pittsburgh since 1865. Mr. Schramm was born in Beaver County, in 1811, and has resided in Pittsburgh for the past twenty-two years. They are all energetic and reliable business men, practically conversant witl all the details of the business. 


\section{WINTERTON ALE \& BEER BREWERY,}

The rapidly increasing popularity of the amber-hued beverige of the "Faderland" among all classes and all nationalities, and the immense sales of Lager Beer by manufacturers from other cities and States of late years to dealers in this section, have been the immediate causes of a determination upon the part of our home brewers to commenee the manufacture of this healthful and nutritious article. Consequently in that spirit of emulation and enterprise relich brooks no rivalry from abroad so characteristic of Pittsburgls's great manufacturers in every branch of industry, unan of the brewers who formerly confined their operations to the production of ale and porter, have recently made extensive additions and improvements with a view to producing an article of Lager Beer of a quality equal to, if not superior to that of any establishment in the country. Tlie old-established and well-known Winterton Brewery of the Messrs. Wainwright was among the first to enter the field in this line, and they have recently put upon the market a beer whieh bas received the most enthusiastic encomiums of connoisseurs and been pronounced by competent judges and by retailers to be superior to any yet offered in this market. The Ale and Porter previously manufactured by this firm had acquired a national reputation, and the indications are that the Lager Beer of Wainwright will, as soon as its nerits become known abroad, attain a like enviable celebrity. The Winterton Brewery, by many years the oldest in this section, dates back its origin to 1818 , and for orer sixty years its proprietorship has been vested in the Wain wright family. Mr. Joseph Vainwright, the founder of this extensive house, was a native of Yorkshire, England. He came to the United States in 1803, and to Pittsburgh the same year, and purchased Wainwright's Island and nine acres of ground adjoining, being what is called a part of tlie "good liquor patent." Here he erected a woolen mill and afterwarrs a grist mill and oil mill, giving them the designation of the "Winterton Mills." Subsequently, in 1818, he enliarked in the ale brewing husiness, manufacturing at first what was known as English Table Beer. Shortly afterwards he commenced brewing Ale of a superior quality, and continued that business with marked success until 1852, when he retired from active connection with the house and turned the business over to his two sons, Jarvis aud Zachariah Wainwright. Mr. Jarvis Wainwright shortly after withdrew from the firm and removed to Zanesville, Ohio, and engaged in business there, his brother Zachariah continuing the management of the brewery here until 1860, at whicl time he associated with himself in the business his three nephews S.J., J. Z. and H. E. Wainwright. In 1865 he turnerl over his interest in the firm to his son, Mr.J. G. Wainwright, the style of the firm still being the same. In 1878 Mr. J. G. Wainwright retired and the present members of the firm are S. J., J. Z. and H. F. Wainwright, doing business under the old firm naue and style. The brewery, which for many years was noted as the most complete and perfectly arranged estahlishment of its kind in the United States, and producing the best quality of ale, was continued exclusively as an ale lirewery until 1879, when perceiving the growing demand for Lager Beer, the firm with their accustomed esiergy and enterprise resolved to produce an article that would surpass all other beers and supply the home demand with a superin quality and ligher grale tlan is now furnished by the brewers of Western cities. Aided by careful olservation and abundant capital, accumulated through their own enterprise and ability, they have made the necessary alterations and improvements and now possess the most complete and thoroughly appointed heer brewery in this country, with facilities for manufacturing Lager on an extensive scale and of a quality not to be surpassed by any in the world. The capacity of their extensive establishment is not less than fifty thousand barrels per annum. Their extensive huildings cover more than an acre of ground, and their malting house, brewery, ice-liouses, cellars and vaults are perfect and complete in all their departments and details, and the pure and clear water used by them is peculiarly adapted to the mannfacture of beer. The firm is to be congratulated upon securing the services of one of the most conpetent and skilled brewers as general supervisor of the brewing department, and their entire corps of assistants are men of experience and thoroughty conversant with the business. The members of the firm are both gentlemen of long practical ex perience, and possess a thorough knowledge of the business in which they have grown up from childhood, and give their personal attention to its management. They are liberal-minded, publir-spirited gentlemen, intimately identified with the business interests of the city and particularly with the material welfare and prosperity of that section in which their immense establish ment is located. Mr. S. J. Wainwright was born in Pitsburgh in 1829 and during a busy and active lifetime has been prominently connected with and interested in all public improvements and movements tending to develop and benefit the city of his birth. He has ever taken an active and promiuent part in mumicipal, county, State and national politics, and as a leading member and enthusiastic worker in the great Republican party has been largely instrumental in securing numerous rictories for his party and his friends. Mr. Wain wright was a nienber of the old Borough Council previous to the consoliclation of Lawrenceville with the city proper, and as a memher of the Select Couneil of Pittsburgh he distinguished himself for ability and devotion to tbe interests of his constituents and of the entire municipality In 1873 and 1871 he represented his district at Harrisburgl in the House of Representatives with marked ability, and left an honorable record as one of the most upright and conscientions members of that bod $y$ He was a member of th National Republican Convention at Cincinnati which nominated President Hayes, and was selected as delegate by Judge Sterrett in his interests at the State Convention one year ago. He is also president of the Arsenal Bank. In all the varied walks of life, in his social and private intercourse, in his commercial career, in the mercautile fommunity, in every department of public life in which he has heen called upon to serve, he has been uniformly noted for courtesy, urbanity and unimpeachable integrity, and we greatly mistake the sentiment of the community if higler political honors are unot yet in store for this accomplished, public-spirited gentleman. Mr. J. Z. Wainwright was also born in the Smoky City in 1832, and, like his brother, hus been actively engaged in business since he was a young man and taken a deep interest in the growth and prosperity of the city. Mr. 1f. E. Wainwright was boro in 1835 . He stands very high jn the estimation of his neighbors and acquaintances. He now represents lis ward in the City Council to the unqualified satisfaction of his constituents. Few business houses in this country can boast so long and honorable a business career as the one now represented by the three gentlemen who form the subject of the present brief and imperfect sketel, and few houses in any hranch of husiness have attained so wirle-spread and enviable a notoriety for the uniform excellence and superiorit.y of their goods during a continuous career of over sixty years. To such men as have nanaged and controlled the business of this house during that long period is Pittsburgh indebted for the proud position she liolds to-day as the great industrial metropolis of the iV ester'n Hemisphere.

ERNST AXTHELI, -No. 103 Third Av.

Agent for ZEtna Sewing Dachines, and Electro and Mechanical Bell Iranger.

Mr. Axthelm is a practical and scientific mechanic, and makes a spccialty of Electro and Mechanical Bell hanging and repairing sewing machines and every description of small machincry. He has had twenty-one ycars experience He has been resident agent for the celebrated Atna Sewing Machines since 1861. 1Te makes a specialty of light mechanical appliances and repairing, baving the most extensire establishment of its lind in the city. Mr. A xthelm was born in Germany in 1826, and came to this city in 1851 , where he has since resided.

\section{A. J. THOMIAS, - Contractor and Builder, 33 Fulton St.}

Mr. Thomas was formerly of Allegheny City, but remored to his present place, where he is preparcd to take cnntracts for carpenter and joiner work and do general job work promptly and in the best manner. He employs none liut practical and experienced hands and the work in all cases is guarantced to give satisfaction. Dir. Thonpson is a skilled inechanjc and understands what he proposes to do. Healways has at his command a supply of lumber and materials to meet the demand of his customers and those who may require his services. Those having work in this line will do well to secure his services. 


\section{EDGAR THOMSON STEEL CO., LIMITED.-Steel Rails,}

office, 48 Fifth Av.

As occupying a prominent position among the iron and steel manufacturers of the United States, and more particularly important with reference to the industries of this community, the Edgar Thomson Steel Co., Limited, is entitled to more than passing attention in a work whose object it is to display fully and in detail the resonrces and advantages
of Pittsburgh as a commercial and manufacturing center. Named after the late President of the Pa. Rail Road Company, the Edgar Thomson Steel Co., Limited, was organized Nov. 1, 1874, under act of the Assembly of Pennsylrania approved June 2, 1874, with a capital of $\$ 1,000,000$, increased Oct. 1 , 1878, to $\$ 1,250,000$. The works were erected, and active operations commenced Sept. 1, 1875. These works, both in extent and productive capacity in the manufacture of Bessemer Steel Rails, Blooms, Billets and large forgings of special designs, are regarded as the most complete and convenient in every appointment in the United States. Located 11 miles East of the city on the P. R. R. and the line of the B.\& O. R. R. Co., as well as fronting the Monongahela River, possessing all the advantages conferred by water navigation, connecting it with all points, West, North, and Southwest, and the benefits derived from proximity to the two most important trunk lines of road in the country, the plant with reference to cheapness and facility of transportation of product or materials is considered unapproached. At this site (Bessemer Station) the company own 106 acres, more than 20 acres of which are covered by the works, at the present time three blast furnaces being in process of erection.

The subdivisions of the works are arranged as follows, the number of employees being given in each department : rolling mills, 360 hands, converting department, 275 men, engines and boilers, 83 men, main tenance and general labor, 247 men, superintendence and elerical force, 23 ıen, in all 988 operati ves, requir'ing a disbursement of about $\$ 45,000$ monthly. All the machinery in use at these works is noted for its perfection and scientific fitness for the various purposes for which it was specially designed and adapted. The Bessemer process is applied in its greatest perfection, an added advantage being gained by the use of $W$. R. Jones' patent compression process (to which the company have an exclusive right), and by which, throngh the operation of steam pressure upon molten steel, a uniformity, solidity, texture, and textile strength are secured, as well as freedom from flaws and atmospheric porosity, that gives to metai so treated the highest value for special constructive purposes. The present officers of the Edgar Thomson Steel Co., Limited, are ranked, outside of their connection with this concern, as among the ablest in the community, and are as follows:

Thomas M. Carnegie, Esq., Chairman, also Treasurer of the Keystone Bridge Co, and of Carnegie Bros. \& Co. and Lucy Furnace Co. : Wm. P. Shinn, Esq., Sect'y, Treas, and General Manager, also Pres't of the Ashtabula \& Pittsburgh R. R. Co.; Wm. R. Jones, Gen'l Supt. John Rinird, Sup't converting works, and Thomas H. Lapsley, Sup't of rail mill. Among the special products to which the company is giving particular attention may be mentioned Steel for Bridges and architectural structures, requiring great strength yet lightness of appearance. As an evidence of the success attendant upon their efforts in this direction may be cited the bridge of the Chicago and Alton $R$. R. Co. over the Missouri River at Glasgow.

The product of the works, so far as Billets are concerned, is mainly monopolized in Pittsburgh, but the Bessemer Steel Rails, for the excellenee of which the company has achieved a surpassing reputation, find buyers in all the principal railroads of this country. It is not the purpose to enter into a minute description of so considerable an enterprise in this volume. The design is accomplished if some idea of the magnitude, resources and product is conveyed to the mind of the reader, and some record made of the vast inflnence exercised for usefulness, and the general wellbeing on the part of the Edgar Thomson Steel Co., Limited.

\section{MERCHANTS \& MANUFACTURERS NATIONAL BANK,}

Perhaps no fiduciary institution in Pittsburgh is more intimately connected with the interests of the community or has had a career uniformly more prosperous or useful. Established in 1833 as a State Bank with a capital stock of $\$ 600,000$, in 1864 a stock dividend was declared and the capital increased to $\$ 800,000$, and the bank organized under the National Bank Act. Among the officers and director's at the present time will be found many names closely identified with the industries of Pittsburgh and her manutacturing resources. Mr. Wm. Rea of the well known iron firm of Robiuson, Rea \& Co., is the chief executive officer of the bank, and Mr. Wilson A. Shaw occupies the position of eashier. The directors are as follows:-Mr. D. A. Stewart, of the Columbia Oil Co. and Pittsburgl Loeomotive \& Car Works; Wm. Miller, Esq., proprietor of Duquesne Forge and president of the Pittslurgh Exposition Society, \&c. ; Mr. Wilson Cunningham of the firm of Cunningham \& Co., Glass Manufacturers: John Scott, Esq., president Allegheny Valley R. R., Pittsburgh Va. \& Charleston R. R. and largely connected with the manufacturing interests of the city ; Stew art McKee, Esq., of the tirm of McKee Bros., Glass Manufacturers, and associated with other public enter-
prises; Wm. Stewart, Esq., of the Penn'a Co. as general freight agent, Henry B. Hars, Esq., senior of the firm of H. prises; W m. Stewart, Esq., of the Penn'a Co. as general freight agent, Henry B. Hays, Esq., senior of the firm of H. With such a management it is not difficult to understand the secret of the success of the bank, a success pretty thoroughly demonstrated by a surplus of $\$ 200,000$. The staff of assistants are Messrs. Geo. Shaw, Teller; W. H. Jack, ass't Teller; W. E. von Bonnhorst, general book-keeper; G. L. Rodgers, individual book-keeper, Thomas B. Rea, discount clerk; and P. C. Young, messenger; W. J. Ward, watchman; Wm. Hamilton, janitor. The structure occupied by the bank was erected expressly for and by it, is one of the handsomest edifices in the city, both arehitecturally and with reference to the interior arpointments and conveniences which are exceptionally ettractive and substantial. In conclusion it is safe to assert that no financial institution in Pittshnrgh ocenpies a higher place in the eonsideration of the community than the Mereliants \& Mannfacturers National Bank.

\section{OTTO KREBS,-Lithographer, No. 6 Sixth Av.}

By far the most important house in Pittsburgh engaged in the Lithographic business is that of Mr. Otto Krebs, not only on account of the magnitude of the business transacted, but because of the really artistic and superior work which cmanates from his establishment. The house was originally founded in 1854 as Krebs \& Bro, ehanging to present style in 1861 , since which time the trade has been successfully conducted with a constantly increasing demand upon its facilities. When Messrs. Krebs \& Bro. first established the business a quarter of a century ago, theirs was the only enterprise of the kind in Pittsburgh, if not in the West, and the introduction and development of the art is mainly owing to their skill and resolution. The spacious establishment now occupied by Mr. Krebs on Sixth avenue is in marked contrast with the little apartments where the firm first began operations. The premises at present consist of one large brick building, three floors of which, $30 \times 75$ feet each, are devoted to the business. Here are employed twenty expert artisans, to pay whom a weelily outlay is required of about $\$ 200$. Six presses of varions sizes, from the smallest to the largest made, form part of the machinery used, besides one steam encine and boiler and other apparatus and appliances, the best and most ingentous that capital or invention could supuly. The husiness employs one traveling salesman and extends through Penusylvania, Ohio and the Western States. Everything in the way of lithographing is executed in this establishment with rapidity and superior excellence, and the facilities for such work are not excelled by any house in the country. Mr. Krebs is of German origin, since 1852 he has been a resident of this city and has done much, not only to perfect his art, but to encourage and foster the general industries of the community. To those who desire work of this descripiion Mr. Krcbs is cordially comnended as having not only the facilities, but the experience to render perfect satisfaction in every case. 


\section{PEOPLES NATIONAL BANK, -No. 79 Wood St.}

Among the most successful financial institutions in Pittsburgh the Peoples National Bank must be accorded an honorable place, not only from the success attendant upon a useful career, but from the extent of its operations and capital. This bank was organized in 1865 with a capital of $\$ 1,000,000$ and a corps of officers in which but little chang has been since made and who are at present as follows:-Barclay Preston, Esq., President, of the firm of Davis, Chambers \& Co., White Lead Manufacturers; J. W. Chalfant, Esq., Vice President, of the house of Spang, Chalfant \& Co and Isabella Furnace Co., and F. M. Gordon, Esq., Cashier since the establishment of the institution, who is assisted by Messrs. W. H. Riddle, Teller; J. F. J. Allison, Gencral Book-keeper; B. F. Thomas, Individual Book-keeper, anc G. M. Murphy, Assistant Teller. Some idea can be gained of the success achieved by the management from the facts that since its establishment over one million dollars have been paid in dividends, and that the surplus now on hand amounts to $\$ 180,000$, with an arerage line of ceposits to about $\$ 600,000$. With snch a history and influence, the Peoples National Bank has become synonymous with solvency and prosperity, and is justly entitled to the consideration it has acquired.

\section{SECOND A VENUE COACH IINE,-James F. Fawcett, Superintendent.}

In a work of this nature, embodying the industries of the Iron eity, its business facilities and prominent features of general information to the public which shall elicit present and fulure interest, it is very proper and will be expected that the various railroad lines centering here and the facilities for reaching various portions of the city and suburbs, be clearly set forth. We, therefore, take pleasure in giving the readers of this work a brief description of this important route under the able management and superintendence of Messrs. Geo. W. and James F. Fa weett, brothers. The route extends from Market street to Glennwood, a distance of five and three-fourth miles. The origin of this line of transit and freight over this route was a long-felt necessity, and the great incon renience to which citizens along this route were subject from a lack of something of this nature which promised to meet the requirements, and as the result has proven, it has been so liberally patronized that additional coaches will be required, (four more new eoaches now building.) The business was started by James F. Fawcett, Esq., in the early part of the present year, in company with George W. Fawcett, his brother. They now have five good, substantial and comfortable coaches, and with the four additional ones wiil make nine, making regular trips, and will shortly put on additional new ones. They have an investment already of about \$7,000 including stock and fixtures, employing thirty-three horses and ten men, with one stable and harn, two stories high and $30 \times 100$ feet in size, and one building for building and repairing coaches. They offer not only a pleasant mode of travel in their convenient and roomy coaches, hut carry passengers and freight at such low rates that this line and its able managers have become decidedly popular and liberally patronized. MIr. James F. Fawcett was born in this city in 185-4, and has all his life been identitied with its growth and progress. He is the inventor of an improved axle box which is considered of much value. Mr. George Fawcett, Sr., was born in England, in 1811, and came to this city in 1833. These gentlemen are wide-awake and energetic citizens and have established a line of transit and freight travel which must continue to grow in importance from year to year.

\section{T. P. BEDILION,--Jeweler, 53 Fifth Av., First National Bank Building.}

Among the most prominent houses in the city engaged in the Jewelry business, the establishment of Mr. T. P. Bedilion is entitled to special mention, not only on account of its elegant appointments, but the admirable taste displayed in the selection of a very comprehensive stock of high class goods and rare articles pertaining to the trade. He carries the choicest line of Table Ware, including Dinner and Tea Sets, W ater Sets, Epergnes Fruit Stands, Cake Baskets, Urns, Entree Dishes, besides Lavatory Sets, Jewel Cases, Candlesticks, Candelabras, goods suitable for bridal and other presents and Watches, Diamonds, French Bronzes, Clocks and Ceremic Ware, etc. The premises are admirahly located in the First National Bank building, on Fifth avenue, $t$ wo floors being occupied, the departments embracing repairing, engraving, jobbing and retailing. The show and salesrooms in the latter division being on the first floor, with a repairing department, managed by thorough mechanics, for the repair of fine $W$ atches, Clocks and setting of precious at Wheeling, removing to Pittsburgh and establishing his present enterprise in 1874. His standing and relations with the trade are such as to enable him to offer special advantages to buyers, particularly in the manufacture of ordered jewelry and the setting of diamonds. In every respect Mr. Bedilion is highly commended to the public.

JOHN BATES,-Stoves \& House Furnishing Goods, 1403 Washington St., South Side.

Mr. Bates is a natire of the South Side and was born in 1852. Hecommenced business for himself at his present loention, To. 1403 IV ashington street, in 1876 , with moderate means, but with an ample capital of perseverance, pluck and energy. He now has a flourishing and lucrative trade, and his capital has considerably increased. He occupies two buildings with a frontage of forty feet and a depth of twenty feet, and carries a full and complete stock of Cooking Parlor and Office Stoves, Grate Fronts, Ranges, Hollow Ware and House Furnishing Goods, in great variety, and manufactures every description of Tin, Copper and Sheet-Iron Ware, making a specialty of Job Work, Tiu Roofing, Conductors. Gutters and Sheet-Iron Work for Mills. He carries an average stock of about three thonsand dollars and enjoys a liberal patronage from both eity and country.

\section{JOHN K. COLLINS,-Cigar Factory No. 407, 219 Federal St., Allegheny.}

The manufactory of John K. Collins, No. 407, is Jocated on the west side of Federal street, a short distance above the parks. The business is carried on in a two-story frame house $20 \times 60$ feet in size. Mr. Collins was born in Clarington, Ohio, in 1855 and came to Allcgheny and engaged in business in 1877 . He manufactures and keeps constantly on hand a large and choice assortment of the best brands of eigars, smokers' supplies, ete., making a specialty in the finest and best grades of tobies to be found in Western Pennsylvania. His trade extends over Ohio and Pennsylvania. He has ten assistants employed.

\section{J. PARKE WILSON, Agt.-Hardware,Cutlery, \&c., 163 Penn'a Av., Allegheny.}

Mr. Wilson was born in Allegheny in 1848 and was formerly in the hardware business at 151 Penn'a avenue, and in October 1878 removed to his present location. His place of business is situated on the east side of Pcnn'a avenue, a short distance below Bidwell strect, in Frazier's block, formerly occupied by F. Mensendeick. He keeps constantly on hand a choice assortment of hardware, cutlery and house furnishing goods of the best quality and is also agent inr the celebrated granite iron ware. Parties desiring anything in this line will do well to call and examine the stock of Mr. Wilson. 


\section{ARMSTRONG \& McKELVY, -Mf'rs, of White Lead \& Colors, 37 Wood St.}

A brief inspection of the various branches of trade and manufacture of our city must convince any one that a decided reaction has set in, and that the manufacturing interests of this centre are rapidly improving, and are of such vitality and magnitude as to be felt through all the arteries of trade. It is the purpose of this work to aid in tbis development by disseminating such intelligence regarding the advantages possessed by our manufacturers here as will draw attention to their facilities. In connection with the manufacture of White Lead, the firma name of Armrtrong \& McKelry at once associated jtself in our mind with this line as being one of the most important and reliable houses. This firm was established about ten years since and has been uniformly successful, having established a national reputation for the "Keystone" brand of Lead, their trade extending from the most eastern part of the country to the Pacific Slope and slore. They pay close attention to the manufacturing department, having a large building fronting on the Allegheny river on the WVest Penn road, exclusively deroted to this specialty. It is named the Keystone White Lead Works, aud has an annual capacity of two thousand tons of white Lead, five hundred tons red lead, litharge and orange mineral. All the unachinery and appliances are of the latest and most improved forma and especially intended for economy as well as excellence of production. The facilities for handling, packing, shipping, etc., are unsurpassed, they having their ow $\mathbf{n}$ side track helping materially to reduce the cost. This is a prime consideration in these times, when the balance sheet of any firm will show on the right side as much from reduction of expenses as frow profits on sales. Mr. Armstrong has charge of the manufacturing departmcnt, and the excellence of these leads, etc., is sufficient evidence of his capacity and administrative ability. Nr. McKelvy lias charge of the office and business department of the firm. This gentleman was one of the firm of McCully \& Co., glass manufacturers, for a number of years and has had an excellent business education. Pittsburgh owes much of its business prosperity to such firms, who not only produce excellent wares, but are noted as well for their probity and honorable business dealings. We may say to our readers who deal in or use white leads or kindrcd goods, that in patroniziug this firm they will consult their own best interests, as all their dealings as well as wares are of the lighcst order.

\section{CHAUTAUQUA IAKE ICE CO.-Twentieth and Railroad Sts.}

Among the various commercial and industrial pursuits of the city, the Ice trade is by no means one of the least extensive, and among the number of establishments engaged in that branch of business the Chautauqua Lake Ice Co. stands preeminently at the head. Any une visiting the city may be able to form some idea of the extent of the trade of this establishment from seeing in every street and in all parts of the city the numerous and beautiful white wagons of this company going to and fro delivering to the sweltering denizens of this Smoky City great chunks of their beautiful Ice, clear as crystal and full of suggesting confort on a hot day. The Chautauqua Lake Ice Co. was organized in 1869 by a party of Pittsburgh gentlemen, and run by them until 1873, when the entire business came into possession of A. Hersperger \& Son, the former having managed the affairs of the company from its organization. The Ice sold by this company- which is by far the finest, purest and most beautiful that is brought to the Pittsburgh market-is taken from Lake Chantauqua, one of the most picturesque sheets of water in the mountains of western New York. The company has erected immense Ice houses at Mayville, a beautiful village situated at the nortli-western end of the lake, and have at present 40,000 tons of Ice stored in them. During the warm weather this Ice is shipped to Pittsburgh daily in the cars of the A. V. R. R. Co. The company has unsurpasesd facilities and the most approved machinery for cutting, packing, shipping and delivering Ice. Indeed, without all these, it could not supply its immense tralle, which, during the Summer, requires from 200 to 500 tons of Ice per week. A. Hersperger is a natire of Allegheny, and lived in the city until recently, when the growth of his business compelled him to remove to Nrayville. A. A. Hersperger, the junior wember of the firm, has the superintendence of its business in the city, and to this he devotes his entire energy and constant attention. The exteuded and growing trade of the company, the systematic, prompt and reliable manner in which this is supplied, speak volumes for the ability and energy of its members.

\section{LUTZ \& SON, - Proprietors of Allegheny Brewery and Lion Brewery, \\ 1 to 11 Spring Garden, Allegheny.}

Next in importance to the productions of the iron, steel and glass works of Pittsburgh and Allegheny, which have given these twiu cities a world wide celebrity as the great industrial and mannfacturing centre of the Western Hemisphere, comes the manufacture of lager beer, in which branch of business an immense annount of capital is invested. Prominent among the firms engaged in this important industry is that of Messrs. D. Lutz \& Sen, which has for more than a quarter of a century been identified with the brewing business in Allegheny county, and which from a compraratively small beginning has become one of the best known and most reliable firms in the West, owning and carrying on two extensive establishments and controlling a trade of nearly $\$ 200.000$ per anuUm. THE ALLEGHENY BREWERY, which is one of the oldest and most complete breweries west of the dlleghen y mountains, was founded in 1853 by the firm of Lutz \& Walz, and is located at Nos. 1, 3, 5, 7, 9 and 11 Spring Garden avenue, Allegheny city. The buildings consist of one three-story brick structure $50 \times 44$, one three-stery brick building $32 \times 140$, one two-story brick strueture $50 \times 108$ and one two-story brick building $25 \times 36$. These spacious and commodious edifices are supplied with the most complete and perfect machinery, appliauces and appurtenances known at the present day for the speedy and satisfactory production of this delicious and invigorating beverage, including one thirty-two horse power steam engine and eapacious boiler, The cellars, vaults, ice houses and refrigerators are admirably constructed and arranged, and all the appointments in every department are thoroughly first-class. The average stock carried at this establishment is not less than $\$ 20,000$ and the annual sales from the Allegheny Brewery alone amount to more than $\$ 105,000$. Over 15,000 harrels of beer are manufactured per annum at this establishment and the demand is always fully equal to the supply. The firm of Lutz of Wal\%, original proprietors of the Allegheny Brewery, was dissolved in March, 1879, by the death of Mr. Xavier Walz, who was lost at sea on the ill-fated steamer "Pommerania" while returning from a visit to his native land. Mr. Anton Lutz, son of the senior partner was admitted to an interest in the business and the firm name and style became as at present. These gentlemen are also proprietors of the celebrated Lrov BrEwERX, on the corner of Vineal and Villa streets, Allegheny city, which was originally established in 1858 by Hechelman \& Co., changed to the Lion Brewing Co. in 1874, and in 1878 to Lutz \& Walz, and in the following rear came into the hands of D. Lutz \& Son. The entire establishment comprises five spacious and commolinus buildings deroted to the man ufacture and storage of the celebrated lager beer, which has attained such an enviable reputation throughout this section for its purity and general excellence. The buildings are as follows : one two-story frame $28 x+6$, une three-story lirick $54 x 72$, one two-story brick storehouse $30 \times 42$, one two-story frame $30 x+2$ and an ice house $46 \times 72$, with a capacity of 1,200 tons. The annual products of the Lion brewery are aoout 12,000 barrels, amounting in value to more than $\$ 70,000$. The average stock on hand is estimated at about $\$ 18,000$. The vats, tubs, tanks and other xcquisite machinery and appliances are of the uost approved construction and style and in every way perfectly adapted to the requirements of the business. Power is supplied by one large boiler and one 26-horse power engine. Every department of this extensive establishment is conducted in the most perfect and systematic manner and all the appointments and appurtenances are of the very best. Eighteen experienced hands are employed with a weekly pay-roll amounting to $\$ 220$. The reputation of Pittshurgh and Allegheny befr is rapidly acquiring a national reputation, and we have no doubt that within a very short time the export trade in this now standard national beverage will exceed that of many of her older and hitherto more inportant industries. MIr. D. Lutz, the senior member of this enterprising and reliable business firm is a native of Wurtemberg, Germany, and was born in 1822. He has resided in Allegheny since 1848 and is one of her unost respected and honored citizens. Mr. Anton Lutz was born in Pittsburgh in 1853, and although yet a roung naan possesses excellent business qualifications. Both gentlemen stand deservedly high in the community. 


\section{BILLINGS' PATENT HORSE SHOE,-G. K. Flowers, 164 Penn Av.}

Another new and important branch of industry has recently been established in Pittsburgh, which is destined to become one of considerable importance, and will undoubtedly entirely revolutionize the old method of horse-shoeing The improvement, which is known as the Billings' Patent Horse Shoe, possesses many advantages over the style at present in use, among which we may enumerate: 1st. Its economy, being far cheaper in the end than the old style of shoe. 2d. Its durability, being constructed on scientific principles and of such material as to outwear any and every description of shoes heretofore in use. 3d. Its convenience, as it requires no fire, and, with little previous experience in shoeing horses, can be put on by any one, thus dispensing with the time, trouble and expense of taking the horse to a blacksmith's shop. 4th. Its utility, being lighter, stronger and better adapted for ensuring a firm, sure foot-liold for the horse, while the conformation of the stioe induces growth and health of the foot, and is a sure remedy for corns and interforing. The shoe consists of a light steel plate properly tempered, with a continuous flange instead of the old-fashioned heel and toe calk, thus obtaining a firm, sure foot-hold on the pavement, giring the horse the purchase and strength of the entire breadth of his foot. As a Summer shoe, it is unequalled for speed or dranght horses; and, as a Winter shoe, it is equally excellent, as the flange presented to the frozen earth is drawn to a sharp edge and deeply serrated. In connection with this unrivalled shoe, $11 \mathrm{r}$. Flowers has also an "Ice Creeper," an ingenious and valuaile invention for preventing horses from slipping on the jce or frozen ground, which can be applied to or detached from this shoe at pleasure, without removing the shoes. The Creepers consist of three pieces of hardened steel attached to the front or toe of the shoe, and to each heel calk, by a small nut and screw bolt. These can be adjusted to any style of shoe, are simple in construction, are perfectly safe aud a sure proof against horses slipping in Winter. These inventions will for all time stand upon record as the most important of the nineteenth century. Horse owners in any section of the country can receive all information relative to these important in rentions by calling upon or addressing Mr. G. K. Flowers, No. 164 Penn A v., Pittsburgh, Pa.

\section{JOSEPH TURNBULL \& CO.-Miners and Shippers of Coal;}

Office, No. 10 Smith field st.

The industries pertaining to the production of Coal, its shipment by rail or river, and conversion to coke, \&c. have always been of such stiple importance to this community as to direct the particular attention of this work to all those firms or individuals whose operations involve any of these interests. In making, therefore, a detailed revicw of the Coal trade of Pittsburgh, the firm of Joseph Turnbull \& Co., as being among the largest producers and shippers. demands more than brief notice. This house was established in 1869, and at once entered upon a remarkably prosperous career as miners and shippers of Coal, Nut Coal, and Slack. The mines are situated in Fayette Co., Penusylvania, where the company possesses 260 acres of choice Coal lands, from which are mined annually from 500,000 to 600,000 bushels of Coal-a product that represents the labor of 100 operatives, to whom are paid not less than $\$ 5,000$ per month. The mines are located near the Monongahela river, in Pool No. 4, with which connection is made by from one to two miles of railway, the Coal being dumped at once into the flats and barges of the firm, of which there are about 35 , the same being conveyed to the western and south-western markets by the steamer Hunter No. 2, also the property of the concern. The bulk of the product, however, being sold in Pittsburgh. Both members of the firm are of English origin, Mr. Joseph Turnbull having been born at Newcastle, Durham Co., in 1827, removing to this country at the age of $2 \overline{5}$, and settling in Pittsburgh at that time. Mr. John Hull is from Northumberland county, born in 1838. He removed to the United States in 1864, and since that period has been a resident of this city. From the honorable character of its policy, the firm has achieved a position in the trade that but few houses ever acquire. It is distinguished for promptness, enterprise and liberality-the exercise of which has greatly augmented the business of the concern during the past few years.

\section{CHESTNUT \& CO.-Leather, Hides \& Oil, 3/5 Liberty St.}

This house was founded in 1857 by the firm of DeLange \& Chestnut, and after ten years the present firm came into possession. They occupy the spacions three-story hrick structure $20 \times 110$ feet in size, at No. 315 Liberty street, and carry a stock ranging from $\$ 12,000$ to $\$ 20,000$, consisting of a full line of every description of leather, hides and oil, belting, hose and packing, saited and dry hides, sheep pelts, fum goods, belt rivets and lacing, fair skirting, pad skins, currier's tools, glue scraps, leather scraps, and in fact every article pertaining to this line of business. Special attention is devoted to the suppiy of red or hemlock sole leather for the trade. They rank among the largest dealers in treen salted and calf hides, which they procure principally from Eastern Ohio and Western Pennsylvania. They also keep every variety of tanners' and curriers' supplies, including pure bank straits and Labrador cod oil. They are sole agents for Western Pennsylvania for a superior quality of raw hide lacing. This firm does a considerable export business in hides, and their trade, which amounts to not less than $\$ 75,000$ per year, extends over the greater portion of the United States. They make a specialty of saddlers' and harness makers' supplies. Mr. Chestnut is a native of Pittsburgh and at present resides at West Bellerue, on the line of the $P$. F t. W. \& $C$. $R$. R. Ile is a self-made man and commenced in this business when but sixteen years of age at a salary of two dollirs and fifty cents per week, and bas followed it without a day's intermission ever since, and on the same street and in the immediate vicinity of present location.

\section{HENRY WILHELM,-Lager-Beer Brewer, 2600 Josephine St., South Side.}

The manufacture of Lager Beer of a superior quality was commenced by Mr. Henry Wilhelm in 1865, with moderate means and on a comparatively small scale. His brewery is located at No. 2600 Josephine St., Sonth Side, and is supplied with all the necessary apparatus and machinery for the production of this popular beverage. The demand for his beer has increased so rapidly of late years that Mr. Wilhelm has been compelled to make frequent additions and improvements to his establishment, in order to meet the requirements of his enstomers; and at the time of compiling this work he is engaged in making still more extensive additions, which, when completed, will add greatly to brewer of many years' experience, and manufactures a high grade of Beer, which is deservediy popular with dealers and consumers throughout the city, and his trade is large and satisfactory. With the completion of his present improvement, his facilities will be such as to enable him to produce, if possible, a better article thau ever before, and to supply the trade promptly with whatever quantity may be desired.

\section{H. F. OLNHAUSEN,-Plumber, Gas\& Steam Fitter, Carson St. bet.12th \&13th, S.S.}

This establishment was started by C. Olnhausen in 1865 with a comparatively small capital, at No. 40 Fourteenth street. The increase of trade has conipeiled removal to present location, where an increased stock of articles are offered as complete as the necessities of the trade calls for. The stock on hand embraces everytling lequired in a plumbing and Gas-fitting establishment. Mr. Olnhausen is a tfroroughly practical Plumber, Gas and Steam Fitter, and is generally looked upon as a first-class mechanic. He also employs from three to six hands constantly and has built up a good paying business, worth from six thousand to eight thousand dollars a year. H. F. Olnhausen was born in Pittsburgh in 1854, on the South Side, his parents being among the first scttlers of Birmingham when it was a village. He is well known as a persevering and energetic business man and a genial, courteous gentleman, with whom it is a pleasure to deal. 


\section{STONER \& McCLURE,-Pittsburgh Saw Mills, 27th St.}

Bridge, Barge, Building and Railway Lumber and Box Factory.

Keg Factory, 25th Street.

The situation of Pitisburgh with reference to the timber growing districts of Western Pennsylvania has always conduced to give it importance in the lumber trade, representing at the present time not less than $\$ 4,000,000$ worth, a trade that has in no little degree added to its industrial prosperity. Its magnitude and extent would perhaps be more thoroughly appreciated, were it not so overshadowed by the greater staples of iron, steel and glass. There are a number of frims engaged in the various branches of the lumber business, employing in the aggregate a vast capital. Some of these establishments are mammoth in their proportions, and are supplied with every requisite facility for the manufacture and handling of lumber in all its varions forms. At the very head of these is the firm of Stoner \& MeClure. Their establishment is one of such vast proportions and of such perfect arrangements, and occupies such a prominent position among the manufacturing interests of Pittsburgh, as to demand prominent mention in a wrk devoted to the industrial history of the day.

This establishment was originally founded by Mr. Leek, then passed into the hands of Heath \& Duff, who were succeeded 30 years ago by McClintork \& Cochran, and eveu in that day was known as the "Old Saw Mill." The changes that have since occurred, however, have spared nothing of the old structure or its machinery, the site alone remaining, upon which stands its enlarged successor. Prior to the organization of the present firm, in 1878, Alex. McClure \& Co. had carried on the business for many years, making frequent additions and improvements, and, by the introduction of the most perfect machinery, adding to the capacity of the mills, which at present exceeds 40,000 feet of lumber per diem, besides the production of the Keg factory on $25 \mathrm{~h}$ street, which is capable of turning out $3,600 \mathrm{kegs}$ a day, to say nothing of the Box factory, which is as well equipped as any in the city. The works are most admirably located, being built on the banks of the Allegheny River, having a large frontage and splendid harbor, in which is anchored at all times millions of feet of the finest stocks of lumber that can be found in the great lumber regions of Western Penisylvania. From the Allegheny Valley Railroad a siding is run into the yards, affording the most complete facilities for loading and unloading. A powerful crane is erected in the yards, by means of which enormous timbers, used for bridge, railroad, or other purposes, are lifted and sw ung on the cars with the greatest ease, enabling two men to do in a short time what it would require a dozen or more a day to do unaided by machinery. From the river to the mill chutes and tramway's are constructed, by means of which the logs and lumber from the river are hoisted rapidly into the mill, which stands like some fabled monster, ready to devour whatever enters its capacious jars. The dust from the saws, by an ingeniously constructed and poweriul fan, is driven through a boxed channel a distance of more than 100 feet into an iron clad building built for its reception, from which it is easily and simply loaded into the wagons that are constantly seeking it. The slabs and other inferior parts of the lumber are cut by special devised saws into various pieces and lengths, some used for boxes and others in their keg factory. In a most wonderful manner is, thus, every particle of the logs cut and used in the production of various nseful and necessary articles. A new mill is now being erected that will have a capacity of cutting 20,000 feet of lumber each day. Four powerful and fine engines are employed to drive the great number of saws, planes and other machinery. These mills and works, indeed, in every respect, are perhaps the most complete and perfectly arranged of anything of the kind in Western Pennsylvania. In the production of bridge timbers and railway lumber supplies and in barge bnilding, the firm has already gained a high repute, especially for long timber and the finer grades of lumber, contracts being made for building barges, boats and flats of all descriptions, and the furnishing of bridge material at any point in the United States with the utmost promptitude. As illustrating the prompt manner in which orders are filled as well as the capacity of the establishment, a telephonic order was received recently, at 4 P. M., for the delivery of 20,000 feet of timbers, $6 x 6$, to be delivered at a distant point in the city the following morning. 'The logs from which the order was to be cut were floating in the river; with remarkable energy the work was commenced, and at daylight the following morning the 20,000 feet were on board the cars ready to be transported to their destination. For the rapid and superior manufacture of nail kegs the firm has unusual advantages, being in possession of ingeniously devised and patented machinery for this purpose, the right to use in this county being vested solely in Stoner \& McClure, and their facilities are unegualled in the United States. There being but one other establishment and that of small dimensions in which this wonderful machinery is used. This keg factory is in many respects a marvelous concern, 7 machines of different kinds are used in the manufarture of various parts of the kegs, and they are capable of turning out 3,600 completed kegs per diem, and require a force of but 3 men and 50 boys to attend them. A perfect machine is used also to count the number of kegs, which is done by it in a wonderful and perfectly correct manner. The keg factory consumes much material from the mills that otherwise would be lost. Mr. C. L. Stoner is a native of Lancaster Co., this State, and was born in 1823 in the town of Millersville. Before coming to Pittsburgh he was engaged in the city of Lancaster in the business of contractor and builder, where he enjoyed a high reputation as enterprising man of business, and an honored and respected citizen. He beld the position of clerk of Orphans' Court in his native county for a number of years, rendering efticient and valuable services to the people in that capacity. He came to this city in 1866, and prior to engaging in his present business was engaged in the conch business, liaring been the head of the firm of Stoner \& Marlatt. In entering his present business he has found a field affording him abundant facilities for the exercise of his known enterprise and abilities. Mr. Aler. McCluve was born in this city in 1843 and has always been identified with the lumber business, of which his knowledge is thorough and detailed. His father baving been engaged in the sane branch of industry, Mr. McClure may proper]y be said to be indigenous to the trade, which he has greatly promoted by his eftorts and enterprise. Mr. Nathan Jones, who is also intimately connected with the firm and has charge of the office business of the concern as weI] as aiding in the general supervision of the business, has been connected with the establishment undel its previous management for 8 years. He is a native of Pitsburgh, born in 1851, and is a gentlem:u of great energy and ahility. As a firm with which to establish desirable relations in connection witl its special work it is universally admitted to be a reliabe one in every respect, and can perhaps offer inducements to buyers not readily duplicated in this or any other market. Liberal, energetic and just in its business policy, the house of Stoner \& Mcclure has achieved a signal success without the sacrifice of an honorable position.

\section{JAMES W. WOODBURN,-Marble, Stone \& Granite Works, 81 Thirteenth St.}

These works were originally established by Mr. James W. Woodburn, in 1875, with a small capital, but which, by economy and industry, combined with enterprise, has been considerably increased. He is now located at No. 81 Thirteenth St., South Side, where he is prepared to fill all orders for Marble or Granite Monuments, Headstones or Slabs for friends of the deceased, or for house or other purposes, upon the most reasonable terms. Mr. Woodburn is a practical mechanic and most skillful workman, and all work being under his personal supervision, will compare favorably with that of any similar establishment in this city, and cannot fail to give satisfaction. All orders entrusted to him will be promptly and accurately filled, and are respectfully solicited. Remember No. 81 Thirteenth St.

\section{JOHIN H. FITZ, -Dealer in Tobacco, Cigars, \&c., No. 64 Seventh Av.}

Mr. Fitz started this business in 1877. He keeps a general assortment of choice Tobaccos, Cigars, Stationery, Confectionery, Toys, \&c., and is doing a fair business. His room is $20 x 35$ feet in size. Mr. Fitz was born in Waynesboro, Franklin Co., Pa., in 1848. Came to this city in 1869 . He is district assessor of his ward, 3d district. He was burned ont during the riot of July 22, 1877, by which he lost nearly all he bad. Since then he has started up, and enjoys a good trade. 
BIRMINGHAM FIRE INS. CO.-General 0ffice, 1325 Carson St., S. S.

Among the financial institutions of the Iron city the Birmingham Fire Insurance Company occupies a prominent position and ranks among the most successfinl and reliable Insurance Companies of the State. It was organized in 1871 with a capital of $\$ 200,000$, and since its beginning has entered upon a very successful and prosperous career and has had from the first the confidence of the business community. Its affairs have always been managed in the most conservative manner and it has al ways inspired, as it justly merited, the most favorable consideration from its patrons and the general public. Its officers and directors are men of high character, possessing the confidence of the community in an eminent degree, a fact that has largely contributed to the prominence its occupics at present. The Company occupies a large handsome brick building, and their office is titted up in a neat and convenient manner. rts business, which at first was mainly local, has been gradually extending throughout the eity and Western portion of the State, and is still growing and widening as it justly is entitled to do. Its patrons are met with the most liberal treatment, and its tosses have always been met in the most prompt manuer. The business the past year, which lias been an unprecedentedly dull one for Insurance Companies, reached very comfortable figures, and has enabled the Company to add very materially to their growing surplus fund. The officers of the Company are:-Chas. Melling, President; a gentleman of high character and financial abilities. He is a native of Germany, born in 1826, and emigrated to this city in 1851, since which time he has been closely identified with the industrial interests of the Iron city. Mr. Wm. Ruske, Secretary, with whom the patrons of the Company more generally come in contact, is a gentleman of abilities, well known throughout the city, and is universally esteemed for his many genial qualities. He was born in Germany in 1842 and came to this countr $y$ in 1867, and in a few years thereafter entered his present position, where his abilities and energies have largely contributed to the success of the Company he represents. The Birmingham Fire Insurance Company is an institution with whom it is always safe to insure.

\section{THOMAS FLEMING,-Grocery and Bakery, 301 Webster Av.}

One of the most enterprising and thorough-going business men in that section of the Iron city is Thomas Fleming, Esq., dealer in groceries and provisions, baker and confectioner, No. 301 Webster avenue. His is the leading establishment in that section and very properly enjoys the patronage of the best class of citizens. The store Mr. Fleming occupies has been a prominent place of business for a number of years and he only opened here in April last, since that time has received a very encouraging support. Ife carries a stock of from $\$ 10,000$ to $\$ 12,000$, embracing every desirable article, fresh and new for home and table consumption. He also produces from select flour the choicest bread, cakes, pies, etc., in the market and hesides giving him credit for keeping one of the leading and most attractive stocks in the city, we are satisfied that he possesses the proper business qualifications, tact and energy to succeed. His courteous attention and prompt habits are such as must continue to add to his numerous friends and patrons. He occupies a two story building $24 \times 40$ feet in size, constantly receiving tresh supplies, and his prices will always be found as low as any establishment of the kind in the city. Special attention is given to producing the finest bread in the city; he will also make choice cakes for parties to order. His business is rapidly growing and his present enterprising spirit will always assure him a high place among the business men of Pittsburgh. He was born in Ireland in 1849 and came to this city in 1869.

\section{ALLEGHENY BREWERY,-Thos. Booth, Prop'r., 459 to 467 Rebecca St.}

The celebrated "Spring Water Ales" manufactured at the Allegheny Brewery, and which have attained such a wide-spread reputation, derive their name from the fact that they are made exclusively from pure spring water, an inexhaustible supply of which is obtained on the premises occupied by the old and well known brewery. This spring water is admirably adapted for the manufacture of ale, as it flows direct from the rocky bed as clear as crystal and as cold as ice. For over half a century it has been running continually without the slightest change in quality or quantity, and for this period utilized quenching the thirst of two generations. The Allegheny Brewery was established more than fifty years ago without the extensive buildings and expensive machinery required in a brewery of the present day. It was subsequentiy re-established on a permanent basis by $R$. A. Irwin \& Co. Half a century has brought many firm changes in its management, Campbell \& Rhem conducted the husiness for over twenty years, followed by W. W. Anderson \& Co., Smith \& Co., Young \& Booth, the present owner, since 1866, who has made many very essential and extensive improvements. The luildings now occupied hy him cover an area of $108 \times 129$ feet, two stories in height, and have a capacity of 30,000 barrels per annum, as running at present he produces about 10,000 barrels. Two steam engines of twenty-horse power are supplied with water from an artisian well on the premises 112 feet deep, which also furnishes an abundance of water for other purposes throughout the building. Mr. Booth mannfactures his ow malt and deals extensively in bops. He employs twenty-five men and his trade extends through al the adjoining counties. The vaults ard cellars used for storage are capacious, coil and conveniently arranged and all the appurtenances of the establishment are first-class in every particular. The ales and porter manufactured here meet with a ready sale and are considered superior in many respects to those of other breweries in the iWest. Its valuable medicinal qualities are highly recommended by leading physicians.

\section{J. HOLZHEIMER,-Furniture and Chairs, Main and Ninth Sts.}

Also Proprietor of the Sharpsburgh Livery and Sale Stables.

The above gentleman began his business career in 1867 , locating in Sharpsburgh, where he has remained ever since. His business consists of the manufacture and sale of Furniture, Chairs, Coffns, \&c. In connection with this, he is sole proprietor of a Livery and Undertaking Establishment, also located in Sharpsburgh. He was born in Germany in 1839 , and came to this country in 1853. His friends have shown their appreciation of his merits by electing him school director, a position which is highly valued by the citizens of that enterprising little borough.

\section{JAMES A. ROBINSON,-Coal, Lime and Cement, Sharpsburgh.}

James A. Robinson is engaged in the Coal, Lime and Cement business, and is doing $a$ rushing trade. His building is $40 \times 130$. He began business life as a coal and feed dealer, but concluded to quit the feed business, and embark in the Coal, Lime and Cement trade. He has met with unbounded success.

\section{JOHN A. LYDICK, -Dealer in Family Groceries, 24 Collins Av., East End.}

The general grocery husiness was begun by Mr. Lydick in 1876, with a capital of about $\$ 600$. This he bas rer considerably increased. He is now doing a business of about $\$ 12,000$ per annum. His stock consists of every variety of first-class Groceries and Provisions, and always gives bottom figures. Mr. Lydick was born in the adjoining country of Indiana, in 1838, and came to this city in 1856. He began here as carpcnter and builder, but gradually glided from that pursuit into his present line of life. He is a popular merchant and esteemed citizen. 


\section{ALLEGHENY CITY FLOUR MILLS, $-L$. Walter, sr., \& Son,} Nos. 149, 150 and 151 South Canai St., Allegheny.

These extensive mills have heen in existence since 1836 under various proprietary titles. Mr. John Vogler was the original owner who conducted the business sucessfully for sixteen years, and in 1852 was succeeded by the firm of Hays \& Walter, (the latter gentleman being senior partner of the present firm). In 1855 the proprietorship was vested in the firm of Nicholas \& Voegtly, who were in turn succeeded in 1862 by Gilmore \& Co. In 1877 Mr. Walter, Sr., again became interested in the firm, and in the following year purchased the interest of Mr. Gilmore and became sole proprietor, subsequently his son, Mr. Leonard Walter, Jr., was adnitted as a partner under the firm name of L. Walter, Sr., \& Son. This firm are also extensive Lumber Dealerss, with Yard located at No. 115 River avenue, where they occupy an area of $120 \times 250$ feet. They deal in Hard Lumber and Pine Lumber only, which they obtain mostly from 'Tennessee and Indiana. They keep a full and choice stock and enjoy an excellent local trade. The average value of the stock carried hy this firm is about $\$ 15,000$ and their annual sales amount to not less than $\$ 150,000$. The mills are supplied with all the latest improved machinery, driven by an engine of ninety horse-power with three boilers. The old mill was destroyed by fire in 1877 and was rebuilt on an enlarged and more extended scale w.ith machinery entirely new and unsurpassed for general completeness by that of any similar establishment in the United States. The tinest grades of choice Family Flour are made a specialty at these mills, and the high character and unblemished reputation of this house during the past forty years have heen fully and honorably inain tained by the present enterprising proprietors. The firm also manufacture large quantities of Mill Feed, which meets with a ready sale. Their trade is principally derived from Pittsburgh, Allegheny and the various towns in the immediate vicinity, and is steadily increasing from year to year. Mr. Leonard Walter, Sr., is a native of German came to Allegheny in 1833 and for forty-six years has been identified with the business interests of the city. He has for many years been a member of the poor board of Allegheny, which position he filled most acceptably and wisely, but for personal reasons he has recently heen compelled to resign. Mr. Leonard Walter, Jr., his son, was born in Allegheny, in 1839, and is an active, energetic business man. Both gentlemen are highly esteemed as citizens and business men in the community in which they reside.

\section{JAMES McKIBBEN,-General Teaming Business, 50 Fountain St.}

This business was started by Mr. McKibben as early as 1849, with a small capital, which he bas since then very largely increased, the result of it being a successful and prosperous business, having at present about one hundred head of horses, with wagons and carts of all kinds and latest improved patterns and styles to suit the various calls, the value of which is over $\$ 40,000$. His annual business is very large, occupying one large building for his horses $100 \mathrm{x} 90$ feet, all well arranged with yard room grounds, $230 \times 109$ feet. Employing 45 hands with a weekly pay-roll of $\$ 500$. His business extends all over the city and vicinity, making regular deliveries of all kinds of merchandise and goods generally. Mr. McKibhen was horn in Ireland in 1833, came to this city in his youth in 1846 at the age of 13 years and three years later, in 1849, he started into business for himself with the then well known and popular drays, and successfully established bimself as one of the popular draymen in this city, always first to receive the goods at the depots and places of business, and make his deliveries with promptness and dispatch, which he still does, being one of the most successful and popular men in his line in this city. Mr. James McKihhen has also graced the halls of City Council as member from his ward and district, also as member of board of School Directors, with present term for sixteen years. He is an intelligent and public-spirited man and an honor to any position. During the ever memorable riots of July 22nd, 1877, he was burnt out, having his buildings, wagons and harness destroyed, barely saving his horses; his loss amounted to over $\$ 10,000$, and without an y recompense whatever, so far, but being energetic and persevering he immediately rebuilt, and at once re-established himself and is doing a flourishing and prosperous business. Mr. McKibben is well worthy the public favor and patronage so liberally be stowed.

\section{FREDERICK KOBER,-Tanks, Oil, Ale and Whiskey Barrels, 44 Fountain St.,} Near Seventh Av.

This business was first started ahout 1849, on these premises. Mr. Frederick Kober commenced business bere for himself in 1865, with a small capital, which he has largely increased. He always kceps a good stock of material on hand and a large force of men at work filling orders as fast as they come in. Mr. Kober is doing a very fair business, amounting to from $\$ 35,000$ to $\$ 40,000$. He has two buildings occupied for his work in manufacturing Barrels. None better made in this market than are daily turned out of his establishment by his skillful and practical workmen. He gives employment to 21 hands of the most skilled men in the trade. The buildings are, one 24 feet front by 64 deep. second, 24 by 38 feel-regular beehives of industry. His arerage weekly pay-roll is about $\$ 250$. Mr. Kober has the reputation of turning out some of the hest Barrels manufactured in this State; lie also has grounds outside his buildings for storing stock in his trade, with his residence close hy. These works are equal to any, and his trade extends over Pennsylvania, Ohio, West Virginia, New York, Maryland, North Carolina, Georgia, and even California. Manufacturing tight Barrels, as he does, and making tiglit work a specialty, they recommend themselves wherever they go. Mr. Kober has made several improvements in his mode of manufacturing. He was born in Germany in 1832, and came to this city in 1860 and established himself in business shortly afterwards. He is energetic industrious and thrifty, and with his native industrial habits is sure to succeed. During the ever-memorable riot of July 22 , 1877, Mr. Kober was unfortunate enough to be located in the midst of it, and was totally burnt out, losing his works and buildings, saving nothing even of his household goods except the clothing on his and his family's backs, and barely saved his desk with his books and papers, his loss amounting to over $\$ 12,000$, for which he received no recompense. But, being energetic and enterprising, he has managed to rehuild, and, Phœnix-like, to rise from the smoldering ruins and burning embers, and is now successfully re-established and doing a very extended business, which is a credit to the city, and of which he may well feel proud.

\section{ALBERT FIEDLER,-Manufacturer of Swiss Bitters, No. 113 Eighteenth St.}

Among the manufactured articles of the Smoky City there are none whose novelty and excellence will find a more ready appreciation than the celebrated Swiss Bitters, manufactured by Mr. Albert Fiedler at No. 113 Eighteenth St. The business was started in 1864 by Mr. Arnold Koch, by Mr. Fiedler in 1878. The present proprietor is making fine, palatable, as well as healtbful goods, which became popular, and has commanded a ready and increasing sale throughout Ohio, Virginia and western Pennsylvania. This business occupies tbree rooms and cellar, and orders are promptly filled on most reasonable terms. Mr. Fiedler was born in Germany in 1842, and came to this city in 1866.

\section{ROB'T CHESSMAN,-Livery and Sale Stables, Etna.}

Rob't Chessman, born in New Hampshire, Jan. 19, 1820, came to Etna, Pa., in 1835 . In 1877 he embarked in the livery and sale stable business, with a capital of $\$ 1,000$. There are two buildings facing on Bridge street, eonsisting of a carriage house, $40 \times 70$, and a stable $30 \times 50$. His trade is located in the borough of Etna and adjacent country. Firstclass rigs can always be obtained here for funeral or pleasure parties. 
WM. FIACCUS \& SON,-Tanners; Office and Worerooms, 357 Liberty St.

Tannery, No. 170 spring Gurden Av, Alteghmy City.

For man $y$ years the tanners of this city have enjoyed the well-earned reputation of making the very hest Leather obtainable in the country-a reputation that has been confirmed by mumerous awards at the great competitive exprsitions of the world. As a brinch of industry peculiarly successful in Pitsburgl, 1 hose engaged in it are more than ordinarily entitled to consideration in the compilation of a work beariug solely upon the resources and advantagcs of the Iron City as a commercial, manufacturing or producing center. Among tliose who liave done no little to estallish the Leather trade upon its present aumirable foundation, the house of Wm. Flaceus \& Son is perhaps the most widely known. The originator of the lusiness was Wm. Flaccus, Sr. (now deceased), who, with an extremely limited rapital, commenced operations as a Tanner 30 years ago. His efforts, thongh backed by very little money, were sustained by rare judgment, natural talent and unwavering integrity; with these, year after year his business increased, until, in the hands of his sons, at the present time (though under the old style), the trade of the firm, at store and tinnery, will a verage $\$ 250,000$ per annum. The individual niembers of the honse are now William, George and Ed ward l'laceus The tannery is located in Allegheny, and is a brick building three stories high and 100 feet square. From 25 to 30 hands are employed here, and a steam engine of 30 horse power, witll every jmproved modern appliance necessary in the manufucturing of Leather. They turn out large quantities of Harness Skirting, bridle and npper Leathers, and Splits. They make a specialty of oak-tanned Hurness, in the production of which they greatly excel. The warehouse, at 357 Liberty St., is devoted not only to the sale of their own products, but a general johbing trade in Leatlier, Finaings, Hides, Pelts, Tallow, Tanners' Oil, Glue, Bark Extracts, and complete lines of Tanners' and Curriers' Supplies. W'ith a capital of $\$ 100,000$, a trade extending over the entire West, North-W est, South and East, and a business policy of the minst liberai kind, it is right that $W m$. Flaccus \& Son should hold the high position accorded them in conmercial and manufacturing circles, and continue a prosperity so well deserved.

\section{SAMUEL BARCKIEY,-Grocers' Produce \& Fresh Meats, Webster Av. \& Gum St.}

Here Mr. Barckley has been located for npwards of thirty years, having started this business at this place originally with a small capital, but. which he has very largely increased, having quite a large establishment and loins a wholesale and retail business, which is a credit not only to the locality in which it is located, but also to the city of Pittslurgh. Mr. Barckley carries a stock of gonds unsurpassed by any establishment of its kind, amounting to ahuut ten thousand dollars. He has a well-established trade, extending over a large part of the city, also to Allegheny City, maklng regular deliveries daily with his wagors which ke keeps going constantly, supplying public houses as well as prirate families, and doing an annual business to the amount of about forty thousand dollirs. This in itself shows the high esteem in which Mr. Samuel Barckley is held. He always keeps a full supply of all the various goods to be found in the market. The very hest Coffees, Teas, Sugars, Butter, Flour, Eggs, Spices, Vegetables of all kinds in their seasons, all kinds of Canned Goods, choice varieties of Fresb Meats daily, Smoked Meats of all kinds, and, in fact, erery variety of articles to be found in any similar establishment. Mr. Barckley attends to his lmsiness himself and has it constantly under bis supervision, with the able assistance of his sous, employing four assistants in his establishment Mr. Barckley has always enjoyed popularity, and held office in the City Council, and has been School Board Director a number of times. At present he holds the office of President of the Grocers' Association of Allegheny City. Mrr. Barckley was born in Ireland in 1823 , came to this city in 1842 , and has heen fully identified with this city and its public good. He has accumulated quite a competence in bank stock and other property.

\section{IMRS. F. M. YOUNG,-Dressmaker \& Milliner, Penn Av., opp. Frankstown Av.}

Mrs. Young has proved herself one of the most persevering and enterprising ladies of Pittsburgh and has been correspondingly successful. She commenced business in the East End, near her present location, in 1876, on a small capital, considerably below one thousand dollars. She possessed, however, talents and taste, which peculiarly fitted her for the business she had chosen. She at present carries a stock varying from three thousand to five thousand dollars in value and does an annual business approximating ten thonsand dollars, and giving constant employment to twelve hands. Mrs. F. M. Young was born in Ireland and came to this country some seven years ago. She is a lady of refinement and rare natural talents, and enjoys in a pre-eminent degree the respect and confidence of all who do business with her. She enjoys a large trade among the elite and fashionable families of the East End.

\section{FRANZ \& DEUTENBERG,-Carriage Builders, etc., /8th \& Jane Sts., S. S.}

Prominent among the firms engaged in business on the Sonth Side is that of Franz \& Deutenberg, Carriage Builders. The business was founded by the present proprietors in 1866 with a capital of four thousand dollars, which has, during the past thirtcen years, considerably increased. These gentlemen occupy four spacious and conveniently arranged builaings fitted up with all the necessary machinery and appliances for carrying on their extensive business in its various departments of Wood Working, Carriage Trimming, Painting, Blacksmithing and Iron Working, and Salesronms. They produce the most improved, stylish and substantial Carriages, Buggies, Spring Express and Rnad Wagons of every description. They also make a specialty of Repairing in wood work or iron, Painting, Trimming, etc., and their business will compare favorably with any similar establishment in the city. They enjoy a high reputation for first-class work, which is their specialty. Mr. J. B. Franz was horn in Germany in 1838 , and came to this country in $185 \overline{4}$. He has resided in Pittsburgh since 1863 , and is a thorough, practical mechanic. Mr. F. A. Dentenberg is also a mative of Germany and was lonrn in 1836 . He has resided in Pittshurgh since 1853 . Both nembers of the firm are thoroughly conversant with all the details of the business in which they are engaged.

\section{BOYLE \& MCGLINCHEY-Livery \& Undertaking, Washington St.\& BedfordAv.}

This firm first started in business here in 1873 with a small capital, which they have since considerably increascd. They have a stock in their lines of business all tirst-class, consisting of horses, carriages, buggies, wagons, etc., of hetween three thousand and four thousand dollars, and are doing a proportionally large annual business. Being clever and accommodating they are rapidly gaining public favor. Their business privicipally is city trade. Mr. Dennis J. Boyle was born in Alleghen y County, near this city, in 1852, and his partner, Mr. Dennis MeGlinchey, was born in Ireland in 1845 , and came to this city in 1568 , where both became associated together in their present business, which they are stcadily increasing. They give special attention to Undertaking in all its brituches. They are well worthy of the patronage they receive.

\section{JA X M. WHITE,-Dealer in Drugs, Medicines and Chemicals, Etna, Pa.}

This business was started by G. Wm. Kredel several years since, and is now owned by Mr. White, who deals in Drugs, Medicines, Chemicals, eic. Plysicians' prescriptions a:e made a specialty at this establishment, and mistakes never occur. Mr. White came to Etna in $18^{m} 8$ where he has a fine trade and enjoys high public esteem. 


\section{WII. SHORE \& CO.-Groceries \& Produce, London "T" House, 20 Roberts St.}

Among the Grocery and Provision houses of the Eleventli Ward, indeed, we may extend the limits, there is none more worthy a conspicuous notice among the business industries of this city than that of $\mathrm{Mr}$. Wm. Shore \& Co., located at No. 20 Roberts street. MIr. Shore is a gentleman of culture and refinement as well as an enterprising business man. He is a native of England, where he was born in 1814, and eame to this country and city as early as 1831, about half a century ago, since which time he lias not only been associated with the business of this city, but has taken an active part in her political and civil well-being, having been one of the active participants of the old Liberty party and fully identified with its early poiitical history. He has held the office of Alderman of the Eighth Ward for ten years. He is a carpenter and builder by trade, but has now for some years, sinee 1873 , given special attention to the grocery trade, making the best class of goods the great object, at corner of Roberts street and Webster a venue. The best Teas in the market, ehoieest fragrant Coffees, choicest brands of Flour, Fruits, Spices, and indeed everything generally found desirable in a tirst-class store, at bottom figures. A stock is usually kept of about four thousand dollars, and the annual business transactions will reach from fifteen thousand to eighteen thousand dollars, the firm employing three hands to assist in the business. The company consisting of Mrs. M. Patterson, the widowed daughter of Mr. Shore, who takes great interest and constantly attends to business herself. This store is in a three-story brick huilding, $24 \times 50$ feet in size, first floor and cellar for store and business purposes, and which has become the noost popular trading place in the ward. 'Squire Wm. Shore still holds the office of Notary Public and transacts any business pertaining to that office.

\section{E. STORCH, -Marble, Granite and Stone Works, 1111 Carson St.}

We eannot forget that to ourselves and our friends death will eventually come, and while those who pass from life's busy scenes are deposited in their last resting place of the hody, we who are living can attest our respect for their memory and virtues by placing over their remains a tombstone or monument according to our affection and means. In this connection we may call attention to the excellent facilities presented in the way of Tombstones, Monunients, etc., at the Marble, Granite ahd Stone Works of Mr. E. Storch, No. 1111 Carson street. His facilities for supplying marble or granite for these purposes or building or paving stonc, are not surpassed by any similar establishment in the eity, and the excellent designs and superior skill displayed in his work is recognized as unsurprassed. The shop of Mr. Storch is at present a oue-story building $20 \times 35$ feet in size, while his yard room is $40 \times 40$ feet. He employs for the most part four skilled workmen and can guarantee the prompt fulfillment of all orders and at prices which must make it, an inducement to those in want of anything in his line. Mr. Storch was born in Germany in 1845 , and came to this city in 1872 . He is a prompt, efficient and reliable gentleman, and worthy the patronage he receives.

\section{J. F. SADLRR \& CO.-Forwarding \& Commission Merchants,}

Dealer's in Cattle, Hogs aud Sheep; Centrat Stock Yards, East End.

This firm is one of the most extensive dealing in live stock in the country, and does business in Philadelphia, Jersey City, Pittshurgh and Cincinnati. It is composed of J. F. Sadler, Philadelphia, J. P. Beal, Pittsburgh, and Fort, Sitder \& Co. of Cincinnati. At Pitsburgh the firm was organized in 1870 with a eash capital of $\$ 5,000$. It has at present $\$ 52,000$ invested in business at Pitisburgh, which anounts, including the forwarding branch, to $\$ 6,600,000$ annually. Enormous as this business seems, it is transacted with the nicest accuracy and precision and withont the slightest confusion or entanglement, so perfect is the system prevailing in and governing all its departments. Messrs. Sadler \& Co. employ twelve men in Pittsburgh, six in Jersey City, and numerous others in Cincinnati, St. Louis, Indianapolis and other places, as their immense business requires. All the members of the firm were born in the United States-in Indiana and Ohio. They are all energetie, enterprising business men, as their remarkable success irrefutably proves. J. P. Beal, the Pittsburgh partner in the firm, came to this eity from Cincinnati in 1872. He is a gentleman of sood character and executive ability and excellent judgment, and enjoys in a pre-eminent degree the confidence, not only of his brethren in the stock business, but of the entire community. His reports and notes of stock transactions are considered reliable and trustworthy, and find favor in the public estimation as well as in the press.

\section{GEO. T. MacCORD, M. D.-Physician \& Surgeon, 141 Wylie Av.}

Dr. George T. MacCord was born in Washington County, Pa., in 1845. He graduated from the Waynesburgh College in 1875 in the degree of $A$. M. and entered life as a teacher, in which profession he met with remarkable success and won a wide and enviable reputation. In 1869 and ' 70 he conducted the public schools of West Liberty, Pa. In 1870 and ' 71 he had charge of the schools at Sharpsburgh, which he resigned in the latter year and accepted the position of principal in the Second Ward schools of Allegheny City, where he remained until 1873, when he assumed professinnal charge of the Curry Normal Institnte, Pittshurgh. Here he remained until 1877, commencing with 60 students and leaving 210 enrolled at the time of bis resignation. In 1877 Professor MacCord entered the Jefferson Medical College of Philadelpliat and graduated with the highest honors of his class in 1879. He immediately entered upon the practice of medicine and surgery in Pittsburgh, where his acknowledged ability and large acquirements, together witli his extensive acquain tance, render bis suecess assured.

\section{THEO. DOERFLINGER,-Druggist, 147 Wylie Av.}

This is one of the most complete and popular retail drug stores in the city. It was opened by the present proprietor in 1876 with a capital of $\$ 2,500$, and a stock embracing every thing required in a first-class drug store, together with a line of toilet articles unsurpassed in variety and exeellence. Mr. Docrflinger's business has been good from the out-set and is steadily extending and increasing. He carries at present from $\$ 3,000$ to $\$ 3,500$ worth of stock, employs one assistant constantly and is doing an average business of from $\$ 5,000$ to $\$ 6,000$ a year. Theodore Doertlinger was born in Pittsburgh in 1854. He commenced the study of chemistry, pharmacy and materia medica in 1865, when hut a child, and has heen a close and earnest student ever since. He is a courteous and refined gentleman, and a thorough and accomplished druggist. Mr. Doertlinger was elected in the winter of ' 79 to the School Board of his ward to serve for a term of three years.

\section{J. J. KEIL,-Druggist and Pharmaceutist, Sharpsburgh.}

Mr. J. J. Keil hegan business here on the 1st dav of January, 1879. He bad formerly been in business in Etua. With unabated zeal he went to work to build up a trade for himself, and has succeeded beyond all his expectations He employs one elerk, at $\$ 60$ per month. He carries a stock valued at $\$ 200 \mathrm{r}$ He was born June 8, 1855, at Sharpsburgh, and started to learn the Drug business at the age of 14 years. 


\section{ABEL \& VOELLGER,-Bottlers of Ph. Best's Milwaukee Export Lager Beer,}

Among the industries of the Smoky City there are few which take precedence in excellence and enterprise to that of Miessrs. A bel and Voellger, bottlers of Phillip Best's Lager Beer, whose extensive establishments are lucit ed at 469 Fifth ave., while their post-ofice adlress is Lock Box 82. This beer lras obtained poptlar favor wherever it has been introduced, for its sparkling clearnesss and excellent qualities. It has met in completition with the largest and best known estali]ishments of the world, and from the best judges has claimed the lighest meed of honor. At the Philadelphia International Exposition in 1876, the Phillip Best Brewing Company was awarded the lughest needal for the superior excellence of their manufacture. At the international exhibition of Paris, in 1878, this company also captured the prize, and was awarded the gold medal. We do not know what greater honor or popularity could be achieved in this direction than has been given this establishment. The business of bottling Phillip Best's Brewing Co.'s Mlilwaukee Lager Beer was originally started by Messrs. Steinmetz \& Voellger in 1872, with muderate capital and facilities. and by them conducted up to 1877 , when Messrs. A bel \& Voellger lecame the owners, and give special attention to this business, being the only bottlers of this beer in this city. The Phillip Best Brewing Company of Milwaukee, Wis., is an organized corporation with Fred. Pitbst, Esq., as President, E. Schandein, V. President, and Afr. Best, Jr., Secretary, and their superior beer has obtained a popularity near and far. While the Milwaukee Lager Beer, bottled exelusirely by $A$ bel \& Voellger, is sold to private families only, with energy and skill of the most connmendable character, this firm is now doing a business of alout $\$ 20,000$ per annum, a business which must increase year by year. The individual members of this firm are M1r. Rohert Abel and Mr. Albert Voellger. Both were born in Germany, the former in 1845 and the latter in 1846, and came here in 1867 and 1872 respectively. Mr. A bel is a gentleman of high standing in the community ; from 1869 to 1773 he was Asst. Cashier of the 5th Ave. Bank, and Secretary of the German Amer. Insurance Company from 1873 to 1875, and has held other positions of trust, which he has filled with credit to himself, and to the satisfaction of his employes.

\section{BEST \& CO.-Printers, No. 9l Fourth Av.}

Of the many firms engaged in the "art preservative" in this city, perlaps none have acquired so enviable a jepntation for the production of elegant and attractive work as the tirm of Best \& Co., Printers, at No. 91 Fourth Av. This house was originally established in 1872 by T. F. Best, who conducted the business for four years, when the firm of Best \& Scott was organized, which was only dissolved during the current year by the death of Mr. Scott, the senior partner, retaining and prosecuting the business under the title of Best \& Co. The establishment occnpied by the fil'u from being originally a very small one, has grown to considerable dimensions, and now engrosses a building $20 \times 110$ feet, with an $L$ at the rear 40 feet long. The mechanical equipments for carrying on the business are very modern and complete, part of the machinery consisting of fonr presses, viz., one Potter cylinder and three job presses, which are operated by one steam engine. From seven to twelve operatives are constantly engaged at this establishment, most of whom are expert printers, the members of the firm also co-operating actively in the work, which embraces every variets of jou, hook and commercial Printing. the trade rapidly increasing and already reaching over the largest part of westeru Peunsylvania. Mir. T. F. Best is a native of Pittsburgl, born in 1854, and, though but a young man, has had a thorough education in his chosen vocttion, and an experience whieh places him among the first in the trade as an expert, reliable and enterprising Printer.

\section{PENNSYLVANIA FEMALE COLLEGE,-Fifth Av., East End.}

Pittsburgh, although essentiall y a manufacturing city, probably comprises within its limits a larger number of educational institutions of a superior order, than any city of equal population in the Union. Certainly annong those for the edueation of young women it would he difficult to select one to compare in thoroughness of instruction and extent of curriculan, with the subject of this sketeh. The Pennsylvania Female College was incorporated in 1869 by the State Legislature, its object being the higher education of young women in the ancient and nudern languages, the arts, sciences and literature. Its management, is vested in a board of thirty trustees, comprising some of our nust prominent elergy men, juilges, law yers and business men. The officers of the board consist of a presiclent, two vice presidents, a secretary and a treasurer, and the present officers are as follows:-President, James Laughlin; Vice Presidents, Hon. J. P. Sterrett and IIon. Rohert MeKnight; Secretary, O. Meclintock; Treasurer, Geo. A. Berry. The faculty headed by Miss Helen E. Pelletreatu, the acting president, comprises fuurteen experienced instructors in the several departments, while the course of study is broad and exhaustive, requiring for its completion the regular freshman, sophomore, junior and senior collegiate years of attendance, as well as embraeing a thorough preparatory departupon the most beautiful avenue within the limits of the corporation, yet far enough from the centre of the city, to be entirely free from its ever-encircling clouds of smoke and dust, and situated upon an eminence from which it commands a fine view of the East Liberty valley and the suburban wards of the city, the location may well be said to mands a fine view of the East Liberty valley and the suburban warls of the city, the location may well be said to
combine all the advautages of city and country. The Pcnnsylvania Railroad, upon which accommodition trans run at intervals of half an hour, winds through the valley about half a mile distant, East Liberty and Roup's Station bcing equally convenient to the college, and either being reached by a ten or fifteen minutes walk, while the Oakland street cars pass dire ctly by the entrance gate every few minutes.

The cut found in another part of this work is a gool refresentation of the building, but gives no idea of the bean ift: 1 landscape which surrounds it, a full descriptfon of which would require an article too extended for the linuitsci ol.r space. The main building is of the Gothic order of architecture, and is of brick with stone facings; the main front on Fifth avenue extending 96 feet, while from the eastern front, which is 140 feet in length, a wing extends a distance of 62 feet, in which are contuined the school rooms and dormitories. The structure is three stories in height throughout, and contains upwards of sixty apartments, each floor leing supplied with gas and hot and cold water. The location is upon Fifth avenue, three and one-half miles from the centre of the eity, a condition which iusures those prime requisites of a sebool, pure air and the ausence of noise. The extensive grounds are entered by a winding drive, which leads through beautiful forest trees to the college: In front of the luilding is a smooth lawn brightened ly tastefnl flower heds. In the rear are fine fruit orchards and a large vineyard of clioice grapes, which are freely nsed by the college inmates. The accommodations for the reception of students are exceptionally aniple. The first and sicond terms of this collegiate year begin on Scptember 10th, 1S79, and Fcbruary 2nd, 1880, respectively, with a valcation for the Christmas holidays from December 19th until Januar 7 th allowing pupils from a distance sufficient time to visit their homes and return in time for the prompt resumption of their studies. The College has won for itself a wide and well-earned reputation throughout this and many states, and therecan be no doult that under its presentable management it will in the foture, as in the past, abundantly justify the pride with which its graduates ererywliere speak of their alma mater.

\section{F. COOK,-Manufacturer of Cigârs, etc., 43 Washington St.}

This establishment is well and ably conducted and worthy of liberal patronage. Mr. F. Cook manufactures the cloicest brands of Cigars and deals in Tobneco, Snutf and Smokers' Articles generally. His Cigars are made from the best leaf tubacco, and in all cases guaranteed to be as represented. Orders will receive prompt attention. Remember No. 43 Washington street. 


\section{EDWARD M. BUTZ,-Architect, 114 Federal St.,}

First National Banl Building, Allegheny City.

In the compilation of a work of this character, we include historical matter and facts regarding the present resources, institutions, \&c., of the sister cities and their en virons, and embrace an interesting notice of a number of our fine public and private buildiugs. Every one admires a handsome, well-proportioned building, and when standing before such an one, as the Dollar Savings Bank Building on Fourth Av., or Dr. Hostetter's Block on the same thoroughfare, and buildings of this class (of which we have many), with their grand solidity, fine proportion, and in every respect perfect architectural design, in proportion to the effect of their commanding appearance upon us, our curjosity is awakened to know who furnished the plans after which they were erected. In the instances aliove mentioned, ii is apparent to every observer that none but one possessing the highest ability in his profession could bring forth such magnificent results. In these cases and the following that we shall mention, such talent and superior alivity was found in the person of Edward M. Butz, Esq., of Allegheny. City. This eminent architect perhaps has, during the past eight or nine years, designed a larger number of prominent buildings in the two cities than any three others in this line of business. We may note aniong the Pittsburgh list the Dollar Savings Bank Building, Sevent th-A venue Hotel, Hostetter's Block, Second National Bank Building, S. Ewart \& Co.'s Stove Buildings, Reineman's Hotel, Reymer Bros.' Store, l) locks of D. Gregg \& Son, and of John D. Thompson on Wood St., John Daub's building, Sunithfield St., the German Evangelical Protestant and Seventh U. P. churches, the Sterrett Sub-District Public School, ete. In Allegbeny City, the Memorial Hall, Western Theological Seminary, the First National and Franklin Savings Bank Buildings, C. C. Boyle's Block, Second Ward Public-School Building, C. Wattley \& Co.'s stores, the 'Trinity Lutherau and Central Presbyterian churches, a large number of the fire-engine houses, and the handsome residences of $J$. W. Dalzell, Esq., H. Sellers MeKee and D. MI Long, and a long list of others equally proninent. In other cities Mr. Butz has become well known in connection with his drawings for the Wicomico county court house, at Salisbury, Md.; Lawrence count y jail, at Nerveastle, Pa. ; Mill vale public school, Millvale, Pa. ; St. Peter's Reform Church, St. Petershurg, Pa.; St. Patrick's R. C. Church, Sugar Creek, Pa.; also, residences of S. D. Karns, Esq., Garver's Ferry, Pa.; P. H. Woodburn, Franklin, Pa.; J. B. Longnecker, Towsontown, Md.; and others in various other localities. In furnishing designs and specifications for State buildings he has achieved a position that only merit and capacity can command. The series of splendid structures at IIorganza, Pa., used as the Peunsylvania Reform School Buildings, mention of which is made in the leading editorial of this work, were designed and drawu by him; and last, but not least (quite the reverse in fact), the proposed new Western Pennsylvania Penitentiary plans and designs are just completed by him. These two last-named buildings may be said to "tax a man's caliber" and fully demonstrate the abilities of the man who can carry them successfully through, as well as the discretion of the State autborities in their appreciation of a high standard of professional acquirements.

\section{ROBT. C. PATTERSON \& BRO.-Florists, 43 sixth St.}

Among the fine establishments in this city engaged in the Floral business is that of $R$. C. Patterson \& Bro., at 43 Sixth street; the business is exclusively in cut flowers. The trade in flowers in this city is a large and growing one, and rarer varieties of both cut flowers and plants are always kept in advance of the supply. This establishment is designed to administer to the growing taste of the people in this direction and to supply the finest an! l rarest flowers arranged in bouquets or baskets, and the various beautiful designs in which the Messrs. Patterson are ingeniously devising new and original forms and patterns. In their beautiful room on Sixth street every description of basket and designs are presented; no more at tractive or recherrhe display is to be found in the city. They are daily in receipt of supplies of rarest exotics from Boston, New York, Philadelphia and elsewhere, in addition to the supply received from their splendid glass structures at Roup's Station, on P. R. R., which is but a few minutes' ride from thejr office. They have superior facilities for the growth of flowers and bedding plants, and the demand for the finer varieties of bedding and ornamental plants is always equal to the capacity of their houses to supply orders frequently coming from a distance. This firm was organized in its present form in 1878, heing the outgrowth of an establishment started some years ago with which Mr. R. C. Patterson was associated. Mr. R. C. Patterson is a native of Pittsburgh, a young gentleman well known and esteemed; early in life he learned the profession of civil engineering, Iollowing it for some time, and in his present business he finds his engineering knowledge of practical benefit, and as a landscape gardener he has no superior. Mr. Nat. Patterson is also a native of Pittsburgh, and since tlie close of his college days has been engaged in the flower business as a floral artist, and during the six years he bas followed that occupation in different places and cities he has acquired enuinent skill.

\section{JOSEPH J. ALAND,-Merchant Tailor \& Dealer in Furnishing Goods, 424 Penn Av}

Mr. Aland, the sulject of this notice, stands high in this section as an artistic and fashionable Merchant Tailor. The establishment now conducted by him, was founded eighteen years ago, by Mr. Wm. Aland, his brother, in the same ward, and by him successfully carried on until four years a when the present proprietor assumed the management He occupies the tbree-story brick building, $25 \times 110$, at No. 424 Penn a venue, carrying a full stock of fine Foreign and Domestic Piece Goods, and Gentlemens' Furnishing Goods, in great variety and of the most desirable styles. His Ierchant Tailoring Department is the main feature of his business, and his suits, ranging in price from $\$ 15$ to $\$ 50$, cannot be excelled by any establishment in the two cities. His stock averages about $\$ 5,000$, and his annual sales will exceed $\$ 12,000$. Mr. Aland is a practical and experienced cutter and attends personally to that department of bis business, guaranteeing perfect fits and the most complete satisfaction. He employs regularly sixteen hands, and turns out only the very best garments, made in the most thoroughly workmanlike and fashionable styles. Mr. Aland was horn in the Old Hifth, now Ninth Ward, and has always resided within its limils, and has a large circle of acquaintances throughout the two cities.

WM. H. MIIIER,-Builder \& Contractor, Cor. Sycamore \& Washington Sts., 32 Wd.

Mr. Miller started into this business in 1870, and sime then has been actively engaged and prominently known as one of the most reliable and skilled operators in this branch and well deserving public notice in a work devoted to the industries of this city. Mr. Miller has built many buildings in this district besides many outside of city limits. He is well prepared to fill all contracts made with hin at very moderate rates, supplying the hest of inaterial and insuring the hest workmanship which must give the fullest satisfaction to all; besides carpenter and builder he also does brick laying and plastering promptly, warranting first-class work.

A. F. MEY ER,-Dealer in Dry Goods, Millinery, Notions, \&c., St Clair St., 32 Ward.

Mr. Meyer started this business in 1875, previously a short time engaged in business on Sycamore street. He carries a full line of goods and doing quite a good husiness, being well and $\mathrm{f}$ avorably known; his business keeps increasing and extending. He is at all times prepared to supply his patrons at the lowest cash prices, always having a good choice selection of dry goods, trimmings, millinery goods of all styles and variety. Mr. Meyer was born in this city in 1853 and will be lound a courteous and agreeable gentleman. 


\section{A. KRUT,-Wagon-Maker, 45 Fourteenth St., South Side.}

The works of Mr. Krut are situated at No. 45 Fourteenth street, South Side, and are quite extensive, the buildings being 60 feet square, two stories bigh and fitted with machinery of various kinds necessary in the business, which is driven by a fine engine. The forge and blacksmith shop is well arranged, affording abundant facilities for this class of work. He unaufactures all descriptions of spring, peddler \& coal wayons, timber wheels, drays, carts, wheelbarrows and a great variety of wood work; and in this branch of work there is no sinilar establishment in the city that enjoys a higher reputation for superior and first-class work. Orders for an y kind of vehicles can be executed on short. notice, and all kinds of repairing is also done in a very prompt manner. Nr. Krut owns one of the finest farms in Beaver county, this State, which he has brought to the highest. state of improvement and on which he has planted large vineyards and orchards. On this farm all the most perfect agricultural machinery is to be found, a fine engine is enolored to drive stationary machinery; he has erected a cider press which is operated by the engiue His enterprise $j$ manifested in an eminent degree. Mr. K. Was born in the province of Alsace, France, in 1832, he came to this country in 1850 , landed in New York city destitute of means; from there he worked his way to Buffalo, New York, where he remained some time, he afterwards came to this city on canal. After coming here he worked at journey work in different shops, among the number that of W. B. Ross. In 1863, having accumulated a small capital, he embarked in business on his own account, since then bis honorable course has brought him abundant success and hosts of friends.

\section{S. SCHNEIDER,-Boots \& Shoes, 1205 Carson St., South Side.}

Carson street, which is the main business thoroughfare of the South Side, boasts many mercantile bouses which will cumpare favorably with similar establishments in any city in the Union. Among the leading bont and shoe houses out this side of the Monongahela may be mentioned that of S. Schneider, successor to Geo. A. Snyder, which is located at No. 1205 Carson street, between 12th and 13th streets. S. Schneider occupies a three-story brick luilding $20 \times 50$, and carries a full and complete stock of ladies', gentlemen's, misses' and children's boots and shoes of the best grades inanufactured, selected expressly for this market, and offered at prices which defy competition. The stock is valued at between $\$ 7,000$ and $\$ 8,000$, and the annual sales will reach fully $\$ 20,000$, and doing business on a cash basis, buying for cash exclusively, and haring the advantage of the market by that means at all times so that the patrons will reap the benefits by dealing with this establishment. S. Schneider devotes personal attention to the l'nsiness aud gives constant employment to four assistants in this extensive establishment. The trade is principally derived from the South Side and the adjacent suburbs. S. Schneider is a native of Germany and was born in 1827; has resided in Pittsburgh for the past thirty-nine years, during a great portion of which time having been actively engaged in mercantile pursuits, commencing business on the South Side in a smaller store near the present location, where the founcantile pursuits, commenc.ng business on the South side in a smaller store
dation of this prosperous and lucrative trade was laid and now carried on.

\section{S. C. WIID, -Dry Goods, Millinery, \&c., Cor. Penn \& Frankstown Avs.}

There are few industries of the city of Pittsburgh which this comprelensive work shall record, which require a higher and more refined taste in its operations than that of the general dry goods and millinerv husiness; but the eminent success which has attended the establishment and conduct of this business by Mr. Wild "since 1867, is a snfficient evidence of his thorough adaptation to its requirements. He first commenced this business in Alleghen y, where he conducted it successfully until 1877, when he removed to his present location, corner of Penn and Frankstown avenucs. This establishment occupies a room $20 \times 40$ feet in size and is kept constantly well stocked with seasonable and desilinble dry goods, millinery goods, trimmings, bosiery and gloves, uotions, \&c. He carries a stock of not less than $\$ 2,200$, constantly replenished with fresh supplies, and is doing a successful trade. His stock nf millinery goods unust attrac't the attention of ladies, as it is supplied with the newest and most desirable in style and taste. Also dress making from latest fashion plates, regularly received, and at reasonal,le prices. He gives special attention to this department. Mr. S. C. Wild was born in Allegheny city in $184^{\circ}$; he has already had a large business experience and his trade in these important branclses is constantly increasing.

\section{S. McKEE \& CO.-Pennsylvania Glass Works, 13th St., South Side.}

Nearly half a century ago this celebrated plant was established under the existing style by Messrs. Samuel, Thomas and James MiKee, who may properly be regarded as the pioneers in the mannfacture of Window glass in this cily. In $1860 \mathrm{Mr}$. Samuel McKee became the sole proprietor of the lusiness, being succeeded in 1877 by Daniel and C. J. McKee and A. U. Dravo, who form the individual members of the present complany. The works of the tirm cover an area of over 4 acres and are eligibly situated on the South Side. They are divided into various departnents, embracing the two window ylass factories, one bottle lactory, flattening house, cntting rooms, store houses, blacksmith shop, engine rooms, pot room and grinding mill, all completely adapted for the manufucture of the special products of the firm by the introduction of the best inachinery and most effective labor-saving appliances. The skilled emplnyees engaged here will a verage from 200 to 280 men and boys, requiring a disbursement of over $\$ 2,600$ per week. In the manufacture of window glass, druggists' glassware, black ware, telerraphic insulators and insulators for liglituing rods and similar wares, the products of S. McKee \& Co. are universally considered as unsurpassed, a reputation so justly placer as to result in a trade extending over the whole United States. As conservators of the ind ustrial thrift of the community and contributing to no suall degree to the general prosperity as well as fostering the best interest of the highly inportant branch of manufactures in which they are engaged, the house of S. McKee \& Co. is the object of a respect and lonorable estimation to which its services and position are justly entitled.

\section{A. PARSLOW,-South Side Barrel Factory, 2320 Carey Alley, South Side,}

Manufacturer and Dealer in all kinds of new and second-hand Barrels, also Flour, Feed and Cement.

Among the industries of the city of Pittshurgh, we gladly present to the readers of this work Mr. A. Farslow, a gentleman whose enterprising spirit and native energy is rapid] No. 2320 Carey alley. Besides carrying on a quite extensive business manufacturing barrels, casks, kegs, dic., of every description, he also keeps a flour and feed store, and is prepared to supply the best flour in the market. at lowest cash prices; also lime and cement. Mr. Parslow was born in England, in 1838 , and came to this city in 1865 , and has ever since been connected with the business of the city in some form. His present enterprise was commenced in $1870 \mathrm{with}$ a comparatively small capital, but his indomitable perseverance, his high business qualifications abl strait forward de:lings ha re won him hosts of friends and giren him a constantly growing and successful tratle, which is located hoth
in the city and country. He occupies large and ample rooms for both the manufacturing and general retail business, in the city and country. He occupies large and ample rooms for both the manufacturing and general retail husiness,
in both of which be eivploys several hands and tessistants of practical experience and ability, always giving general satisfaction to all who favor him with their orders and patronage. Kceping a general supply of all articles in his line of business and is at all times prepared to fill orders promptly and nalke deliveries to all parts of the eity. He gires special attention to all second-hand packages for pork houses, glass houses, also for fruit packilges of all kinds and quantities, upon the shortest notice. 


\section{LEWIS. OLIVER \& PHILLIPS,-Iron, Bolts \& Heavy Hardware.}

Office, Nos. 91, 92 and 93 Water St.

In connection with the iron trade of Pittsburgh and its influence upon the development and productive wealth of this community, it is but fair to assert that on this branch of our industries, the firm of Messrs. Lewis, Oliver \& Phillips, has made an indelible impression. Established in 1863 by Wm. J. Lewis, Henry W. Oliver, Jr., and John Phillips, and in 1866 enlarged by the admission of Messrs. D. B. and Jas. B. Oliver, the efforts of the firm were at first directed to the manufacture mainly of Bolts, Nuts and cêrtain lines of Heavy Hardware. It caunot be denied that in each subdivision of the labor the ability emplo yed was of no ordinary character, as partially evinced by the prodigious success that attended the enterprise from its very inception.

The business from the first increased with rapid strides, and the consumption of iron became so great that in 1866 the erection of a rolling mill to supply the growing demand for iron of certain qualities and shapes became almost essential to the continued prosperity of the firm. With this addition to their resources there were left but few successful competitors to Lewis, Oliver \& Phillips in those special branches of manufacture to which their attention was directed, and from that time the firm assumed a position the advantages of which have been since sedulously maintained and constantly enhanced. Some idea of the present status and usefulness of the house may be gained from the fact that its plant consists of thirteen buildings, mainly of brick, with iron frames and roofs, used as rolling mills, machine shops, bolt factorys, foundrys, etc., engaging the labor of 1,600 men and boys, most of whom are skilled artisans, and making requiste a inonthly disbursement of $\$ 65,000$ to this source alone. Part of the machinery, which is operated by 19 steam engines and 21 boilers, agcregating over 1,000-horse power, consists of 100 bolt machines, 20 nut machines, 10 hammers, $10 \mathrm{~s}$ varied miscellaneous pieces of mechanism for special work and 25 punching machines, besides all the vast and costly apparatus for boiler-making and rolling iron, most of which is of the latest and most approved character.

The works of the firm may be said to be in two sections, one entitled the Upper Mills being located upon the south side of the Monongahela River, opposite the old city, and the other, called the Lower Mills, on the Ohio River in Allegheny City, havings sidings and tracks which connect directly with the P., Ft. W. \& C. R. R. and P. \& C. R. R.; the Upper Mills having side tracks running in from the newly-built P. \& $\dot{L}$. E. $\dot{R}$. R., both establishments in all embracing an area of about 30 acres.

The specialties alone manufactured in these works number over 100 , upon many of which the house has secured letters-patent, both in the articles themselves and the appliances ly which they are constructed. This list includes all kinds of hard ware for wagons, plows and agricultural implements, 15 different grades of chain, hinges, rings, bolts, screws, fire-irons, steel and iron wire, rods, crow-bars of iron and steel, fence-pickets, washers, blacksmiths' sledges stone-liammers, etc., etc., toget.lier with and almost endless variety of other wares, celebrated for excellence and adaptability, wherever the trade of the house extends, which means every State in the Union.

Perhaps no men in this city have done more to increase the reputation of Pittsburgh as a manufacturing and wechanic centre than Messrs. Lewis, Oliver and Phillips. As a firm, that of Messrs. Lewis, Oliver \& Phillips is tiso well and widely known by its brilliant career and untarnished repute to rcquire any commendation here. Its work, enterprise and general usefulness speak for it in terms sufficiently expressive and entitle it to the esteem and consideration of that community to whose prosperity its labors have been so highly conducive.

\section{PHILLIPS, NIMICK \& CO.-Sligo Iron Mills,}

Office and Mills, South Side below Monongahela Bridge.

In reviewing the great iron interests of Pittshurgh as developed in the various enterprises for the con rersion and manufacture of this important staple, it will be particularly observed that in each separate concern some specialty is selected, to the production of which in its highest perfection the best energies of the establishment are directed. The widely known house of Phillips, Ninick \& Co. is by 10 means an exception to this rule, as in the nuanufacture of certaiu brands of iron possessing marked pronerties, the celelority of the firm and its husiness mainly denends. The plant now owner by the company was estallished over half a century ago by John Lyon and Robert T. Stewart, who were succeeded in 1828 by Barnet, Shorb \& Co., who continued the business until 1831, when it passed into the hands of Lyon, Shorb \& Co., the existing firm acquiring possession in 1873. The works are very extensive, ranking aumong the jargest in the State, and occtipy an area of several acres, heing divided into several departments for puddling, forging, rolling, storing etc. Amoug the appliances and machinery in use are 25 puddling furnaces, 10 heating furnaces, eight steam engines with 14 bnilers in four separate batteries, three stcam hammers, one of which is the largest and uost powerful in the city, liaving a twelve ton blow, and other maclinery for flanging boiler heads aud flue holes, upon which the firm hold exclusive rights and letters patent, luving no competitors in this specialty in this country. These flanged boiler heads and flue holes are made liy machinery t'iat greatly increases the strength of the flange in ali its parts liy a rolling or staving-up process instend of beniling, giving cqual if not greater strength to that portion of the head where it is curved, and imparting a toughness and tcnacit y of the lighest. order a second advantage, added to the first-the use of the sligo iron. The perfection of the process is due to the original quality of the material as well as the mechanism employed, which as before stated is owned solely by this firm, and is the most perfect for the purpose that can be devised.

Two hundred and fifty men are employed in these works, and the consumption of coal alone will average from 50 to 75,000 bushels per month. The Sligo and Tyrone brands of iron made liy Phillips, Nimick \& Co., are noted for toughness, malleahility and tensile strength in these properties fully rivaling the best production of the Nortwegian and Swerlish wills. With an increasing trade that already extends from Novia Scotia to the Sand wich Islands, and a home demand especially for flanged iron work that rapidly aurments. The firm of Messrs. Phillips, Nimick \& Co. has achieved not only a prosperity to which it is amply entitled, but a position and standing in the manufacturing community that reflects the highest credit upon the firm itself and adds as well to the repute of Pittsburgh as a productive centre.

JOSEPH FITZPATRICK,-Groceries \& Produce, Cor. Wylie Av. \& Arthur St.

This business wa sstarted by Mr. Fitzpatrick in 1874. He carries a general assortment of choice groceries and produce of all kinds, such as flour, sugar, teas, spices, coffee, canned goods of all kinds hesides fruits and vegetables and all other goods generally found in a family grocery store. Mr. Fitzpatrick does a very fair annual business, he was born in this city in $1858^{\circ}$ and began business at an early age. He is an enterprising business man such as there are few in this city. He oceujies a building 20x54 fnet, employing extra liclp besides himself and at all times fully prepare to serve all who favor him with their patronage, alwais aims to sell as low as the lowest and keeps the best goods in the market.

\section{G. M. IRELLY, M. D.-Physician, 181 Wylie Av.}

Dr. George M. Kelly is a native of Claysville, Washington eounty, Pa., where he was born February 11th, 1854. He graduated with hich hanors at the Jefferson Collese, Philadelulia and commenced the practice of his profecsion at Washington, Pi. In 1875 and 1876 he occupied the responsible position of resident physician at Miercy Hospital, $j$ this city, and since that time las been practicing medicine with marked success in this city. His office is located at No. 181 W ylie avenue, and his office hours are from 9 to 11 A. M., 2 to 4 P. M., and 7 to 9 P. M. 


\section{FIRST INATIONAL BANK OF ALLEGHENY,-114 Federal $S t$.}

Among the fiduciary institutions of Allegheny City, the First National Bank doubtless commands the largest line of deposits and does the most extensive discounting business. This Bank was incorporated under the National Bank act in 1864 , with a capital stock of $\$ 350,000$, and during its entire cureer has been regarded as one of the best-managed monetary concerns in the country. Upon its orgunization it was appointed a United States Depository for tlue 230 U.S. Revenue District, a trust which it still retaius, and so successfuliy have the affairs been inanaged, that, aftcr paying a yearly dividend to the stockholders of 10 per cent., they still have a surplus of $\$ 110,000$ and one of the finest bankiug houses in the State. This structure, designed by and built under the supervision of the eminent architect, E. M. Butz, Esq., who occupies the front rooms of the second story, over the banking room, for his offices and drawiug rooms, is of three stories and basement, and was erected in 1877 at an expenditure (including lot) of $\$ 81,000-$ is fireproof throughout, and is considered unsurpassed in its appointments, with chronometer locks, ce, by any similir structure in either of the two cities. The officers and director's of this corporation are of the most substantial busines men of the community, and are as follows: T. H. Nevin, Esq., Pres't, who is also one of the Board of I)ircetors with C. C. Boyle, J. B. Smith, John Thompson, William Harhaugh, James MicCutcheon, James B. Orr, George W. Cochran and Edward Groetzinger. The Cashier, E. R. Kramer, Esq., has filled this position with marked ability since his succession to Mr. J. P. Kramer in 1878, and is assisted by the following staff: Wilson Miller, Teller; A. B. Nevin, A ssistant Teller; John D. Kramer, General Bookkeeper; Thomas G. Christie, Individual Bonklkeeper; T. H. Nevin, Jr. Collec tion Clerk; W. H. Casady, Messenger; while Eastern and Foreign exchanges are made through the Third National and National Park Banks of New York, and the First National Bank of Philadelphia; conducting a legitinate banking business in deposits, discounts, collections and exchanges.

\section{W. H. IRWIN,-Rosedale Foundry, Steel Molds, Hammer Dies, Furnaces.}

In connection with a detailed account of the industries of Pittsburgh, particularly those that are allier io its great staple manufactures, the en terprise of Mr. W. H. Irwin, in the work of Founding, Casting, and the construction of the celebrated Pittsburgh hot-air, rolling-mill and machine-castings Furnace, should not he overlooked. The business was established in 1865 by Messrs. L. Peterson, Jr., and the present proprietor, under the st yle of L. Peterson, Jr., \& Co., which so continued till 1878, when, by the withdrawal of the senior partuer and the purchase of his interest, the entire control became vested in Mr. Irwin. The plant is a very extensive and valuable one. Situated in the lower part of Allegheny City, on the bank of the Ohio river and line of the Pittsburgh and Cleveland Railroad, it embraces about $2 \frac{1}{2}$ acres, the buildings covering ncarly half that area. Thoroughly supplied with all the best modern machinery and improved appliances, the works are noted for the excellence of their products in large and small railroad and rolling-mill Castings, Steel Molds, Hammer Dies, and special work in this direction of every description. Of the Pittsburgh Furnace it is justly remarked and may be safely asserted that it combines in itself more solid and substantial merits than any other similar apparatus known; perfectly effectire in use, free from dust or smoke, sinple and economic in structure, with arrangenents for combustion that permit of the employment of any fuel, from wood or hard conl to bituminous dust or coke. The encomiums passed upon this invention ly those who have enjoved its bencfits and conveniences for years, would fill several pages of this volume and embrace the names of many of the nuost prominent citizens. The business of the concern, which is confined mostly to this specialty, under past conditions has ranged over $\$ 100,000$ per annum, and at present low prices wjll average between $\$ 80,000$ and $\$ 90,000$. A hout 70 skilled artisiuns are employed at the works, and one 20 horse-power engine, requiring a monthly outlay of $\$ 2,500$. Mr. Irwin is it native of Alleghen y City, and, after returning from an arduous and eventful carcer as an officer in the Union army during the late war, he engaged in the present enterprise, with which he has since been identified in such a way as to conduce not only to the general industrial thrift, but the achievement of a high position among those interests for which Pittsburgh is most celebrated.

DA VIS, CHAMRERS \& CO.-White and Red Lead, Litharge, Colors, \&c., \&c.

One of the most extensive establishments in this city or the United States, engaged in the manufacture of White Lead and its contingent products, is that of Messrs. Davis, Chambers \& Co., and as such should receive more than brief consideration in this work. The prime object to which the attention of this firm was directed, after its formation in 1866, was the production of goods that should be entirely free from adulteration, and it is not ton much to assert that their efforts have heen attended hy the most satisfactory results. On every keg of White Lead turned ont hy this concern is hranded the analysis of its contents-9) parts pure Lead and 9 parts Linseed Oil-and an accompanying offer of $\$ 25$ in gold to any one disproving the truth of this statement. The general recognition of the smperiority of the goods manufactured liv this housc led to the rapid increase of its trade, capacity and resources-the plant, which is located on 45th and 46th Sts., coniparing favorably in size and every requisite appointment with any similar establishment in the country, over the whole of which, and liargely in the Southern States, the business is transacted. A large force of hands is employed by the firm in the various operative departments of the work, from the corroding heds to the packing room; the total product being e'qual to any house in the country, which consists of White, Red and Potters' Lead, Litharge, Putty, Colors, and strictly pure Paints, an increasing demand for which has augmented this lranch of the business and given it the cluaracter of a specialty. The individual members of the concern are Gen. C. Davis, B. Preston and John S. Davis, who do business under the original firm name, though Mr. Chambers has been deceased for some years. So far as the advantages offered to the trade by this house are concerned, it may-be stated that they are as liberal ant desirable as those offered by any competitor in the country, while the inferences in favor of the quality of their goods being vastly superior are very strong and should weigh greatly in their favor. The jolicy upon which the trade is conducted is an enterprising and hourable one, and in achieving the prosperity that marks its present condition, the firm lits not neglected those principles which entitle it to the just esteem of the community. 


\section{EMPIRE OIL WORIXS,-D. P. Reighard, Cor. of 9th Av, and Duquesne Way.}

From its advantages of location Pittsburgl is undoubtedly the natural refining point for the immense quantities of petroleum produced in Western Pennsylvania, and the value of the products of her refineries to-day constitutes an immense item in the general sum total of her commerce. Among the many establishments engaged in this line of business, the Empire Oil Works of Mr. D. P. Reighard are deserving of a prominent position. Established in 1865, upon a moderate scale and with a limited capital, the business has increased until the works now cover over six acres of ground near the Sharpsburg bridge, on the line of the A. V. R. R., with eight engines for pumping, and furnishing employment to about thirty hands. The business amounts annually to a very large sum and extends over every portion of the United States. Mr. Reighard was born in Pennsvlvania in 1844 and now ranks as one of the principal refiners of the country. He manufactures as a specialty for illuminating purposes the widely-known snow-white Astraline, with a burning test of $150^{\circ}$, and the Head Light Oil, water white, of the same test, both of which articles stand very high in the market and command a ready sale. He also manufact ures Standard White Refined Petroleum, $110^{\circ}$ test, and Lubricating, Paraffine and Machinery Oil of superior grades and cxcellence.

\section{ROBINSON BROS.-Bankers, No. 75 Fourth Av.}

This widely and well-known house was established in 1858, under the style of Robinson, McClean \& Co., was succeeded in $1861 \mathrm{by}$ the present firm, composed of the hrothers J. F., W m. A., and David Robinson. These gentlemen are natives of Erie County, Pa., but for thirty years have been residents of this city and favorably identified with the financial interests of the community. While engaged in a general banking business of discount and deposit, the special operations of the firm consist in the purchase, sale and negotiation of bonds, stocks, mortgages and other trans-
ferable securities, upon a commission hasis. By immediate telegraphic connection with the New York and Philadelphia stock markets, every advantage is afforded investors or operators, wlile the excellent standing of the bouse is a guarantee that every matter entrusted to it will receive prompt attention. It is not the province of this work to deal in laudation, but it may be properly as well as justly asserted that, as an honorable, reliable and enterprising firm, that of Robinson Bros. has few compeers in this or any other community.

\section{R. 33. WARD, -London Bakery, \&c., Cor. Penn Av. and P. R. R., East End.}

This gentleman, who succeeded Kechin Bros. in 1878, began business with a capital of $\$ 400$. This moderate investment has risen to $\$ 1,500$ and bids fair to be further increased with the increasing patronage received by $\mathrm{Mr}$. Ward. His annual sales mount up to $\$ 7,000$. The establishment embraces a Store and Bakery where four hands are employ ed. The pay-roll is about $\$ 150$ monthly. Mr. Ward employs one salesman. The excellent quality of Ward's London Bread finds it a ready markct in every part of the eity and none has a greater popularity. He employs only first-class workmen and uses nothing but the best material. Mr. Ward was born in the city of New York in 1852 and came to this city in 1856. He was in the grocery business three years before opening in the East End. He is a very energetic man of business and popular with all classes.

\section{CEAS. GARDNER,-Merchant Tailor, No. 19 Federal St., Allegheny.}

With an experience of twenty-two years in the Merchant Tailoring business, Mr. Chas. Gardner, of No. 19 Federal street, Allegheny, possesses many advantages which cannot fail to commend his establishment to favorable notice. $\mathrm{His}$ salesrooms are located in the commodions brick structure, $20 \times 120$ feet, near the suspension bridge, and his stock comprises a fine and judiciously selected assortment of foreign and domestic fahrics for gentlemen's wear, from which customers may select. He inakes to order, in the best style, elegant suits, at prices ranging from $\$ 14$ to $\$ 40$. He also carries a line of Custom-made Clothing, from which serviceable suits may be procured from $\$ 4.50$ to $\$ 20$. He carries a stock valued at about $\$ 3,000$ and employs eight hands at an average weekly expense of $\$ 80$. AIthough he has only occupied his present quarters since March 3,1879 , his trade has been large and satisfactory and his prospects nost encouraging. Mr. Gardner is a native of Germany and was born in 1836. He learned his trade in the old country, but has for many years resided in the United Stites.

\section{WIM. IOSACIR,-Flour, Oats, \&c., Wholesale \& Retail. Cor. 34th St. \& Penn Av.}

Will be found at tlie corner of 34 th street and Penn avenue, where he keeps an extensive stock of feed, etc., of all descriptions and does a very large business. The business was started hy Mr. Hosack in 1876, since then he has enlarged his stock as business demanded, buying exclusively for cash, thus securing lowest rates. Mr. H. Was born in Allegheny City in 1830 and has lived in this city ever since; he first began life as a butcher and continued in that occupation a number of years. Served the city in the capacity of Street Commissioner seven years, was meat inspector of Allegheny City the first year after that office was created ; shortly after leaving that position engaged in present business, in which he is now doing a prosperous business. He takes a prominent part in political affairs and wields a large influence in his section. His experience as proprietor of a race course we shall have to omit for want of room.

\section{J. DOUGHERTY,-Cigar Manufacturer, 434 Penn Av.}

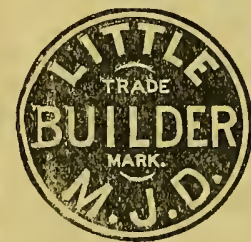

The accompanying "Trade Mark," the exclusive property of Mr. M. J. Dougherty, of No. 434 Penn avenue, has become familiar to the readers of local and class papers from Maine to California, and the Little Builder Cigars are smoked to-day in every State in the Union and in the camps of the Regular Arm y on the plains, and by the officers of the Nary on every sea. Mr. Dougherty, who is an enterprising, energetic and pushing young man, has advertised this specialty of his extensively, and as a result has received order's from all sections of the country. Where they have once been introduced and tested they have never failed to advertise thenselves, and his trade is constantly increasing. The "Jittle Buillers" are made from the best quality of leaf tobacco, are neatly put up and sent by mail or express to any part of the country at the very low price of $\$ 2$ per hundred or $\$ 16$ per thousand, by express $-\$ 20$ per thousand by mail. In addition to this favorite cigar, Mr. Dougherty manufactures a variety of other popular brands, at prices ranging from $\$ 10.50$ to $\$ 30$ per thousand. He commeneed business at his present stand Aug 4, 1874, on a comparatively smull scale, and since that time his trade las been steadily increasing He is a practical cigar maker and employs four experienced assistants, turning out not less than 350,000 cigars annually. He also carries in stock a full line of Fine Cigars, hoth imported and of his own make, and Mlanufact ured Tobacco and Smokers' Articles of every description, transacting a flourishing wholesale and retail business throughout the two cities and adjoining towns. Ifr. Dougherty is a native of Pitsburgh, born on Penn street in 1845. He is a wide-awake and enterprising gentlem:n and is deservilig of the success wh" hh he has attained in his business carcer. 


\section{PIER, DANINALS \& CO.-Brewers of Ale, Porter, Lager Beer. Stephenson St.}

There is perlians no branch of business outside of her great specialties of steel, iron and glass, whicl bas contributed so largely to the wide-spread reputation oi Pittsburgh, which has given her a greater national celehrity, than that of her extensive ale and porter breweries, prominent among which is the bouse of Pier, Danisils \& Co. Pittsburgh ales hare for many years enjoyed the highest rejut:tion and met with ready sales in almost every portion of the United States, and the trade-mark of the "Oregon Brewery" has everywhere been accepted as a guarantee of superior excellence. During the past few years, however, the "national bererage" of the "laderland" has become so universally popular as to supersede, to a certain extent, the use of ale, and the leading brewers hive succumbed to the ineritable and completed arrangements to supply the demand at home. W'ith that enterprise and far-sightedness which hus erer characterized the operations of this well-known tirm, Messis. Pier, Dannals \& Co. were the first to inaugurate the "new departure" and commence the mauufarture of a superior quality of Lager Beer, which, though but recently in. troduced, has already acquired a reputation which bids fair to equal that which for the past twe.se years has been a warded to their ales throughout the United States. This house was established in 1867 in the Ale Browing husiness,
the firm at that time purchasing the establishment on Stephenson street previously owned by D. Fawcett \& Co. The building, which was originally constructed for the manufacture of white lead, was subsequently sold to Rhodes \& Verner, who converted it into an ale brewery and then disposed of their interest to Messrs. Fawcett $\dot{d}$ Co., the immediate predecessors of the present proprietors. The original strueture was a three-stor 5 brick building, fronting on Stephenson street 130 feet and extending back to an alley 130 feet. The present owners have erected an addition $50 \mathrm{x}$ 50 feet, on the corner of Stephenson and Forljes streets, thus making their buldings corer nearly a half square. The malting and brewing departments are supplied with the best and latest improved machinery of every description required in the business, with a twenty-horse power engine and the necessary boilers and appliances Twenty-five hands are employed, with a weekly pay-roll aggregating about $\$ 350$. The amount of capital originally in rested in the business by the present proprietors was $\$ 30,000$, which has been inereased to $\$ 100,000$. They carry an arerage stock of not less than 3,000 burrels of beer and 1,000 of ale and their annual sales in past jears hare areraged about $\$ 100,000$. W'ith their increased facilities and the introduction of Lager Beer brewing, they will undoubtedly largely exceed that amount. Their buildings, vaults and cellars are admirably adapterl to the successful prosecution of the new business in which ther have embarked and they have decided to spare no pains or expense to produce the hest beer in the country. With this end in riew, ther have seeured the serrices of an experiencerl practical beer brewer fro'n Ifilwaukee, who was formerly connected with the famous brewery of Philip Best, in that city, and as they use only the very best material, there seems to be no valid reason why Pier, Dannals \& Co's. beer should not, like their ale, become noted as the very best made in this country. The members of the firm are $R$. WT. Pier, If. F. Dinnals and W. S. Pier. Mr. F, UhInan has charge of the offices, books and clerical force at the brewery, and Mr. John W. Carle represents the house as salesman in the city and throughout the adjoint
upou securing the services of two such competent and able assistants.

\section{JOHN G. BRANT,-Leather, Hides, \&c., 329 Liberty St.}

Under various changes of style and firm this well known house has been in existence for more than twenty years, during which period it has always maintained a prominent position among the representative business housf's of the Iron City. The present proprietor, Mr. John G. Brant, is the immediate suecessor of John Hamcett \& son, and commenced in his ow name in 1875. He had preriously been connected for four years with the well known bouse of (i. $\mathrm{N}$. Hoffstatt, and has the advautages of an experience of over seventeen years in this particular line of business. His extensive tannery is located ai Steward Station, on the Baltimore \& Ohio Rajlroad, and has a capacity for tanning 200 hides per month. He manufactures i superior quality of oak tanned harness and bridle leather, fair skirting, shoe splits, \&c., and is a general dealer in all kinds of leather, hides, oils, tallow, sumae, lace leather, shoe findings, \&c. His office and salesrooms are located in the commodious four-story brick business structure 24x110, at No. 329 Liberty st., and his average stock of the various articles abore enumerated is estimated at from $\$ 10,000$ to $\$ 13,000$. He employs ten hands regularly at a weekly expense of about $\$ 100$, and his trade which extends throughout the Eastern aud Western ener annum and is steadily increasing. The reputation of the leather produced in Pittshurgh extends orer the entire Union and even to foreign lands. Mr. Braut is a native of Pittshurgh, and was born in 1847; he has been identified with the business in which be is now engaged for wany years and is thoroughly conversant with all its details.

\section{MILILER \& HOUSTON,-Groceries and Provisions, cor. 48th \& Butler Sts.}

At the corner of 48th and Butler sts., in a handsome and well located and arranged store room, piler up with a Iarge, varied and superior stock of Groceries, Teas, Provisions, ete. of the finest quality, will be foupt the firm of Miller \& Houston, where they are doing a rushing business of about $\$ 25,000$ per annum. They started in this location iu 1878, buying out Mr. Riley, who bad previously condueterl the business at this point. After getting possession these young gentlemen enlarged the stock, pushed the business with the greatest energs, rapidly runniug it uj to its present

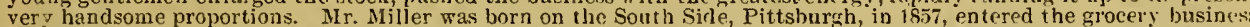
as a clerk when but 13 years old, and has continued in it erer since, succeeding by his own frugality and industry. At the age of 22 years he is among the most successful retail grocers. Mr. Houston, who is abnut the same age of Mr. Miller, was born in Kittanning, Pa., in 1856, and came to Pittshurgh 7 years ago, was in the employ of Cistle shannon R. R. a number of years previously to engaging in his present business, baving prudently stved his earnings, which he united to those of Mr. Miller, and embarked in thcir present business, in which they hase achicved so remarkalule and notable a success of which they are every wily worthy and deserving, having accomplished it by their unaided and well directed efforts.

\section{PIENN BANK,-Corner of Wood and Liberty Sts.}

Arnong the institutions of a fiduciary character in this city, the Penn Bank, though established only in 187R, lws obtained a foothold and standing in the commereial community that ranks it with the oldest and most s(s)lvent (")incerns in the Iron city. Upon its organization Hon. Jas. H. Hopkins became the presiding otticer, a position which he continues to fill with marked ability. Mr. Hopkins, as a member of the legal profession, oecupies a position to which few ever attin, as the result of solid acquirements and an untarnished career. His late representation of this distrjet in Congress was a splendid endorsement of the wisdom of those who secured his election. Mr. W. N. Riddle, the cashier, has also been identified with the hank since its inception and has established a well deserved reputation for financial capacity of a high order. The following gentlemen are efficient aids in the conduct of the business in their respective departments:-G. L. Reiber, Teller : Thos. S. Gordon, General Bonk-keeper; Wm. H. D. Barr, Individual Book-keeper: Wm. D. Trew, Corresponding Clerk; Wm. Hutehison, Collection Clerk, and James Hutehison, Iressenger. The Directors being:-Jacob H. Walter, Samuel Severanee, James Herdman, D. W. C. Carroll, F. 13. Lauglilin, T. B. Swearingen, Geo. C. Davis, Alex. Reynolds, Philip Reymer, Thomas Hare, F. Rahm, John Hall, W. S. Mars:hal. The Penı Bank is incorporated under the State law $\mathrm{S}$, with a capital of $\$ 250,000$, while a rapidly inereasing business and ever unshaken repute conduce no little to its prosper:ty. 


\section{JAMES MCCLURG \& CO.-Cracker Bakers \& Confectioners,}

In a historical review of the manufacturing and business interests of the two cities, the establishment of James McClurg \& Co., Craker Bakers and Confectioners, whose office, warerooms and manufactory are located at Nos. 18; Rebecca strect, and $10 \& 12$ Walker street, Allegheny City, is deserving of especial mention and a prominent position. This business was established in 1870 hy Mr. James McClurg, the present senior partner of the firm, with a small capital and on a comparatively moderate scale, but owing to the steady and gratifying increase in business he was compelled to enlarge his facilities and new members were idmitted to the firm, the present proprietors being Mr. Janies McClurg, Mr. Thos. R. Herd, Mr. Johu MeClurg and Mr. Aaron MeClurg. Their office and salesroom at No. $187 \mathrm{Re}-$ becca street is a three-story brick building $20 \times 75$ feet, which is stocked with a large and complete assortment of crackers in every variety and style, Cakes, Snaps, Biscuit and fancy articles pertaining to their line, fine confectionery, \&c. They are also extensive manufacturer's and dealers in prepared flour, an article highly recommended by dealers and consumers for griddle cakes, sugar cakes, waffles, \&c. Their factory at Nos. $10 \& 12$ Walker street, is a three-story brick struct ure $60 \times 100$ feet, fitted up with all the requisite machinery for carrying on their extensive business. They employ one thirty-horse power engine, two cracker machines, one snap machine, two soft dough machines and other smaller machines and appliances of the most approved patterns. They have two large reel ovens, one of which is the largest used in the business in the United States. The entire establishment is fitted up in a unost thorough and complete manner and will compare favorably with an y similar establishment in the country. They employ thirty hands at a weekly expense of about $\$ 300$. The amount of capital in rested in the business is $\$ 50,000$ and the average value or stock carried by the firm is about $\$ 25,000$. Their trade extends throughout the twe cities, Western Pennsylvania, Eastern Ohio and W est Virginia, and will reach $\$ 100,000$ per annum. The reputation of the various articles manufactured by this well known house is now well estahlished and their trude is constantly increasing. Mr. James McClurg and Mir. John McClurg were born in Ireland and Mr. J. R. Herd and Mr. Aaron MeClurg are natives of Pennsylrania. All the members of the firm are energetic and active business men, thoroughly conversant with the busincss in which they are engaged, and stand high in the mercantile community.

\section{DAVID GRIM,-Carriage Manufacturer, Cor. $32 d$ St. and Penn Av.}

This enterprising manufacturer commenced business at his present stand in 1874. His capital was small, but he had, what is often inuch better, indnstry and skill. As the result he has now generally on hand, of his own manufacture, a stock of $\$ 7,000$. He constuntly employs 8 or 10 hands, and his work finds a ready and profitable market in Pittshurgh and the adjacent neighborhood. His shop, buildings and grounds occupy a space of 96 by 100 feet. He makes the manufacture of Rockaways and Buggies a specialty. Indeed, all the work turned out by Mr. Grin is of the best quality, and no articies of inferior mannfactmre are found at his establishment. The superior hand-made
work, including the several varieties of Rockawars and Buggies, fears no competition here or elsewhere. Chealp or flimsy work is unknown at this establishment, and consequently the business has scarcely fclt the depression of the times. Mr. Grim was born in Beaver Co. Pa., in 1831, and, having learned the trade of a carriage-maker, passed a number of ycars as a journeyman in various establishments. Hc spent three years profitably in the shols of New Haven, Conu, and no less that six years in Tonnessce. Aftex the commencement of the war hie came to Pittsburgh, and started in business. Mr. Grim next procecded to assume the management of his growing business alone at his present location, and still continues to do so.

\section{D. HOWLEX,-Dealer in Real Estate, Securities etc., Cor. 39th \& Butler Sts.}

This gentleman will be found at the above location, where he opened his office the 1st of Jan. 1879, and where he does a general Real Estate, Insurance, Collection and Broker business. Although but recently starting in his present location, Mr. Howley's genial qualities, known integrity, ability and experience in financial matters has already secured him a large business. Mr. Howley was born in Ireland in 1839 , and came to the United States in 1853 . He spent some years in the Western and Southern country, traveling through many sections of Missunri and Mlississippi Pirer country. He afterwards was induced to go to Canada and talke charge of the large estates of lis father, where his ability and energy was manifested in an eminent degree in placing the affairs of the large and complicated estates in perfect order. He came from there to this city in 1665 , when he married and accepted a position in the 4 th National Bank, remaining for 11 years, leaving there to engage in his present business, and to look after his large property interests. Mr. H. is a cultured and agreeable gentleman, and possesses the esteem of all who know him.

\section{IRON CITY MARBLE WORKS,-Geo. Metcalfe, Butler St., near 45th.}

The extensive Marble and Stone Works of Geo. Metcalfe are located on Butler st., near 45th st., where are manufactured and kept on sale Monuments, Tomb Stones, and Marble and Granite Stone Work of all kinds on a large scale, employing constautly 5 skilled workmen. Mr. Metcalfe carries a complete stock, not being excelled by any establishmenl in the city. These works were established by the father of the nresent proprietor in 1872, who had previously been engaged in the same business for 20 years in another locality, being a member of the old firm of Evans \& Mretcalfe. Mr. Metcalfe was born in Pittsburgh in 1856, and has lived here ever since, learning the business of martle and stone cutting with his fither, working in the establishuent ever since he was old enough to work. He has now taken the husiness in consequence of the deatl of his father. Mr. M. is fully qualified for carrying on the business in a successful inanner, and to the entire satisfaction of the large number of patrons of the establishment.

\section{J. POTZER,-Hats, Caps and Furnishing Goods, 23 Federal St., Allegheny.}

Mr. Potzer has been cngaged in his present line of business in Pittshurgh and Allegheny since 1851. He opened at his present location, No. 23 Federal street, in 1877, with a full line of Hats, Caps and Gents' Furnishing Goods, and his trade has been eminently satislactory since that time. TW hile he kceps it carefully selected stock of articles in his Jine, he makes a specialty of sclling at reduced prices, and has established a wide spread reputation for sclling at low cr rates than any house in town. His sales-rooms aro $20 \times 110$ feet, in the elegant four-story bricls building, No. 23 Federal street, near Suspension bridge.

DR. J. M. STEVENSON,-Physician \& Surgeon, Penn \& Washington Av's., E. E.

Dr. Stevenson was born in Allegheny County December 30, 1836. He graduated at Jefferson Mledical College, Philadelphia, in 1859. For thirteen years previous to settling in Pittsburgh lie practiced with success in Westmorelind County, Pa. He removed to his present location in August, 1872, and has a large and steadily increasing practice. amounting to not less than $\$ 7,000$ or $\$ \$, 000$ per annum, in Pittsburgh and the East End W irds. His tfioce is located at the corner of Penn and Washington avenues. 
JOHIN O'DOHERTY, - Wholesale Wines \& Liquors, 17 \& 18 Water St., cor. Penn Av.

One of the ancient landmarks of Pittsburgh is the old brick structure at the corner of Penn avenue and Water street, located upon historic ground, where in ante-Revolutionary times stond Forts Duquesne and Pitt and in the rear of which nlay to-day be seen the old buildings of quaint French architecture crected in 1764 by Col. Boquet as a portion of the fort. The old three-story brick structure, $90 \times 10$ feet, now occupied by Mr. O'Doherty as a Whalesale Wine and Liquor Store, was erected in 1810, and at that day was considered one of the most imposing business structures in the city. During the great flood of 1832 the water covered the first floor of this building to in depth of tive feet and on several occasions the water has flooded a portion of the buildings. On the Water street front of this store is painted a record of the various "great floods" since its construction with marks showing the various stages of high water. Mr. Eichenbaum, now of the firm of Johnson \& Co., printers, was the first occupant of this building, using it for the manufacture of mcad, a light beverage at that time very popular in the city. Then it was occupied for a time by Mr. Garrett as a malt house. After this it remained idle for a number of years, and in 1870 Mr. M. Munhall and Mr. J. O'Doherty open In $1879 \mathrm{Mr}$. Alunhall disposed of his jaterest in the business to Mr. O'Doherty, who has since been sole proprietor. This is one of the largest and best-known establishments of its kind in the city and Mr. O'Doherty carries continually in stock and in bond a full line of the choicest and purest brands of Foreign and Domestic Wines, Brandies, Gins, Rums, etc., and pure Old Monongahela Rye and Rectified Whiskies of the finest quality, valued at not less than $\$ 70,000$. His trade extends over the two cities and adjacent territory throughout Pennsylvania, New York, Ohio, Haryland, West Virginia, Illinois and mauy of the Western States, his anuual sales amounting to not less than a quarter of a million dollars. This house is noted for the excellent quality of all articles pertaining to this line of business. ter of a million dollars. This house is noted for the excellent quality of all articles pertaining to this line of busincss.
Mr. O'Doherty is a gentleman of long experience in the business, having been the principal part of his life identitied with the liquor trade, and dealers inay at all times be assured that every article will be found exactly as represented.

\section{F. HAMPE,-Birmingham Bottling House, Head of 23d St., South Side.}

Manufacturer of Sarsaperilla, Raspberry, Lemon, Ginger Ale and Soda Water.

Notwithstanding the fact that there has of late been an increased demand for lager heer in this locality, the several beveraves known as soft drinks, such as are manufactured by the establishment named above, are in great demand, and their preparation is a large and important branch of industry in this city. This house was started in 1869 by the Birmingham Bottling House Company, of which Mr. F. Humpe is manager and principal stockholder, the other stockholders being August Ammon, Esq., and Mr. Nusser. The business is now entirely controlled by Mr. Hampe, who has increased the facilities for working and the capacity of the works in order to keep pace with the times and neet the demands of the trade. In addition to the various soft drinks prepared and bottled at this concern, a specialty is made of bottling the best brands of beer for family nse, which is delivered at any place desired in the two cities. A full stock is kept on hand of all goods in his line of trade aud the yearly business is estimated at about $\$ 15,000$. Two huildings are occupied by the works, one a two-story brick structure, $40 \times 60$ feet. The business is divided in to several departments, and all the latest improved maclinery used for the purpose, including a 20 -feet boiler, two copper generators, three copper fonts and a Blake pump. The trade is mostly local, being confined to the city and surrounding towns. Mr. Hampe was born in Germany and came to this country in 1857. Since then he has made it his home. He is a man of large atquaintance in business circles and his reputation as an upright business man is second to none in the city. A man of public spirit and enterprise, who takes a prominent position in all matters pertaining to the welfare of the community.

PITTSBURGH ACID WORIS,-Sulphuric Acid, Office, No. 54 9th St.

For nearly fifteen years Messrs. F. F. Farrar, G. B. Littlefield and C. W. Farrar have, under the above style, been engared largely in the manufacture of Sulphuric Acid for commercial, manufacturing and chenical purposes. As one of the only lour manufactories of this kind in the United States it is deserving of more than ordinary notice in this volume. The plant of the house is located at Sandy Creek, on the line of the Allegheny Valley R. R., the building being substantially built of brick, 28 feet from floor to ceiling, and covering an area of over one and one-third acres. The manufacture here of the acid is carried on upon an improved process, highly conducive to its perfection in the matter of strength and purity. All the necessary apparatus and machinery, together with one powcrful engine, and several large steam puimps, are of the most approved kind, and 20 hands are engaged in the works. Since the comulencenent of operations the business has increased fully 100 per cent., most of the product finding it ready market in this city and immediate surroundings. In comparison with other cotcmporaneous establisiments it compares most favorably, especially in regard to the quality of the article manufactured, which is said to be of :uperior excellence.

\section{F. GARDNER,-Family Groceries, 93 Chartiers St., Allegheny.}

Mr. Gardner is an active and wide-awake roung man who has recently commenced business for bimself at No. 93 Chartier's street, Allegheny City. He has been fortunate in his selection of a location and keeps only the best and innst rehiahle goods, and has a liberal share of the patronage of this section. He occupies a two-story brick building, $18 \times 38$, and carries a full and complete stock of Choice Family Groceries, Teas and all articles usually found in an estabfriends wbo unite in wishing him success.

\section{כ. W. ROBERTS,-Groceries and Provisions, No. 3808 Butler St.}

At the above location, in the midst of piles of Groceries, Provisions, etc, of the hest quality, with his large store room, kept full of all the leading gonds in his line, provisions, fruits, etc., in their seasen, the rers popular and courteous gentleman, $C$. W. Roberts, will be found always busy serving the nunerous custemers. There is no estiblishment in this portion of the cits more worthy of the liheral patronage of the community. He started the business in 1875 on a very small capital, but enterprise and business abilit $y$ h:tre increased his trade so that he now carries a stock of from $\$ 2,000$ to $\$ 3,000$, and does an annual business of trom $\$ 15,000$ to $\$ 20,000$, which is constantly increasing. Mr. koberts was born in the State of Maine, and came to this city in 1872, where he has resided ever since.

\section{MoSTEEN,-Plumber, Brass Founder, Gas and Steam Fitter,}

Peun Av., bet. 32nd \& 33 rd sts.

The establishment of Mr. McSteen is on Penn avenue, hetween $32 \mathrm{~d}$ and 33d sts. Started 17 years ago by J.\& M. McSteen, they roing out of the business, it has-since leen continued by the present proprietor. A general Plumbing, Brass Foundry, Steutu and Gas Fitting business is done, for which he is well prepared. Mr. MIcsteen was bern in Ireland in 1818, came to the United States in 1836, worked 22 years in the well known liulton's Brass and Bell Foundry. He was captain of the old Allegheny Volunteer Fire Company for a number of years. participating in many of the exciting iacidents cunnected with that 


\section{PITTSBURGH \& LAKE ERIE R. R.}

The Pittslurgh and Lake Erie laalroad is mainly indebted for its existence to the capitalists and lusiness men of Pittsburgh, who, becoming dissatislied with the freight discriminations of older and wealthier corporations agaiust Pittsburgh, determined to construct a road which should furnish an outlet for their nanufactures, and carry their productions al reasonable yet paying rates. This line is the exclusive connection of the Atlantic and Great Western, Lako Shore and Michigan Suuthern, New York Central, and Erie liailroads for passengers and freight to and from Pittsburgh, East and West, and offers to our manulacturers and business men competing facilities, which must be appreciated. Rililruad passes through a thickly settled portion of country, and presents to the traveler scenes of pieturesque beauty and grandeur unexceiled in Pennsylvania and Ohio, and forms connections with leading trunk lines at various points. The advantages of this new route can scarcely be over-estinuted in the facilities it presents to the manufacturers and shippers of Pittsburgh. At New Castle junction a branch, extending three miles, has been constructed to New Castle for the purpose of obtaining the business at that point, which is an item of no sinall importance. The tracks of the Pittsburgli and Lake Erie Road extend for five miles through that portion of the city, formerly known as Birmingham, where the principal iron and glass manufactories of the city are located, and has side tracks ruuning into all of the leading works, which will insure to the road the bulk of their business. An inclined track has also been constructed in Pool No. 1, near the American Iron Works, by which loaded cars are run on barges and taken across the Monongabela River to the manufactories on the North Side, and unloaded into the mills direct. This feature is one of the most promising characteristics of the new road, furnishing, as it does, the means of securing a large business that could not otherwise be reached. The depots of this road are on Carson street, on the South bank of the Monongahela River, at the terminus of the Smithfield Street Suspension Bridge, and are admirably arranged for the purposes of the road. The officers of the company are men of rare comprehensive, ability and experience, Mr. W. C. Quincy, the general manager, was for several years connected with the Western Division of the B. \& 0 . R. R., and was one of the most popular and efficient superintendents ever connected with that road. Mr. A. D. Sinith, General Passenger and Ticket Agent, was formerly Auditor of the B. \& O. R. R. at Columbus, Olio, which office he filled with credit and consummate ability. The freight department is in charge of Mr. C. A. Chipley, a gentleman eminently qualified for the position, and deservedly popular with the patrons of the road. The principal a rery capable and efficient officer, and was formerly connected with the B. \& O. R. R.

\section{MOUNT OLIVER INCLINE-PLANE RAILWAY CO.} ties of ties of the cities of Pittsburgh and Allegheny, should there be an omission to chronicle the enterprise and engineering skill associated with our beautiful Incline-Plane failroads. Among these we take pleasure in calling attention ated by the gradual growth in population of the South Side, and the attractive sites for residences offered in the beantiful section of Mout Oliver. This Company was oryanized in 1872 under a State charter, with a capital of beautiful section of Mouut Oliver. This Company was oryanized in 1872 under a State charter, with a capital of
$\$ 80,000$. Having commenced operations at an inauspicious time, when onr national financial difticulties were causing great shrinkage in all values, and in the midst of one of the severest panics through which the country has ever passed, the heavy expense and outlay for material, and the proper machinery, cars, buildings, \&c., the shrinkage in values so affected this organization that it was obliged to go into ilquidation and allow the sale of all stock and appurtenances to be sold at sheriff sale in $\mathbf{1 8 7 5}$. Twelve of the original stockholders found it necessary, to protect themselves, to purchase the road, with the lope of saring, in time, the amount they had previonsly invested. Since that time the Mount Olirer Incline-Plane Railroad Company have placed their line in the most perfect and safe condition for the conveyance of passengers and freight up that lofty and attractive eminence, and is becoming, year after year, more popular with the general public. Since its organization the population of this locality lus continued to increase and gives sure promise that, before many years more, Mount Oliver will be one of the most thickly-settled sulurhan towns in this vicinity, as it certainly is one of the most beautiful and inviting. Taking the car at the foot of Twelfth St., South Side, you are gradually elevated to an eminence which, perhaps, gives the most comprehensjve and extended view of the city and surronnding country to be had in this vicinity, the distance between the two stations being about 1600 feet. In fact it secures the most perfect view to be had of the city, and spreads out a landscape view for a distauce of 18 miles, making it the nost desirable and popular resort for sight t-seeing, day or night. A double track is provided, so that while one car is ascending the other is descending, making trips every five niinutes, the operating machinery being on the summit of the Nount. While this, as previously remarked, is yearly becoming more and nore popular with the citizens of Pittsburgh, it cannot fail to attract the attention of all visitors from a distance, for you cannot really say that you have seen Pittstrurgh until you have elijoyed the view presented and become exhilarated by the enchanting scene presented from Mount Oliver. The street cars from the city run within a short distance of the Twelfth-St. station, South Side, and for the small expense of five cents you can enjoy a view which creates a more

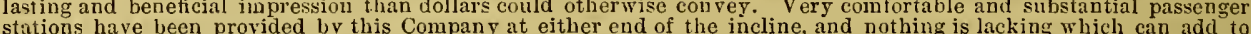
the ronvenience and at tractiveness of this route. Those desiring can be accommodated with refreshments or meals at very smatl expense, while beautiful gardens, parks and groves offer a delightful retreat. The machinery and appliances of this Company are thoroughly tested and inspected to conserve the convenience and safety of passengers. "What if an accident would happen?" is a common remark. In answer to this we can cheerfully say no accident has ever happened, and, to make assurance doubly sure, double wire cables, each thoroughly tested, are provided, so that there is no possibility of accident or injury. The stcel-wire drag cable is used, so that, if, in any possibility, the first cable should at any time give way, it will still be secure. The officers of this Company are all men of the hirhest standing, well and favorably known in social and business circles. They are as follows: C. J. Schultz, President ; Peter Haverman, Joseph Keeling, Joln N Nusser, Ferdinand Bentz, John B. Beach, and Frederick Hampe, Dircetors. At the head of this incline the visitor will find a comfortable place of resort, the National Beer Garden, John Nusser, proprietor, where meals and all the luxuries of the season can be liad at all times.

\section{H. COLEMAN,-Groceries and Provisions, 2836 Carson St.}

This enterprising caterer to the home and table of families in this section of the Smoky City is entitled to worthy mentiou among the best class of Grocery and Provision houses and the general business interesis of this city. Mr. H. Coleman was born in Port Perry, this county, in 1841, and came to this city in 1866, and in 1867, in eonnection with a brother, commenced business with a small capital. Since then he has taken the business alone, aud has manased, by industry and economy, to gradually increase the original in vestment and stock. He orcupies a three-story brick building, which is $20 \times 50$ feet in size, lncated at No. 2836 Carson St., Soutl Side, and is patronized by the best class of citizens in that part of the city, as well as a large country trade. Ilis Store will at all times be found fully stocked with the very best class of Family Groceries and Provisions of every description, Flour, Feed, \&c., and his prices as low as you can huy articles of same quality in the best houses of the kind in Pittshurgh. Mir. Coleman has not only built up a permanent and growing business, but established a character for fair and square dealing and courteous manners, which has gained the esteem of a wide circle of friends and patrons. 
GRAFF, BENNETT \& CO.-Clinton Iron \& Nail Works, Millvale Iron Works.

office and Wurerooms, 97 Water st.

Among the most distinguished iron works whose works have assumed such an extent as to exert a powerful, if not vital infuence upon the prosperity and developinent of the city, MIessrs. Graff; Benuett \& Co. may be said to occupy a leading position. This house was establislied in 1854 hy a copartnership effected bet ween Messrs. John Graff, James I. Bennett, Wm. B. English and R. H. Marshall, under the existing style, no change having occurred from that time except the demise of Mr. English in 1865, whose interest was absorbed by the other members of the tirn. Within a vear from the time of its formation the compan y became possessed by purchase of the Clinton Mfills, which had hecn built seven years previously and were owned by Cuddy, Jones \& Co., who retired from business. This plant, whicli was the first property acquired by Graff, Bennett \& Co., was, at that time even, regarded as a small one, and in coumparison with the extensive works now occupying the same site, must have been almost insigniticant To the work of increasing their business, resources and facilities, however, the firm devoted itself with unusual tilent and vigor, enlarging oll these annually at a rapid ratio, keeping pace with every improvement suggested by inventive skill or experience The Clinton Iron and Nail Mills, which still occupy the original site on the south bank of the Monongahela river, opposite the lower part of the city, now cover an area of ahout eleven acres, having a frontage on the river of 1,500 feet, extending back to the base of the bluff known as Mt. Washington. Within these fimits are the rolling mills, nail factories and blast furnaces of the firm, the latter constructed in $185 \overline{8}$, being the first e.ver operated in Alleghen County. Here are employed about 400 men in the various departments in operating the machinery, which is most complete in every respect, consisting in part of 6 trains of rolls, 7 double puddling furnaces, 12 single puddling furnaces, about 50 nuil and spike machines, 7 steam engines, with 12 boilers in 3 batteries, aggregating about 400-liorse power, and other appliances, the total consumption of coke being 80,000 bushels and of coal 65,000 per month, the furnace having an annual productive capacity of 12,000 tons of iron. In 1863, owing to the rapid]y increasing husiness of the firm. which found its existing facilities too contracted to supply the requisite product, it wis considered expedient to purchase an additional plant, and the Millvale Iron Works were at once added to the assels of the concern. These works are situated on the north bank of the Allegheny river, nearly opposite 49tll street, and were established originally in 1847 by the Mechanic's Iron Company, now long extinct. When they came into possession of the present owners the plant was a small one, but underwent the same changes, enlargenents and improvenents that characterized the history of the Clinton Works. The dimensions of the main hnilding of the MLillvale MIill are $150 \times 900$ feet, besides which there are numerous dependent structures and dwellings for employes (who number from 400 to 600 ), forming one of the most desirable mill properties in the State. The machinery and appliances in operation : $t$ this estal,lishment are of the best construction and most recent design, consisting, with other apparatus, of 10 Danks rotary furnaces, after Dinks' pateut, but naterially improved upon in many respects by the experience and knowledge of the house ; trains, 12 -inch hoop and guide trains, bar rolls, 46 cylinders, and 4 batteries of powerful boilers. This mill is the only one in the country where the introduction of the Danks furnace has been attended with such success as to make unone in the country where the introduction of the Danks furnace has been attended with such success as to urake un-
necessiry the labor of skilled puddlers, the rotary action supplying all the requisite manipulation. The product, of these works is mainly Pipe Iron, Tank Sheet Iron, Bridge Iron, Iron Plate and Nerchant Bars, the total capacity of which in manufactured iron is stated at 20,000 tons annually, not including the output of the Clinton Mills or the firm's interest in the Isalella Furnaces, the last named having a productive capacity of 75,000 tons per year. Added to these home interests of this honse are others located $i$ the state of Ohio of no inconsiderable capacity and prodact. At Latonia, in that State, are two blast furnaces, known as the "Graffton Fnrnaces," owned and operated by this firm in the manufacture of Bessemer Pig Iron, and a Charcoal Furnace in Paulding County, Ohio. The louse established in 1860 for the more convenient accommodation to their Southern and South-western trade, a branch house in St. Louis at 622 North Second street, to which point large quantities of their inanufactures are shipped for sale. There, also, is kept in stock a complete line of heavy hardware, wagon stock and agricultural implement irons and trimmings. Of the character of the firm or its individual m 'mbers, little need be said here, that for more than a quartcr of a century it has been deeply involped with the most exigent interests of the community is a fact too well know $n$ to require comment. Mr. Bennett, the senior partner in age, is a man widely known and respected for his undaunted eLterprise and expansive views. As President of the Pittsburgh and Lake Erie Railroad, he has just brou; int that great project to a successful issue, conferring by the acconplishment of this scheme a benefit upen the industries of Pittshurgh not yet fully realized, a director of the Peoples National Bank, the M. \& M. Insurance Co., as well as Presi lent of the Ewalt St. Bridge Co, and connected with numerous organizations, MIr. Bennett, since 1845, the- period of his settlement in this city, has been prompt to foster every measure that pointed to the conservation of the public welfare, nr gave an increased impetus to the general prosperity. The removal of Mr. John Griff to Pittsburgh was (n)-incidental with that of Mrr. Bennett, though the latter was born in Franklin, Crawford Co., Pa., and the former in Westmoreland Co., this State. Mr. Graff is recognized as one of the most active and enterprising husiness men in our fity, and his connection with this house has been highly conducive to its stability and suceess The firm duties of Mr. Marshall represent by no means the least important part of the work, and from the skill displayed in the operative practical management of the Clinton Mills, he takes a high rank in the trade as an accomplished iron man and metallurgist. With a trade that extends over the extreme limits of civilization upon this continent, and that involves millinns annually, the house of Graff, Bennett \& Co., as one of the institutions indissolubly connected with every inverest that airls or retards the progress of Pittsburgh, is justly entitled to the place it has at tained and the eonsideration with which it is universally regarded.

\section{SECOND NATIONAL BANK OF PITTSBURGH,}

Among the banking associations of this city a few of course take positions in importance, wealth and business capacity in advance of the remaining large majority in numbers, and as one of these few, the Second National is one of the most important. The incention of this bank was under the name of "The Iron City Trust Company", which was organized in July 1859, and did business under that title until February 1864, when its managers complied with the National Bank Act, and its name was changed to the present style with a capital of $\$ 300,000$. Upm the last named event the late Judge G. E. Warner, who was president of the old organization was chosen president. He was succeeded in 1871 hy George S. Head, Esq., who still fills this important position and is a member of the board of directors, composed of the additional following gentlenen:-Wm. Cooper, G. N. Hoffstot, Geo. E. Neiman, John Hays,

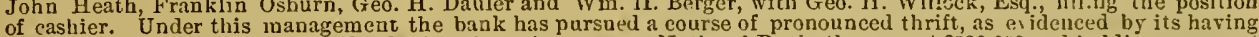
paid up to A pril 30,1879 , as dividends since its existence as a National Bank, the sum of $\$ 330,000$ and bolding a present surplus of $\$ 75,000$ in addition. The huilding occupied by this bank is of its own ownership, and was erected in $1870-77$ at an outlay (including lot) to the institution of $\$ 100,000$. This building is one of the finest and most eostly in the cily, and was designed by one of the ablest architects in the State-Edward If. Butz, Esq., of Alleghelly city, who is known

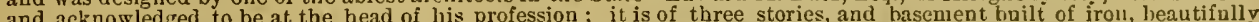
trimmed and ornamented, the room occupied for banking purposes being 40 feet square with 20 feet eciling, which has lately been tastil - frescoed and decorated. The cashier's assistants are composed of the following list:-T. W. Welsh, Jr., teller; Samuel Lewis, general bookkeeper; James McElroy, individual bookkceper; Samnel MrClurkan, J1., discount and collection clerk, and H. Sproul, messenger. The Eastern and Foreigis exchanges are made through the Central National Bank and National Park Bank of New York and the Union National Bank of Philadelphia, while the tral Nation Bancipal correspondences for their respective districts. The business of this bank is catalogued as among the heaviest of its cotenporaries in loans, liscounts and exchanges, and carries a line of deposits generally aggregating the $8 u m$ of $\$ 125,000$, a circumstance shuwing in the inost expressive language $t$ he degree of confidence in the ability of its management. 


\section{JOHNSON, EAGYE \& EARL,-Wholesale Grocers, $1202 d$ \& 149 1st Avs.}

One of the largest and most thoroughly reliable wholesale Grocery Houses of Pittsburgh, is that now conducted hy Messrs. Johuson, Litrye \& Earl, who occupy the spacious and eommodious warehouse at No. 120 Second avenue, cxtending through to First avenue, No. 149. The house was originally founded in 1844 by Mr. John Irvine and Mr. Mablon Martin, under the firm name and style of Irvine \& Martia. Two years later Mr. Irvine disposed of his interest in the business to Mr. Wm. II. Smith, and the style became Martin \& Smith. In the following year, 1847, Mr. Wm. M. Sinchair purchised the interest of Mr. Martin, and the business was eonducted until 1855 under the firm name of Smith \& Sinclatir. During that year Mrr. Sinclair retired and a new firm was organized ly Mr. W. H. Snith, W. W. Mair and Joseph R. Hunter, doing business as Sinith, Mair \& Hunter. In $1857 \mathrm{Mr}$. Mair retired, the remaining partners continuing the business as WM. H. Smith \& Co., until 1866, when Mr. Hunter retired and Mrr. Sullivan Johnson and Joseph T. Colvin were admitted as partners and the firm name became Smith, Johnson \& Colvin. In 1869 Mr. Smith retired frolu the firm, which then became Johnson \& Colvin and subsequently Johnson, Colvin \& Co. This frm was sueceeded by the present one of Johuson, Eingye \& Earl in 1876. It will be seen from the above sketch that this is one of the oldest wholesale grocery houses in the city, having under the various styles mentioned been continuously engaged in business for the past thirty-five years, and during all that period recognized as one of the leading lsouses in the trade. The capital at present invested in the business is $\$ 90,000$, and their stock, which is always full and complete in all departments, ranges in value from $\$ 40,000$ to $\$ 65,000$. The trade of the house extends througbout Penusylvatuia. Ohio, Maryland and West Virginia, and amounts to between $\$ 500,000$ and $\$ 600,000$ per annum. Twelve elerks and assistants are regtzlarly employed and their business is steadily increasing from year to year. While they transact a general grocery business, dealing in every description of staple goods pertaining to that line, the leading specialty of the house is tobaceo, of which they now carry a very large stock. Mr. Sullivan Johnson, the sevior member of the firm, was bern in Somerfield, Somerset county, Pa., in 1831, and was for fourteen years engaged in active business at Adison, Somerset eounty, as a member of the firm of Ross \& Johnson. He came to Pittsburgh in 1866 and has since heen prominently identified with the wholesale grocery trade bere. Mi. Geo W. Eagye is a native of Washington county, Pa., and was born in 1813. He was for several years engaged in mercantile pursuits at Upper Middletown, $\mathrm{Pa}$, and has been a resident of Pittsburgh since 1867. Mr. Edwin F. Earl was born in Somerset county, Pa., in 1842. For nineteen years he was in business at Jener Cross Roads, Pa., eight years of which time he was a member of the firm of Kierman \& Earl. He has resided in Pittsburgh since 1S76. The members of this enterprising louse are all active, energetic business men and worthy representatives of the important commercial interests of Pittsburgh.

\section{ANCHOR SA VINGS BANK,-134 Fifth Av.}

Reliable insitutions for savings in a great manufacturing city like Pittsburgh are acknowledged necessities, and the amout of funds annually placed on deposit by the working classes alone would appear almost ineredible were the exact figures attainable. The Anchor Savings Bank is one of the most thoroughly reliable and responsible tinancial institutions of Pittsburgh, and as such cnjoys the confidence of all classes of eitizens from the "horny-handed sons of toil" to the capitalists, manufacturers and merchints, who transact business over its counters. The Anchor Bank was fo'tuded in April, 1S73, as an individual banking house, and became a chartered institution in July 1877 with a eapital of $\$ 100,000$. It transacts a general banking business, receiving deposits, making collections, discounting paper and miking loans on reliable security. The amount of deposits at present exceed $\$ 60,000$ and the latest reports show the affairs of the bank to be in a most prosperous condition. The board of directors is composed of well known and reliable eitizens of high standing in the community under whose able and judicious managements the interests of all are eareteller.

\section{H. ANSHUTZ \& CO.-Lafayette Stove Works, 214 Liberty St.}

In making an examination of the industries of Pittsburgh with reference to its resources in the casting and founding of iron, there are several establishments engaged in this branch of unaufactures that deserve special mention in this work. Of these the tirm of $\mathrm{H}$. Anshutz \& $\mathrm{CO}$., is by no means the least important, either in the cliaracter of its productions or the extent with which its operations are conducted. The Lafirette Stove Works were established in 1844 by S. Showers \& Anslut\%, who commeneed business with but a very suall capital, gradually increasing the same year after year by industry and a polic $y$ of uniform and spotless integrity. In $1854 \mathrm{Mr}$. Showers retired from the concern, leaving Mr. H. Anshutz sole proprietor until 1863, when he admitted John H. \& C. W. Anshutz, his two sons, and the firm became $H$. Anshntz \& Sons, continuing so until 1872, when upon the death of John $H$. the tirm remained composed of H. \& C. W. Ansliutz under the title of H. Anshutz it Son, and became widely known under the style, a title which was not changed until January 1,1879 , when by the admission of W. T. Bradberry the tirm became H. Anshutz \& Co., as at present. The foundry is located on River avenue, Allegheny city, and is an extensive strucrure $150 \times 233$ feet in dimensions. Here are manufactured cooking and heating stoves, portable ranges, grate fronts, fenders, registers, furnaces, dc., besides other castings to order. Filty moulders and other skilled artisans are employed at these warks. requiring a disbursement monthly of about $\$ 2,000$. All the machinery and appliances requisite for securing the best results are here found in the greatest perfection; one steam engine and boiler 20-horse power are in use and no appiratus is wanting that invention can suggest or capital supply to meet every modern demand. In addition Io this establishment the firm possesses two capacious ware rooms, one on Ohio street, Alleghen $y$, No 196, 30x82 feet stocked throughout with goods of the finest quality, and another, the principal one and wholesale house, at No. 214 Libcrty street, Pittshurgh, $18 \times 135$ feet, also replete with a valuable and ample stock, which at both stores is estinuated a beitin worth not less than from $\$ 15,000$ to $\$ 20,000$, the patterus, dc., at the factory exceeding a value of orer $\$ 10.000$, while the annulat business avernges between $\$ 60,000$ and $\$ 75,000$. This trade is by no means confined to these cities or even to their immedliate envirens, but reaches through Ohio, West Virginia, Indiana, Iowa and man $y$ other Western Siates; gools having been exported to Cubs and other foreign markets. Since its establishment many important improrements have bern made by this holse in cooking stores, grates and ranges, so great indeed are the advantages possessed by sime of the makes peculiar to the firm that the demand is rapidy increasing, especially for the Tremont, Glendale and Monitor ranges and stoves of which they east no less thin fifty different patterns. Mr. WV. C. Anstuutz is a native of Louisville, Ky., from which place he was removed to Pitsburgh at an early age. He is well known in business circles and oeeupies a directorship in the (rerman National Bank of Alleghen $y$ and the Teutonia Insurance Co. of the sime place, and is connected with other institutions of a public character. Mir. Bradberry is also well identitied with the industries of this community and is a native of Allegheny city. Henry Anshutz, Esq., the senior pirtuer and founder of the firm, was born in Alsace, a province of France at that time, in 1812. At the age of twent $y$ years he decided to emigrate to this country and arrived in Pittsburgh in 1832, and after laboring for twelve 5ears originated his present enterprise with a total capital of $\$ 200$. More than a third of a century has elapsed since that time and the house of which he is now the head, has acquired an active capital of from $\$ 60,000$ to $\$ 75,000$, which is supplemented by ample private resources-a direetor in the Pitsburgh Gas Co. and conneeted with other influential nilterprises and corporations. Mr. Harry Anshut\% represents in himself the best elass of self-made men, who without ostentation, but endowed with singular courage, resolution and integrity have risen from the ranks to positions of privite honor and public trust. In every way the tirm of which this is but a brief account, is worthy of the suecess it has attined, and the esteem in which it is held by the entire community. 


\section{WM. VELTE \& CO.-Machinists and Engine Builders, Penn Av. and $32 d$ St.}

The establisliment of Wm. Velte \& Co., the subjects of the present sketch, was founded in 1876, at. No. 1023 Penn Avenue, by this firin. They sonn entered upon a successful career, ind found themselves pressed with a rapidly growing business, which necessitated in 1879 removal to their present very convenient and finely located situation, where they hitve a very tine shop, $25 \times 1110$ feet in dimensions, supplied with every needed tool and appliance, driven by a fine engioe, affording them abundaut and conveuient facilities for the successful manufacture of everything in their line. They are employed largely in building Stationary and Hoisting Engines, Portable Engines for sinking wells, and for agricultural or other purposes, turuing out very superior and exeellent work of this eharacter, also do all kinds of machinists' work in their line. They employ from 12 to 20 skilled and experienced machinists, who are directly under the careful supervision of Mr. Velte himself. Mr. Wm. Velte is a natire of Pittsburgh, learned the trade of maclinisi early in life and has followed thit vocation eontinuously ever since. He held the position of master mechanic of the extensive machine shops of the Atlas Works, for seven years, thus acquiring a very extensive and valuable experience tnd a thorough knowledge of all branches of the busincss. $\mathrm{Mr} \mathrm{V}$. is an accomplished and ingenious machinist and enterprising and reliable business man, and a popular and eourteous gentleman.

\section{J. WEAVER \& CO.-Advertising Agents, 716 Smithfield St.}

Advertising agencies, when properly condueted, have not only become necessary to the publishers of eountry newspapers, but a great eonvenience to eity advertisers desirous of placing before the public in an advantageous and conspicuous manner the inducements which they offer in their line of business. The agency of J. Weaver \& Co., at No. 116 Sinith field street, is the ouly thoroughly reliable newspaper advertising agency in the city, and as such is entitled to the farorable notice and consideration of nanufacturers and merchants desirous of reaching the attention of rural readers. Mr. Weaver established his agency here in 1870 with only twenty-eight newspapers upon his list. He has now regular contracts with over fifteen hundred and represents every reliable paper on the continent He also is prepared to furnish estimates and insert advertisements in foreign journaIs, magazines and periodicals. His facilities are not surpassed by those of any similar establishment in the United States and his relations wirh publishers and advertisers have always been of the most anicable and satisfactory character. His business, which extends all over the United States, amounts to more than $\$ 50,000$ per annum. Mr. Weaver is a native of Washington county, this State, a graduate of the famous Washington and Jefferson college, and a gentleman of culture, ability and fine business qualifications Commeneing with moderate means and upon a comparatively small scale, he has established a business of which he may well feel proud and which entitles him to favorable notice in a work of this description.

\section{GEO. S. HAINES,-Manufr. of Trunks, Valises \& Satchels, $144 \& 146$ Wood St.}

Mr. Geo. S. Haines has heen engaged in the manufacture of Trunks, Valises, Traveling Bags, Satelhels and Tourists Equipments, as well as the varied outfits of eommercial travelers, for the past six years. Realizing the fact that the traveling public should have a reliable article, Mr. Haines has made it a special study to make a perfect and durable trunk, whieh is know a the world nver as the "Haines trunk." It is decidedly the best trunk we have ever seen. Mr. Haines has lately increased his nuanufacturing facilities, and his factories are now located al numbers $6,8,10,12$ \& 14 Diamond street, 29 and 30 Union street and $22,24,26,28,30$ and 32 Decatur street, city. His salesroons are at 144 and 146 Wood street, corner Virgin Way. They are large and commodious, and are well filled with the trunks for which Mr. Haines is so popular. A specialty to which we would direct our readers, is the line of Agent's Sample Cases or Trunks for carrying glassware, groceries, tolaccos, boots and shoes, Hats, Hardware, Books, Toys, etc. In fact they are the very thing an agent requires to display his samples to the brst advantage, and earry them in safety. The repairing department is also complete in every respect. Any dealings our readers may have with Mr. Geo. S. Haines, 144 and 146 Wood street, will be eminently satisfactory.

\section{AIBERT H. WILSON,-Druggist, Junction of Penn \& Frankstown Avs.}

Among the prominent business houses of the East End, this work will reeord none more worthy of eonsideration than that of the very handsome and couveniently located druy store of Mr. Allert $\mathrm{H}$. Wilson, situated at the junction of Penu and Frankstown avenues. Mr. Wilson tirst opened his business here in 1876. His room is well stocked witl pure drugs and medicines, all popular and desirable patent medicincs, perfumeries and tuilet articles, notions, \&c. He gives special attention to the compounding of physician's prescriptions and ean be depended on for the purest medigiving several years stud y and application to the drug business and to the conpounding of medieines, he estublislied his present business, where he has met with a liberal patrouage.

\section{KNOX, IMORRIS \& CO.-Coal, Slack and Coke, foot of Western Av., Allegheny.}

That which lies at the root and is the basis of the immense manufacturing industries of the Smoky City and her environs is the accessibility of immense coal fields. If, then, so great importance attaches to results, equal significance may properly be given in a comprehelssive work of this character to the great coal interests of the two
cities. That which promises to become one of the leading firms in the Coal trade is the firm of Knox, Morris \& Co., who commenced operations only this year, and will handle about 1,500,000 bushels before the expiration of the year. The muin office and yards are located at the foot of Western Alley, besides which they have another office and yards at the foot of Locust St., Allegheny, giviug employment at the 1 wo places to about 30 men. In eonnection with the Western Av. yards they have one of the largest elevators for the purposes of handling and slipping Coal, and are al ready doing a business that will eompare favorably with that of any otluer dealers in this eity. This firm consists of J. P. Knox, R. H-Knox and James H. Morris, under the firm uame of Knox, Morris \& Co., wholesale and retail dealers in Coal, Nut Coal, Slaek and Coke. Orders by mail will receive their prompt attention. The energy and ability of the lirm entitle it to the most favorable public consideration.

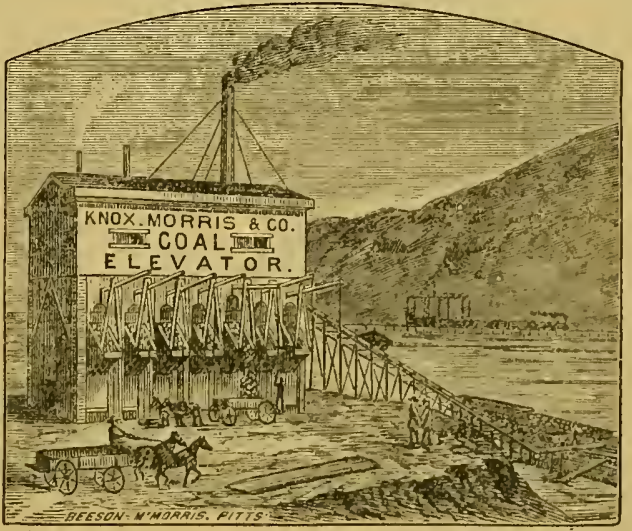




\section{PITTSBURGH LOCOMOTIVE AND CAR WORKS,}

Mannfacturers of Locomotives, Engines and Boilers.

The Pittsburgh Locomotive and Car Works is a joint stock company, organized in 1865 , and chartered by the State of Penusylvania. It is the oldest establishment of the kind in the two cities and one of the most extensive in the United States. The works are located in the Sixth Ward, Allegheny, and cover an area of about eiglit acres, the buildings alone occupying more than one-half of that space. 'They are constructed in the nost thorough and substantial manner, supplied with machinery of the finest and most approved styles required in the various departments, luecessary in the construction of a locomotive entire and complete. For the past twelve years the works have been in alnost continuous operation and the business has been steadily increasing, necessitating the enlargennent and improvement of buildings and machinery from year to year. The present buildings are admirably arranged and consist of spacious machine shops, engine houses, smith shops, paint shops, carpenter shop and pattern manufactory, iron foundry, flask shop, cupola house, brass foundry and finishing rooms, boiler manufactory, pattern storerooms and numerous other smaller building back some thousand teet to the banks of the Ohio river. Switches of the Cleveland and Pittsburgh Railroad Company, with tracks running in to the enclosure, connect these works by rail with the various railroads centering in Pittsburgh, greatly facilitating the receipt of supplies and the shipments of finished work to all parts of the Union. The manufacture of Locomotives for broad and narrow-gauge service, oil engines and portahle and stationary boilers, has thus far occupied the attention of this company, not having yet engaged in the mannfacture of cars. They pay especial attention to Patent Slide-valve Engines, and Superior Flange Iron Boilers, and all their work is fitted to gauge and templets and made thoronghly interchangeable in all its parts. From 400 to 600 skilled workmen are constantly employed, the capacity of the works being one hundred locomotives, two hundred and fifty stationary engines, and seventy-five boilers per annum. During the past two years they have turned out an immense amount of pumping and oil machinery for the oil regions. Six large steam engines, aggregating more than 400-horse power, are required in the various departments of these works, and four large steam hammers of immense power may be especially mentioned as remarkable for size and capacity. All of the machinery, however, is of the most perfect description and approved Cesigns. The officers of the Company are-Mir. D. A. Stewart, President; Mr. Reuben Miller, Vice President; Mr. Nelson Miller, Secretary and Treasurer, and Mr. D. A. Wightman, Superintendent of the Works. These gentlemen are thoroughly qualified for the important positions which they have so satisfactorily filfed, and to them is due great credit for the success of the corporation and the high reputation which the products of the company have acquired throughout the length and breadth of the United States.

\section{ST. CLAIR HOTEL, - C. P. Bailey, Prop., Cor. Penn Av. \& Sixth St.}

Established forty years ago, this celebrated hotel has always maintained a favorite position in the esteem of the traveling public. Four years since the present incumbent succeeded to the management of the concern, Joseph N. Anderson, the owner of the property, being his predecessor. No hotel iu the city is wore admirably situated to suit the requirements of the commercial traveler, occupying the corner of Penn avenue and Sixth street, the two greatest arteries of transit between Pittsburgh and Allegheny City and outlet to the eastern part of the city as well as the South Side from the Point bridge, no site could be better adapted as a center for reaching in all directions. This fact is not overlooked by the public who patronize this hotel iu no stinted manner. Every modern convenience and appliunce is brought into requisition to make the house equal in every respect to more pretentious eststablishments. The furnishing is in keeping with neatness and comfort, the dining room affording ample accommodations for 200 people at one time, while the parlors, reception rooms, offices, billiard room and all the appointments are such as to conduce to the ease and comfort of every boarder. The hotel has a capacity for 250 guests, requiring the attendance of 60 servatnts and employes in various departments. Mr, C. P. Bailey is a native of this state, and as a host is deservedly popular. He occupies the position of School Director in his district and is highly esteemed for the very able manner in which he conducts his business. Mr. W. H. Filler, a favorite with traveling men, has charge of the office. The regular terms are $\$ 2.50$ per day, aud as a commodious and well-regulated hotel, it is cordially commended.

\section{THOS. M.COY,-Oysters, Fish \& Game, 46 and 47 Diamond Market.}

Mr. Thos. McCoy, the pioneer in this business, is deserving of more than passing notice in this work for the extent and activity of his business, as it is one that reaches very larger proportions than is generally supposed. The trade of this house alone reaching very large figures annually, and extends to all portions of Western Pennsylvania, Eastern Ohio and adjacent districts. Mr. McCoy founded his present business thirty years ago, and has during all that period continuously devoted his close personal attention to the business that has grown under his enterprising management into such large proportions. He has during that long time acquired an experience and knowledge of the business, and formed an acquaintance that gives him the largest advantages over younger and less noted firmsevery convenieuce and appliance necessary or useful in preserving in fresh condition the fish, etc., in which he deals, is had, and the most complete and extensive stock of goods in his line of the best quality is always to be had of this house in proper season. In connection with another firm in the same line, a large and perfect refrigerator was ereeted in which large quantities of their goods are kept in perfect order, the temperature being kept at 28 degrees during the hottest weather. Fish is received by them by the car load by fast freight lines and they are enalled to keep them in their refrigerator in perfect condition, which gives them a great advantage in saving the enormous charges made by the express companies, to those less favored in their line. Mr. Thos. McCoy was born in this county in 1831, and has continuonsly resided here, and since his maturity has been engaged in his present business. He is a well known, highly respected and popular gentlemau and an enterprising, reliable business nan; ; National Bank. Mr.J. S. Brazier, who is identified with this house and is well known and highly esteemed by the patrons of the establishıent as well as the community generally, was born in Waslington county in 1833; he now resides in Baden, Beaver county, and is one of the leading citizens of that town. He is a member of the town council and of the school hoard, and is also a justice of the peace. He is highly esteemed by all who know him. Prompt, energetic and reliable, the house of Thos. McCoy is every way worthy of the most liberal public patronge.

\section{W. GARRETT,-Dealer in Oysters, Fish and Game, 44 Diamond Market.}

Mr. D. W. Garrett and the business in which he is engaged is worthy of mention in this work. Mr. Garrett is located in the Diamond Market, the leading market house in the city, where he handles an inumense quantity of Fish, Oysters and Game, both by wholesale and retail. He began business at his present place in 1866. Five years later Mr. W. C. Sykes associated with him in the business, who remained with him until 1877 , at which time be retired, and the business has since been conducted by Mr. Garrett himself, who, in connection with another firm in the same line, have erected a splendid refrigerator, which is perfect in its way, and is kept at the low femperature of 28 degrces during the hottest weather. Their fish are brought from the lakes and other points, by the carload, in refrigerating cars, by fast freight. They are thus enabled to sell to the trade at prices to compete with the lake and eastern fisheries, especially to those lying ncarer to this city than points named. Mr. Garrett has a yery large and growing wholesale trade throughout the entire county, contributing to this city. He was born in Union Co., this State, in 1842, came to this city in 1866, and embarked in his present business, prior to which time he had been engaged in farming and general business pursuits. 


\section{JUNIATA BOLT WORISE VATKEX FORGE,-Gillespie Bros.\&Co.}

Twenty-first and Railroad Streets and Allegheny River.

Tho "Juniata Bolt Works \& Valley Forge" was established in 1875 by Biggerstaff is Co., Mr. T. A. Gillespie, one of the present proprietors being a member of the firm. The business was at first contined exrlusively to the unautacture of Oil Well supplies. Mr. Biggerstalf \& Co. were succeeded in $1877 \mathrm{hy}$ the present tirm consisting of Ml. T. A. Gillespie, Mr. R. G. Gillespie and T. J. Bray, the latter retiring af ter il time, the husiness was eontinued by the Mross's. (tillespie, under the firm name and style of Gillispie Bros. \& Co. Their exiensive works are located at the cormer of 'Twenty-lirst and Ratilroad Streets, on the hanks of the Allegheny Rirer, and cover an atrat of $45 x 200$ feet. The Forge and Finishing llepaltuneuts are each under the immediate supervision of skilled and axperienced mechinies and are

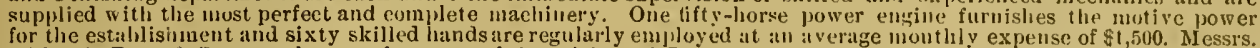
Gillespie Bros. \& Co. are sole manufacturer's of the celebrated Juniata Plow Bolts, which ate made frou the very best quality of refined charcoal iron aut are ackuowledged to he equal to any plow holts in use. They also manufacture a superior style of Solid Bux Vises, making a specialfy of this partictulur liruch of their business. They also manufacture every deseriftion of jron and steel forgings for agricultural implements, and for plumbers, machinist and agrieultural purposes. Oil well supplies in great variety, including single and doulble-swivel snatch blocks, iron and stoel sucker rods, joints, hooks and swirels, bull-rope couplings, sledges, chisels, wedges, efc., ind are sole proprietors of a

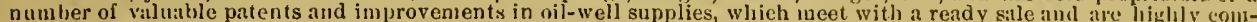
meuded by practical men. Au improved wrought-iron water tuyere is among the products of this estahisslineut. It is prounumed the cheapest and best ever offered to the trude and possesses many advantages over any otlier tuyere now in use. The Adams Patent Self-]nading Truek is another speeialty of the "Valley Forge" and is lighly commended and endorsed by many of the leading houses, railroid companies and manufacturers of the United States. In fact, it would be impossible in the limits of an article of this description to enumerate all the varieties of iron and steel work produred at this estalslishment. An Illustrated Catalogue and Price List. will lue furnished by the firm upon application, and all correspondence will he promptly and earefully attended to. Thu trade of this louse extends over every portion of the United States, and many of their products find a ready sale in foreign markets. Both members of the firm are "natives here and to the manor born," and although yet young men bive for years been identified with the industrial interests of their native eity and oceuly a prominent position among the representative business men and manufacturers of the Iron City. They are publir-spirited, enterprising and energetic gentlemen, wlio by industry, application to business, unswerving integrity and prohity have attained their present envialble reputation and built up a business that will compare favorably with that of any similar estakJishment in the United States.

\section{A. A. ANDERSON \& SON,-Bock \& Job Printers, 99 Fifth Av.}

A mong the Book and Job Printers of the city the firm of A. A. Anderson \& Son is not less widely or favorably know II than any louse in Pittslurglı engaged in the same industry. Tlie business was founded in 1826 hy Johus $B$. Butler, who came from Rilvenna, Olijo and with whom the senior, Mr. Anderson, was then an apprentjee. After the expirntion of his apprenticeship he hought out $\mathrm{Mr}$. Butler and carried on the business until 1836, when he formnel a partnership with Luke Loomis, under the firm uame of Anderson \& Lumis ; continuing for lwo vears, whell $11 \mathrm{r}$. Ionmis retired. Mr. A. continued until tlie year 1863 , when the present firm of A. A. A nderson \& Son was formerl. The facilities enjoyed by this concern for the prompt and elegant execution of all contricts either in the way of elatio-

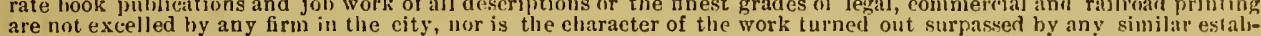

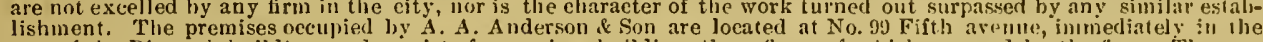
rear of the Dispateh huilding, and eninsist of a spacinus lumilding, three floors of which are 11 ecd by the firm. The no: chinerv is of the hest and finest makes, consisting in part of Cottrell \& Babcork, Potter and (inrinom vresres; 15 to 20 lumds heing employed in the various clepartments of the work. Mr. A. A. Anferson is a native of Ohio, having been horn in Portage cuinty in 1811, settling in this eity as a youth of sixteen, from which period his identifieation witl the industries of Pittshurgh date. A self-made man of the truest type, earnest, unassuning and linnoralule, Mr. Anderson hats achieved a high position in the respect of the ecmmunity with whose internsts he has heen so long cuncerned. As a reliable firm in every respeet, the linuse of A. A. Anderson \& Son can lie susely commended as a desirable one with which to do business, and form permanent, profitable and pleasint relations.

\section{W. B. LUPTON \& CO.-Slate Roofers, No. 354 Penn Av.}

This husiness was established in 1862 by Mr. W. B. Lupton. In $1868 \mathrm{Mr}$. P. Le Gouljon becane assoctated with Mr. Iupton, and since that lime the husiness has largely increased, and the firm has transacted it husiness of not less Ili:tn $\$ 75,000$ per annum. But, owing to the general depression in business of all kinds, especjally that of building, it will not :mount to that at the present time. They nccupy the prenises No. 354 Pem, ave., $20 \times 110$ fert in siza, as office anl witreroon, with an alditional watehouse, $25 \times 80 \mathrm{ft}$. They have also extensive works in IHarrisburg, Pa., for the mannfacture of pitch and saturated tar paper, and a sinilar estahlishment in the 35th ward in this eity. Their facilities are conplete in every partieular for all deseriptions of Iinofing, and are extensive manutactirers of all kjnds Pine and Coal Tar, ete. Thiny are also dealers in Slate of superior quality and various rolors. This firm is prepared at all times to make contracts tor every deseription of work pertaining to their line, howeverextensive and in any sec-

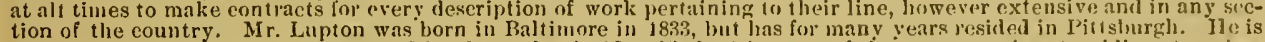
an active, energetic business man, and has been elessely jdentified with many of the most prominent public enterprises of Pittsburgh. Mr. P. Le Goulleu is a native of Pennsylvania, and was boru in 1837.

\section{H. S. GARROW,-Florist, S. W. Cor. Diamond Market.}

Among the establishments in the Smoky City engaged in Floral and Plant business, the establishment of tho very popular and enterprising young gentlemen H. S. Garrow, S. W. C. Diamund IIarket, is deserving of mention. Mr. Garrow is now proprietor of the floral business of the famous Knox Fruit Firm, his extensive greenhouse being locaterl on that farm, and it which anumally millions of the most choice and popmlit bedding and ornamental plants are growth, and are shipperl hy mail and express to every portion of the United States and British Dominions. MIs. (ialrow produces a large quantity of ehoice eut flowers, illso, in his greenhouses, and does a lawe cut flower liusiness, lwaquets, biskets. funer:il designs and rare ant heauliful desisns. As al floral artist, and for skill and taste in the urrangement of all kinds of flowers, Mr. Garrow is not excelleel by any artist in this city, and he las a large and growing tracle in this tranch of lis business. Mr. Garrow is a mative of Pi tshurgh, born in $18 . \pi$, and since his linyhood hias herell crnnected with the floral business, having worked in the estalilishnent of Rev. J. Kuox many years, and has fomainm
with that institution until now being proprietor of tbe business. He is a popular young geutleunan of character, and possessed of energy and ability. 


\section{REYSTONE BRIDGE COMPANY,-51st \& 52nd Sts.}

Prominently associated and identified with the iron and steel mannfacturing interests of Pittsburgh, the Kcystone Bridge Works deserve most creditable nuention as a type of the ingenuity, skill and enterprise of the Iron city. The original works of this Company were establishcd in 1863, under the firm nanie of Piper \& Schaffer, with the object of constructing iron bridges; two years later the Keystone Bridge Company was organized with a capital of $\$ 300,000$, absorbing the former firm and works. The business and facilities were at once largely augmented and increased. In 1872 the Company became incorporated under the laws of Pennsylvanja by special act, the charter authorizing an increase in the cupital stock to the amount of $\$ 15,0,000$, and conferring privileges for building, etc. This establislyment covers an area of over six acres and is divided into the following depariments: - nuachine sliops 80x3co fcct; smith and holt shops $80 \times 300$ feet, erecting shops $70 \times 400$ feet, foundry $60 \times 120$ feet, besides other shops. The shop plant enbraces machinery of the latest approved kind for the most superior and accurate work, driven by an engine of ageregate 400-horse power and employiug from 300 to 500 most skilled artisuns, and we bclieve it 10 nore than just to assert that no estahlishment of like character in the United States is hetter equijped with tools and appliances for the construction of light or heavy iron or steel bridges. Special atteution is paid by the Keystone Bridge Company through its management to the quality of iron and steel used in bridge work, both at the rolling mills and at the bridge shops, and tests are extensively made, to insure the perfect adaptability of the material to the use for which it is int inded.
This Company erected the double roading iron loridge 348 feet span over the Schuylkill river at Fairmount, Philadelplia, which in all respects warrants the success of the tests applied. We might also mention among the notable bridges of their construction the wrought iron railroad bridges crossing the Conneticut river, at Middletown, Conn. 1232 feet in length, $t$ wo spans 54 feet, four spans of 206 feet and onte pi vot or draw span of 300 fect; also the wrought iron double track railroad tridge orer the Mississippi river at Keokuk, Iowa, with a total length of 2012 feet, the dritw span having a length of 376 feet. To the construction of wrouglit iron turn-tables this company has given consider:ble attention, and has brought the appliances to the highest degree of perfection. These turn-tables are superior to those made of cast iron, and have given entire satisfaction wherever used. Of the many hridges of their construction, perhaps the master-piece of bridge engineering is manifest in the great steel bridge over the Mississippi at St. Lonis, constructed by this Company on plans of Capt. .J. B. Eads. The tubular system was met and its difficulties overcome in the most acconplished manner. It may be here stated that the aggregate length of railroad lirifges and viaducts constructed hy this Company during the past two year's and those now in hand is fifty-four thousand feet, located in
various portions of the United States, from ILain to Texas, and in the West Indies and South America. The officers of the Keystone Bridge Company at present are A. Gottlieb, President; T. M. Carnegie, Tieasurer; A. D. Cherry, Secretary ; and J. H. Linville, Consulting Engineer. The President, as Chief Engineer, is ably supported by a number of assistants, amonir those prominentl 5 lnown are Messrs. C. X. Strolicl. C. E., issistant of the president; J. W. Walker, C. E; S. B. Opedyke, C. E. ; W. Benner, M. E., in charge of drafting department; C. H. Springer, in charge of shops; and a lirge number of draftsmen and assistant engineers. To the energy and enterprise of the men who have them she has reared Instiug monuments of her iudustries throughout this conutry and forcign lands.

\section{ANDERSON \& CO.-Pittsburgh Steel Works; Rose, Second \& Try Sts.}

The annually increasing importance of the steel business of Pittsburgh and the marvelous advances that have been made during the past quarter of a century in perfecting this essential product, leads to a more than ordinary interest in all those enterprises which are identified with this branch of our manulacturing industries and resources. Especially is attention directed to those firms which are the acknowledged pioneers in the production of steel, aud to whon may be directly ascribed the extraordinary vitality that has characterized the husiness during the last decade. It is but fittiug to say that among such, the house of Anderson \& Co. niay properly be assigned a first place, not only from the fact of its being the prime mover in the inauguration of the steel nianufacture, but also on account of its extensive operations and the undeniable excellence of its productions. The plant was originated in 1845 by Isaac Jones, who confined his efforts to the construction of one furnace upon the old fashioned English plan and employed a verv limited force of workmen. Within a short period however, others became interested in the enterprise with liim, and under the style of Jones, Boyd \& Co., the plant was enlarged, the quality of the steel greatly improved, and no inconsiderable success attended the operations of the concern. In 1865 Rohert J. Anderson, Wm. Wood and J. W. Conk bought out J. B. \& Co., and obtained an interest in the house which they fillall monopolized, changing the title to Anderson \& Wood, which still remained the same after the withdrawal of Mr. Wood in 1871; the senior partner becoming sole proprietor, and so continuing from that time, except during a brief period, when he associated with himself Mr. Passirant, under the style of Anderson \& Passirant, which upon the retirement of the latter it hecame Anderson \& Co., as at present. The whole history of the enterprise is marked by constant and obvious improvenents and enlargements; resolution, ability and experience seem to h:tve guided its operations and conducted it through a serie: of signal successes. As an illustration of the uagnitude assum od by the Pittsburgh Steel Wwrks, it may be stated that the plant uow covers an area of about four acres, and is supplied with an equipment as perfect as the ingenuity of man can suggest or capital supply. The first concern in the United Slates to adopt and apply the Siemen's furnace, not less than six of these invaluable adjuncts to the manuiacture of steel are now kept in constant use, besides three sets of coke hole furnaces, six converting furnaces, thrce puddling furnaces, twentw-live heating furnaces, sixteen steam hammers, plate, bar, universal, sheet and guide mills of great size and capacity; rolls for honogeneous steel plates, for boilers, plow plates, circular saws, locomotive fire loxes, \&c., with other appliances and machinery of great efficacy,
rapid and labor saving to the highest degree. In addition to all these advantages the firm constructed within a limited period works for the manufacture of steel rods for wire, and were atwarded the contract for supplying the new Brooklyn suspension bridge with this material. From a total annual capacity at the beginning of but a few hundred tons, the product now reaches between six and eight thousand, and this year just closed 8,600 tons. From 300 to 400 worknen are employed in the various departments of the work, resulting in a business that exceeds $\$ 1,000,000$ per annum, and necessitating a disbursement for labor alone of over $\$ 300,000$ yearly. Over the whole of this establishment, directing. instructing and managing, from the suallest detail to largest and most critical operations the influence of Mr. Andersou is ever active, and from this personal and incessant supervision arises the superior uniform quality of the products and their high appreciation in every American market. Such being a brief outline of the history of this celebrated house, it is hardly necessarr to add that its influence upon the industrial thrift of the comnunity has been, and is, promotive of the general uell being to no small degree, and it is not going ton far to assert that the firm of Andersoll \& Co. in achieving material prosperity, has also established a high standard of commercial honor, in the adherence to which it has secured the respect and esteem of this community and those with whom it has effected relations.

JOSEPH MILHOLLAND,-Groceries and Produce, St. Clair St., 32d Ward.

This stand was originally started by $\mathrm{Mr}$. Fred. Kauff many years ago, and after many changes Mr. Miilholland started in 1878 with a moderate capital. With a good stock of goods, he has succeeded in working up a liberal trade, and $110 \mathrm{w}$ receives the patronage of the best class of citizens in that part of the city. He occupies a two-story building, $25 \times 50$ feet in size, divided in to $t$ wo departments, which he keens stocked with everything in the line adapted to house and home use. The choicest Teas, Cottees, Sugars, Molasses, Syrups, Canned Goods, Fruits, Vegetables, etc. Mr. Milholland, with his assistants in his store, will always show every attention to his patrons and gire closest prices. He was born in Dauphin County, this State, in 1818, and came to this city in 1823, where he has resided ever slnce. 


\section{KREPS \& BOWERS,-Hardware, Cutlery, etc., 224 Beaver Av., Allegheny.}

In a comprehensive review of the manufacturing and mechanical interests and industries of these two important cities, the establishment of Messrs. Kreps \& Bowers is entitled to creditable mention. This business house was orrginally started by Mr. Calhoun a number of years aso, and came into the hands of the present proprietors in 1878 The enterprise and excellent business capacity of this firm has already had a narked effect upon the trade. which is greatly improved. They are also lock and tool smiths, and embrace, in connection with their general hardware trade, a mechanical department, with the most complete appliances for ennducting this liranch, and also for building Iron Fences, Railings, Grates, Wire Work, etc. Contracts are taken to supply anything in this line upon the nost facorable terus, and work guaranteed first-class. The hardware department embraces Farmer's and Mechanie's Tools, Talule and Pocket Cutlery, House-keeper's Goods, etc. They occupv a two-story brick huilding, 20x45 feet in size, for the general store, with the mechanical department, $16 \times 30$ feet in size. They also conduct a prosperous business at 742 Carson strent, where a full and complete stock of Stoves, Tin Warc, and Hardware in select vitriety is to be found. Capt. Geo. W. Bowers has full charge of this branch of the business. The captain is a lirother to Joln $R$. Bnwers, and is undouhtediy the right man in the right plare. The individual members of the firm are Mr. F A. M. Kreps and Mr. John R. Bowers. The former was born in Franklin Co., this State, jn 1839, and came to this city is 1861. The latter is a native of this rity, where he was born in 1834. These gentleman liave bad an ample business experience, and the energy and enterprise which characterizes their business transactions, fully entitles them to a bigh rank among the lusiness men of the two cities.

\section{COCHRAN \& BRO.-Contractors \& Builders, $121 \& 123$ Pennsylvania Av., Alleg'y.}

The enterprising and well known firm of Cochran \& Bro. was founded in 1865 with a comparatively ninderate capital, which has since been considerably augmented. They ocrupy the two-story iron clad frame building $48 \times 138$ feet in size, at Nos. 121 of 128 Pennsylvania avenue, Allegheny eity, as a planing mill and finishing sliop, manufacturing every description of sash, doors, frames, blinds, shutters, inouldings and inside and outside finish, and are prepared to furnish estimates and mike contracts for the erection of public and private buildings of cvery description. Their present stock of seasoned lumber and material is valued at about $\$ 5,000$, and their facilities for prneuring at short notice any amount of dimension lumber and huilding materials required are most perfect. Their average annual business for the past twn years has been about $\$ 10,000$, while in former prosperous times it has reached as high as $\$ 200,000$ per vear. Their planing inill is supplied with latest and most approved machinery for the various purposes required, including one fifty-lyorse power engine and a sixty-horse power lwiler, saws, mnulding, planing and matching machines and all the appliances and inventions of the present day. From fifteen to $f$ wenty experienced workmen are regularly employed, and during the busy season a much larger fore is required. The individual members of the firm are Mr. John A. Cochran and Mr. Loyal Y. Cochran, both natives of Butler cousty in this State, hut residents of Allerhen $\mathrm{c}$ eity since 1859 . They are thorougbly practical mechanies, conversant with all the details and requirements of the business in which they are engaged, and perfectly reliable, conscientious and honomahle in all their transactions. They have established a lucrative and emineutly satisfactory business, which will compare favorably with that of any similar establishıuent in the two cities.

\section{MILLS \& BROTHER,-Printers, Stationers and Engravers, 55 Ninth St.}

Pursuing the a vocation of the art preservative of arts, no firm of Printers, Stationer's and Engravers in this city bave estalilished a better reputation for perfection in work than Milis \& Brnther, or are more justly entitled to notice in this publicition. Commencing business in 1870, under the above style, with a very limited capital, their work sonn became recognized as the most desirable in typography and letter press to be olitained in Pitslumrgh, and with the growth of this repute their business naturally increased, until at the present time it. a verages $\$ 3 \overline{5}, 000$ per annum, and gives einplovment to 25 workmen in its various departments. With an enlarged trade the resources and facilities of the house, for the rapid and perfect execution of work, were continuall y augmented, and now consist of news presses, and presses for all the varinus kinds of job work, folding machines, steam engine. and all the latest modern apparatus for the successful operation of a first-class general printing office. Engraving in wnod or metal is promptly executed. The trade of Messrs. Mills \& Brother is located mainly in the city, but those at a distance who reallr desire printing or engraving done that reflects the bighest progress of the art, should at once address themselves to this firm.

\section{JAMES R. REED \& CO.-Diamonds, Watches \& Jewelry, 93 Market St.}

The well known and popular gentlemen comprising the above naned firm, started at 36 Snithtield street, in 1847, and continued for eight years, where they manufartured mathematical instruments in eonnection with the jewelry business. From that location they moved to $9+$ Fifth avenue, where they remained for 21 years, cuming to their present building, No. 93 Market street, in July, 1876. Here they carry a stock of fine jewelry valued at alwut $\$ 60,000$, transacting a business of not less than $\$ 60,000$ per anmum. They occupy a large four-stors building $22 \times 75$ fect, employing eight assistants. Their trade has steadily increased, until at the present time it is one of the leading houses of the city. They carry a large, el gant and recherche collection of diamonds, ruhies, einerillis, npals, pe:tr's anil other mecinus stones, seal rings, cameos, plain gold hands, bracelets, brooches, charmis and all manner of adornments in the way of tine jewelry, together with a large line of fine watches of the most approved workmanship and celelirated manufacture. Silverware of cliaste ani elegant designs from spoons and forks to epergnes and ornaments of elahorate and artistic form and workmanship. This firm makes a specialty of repairing fine watches, doing it in the best and unost thornugh masuner. Tlue members of the presunt firm are James R. Reed and Genrge Mr. Reed, brotliers and natives of Washingtnn, Pat. Mr. Tames R. Reed, the senior partner, is now a memher of Alleghesly City Councils, and for twelve years he represented his ward with fidelity and eredit in the City Councils of Pit1sburgh.

\section{H. BEACH, - Practical Druggist, Corner St. Clair and Sycamore Sts.}

One of the neatest and most pnpular Drug Stores in the $32 \mathrm{~d}$ Ward is that of Mr. C. H. Beach, on the enrner of 8 t. Clair anl sycamore streets. The location is a desirable one and the stock is of the most perfeet to be found in that part of the eity, consisting of Pure Drugs and Medicines, all popular and really desirable Patent Medicines, Perfumery and Toilet Articles of most popular kinds. Pure Wiues and Liquors for melicinal uses, also Notinns, Choice Tobaccos and Cigars. The business transacted annually will average about $\$ \bar{j}, 000$. IInving said this much of the general busiOhio, June 16,1845 , and eanie to this city and hegan business in 1867 , is a thornughly acromplished druggist and cliemist, and has the highest standing anong the ablest phrsicians fur filling prescriptions. This, with lis crutrteous attention fo all and general high standing in the community, entitles him to the confidence and patronage of the public in that part of the city. 


\section{CONSOLIDATED GAS CO.-Office, No. 8 Sixth Av.}

The history of the above corporation, which extends only over a period of les: than a decade, is nevertheless so intimately connected with the ellargement of those facilities for the illumination of the city with unparalelled economy, as to demand more than passing recognition in this work. The Consolidalel Gias Co. originated in 1s71, and was incorporated under is special charter, with a capital of $\$ 300,000$. Up to this period the sole right. to supply the city with gas had been ve:ted in the l'atıshu. grh Gas Co., which hald assumed monopolizing preroratives, and exacted such rates as to create a deep seated aversion, which was widely exhilited toward it. The establishment, therefore, of the Consolidated was looked forward to with universal approval, and with the expectation that prevalent abuses would be at once checked and permanently aholished. In such an anticipation the public were not in error, and though every legal, technical, physicai and finantial influence under the control of the possessors of the tield was used, withont scruple, at every point to destroy the Consolidated, and hamper its operations, these means moved finally futile, and the expectations of the community were almost instantly realized hy at reduction iu the price of gas f:om $\$ 1.85$ per 1,000 leet to $\$ 1$, withuut doubt. the eheapest coal gas furnished in the world.

The officers of the Consolidated Gas Co. are H. M. Bennett, President, D'A reg E. Bnulton, Jr.. Secretary and Treasurer. and J. T. Duff, Chief Engineer. The works are located on 33id street, near the Allegheny River, and cover an area of about four acres, having a gas holder with a capacity of 200,000 cubic feet, the company having a capacity for turning out 500,000 feet per day, and being equipped with the liest modern appliances for the mantufacture of gas and yas coke. During the past year not less than a quirter of a million busbels of slack coal lave been consumed in carrying on the enterprise, the main portion of the city and most of the public buildings being reached ly a system of pipes about 20 miles in length. Nurtured in the midst of litigation, and fostered rather than crushed by opposition, the Consolidated Gas Co. has achieved a position in the popular approhation from which it can lut be easily aislodged.

The officers of the company are well known in this community as promnt, reliable and thorough business mell. They have been connected with the enterprise almost from its inception, and have labored sedulously to establish it upon the present satisfactory foothng, and are entitled to no small commendation for the admirable manner in which they have performed their allotted duties. The "Co." is one of the prominent institutions of the fron City, and conduces in at mirked degree to the general welfare and prosperity, increasing every year its sphere of usefulness, as well as augmenting its resourtes.

\section{AIBERT DIEHL,-Photographer, Mt. Washington.}

It requires a combination of native ingenuity with art, and these essential qualities are thoroughly demonstrated in this work of the Mt. Washington artist, Mr. Alhert Diehl, at the head of the Monongahela Incline plain. Mr. Diehl started here in business, under favorable circumstances, in 1874, and occupies one of the most picturesque and attractive locations to be found in the surrounding country, giving from lis gallery a fine view of the city, the rivers and the surrounding country, such as could not fail to attract the attention and elicit the admiration of all lovers of nature and art. He keeps tine specinens of his work for the inspection of visitors, and has no fear of losing from comparison with any work done in the city. His facilities and instruments enable biu to put up first-cla $s$ work in every respect, and he will always be pleased to have visitors eall at his rooms to inspect his work, or take oiservations of the heautiful seenery presented to the eye from his rooms. He occupies a twn-story building, in which his reception room and operating room is $15 \times 30$ feet in size, besides additional room for theni. ical operations. He is the inventor of a new and beautiful picture imitation of Porcelain Ferreot rpe, which gives a clear, soft and natural appearance. He is now working on a plan and process to get a perfect view of the city of Pittsburgh on the background of pictures, which will he an attainment worthy of ligh commendatiın. He is prepared to take pictures in all popular styles of the art, also residences and landscape views on sliort notice and upon reasonalile terms. Mr. Diehl was born in (iermany, in 1850, and came to this city when but a child, iu 185̃. He first. commenced business at the corner of Penn ave. and sixth street, in 1872, and subsequently removed to this pluce. He is a young man of high culture, as well as courteous and agreeable to all.

\section{THOMAS B. MORELAND, Agt.-Undertaking \& Livery, Penn Av., E. E.}

This is the oldest estahlishment of the kind in the East. End, Messrs. Moreland \& Mitchell having commenccl in 1858. Their capital, at that time, amounted to hut $\$ 600$, and when Mr. Mitchell retired in 1874 , the stock and hook accounts of the firm were valued at $\$ 70,100$. It is only necessary to say that his carriages, bugries and other velicles are new and of the latest st yles, while the undertaking department, which is earried on in all its branches, enbalming, \&c. is not excelled by any establishment in the city. Mr. Moreland furnishes coffins, shrouls, crave, gloves, etc., and also provides hearses and carriages, for all of which his terns are extremely moderate. For weddings and parties, and to acconmodate ladies shopping, he fu, nishes Berlin coaches of the very latest style with careful and experienced drivers, and his regular carriages are models of comfort and beauty. His building is $46 \times 140$ foet. and two stories high. He employs six to eight men in his stable at liberal salaries, while lis stock is yalurd at $\$ 5,000$ to $\$ 6,000$. Mr. Moreland is a native of Ireland. horn in 1829. He came to this city A pril 19, 1850, and in 1858 begin business on Penn avenue, old 5 th ward, where the public schonl now is, and then moved to Liberty street opposiie Uniun Depot in 1860, and beg.n business here in Eilst Liberty in 187), under the firm nime of Moreland \& Mitcliell, until 187t. Mr. Moreland is now doing a business of about $\$ 10,000$ per year, which is of course constantly increasing as tho city grows in that direction.

\section{IRANCHESTER COAL YARD,-Marshall \& Thompson, Agents,}

\section{Spruce \& Marliet Sts., Allegheny.}

The husiness now conducted br the firm of Marshall \& Thompson was founded ciglat or nine years ago hy Mr. William MIIlwatin and passerl into the han is of the present proprietars in 1878. The original capital, which was $\$ 2,500$ has been considerably increased and the firm now carries an average stock of about $\$ 1,000$, consisting of the best grades of anthracite and bituminous coal, nut coal and slack, for family use or manufacturing purposes. Their office and yard is at the e rner of Spruce and Market streets. Their anuual sales amount to uot less than $\$ 20,000$; nine hauds are regularly employed. Mr. J. C. Thompson was born in the uorth of Ireland, but. has resided in this country since bovhood. Mr. Alexander Marshall is a native of Scotland, but is somewhat a cosmonclite, as he has the greater portion of his life lieen identified or actively engaged in public work, construction of railroads. etc., in England, Ireland, Scotland, Wales, Belgium, Prussia, Russia and France, previous to bis coming to this country six years ago.

\section{JOHN KEMPER,-Boots and Shoes, 175 Center Av.}

This bitsiness was originally started by Mr. Keniper and his hrother in March, 1S78, and since April 1, 1879, his brother hiviur retired, the business has been carried on alone hy Mr. Kemper, who kceps a rood and reJiable stock of Boots and Shues for men, women, boys, misses or children and sells at very low figures. He also has a Custom Department, and will take your measure and guarantee yo": good stock, good work and neat fits. Repairing also ucatly and promptly done. Those desiring to purchase will tind Mr. Kemper a reliable and pleasant man to deal with aud sure to give you lowest prices, at No. 175 Center avenue. 


\section{METROPOLITAN NATIONAL BANK, -4509 Butler St.}

Among the Banking institutions of the Iron City, the Metropolitan National Bank, in the East End, is deserving of particular mention as among the more prosperous and solid institutions. The hank was tirst organized in 1873, is a State institution, by a number of the prominent citizens of this section, who in 1875 changed it to a National Bank. It is located in the midst of the finest business portion of Lawrenceville, and enjoys an extensive and prosperous business. D. R. McIntire, Lsq., of the firm of MeIntire \& Brand, is President, and Cant. C. A. Dravo, Casher, under whose careful management the Bank enjoys a high degree of popularity ant jublic tavor. The capital is $\$ 200,000$. The Buard of Directors is cumposed of D. R. McIntire, W. T. Dunn, Jas. Rolsison, Jos. Vogel, Henry Daul, D. W. Riggs, E. L. Clark, J. C. O' Donnell and Jno. A. Hoffman, all of whom are men of the highest character, and rank among the most prominent citizens of the two cities. Capt. C. A. Dravo, the courteous cashitz, lias heen connected with the Bank ever since its inception. He was its first President, in whicli capacity lie served for a number of years, and afterwards became Cashier, and tn his energy and abilities much of the suceess of the institution is due. He is a native of Alleghen y Co., born at. Elizalherh in 1824, and is a descendant of some of the earliest settlers of that section. From 1848 to 1872 he was closely identified with the river interests, and is well known and esteemed by all the river interests and men of to-day. Since his connection with the banking interests he lias shown himself possessed of tin:tncial ability of a high order, and has made unany uew friends in his present position.

\section{W M. A. HERRON \& SON,-Real Estate Agents, 83 Wood St.}

The firm of Wm. A. Herron \& Son is the most prominent one in the two cities engaged in the Real Estate husiness, representing, as they do, over $\$ 1,000,000$ worth of property in Allegheny County, consisting of lunsiness hlorks, stores, offices and private residences. Col. W. A. Herron, the senior member of the tirm, has been engaged in this bine of business since 1871. Mr. John W. Herron, his son, was admitted to the firm in 1876, and now has sole man:agement and control of the business. In addition to the rencing of propert $y$ in all parts of the county and State, the firm devotes special attention to the managewent of estates, enllecting rents, paying taxes for non-residents, placing insurance in reliable and responsilile companies at advantageous rates. and every description of notarial business. Col. Herron is a native of Pitssourgh and was horn in 1821. He has been prominently identified with the manufacturing interests and industrial prosperity of the city, and although by no means a politician, has alwars taken a decp and prominent interest in all matters pertaining to the public welfare in State, County or Nutional affairs. During the two terms extending from 1862 to 1868 , he held the responsible position of Clerk of Courts, and during the past year was notninated by His Excellency President Hayes and confirmed hy the Senate as United States Pension Agent, with lieadquarters in this city. He has in every position occupied by him proved to he a genial, courteous and affable gentleman of unblentished character and irreproachable reputation. As a member of the City Council, he proved in he a trne friend of the people, while manifesting a deep interest in the development and prosperity of his native city. MIr. John W. Herron is allso a native of Pitshirgh, born in 1851 . He has been al life-long resident of the city, previously identified with the iron and nanufapturing interests. He is an active, energetic and reliable young man. He now has charge of the entire business of the tim, his tather's time being devoted to lis pullic duties.

\section{DUFF, McKEAN \& CO.--Implements \& Seeds, $149 \& 151$ Liberty St.}

A mong a number of fine estahlishments engaged in the business of agricultural implements and seeds in this eity there is un tiner or more extensire house than Messrs. Duff, McKean \& Co. The house was founded by Young it M curphy in 1870. They sold out to Duff \& HICKean fn 1876, who enlurred the husiness and extended the tritcle. In 1879 they were compelled to seek more commodious quarters to accommolate their rapidly growing husiness, and removed to their present location, the style of the firm being changecl to Dutt. AIcKean \& Co., where they occupy one of the best arranged buildings in the city for their purposes. The huilding is a substantial brick, $30 \times 140$ feet in size, three stories high, with commodious cellars, and they occupy the entire building will their Implements, Farm Machinery, Hardware, Seeds, etc.. carrying in stock from $\$ 20,000$ to $\$ 50,000$, eml,racing the most popular and improved makes of all farm machinery, such is Plows, Reapers and Mowers, Threshing Machines-horse powers-and tools of every description to the smailest article are to be found at this establishment. In their Seed Department, in which particular attention is given, none but the freshest and best seeds are handled, and the firm hiss heen successful in establishing a reputation for superiority in this branch of husiness of which they have erery resson to be proud. The house is in every way a representative one in their line, and has risen through the indomitable energy and push of its proprietors. portions of the country and aurounts neary $\$ 100,079$ per an have sold 700 of the famous Champion Mowing Machines. these gentlemen, the fact that the prosent season (1879) they have sold 700 of the fanous Champion Monsing Michines.
$\mathrm{Mr}$. W. G. Dulf, the senior menher of the firm, is a native of Pitsburgh, and has been connected witli the seed and implement trade many years formerly in eonnection with other establishments, acquiring during the time a thorongh knowledge of the husiness and an extended acquaintance throughout this portion of the Statr. His long experience has served in no small degree to build up the husiness to jts present large dimensions. J. S. McKean was born in the town of Dumfreeshire Scotland, in 1850 , hut came to this country with his purents at the carly atge of $t w 0$ years. and was raised near the city. Prior to enterinu this business he had for a mumber of vears been engaged in the gardening and fruit-growing business, and during that time acquired a practical knowledge of the needs of the agricultural community. He is a young gentlem'n of much energy, possessed of many generous qualities that have in no suall degree served in promote his own and the popularity of the house with which he is conneeted. Mr. Gus. B. Young, one of the original founders of the house, is the general superintendent of the business. He is a popular gentleman so well known to the numerous patrons of the house that any mention of this house would be incomplete whlome being young hin. The firm of Duff, Mekean \& Co. in every lespect is a very worthy one, the individual members being young
mn of irreproachable character, enterprising and reliable, and the house presents advantages not easily duplicated by man of irreproachahle character, enterprising and reliable, and the hou
any contemporaneons establishment and is wost heartily commended.

ISABELLA FURNACE CO.-Manf'rs. of Pig Iron, Etna Station, W. P. R. R.

The above establishment is one of the largest and most complete west of the Alleghen $y$ mountains, and was started in 1871 on a very large eapital which has favorably jncreased, and the business now amounts to the large sum of $\$ 1,000,000$ per annum, with \& stock on hand of $\$ 250,000$. The huildings are eight in number, the main building being 240 feet long by 80 in width, and the entire establishment eovering 37 acres of ground. They have a capacity of 60,000 tons of pig metal per annum. The power necessary to run the works consists of 12 boilers 65 feet long and 42 inches in diameter, with five large engines of 200 -horse power, the engine house being $40 \times 100$ feet. There are two large furnace stacks 75 feet high and 20 feet bosh. The Conpany manulacture their own coke, having 200 coke ovens near Blairsville on the W. P. R. R loe locality. They have a force of $150 \mathrm{men}$ constantly employed at the furnace, and their average pay-roll foots up to about $\$ 1,600$ per week. The works are superior to any similar estatlishment in the country, and are condncted and managed by men of large experience in business. II aving been permitter free access to the entire works we can sffely assert the same to be the most complete estallishment of the kind we have ever risited. We are under many obligations to the firm for courtesies extended and information furnished. 


\section{A. M. BYERS \& CO.-Wrought Iron and Lap-Welded Galvanized Iron Pipe.}

Office, 98 Water Street and 132 First Avenue.

In making a detailed review of the iron trade, prominent among these will be noticed the house of $A$ M. By ers \& Co., which from the special character of its products and the magnitude of its operations, shonld not escape mention in uny work relating to the development, resourees or staple industries of this city Originally established in 1864, by A. MI. Byers, Wm. (iratf and Jacob lieese, under the style of Grafl, byers \& Co, the business was prosecuted with marked suecess until 1870, when the title changed to Byers, MeCullough \& Co., who still eontinued a career of usefulness and prosperity till is 76 , when the firm assumed its present style and status, being eouposed of A. M. and E. M. Byer's The plant of the concern is located on the South side and covers au area of about five acres, being divided into several departments, made necessary by the diversity of the work and the various products nuallufactured, as well as to secure that high deyree of perfection in every process for which the house has attuned so wide a repute. Of these, the rolling mill, us prepariug the material, naturally comes first, and is worthy of more than the brief attention to which our space confines us. Besides being equipjed with much modern mathivery and many lahor-saving app.iances, the mill is furnished with 26 puddling furnaces, 6 heating furnaces, and 3 trains of rolls, the annual capacity being from 15 to 20 thous:and tolls. Two mills for the manufacture of Butt and Lap-welded Wrought Iron Tubes and I'jpe, form an inportant feature of the plant. Galvanizing works are also in operation, besides a large machine shop and gas works, which supply the entire establishment with gas for illuminating purposes. In these and other sulsdivisions of the work are employed about 500 operatives, more than three-fourtis of whom are skilled artisans, necessitating a monthly dishursement for labor alone of not less than $\$ 35,000$. The requisite nuotive power for moving the unultifarious machinery is supplied by 12 steum engines and $a$ nest of 13 boilers in 4 batteries, this mechanisui and its arrangement being considered unsurpassed for effective completeness anywhere. live steam pumps are also required to furnish water for boilers and elsewhere in the works, and it is sale to asseat that in the perfection and adilptability of all apparatus employed, this estahlishment is almost without a compeer and is certainly excelled by none in the sime branch of manulactures. The products for which the tirm of $\mathrm{A}$. M. Byers de Co. is particularly noted, and to which special attention is directed, are Skelp, or Pipe Iron, Sheet, Bar and shafting Iron, Lapwelded Wrought Iron Pipe, Block or Galvanized, for Gas, steam and Water, also Boilex'Tubes of all dimensions to order, and Core Barrels, Tweer-pipe Nipples, and Patent $\$$ wedged Sockets, etc. For these goods the trade of the house is very extensive, requiring the assistance of special agents at prominent points. Mr. A. J. Mclonald is the resident factor of the cuncern at. Chicagro No. 2:6 Lake strect, N1r. John Ntancely occupying a like position in I'hiladelphial, at No. 309 Arch street, for the convenience of Eastern buyers. As sole manufacturers of Gatvanized Iron lipe in this city, IIessrs. Byers \& Co. transact a lurge trade in this article, which possesses advantages of marked superiorit y over rubber coated or enameled tubing, and is yearly meeting with more favor, occasioning a rapidly increasing demand. The senior partner of the house is President of the Iron City Nat. Bank and connected with other financial institutions and enterprises of a pullic character, and the firm ranks second to none of its cotemporaries in enterprise, public spirit, and a business policy that entitles it to the ligh esteem of that community which has derived such pronounced advantages froul its operation.

\section{G. HUSSEY \& CO.-Pittsburgh Copper \& Brass Works, Office, Fifth Av.}

These works are located at Soho, a suburb of Pittshurgh on the banks of the Monongahela river. As the first establishment in the country devoted exclusively to the reduction of American ore, its history is worthy of special at tention. In $1843 \mathrm{Dr}$. Hussey becane interested in the copper territory of the upper peninsula of M Michigan, and it first acquiring his title by lease and locatiug his claims, he purchased the property which he had located as soon th the Goverument placed it in the uurket. In 1S45, with certain Eastern capitalists whose interests were identical, he formed a joint stock company entitled "The Pittsburgh and Boston Mining Company," of which be subsequently becime president. "The same year they opened the "Cliff' Mine" on Eagle river, which established the value of tlie minin clistrict of that section and produced about eight million dolkars worth of copper before exhaustion. Rendering this ore into metal was at first as slow operation. There were but four smelting furnaces in the conntry at that date, and noue were able to ineet the requirements of reducing the ponderous blocks of almost pure copper produced in this region. Dr. Hussey conceived and perfected an ideal wherely these heavy blocks, sometimes weighing four or five tons, were depusited in the oven of the reverberatory by means of a movaloje top, which he proceeded to practically test by erecting the Pittsburgh furnace in 1850 . The suecess wis so complete that the improvement was adopted by every furnace using Lake Superior ore. The mines from whieh the raw malerial was oitained have of litte heen exhausted, the metal at present being obtained from smelting works on the lakes and is received in flat thlocks weighing about one hundred pounds each. These, after being heated and reduced to the required thickness by pissing throut li rolls, have the oxide which furms upon the surface from con taet with the air removed by a process peeuliar to these works. This process, though simple, requires great experience and skill in its froper manipulation. From one to three hundred hands are here constantly employed, being mostly Welsh from the Swansea district. The liass foundry contains ten furnaces. The copper and zine placed together ill crucibles in such proportion as will prodilee the liest quality of brass, and when melied the metal is moulded in flat cakes, which after being dnnealed in an oven are rollecl into whatever thickness of sheet is desired, the oxide being removed and the product left pure and ready for warket.

\section{WIM. W. NISBET,-Druggist, Washington Av., 31st Ward.}

Mr. W. W. Nisbet is locatcd on Washington avenue, in the 31st ward, hetter known perbaps os Allentown, where he is engaged in the retail drug and prescription business. He owns and oecupies a handsome two-story frame l,uilding $49 \times 50$ feet in size, and earries a large and varied stock of drugs, chemicals, toilet and fancy articles. periunery, p:unts, vils, varnishes, etc., making a neat display and where he is doing a prosperous and growing business. Yariceulic at tention is given to his prescruption business, Mr. N. being a thoroughly skilled and conscientious pharmaceutist. 1 o betul business in 1872 near his present location, but the following year lie purchased his prcsent fine location and remored to it. Mr. N. was born in Freeport, Armstrong county, and hits been a resident of this county twelre years, he came to this eity in 1872 and located in Allentown, where he has continunusly remained and met with flatiering success. He is a popular, enterprising and public-spirited gentleman. In 1874 lie was elected a member of the contmon branch of city councils, in which borly he served two successive terms: in 1875 he wis elected to the select branch of councils, and is now serving his serond term in that body. He was elected in 1879 a member of the cential buard of education, a lact that shows his efficient sul l faithful performance of duty.

\section{GEORGE SANDS,-Plumber, Gas and Steam Fitter, 85 Franklin St.}

With a thoronghly practimal knowledge of this business, Mr. Sands started in 1867 , and by his excellent and reliable work his succeded in estsblishinis a permanent and remunerative patronage throughout the city and surrounding cou :try. Mr. Sands is careful to employ none lut competent assistants and can therefore guarantee all work to give satisfaction, either in Plumbing. Steam or Gas Fitting, or any work pertaining thereto in public laalls, churches or privite residences or general repairing. Orders will receive prompt attention. Those disiring work of this character will do well to consult Mr. Sands at No 85 Frauklin street. 


\section{SOLAR IRON WORKS,-Wm. Clark \& Co., 35th \& Railroad Sts.}

When we glance at the almost innumerable advantages which Pittsburgh possesses, her geographical position and river facilities, commanding an inland navigation of many thousand miles, her artificial facifities for transportationbeing the railroad centre of numerous lines diverging in ill elirections, her immense iron cipjital conisting not only of money but of mills, furnaces, ore lanks, iron mountains, coal mines, inexpensive fuel from her nunerous ras nills, and what is of vastly greater importance, her hosts of skilled, enterprising and thoroughly practical mechanies and irout workers, familiar with the eonstitution and eapabilities of iron from the crude ore to its perfected forms. To ler skilled iron workers and able artificers is Pittsburgh litrfely iodelited for the proud and prominent position she holds to-day arnong the cities of the land, and in a work designed to give a brief history of this great centre ancl a detailed sketch of her numerous, vist and wonderful establishments. The solar lron Works and the accomplishecl head of t!le establishment, $\mathrm{Mr}$. Wm. Clark, are deserving of more extended mention than is accorded to many cotemporan eous establishments. Mr. Wm. Clark is the only living male member of the well kuown firm of Willian Clark \& Co. proprietors of the Solar Iron Works, at the corner of 35 th \& Railroad streets. These extensive works as complete of the kind as in the United States, were establislied by William Clark, liss brother Ed ward Clark, and his brother-in-law Charles Fownes. The premises occupied by this firm cover an area of nearly three acres at the location ahove named, extending from the railroad to the Alleglieny river, with two buildings, each $130 \times 150$ feet in size, fil.ed up with the most perfect and complete machinery, appurtenances and appliances to be found in any establishment in this count $y$, with seven stean engines of from 10 to 300 -horse power each, seven large boilers, single puddling furnaces, five heating furmaces, five trains of rolls, and every description of heavy and Jight machivery of the inost approved patterns and designs required in the various departments of the business. Two hundred and fity workmen, (many of them skilled hands), are regularly employed and the averige weekly pay-roll aggregates $\$ 3,500$. The special productions of this establishment is hoop, band and scroll iron in all the various forms and styles, and the celebrated Delta Cotion Tie, the invention of Mr. Wm. Clark, an article which is pronounced by planters and packers emplatically the hest in uxe. Their trade extends all over the Uuited States, North, South, East and West, and amounts to not less than S450,nio per annum. The eapacity of the works is about 10,000 tons of finished work. Certificates of merit have heen awarderl the Solur lron Works at virious times and at the International Centennial Exhibition at Phila. in 1876 . $\Lambda$ hronze medal and certiticate of award was given for hoop iron and the $D$ ulta Cotton Tie. Twosilver medals have been awarded by the Ciocinnati Exposition Society. and testimonials innumerable as to the superiority of their products have heen received by the firm. Mr. Chas, Fownes and Mr. Edward Ciark lare both died since the organization of the firm, hut the 1 anue and style remains the same, and their estates are still represented in the firm. Mlr. William Clark is a native of Ensland, but has resided in this country for a number of years. Although yet a young man, he is younger in appearanee than in fact, and has been all his life identified with the iron business, liaving commenced working in an iron nill at an early age, and ever since that time he has been closely identified with the iron industry, and has practically mastered it in all its scientific and mechanical deptrtments, acquiring a thorough practical knowledge and insight of every department of the business as he proceeded to the prominent position he now holds as one of the leading representative manufacturers of the Iron city. He has heen a lesident of Pittshurgh since 1841, and the city of his adoption mas well point with justifiable pride to this noted establishment and its enterprising heal as proof of what may he accomplished by a life of industry, probity and devotion to his chosen occupation. The Sular Iron Works in its particular branch presents aclvautages not to be excelled.

\section{PITTSBURGH CATHOLIC COLIEGE,-No. 98 Wylie Av.}

Among the various educational institutions of Pittsburgh the Catholic College, located at No. 98 Wylie avenue, is entitled to a prominent position in a work of this description. This college was estahlished on its present soliel hasis fious names had previously been attempted with indilferent success. The prest college has been established under the high patronage of the Rt. Rev. Bishop of this diocese, and is conducted and directed by the fathers of the Holy Ghost and the Immaculate Heart of Mary, an order of educated men who have devoted their entire lives to the cause of educating and christianizing the human race. The order is now conducting a large number of colleges and academies throughout Europe and Africa. The object of the Pitshurgh Catholic College is to offer to Catibolic parents an apportunity of sending their children to a schosl where the religious and moral training of the pupils is combined with a thorough instruction in every branch of liberal education. The children of p:rents of other denominations are admitted on equal footing with the children of Catlulic parents, and while they receive the most liberal education, religious instruction is being left entirely at their options. A strict atul effective, yet mild system of discipline is maintained, and the spirit of cmulation is exeited anong the pupils by periodical examinations and the distribution of honorary certificates to the most deserving. Monthly reports on the conduct, applieation and progress of students are sulmittcl to the parents. The cutrse of classical studies canleraces the English, Latin, Greek, German aud French languages, history and geography, mathematies, physics and chenistry. astronomy and the natural scienees. In the commercial course particular attention is devoted to English grammar and composition, bookkeeping, correspondence in English, German and French, conmercial law, practieal arithmetic, geography and listory, political econom y and penmanship. The preparatory course cmiraces grammar, spclling, reading, arithmetic, gengraphy and penmanship. Instruction is given in drawing and vocal and instrumental music loy coupetent and talented professors. The system and mode of instruction is far more thornugh and practical than that atforded at any other college, and students in either of the languages are instructed hy a native of that particular country, and ordinary conversation is conducted in that language, thus ensuring correct pronunciation and a thorough knowledge of the idions and peculiarities of that tonque. The number of professors at present engager in this college is ten, ach one being a thorough master of the special branch to which he devotes his attention. The number of pupils enrolled at the last term was 90 , but a much larger at tendance is confidently expected during the coming year. The closing exercises of the first term, which were held at the Fifth A venue Lyceum on the afternoon of Tuesday, June $30 \mathrm{~h}$, gave ample proof to the public of the thorougl and excellent method of instruction pursued at this college. The course of studies will he resumed on Monday, Sipt. 1. During the compararively brief period in which this school has been in existence, the directors have every reason to feel highly gratilied and encouraged hy what has already been accomplished, and at the prospects for the future. The order is even now conteinulating the erection of a spuious and elegant building expressly for college purposes, with molern improvements and ample facilities for the aceomn lation of a large number of students. Full information and particulars may be obtained upon application to Rev. P. W. Powers, President, or Rev. J. Graff, Viee President of the college, at No. 98 W ylie avenue.

\section{KUHN BROS.-Wholesale and Retail Grocers, Penn and Frankstown Avs.}

Conspicuous among the leading Wholesale and Retail Groeeries of the Irou City is the well-known firm of Kuhn Brothers, whose excellent management and high business qualilientions entitle them to honorable mention auron the leading business houses of the city. The business of the house was stirted in 1874. They now 'arry a stork of Staple and Fancy Groceries and Provisions amounting to about $\$ 4,000$, while their annual business transactions will foet up to about $\$ 60,000$. Their business is located on Penn and Frankstown avenues, where they occupy at room $24 \times 84$ feet in gize. James C. and Harry $\mathrm{P}$ Kuhn are widely and favorably known as gellial as well as prompt and aceurate lusiness honse is destined to become one of the leading business establishments while under their control. 


\section{PITTSBURGH ENCAUSTIC TILE CO. (Limited).}

Office and Works, corner Bluff and Gist streets, Fourteenth IVard.

Among the manufaeturing interests and husiness enterprises of this eity, we cannot f:il to make lileral mention of the Pittslourgh Encoustie Tjle Company (Limited), Oflice and Works situated corner of Bluff and Gist streets, Fourternth Ward. This Company is not only condueted in the most nl,le and enterprising matuer, but presents as well an article most thoroughly and praetically adapted to the uses for which it is male - vi\%., the manufacture of Floor Tile of the most desirable charicter. The business was origibally started ly a limited sinek company in 1876 as the pioneer company of the United States, with a capital of $\$ 4,000$, which was niterwards increased to $\$ 10,000$ ), and subequently again increased as other chatges have taken place under reorganization. This company is now prepalyed wills ample capital and every facility for prosecuting at thriving husiness, and have on halul from 15,000 to 20 , 040 square feet of most superior tile, with a capacity of manuficturing 1,000 square feet per week. While ther are met. with a large and increasing business, they feel justified in the assertion that they can fill promptly all orders upon the most liberal terms, as their ground room yet unoccupied affords then the alsility of still grently inereasing their facilitics. This is an enterprise embracing artistic and ornamental work, deserving the fostering eare and encouragement of the cily and surrounding States, as its sales extend throughout the entire county. This peculiar tile was, previous to the organization of these works, entirely obtained from foreign countries, while the article here mate is pronouncer by eritics far superior to that of foreign manufacture: and consequently, this establishment is insured a lurge and increasing business which will compare favorably with the most prominent manufacturing estahlishments of this (ity, both in its utility and wanagement. The slip house covers an area of $60 \times 80$ feet; the furnale luilding is 35 feet square; besides this they have a third building for other purposes $30 \times 90$ feet in size, and a large aunount of vacant ground room. They employ one 16 -horse power engine and hoiler of larger capacity, and a large force of competent workmen. They have four color mills of various sizes, one dust mill, one cracker or breaker, one plunger, eicch perfectly adapted to its speeial work. They have two largetanks, $7 \times 14$ feet in size, dumping lied $8 \times 20$ feet, one dryjng kiln $5 \times 30$ feet, one eleven feet square, and three presses of 10 tons, 145 tons, and 75 tous yressure. In facr, 1 hese works ombraee the most improved and complete alpliances for the manufacture of Encaustic. Tile in all the different colors, which must conpletely drive the foreiga article from the market. The individual members of the firm are, Joseph Rowell, business manager, a native of fngland; Mr. Jolnu Parkin, also a native of England; both have been in Alexander Flowers, who is a native of this State-a thorougl and practical workman. Ton high praise cannot he awarded this Coupany for the suceess of an industry which unst crown their lahors with suecess and redond th the credit of onr large manufacturing city. The original stockhulders of the Company were, Joseph Rowell, John Parkin, Frank Wright, Mr. Conard Wm. Cartlidge and Samuel Keys. The latter is it scientitie operator and faniliar with all the varions departments of the business. After the works were partly built, Mr. Cartlidge sold his interest out to Mr. R. Conard, which createrl some dissat isfaction and resulted in erippling the progress of the operntions for abont two years, subsequently resulting in the formation of the present Company, which holds a diploma from the United States Government frr superior quality of work. Those interested will do well to call and see samples at these works, or in the Boatmen's Insurance Company's rooms, at the U. S. Postofice and other public enlitices, and at the U. S. Capitol Building, Wasbington City, D. C., where two floors are laid with the product of these works.

\section{IRON CITY COLEIGE,-J. C. Smith, A. M., Principal; Cor. Penn Av. \& 6th St.}

No man, young or old, is fitted to go out into the world without a knowledge of book-keeping and the principles of commercial law. The "Iron City College." licated at the corner of Penn Avenue and Sixth street, was ineorporated in 1S.5 with the object in view of firting young men with a thormeg practical education for actire husiness life. Its patrons are, aud have been among the most intelligent and successful business men of Pittshurgh and Allegheny and of the entire country. A large proporrion of the successful merehants of the iwo citirs received their husiness education here, and many of the leading and most influential lankers and lousiness intn are graduates of this popular institution. The whole number of students matriculated since the organization of the Iron City College is let ween 19.1000 and 20,1000. representing every State in the Union. The crurse of study, which is eminentily thorough and practical, embraces l'enniabship, Arithmetic, Rapid business catculations, Commereial rurrespondence, Book-keeping in all its forms and applications by the most approved methods. l'actical banking, Lectures on Commercial law, Iolitical Economy, Business Customs, Usages, \&c. The method of instruction is chiefly individual, there leing no class arrangements and no one is dependent on another for his progress. The time for completing the course is not fixed and each student is allowed all necessary time within reasonable limits for empleting his studies. The intiturion, which has heen in continuous and successful operation for a quarter of a century, offers every possible ad vantage for the acquisition of a comny time. Prof. J. C. Smith, the talented furs sucessively prineipal of the Union Schoo's in Rome, N. Y., Professor of Enst sh J.jterature in Carliste seminary and Professor of Dlathematics in Fairfield Seminary, two large and fourisling institutions of learning in New York siate.

\section{SHOE \& IEATHER BANK, -78 Fourth Av.}

The Shoe and Leather Bank of Pittsburgh was incorporated under the laws of the State of Pennsvl rania in March, 1872, with a capital of $\$ 200,000$. The first offieers of the Bank were Geo. H. Anderson. now postmasier of Pittsburgh, as president, and John D. Fraser, cashier. Since its organization the affairs of the hank liave heen conducted with zuarked ability, and it to-day possesses the confidence of the mercantile community to a remarkahle degrce, and its transaetions are eminently satisfactory to all parties interested. The present officers of the batrk are as follows:Daniel R. Davidson, President; M. W. Pankin, Vice President; John D. Fraser, Cashier; Daniel R. Daridson. M. W. Rankin, Joseph H. Borland, Thos. J. Craig. Calvin King, Jacoh S. Reamer. John Thoma, Conrad Dietrieh, (ien, J. Luckey, Direetors; W. F. Church, Teller, and H. W. Birkel, Bonkkeeper. The Eastern corresprndents of the Shoe and Leather Bank are, in New York the Fourth National Bank, and in Philadelphia the Second National Bank.

\section{ANDREW THOMPSON,-Flint and Green Glass Moulds,}

90 Eighth St. and 724 Washington St., South Side.

The first establishment in Pittsburgh deroted to the manufacture of flint and green glass moulds, presses and light machinery and mechanical appliances for the production of glasswitre, was founded in 15.17 by the firm of A. J. Miller it $\mathrm{C}_{n_{n}}$, who were succeeded two ycars liter by $\mathrm{Mr}$. A ndrew Thompson, who for the past thirti years has carried on the business and built up a tranle whicli will compare farorably with that of any similar estahlishment in the eountry. He $10 \mathrm{w}$ oeetupies the $t$ wo-story building $24 \times 40$ with hlacksinith shop adjoining, at No. 90 Eighth street, South Side, fitted up with all the requisite machinery and applianees for conducting the business in all its varien departments ; the machinery is propelled by one twelve-horse power engine. Mr. Thompson was born in Ireland. November 1S18, liut cann to this city with his parents before he was one year of age. For over sixty years he hats heen a resident of the Smoky city and is a skilled workman. Ho is, duing an excellent business and is a worthy and reliable gentleman. 


\section{PARAGON OIL \& GREASE WORKS.-W. J. Smith \& Co.,}

Railroad near 28th St. burgh than is geuerally supposed. The product of our enterprise in this line to to a much larger extent in I'ittsfur Works" "1s they are now known, were originally founded in $1867 \mathrm{by}$ Mr. Wm where he occupied extensive works and built up a large and thourishing trade. In the Spring of 1879 the works removed to the present location, corner of Railroad and $28 \mathrm{th}$ streets, assuming the style of the Faragun Oil ind (irease Works. In $1878 \mathrm{Mr}$. Wm. Smith transferred a one-half interest in the business to his son, Mr. W. J. Smith, and in the following $y$ ear disposed of the remaining half interest to Mr. H. L. Harbison, the firm nande and style heronuing WV. J. Simith \& $\mathrm{Co}$. The works eover an area of $47 \times 120$ feet, and are supplied with kettles, boilers, furnaces and all the appurtenances and applianees requisite for earrying on their extensive business. Among the products of this house we may mention all grades of rolling mill, ear and wagon axle grease and lubrieating and machinery vils yellow culd roll and black cold roll hot neek grease and white axle grease. All these articles hare been thoroughly itested aud lighly reeomuended for the various purposes for which they are intended by leading manufacturers throughout the United states. Mr. W. J. Smith is a native of Pitslurgh, lorn in 1856 ; prior to engaging in the present line of business he was connected with the newspuper press of this eity and was well ind faverably known in journalistic circles. Mr. H. L. Harbison was horn in Blair eounty, Pa., in 185̃2, coming 10 Pittshurgh in 1879 to embark in this line of business, havin, previously been engaged ehiefly in agricultural pursuits. Both mein bers of the firm are aetive, stirring and energetic youns men with more than ordinary business qualifications. They are doing a safe, lucrative aud sulisfactory business, with most excellent and faltering prospects for the future.

\section{W-M. PEOPLES,-Stair Builder, 142, $144 \& 146$ Webster St., Allegheny.}

This business was established by the present proprietor in 1856 on a rery moderate capital. The building oceupied Is a three-stury frame 80 feet front on Webster street extending back 100 feet, and was buill with a Fiew tı the requirements of the business for which it is used. It is furnished within with all the latest and most improved machinery for turning out work in this line. Mr. Peoples is a practieal mechanic and gives his persontal attention to the estalllislıment and its operations. The work done bere is prineipally stair building in all its luranelies, and a very large percentage of the tine stair cases, espeeially those made iu costly woed, erected in Allegheny, Pittsburgh and in the ritics and towns for miles around, have been furnished from this shop; ; probably no enncern in the country lias better faejlities tor turuing out first-class work in this line. Mr. Peoples is an accomplish d carpenter and joiner, at whieh avoca.ion he has given soveral years' service; the stock carried amounts to about $\$ 5,000$ and at present il force of ten hands is employed. Mr Peoples is a native of Allegheny county, in this State, was born in 1831, and is well and favorilly known personally as a gentlemaa of high and honorable character and excellent business qualifications. This estalilishment and its able management will bear comparison with any similar institution in the country and is worthy of most farurable consideration from the thousands of readers of this work.

\section{THE URSUIINE ACADEMY,-Cliff Street.}

The young ladies" academy, under the care of "Les Dames Ursulines" or the Ursuline ladies, is at present locater on Cliff street, Pittsburyli, and is in a most prosperons and flourishing condition. The situation is well ithayterl ly its elevation and salubrious air as well as by its comparative retirement for the purposes of a schoil of this deseription, liut the suecess which has thus far attended the efforts of the ladies in charge has rendererl it necessary to ser"ure even more commoulious quarters, and the community has recently purchased at Oakland an elegant and attractive site upon whieh to erect an acadcmy of sufficient dimensions. The orter of "Les Dames Ursulines" was founded at Brescia, in Itals, in 1532, by St. Augela, and was reeognized by thegovernment in 1535 . The netw oriler s pread rapilly throughout Europe and towards the yeur 1639 was introduced into the Western Continent. The inmmunity of Pittsburgh was founded in 1570 by a small number of Freuch and Engiish ladies, who leing authorizerl by the Cardinal Arch-Bishop of Rouen, came over from France at the time of the Franco-Prussian war. Eight latlies of this devoted baml, driven from their convent by the threatening storm of war, arrired in Pittsturgh in 18.0 ind were graciously receilcd hy the Rt. Rev. Bishop Dominee, who most kindly afforded them his protection; after reminining nearly a year in a small establishment on Eighth street they renored to their present loeation. The new buildings to lie crected on the Oakland site will be specially adapted to the requirements of the order, and will accommuditc a mum $h$ Iarrer number of pupits than the prese:at establishment. The lady superioress is Madame Marie Alphonse, al member of one of the ancient families of France. The plan adopted by the Ursuliue ladies for the instruction of their pupils $h$ is for its special object the derelopment of the mind and heart. In most cases the ladies dis'ard the ordinary text books except for reading, reference, \&c. Pupils may enter the acallewy at any age letwcen fire and lwenty, hut it must be understood that a child cannot completo her edueation under a certain number of years, which it is uf cours i:ulpossible to determine until the teacher has aequired at thoroughowedne of the capacity and int lise sindent in pupil. The course of instruction comprises six classes, each carefully arranged to meet the wants of the student in
regular progressive steps from the rudiments to the highest branches of English literature and classical lore. When regular progressive steps from the rudiments to the highest branches of English literature and classieal hore. When
a pupil has aceomplislied the six clisses comprising the regular course, she is permitted to pass a pultip eximination in the branches tausht and receivo a gold medal and d ploma as a graduite of the second degree. In order, hinwerer, to receive the highest honors of the institution and a diploma of the first degree it is neessary for the pupil to enter the superior course, which comprises the following extra branches : Logic, Literary Essays, Literature-English, Americall, Frinelı and Geruman; Versification, Philology, Universal History, Chronology, Ethnology, Physinlugicul and (i mographical Botany, Geology, Mineralogy, Metallurgy, Geometry, Numismatology. Besides the course of Euglisli insiruction partieular pains are tiken hy the lidies to render their pupils proticient in the French language, for this purpose they art required to eonverse in French during the recitation hours and at table, except on Saturlay and sundas. Two examinations take place overy year, one at the end of each session, they are partly oral anil partly writtell, including all the principal branehes of study pursued during the course of the scholastic year. Besides monthly examinatims, the pupils are requirod every week to write out in their own style a narration of the facts of any particular history they may have been stulving. In order to exeite emulation among the pupils, medals are awarled every month to those who have attained the highest number of marks in each branch; musical reviews take place every three montls. Pujils not desiruus of fulfilling the complete course of study can nevertheless obtain a pold medal before leaving the acadcuy provited thoy give full satisfaction both for conduet and application. Great attention is paid to the exterior deportment and polite manners of the young ladies, in order to tit them for entering any snciety in their own country or in Europe. They reecive lessons frcquently in this important branch of cducution and are taught the smallest detail with regard to etiquet to and gnod breeding. Great care is also given to the health of the pupils and the ladies untke a point of acting in every way towards them with materna! tenderness. The system of gond marks and other rewards forms the ground work of the education given by the Ursuline ladies, and their milal treatment of the young seems to be the s cret of their suecess. Gentleness combined with firmness is the leading principle of their government, and no punishment whatevar is inflicted except the privation of a certnin number of gond nurks or uf a certain rewarch. The pup:ls thits attach inmense importance to these marks, and will make every fiffit to merit thent. They are taught to respect order and authority, thus forming their elasraeter for after life. We have thus given tub the fulilie a brief skeleh of one of the most worthy and best regulated justitutions for the edueation of all classes regarilless of religious faith. We can cheeriully recoumend the Ursuliue Acadcmy to guardians and parents. 


\section{GREAT WESTERN HAY, GRAIN \& FEED HOUSE.}

JAS. GRAHAM \& SON, 364, 366, 368 \& 370 Penn Av.

A mong the various bouses engaged in handling hay, grain and feed in Pittshurgh is that of Messrs. James Graham \& Son, whuse extensive establisliment $\mathrm{i} 3$ located at Nos. $364,366,368$ \& 370 Penn avenue, $100 \times 100$ feet in size. Thís louse wis founded more than forty ycars ago, and has been conducted by the present proprietors for alout fiftceu years, and is to-day the largest establishment of its kind in the two cities. During the year ending May 1st, 1879, these gentlemen handled 318 car loads of oats aggregating 213,060 lushels, 122 car loads of shelled corn or 51,850 buslicls, 47 car loalds of ear corn or 16,450 bushels, 77 car loads of hay agoregating $6: 3$ tons, 31 car loads chop feed or 372 tuns, 22 car lo:ds of bran or 242 tons, and 36 car loads of middlings amounting to 432 tons. These are the only kinds of grain alul feed handled by this housc. In addition to their grain business they are also dealers in anthracite cual; this branch of their trade is growing steadily and has already assumed large proportions during the past year. Three thousand two hundred tons were handled by them, the demand so far being all local, they deliver promptly to order to all parts of both cities at the lowest ruling market quotations. Buth members of the tirm are vatives of this State and have been for luany years identified with the business interests of Pittsburgh.

\section{JOSEPH IIIMMEL \& CO.-Druggists and Pharmaceutists, Penn Av. \& Ninth St.}

Mr. Joseph Kimmel, whose establishment is located at the corner of Penn avenue and Ninth street, is a thorouglnly competent Pharmaceutist and Druggist of long experience in the business, and emploss only educated and practical assistants who pay especial attention to compounding physician's prescriptions and family recipes, using only such ingredients as are known to be of the proper strength and purity. He keeps in stock at all times a coniplete assortment of the best and freshest Drugs and Chemicals, Patent Medicines, Fine Perfumery, Toilet Articles, etc., making a specialty of Rare Drugs and Chemicals seldom found with ordinary apothecaries, carrying a stock of about \$10,000. The present proprietor has been engaged in this corner siuce 1876 . The building was erected especiall $y$ for the drug business and possesses all the modern conveniences. The store room proper is $25 \mathrm{x} 60$ feet ; the upper portion of the building is occupied by him as a residence. Their trade, which is gener:ally of the better class, will compare favorably with that of an y similar establishment in the two cifies. Mr. Joseply Kimmel, the active partner in this popular house, was born in Pittsburgu Oct 20, 1847. Mr. S. S. Holland, the well-known druggist of Smithfield street, is a special partner.

\section{W. S. SMITH, -Undertaker and Embalmer, 39 Ohio St., Allegheny.}

The establishment of Mr. Smith and his stock of burial cases, caskets, shrouds, \&c., will compare farorably with the best. Mrr. Smith has had loug experience and will give entire satisfaction in all branches of the business, and is unsurpassed in the art of embalming. He was born in Allegheny in 1532; first eng:aged in business in the Diamond in 1850 , but retired from the same to engage in the exploy of the A. V. R. R., where he remained until 1854; he was one of the first conductors on that railroad. Resigning this position he entered the employ of Adams Express Co. until 1832, after which he engaged in the grocery business. He afterwards engaged in the undertaking business under the name and style of Rodney \& Smith, which was dissolved in November 1876 by the withdrawal of Mr. Rodney, Mrr. Smith continuing the business at the old stand. The building is a large tluree-story brick $20 \times 100$ and of neat and commanding appearance. The business has increased largely and now amounts to the comfortable sum of $\$ 5,000$ per annum.

\section{J. T. EVANS,-Marble and Stone Cutter, Cor. Washington and Webster Av's.}

This business was originally started by Mr. J. T. Erans in July, 1877, with a comparatively small capital, but which, by his superior skill as a workman and industry and integrity as a man, has been largely increased. He keeps constantly on liand a supply of both Foreign and American Marble and Granite, also other qualities of stone, ur can supply Monumeuts, Headstones, Slabs or Building Stone upon the mest liberal terms and guarantee workmanship of the most superior character. Those desiring anything in this line will do well to consult him, at the corner of Washington and Wehster avenues. Mr. Evans employs on ly skilled workmen and heing prictical and prom $t$ in all his transactions, is worthy the esteem and patronage of all. He was born in Lehigh county, this State, in 1849, and caune to this city in 1871.

\section{A. JACKMAN \& SONS,-Exchange Livery Stables, 174 to 184 Pern Av.}

The mammoth Livery Stables of this firm present a fine display and equally fine equipage. The business was started thirt y yeturs ago by A. Jackinan, Sr., who conducted it with eminent success, which secured him a wide popularity. The firm is composed of limself and sons, A. Jackman, Jr., and E. F. Jackman, each of whom bave at thorough knowledge of the business. Their stables are classed with the largest in the United States, covering ground $150 \times 150$ fect, and are equipped in tbe most approved and thorough manner. All the members of the firm are natires of Pitsburgh, courteous and efficient gentlemen and business men.

\section{OTTO E. HEINEMAN,-Watchmaker and Jeweler, 118 Ohio St., Allegheny.}

One of the most energetic and enterprising young business men of Allegheny City is the above named watchmaker and jweler, duing lousiness at No. 118 Ohio street. Starting in lusiness in April, is78 with no capital, excepting a thurvugh knowledec of his trade, he has built up a yearly business ralued at $\$ 2,500$ to $\$ 3,000$, and his stock in tratie, cunsisting of Watclies, Clocks, Jewelry etc of the latest and most fasbionable styles, is estimated to be worth $\$ 1,500$ while his capital is now $\$ 1,000$. Mrr. Heineman makes a specialty of wateh repairing, and his worlimanship in this department is uncxcelled for neatness and durability. Born in Saxony, Prussia, June 26, 1855, the subjrct of this notice came to this city in 1870, where he learned his trade with $R$. Siedle, on Fifth avenue. Judging from his past suecess, it is safe to predict for hin an equally satisfactory future, while be fully merits the liberal patronage and increasing business lie receires.

WM. MAHLER,-Watches, Clocks, Jewelry, Silverware, 149 Federal St., Allegheny.

Wm. Mahler was born in Baden, Germany, in 1826, and emigrated to this country and settled in Allegheny in 18.18. If wats for al long time engiged in business on Chestnut street, but removed to his present place some ycars ajo. Mr. Mahler is a practical wa climaker and jeweler. His store is located three doors above City Hall, on Federal street, Allegheny. His long experience in business enables laim to give entire satisfaction to all. He keeps a full line of Watches, Clocks, Jewelry, \&c., which will compare favorably with any in the city, and his business is on the increase. Iuwember No. 149 Federal strcet, Alleghen y, three doors above City Hiall. 
IMPROVED MERCANTILE AGENCY,-Of The Bradstreet Company.

\author{
Pittsburgh Ofice, No. 80 Fourth Ave.
}

As an institution protective of the industry of others, a history of the mercantile and manufacturing progress of

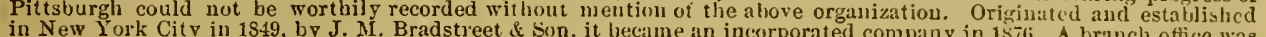
in New York City in 1849 , by J. Mi. Bradstreet \& Son, it became an incorporated company in 1 siti. A branch office was
opened in this city more than twenty years ago, which in its laturs dusing the period that has elapsed, has done as much to fuster and conserve the solid and substantial intrrests of the community as any other one institution. With an inception that was almost obscure and generally regarled will disfavor, the Agency, from the absolute force of its utilif $y$, has grown to proportions that extend to the utunost linits of our commerce and trade, keeping a wholesono check upon the evils of an iudiseriminate credit system, and protecting honest industry tliroughout the entire ramifications of the mercantile world. Surh being its recold, it is not strange that from the cartiest period of its establishment in this eity, it should hare inspired contidence, and to-day occupies a position in the community, indicative of the most signal success in its undertakings. Not only in the publication of four volumes annually, containing the names and fivancial responsibility of every tirm and busivess witu in the United States and Canada, have Tho Bradstreet Coupany performed a stupendous work, but in the perhaps inore important details of their labor, such as the compilation of special and elaborate reports, and the collection of the records of legal actions of a tiduciary cliaracter, is displayed the true usefulness and nagnitude of their operations. The company liave offices in all the larger cities of the country, and an almost in numerable host of special agents, correspondents and attorneys in every town, hamlet and county, which afford the patrons of this euterprise an almust certain protection against loss, and a safety in the trinsactions of business hitherto unknown. M. Charles F. Clark, the President of the Company, has been identilied with the Agency almost from its inception and his large experience gives him a thurough knowledge of the wints of the coumercial world, and the present exalted position which the Agency loolds in the estimation of the business
putlic is largely owing to bis uncensing labors. For three ycars Mr. S. N. Dickey hats managed the Pitsturgh office, and for more than ten years he has bere been connected with the agency. A large force of employees is required in the various departments, which are conducted with promptness and thorough efficacy, enubracing a ticlil included in Western Pennsylvania, Eastern Ohio, and a large part of West Virginia, and is in erery sense entitlel to the support of the commercial community. The officers of he company are at present, Charles F. Clark, President, Henry C. Youug, Secretary, and Edward F. Randolph, Treasurer, witu offices at 279, 281 \& 283 Broadway, N. Y. City.

\title{
THE PITTSBURGF STEEL CASTING CO.
}

Manufacturers of Improved Steel Castings. Office and Jiorks, $26 t h$ \& Pailrond Sts.
The great improrements that liave taken place during the past decade in metallurgical science, and more especinll with reference to the manufacture and conversion of steel, finds a striking exemplitication in the enterprise of the Pittsburgh Steel Casting Co., a corporition chartered in 1871, and conspicuously priminent among the most extensive establishments in Pittsburgh. The efforts of this company have been dirccted exclusively to the hetter producrion of Steel Castings for Railway, Agricultural and general mechanical appliances, ind to attain the required degrec of perfection much time, labor and capital has been spent, with final results, lowerer, of the most satisfactery character. In possession of complete facilities, and all the advantages secured by the application of the hest modern apparatus, as well as a profound, practical and theoretical knowlenge of the conversion of stect and its properties, the company lias for many years held a pre-eminent position as manufucturing castings, whicli, for all essential purposes, are regarderl is flawless. By ingenious methods of moulding (processes secured to the company exclusively liy patent) castings ire wade of the nicest accuracy, surfaces without roughness, uniform in qualify and tensile strength, which, by the most critical tests, is ascertained to be from 65,000 to 90,000 pounds per square incll. Nor is this all, for these castings are mitde of any desired grade, with reference to ductility, and are eapable of bing welded or forged, and manipulated under the liammer as readily as any steel made. The plant of the Pittsburgh steel Casting Co. is located on 26 th and Ritilroad streets, and consists in part of one main building of brick, with ircn fire-proof roof, $256 \times 122$ feet, occupied by the crucible, annealing and heating furnaces, hammers and castiny appliances. Besides this extensive structure there the crucible, annealing and heating furnaces, hammers and casting alpliances. Besides his extensive structure there

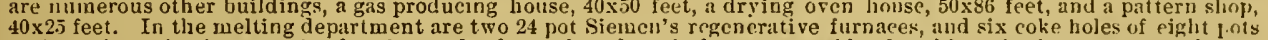
each, eacli pot having capacity for 88 pounds of metal, and each furnace capable of making six heats every 24 hous giving a total product of 24 net tons per day. No cast iron is used in the nuanufacturc of this stecl, wrought ironl and steel alone are employed, the mixture being entirely under the control of the melter, who, by the proper regulation of his metals, can secure any desired grade of prorluct. In the cisting of Reaper and Afower Guards, Plow Sharrs, Plıw Mold Buards, Plow Jointers, Plow Landslides, Bevel and Spur Wheels, (ruides, Spindles, Dies, Cross Heads, C'ranks, Rods, Straps, Liuks, Pulleys, Pocker Arnis, Rail Road Frogs and Crossings, and machinery castings of all desciptinis, the company has achieved a reputation that has led to the exiension of its trade over the cntire United Statcs. The officers of the corporation are James Irwin, Esq., President, Henry W. Patterson, General Manager aud Treasurer, and W 1 . Hainesworth, Superintendent, and under the management of these gentlemen the company has entered upon a career of success that augurs well for its future usefulness and prosperity. A great enterprise promoting the industrial welfure of the community to the highest degree, and developing the resourees of the stecl manufarturing intcrests, the Pittshurgh Steel Casting (Co. is jnstly entitled to the elevated position it has acquired, aud the endorsenient, alike of its cotemporaries and the putlic at largc.

\section{N. H. SNIDER,-Dealer in Groceries and Produce, 2400 Sarah St.}

This establishment was started by Mr. Snider as early as 1873 , first as a cigar and tobacco stnrc, but he subscquently changed into the present business in 1877 , and since then he lias established a very fair and prospcrous trato in Groceries, Provisions, etc. He keeps a full stock and general variety of the best class of guods, Choicest Family Flour, Fresh Butter and Eggs, Sugars, Coffees, Teas, Canned Gnods, Spices, Notions, Cigars, Tohaccos, etc, at lowest prices. He occupies the first floor of a three-story hrick luilding of ample size and conveniently located at 2400 Saral street. MIr. Snider was born in Franklin count $\%$ Pa., in 1823 and came to this city in 184t, where he has resided crer since. He held the office of Chief Burgess of the Burough, in 1860, of East Birmingliam, before its incor poration into this city.

\section{W M. SEMMELROCK,-Undertaking and Livery Stables, 1720 Carson St., S. S.}

Mr. Willian Semulrock is one of the leading Livery nen and Undertakers of the South Side. He started tho business several years ago on a small capital which he has since increased to tneet the dematuds of his growing traclc. He has a good stock of horses and rehicles of most improred makes and a full line of Uurlertaker's giouls. Il is jutace of business is No. 1723 Carson street, where he occupies a two-story frame building $24 x 60$ feet in sizc. IIe was born in Gerinany in 1826 , and came to this city in 1818, where he bas been ever since. He is doirg a gond lusiness, which is Germany in 1826, and came to this city in 1848, where he has heentinues to control it. Mr. Scmmelrnek n.lways keeps

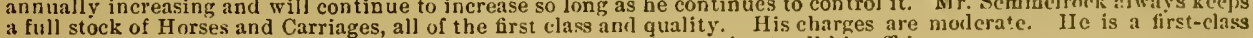
business man, alway's accommodating, and giving his personal attention to all his affairs. 


\section{S. V. ALBEE,-Practical Business Photographer, 99 Fifth Av.}

The tendency of an occupation of this nature is to develop in the artist the inost critical and analy tircal distinction of lights and shades; bat only that native genius which helongs to the true artist can properly conprehenil the true effect of eath in its exact relation to the subject. Indeed, the practical business photographer can ouly secure the highest results from the possession of those normal qualities which comprebeud the adaptation of science to art. These reflections are the result of a brief consideration of the superior slill exhibited in the work of Mr. S. V. Albee, now located at No. 99 Fifth arenue. Here is clearly unifest to the connoisseur a natural grift conjoined with a seientitic knowledge of chemical adaptation in the production of the desired light and shude, especially in his success in securing correct lines, and the skill and taste necessary to produce the strongest and nost subtie life-jike eftect. With these qualities in his fivor, the hatural result must he a grudual increasing jublic patronage and popularity. Mr. Albee was formerlv Jocated at 784 Fifth avenue, but wis induced to remove to his present rooms, No. 99 Fufth avenue, which offered better facilities for exteusive operations. He is prepared to execute all kinds of Photographic work, lut makes a specialty of Architectural and Mecbinical Photography, also of Painting in Oil or Water Colors, Crayon Work and to taking enlarged views of landscapes. Ho lias executed contract worli frum various parts of the different States, aud canuot fail to secure mechanical implements and architectural work wherever specimens of his operations are slown. He also takes views of public huildings, residences, hridges, tunnels, etc., and can produce testimonials of some of the most celebrated eivil engineers in this country. MIr. S. V. Albee is a native of Thomaston, Maine, where he was born in 1838, and came to this city in 1867. He is a gentleman of excellent social qualities and high artistic attaimments, whose work will bear comparison with the best artists in the nation.

\section{JNO. BER GER, Jr.-Cigar Manufacturer, 2525 Carson St., South Side.}

On the day of the inauguration of the International Exhibition in Philadelphia, May 10, 1876, Jr. Jno. Berger, Jr. Tobacconist aid Cigar Manufacturer, of the South side, commenced business for himself in the two-story fraue siructure, $17 \times 34$, at No. 2525 Carson street. Since then his capital has considerably increased. He manufactures a variety of popular brands of Cigars, malsing a specialty of Mould Tubies, which have aequired a wide reputation for superior excellence. He also carries a tull stock of Choice Cigars. Minufactured Tobaceo and smoker's' Articles, and is doing a flourishing business, which is gradually increasing. Mr. Berger is a native of Prussia, and was horn in the Rhine province, celebrated in song and story. He has been a resident of Pittsburgh sirice 1555 , and is well and favorably known through the medium of the excellent cigars bearing his trade mark and guarantee.

\section{JAMES CAILIRY \& CO.-Leather, Hides, Pelts, etc., 102 Liberty St.}

Few establishments are hetter known in this or foreign countries than th-t of the above firm, whose warehnuse is located at No. 102 Liherty street. This house was founded ia 1792 hy Judge Havs, father of the well-known gentlemen, William, Richard and Charles Hays, of Pittshurgh. The husiness was conducted successfully hy the Judge for many years, when he was succeeded by two of his sons, Richard and Charles Hays, and they in turn by the firm of Hays \& Stewart. The losiness remained in the Hays lamily until 1870, when the present proprietor's assumed its control. The office and wareroms oceupy a substantial threc-story lirick edifice $20 \times 110$ feet in size, and is stocked with Hides and Leather, Oils. Tallow, Wool, Shoe Findings, etc. The specialty of the house, however, is Harness and Belting Leather, of their own minufacture, a product which has gained for them the prize medals of the Pittsburgh Exposition Societr, a pri\%e medil at the Philadelphia Centennial Exhibition of 1876, and a bronze medul at the Paris Exposition of 1878. Their tanneries are located in Alleghen City, and cover one and a-half acres of ground, ind have a capacity of 16,536 tauned hides per annum. The stuck carried hy the firm amounts in value to not less that $\$ 100,000$. Their trade extends all over the United States and Europe, their annual sales reaching $\$ 250,000$. Mir. Callery has heen operating this establishment since 1870 , but had been previously engaged in the same line of business in Allegheny fur twelve years.

\section{W. F. CASEY,-Carpenter, Contractor and Buiider, 5 and 7 Chatham St.}

This business was origirally started by Mr. Casey in 1864 with limited capital, heing quite a young man, but with individual pluek and courage he built upa very flourishing husiness. In 1867 he was burned out and nut with very heavy loss, but he soon reluilt and reestablished himself more firmly than before, so that his present annual bisiness in Carpenter Work amounts to about $\$ 18,000$ per annum, and kuilding contracts would augment this sum to about $\$ 30,000$. He keeps on hand an ample stock of lumber and material and is prepared to take contracts for Carpenter Work or Buildings upon liheral terms. He will execute his work promptly and to the satisfaction of those who employ him. He has put up some of the best buildings in the city and can refer with pride to his work. His workshop is fifty feet square, besides yards for stock $60 \times 80$ feet, and employs skilled workmen. Mr. Casey is a practical workman and stands high in the community for relialility and promptness.

\section{F. H. BUSSMAN,-Groceries and Produce, 50/ Carson St.}

Every family and every member of it feels more or less interest in the Grocery and Provision trade which supplies so large a proportion, directly and indirectly, of the articles of food. Therefore, in noticing the prominent and pupular business houses of this city, we desire io call attention to the well stocked Store and excellent Grocery and Provision house of F. H. Busstnan, No. 5ill Car'son streel, South Side. This old estal, lishnent has existed for orer twenty years as a supply for articles in this line, thongh it only cause into the hands of Mr. Bussunau in 1878 . He has an antple capital for the transaction of a flourishing business and is doing a tracle of about $\$ 8,000$ per annum, which is grarlually increasing. He carries a stock of about $\$ 1,500$ in his lusiness room, which is in a two-story brick building $24 \times 60$ feet in size, and keeps the best and freshest goods in this line, embricing all desirable articles isually found in a firstclass grocery and provision store. Mr. Bussman was born in Germany March 26, 1837, and came to this eity in $185 \tilde{n}$, though he did not eng tge in business for himsclf until he opened his present place in June of last. year though previonsly in partnership with others. He is in man of excelient business qualifications, and his store retains many of its old and new patrons.

\section{GUST. A. SEXAUER, - House, Sign and Fresco Painter, 2001 Sarah St.}

Mr. Sexauer started this business in 1869 and has been quite successful, owing to the excellent character of his work. He carries ample stock and is one of the most skilled workmen in this city, doing in fair annual business. Ilis grounds cover as area of $24 \times 120$ feet and his shop is $24 \times 26$ feet, giving employment to tive hands. He dues House, Sigu and Ornamental Pitinting, Lettering, Gilding, Fresco Painting, Graining, Glazing, etc., in the most artistic manner. Mr. Sexauer was born in Germany in 1838 and came to this city in 1869. His excellent work eannot fail to give sutisfaction to his patrons. 
A. FULTON'S SON \& CO.-Bell \& Brass Founders, 70 Second Av. \& 91 First Av.

As the only establishment in this city engaged in the manufacture of Bells as a specialty, and on account of a career, that in three years will have traversed the changes of half a cenumy, the tirm of A. Fulton's Son \& Co. is particularly entitled to consideration in a review of the industries of Pittshurgh. 'The business was oripiluted in 1832 hy Ancirew Fulton, Sr, with a capital so small that lis operations were contined to one room, lis only employee being himself. With so great a lack of material resomces, however, the elder Fulton had a backing in resolution, enengy and ingenuity, to an extent possessed by few men, and upon which no drafts ever went to profest. For years le struggled in with varied success, bis husiness enlarging, and as steamboat builutug increased, the bells of his manufacture becatne in great request, and the brass castings turued out from his shop were the best to be obtained in the country. His successors, S. M. \& W W. M. Fulton, under the above style, now conduct the business in in manter and apon a scale absolutely unlieard of, when the founder of the house with crude and inadequare appliances cast the first tell west of the Allegheny mountains. The premises now uccupied consist of two large brick liuildings three-stories hirls, and respectively $35 \times 80$ and $70 \times 80$ feet with frontages on First and Second avenues. Here the nechanjeal cquipments in every respect are as complete as capital can proville or ingenuity devise. Twenty-tive expert mechanies are cmiployed at a weekly outlay of $\$ 300$ or more, and a 25 -horse power engine is kept in constant operation. The ancient reputation of the house for manufacturing the best products is sedulously matintuined, and the bells that are cast at this foundry vibrate over ihe entire Uniteil States, and peal across the remotest waters of the globe. The members of the tirm hesides inheriting the business liave terjved from its founder much of the constructive genius for wlich lie was celehrated; Mr. S. M. \& WW. M. Fulton having obtained patents on sereral clever devices, among. which the patent stean water lieater and rotary bell fixture, are perliajs the most useful. The jdentification of this liouse with ilhe productive industries of the community for so long a period, and tho bonorable policy upon which its business has uniformly heen conducted, inake it to a cort:in extent a representative institution.

\section{JOSEPH EHRSTEIN,-Druggist, Cor. Penn Av. \& 28th St.}

One of the neatest and jnost at tractive drug stores on Pena avenue is that of the cnurteous gentleman, Mr. Joseph Ehrstein, at the corner of Penn avenue and 28 th street. He occupies a large and handsome rom which is liand somely fitted up, and presents an attractive and elerant ippearance. He carries a large and varied stork of drums, chemiculs and nedicines, surgical instruments and appliances of the finest quality, toilet and fancy articles perfumery, and such goods as are to be found in well regulated estallishments of the kind in great variety, all of which are handsomely displayed in numerous show eases, counters aud slielvings. This store was founded in 1866 by J. J. Caicl well, w lio built up quite a fair trade ; it passed from him into the hands of Becker Bros., who conducted ii for a lime, selling it out in 1876 to its present popular proprietor, who has carrjed it on with energy and to the satisfaction of its large number of patrons ever since. The store is well located in the midst of a prusperous district, and is doing a fine husiness that is increasing from time to time. IIr. Joseph Ehrstein, its present proprietor, is a young gentlewin of ability aud energy, possessing every requisite of success in the business in which he is engaged. He was horn in Birmingham or Southi Side, part of the eity, in 1841, early in life he learned the drug business, to wlich he has studiously and continunusly devoted his life. He is a thurnighly skilled, scientitic and practical druggist and pharnnaceulist, enjoring a high reputation in this respect. He gives personal attention to his large and growing prescription business, in whicli bumch of his profession he stands unrivalleil. He possesses the confidence and esteem of the inedical fraternity in an eminent degree. He is an active memlier of the State Pharnaceutical Associtition, and an upright and puhlic-spiriter eminent degration.
gentlent.

\section{THE HUMBOLDT FIRE INS. CO.-No. 1 Pennsylvania Av., Allegheny.}

The Humboldt Fire Insurance Company of Alleghen y shoull be noticed among the hest husiness concerns of this city. 'This Company commenced business in 1871 on a capital of $\$ 25,000$, transicting a gereral fire insurance business, confined chiefly to Allegheny county. The importance of the business transacted by our local underw riters is frequently lost sight of, but when we take into consideration the vast amounts of insurance rhat must necessarilv he carried in a husiness coinmunity Jike this, the importance of these transactions becomes apparent. That the Humbridt Insurance Coupany has met with success is evinced by the fict that their capital in this short 1 me intervening since 1871, has iucreased to $\$ 75,000$, aud the Compan y now carry $81,300,000$ insurance. Their effice is locited at No. I Pennsylvania avenue, Allegheny, in the Enterprise Bank building, one of the finest husiness structures in that heaurifu] city. The President is L. Wiederlnold, Esq., with Mr. Thomas J. (iraft', as Vice President ; Jno. Seiling. Trensurer; and Jos. P. Fisher, Secretary. The board oi Directors as at present organized are :-L. Wiedcrhold, F, G. Weise, Jno.' Berger, A. Heyl, Thos. J. Graft; Wederick Gwinner, A. F. Schw (srd, P. J. Urli!:g, Juo. A. Eckert, John Seiling, G. Irongenlity as gentlemen of high, social and lusiness standing, and their financial rexponsibility is of such a nat ure as to warrant unbounded confidence in this Company. The Humboldt has enjoyed its full share of patronage, and its judicinus and eonservative policy unust remain among the most solid and sulsstantial institutions in this line in the country. The business of local underwriting, which invariably increases as cities wow in wealth and importance, capital accumulates, and the necessity no longer exists to pay forejgn rajpitalists for risks on their property, and no Complany at present engaged in the business has done more to pronmte the local insurinee intere:ts of the f wo pities than the Humboldt Fire Insurance Company, certainly none are better entilled to the patronage of the citizens of Allegheny' county.

SCHIMMEL'S FRUIT BUTTER,-W. M. Gray, Agt., Cor.4th \& Liberty Sts.

While the industry relating to the manufacture of Fruit Butter is by no means a cornmon one, vet the extent. to which this useful business lias developed witlin the past few years entitles it to romment in this work. The peacl, pear, quince and apple butter prepared for this market and for which Mi. IV. Mt. Grily lats the sule agence, are readily

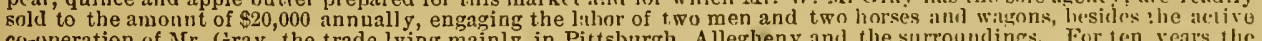
co-t)peration of Mr. (iray, the trade lying mainly in Pittshurgh, Allegheny and the surroundings. For ten veals the business has been estahlished in this city, growing in dimpnsions annually, for half that time the prent husiness premises have heen occupied. Mr. Gray is a nitire nl this State,
to this city in 1865 , from which time he began lis business career.

\section{F. KUHLMAN, -Wholesale and Retail Grocer, 49 Federal St., Allegheny.}

The establishment of Mr. Kuhlman is situnted on the west side of Federal strept, a short distance below 1 he $R$. $R$. depots, and immediately on the line of the Pittslurgh of Allegheny and The Troy IIill Passenger Railways Mr. Kull]man was horn in Germany in 1839, and came to this country and set led in Pittshurgh in 185.4. He obtainc.d a position as clerk with $\mathrm{Wm}$. Haslage, and by industry, perseverance and clnse altention to lusiness was admitted into partnership in 1862 . The martnership was dlissnlved in 1874 hy the witidrawal of Mr. Kuhlman, whoshortly after engaged in business, on his owul secount, at lis present loeation, where he keeps a full stork of everything in the line for homo und tahle, at lowest prices, and is doine a lare ammikl business, which at present amounts to $\$ 50,000$. Wm. Vauder, Louis Shuster and Chas. Sleejer, his able assistants, are jolite and agreenlile gentlemen. 


\section{Pittsb'gh, Phonix, Sligo, Empire \& Mastodon Glass Factories,}

Win. HicCully \& Co., Proprietors; Office, 18 and 20 Wood St.

Established nearly half a century ago, there is associated with the business interests of Pittshurgh no establishment in this line which his attained gretter magnitude or more creditable celebrity than that of Messrs. Wm. McCully \& Co., whose principal office is located at 18 and 20 Wood street, in this city. The enduring and world-wide reputation which the city of Pitishurgh enjoys as the central mart for gliss in all its various forms, is a matter of just pride, not only to all wbo are associated with the industrles of this city, but to the citizens of the whole country as well. In no small degree have the house of Messrs. Wm. McCully di Co. contributed to establish and maintain this reputation at home and abroad. The business was originally started, in 1830 , hy Mr. Wm. McCully, and although since its inception the country has passed through severe and trying times, affecting all general transactions, and some of which have been especially severe upon the glass trade, this house has maintitined its business reputation to suclı a degree as to entitle it to the unbounded couffidence and high esteem it holds before the commercial world. Conducting its operations upon a conservative and solid basis, it has grown in the magnitude of its facilities and transactions from a comparatively small beginning, until it now employs and operates six different establishments, in each of which are employed a large number of workmen. Two situater on Carson street, South Side, one on Liberty street, one on 2211d street and two on 2Sth street, lieing the Pit tsburgh, Phœnix, Sligo, Empire and Mastodon Glass factories. The extent of the operations are without doubt unsurpassed by any similar house in this country or Europe, while the products tind a market all orer the civilized world. Associated with Mr. McCully are Mr. Mark W. Watson and Mr. John MeM. King, each of whom are thoroughily conversant with the glass trade of the country, and gentlemen whose financial and executive ability have largely contributed to the prosperity attending the enterprise in which they are engaged. The general business embraces the manufacture of Window Glass, white, green and black Glassware, Demijolnns, Fruit jars, etc. It would be impossible in a work of this nature, to give to the distant reader a clear idea of the perfection of all the appliances associated with their various works, which are, however, the most advanced and thorongh which ingenuity or energy can devise, and we have no hesitation in suying that those interestcd in the glassware trade can form no more advantageous commereial relations than those which may be established with the house of Wm. McCully \& Co., Nas. $18 \& 20$ Waod strcet.

JOHIN P. VIERHELLER,-Dry Goods, etc., 119 Chestnut Street, South Side.

Mr. John P. Vierheller occupies an excellent location at 119 Chestnut Street, in the 36th ward, where he keeps a full stock of fresil and desirable Goods suitei to the market, and embraces Staple and Fancy Dry Goods, including Ladies' Dress Goods, Domestic Goods, Hosiery and Gloves, Trimmings and Furnishing Goods, Notions, \&c.; ; also Boots and Shoes, for men, women, boys, misses or children, Carpets and Oilcloths, Hats, Caps and Millinery Gonds. This latter department is under the supervision of the nust experienced ladies. Mr. Vierheller is an experienced and excellent buyer, and uses the most discriminating taste and excellent judgment in the selection of goods for the different departments of his trade. The business was originally started by him in 1869, and now amounts to from $\$ 12,000$ to $\$ 20,000$ per annum,-He was born in Germany in 1832 , and came to this city in 1849.

\section{ATWOOD PAXSON,-Custom Fine Shirts, 228 Liberty St.}

Mr. Paxson bas been in the Shirt business for a number of years, in which time he has represented the makers of the finest work turned out in Eastern cities. Having built ul) a large trade in Pittsburgh, and finding it increasiug witl each successive visit, he determined to locate himself permanently in the city. In March, 1S79, he opened a haudsome office and salesroom at No. 228 Liberty St, next to the Penn Bank, where, in addition to a full line of samples of Dress and Fancy Shirts, he keeps a stock of the latest shapes and styles in Collars and Cuffs. A specialty in this line is a grade of full Linen Collurs and Cuffs-band, neck-band and living heing all linen; thus assuring even shrinkage in washing, and admitting of the goods being done up at home as well as at the best steam laundrv. The gentlemen of Pittsburgh and surrounding towns are now afforded the advantages of procuring work of a really high and excellent character, and the rapid increase in orders attests how much the goods of the house are appreciated by those who desire a perfect-fitting, elegant and durable article in this line.

CHAS. LOUDER,-Manufacturer of LAUNDRY BLUE, 85 Beaver Av., Allegheny.

There may be more extensive enterprises, but none more worthy of notice in this work than that of Mr. Chas. Louder, manufacturer of Laundry Blue, also Flavoring Extracts, Oils, Perfumeries, Inks, Essences, etc., 85 Beaver A venue, Allegheny City. The laboratory and business department is situated at No. 85 Beaver Avenue, and the transactions which were commenced in 1876 have gradually increased from year to year. The excellent qualities of the articles nianufactured by Mr. Louder show a thorough knowledge of chemical analysis, which must result in increased and cnlarged operations, as tlese articles are in constant demand.-Mr. Chas. Louder was born in New York city in 1850 , and came to this eity in 1870 . He is a gentleman of progressive tendencies and enterprising spirit.

\section{WIM. BURN,-Union Barrel and Cask Factory, No. 1709 Fox Alley, South Side.}

This business was started here by Mr. Burn in the spring of 1878. He has a good supply of material and every arrangement made to receive all the stock required in his business, and to fill all orders promptly. Mr. Burn is yet quite a young man, and is destined to succeed, with his enterprise and business capacity. He was born in London, lingland, in 1856, and in his infancy, with his parents, came to this country, and since 1870 he has resided in this city. II is specialt $y$ in trade is the manufacturing of Glass-House Packing Barrels, besides being prepared to make all kinds of Casks that may be required. He gives close attention to his business atud selects all his stock with the greatest care, and his prices will be sutisfactory and agceptable to all.

\section{H. C. SKELLEX, -News Dealer, Stationery and Tobacco, 89 Fifth St., McKeesport.}

Mr. Skelley started in business in 1878. He now carries a full line of School Bnoks, Magazines, Periodicals, Papers, Stutiouery, Tobaccos, Cigars, Notiens, Confectioneries, etc., and is doing a very liberal trade. Mr. H. C. Skelley was born in Latrolve, Pa., in 1859 , and came to McKeesport, in 1872.

\section{ANTON LANG,-Glassware, Lamps, Oils, etc., 139 Market St., McKeesport.}

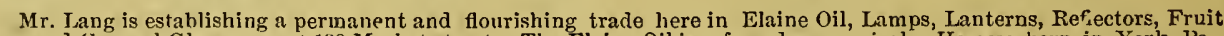
Jars, and General Glassware, at 139 Market street. The Elaine Oil is safe and economical. He was born in York, Pa., itl 1841, and came to McKeesport in 1876. Commenced this business last Spring. He is a pleasant gentleman and worthy of liberal patronage. 


\section{THE NEW YORK GRAPHIC,-Goodsell Bros., Publishers \& Proprietors.}

Anong the various newspapers of the United States none hold to-lity a higher rank or more enviahle position than the Nisw YoRk GRAPIIC, the only illustrated daily journal in the world. This paper, which notwithstanding the opposition of the leading dailies of New York las olitained an iumense circulation is now established on a tirm basis and is one of the ablest periodic:ts in the country. The (toodsell Brothers are natives of Pontiac, Michigan, aud at an early age hegan to exhibit unmistakahle traits of "yankce" enterprise. They at first decidled to adopt the udvice of IInrace Greeley and "go West," and for a time they occupied positions on the local press of Chicago. Their aspirations were, however, upward and ouward, and they shortly afterwards established the spectator, a journal deroted to the interests of insurance compunies, and which his ever been acknowledged as a standard publication hy the members of that fraternity. Althougl eminently suecessful in this enterprise the brothers had still higher aspirations, and after mature deliberition they decided to remove to New York and establish at daily illustrated isewspaper, giving all the latest relegraphic and local news with correct illustrations of current events in an attractive form, and terse aud practical editorial notes. The rosult of their venture has more than equalled their expectitions, and the New York Grapric has to-day a circulation of which the older journals might well feel proud. In connection with their illusirated paper they have the most varied and extensive printing establishment in the country, where all the different styles :und designis of photo-lithogratphy and illustrated printing are executed in the highest style of the art.

\section{PITTSBURGH, FT. WAYNE \& CHICAGO RAILROAD.}

This old, reliable and thoroughly first-class line, now under the nanagement of the Pennsylvania Company, is the only direct route from Pittshurgh to the West. In nonnection with the great Pennsylvania Ritilroad, (with which it is operated as one continuous line), it is the only line running three trains with through cars between Chicago, New York, Biltimore and Washington City viat Pittshurgh. Pissengers from Pitssburgh to any portion of the great West will find this the most direct as well as the most eronomical routc, als all railway lines centering in Chicagro connect with the through trains of the Pittsburgh, Fort Wayne and Chicago Railroad, and all pissengers holding throngh tickets by this line are transferred from other roads to the Chicago depot, corner of Madison and Canal streets free. The effort of the managers to make this road the hest on the continent are fully appreciated by the traveling public. Its rolling stock is always of the best, its locollutives the most powerful and rapid, its passenger coaches of the wost elerant, luxurious and comfortable deseription, and on all through trains Pullman Palace, Drawing Rnom and Hotel cars of the finest and most perfect construetion furnish unrivalled facilities for travelers. The schedules on this line arc so arranged that each train is independent and runs through on its own time, regardless of all other connections. The bridges on this line are all constructed of iron and stone, and no expense has heen spared to render them perfectly safe. Its double track is laid witls steel rails, and the greater portion of the line is ballasted with loroken stone, forming a firm and solid road hed and avoiding the dust so annoying to passengers on other roads. fll locomolives and passenger cars are provided with the Westinghouse patent air brake and all the latest and nost approved runveniences and improvements of the age. To the business men of Pittshurgh desirous of escaping from the smoke, dust and heat of the "ity to their suburban residences. the Fort Wayne road offers the greatest inducements, as accommodation trains arrive and depart from the Alleghen y depot almost every hour, stopping at all the stations which are located less than half a mile apart alon\% the hank of "La Belle Riviere," from Allegheny to the sylvan shades of Enon valley. No more desirable locations for rural residences ean be found in the suburbs of any Anerican city than on the picturesque hills bordering the Ohio river, with their many advantages of location, pure air, delightful scenery and picturesque surroundings, and it is not surprising that so many professional and business men of Pittsburgh avail thenselves of the opportunities offered by the Fort Wayne road to breathe the pure fresh air of the country after a day of toil amid the din, confusion and smoke of the eity. Mr. J. D. Layng is the general nanager of this road, with headquarters at Pittsburgh, and Mr. F. P. Myers, the general passenger and ticket. agent, who has had an experience of wore than twenty-five yeurs in this position, most acceptably fills that office, with headquarlers at No. $6 \bar{j}$, Suuth Clirk street, Chicago.

\section{THE ALLEGHENY VALLEY RAILROAD.}

This is the only direct route between Pittsburgh and Buffilo and Niagara Falls, and is one of great beauty and interest, passing, as it does, through many of the most. picturesque regions of America, following the lovely valdey of the Allerheny River, passing through the oil regions of Pennsylvania, and the romantic scenery in the recrion of Lake Chautauqua, a most delightful spot, and the highest navigal)le water in the United States, being 1,454 feet above the level of the seil, with a pure, dry, and invigorating atmosphere, milking it one of the most delightful resorts on the culinent. Like Chautuqua is a heautiful sheet of water, clear, pure and calm. It is four miles in length, and varies in width from two to five miles. Picturesque scenery, well cultivated farms and magnificent croves surround it. Cood hotels, hand some residences and at tractive cottages ma bere be found and steamers and sail hoats ply upon the lake for the convenience of guests and tourists. At this point are also the grounds of the great Nationil Sunday School Assembly, whose annual conventions at ract risitors from all portions of the Union. The Allegheny Valley Ritilroad, with its various connections, is rapidly becoming the most popular route from Pittsburgh to all points North. The liue possesses one of the suroothest road heds in the country, litid with steel rails and hallasted with broken stone, re iderine it free from dust. First-class conches are run on all trains, equipped w th the Westinghouse patent air brake and the iuproved Miller platiorm. Pullman Drawing Room Sleeping Cars accompany all night express trains between Pittshurgh and Buffilo, and all the accomodalions and arrangements are first-class in every particular. Baggiag will be checked and tickets sold by this route to all important points at the Union Depot, at No. 78 Fifth avenue, ind at the general offece of the company in Pittsburgh. Mr. David If Cargo is the general superintendent of the company, and Mr. J. Morton Frall the aetive, energetic and affable General Passenger and Ticket Agent. Passengers to Butfalo, Niagara Fadls and all points in Northwestern New York and Canada will find the Alleghen y Valley Rati]road the most coluiortable, pleasant and direct route.

\section{THE IMPROVED TEIOTVIE \\ STANDARD SCALES}

The only Scale having Protected Bearings. Scalcs for every use. Trucks, Spring Balances, Alarm Cash Dratwers, Groceres Fixtures, etc. Particnlar attention paid to Repairing Scales of all kinds and make.

PRIFSI, PAGF de COn, General Agents, Branch Warerooms, 63 Wood St., Pittsburgh. 


\section{DEXTER SPRING CO.-Manfr's. of the Celebrated Dexter Carriage Springs, \\ IIulton Station, I'a.}

The celchrated Dexter Buggy and Carriage Springs, manufactured by the above named Company, have alrealy acquired a world-wide reputaniun for superiority oves an y utler spring in the market, and the production of the vilrious patterns now in use forms no incousideralile item of the ununfacturing and industrial interests of Pennsylvauia. The Dexter Spring Company was incorporated under the laws of this state in 1875, with a capital stock of "\$24,000, which has since been considerably increased. The works are loeated at Edgewater Station, on the line of the Allegheny Valley Railruad, in the borough of Verona, Hulton post-office, eleven miles alove Pittsburrh, and occupy an area of abrui one acr'c. The nain building is $40 \times 150$ feet, and is supplied witl the most perfect and complete naichinery, the motive power for which is furnished by one twenty-hurse power engine and boiler. The Company also owns a number of comfortalle (Iwelling houses which are rented to employees and utliers. The lusiness is curried on in six different departments, eacls being under the immediate management of skilled and competent superintendents, alsd which may be classitied as follows:- The woud wurking departwent, machine and engine department, blacksmithing department, grinding department, fitting dep.rtment, and the tinisling department. Employment is regularly furnished tu about thirty hands and sometimes a much larger force is required. These works are the most complete and extensive of the kind in the United States, making only the special Dexter Springs. From $\$ 10,000$ to $\$ 15,000$ wortls of finished stock is usually carried on liand, and the anual business of the Company exceeds $\$ 60,000$. Their trade extends all over the Untide st:tes, with a steadily increasing demand from Anstralia and uther foreign markets. M1r. J. C. Yarmell, the genial and accomplished bookleceper, presides over the uffice department and clerical force, and ilr. H. Barr, a skilled and competent artificer, exercises a generil superintendence over the mechinical departments. 'Tlie spriugs manufacturel at this estal)lislsment, which are known as the "Dexter," the "Dexter King," the "Dexter Queen" and "Firy Quecu," are universally acknowledred to be of faultless'mechanical construction and are miade from a superior quality of crucille steel, thus ensuring elegance, lightness and durability. The crowning feature of their excellence is their special adiptalility to earriages and road wiagons for use on paved streets or uneven surfaces, combining as they do, strengtls, elasticity and durability. 'The spring motion is such that in riding over the roughest roads, rocks, boulders, stumps or logs, the jar is less perceptible to the occupant of the vehicle than with any other form of spring and less danger of breaking is experienced. The ordinary two passenger velicle springs latve been tested by placing 2,050 llss. weight on them over nirht, when the pressure was removed they resumed their original shape. These spriniss are warranted under all circumstinces. They were exhibiterl to adiniring thousands durinir the Centennial Exposition, in Philadelphia, in 1876, and at the various expositions of the Pittsburgh society, and have been gitining in faror ever since. They are in use by wany of the leading carriage manufucturers in all portions of the United States, and give the inost perfect satisfaction. Every carriage builder in the country should order a trial set of each style of springs, especially the Dexter Queels, which carries the palm in our estimation over every known inrm of springs, and be convinced by actual use that they are superior to any now hefore the public. Mr. WV. WV. Grier should be given the credit of developing the Dexter class of springs, as he is the inventor and proprietor of inan of the valuable points in their construction. He is the patentee of many springs and the founder of the Company. He now holds the position of secretary and treasurer and is also general business mauager. He is a practical mechanic, and it is owing largely to his effurts, especially at the Centennial, that the Dexter class of springs came to their present favorable position before the public. In addilion to the springs which we have mentioned, he has patented a number of ingenious and important improvements, among which we mav mention a new device to be used as a fifth wheel, wlickl will in many cases supersede others now in use. This business wnich lias now assumed such a magnitude, wis started originally loy Mr. Grier in a sinall rude way, he doing his own work and carrying on his experiments in lis own baro. He subsequently removed to a small frame building, lut su rapidly did the reputation of his springs increase when their merits and advantages became known, that he was compelled to seek more commodions quarters and the present sp:acious buildino was erected and fitted up with the most ingenjous and perfect machinery especially aldajted for the uses to which it is applied. Mr. Grier is an enterprising and energetic gentlematn ind puhlic-spirited to a fault, highly respested and esteemed, and a strong and unwavering ad rocate of tempertnce and morality. By his uw efforts and exertions he has achieved a proud and prominent position in the business community and as one of the leading maunfacturers of Western Pennsylvania.

\section{J. II. ORTMAN \& CO. -Wholesale Grocers \& Dealers in Flour, 112 Second Av.}

Transacting a very heavy trade in the line of Groceries, and especially in Flour, of which the "Young America" brand is the leading, the firm of J. H. Ortman \& Co. should not escupe mention in this work. Established in $18 ; 6$ liy

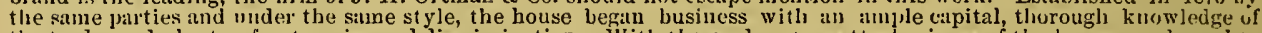
the trade, and plenty of enterprise and discrimination. With these ad vantages the husiness of the house was bound to inerease rapidily, as proved l,y its present status and traffic. The firm is individually composed of J. H and Theodorr Ortman, F. IV. Spreen and Joseph Ortman, the last three forming the "Co." The firm is a favorite one, and in all lines of "general Groceries and in the special brands of "Royal Paris," "Gilt Edge" and "J. H. O. \& Co. Pattent St. Lonis rarely duplicared, never excelled. In every respect this house is cordially commended as being fitir, liberal and enterprising, with facilities for the successful operation of their trade tliat prove of the lighest benetit to their customers.

\section{THOS. MCMICHAEL, -Grain, Flour and Produce, 222 and 224 Fifth Av.}

Mr. McMichael commenced business at his present location fn 1866, and has now an available capital of $\$ 10,000$. He trinsacts a wholes:le and retail husiness in Grain, Feed, Hay, Flour and Produce, carrying an average stock of about $\$ 1,000$. He occupies tivo buildings, each $20 \times 60$, at the numbers named, and his biness is conducted in two separate departments, requiring the services of four assistants, with a weckly paly-roll aggregating s42. MIr Jolm Mcarty is look-keeper and presides over the office business and general in-dour mantigenent of the lusiness. Mr. MeMichael lats a large and lucrative trade, extending throughout the city and its suburhs and his establishnent wili compure favoral, ly with any in the city engaged in the same line of business. He was born in Ireland January 1 , 18:28, and hats resiled in this city' ever since lie came to this country.

\section{HENRY J. SMITH,-Dry Goods and Notions, Washington Av., 31st Ward, S. S.}

This business was origiually started by Mr. Henry J. Smith in 1873 and has met with a very encouraging patronage from the neigliborhood. It embraces a full line of everything in the way of dry goods suited to the locality, also Notions, Faney froods, etc. Mrs. Smitls, with an attentive assistant, is aiways on hand to attend customers. The building occupied is is two-story brick, $21 \times 36$ feet in sizc, and is conveniently located. Mr. Smith was born in this city in 1817 and has resided here ever since. Mr. Smith is a glass monld maker, having special charge of that depirtument in the works of Bryce, Walker \& Co., South Side. He serverl as :t volunteerin the late war, had the honor of being the last captain of the iV al tull Hose Company in the Volunteer Fire Department of East Birmingluam hefore its incos puration into the city. 


\section{H. C. FRICK \& CO.-Manf'rs. of Connellsville Coke, 104 Fifth Av.}

The Connellsville Coke region produces the largest quantity of coke of any in the United States. According to the latest information there are in this region 3,668 coke ovells, and of these over 1,000 are either owned or controlled by H. C. Frick \& Co. This fact, in itself, may give some idea, however inadequite, of the magnitude of the business of the firm, and when it is further stated, that their coal lands lying in Westmureland and Fayetie counties amount to 2,500 acres, it will be readily seen that they are the largest coke producers in this country, and probably in the world. The great proportions which the business of Messrs. Frick d Co. hats assumed, may, perhajs, be attributed in a large degree to the peculiar advantages which the Connellsville region offers for the husiness of coking, and also, in part, to the fact that the firm convert all the coal mined hy them into coke, thus making the latter an exclusive speciult.v. The coal bed or stratum of what is known as the Coinellsville region, is about fift y miles distant from Pittsburgh, and lies mainly in the counties of Fayette and Westworeland. The tract is of at triangular shape, being generally ahout three miles wide and fifty miles long. The vein is a peculiarly good one, the beds producing from eight to nine feet of workable coal. Regarding the coal itself, it is described as leing lituminous, with generally a dull, resinous lustre, alternating with seams of bright, shining erystalline coal, coated with a yellowish silt and containing numerous particles of slate and some crystals of pyrites. From this material the celcbrated Connellsville coke, which is shipped to all parts of the country, and which is known wherever there is a smelting furnace is matle. In his report on coke, Mr. Plat.t describes that prol uced hy Messrs. Frick \& Co. as the typical coke, declaring it to be " as thoroughly burned and as well unde as can be produced in the Connellsville basin." A sample of the coke made by this firm and analyzed by Mr. McCreath, gave the following result.- - Water at 225 degrees, 030 ; volatile natter, 460 ; fixed carbon, $\$ 9,576$; sulphur, 821 ; ash, 9,113; total, 100,000 . The coke made by the irru is of a silvery lustre cellular, witl a metallic ring, tenacious, as free, irom impurities as it is possible to be got, and eapable of bearing a heavy weight in the furnace. I is partícularly in demand as a blast furnate fuel, and also to be mixed with anthracite and bituminous coal in the production of open iron, such as used in the Bessemer process. The resistance to compression displayed in the coke pro-
duced by this firm, together with its porosity, have rendered it indispensible in this class of work. Another departduced by this firm, tagether with its porosity, have rendered it indispensable in this class of work. Another depart-
inent of iron working, in which Messrs. Frick \& Co.'s coke has earned a high reputation, is that of stove moulding. Their coke, as a fuel, melts much faster and works lotter, thus effecting a large saving in had castings and waste in ibe furnace. The estimation in which it is held by sinelters of the precious metals, is seen in the fact. that in some cases the freight is as high as $\$ 2 \bar{j}$ per ton to points in the far west, to which the firm ship. In fact their coke may be sajd to have attained a universal use in the working of metals, and in blast furnaces for iron smelting: it is used all over the country from Lake Champlain in the East to Salt Lake City in the West. Messrs. Frick \& Co produce about 600,000 tous of coke per year, employing in their mines and elsewhere 1,200 men, with a monthly pay-roll of ahout $\$ 50,000$. For their river transportation, (which is comparatively small, the greater part of their shipments being by rail), they use six of their own barges, and for the purbose of transferring coke from the railroad cars to the barges employ a large tipple. The kusiness of the firm extends throughout the Union, wherever metal is worked.

\section{STAR BREW ERY,-C. Bcuerlein, Bro. \& Co., Bennett's Station, Shaler Township.}

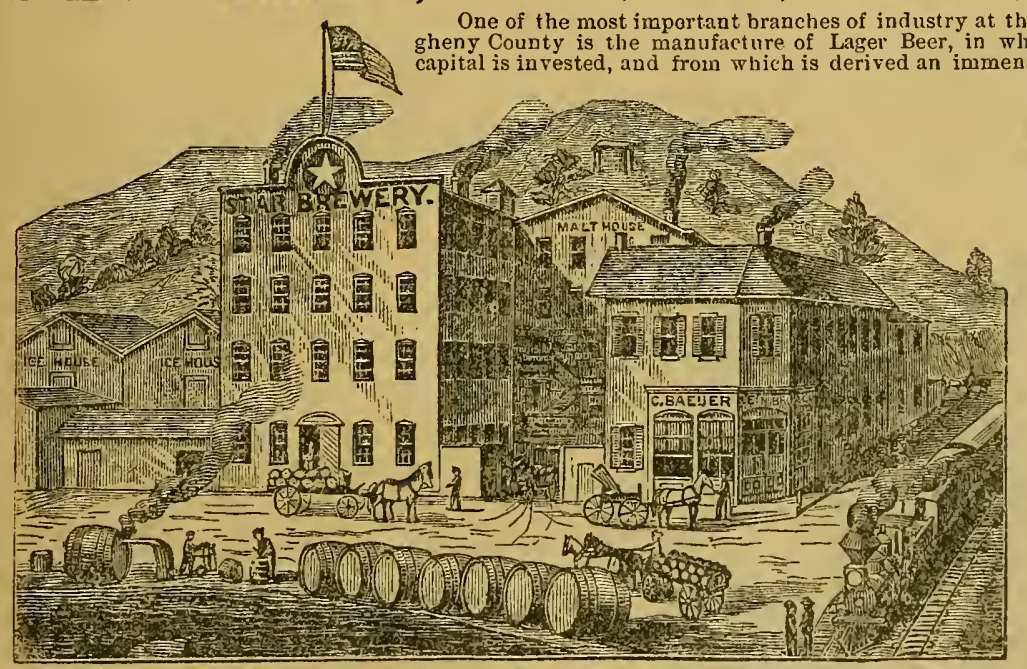

ge amount of the largely increased demand for this now st a ple production years, nuost of the firms formerly engrms in the mantfacture of ale exclusively, have heen compelled to yield to abandon their former business to engage in the manufactire of Lager Beer, and those firms who for years have been brewing their trade so much mand enlarged facilities, and more commodious quarters in which to e ond uct their husiness. To the old established houses, who for years have furnished an Beer, too arlicle cannot be a warded for their efforts in developing the taste for this delicious and health -:ving hercrage. Probably one of the oldest and most successful beer hreweries in this section is that of Mes-rs. C. Breucrlein, J3ro. of Co., locatiul at Bennett's Station, on the West Pa. R. R., ahout two miles from the Allegheny' Statinn, and known as the Star Brewrer:, which is one of the most perfect and complete jn all its appointments of any similar establishment in the West. The business was founded in 1845, by Mr. Adam Bxuerlein, in the 5th ward, Pittslurgh, and subsequently reuroved to its present location, where better facilities were olotained, and the business enlliderahly inerea ed. The present menbers of the firm are Mr. C. Bxuerlein, Mr. Adim A. Bieuerlein and Mr. Fred Klusman. The huildings necupied by the firm are large and admirally arranged, consisting of one large four-story frame huilding, with a three-siory stone structure in the rear, a malt house five storins in height, with a capacity of 25,000 hushels, two ice houses, liaving a capacity of more than 1,200 tons, ind two additional ones, situated a sliort distanse from the main buildings, with a capacity of 3,000 tons. The brewery and malt house are supplied with all the latest improved machinery and appliances, steam power, \&c., while their raults and ice houses are admirably arrantrer. They carry an average stock appliances, steam power, cc., while their valu reach fully $\$ 60,000$, the principal deminu for their products being in Allegheny and Butler counties. The beer manufactured hy this firm is unrivalled fir purity, tlitor and general excellence, and has attained a wide spread popularity throushout this section, and as an evidence of the appreciation of its fune quality by the public, it is only necessary to cite the fact that each year hrings them greatly increasced trade. Messrs. C. A. and A. A. Bxuerlein are natives of Prtsurg, an the business, and as they use only the very bes practical brewers and inalisters, convel'sant with all the details of the brivin that their success has been fully equal

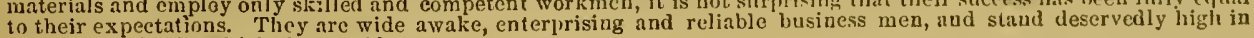
the community in which they reside. 


\section{ST. CHARLES LIVERY AND SALE STABLES,-}

The superior management and fine equipage in connection with the Livery and Sale Stables, now conducted by Mr. J. H. Skelton, at Nos. 121, 123 and 125 Third avenue, is worthy of notice in this work. This establishment is one of the best, as well as one of the oldest of the kind in the city, having been in existence now for over twenty years. It was originally occupied by MIr. W. S. Jackson, and came in to the hands of Mr. J. H. Skelton in 1875 . With characteristic ener y he at once proceeded to improve the facilities, and enlarge the capacity of the St. Charles Livery and sale Stables to fully meet the popular demand. The building occupied is $90 \times 75$ feet iu size, $t$ wo stories high, and is most eligble and conveniently arranged for the business. The newest aud best styles of Curriages and Buggies, Phaetons, etc., may alwitys be found, also good travelers, as well as gentle and reliable liorses, while this is noted as one of the best feed stables in the city. Carriages supplied for funerals or parties on reasonable ternis. Mir. Skelton gives special attention to the undertaking business. with good hearses, which, with or without carriages, will be supplied upon the most reasonable terms, must commend him to the public. Mr. Skelton was born in Chester Co., Pa., in 1838, and came to this city in 186t. He served an apprenticeship and was engaged in the business of carriage manufacturing for a time, which he subsequeutly abandoned for his present occupation. For so many yeurs associated with the industries of this city, Mr. Skelton has won the entire confidence of the community, not only for his agreeable manvers and conrteous attention, but equally for his promptness and reliability in all business transactions.

\section{G.W. \& B. F. GREENE \& CO..-Mfrs. of Ingot Brass, 41st St. \& A. V. R. R.}

In as much as all products of utility do not so shape their condition by chance, or resolve their atomic character in the varied forms in which we find them, it is but fair to say that a superintending hand, as well as a considerate metaphysical mind should have due recognition in the results produced. And so it is creditable to the firm of $G$. W. \& $B$. $\mathrm{F}$. Greene \& Co. that they have in the person of one of their firm, experience and metallurgic ability of rare attainment, and whose familiarity with the varied physical scieuces has enabled him to contribute much of general utility to the world at large, and whose name stands honored in membership with the "American Association for the Advancement of Scievce." All the metallurgic industries of the world depend upon successful results in the preparations of simple and multiple alloys, as that of changing fibrous irou into steel, or metamorphosing copper by cementation from its fibrous nature to an assumed crystalline form, in which condition it is like that of steel, the better suited to rank among the Metaloids used in the construction of seatings in machinery. The novel, as well as wonderful process of carbonizing copper, renders it a carburete, and when conditioned by the desirable equiralents of metallic tin, is properly a bronze, and hence the name "Carburetted Bronze." This alloy possessing the varied gradations of density according to certain standards already determined, becomes the best combinations of copper and tin the world has yet been apprised of. Rolling mill journals, railway, high speed and general machine bearings have therefore in the product of this house, and by its own merit, the best seating superlatively now knowu.

\section{DR. F. LE MOYNE,-Surgeon and Physician, Amberson Av.}

Among those engaged in the practice of Medicine and Surgery, none are more worthy of notice than Dr. F. Le Moyne. He is native of Washington, Pa., and son of Dr. F. J. Le Moyne. He graduated with honor at the University of Pennsylvania in 1863 . Upon leaving college he receired an appointment as Assistant Surgeon in the U. S. Army and shortly rose to the post of Surgeon. At the close of the War he settled in Pittsburgh and began the practice of medicine, when he received the appointment of Assistant Surgeon to the Western Pennsylvania Hospital, and afterwards Consulting Surgeon, a position he still holds. He now enjoys a wide and enviable reputation and large practice, and is especially noted in the department of Surgery.

\section{G. IUDEW IG, -Dealer in Bottled Beer, Foreign \& Domestic Wines, \&c., 100 Centre Av.}

Among the energetic and worthy business houses of this city, we call attention in this work to the house of Mr. G. Ludewig, Wholesale and Retail Dealer in Bot tled Beer, Foreign and Domestic Wines and Liquors, No. 100 Centre avenue. The specialty of Mr. Ludewig is Fine California Wines and Bottled Beer. Orders by mail will receive prompt attention. This business, which was opened in this house by Mr. Ludewig on May 1, 1879, is destined to liecome a popular and important business under the able management of its present proprietor, who has had ample experience and capital, having been engaged in the business at No. 307 Liberty street for a number of years before removing up employs one waonn regulurly and four bands engaged in the business, size, embracing store and packing house, ant specialty is Bottling the celebrated Queen City Brewery's Beer, of Cincinnati, Foss \& Schneider, proprietors, of which concern he is the duly authorized agent. This beer is rapidly gaining in public favor, and is by good judges said to be equal to the best beer in the market. He also makes a specialty of the best California Wines, shipped to him dircet from Sonoma, and can supply families with that upon which they can rely, on short notice. Jir. Ludewig was born in Germany in 1833 and came to this city in 1852 . His experience, excellent business habits and genial manners insure him many friends and patrons and a gradually increasing trade throughout city and country.

\section{F. REILING \& SON,-Iron Railing and Wire Works, cor. Butler and 35th Sts.}

The works of Messrs. Reiling \& Son are located at the corner of Butler and 35th streets, where tliey munufacture all kinds of Iron Railing, Fences, Builder's Iron Work, Iron Shutters, etc. They also manufacture very beautiful Iron Crosses and dexigns for Memorials in Cemeteries, etc. These gentlemen started their industry in 1877 at 34 th street, removing to present location in 1879. This firm holds the proprietorship of a patent invented by C. J. Reiling for Iron Fences, by which they are enabled to make a better, stronger and more handsome fence than by any other method. Mr. Reiling, Sr. was born in Germany and came to the United States in 1850, and has been an iron-worker in this city all his life. His son, C. J., was born in this city and has worked at the same business for eleven years.

\section{WM. MITCHELI \& CO.-Importers \& Jobbers, Hosiery, Notions, etc., 46 Wood St.}

For more than a quarter of a century this house has been engaged, though unostentatiously, in the wholesale trade, doing a good and healthy jobbing trade in Notions and Fancy Goods, Hosiery, Gloves, etc. Thie firm was organized in 1845 as Casey \& Mitchell. Mr. Casey retired in 1870. In 1874 Mr. P. Casey and Mr. W. F. Volmer were taken in partnership under the present firm name. Mr. Mitchell was born in Ireland in 1819-has resided in this city for about forty years. Mr. Casey is also a native of Ireland, while Mr. Volmer was born in this city in 1854. The house offers special advantages to the trade and the business is conducted upon the most conservative and substantial business principles. 


\section{McKEEVER BROS.-Barrel and Keg Manuf'rs, Cor. 3rd \& Bingham Sts., S. S.}

An industry of this nature, especially where conducted with the enterprise and skill associated with that of the firm of McKeever Brothers, is worthy of extended notice in a work of this nature. The business was oriunally started by these practical workmen iv 1874, with moderate capital, but which has been largely inereased by the individual industry and excellent manigement of this frm, until it is now one of the leading firms, in this line of husiness, in this city. They are careful not only to use the very best and serviceable timber, but put up their work in the most subst:tntial manner. They are prepared to fill orders on short notice, as they keep a large stock of matesial ready for use, and the best facilities and appliances to supply barrels or kegs of any variety, either for packing house, glass house, or general country use of auy description. They employ a large force of skilled workmen, and manuficture and deliver to all parts of the eity on short notice, and at lowest market rates. One hoiler and engine of ample capacity are used in these works, and the latest appliances known for faciliating operations. Mr. Thonnas MLKeever, one of the frum, is the inventor of the Patent Grooving Machine in use here, and which has no equal in perfection for it purposes. The individual members of the frm are Thomas, George and James Mclieever. Their trade extents over the two cities and county, and their reputation for promptness, reliability and fair dealing is acknowledged wherever they are known. Among the numler of inventions for which this film have obtained celebrity, we cannot omit lo eall attention to their keg machine, by which they are able to turn out 1000 kegs per day, with very little cost for running the machine. They have iu operation a new barrel machine for chaupering, grooving and leveling harrels, whicl: was patented ina 20th, 1879 . It has proved itself perfect for this work. It has a capacity of turning out 560 bitrrels per day. Both of these machines are of the greatest benefit to those engaged in this business, and cannot fail to tribly pay for themselves in their utility and practicability as labor-saving machines.

\section{JOSEPH BLACKLEY,-Successor to Blackley Bros., Coal and Slack Coke,}

This business was first started by Blacklev Bros. as early as 1858, and continued Do. 120 Twenty-First st. the firm changed and the present proprietor", Mr. Joseph Blackley, bceame owner. Since that time April, 1877, when business. He alwass keeps a sufficient stock to meet all demands, with ample capital and facilities to fill all orders. He has a large number of ovens in use, and is prepared to fill all orders of colie with the greatest of promptness. He does a very fair lusiness, hitving a large number of regular customers whom he supplies. He enploys such a number of hands as the demands of his business require, and will be found a prompt and agreeable business man.

\section{NATIONAL GARDEN AND PUBLIC RESORT,}

We would like to give a fuller notice than our space will justify of this pleasant, popular resort. The National Grarlens are siluated at the head of Mt. Oliver Incline Plane, and is one of the most desirable places of popular resort associated with the two cities. It is owned and conducted by that popular, genial and enterprising gentleman, John N isser, Esq. The place was first prepared for this purpose in 1877, and is now most efficiently conducted and provided with everything which can make it inviting and at tractive to guests. Besides this the visitor can here lave the hest view of the city and surrounding country to be had in the neighborhood, a view which extends from 18 to 30 miles over the most leiutiful landscape in the world, the two cities, the three rivers in all their beauty and grandeur as they traverse the benutiful valleys. Regular botel accommodiations can be had at most reasonable ratrs, tiesides all other refreshments of the season to order. No stranger should visit the eity without takıng view from Mt. Oliver Garden and enjoying the luxuries there.

\section{MONONGAHELA INCLINE-PLANE COMPANY.}

It is a picturesque and beautiful sight to stand upon the northern bank ot the Mlonongahela, looking south ward at the almost mountainous bank, towering like a protecting bulwark to the lieight of sereral hundred feet, and then to witness its scientific mastery by liumal science and engineering skill. Ascending and descending its rugged and almost perpenticular front, the smooth track of the various Incline-Ritilway tracks convey cars ascending and descending like mammoth balloons iraversing the air. Perhaps the most noteworthy and conspicuous of these is the Monongahela Incline Plane, which affords access to Mount Washington, and is operated athout 250 feet. below the Monongahela bridge. In July, 1868, a plan, submitted by Mr. John J. Endress, a civil and mining engineer of celebrity, was adopted, and measures takent to enry it into execution. The Monougahela Ineline-Plane Company was organized under the laws of the Stute and charter obtained in 1869 , with a eapital stock of $\$ 75,000$. The almost Hereulean difficulties were surmounted, the work completed and the operation of this road commenced in Maty, 1870. Its success was assured in the feasilvility of the plan, thus securing most incomprehensible benefits to the rapidly-growing lorough situated upon this lively summit. As an evidence of its suceess, we may mention that during the year 1878 the receipts were

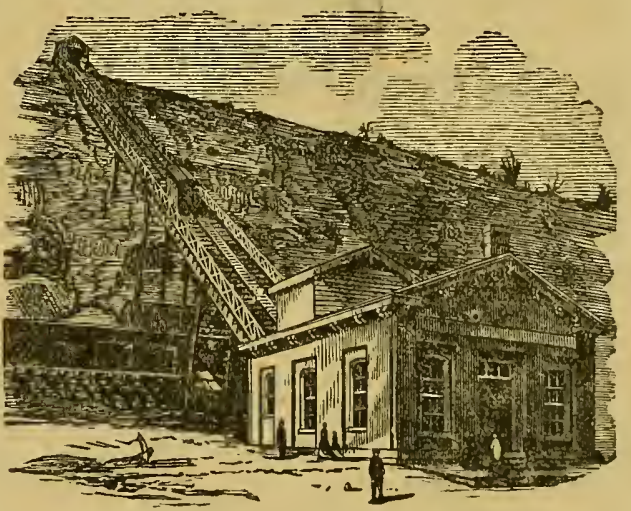
$\$ 15,000$. A double track is laid, with excellent ind convenient buildings for stations at the base and summit, while the operating uachinery is in an additional huilding on the summit, the engine house fronting on High St., unrthward. While one car ascends the other descends, and thus trijs are made every five minutes throughout the daly and until after midnight. The engine used is a twelve-incly cylinder, with two-feet stroke, and the hoiler is Witherow Donglass' patent, and the stecl-wire cables which are operated from the engine house over Higl Street, are of the must approvel mike for' securinu safety and are supported on the track hy wooden rollers. In addition to these, a second steel-wire cable is used, called a "drag calle," one and wne-eighth inch in diameter, which is provided as a doulile suret y against any ancident, making it an utter impossibility that any accident of a serious nature could ever occur. The length of the plane is 640 feet, waking an elevation of 370 feet, while the angle of the plane is 30 degrees. The ears, rope, and all parts of machinery are inspected daily, so that there is no more danger, indeed not so much as upon an ordinary street railroal. These high and beautiful elevations are brought into eas communication with the city and pleasant and inviting views presented to the lovers of all that is beatiful in lindscape scenery where everything in nature and art combines to forn loveliness and beanty. The beatutiful rivers, the cities of Pittsburgh and Alleghen $y$ and the nutlying country surrounding for a score of miles never loses its joveliness or attractions. The officers of this Company are: Samuel Harper, Esq., President, Jolun Aull, Secretary and Treasurer; with Wm. M. Lyon, M. Bailey, Witherow Douglass, John S. MIcilijlin, Wm. Halpin, Geo. W. Bertzhoover and John L. Aull, Directors. No stranger should visit Pitusburgh without taklng a view both in daytime and at night from Mount Washiugton. 


\section{REED \& CO.-Advertisers' Agents, 55 Fifth Av., First National Bank Building.}

The absolute necessity of advertising to the mercantile community, and the annoyance as well as difficulty of giving personal attention to the details of this essential department in every well conducted business, has naturally led to the establishment of agencies through which to reach the various mediums in any given district. It has been the course of these agencies in the past to represent certain papers for which to obtain from advertisers the largest possible price for the matter inserted, which order of doing business las been lately entirely revolutionized by Reed \& Co., who may be more accurately called "Advertising Brokers" instead of "Agents" inasmuch as they represent not the papers, but the advertiser instead. This firm's mode of doing business is, as before intimated, to manage to the interest of the advertiser in securing the best possible terms from the various journals conducive to the advantage of their patrons, thus procuring contracts, from their knowledge of actual worth and extensive dealings, at a much less cost than could be stipulated for by any private or separate concern. This business was estatlished upon this improved plan in 1875 by Mr. C. McF. Reed, the present senior partner, and has met with the most substantial success, engaging the attention of one book-keeper and from two to four solicitors. The firm has special arrangements with all the various newspapers within a radius of one hundred miles, making a specialty of advertising manufacturers in all the leading class journals of the United States, by which special advantages are secured for the advertiser, who is, if desired, relieved even from the onerous duty of furnishing the copy, Messrs. Reed \& Co. contracting to conduct every part of the business, upon terms that prove highly ad vantageous to those who avail themselves of this house. Mr. Reed is a native of Washington, Pa., where he was born in 1848, removing to this city and becoming a permanent resident bere in 1873, from which date to 1875 he was engaged as publisher of "The People's Monthly," since which latter date he has been identified with his present vocation, in which his aptitude is widely recognized. The firm is a particularly pleasant one with which to transact business, and to those who are seeking the best means of hringing their trade to the notice of the public, Reed \& Co. are cordially commended as being able to assist and advise them in a rery effectjve manner, and at a saving of a large percentage on contracts.

\section{LINDSAY \& McCUTCHEON,-Iron Manufacturers, Rebecca St., Allegheny.}

Messrs. Lindsay \& McCutcheon occupy a prominent position among the industrial avocations of this community. Established in 1863 by Messrs. Jas. H. Lindsay and H. D. Whipple, the house was founded with a capital of very limited proportions in cash but an extensive fund of experience, tact and resolution from the very first, assuring the brilliant success that followed. In 1864 Mr. Whipple retired from the concern and was succeeded by Mr. James McCutcheon, when the present style of firm was adopted. Devoting itself especially to the nlanufacture of hoop, band and horse shoe iron, cotton ties and horse shoes, the product of the house became widely recognized for jts excellence, naturally resulting in a rapidly augmenting trade. Various improvements and additious were made to the works which are now classed with the largest and most complete in the country. They consist of two inain iron roofed structures respectively $225 \times 127$ and $90 \times 220$ feet, together with numerous smaller buildings, covering in all an area of more than two acres. The manufacturing operations are sub-divider jnto three departments, the machinery of which is operated by ten engines with eleven boilers, embracing a total of 550 horse-power and employing 270 men and boys, requiring an outlay to this source alone of over $\$ 120,000$ per annum. Several valuable patents have been secured hy this house in the line of their manufactures, particularly on machires for making horse slioes and cotton ties, the former being turned out at the rate of 60 per minute. In order to secure a coal supply for themselves, the firm some time ago secured the new Eagle Coal Works, at Monongahela city, a fine property of 160 acres, with mining capacity of 6,000 bushels per day. In operating these works the house have invested a capital of $\$ 10,000$. They employ 100 bands, 64 coal cars, 4 mules, one coal tipple, 13 flat boats, steam engines, boilers and other machiuery, producing about $1,200,000$ bushels of coal per annum, at a cost for labor of nearly $\$ 6,000$ per month. This product, large as it seems, and convenient for shipment to the works, falls considerably short of the requisite amount to supply the consumption of the mills. Both members of this firm are not only active and indefatigable in their immediute business, but are largely connected with other enterprises-banks, insurance companies, successful corporations, and the municipal gorernment. Considered individually and as a firm, there are fow concerns that conduce more to the general prosperity or receive a greater share of the public esteem and appreciation.

\section{B. H. LUBBER,S,-Wines and Liquors, 386 Fifth Av.}

The wholesale and retail establishment of Mr. B. H. Lubbers was founded in 1864 by the present proprietor, and is one of the most widely known and firmly established houses in this line of business to be found in the Tron city. Mr. Lubbers keeps constantly on hand the best brands of foreign and domestic wines and l'quors, and wakes a specialty of champagnes and bottled beer. M. Werk \& Son's celebrated brand of Golden Eagle Champagne may always be found at this estahlishment by the case or single bottle. Mr. William Moeck has charge of the books and office department and is thoroughly conversant with all the requirements of the trade. Mr. Lubbers was born in Holland in 1820 , be came to the United States in 1837 and located in Pittsburgh in 1864, establishing his present flourishing business the same year.

\section{P. SEIP,-Fine Confectioneries \& Candies, Bread \& Cake Baker, 4303 Butler St.}

Mr. Sejp has in his store room a fine stock of candies, confectionery, cakes, etc. The husiness was started in 1869 at the corner of 21 st street, moving irom there to present location in 1871 . Mr. S. was born in Germany in 1806 , came to the United States in 1833, stopped in Chambersburg, Pa., five years. Was overseer for two years of a uegro plantation in Virginia, came over the mountains to Pittsburgh in an old Conestoga wagon, in 1838; working at lahoring work of different kinds after coming here, at very low wages; in 1841 he started a grocery store in the old Fiftl ward, afterwards added hardware to the business, continuing in that business $17 \mathrm{years}$. In 1859 he bought a ferm, living on it ten years, returning from that he embarked in present business, bis son having acquired a knowlege of the bakery and confectionery business.

\section{CRAIG \& WILSON,-Groceries and Feed, 329 Fifth Avenue.}

The business now conducted by the ahore-named firm was originally established by Mr. Henry Swan, who was succeeded by the present firm. They carry a large and desirable stock of Choice Family froceries of every description, at wholesale and retail, also a Feed Department, where all kinds of Grain, Oats, Mfeal and Mill Fced is kept constantly on hand. S. H. Wilson is a native of Pittsburgh. Mr. Wm. Craig was born in Allegleny county in 1840 .

\section{FERMANN RUFF,-Practical Hatter, 2031/2 Fifth Av. Extension.}

Mr. Ruff commenced business at his present location A pril, 1, 1877. He is a thorough practical hatter, manufacturing every description of silk and felt hats of the finest quality. He makes a specialty of manufacturing fine hats to order and of altering silk and felt hats to the present style at moderate prices. Mr. Rufr was born in Germany in 1837, and has resided in Pittsburgh since 1876, where he has built up a thriving and prosperous business. 


\section{THE BANK OF PITTSBURGH,-Fourth Avenue.}

burgh and other tinancial institutions of this city, to say that history and magnitude, in a tiduciary sense, peculiarly eminent and peculiarly its own. Organized in 1810, and chartered by special enactment in 1814, the Bank of Pittsburgh from that time has wielded a controlling intluence upon the finances of this community, an influence uniformly of the most benign character consistent with the successful management of any monetary concern. This is one of those signally few institutions in the United States which were a few days in 1837 when by a formal request of the citizens the bank withheld its butlion. At all uther periods, however, and even at that time, the policy of the bank was held inviolate, that its obligations issued ujon a coin basis were at all times redeemable in coin. During the disastrous years of $1839,1841,1857-8$ and 1861 , when nearly every banking institution in the country suspended specie payments, this financial Gibraltar continued to disburse gold, and in pursuance of this policy paid out ietween December 30,1861 , and December $1,1866, \$ 1,374,938.99$ in lullion. The capital of the Bank of Pittsburgh is $\$ 1,200,000$, and its accumulated surplus $\$ 244,996.40$, while a line of deposits is carried ranging in round numbers, $\$ 1,500,000$. Among its officer's and directors will be olsserved names that are synonymous with in tegrity and closely associated with the history of Pittsburgh's progress and development in the naterial industries for which she is celcbrated. The first president of the institution, elected in 1814, was William Wilkins, who heads the list of chief executive officers, the same being in order of office as follows:-John Darragh, John McDonald, Ww. H. Denny, Toln Graham and John Harper-the last named incumbent at the present time. Ou the first Tuesday of May, 1815, the bank declared its intial dividend of four per cent., and from that time, with no omjssions, and unfailing regularity, semi-annually, on the first Tuesdays of Mlay and November of each year, a ctivision of the protits has taken place. The total amount of earnings so disbursed reaches in the aggregate the sum of $\$ 4,728,793,66$, which till 1833 , when the capital was increased to its present dimensions, was derived from an actually paid-up capilal of only a quarter of a million dollars. During the late war the Bank of Pittsburgh loaned to the general Government $\$ 820,000$ and to the state $\$ 9 j, 000$, besides contributing voluntarily to the aid of voluuteers and the construction of home defences $\$ 16,280$. Originally a bank of issue, since 1862 its notes have been destroyed as fast as redeemed, and at this time none are in general circulation, the books showing the outstanding paper to be only $\$ 18,000$, much of which is presumed to have been lost, mutilated heyond recognition or consumed by fire. The untarnished policy of commercial houor that has always controlled the operations of the Bank of Pittshurgh seems to have had a powerful reflex influence upon those with whom it estallislies business relations, as an eridence of which it may be stated that, though many of its customers were bankrupt and utterly ruined by the great fire of 1845 , yet, strange to say, the ljank did not lose a dollar by this disastrous conflagration. The chief executive of the institution at the present time is, as before mentioned, Mr. John Harper, who for nearly half a century has been identified with it, having acquired his present position through the channels of promotion fron subordinate offices. Wm. Roseburg, Esq., Caslier, has also been connected with the bank for no ordinary period, aided by John A. Harper, Esq., Assistant Cashier. The Board of Directors is composed as follows: John Harper, President, Wm. Morrison, Joseph Woodwell, Reuben Miller, Jas. Dalzell, W m. MeKnight, Chas. Hays, Wu. A. Caldwell, Wm. Holmes, Hon. James Veech and Hon. Felix R. Brunot, gentlemen too well and widely known in this community to require personal mention or individual assignment. The subordinate officers of the bank count Clerk, and others in minor positions. The bank effects foreign and eastern exchanges through the National count Clerk, and others in minor positions. The bank effects foreign and eastern exchanges through Pre Natrania, with a history reaching through three wars, always patriotic, lending to the Government in troublous times when others sbrank back, giving lilierally, even with prodigality, for sanitary purposes during the late rebellion, the Bank of Pittsburgh is an institution of which every citizen is justly proud and iu the possession of which the Iron City is to be felicitated.

Wm. Wilkins, 1st President, John Darragh, 2nd President, Jolın McDonald, 3d President, Wm. II. Denny, 4th President, John Graham, 5th President, John Harper, 6th Presilcnt-snceeded 1866, connected with the bauk since 1832 and for a long period filled the position of Cashier. 1st Cashier, Alexander Johnst.on, Jr., 2d Cashier, John Sny$\$ 700,000$. Never failed to pay a dividend.

\section{AMERICAN BANIR,-Cor. Wood St. and Sixth Av.}

This widely-known and favorite financial institution was organized in 1869 with a capital of $\$ 200,000$. By the organizalion effected John Floyd, Esq., practically the founder of the institution, lecame President and W ml. Floyd, Cashier. Mr. Floyd is one of the merchants of De old regive. Mr. W. Floyd, the Cashier, enjoy's a ligh reputation for capacity as a t-Law; James W. Anote, Underwriter; Jno. M. Murtland, Real Estate; Arehibald Wrallace, Marshall, Attorney-at-Law; James W. Anote, Underwriter; Jno. M. Whorced Charles B. Leech, late deceased. Under the supervision of this Board the prosperity and success of the concern was a "foregone conclusion."

\section{PETER ZERN,-Tobacco and Cigars, 400 Penn Av.}

One of the hest known Cigar and Tobacco establishments in Pittsburgh is that of Peter Zern, Esq., at No. 400 Penn avenue. For the past fifteen years Mr. Zern has been engaged in business on this same square. He carries a fine stock of imported and domestic Cigars, Manufactured Tobaces, Smokers' Articles, etc. Among his special brands we notice "Our Mary" and "Zern's Delight," which are deservedly popular. Mr. Zern has resided in Pittslurgh for the past forty-two years and has taken an active part in State and usunicipal atfairs, having great influence in that section of the city. He was a member of the State Legislature from 1875 to 1878 inclusive, represented bis ward in the councils of the city for six year's-tive years in' the common and one year in the select braneh.

\section{CENTRAL HOTEL, -Geo. J. Bridge, Propr., 17 Carson St., South Side.}

This house is a large and handsome building of brick and stone, having a frontage of 70 feet on Carson street and extending back 60 feet-four sturies high. This estahlishment, which maj be considered the leading lotel on the South Side, affords ample and superior accommodations at moderate charges. It deserves and receives a large share of patronage. Mr. Briclge enjoys the confidence of his patrons, and those who favor his house with a call will always patronage. Mr. Bridge enjoys the conf colifort.

\section{PROF. SLACK DAVIS,-Instructor, 285 Fifth Avenue.}

All persons interested in education, which alone can elevate the standard and promote the happiness of mankind, are conscious of the importance of securing for their clildren, or those in whom they are interested, the most able, accomplished and thoroughly qualified insiructors. We take pleastre in assuring those who may peruse this work accomplished and thoroughly qualied in this city who bear a higher reputation than Prof. Slack inaris, not only for that in this a vocation there are none in this cit who bear a hich is in a great clegrce intuitive, of communtuicntiug or high moral character and attainments, but also for that gift wheh is in a gavestruction privately, or in classes, in all transmitting knowlerge and its value to others. Professor Davis gires instruction prom patrons and pupils of this city in according him the fullest commendation. 
BRTGGS \& DRUIM,-Com. Merchants of Cattle, Hogs \& Sheep, Central Stock Yds.

To many the large amount of business conducted at the Central Stock Yavds will he a matter of surprise. We proeeed here to give a hrief notice of one of the most prominent and Jeading firms ansociated with this liranchl of business; Mr. C. Q. Brigfs having jreviously had a thorough knowledge of the feneral stock trade, eommenced lusiness here in 1871, ufterwards associuled with himself Mr. John Drum, and the business is now conducted under the abore firm name, with Mr. C. Q. Briggrs eattle salesman, Mr. L. Dyer, hog salesman, and Mr. John Drum, sheep salesman, S. B. Sedwick, agent, Indiunapolis, Ind. Those who may not be familiar with them can refer to 'T. Robinson, Columbus, Ohio, C. M. Keys, East St. Louis, Ill., Weber, Loper \& Co., Cincinnati, and City Deposit Bank and Trust Company, Pittsburgh. Messrs. Briggs \& Drum are perhays the most extensive operators and enjoy the most superior faeiities for the disposition of stock of any firm in this city. They bave ample capital and their transactions for the year will foot up to about $\$ 2,000,000$. Besides providing for each department a special salesman, they cuploy several extra men in the business. Mlr. C. Q. Briggs was born in Ohio in 1831 and Mr. Drum in this city in 1837. These gentlemen are men of high standiug in the community and are eminently entitled to the popularity accorded to them.

\section{ARSENAL BANK, - Butler and 43rd Sts.}

This popular and reliable institution has now been in existence eiglit years, liaving been ehartered in 1871, during which tiue it has sucessfully competed with older and larger institutions and has won a hiori degree of liublic favor as a relial,le and solid bank. Its capital js $\$ 55,000$ and it has an average deposit of $\$ 150000$; its influence and popularity is yearly extending "uder the popular management of its enterprising officers. Mr. S. J. Wainwright, the senior member of the tirm of $Z$. Wainwright \& Co., is president; Mr. G. C. Gerwig, the cashier, is a native of Allegheny city. He has held the position of cashier in this bauk for a number of years, and the success of the institution is largely due to his albilities as an able financier-previous to his eonnection with this hank he had been eonnected for many years with other hanking institutions, acquiring a thoroughly practical knowledge and experience so neeessary in financial matters. The director's are all men of ligh ability and integrity, the ho:udd is composed of $S$. J. Wainwright, J. G. Wainwright, H. E. Wainwright, J. W. Campbell, Wm. Bowersinith, J. C. Wallace, G. W. Smith, James Sugden, Sumuel Mckinley, Wm. Reardon, K. J. Riehardson, T. H. Sugden, all of whom are well known and respected citizens.

F. BAXMYER \& CO.-Flour, Feed, Groceries, \&c., Washington Av., 31st Ward.

With an ample capitul for the transaction of the business in the start, this firm commenced business in their present location, Washington avenue, 31st ward, in 1876, as a branch store of house on Binghan street anut Diamond, South Side, since which time the business has met with a liheral patronage. They keep a choice stock of flour and feed and an ample stock and variety of groceries and provisions, embracing every desirable article usually found in a first-class grocery and provision house. The menbers of the tirm are Mlr. Henry Logemen, Mr. Henry Rudel and XIr. F. Baxmyer, of the sane firm on Diamond, South Side, each of whom is an accomplished business man. They delirer goods free to any part of the eity. This is the only tirm that handles the "Oeean Spring Mill" brand of flour, which has no superior in this city or State. The prineipal store of this firm is on eorner of Binglam and Diamond, South Side, where they have been established for many years and well known. Mr. Henry Logenan was born in Prussia in 18.13 and came to this city in 1849. The energy and enterprise, with which this business is eundueted by these gentlemen entitles them to a place among the principal business houses of this city.

R. S. HEMIUP,-Dry Goods, Groceries, Boots \& Shoes, 554 \& 556 W. Carson St.

This is one of the most prosperous establishments on the South Side of the eity. A full and eomplete stock is always carried, giving the public a varied and select assortment of general merchindise to select from. The stock canried by this house embraces dry goods, trimmings, hats, caps, hoots and shoes, groceries, provisions, hardware, house furnisining goods, ete. The premises occupied are two buildings which are well and conventiently arranged for lusiness purposes. Seven salesmen or assistants are eonstantly employed the trade of this house is stendily increasing from year to year, and a business of not. less than $\$ 100,000$ is transacted annually. Mr. R. S. Hemiup is yet comParatively a yeung man, possessing yood business qualifications. Some years ago he commenced business on a yery Hemiup stands prominently among the leading retail houses of the Iron city.

BTSSELL \& CO.-Stoves, Ranges, Grates, Fenders, Railroad-Car Heaters, \&c., \&.c., ¿35 Liberty St. and 24: Penn Av.

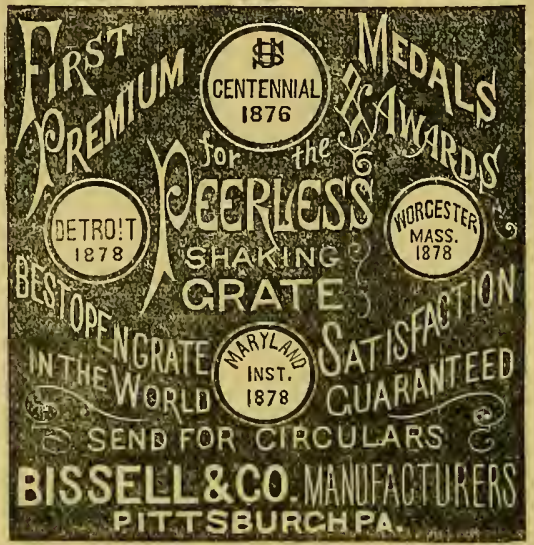

The firm of Bissell \& Ce. occupying the extensive ware-rooms at 235 Liberty strect, and extending through to Penn arenue, are successors in a dircet line to the first house in Pitishurgh which engaged in the manufacture of stoves, a husiness which has since become one of the leading industries of the city. Their foundry and slonps are located in Allegheny eity and are fitted uj) with aill the appliances for turning out work of a superior character. Besides their extensive jroduetion of a great ririety of Cooking, Parlor and Heating stoves, Ranges and (trates, they manuficture several specialtics, amonest which are their "Preiless" slatking Grates and salety Railroad Car Stoves. Their "Peeriess" (irates, adapted fer the use of either lard or soft coal, have met with a ready sale throughout the cutire extent of this country and Canada, and judging from the rapilly increasing demand and the many mclials and premiums reeived, they must be the liest grates at present in the murket. Their Salety Car Stove, called the "Bissell sufety Car Stow" is the result of al long series of triuls and experiments, and having been thoroughIy tested by some of our leading milroal men is by them prononnced a decided suceess. This stove is so constructed that in the event of accident the fire is instantly tingujshed, thus insuring safety to life and property ; hesicles importint features the stove is bandsome, durable and a (n)werful heater, lecing the only railroad stove known of that thus fully meets ail the requirements of the times. In addition tis the ahore lines of goods of their own manufacture, Bisseli of $\mathrm{Co}$. deal ahore lines of goods of thcir own manufacture, Bisseli ct Co. deal
cxtcusively in marlile and slate mantels, and show in their warerowms the finest assortment of these goods to be found in any ("ity in the eountry. In eonclusion we can ouly say that for heaty of design, supcriority of workmanship and perfection of linish Bissell \& Co.'s products will take rank with those of any house in this country. 


\section{PITTSBURGH FOUNDRY,-A. Garrison \& Co., Office, No. 6 Wood St.}

There is much that is of more than ordinary interest in the contemplation of the rise and progress of the Iron interests associated with this city. Its development in its various branches has called into active employment thousands of hborers, and exhibited as high a degree of excculive aud tinancial ability as any operntions in which human enerey and enterprise have been employed. There is perhaps no one establishment to which Pittsburgh is nore indebted for the enviable and world-wide reputation enjoyed, which stands more conspiculously before the public for the magnitude of its transactions than that of the Pittsluggh Foundry, which bas had an existence ol over half a century; and in a work of this nature, giving somewhat in detail the prominent industries and activities of the Iron city, the firm of $\mathrm{A}$. (iarrison \& $\mathrm{Co}$. are entitled to more than a passing notice. Through the vicissitudes of trade and the various financial embarrasments which lave alficted the nation since the orgatuization of this establishment, it has maintained an unblemished character, and continued its operations upon the most bonoralle and successful liasis. 'The works of the Pittsburgh Foundry are situated at the corner of 9th and Birmingham streets, Birmingham, where the plant covers an extensive area, and where every facility, which the gradual development of time and expericnce has been abje to suggest as an allxiliary to the production of the highest grade of products in this lisie, has been froun time to time promptly introduced, until now the machinery and appliances employed by this firm are unsurpassed by any similar establishment in the country. The specialties to which the firm are devoted are Soljd and Hollow, Chilled, Sand and Patent. Homogencous Steel Polls and Rolling Mill Castings. It is unnecessary here to enlarge upon the quality of the Rolls produred by the Pittsburgh Foundry, berause they have by their superior excellence established for themselves a permanent and enduring reputation, which has created a demand through all parts of the country, and the enterprising charaeter and liberal policy pursued liy this firm in all its operations and business transactions warrants the highest eonfdence in the superiority of its products. There are few anong those engatged in the ellterprises of magnitude in this city, who have held so long and contiuned association with its industries as that of the senior member of this firm. Mr. A. Garrison became associated with this enterprise about forty-six years ago, which marks a period of the most rapid strides of seience, national and commercial growth, and yet in these years this establishment lits kept in the van of progression and now stands unrivaled bolh in its faeilities and products.

\section{DILWORTH, PORTER \& CO.-Railroad \& Boat Spikes, Angle Bars \& Bolts,} office, No. 5 Mononyalela House; Worles, South Side.

For the extent of its operations and the high quality of its products, the establishment of Dil worth, Porter \& Co. benrs an enviable reputation and is justly entitled to more than brief mention in connection with olber enterprises through which the celebrity of Pittshurgh as a manufaeturing center has been so thoroughly established. Founded in 1352 by and under the style of Porter, Rolfe s swelt, the house assumed, tive years later, its present tille and status, continuing from that period a career of unbroken prosperity and uselulness. The inception of the enterprise was by no means upon a scale of such magnitude, its growth being the result of more than a quarter of a century of honest and inventive effort. New devices, ingenious machinery and labor-saving and perfecting mypliances have been gradually introduced, with widening experience, until the present plant of the firm is justly regarded as being the largest and most thoroughly equipped of any similar conceru in the country. As an illustration of tlie truth of this statement, it may be said that the works which are loeated on the sout bide corer an area of over two acres, and enploy about two hundred workmen, most of whom are skilled artisans, the monthly disbursement to this source alone averaging $\$ 12,000$. Mfuch of the machinery was patented by the firm, and is exelusively controlled l,y it; requiriug two steam engines of two-hundred horse-power to supply the necessary motive force. The products of the concern are Railroal and loat Spikes, Solid-Lip, Wrought-Iron Railroad Cliairs, Fish Bars, Angle Bars and Bolts, the annual cap:ceity heing about 8,000 tons, and the trade extending over the entire United States, being, however, mainly in the James $\mathrm{H}$. Swett, all of whom are prominently identitied with the industrial interest and material ilevetopment of this city.-With a history extendin't over so considerable a period, and a recorl untarnished by any deiection from an honorable business policy, keeping equal pace with every progressive movement conducive to a hightier grade of procluet or the improvement of the condition of its dependents, the house of Dilworth, Porter \& Co. has justly aclieved with its suecess a reputation that confers upon it the respeet and conlidence of all those with whom it has established commercial relations, as well as the public at large.

\section{H. W. FULTON, M. D.-Penn and Hiland Av's, East End.}

Doctor Fulton is a native of Westmoreland Co., Pa., and was born in 1838. Just at the close of his classical and aeademical course under Dr. Donalson at Elder's Ridure Arulemy, the war broke out and young Fulton, with many of his associates, went nut with the "three montbs' men," subsequently enlisting in Col. Jarrets (53rd) regiment for the w:r. Il is quick intelligence and attention to duty, together witl his soldierly bearing and genial disposition, soun attricted the notice of the general offecrs of the corns, and he was detailed and assigned to headquarters on duty in t. 1 Signal Corps. Here during the war he attained eminence and was mentioned in dispatches from chicfs of this particular and most exacting demartment of the serviee to headquarter's in the most flattering reports. Upon the expiration of a 3 years' term of serviee he began the study of medicine with Dr. Willard of Allegheny City, and graduateel with honor at the Pliladelphia Hahnemann College in 1872, and located in what is known as East. Lilierty, 19th wird, in the Spring of the same year. Among the inembers of his profession, Dr. Fulton is ranked ju the first class as a physician and surgeon, and by all the community as a cuitured gentleman and one of the most liberal and enterprisiug citizens.

\section{F. HAMPE,-Hotel and Groceries, Main Street, Mount Oliver.}

Among the leading business houses of Mount Oliver is the Hotel, Grocery and Provision Store of Mr. F. Hampe. He started the husiness iu 1862, and has all along enjored a good patronage. The busincsa is embraced in at threeswory brick huilling, $40 \times 45$ feet in size, and a frame building two stories high of the same dimensions. II is stables are $24 \times 90$ feet in size. He owns one of the most prominent residences in that lncality, with grounds surrounding beautifully environed with trees, shrubs and flowers. This site commands a fine prospect of all points of the compass: it is in sight of the Mount-Oliver Ineline-Pline, of which Mr. Hampe is one of the original direetors. II was the originator and principal projector of the Minunt-Oliver Insurance Commany, of which he was elected President, which position he still holds. The Hotel of Mr. Hanje is a popular and desirable stopping place, and enjoyed by all who stop there.

\section{CHAS. F. NOURSE,-Druggist and Pharmaceutist, 190 Centre Av}

Mr. Charles F. Nourse started in husiness in the spring of 1873. Dr. Nourse carries a full line of Drugs, Medicines, Chemicals, Paints, Varnishes, Faney Goods, Perfumery, Toilet Articles, ete. Dr. Nourse is a native of Laneaster City, $\mathrm{Pa}$, where he was born in 1845 , and came to this city in 1873 . Special attention is given to filling ply ysicians' preseriptions. 


\section{MeVAY \& WALKER,-Manufacturers R. R. Cars, Car Castings and Irons,} Pitt Cars, Wheels and Coal-Works Castings, Oil-Rig Irons, \&c., Braddock's Field, Pa.

Among the most extensive manufacturing establishments in the environs of Pittsburgh must be classed the works of MeVay \& Walker, located at Braddock's Field, on the line of the B. and O. R. R., and ahout eight miles from the center of trade. The firm was organized in 1863 and the buildings erected in 1864, and form in all a plant of large dimensions. The various structures are at present of the following dimensions: one building $91 \mathrm{x} 165$ feet, one $60 \times 120$ feet, two $40 \times 100$ feet, besides blacksmith shops and other buildings, yards for sidings, metal, and covering in all an area of several acres. Nine forges are in constant operation, the consumption of iron daily amounting from two to eight tons, and from 25 to 80 skilled artisans are employed, the number depending upon the exigencies of the trade. The establishment is divided into three main departments, in which is carried on the work of Founding, Car-Building and Forging, the ploducts consisting of all varieties of Railroad and Coal-Works Castings, and Forged Irons, as weli as the manufacture of Railroad, Pit and Dump Cars of every description. Witl reference to the latter, it should be stated that Thomas McVay, the senior partner, has invented an automatic Dump Car that possesses many adrantages over anything of the kind male, and over similar devices heretofore introduced, having advantages in construction and operation of marked superiority. The business of the house, which was legun on a very limited scale, now extends over the entire United States, an order for 100 Mining Cars being lately filled for the Colorado Mining Co., Colorado. - The individual members of the firm are Messis. Thos. M'Vay and Thos. Walker; the former is a native of Washingtou county, this State, and was born in 1815. At an early age he acquired the blacksmithing trade, and in 1836 remored to Pittslurgh, and, in the pursuit of his avocation, with a gradually widening range, has achieved a substantial success. Mr. MeVay is an expert and practical mechanician, as evinced in the construction of the Dump Car lieretofore referred to, and other useful and ingenious devices. Mr. Walker is a native of Pittsburgh, and has always heen a resident of this city. At an early age he became an apprentice to James Rees, where he learned thoroughly the trade of machinist, which he followed until his association with Mr. McVay in the present enterprise. Both gentlcmen are widely known and esteemed, and both, at various times, have been elected to city eouncils, in which body their advocacy of every measure designed to promote the general welfare is recognized and appreciated by the community.

\section{WILSON, SNYDER \& CO.-Brass Founders, Iron Pipe Fitters and Steam Pump} Manufacturers, Nos. 51 and 52 Water $S t$.

Intimately connected and identified with the industries of the Iron City, this firm-established by MLessrs. R. J. Wilson, August Snyder, Robert Marks and Joseph Hite, in 1875-bas developed into a prominence commensurate with its multifarious products and the justly-celebrated excellence of its work. The business and manufacturing premises occupied by the house are situated at Nos, 51 and 52 Water St., and 44 and 46 First Av, and consist of one extensive double-hrick edifice, two stories in height, $54 \times 160$ feet, and divided into the five following departnents: pattern shop, machine shop, brass foundry and finishing shop, steam-fitting and pipe-bending; all of which are supplicd with the most improved tools and machinery, operated by one thirty horse-power engine. As manufacturers of or dealers in Wrought and Cast-Iron Pipe, Brass and Iron Valves, Snyder's Patent Cocks, Lubricators, Whistles,
Tomls, Malleable and Cast-Iron Fittings, Gauge Cocks, Oil Cups, Gum Hose and Packing, Staudard Bronze and Brass Castings, Babbitt's Metal, Steam, Water and Blast. Gauges, the firm does a liırge and extended trade throush Pennsylvania and contiguous States, besides fitting up Rolling Mills, Blast Furnaces, Conl and Coke Works, Oil Refineries, sc., making specialties of the Fort Pitt Steam Pump, patented by the firm, and Russell's Heater for Steam Boilers. As a manufacturing concern, this house enjoys a position with relation to the constructive industries of Pittsburgh that adds no lfttle to the general repute and prosperity of the community. All natives of this city, the several ulembers of the firm are not only practical and active workers in the various departments of their business, but vitally interested in evcry movement that tends to foster the general good. Compared with other establishments of like nature, this eoncern will rank with the largest, and in excellence of work is not surpassed by any. With a stock of $\$ 30,000$ in value, and an annual trade of trom $\$ 70,000$ to $\$ 100,000$, every facility is afforded for the speedy and economical fulfillment of any coutracts that ma be awarded Messis. Wilson, Snyder \& Co.

\section{THE A MIBER BREW ERY. -F. L. Ober \& Bro., 12,14\&16 Vineal St., Alleg'y.}

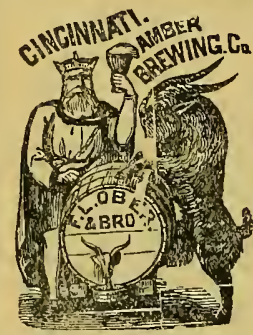

One of the most thoroughlv-appointed and conveniently-arranged Breweries west of the mountains is that known as The Amber Brewery, located at Nos. 12, 14 and 16 Vineal St. Allegheny City, and owned and condncted by Messrs. F. L. Ober \& Bro. The business was Koenig \& Weiser. This firm was, in turn, succeeded by Ober \& Koenig, in 1860. In 1863 Mr. George Ober became sole proprietor, and in 1877 his son, Mr. F. L. Olser succeeded to the business, and in the following year Mr. C. F. Oher hecame associated with his brother, under the firm name and style as at present. Under all these clianges of administration, the quality of Beer luanufactured maintained the same bigh standard of excellence aimcd at from the - tart, and which has given the products of this establishment a wide-spread reputation. The original building in which this business was first commenced was a two-story frame structure, on the same site where now stands the magnificent monument of success. The old huilding was found inadequate to supply the rapidly-increasing business of the firm, and was demolished in 1870 , and in its place was erected the commodious four-stor $y$ brick edifice now occupied by the firm, covering an area of $180 \times 245$ feet, with a brewing capacity of 14,000 barrels, and a malting eapacity of 30,000 bushels per annum. On the opposite side of the street is another building, used as a stable, $75 \times 115 \mathrm{fcet}$. The rock vaults or cellars are three in number, corering a space $30 \times 120$ feet, and are admirably arranged for the storage of Beer. An ice-house, with a cajacity of 1500 tons of ice, is always supplied with erystal icc from Pinc Creek, at Stewartstown, and an unfailing flow of pure and cool suring water is ohtained from an artesian well 300 feet in depth.-The senior member of the tirm is a practical brewer and maltster of more thau fifteen years' experience, and exereises a genera] supervision over the various departments of this model establishment, in which ten competent workmen find steady and remunerative employment. Four double teans and a wagon for bottled Beer are kept busy delivering goods to their regular customers in the two eities. - In adtition to the Brewery business, this house is largely engagel in malting for other breweries. Only the very best quality of inalt and hops is used in this establishuent, and, with the numerous advantages which we have already named possessed by this firm, it is no wonder that the Amber Beer has attained such an enviable reputation in this section. This Beer is speeially adapted for bottling jurposes, and the demand for it in this form for fanily and molicinal purposes is steadily increasing. Over 7,000 barrels of this delicious and invigorating beverage are annually disposed of in this immediate vieinity and in the oil region. An ingenius and elegantly-finishcd apparatus for showing the amount of gas contained in each barrel of Beer may be seen in the office of this Brewery, and is known as the Excelsior Pressure Regulator.-Both members of the firm are natives of Allegheny, and are activc, energetic and reliable business men. They have had long practical experience in the business in which they are engaged, and thoroughly understand all its requirements. They manufacture as fine a quality of Beer as can be made in the Unitcd States, and are pushing their business vigorously and meeting witl the most gratifying encouragement in every quarter. Mr. F. L. Ober devotes his entire attention to the general management and superintendence of the Brewery, and Mr. C. F. Oher presirles orer the office and financial department with marked ability. They are both genial and accomplished gentlemen, richly deserving the success which has already crowned their cfforts io excel in the manufacture of a strietly tirst-class artiele, and the future prospects of this establishment are flattering in the extreme. 
WOLFF, LANE \& CO.,

(Sign of the Anvil,)

Importers and Dealer's in

HARDW ARE \& CUTLERY,

50 Wood Street,

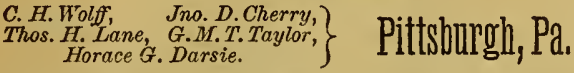
See page 98.

PIITSBURG

CAR WHEEL WORKS,

JOFN I. GILI, Jr., Proprietor,

Office, 83 Wood Street,

PITTSBURGH, PA.

See page 174

\section{NEW YORR \& CWEELAND GAS COAR CO. Miners and Shippers of

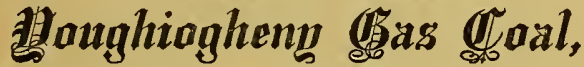

GENERAL OFFICE:

89 Wood Street, Pittsburgh, Pa.

Branch Office: 130 Water St., Cleveland, 0.

T. AXWORTHY, Agent, Cleveland, $O$.

See page 149

John C. Risher.

J. G. RISHER \& Co.,

Miners and Shippers of

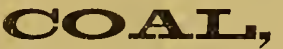

Office, No. 116 Water St., PITTSBURGH, PA.

See page 153.

Fairbanks' Standard Scales OF ALL KINDS; Also, the

"Hancock Inspirator,"

- THE BEST BOILER FEEDER IN THE WORLD;

Store, Warehouse, Platform, Railroad and

Express Trucks and Baggage Barrows.

FAIRBANKS \& COMPANY,

No. 48 Wood Street, Pittsburgh, $\mathbf{P a}$. See page 110.

\section{CONSOLIDATED}

\section{FIRE EXTIMGUISHER CO.}

Manufacturers of FIRE APPARATUS of every description.

Office and Wareroom,

272 Liberty St., in Seventh Avenue Hotel, PITTSBURGH, PA.

J. H. CONNELLY \& SON, Agents. See page 170.

S. Boyd, D. T. Boyd, J. B. Nevin.

S. BOYD \& CO.,

Wholesale \& Retail Dealers in

LOOKING GLLASES, PFCTLRE FRMIME,

MOVLDINGS, dic.

No. 100 Wood Street, PITTSBURGH, PA.

See page 116

\section{W. C. BIDWELL \& CO., GENERAL AGENTS \\ DUPONT POWDER CO.,}

143 Water Street,

Corner Cherry Alley, PITTSBURGH, PA. See page 175.

Chas. B. Head.

Ed 'e'd F. Me Elroy.

\section{HEAD \& MGEROY,}

GENERAL PRODUCE

Commission Merchants,

249 Liberty Street,

PITISTEURGH, PA. See page 118.

R.C.GRAY, W.P. MCCONNELL, J. H. DUNLAP, Gen'l Manager. Secretary. Siny't GRA Y S YRON MTNB Office, 94 Water St., Pittsburgh, Pa.

R. C. GRAY \& M.W. BELTZHOOVER, - Prop'rs.

'Steaners "Tron Mountain," "Fearless," "Ironsides"; with 35 model barges. Les Special attention given to the transportation of STEEL and IRON RAILS and RAILROAD SUPPLIES, and Pittshurerl Inumfinctures gonerally, from PIJTS'BURGII to all points South and West. 


\section{J ACOB J. BRONDER,-Groceries and Produce, Brownsville Road.}

In 1853 the business of this liouse was established by Mr. A. Henger, now over a quarter of a century ago; it rame into the hands of Mr. Tacob Bronder, who started in business here in 1562 . He carries a stock embracing every desirable variety of staple and fancy family grocernes and provisions, usually kept in an establishment of this kind, also coal, flour and feed and has a flourishing and gradually inereasing trade to which he gives his personal attention. Mr. Bronder was born in tlis place in 1512, and is respected by a large number of friends and patrons for his genial manners and excellent business qualifications, and is worthy the reniakibly excellent patronage he receives.

\section{A. I. DUEF,-Livery and Express Stables, Cor. Bingham and 16th St., S. S.}

This is an old established livery stand. Mr. Duff came to this stand in April, 1877, and since that time has conducted this business with eminent success. He started the South avenue liack line from this stand out the Brownsville road, running out five miles, carryiug passengers and freight two trips daily both ways, and startiug from here at $6.30 \mathrm{~A}$. M. and $4 \mathrm{P}$. M. This is found to be quite a convenience and long-felt want now liappily supplied hy this enterprising gentleman. It is well patronized by the puhlic. Mr. Duff has a good stock of Horses, Waggons, Hacks and Buggies, with which he can accommodate the public at all times with safe conveyances and drivers, and at very moderate charges, as he is hichly appreciated in this business. He gives special attention to expressing goods, merchandise, or luggage to and from all the depots, and makes deliveries to ull parts of the city. Moving a speciaity.

\section{RAMSEY \& CO.-Practical Druggists and Apothecaries,}

The Drng and Prescription business of Ransey \& Co., on Main St., Sharpshurgh, was established by James Ramsey ij 1875 , who conducted the business up to the time of his death, when it passed in to the hands of the present frm. They now carry a stock of about $\$ 3,000$ and enjoy a liberal share of the trade. The Store is in a three-story lirick building, fronting 40 fect on two streets, the property of the $F$. and $M$. hank. The business is now conducted by $\mathrm{E}$. Hack, salesman, 0. Hamell, bookkeeper, and Mrs. Maggie E. Panisey, widow of the former proprietor. The salesinan is a practical druggist of several years' experience, makes a specialty of physicians' prescriptions, and understands the business in all its ctetails.

\section{W. A. IMARTIN,-Dealer in Groceries and Produce, 133 Center Av.}

This is an old established stand, Mr. Martin starting business in this place in 1859. He carries a general assortment and full stock of Family Groceries and Produce, and does il very fair busincss. His Store is situated on the corner of Green St. and Center Av., 24 feet front by 60 feet deep. With the assistance of his wife and daugliter, he is at all times prepared to serve patrons with good goods and lowest prices. MIr. Martin is a native of Germany, born in 1816 , and since 1854 he has resided in this city.

\section{A. KUEHNEISEN, - Hats, Caps, and Furs, 1410.Carson St., South Side.}

The Hat, Cap and Fur establishment of A. Kuebneisen, which is located at 1410 Carson St., and in which a very choice and complete stock of all the latest seasonable styles is constantly catried on, is a very popular one, and enjoys a large and growing trade. The business was started at this point a number of yeurs ago by $L$. Kuehneisen, fither of the present proprietor. This house has long been the leading one in this line of grods. Mr. Kuehneisen was born in New York city, but his parents removed to this city when he was but two years of age. He bas sinee been identified with Pittsburgh, and is a popular, courteous and agreenhle young gentlemin.

DANIEL BRAUN,-Dealer in Groceries and Produce, 145 Eighteenth St., S. S.

Mr. Braun moved to this place, his own property, in 1877 , with a capital of $\$ 5,000$. He always keeps a general assortment and a good stoek of all the choice articles to be found in a well-stocked Grocery and Provision Store Under his able management, the business is well patronized. IHe is a native of Germany, born in 1816, and came to this city in bis childhood, in 1852 , where he has remained. II was engaged ia business with his brother in 1866, with a joint capital, then, of $\$ 1500$. He is well and favorably known, and all who patronize him will find him a clever business man to deal with.

\section{WIM. C. KIEIN,-Groceries and Country Produce, 1710 Carson St., South Side.}

One of the leading dealers on the South Side is Mr. W. C. Klein, who started the Grocery and Produce business at his present stand, No. 1710 Carson St., in $187 i$. The demands of trade gradually increased until he is now carrying in stock a full and complete assortment of goods in his line of business; and he is doing a flourishing and prosperous trade. He occupies the building fronting Cirson St, $24 \times 80$ feet in size, and employs several assistants. His trade is local, but is rapidly extending. Ar. IKlein was born in this city, in 1853, and is thoronghly familiar with the locaiity and the wants of his trade. He is active, enterprising and honest, and is deserving of the patronage he so liherally receives.

\section{ADAM HENNING?-Manufacturer of Saddles \& Harness, Mt. Oliver.}

Mr. Adam Henning started in the Saddle and Harness husiness here in 1866. Since then he has built up and established a very flourishing and remunerative business. He is located in a two-story building 36 fect square, Miount Oliver, opposite Geo. Goldbach's where he manufactures and deals in Saddles, Harness, Collars, Bridles, Halters, Check Reins, Whips, Blankets, Harness Oils, etc, and does Repairing neatly and promptly to order. II is work is put up from good stock and warranted. To Custom Work he gives special attention. He was born in Germany in 1343 and came to this city with his parents in 1845 , and has resided here ever since.

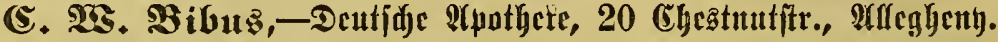

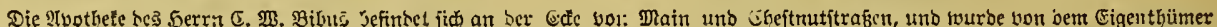

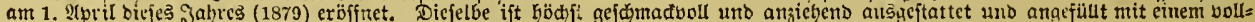

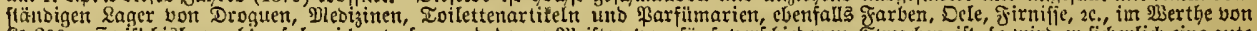

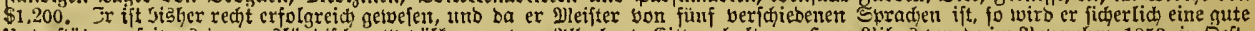

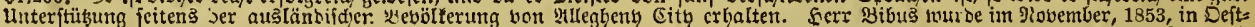

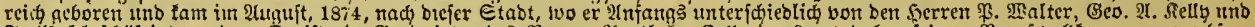

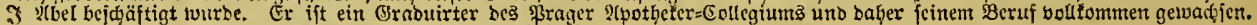

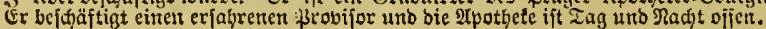


CHAMBER OF COMMERCE CARD RACK. B

WM. PICKERSGILL, JR.,

MANUFACTURER OF

BOOTS AND SHOES,

149 Wood Street,

Factory in Rear of Store,

PITTSBURGH, PA.

See Page 111.

\section{TOTTEN \& CO.,}

Fulton Foundry,

Cor. 24th and Railroad streets,

PITTSBURGH, PA.

Only Makers of

HOLLOW CHILLEI) ROLLS, CHILLED GR00VE ROLLS.

See page $13 \overline{5}$.

\section{FRANK ARMSTRONG,}

SUCCESSOR TO

PITSBURGH NATHNAL COAL \& COKE CO

OFFICE AND YARD:

Corner Fourth Avenue and Try Street,

PITTSBURGH, PA.

Best Family Coal, Nut Coal and Slack, always on hand. See page 101.

\section{COYME \& HATRY, \\ Patentees and Bullders of \\ PATENT AUTOHATIC NALL SELECTORS

$$
\text { A. }
$$ \\ Improved Cut Nail Machines, OFFICE, 114 \& 115 Water St., WORKS, cor. 28th \& Smallman Sts., \\ PITTSBURGH, PA. See page 125 .}

W. C. BERINGER \& CO., Claim and Patent Agents,

116 SMITHFIELD STREET,

PITTSBURGH, P-A.

Pensions and Patents procurerl. Bounty, Prize Iloney, \&c., Promptly Collected.

SPECLAL ATTENTIOY GIVEN TO THR SALE OF PATENTS.

\section{GHARLES A. SCOTT, GENERAL \\ BOOK \& JOB PRINTER, \\ No. 132 Fifth Arenue, "Methodist Recorder"
Building, PITTSBURGI, PA. \\ COMMERCIAL WORK A SPECIALTY. See page 148.}

Thos. Wightman \& Co.,

Glass Manulacturers,

43 Wood Street,

PITTSB URG H, PA.

See page 187.

\section{GARDNER BROTHERS,}

\section{CLAY GIS RETORTS AND SETTINGS}

Fire Brick, Tile and Furuace Blocks, BRANCH OFFICE, 116 SMITHFIELD STREET, PITTSBURGH, PA.

Works, Lockport, Pa., and Mt. Savage Junction, Md. See page 192.

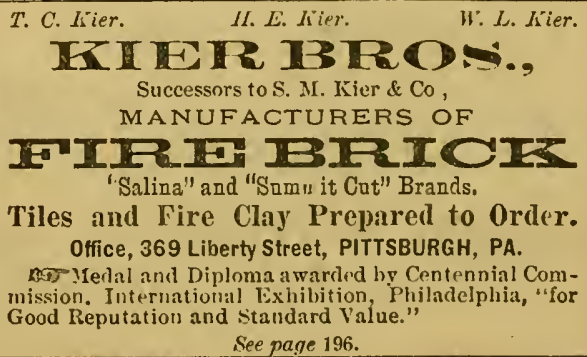




\section{ST. VINCENT'S ABBEY AND COLIEGE,-Westmoreland Co., Pa.}

The Abbey and College of St. Vincent is situated in Westmoreland county, Pennsylvania, forty miles east of Pittsburgh, two miles from Latrobe, and one from Beatty's Station. St. Vincent's Abbey is a colony of the Abbey of Metten, a Benedictine monastery on the river Danube, in the kingdon of Bavaria, which was established by Charlentagne during his war with the Avar's, in the year 796 ; secularized in consequence of the peace of Luncville, $A$. D. 1803; and re-established by King Louis I., of Bavaria, in 1830. The order of St. Benedict has a history of almost fourteen hundred years, having been founded in the year of our Lord 500, in Italy, by Saint Benedict, the son of a Roman senator who established the lamous monastery of Monte Cassino (near Mt. Vesuvins), which is still in existence. In 1846, Gregory Scherr (late archbishop of Munich), the first abbot of (new) Metten, at the request of the Bavarian Missionary Society, sent to this country the Rev. Boniface Wimmer, with four clerical students and fifteen lay brothers, for the task of establishing a branch of the order in America, and to erect one or more monasteries and schools for the education of youth, and particularly as seminaries for the education of German Catholic priests, to take charge of the rapidly increasing German Catholic population of the United States. Father Wimmer and his associates were most graciously received, upon their arrival in this country, by Rt. Rev. Doctor O'Connor, bishop of Pittsburgh, who was anxious to secure to his diocese the aid and services of the Benedictine brothers from Bavaria, and wlio offered them the church farm of St. Vincent as a desirable and convenient location for the proposed monastery. Father Wimmer, during the same year, took formal possession as pastor of St. Vincent's congregation, Rev. M. Gallagher resigning in his favor, but remaining as assistant pastor for the English-speaking portion of the congregation. In 1830 a church and parsonage had beeu erected at the place by Rev. T. O. Stillinger, to which Father Gallagher had subsequently added a schoolhouse. In addition to these buildings, an old log-house was yet standing, which was erected in 1789 by the tirst missionaries at this point. When Fatler Wimmer arrived, the parsonage was occupied by the Sisters of Mercy, the priest lived in the school-house, and the log-house was used as a residence by the tenant of the farm, Mr. Schowalter, with his large family. The Benedictines were compelled to take up their quarters in the school-house, which, thereby, was unpleasantly crowded. In the following Mar, the Sisters removed to Saint Xavier's, where they established a convent and an academy. Father Gallagher removed to Philadelphia, where he joined the Augustinians, and the place was left to the Benedictines. They were reinforced in August, 1847, by another detachmient from Bavaria of candidates for the order, who immediately proceeded to build the monastery and work upon the farm. Father Wimuer and the young priests whom he had got orlained attended to the missions and to the instruction and education of boys. At this time there was no Catholic institution of learning ncar or far, nor was there any German Catholic priest in Western Pennsylvania, with the exception of Rev. N. Lemke, who was located in the wilds of Cambria county, and in the city of Pittsburgh, where two Redemptionist fathers had located and erected St. Philomena's church. 'In 1850 the new institution was acknowledged as a monastery, and in 1855 as an Abbey, when Father Wimmer was made A blot-first for a term of three years, and in 1865 for life. Meantime the number of priests increased, and their sphere of usefulness enlarged. Some took charge of the German Catholic population in Canjbria county, and established a priory in Carrolltown. Others took charge of a German colony in Elk connty, and erected the priory of St. Mary's, from which they, for many years, attended to all the German Catholic congregations in North-Westeru Pennsylvania. Others settled in the city of Newark, New Jersey, where they have two congregations under their charge and a collese. Others went to Stearns county, Minnesota, where they established first a priory, which, in 1866, became an abbey, and has now a large and flourishing college connected with 1t. Another party was sent to Atchison, Kansas, where they likewise established a priory, which became an Abbey in 1876. There are now, also, houses of the order in Allegheny Cî̀, Pa., Covington, Ky., Erie, Pa., Chicago, Ill., Baltimore, Md., Richmond, Va., Kidaway Isle, near Savannah, Ga.; near Charlotte, N. C., Tuscumbia, Ala., Covington, La., \&c. Abhot Boniface Wimmer is also Abbot-general of the other houses and establishments mentioned above, of which St. Vincent is the mother.

ST. VINCENT's CoLLEGE, which was founded in 1846 by the Rt. Rev. Boniface Wimmer, O. S. B. of St. Vincent's A bbey, is now one of the largest Catholic institutions of learning in this country. It is adapted to the requirements of the country, most of the teachers being of American birth, although proper attention is yet paid to the German element. Man $y$ of the professors have been edneated in the universities of Rome, Insbruck and Munich. The College of St. Vincent was chartered in 1870. The students are divided, according to their ages, into three classes, each of which has its own study hall and dormitory, and is under the coutrol of two prefects. The College possesses a large library, excellent chemical and plilosophical apparatus for the use of more advanced students, a splendid collection of minerals, shells and plants, a valuable and interesting collection of samples, for drawing and painting, a fine physical cabinet and all the adjuncts for imparting thorough and conprehensive instruction in all branches. Thirty-four professors and assistant professors compose the faculty, and the board of trustees is as follows: Rt. Rev. Bouiface Wimmer, O. S. B., President; Rev. Hilary Pirængle, O. S. B., Vice-President; Rev, Leo Haid, O. S. B., Secretary; and V. Rev. Andrew Hintenach, O. S. B.; Rev. Adelbert Mueller, O. S. B.; Rev. John B. Sommer, O. S. B.; and Rev. James Zilliox, O. S. B. The present number of students is three hundred and thirty-seven, and pirticular attention is paid to their religious instruction, in addition to the theological, scientific, classical and commercial branches. The cultivation of classical music is also an important feature at this institution. Letters of inquiry should be addressed to the Director of St. Vincent's College, Beatty's P. O., Westmoreland County, Pa.

\section{IDIEW OOD,-Summer Resort, W. S. Jackson, Proprietor.}

Situated in a natural forest, with pure spring water, delightful atmosphere, and at an elevation which commands a splendid view over the Chartiers Valley with its diversified and captivating scenery, Idlewood is rapidly becoming appreciated by business men as an excellent place for their families during Summer, and also as a desirable place for those from all parts of the country, troubled with throat or lung diseases. Distant from the city avout seven miles by the P. C. \& St. L. K. R., and about five miles by wagon road, its accessibility and advantages in everything pertaining to health-oiving qualities in air, water and every sanitary condition. Idlewood hotel (a model of neatuess) with its series of cottares for fanilies, has in the list two years attained a high reputation as a popular resort, and is destined to be one of the leading resorts of Western Pennsylrania. To the business men of Pittsburgl, Idicwood aftiords a splendid Summer home, which may be reached every evening, while to their wives and childien its benefits are incalculable. Those who visit our city during the Summer months, either on lousiness or pleasure, will find this the most fascinating spot in I'ittsburgh's en virons.

A. GOEDDEL,-Restaurant and Saloon, Frankstown Av, and Broad St., East End.

Mr. Goudel was the first to succeed in the restaurant business in the East End, by giving thorough attention to supplying his tables with the best the market affords, and liaving everything cooked and served up promptly ancl in the best style. Meals can be had at all hours. In addition to the restaurant he also conducts a saloon which is leadquarters for Cincinnati and Milwaukee beer. Mr. Goddel was born in the East End, August 29, 1851, and commenced business in 1876, establishing his restaurant in 1878.

\section{PHILIP H. ITTEL,-Flour, Feed, \&c., 362 Ohio St., Allegheny.}

The above caption represents one of the most reliable houses in the city dealing in flour, grain, seeds, mill feed, potatoes, hay, straw, salt and produce generally. and being very complete in this line. 
AGIJWV de 00. MANUFACTURERS OF

FLINT GLASS VIALS BOTTIES,

153 First Avenue, PITTSBURGH, PA. See Page $1+1$.

\section{J. H. STEVENSON, Attorney at Iav,}

Solicitor of American \& Foreign Patents,

No. 100 Fifth Avenue,

PITTSBCRGH, PA. See Page 113.

LEECHB ORG IR ON W ORKS.

Kirkpatrick, Beale \& Co.,

Manufacturers of all Grades of

FHE SHEE IRON AND TERNE FLAT,

Office, 143 First Avenue,

(Works, Leechburg, Pa.)

PITTSBURGH.

\section{J. B. KAERCHER,}

Dealer in

Hardware \& Cutlery,

\%3 Market Street,

Bet. Fourth Ave. and

Diamond St.,

PITSBURGH, PA.

See Page 118.

\section{JAmES A. Monally,}

Importer and Jobber of

FOREIGN and DOMESTIC

WOOIENS,

60 Wood Street,

PITTSBURGH, PA.

$$
\text { See Page } 125 .
$$

\section{DITHRIDGE GHIHNEY CO. LIMITED, Manufacturers of \\ LAMP CHIMNEYS,}

17th Street, South Side,

PITTSBURGH, PA.

W. II. IEOISIMES, Manujacturer \& Wholesale Dealer in

FINE OLD \& NEW COPPER DISTILLED $\frac{(2)}{\text { GENUINE IMPORTED }}$

Tines, Brandies, Gins, and Champagnes, 117 Water Street \& $15 t$ First Arenue, PITTSBURGH.

Sago Pag 195

\section{JAMES FEFS,} MANCFACTLRER OF

\section{William Guckert \& Co.,} Manufacturers of

Extension \& Centre Tables,

DESKS, WARDROBES, \&c.,

of every Description on Hand and Made to Order. Cor. Cherry \& Strawberry Alleys, Pittsolloh.
(Bet. Smithrield d Grant Sis.)

Pltsulfoll.

All kinds of Wood Turning and Sawing Done

Orders Respectfully

\section{Marine \& Land Engines,}

BLAST FURNACE, MACHINERY \& CASTINGS,

Iron \& Brass Castings, Sheet Iron \& Copper Pipes, Sterm Hoilers, Oil Tanks, sult Paus, dec.,

COR. DLQLESNE WAY K FOLPTH ST., PITTSBURGH, PA. 


\section{GEO. B. JOHNSTON, Successor to Geo. B. Johnston \& Co.}

Ury Guods, Trimmings, Boots, shocs, Huts, Caps, etc., MIrin St., South Side.

A mong the best known and most deservedly successful merchants on the South Side, George B. Johnston is prominent. He commenced business for himself in 1864 , on a small capital, which he had previously earned by lis own industry, and since that time he has persevered with an energy and determination that could not fail to command success. He now occupies a handsome three-story brick building. 25 . feet front by 120 feet deep, titted up and furnished with an especial view to the requirements of a first-class Dry Goods store and stocked with a full and complete assortment of Foreign and Domestic Dry Goods, Trimmings, Hats, Caps, Boots, Shoes, etc. Mr. Johnston las alınt $\$ 35,000$ invested in his business and always carries from $\$ 15,000$ to $\$ 20,000$ wortl of stock. His trade, which is extensive both in city and country, ranges between $\$ 30,000$ and $\$ 35,000$ per annum and gives constant employ ment to seven clerks and salesinen, whose monthly pay-roll will average over two hundred dollats. Mr. Johnston is a native of Franklin Coun(y, Pa., but has lived jn Pittshurgh since 1863. To his own unaided exertions is due his present success. He possesses perseverance, untiring enercy, promptncss and punctuality in all matters pertaining to lusiness. Strictly co:rect in all transactions with all customers, courteous in his manners and attentire to every detail of his business, Mr. Johuston is deservedly popular with a large class. His louse stands high in the estimation of the trading public.

\section{WII. SCHUETZ, -Wagon\& Buggy Manuf'r, Cor. Arlington Av.\& First St., 31st Ward.}

This business was started by Mr. Schuetz in 1870, with a moderate capital, where he has continued to do business to the present time. He occupies a double huilding, for Wagon-making and Elacksnithing, fronting on Arlington avenue 50 feet, having ample room to accommodate all. Everyone who calls upon him and farors him with their custom will be guaranteed first-class work at the very lowest figures Mr. Schuetz is al practicul mechanic in his trade and having the experience of mañy years in his business, none will go away withnut being fully satisfied with his workmanship as well as his prices. His residence and dwelling is immediately adjoining this shop, all of which is his own and improved property. He is prepared to nimufacture to order two-horse wagons, buggies or spring wagons, and guarantees good stock and styles. Also will do Repairing promptly to order.

\section{JOSEPH GANSTER,-Union Hotel, Penn Av, and P. R. R., East End.}

This Hotel was opened in 1863 by Mr. Ganster, its genial landlord. The house is large and well arranged, and adapted to the business; and for the accommodation of guests a good bar is kept, also good stabling in connection. Prices will always he found reasonable. Mr. Ganster was born in France in 1817, and cane to Pittshurgh in 18:38. He commenced business where the Union Depot now stands. He is among our most popular landlords, and is lighly esteemed.

\section{J. B. RICHARDS,-Real Estate Broker and Insurance Agent, 42d \&Butler Sts.}

$\mathrm{Mr}$. Richards engaged in the Real Estate and Insurance business in 1872 , at his present place, corner $42 \mathrm{~d}$ and Butler. Sts, removing from there to $43 d$ and Butler, then to $42 \mathrm{~d}$ and Butler, where lie has heen successful in building up quite an extensive and profitable business in selling, Jenting and insuring property, placing loans, etc. Mr. Richards has held the oftice of notary public for three years. He is editor and publisher of the spicy and popular weekly publication, "The East Ender," "lhe publication of which was commenced some years since, and which sprung very rapidly into public fatvor. He was born in Brockville, Canada, in 1849, ancl came to the States in 1870. Shortly afterwards engaged in his present business. He was engaged in the banking lusiness in Canada prior to coming to this cit.y.

\section{BRILLIANT ICE COMPANY,-Seely Brothers,}

P'enn Av, near Liberty Hall, Erest Eud.

The purity and general excellence of the Ice put up by this well-knewn company commend it to familics and all others. The Brilliant Ice Compuny was established in November, 1877, by Seely Brothers. Four Ice-hususes are required for the storage of their Ice; and their stock in trade, including Ice, wagons, \&c., is alout $\$ 10$ coo. They do a general business, clelivering Ice through the city proper and the East End. Their main office is on Penn Av., near Liberty Hall, East End, but eity eustomers can leave orders with W. W. Barker, 125 Fifth Av. MIr. F. H. Seely was born in Pittsburgh August 5, 1855, and Mr. D. N. Seely at the same place December 27, 1856 . Tne latter gentleman is notary public.

\section{B. SEELY,-Real Estate and Insurance Agent, Penn Avenue, East End.}

Capt. Seely is one of the prominent citizens of the East End. He was born in Ehensburgh, Cambria county; Pa., May 11, 1824, and cane to Pitsburgh in 1841. He has represented the East End district in the City Council, and has held other positions. In March, 1879, he opened an ofice on Penn Av, as a Real-Estate and Insurance agent. He represents some of the best and most reliable insurance conpanies in the country, and attends to the collection of rents, buying, sclling $0 r^{*}$ exchanging Real Estate, \&c. Messages left at the office of John C. McCombs, 134 Fiffh $\Lambda \mathrm{v}$., city, will receive prompt attention.

\section{BANNER TEA HOUSE,-W. H. Price, Proprietor, 170 Wylie Avenue.}

At the sign of the big banner, No. $170 \mathrm{Wr}$.lie Av., hetween Elm and Logan Sts., is located the mocled Tea and Grocery establishuent of Mr. W. H. Price. This house was founded April 1, 1877, by the present proprietor. IIe carries a choice and desirables ock of tine family Groceries, Japan, Oolong and all orher popular Teas, Cotferes, spices, Sugars, Jellies and Cinned Goods, Butter Cheese, Eqgs, country produec and all articles usually found in a first-cliss metropolitan establishment. Mr. Price was horn in Cambridge Co., Penusylvania, April 13, is43, and came io Pittshurgh when but one vear of age. For six years previous to engaging in business at his present location, he was proprictor of a similar establishment on the South Side.

W M. KOSSLER,-Man'f. of Tin, Copper \& Sheet Iron Ware, 200 Main St., 36th W.

This popular and thriving establishment was npened loy Mr. Kossler in a three-story brick building in 1873 . The stock is liage and varied, and includes stoves, hardware and every variety of house furnishing gonds arranged in thrce departments. Mr. Kossler was bern in Pittsburry in 1850; he is genial in manoer, popular with all who kuow him and enjoys a trade extending over both cities and country. 
JOHNSON, EAGYR \& EARL,

\section{Wholesale Grocers,}

Nos. 120 Second \& 149 First Ave.,

Sullivan Johnson,

Geo. W. Eagye, $\}$

See Page 238.

PITPSBURGH, PA.

\section{RODY PATTERSON, Jr.}

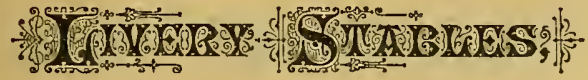

117 FOURTH AVENUE,

PITTSBURGH, PA.

Boarding Horges a Specialty.

A. A. Hutchinson \& Bro.,

Manufecturers and Shippers of

Hare Eannellsuille Sake,

Office, 94 Fifth Ave., PITTSBURGH, PA.

GLOBE MINES, Broadford, Pa., STANDARD MINES, Mit. Pleasant.

CAPACITY 500 TONS.PER DAY. See page 97.

Roaring Spring Mills. West Newton Mills. Mirl Grove Mills.

KEYSTONE PAPER CO., AlL Kinds OF PAPER, Rag \& Straw Wrapping, Roofing Felt,

Lining Felt, Printed Wrapping, \&c. OFFICE AND WAREHOUSES:

Nos. 126 and 128 Second Avenue, PITTSBURGH, PA., 22 Vesey Sireet, NEW YORK. See Page 124.

\section{J. II. Borland. \\ J. H. BORLARD \& CO., Wholesale Auctioneers and Jobbers of Boots, Shoes\&Griters,} Nos. 53 and 55 Wood Street, Aud 105 Third Avenue, Auction Sales every Tuesday,
at $10 \% / 2$ A. M.

Goods sold at Private Sale throughout the week at Auction Prices.

\section{F. AHLERS,}

MERCHANT TAILOR,

No. 77 Smithfield Si., PITTSBUR( $\mathrm{xH}$, PA.

Good Goods, Latest Styles \& Perfect Fits.

See Page 113.

\section{Geo. A. Berry, Pres. John Scott,
Chas. G. Milnor, Sec. and T'reas. $\quad$ L. M. Plumer, Solicilor. \\ PIITSBURG \\ BANK FOR SAVINGS,}

61 Fourth Avenue,

PITTSBURGH, PA. See Page 90 .

\section{H. LLOYD, SOW \& CO.}

Manufacturers of Best Grades

Juniata Charcoal Eloom,

BAR, SHEET \& BOILER PLATE

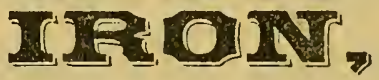

KENSINGTON IRON WORKS,

Second Avenue, Pittshurgl, Pa.

I'ITTSBURGH CHEMICAL WORTS.

MIIIIES de CO., Manufacturers of

CONCENTRATED LYE AND KA-LYE, And Dealers in HYDRAULIC CEMENTS,

White Line, White Sand, Calcined Plaster, Fertilizers, Sewer Pipe, Chimney Tops, Fire Brick, Grate Tiles, dc

Isaac Mills, Jr., ] Wareroom, 260 Iiherty St., $\left.\begin{array}{l}\text { Geo. Sheppard, } \\ \text { Brankstone, }\end{array}\right\}$ PITTSBURGH, PA.

S. C Jivllock : Sep Page lsi.

\section{WIF. HASRAGE,} WHOLESALE \& RETAIL

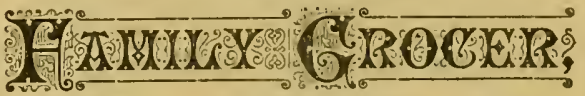

Tea, Wine and Liquor Dealer, Cofree Roaster, Spice Grinder, sc.

No. 18 Diamond Square, PITTSBURGH, PA. 


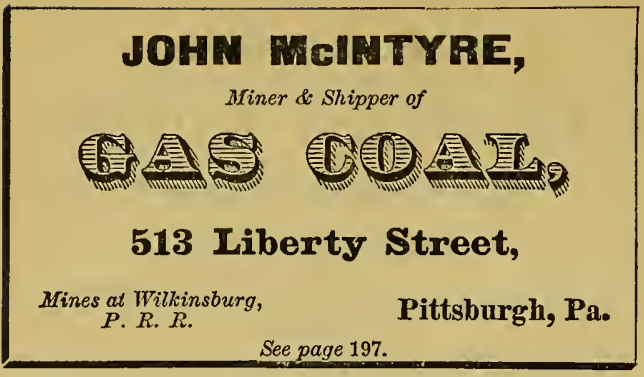

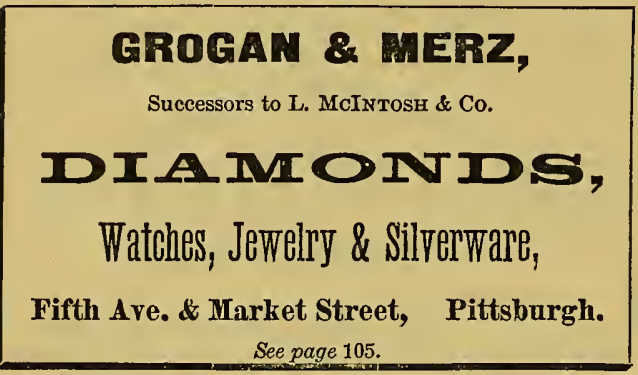

Wm. Luebbe.

\section{LUEBBE \& BRO.,}

Wholesale \& Retail

파 $O$ 표 $S$,

AND DEALERS IN

CHOICE TEAS, WINES, LIQUORS, \&c.,

Nos. 23 \& 24 Diamond Square,

Pittsburgh, Pa.

See page 126.

\section{KEYSTONE \\ Gas Light Co., Limited, \\ Manufacturers of}

Street Lamps \& Gas Attachments, FOR LIGHTING

Streets, Parks, Private Grounds, \&c. 44 NINTH STREET,

Solicit Contracts for Lighting $\quad$ rittsburgh, Pa.
Streets in Cities \& Towns. See page 84.

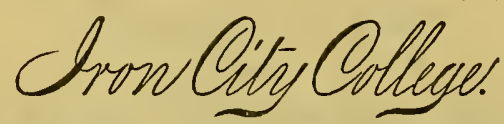

Cor. Penn Ave. \& Sixth St.,

The most Complete, and the only Thoroughly Practical Business College In the United States.

Circulars giving full particulars sent on application to

J. C. SMITH, A. M., Principal. See Page $2+8$
W. Dewees Wood. $\quad$ Rich'd. G. Wood. Alan W. Wood.

MaKeesport Iren Works.

W. D. WOOD POCO

111 Water Street,

PITTSBURGH, PA.

See page 81.

\section{WM. E. GRAY,}

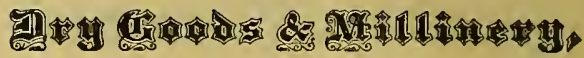

$$
\text { 1309 Carson Street, }
$$

PITTSBURGH, S. S.

See page 214.

\section{LIVINGSTONE NOVELTY WORKS, Pittsburgh, Pa. \\ Manufacturers of}

Builders' Hardware, Light Gray Iron and Brass

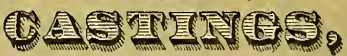

PLAIN, JAPANNED, BRONZED \& GALVANIZED.

We make a specialty of Light Castings for Agricultural Implements, Light Machinery, and miscellaneous articles, using a high grade of A No. $1 \mathrm{H}$. R. Charcoal Iron; which gives a clean, smooth casting, very strong, and easy on drill or lathe. Sers for Estimates. See pages 208 \& 211. 
CHAMBER OF COMMERCE CARD RACK. $\mathrm{F}$

\section{JOHN. S. FERGUSON,}

Attorney at Law,

No. 162 FOURPH AVENUE,

PITTSBURGH, PA.
John IT. IIampton.

John DaLzell.

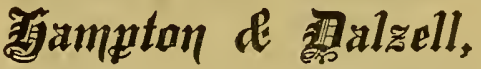
ATTORNEYS AT LAW,

64 Grant Street,

PITTSBURGH, PA.

WILLIAF REARDON

\section{AND \\ IOHN MARRON,}

ATIORNEYS AT LAW,

64 GRANT STREET,

S. W. CUNNINGHAM,

Attorney at Law,

58 Grant Street,

Pittsburgh, Pa.

KNOX \& REED,

Attorneys at Law, OFFICE :

60 Grant Street,

PITTSBURGH, PA.

BIRMINGHAMI BEER BOPPLING CO, Nanufacturers of

MINERAL WATER, SARSAPARILLA, dc.

F. HADPE, Proprietor.

HEAD OF 23d STREET, SOUTH SIDE.

Speclal Attention to Bottling Beer fo: Family Use.

ORDERS PROMPTLY FILLED
M. F. CASSIDY, Esq.,

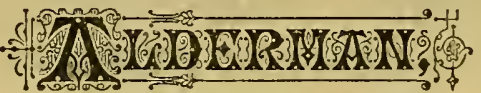

No. OA Ihird Averue, PITTSBURGH, PA.
No, 72 Grant Street, Pittsburgh, Pa.
Attorney ax LAw,

89 Diamond Street,

Pittsburgh, Pa.

\section{WILSON \& GORMAR,} Danufacturers of

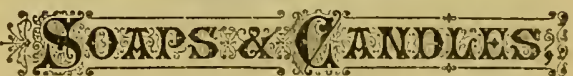

IUBRICATING TAIIOW \& SOAPS, For Raliroad Purposes, a Specialty.

No. 199 Fourth Avenue, Pittsburgh, Pa. 
CHAS. F. MENHA,

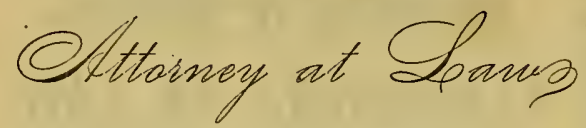

No. 146 FIFTH AVENUE,

Pittsburgh, Pa.

\section{W. N. PAXTON,}

\section{Attorney at Law,}

COR. DIAMOND \& GRANT STSS,

PITTSBURGH, PA.

Edward A. Montooth.

Charles C. Montooth.

E. A. MONTOOTH \& BROTHER,

\section{Attorneys at LaW,}

Cor. Grant \& Diamond Streets,

(Entrance on Diamond St.) Pitsburgh, Pa.

W. Bakewell.

Thos. B. Kerr.

\section{Bakewell \&. Kerr,}

ATIORNEYS \& COUNSELLORS AT LAW IN PAPENT CASES,

No. 94 Diamond Street, PITTSBURGH, PA.

John Barton.

E. L. Barton.

J. H. Barlon.

L. C. Barton.

BAZTON SOAS? EUROPEAN SPEAMSHIP EXCHANGE.

COLIACTION \& R. R. TICRET OFRICE,

No. 131 Smithfield Street,

Established in 1866.

PITTSBURGH, PA.

Consulate of Austria, Hungary, and Consular Correspondent for Germany.

IRON CITY STEAM PAPER BOX FACTORY.

\section{J. REX \& CO.,}

Manufacturers of all kinds of

Paper Boxes, Tea Caddies \& Cigar Boxes. DEALERS IN

Labels, Cigar Brands \& Ribbons,

Cor. Grant St. \& Seventh Ave., Pittsburgh, Pa.

\section{ISAAC M. PENNOCK,}

REAL ESTAPF \& MORTGAGE BROKER.

Farm, Mineral and Lumber Lands for sale in Pennsylvania, West Virginia, Iowa, Arkansas, East Virginia, Illinois, Missour, Texas, Ohio, Kansas, \&c.

MONEY LOANED ON BOND \& MORTGAGE.

Irouses and Lots for Sale in Pittshurgh and Allegheny Cities, ulso Suburban Property.

Houses Rented.

No. 129 Fourth Arenue,

PITTSBURGH, PA.
Bruce \& Negley,

\section{ATTORNEYS AT LAW,}

Cor. Fifth Avenue \& Grant Street, PITTSBURGH, PA.

\section{ALLEGHENY CITY FLOUR MILLS.}

L. WALTER, Sr. \& SON, Proprietors.

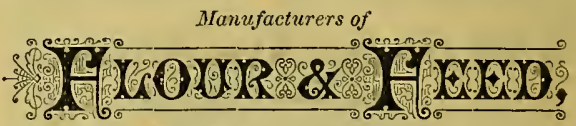

$148,149,150$ \& 151 South Canal St., Altegheny. Also Dealers in

Hard and Pine Lumber, 115 RIVER AVENUE. See page 224. 
CHAMBER OF COMMERCE CARD RACK. H

Washington Works.

\section{ROBIASON, REA \& CO.,}

Foundry \& Engine Builders,

Office, cor. 2d Ave. \& Smithfield St.,

PITTSBURGH, PA.

Blast Furnace and Rolling Mill Work a Specialty. See page 263.

GODFREY \& CLARK, Manufacturers of

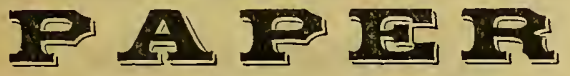

And PAPER FLOUR SACKS,

Warehouse, 270 Liberty St., Pittsburgh.

Branch House, 84 Lake Street, Chicago.

Mills, Elkhorn, Pa.
J.S. \& A. P. MORRISON,

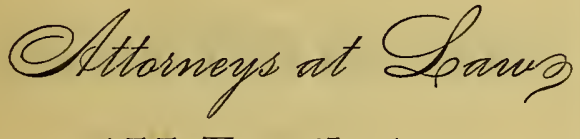
155 Fourth Ave.,

PITTSBURGH, PA.

\section{BISSELL \& CO., \\ Manufacturers of \\ Stoves, Ranges, Grates, \&c,}

Dealers in MANTELS,

Sole Manufacturers of the "PEERLESS" Shaking Grate and Bissell's Safety Railway Car Stove,

235 Liberty St. and 242 Penn Avenue, Pittshurgh, Pa.
S. Cuthbert. R. B. Cuthbert.

S. CUTHBERT \& SON, Real Estate Agents,

64 Grant Street, PITTSBURGH, PA.

Management of Prcperty ; Collect Rents; Sell Real Estate, Mortgages, etc.

Office established in 1845 .

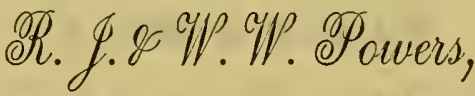 \\ ATTORNEYS AT LAW,}

No. 64 Grant Street, PITTSBURGH, PA.

Hill Burgwin.

Geo. C. Burguin.

WM. L. CHALFANT, Attorney at Law, 149 Fourth Ave., Pittsburgh, Pa.

Established in 1860 .

DUQUESNE BRASS WORKS \& FOUNDRY. A. W. CADMAN \& CO.,

Brass Manufacturers and Pipe Fitters.

Manufacturing and Repairing of Light Machinery in Brass or Iron a Specialty. Castings in Iron, Brass, Bronze or Soft Metals made to Order.

Cor. Duquesne Way \& Sizth St., Pittsburgh.

\section{Attorneys at Law,}

No. 150 Fourth Avenue,

Pittsburgh, Pa.

\section{WILLIAM FLACCUS \& SON,}

\section{TANTERS.}

And Wholesale Dealers in

Leather Findings, Gllle, Hides, Tallow,

TANNERS' OILS, \&c.

Store, 357 Liberty St., Pittsburgh. Tannery, 170 Spring Garden Arenue, Allegheny, $\mathrm{Pa}$.

Specialty-Oak Tanned Harness Lerther; also, Skirting, fair \& black Bridle \& Collar Leather, elc. SEE PAGE 225. 
CHAMBER OF COMMERCE CARD RACK. I

Porter \& Donaldson, Wholesale Millinery,

COR. FIFTH AV. \& LIBERTY ST.

PITTSBURGH, PA.

Ribbons, Silks, Corsets, Embroideries, Flowers and Straw Goods. See Page 110.

M. Swartzwelder, ही 66 Grant St.,

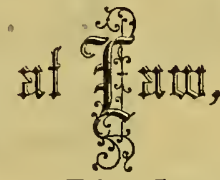

Pittsburgh.

\section{JOHR GRAY \& CO.,}

Dry Coods, rapess and Qil Croths,

LOWEST PRICES GUARANTEED.

1316 CARSON STREET, PITTSBUR木AH, PA.

See page 214.

A. H. Bowman, Nolary Public. Sam't R. Frazier.

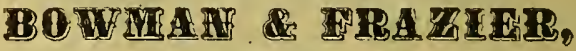

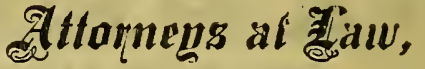

No. 93 Diamond street, Kuhn's Law Building, Second Floor, PITTSBURGH, PA.

R. A. Wilson.

WILSON \& BAILEY,

Pig Iron, Blooms \& Ore,

No. 88 FOURTH AVENUE,

Corner Wood Street,

\section{Pittsburgh.}

General Office, 182 SECONI) A VE. Pittsburgh, $\mathrm{Pa}$.

Pittsburgh Transfer Co. ALL DFSCRIPTIONS OF

Freight Transferred and Forwarded

To all parts of the United States and Canada, ON THE MOST REASONABLE TERMS. See page 183.
C. E. MILLIKEN,

\section{ALDERMAN AND POLCE MAGISTRATE}

No. 69 Grant Street,

PITTSBURGH, PA.

\section{WETCALF, PAUL \& 60. .,}

VERUNA TOOL WORKS.

Manufacturers of SPECIAL R.TR. Treach' Hools. The Celebrated

Patent Verona Nut Lock, and Standard Solid Steel Picks.

Offlee, 7th Ave. \& Liberty Street, PITTSBURGH, PA.

See page 133

\section{Mulholland \& McGaffick,}

\section{LUMBER, BOARDS,' SHINGLES,}

ALL SIZES OF LUMBER. JOB WORK DONE PROMPTLY. Main Street, - - - SHARPSBURG. 





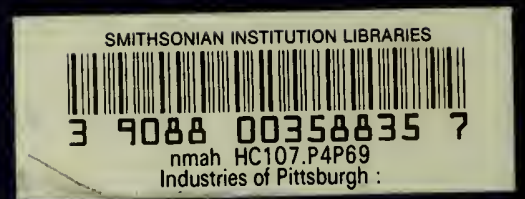

